\title{
$7 V$
}
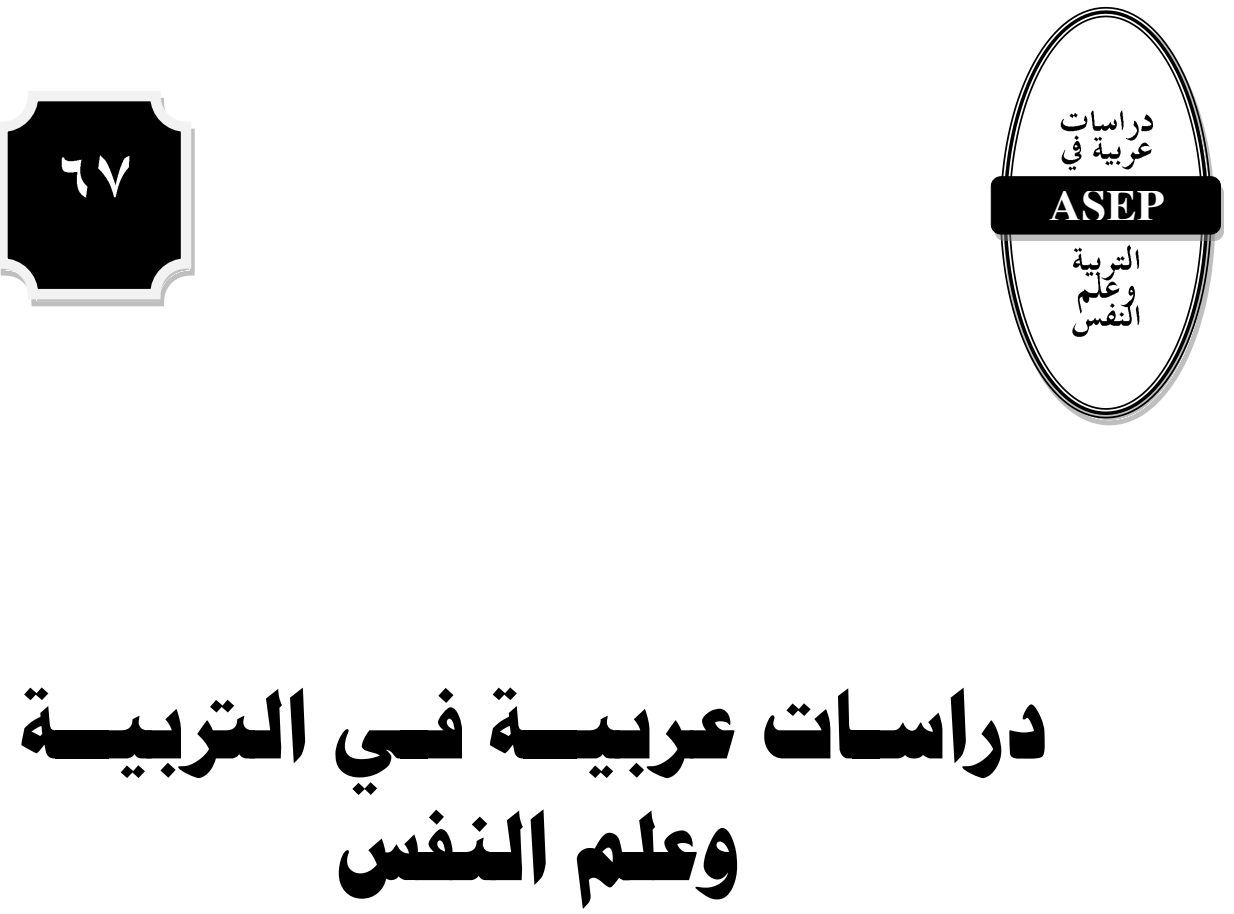

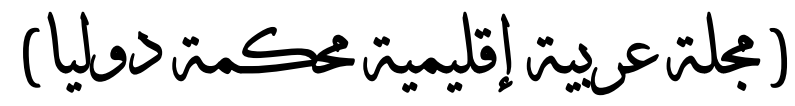

دوريتّ شهريتّ تصلدرها : رابطت التربويين العرب

مفهرست ومصنفتَ فِ عدد من قواعد البيانات الدوليت

العدد السابع والستون .. نوفمبر 10 10

الترقيم الدولي للمجلت :

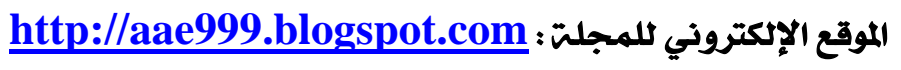




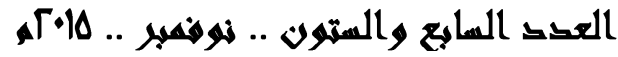

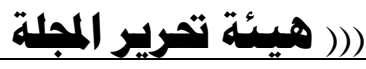

\begin{tabular}{|c|c|c|}
\hline الوظيفة & الاسيم & $p$ \\
\hline رئيس هيئت التحرير & 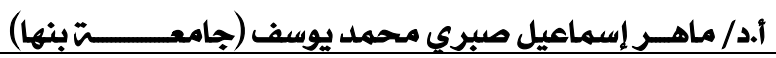 & 1 \\
\hline نائب رئيس التحرير & 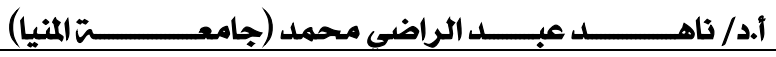 & $r$ \\
\hline مدير التحرير & أ.د.م / هشام بركــات بشـر حسين (جامعـــــ الملكك سعود) & $r$ \\
\hline عضواً & 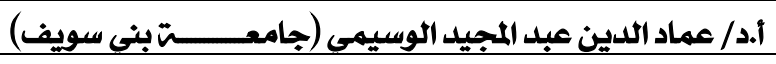 & $\varepsilon$ \\
\hline عضواً & 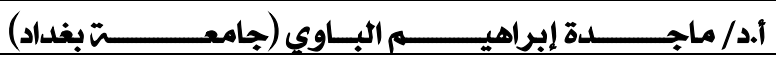 & 0 \\
\hline مضواً ( مراجعت لغويتة) & 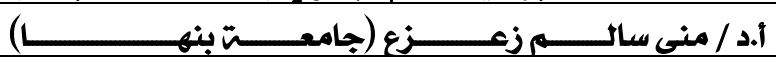 & 7 \\
\hline عضواً (مراجعت لغويت ) & 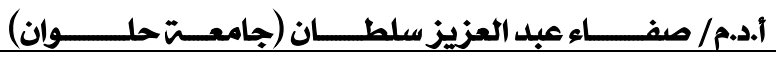 & $\mathbf{v}$ \\
\hline عضوًا (مراجعت عامت ) & 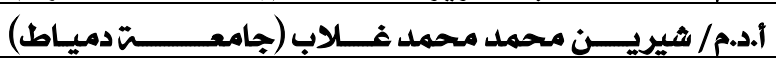 & $\Lambda$ \\
\hline عضواً (مشرفاً تقنيا) & أ/ أمينت سلوم الرحيلى (ماجستير من جامعت طيبت) & 9 \\
\hline سكرتيرة التحرير & 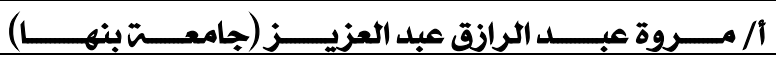 & 1. \\
\hline
\end{tabular}

(( الهيئة الاستشارية العربيةلايمجلة بالتزتيب الأبمدي)):

\begin{tabular}{|c|c|c|c|}
\hline " الجاهمة & الكبية & الاسيم & $p$ \\
\hline وهران بالجزائر & التربيت & 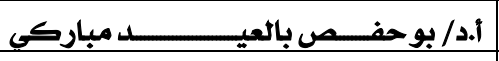 & 1 \\
\hline المنصورة & رياض الأطفال & أ.د/ جابر محمــــــود طلبــــــــــــ الكارف & $r$ \\
\hline حلوان & التربيت الموسيقيت & 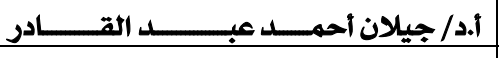 & $r$ \\
\hline عين شمس & التربيت & 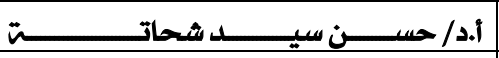 & $\varepsilon$ \\
\hline الأميرة نورة بنت عبد الرحمن بالرياض & التربيت & أ.د / حمـــــــد بن خالـــــــــــــالخالـــــــــي & • \\
\hline 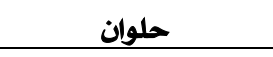 & التربيت الفنيت & 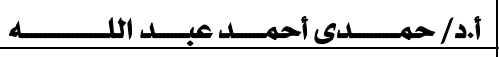 & 7 \\
\hline الملك عبد العزيز بجدة & التربيت & 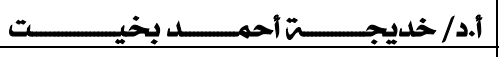 & $\mathbf{v}$ \\
\hline البحرين & التربيت & 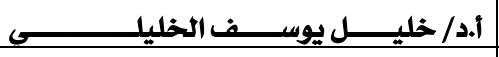 & $\Lambda$ \\
\hline الإسكندريت & تربيت رياضيت بنين & 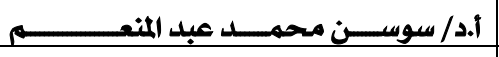 & 9 \\
\hline الكويت & التربيت & أ.د / عبد الرحمـــــن أحمـــــد الأحمـــــــد & 1. \\
\hline اليرموك الآردن & التربيت & 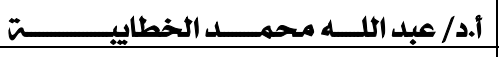 & 11 \\
\hline 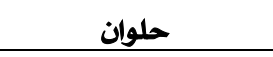 & تربيت رياضيت بنات & أ.د/ عزيــــــزة محمـــــود محمد ساهــــم & ir \\
\hline مين شمس & التربيت & 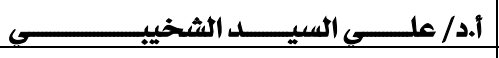 & ir \\
\hline أم القرى مكت المكرمتة & التربيت & أ.د/ عليـــــــاء عبـــــــــــــــــــــــه الجندي & $1 \varepsilon$ \\
\hline بغداد العراق & التربيت & 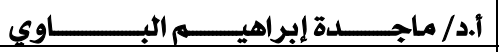 & 10 \\
\hline دمشق سوريا & التربيت & 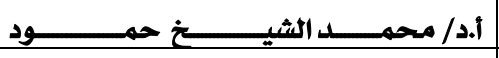 & 17 \\
\hline 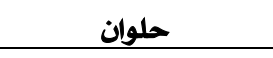 & تربيت رياضيت بنين & أ.د/محمد نصر الدين رضوان إبراهيي & IV \\
\hline الإسكندريت & التربيت & أ.د/محمود عبد الحليم حامد منســــي & M \\
\hline 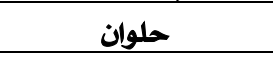 & الآداب & أ.د/ ممدوحت محمد محمد سلامــــــــتة & 19 \\
\hline 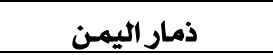 & التربيت & أ.دد/ نعمان سعيد نعمــــــــــان الأســــودي & $r \cdot$ \\
\hline
\end{tabular}




\begin{tabular}{|c|c|c|c|}
\hline \multicolumn{4}{|c|}{ International Advisory Editorial Board : الهيسة الاستشارية الدولية } \\
\hline $\mathbf{N}$ & Name in English & الاسم بالعربيت & Contrey \\
\hline 1. & $\begin{array}{l}\text { Prof.DR Allan Thomas Rogerson, Director } \\
\text { of CDNALMA, Teacher Training Institute, } \\
\text { Poland }\end{array}$ & 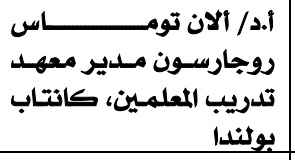 & \\
\hline 2. & $\begin{array}{l}\text { Prof. Dr. Ann Macaskill. Head of Research } \\
\text { Ethics/ Professor of Health Psychology, } \\
\text { Sheffield Hallam University. (UK). }\end{array}$ & 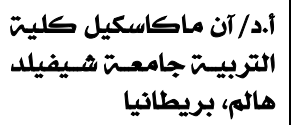 & \\
\hline 3. & $\begin{array}{l}\text { Prof. Dr. Aytekin ISSMAN, Proffessor of } \\
\text { Educational Technology and Dean of } \\
\text { College of Communication, Department of } \\
\text { Communication Design \& Media, Esentepe } \\
\text { Campus, Sakarya University. Sakarya } \\
\text { TURKEY }\end{array}$ & تركيا & \\
\hline 4. & $\begin{array}{l}\text { Prof. Dr. David HungWeiLoong, Professor } \\
\text { of the Learning Sciences, Associate Dean of } \\
\text { Educational Research Office. National } \\
\text { Institute of Education.Nanyang Techno- } \\
\text { logical University. Singapore }\end{array}$ & 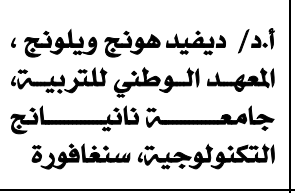 & \\
\hline 5. & $\begin{array}{l}\text { Prof. dr. Fatos Silman. professor of } \\
\text { educational administration and planning. } \\
\text { Cyprus international university. Northern } \\
\text { Cyprus. }\end{array}$ & قبرص & \\
\hline 6. & $\begin{array}{l}\text { Prof. dr. James Paul Gee, Mary Lou Fulton } \\
\text { Presidential Professor of Literacy Studies, } \\
\text { Regents, Professor, Arizona State } \\
\text { University. (USA). }\end{array}$ & 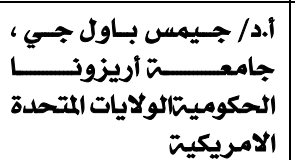 & \\
\hline 7. & $\begin{array}{l}\text { Prof. DR. jayray freeman fiene. Proffessor } \\
\text { and Dean Of College of Education } \\
\text {, California State University, San } \\
\text { Bernardino. CA } 92407-2393 \text {. (USA). }\end{array}$ & 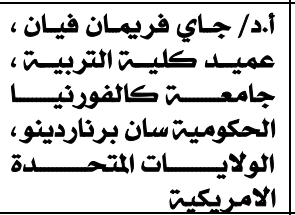 & \\
\hline 8. & $\begin{array}{l}\text { Prof. DR. John Hattie. Director of } \\
\text { Melbourne Education Research Institute, } \\
\text { Melbourne Graduate School of Education, } \\
\text { University of Melbourne, and the Associate } \\
\text { Director of the ARC-SRI: Science of } \\
\text { Learning Research Centre. }\end{array}$ & 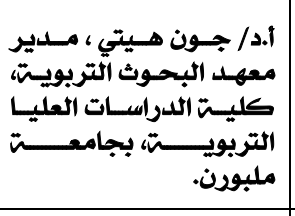 & 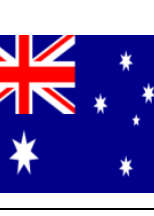 \\
\hline 9. & $\begin{array}{l}\text { Prof. DR. John Leach, Professor and Dean } \\
\text { of the Faculty of Development and Society, } \\
\text { Sheffield Hallam University. Unit 2, } \\
\text { Science Park. Sheffield S1 1WB. (UK) }\end{array}$ & 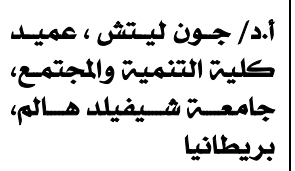 & \\
\hline
\end{tabular}




\begin{tabular}{|c|c|c|c|}
\hline $\mathbf{N}$ & Name in English & الاسم بالعربيت & Contrey \\
\hline 10. & $\begin{array}{l}\text { Prof. Dr. Lawrence H. Shirley, professor of } \\
\text { MathematicsEducation, Towson University, } \\
8000 \text { York Road. Towson,Maryland 21252- } \\
0001 .(\text { USA). }\end{array}$ & 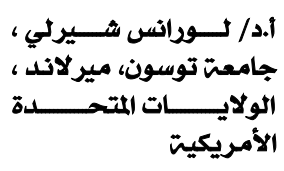 & \\
\hline 11. & $\begin{array}{l}\text { Prof. Dr. Lee Sing Kong. Director, National } \\
\text { Institute of Education, Nanyang Techno- } \\
\text { logical University, Singapore }\end{array}$ & 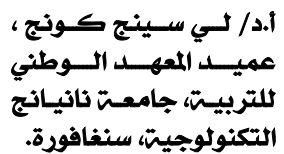 & \\
\hline 12. & $\begin{array}{l}\text { Prof. Dr. Maha Elkaisy Friemuth, } \\
\text { Department für Islamisch-Religiöse Studien } \\
\text { DIRS,praktischem Schwerpunkt, Friedrich- } \\
\text { Alexander Universität Erlangen-Nürnberg. } \\
\text { Germany }\end{array}$ & 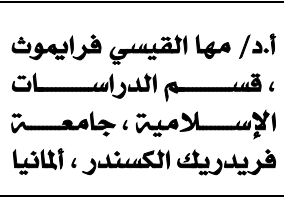 & \\
\hline 13. & $\begin{array}{l}\text { Prof. Dr. María Luisa Oliveras, Doctora } \\
\text { Senior, Catedrática acreditada y Profesora } \\
\text { Titular de la Universidad de Granada, } \\
\text { (España) }\end{array}$ & 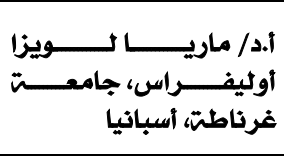 & \\
\hline 14. & $\begin{array}{l}\text { Prof. Dr. Michael Connelly, Professor } \\
\text { Emeritus, Department of Curriculum, } \\
\text { Teaching and Learning, Ontario Institute } \\
\text { for Studies in Education of the University } \\
\text { of Toronto. (Canada).Honorary Professor, } \\
\text { Southwest University, Chongqing. (China) }\end{array}$ & 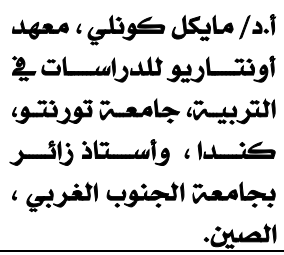 & \\
\hline 15. & $\begin{array}{l}\text { Prof. Dr. Patrick (Rick) Scott, Professor } \\
\text { Emeritus, New Mexico State University, } \\
\text { International Representative, National } \\
\text { Council of Teachers of Mathematics. (USA) }\end{array}$ & 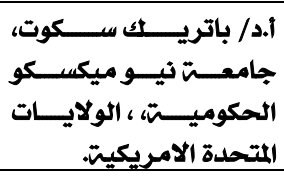 & \\
\hline 16. & $\begin{array}{l}\text { Prof. Dr. Robert Calfee, Professor Emeritus } \\
\text { on Recall, School of Education, Stanford } \\
\text { University, } 485 \text { Lasuen Mall, Stanford CA } \\
\text { 94305-3096. (USA). }\end{array}$ & 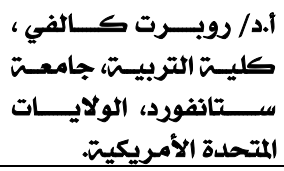 & \\
\hline 17. & $\begin{array}{l}\text { Prof. Dr. Rosemary Talab, Coordinator, } \\
\text { Educational Computing, Design and Online } \\
\text { LearningDepartment of Curriculum and } \\
\text { Instruction. } 226 \text { Bluemont Hall, Kansas } \\
\text { State University. (USA). }\end{array}$ & 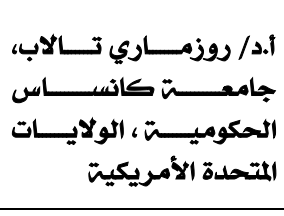 & \\
\hline 18. & $\begin{array}{l}\text { Prof. Dr. Rozhan M. Idrus, Professor of } \\
\text { Open and Distance Learning \& } \\
\text { Technogogy. School of Distance Education, } \\
\text { Universiti Sains Malaysia, } 11800 \text { USM } \\
\text {,Penang, MALAYSIA }\end{array}$ & 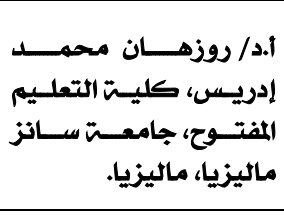 & \\
\hline
\end{tabular}




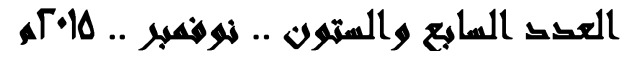

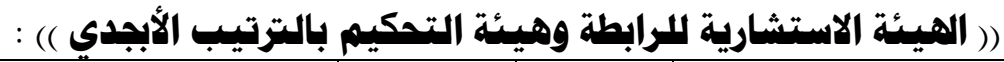

\begin{tabular}{|c|c|c|c|c|}
\hline التخصص العملمي & الباهمة & الكاية & الاستيم & $P$ \\
\hline رياض أطفال ( المناهج وبرامج الطفل) & 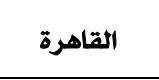 & رالاضفال & | أد// ابتهاج محمود طلبه بدوى & 1 \\
\hline مناهج (لفت عربيت) & 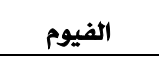 & التربيت & |ا.د/ إبراهيم محمد المتولي عطا & $r$ \\
\hline تربيت مقارنت وإدارة تعليميت & 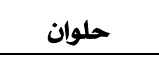 & التربيت & | أ.د/ إبراهيم عباس الزهيري & $r$ \\
\hline تربيت مقارنت وإدارة تعليميت & بنها & التربيت & | أ.د/ أحمد إبراهيم احمد & $\varepsilon$ \\
\hline مناهج ( دراسات إسلاميتة) & الأزهر & التربيت & | أ.د/ أحمد الضوي سعد & ○ \\
\hline مناهج (لفت إنجليزيت) & المنوفيت & التربيت & | أ.د/ احمد حسن سيف الدين & 7 \\
\hline مناهج (علوم بيولوجيتة) & أسيوط & التربيت & |أد/ السيد ثحاتت محمد أحمد & $v$ \\
\hline مناهج (علوم) & الزقازيق & التربيت & | أ.د/ السيد على السيد شهده & $\wedge$ \\
\hline مناهج (لفت إنجليزيت) & دمياط & التربيت & |أد/ السيد محمد السيد دمدور & 9 \\
\hline 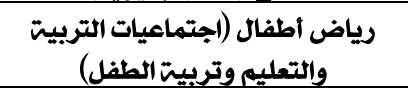 & الإسكندريت & التربيت & | ا.د/ إلهام مصطفى محمد عبيد & 1. \\
\hline الصحت النفسيت & كفر الشيخ & التربيت & أ.د/ آمال عبد السميع مليجى باظت & 11 \\
\hline أصول التربيت & 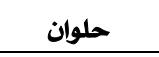 & التربيت & | أ.د/ إميل فهمي حنا ثنودة & ir \\
\hline الصحت النفسيت & الززقازيق & التربيت & | أ.د/ ايمان فؤاد محمد كاثف & ir \\
\hline تربيت مقارنت وإدارة تعليميت & ق ق ق اة السويس & التربيت & | أدد/ بيومى محمد ضحاوى على & $1 \varepsilon$ \\
\hline التربيت الموسيقيت & 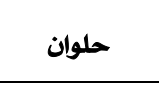 & الموسيقيت & | أ.د/ جلال الدين صالح احمد & 10 \\
\hline أصول التربيت & المنوفيت & التربيت & | أ.د/ جمال على خليل الدهشان & 17 \\
\hline تربيت مقارنت وإدارة تعليميت & بنها & التربيت & | أ.د/ جمال محمد محمد ابو الوفا & IV \\
\hline مناهج (رياضيات) & أسيوط & التربيت & | أ.د/ جمال محمد فكري & M \\
\hline المناهج وطرق التدريس (علوم) & 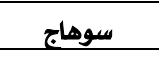 & التربيت & أ.د/ حسام الدين محمد مازن & 19 \\
\hline علم النفس التربوي & المنوفيت & التربيت & | أ.د/ حمدي على أحمد الفرماوي & r. \\
\hline مناهج (فرنسي) & عين شمس & التربيت & | أ.د/ حنان محمد حافظ & r \\
\hline أصول الترييت & بور سعيد & التربيت & | أ.د/ راشد صبري محمود القصبي & rr \\
\hline مناهج ( علوم) & 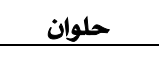 & التربيت & | ا. د / رجب السيد الميهي & rr \\
\hline تكنولوجيا تعليم & 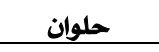 & التربيت & | أ.د/ رضا عبده القاضي & $r \varepsilon$ \\
\hline مناهج (رياضيات) & دمياط & التربيت & | 1. & ro \\
\hline مناهج (علوم) & دمياط & التربيت & |أ.د/ رمضان عبد الحميد الطنطاوي & ry \\
\hline تكنولوجيا التعليم & 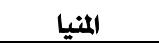 & التربيت & | أ.د/ زينب محمد أمين & $r v$ \\
\hline تربيت خاصت & طنطا & التربيت & | ا ـ د / زينب محمود ثقير & rA \\
\hline اصول التربيت & 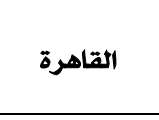 & البحريت & 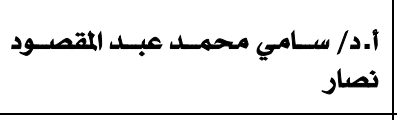 & rq \\
\hline تربيت مقارنت وإدارة تعليميت & عين ثمس & التربيت & | أ.د/ سعاد بسيونى محمد عياد & $r$. \\
\hline
\end{tabular}




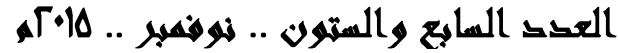

\begin{tabular}{|c|c|c|c|c|}
\hline مناهج ( فلسفت) & عين ثمس & 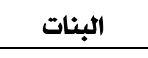 & | ا ـ د / سعاد محمد فتحي & m \\
\hline مناهج (تجاري) & الإسماعيليت & التربيت & ا أ ـ د / سعد أحمد الجبالي & rr \\
\hline اصول التربيت & مين شمس & التربيت & ا ا. د/ سعيد إسماعيل علي & rr \\
\hline علم النفس (قياس نفسي وإحصاء) & بني سويف & التربيت & | أد/ سليمان محمد سليمان & $r \varepsilon$ \\
\hline رياض أطفال (مناهج وطرق تعليم الطفل ) & ا ل المنصورة & رياض الأفال & | أ.د/ سميت عبد الحميد أحمد & ro \\
\hline علم النفس & عين شمس & 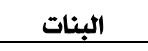 & أ.د/ سناء محمد سليمان عبد العليم & r \\
\hline تربيت مقارنت وإدارة تعليميت & 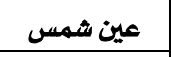 & التربيت & أ.د/ ثاكر محمد فتحي أحمد & $r v$ \\
\hline مناهج (تجاري) & عين شمس & التربيت & | 1 ـ / صابر حسين محمود & rA \\
\hline أصول تربيت & بنها & التربيت & أ أد / صلاح الدين محمد توفيق & rq \\
\hline مناهج ( تربيت فنيتً) & 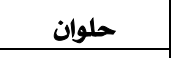 & التربيت & أ.د/ صلاح الدين محمد خضر & \&. \\
\hline الرياضت المدرسيتة & 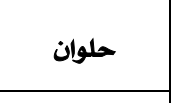 & رياضيت بنين & أ.د/ ضياء الدين محمد أحمد العزب & \&) \\
\hline تخطيط تربوي & عين ثمس & تربيت & ا . د / ضياء الدين عبد الشكور زاهر & $\varepsilon r$ \\
\hline اصول التربيت & عين ثمس & التربيت & أ.د/ طلعت عبدالحميد فايق حسن & $\varepsilon r$ \\
\hline مناهج (علوم) & المنوفيت & التربيت & أ.د/ عادل ابو العز أحمد سلامه & $\varepsilon \varepsilon$ \\
\hline تكنولوجيا التعليم & ق قناة السويس & التربيت & ا ا.د/ عادل السيد سرايا & £o \\
\hline تربيت مقارنت وإدارة تعليميت & عين ثمس & التربيت & أ.د/ عادل عبد الفتاح سلامة & $\varepsilon 7$ \\
\hline الصحت النفسيت & 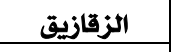 & التربيت & أ.د/ عادل عبدالله محمد محمد & $\varepsilon v$ \\
\hline أصول التربيت & المنيا - ايا & التربيت & | أ.د/ عازةمحمدأحمدسلام & $\varepsilon \wedge$ \\
\hline مناهج (لفت إنجليزيت) & 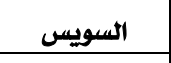 & التربيت & أ.د/ عبد السلام عبد الخالق الكومى & $\varepsilon 9$ \\
\hline مناهج (رياضيات) & الاززهر & التربيت & أ.د/ عبد العزيز محمد عبد العزيز & o. \\
\hline 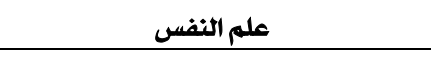 & الززقازيق & الآداب & أ.د/ عبد الله السيد أحمد عسكر & 01 \\
\hline مناهج (تربيت بيئيت) & 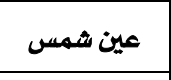 & معهد الدراسات & |أد/ عبد المسيح سمعان عبد المسيح & or \\
\hline مناهج (علوم) & الوادي الجديد & التربيت & أ.د/ عبد المنعم محمد حساثين & or \\
\hline علم النفس التعليمي & طنطا & التربيت & | أد/ عبد الوهاب محمد كامل السيد & o\& \\
\hline تربيت مقارنت وإدارة تعليميت & كفر الشيخ & التربيت & أ.د/ عبد الجواد السيد سعد بكر & \$0 \\
\hline مناهج ( فلسفترواجتماع) & طنطا & التربيت & | 1 . د / عفاف سعد حماد & or \\
\hline مناهج (علوم) & دمياط & التربيت & أ.د / عفت مصطفى مسعد الطناوي & or \\
\hline مناهج ( دراسات اجتماعيت) & عين ثمس & التربيت & ا 1 ـ د / على أحمد الجمل & $0 \wedge$ \\
\hline مناهج (دراسات اجتماعيت) & بنها & التربيت & أ.د/ على جودة محمد عبد الوهاب & $\Delta 9$ \\
\hline علم النفس التربوي & 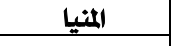 & التربيت & أ.د/ على حسين على بدارى & 7. \\
\hline اصول التربيت & دمياط & التربيت & | أ.د/ على صالح جوهر & $\pi$ \\
\hline مناهج (لغت إنجليزيت) & المنصورة & التربيت & أ.د/ على عبد السميع محمد قورة & $\pi$ \\
\hline مناهج (علوم بيولوجيت) & المنصورة & التربيت & أ.د/ فاديت ديمتري يوسف بغدادي & ir \\
\hline
\end{tabular}




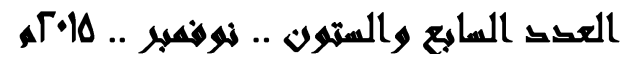

\begin{tabular}{|c|c|c|c|c|}
\hline 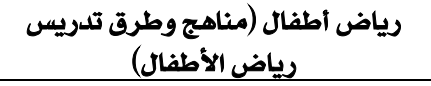 & 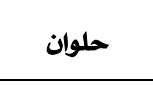 & التربيت & | أدد/فرماوى محمد فرماوى عمر & $7 \varepsilon$ \\
\hline مناهج ( فرنسي) & 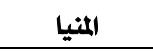 & التربيت & | أ. د / لوسيل برسوم سلامتة & 70 \\
\hline مناهج (علوم) & الإسكندرية & التربيت & | أ.د/ ماجدة حبشي محمد سليمان & $\pi$ \\
\hline مناهج ( تربيت فنيتة) & حلوان & التربيت & | أ. د / ماجدة مصطفى السيد & TV \\
\hline مناهج وطرق تعليم الطفل & الإسكندريت & 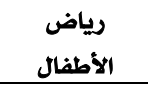 & | أ.د/ ماجدة محمود محمد صالح & $u$ \\
\hline مناهج (علوم) & بنها & التربيت & | أ.د/ ماهر إسماعيل صبري & 79 \\
\hline أصول التربيت & المنصورة & التربيت & | أد/مجدى صلاح طه المهدى & v. \\
\hline ملم النفس التعليمي & طنطا & التربيت & | أد/ مجلدي عبد الكريم حبيب & n \\
\hline أصول التربيت & كفر الشيخ & التربيت & أ.د/ محمد إبراهيم إبراهيم المنوفى & vr \\
\hline أصول التربيت & المنصورة & التربيت & | أ.د/محمد إبراهيم عطوه مجاهد & $v_{r}$ \\
\hline صحت نفسيت وتربيت خاصت & الزقازيق & التربيت & |أدد/ محمد السيد عبد الرحمن & v\& \\
\hline التدريب الرياضي & طنطا & تربيت رياضيت & | ا.دد/ محمد جابر احمد بريقع & vo \\
\hline الصحتَ النفسيت & طنطا & التربيت & أ.د/ محمد عبد الظاهر الطيب & vi \\
\hline الإدارة الرياضيت & الإسكندريت & تربيترياضيت & | أ.د/محمد عبد العزيز احمدد سلامة & v \\
\hline مناهج (رياضيات) & 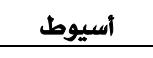 & التربيت & | أ.د/ محمود محمدحسن عوض & vA \\
\hline مناهج (رياضيات) & بني سويف & التربيت & | أ.د/ مديحت حسن محمد & va \\
\hline التربيت الفنيت & 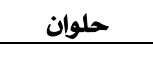 & تربيت فنيت & | أ.د/ مصطفى محمد عبد العزيز & A. \\
\hline رياض اطفال (مناهج التربيت الحركيت & 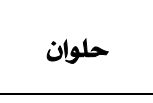 & التربيت & | أ.د/ مني أحمد الازهري & $\wedge 1$ \\
\hline أصول التربيت والتخطيط التربوي & المنصورة & التربيت & | أ.د/ مهنى محمد إبراهيم غنايم & Ar \\
\hline علم النفس المعري2 & الإسكندريت & التربيت & أ.د/ ناجى محمد قاسم الدمنهورى & Ar \\
\hline رياض أطفال (علمنفسالطفل) & القاهرة القاه & معهد البحوث & | أد// ناديت محمود صالح شريف & $\wedge \varepsilon$ \\
\hline أصول التربيت & عين شمس & 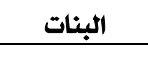 & |أد/ناديت يوسف كمال & ^ै0 \\
\hline تكنولوجيا التعليم & حلوان & التربيت & | أد/ نبيل جاد عزمي & Aт \\
\hline تربيت مقارنت وإدارة تعليميت & 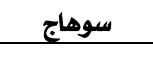 & التربيت & | أ.د/ نبيل سعد خليل جرجس & $\wedge \vee$ \\
\hline 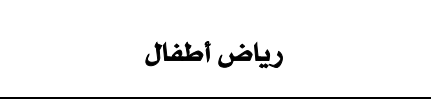 & بور سعيد & رياض & | أ.د/ هدى محمد قناوى & $\wedge \wedge$ \\
\hline رياض أطفال (علم ثفس طفولة) & 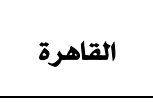 & الأطفال & | أ.د/ وفاء محمد كمال عبد الخالق & $\wedge 9$ \\
\hline مناهج ( دراسات اجتماعيت) & عين ثمس & التربيت & | أ. ـ / يحي عطيت سليمان & a. \\
\hline
\end{tabular}




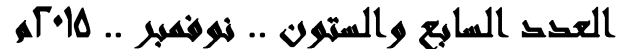

\section{همتوبات الهدد (TV):}

|الصفحات

بحوث ودراسات محكمتة :

P

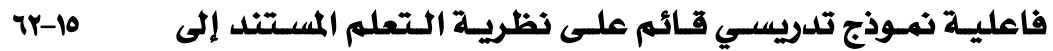

اللدماغ يخ اكتساب المفاهيي الفيزيائية وبقاء أثر التعلم وتنمية

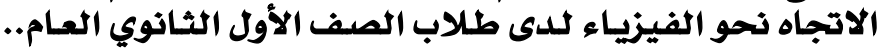

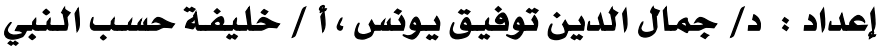
عبد الفتاح على.

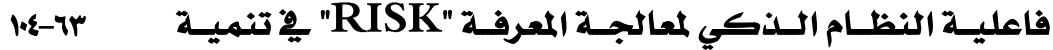

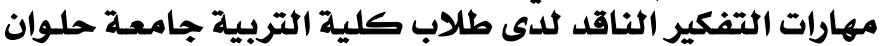

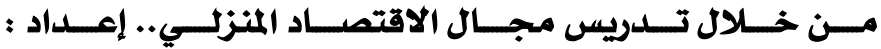
د/ أمانى عبد الوهاب منتصدر.

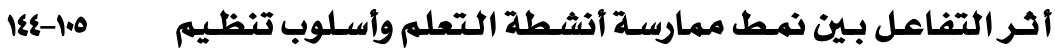

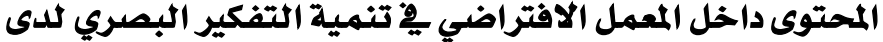

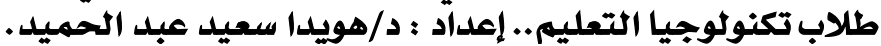

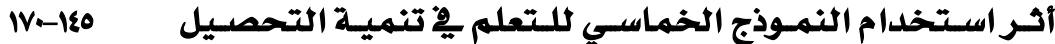

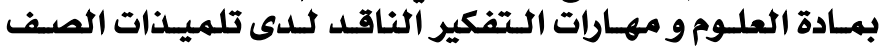

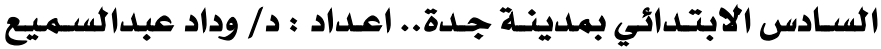
إسماعيل نورالدين.

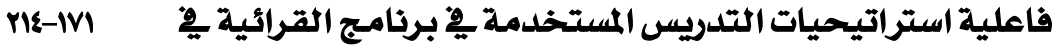

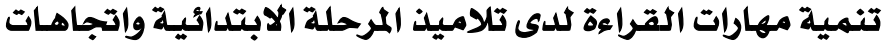

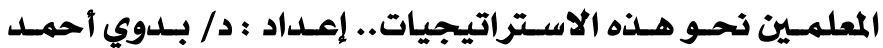
محمدل الطيب.

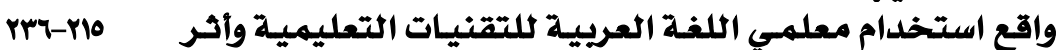

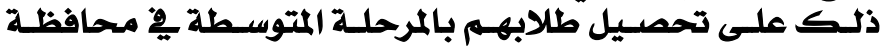

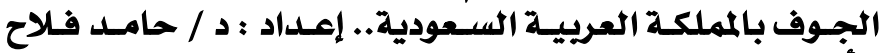

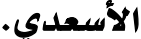

الاحتياجات التدريبيه الازمة لتحسين الأداء الوظيفى لمشرفات

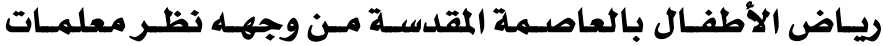

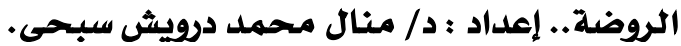

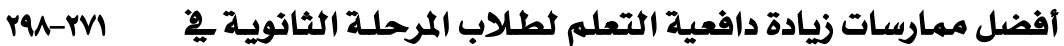

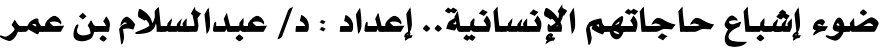
الثناجى.

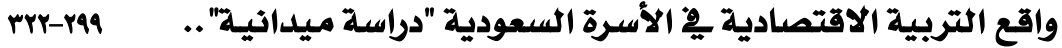

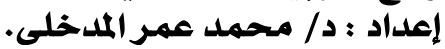

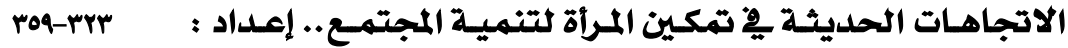
د/ أميرة عبدالسالام زايل. 


\section{تمريف بالمبلة :

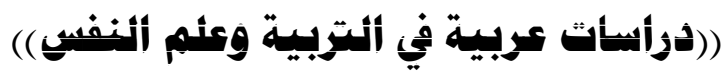

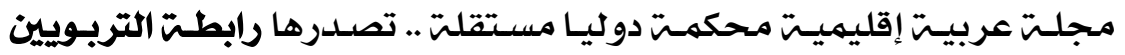

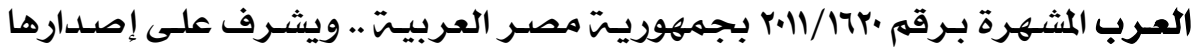

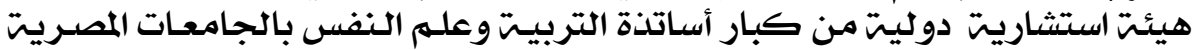

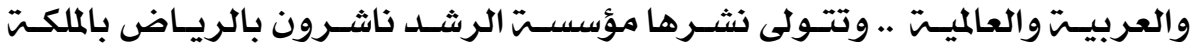

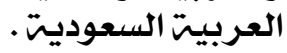

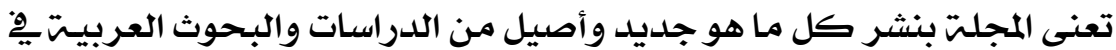

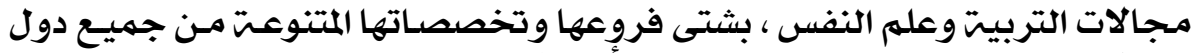

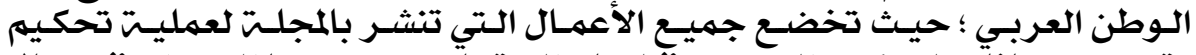

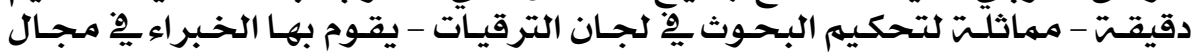
كل دراست.

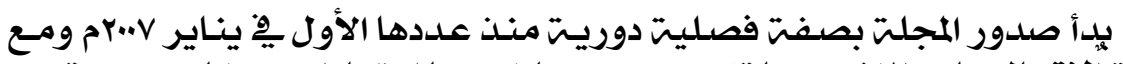

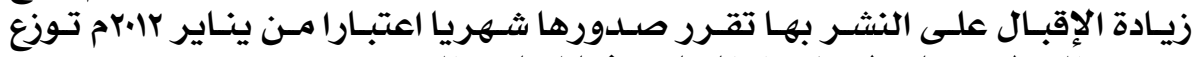

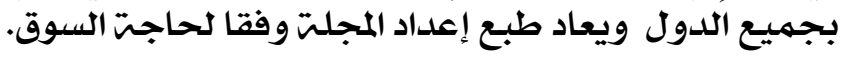

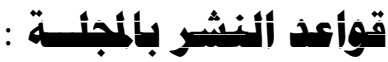

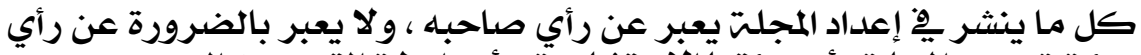

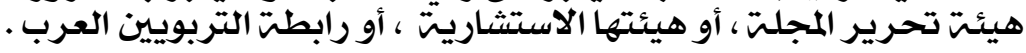

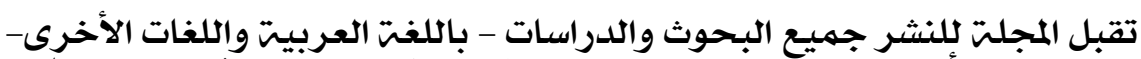

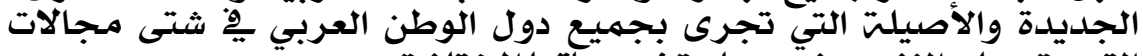

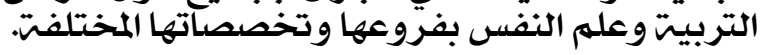

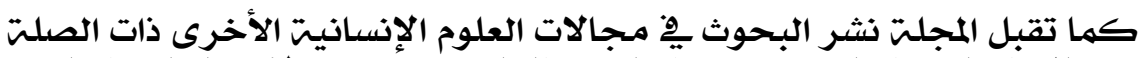

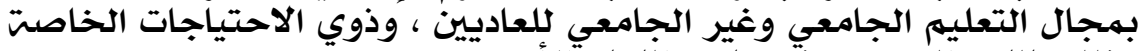

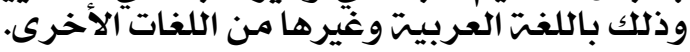

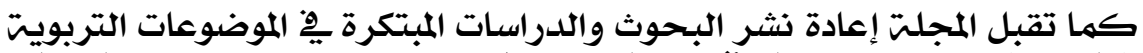

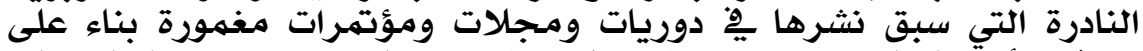

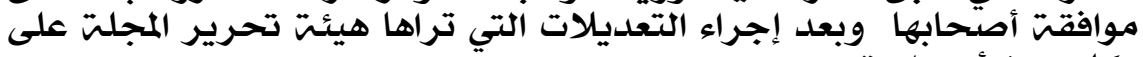
كل بحث أو دراستة.

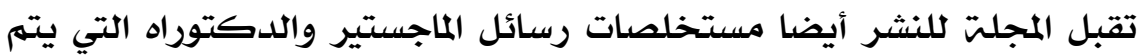

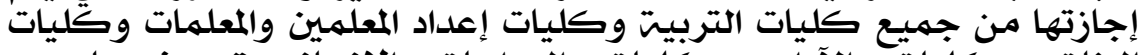

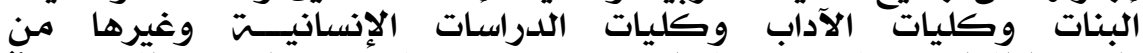

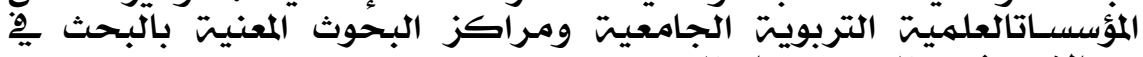

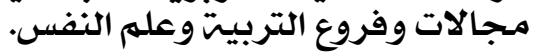

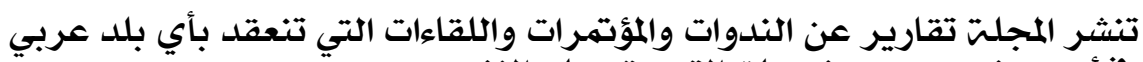
4 41 11 4 هُ أي موضوع من موضوعات التربيت وعلهم النفس. 


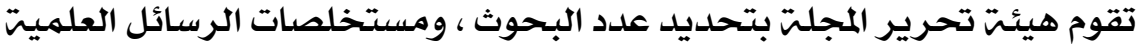

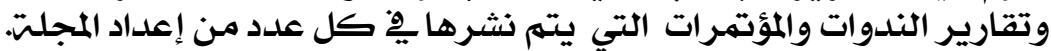

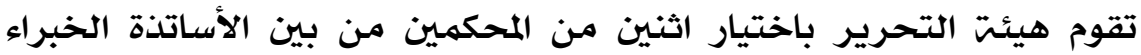
4

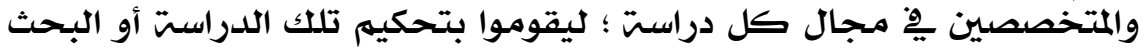

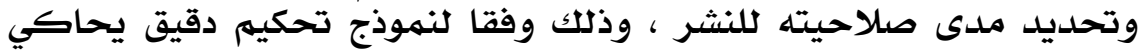

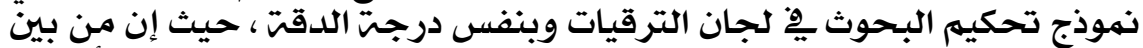

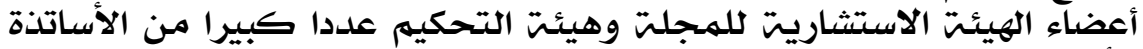

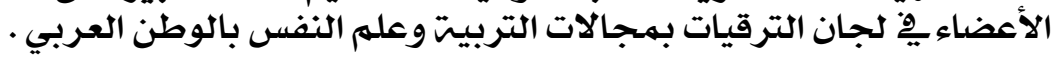

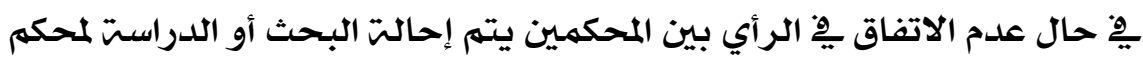

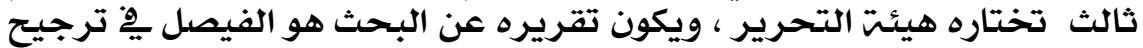

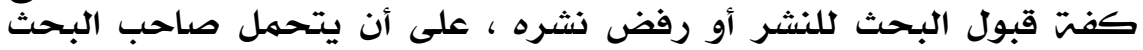
مصروفات التحكيهم.

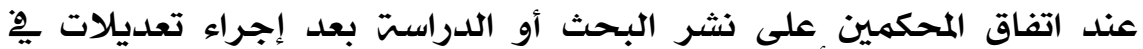

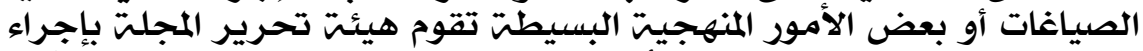

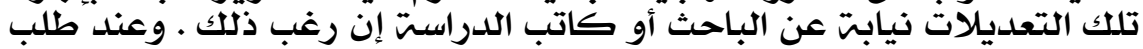

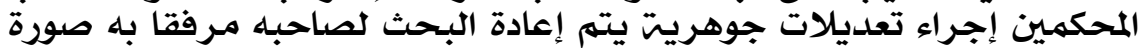

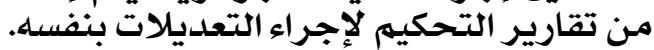

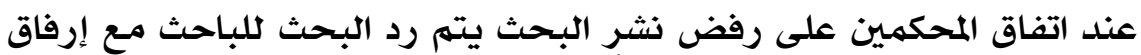

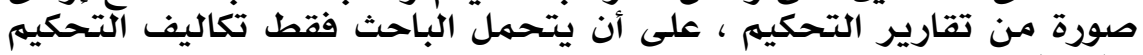
والمراسلت:

يتهم عرض جميع المواد المقبولت للنشر بالمجلتة على المستشار اللغوي لمراجعتها

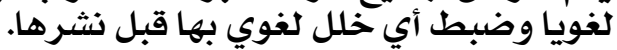

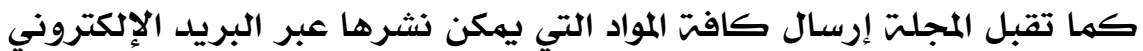

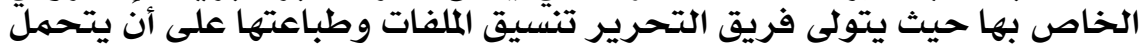

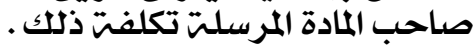

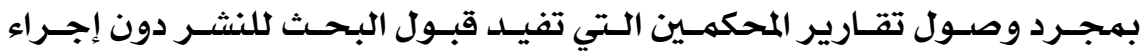

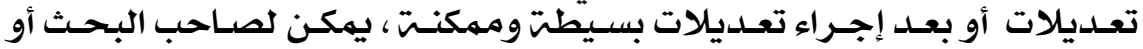

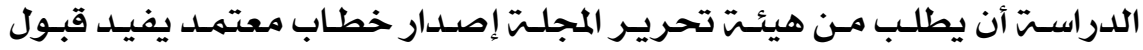

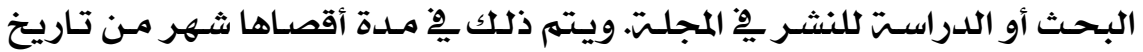

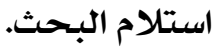

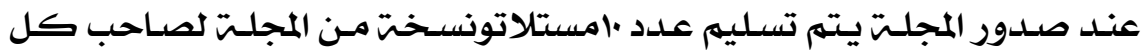

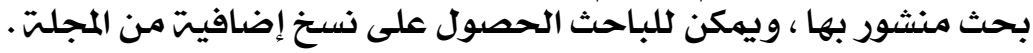

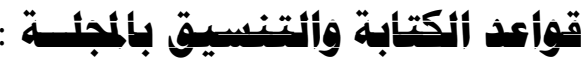

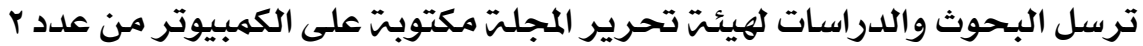

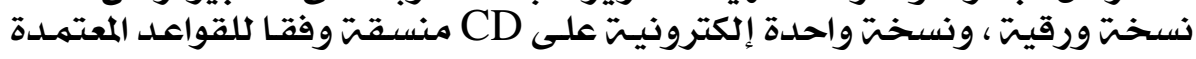

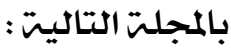

\section{9}




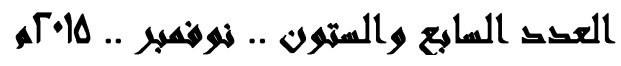

14 تتمر كتابت البحث وفق قالب التنسيق الخاص بالمجلت ( يطلب من هيئت

4 كتابت متن البحث بخط AL-Mohanad Bold مقاس ع ع المسافت مفردة بين

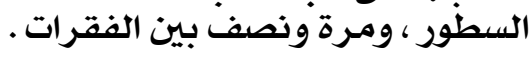

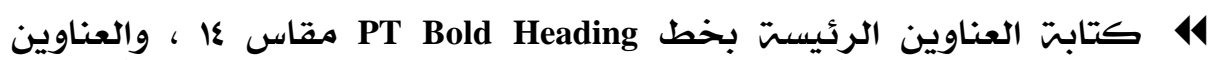

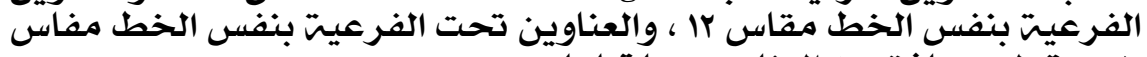

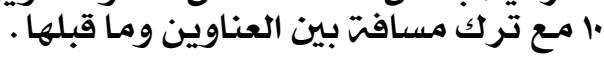

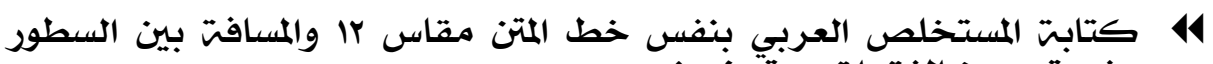

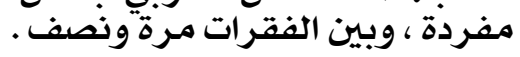

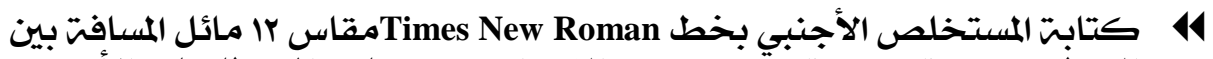

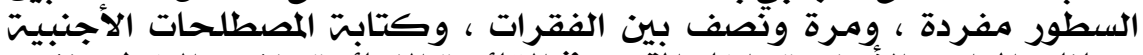

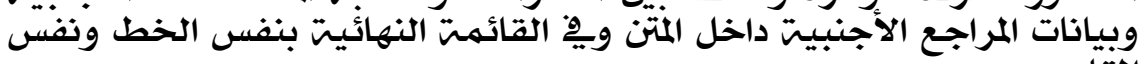

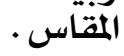

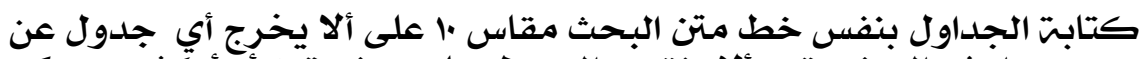

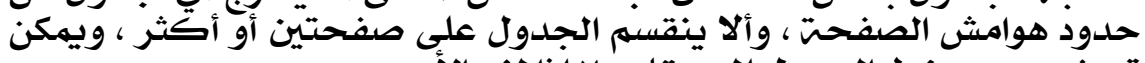

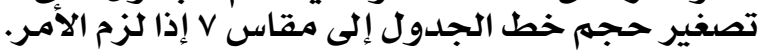

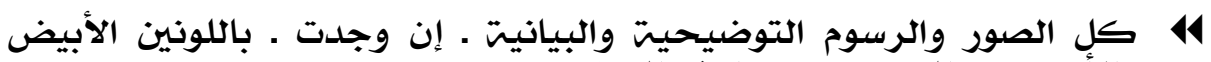

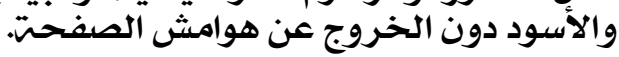

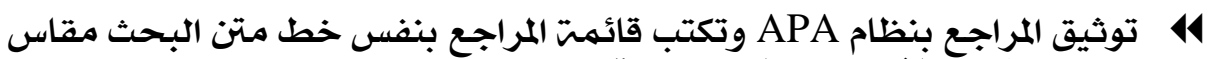

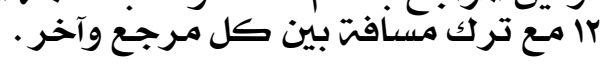

\section{:}

ترسل جميع مراسلات المجلتَ باسم رئيس التحرير ملى العنوان التالي :

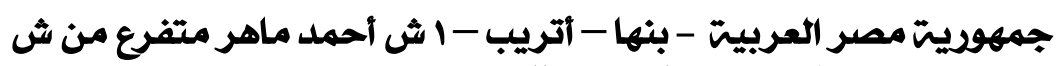

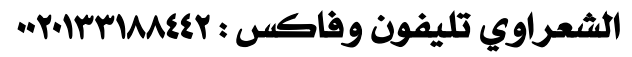

أو المراسلت عبر البريد الإلكتروني لرئيس التحرير

mahersabry2121@yahoo.com:

أو عبر البريد الإلكتروني للمدير الإداري للرابطتة :

Safaasultan25@hotmail.com

متابعت أخبار المجلت وقواعد النشر على موقعها الإلكتروني بجوجل على الرابط :

http://aae999.blogspot.com

أو على الموقع الإلكتروني لرابطت التربويين العرب :

http://www.aaeducators.org

\section{1.}




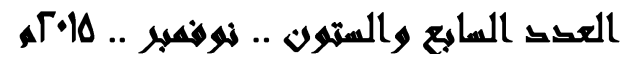

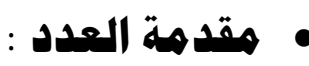

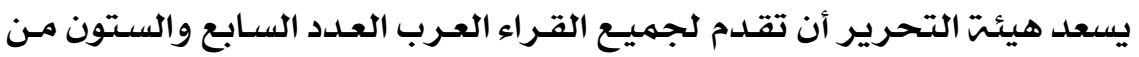

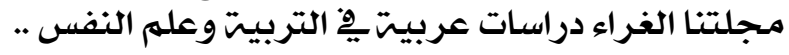

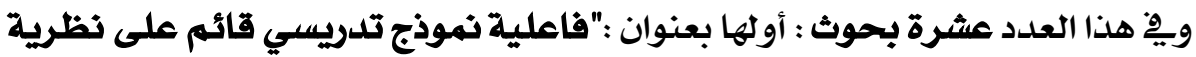

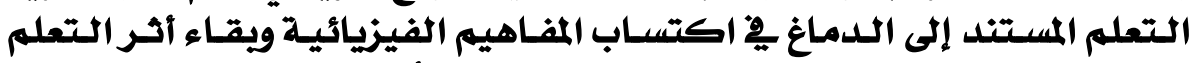

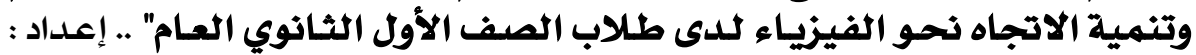

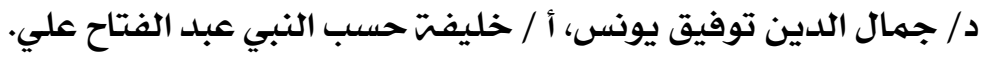

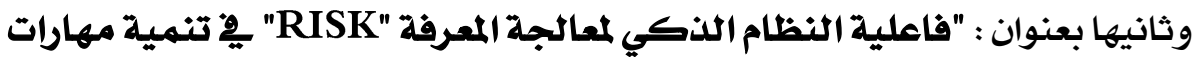

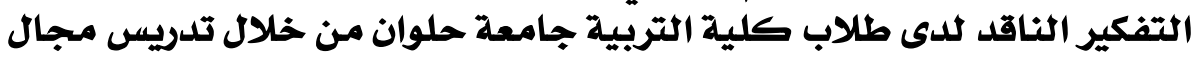

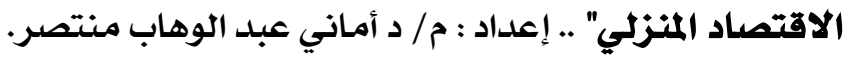

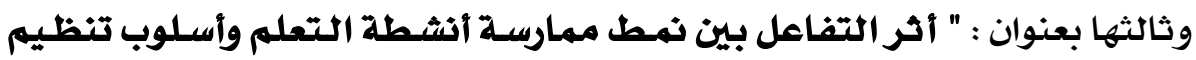

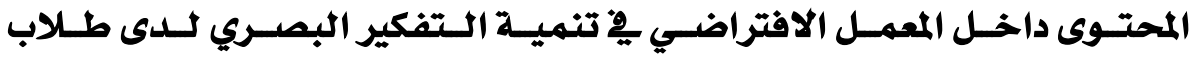

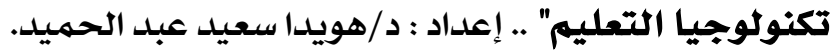

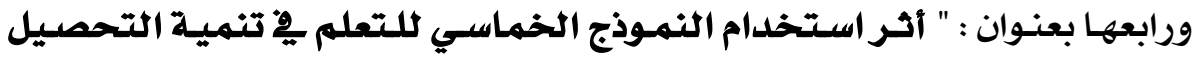

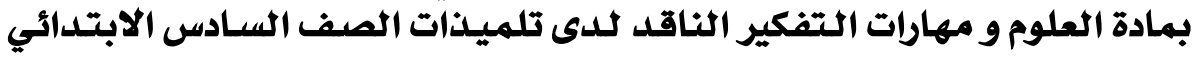

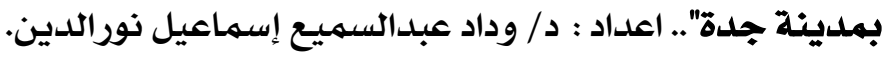

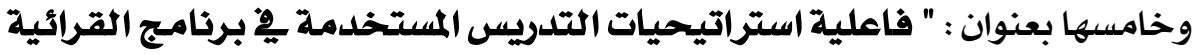

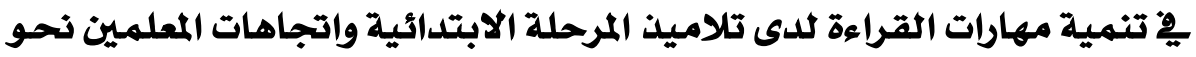

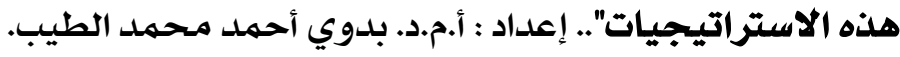

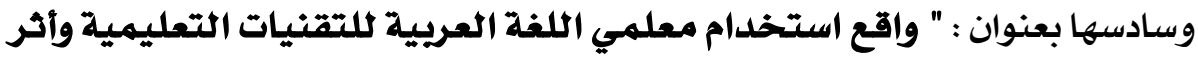

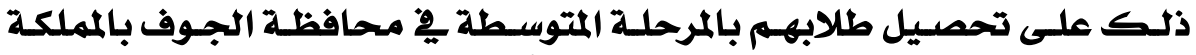

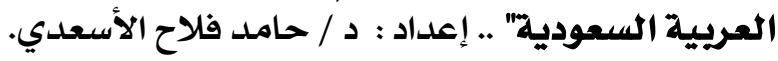

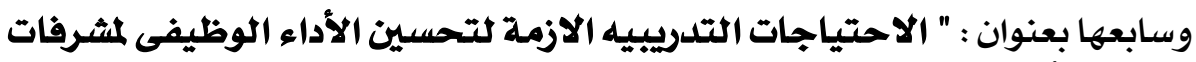

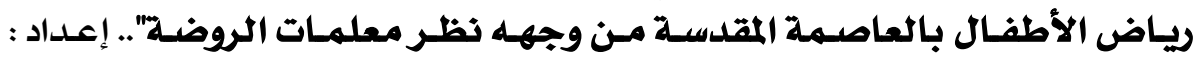

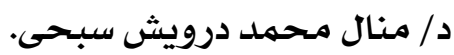

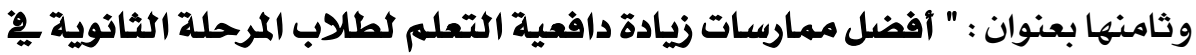

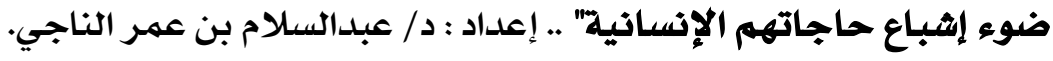

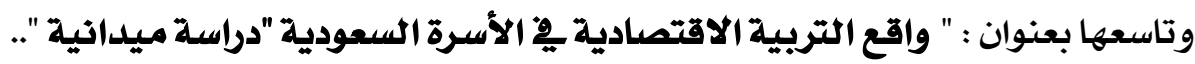

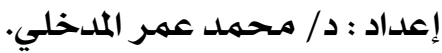

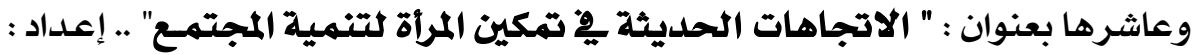
د/ أميرة عبدالسيلام زايل. بعدوان.

\section{1}




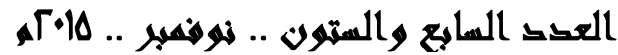

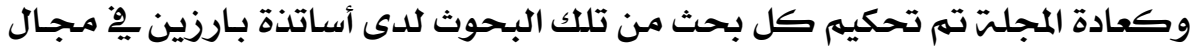

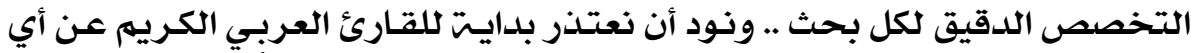

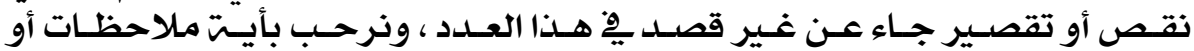

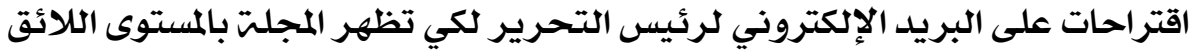

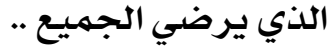

والله أسأل التوفيق والسداد وآخر دعوانا أن الحمد لله رب العالمين ،،؛

رئيس تحرير المجلت 


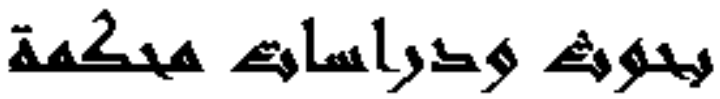





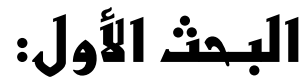

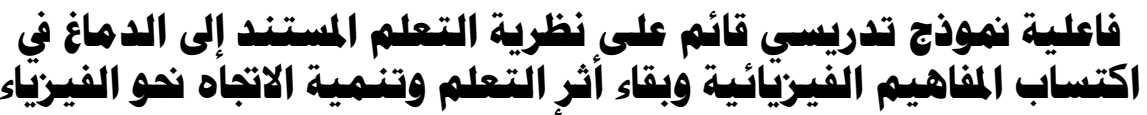

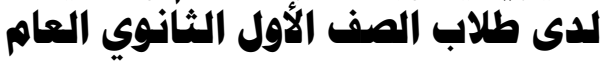

: إلطاك

أ / خليفت حسب النبي عبد الفتاح

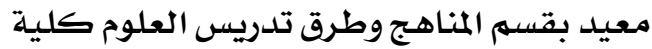

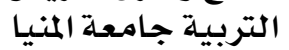

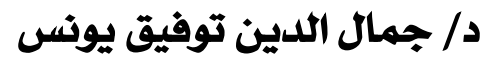

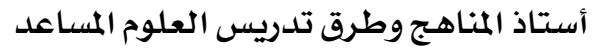
كلية التربية جامعة تلميس المنيا 



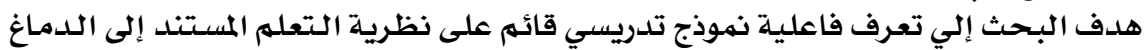

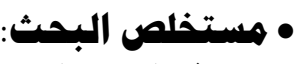

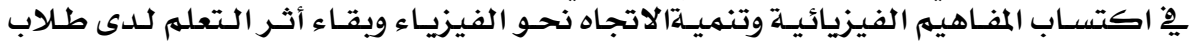

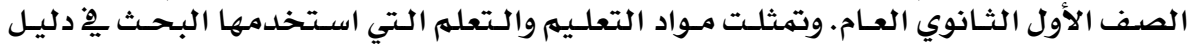

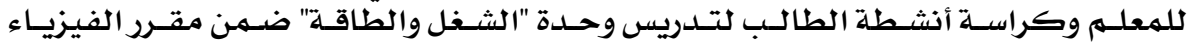

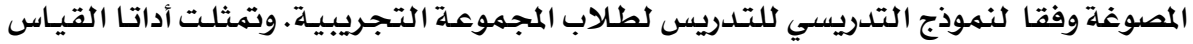

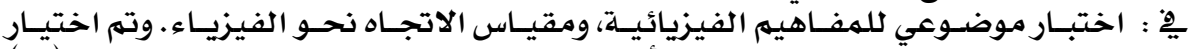

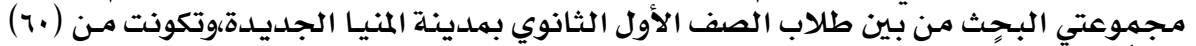

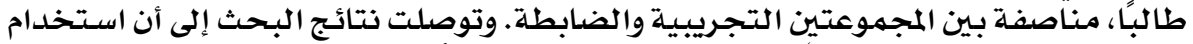

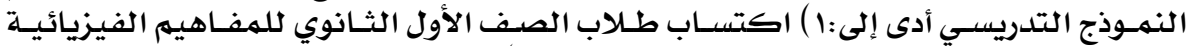

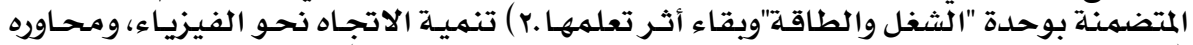

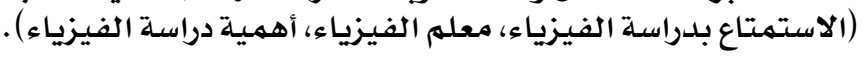

The Effectiveness of a Brain-Based Teaching Model on the Acquisition of Physical Concepts and the Development of Attitudes towards Physics and Maintaining the Effect of Learning of 1st Year High School Students

Abstract:

The present study aims at acquainting the reader with the effectiveness of a suggested brain-based teaching model on the acquisition of concepts within physics and on the development of students' attitudes toward physics and the maintenance of the effect of their learning.The investigator has used the teacher's guide and the activity notebook of the students as tools of the study. The unit of "Work and Energy" has been especially selected to be taught to the students (the sample of the study). The unit has been taught to the experimental group in the light of the teaching model proposed by the researcher. The measurement tools have been designed to test the concepts of physics under study and to measure the attitudes towards physics. Sixty high school students have been randomly selected from one of the schools at the New Minia region. The 66 students have been randomly divided into two equal groups to represent both the control and the experimental groups of the study.1-The teaching model designed and adopted by the researcher has been of a great support to help 1st year high school students: a- acquire the required concepts of 
physics under investigation particularly included in the unit of "Work \& Energy", and to maintain the learning effect of these concepts.bdevelop the attitudes towards physics with respect to enjoying learning physics, the attitudes toward the teachers of physics, and the study of physics as a significant subject.

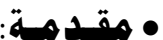

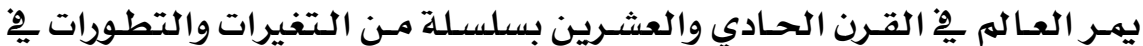

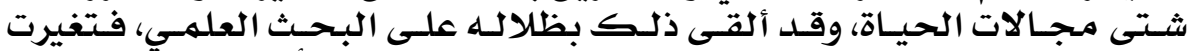

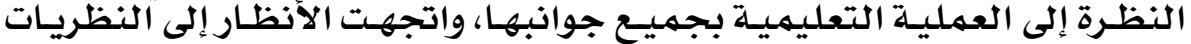

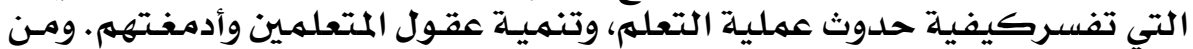

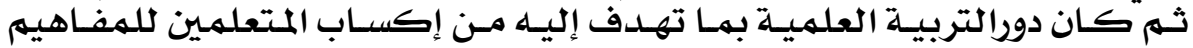

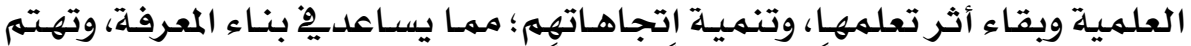

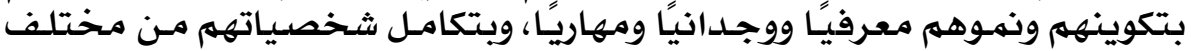
الجوانب.

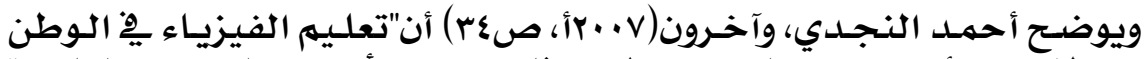

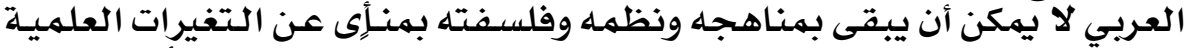

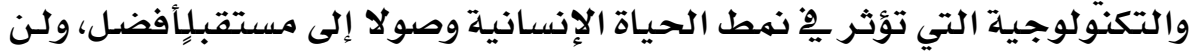

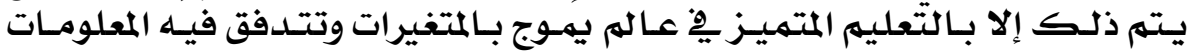

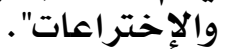

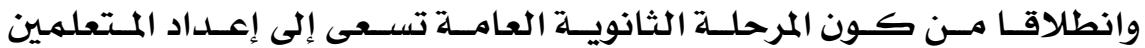

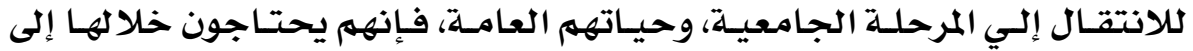

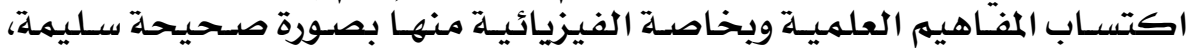

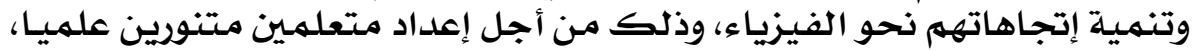

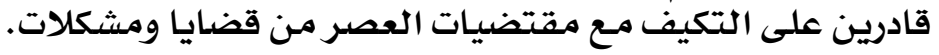

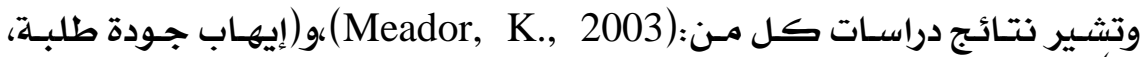

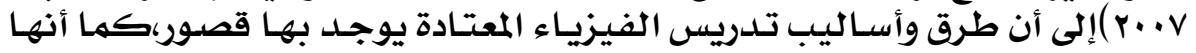

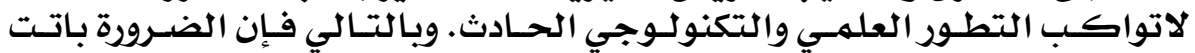

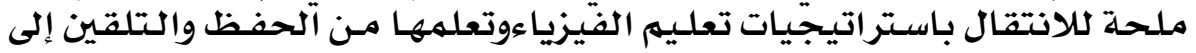

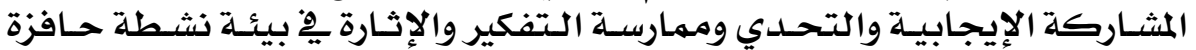

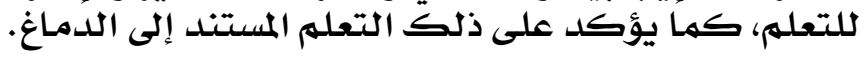

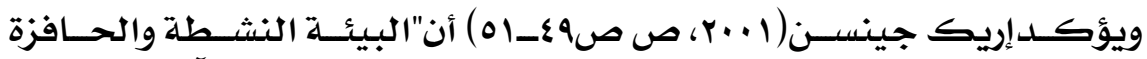

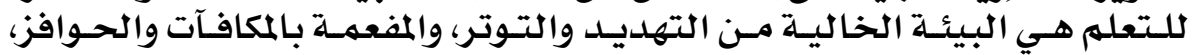

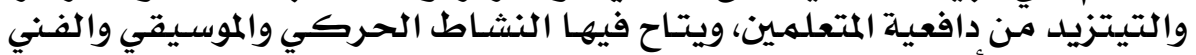

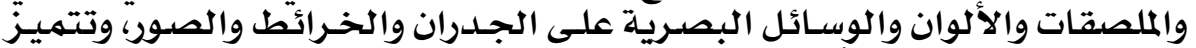

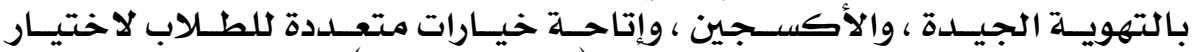

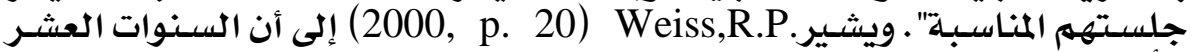

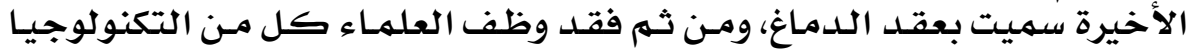




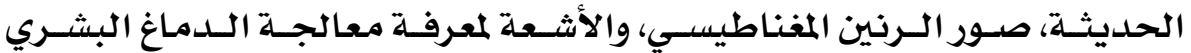

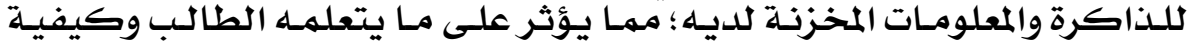
حلدوث عملية التعلهم. تلمعات

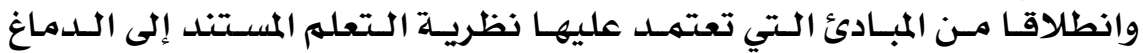

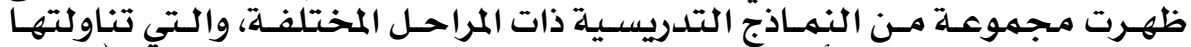

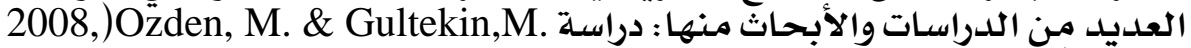

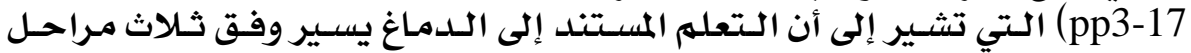
كالتالي:

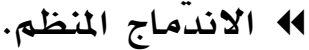
14 اليقظة الهادئة. 14 المعالجة النشطة النشئ.

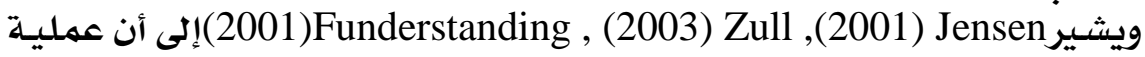

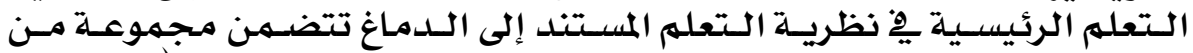

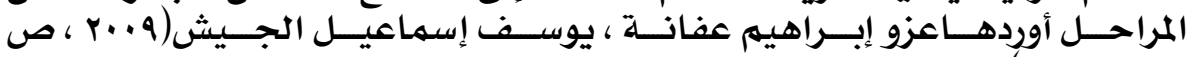

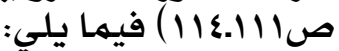

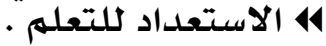

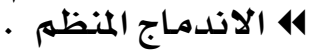

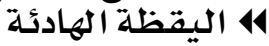

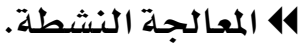

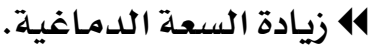

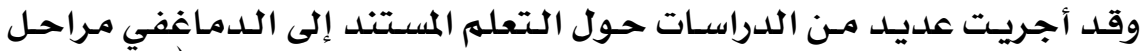

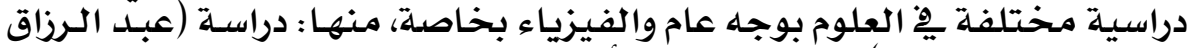

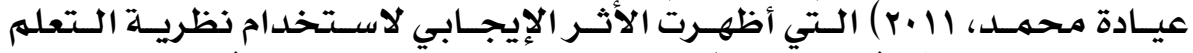

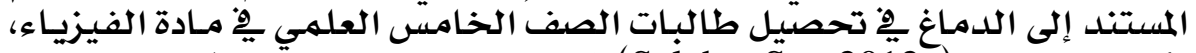

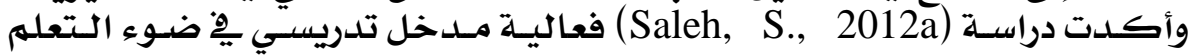

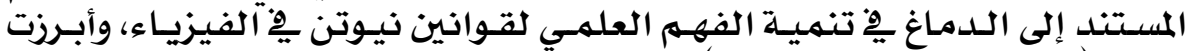

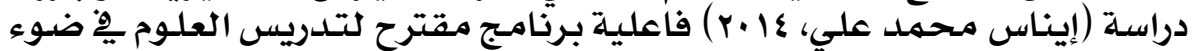

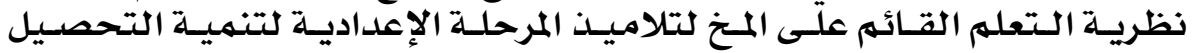
ومهارات التفكير الإبداعي.

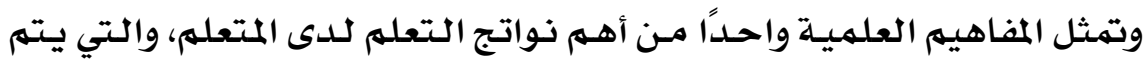

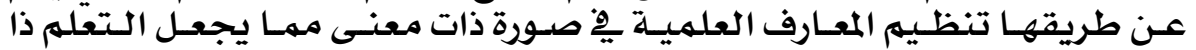

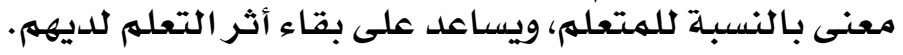

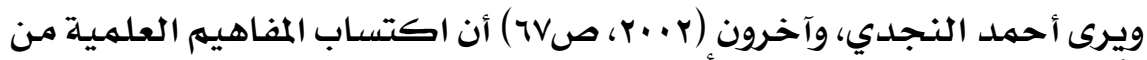

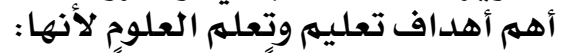

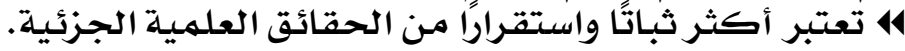
414 تسهل دراسة البيئة.

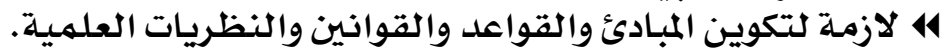

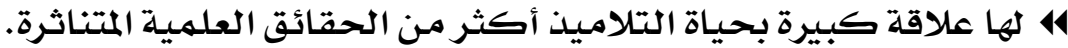

\section{9}




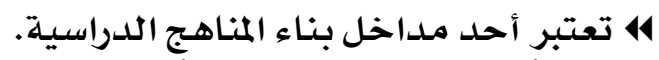

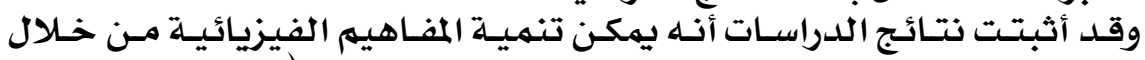

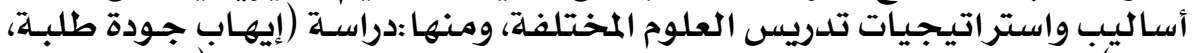

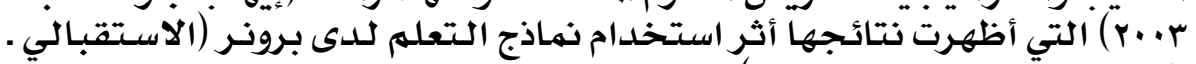

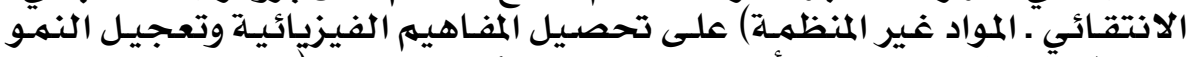

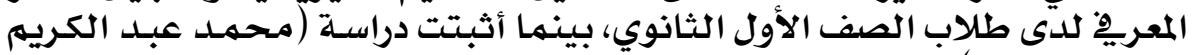

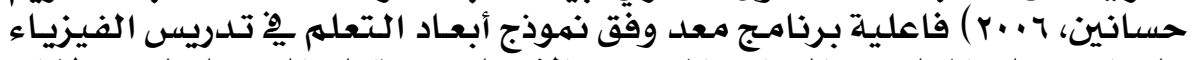

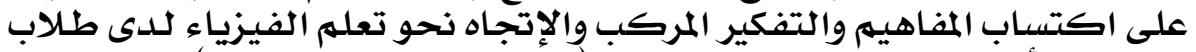

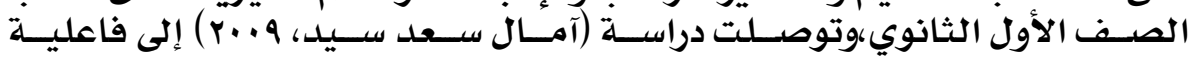

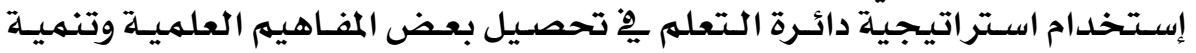

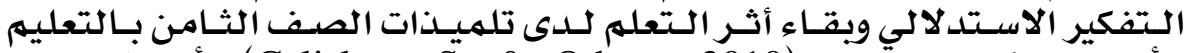

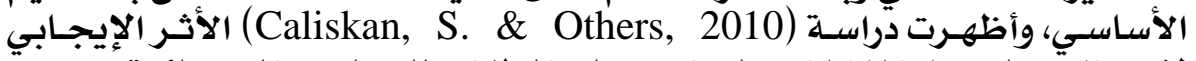

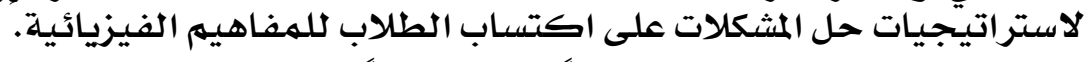

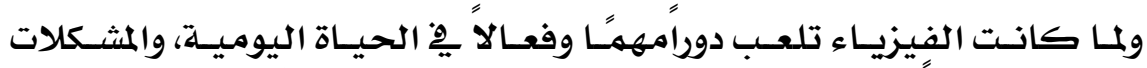

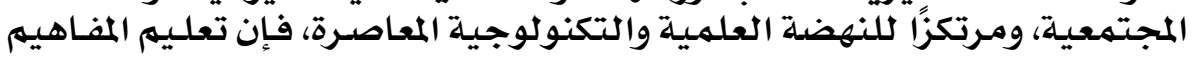

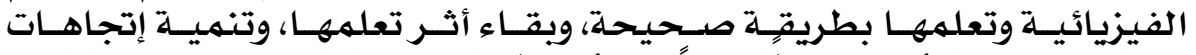

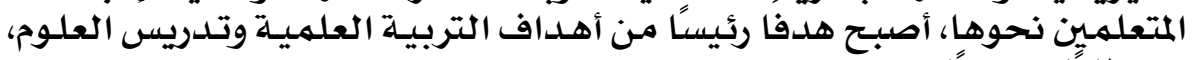

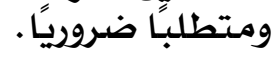

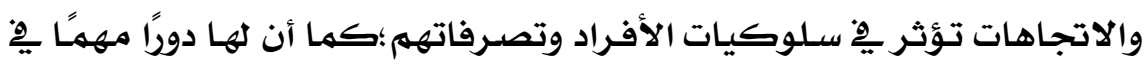

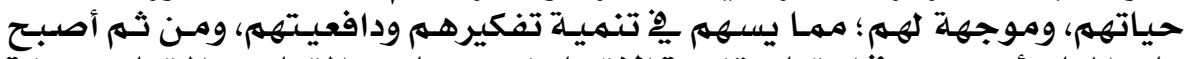

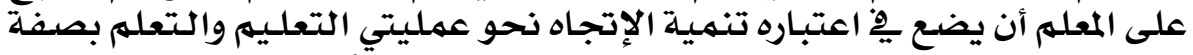

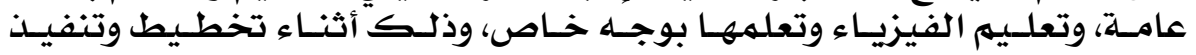
التدربس.

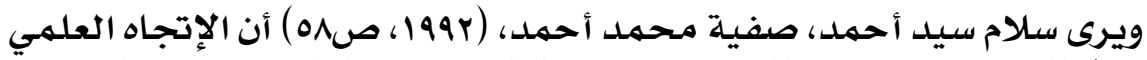

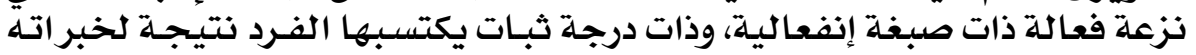

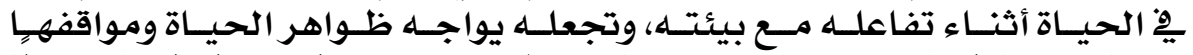

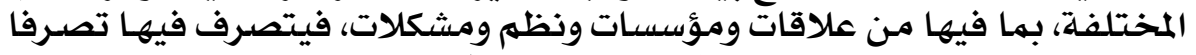

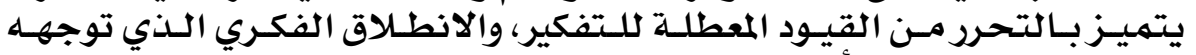

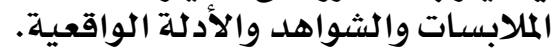

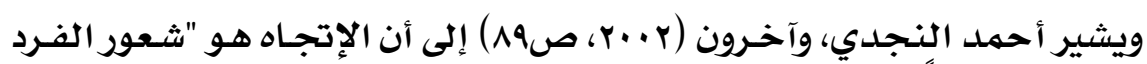

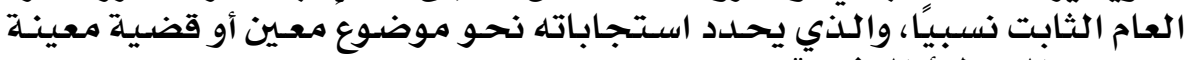

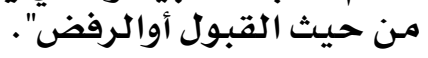

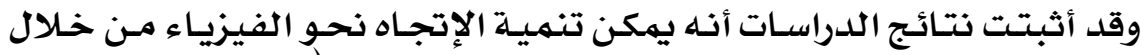

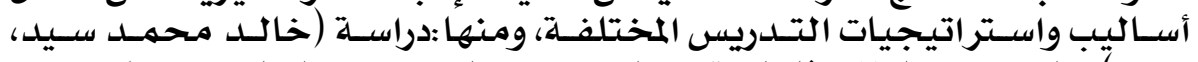

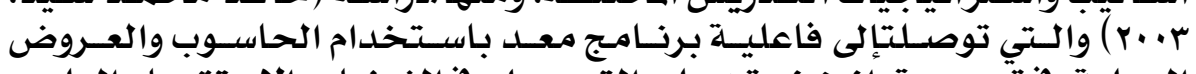

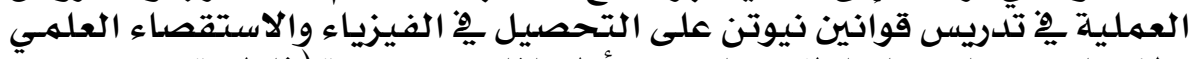

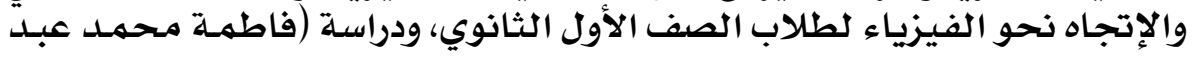




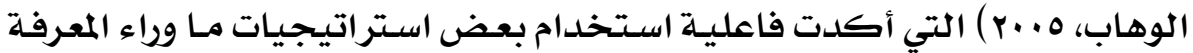

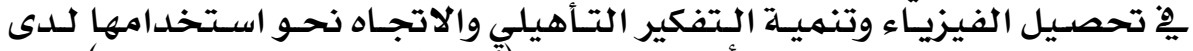

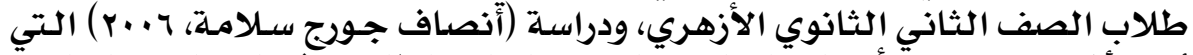

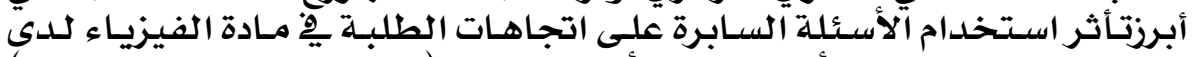

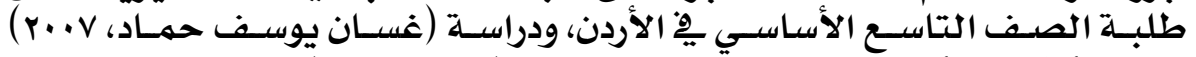

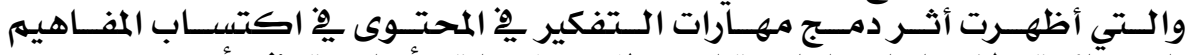

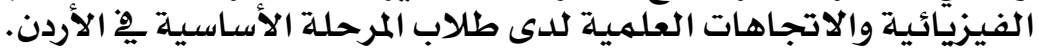

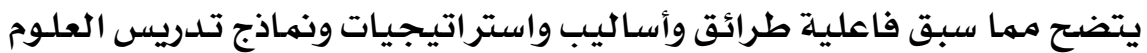

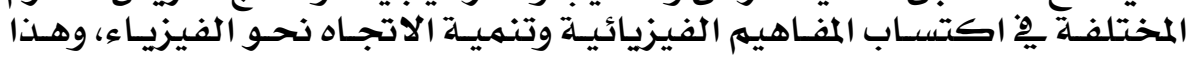

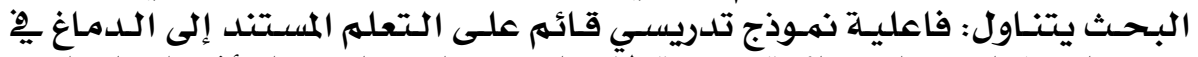

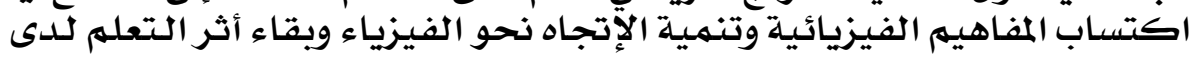
طلاب المرحلة الثانوية المابية العـامـة. • الإحساس بالمشكلة وتمديدها:

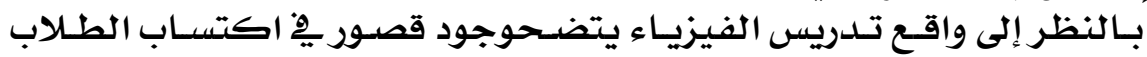

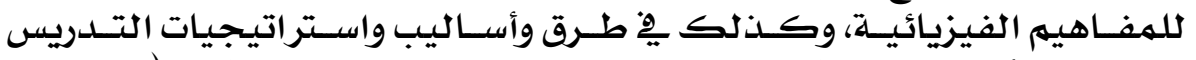

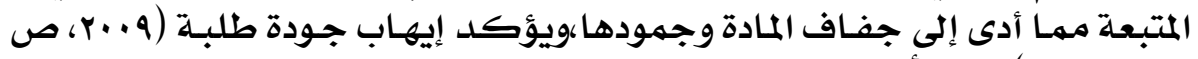

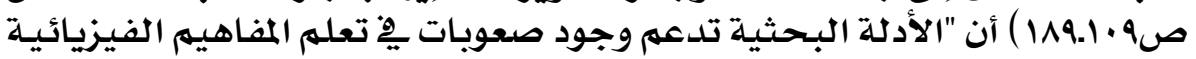

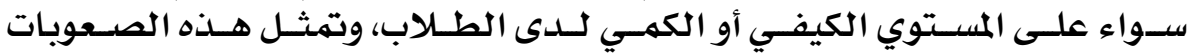

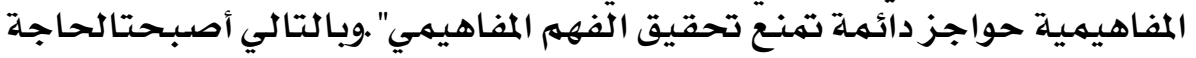

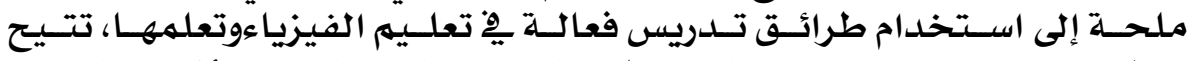

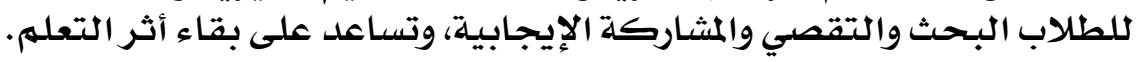

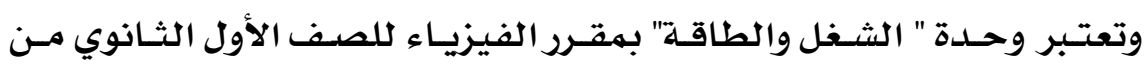

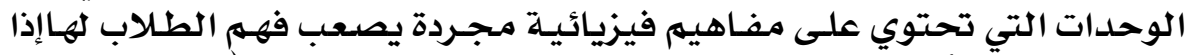

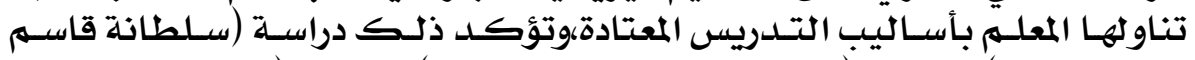

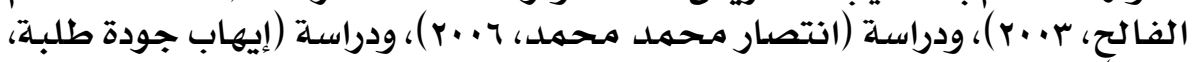
(r...

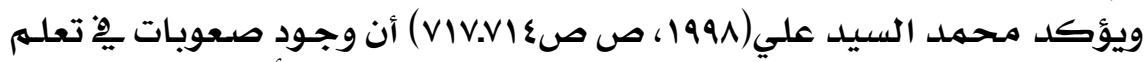

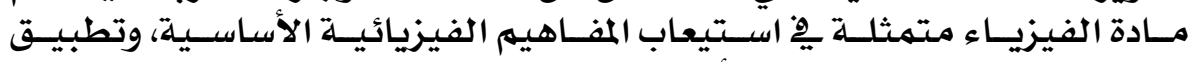

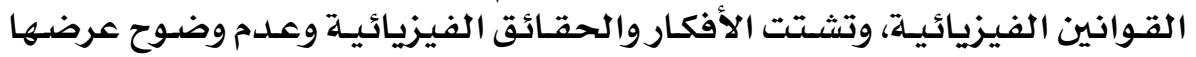

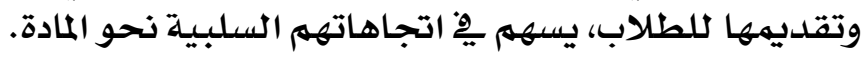

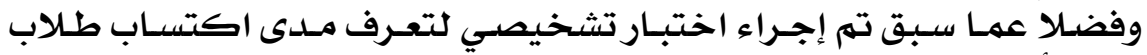

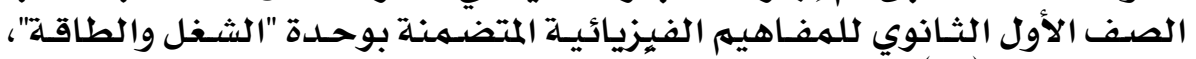

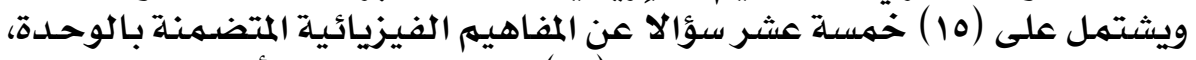

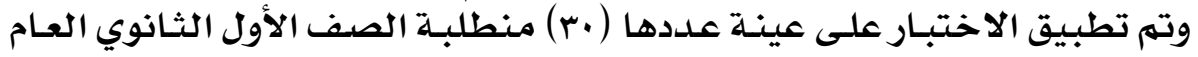

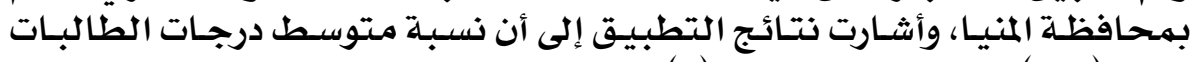
بلغت (rع٪)، والانحراف المنيـارت المعياري (r). 


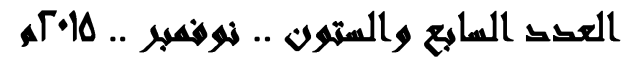

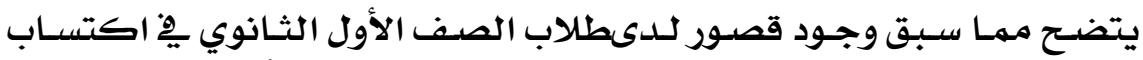

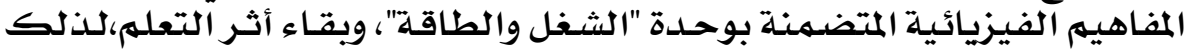

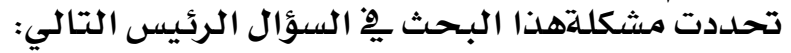

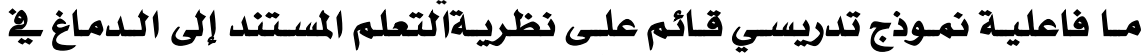

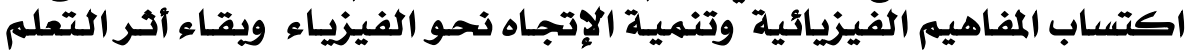

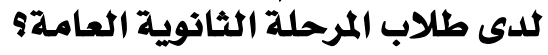

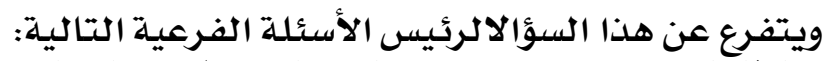

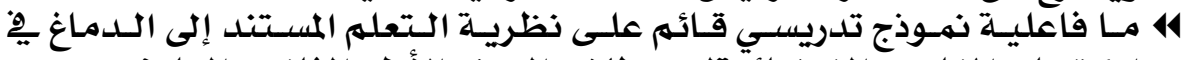

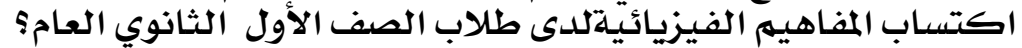

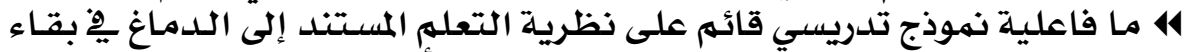

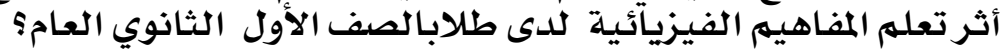

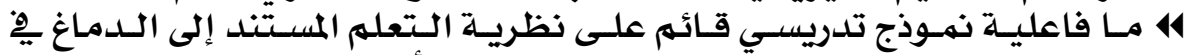

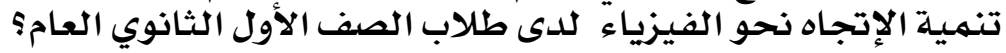
استهـدف هذا البـا البحث تعرف:

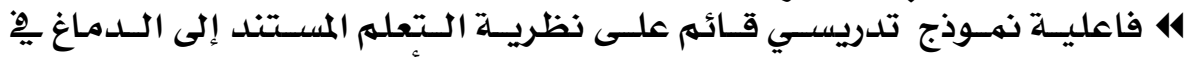

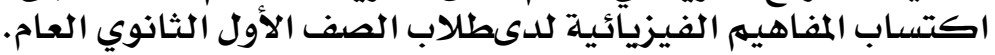

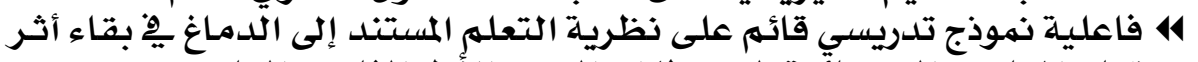

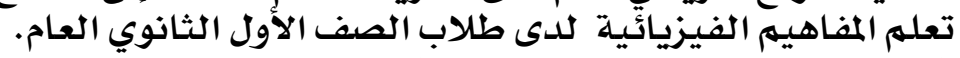

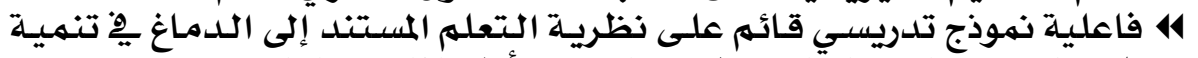

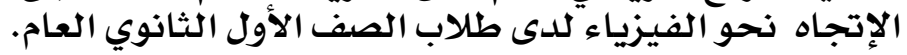

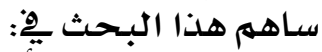

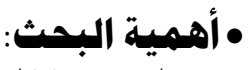

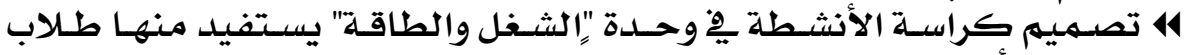

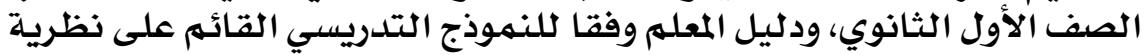

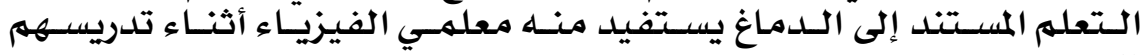

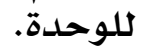

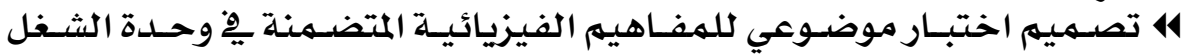

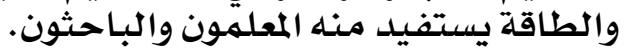
4 تصميهم مقياس الإتجاه نحو الفيزئياء يستفيد منيد منه الباحثون.

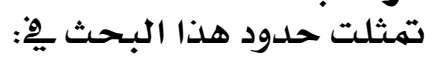

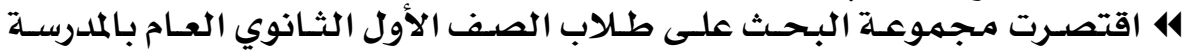

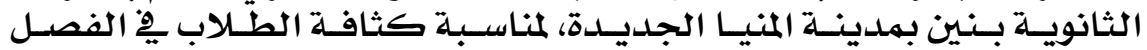
ولتجربية البـحثث.

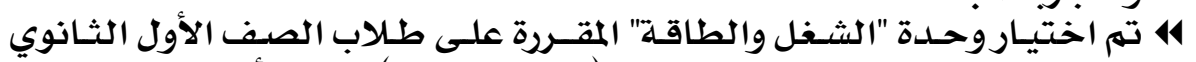

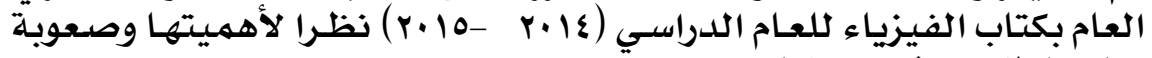

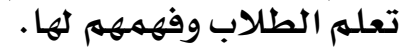

\section{YY}

دراسات عربية في التربية وعلم النفس (ASEP) 


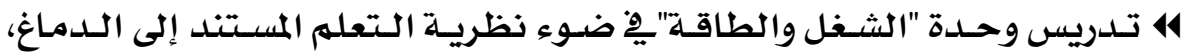

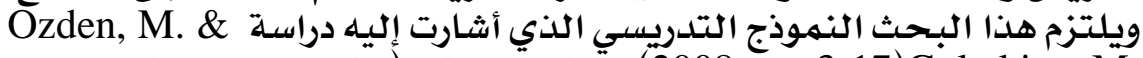

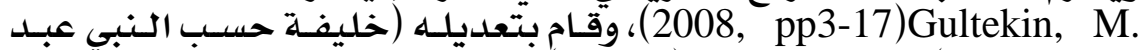

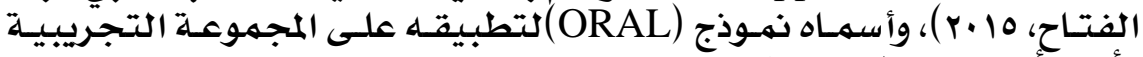

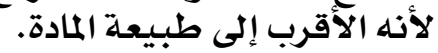

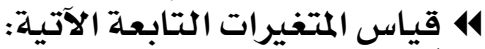

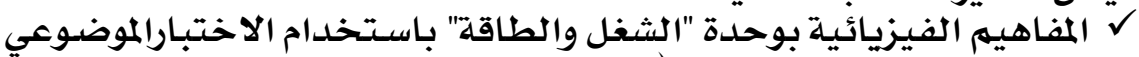

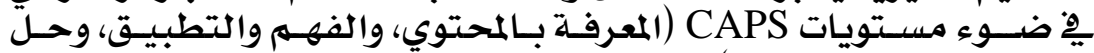

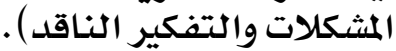

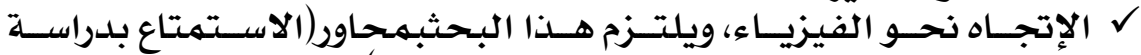

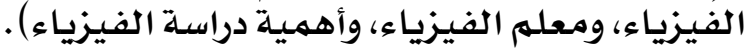
$\checkmark$

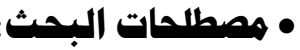

• (1) النموذج التدريسي (Teaching Model):

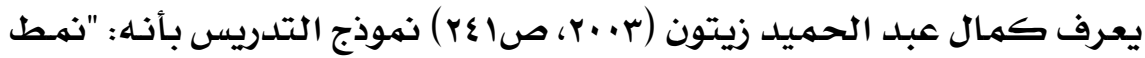

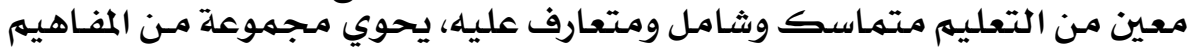

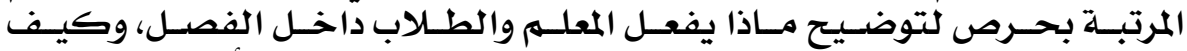

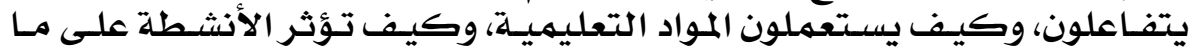

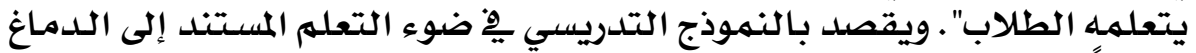

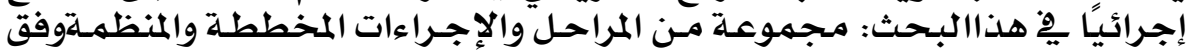

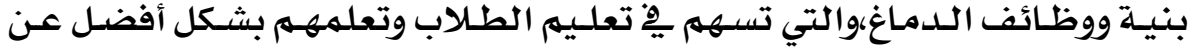

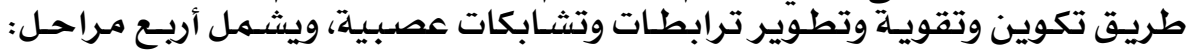

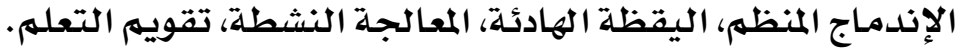

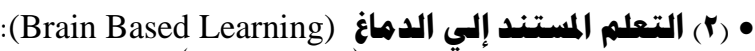

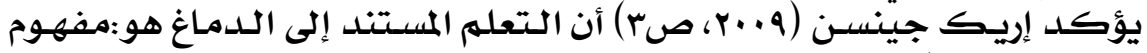

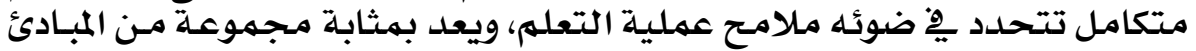

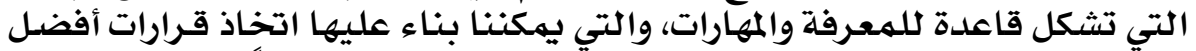

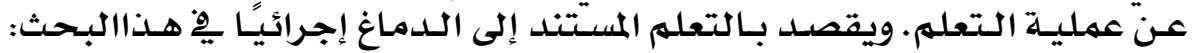

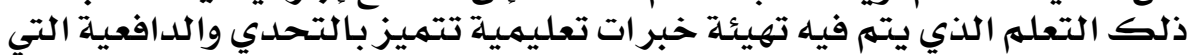

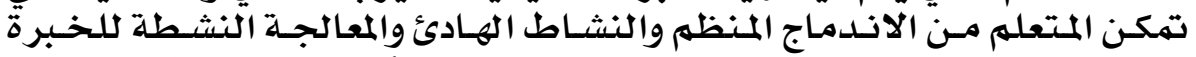

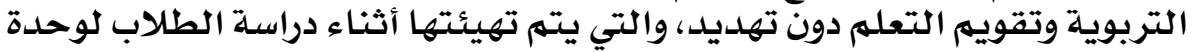

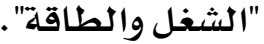

• (ז) المفاهيم الفيريائية (Physics Concepts):

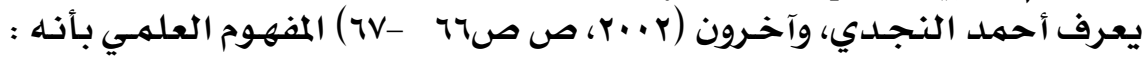

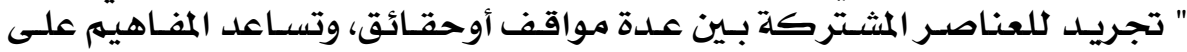

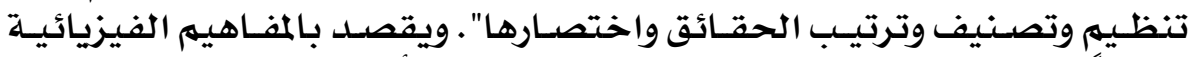

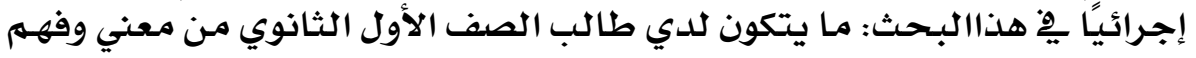

\section{Yr}




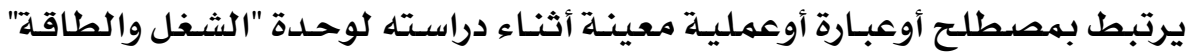

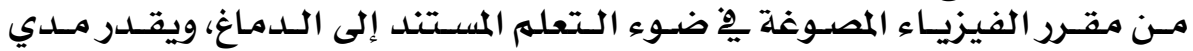

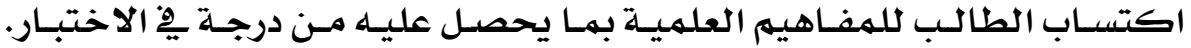

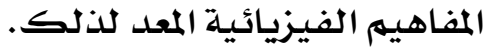

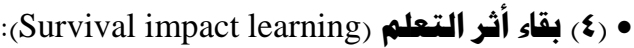

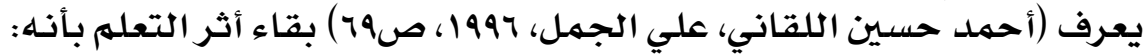

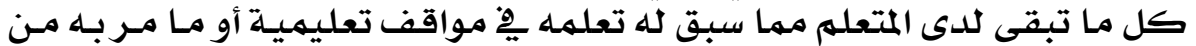

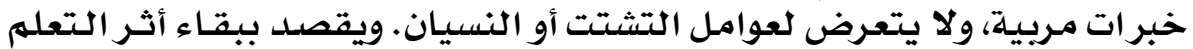

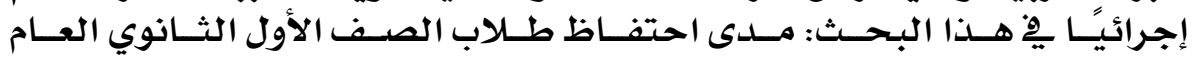

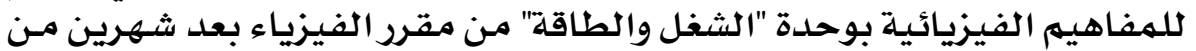

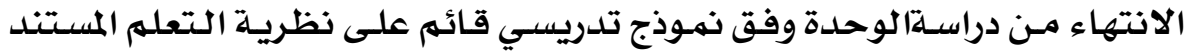

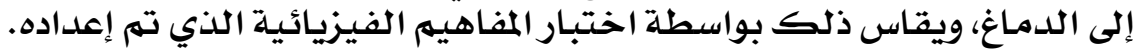

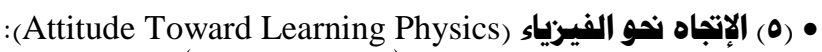

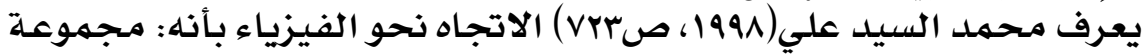

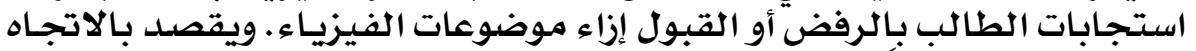

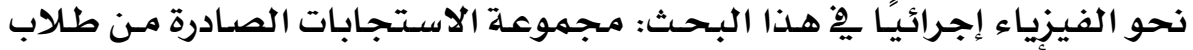

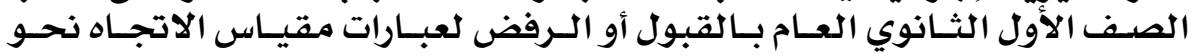

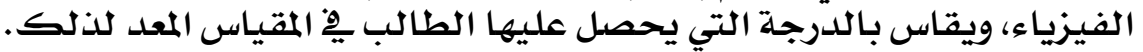

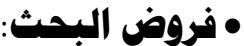

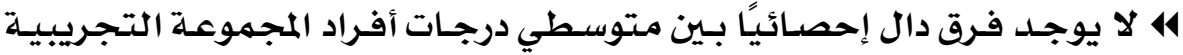

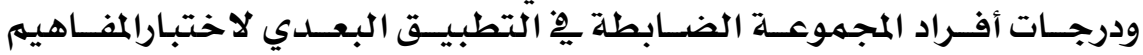
الفيزيائية.

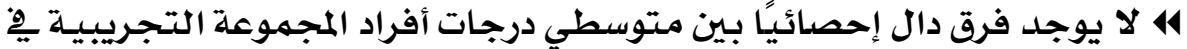

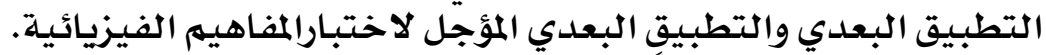

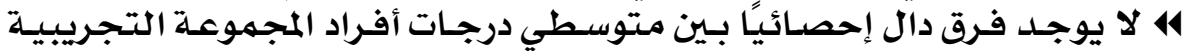

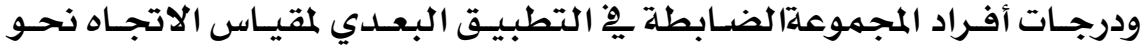
الفيزياء.

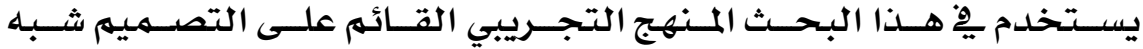

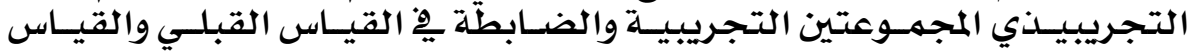

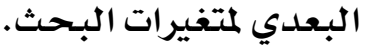

يتضمن هذا البـا البحث المتغيرات الآتية:

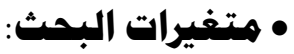

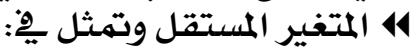

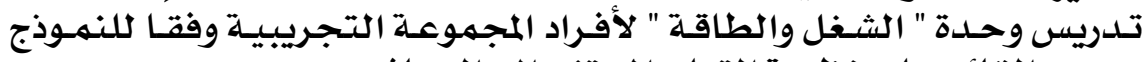

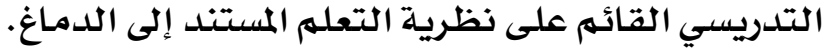

\section{Yध}




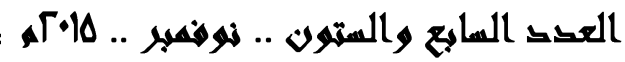

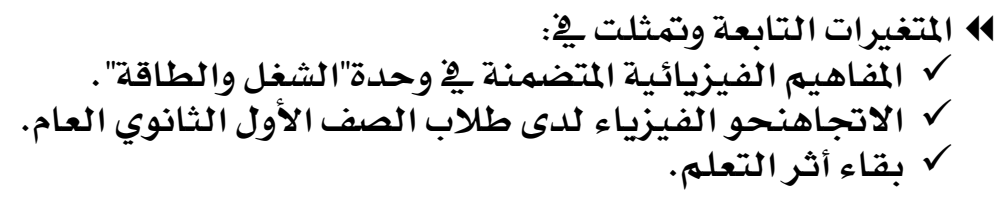

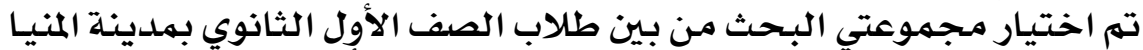

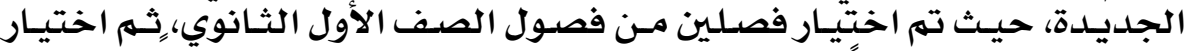

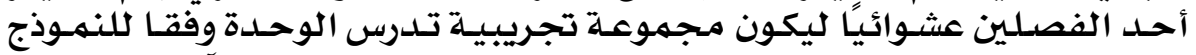

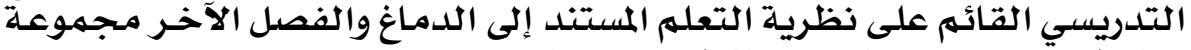
ضابطة تدرس نفس الوحدة بالطريقة المعتادة.

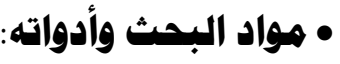
اعتمدالبحث الحالي يٌْ إجرائه على الأدوات التالية:

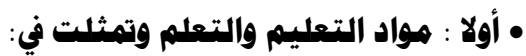

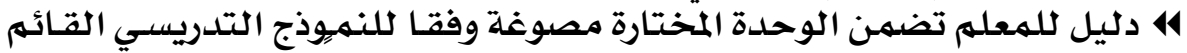

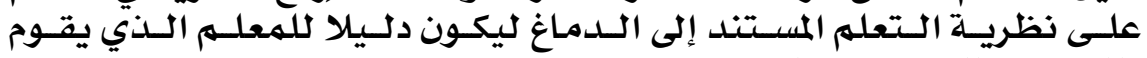

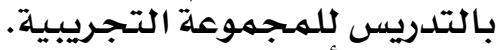

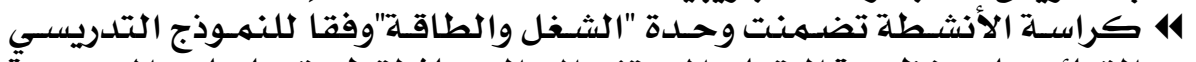

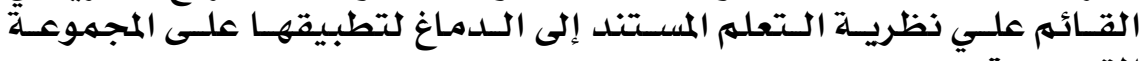

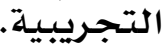

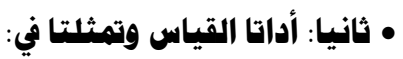

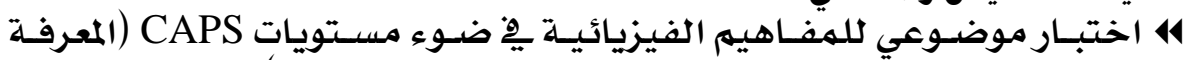
بالمحتوي، والفهم والتطبيق، وحل المشكيملات والتفكير الناقدة). 414 مقياس الاتجاه نحو الفيزياء.

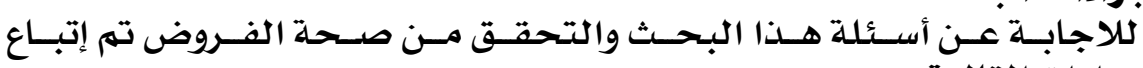

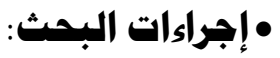

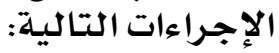

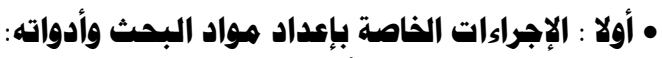

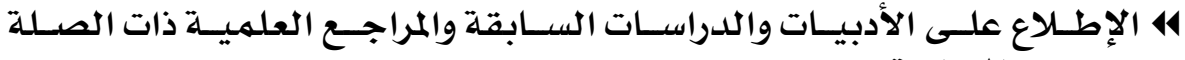

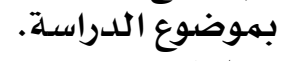

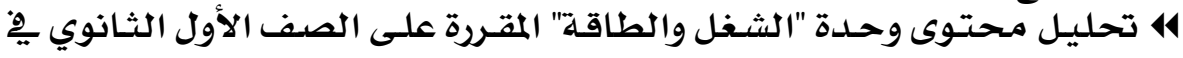

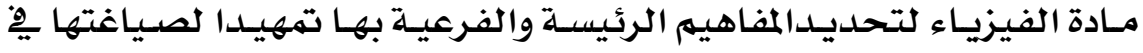

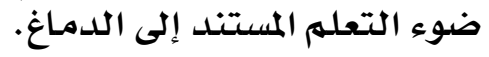

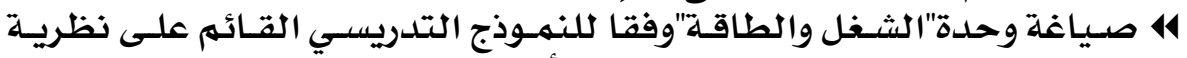

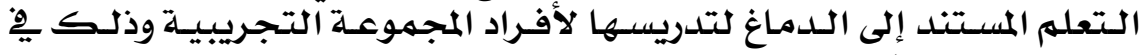

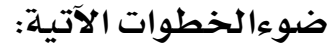
ل تحديد الأهداف العامة والإجرائية وعرضها على المحكمين. 


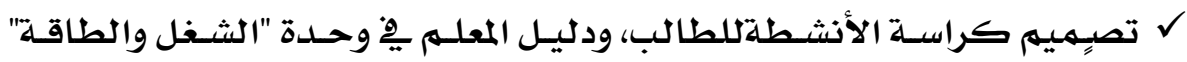

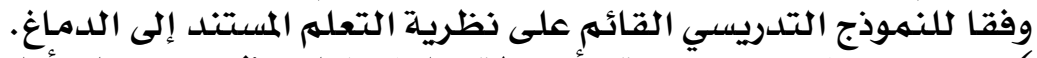

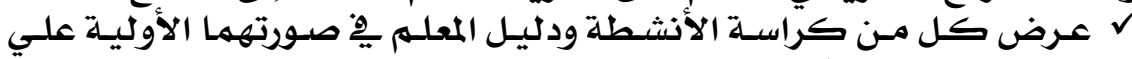

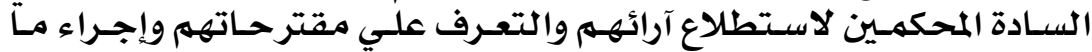

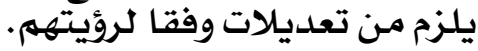

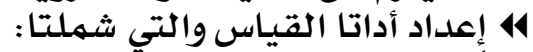

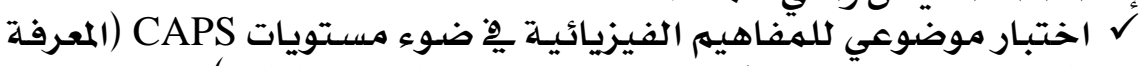

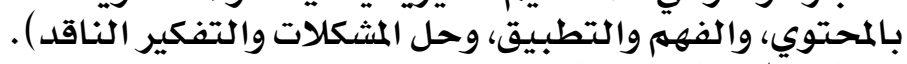
مقياس ألاتجاه والفحو الفيزئياء.

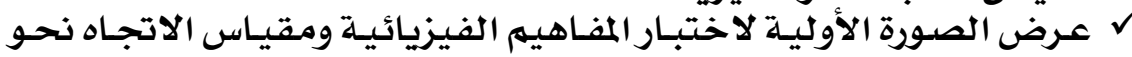

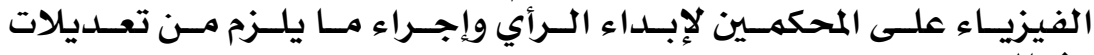
وفقالرؤيتهمه ل تطبيـق أدوات القيـاس على عينـة اسـتطلاعيـة لحسـاب القـيهم الإحصـائية

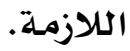

\section{• ل ثانيا : الإجراءات الخاصة بتطبيق تجربة البحث:}

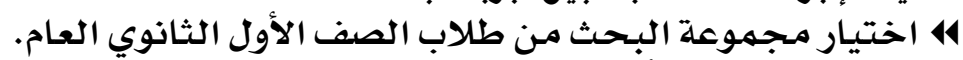

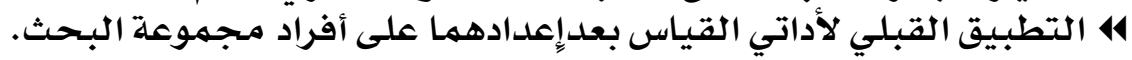

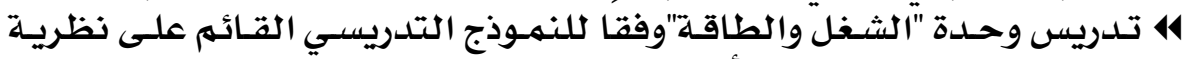

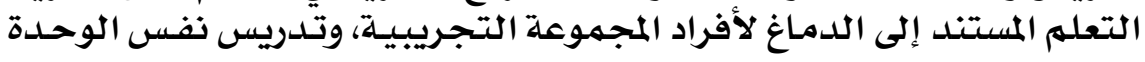

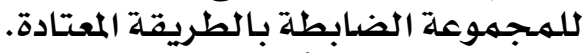

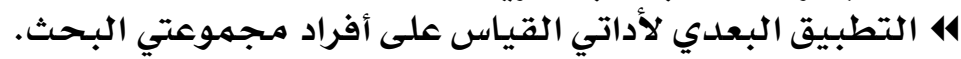

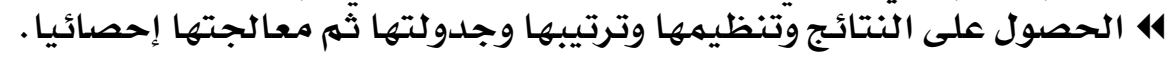

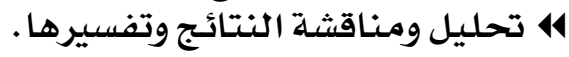

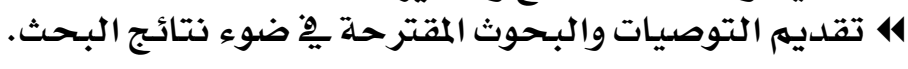

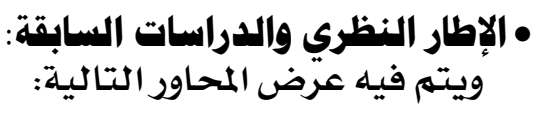

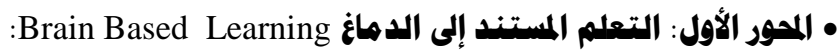

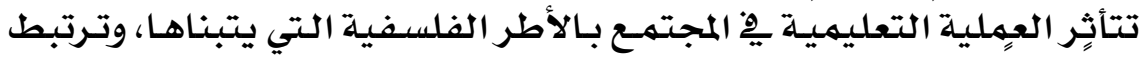

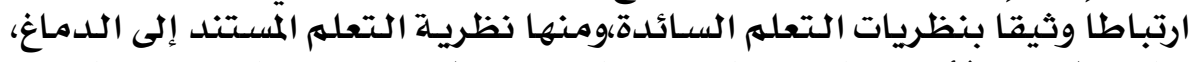

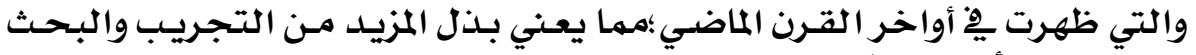

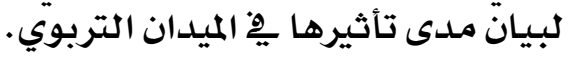

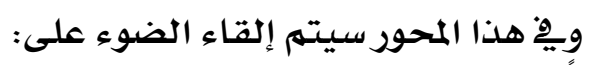

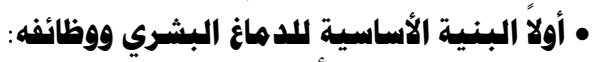

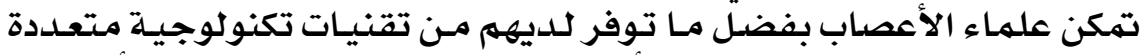

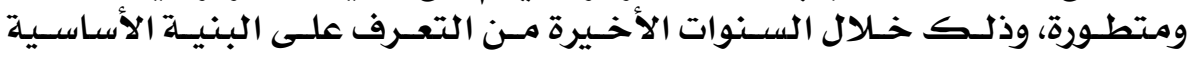

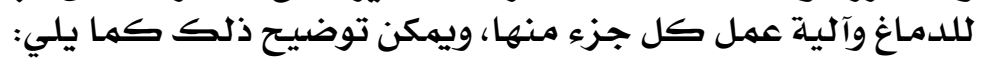

\section{Y7}




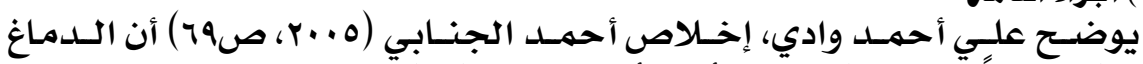

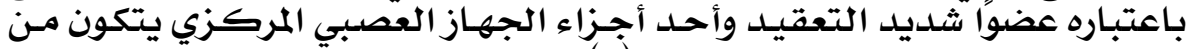

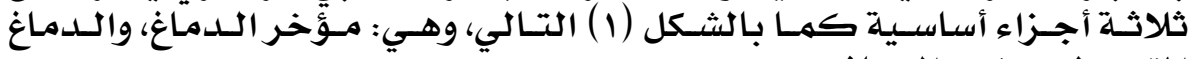

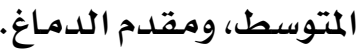

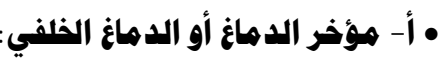

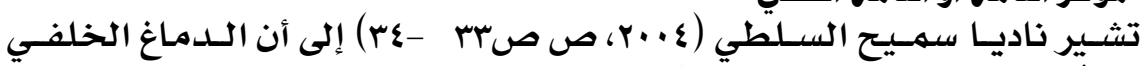

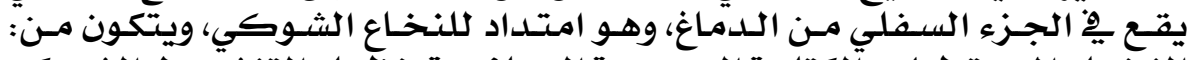

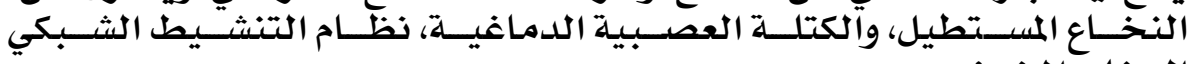
السفلي،المخيخ.

\section{• ب- بوسط الدهاغ أو الدهاغ المتوسط:}

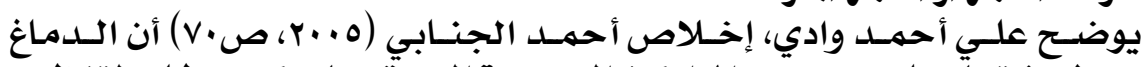

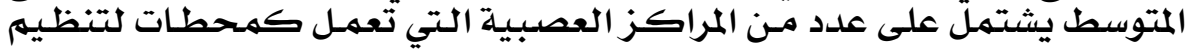

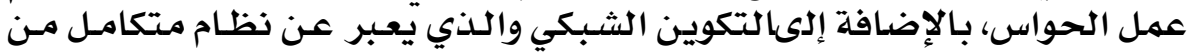

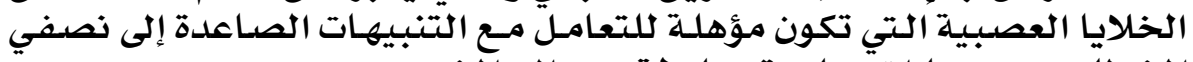
المخخ، لما به من مسارات العاعدة وهابطة من وإلى الميخ.

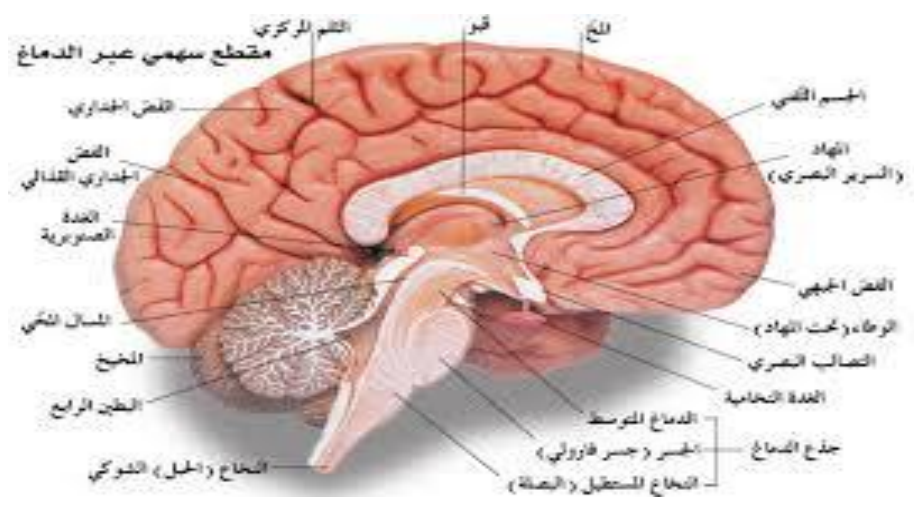

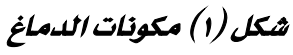

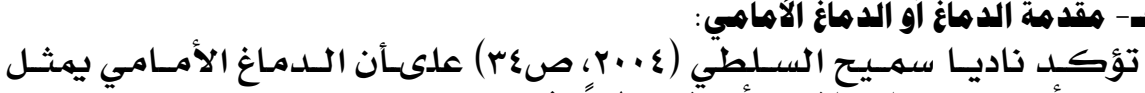

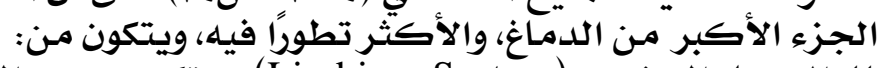

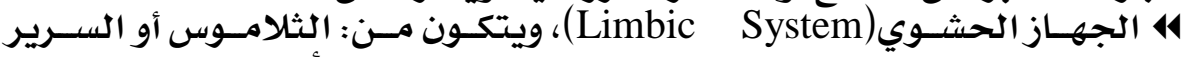

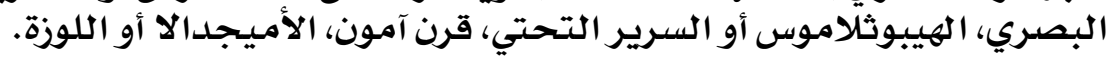

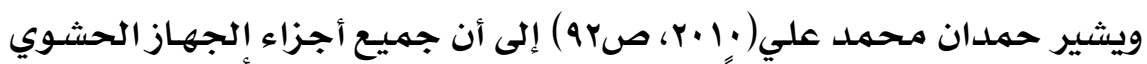

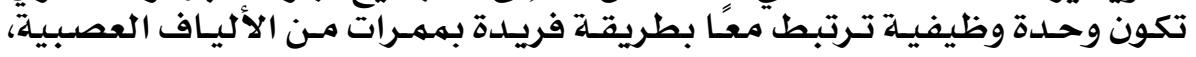

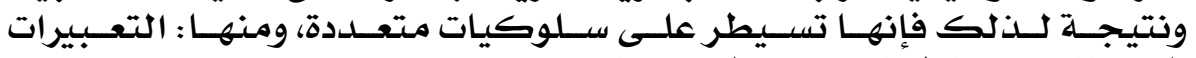
الإنفعالية، ونشاط الذاكرة والاستدعاء.

\section{YV}




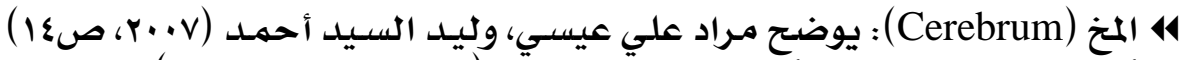

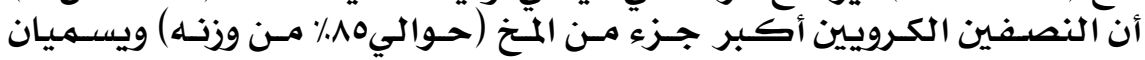

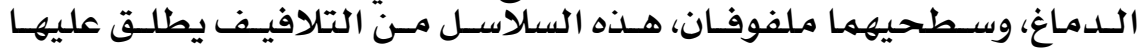

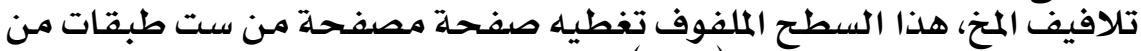

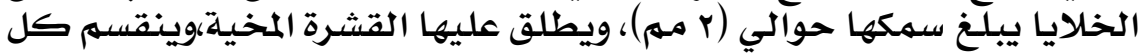

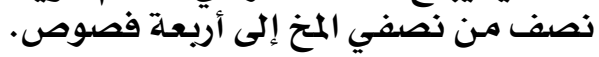

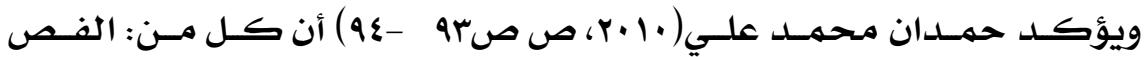

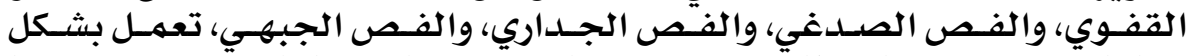

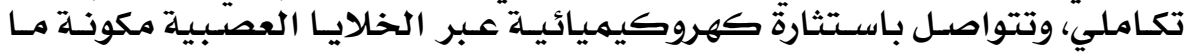

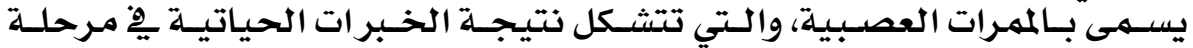
الطفولة وتستهمر طوال المعرات الحياة.

• (ז) خلايا الدهاغ (Brain Cells):

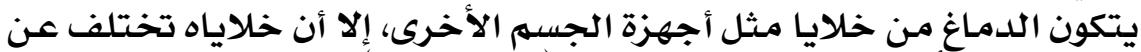

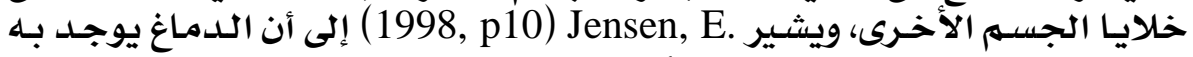

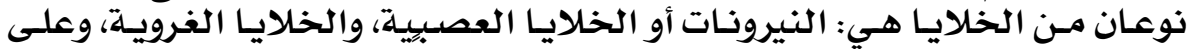

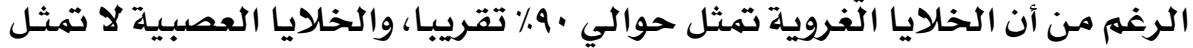

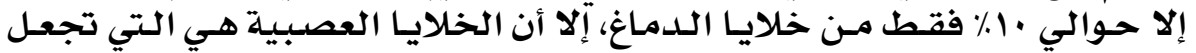

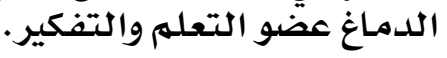

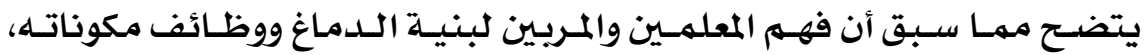

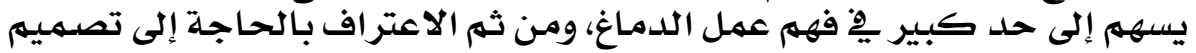

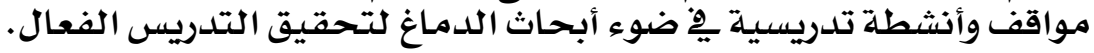

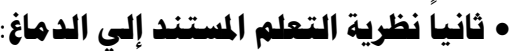

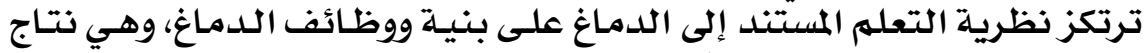

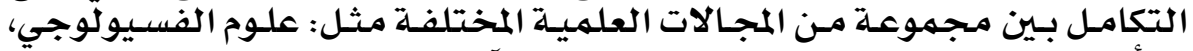

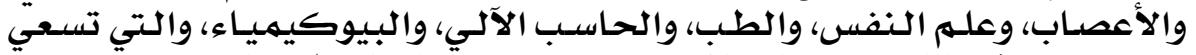
إلى تفسير وفهم آلية عمل الدماغ، و والفيفية والحمل حلدوث التعلهم الإنساني.

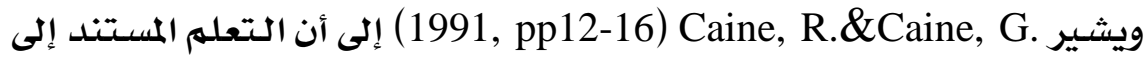

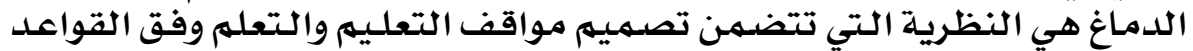

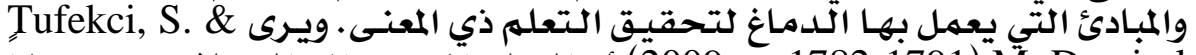

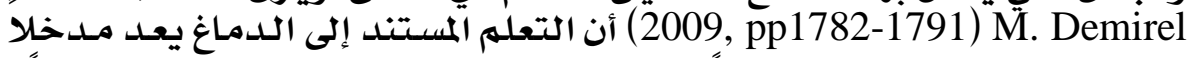

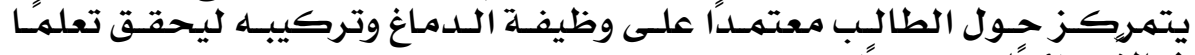
فعالا، ودائهمًا، ومستهمراً

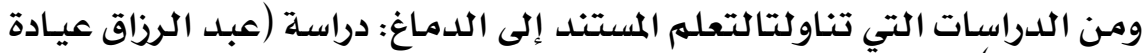

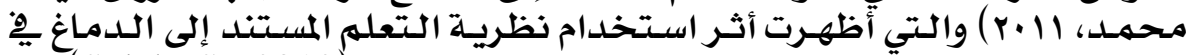

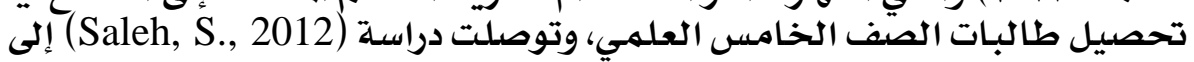

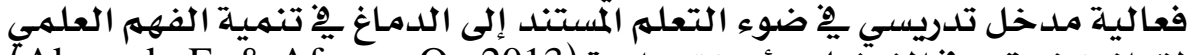
لقوانين نيوتن يخ الفيزياء، وأبرزت دراسـة (Akyurek, E. \& Afacan, O., 2013)

\section{Y^}


العكد العابع والستهون .. نهوهمبر ..

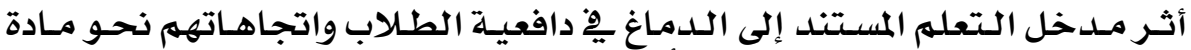
العلوم لدى طلاب الصف المت الثامن الأساسي.

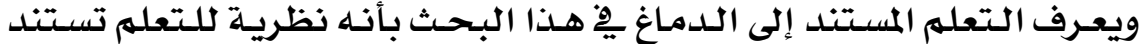

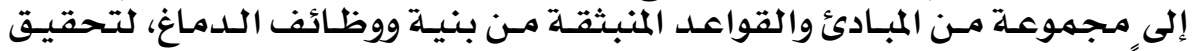

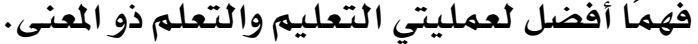

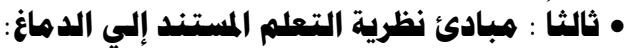

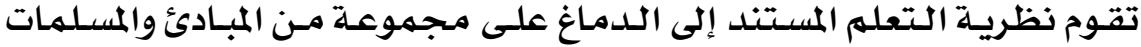

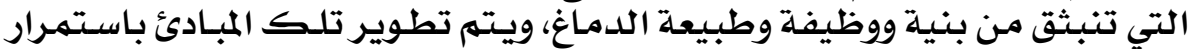

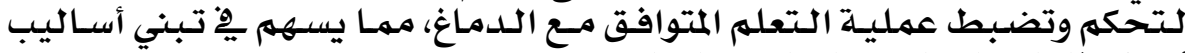
أكثر فاعلية لعمليتي التعليه والتعلهم.

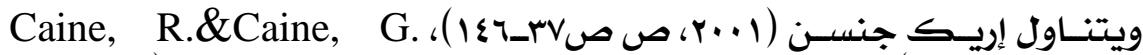

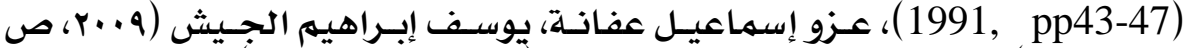

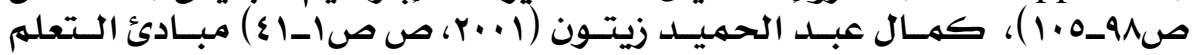

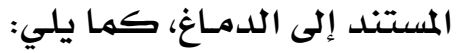

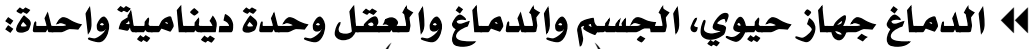

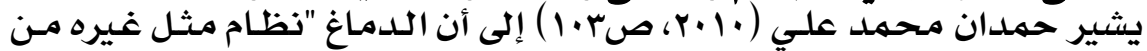

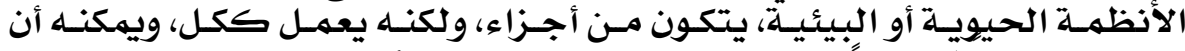

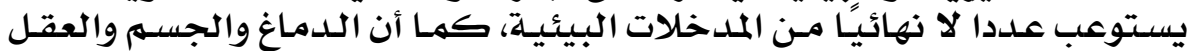

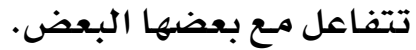

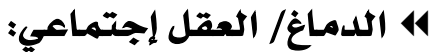

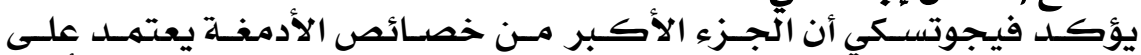

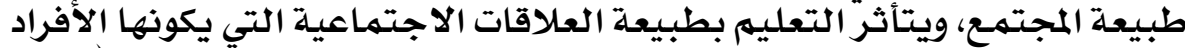

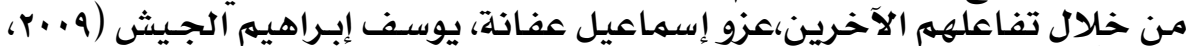

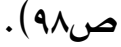

14 البحث عن المعني فطري:

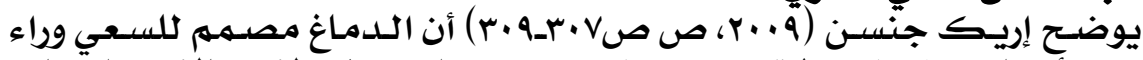

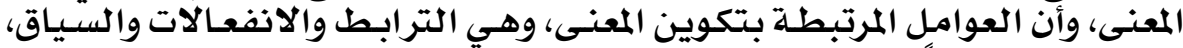

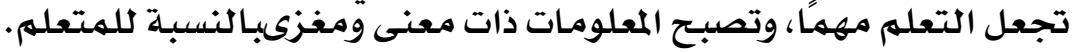

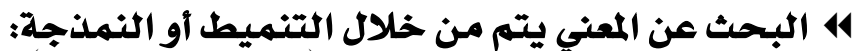

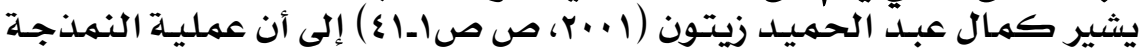

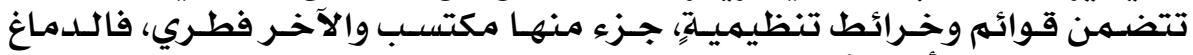

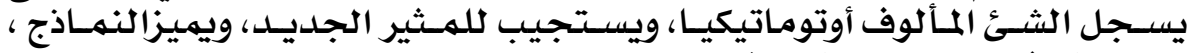

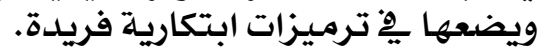

414

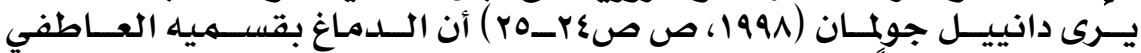

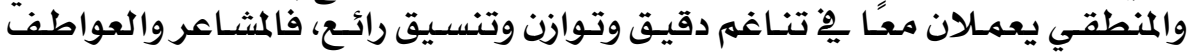




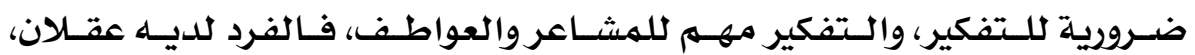

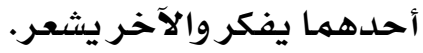

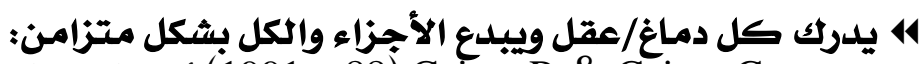

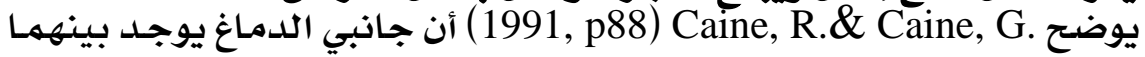

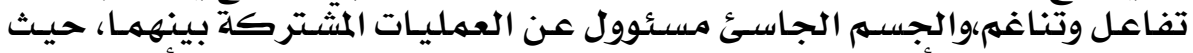

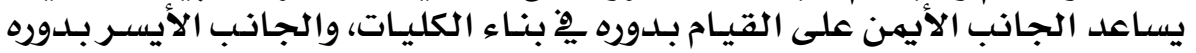

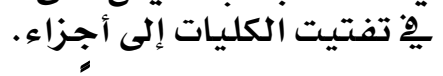

414

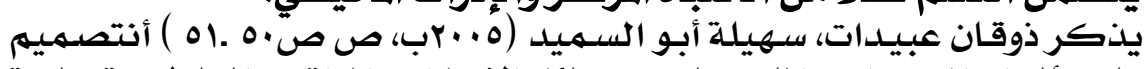

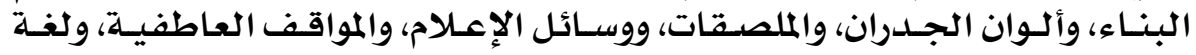

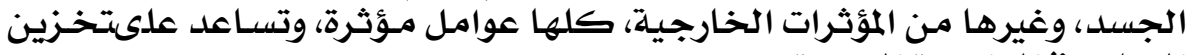

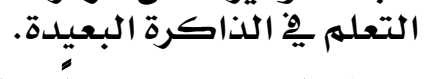

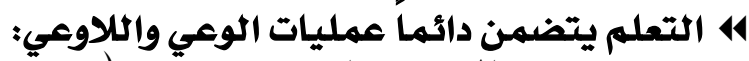

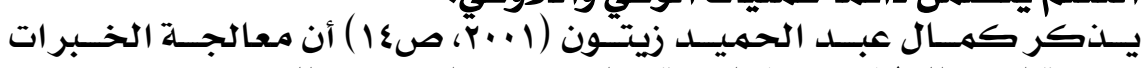

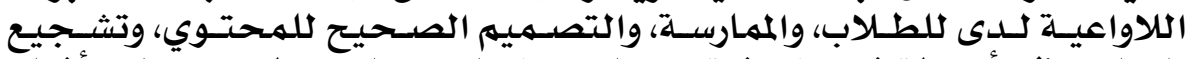

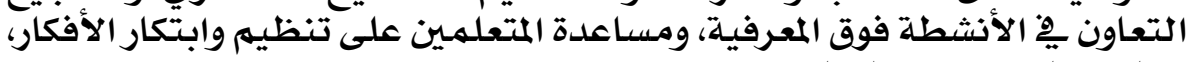

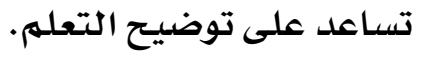

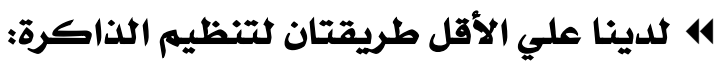

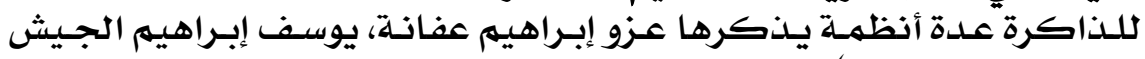

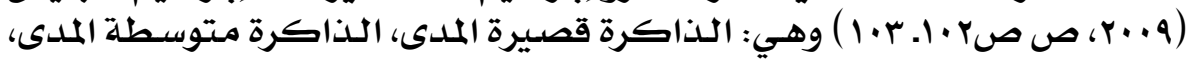

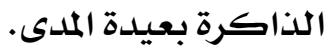

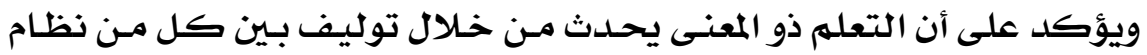

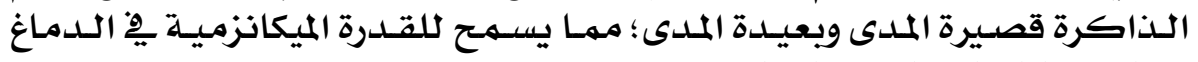
بتوليفهما لزيادة السعة العقلية المبلية.

\section{4}

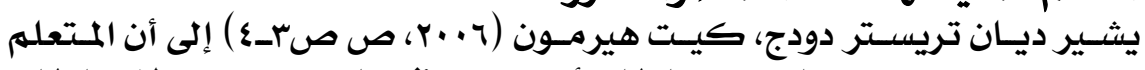

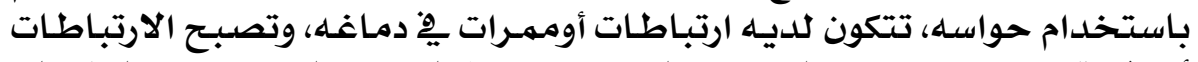

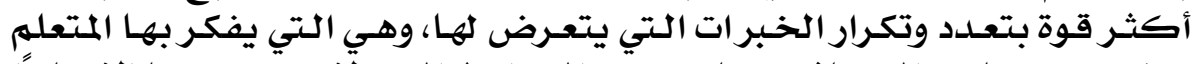

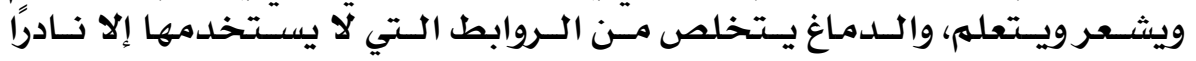
ويحتفظ فقط بـ بالروابط والبط المهمهة. 4 يدعَم التعلم المعقد بالتحلفي ويكَف بالتهلديل:

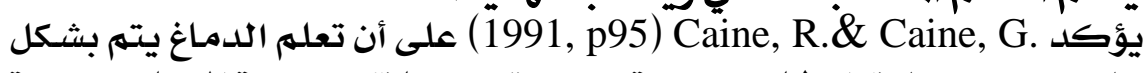

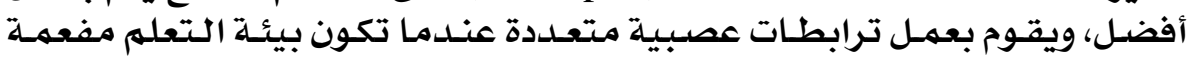

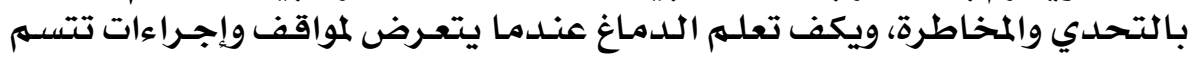

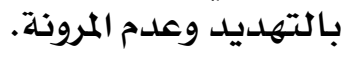




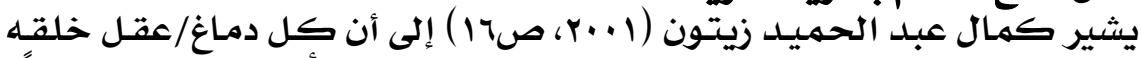

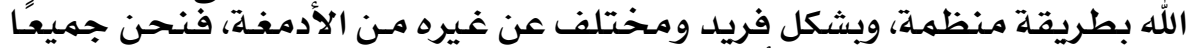

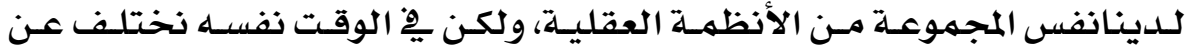

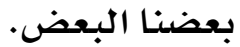

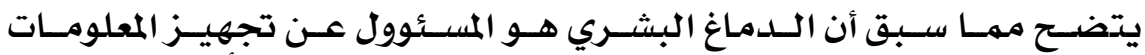

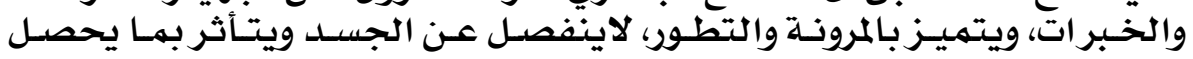

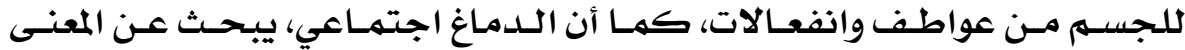

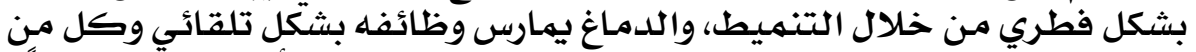

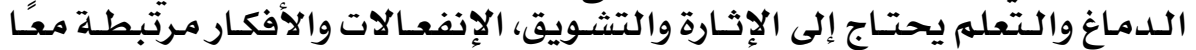

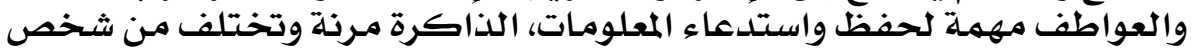

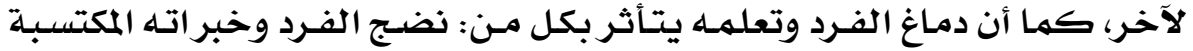

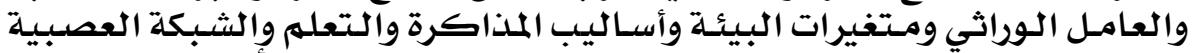

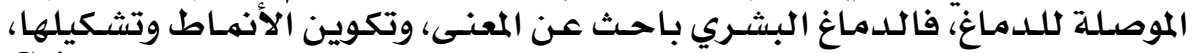

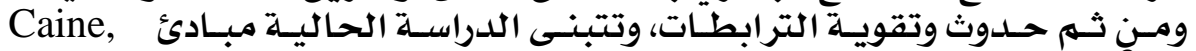
Caine, R.\&G.

• رابعاً: التعلم المستند إلبي الدهاغ وعلاقته بالبنائيسة:

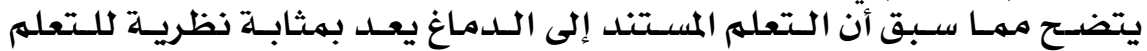

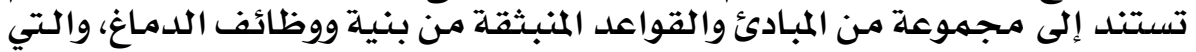

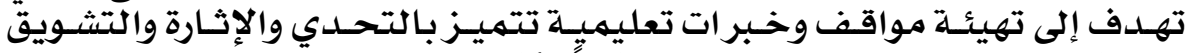

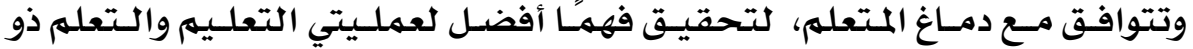

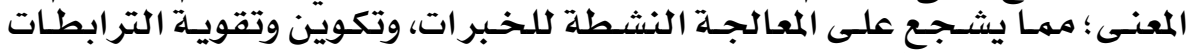

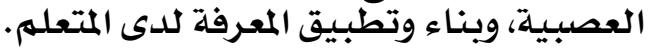

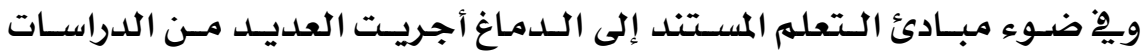

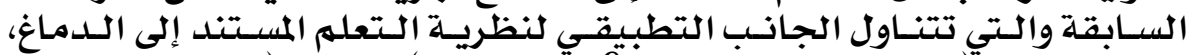

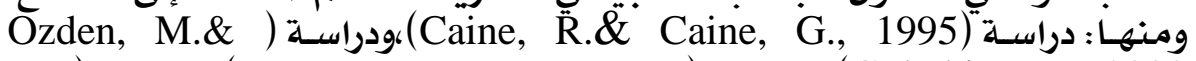

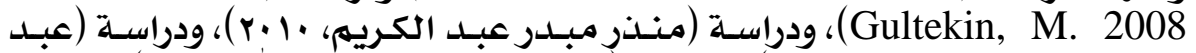

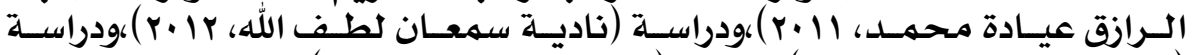

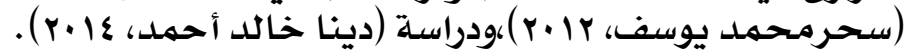

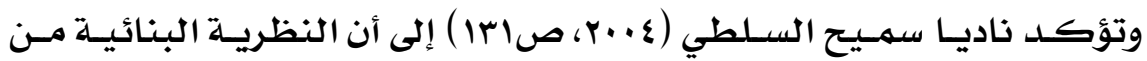

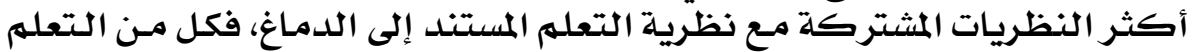

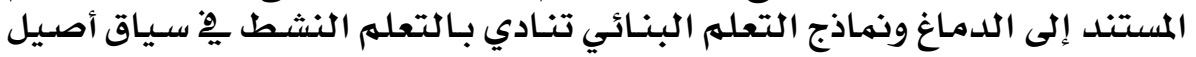

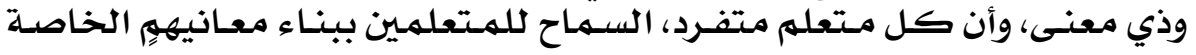

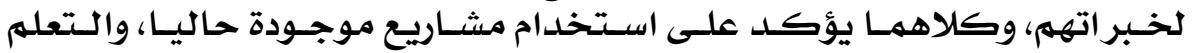

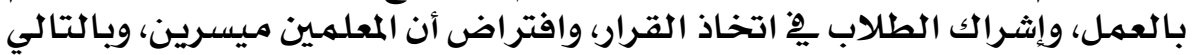

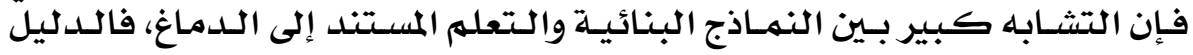

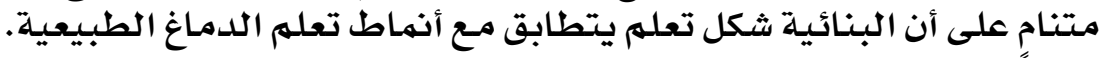




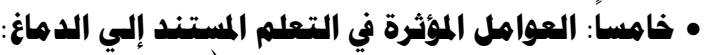

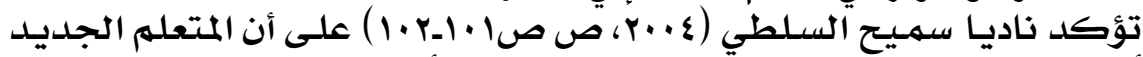

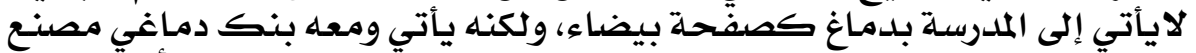

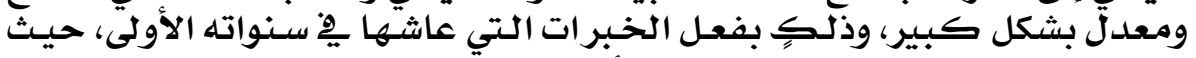

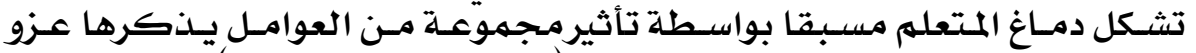

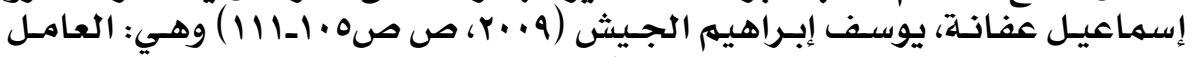

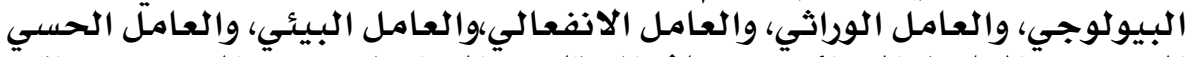

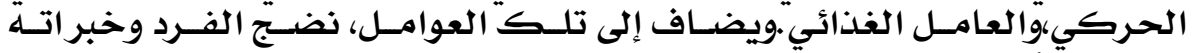

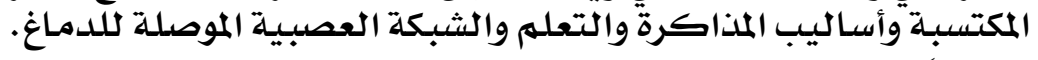

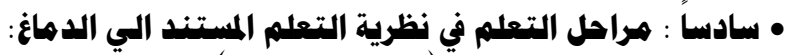

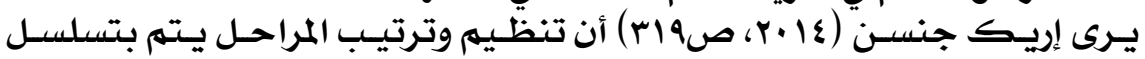

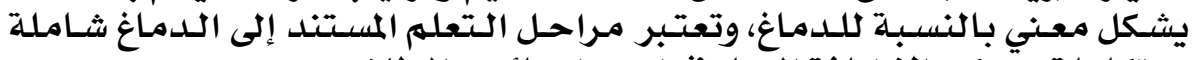

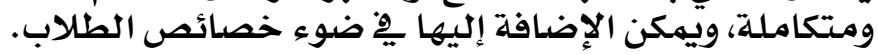

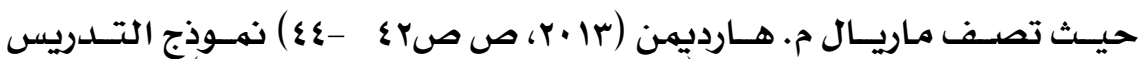

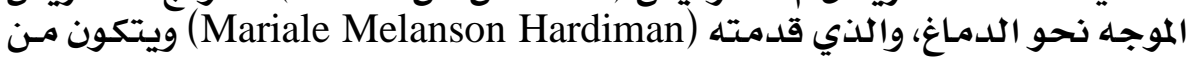

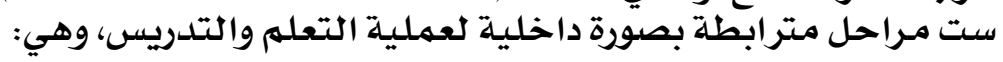

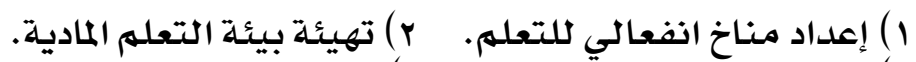

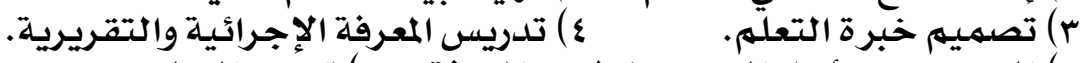

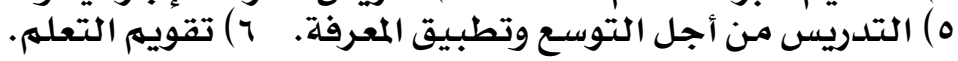

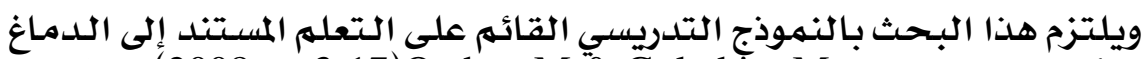

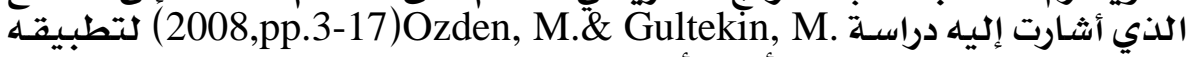

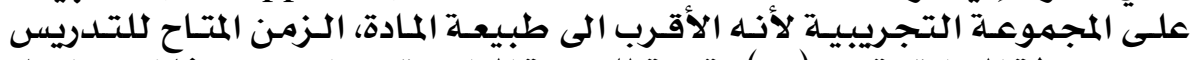

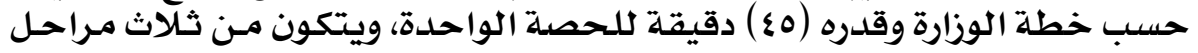

• هي: المّرحة الأولي: الإند ماه المنظم:

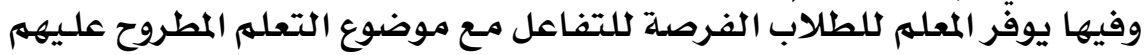

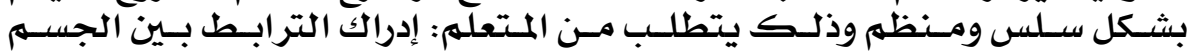

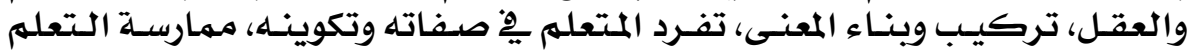
التعاوني.

\section{• المرحلة الثانية: اليقظة الهادئة:}

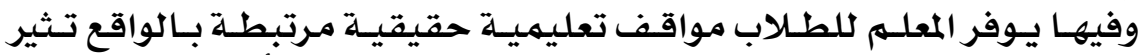

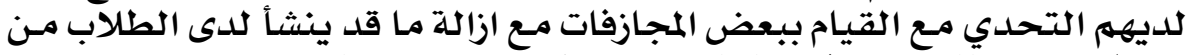

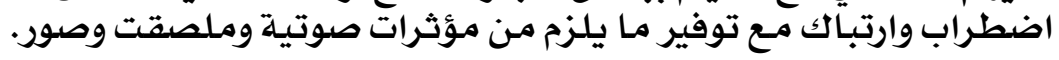

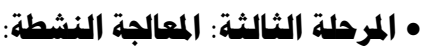

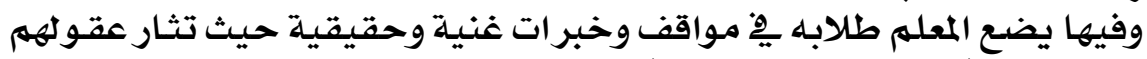

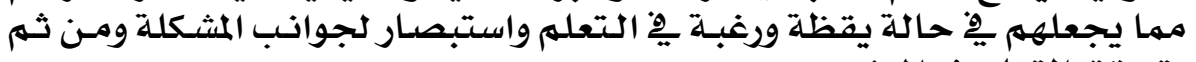
يتحقق التعلمى ذو المعنى. 


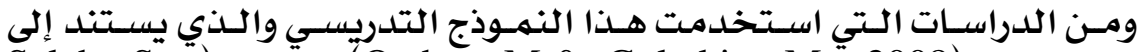

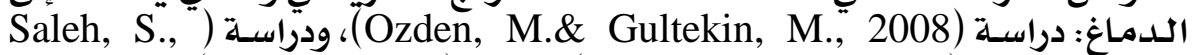

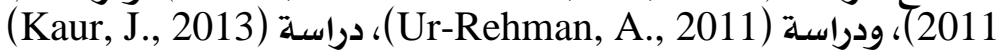

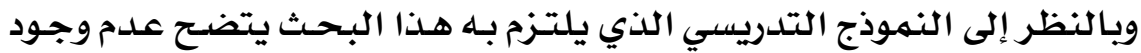

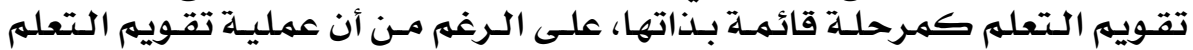

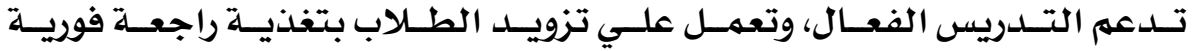

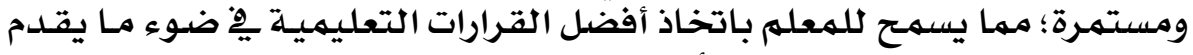

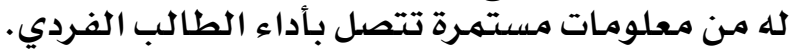

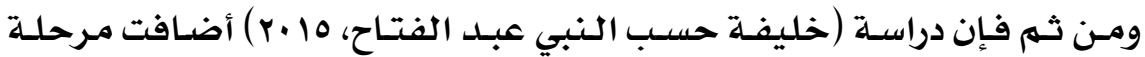

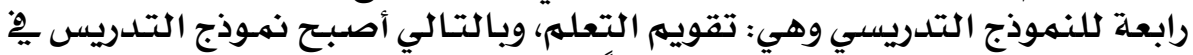

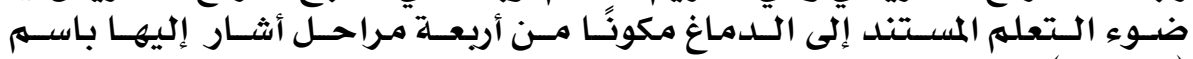

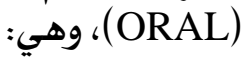

4 الإندماج المنظم (Orchestrated Immersion). 4 اليقظة الهادئة( (Relaxes Alertnes). 41 المعالجة النشطة الهية (Active Processing). 4 تقويه التعلهم (Learning Evaluation).

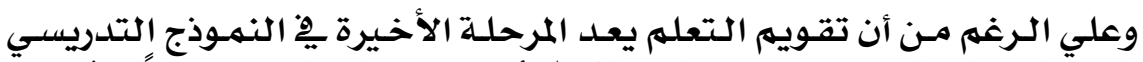

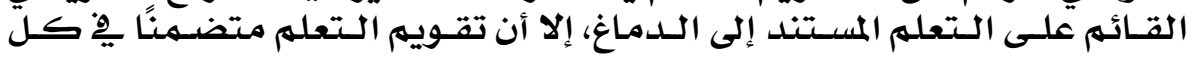

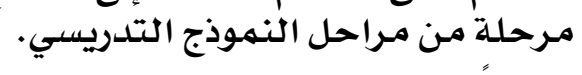

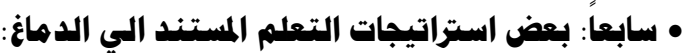

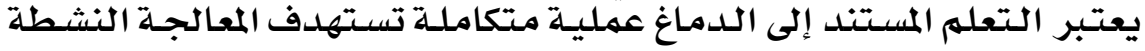

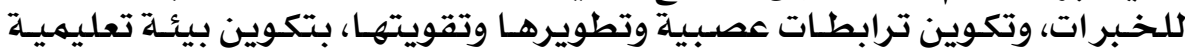

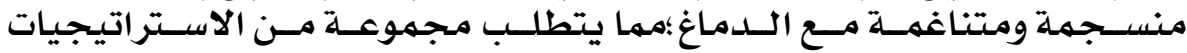

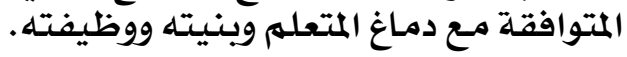

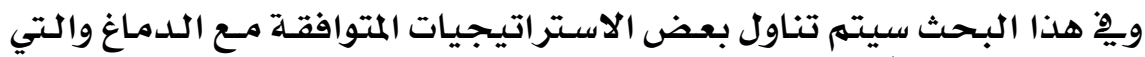

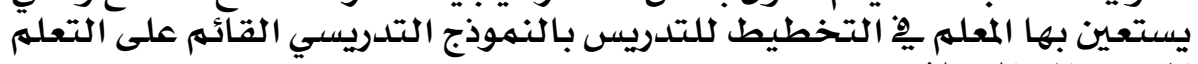
المستند إلى الدماغ، وهي: المعاني:

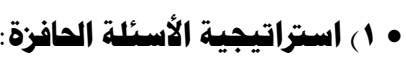

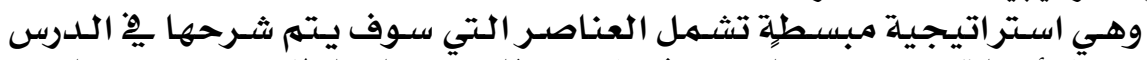

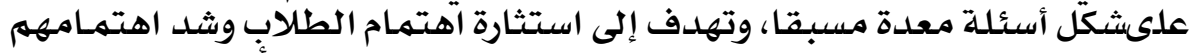

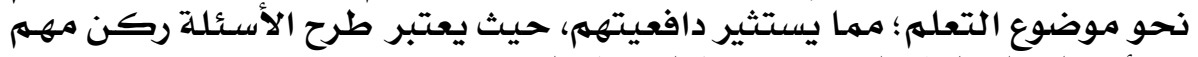

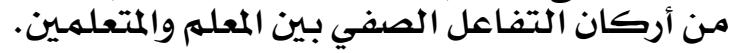

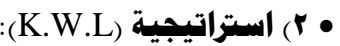

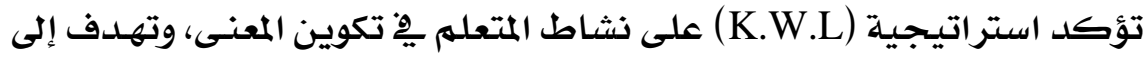

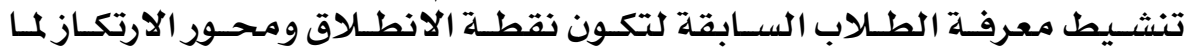




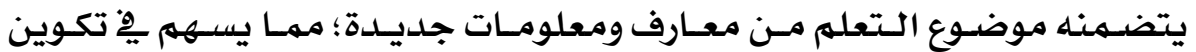

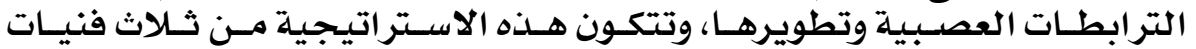

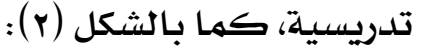

\begin{tabular}{|c|c|c|}
\hline مـا تعلهـه (L) & مـا يريـــ معرفتته (W) & ماذا يعرفه (K) \\
\hline
\end{tabular}

(K.W.L) شكل (r) جلول استراتيجية

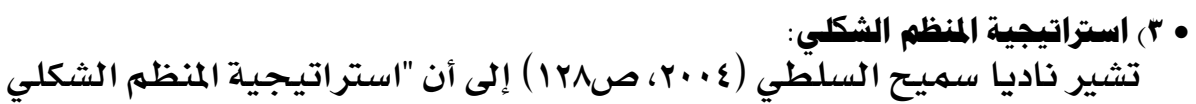

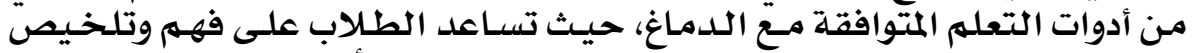

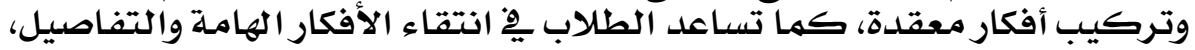

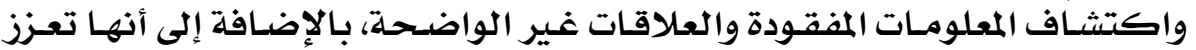

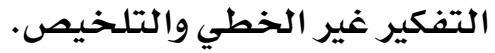

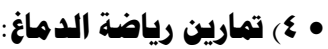

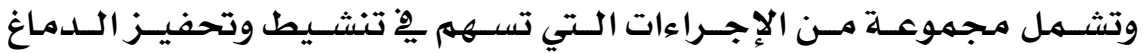

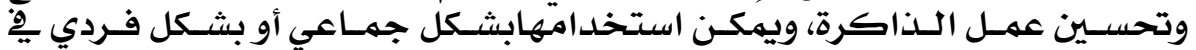
الصف، ومنها:

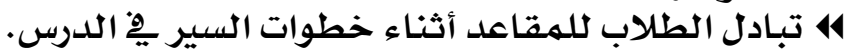

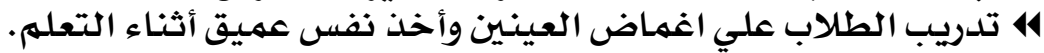

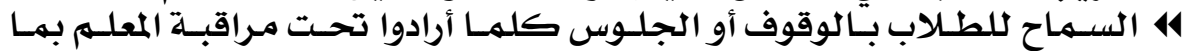

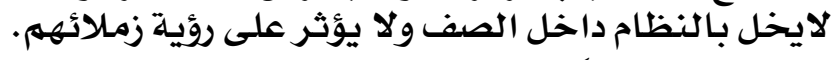

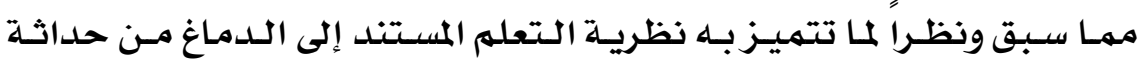

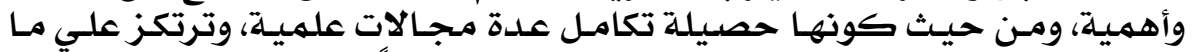

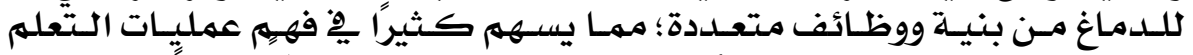

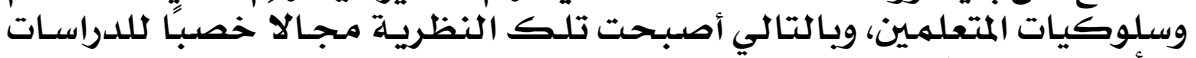

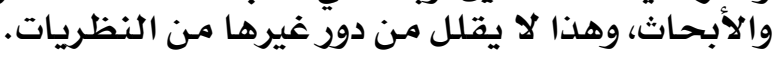

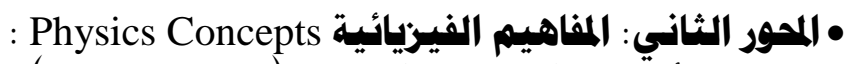

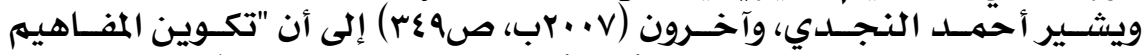

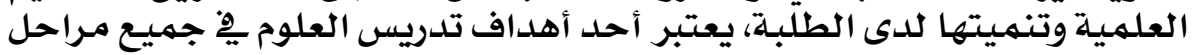

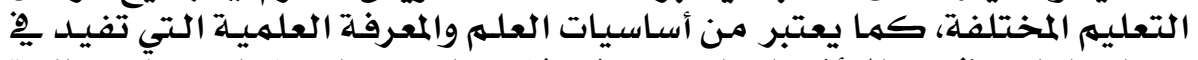

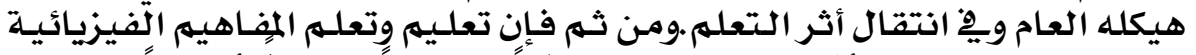

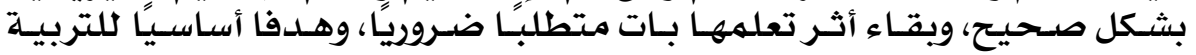

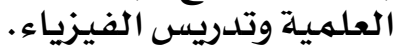

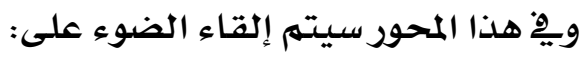

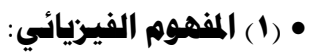

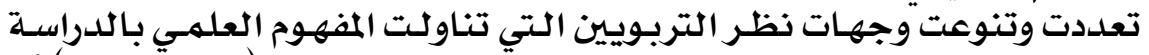

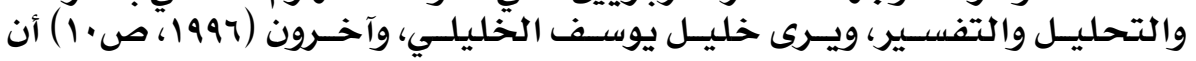

$r \varepsilon$

دراسات عربية في التربية وعلم النفس (ASEP) 


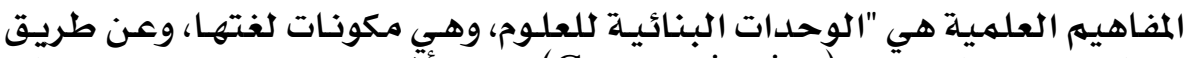

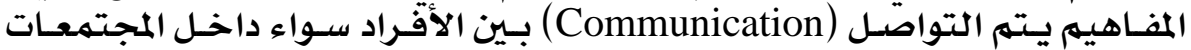
العلمية أو خارجها لـ التواهل

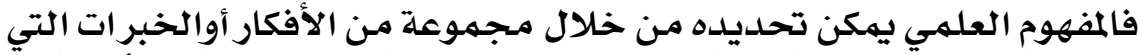

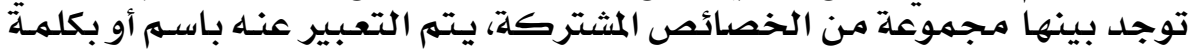

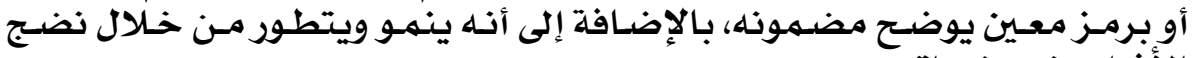
الأفراد ونمو خبر اتهنه.

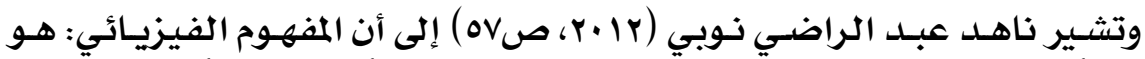

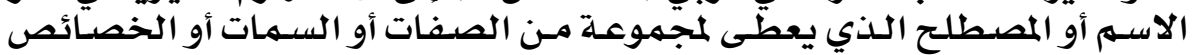

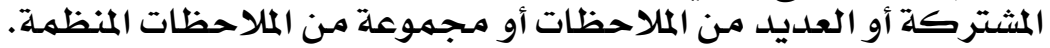

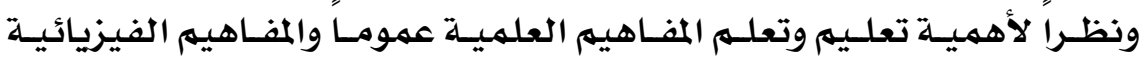

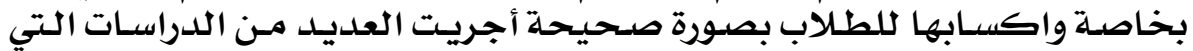

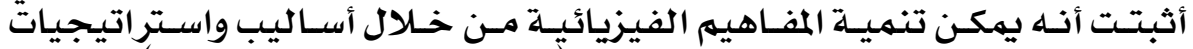

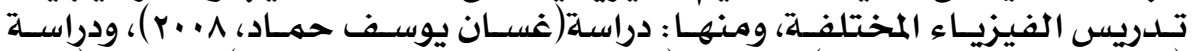

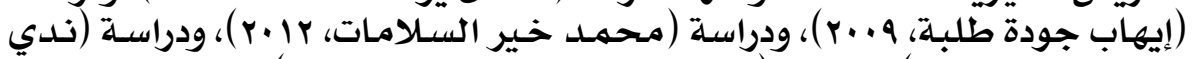

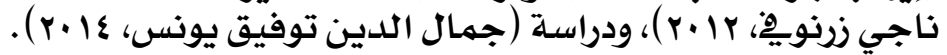

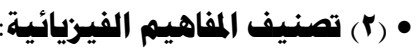

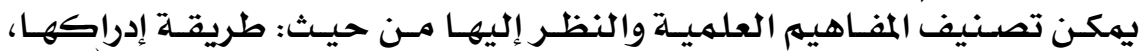

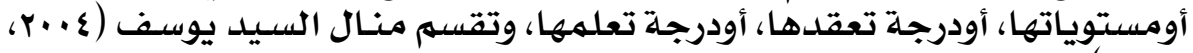

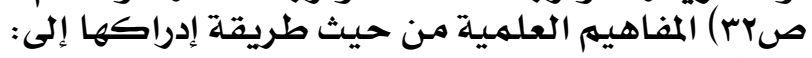

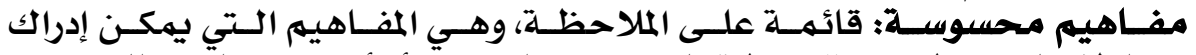

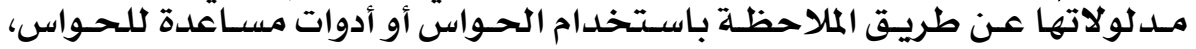

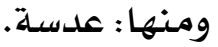

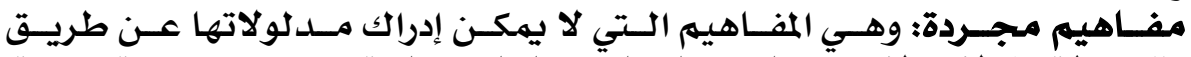

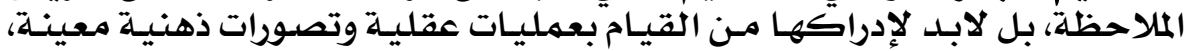

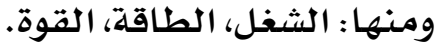

\section{• (ז) صعوبات تعلم المفاهيم الفيريائية:}

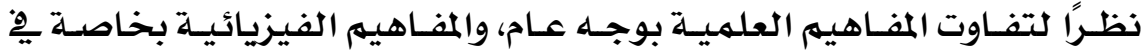

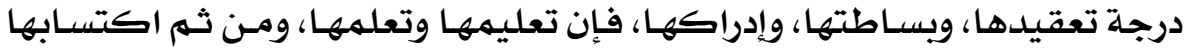

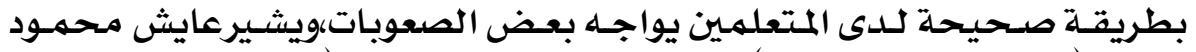

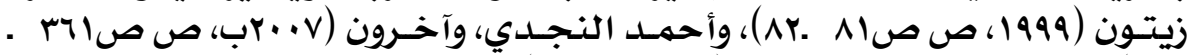

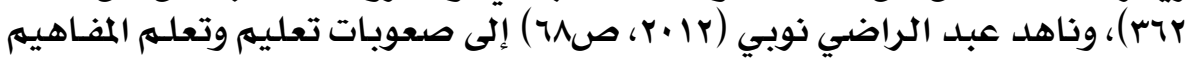

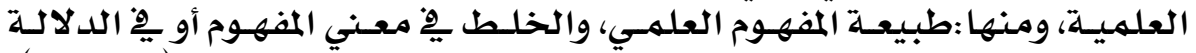

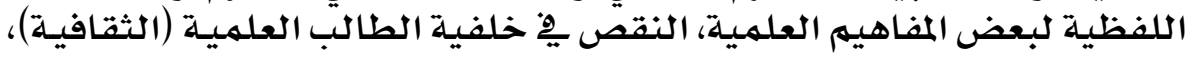

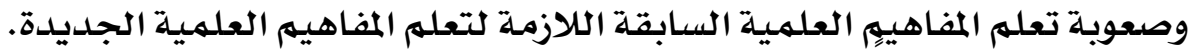

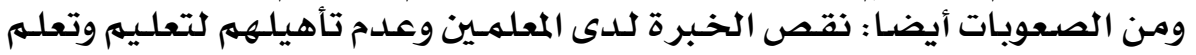

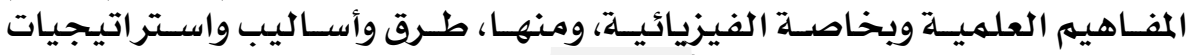




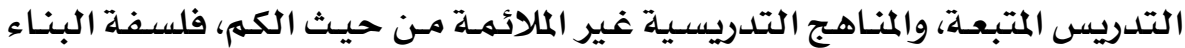

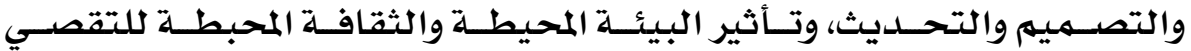
والاستكشاف.

• (؟) العواهل المؤثرة في تعلم المفاهيم الفيزيائية:

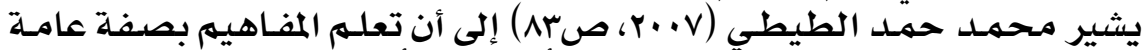

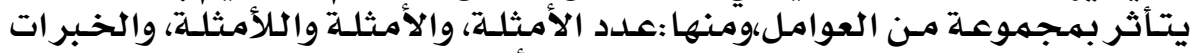

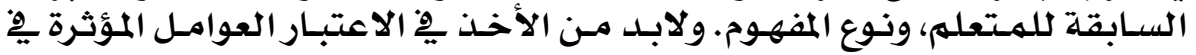

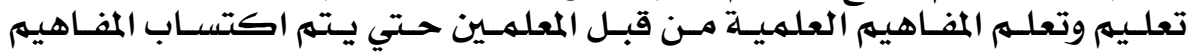

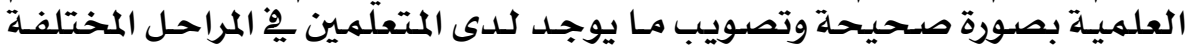

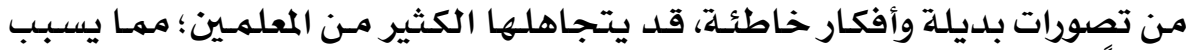

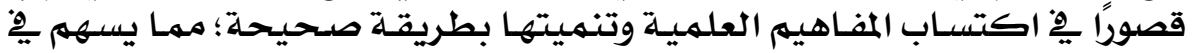

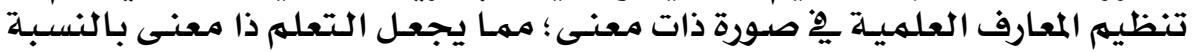

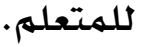

\section{• (0) بعض إجراءات تعليم وتعلم المفاهيم الفيزيائية:}

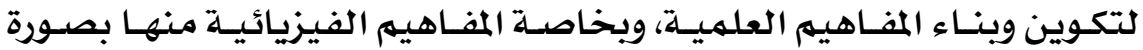

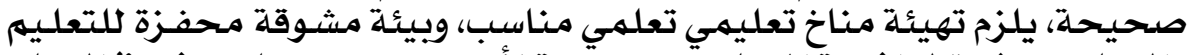

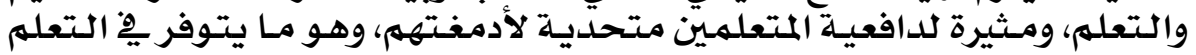

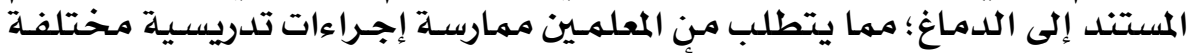

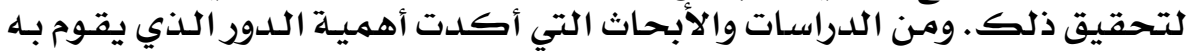

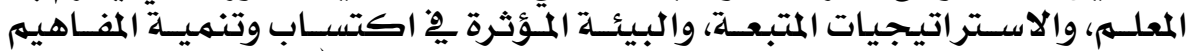

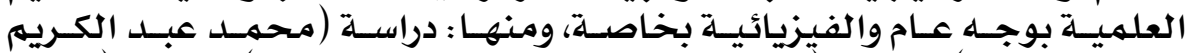

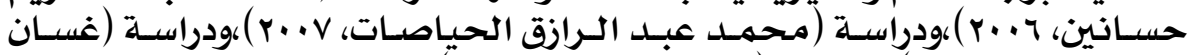

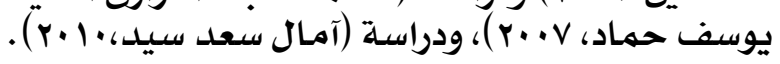

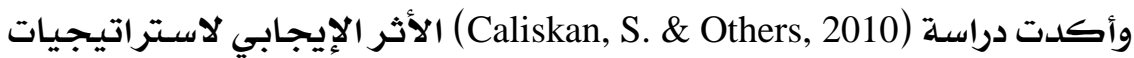

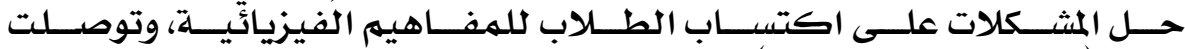

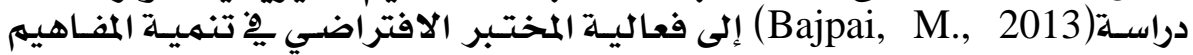
الفيزيائية.

•المور الثالث: الاتجاه نهو الفيرنياء (Attitude Toward Learning Physics):

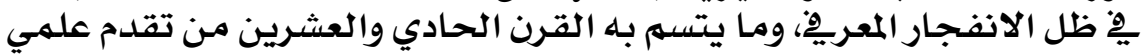

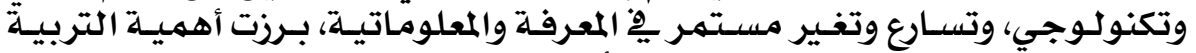

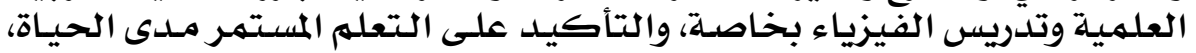

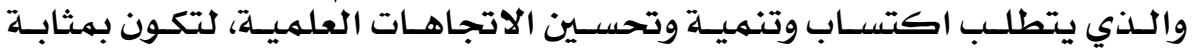

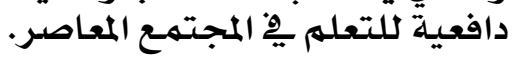

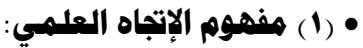

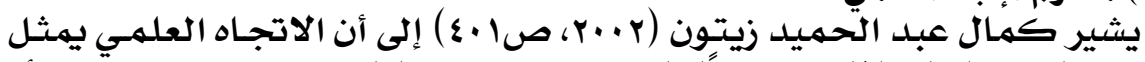

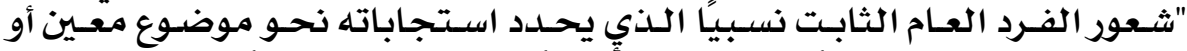

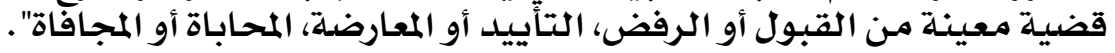

\section{ry}




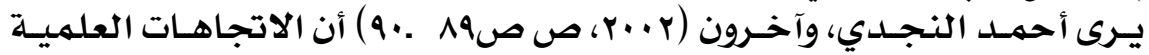

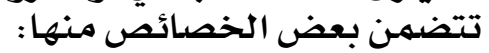

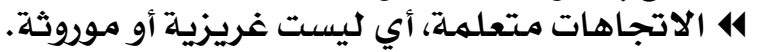
14 الاتجاهات تنبئ بالسلوكاتك.

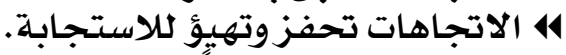

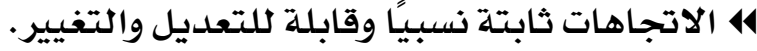
14 الاتجاهات قابلة للقياس.

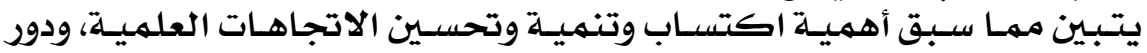

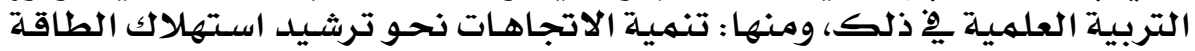

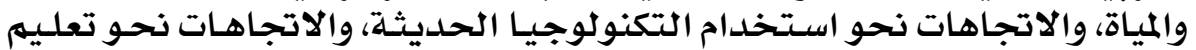
وتعلمم العلوم والفيزياء بلاهوات نحواصدة.

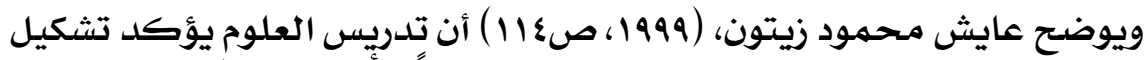

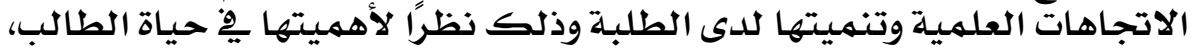

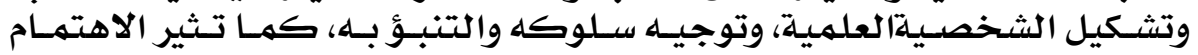

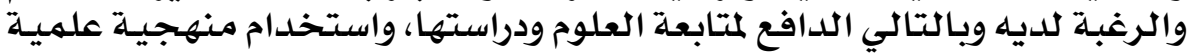

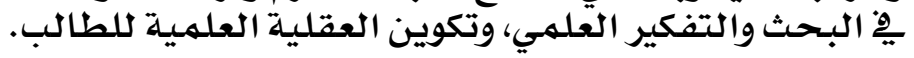

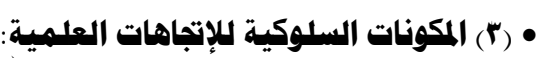

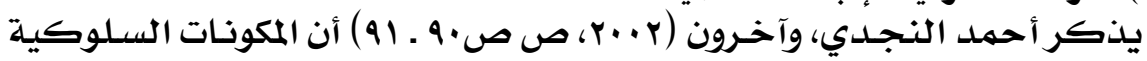

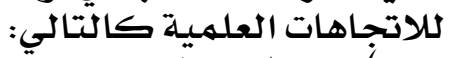

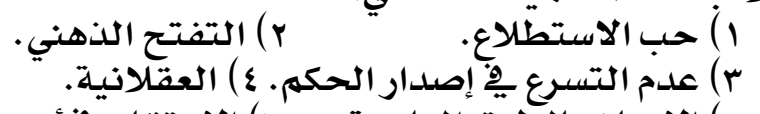

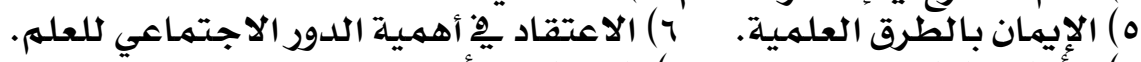

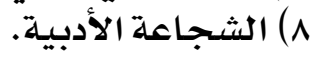

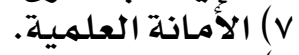
9) الاستعداد لتغيير الرأية.

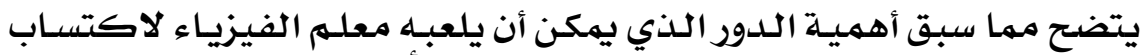

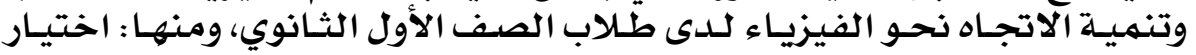

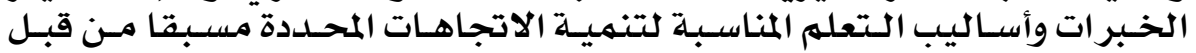

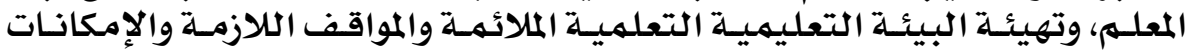

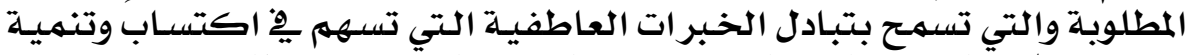

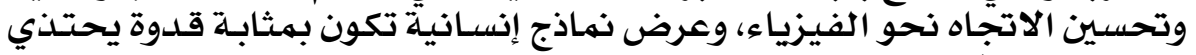

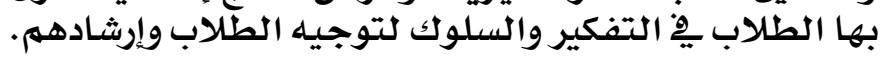

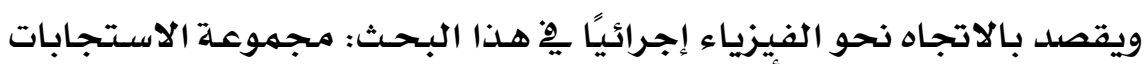

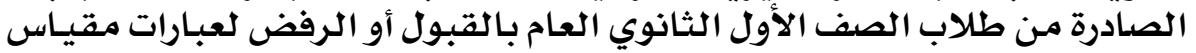

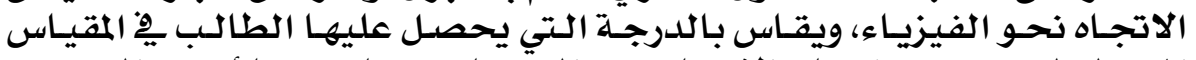

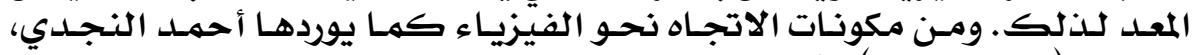

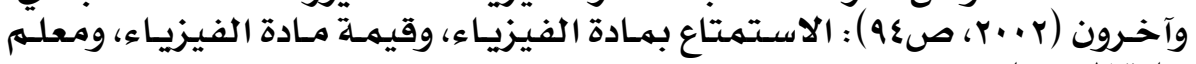
مادة الفيزياء.

\section{rv}




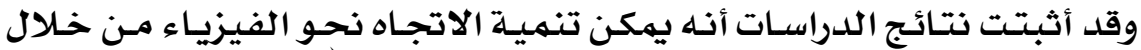

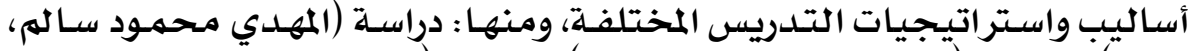

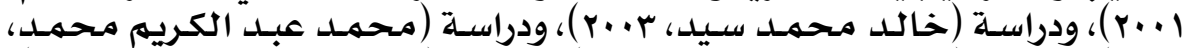

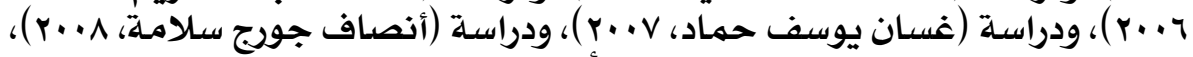

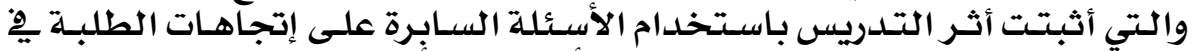

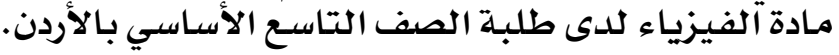

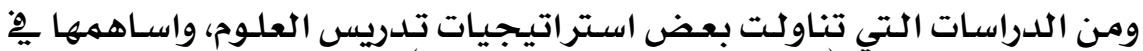

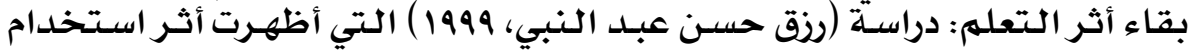

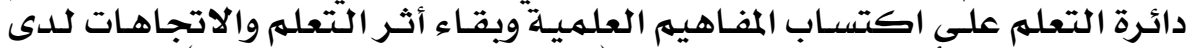

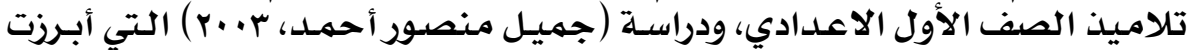

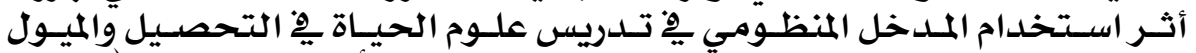

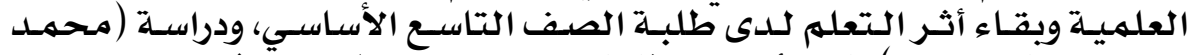

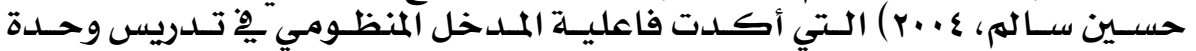

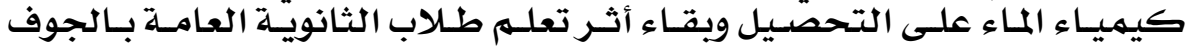
واتجاهاتهم نحوه.

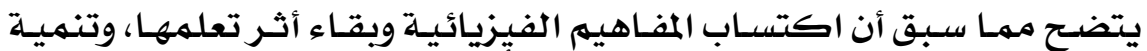

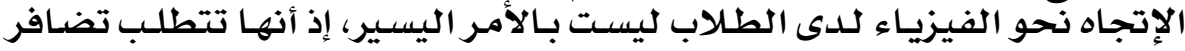

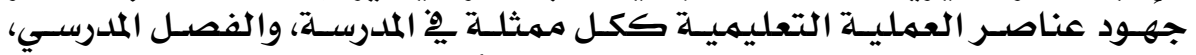

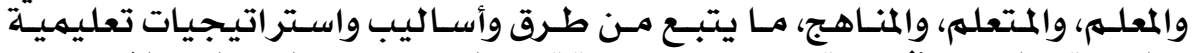

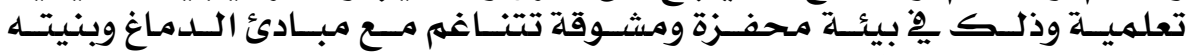

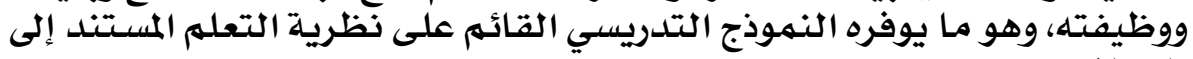
الدماغ.

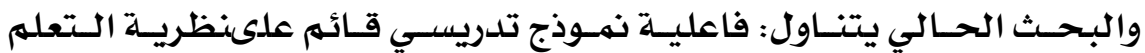

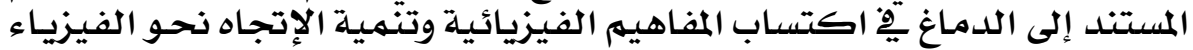

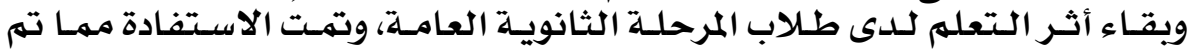

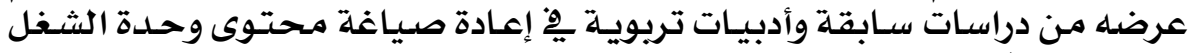

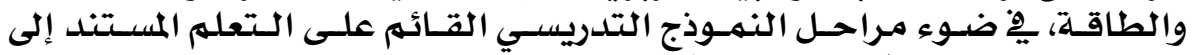

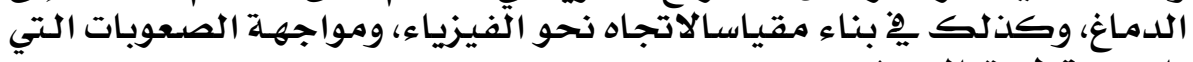
واجهت تطبيق البحثث.

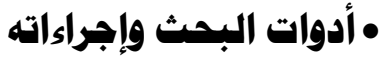

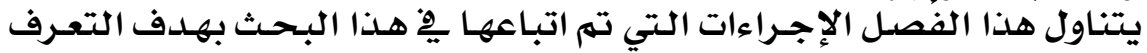

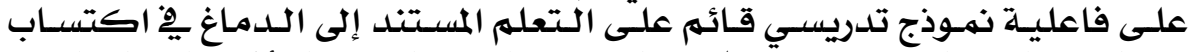

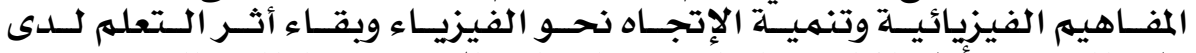

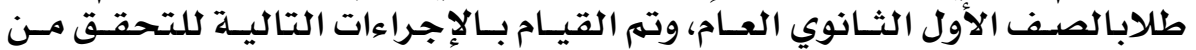

$$
\text { ذلك: }
$$

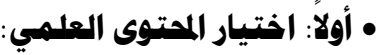

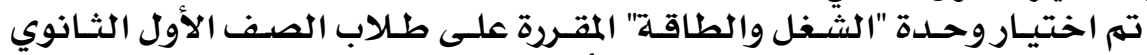

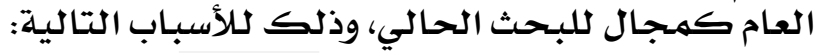

rᄉ 
14 انخفـاض درجـات الطـلاب ِِِ بعـض الاختبـارات الـتي تتضـهن محتـوى وحسدة

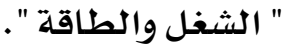
14 احتواء وحلدة "الشغل والطاقة"على مجمهوعة من المفاهيه المجردة التي يصعب

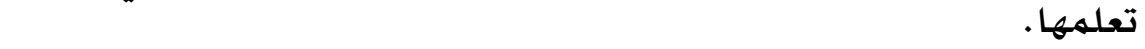
4 تضمن الوحدة موضوعات تثير تساؤلات لدى الطلاب تتيح لهم فرصدة ممارسـة

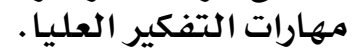

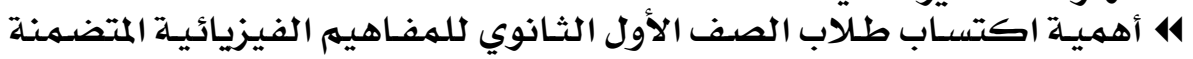

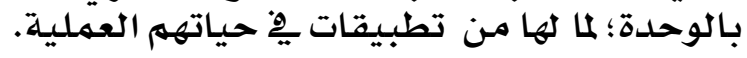

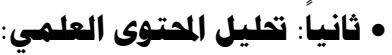

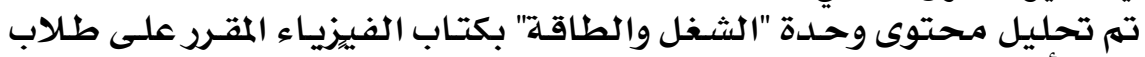

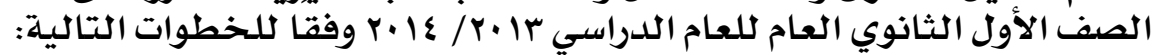

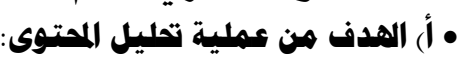

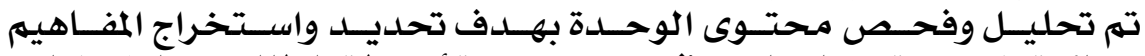

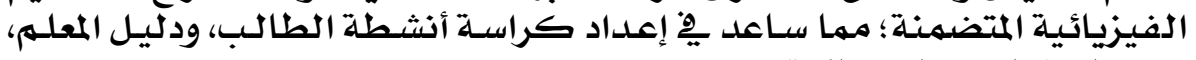
واختبار المفاهيهم الفيزيائية المتية.

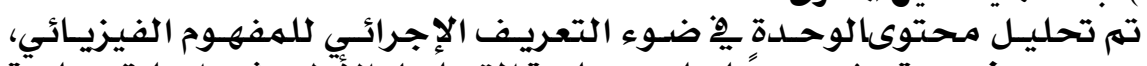

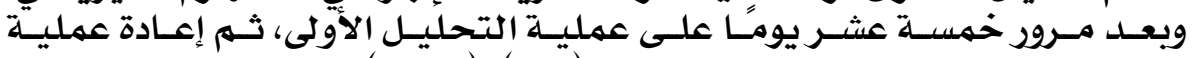

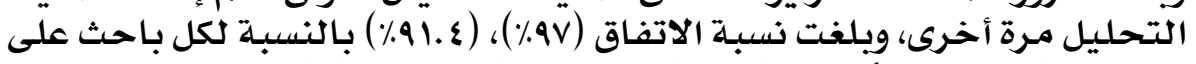

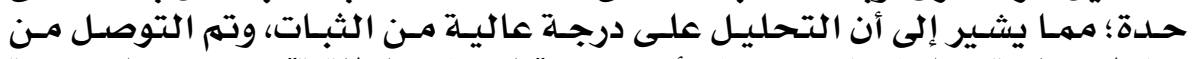

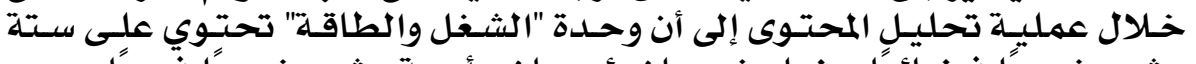

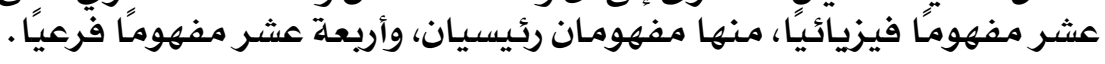

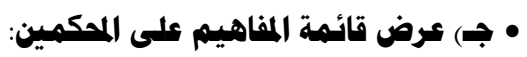

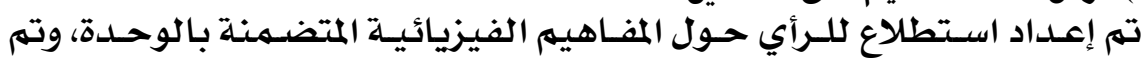

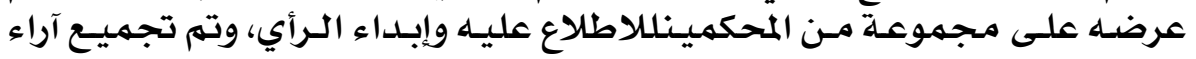

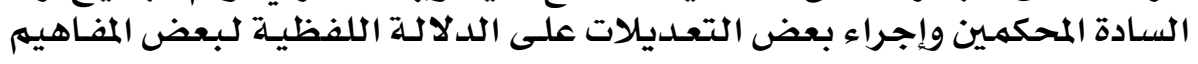

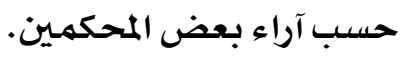

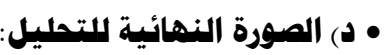

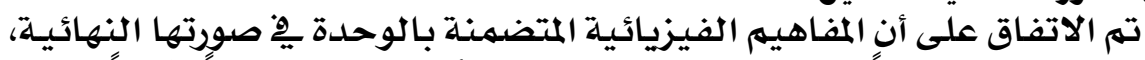

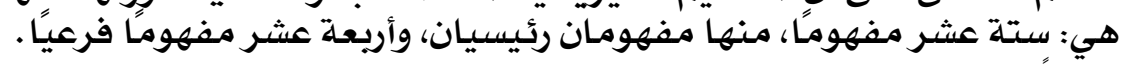

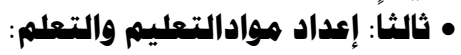

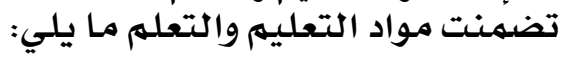

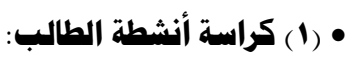

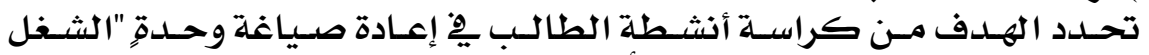

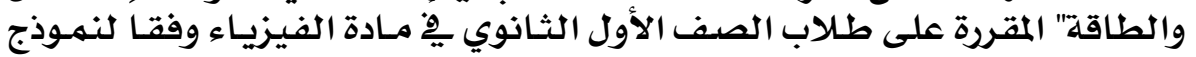

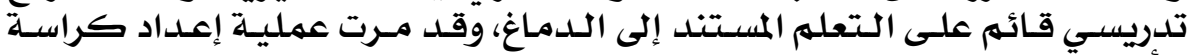

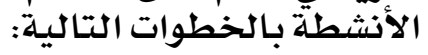

\section{rq}




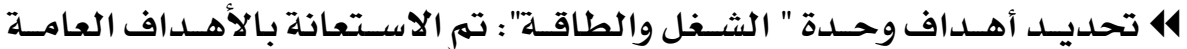

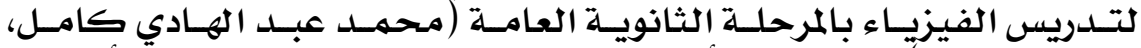

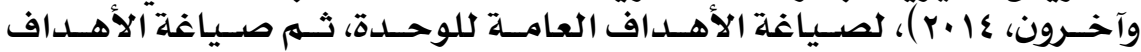

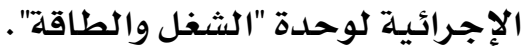
414

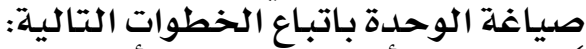

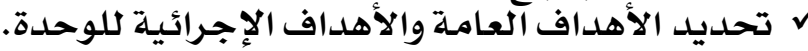

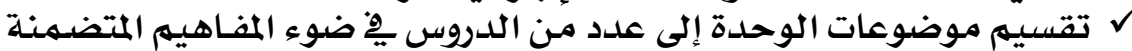

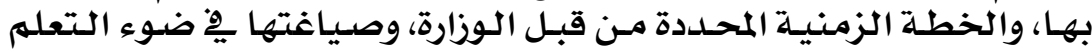

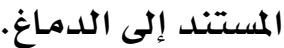

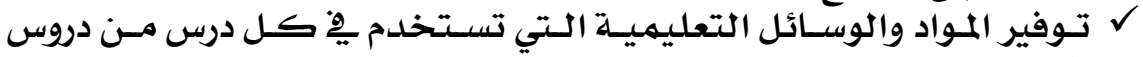

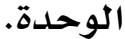

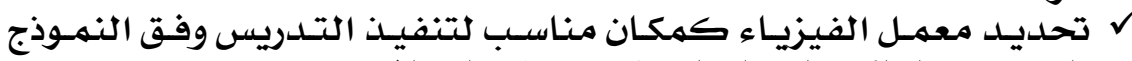

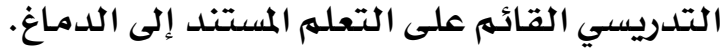

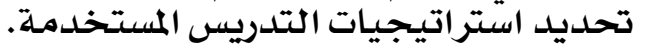

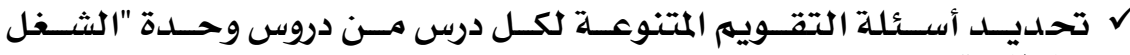
والطاقة".

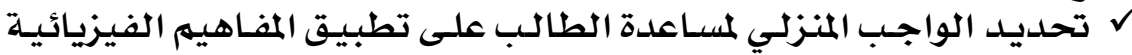

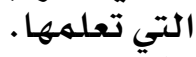

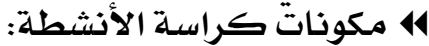

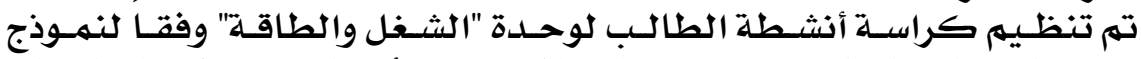

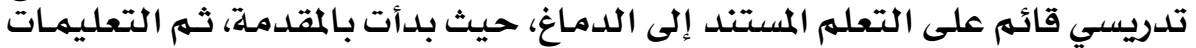

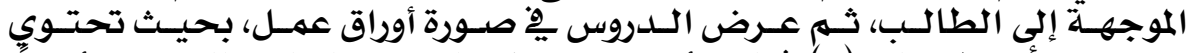

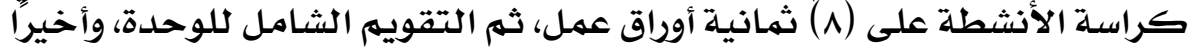

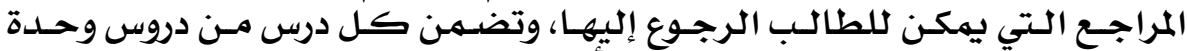

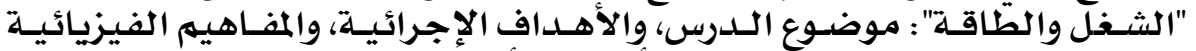

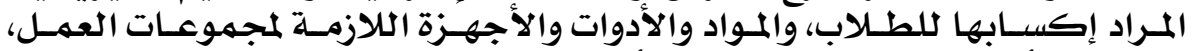

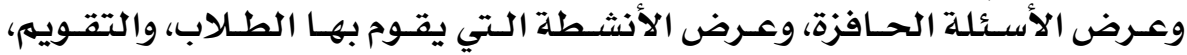

$$
\text { والواجب المنزلي. }
$$

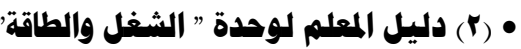

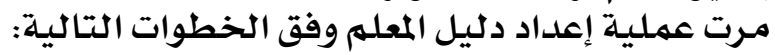

تحديد الهدف هن دليل المعلم: المبل

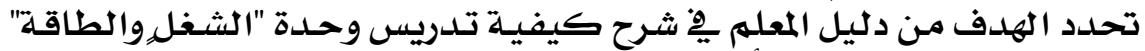

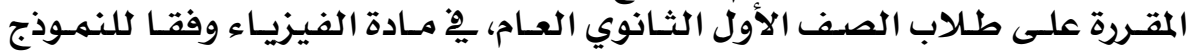

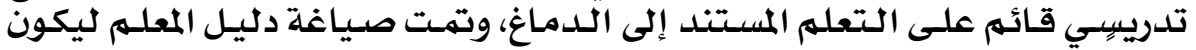

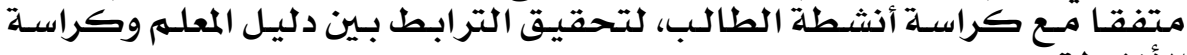


44 مقدمة عن التعلدم المستتد إلى الدماغ.

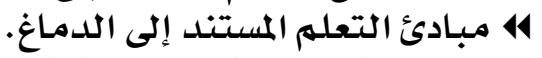

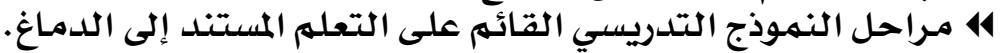

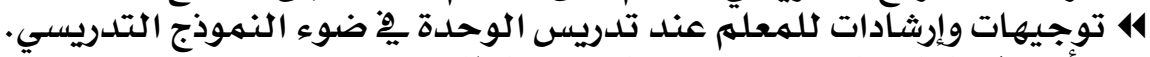

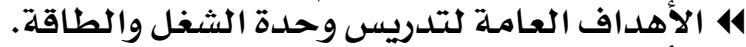

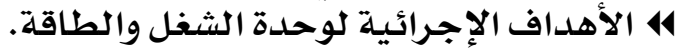

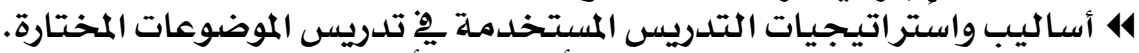

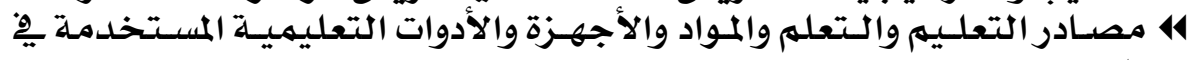
التدريس.

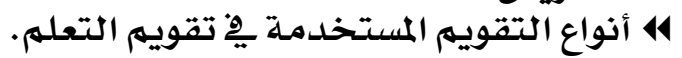

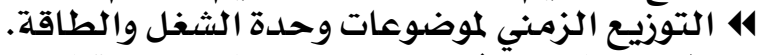

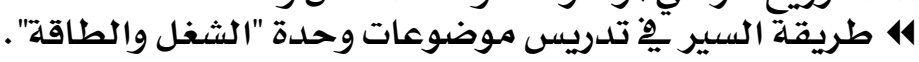

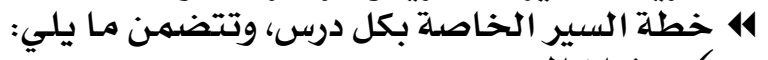
ل $\checkmark$

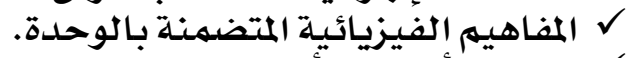
$\checkmark$

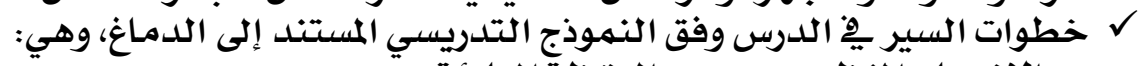

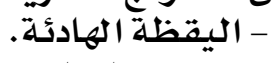
- تقويم التعلهم. - تليقلة

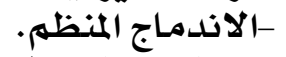

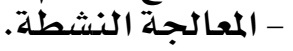
\ إجابة أسئلة التقويهم. $\checkmark$

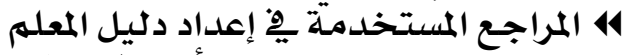

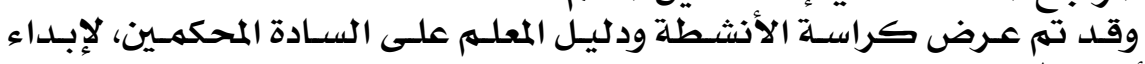

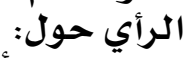

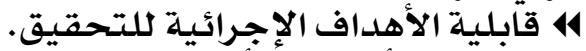

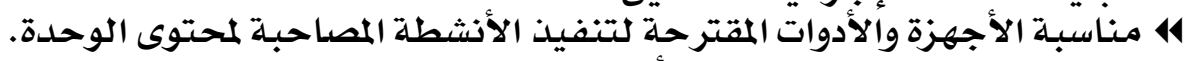

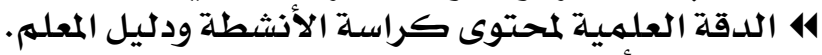

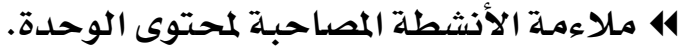

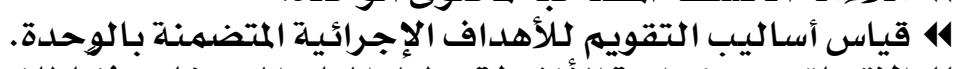

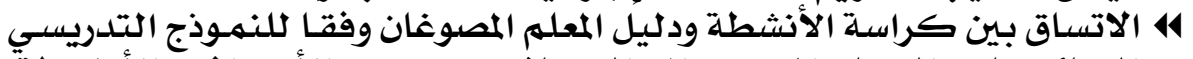

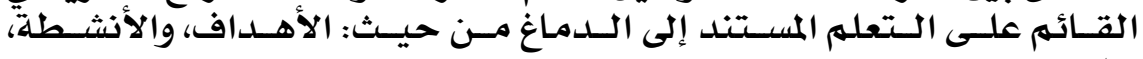

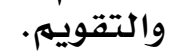

41 حذف أو إضـافة أو تعديل ما يرونه ضروريًا.

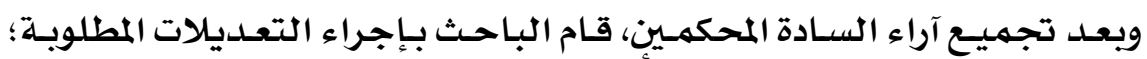

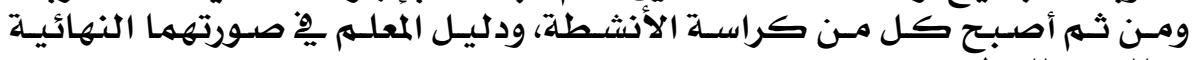
صالحين للتطبيق. • رابعاً: إعداد أداتا القياس لـاست

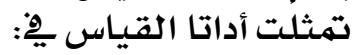

\section{$\varepsilon 1$}




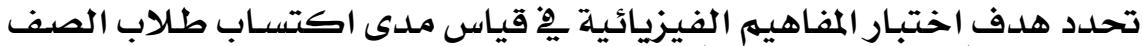

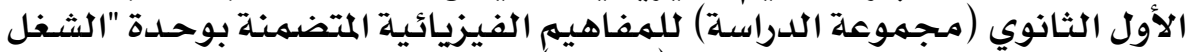

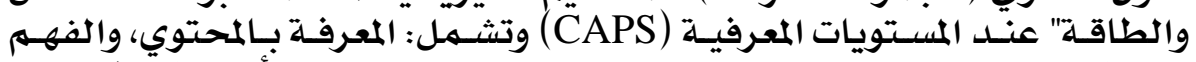

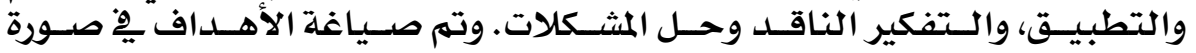

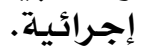

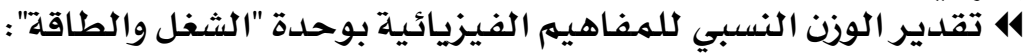

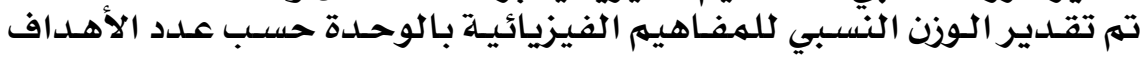

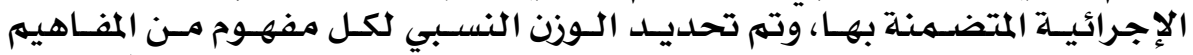

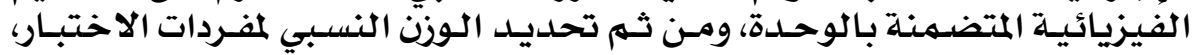

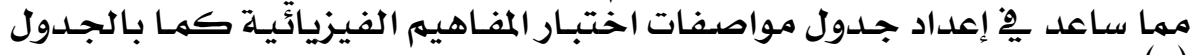

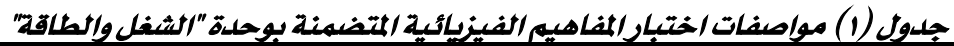

\begin{tabular}{|c|c|c|c|c|c|}
\hline \multirow[t]{2}{*}{ 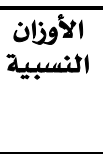 } & \multirow[t]{2}{*}{ الأهداف } & \multicolumn{3}{|c|}{ توزيع الأسئلة طبقأ لمستويات كابس(CAPS) } & \multirow[t]{2}{*}{ المفاهيم الرئيسية وما تتضمنه من مفيم } \\
\hline & & وحلف المشكلات الناقد & والتطبيق & بالمحتوفي & \\
\hline$\% \varepsilon$. & ir & 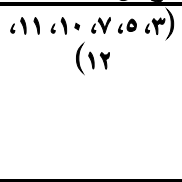 & $(\Lambda, \gamma, \varepsilon, \gamma)$ & $(9,1)$ & 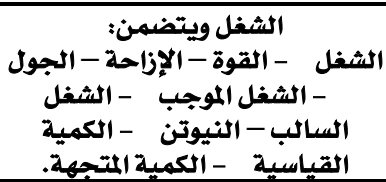 \\
\hline$\%$. & 11 & $(r|, r+,| \gamma)$ & 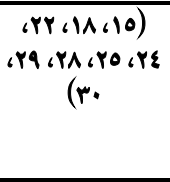 & 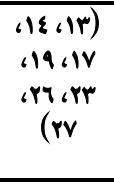 & 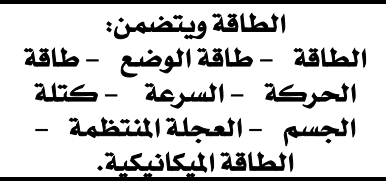 \\
\hline$\%$ & $r$. & 9 & ir & 9 & المجموع \\
\hline$\%$ & & $\% r$. & $\% \varepsilon$. & $\%$ r. & النسب المئوية \\
\hline
\end{tabular}

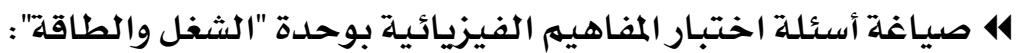

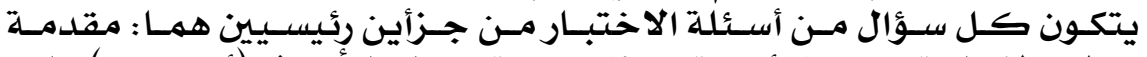

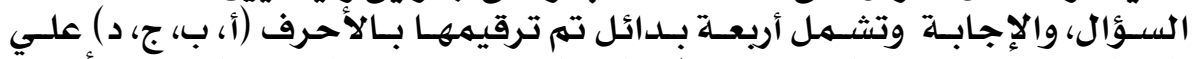

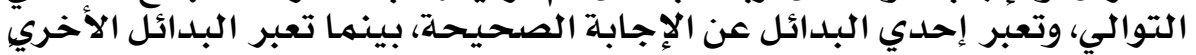

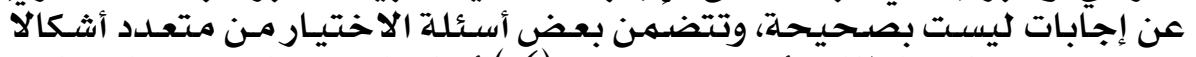

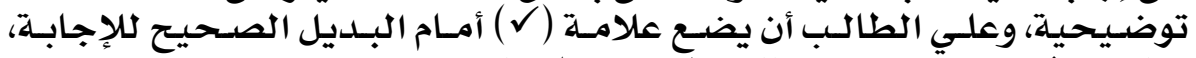

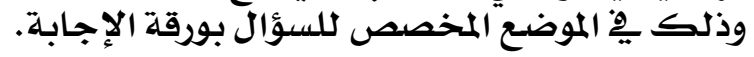
4 تصميهم ورقة الإجابة عن اختبار المفاهيم الفئيزيائية:

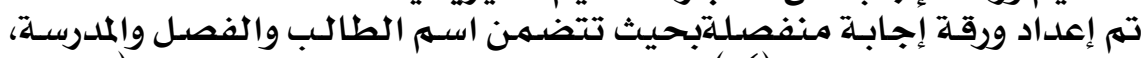

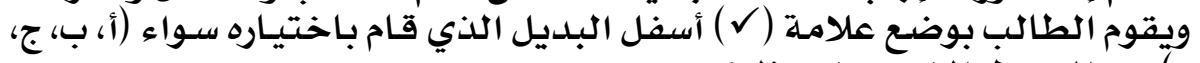

\section{$\varepsilon Y$}


44 تعليمات اختبار المفاهيم الفيزيائية:

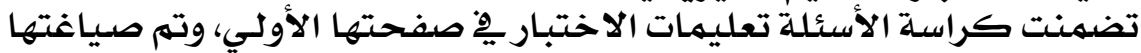

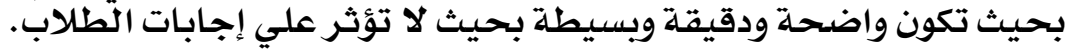

414

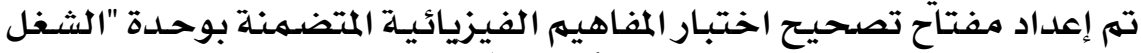

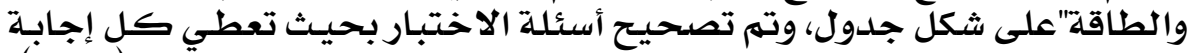

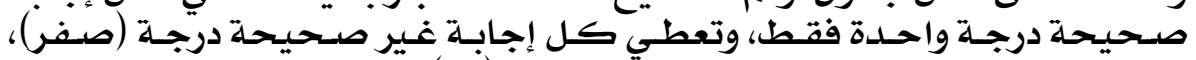

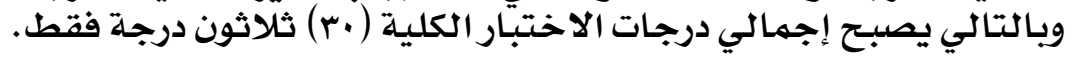

4 هساب القيم الإحصائية للاحتبار: صدق الحتوى (صدق المكمين):

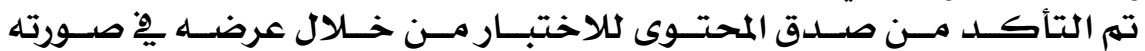

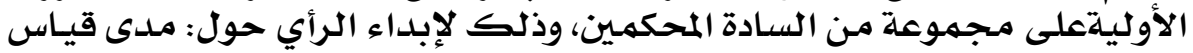

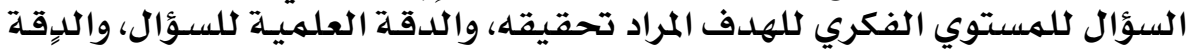

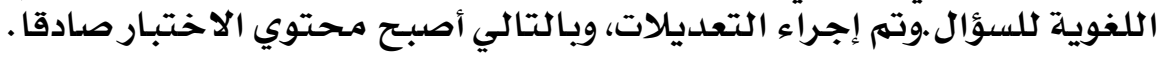

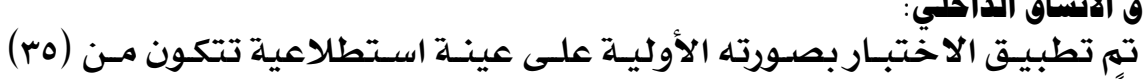

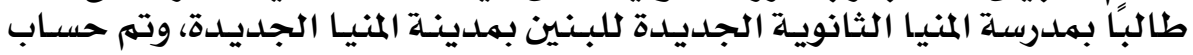

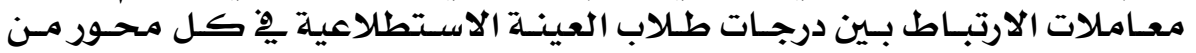

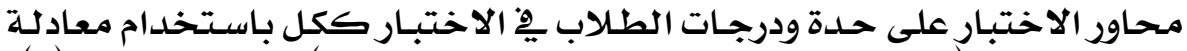

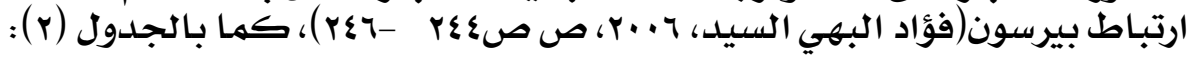

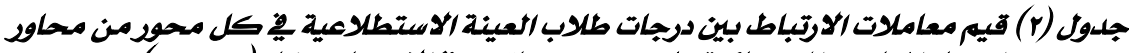

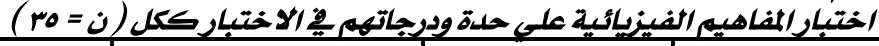

\begin{tabular}{|c|c|c|c|}
\hline الناقد وحل المشكلات & الفهم والتطبيق & المعرفة بالمحتوى & محاور اختبار المفاهيمي \\
\hline. VVTV & •.^१ץ & - AYY & معاملات الارتباط \\
\hline
\end{tabular}

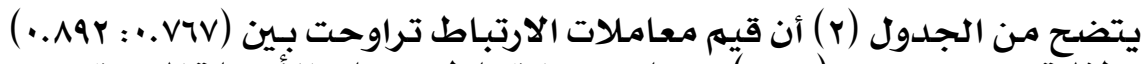

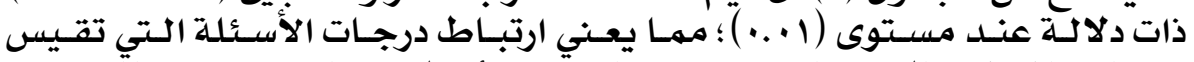

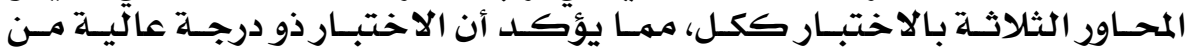

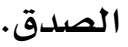

حساب هعاهلات السهولة والصعوبة والتمييز للفردات الاختبار:

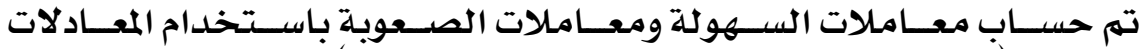

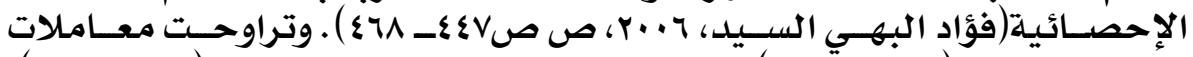

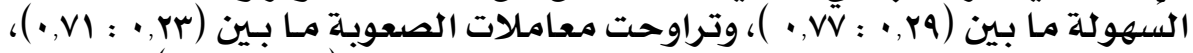

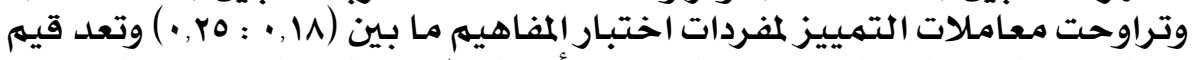

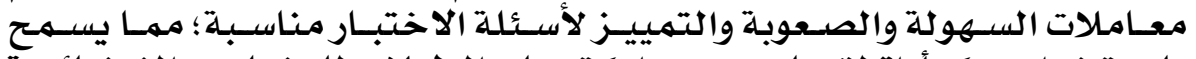

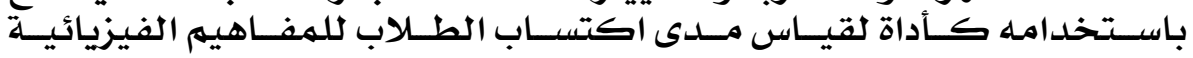

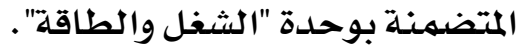




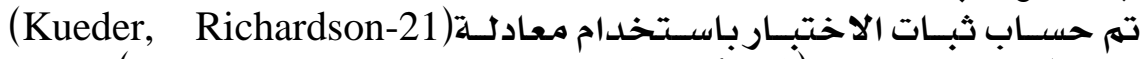

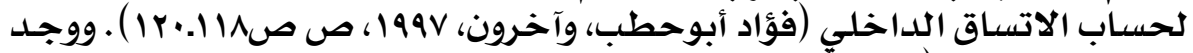

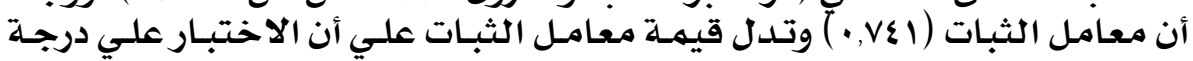

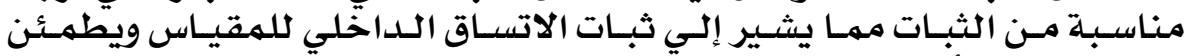
لاستخدامـه كأداة للقياس.

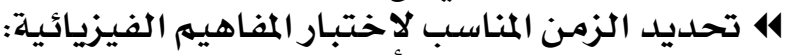

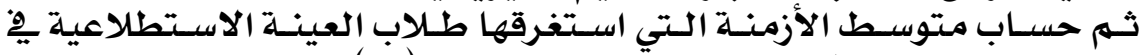

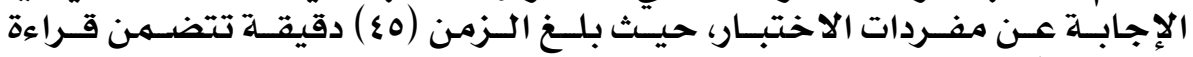

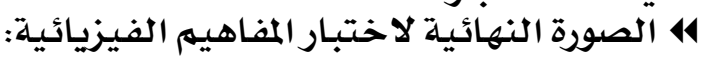

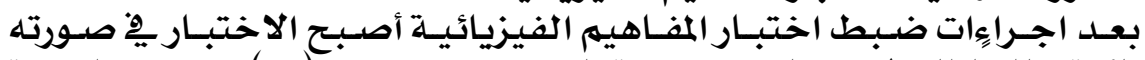

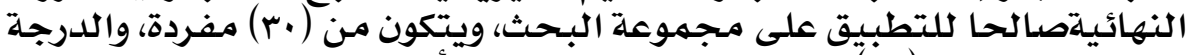

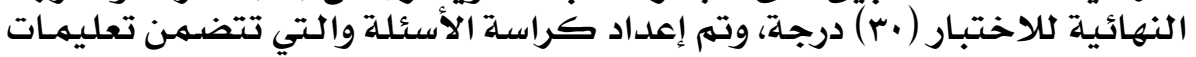

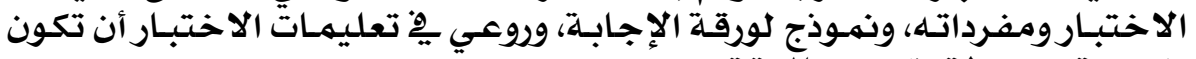

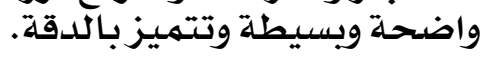

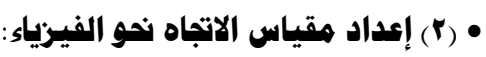

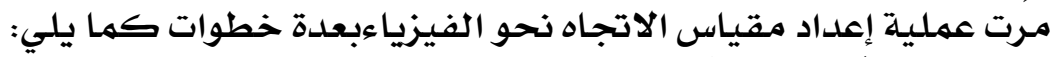

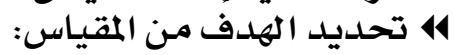

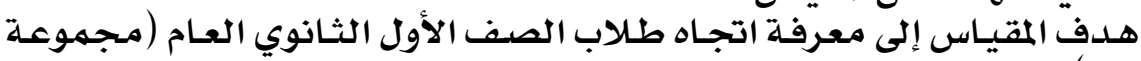

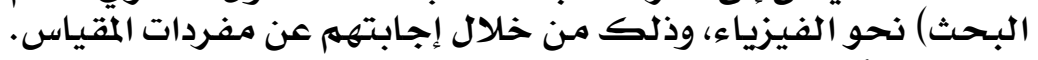

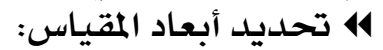

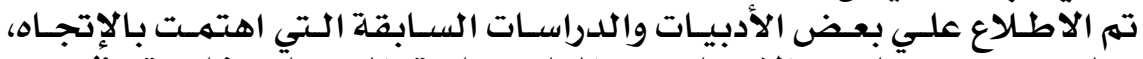

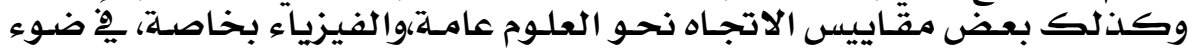

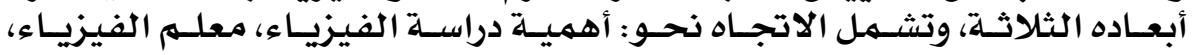

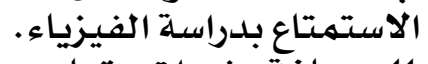

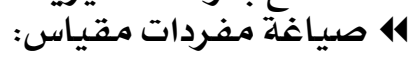
وروعي عندصياغة مفردات مقيانة مفردات المقياس:مناسبتها لأبعاد المقيـاس المحسددة، ووضدوح

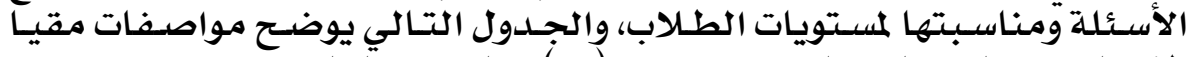

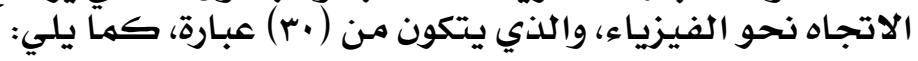

جلدول (r) مواصفات مقياس الاتجاه نحو الفيزياء

\begin{tabular}{|c|c|c|c|c|}
\hline الأوزان النسبية & عدد العبارات & العبارات السالبية & العبارات الموحبة & أبعاد المقياس \\
\hline \% & 1. & Yq,rY, 19 ،o,r & IA, Ir، 7,9, & الاستمتاع بلراسة الفيزياء \\
\hline \% & 1. & 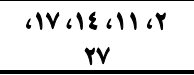 & $r \cdot d Y \varepsilon, r+c r c \varepsilon$ & معلم الفيزياء \\
\hline \%rr,rry & 1. & $\begin{array}{c}\text { Grr } / Y 1 / 10, I Y \\
\text { YO }\end{array}$ & 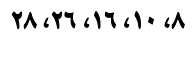 & أهمية دراسة الفيزياء \\
\hline$\% 1 \ldots$ & $r$. & 10 & 10 & المجموع \\
\hline$\% 1 \ldots$ & $r$. & $\%$. & $\%$. & النسب المئوية \\
\hline
\end{tabular}


4 تعليمات المقياس: 14

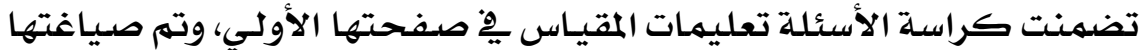

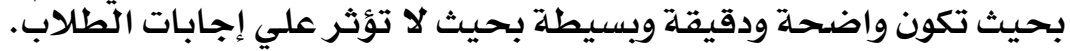

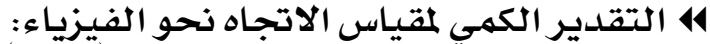

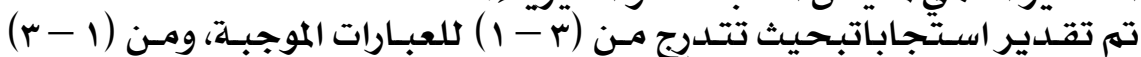

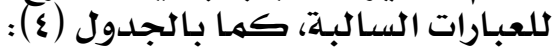
جلدول (ع) التقلير الكمي لمقياس الاتجاه نحو الفيزياء

\begin{tabular}{|c|c|c|c|}
\hline غير موافق & فير متاكد & موافق & نوع العبارة الاستجابات \\
\hline 1 & $r$ & $r$ & موجية \\
\hline r & $r$ & 1 & سالبة \\
\hline
\end{tabular}

14 الضبط الإحصائي لمقياس الاتجاه نحو الفيزياء: صدق المتوي (صدق المكمين):

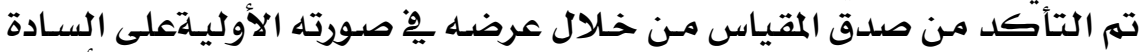

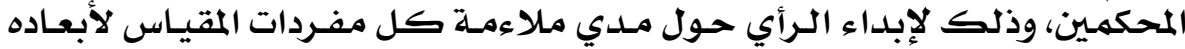

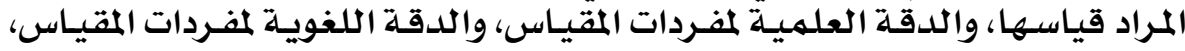

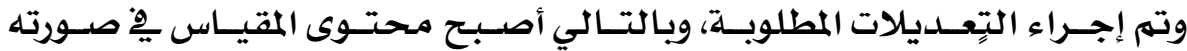

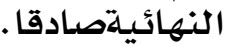

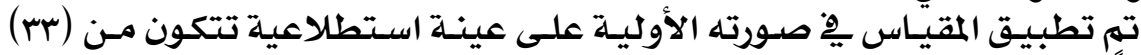

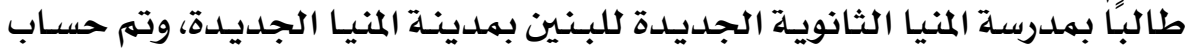

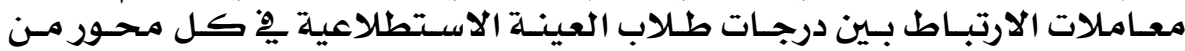

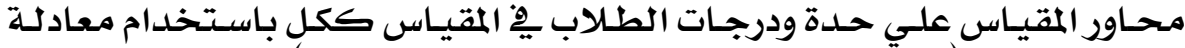

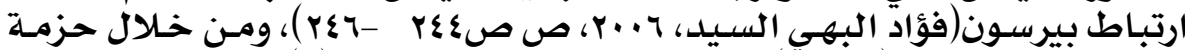

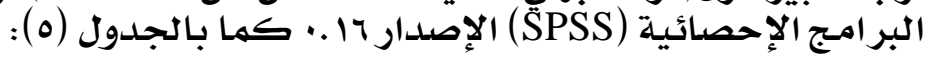

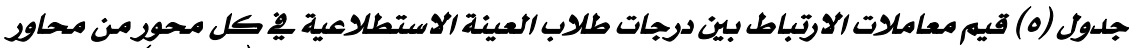

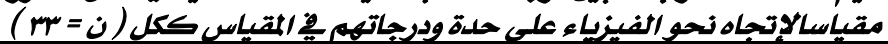

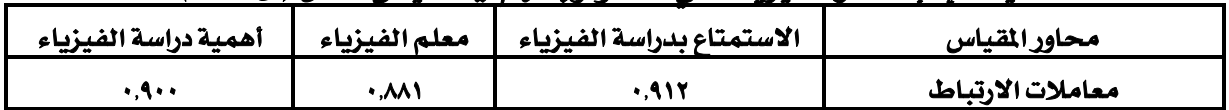

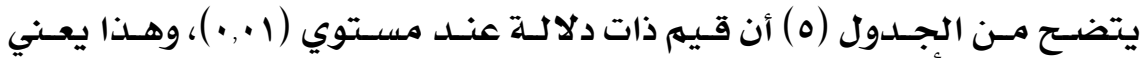

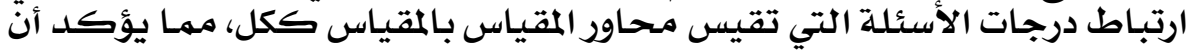

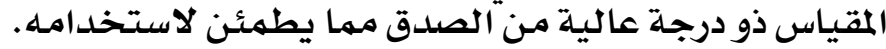

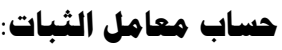

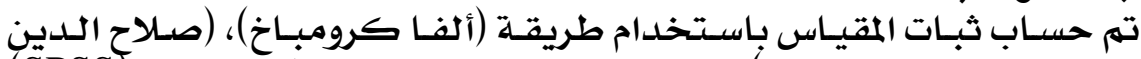

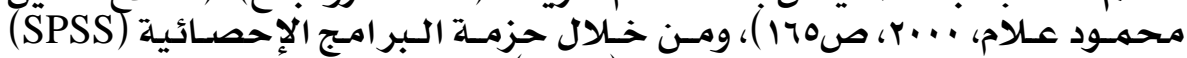

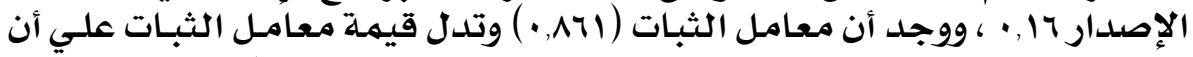

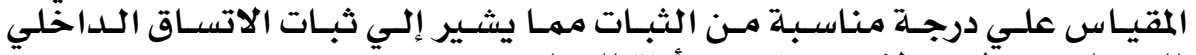

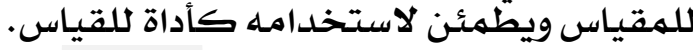


4 تحديد الزمن المناسب لمقياس الإتجاه نحو الفيزياء:

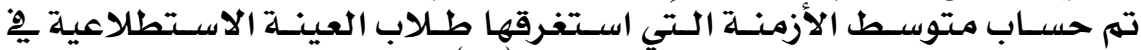

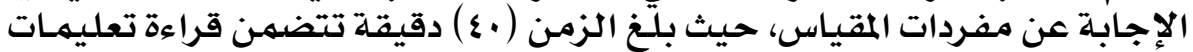

41 الصورة النهائية للهقياس:

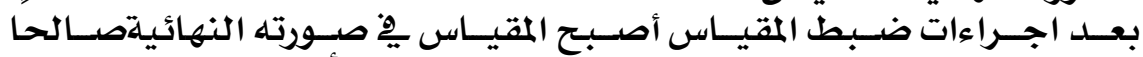

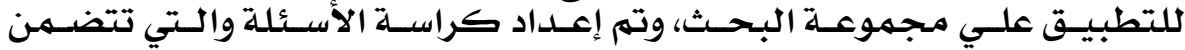

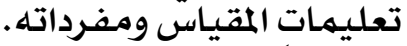

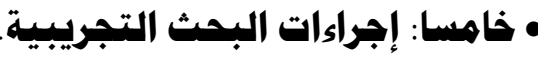

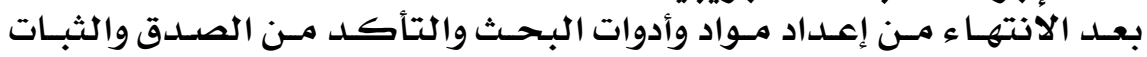

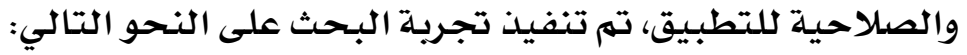
• (أ) إجراءات الإعداد لتجربة البحث:

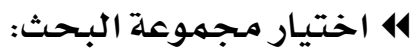

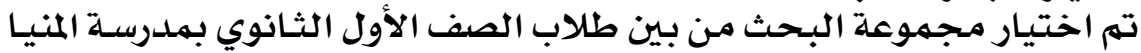

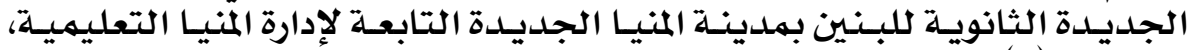

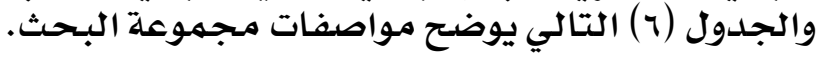

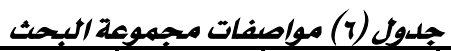

\begin{tabular}{|c|c|c|c|c|}
\hline طريقة التدريس المستخدمة & الجنس & عدد الطلاب & الفصل & مجموعة البحث \\
\hline الطريقة المعتادة & بنين & $r v$ & $\varepsilon / 1$ & المجموعة الضابطة \\
\hline ثموذج تلدريسي قائم علي التعلم المستند إلىي & بنين & $r \varepsilon$ & $r / 1$ & المجموعة التجريبية \\
\hline
\end{tabular}

414 الحصول على الموافقات الرسمية لتطبيق تجرية البـحث:

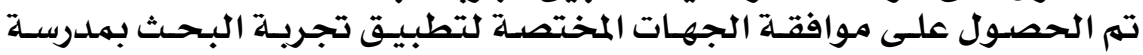

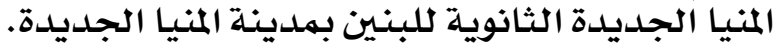

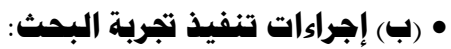

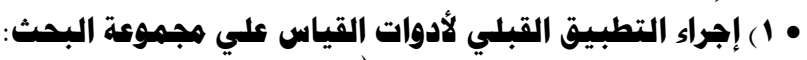

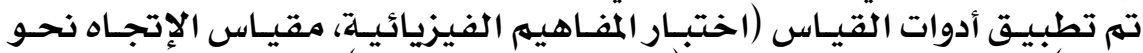

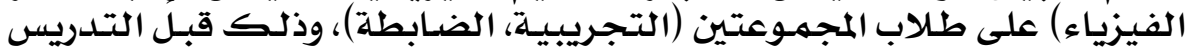

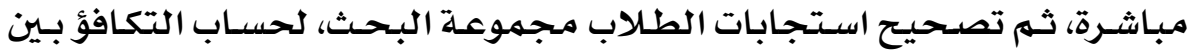

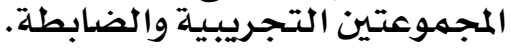

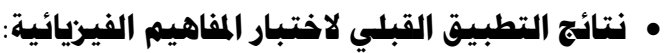

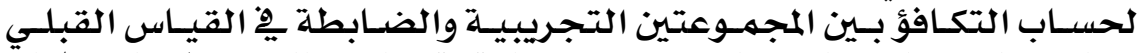

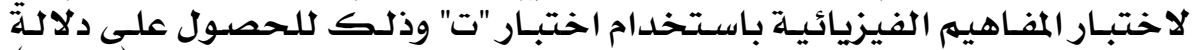

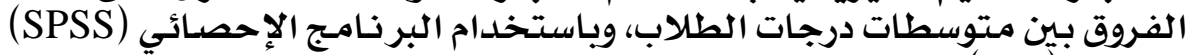

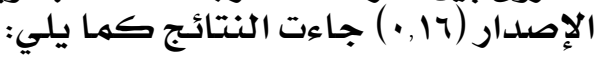




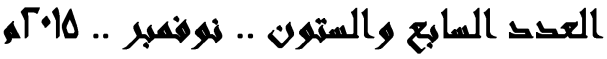

جلول (v) قيمة "ت" للفروق بين متوسطي درجات طلاب المجموعة التجريبية والضابطة فِ التطبيق

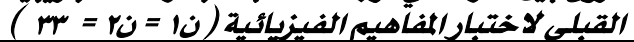

\begin{tabular}{|c|c|c|c|c|c|c|c|c|}
\hline \multirow[t]{2}{*}{ الدلالة } & \multirow[t]{2}{*}{$\Xi$} & \multirow{2}{*}{ الفترقطين } & \multicolumn{2}{|c|}{ الضابطة } & \multicolumn{2}{|c|}{ التجريبية } & \multirow{2}{*}{ الكلية الدرجة } & \multirow[t]{2}{*}{ محاور الاختبار } \\
\hline & & & $\varepsilon$ & م & $\varepsilon$ & م & & \\
\hline غير دالة & $\cdot, \mathrm{V} \cdot \varepsilon$ & $\cdot,+r$ & $1, \wedge 1$ & $r, Y V$ & $1, \varepsilon \wedge$ & $r, r$ & 9 & المعرفة بالمحتوي \\
\hline غير دالة & •, Aro & $\bullet, r \varepsilon$ & 1,9 & r,vi & $1, Y \Lambda$ & $r, \varepsilon Y$ & ir & الفهه والتطبيق \\
\hline غير دالة & . & $\cdot, 10$ & $1, Y_{0}$ & $r, T I$ & $1, \mathrm{TM}$ & Y,VT & 9 & الناقد وحل المشكلات \\
\hline غير دالة & $\cdot, I V A$ & $\cdot, 17$ & $\mathrm{r}, \mathrm{OV}$ & $9,7 \varepsilon$ & r,ro & $9, £ \wedge$ & $r$. & المجموع الكلي \\
\hline
\end{tabular}

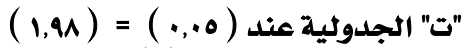

يتضح من الجدولية الجدول (v) (v) ما ميلي:

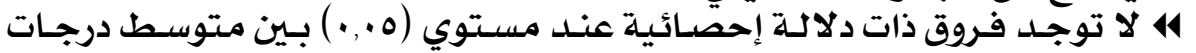

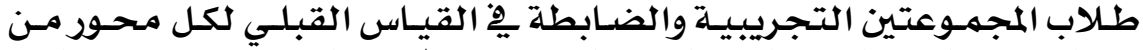

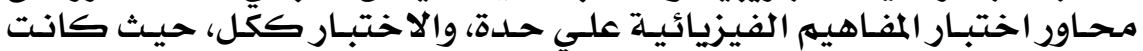

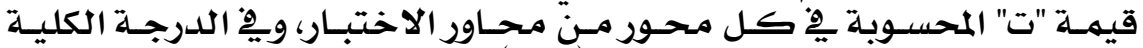

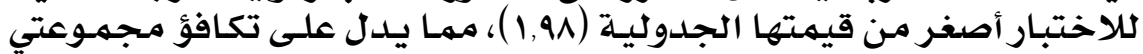

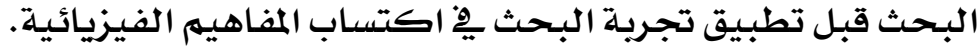

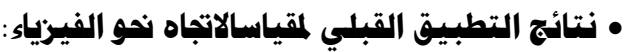

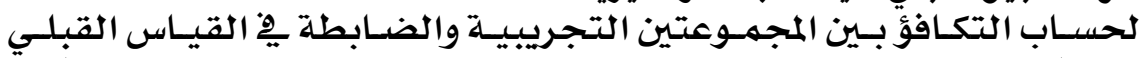

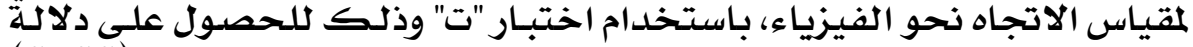

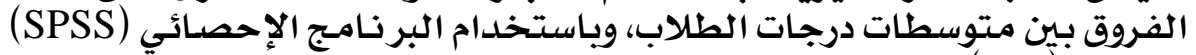

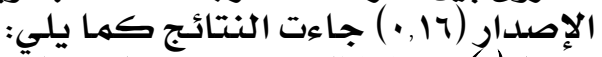
جلدول (1) قيمة "ت" للفروق بين متوسطي درجاتي طلاب المجموعة التجريبية والضابطة فِ التطبيق

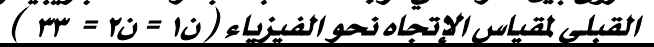

\begin{tabular}{|c|c|c|c|c|c|c|c|}
\hline \multirow[t]{2}{*}{ الدلالة } & \multirow[t]{2}{*}{ ت } & \multirow{2}{*}{ المتوسطين بين } & \multicolumn{2}{|c|}{ الضابطة } & \multicolumn{2}{|c|}{ التحرييية } & \multirow{2}{*}{ أبعاد المقياس } \\
\hline & & & $\varepsilon$ & م & $\varepsilon$ & م & \\
\hline فير دالة & •,rir & $\cdot,\{Y$ & $0, \sqrt{ } y$ & $19,9 \varepsilon$ & $0, Y 4$ & $19,0 Y$ & الاستمتاع بلراسة الفيزياء \\
\hline فير دالة - مي & $\cdot, 0 \wedge 9$ & . & $\varepsilon, \mathrm{rq}$ & YI,or & $\varepsilon, 17$ & $r \cdot, 91$ & معلم الفيزياء \\
\hline فير دالة &., 071 & $\cdot, \mathrm{VA}$ & $0, \wedge 7$ & rr,rq & $0, r 9$ & $r Y, T 1$ & أهمية دراسة الفيزياء \\
\hline فير دالة &., $0 \varepsilon$. & I,Ar & $1 \varepsilon,\{\Lambda$ & 70,1 & IY,AY & $T r, r V$ & المجموع الكلي \\
\hline
\end{tabular}

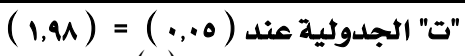

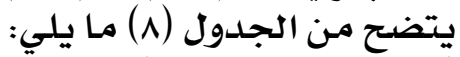

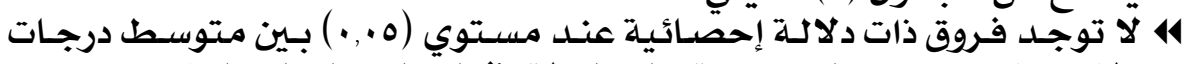

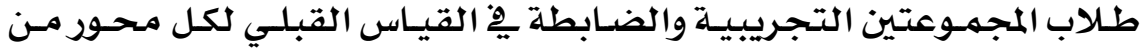

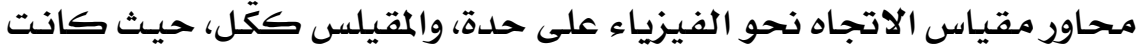

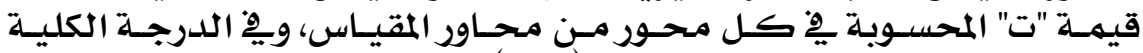

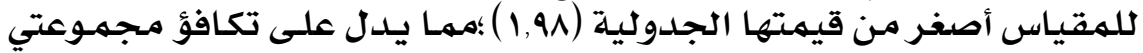

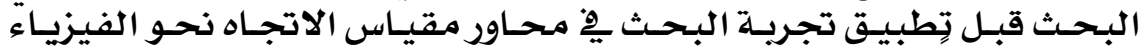

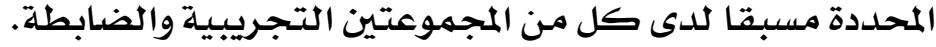

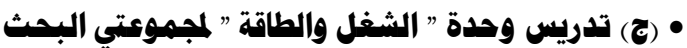

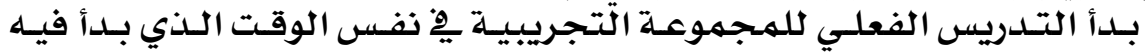

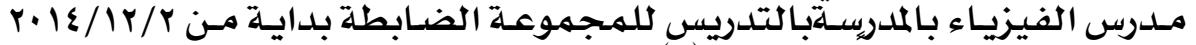

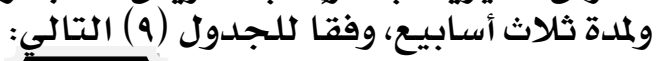
$\varepsilon V$ 
العقد السابي والستون .. نهوهمبر ..

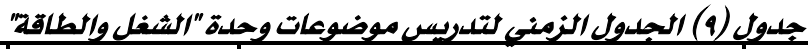

\begin{tabular}{|c|c|c|c|}
\hline عدد الأسابيع & عدد الحصص & الموضوعات & المعالحة التحريبية \\
\hline$r$ & $\Lambda$ & الشغل، الطاقة، طاقة الحركة، الطاقة & الشغل والطاقة \\
\hline 1 & $\varepsilon$ & قانون بقاء الطاقة، الطاقة الميكانيكية، قانون & قانون بقاء الطاقية \\
\hline$r$ & ir & المجموع & \\
\hline
\end{tabular}

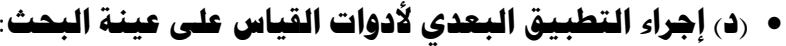

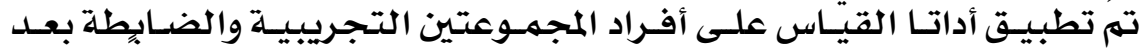

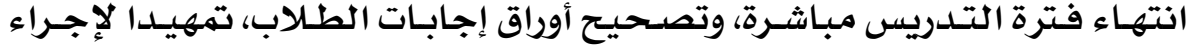

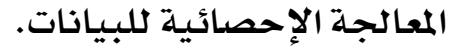

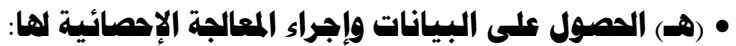

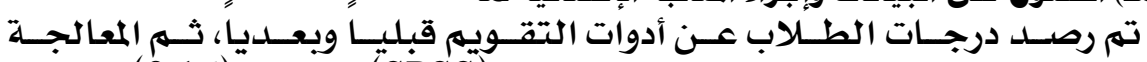

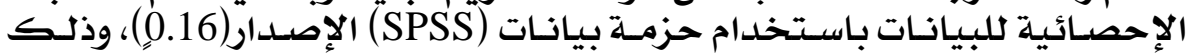

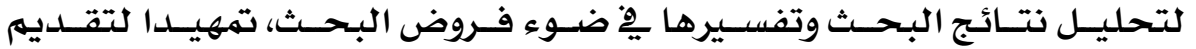

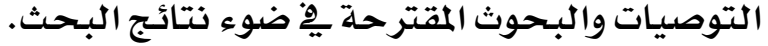

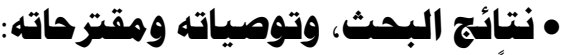

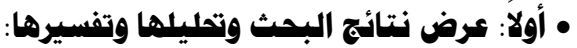

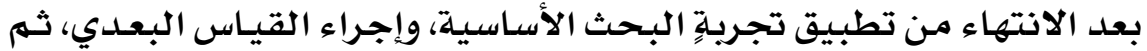

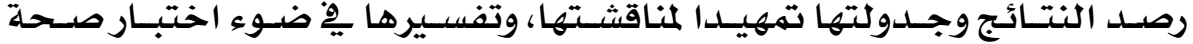

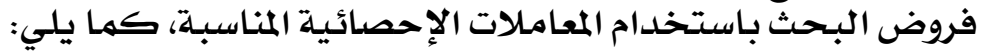

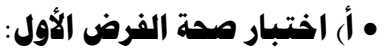

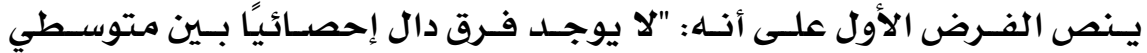

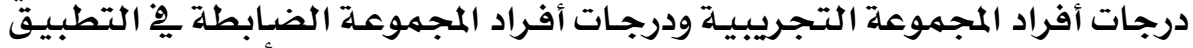

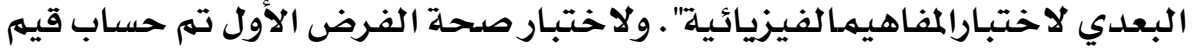

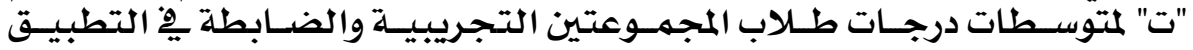

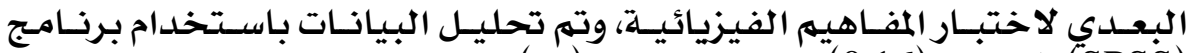

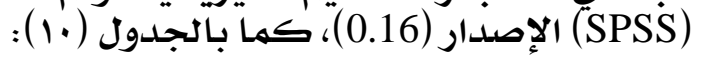

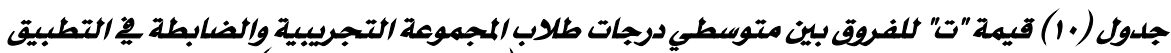

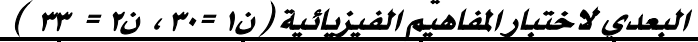

\begin{tabular}{|c|c|c|c|c|c|c|}
\hline الفرقة & "ت" المحسوية & الإنحراف المعياري & الحتوسطي & المجمومة & الدرجة & محاور الاختبار \\
\hline \multirow[t]{2}{*}{ دالة } & \multirow[t]{2}{*}{$v .4 u^{\prime}$} & r.1. & V.YV & التحريبية & \multirow[t]{2}{*}{9} & \multirow{2}{*}{ بالمحتوفي } \\
\hline & & 1.9. & r.rq & الضابطة & & \\
\hline \multirow[t]{2}{*}{ دالة } & \multirow[t]{2}{*}{$1 . . V Y A$} & $r_{0.9}$ & A. Tr & التجريبية & \multirow[t]{2}{*}{ ir } & \multirow{2}{*}{ والتطبيقي } \\
\hline & & $1.7 \varepsilon$ & r.01 & الضابطة & & \\
\hline \multirow[t]{2}{*}{ دالة } & \multirow[t]{2}{*}{$9.0 Y 1$} & 1.07 & 7.9. & التحريية & \multirow[t]{2}{*}{9} & \multirow{2}{*}{ التفكير الناقد } \\
\hline & & 1.71 & $r .1$ & الضابطة & & \\
\hline \multirow[t]{2}{*}{ دالة } & \multirow[t]{2}{*}{$11 .+r}$. & $0 . .0$ & YY.A. & التجريبية & \multirow[t]{2}{*}{$r}$. & \multirow[t]{2}{*}{ الدرجة الكلية } \\
\hline & & $\varepsilon .11$ & $1 . . .0$ & الضابطة & & \\
\hline
\end{tabular}

"ت" الجلدولية عند (0...) = (1.91) 


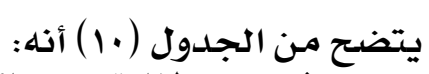

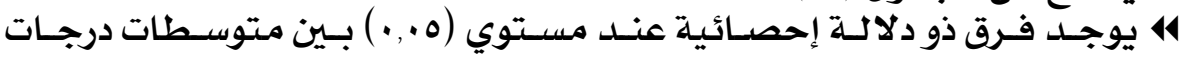

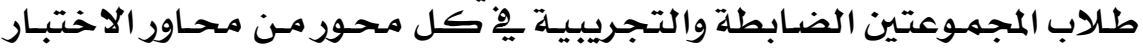

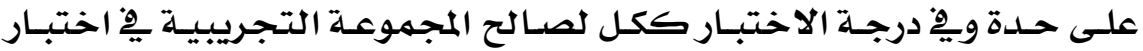

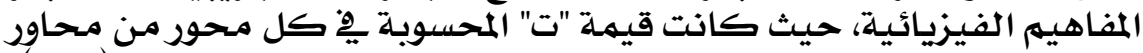

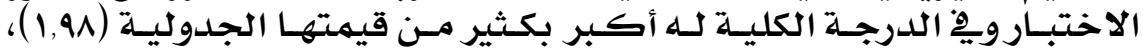

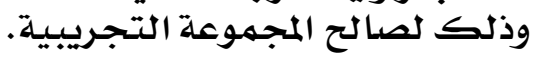

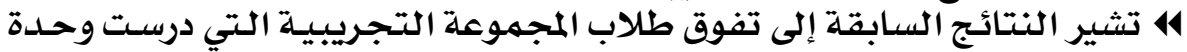

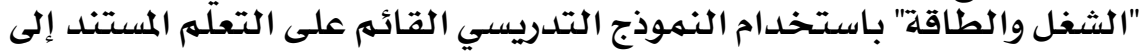

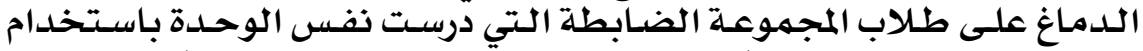

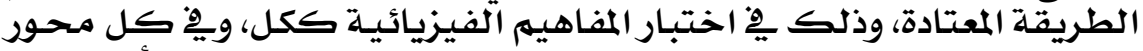

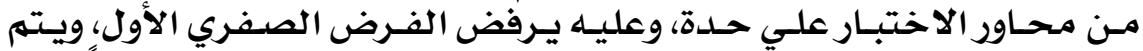

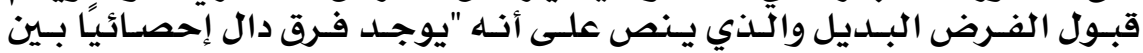

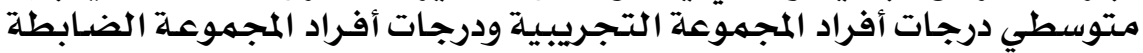

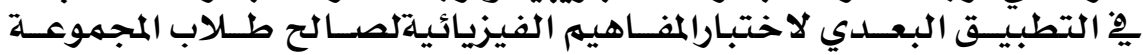

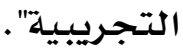

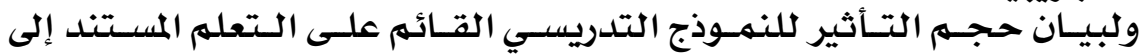

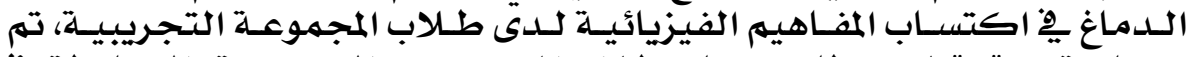

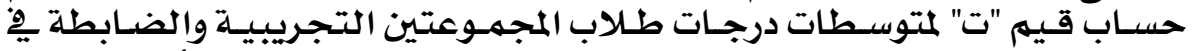

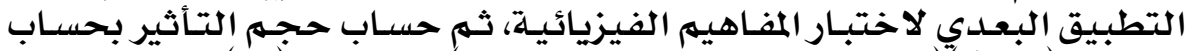

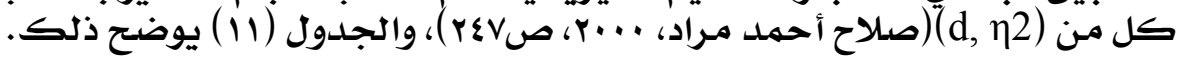

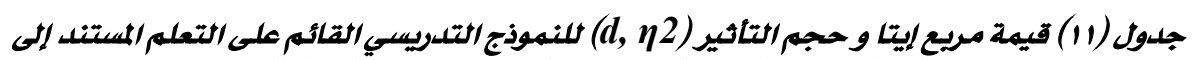

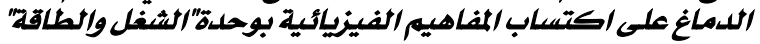

\begin{tabular}{|c|c|c|c|c|c|c|}
\hline التأثير & $\mathbf{d}$ & $\eta 2$ & تr & ت & المتغير التابع & المتغير المستقل \\
\hline كبيرجلًا & $r .10$ &. $.7 V$ & $|r|, V$ & $11 . . r$ & الفيزياثيميم & التموذج التدريسي ألثى الدائم على التماغ \\
\hline
\end{tabular}

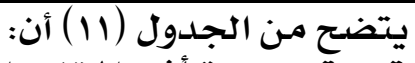

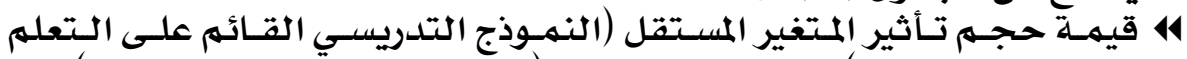

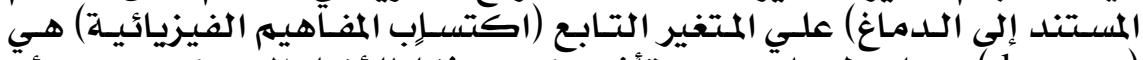

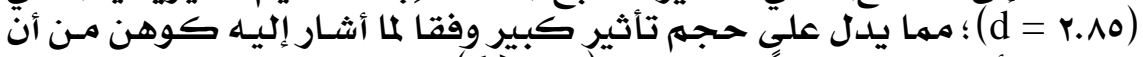

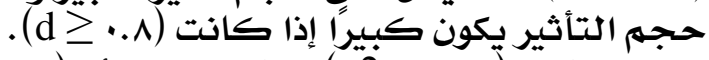

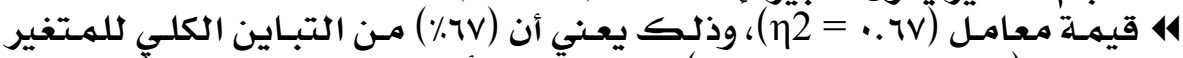

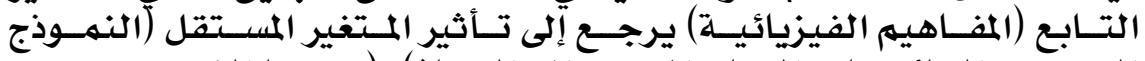

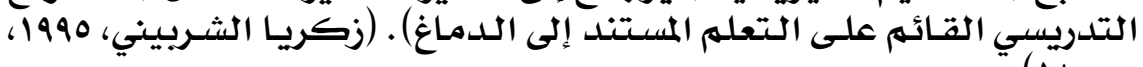

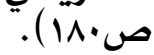

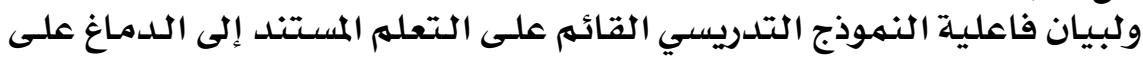

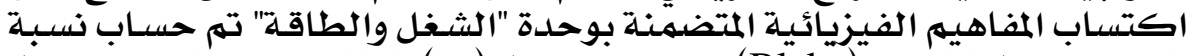

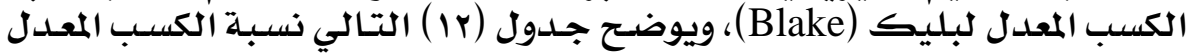

\section{$\varepsilon 9$}




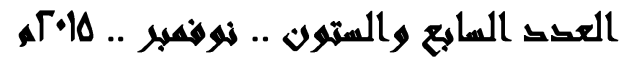

لبليك لدرجات طلاب المجموعة التجريبية يِّان التطبيق القبلي والبعدي لاختبار

المفاهيم الفيزيائية.

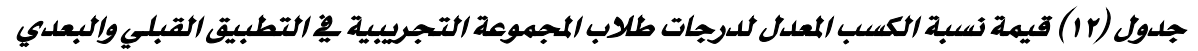

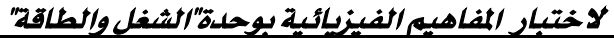

\begin{tabular}{|c|c|c|c|c|}
\hline \multirow{2}{*}{ نسبة الكسب } & \multicolumn{2}{|c|}{ المتوسط الحسابى } & \multirow{2}{*}{ العظهمية } & \multirow[t]{2}{*}{ الاختبار } \\
\hline & التطبيق البعدي & التطبيق القبلي & & \\
\hline 1,1 & $Y Y, \Lambda$ & $9, \varepsilon \wedge$ & r. & اختبار المفاهيم الفيزيائية \\
\hline
\end{tabular}

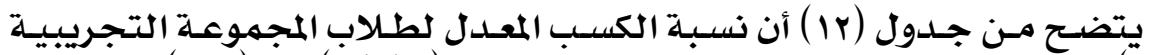

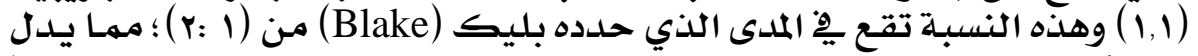

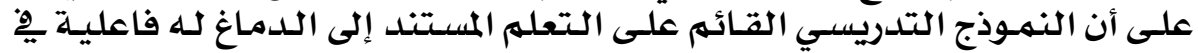

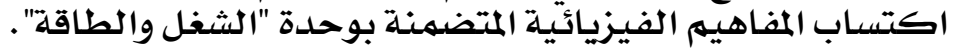

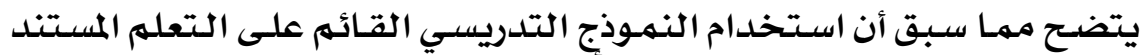

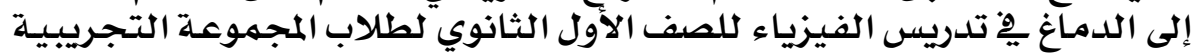

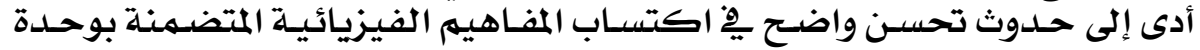

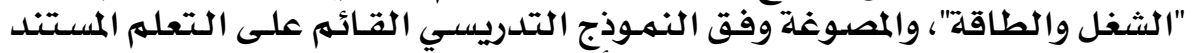

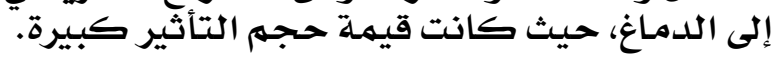

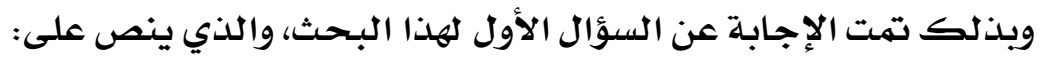

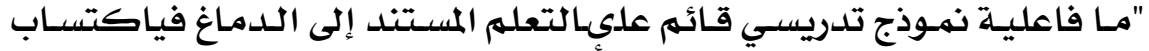

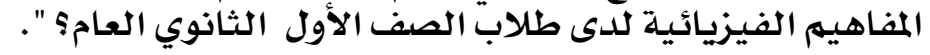

\section{• مناقشة نتائج الفرض الأول وتفسيرها:}

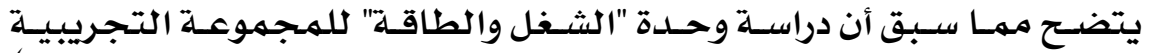

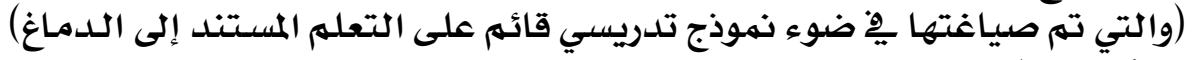

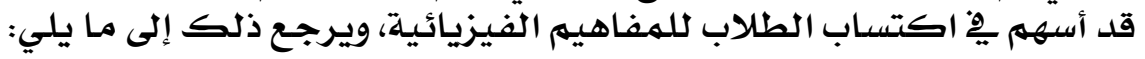

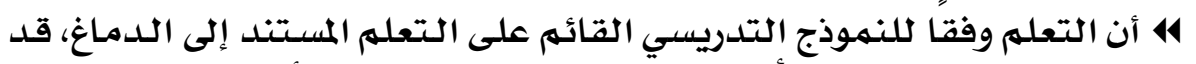

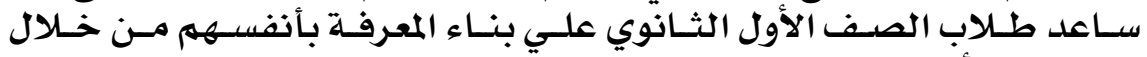

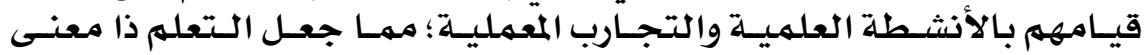

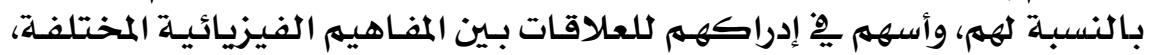

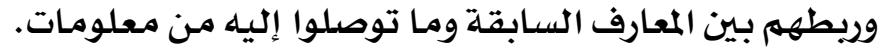

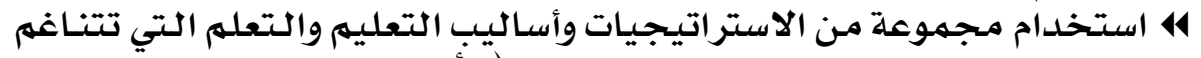

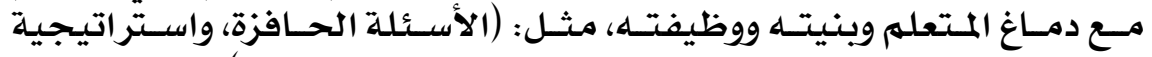

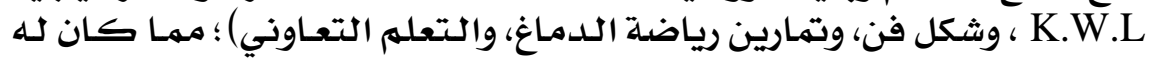

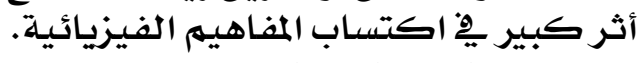

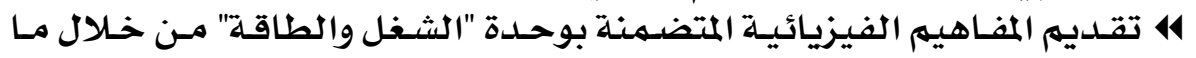

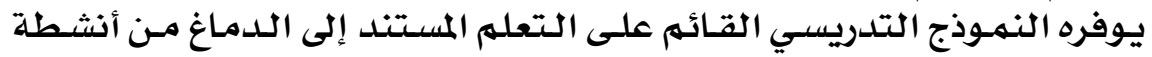

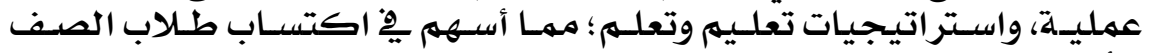

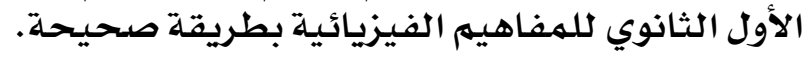




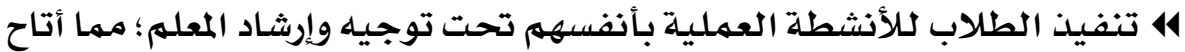

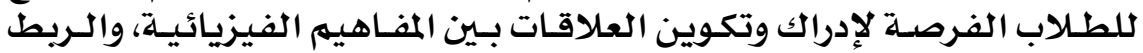

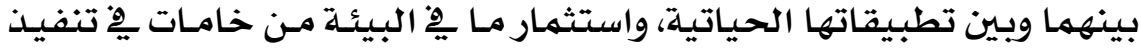
تلك الأنشطة.

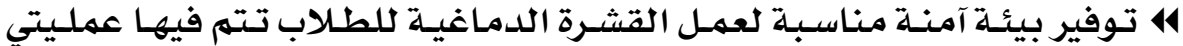

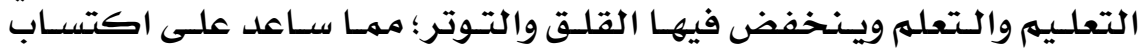

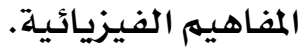

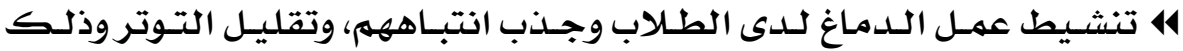

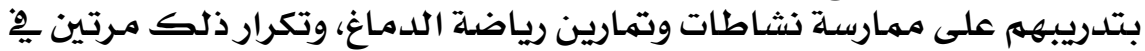

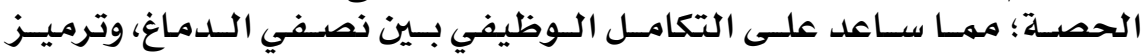

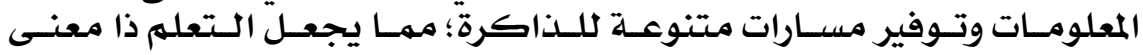

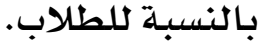

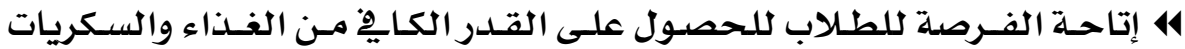

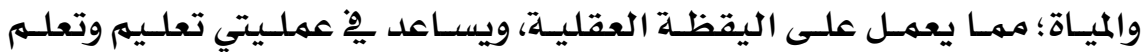
المفاهيه الفيزيائية.

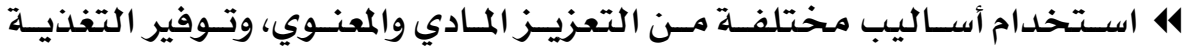

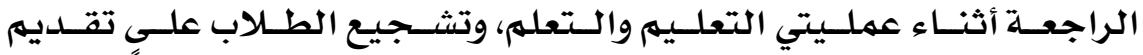

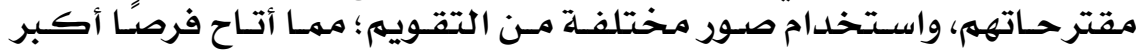

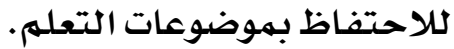

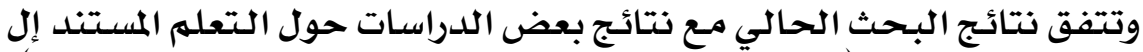

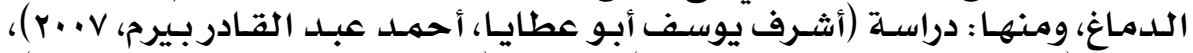

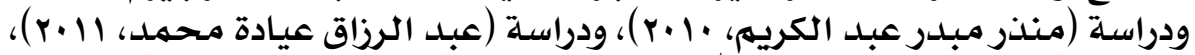

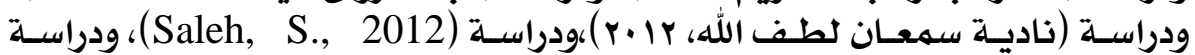
.(Akyurek, E. \& Afacan, O., 2013)

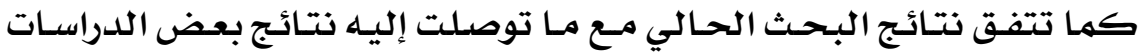

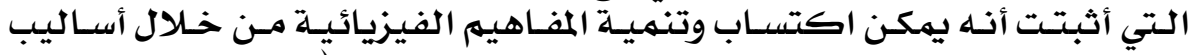

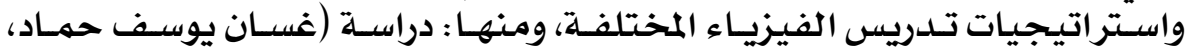

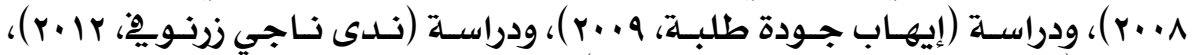

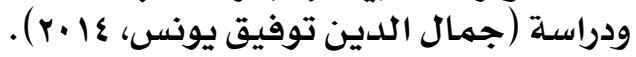

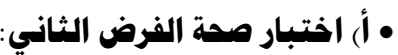

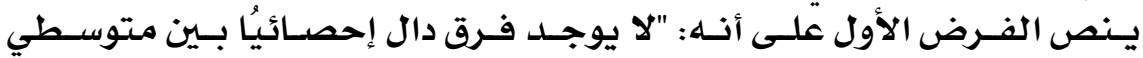

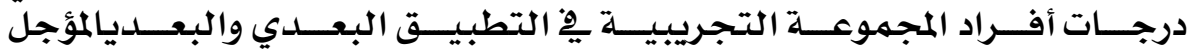

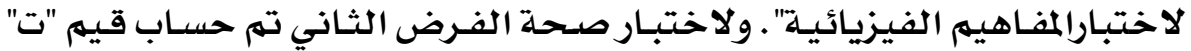

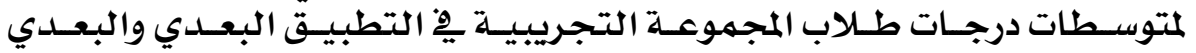

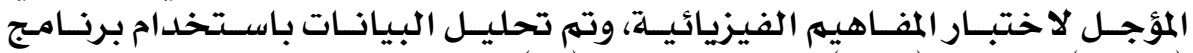
(الإصدار (SPSS)

\section{1}




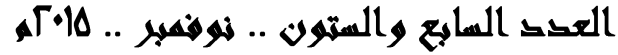

جلدول (r ا ) قيمة "ت" للفروق بين متوسطي درجات طلاب المجموعة التجبريبية 2ِ التطبيق البعلي

\begin{tabular}{|c|c|c|c|c|c|c|c|c|}
\hline \multirow[t]{2}{*}{ الدلالة } & \multirow[t]{2}{*}{ ت } & \multirow[t]{2}{*}{ المتوسطين بين } & \multicolumn{2}{|c|}{ التجريبية بعدي } & \multicolumn{2}{|c|}{ التجريبية بعدي } & \multirow[t]{2}{*}{ الكلية الدرجة } & \multirow[t]{2}{*}{ محاور الاختبار } \\
\hline & & & $\varepsilon$ & م & $\varepsilon$ & م م & & \\
\hline غير داثلة & $1, r 10$ & $\cdot, 7$ & 1,79 & $7,7 \mathrm{~V}$ & Y,1. & $V, Y V$ & 9 & المعرفة بالمحتوي \\
\hline غيردالة & $1, \cdot 91$ & - & Y,Yq & $\Lambda, \cdots$ & $r, \cdot 9$ & A,Tr & ir & الفهـموالتطبيق \\
\hline غير دالة & $\cdot, \mathrm{YTA}$ & $\cdot, 1$ & 1,Vo & $7, \Lambda$. & 1,07 & $7,9$. & 9 & الناقد وحل المشكلات \\
\hline غير داتلة & $1, \cdot v \wedge$ & $1, r r$ & $\varepsilon, \wedge V$ & $r 1, \varepsilon V$ & $0, \cdot 0$ & Yr,A. & $r$. & المحموي الكلي \\
\hline
\end{tabular}

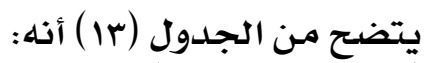

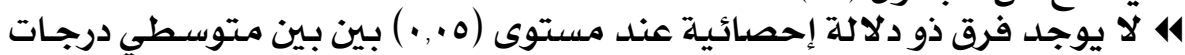

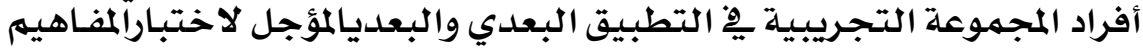

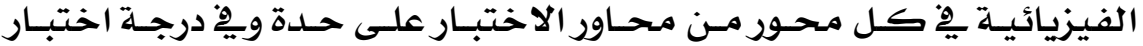

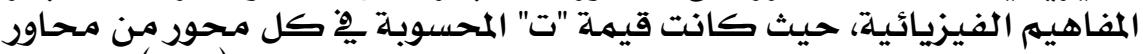

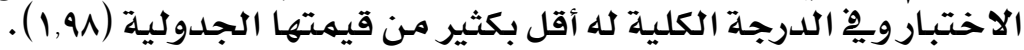

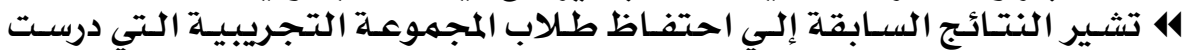

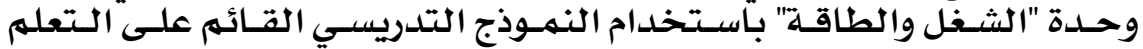

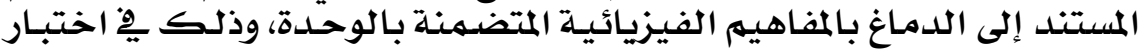

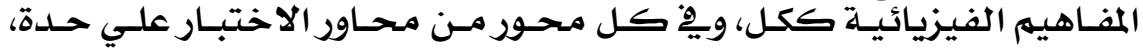

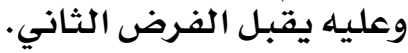

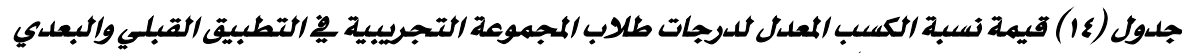

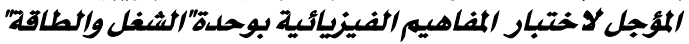

\begin{tabular}{|c|c|c|c|c|}
\hline \multirow{2}{*}{ نسبة الكسب } & \multicolumn{2}{|c|}{ المتوسط الحسابي } & \multirow{2}{*}{ العظمي النهاية } & \multirow[t]{2}{*}{ الاختبار } \\
\hline & التطبيق البعدي & التطبيق القبلي & & \\
\hline $1, \cdots$ & $r 1, \varepsilon V$ & $9, \varepsilon \wedge$ & r. & اختبار المفاهيه الفيزيائية \\
\hline
\end{tabular}

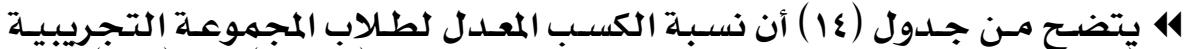

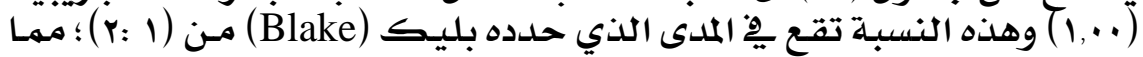

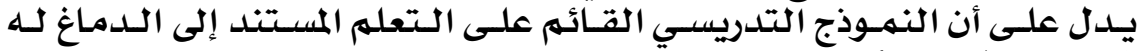

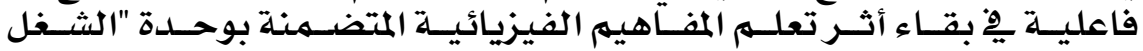
والطاقة".

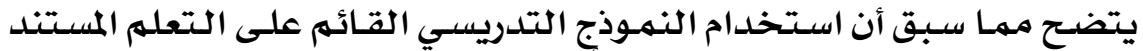

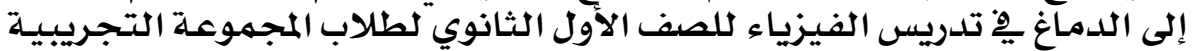

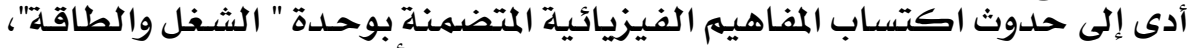

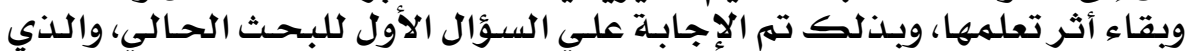

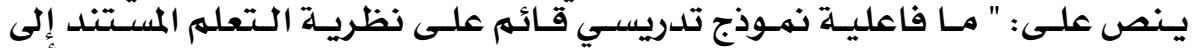

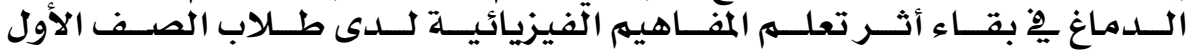

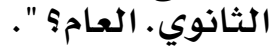




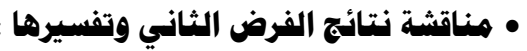

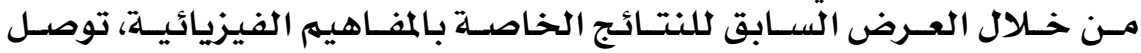

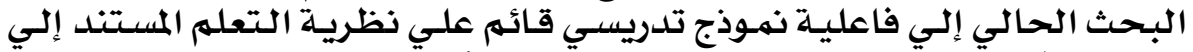

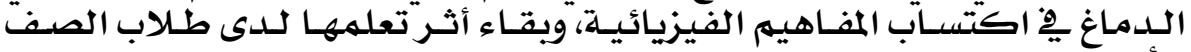

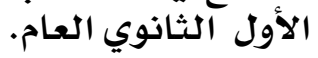

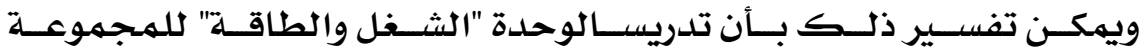

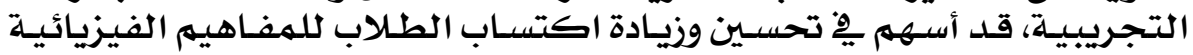
وبقاء أثر تعلهمها، ويرجيع ذلك ألك إلى:

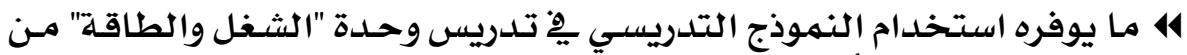

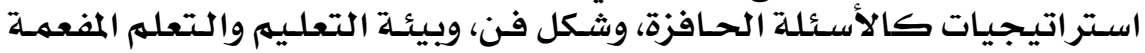

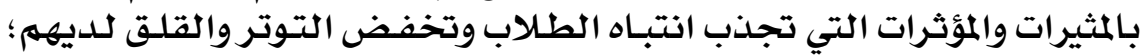

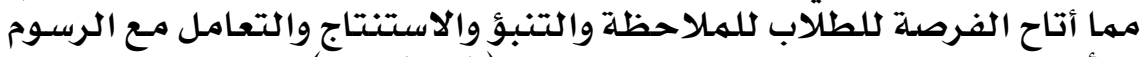

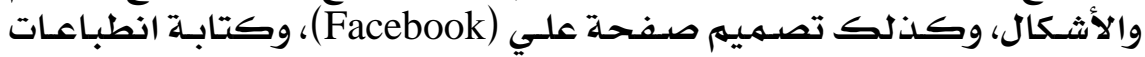

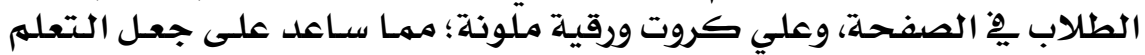

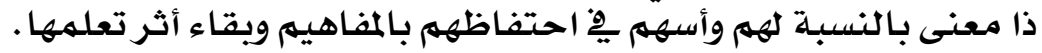

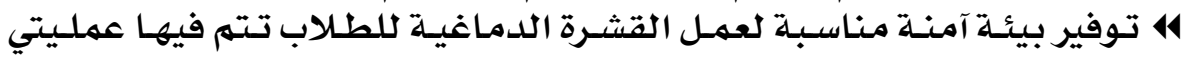

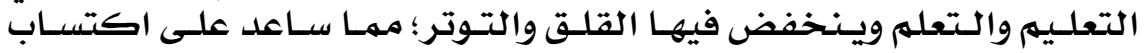

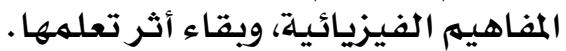

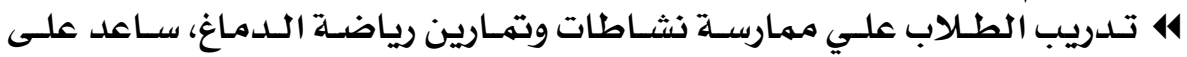

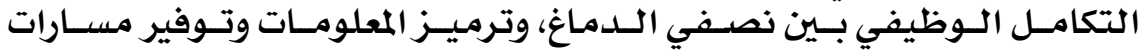

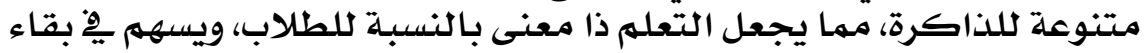
أثر التعلهم.

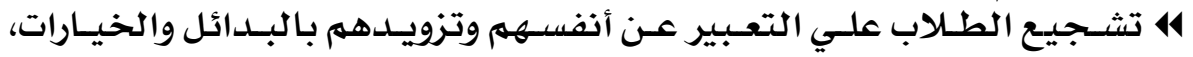

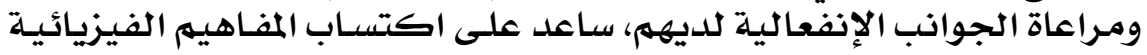

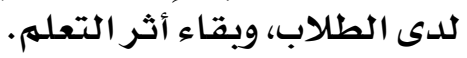

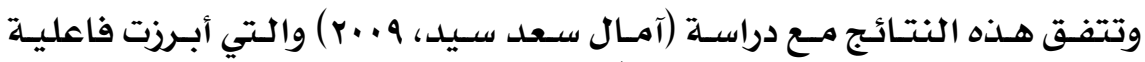

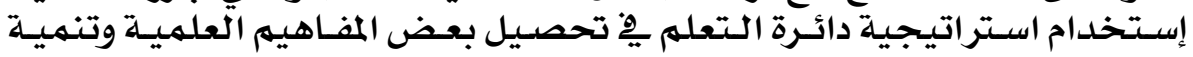

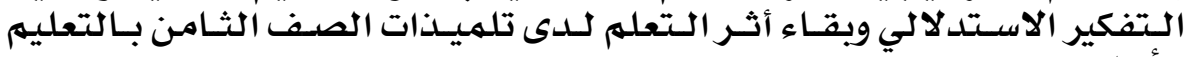
الأساسي.

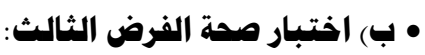

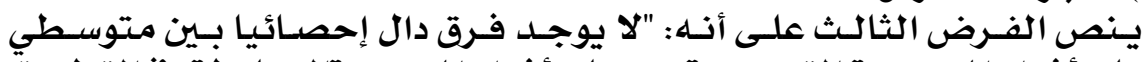

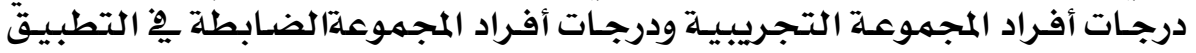

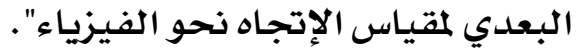

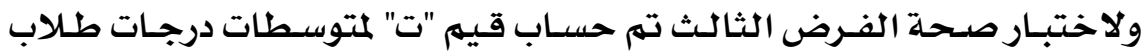

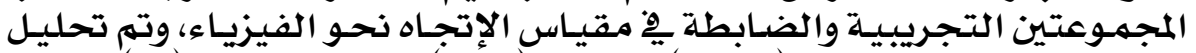

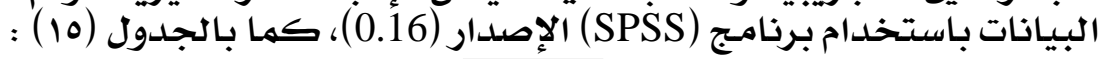

\section{O}




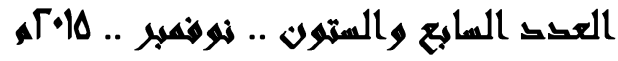

جلول (10) قيمة "ت" للفروق بين متوسطي درجات طلاب المجموعة التجريبية والضابطة وِ التطبيق

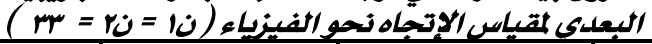

\begin{tabular}{|c|c|c|c|c|c|c|c|}
\hline \multirow[t]{2}{*}{ الدلالة } & \multirow[t]{2}{*}{ ت } & \multirow{2}{*}{ المتوسطين بين } & \multicolumn{2}{|c|}{ الضابطة } & \multicolumn{2}{|c|}{ التحريبية } & \multirow{2}{*}{ محاور المقياس } \\
\hline & & & $\varepsilon$ & م & $\varepsilon$ & م & \\
\hline دالة & r,riv & $r, \wedge$ & $0, V 7$ & $19,9 \varepsilon$ & r,ro & rriva & الاستمتاع بلدراسة الفيزياء \\
\hline دالة دالة & $r, r^{\prime}$. & $r, £ 0$ & $\varepsilon, \varepsilon 9$ & YI,VT & Y,AT & $Y O, Y I$ & معلم الفيزياء \\
\hline دالة & $r, \varepsilon 7$. & $\mathbf{r}, \mathbf{\Lambda} \cdot$ & $0, \Lambda T$ & rr,rA & $\mathrm{r}, \boldsymbol{A r}$ & $\mathrm{YT,1 \Lambda}$ & أهمية دراسة الفيزياء \\
\hline دالة & r,TrV & $1 \cdot, .9$ & $1 \varepsilon,\{\Lambda$ & $70, \cdot 9$ & $7, V 7$ & vo, IA & المجموع الكلب \\
\hline
\end{tabular}

"ت" الجدولية عند (1,0., ) ) (1,94)

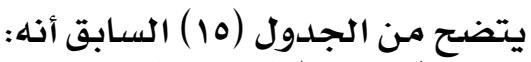

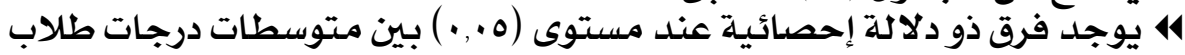

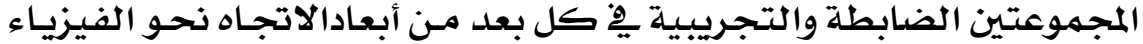

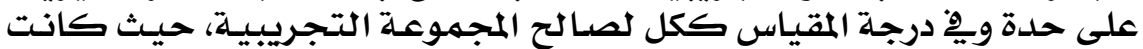

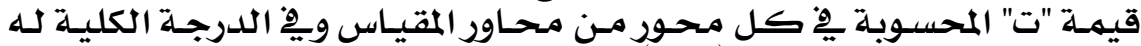

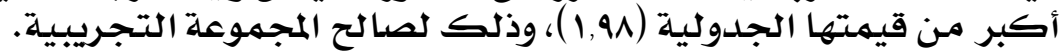

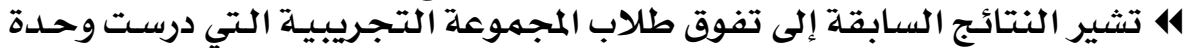

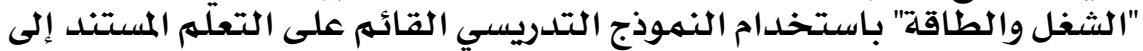

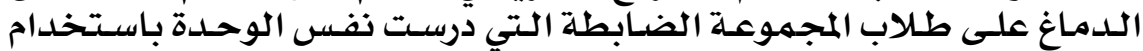

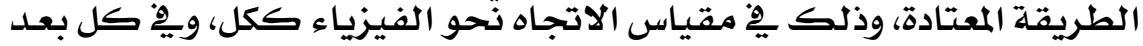

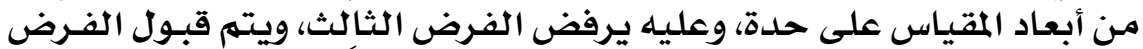

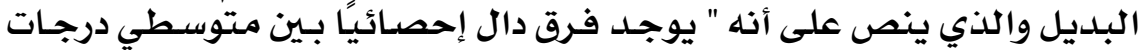

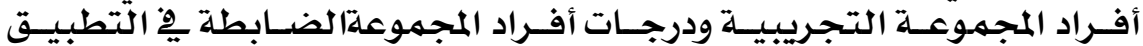

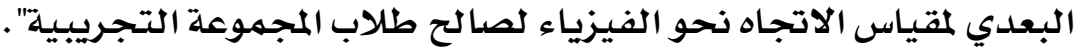

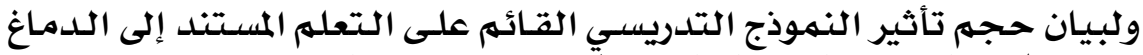

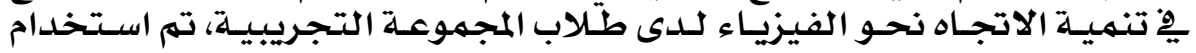

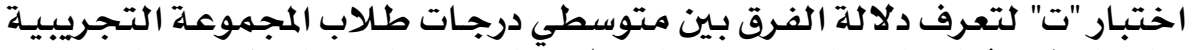

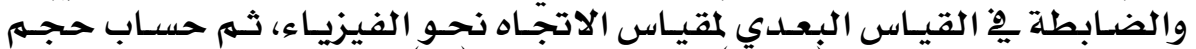

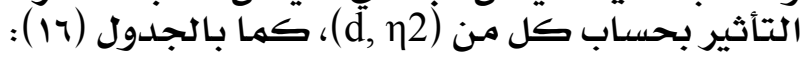

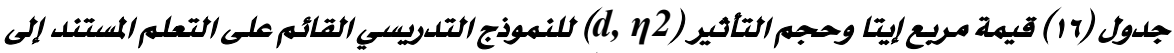
اللدماغ على تنمية الاتجاه نحوف الفيزياء

\begin{tabular}{|c|c|c|c|c|c|c|}
\hline التأثر & D & $\eta 2$ & تr & ت & المتغير التابع & المتغير المستقل \\
\hline كبير &. .91 &. $.1 V$ & 17.17 & r.TrV & الاتجاه نحو & 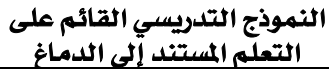 \\
\hline
\end{tabular}

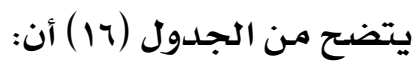

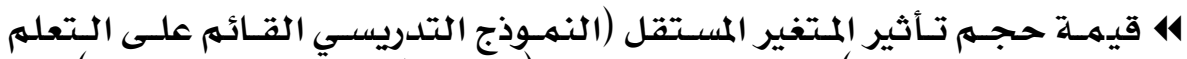

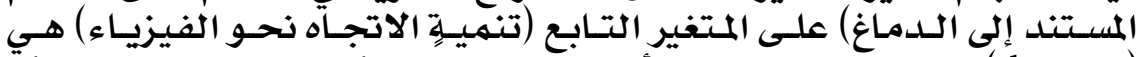

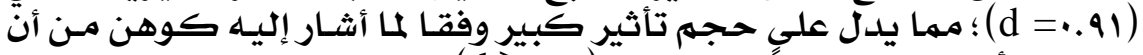

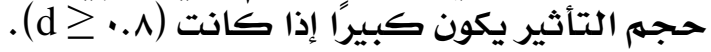

\section{○\&}




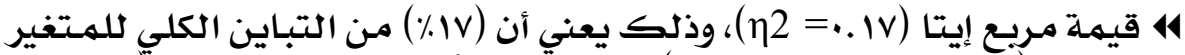

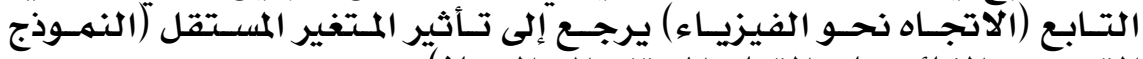

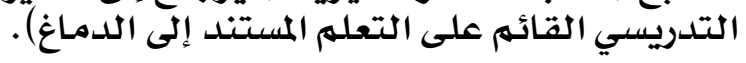

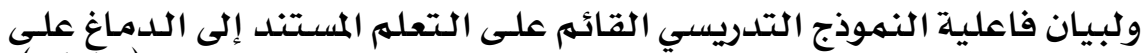

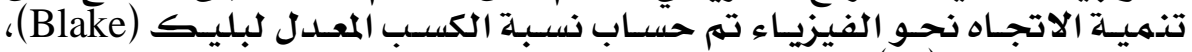

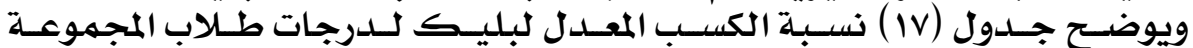

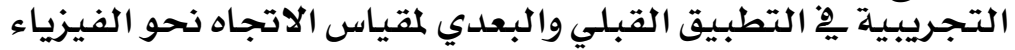

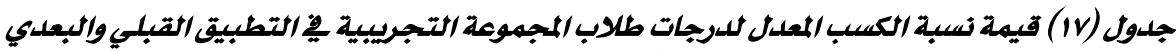

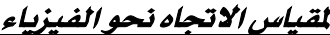

\begin{tabular}{|c|c|c|c|c|}
\hline \multirow{2}{*}{ نسبة الكسب } & \multicolumn{2}{|c|}{ المتوسط الحسابى } & \multirow{2}{*}{ العظمي } & \multirow{2}{*}{ الاختبار } \\
\hline & التطبيق البعدي & التطبيق القبلي & & \\
\hline., $0 \mathrm{v}$ & vo, 11 & Tr,Vז & 9. & مقياس الاتجاه نحو الفيزياء \\
\hline
\end{tabular}

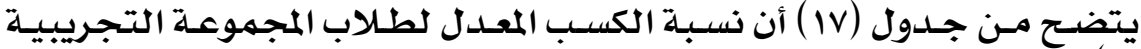

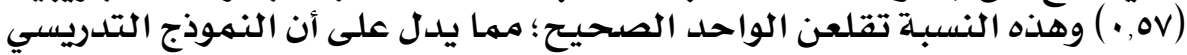

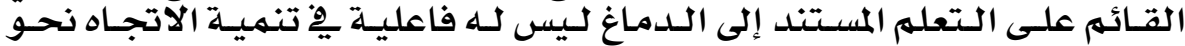

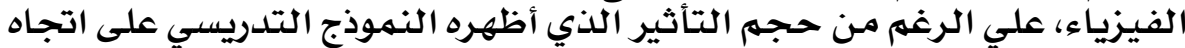

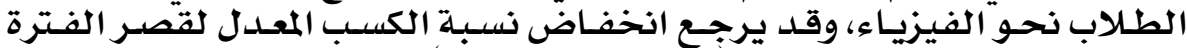

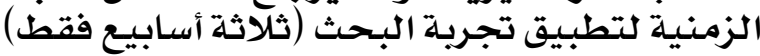

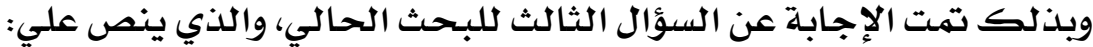

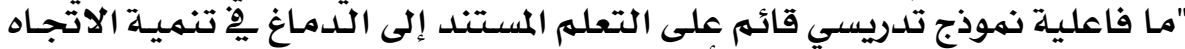

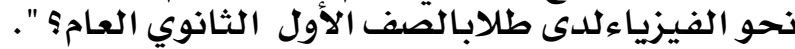

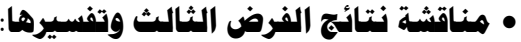

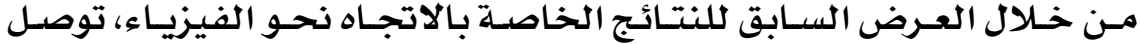

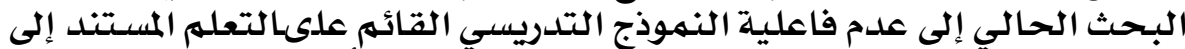

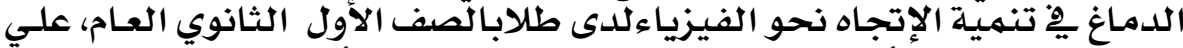

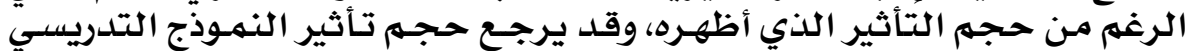
على اتجاه الطلاب نحو النتانير الذيزياء إلي:

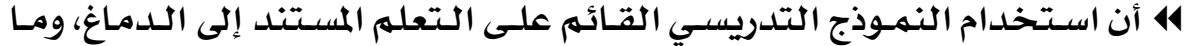

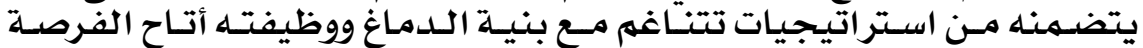

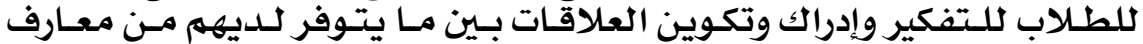

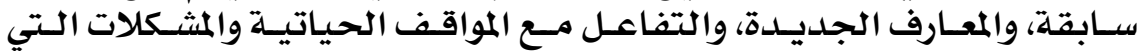

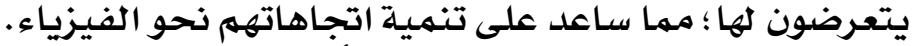

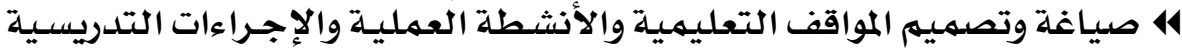

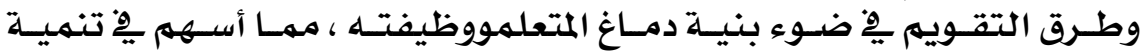

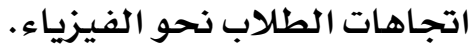

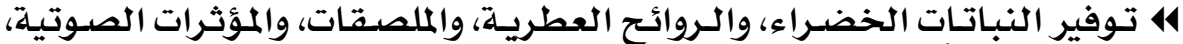

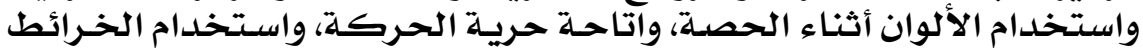




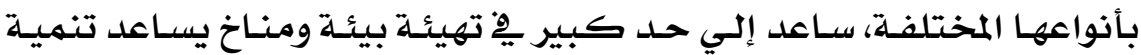

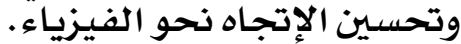

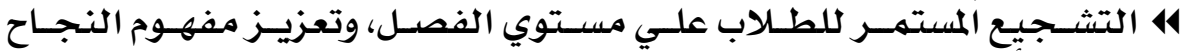

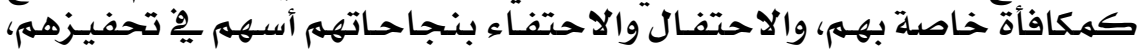

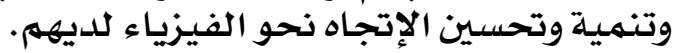

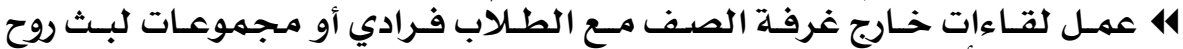

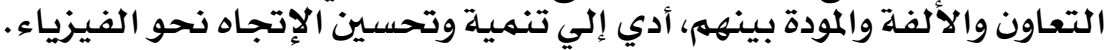

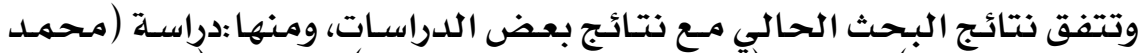

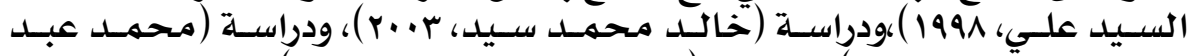

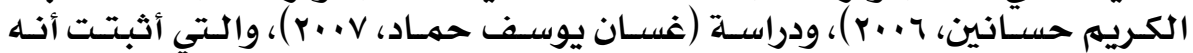

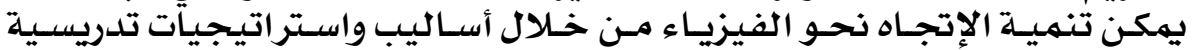
مختلفة.

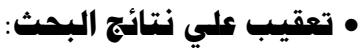

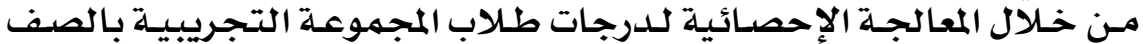

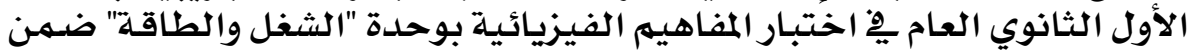

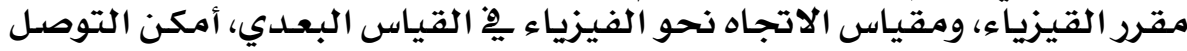

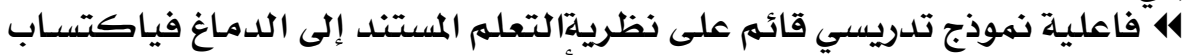

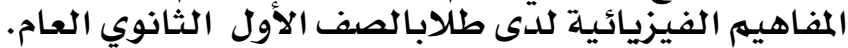

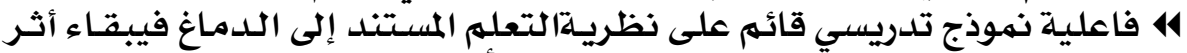

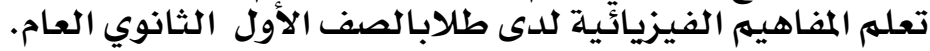

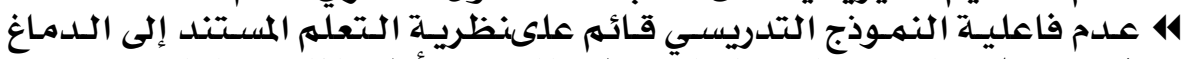

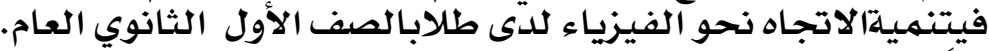

\section{• • ثانيا: التوصيات والبحمث المقترحة:}

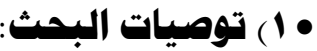

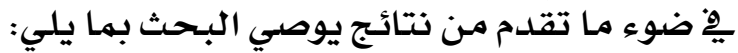

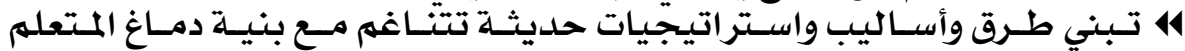

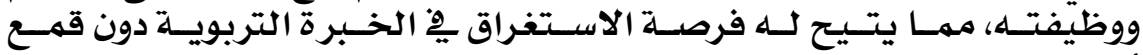

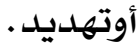

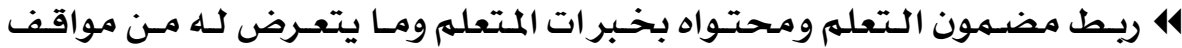

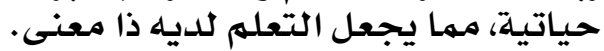

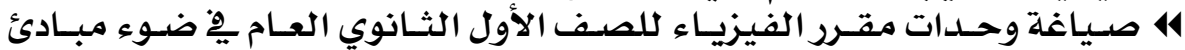

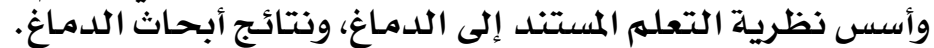

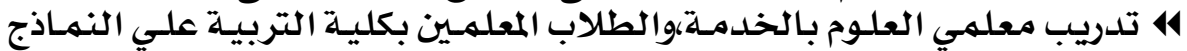

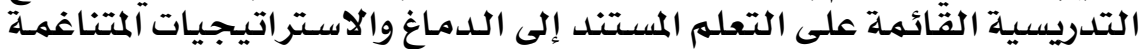

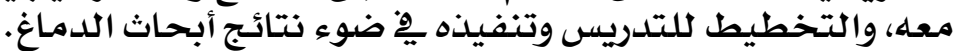

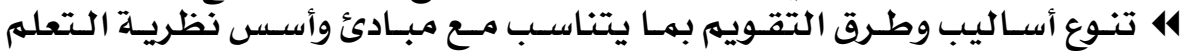
المستند إلى الدماغ، ونتائج أبحاث الدماغ الدئن

\section{7}




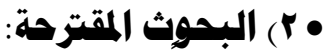

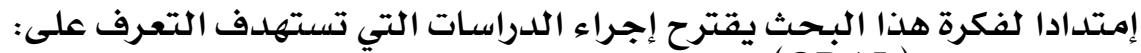

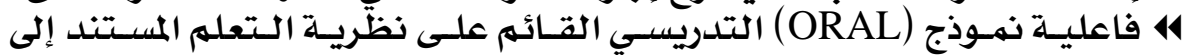

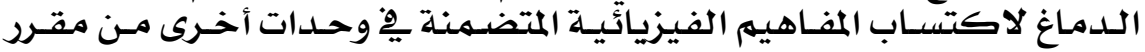

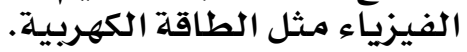

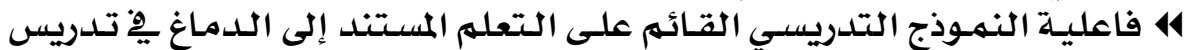

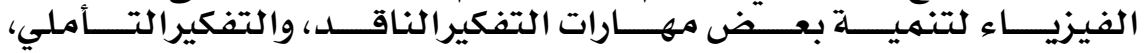
والتفكيرالعلمي. لتئي.

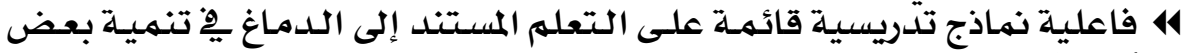

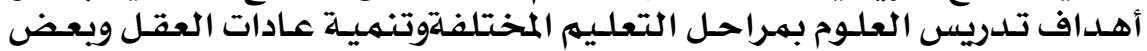

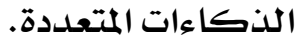

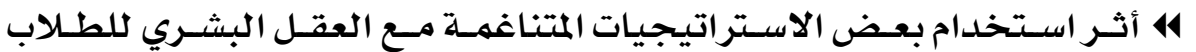

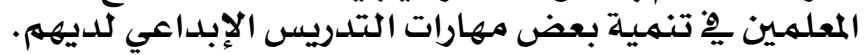

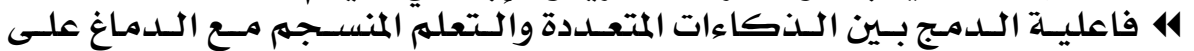

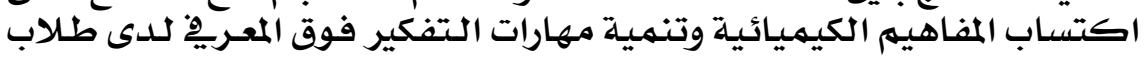
المرحلة الثانويية.

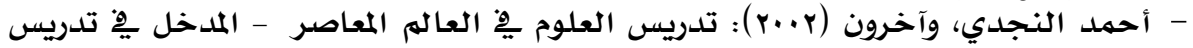

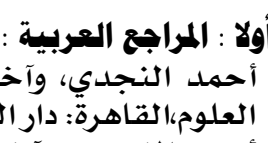

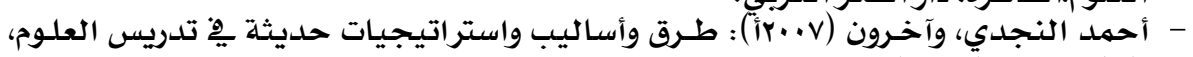

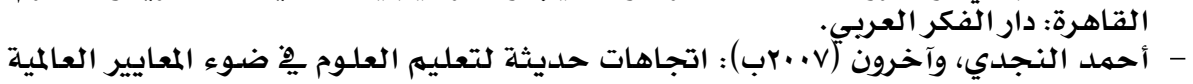

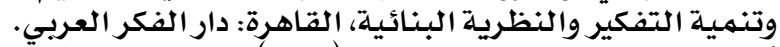

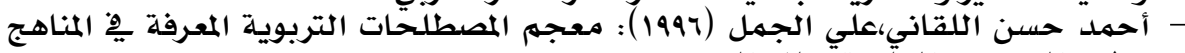

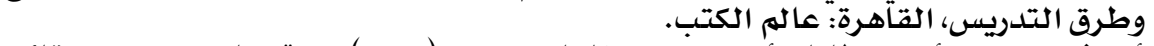

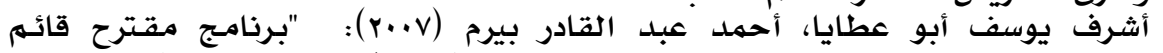

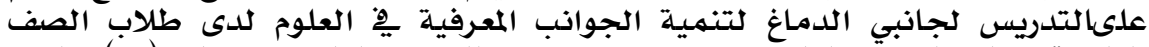

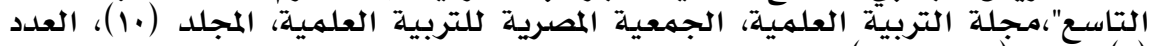

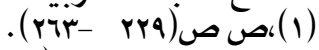

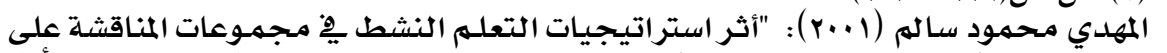

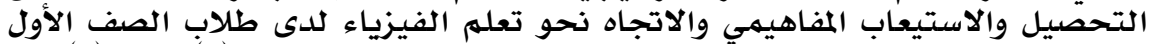

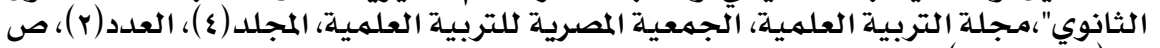

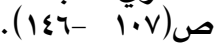

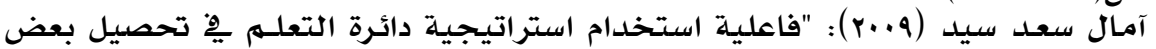

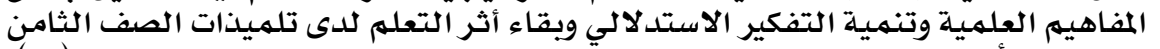

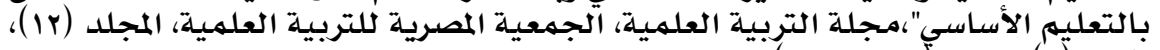

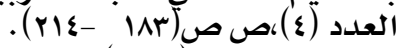

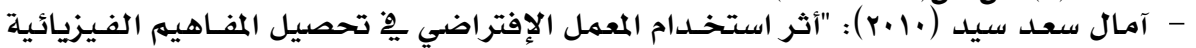

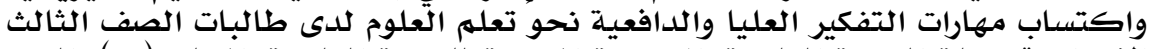

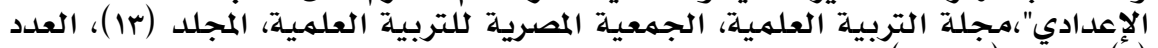

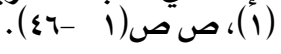

\section{$\bullet V$}




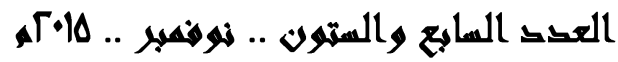

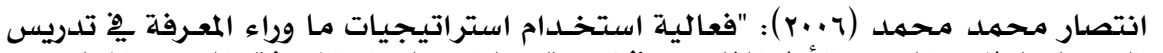

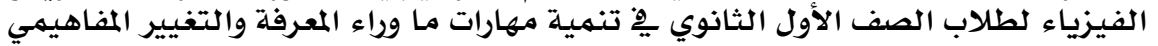

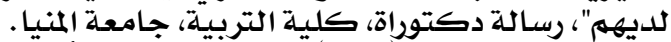

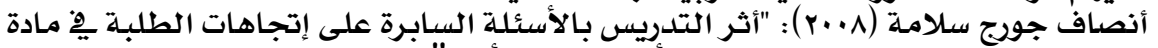

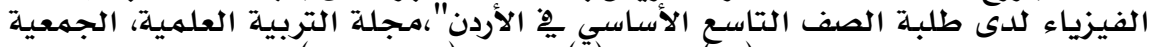

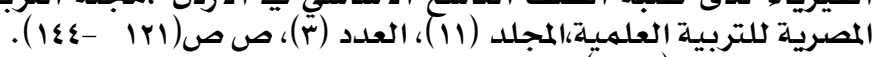

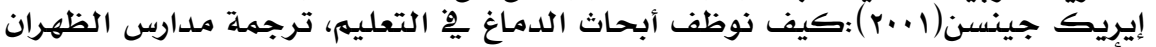

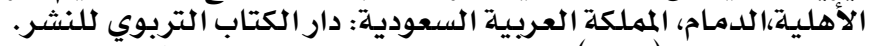

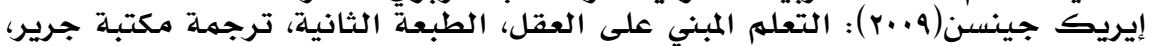

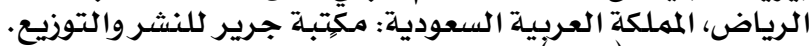

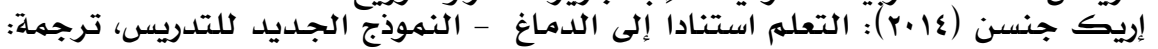

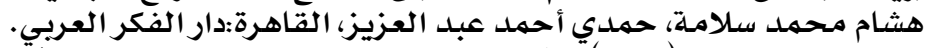

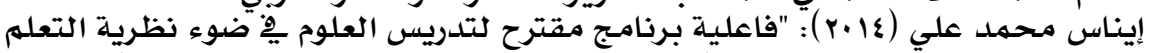

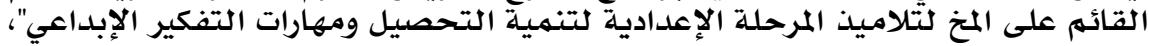

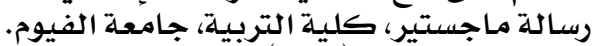

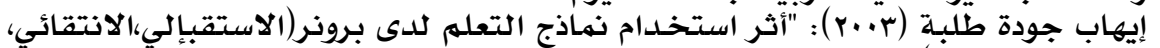

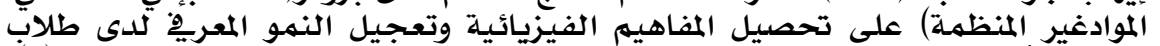

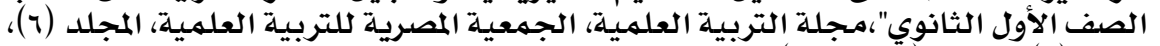

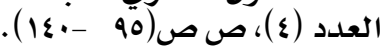

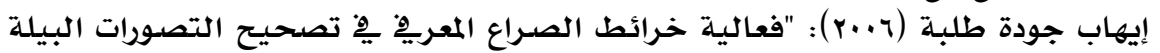

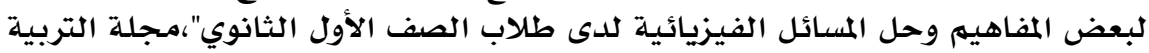

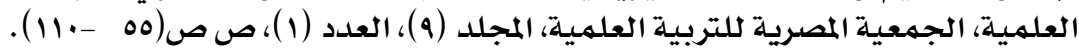

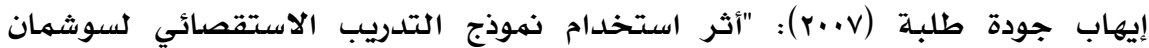

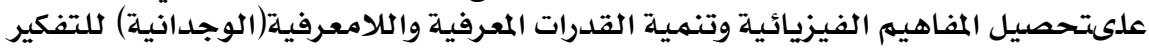

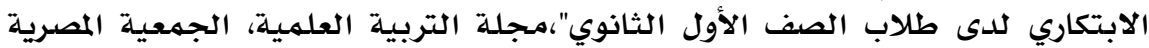

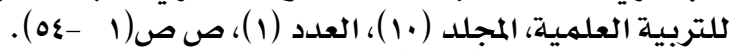

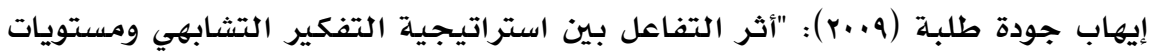

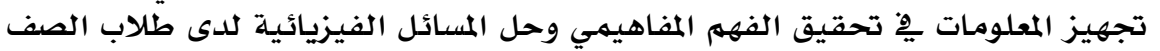

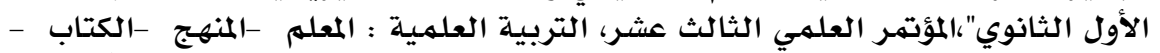

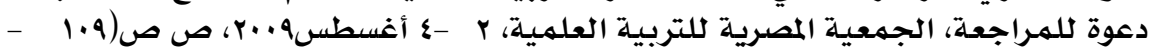
.$(1 \wedge 9$

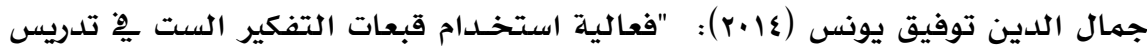

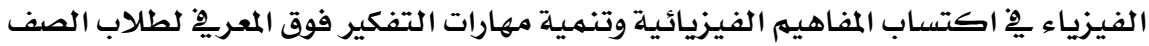

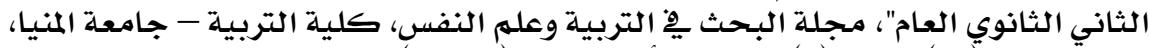

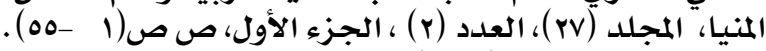

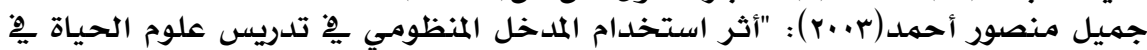

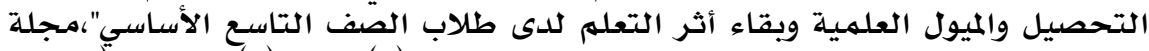

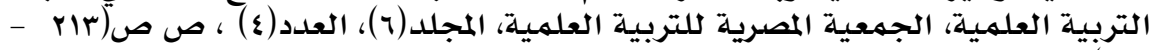

حrry

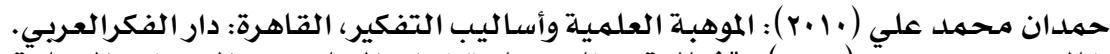

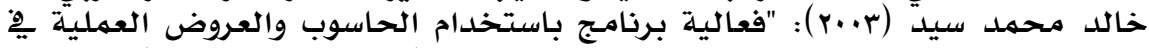

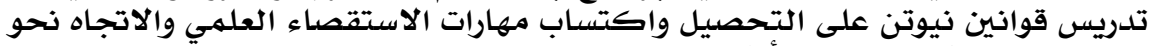

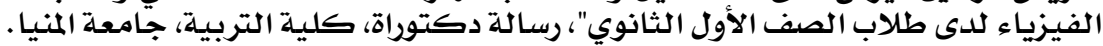

\section{$\bullet \wedge$}




\section{العضك السابع والسترن .. نهوهمبر ..}

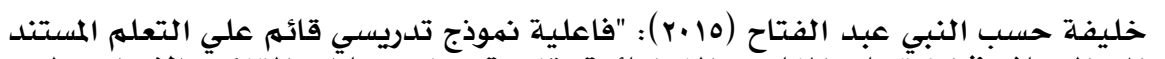

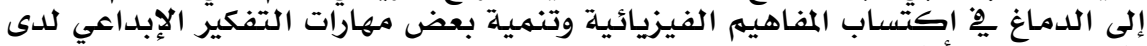

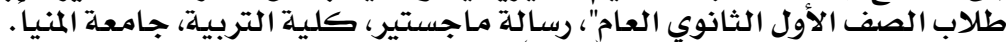

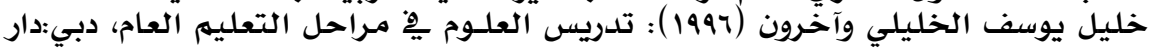

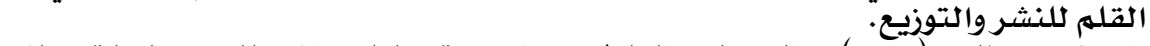

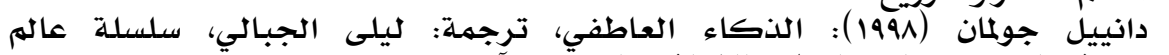

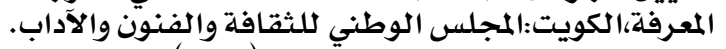

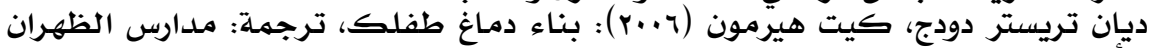

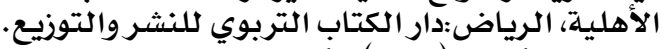

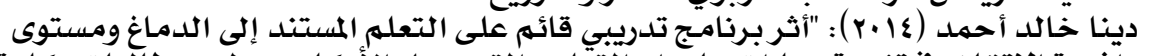

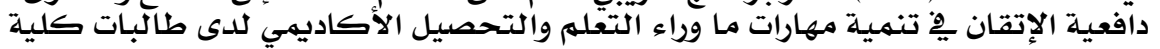

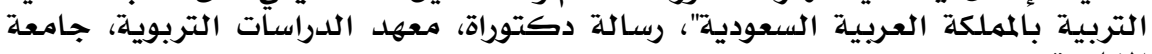

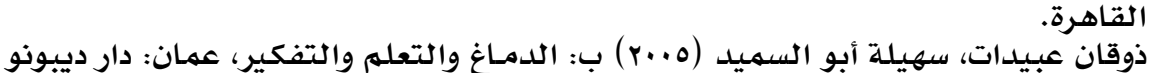

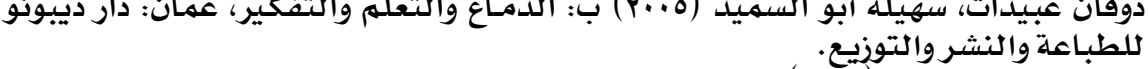

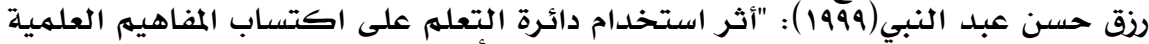

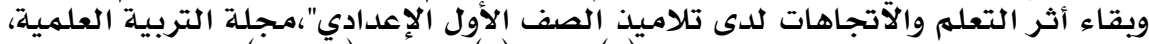

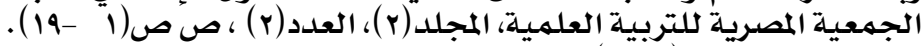

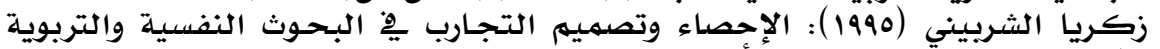

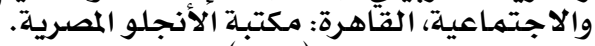

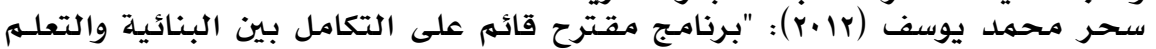

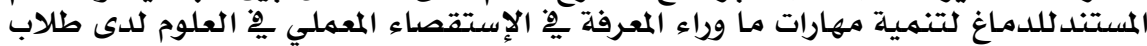

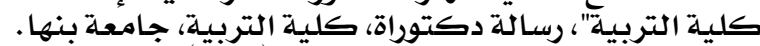

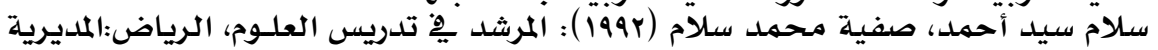
العامـة للمطبوعات بوزارة العارة الإعلام.

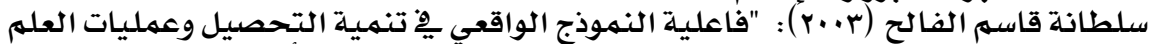

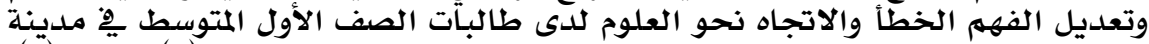

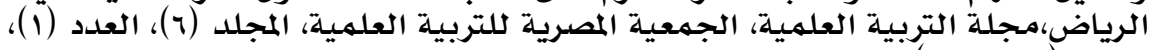

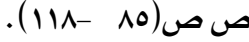

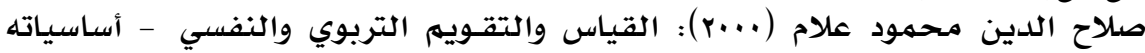

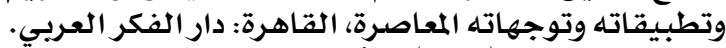

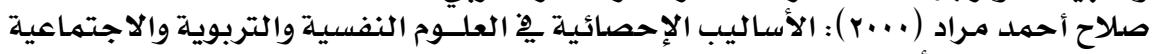

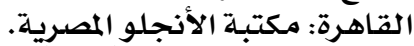

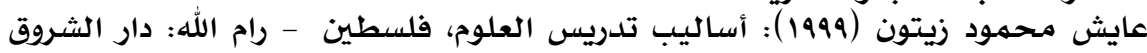

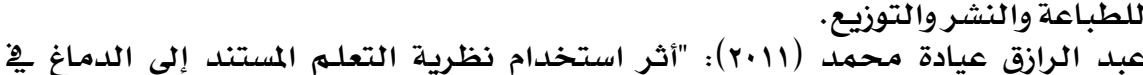

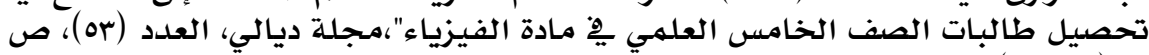

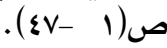

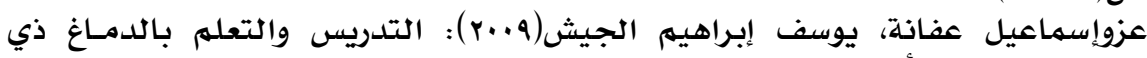

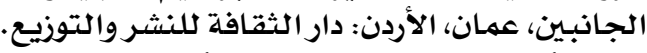

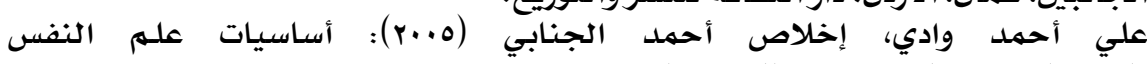

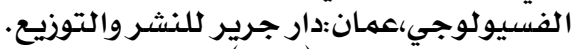

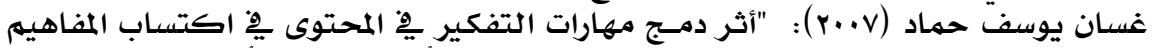

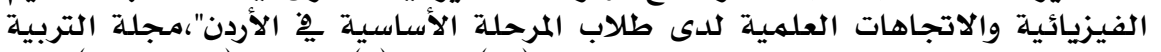

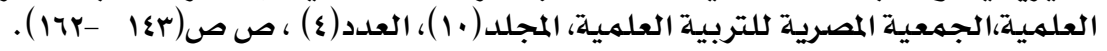

\section{$\odot 9$}




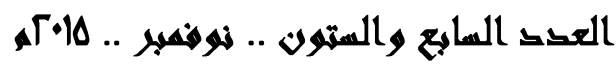

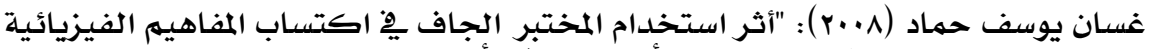

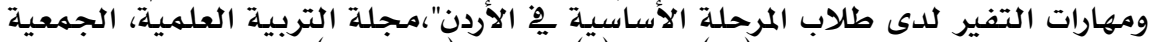

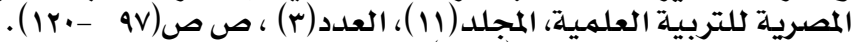

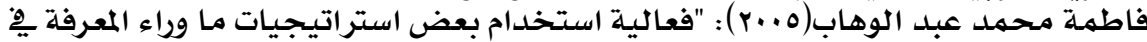

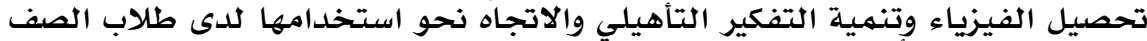

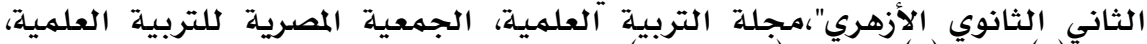

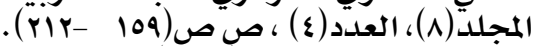

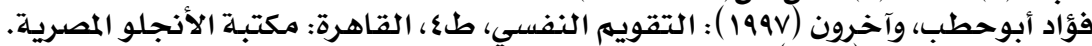

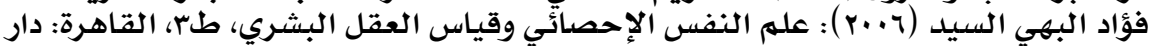

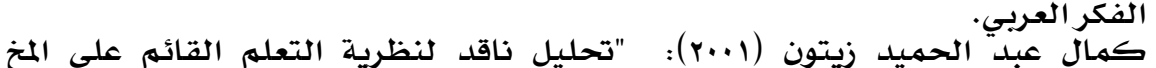

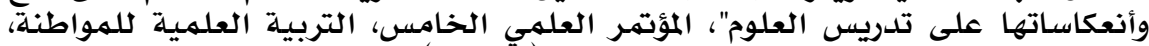

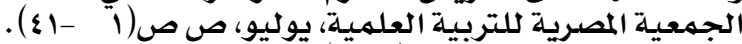

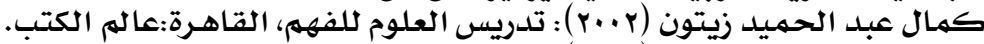

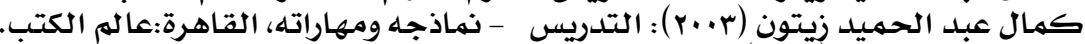

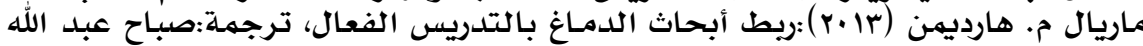

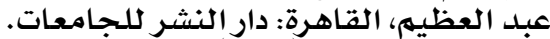

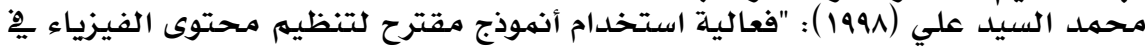

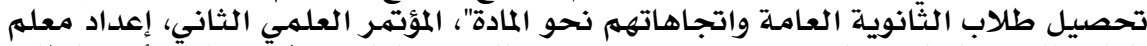

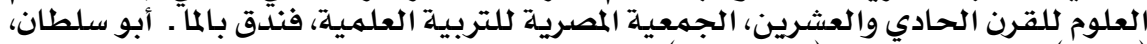

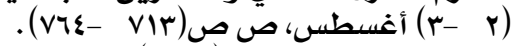

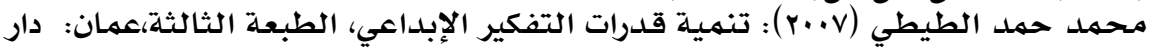

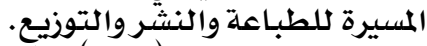

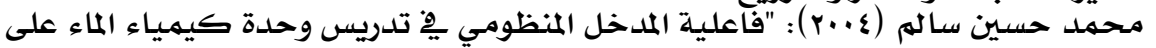

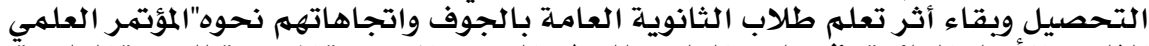

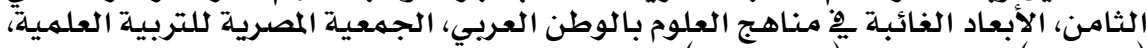
(rی- ro)

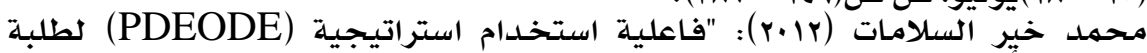

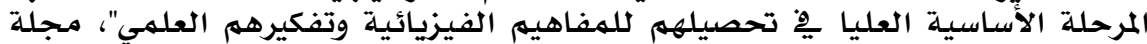

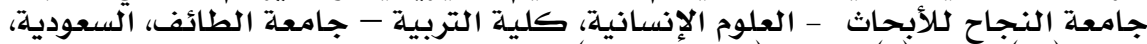

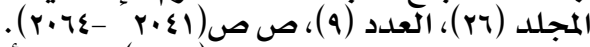

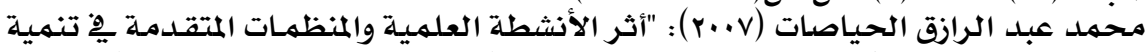

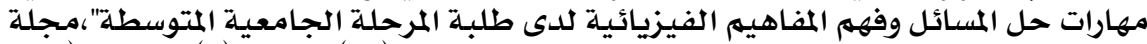

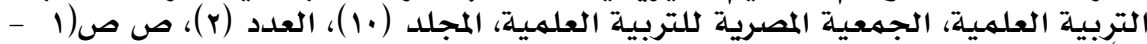

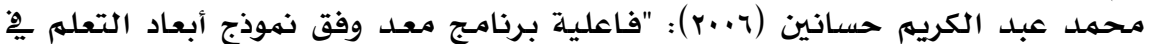

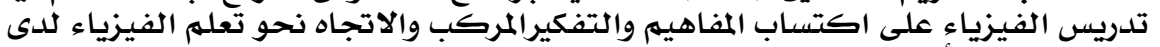

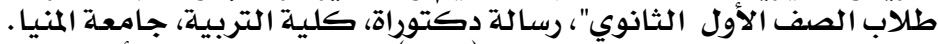

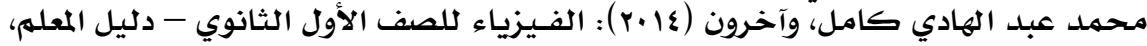

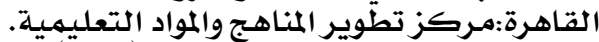

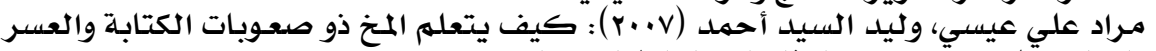

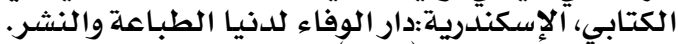

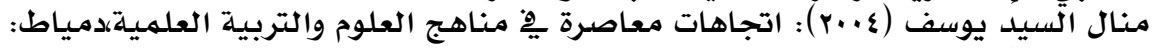

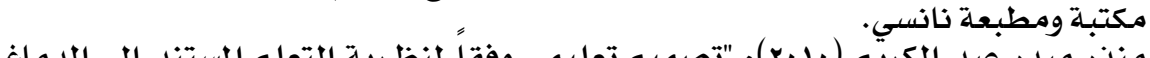

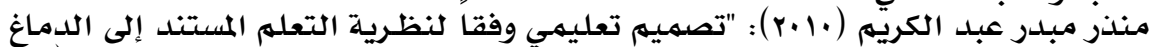

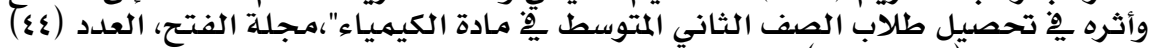

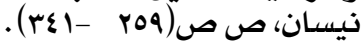

\section{7.}




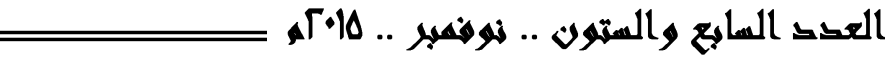

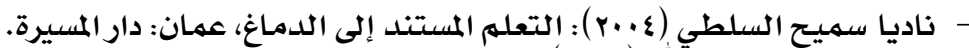

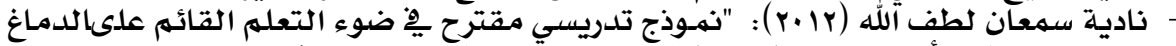

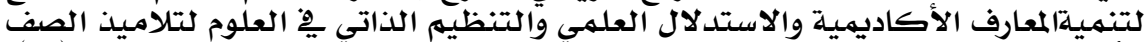

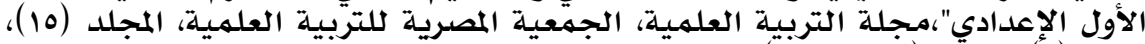

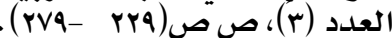

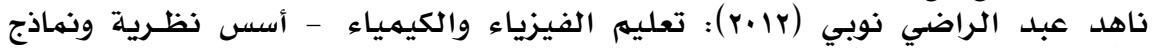

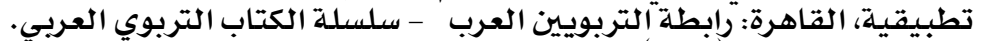

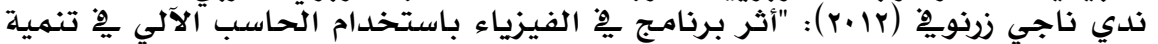

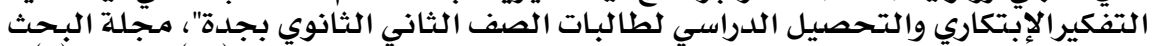

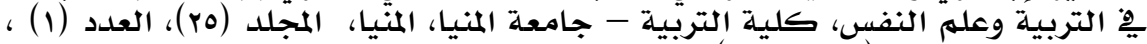

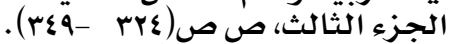

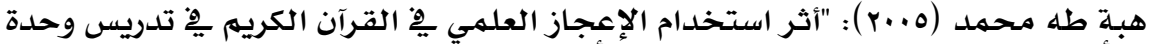

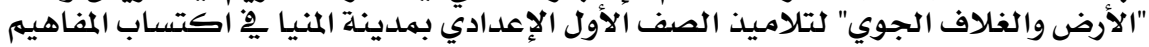

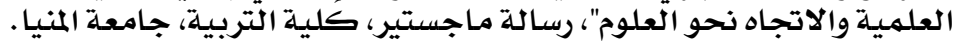

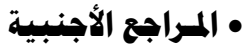

-Akyurek, E., \& Afacan, O., (2013): "Effects of Brain Based Learning Approach on Students Motivation and Attitudes Levels in Science Class", Mevlana International Journal of education, Vol. (3), No. (1), pp. (104-119).(65) Bajpai, M., (2013): "Developing Concepts in Physics Through Virtual Lab Experiment: An Effectiveness Study", AnInternational Journal of Educational Technology, Vol. (3), No. (1), pp. (43-50).

- Caine, R. N. \& Caine, G., (1991):Making Connection: Teaching and Brain, Alexandria, VA: ASCD.

-Caine, R. N. \& Caine, G., (1995):" Reinventing school through Brain-basedlearning",Educational leadership, Vol. ( 52), No. (7), pp. (43-47).(68) Caliskan, S. \& Others (2010): "Effects of the Problem Solving Strategies Instruction on the Students Physics Problem Solving Performances and Strategy Usage", Procedia Social and Behavioral Sciences, Vol. (2), pp. (2239-2243).

- Jensen, E., (1998):Teaching with the brain in mind,Alexandria, Verginia: ASCD.

- Kaur, J., (2013): "Effectiveness of Brain Based Learning Strategies on Enhancement of Life Skills among Primary School Students with internal and external Locus of Control", International Journal of Advancements in Reasearch\&Technology, Vol. (2), No. (6), pp. (128-143).

-Meador, K., (2003):" Thinking Creativity about Science: Suggestion For Primary Teacher", Science Education ,Vol. (26),pp. (23-29).

- Ozden, M. \& Gultekin,M., ( 2008):" The Effect of Brain-based learning onAcademic Achievement and Rentention of Knowledge in 
ScienceCourse",Electronic Journal of Science Education, Vol.. (12), No. (1), pp.( 3-17).

-Saleh, S., (2011):"The effectiveness of Brain-Based Teaching Approach in dealing with problemsof Form Four students' conceptual understanding Newtonian physics",Asia Pacific Journal of Educators and Education,Vol. (26), No. (1), pp. (91-106).

-Saleh, S., (2012a): "The effectiveness of the Brain-Based Teaching Approach in Enhanching Scientific understaning ofNewtonian Physics among form four Students",International Journal of Environmental \& Science Education, Vol. (7), No. (1),pp. (107122).

-Tufekci, S., \& Demirel, M., (2009):"The effect of brain based learning on achievement, retention, attitude and learning process", Procedia Social and Behavioral Sciences,Vol. (1), pp. (17821791).

-Ur-Rehman, A., (2011): "Effectiveness of Brain Based Learning Method and Conventional Method in the Teaching of Mathematics at Secondary Level in Pakistan", Degree of Doctor, Faculty of Social Sciences, International, Islamic University, Islamabad.

- Weiss, R. P., (2000): Brain-based learning,Training\& Development, Vol.( 54), pp.( 20). 


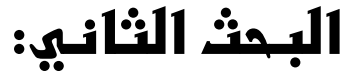

فاعلية النظام الذكي لمعالجة المعرفة "RISK" في تنهية ههارات التفكير

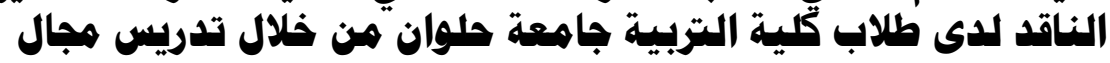
الاقتصاد المنزلي

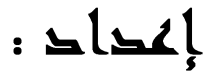

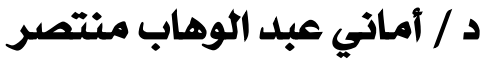

مدرس المناهـج وطرق تدريس الاقتصاد المنزلي

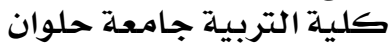





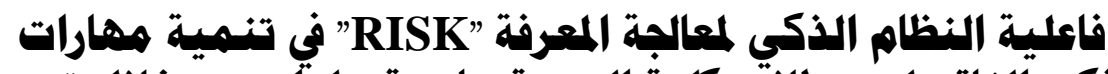

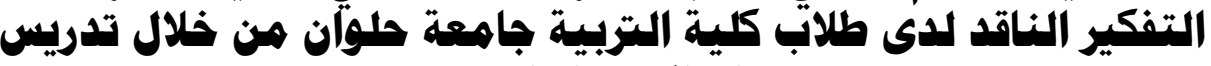 هبال الاقتصاد المنزلي
}

\author{
د / أماني عبل الوهاب منتصر
}

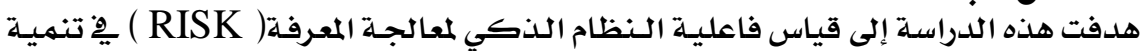

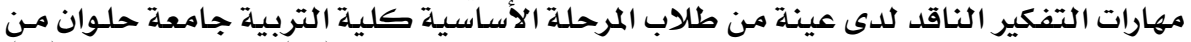

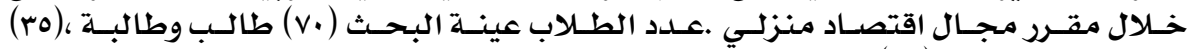

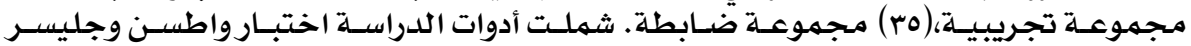

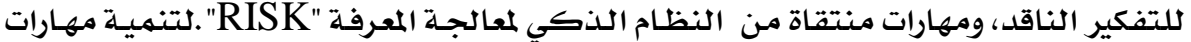

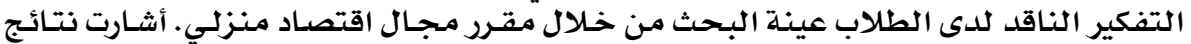

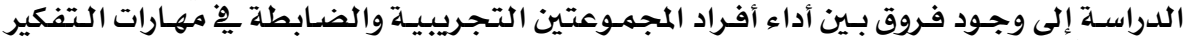

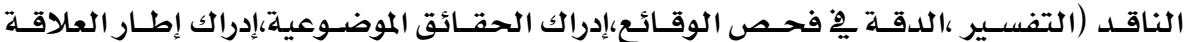

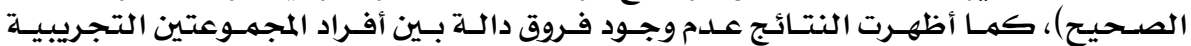
والضابطة على مهارة التطرف يخ الهرت الرأي.

\section{The Effect of the Right Intelligent System of Knowledge "RISK"} Program on Developing the Critical Skills of Basic Education $\underline{\text { Abstract }}$ Students in Helwan Univerisity

This study aimed at determining the effectiveness of the right intelligent system of knowledge (RISK) in developing the critical thinking of a sample of Basic Education students at Helwan University using a course in the home economics field. The sample of the study consisted of 70 students(males and females) distributed into two groups: an experimental group $(N=35)$ and control group $(N=35)$. Watson and Glyster"s test for critical thinking was used. Furthermore, some skills selected from the right intelligent system of knowledge (RISK) were used to develop the students" critical thinking within a home economics course.The results showed statistically significant differences between the experimental and the control group in favor of the former in the following critical skills: interpretation, accuracy in investigating events, perception of objective facts and perception of the right relationship framework). The results, meanwhile, indicated that there were not differences in the skill of holding extreme opinions between both experimental and control groups

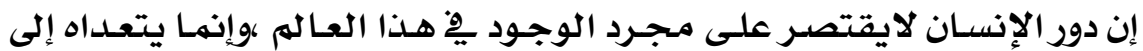

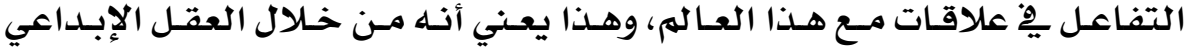

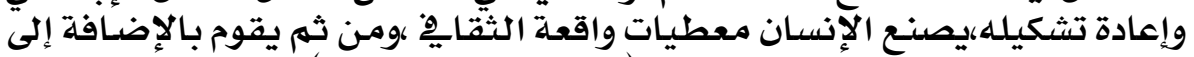

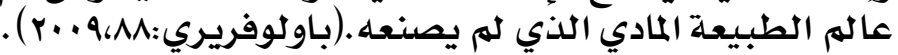


والتفكير عمليـة يوميـة طبيعيـة تحسدث لإِنسـان بشـكل مسـتمهر ، فـاتتفكير

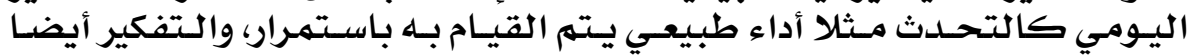

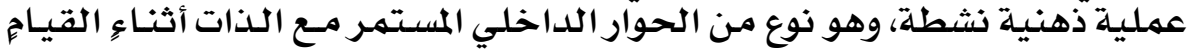

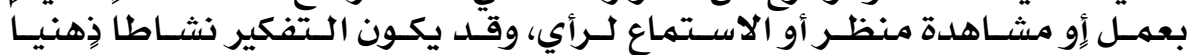

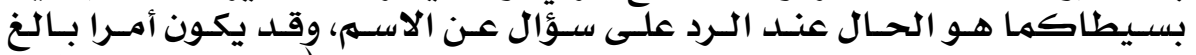

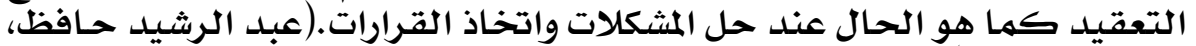

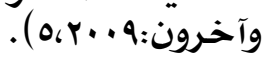

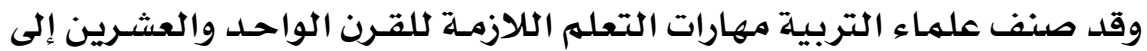

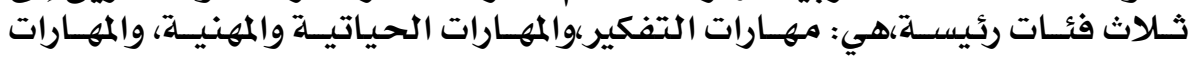

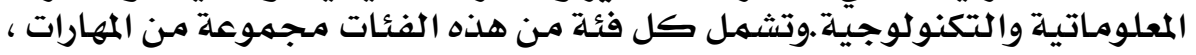

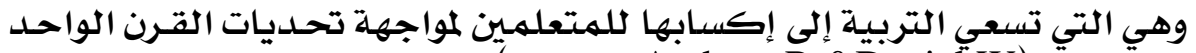

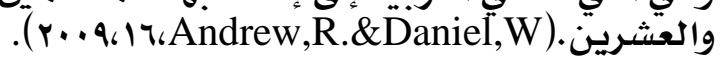

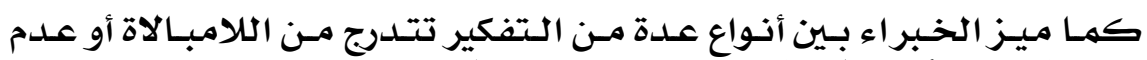

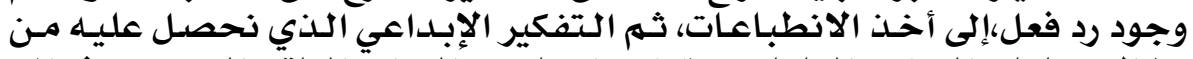

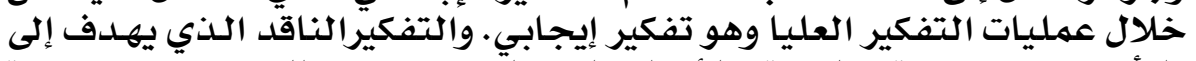

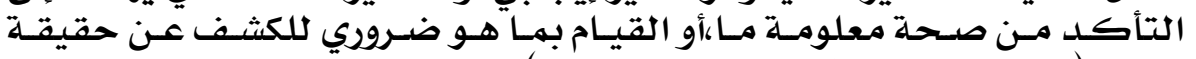

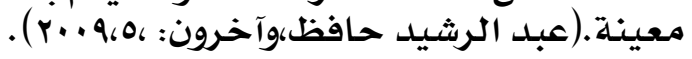

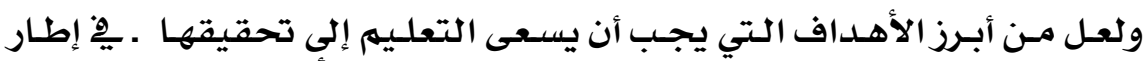

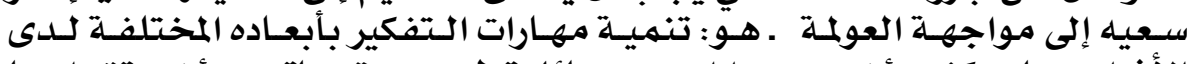

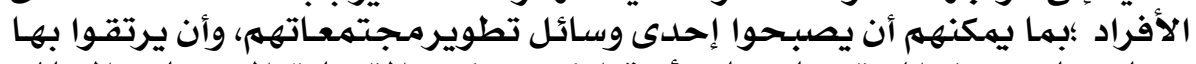

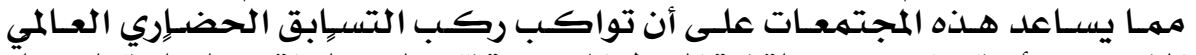

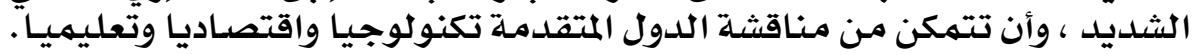

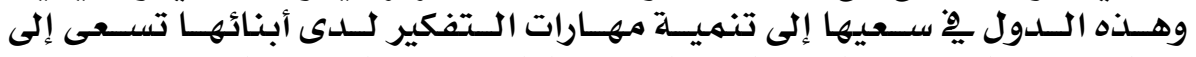

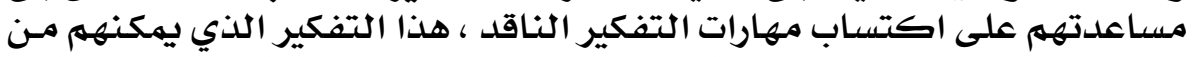

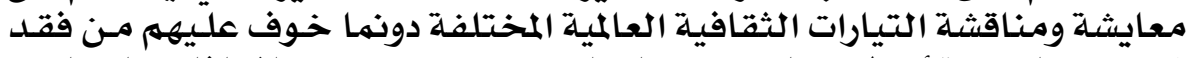

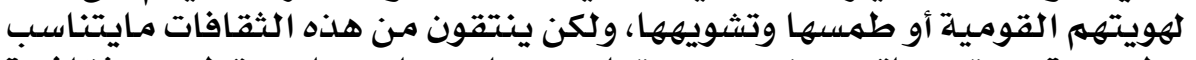

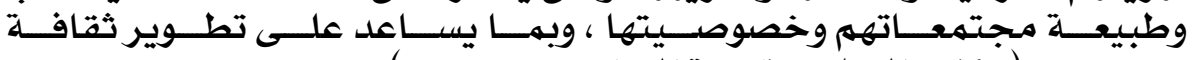

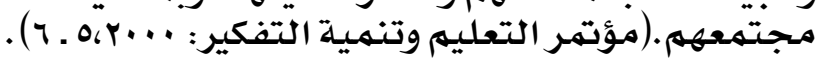

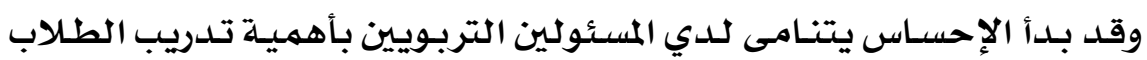

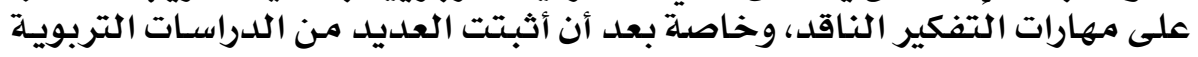

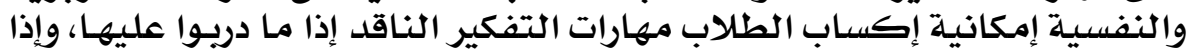

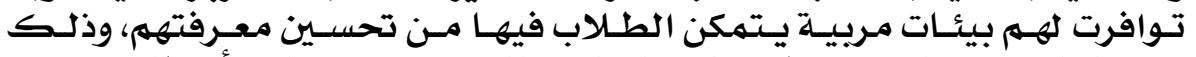

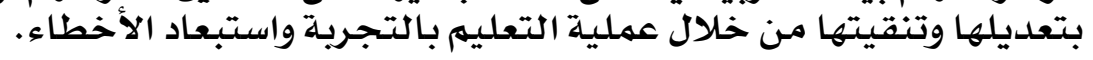

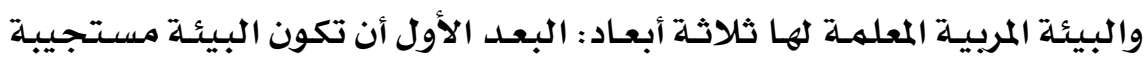

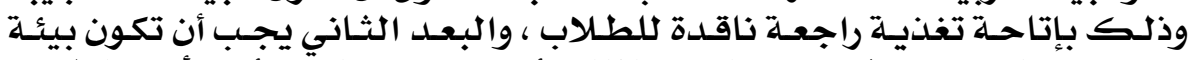

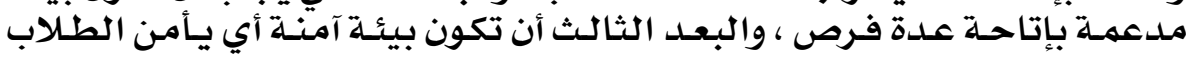

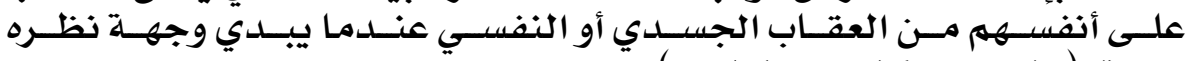

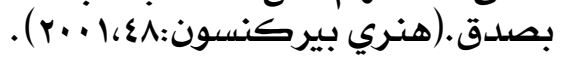

\section{7}




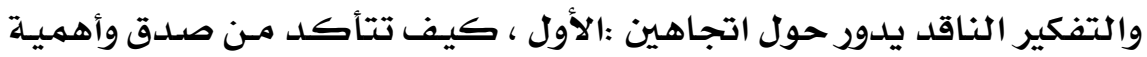

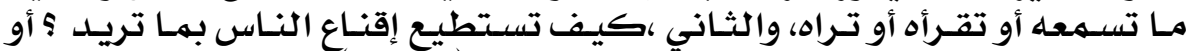

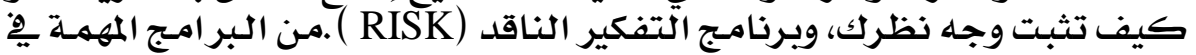

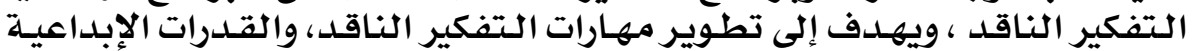

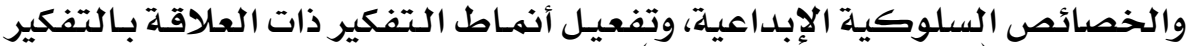

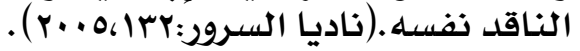

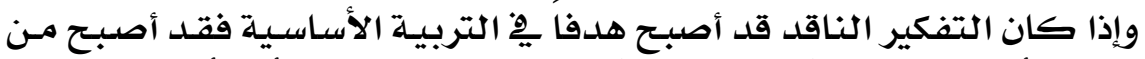

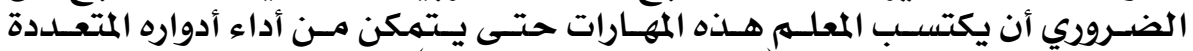

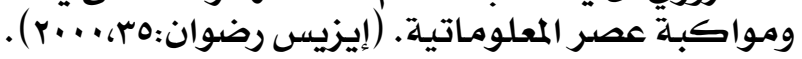

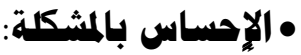

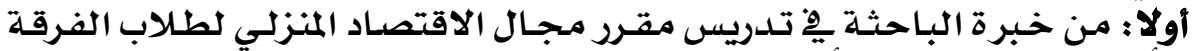

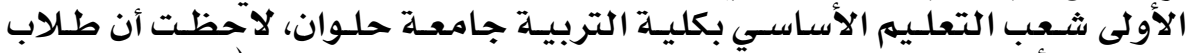

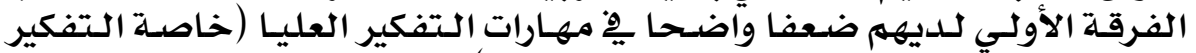

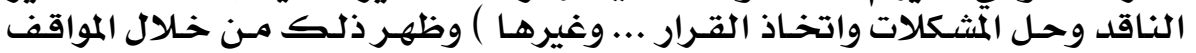

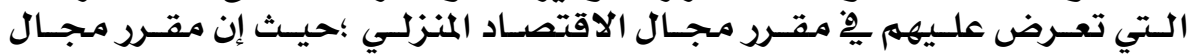

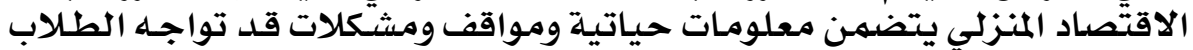

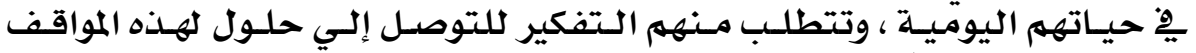

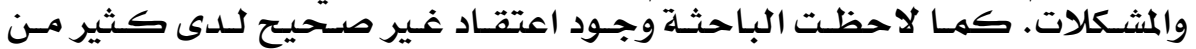

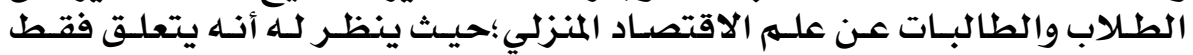

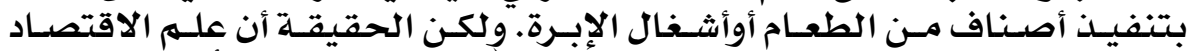

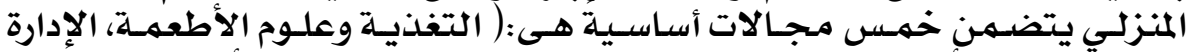

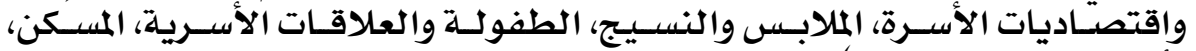

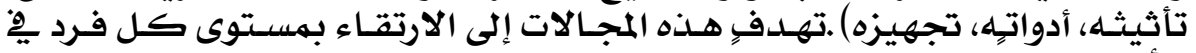

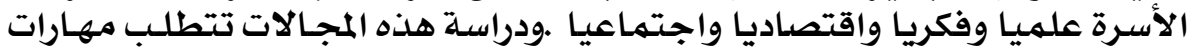

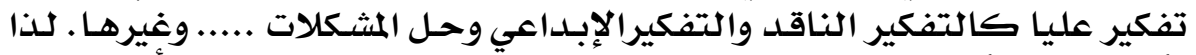

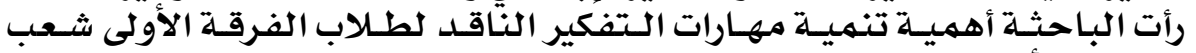

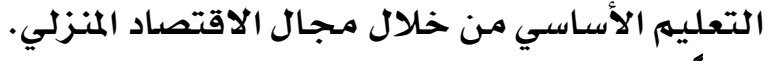

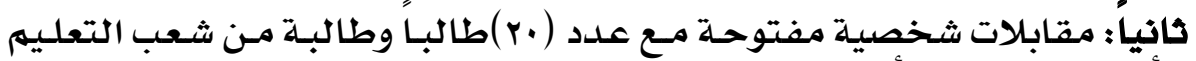

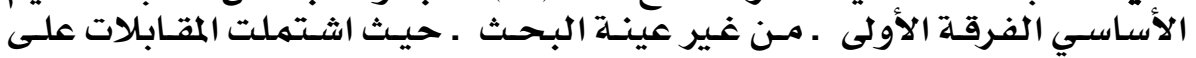

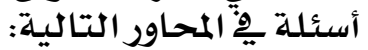

414 مفهوم الاقتصاد المنزلي.

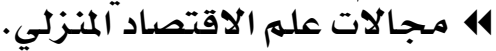

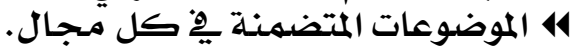

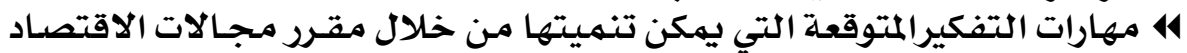
المنزلي.

$$
\text { وأسفرت المقابلات عما يليزي: }
$$

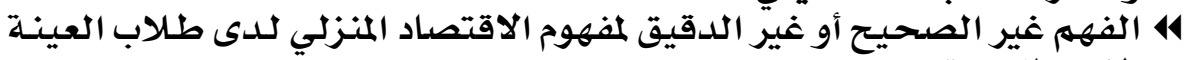
الاستطلاعية . الفعير التحية 
14 ضعف معرفةطلاب العينـة الاستطلاعية للمعلومـات الصـحيحة عن مجـالات

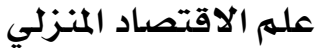
414

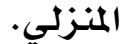

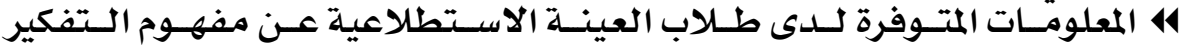

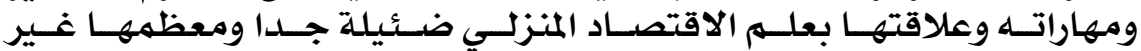

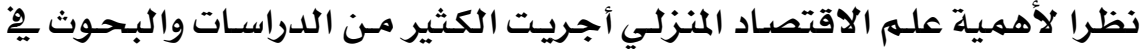

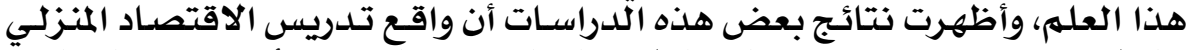

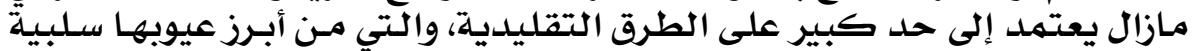

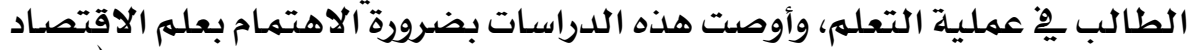

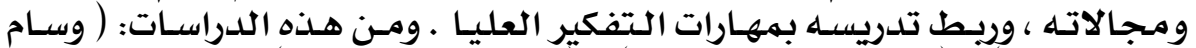

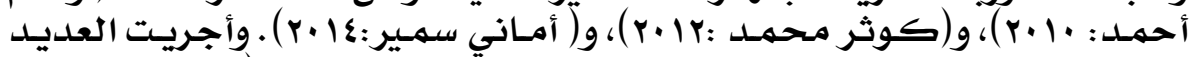

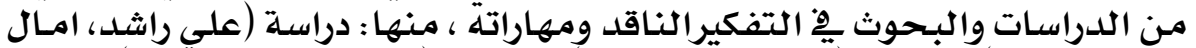

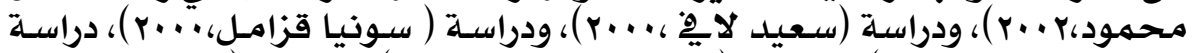

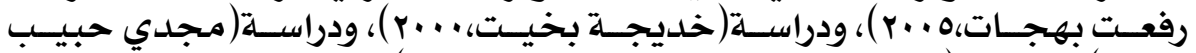

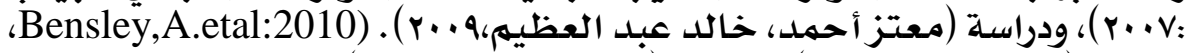

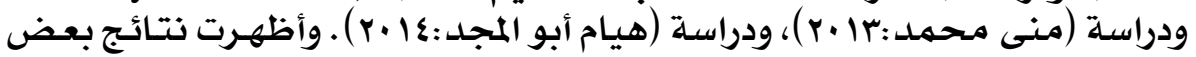

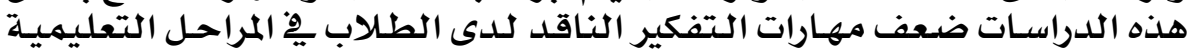

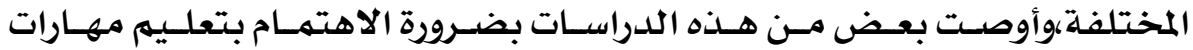

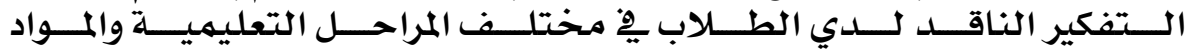

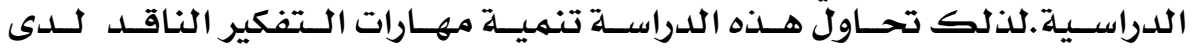

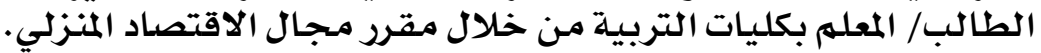

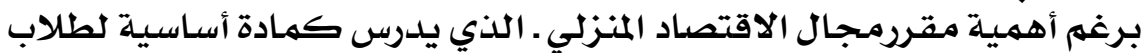

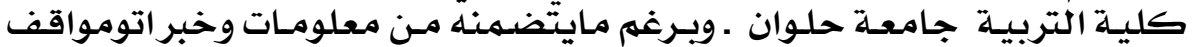

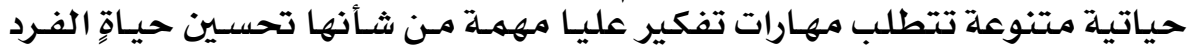

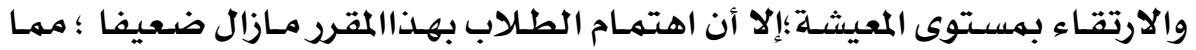

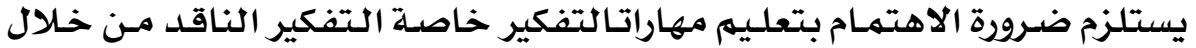

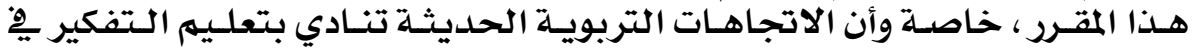

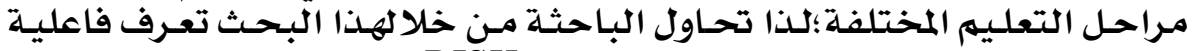

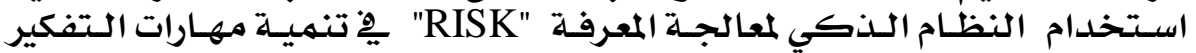

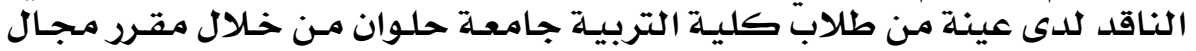

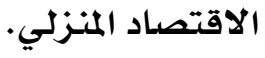

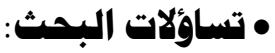
تحاول هذه الدراسلة الإجابة الدابة عن الأسئلة:

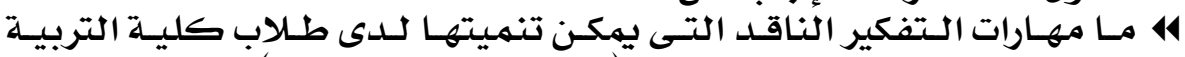

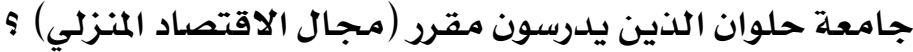

\section{$7 \wedge$}




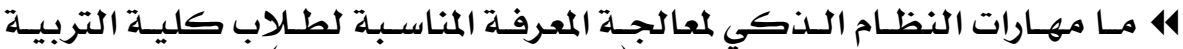

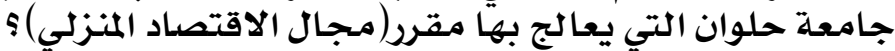

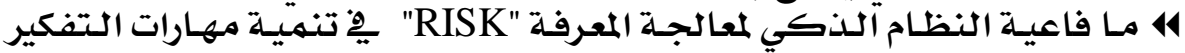

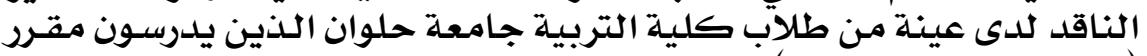

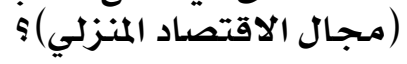

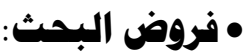

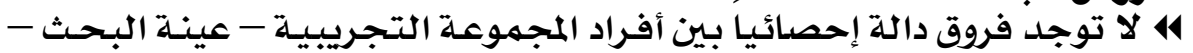

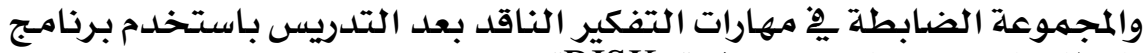

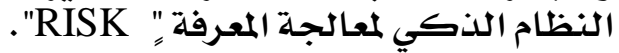

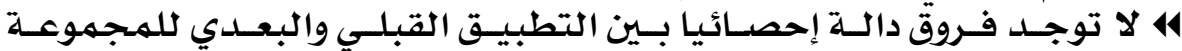

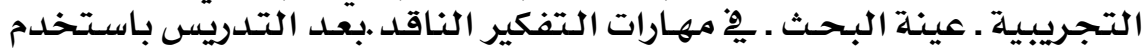

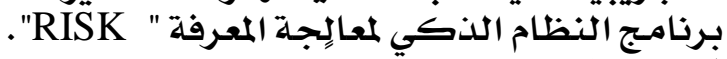

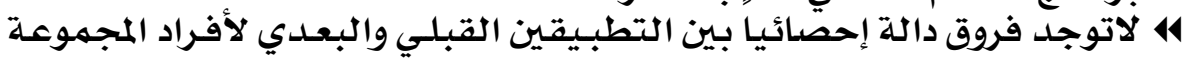

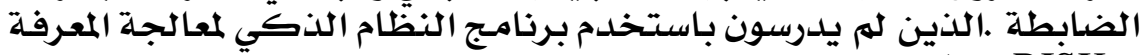

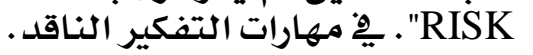

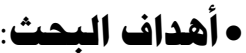

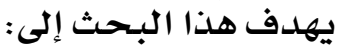

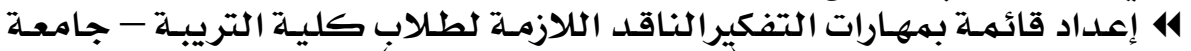

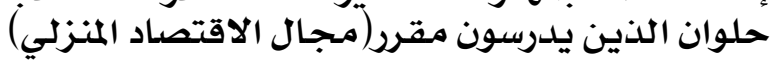

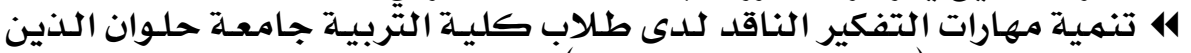

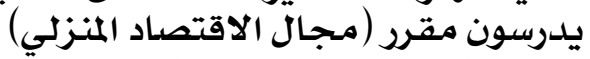

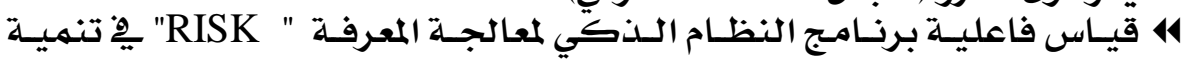

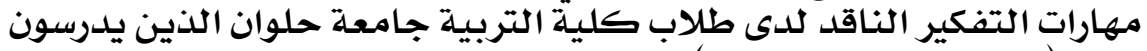

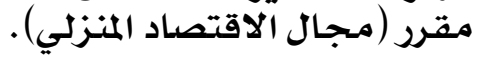

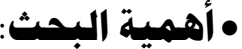

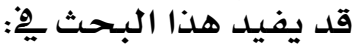

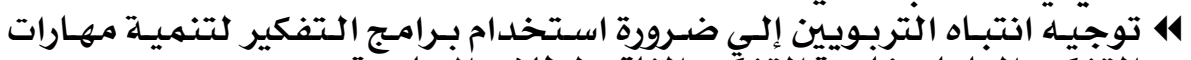

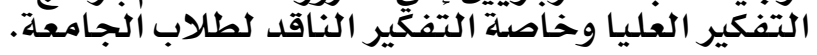

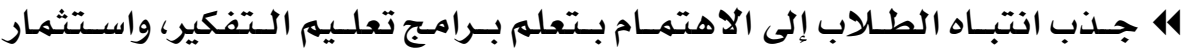

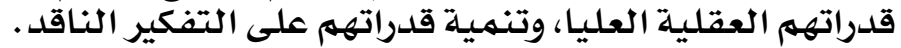

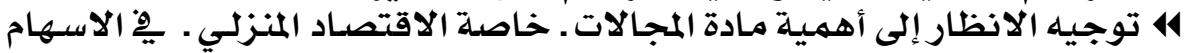

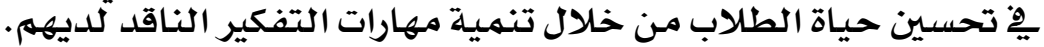

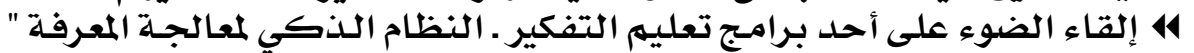

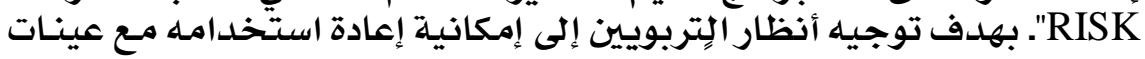

$$
\text { مختلفة من الطلاب مستقبيلا. }
$$

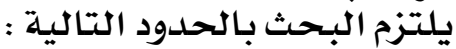

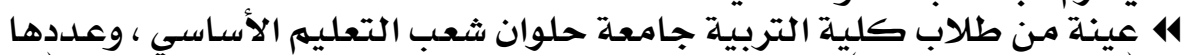

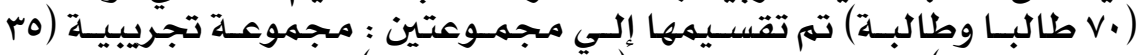

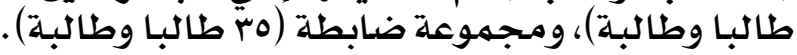

\section{9}




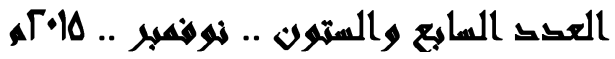

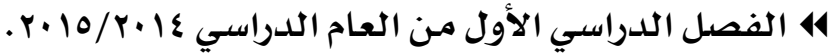

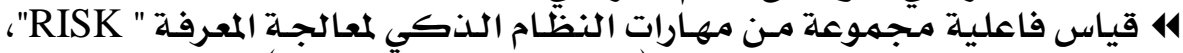

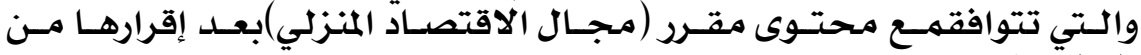

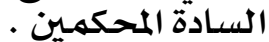

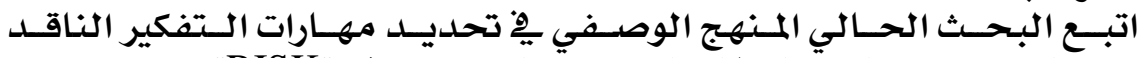

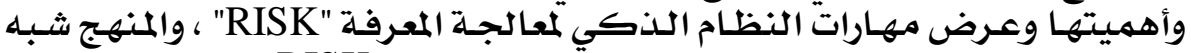

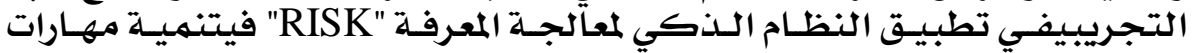

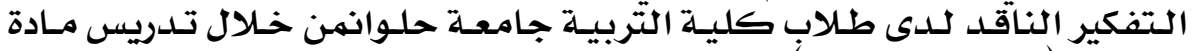

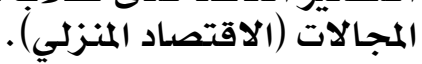

:

: Critical Thinking التفكير الناقد :

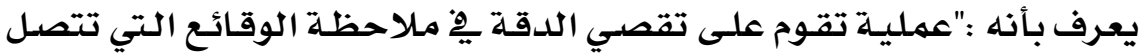

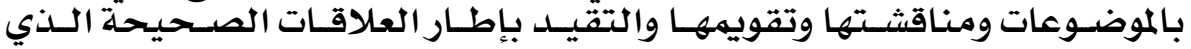

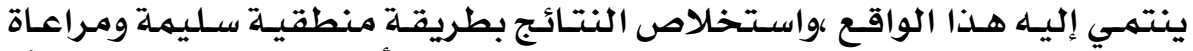

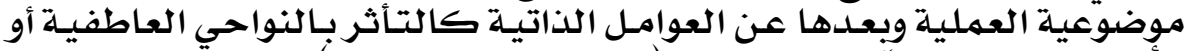

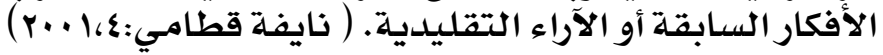
كما يعـرف بأنه"نوع من التفكير المسئول الذي يـيسـر عمليـات الوصـول للقـرار.

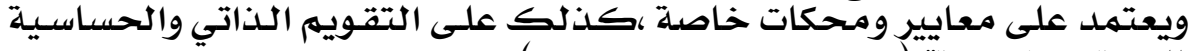

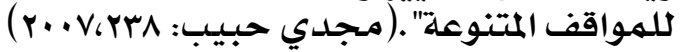

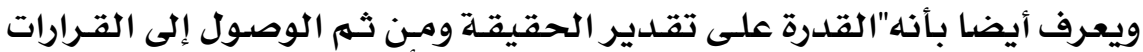

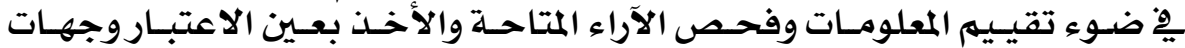

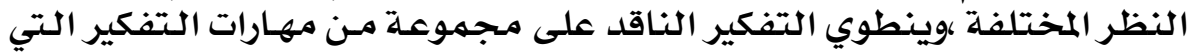

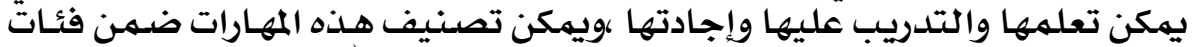

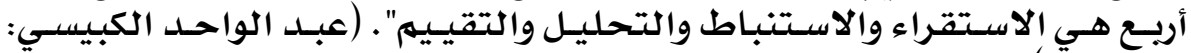

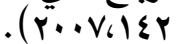

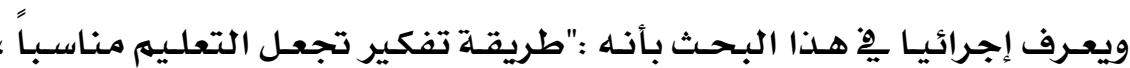

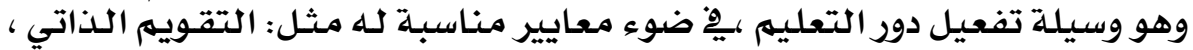

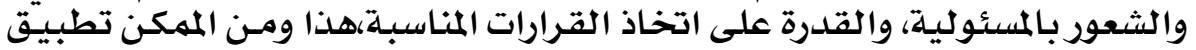

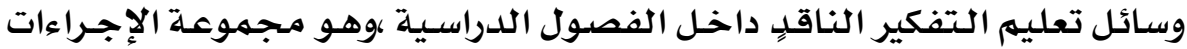

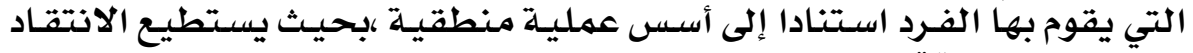

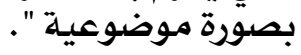

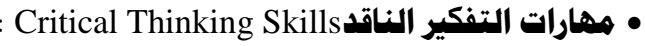

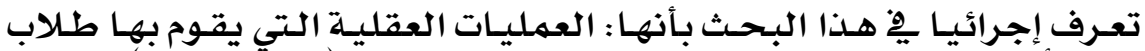

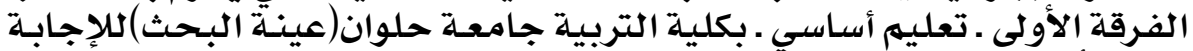

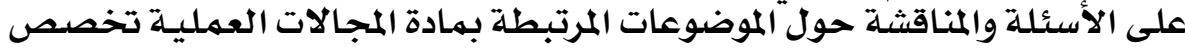

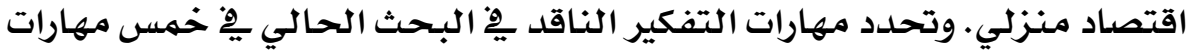




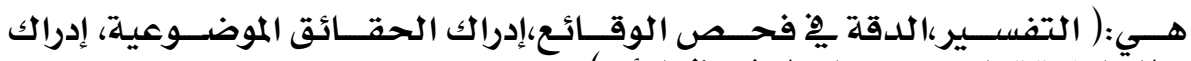

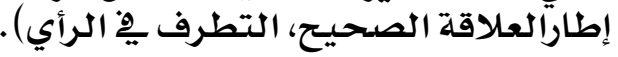

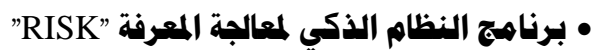

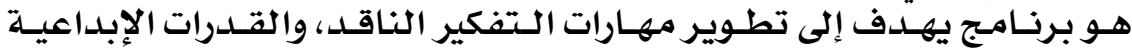

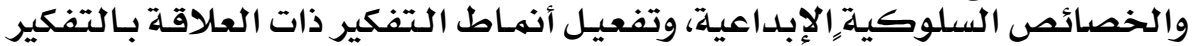

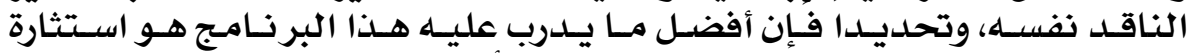

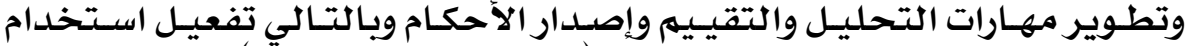

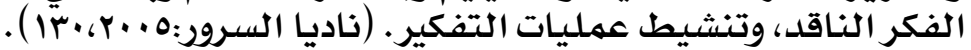

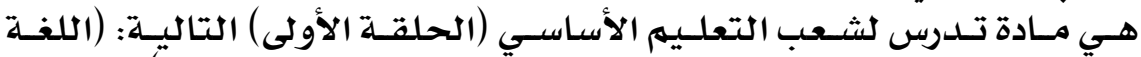

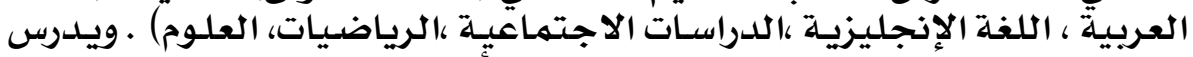

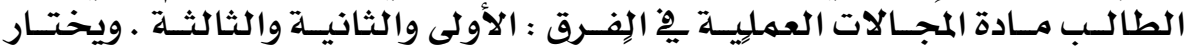

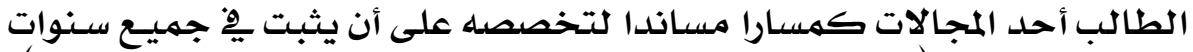

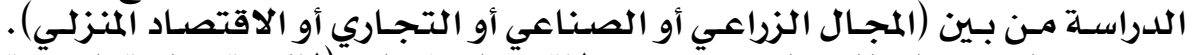

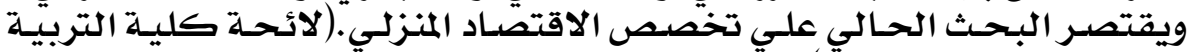

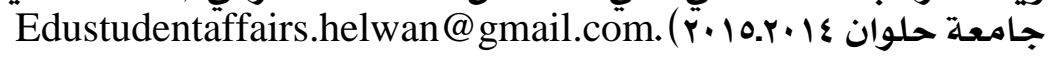

• الإطار النظري: جامعان

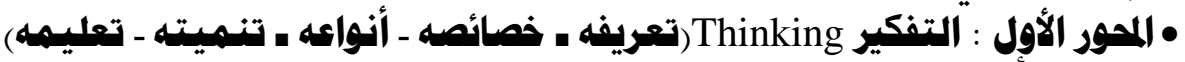

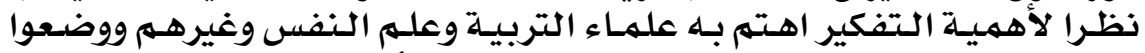

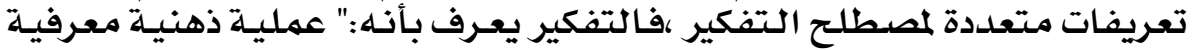

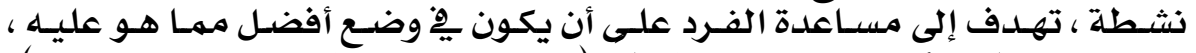

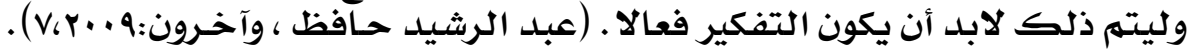

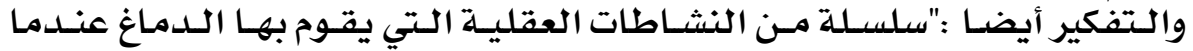

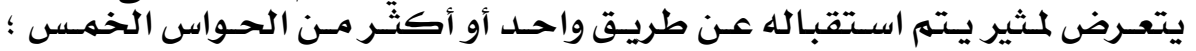

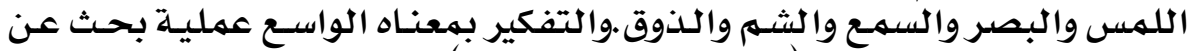

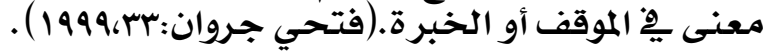

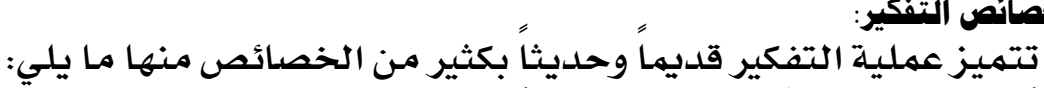

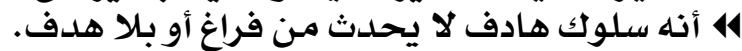

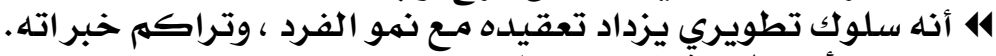
41

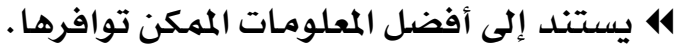

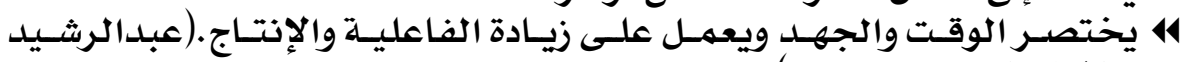

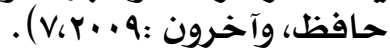

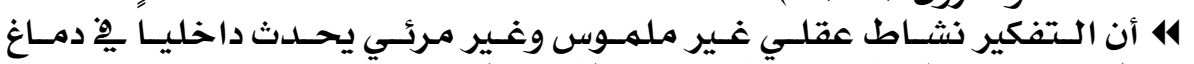

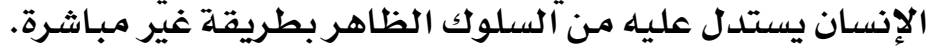

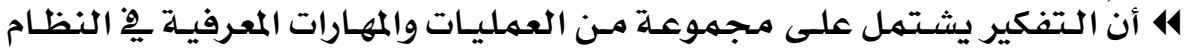

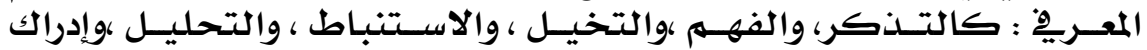

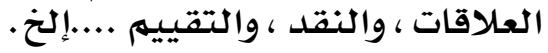

\section{VI}




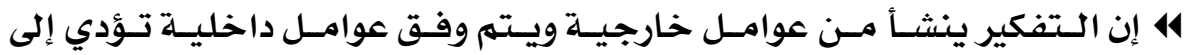

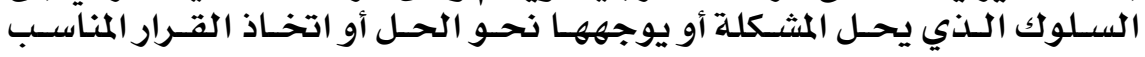

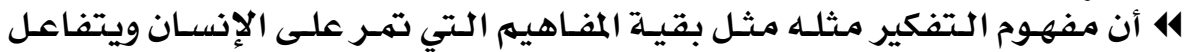

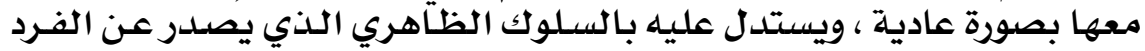

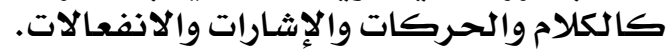

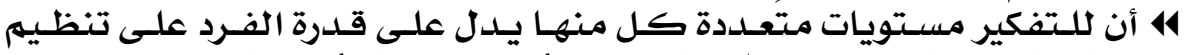

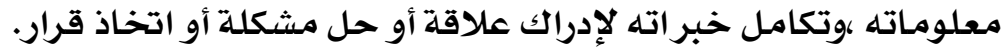

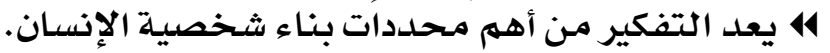

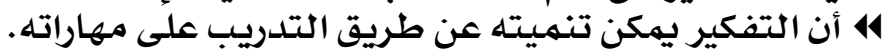

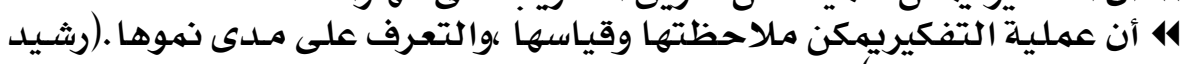

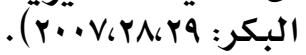

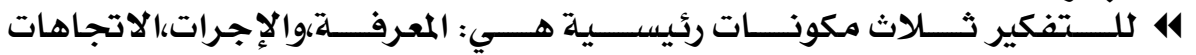

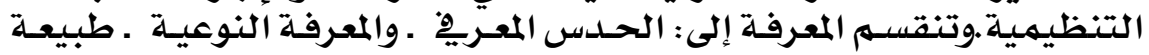

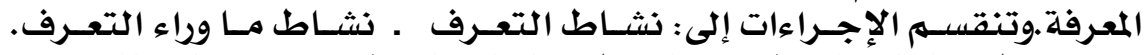

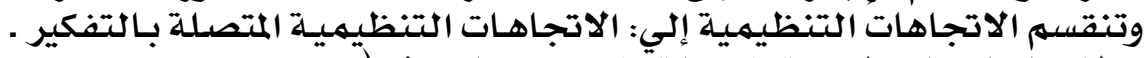

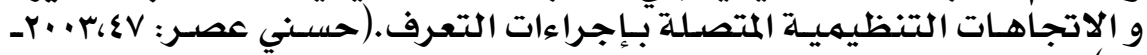
.

\section{تحداع أنواع التفكير بأنها سبعة أنواع وهي:}

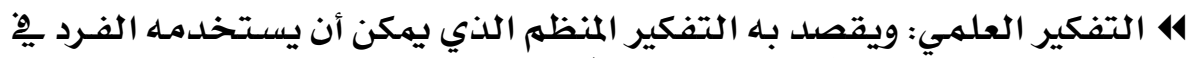

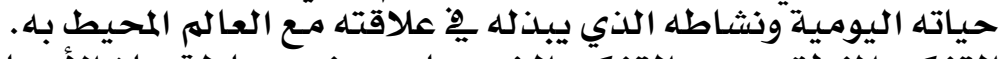

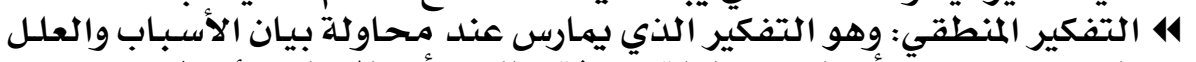

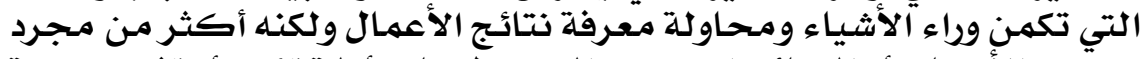

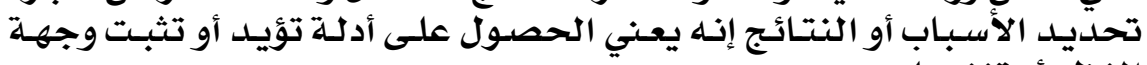
النظر أو تنفيهان.

4 التفكير الناقده: وهو الذي يقوم على تقصي الدقة يِّ ملاحظة الوقائع التي

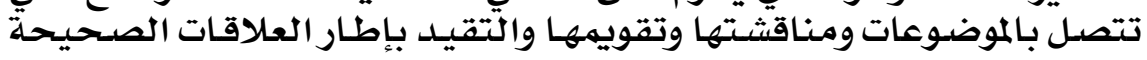

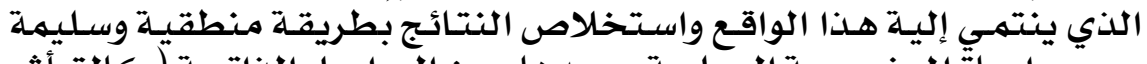

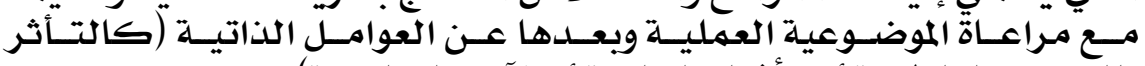

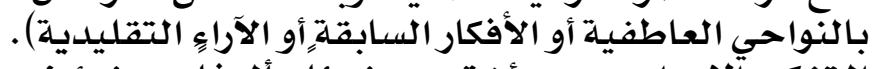

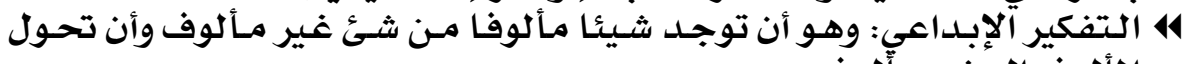

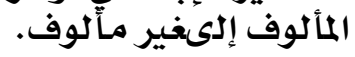

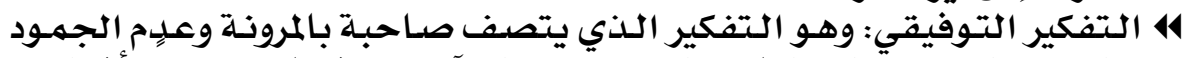

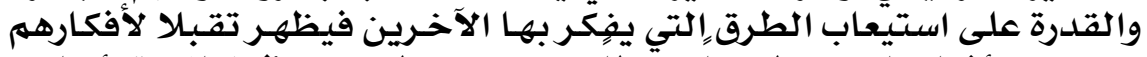

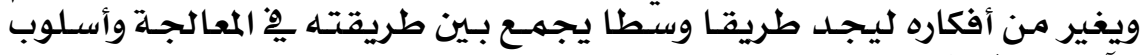

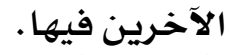

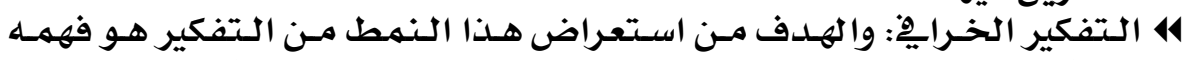

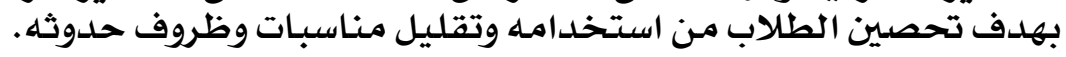

\section{VY}




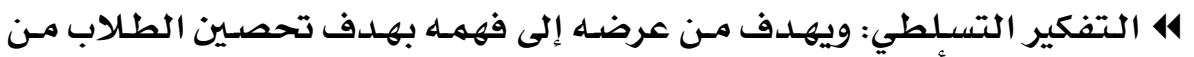

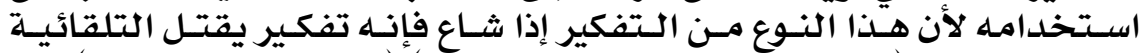

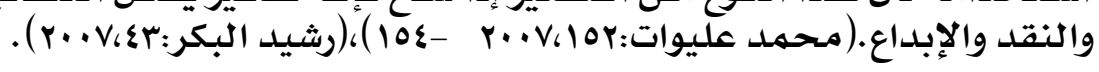

\section{• تمليسم التفكير في المناهج الدراسية:}

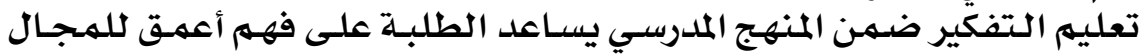

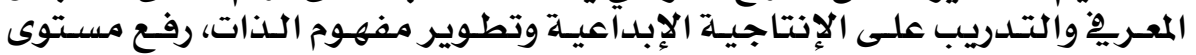

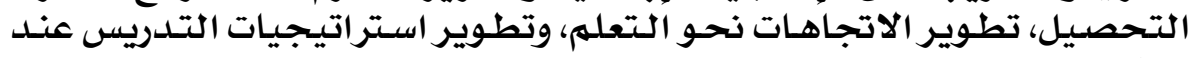
المعلمهين.

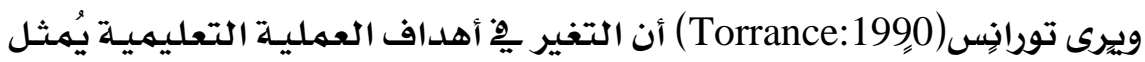

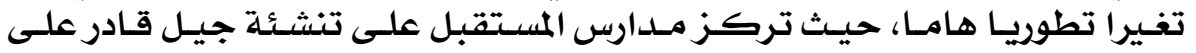

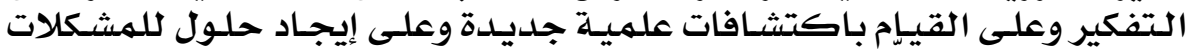

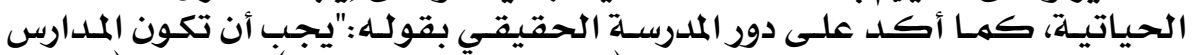

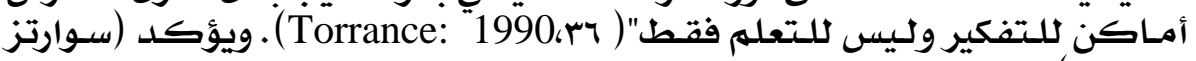

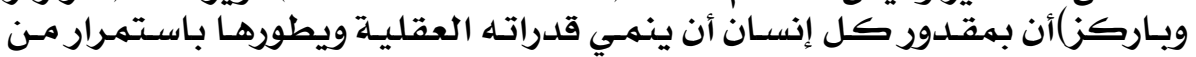

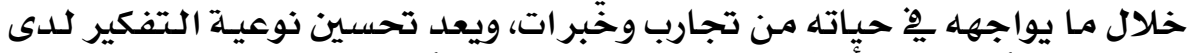

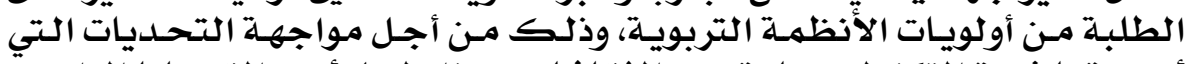

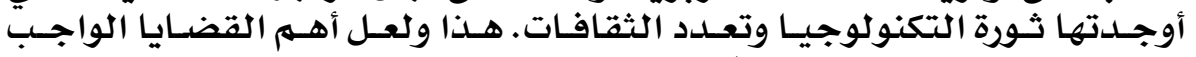

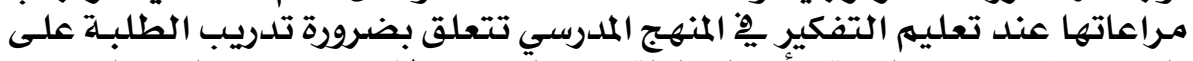

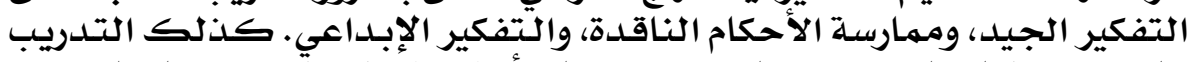

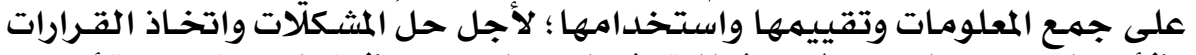

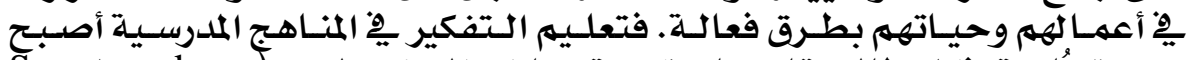

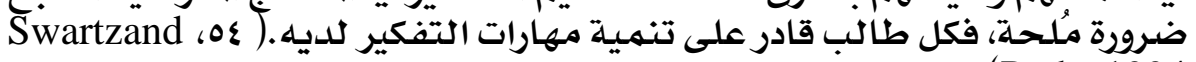
(Parks, 1994

\section{• وينطلق تعليم التفكير هن عدة هبادئ، هنها:}

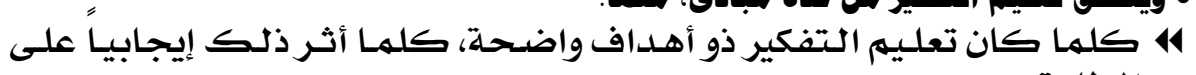
الطلبـة.

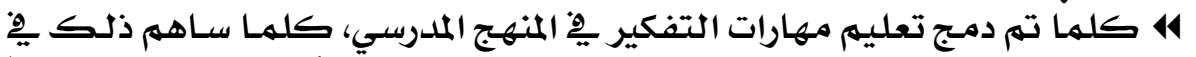

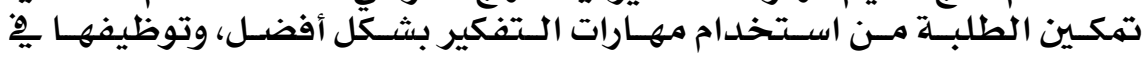

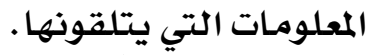

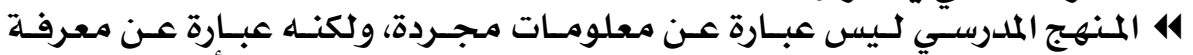

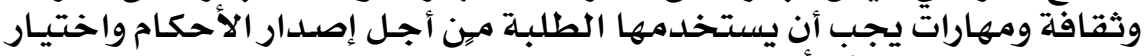

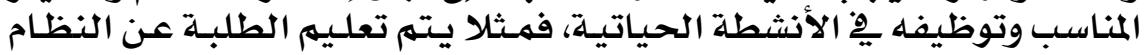

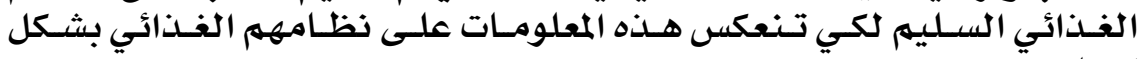

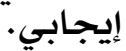

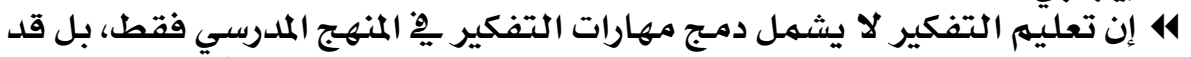

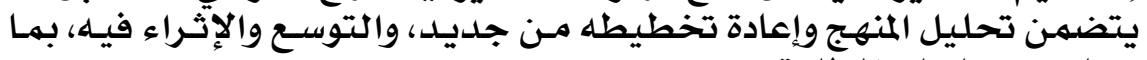

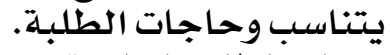

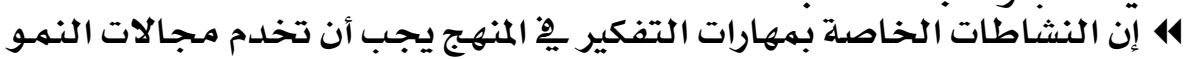

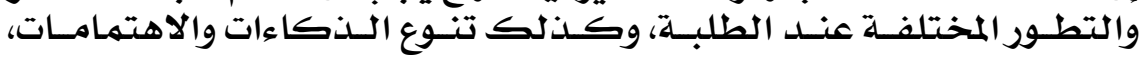

\section{$V^{r}$}




\section{العثى العابع والستهو .. نوهمبر ..}

بـالإضـافة إلى تنـوع أنهاط التفكير والتعلهم، وجميـع مجـالات الفـروق الفرديـة

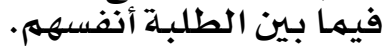

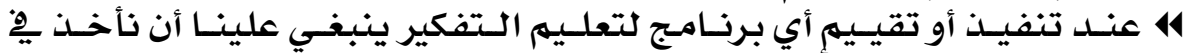

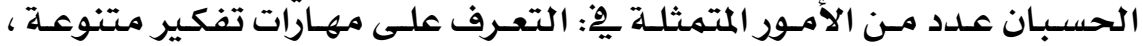

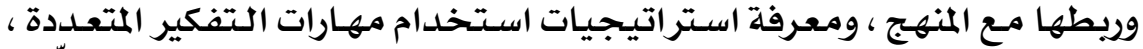

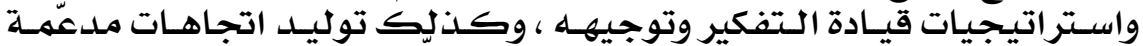

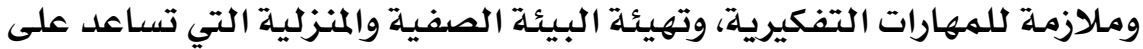

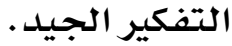

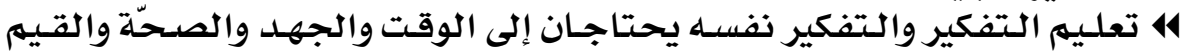

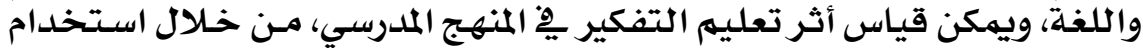

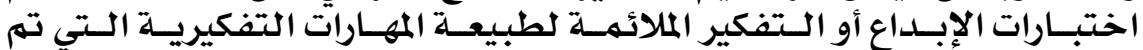

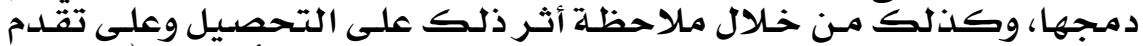

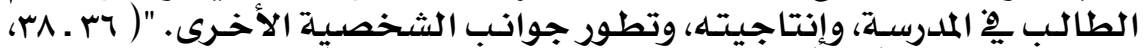
.(Twartzand Parks, 1994،or. os ) ، (Torrance: 1990

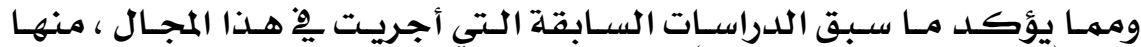

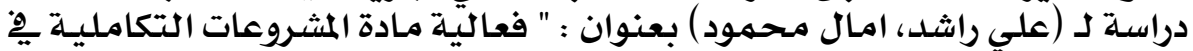

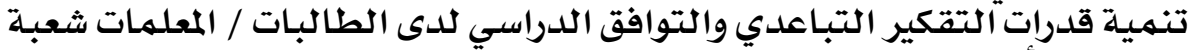

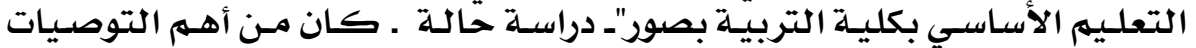

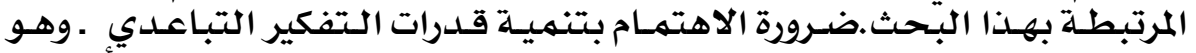

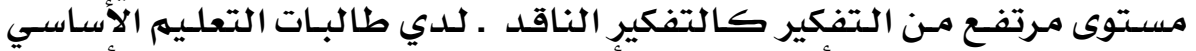

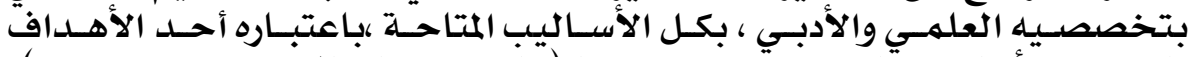

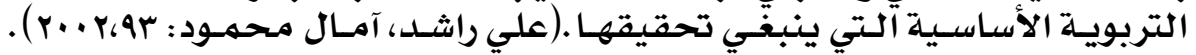

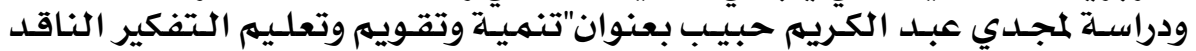

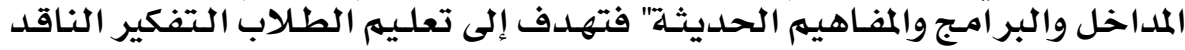

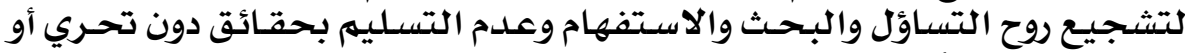

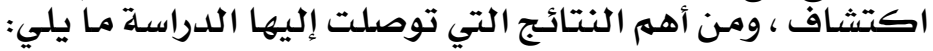

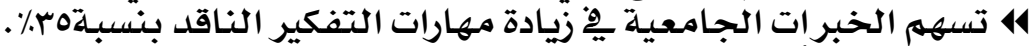

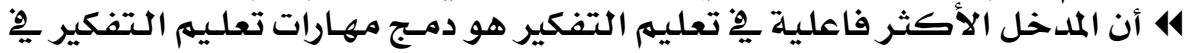
سياق المناهج التعليميلة.

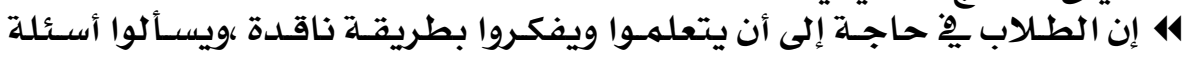

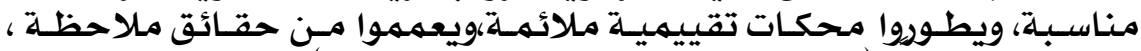

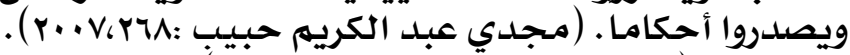

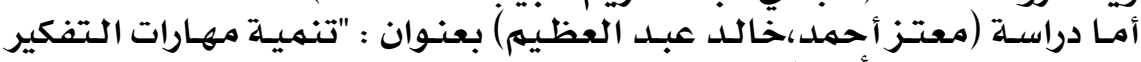

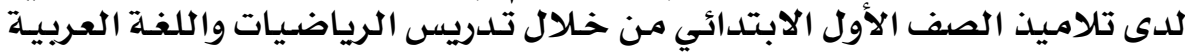

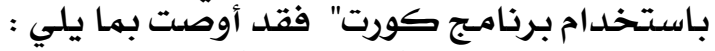

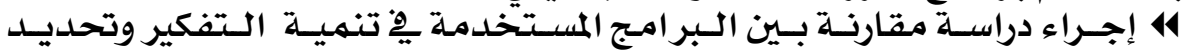

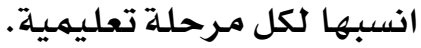

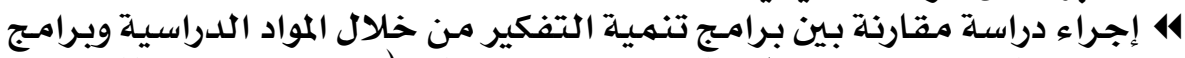

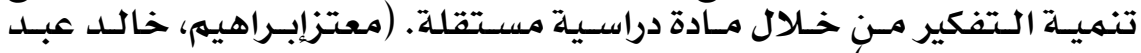

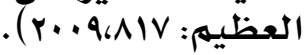

\section{V $\varepsilon$}




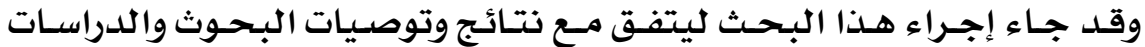

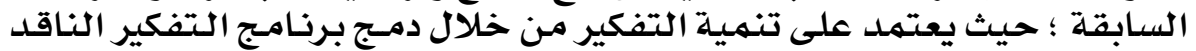

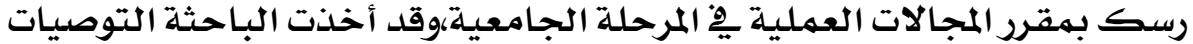

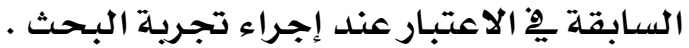

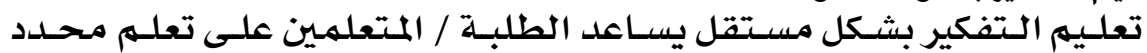
لمهارات التفكير المختلفة، حتى يتمكنوا من إتقان تعله كل مهل مهارة على حلده.

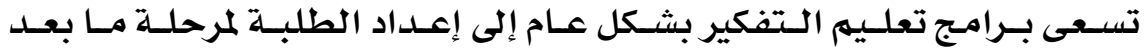

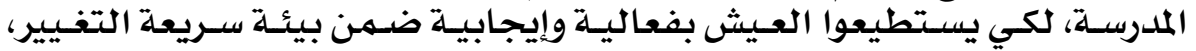

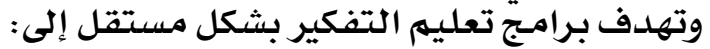

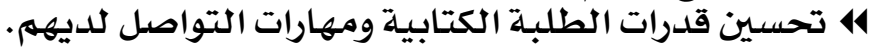

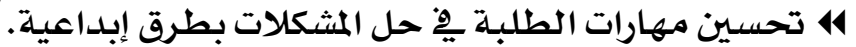

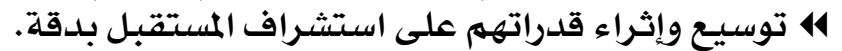
4 تطوير أنماط تفكير كثيرة ونشطة

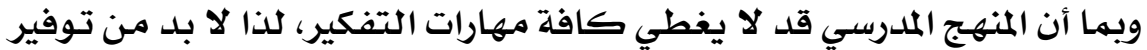

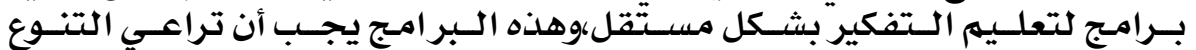

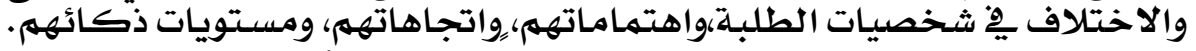

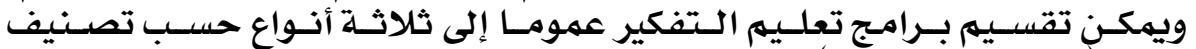

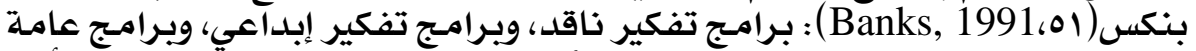

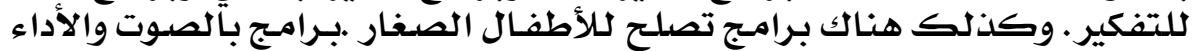

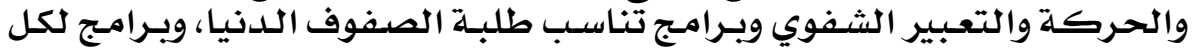

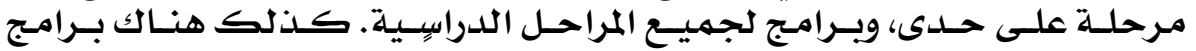

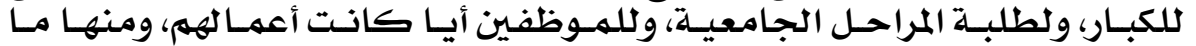

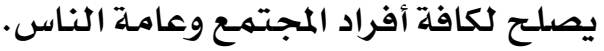

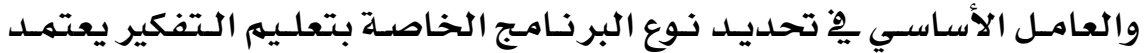

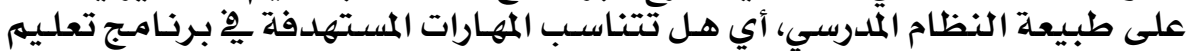

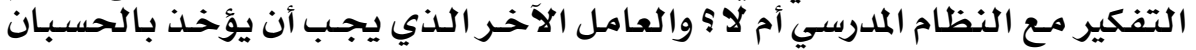

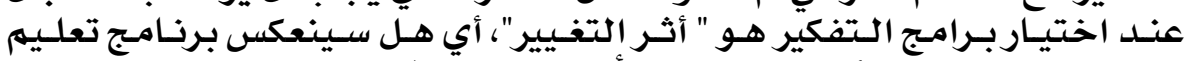

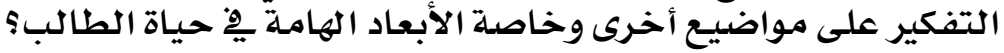

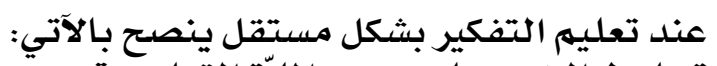

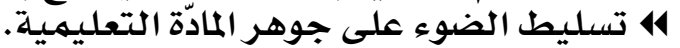
414 اختيار مهارات التفكير الملائمة. 14

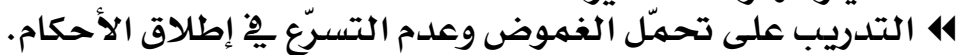

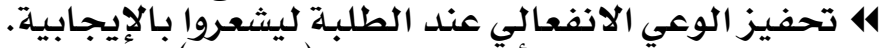

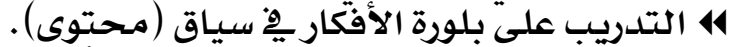

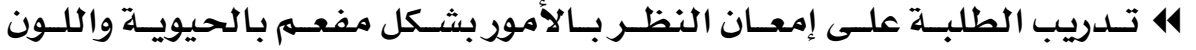

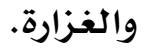
41 تدريب الطلبـة على استخدام الخيال.

\section{V०}




\section{العقد العابع والستهو .. نوهمبر ..}

44 استخدام الحركة والصوت المرافقة لتوظيف مهارة التفكير.

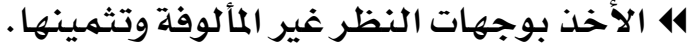
414

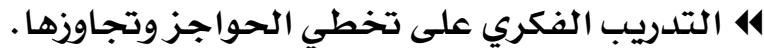

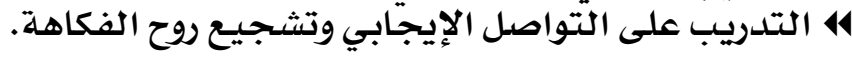

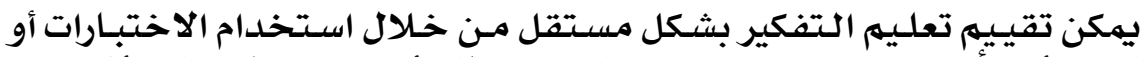

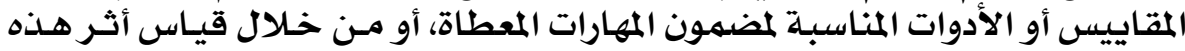

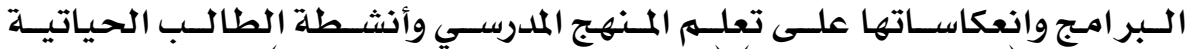

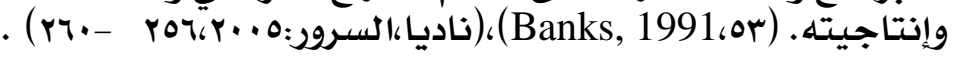

4 هساعدة الأفراد الذين لايمتلكون أيّة مهارات أو بعض مهارات التفكير المرغوب

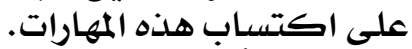

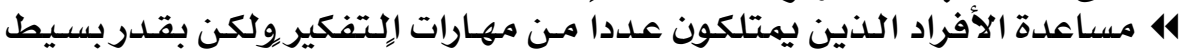

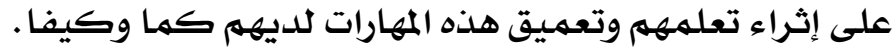
414 البعضر وإكسابهم بدلا منها مهارات التفكير المرغوبي. (مؤتمر التعليم وتنهية

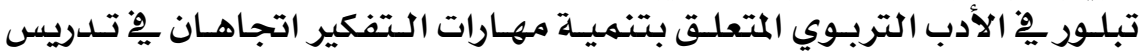

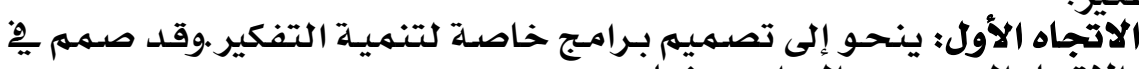
التفكير

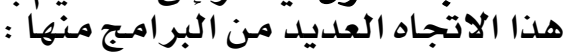

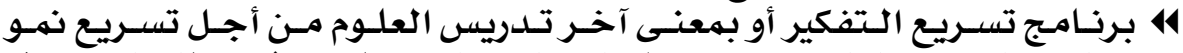

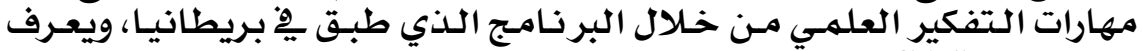

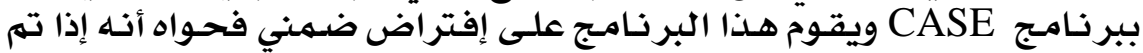

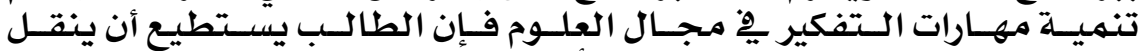

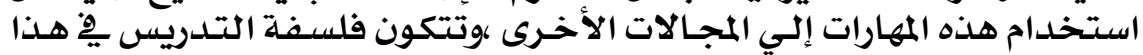
البرنامج من أربعة عناصرات $\checkmark$

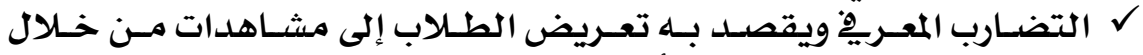

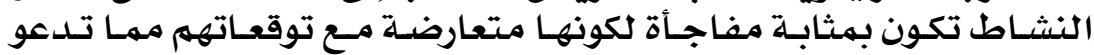

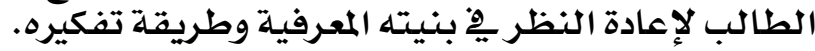

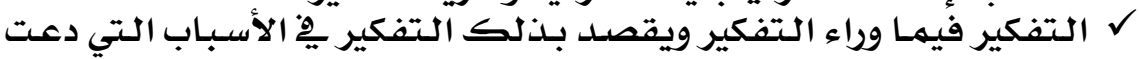
إلى التفكير يِّ المشكلة بطريقة معينة.

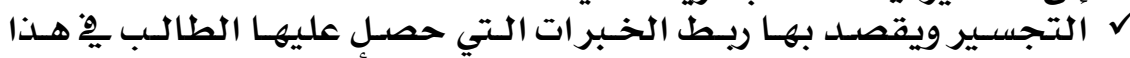

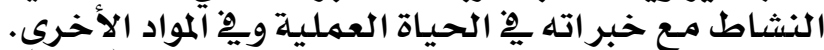

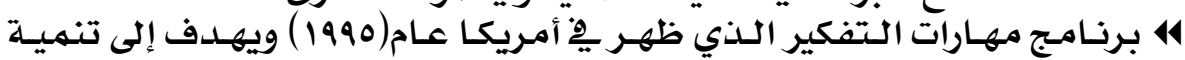

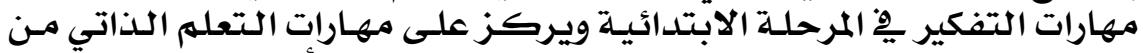

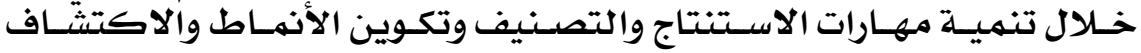

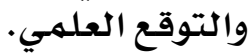

\section{V7}




$$
4 \text { برنامـج تحسين التفكير بطريقة القبعات الست . }
$$

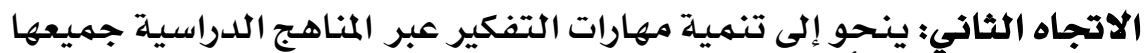

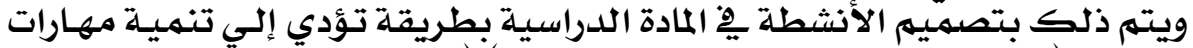

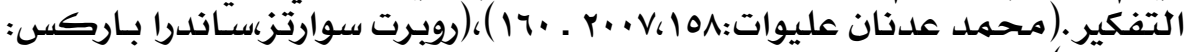

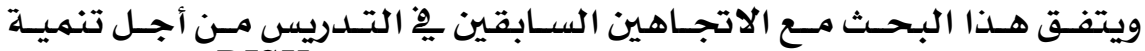

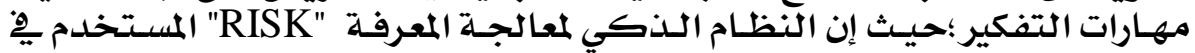

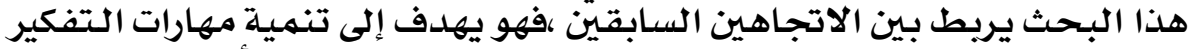

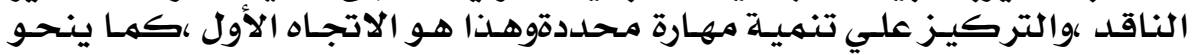

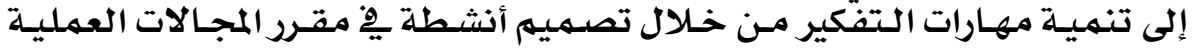

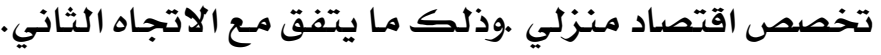

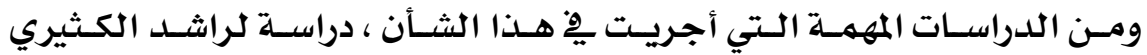

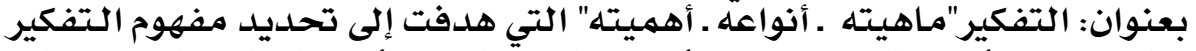

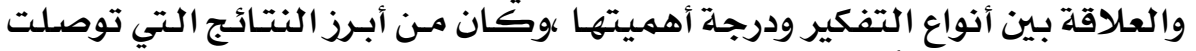

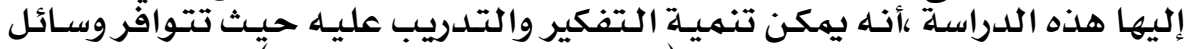

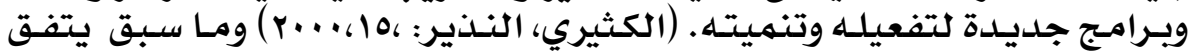

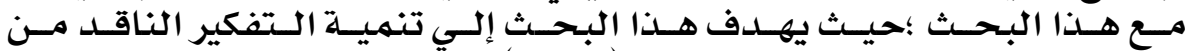

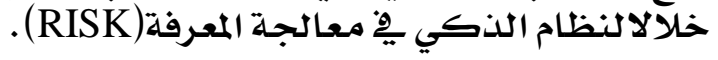

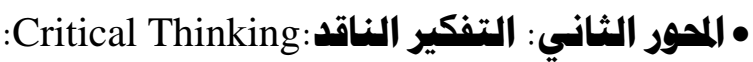

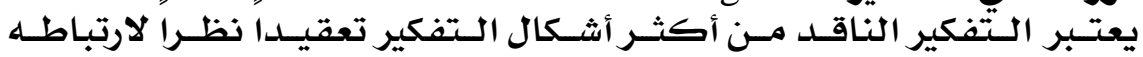

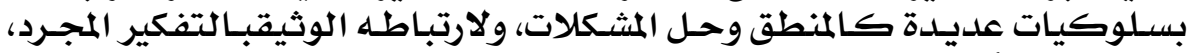

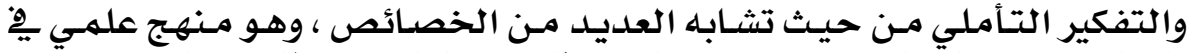

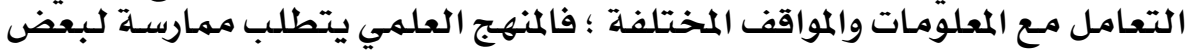

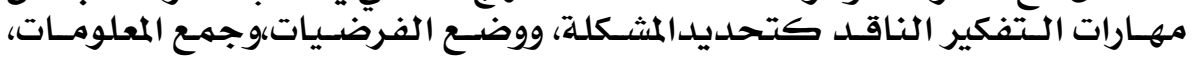

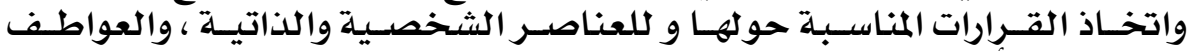

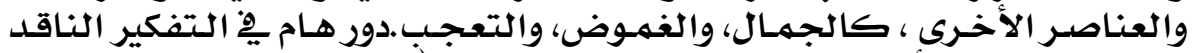

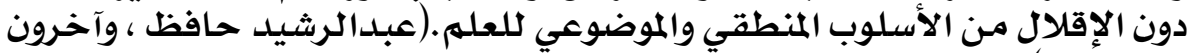
. ( r P Q r r r :

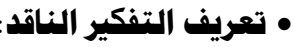

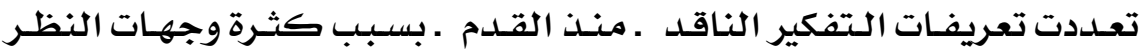

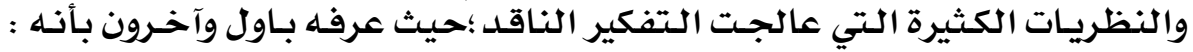

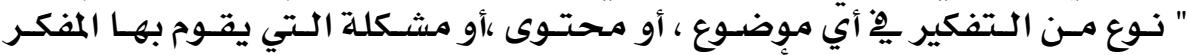

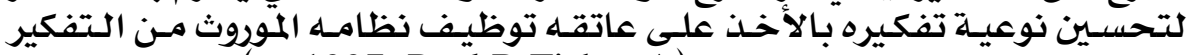

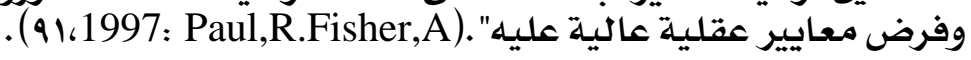

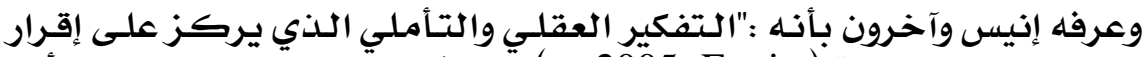

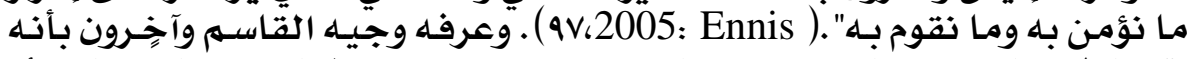

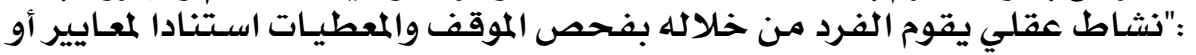

\section{V}




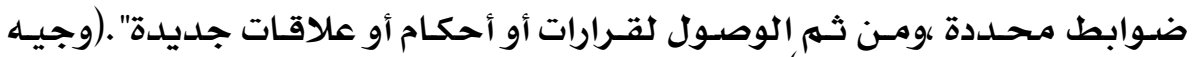

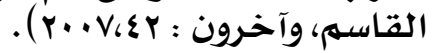

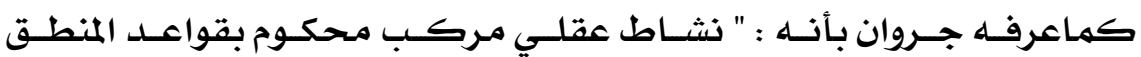

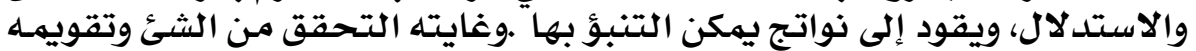

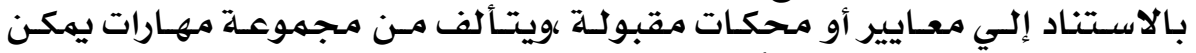

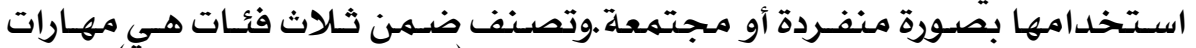

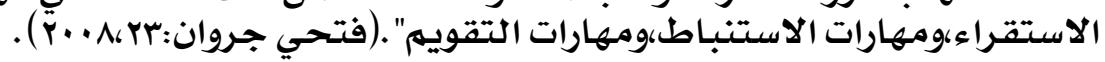

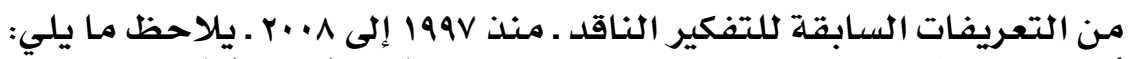

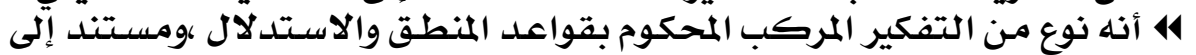

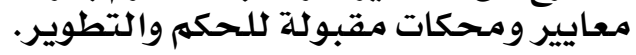

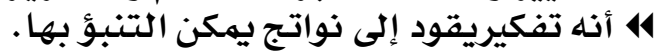

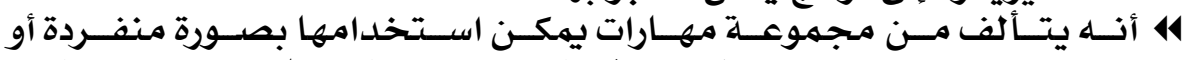

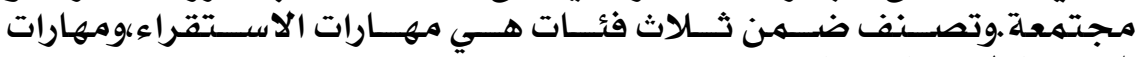

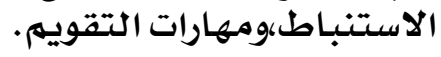

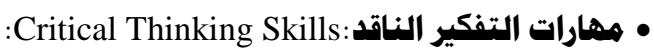

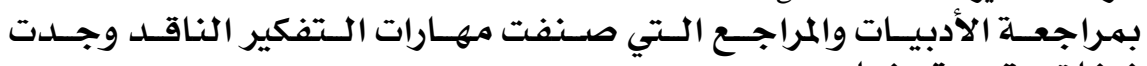
تصنيفات متعددة منهاجها

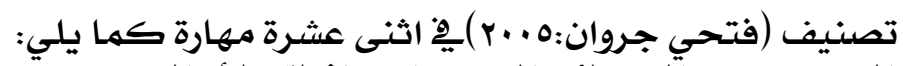

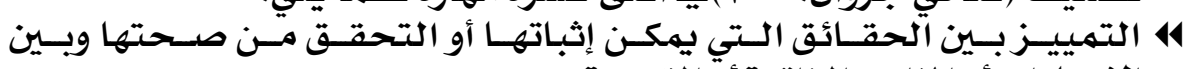

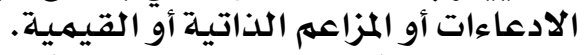

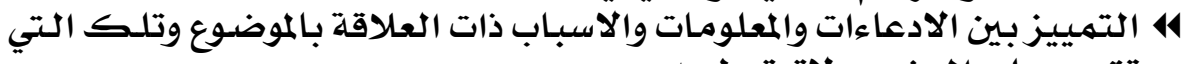

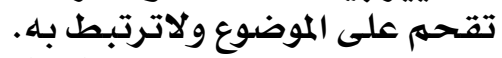

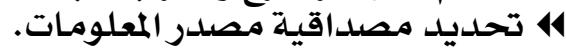

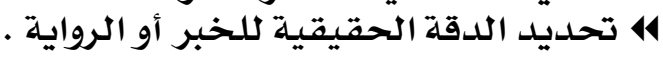

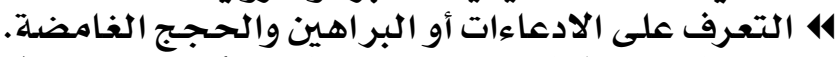

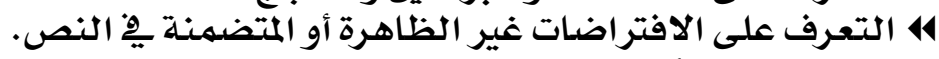
414 تحري التحيز أو التحفرفي التحامل.

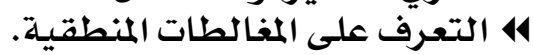

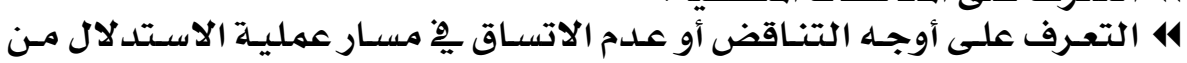

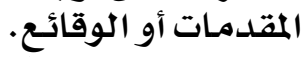

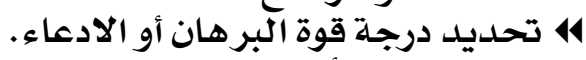

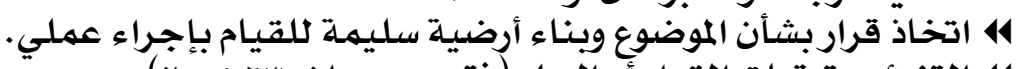

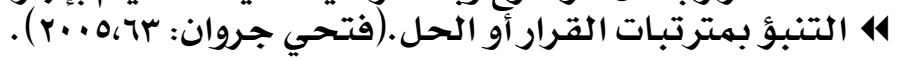

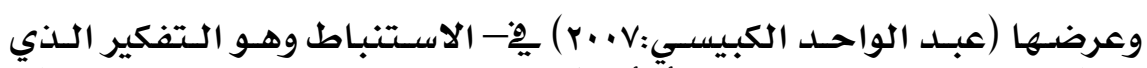

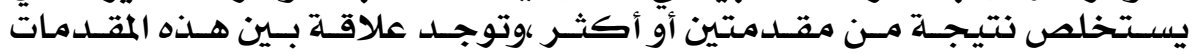
والنتيجنة.

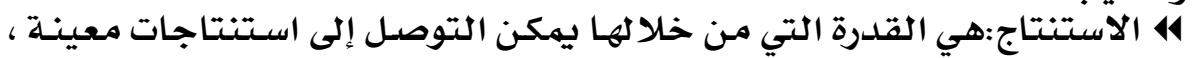

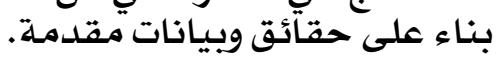

\section{$\vee \wedge$}




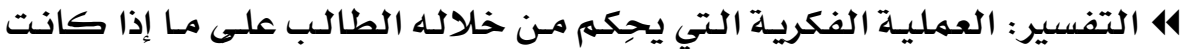

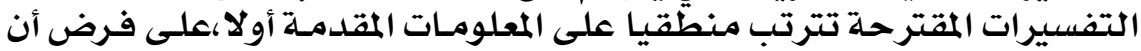

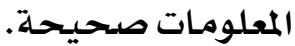

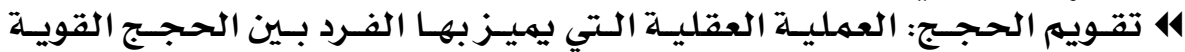

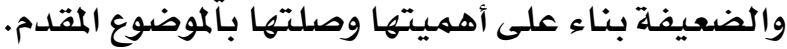

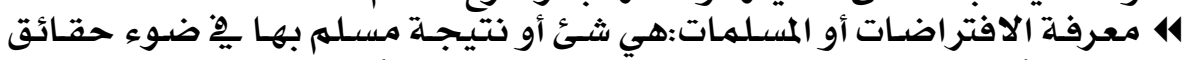

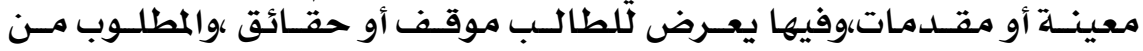

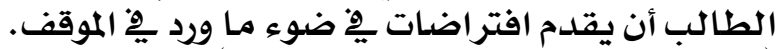

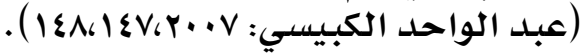

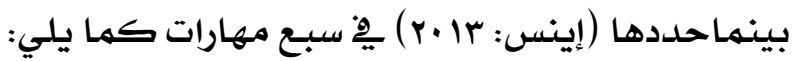

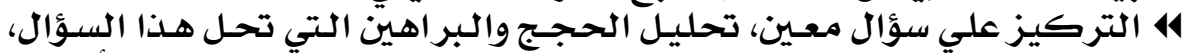

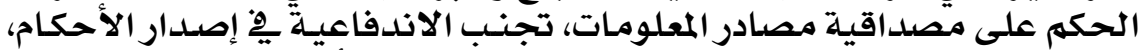

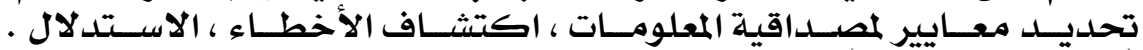
.( Ennis, R 2013)

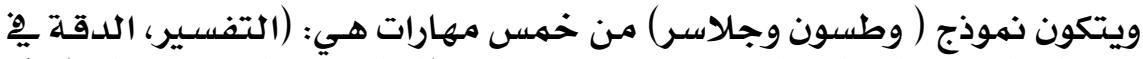

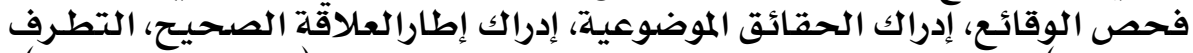

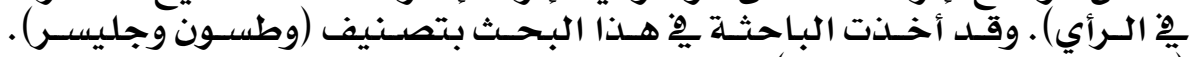

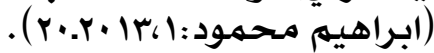

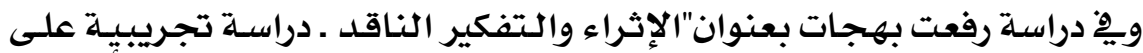

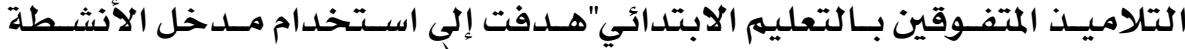

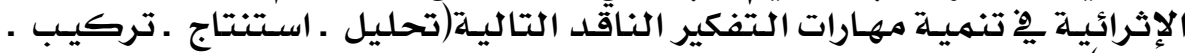

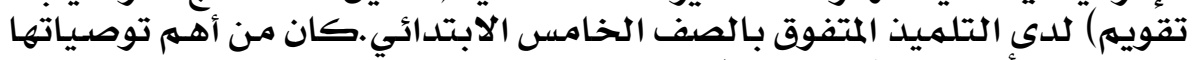

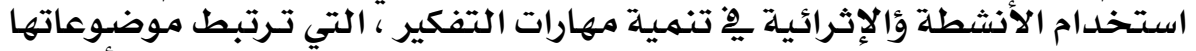

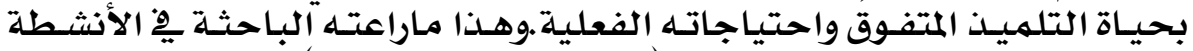

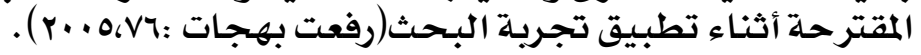

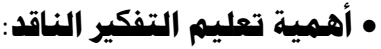

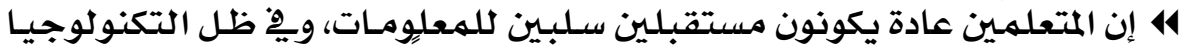

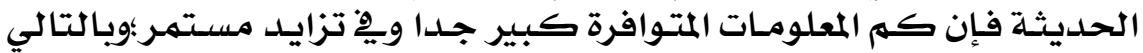

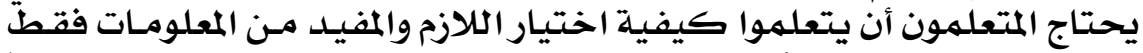

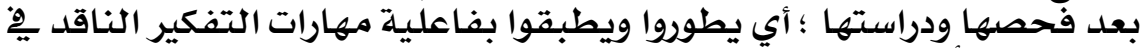

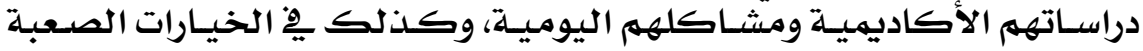

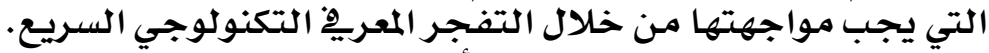

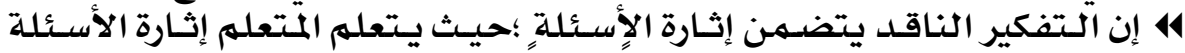

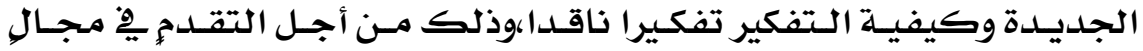

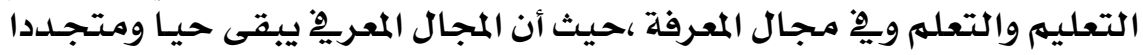

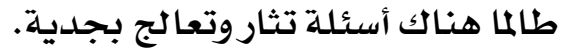

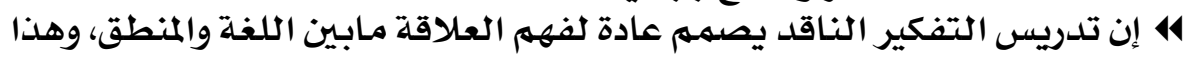

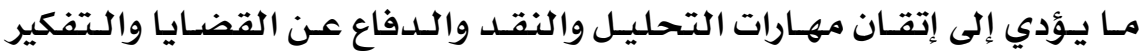

\section{$\vee 9$}




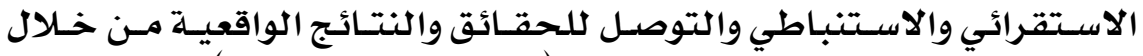

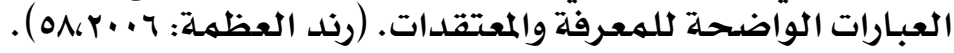

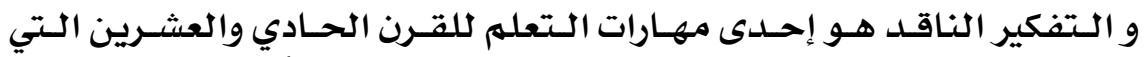

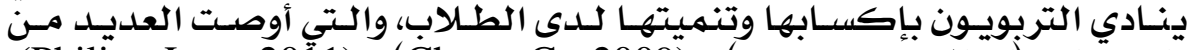

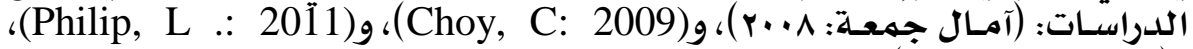

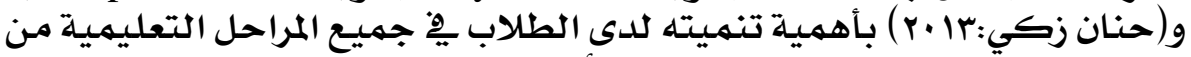

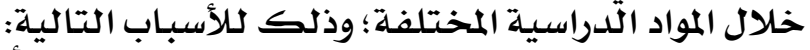

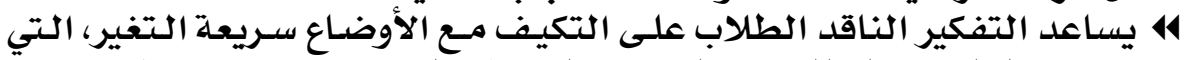

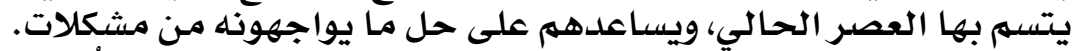

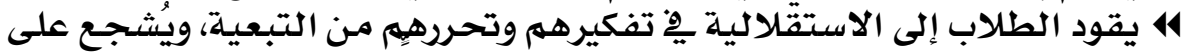

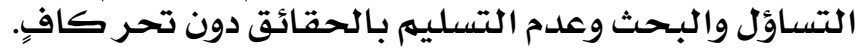

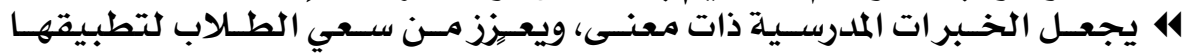

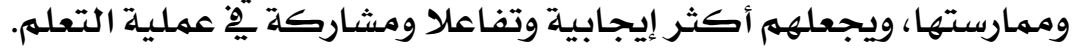

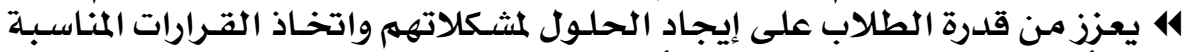

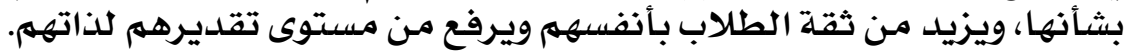

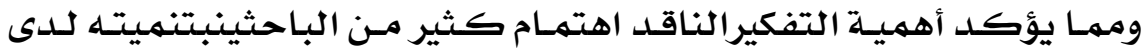

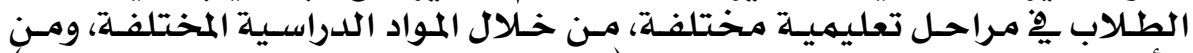

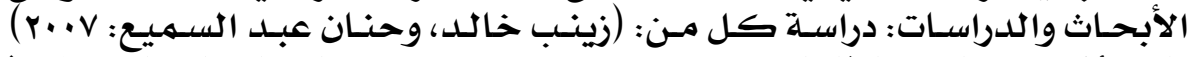

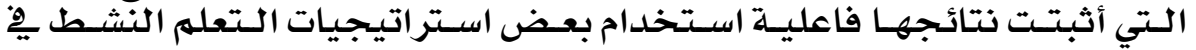

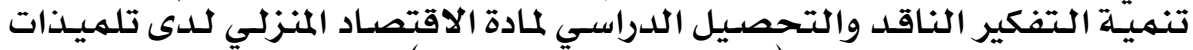

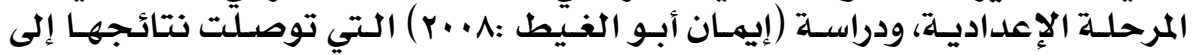

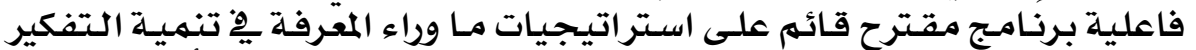

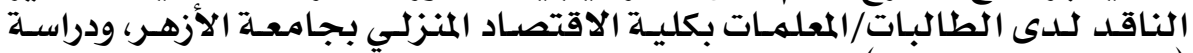

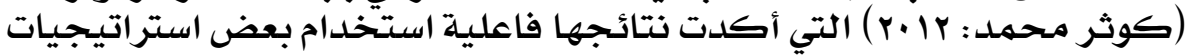

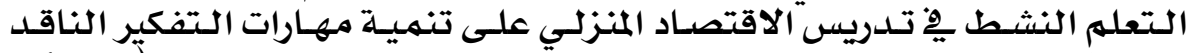

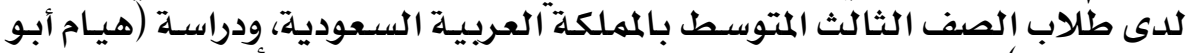

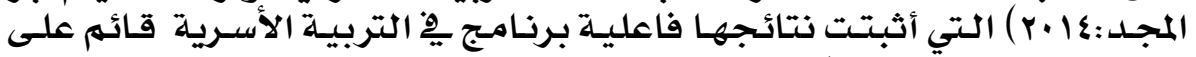

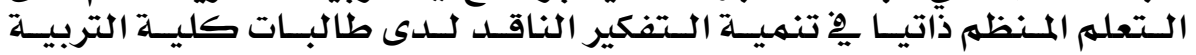

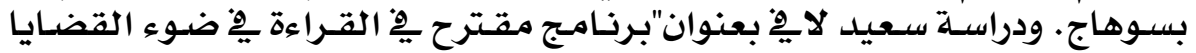

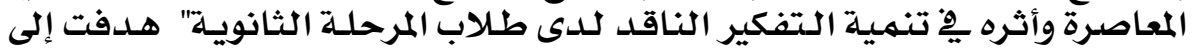

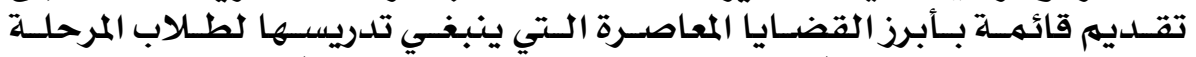

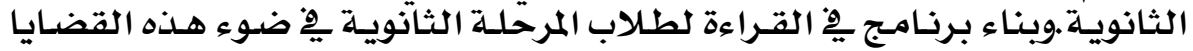

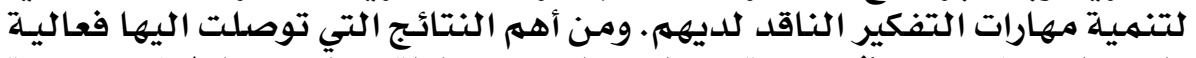

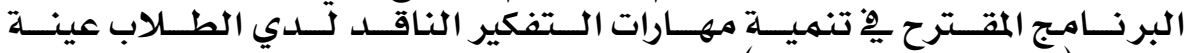

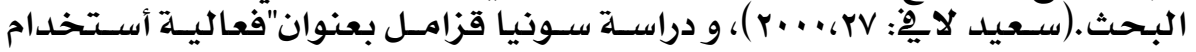

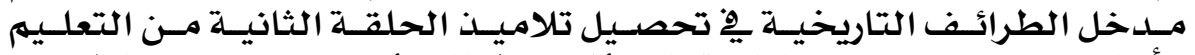

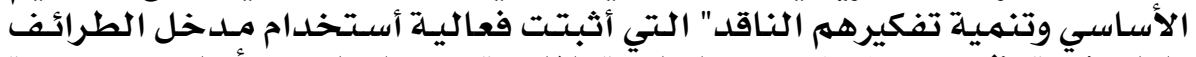

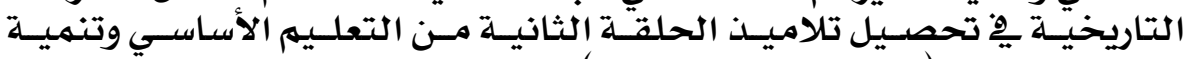

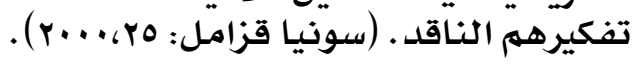

\section{$\Lambda$}




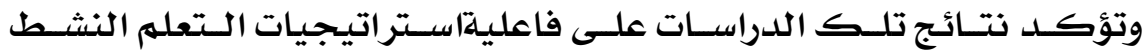

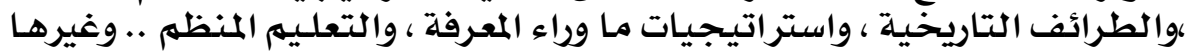

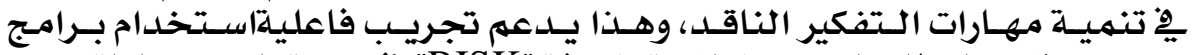

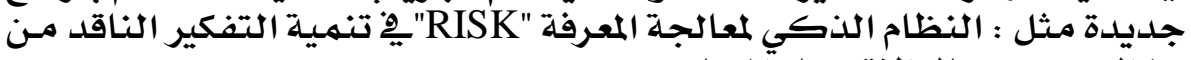

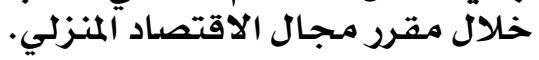

• خصائص التفكير الناقد وسمات المفكر الناقد:

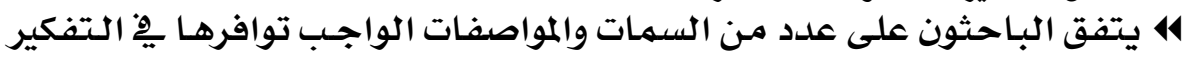

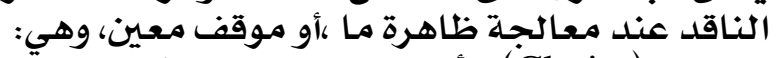

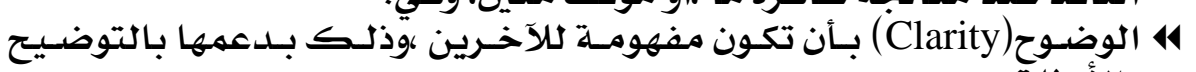

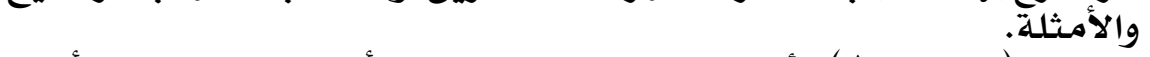
1 الصسحة (Accuracy) بـأن تكون موثقـة مـن خـلال الأدلـة ،والـبر اهين، والأرقام

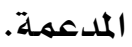

4 الدقة (Precision) بأن تكون على درجة عالية مـن التحديد والتفصيل.

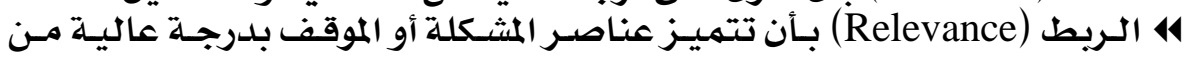

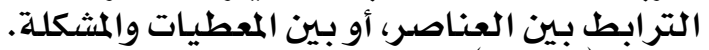

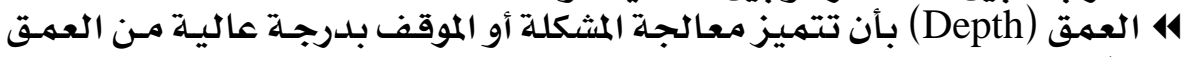
12

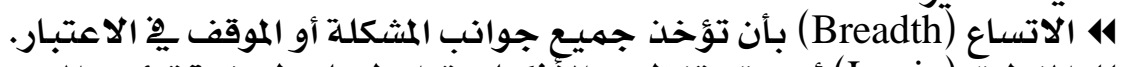

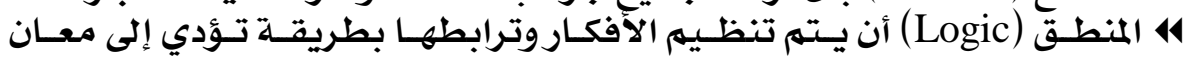

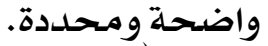

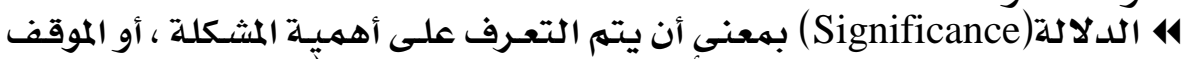

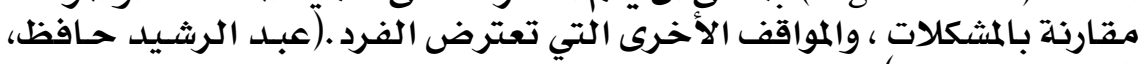

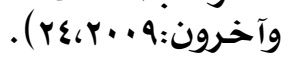

أما المفكر الناقل فيجب أن يتمتح بخمسائم ، منها :

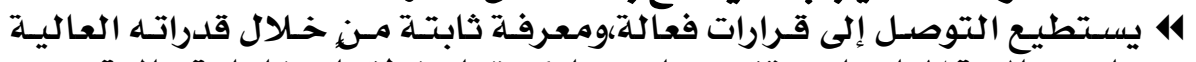

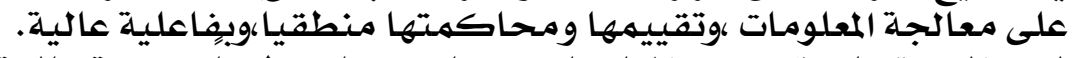

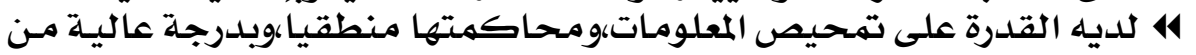

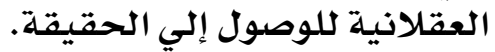

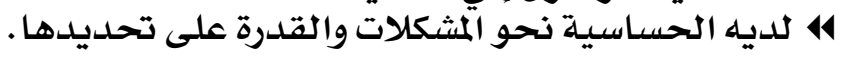

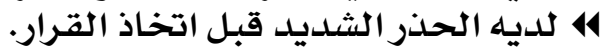

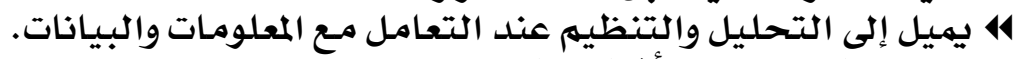

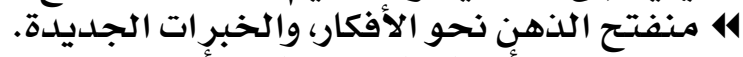

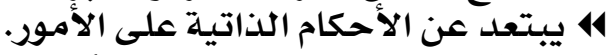

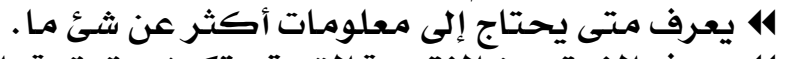

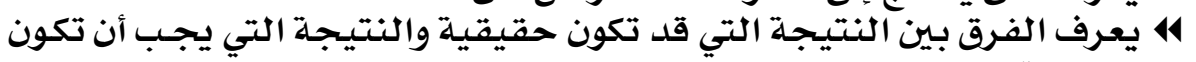
حقيقية. ه يعرفّ أن لدى الناس أفكاراً مختلفة نحو نحو معاني الكلهات.

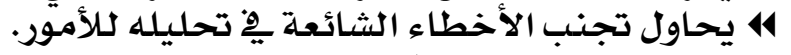

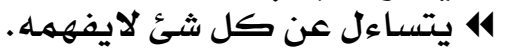

\section{$\Lambda 1$}


العقد العابع والستون .. نوهمبر ..

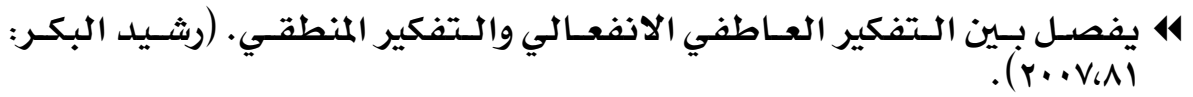

\section{• خصائص المناخات الصفية التي تعرز تعليم ههارات التفكير الناقد:}

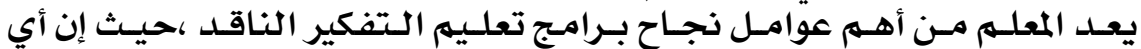

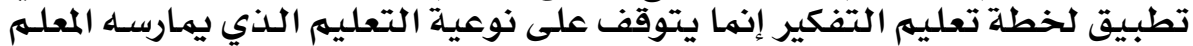

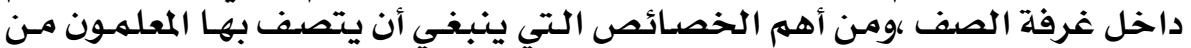

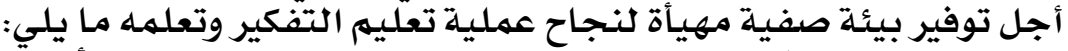

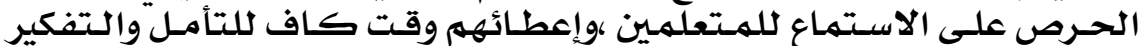

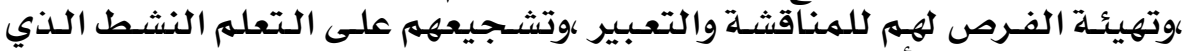

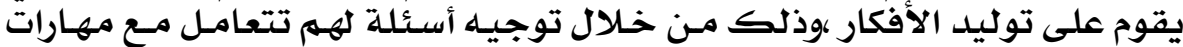

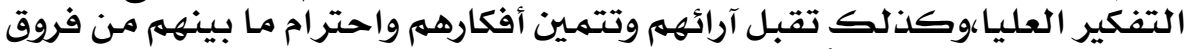

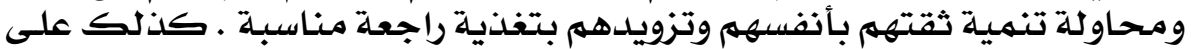

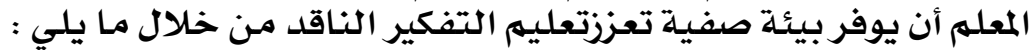

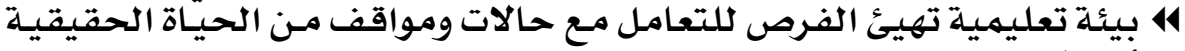

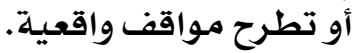

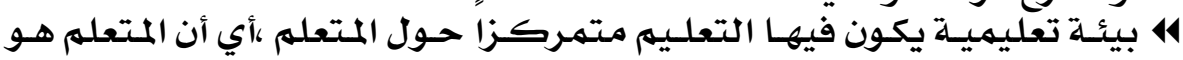
محور النشاط.

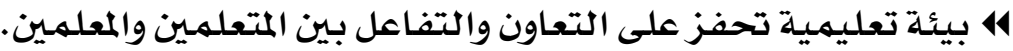

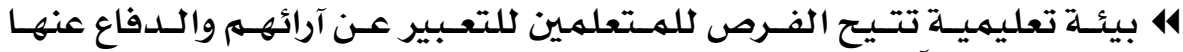

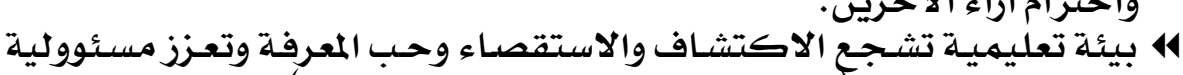

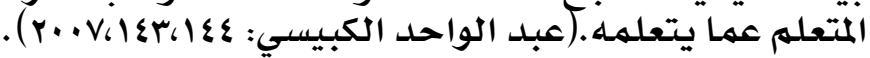

• مراحل تعلم التفكير الناقد:

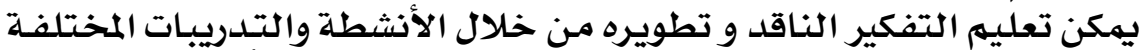

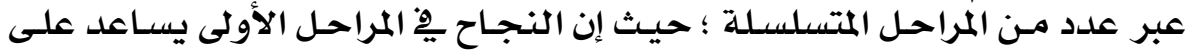

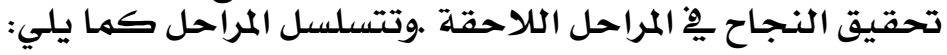

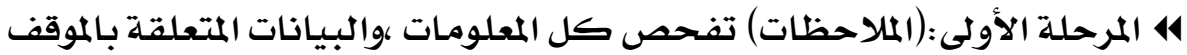

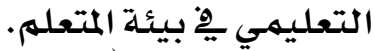

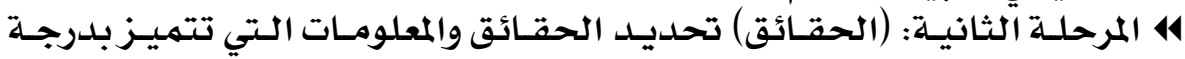

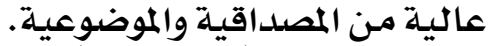

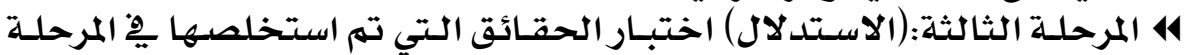
السبابقة.

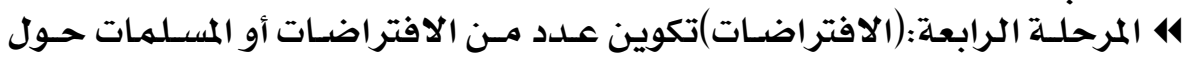
موضوع التعلمه.

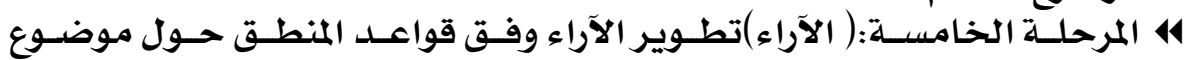
التعلبه.

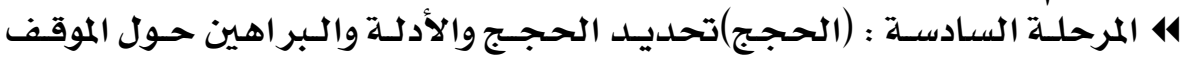

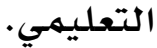

\section{$\Lambda Y$}




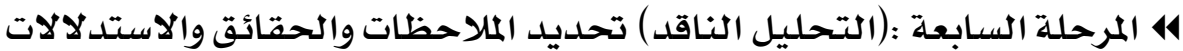

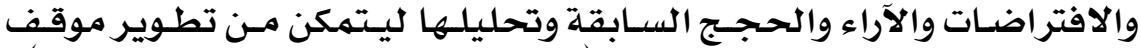

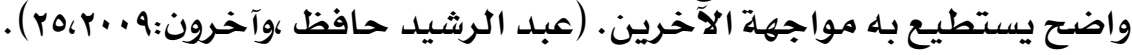

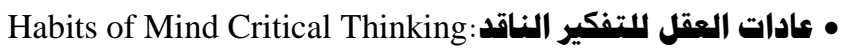

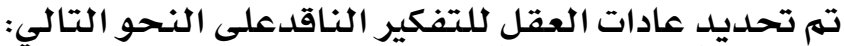

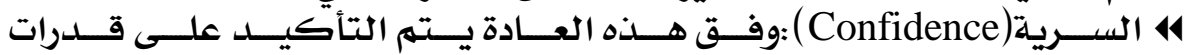

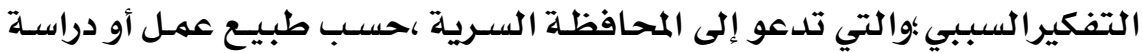
المفحوص. التفكيراليبي

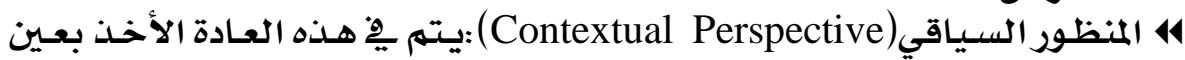

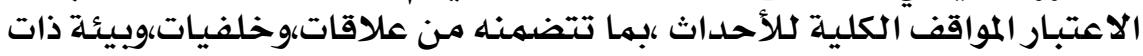

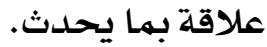

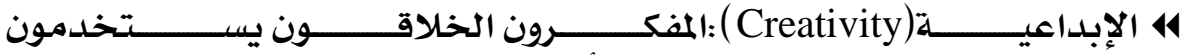

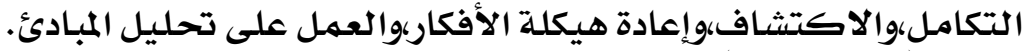

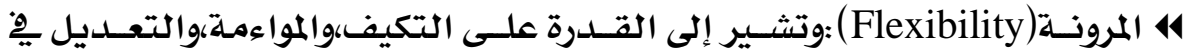

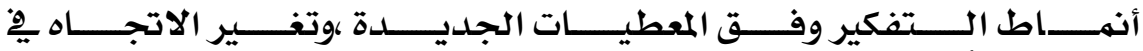

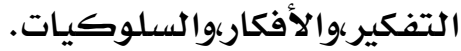

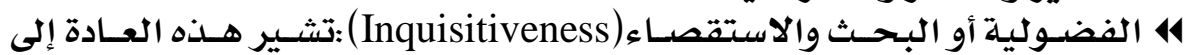

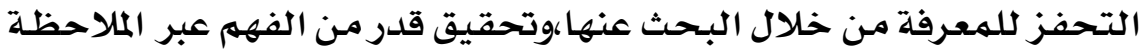

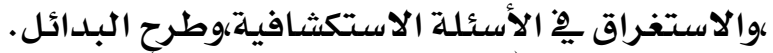

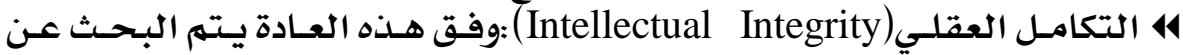

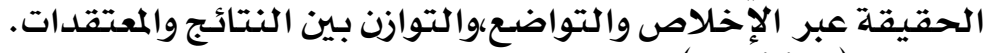

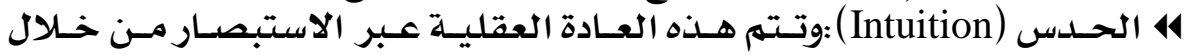

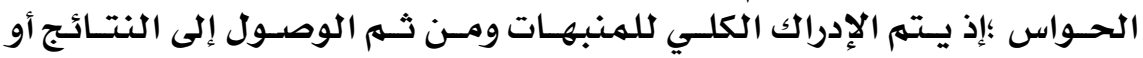
الحل. الحن.

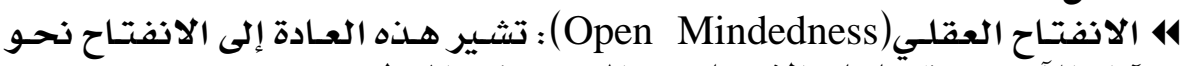

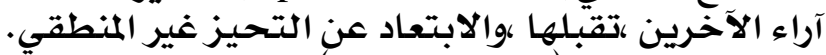

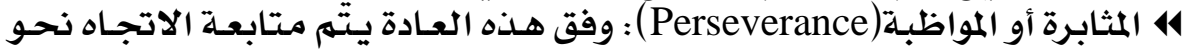

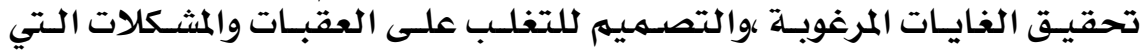

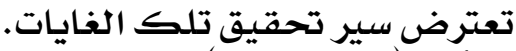

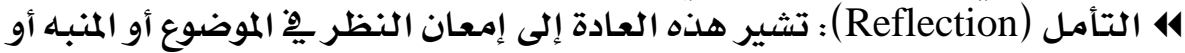

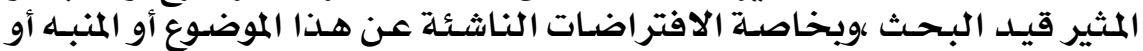

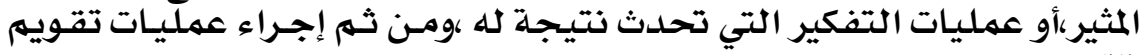
ذاتي.

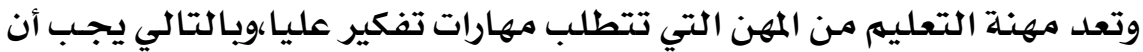

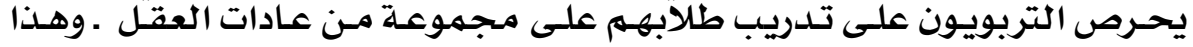

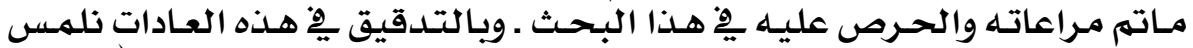

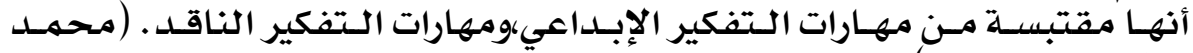

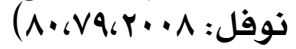

\section{$\Lambda \mathrm{r}$}




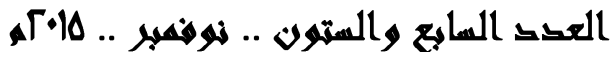

• الأساليب الفعالة في تعليم مهارات التفكيرالناقد:

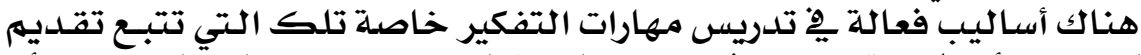

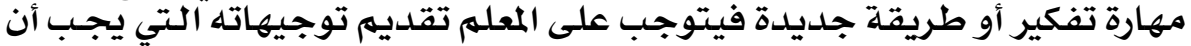

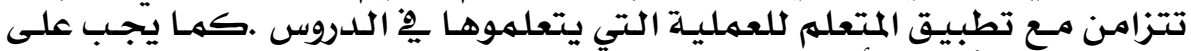

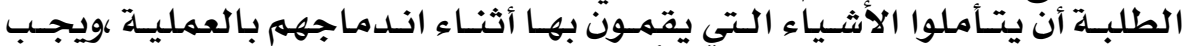

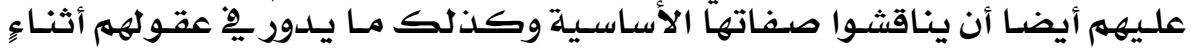

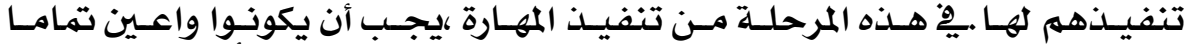

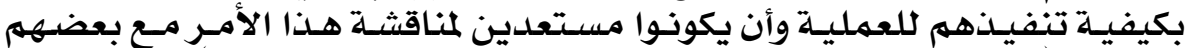

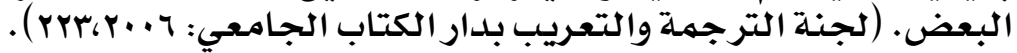

• خطوات تعلم هذارات التفكير الناقد بإسلوب المامسارسة الموجهة:

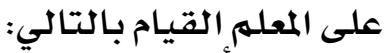

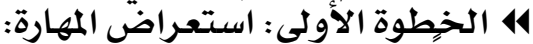

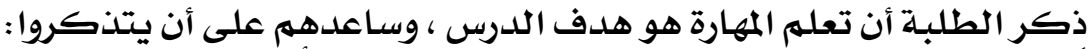

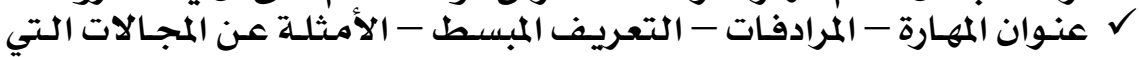

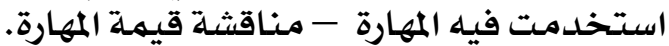

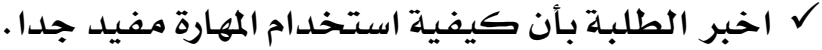

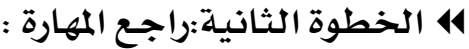

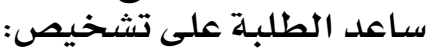

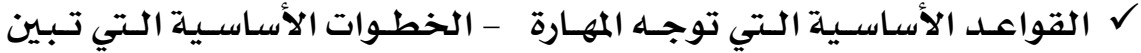

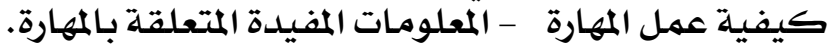

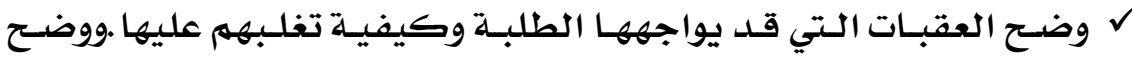

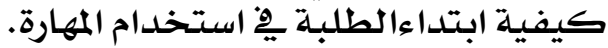

14 الخطوة الثالثة :نفذ المهارة:

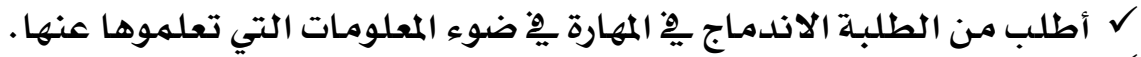

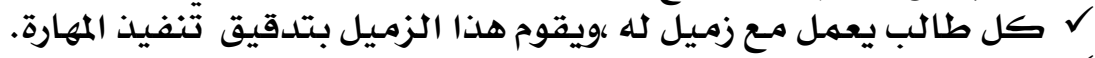

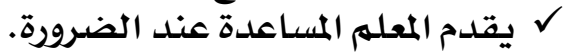

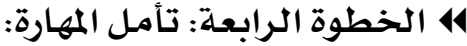

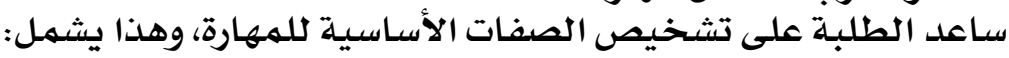

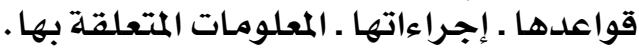

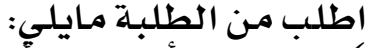

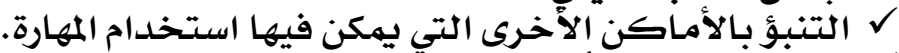

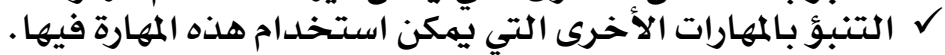

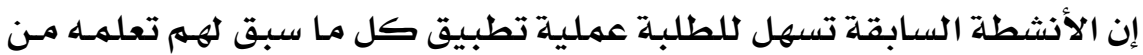

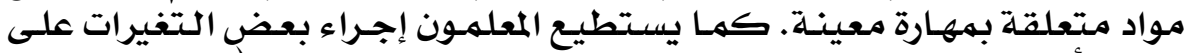

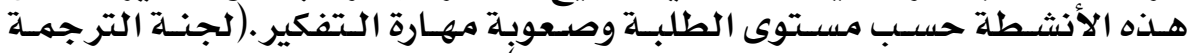

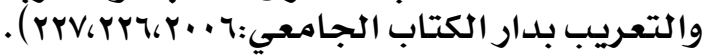

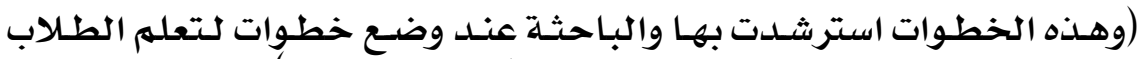

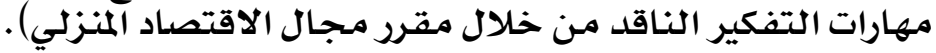

\section{$\Lambda \varepsilon$}




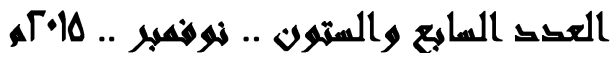

\section{• المعور الثالث:النظام الذكي في هعالجةالمعرفة ) Right Intelligent System of (Knowledge}

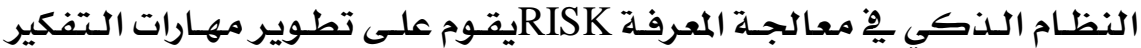

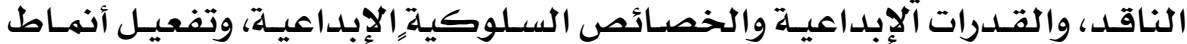

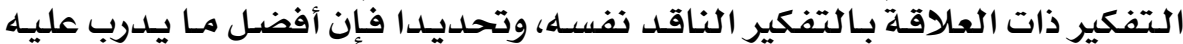

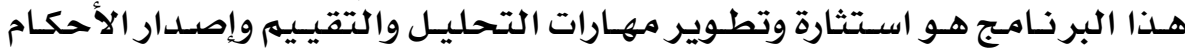

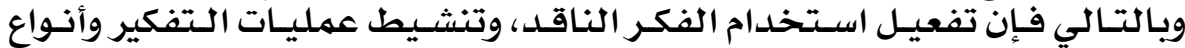
التفكير بشكل عام يساعد على اليقظة الفيس الذهنية.

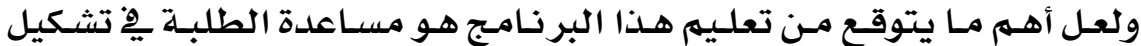

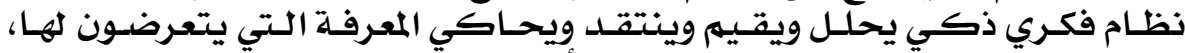

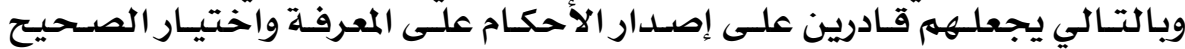

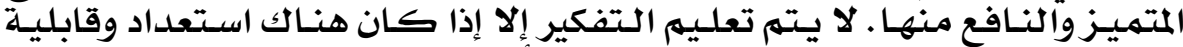

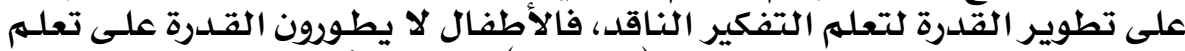

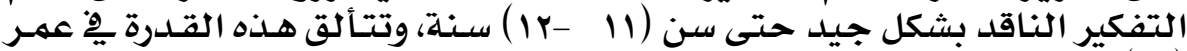

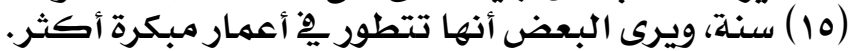

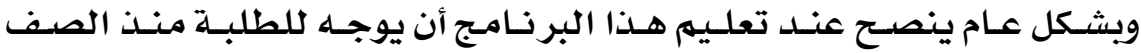

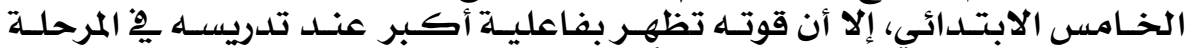

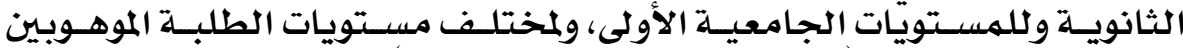

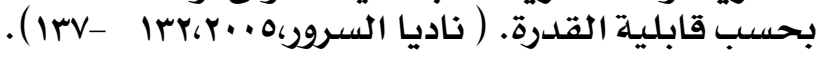

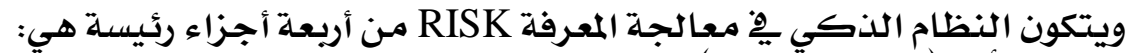

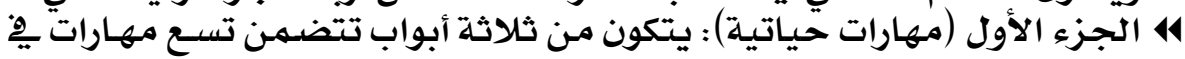

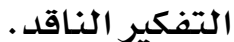

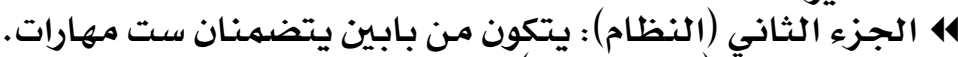

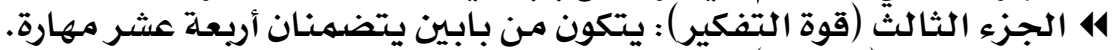

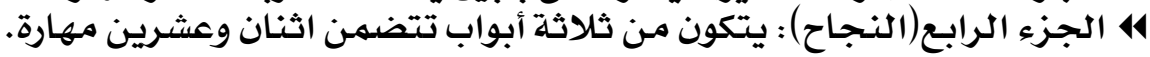

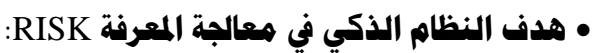

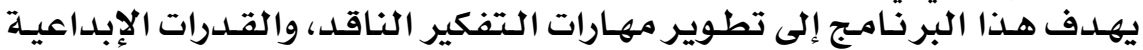

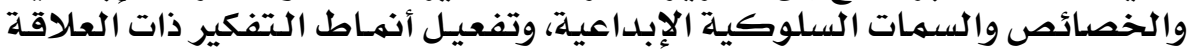

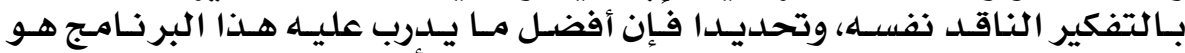

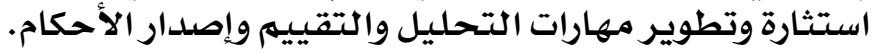

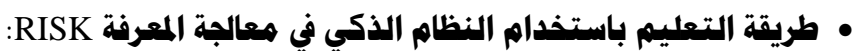

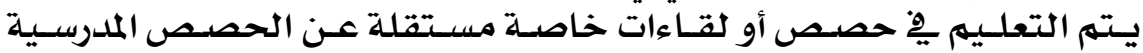

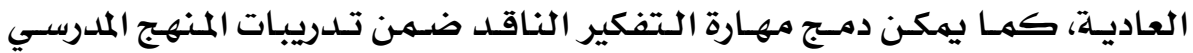

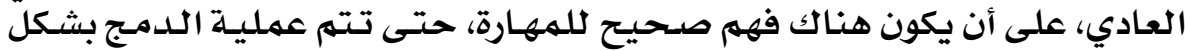

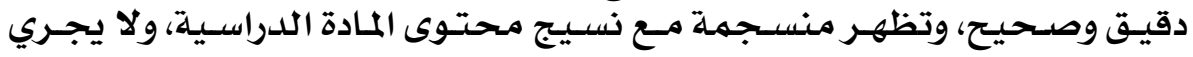

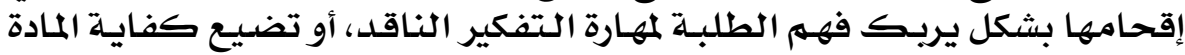

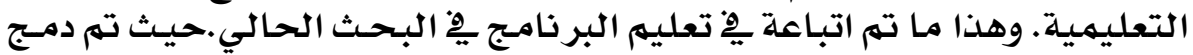

\section{$\Lambda \odot$}


مهارات التفكير الناقد ضـهـن تـدريبات مقرر المجـالات العمليـة تخصص اقتصـاد منزبي.

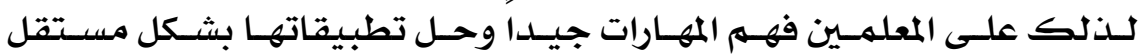

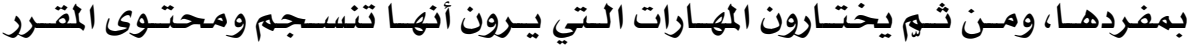

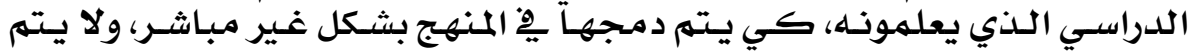

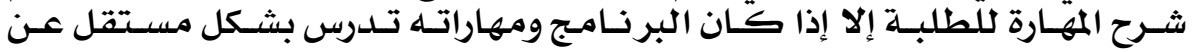
المنهجج.

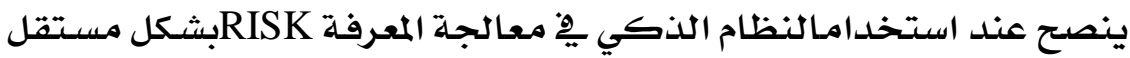

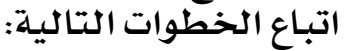

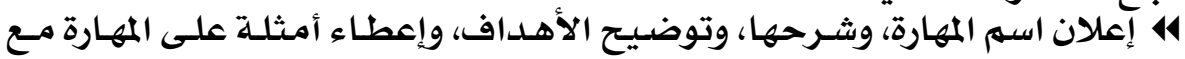

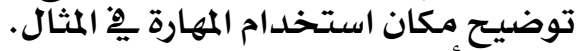

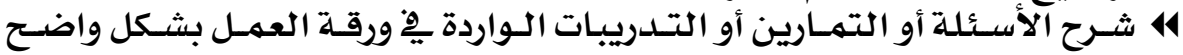
ومبسط.

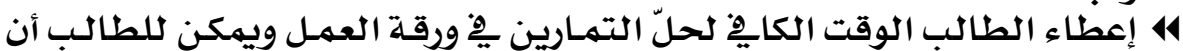

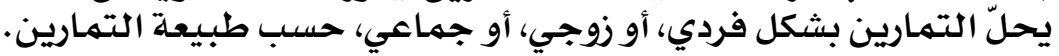

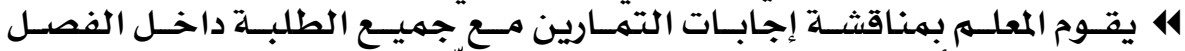

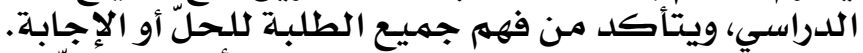

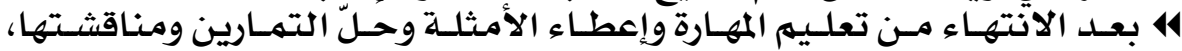

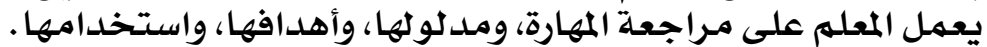

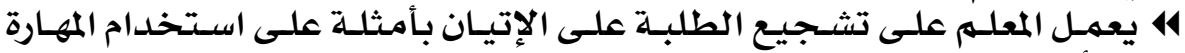

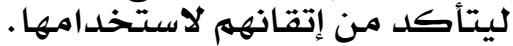

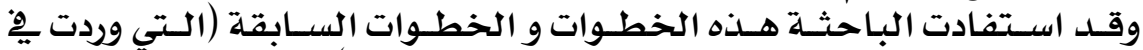

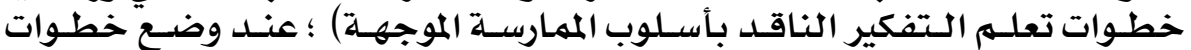

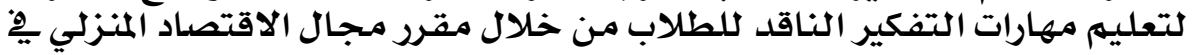

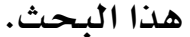

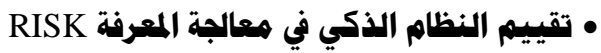

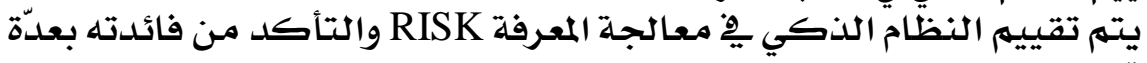
414 استخدام اختبـار كورنيل للتفكير الناقد.

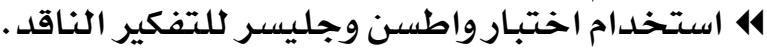

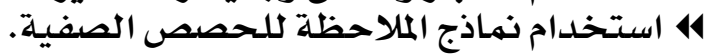

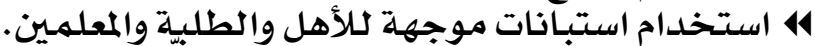

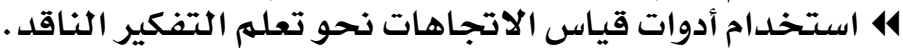

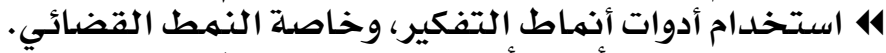

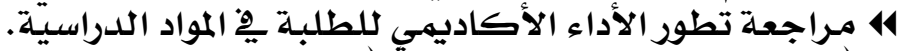

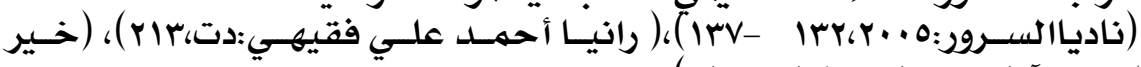

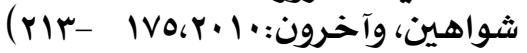
وقد استخدم هذا البحث اختبار واطسن وجليسر للتفكير الناقد.

\section{$\Lambda 7$}




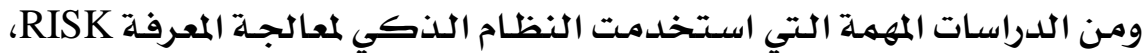

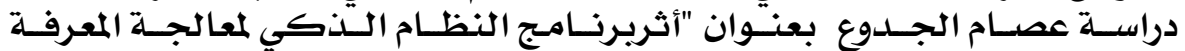

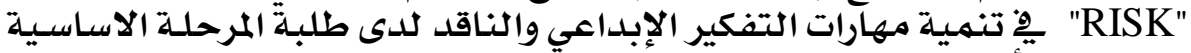

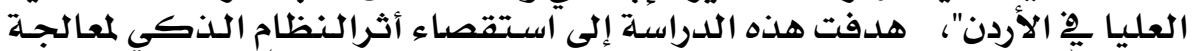

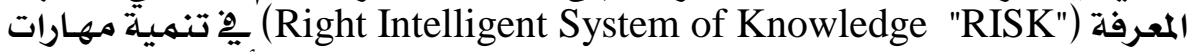

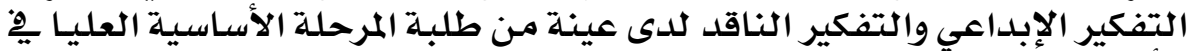

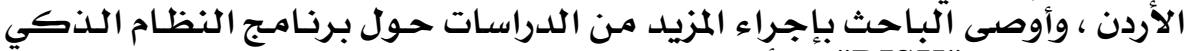

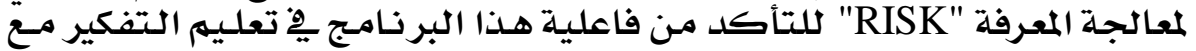

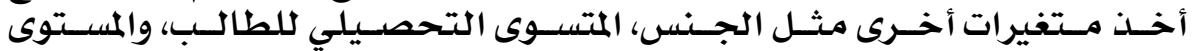

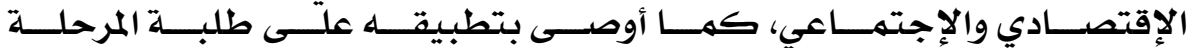

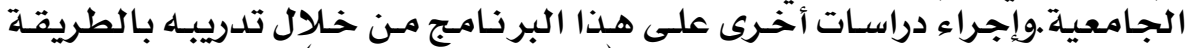

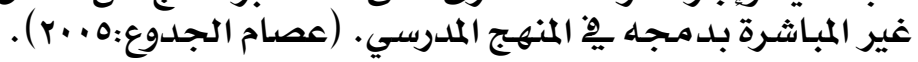
• مهارات النظام الذكي لمعالجة المعرنة (RISK):

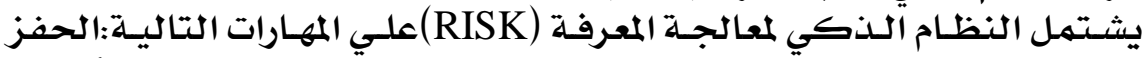

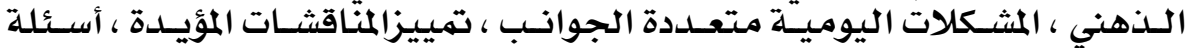

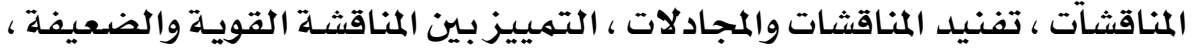

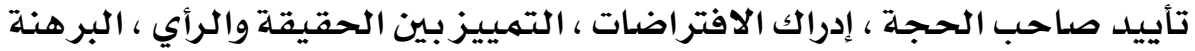

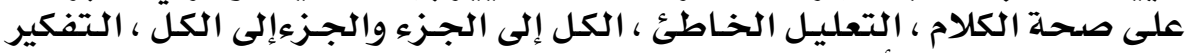

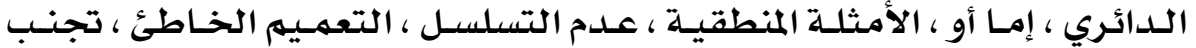

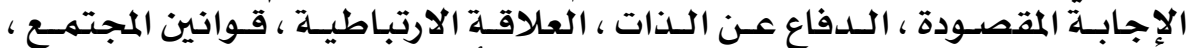

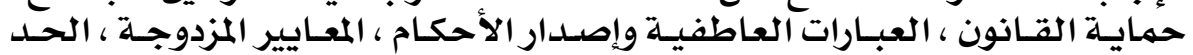

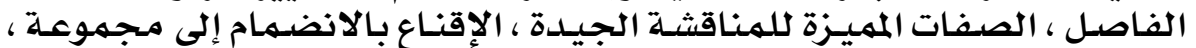

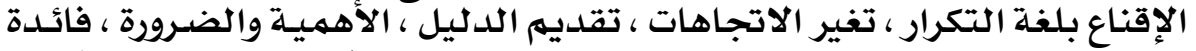

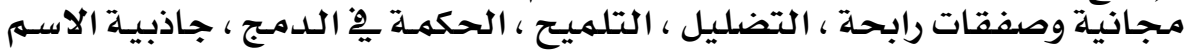

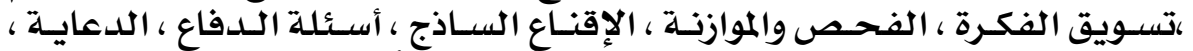

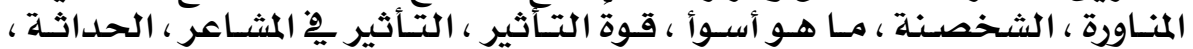

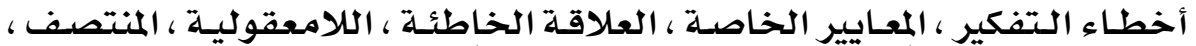

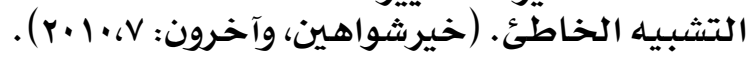

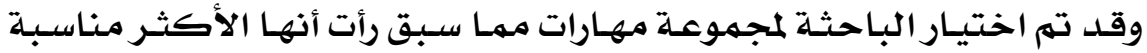

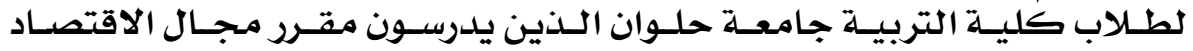

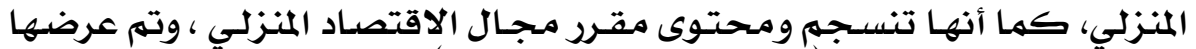

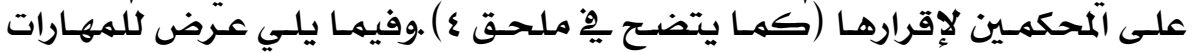

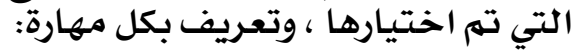

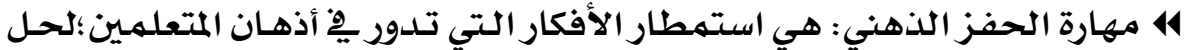

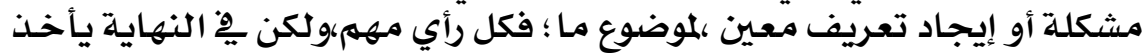

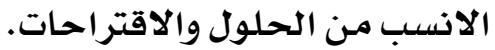

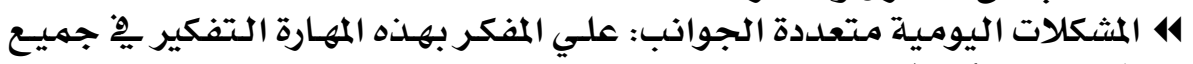

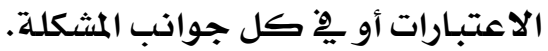

\section{$\Lambda \mathrm{V}$}




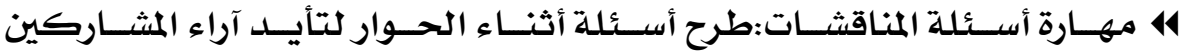
والمحافظة عليها ودعمها.

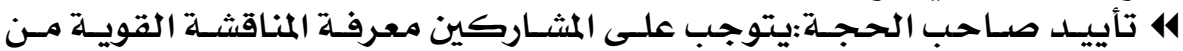

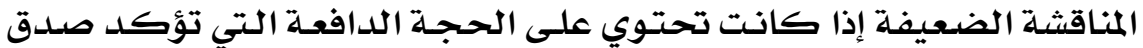

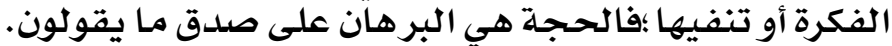

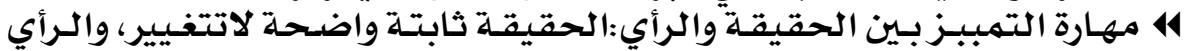

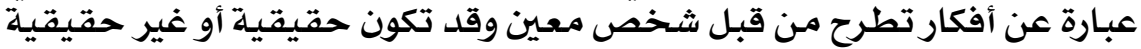

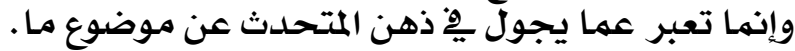

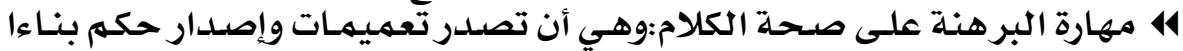

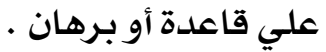

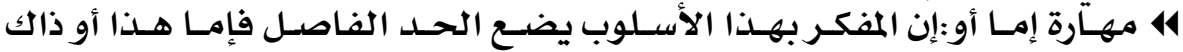

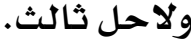

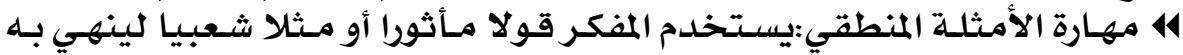

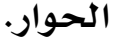

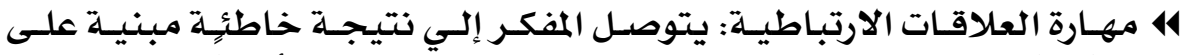

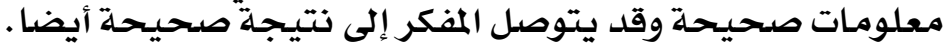

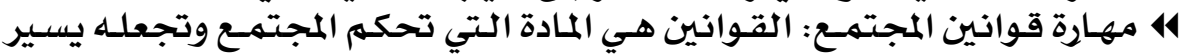

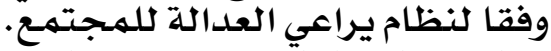

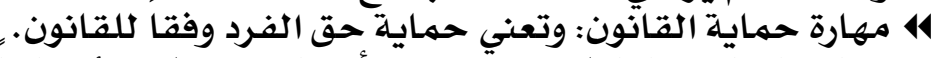

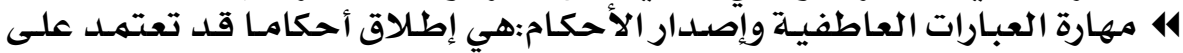
العواطف وتبتعلد عن المنطق.

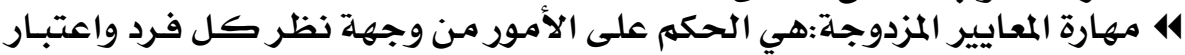

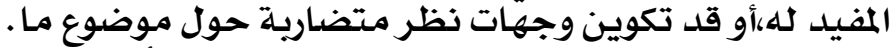

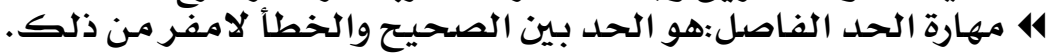

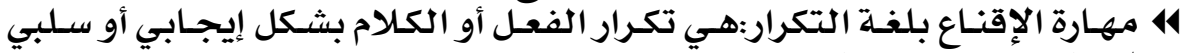

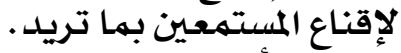

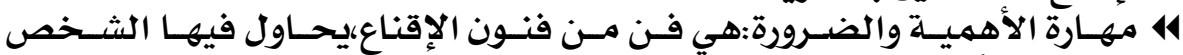

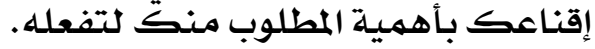

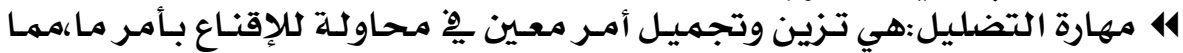

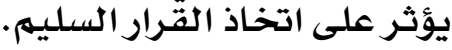

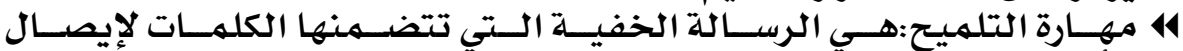

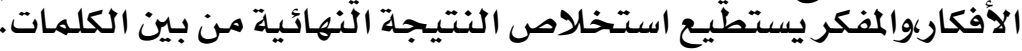

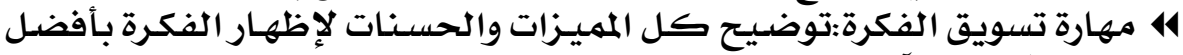

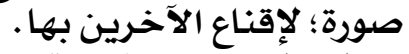

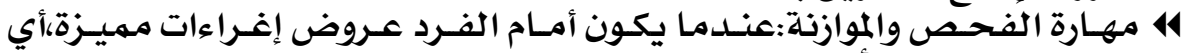

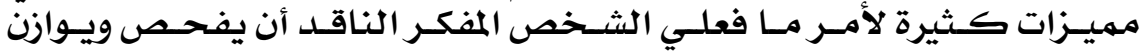

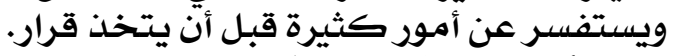

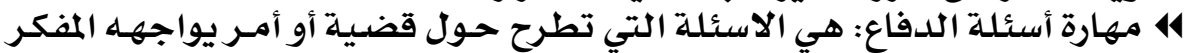

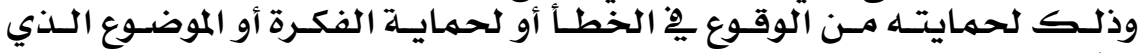
يطرحه.

\section{$\wedge \wedge$}




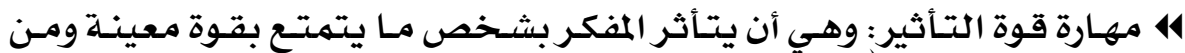

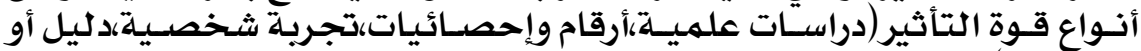

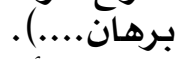

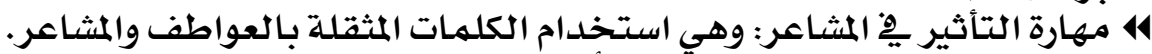

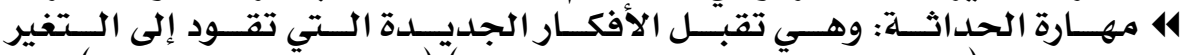

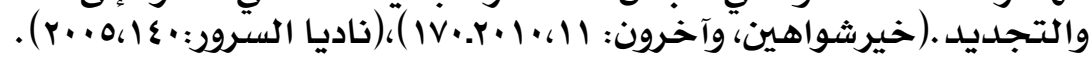

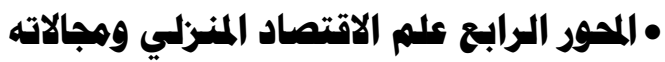

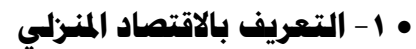

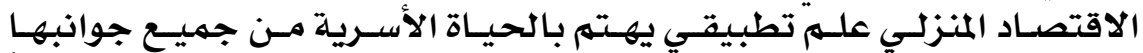

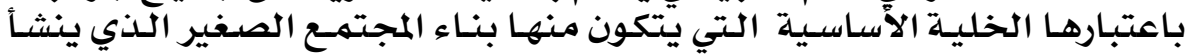

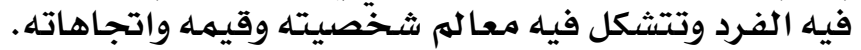

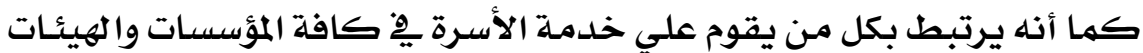

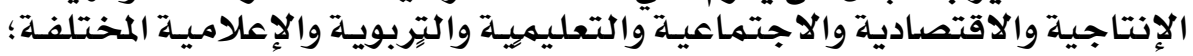

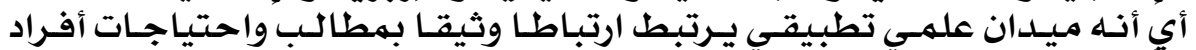

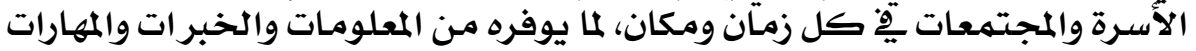

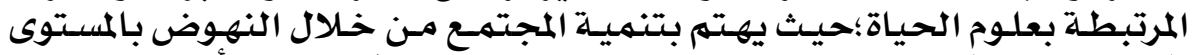

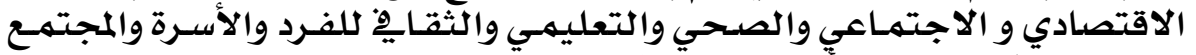

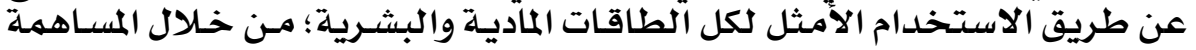

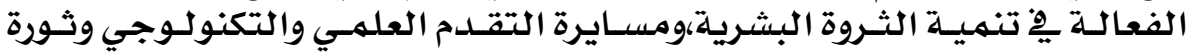

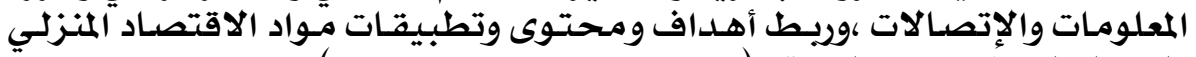

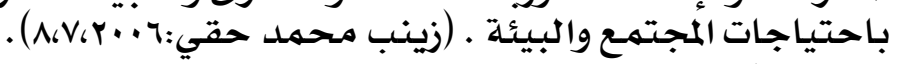

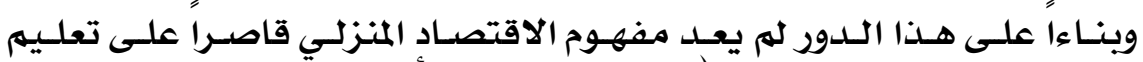

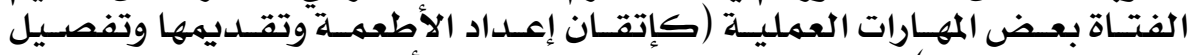

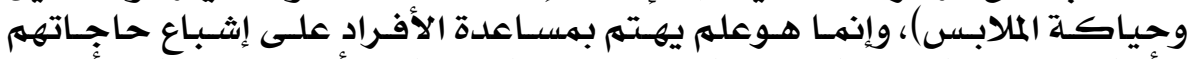

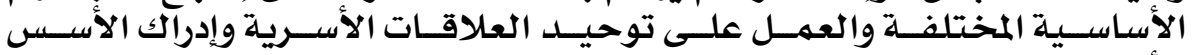

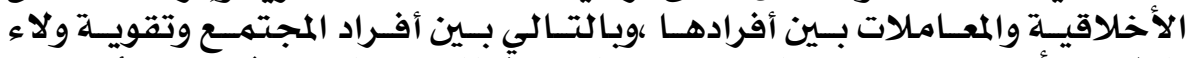

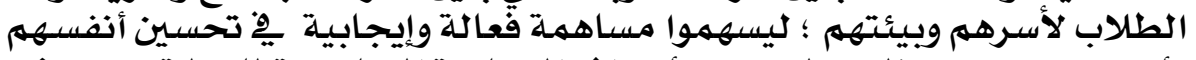

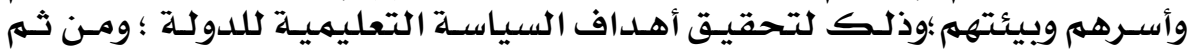

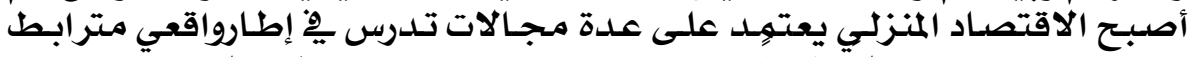

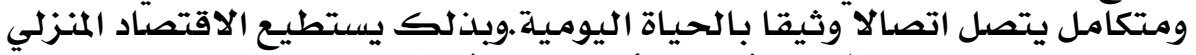

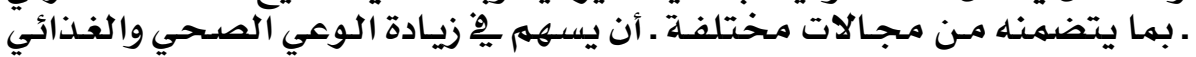

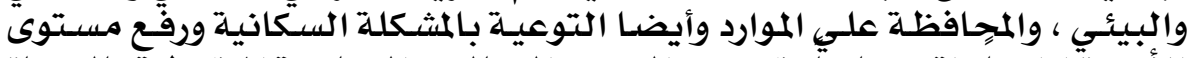

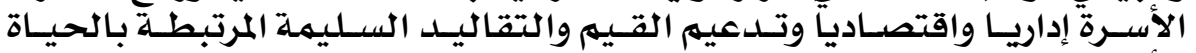

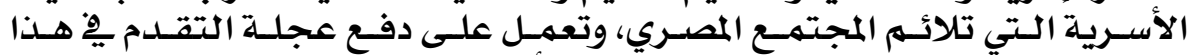

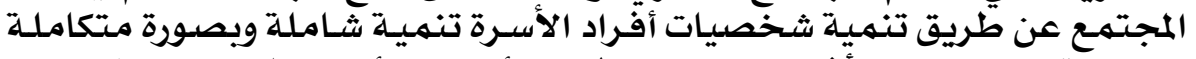

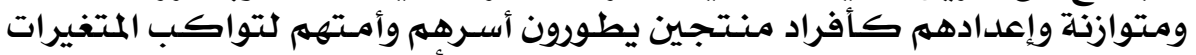

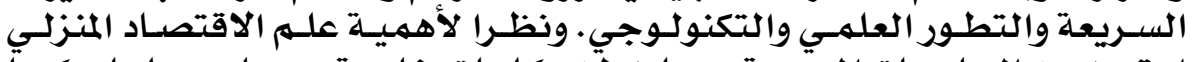

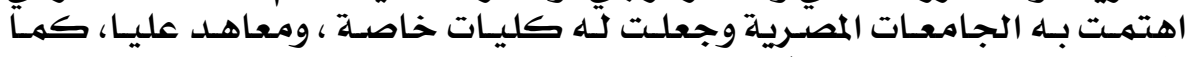

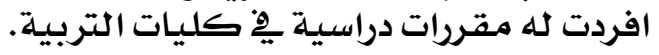

\section{$\wedge 9$}




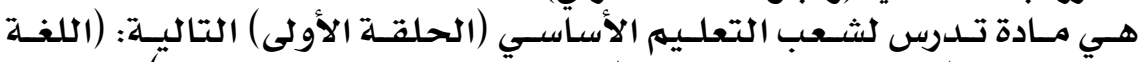

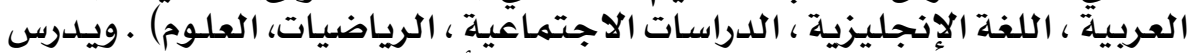

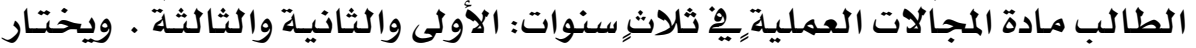

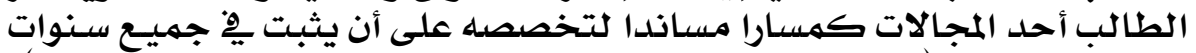

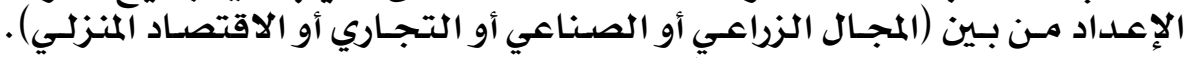

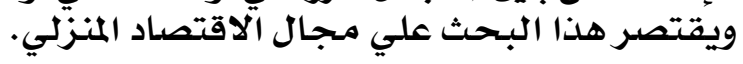

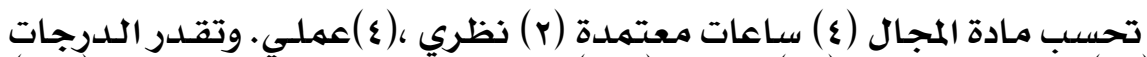

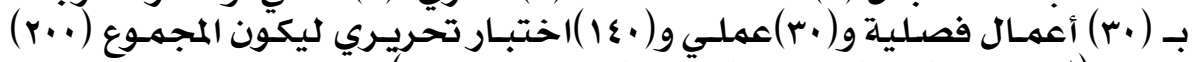

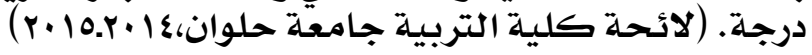

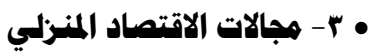

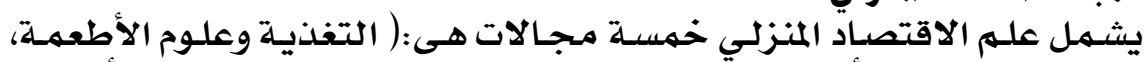

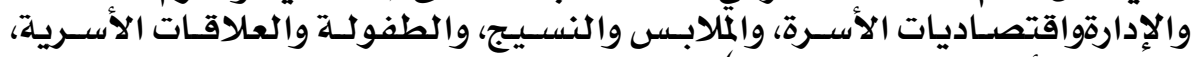

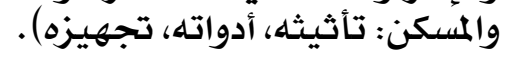

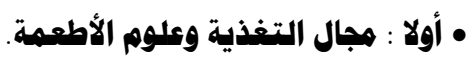

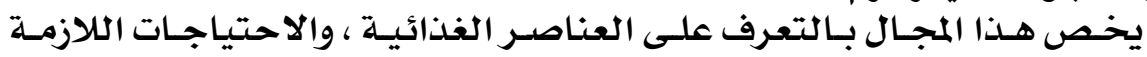

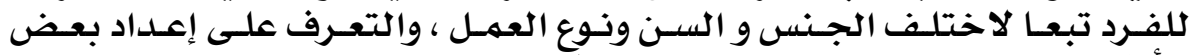

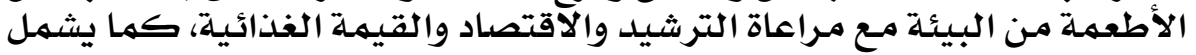

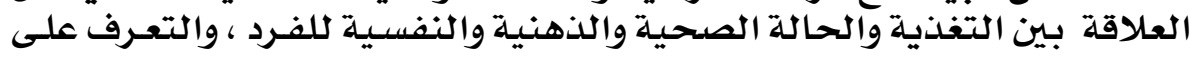

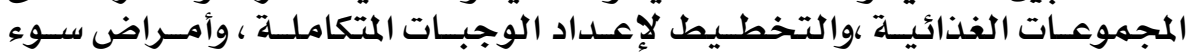

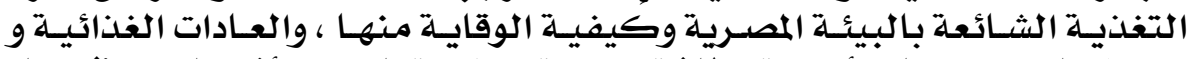

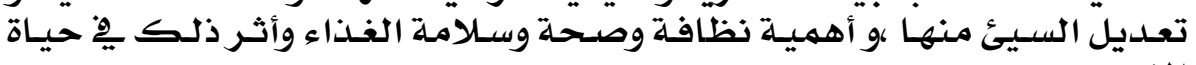

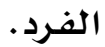

\section{• بانيا : إدارة المنزل واتتصاديات الأسرة.}

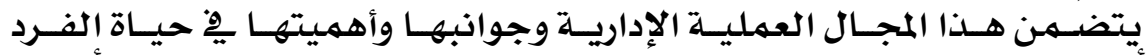

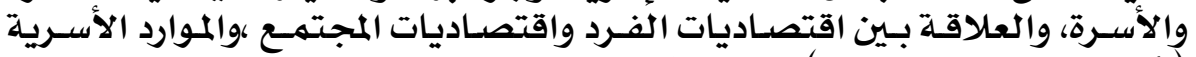

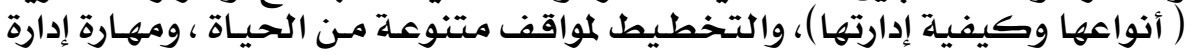

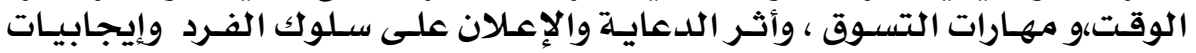

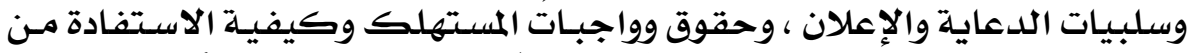

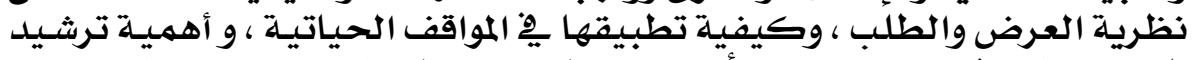

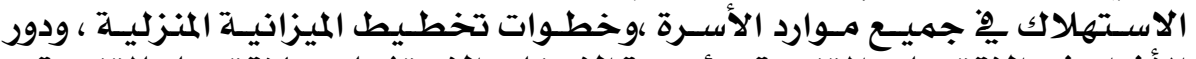

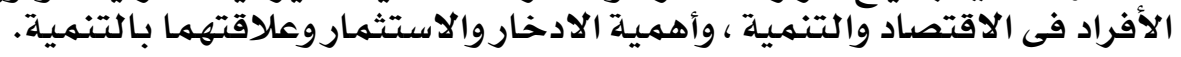

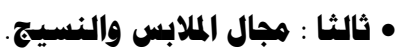

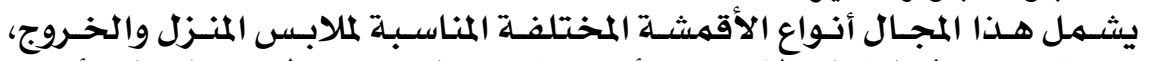

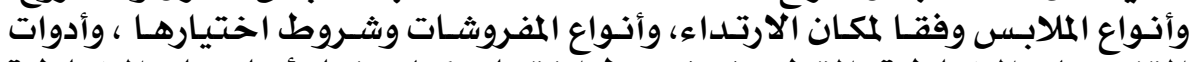

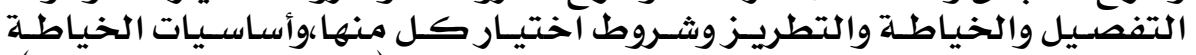

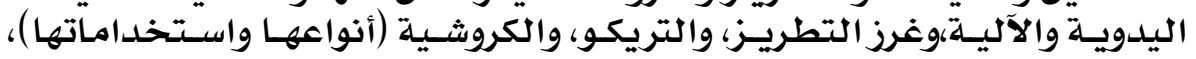

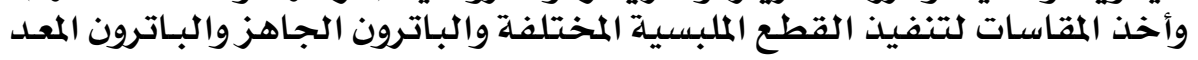




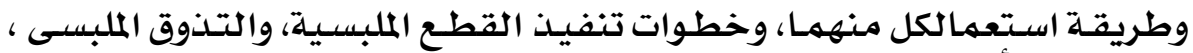

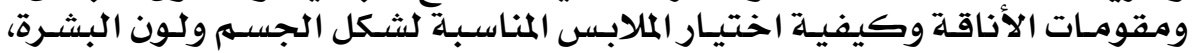

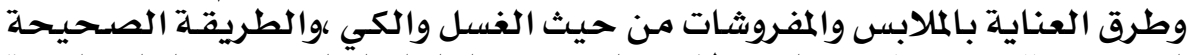

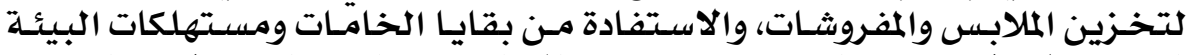

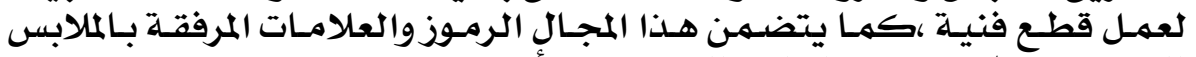

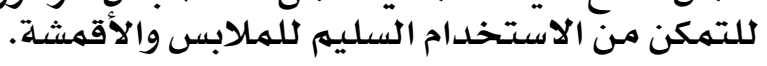

\section{• رابعا : هجال الطفولة والعلاقات الأسرية.}

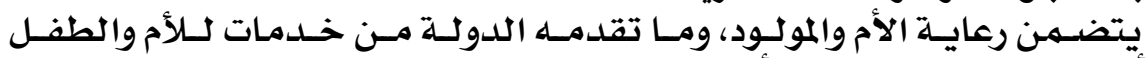

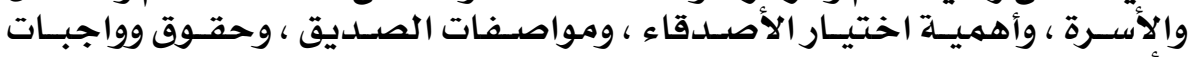

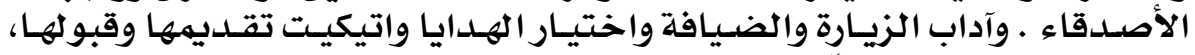

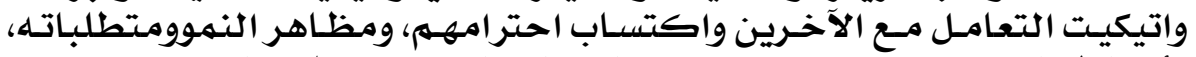

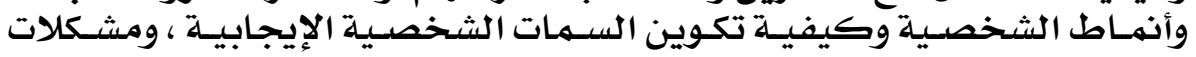

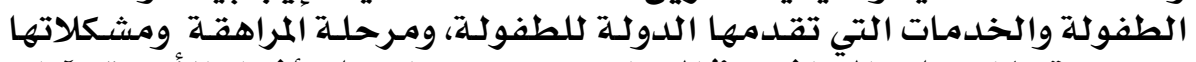

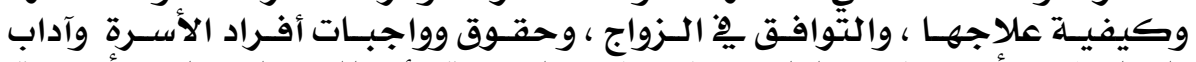

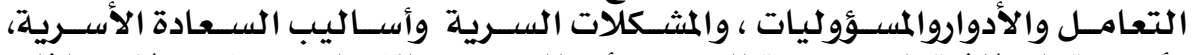

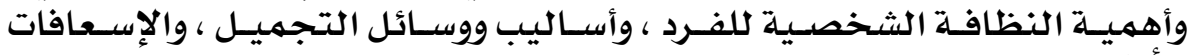

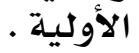

• خاهسا : هبال المسكن (تأثيثه وأدواته وتجهيزه).

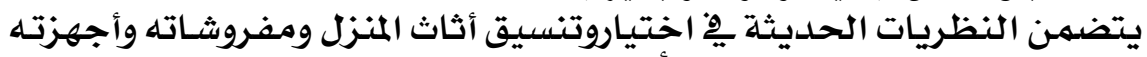

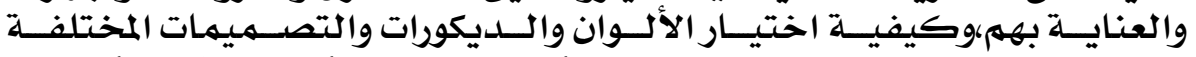

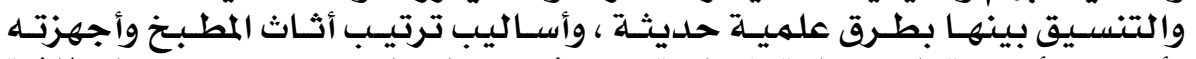

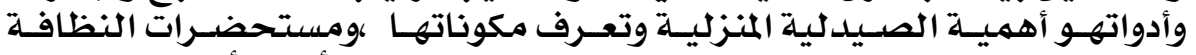

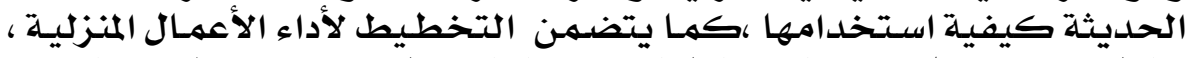

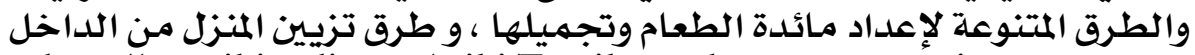

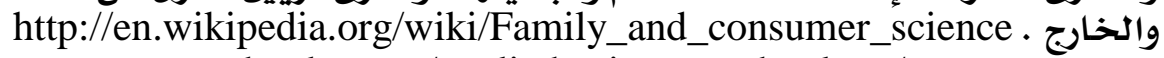
Www.nooonbooks.com/applied-science-technology/o-u-o-u-o-o

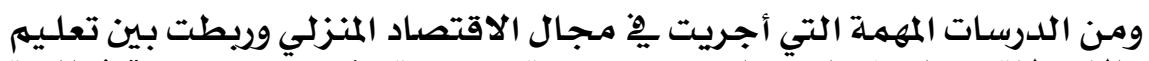

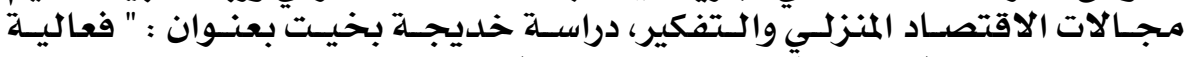

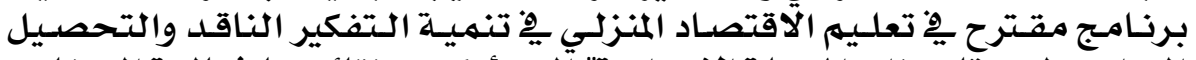

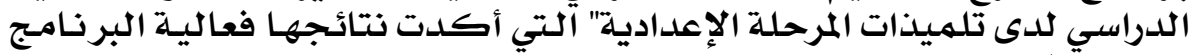

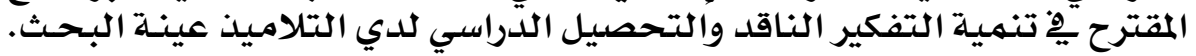

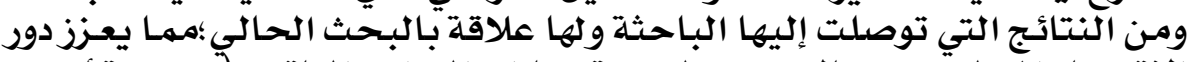

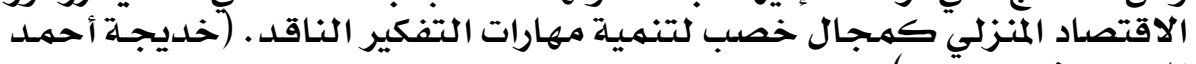
السيد بخيت: .... (r. ).

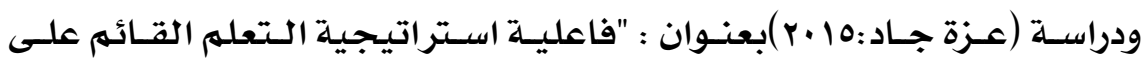

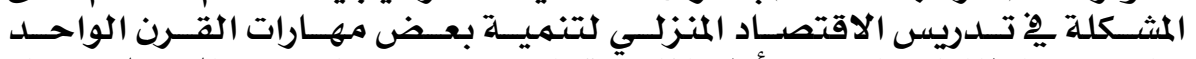

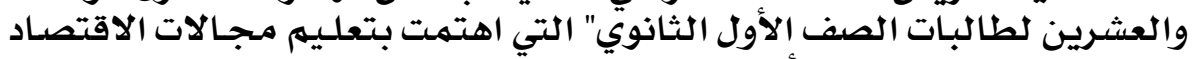

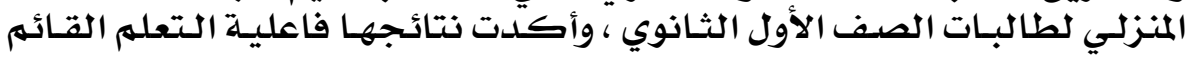

\section{$9)$}




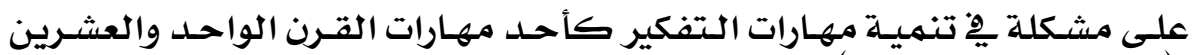

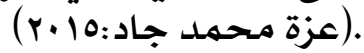

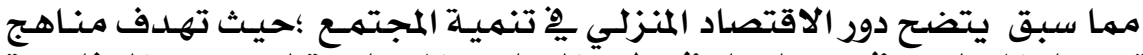

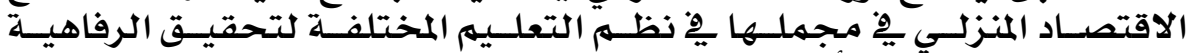

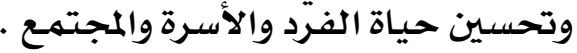

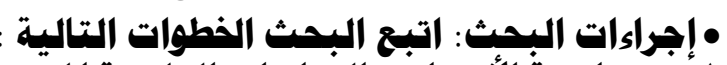

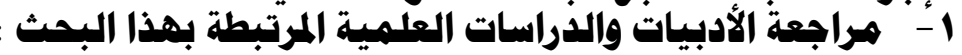

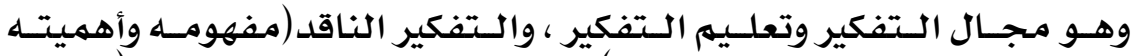

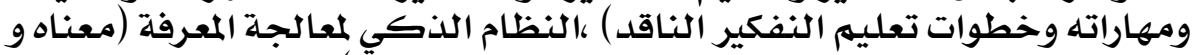

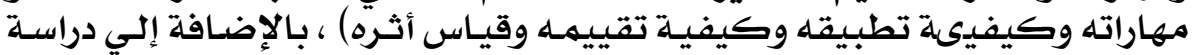

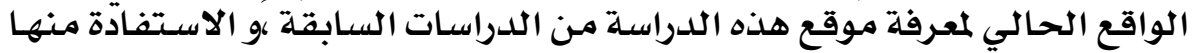

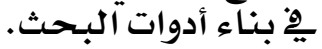

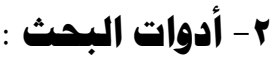

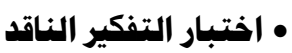

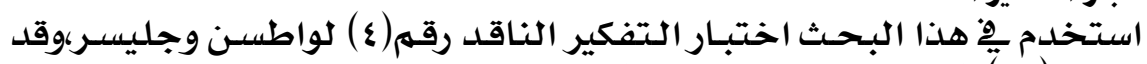

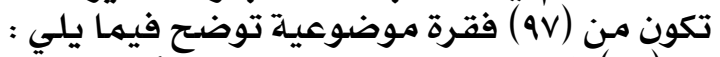

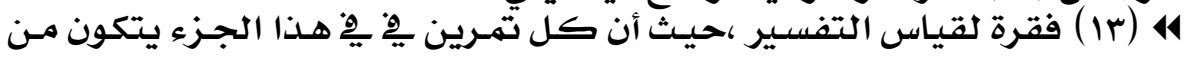

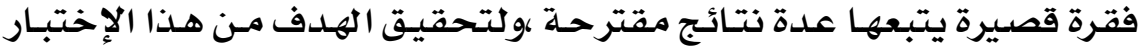

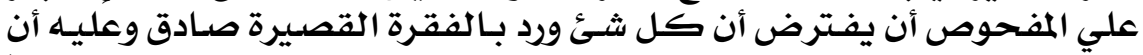

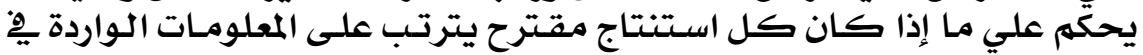

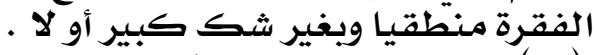

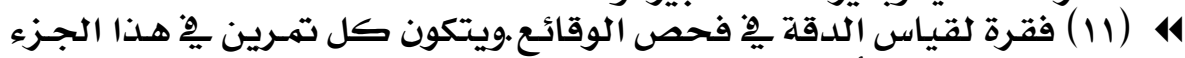

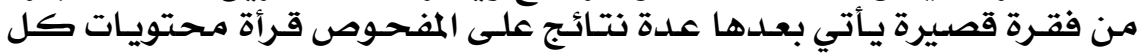

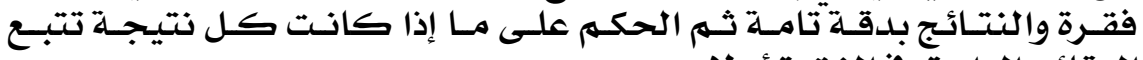

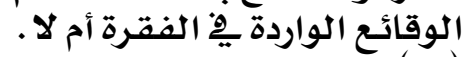

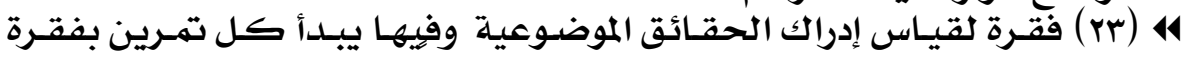

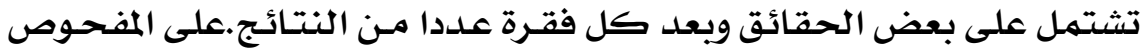

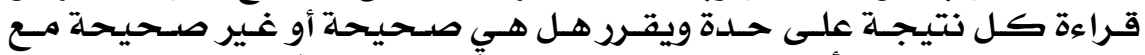

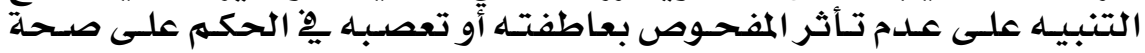

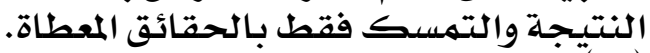

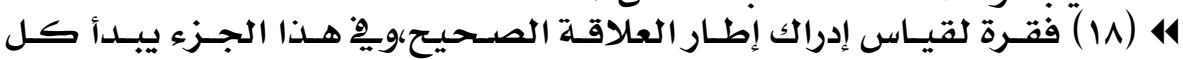

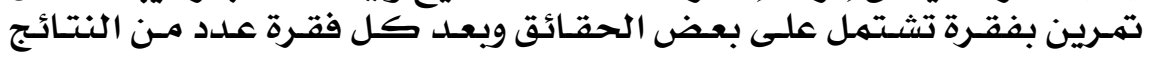

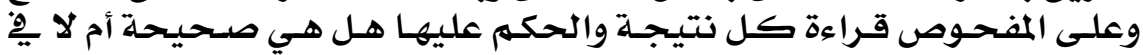

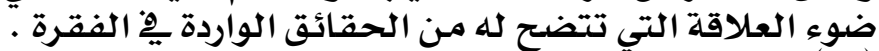

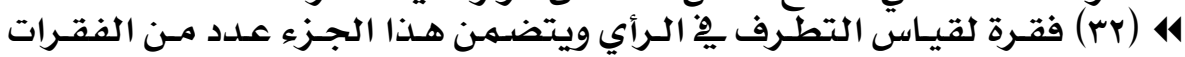

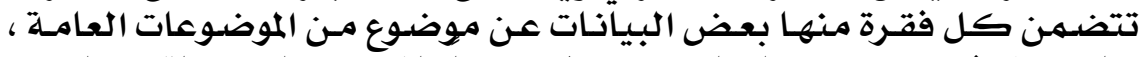

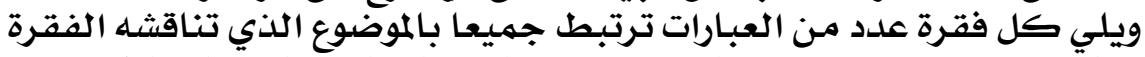

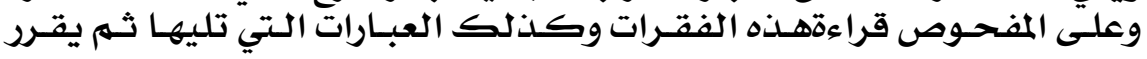

\section{4}


بالنسبة لكل عبارة هل هي متطرفة أم غير متطرفة ِِِ ضـوء الحقـائق الواردة

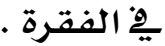

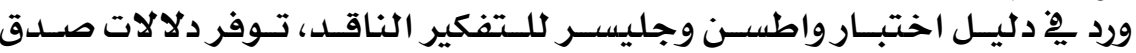

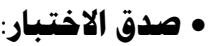

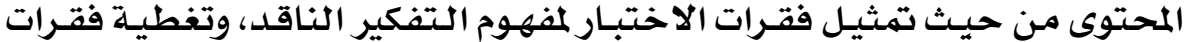

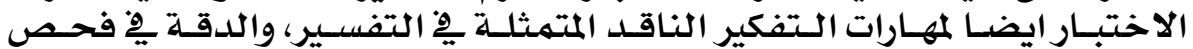

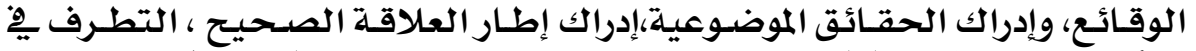

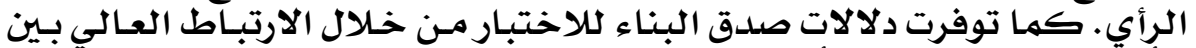

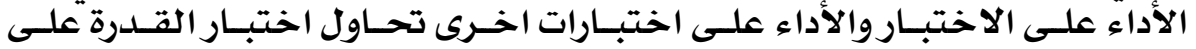

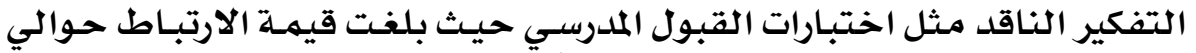

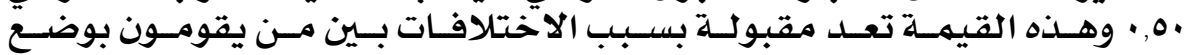

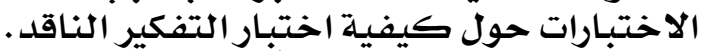

(Ennis, R.H.\& Millman, J,\& Tomko, 1985)

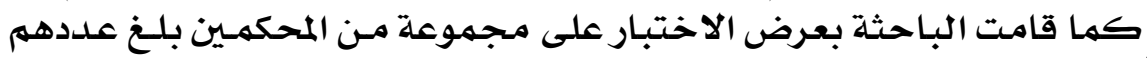

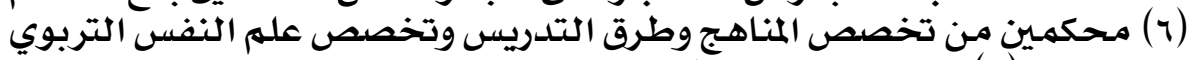

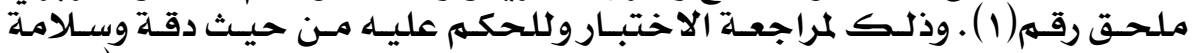

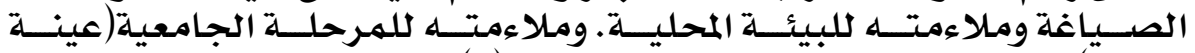

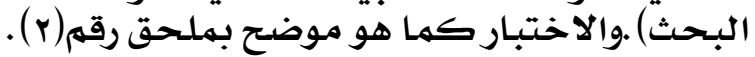

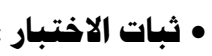

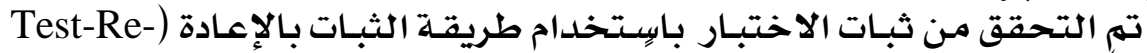

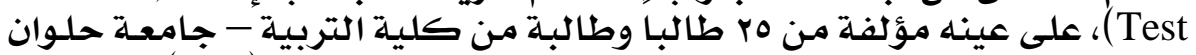

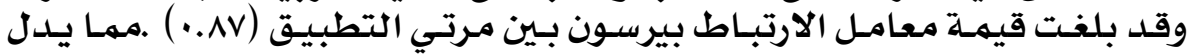

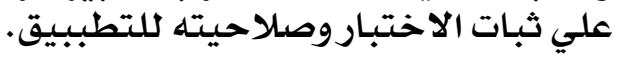

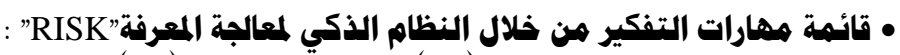

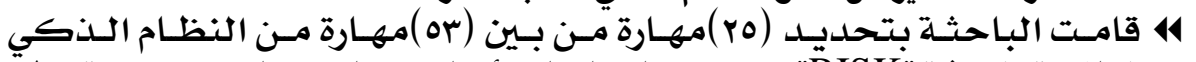

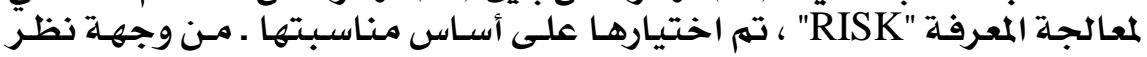

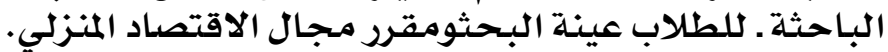

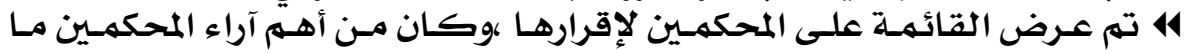
4 توضيّيح الموضوعات المناسبة لتوظيف كل كل مهارة.

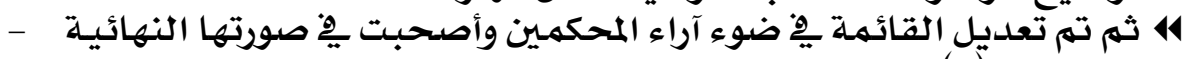

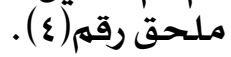

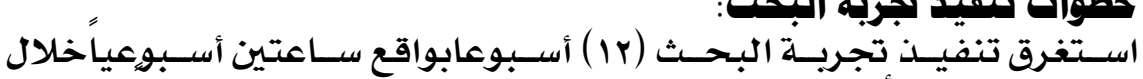

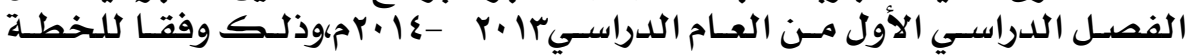

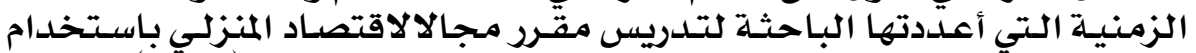

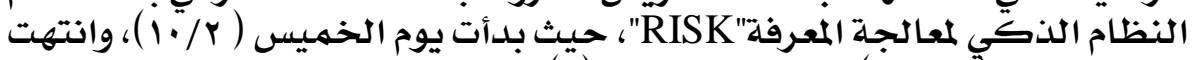

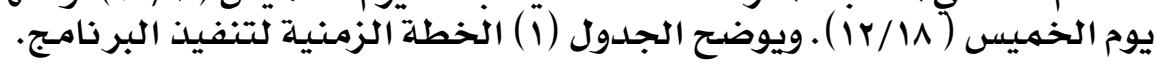

\section{$9 \%$}




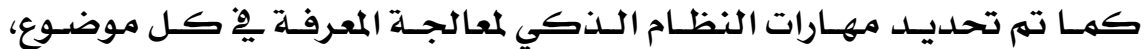

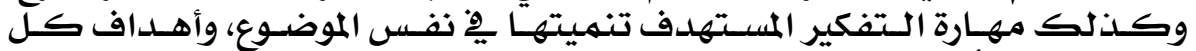

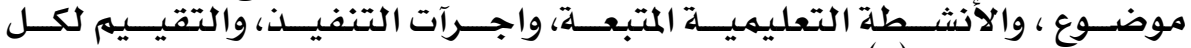

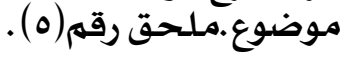

جلول(1) بوضتح الخطة الزمنية لتنفيذ البرنامجه.

\begin{tabular}{|c|c|c|c|}
\hline التدريس زمن & 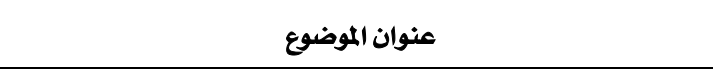 & التاريخ & P \\
\hline 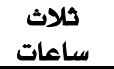 & تطبيق الاختبار القبلي للمجموعتين التجريبية والضابطة & $r+1 \varepsilon-1 .-r$ & 1 \\
\hline ساعتبن & التعريف بالمادة ومجالات علم الاقتصاد المنزلي. & $r+1 \varepsilon-1 \cdot-1$ & $r$ \\
\hline ساعتان & العناصر الغذائية(أقسامها،مصادرها،احتياجات الجسيم منها....). & $Y+1 \varepsilon-1 \cdot-17$ & $r$ \\
\hline ساعتان & أمراض سوء التغذية. & $r+1 \varepsilon-1 .-r r$ & $\varepsilon$ \\
\hline ساعتان & لإلتهاب الكبدى الفيروسي(سى). & $r+1 \varepsilon-1 .-r$. & 0 \\
\hline ساعتان & كيف نكسب احترام الآخرين،أداب الزيارات. & $r+1 \varepsilon-11-7$ & 7 \\
\hline ساعتان & قواعد التواصل،اتيكيت تناول الطعام & $r+1 \varepsilon-11-1 r$ & $v$ \\
\hline ساعتان & مشكلات الأطفال(الخوف،الكذب،التأخر الدراسي،|الخجل،العدوان) & $r+1 \varepsilon-11-r$. & $\hat{\Lambda}$ \\
\hline 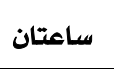 & 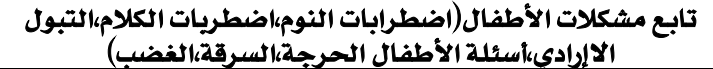 & $r+1 \varepsilon-11-r V$ & 9 \\
\hline 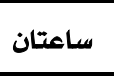 & الأناقة والموضة ،الملابس التي تتناسب مع شكل الجسم وتلايٌ عيوب & $r+1 \varepsilon-1 Y-\varepsilon$ & 1. \\
\hline ساعتان & المسكن وأسس إختياروترتيب الأثاث . & $r+1 \varepsilon-1 Y-11$ & 11 \\
\hline 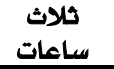 & تطبيق الاختبار البعدي للمجموعتين التجريبية والضابطة & $r+1 \varepsilon-1 r-11$ & ir \\
\hline
\end{tabular}

• التطبيتق القبلب لأدوات البحث:

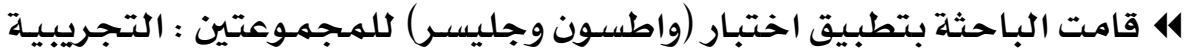

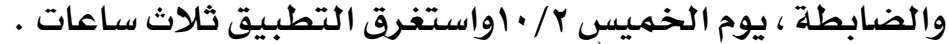

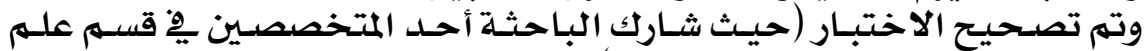

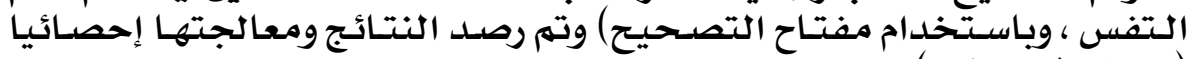

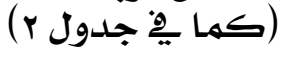

جلدول (r) نتائج اختبار"ت" للفرق بين متوسطي درجات المجموعتين التجريبية والضابطة فِ مهارات التفكيرالناقل قبل التطبيق

\begin{tabular}{|c|c|c|c|c|c|c|}
\hline \multirow{2}{*}{ الدلاكلة } & \multirow{2}{*}{ قيمةت } & \multicolumn{2}{|c|}{ التحريبية } & \multicolumn{2}{|c|}{ الضابطة } & \multirow{2}{*}{ المهارة } \\
\hline & & (घ) & م & (q) & م & \\
\hline ليست دالة & 1.640 & $(2.01)$ & 6.17 & $(1.62)$ & 5.46 & التفسير \\
\hline ليست دالة & 1.449 & $(\mathbf{1 . 5 0})$ & 4.09 & (2.08) & 4.71 & الدقة فِّح فحص \\
\hline ليست دالة & 1.092 & $(2.21)$ & 6.40 & (3.36) & 7.14 & إدراك الحقوضائق \\
\hline ليست دالة & 0.947 & (2.12) & 6.09 & (3.30) & 6.71 & إدراك إطار العلاقة \\
\hline دالة عند ا... & $* * 6.439$ & $(2.91)$ & 7.49 & $(5.08)$ & 13.86 & التطرف ِِ الرأي \\
\hline دالة عند ا... & $* * 2.921$ & $(4.96)$ & 33.93 & $(9.68)$ & 39.30 & محموع المهارات \\
\hline
\end{tabular}

\section{$9 \varepsilon$}


العقد المائ والستون .. نوهمبر .. ها•م.

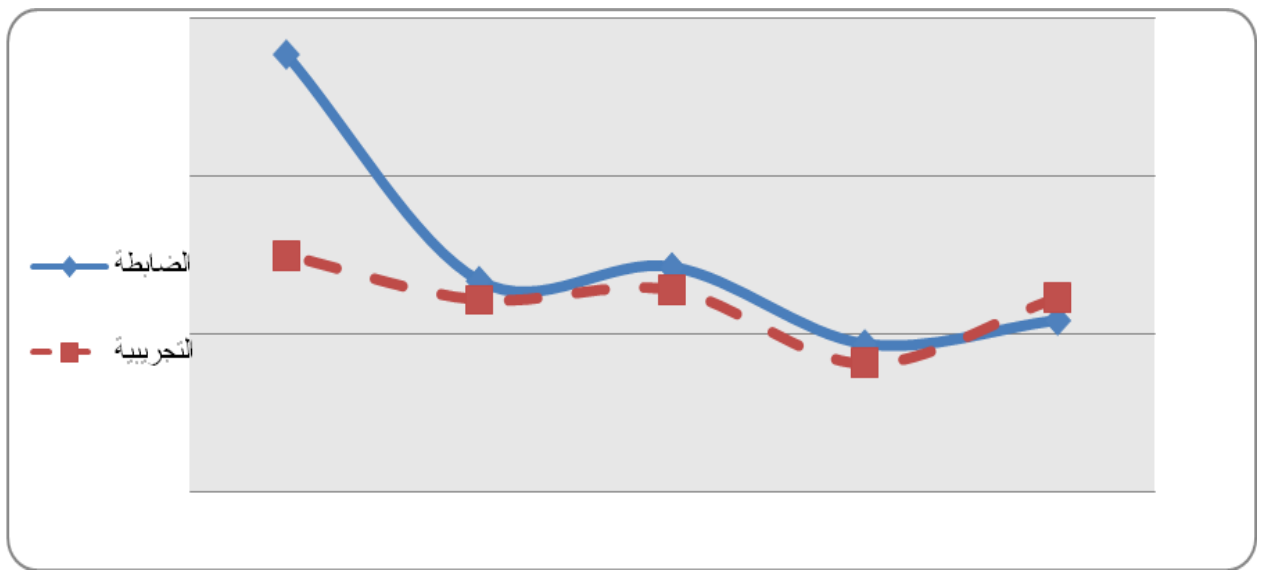

هكل (1) مهارات التفكير الناقل للمجموعتين التجريبية والضابطة قبل التطبيق

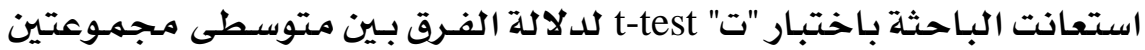

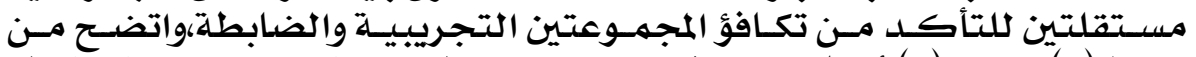

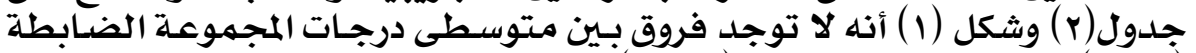

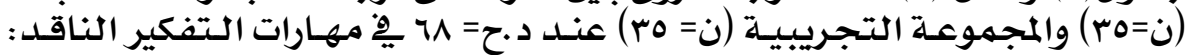

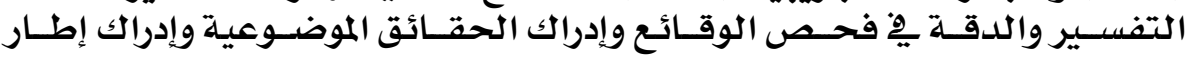

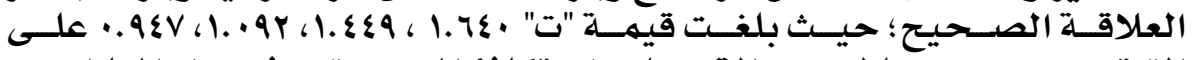

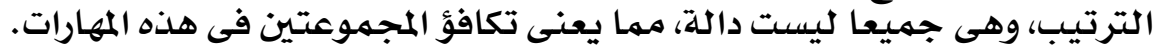

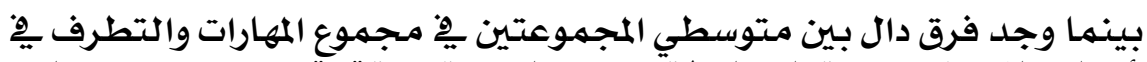

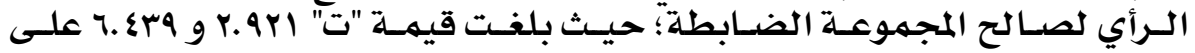

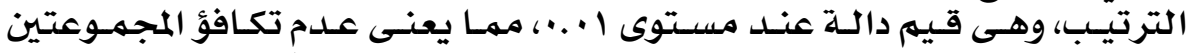

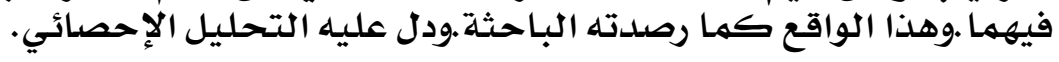

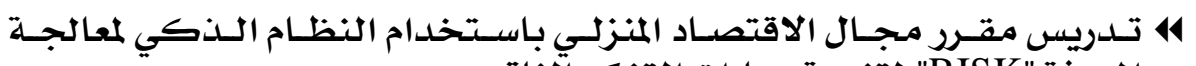

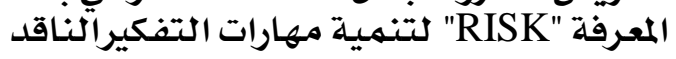

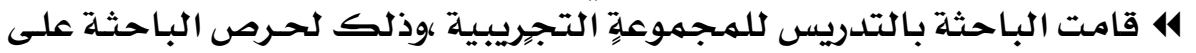

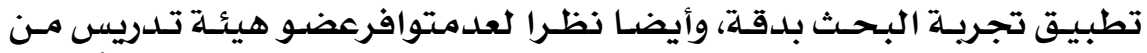

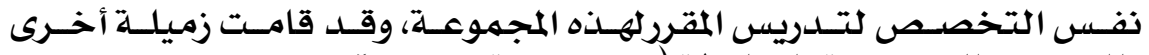

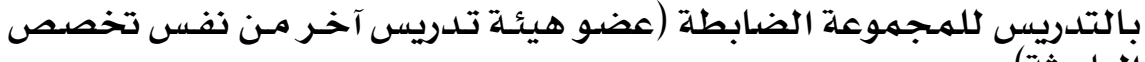
ألباحثة) . البتديس واتبعت الباحثة البـاحثة الخطوات التالية:

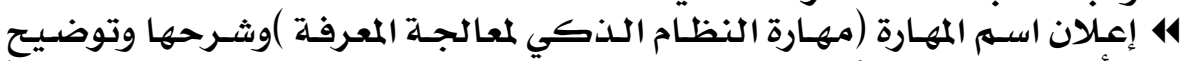

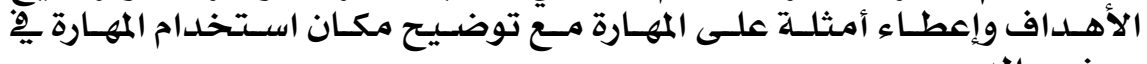
موضوع الدربس.

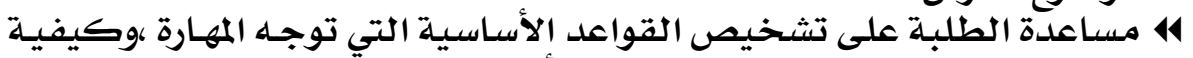

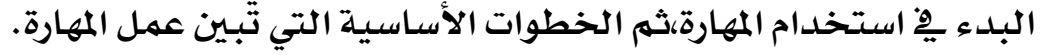

\section{0}


4 تشرح الباحثة الأسسئلة أو التهمارين أو التـدريبات الواردة يِّورقة العهل بشكل واضح ومبسط. 414

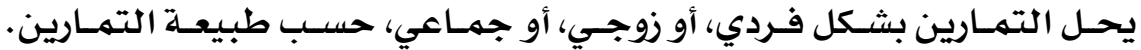

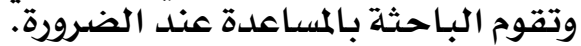

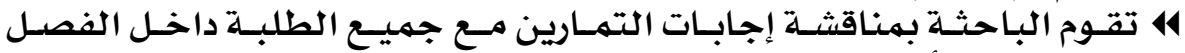

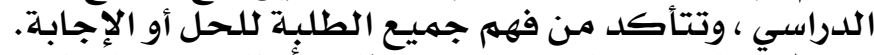

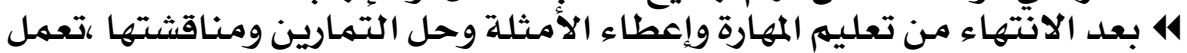

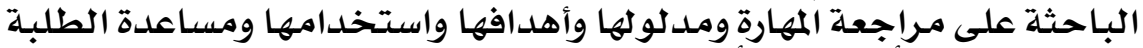

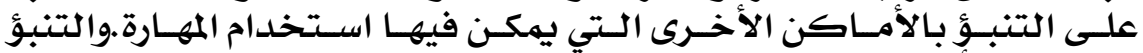

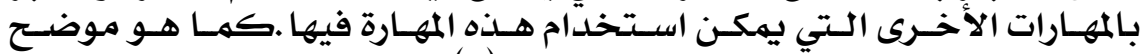

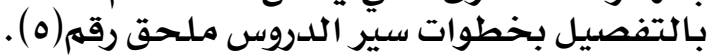

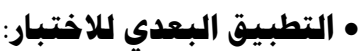

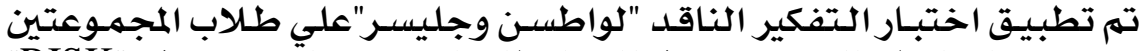

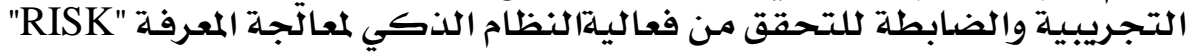

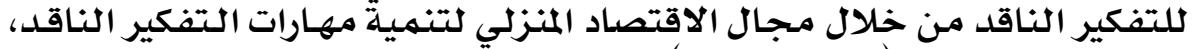

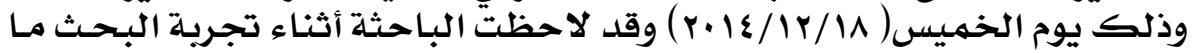

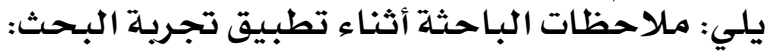

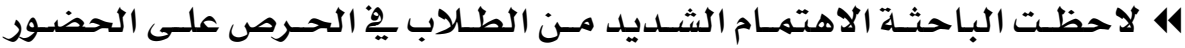

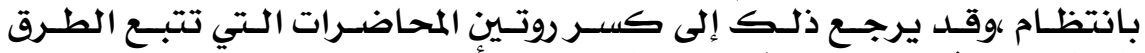

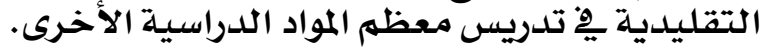

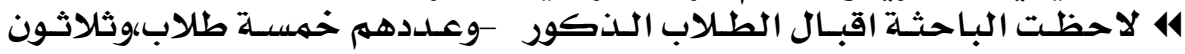

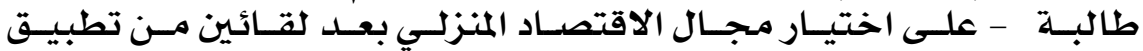

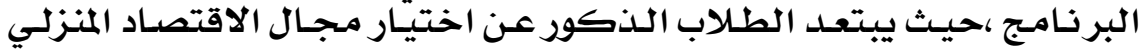

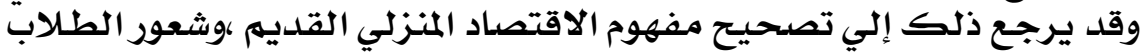

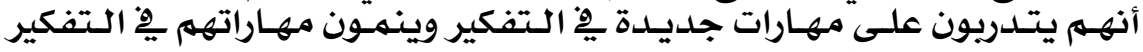

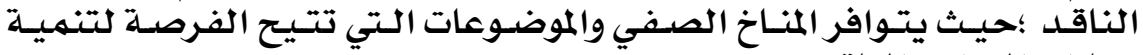

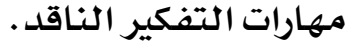

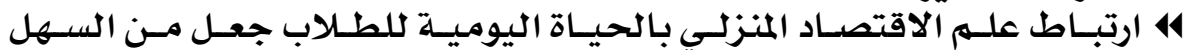

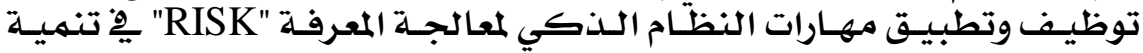

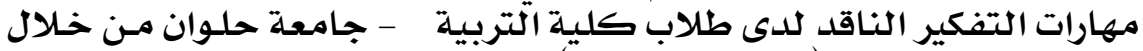

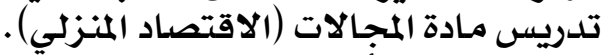

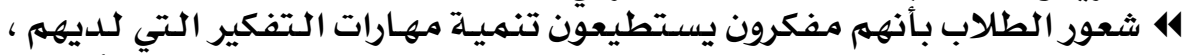

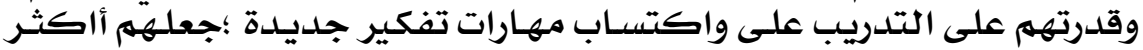

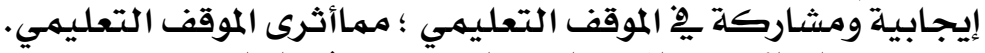

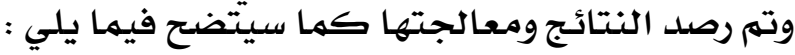

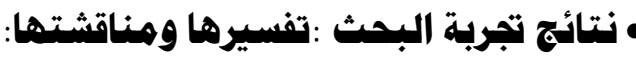

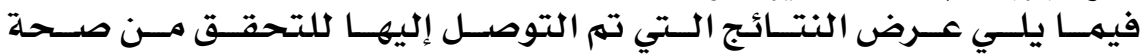

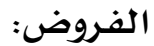

\section{7}


العكى العابي والعترن .. نوهمبر ..

• الفرض الأول:

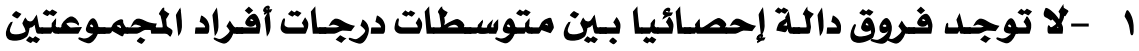

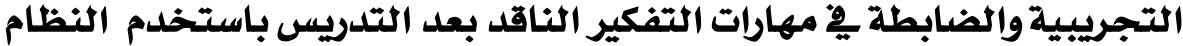

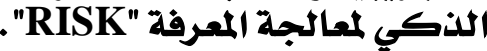

جلدول (r) نتائج تحليل التغايرللمجموعتين التجريبية والضابطة فى التطبيق البعلى لمهارات |التفكير الناقل

\begin{tabular}{|c|c|c|c|c|c|c|}
\hline \multirow{2}{*}{ مريع إيتا } & \multirow{2}{*}{ قيمة ف } & \multicolumn{2}{|c|}{ الضابطة } & \multicolumn{2}{|c|}{ التحرييية } & \multirow[b]{2}{*}{ المهارة } \\
\hline & & (q) & p & (q) & p & \\
\hline 0.37 & $* * 39.261$ & $(1.19)$ & 9.60 & $(1.71)$ & 6.20 & التفسير \\
\hline 0.71 & $* * 158.500$ & $(\mathbf{0 . 8 7})$ & 8.11 & (1.17) & 4.09 & الدقة فِّْ فحص فص الوقع \\
\hline 0.76 & $* * 209.052$ & (1.95) & 17.31 & (3.06) & 8.06 & إدراك الحمقائق \\
\hline 0.60 & $* * 100.202$ & (1.12) & 12.86 & (2.76) & 7.40 & إدراك إطار العلاقة \\
\hline 0.60 & $* * 99.306$ & (3.64) & 22.29 & $(4.89)$ & 14.14 & التطرف 2 الرأي \\
\hline 0.90 & $* * 587.734$ & $(3.45)$ & 72.79 & $(6.61)$ & 41.03 & محموو المهارات \\
\hline
\end{tabular}

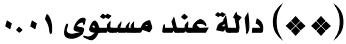

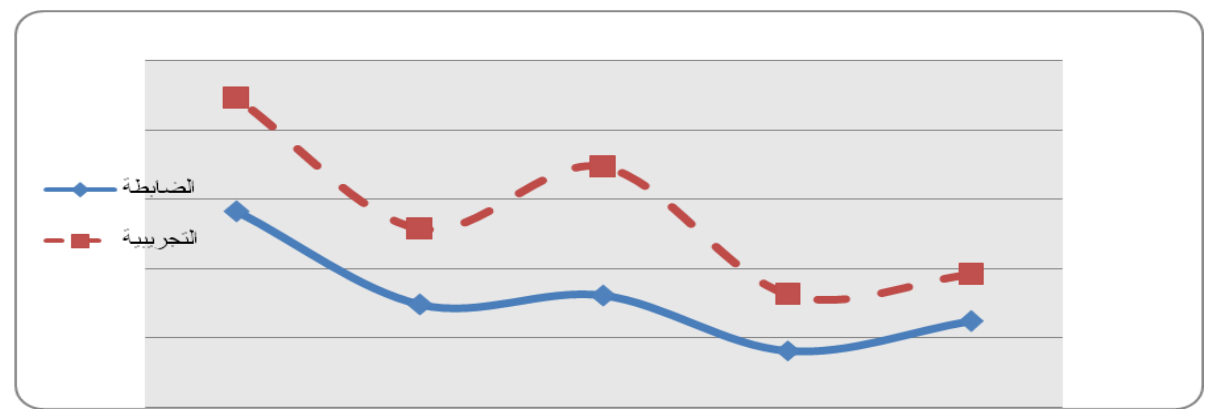

ثكل (r) مهارات التفكير الناقل للمجموعتين التجريبية والضابطة بعل التطبيق

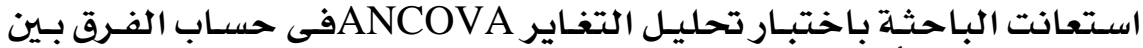

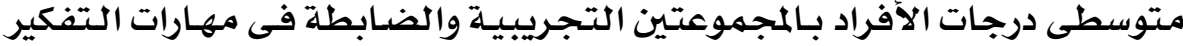

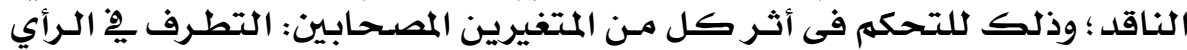

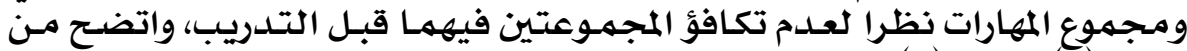

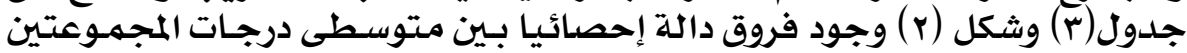

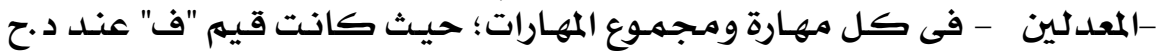

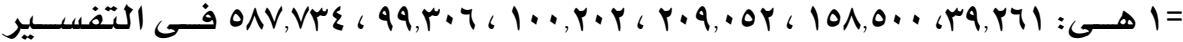

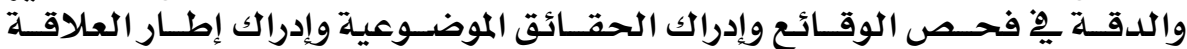

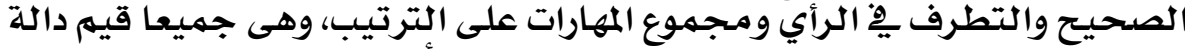

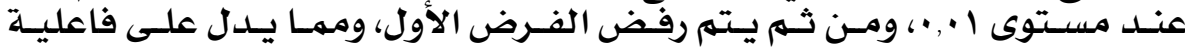

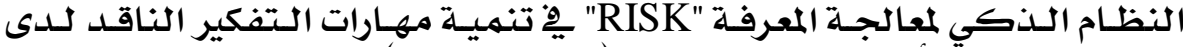

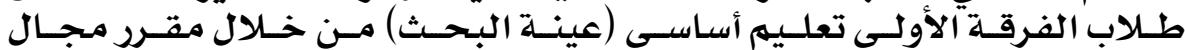

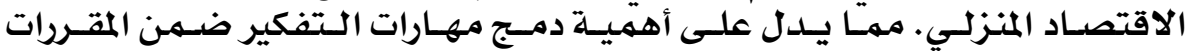

\section{$9 \mathrm{~V}$}




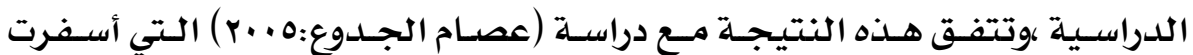

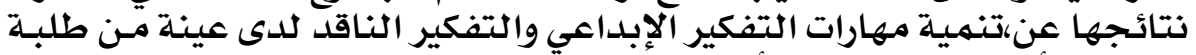

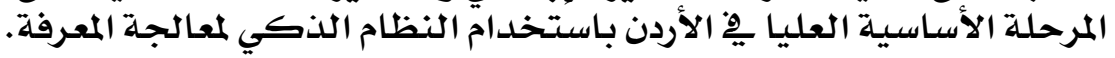

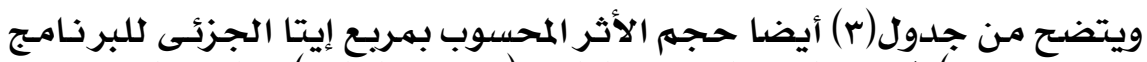

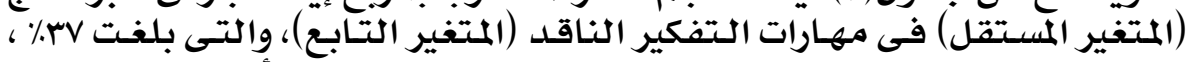

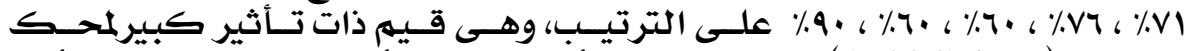

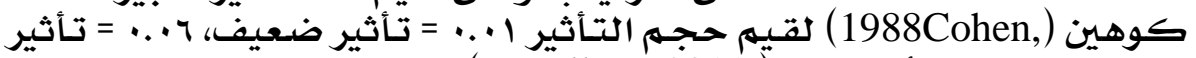

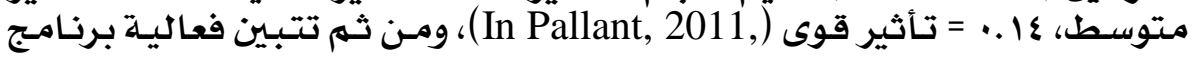

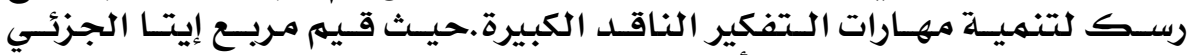

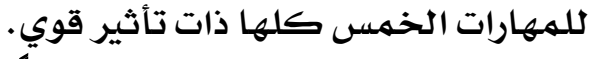

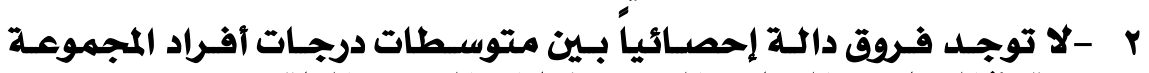

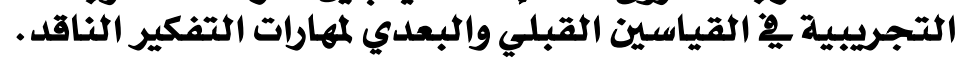

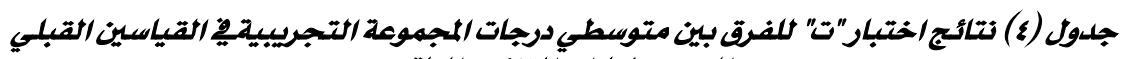
والبعلي المهارات ألتفكير الناقلد

\begin{tabular}{|c|c|c|c|c|c|c|}
\hline \multirow{2}{*}{ مريع إيتا } & \multirow{2}{*}{ قيمةت } & \multicolumn{2}{|c|}{ القياس البعدي } & \multicolumn{2}{|c|}{ القياسي القبلي } & \multirow{2}{*}{ المهارة } \\
\hline & & (q) & P & $(\varepsilon)$ & $\rho$ & \\
\hline $\mathbf{0 . 8 0}$ & $* * 11.050$ & $(1.19)$ & 9.60 & (2.01) & 6.17 & التفسير \\
\hline 0.91 & $* * 18.412$ & $(0.87)$ & 8.11 & $(\mathbf{1 . 5 0})$ & 4.09 & الدقة ـِّحص فحص \\
\hline 0.97 & $* * 32.435$ & (1.95) & 17.31 & (2.21) & 6.40 & إدراك الحقائق \\
\hline 0.96 & $* * 28.716$ & (1.12) & 12.86 & (2.12) & 6.09 & إدراك إطار العلاقة \\
\hline 0.96 & $* * 27.305$ & $(3.64)$ & 22.29 & $(2.91)$ & 7.49 & التطرف 2 الرأي \\
\hline 0.99 & $* * 57.036$ & $(3.45)$ & 72.79 & $(4.96)$ & 33.93 & مجموع المهارات \\
\hline
\end{tabular}

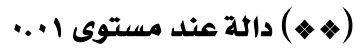

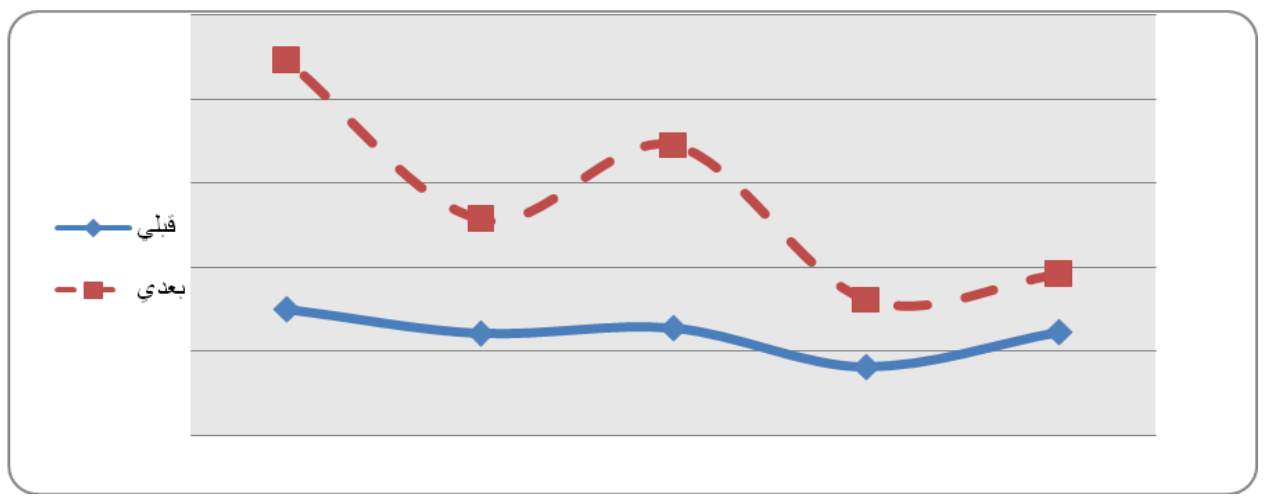

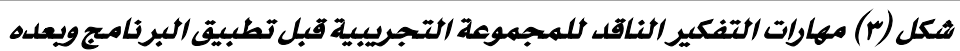

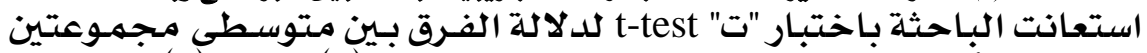

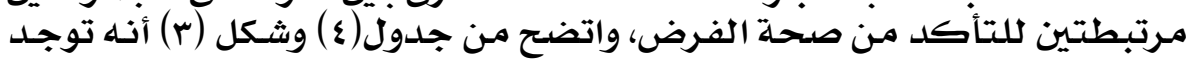

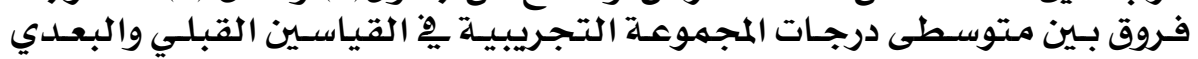

\section{1}




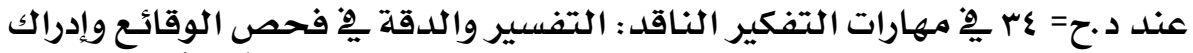

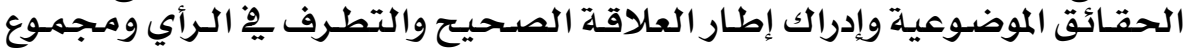

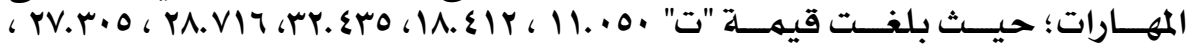

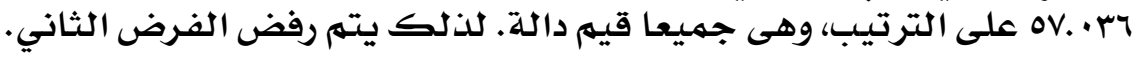

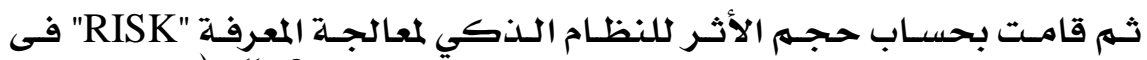

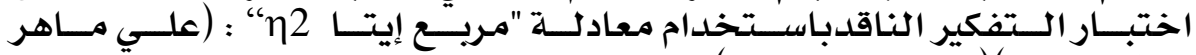

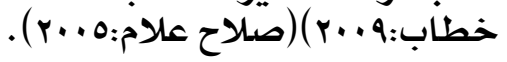

$$
\frac{r}{ت \cdot د+r}=\eta 2
$$

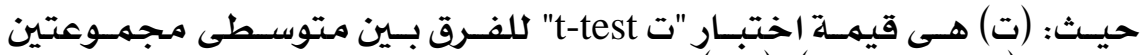

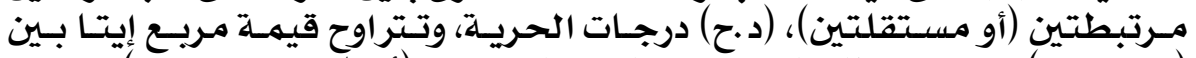

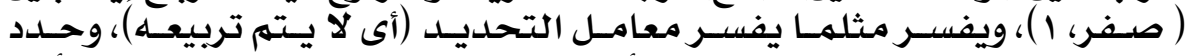

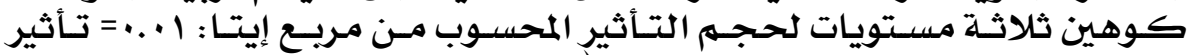

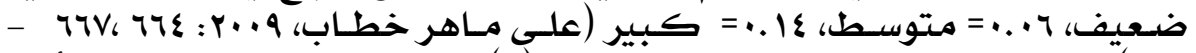

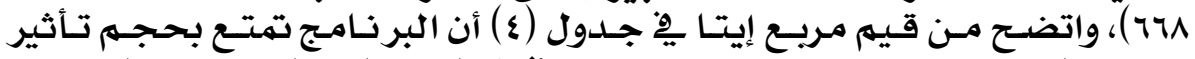

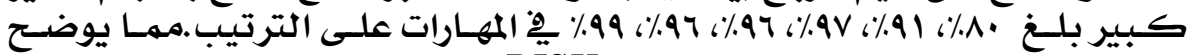

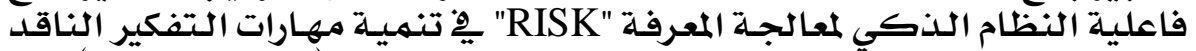

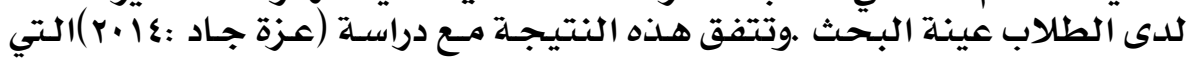

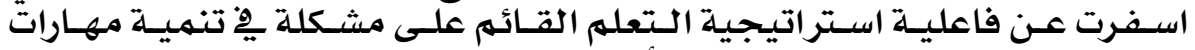

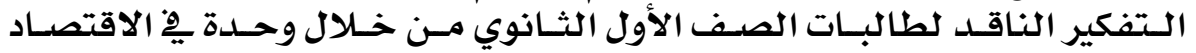
المنزلي.

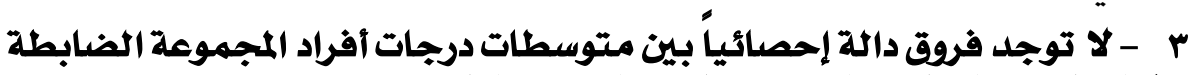

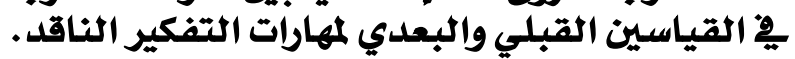

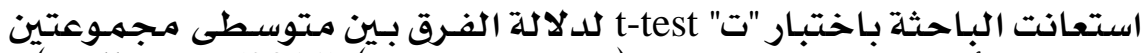

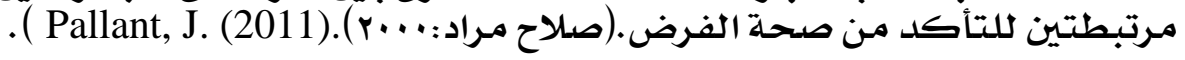

\begin{tabular}{|c|c|c|c|c|c|c|}
\hline \multirow[t]{2}{*}{ الدلالة الدل } & \multirow[t]{2}{*}{ قيمةت } & \multicolumn{2}{|c|}{ القياس البعلى } & \multicolumn{2}{|c|}{ القياس القبلي } & \multirow[t]{2}{*}{ المهارة } \\
\hline & & $(\varepsilon)$ & & (द) & & \\
\hline دالة عند ه... & $* 2.145$ & (1.71) & 6.20 & $(1.62)$ & 5.46 & التفسير \\
\hline ليست دالة & 1.672 & (1.17) & 4.09 & (2.08) & 4.71 & الدقة فو فحص \\
\hline ليست دالة & 1.427 & (3.06) & 8.06 & $\begin{array}{l}\mathbf{3 . 3 6}) \\
\end{array}$ & 7.14 & إدراكلك الحقائق \\
\hline ليست دالة & 1.522 & (2.76) & 7.40 & $\overline{(\mathbf{3 . 3 0})}$ & 6.71 & إدراك إطحار العلاقة \\
\hline ليست دالة & 0.336 & $(\mathbf{4 . 8 9})$ & 14.14 & $(5.08)$ & 13.86 & التطرف 2 الرأي \\
\hline ليست دالة & 1.192 & (6.61) & 41.03 & $(\mathbf{9 . 6 8 )}$ & 39.30 & مجموع المهارات \\
\hline
\end{tabular}

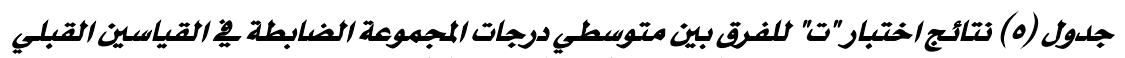
والبعلي أمارات ألتفكير الناقل

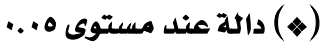

\section{9}




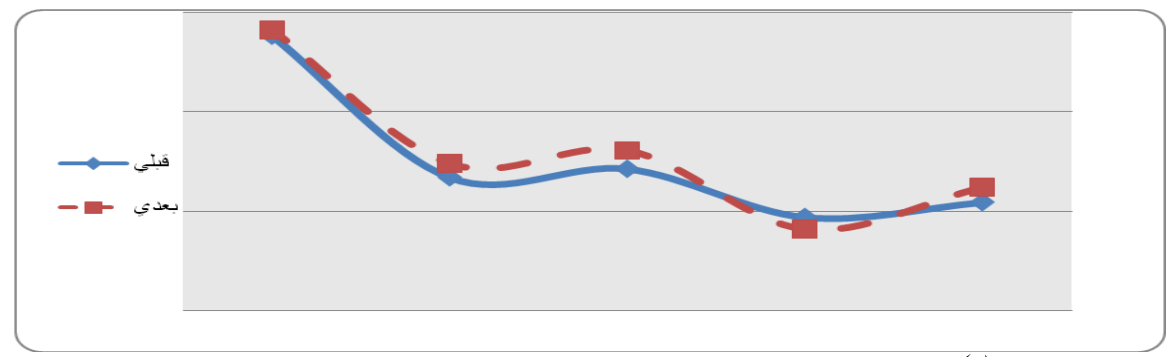

ثكل (ع) مهارات التفكير الناقل للمجموعة الضابطة قبل تطبيق البرنامج ويعله

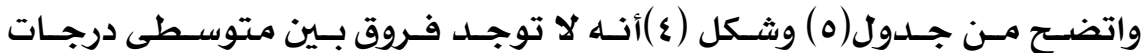

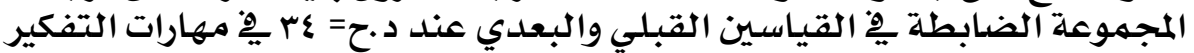

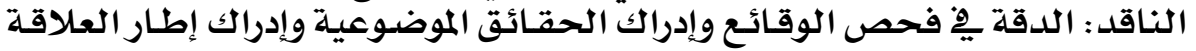

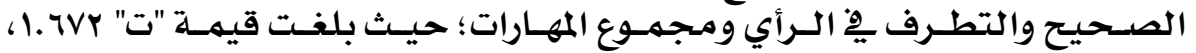

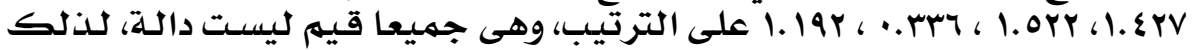

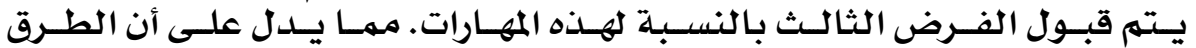

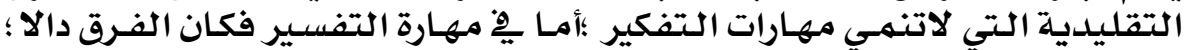

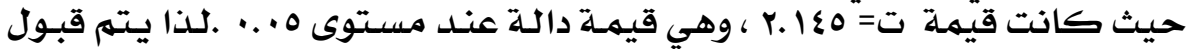

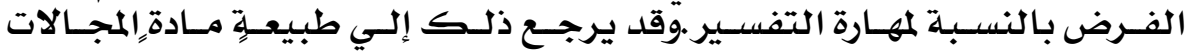

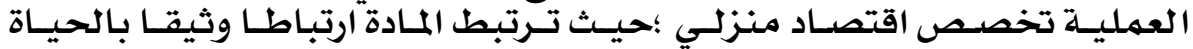

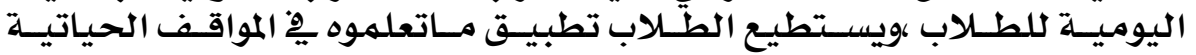

بناءً على نتائج هذه الدراسـة فإن الباحثة توصي بها يلي:

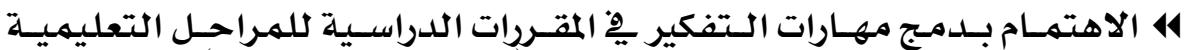

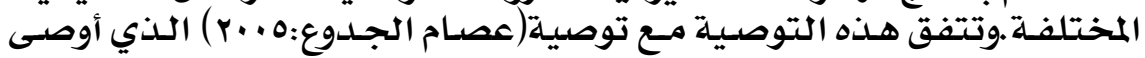

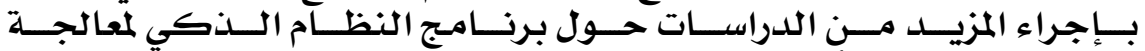

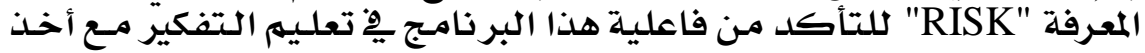

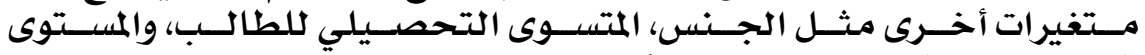

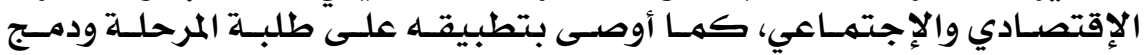

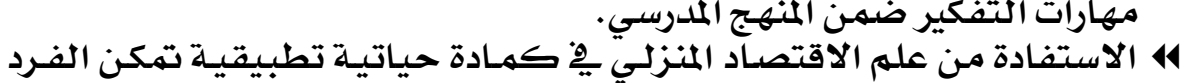

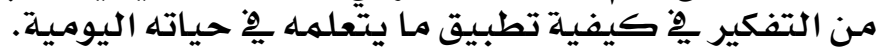

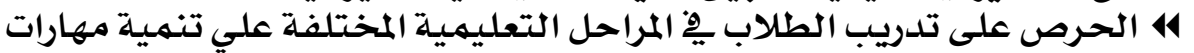

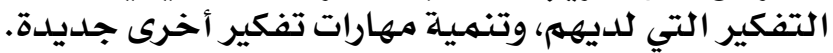

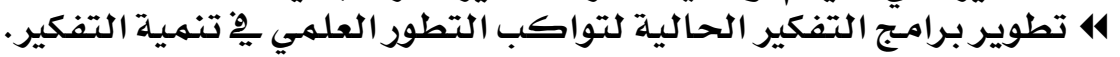

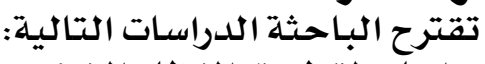

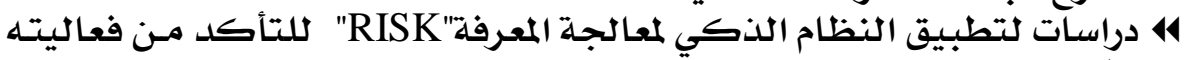

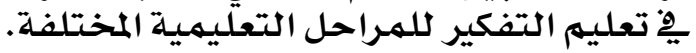


4 دراسـات حـول اسـتراتيجيات التـدريس المختلفــة التتي تنهـي التفكير مـن خـلال علهم الاقتصاد المنزئي.

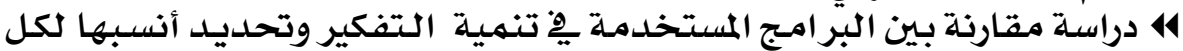
مرحلة تعليمية.

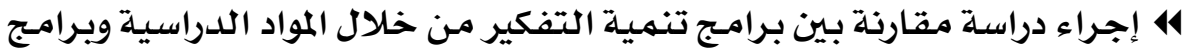

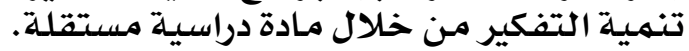

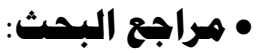

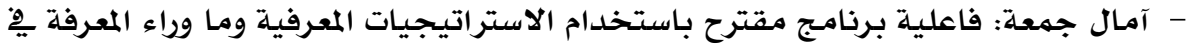

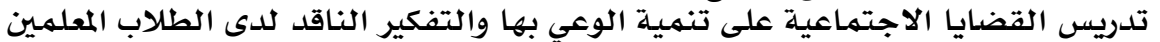

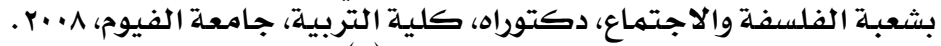

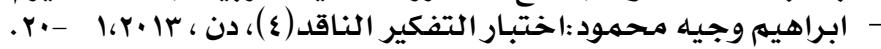

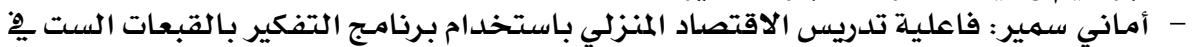

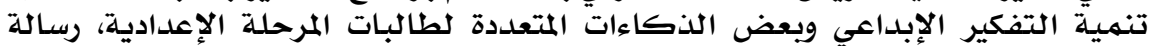

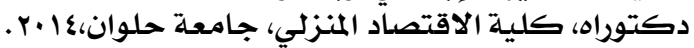

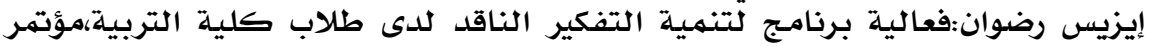

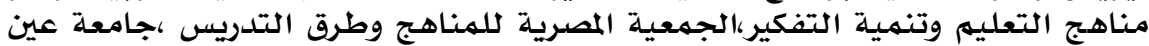

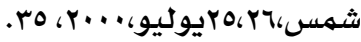

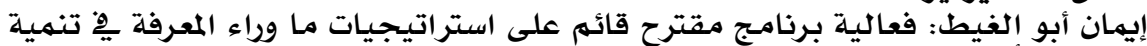

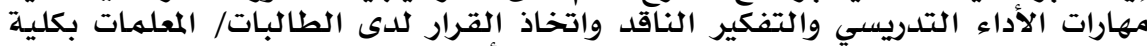

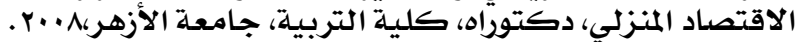

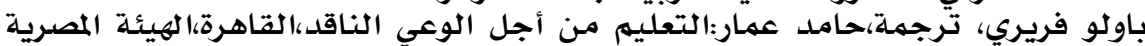

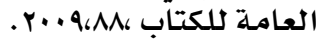

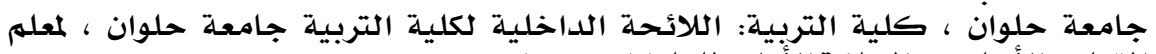

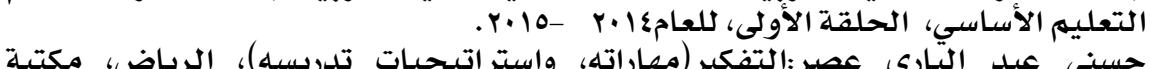
حسني عبد البّاري عصر:التفكير(مهاراته، واستراتيجيات تلدريسه)، الرياض، مكتبة

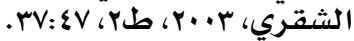

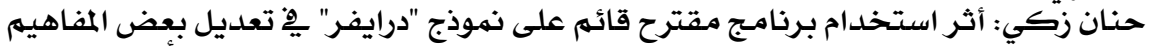

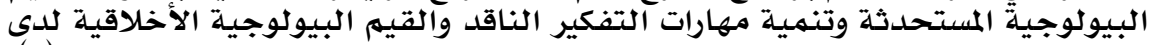

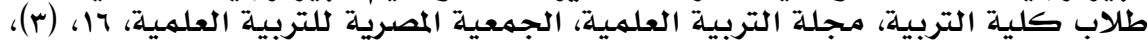

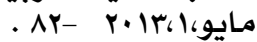

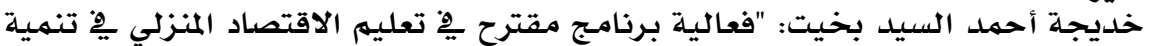

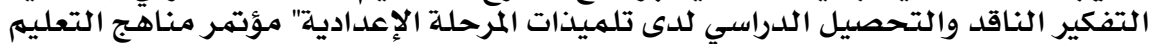

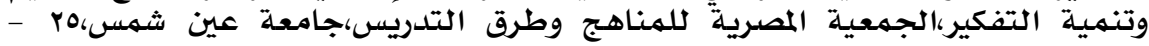

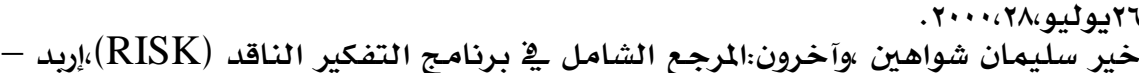

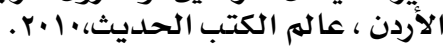

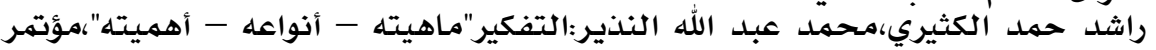

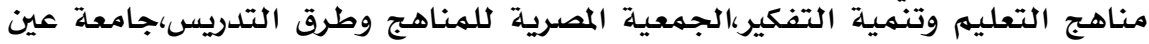

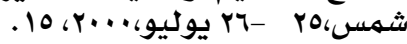

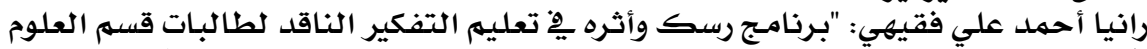

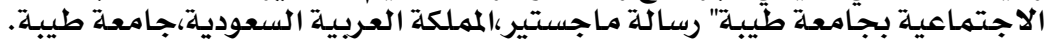

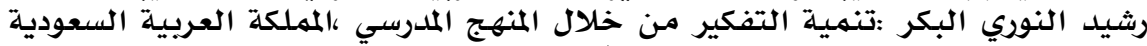

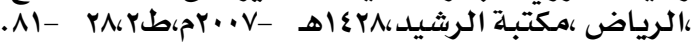

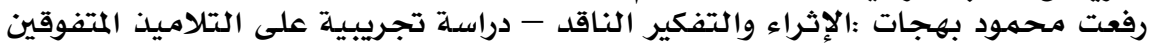

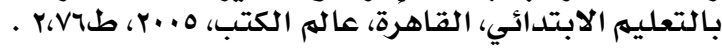




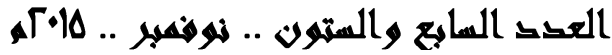

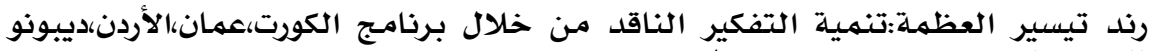

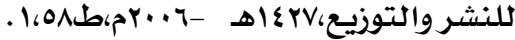

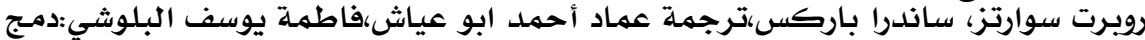

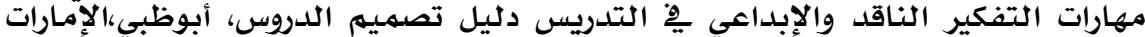

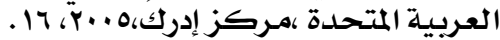

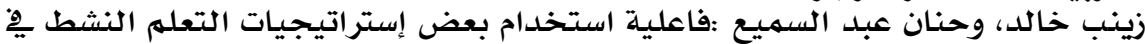

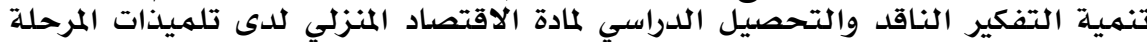

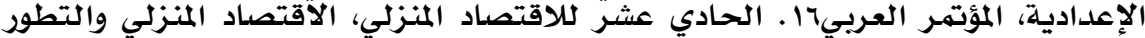

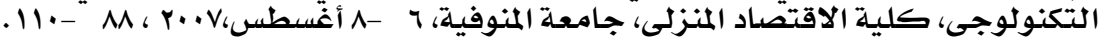

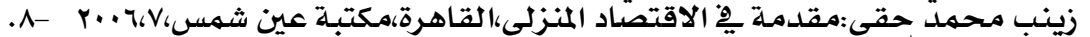

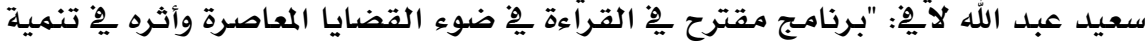

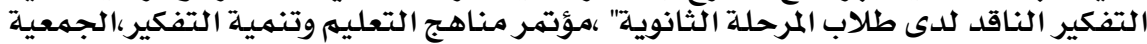

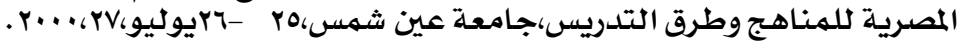

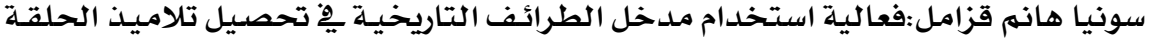

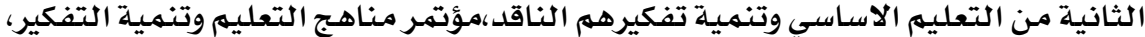

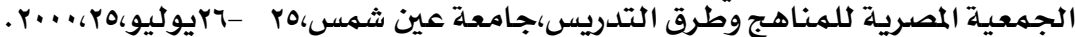

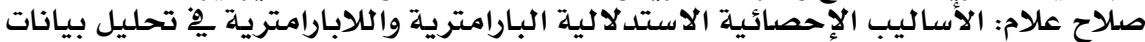

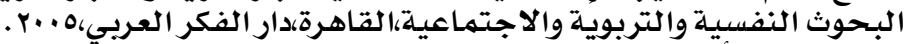

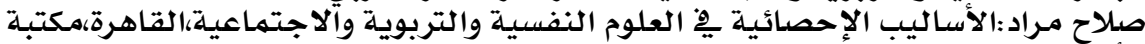

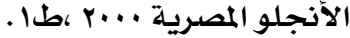

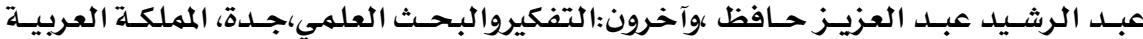

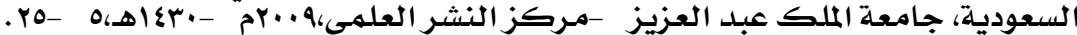

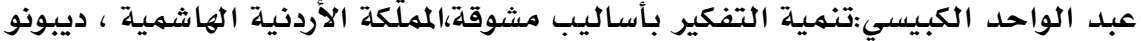

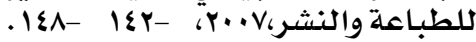

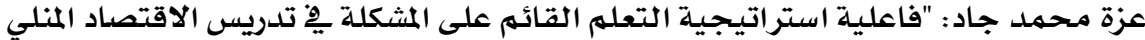

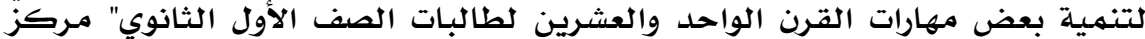

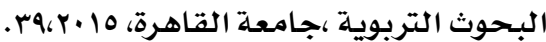

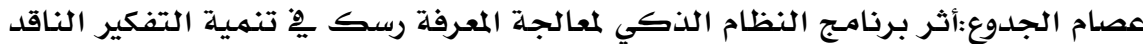

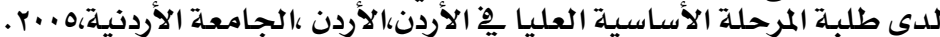

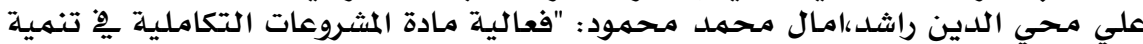

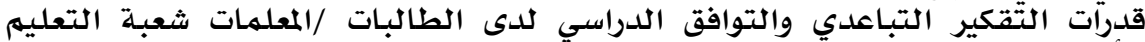

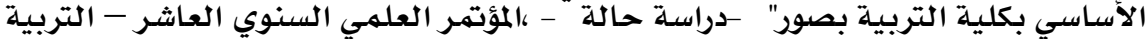

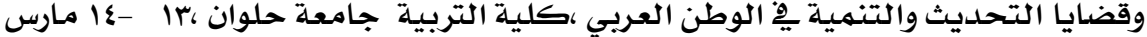
r.r.r.qr

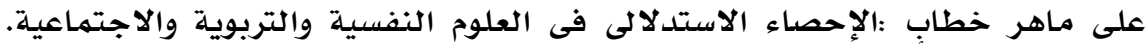

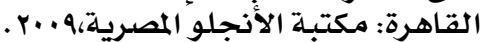

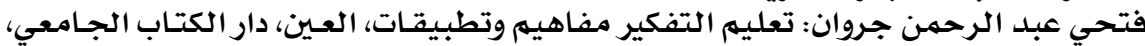
1.1. 19.1999

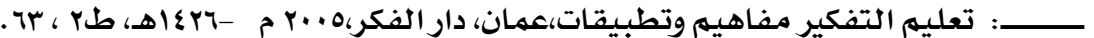

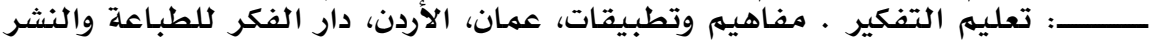

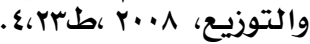

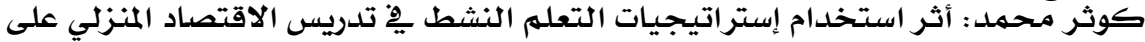

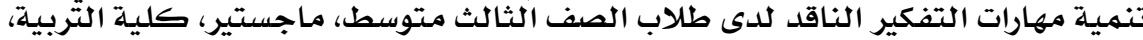

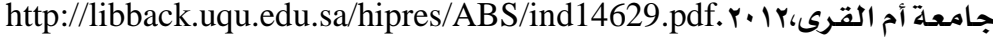

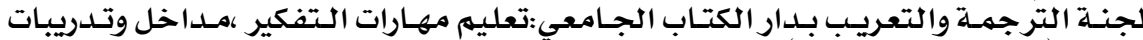

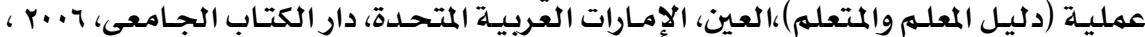
rrV- rrr

\section{$1 \cdot Y$}




\section{العضى العابع والستهو .. نوهمبر ..}

مجدي عبد الكرييم حبيب:اتجاهات حديثة يخ إِ تعليم التفكير ،استراتيجيات مستقبلية

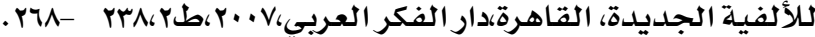

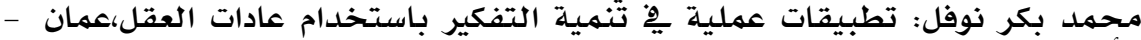

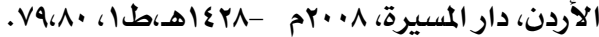

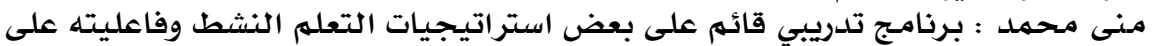

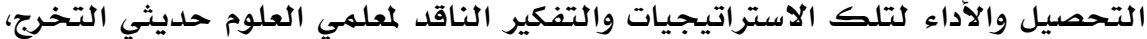

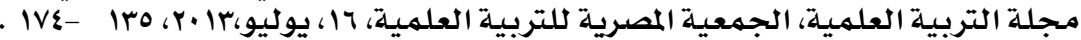

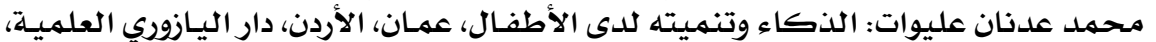
. $10 \varepsilon$ - lor، r..V

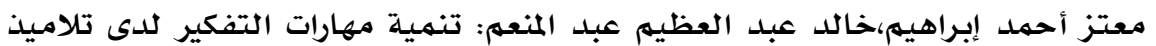

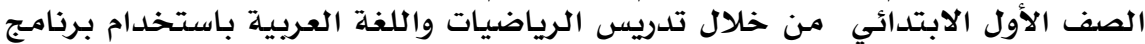

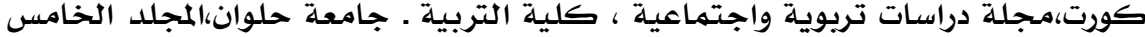

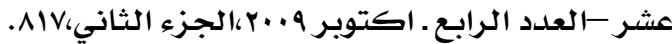

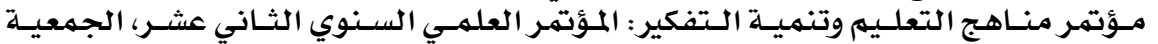

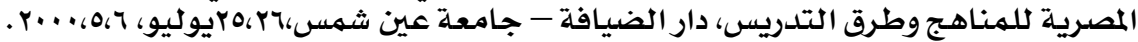

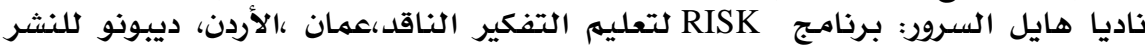

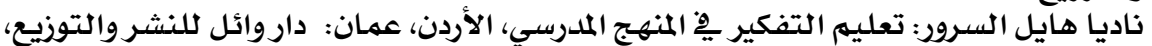

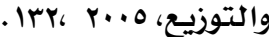

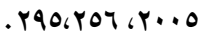

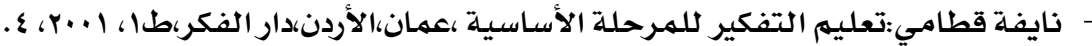

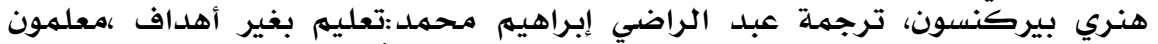

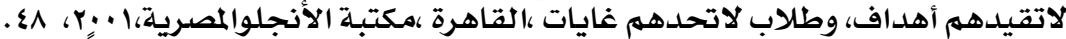

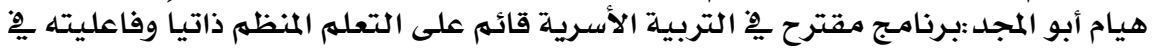

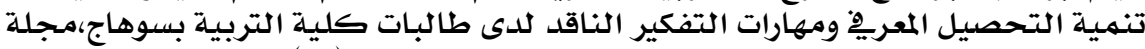

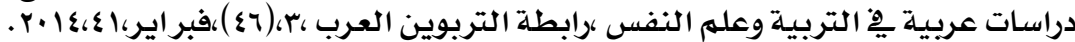

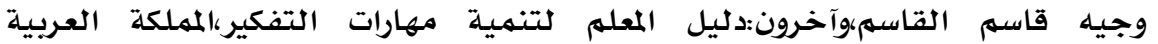

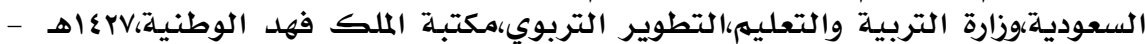

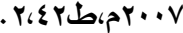

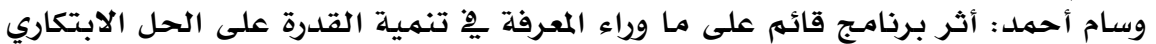

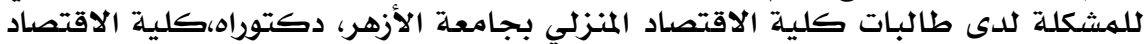

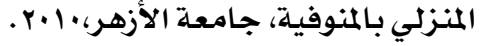

- Andrew,R.\&Daniel,W. 21stCentury Teaching and Learning :The Challenges Ahead, Educational Leadership, ASCD,September, 67(1),16-21,2009.

- Banks , J. Selecting a Thinking Skills program . Technomic Publishing Company . Inc ,1991.

- Bensley, A. et al. Teaching and Assessing Critical Thinking Skill for Argument Analysis in Psychology, Teaching of Psychology, 37 (2), 91-96,2010.

- Choy, C. Teacher Perception of Critical Thinking Among Students and its Influence on Higher Education, International Journal of Teaching and Learning in Higher Education, 20 (2),103-115,2009. 


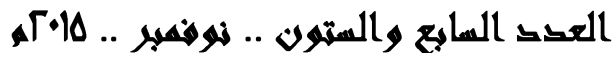

-Ennis, R.H.\& Millman, J,\& Tomko, T.N. Cornell Critical Thinking Test, Manual. (3rd ed.) Critical Thinking Books and Software.Pacific Groge,CA,Midwest Publication, 1985.

-Ennis ,R. H.,Millman,J. and Tomko, T.N.,Cornell Critical thinking Tests .CA: Critical thinking Press \&Software,2005.

-Ennis,R.A super-Streamlined Conception Of Critical Thinking. Available at:htt//www.kemtertro.cc.mous/lognview/ctacdefinition.html.2013.

-55-Pallant, J. SPSS survival manual: A step by step guide to data analysis using SPSS (4th Edition).Australia: Allen \& Unwin,2011. pp. 210

-Paul,R.Fisher,A.\& Nosich,G:Workshop On Critical Thinking Strategies . In: Alec Fisher \& Michael Scriven. Critical Thinking:Its Definition\& Assessment. UK:Center For Research In Critical Thinking, 1997.p.91

-Philip, L.: The Pedagogy of Critical Thinking : Object Design Implications for Improving Students Thoughtful Engagement

Within E-Learning Environment, B3,2011, 354-363.

-Swartz , J;Parks ,S. Infusing the Teaching of Critical and Creative Thinking into Content Instruction.Critical Thinking Press Software . U.S.A, 1994.

- Torrance, P;Safter .T. The Incubation Model of Teaching, Getting Beyond The Aha !.Bearly limited . U.S.A ,NY,1990.

- http://omya3rob.blogspot.com/p/blog-page_20.html

- http://www.stooob.com/133364.html

-http://en.wikipedia.org/wiki/Family_and_consumer_science

- www.nooonbooks.com/applied-science-technology/o-u-o-u-o-o

-Edustudentaffairs.helwan@gmail.com

\section{溇溇溇溇溇溇}




\section{البـثَ الثنالث:}

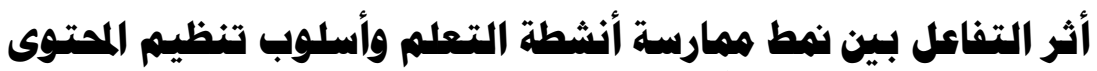

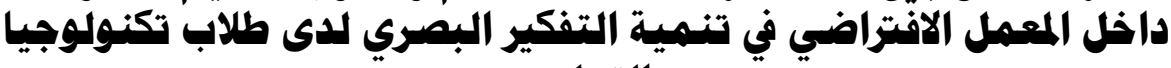
التعليم التير

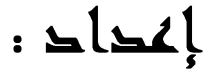

د/ هويلا سعيد عبد الحميل

مدرس تكنولوجيا التعليه والتربية الخاصية

كلية التربية النوعية جامعة التعليه عين شمس الخساه 



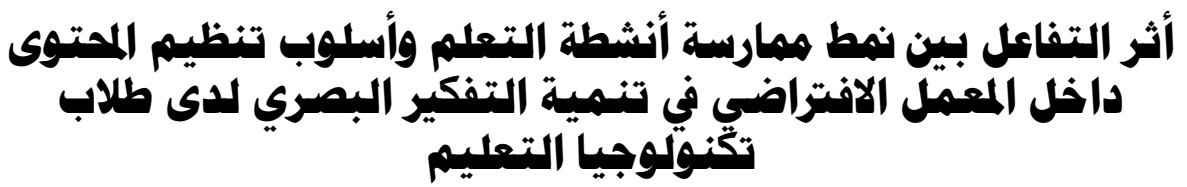

\section{د/هويلا سعيل عبل الحميل}

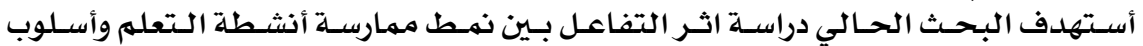

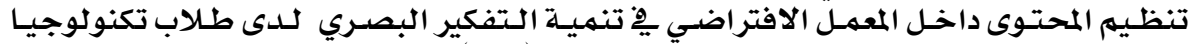

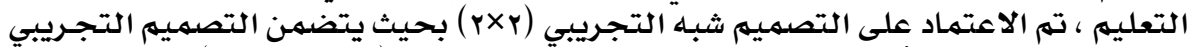

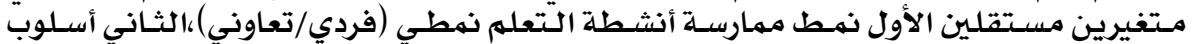

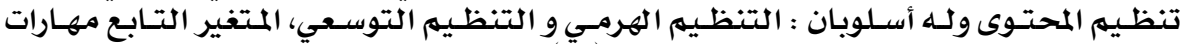

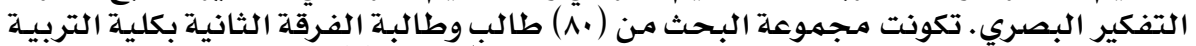

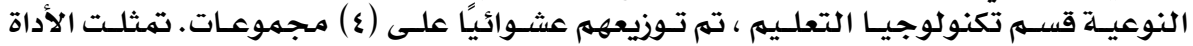

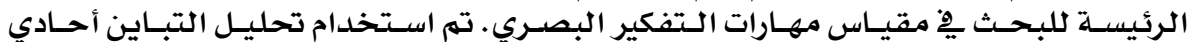

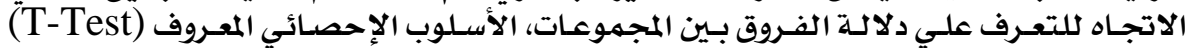

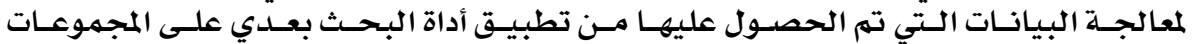

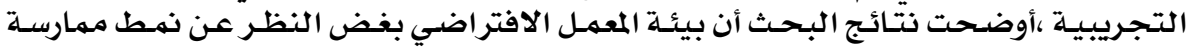

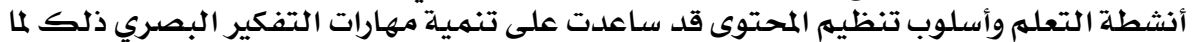

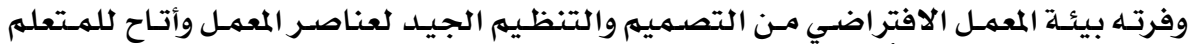

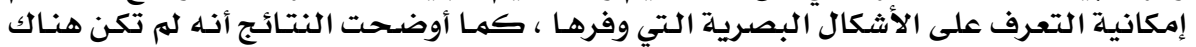

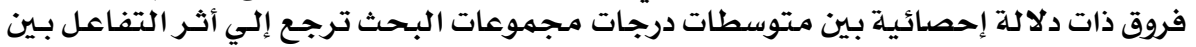

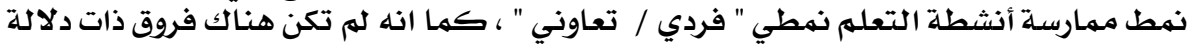

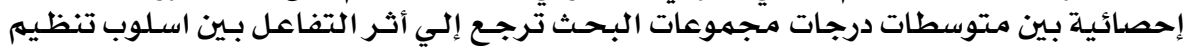

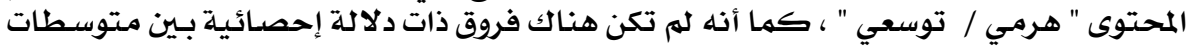

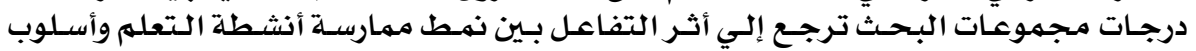

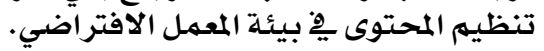

الكلمات المفتاحية : المعمل الافتراضي ، تكنولوجيا التعليم ، التفكير البصري ، تنظيم المحتوى

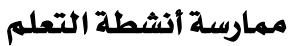

The effect of interaction between the learning activities and method of organizing content into a virtual laboratory in the development of Visual thinking among students in technology education

\section{Dr. howaida Saied Abdel Hamed}

\section{Abstract:}

this research aimed to study the effect of the interaction between the learning activities and method of organizing content into a virtual laboratory in the development of Visual thinking among students in educational technology, is based on the design almost demo $(2 \times 2)$ including experimental design variables the first style of doing independent learning module (individual/cooperative), the second method of organizing content and has two methods: (Hierarchical lexpansionist) dependent variable visual thinking skills. Research Group (80) students 2nd Faculty of

\section{V}


specific education Department of education technology, were randomized to (4) groups. The main tool for research in Visual thinking skills scale. Been using one-way analysis of variance to identify significant differences between the groups. The results of research that the lab environment the default regardless of the style of learning activities and the method of organizing content has helped to develop the skills of Visual thinking to the virtual lab environment design and good organization of the elements of the plant, enabling the learner to identify the Visual forms, and the results showed that there were significant differences between the average degrees of research groups is due to the effect of the interaction between learning activities typical style ' single/cooperative', as there was no Significant differences between the average degrees of research groups is due to the impact of the interaction between the hierarchical organization of content/expansion ', as there were no significant differences between the average degrees of research groups is due to the impact of the interaction between the learning activities and organize content in a virtual lab environment.

Keywords: virtual lab, educational technology, visual thinking, organize content, practice learning activities

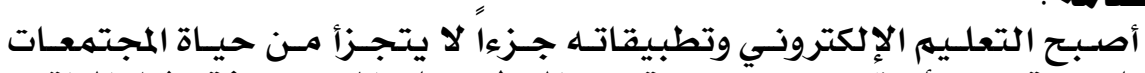

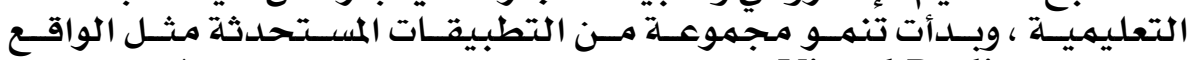

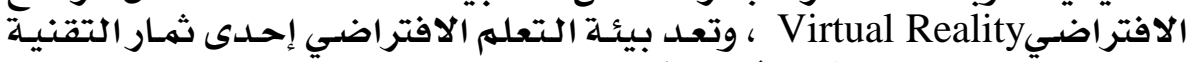

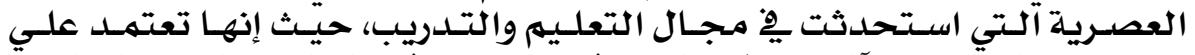

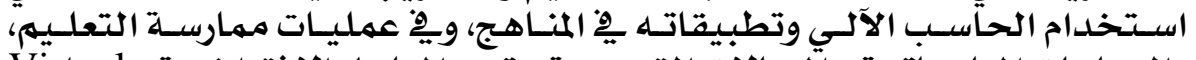

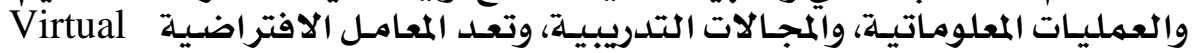

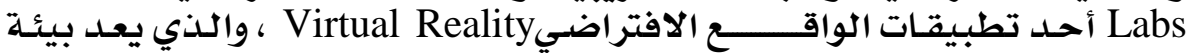

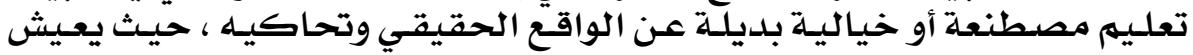

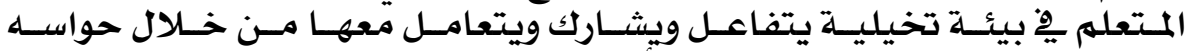

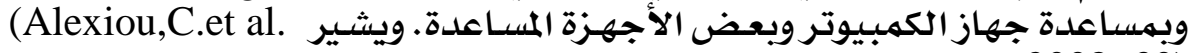

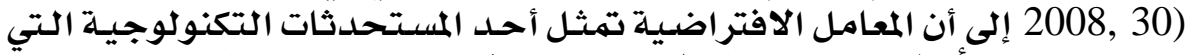

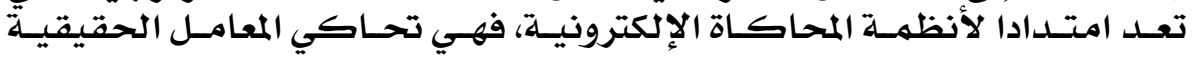

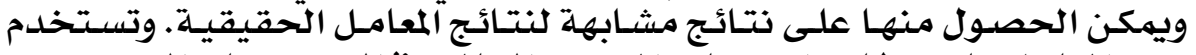

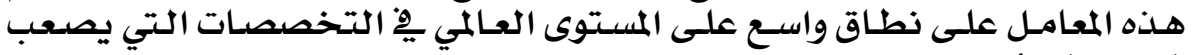

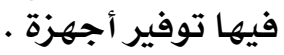

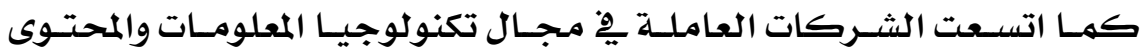

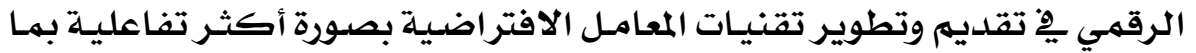

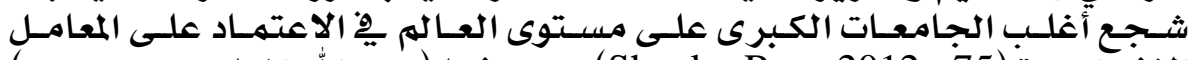

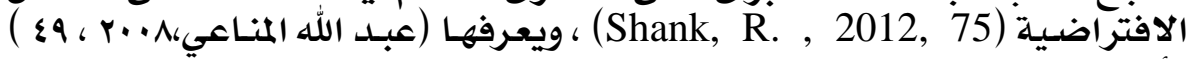

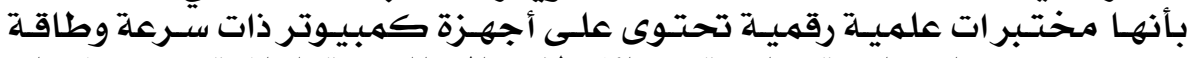

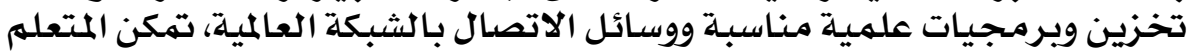




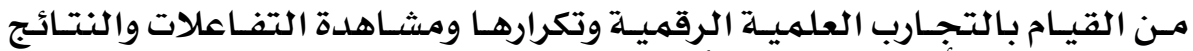

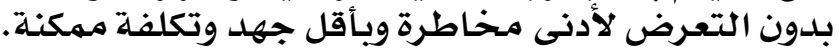

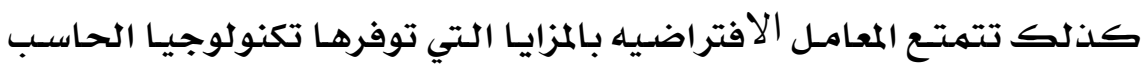

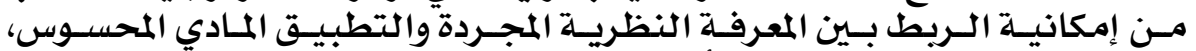

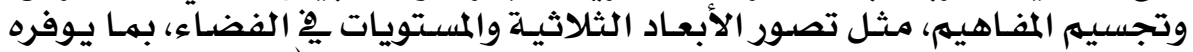

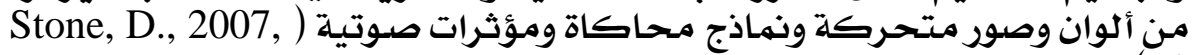

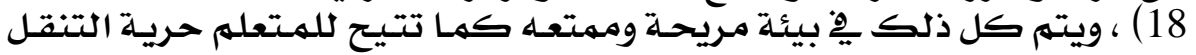

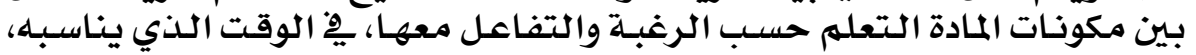

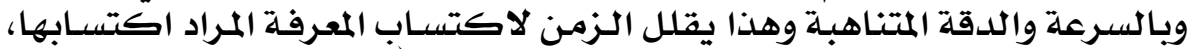

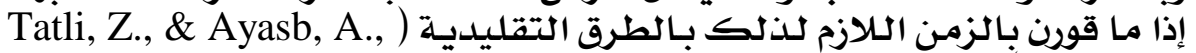
. (2010, 941

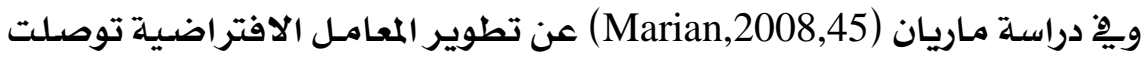

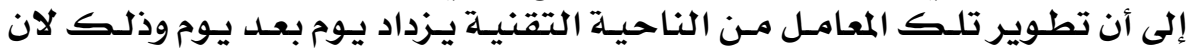

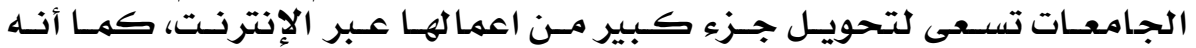

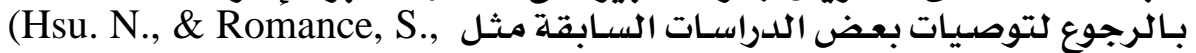
،2012; Tracey, A. \& Stuckey, M., 2007; Yiar, M., \& Litvak, S., 2006)

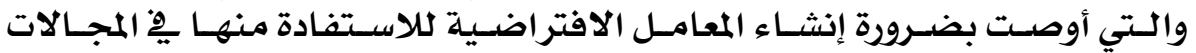

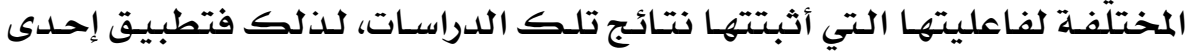

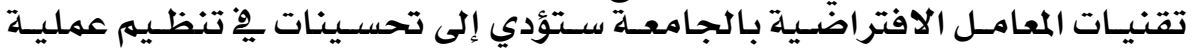

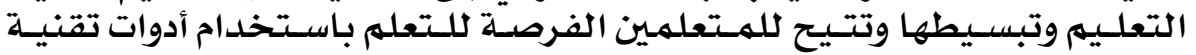

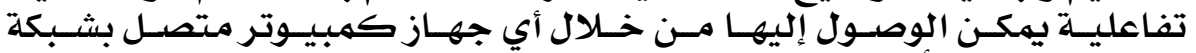

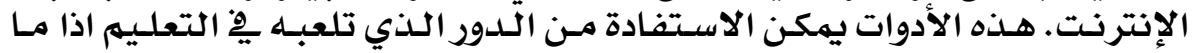

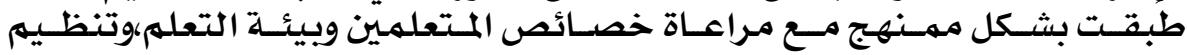

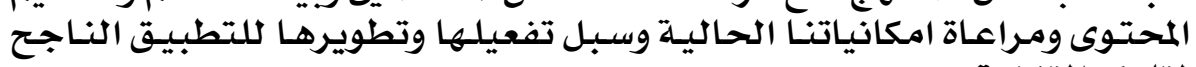
لتلك التقنية.

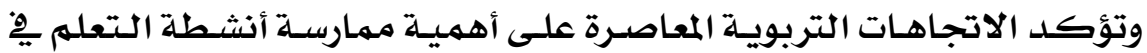

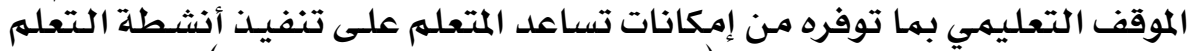

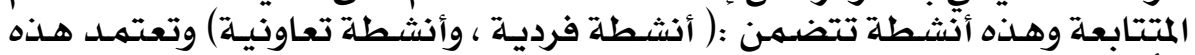

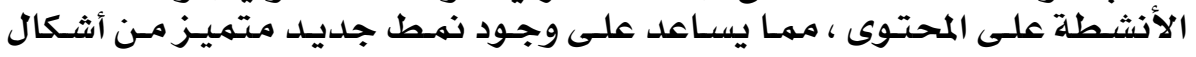

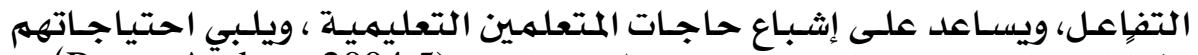

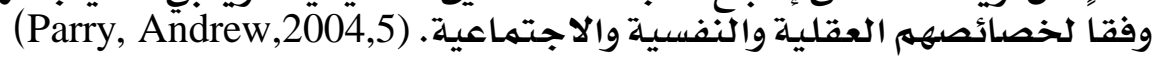

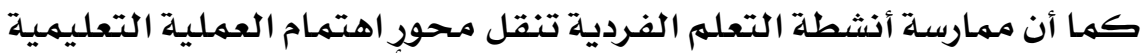

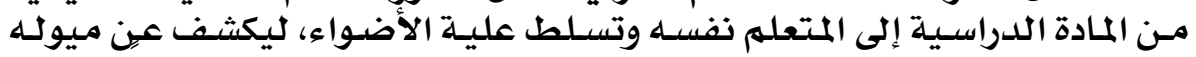

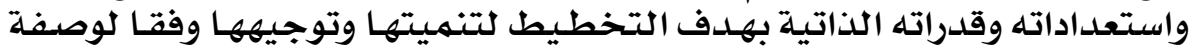

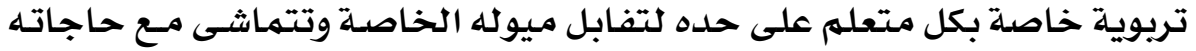

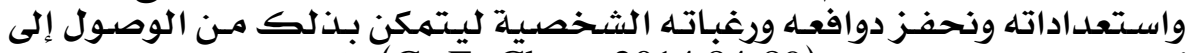

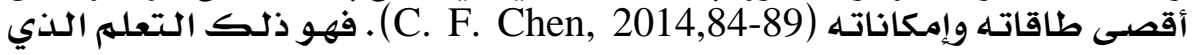

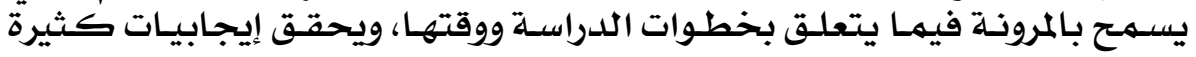

\section{$1 \cdot 9$}




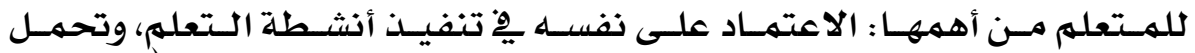

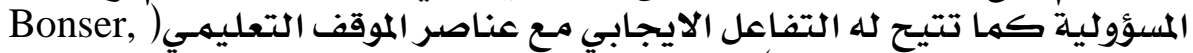

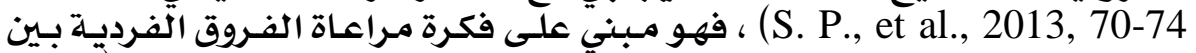

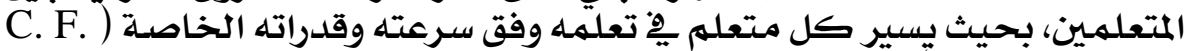

(Chen, 2014, 89

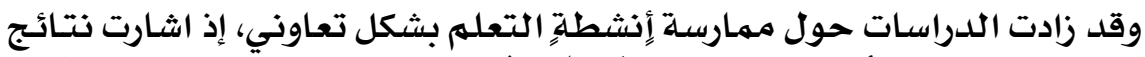

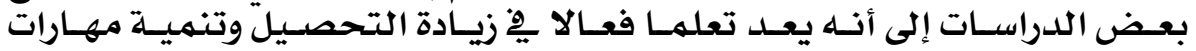

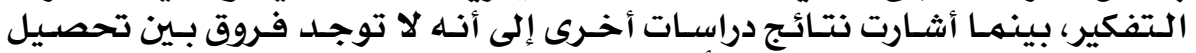

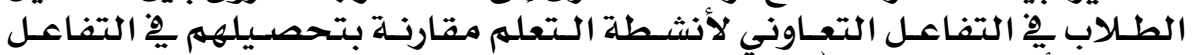

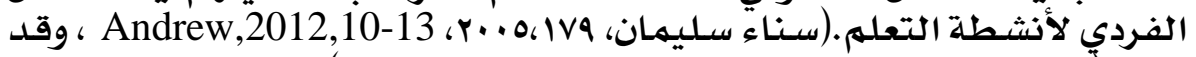

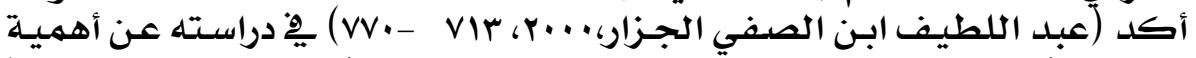

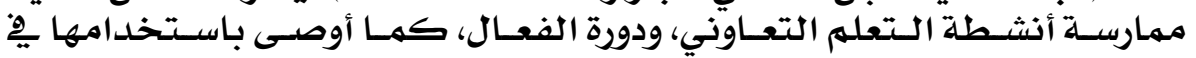

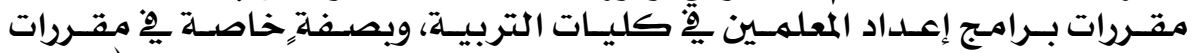

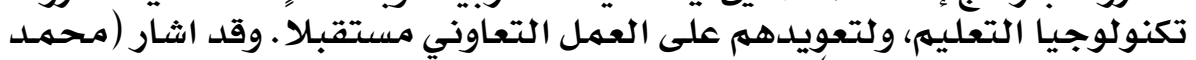

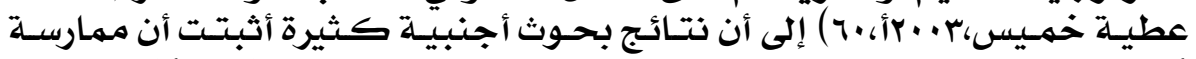

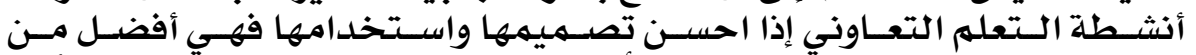

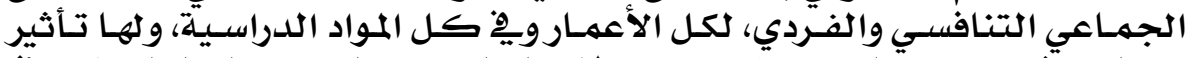

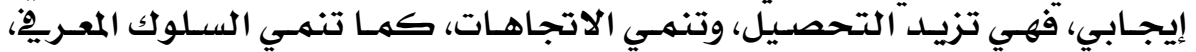

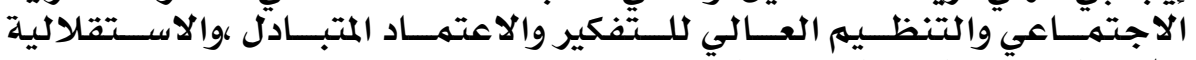
والابتكاريية، ومههارات التتقويهم الذاتخي.

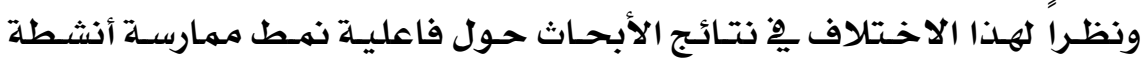

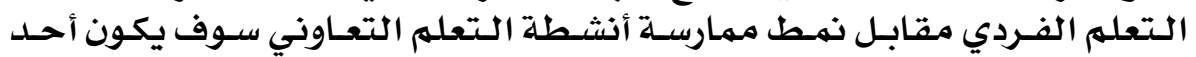

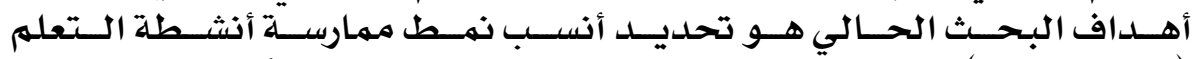

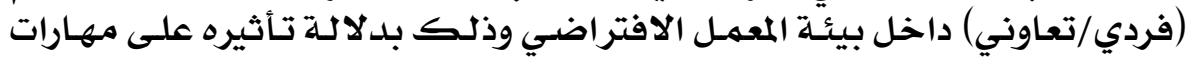
التفكير البصريري.

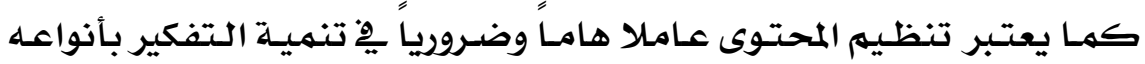

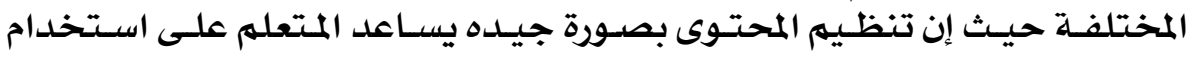

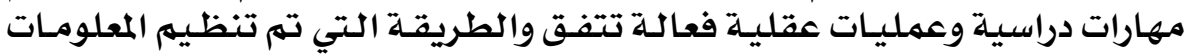

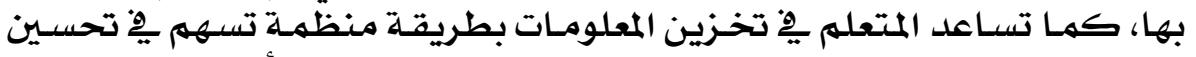

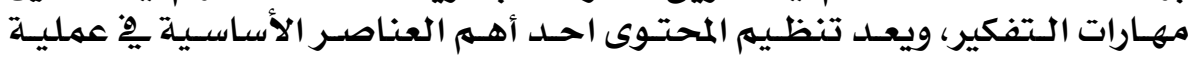

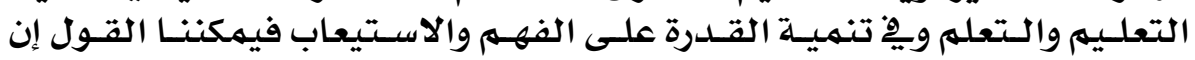

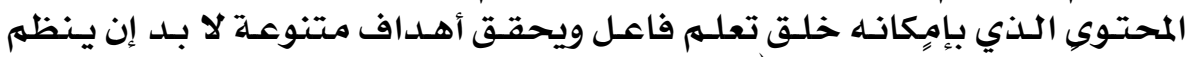

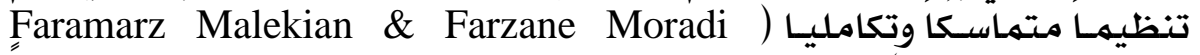

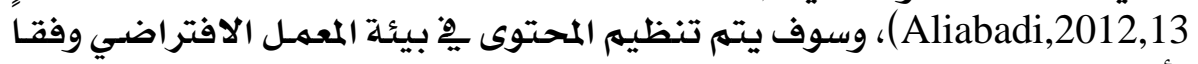
لأسلوبين التتظيم الهرهي والتتظيهم التوسعي.

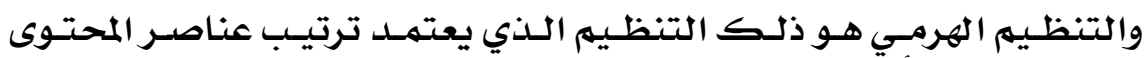

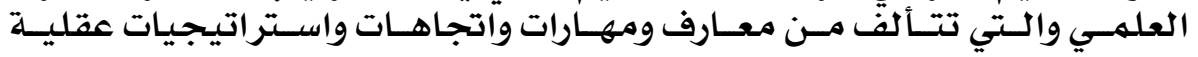

\section{1.}


ومتطلباتها الأساسية من الخاص إلى العام بهـا يؤدي بالمتعلهم تلدريجياً إلى المهمة

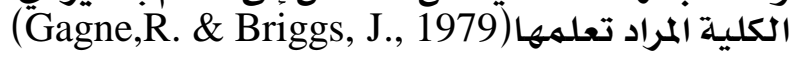

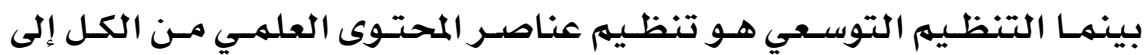

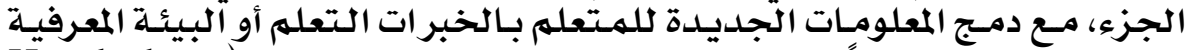

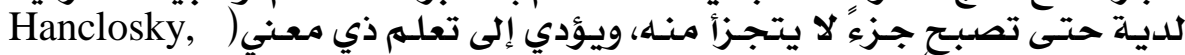
(W.V., 1986, 72

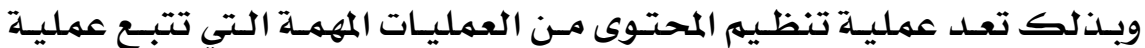

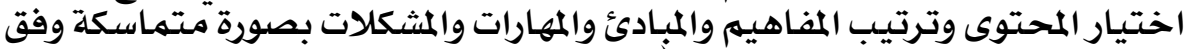

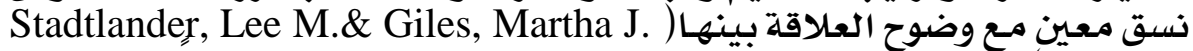

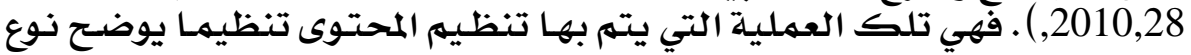

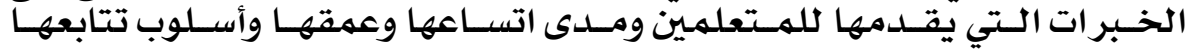

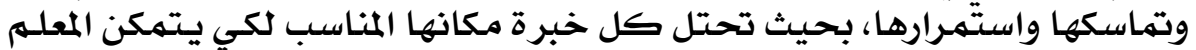

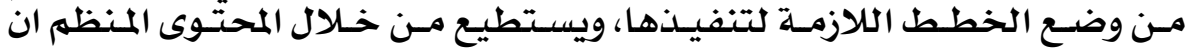

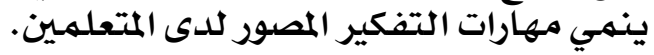

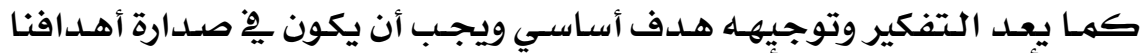

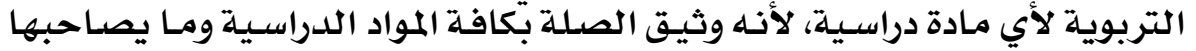

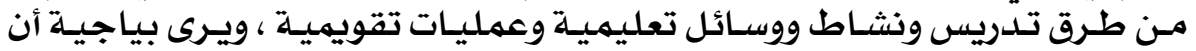

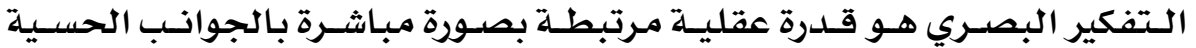

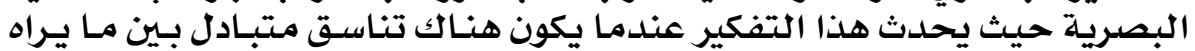

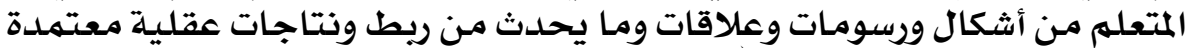

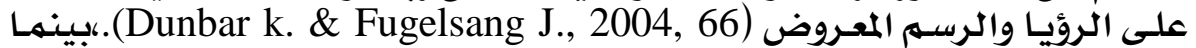

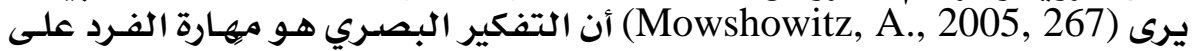

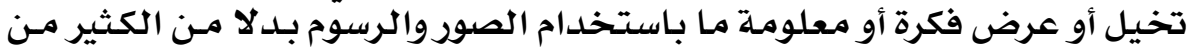

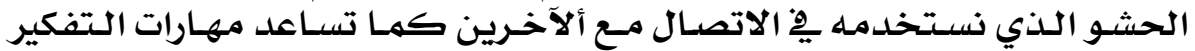

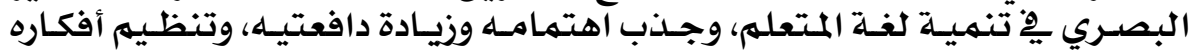

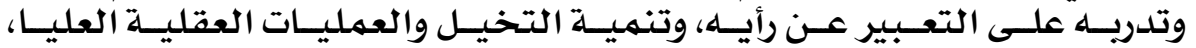

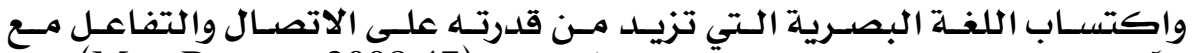

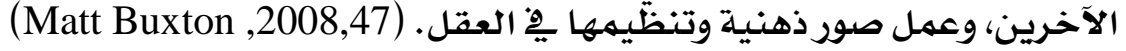

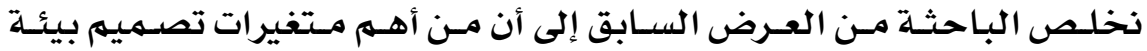

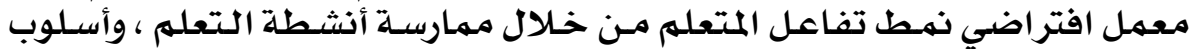

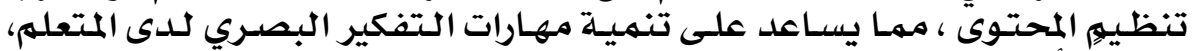

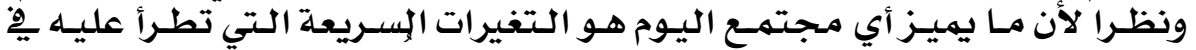

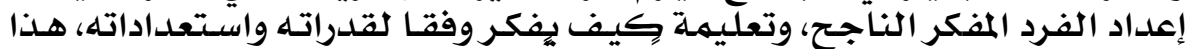

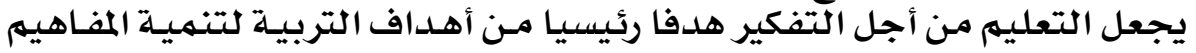

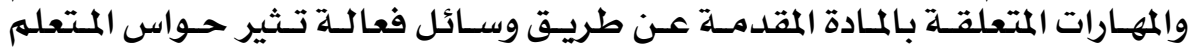

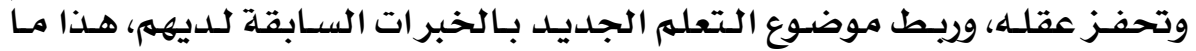

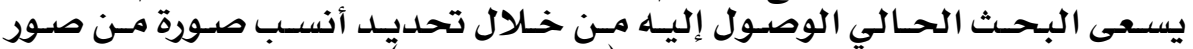

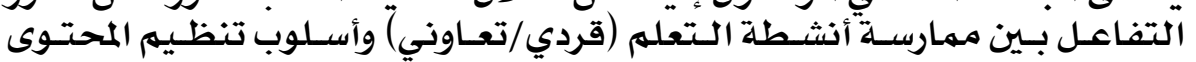

\section{1}


(هرمي/ توسعي) داخل بيئة المعمل الافتراضي وذلك بدلالة التأثير على مهارات

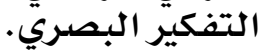

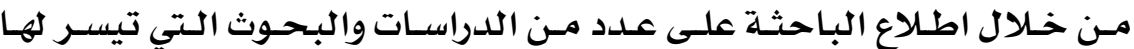

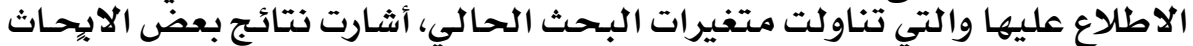

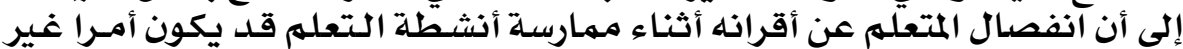

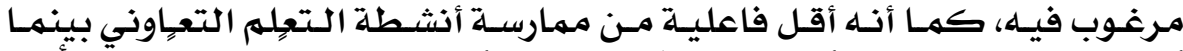

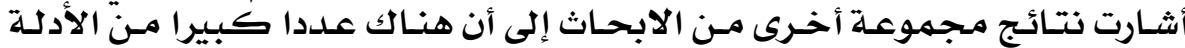

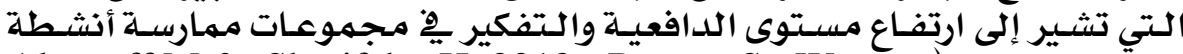

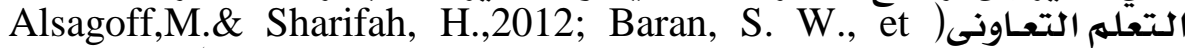
تباينة.al.,2010; Boling,N,Carol.,2011

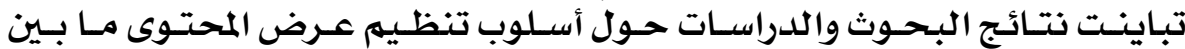

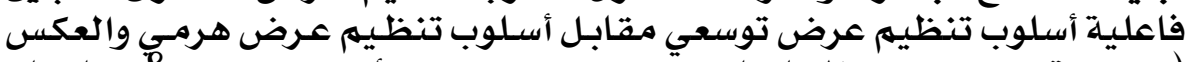

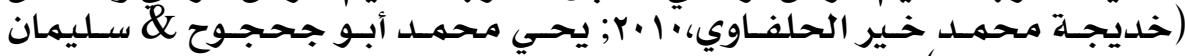

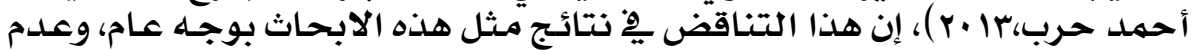

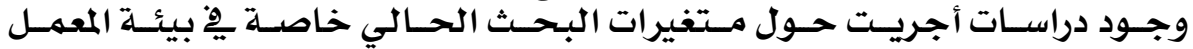

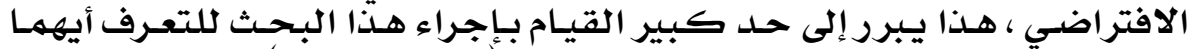

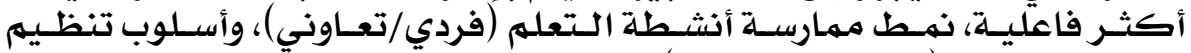

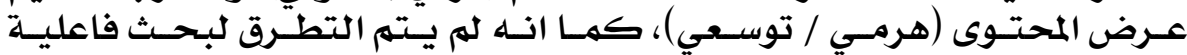

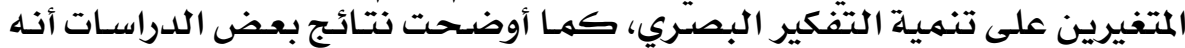

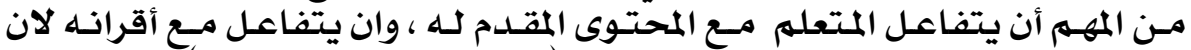
ذلك يؤدي إثى نتائج افضل لعملية التعلم (2012, Parry, Andrew).

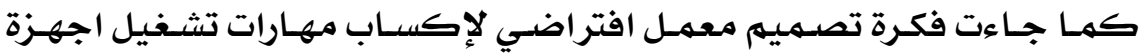

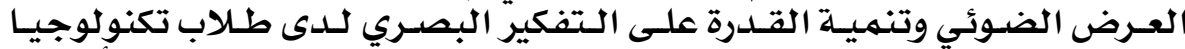

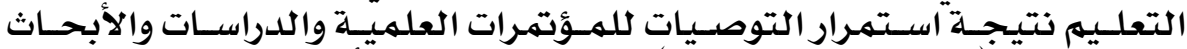

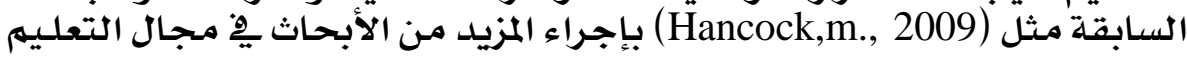

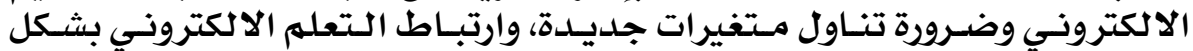
وثيق بالتفكير البصري.

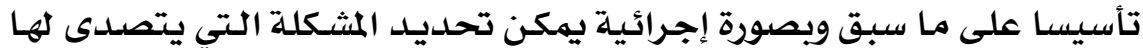

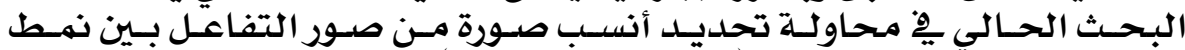

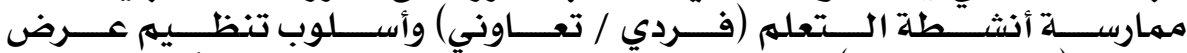

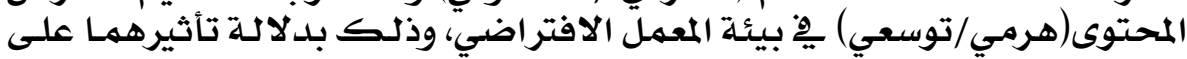

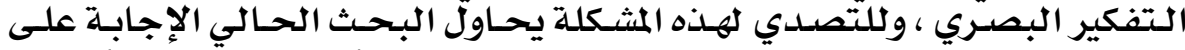

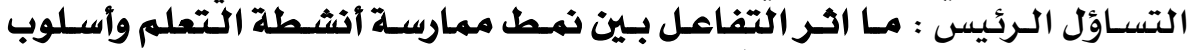

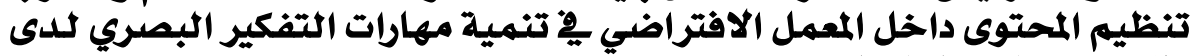

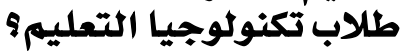
ويتفرع من هذار السؤال التساؤلات الفرعية التالية:

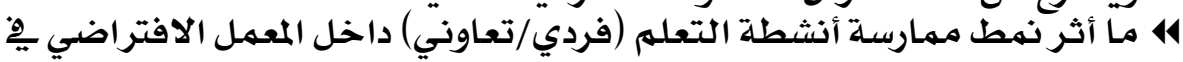

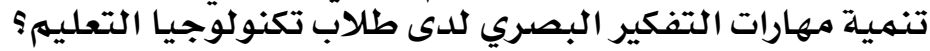

\section{IIY}




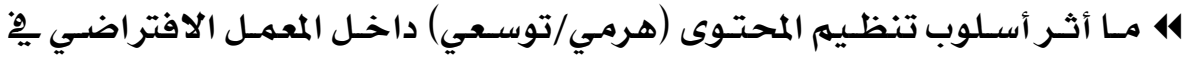

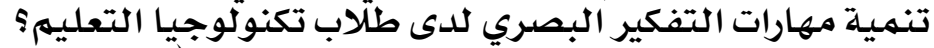

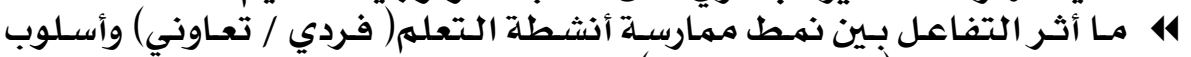

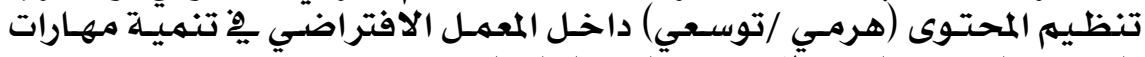

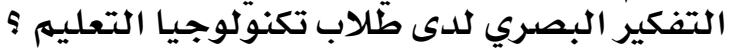

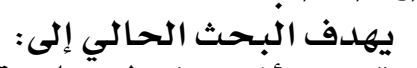

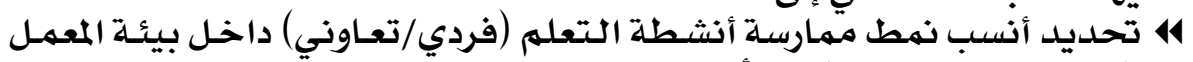

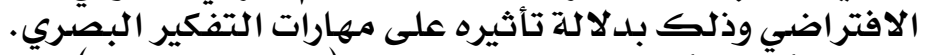

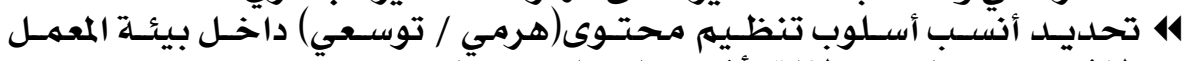

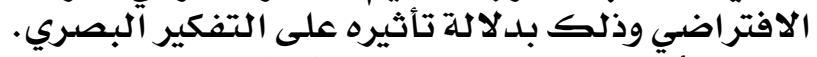

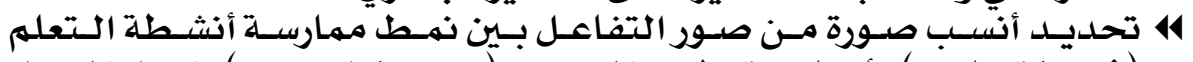

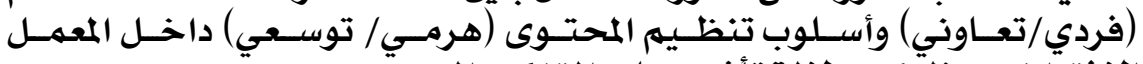

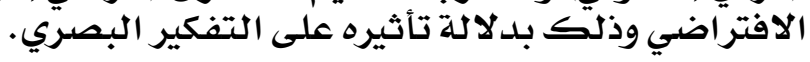

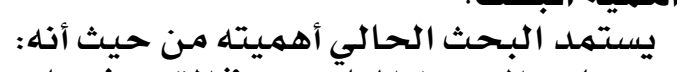

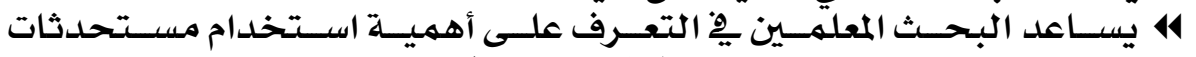

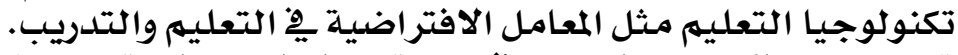

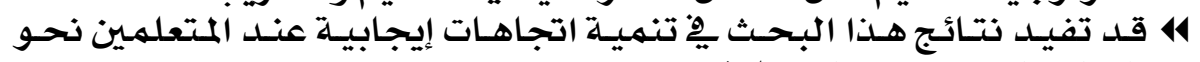

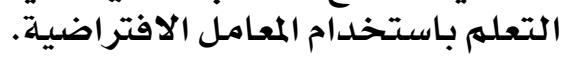

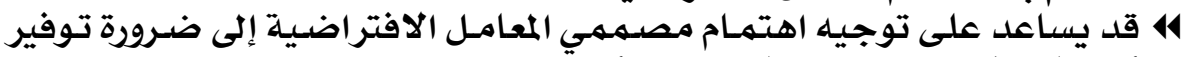

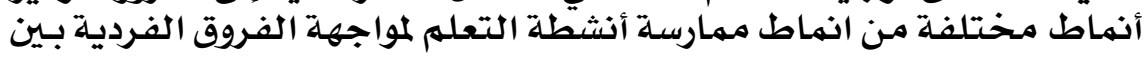
المتعلمـين.

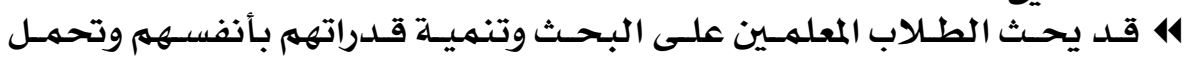

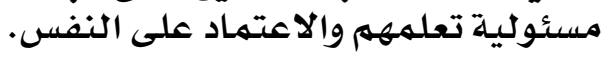

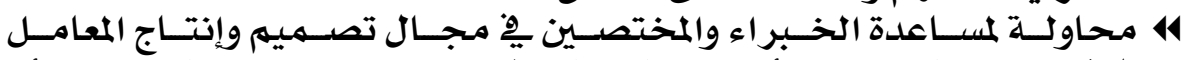

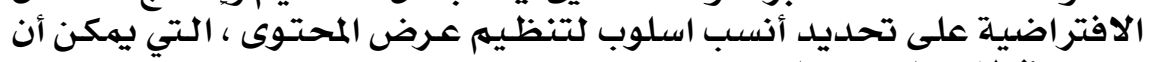

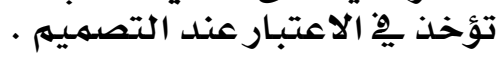

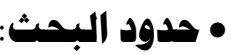

$$
\begin{aligned}
& \text { اقتصر البحثث الحالي على الحدلدود التالية: }
\end{aligned}
$$

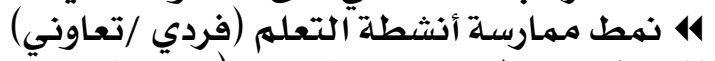

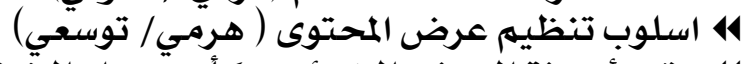

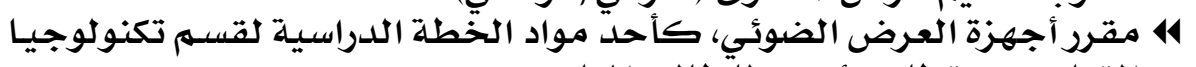

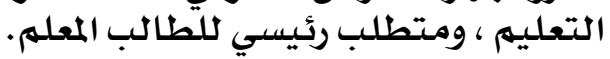

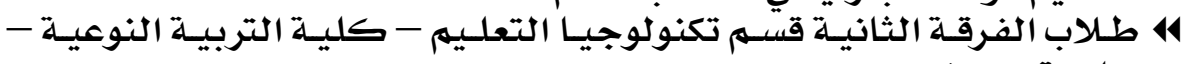
جامعة عين شمس.

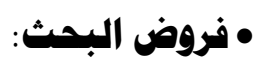
سعي البحثث الحالبي للتحقق من صحة الفروض التالية:

\section{$11 \mathrm{r}$}




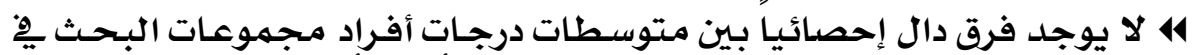

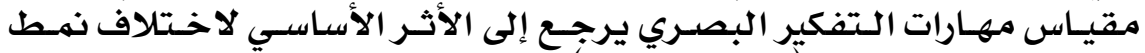

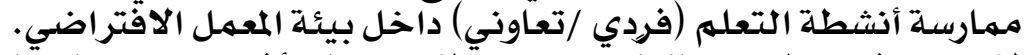
414

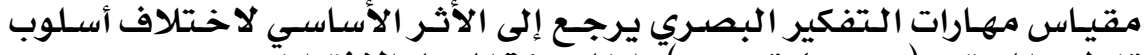

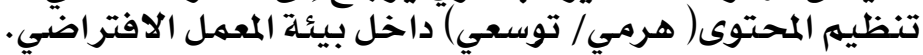

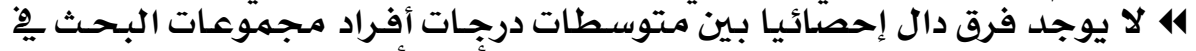

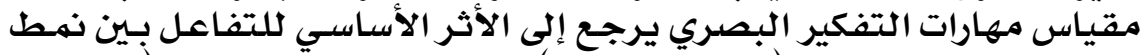

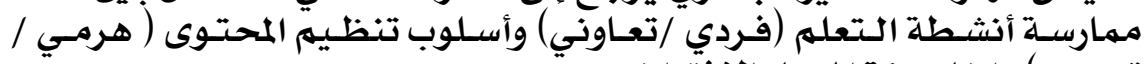

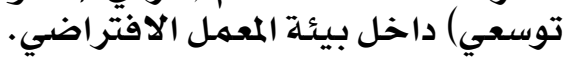

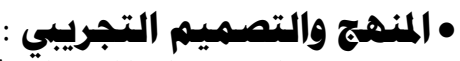

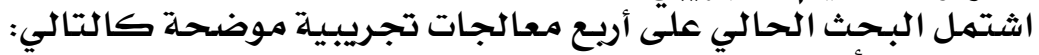

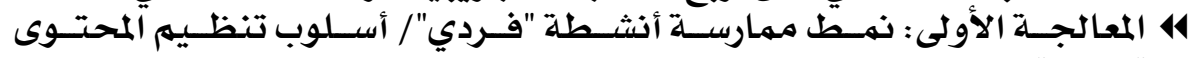

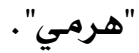
14 المعالجــة الثانيـة : نهـط مهمارســة أنثـطة "تعـاوني"/ أسـلوب تنظـيم المحتـوى

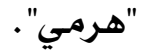

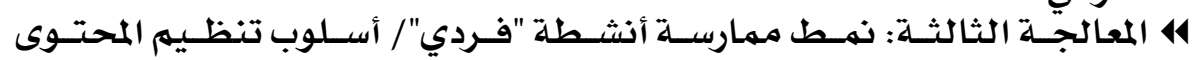

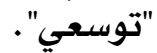

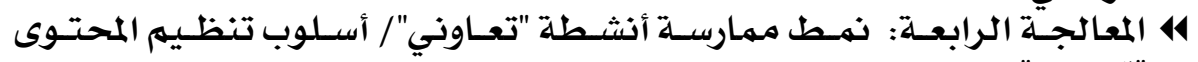
"توسعي". جلول (1) التصميم التجرييب) للبحث

\begin{tabular}{|c|c|c|}
\hline تعاون & & نمط ممارسة أنشطة \\
\hline لمعاوتي & صرتي & أسلوب تنظيم المحتوى \\
\hline مجموعة (r) & مجموعة (1) & هرمي \\
\hline مجموعة (ع) & مجموعة (r) & توسعى \\
\hline
\end{tabular}

وقد تم استخدام المنهج شبـه التجريبي يِّه البحث الحسالي للكثف عن العلاقة

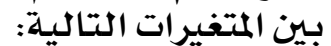

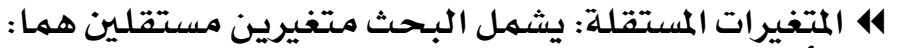

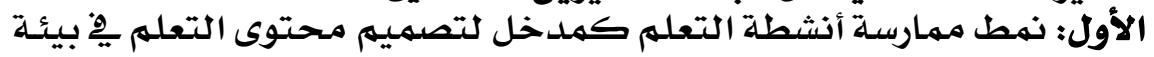

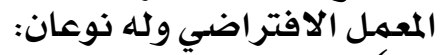
ل

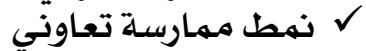

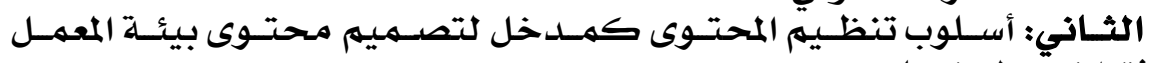

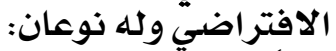
ل ل 41 أمتغيرات التتابعة: مهارات التفكير البصري

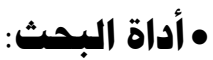
مقياس مهارات التفكير البصري

\section{$11 \varepsilon$}




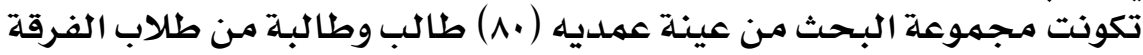

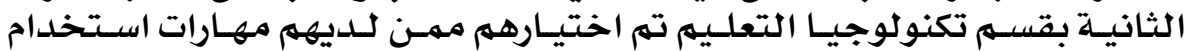

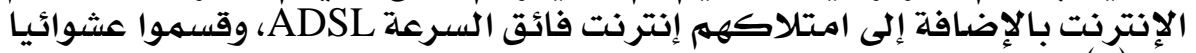

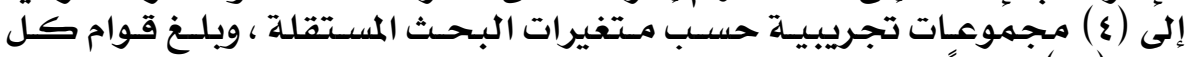

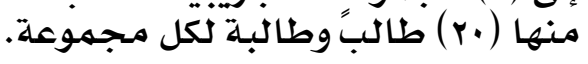

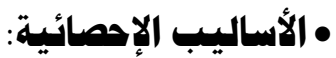

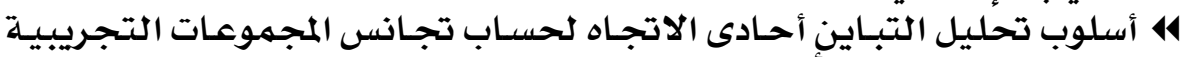

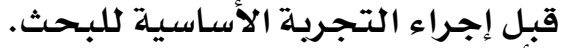

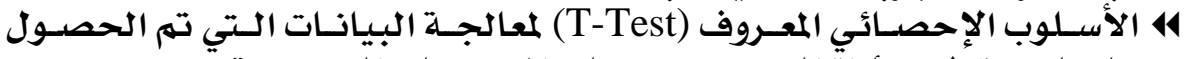

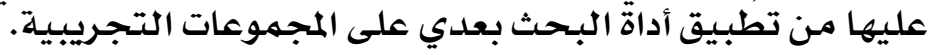

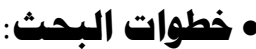

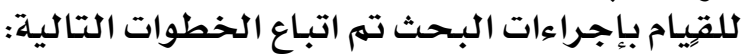

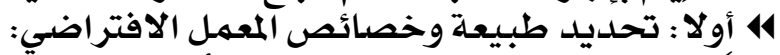

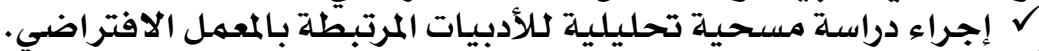

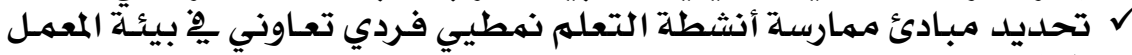
الافتراضي.

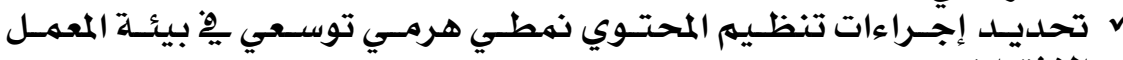
الافتراضي.

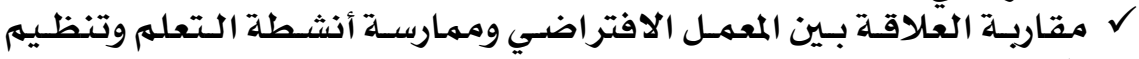

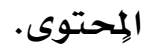

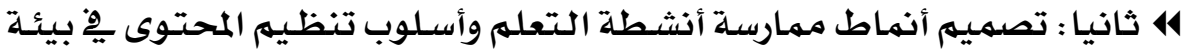

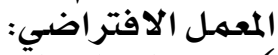

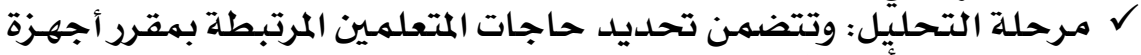

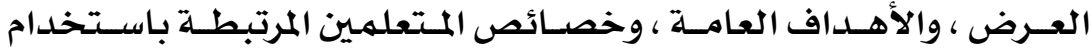

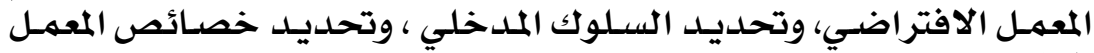

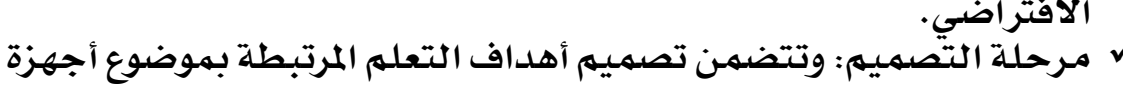

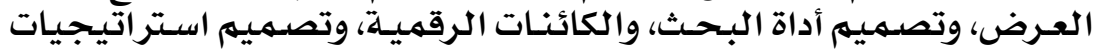

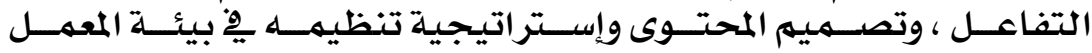

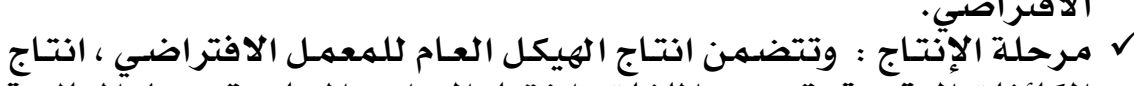

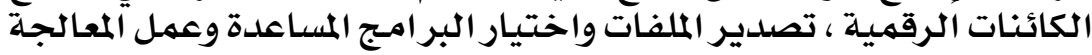
الرقرميـة.

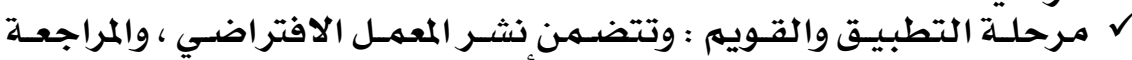

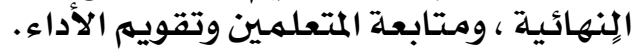

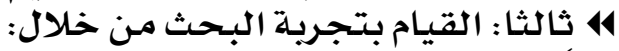

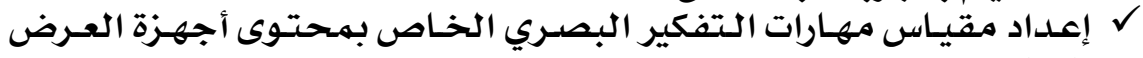
التعليمية اعلية

\section{0}


ل تحديد مجموعة البـحث وتقسيهمها إلى مهجموعات تجريبية عشوائية.

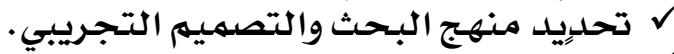

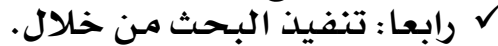

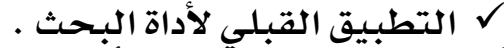

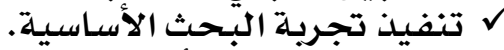

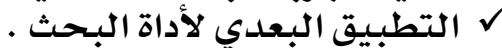

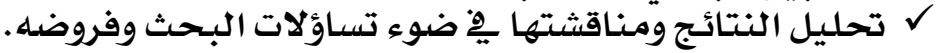

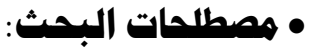

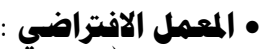

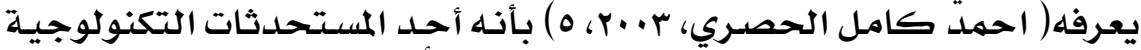

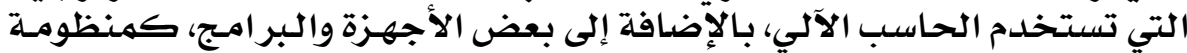

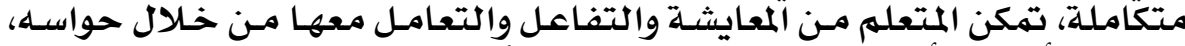

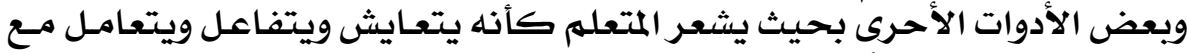
الواقع الحقيقي بكل أبعاده.

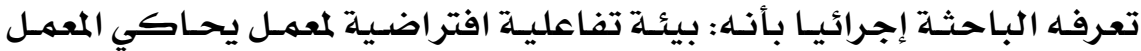

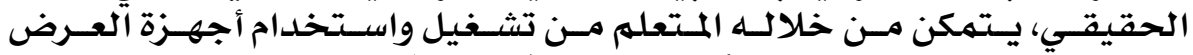

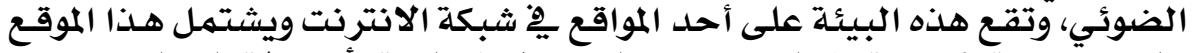

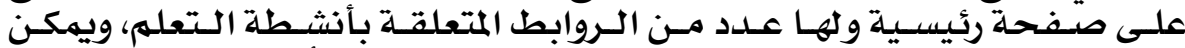

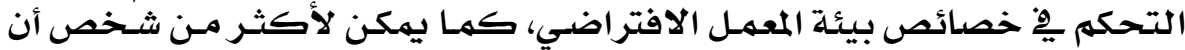

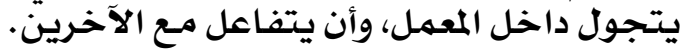

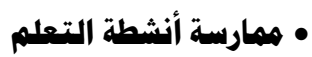

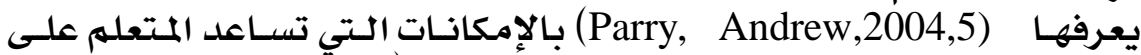

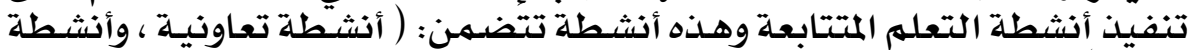

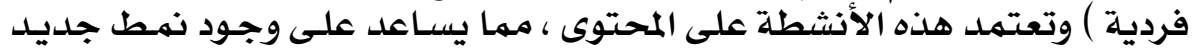

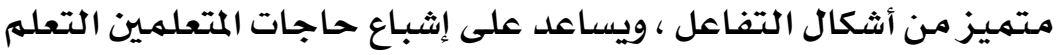

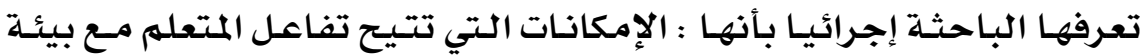

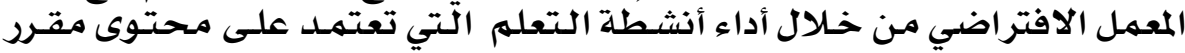

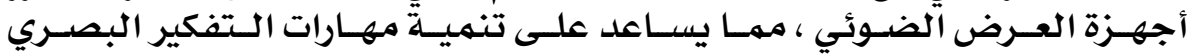

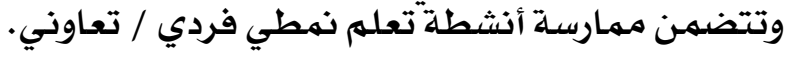

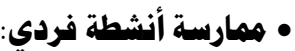

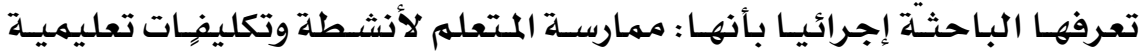

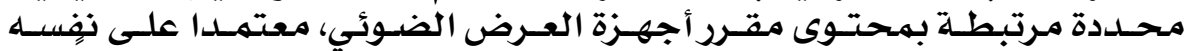

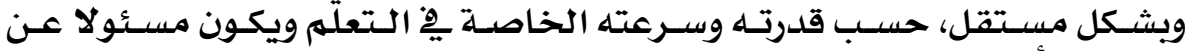

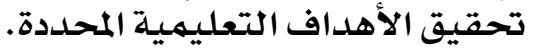

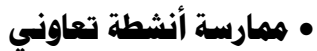

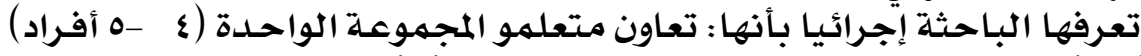

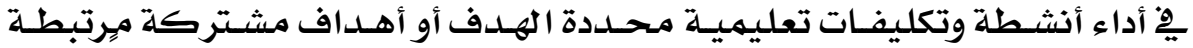

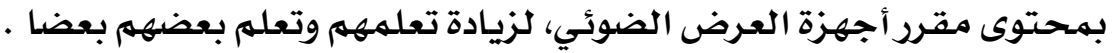

\section{7}




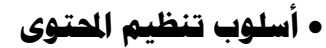

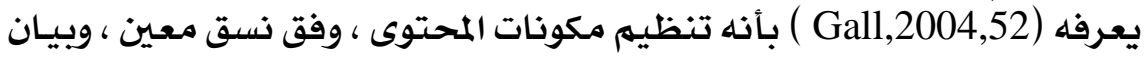

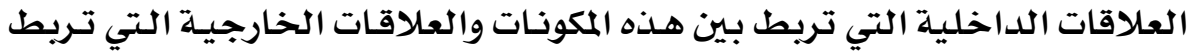
هذا المحتوى بهوضوعات التهات أخرى .

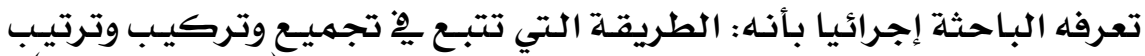

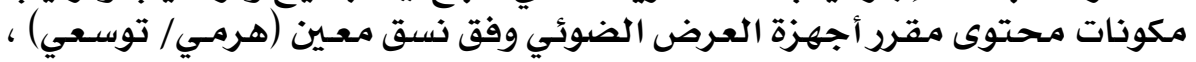

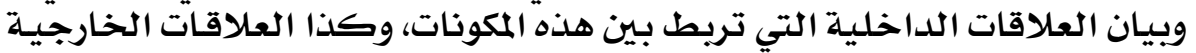

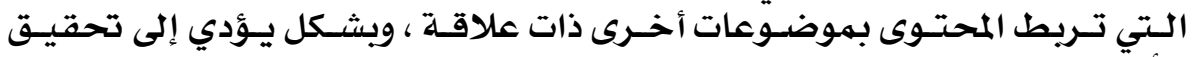

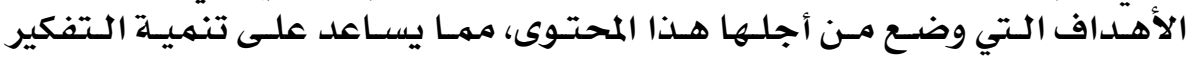
البصري.

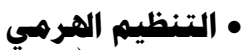

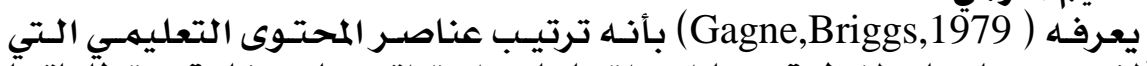

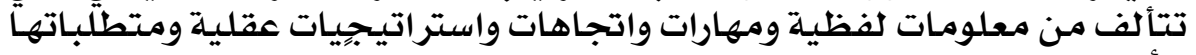

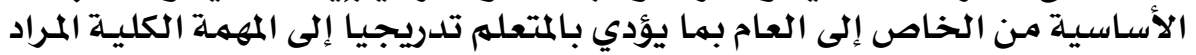

تعلمها الهيا

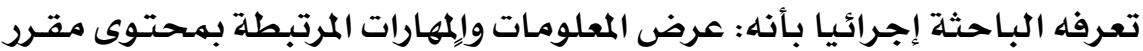

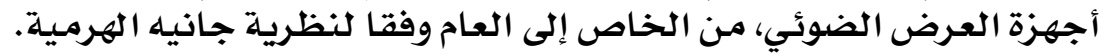

• التنظيم التوسعي:

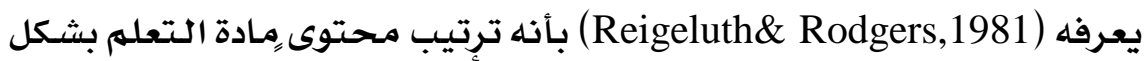

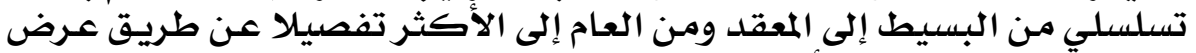

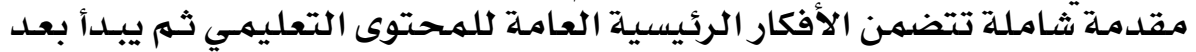

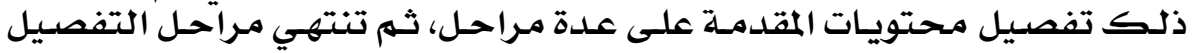

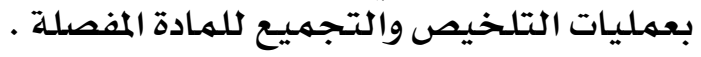

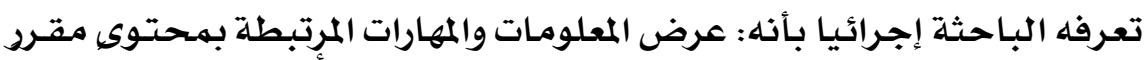

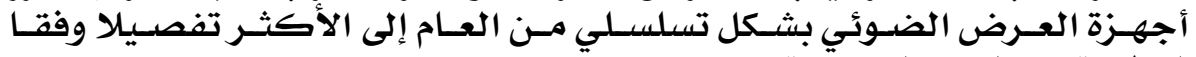
لنظريـة رايجلوس العرفس التوسعيـية.

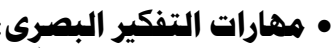

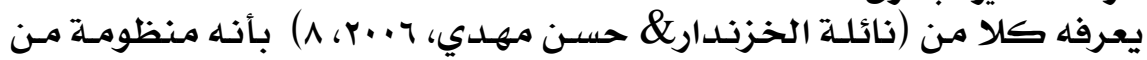

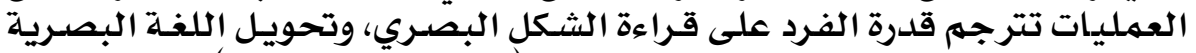

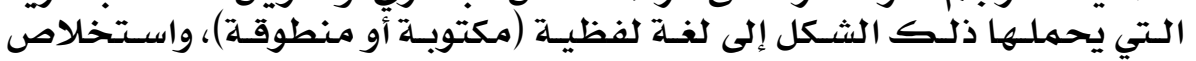

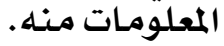

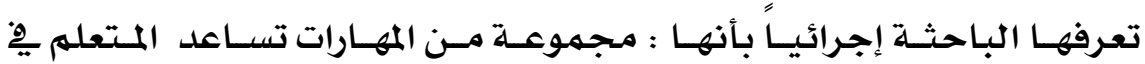

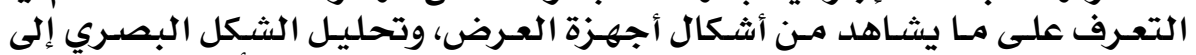

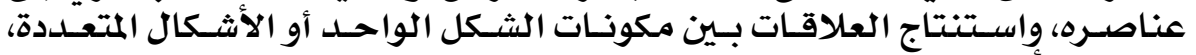

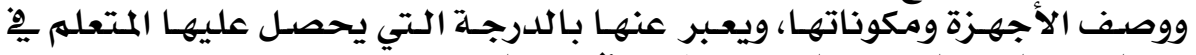

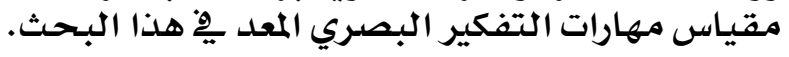

\section{$11 \mathrm{~V}$}




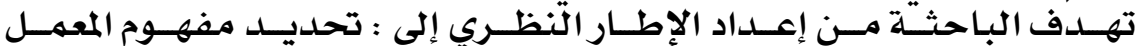

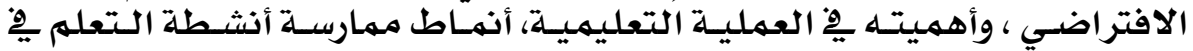

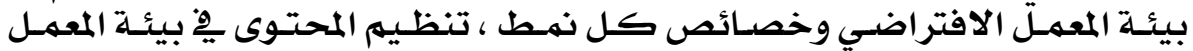

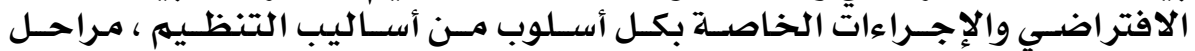

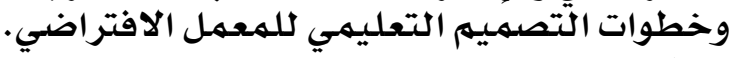

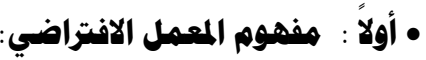

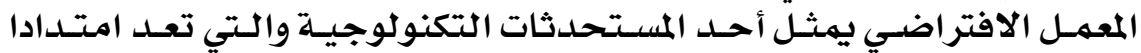

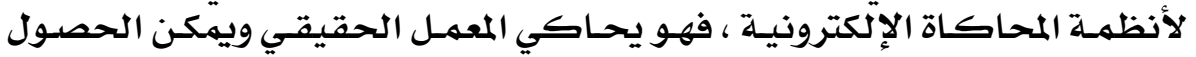

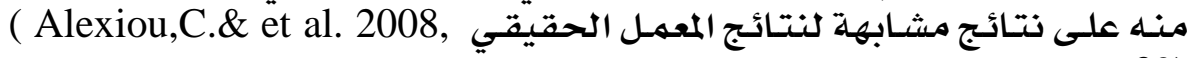

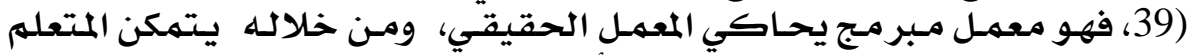

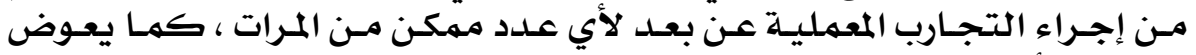

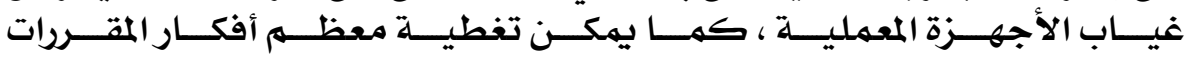

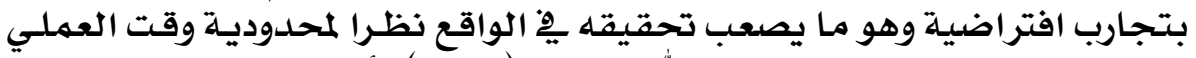

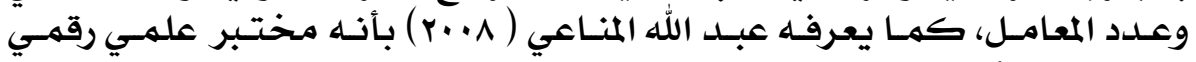

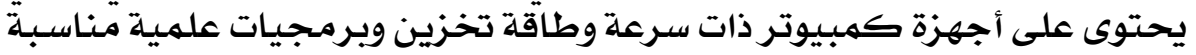

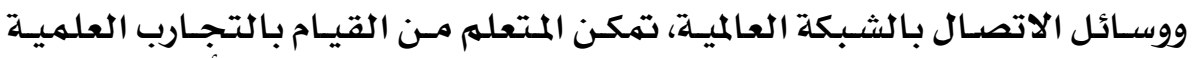

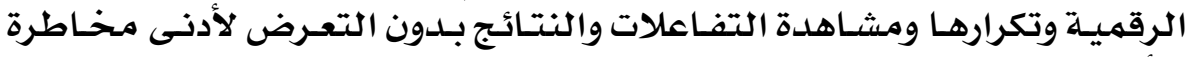

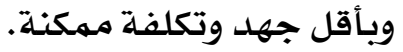

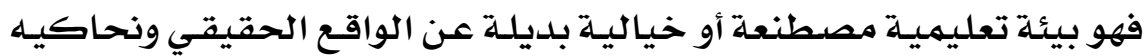

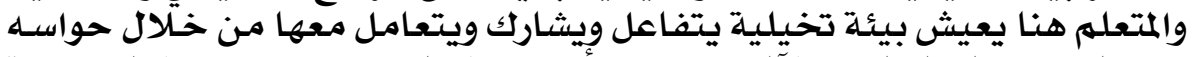

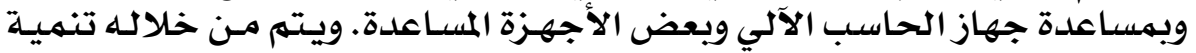

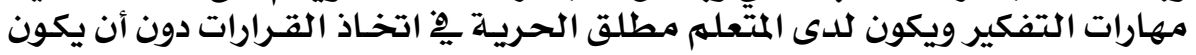

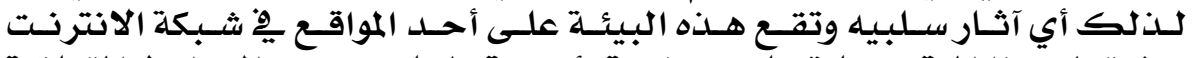

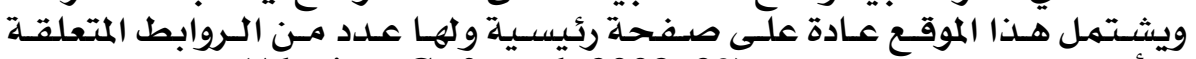
بالأنشطة المعملية وتقويهمها. (Alexiou, C. \& et al. 2008, 39)

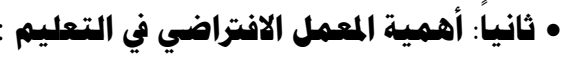

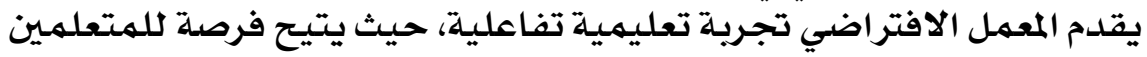

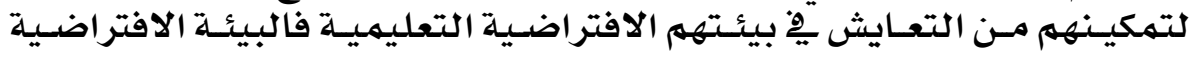

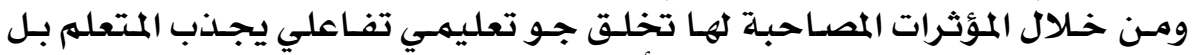

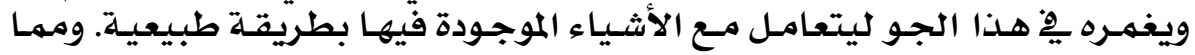

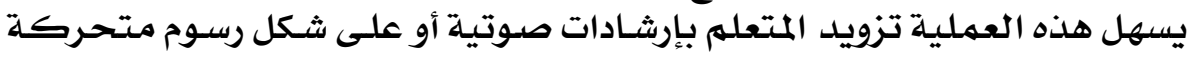

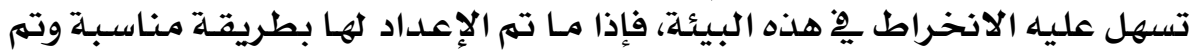

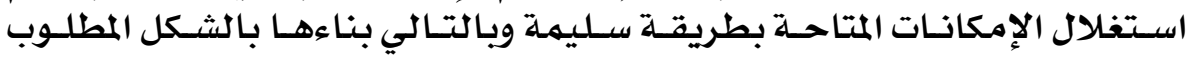

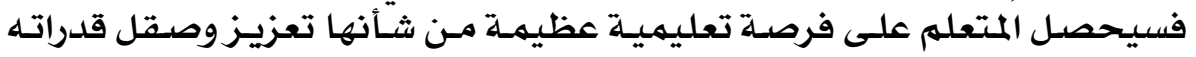

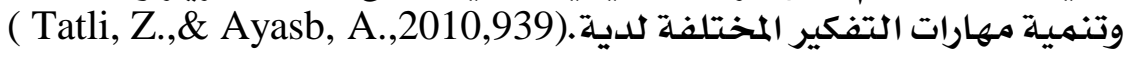

\section{1}




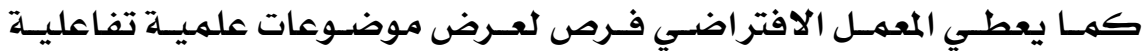

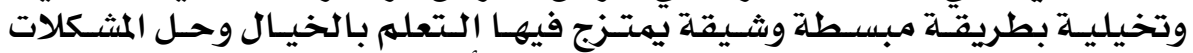

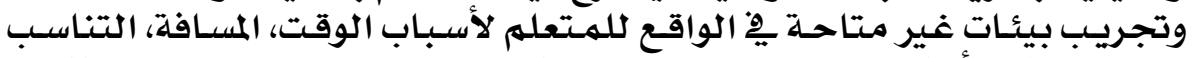

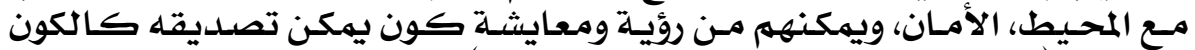

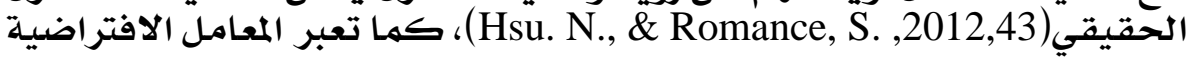

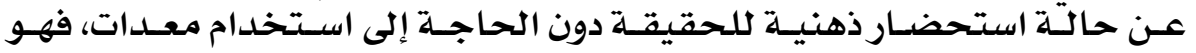

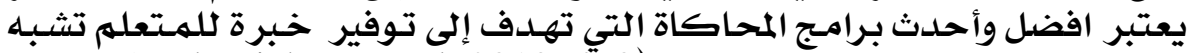

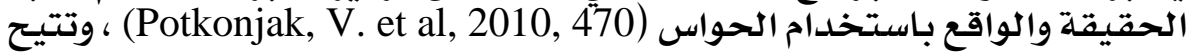

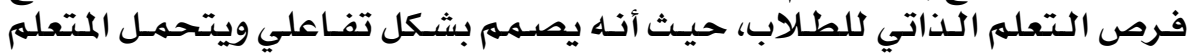

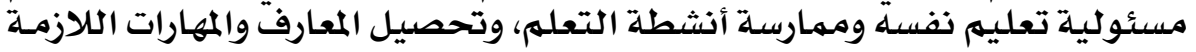

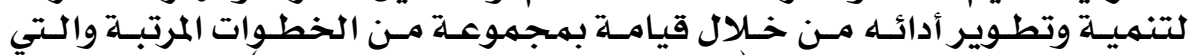

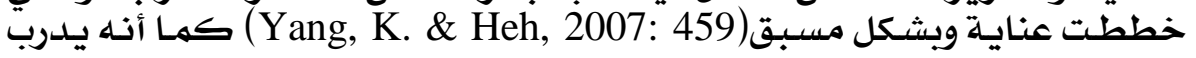

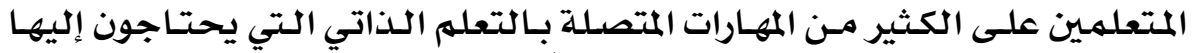

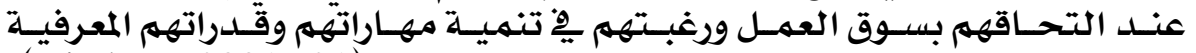

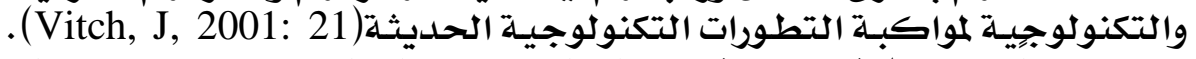

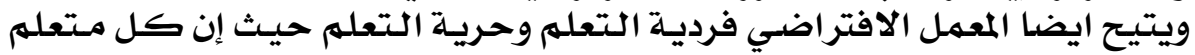

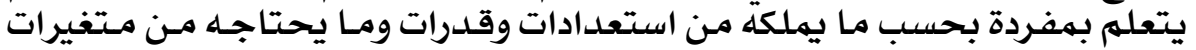

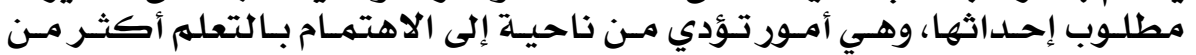

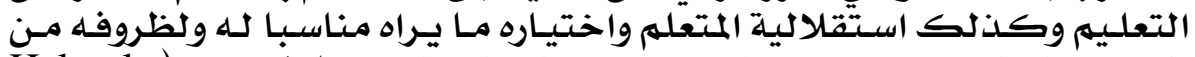

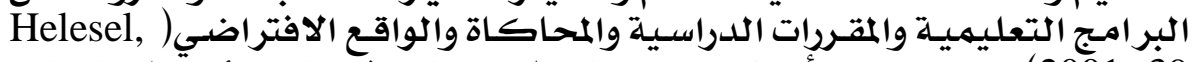
و 39

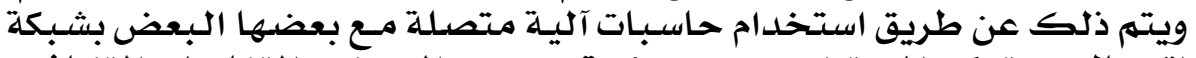

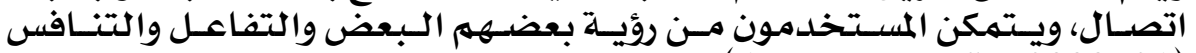

(Anonymous, S. , 2000: 21)

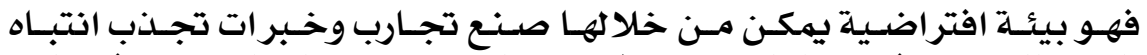

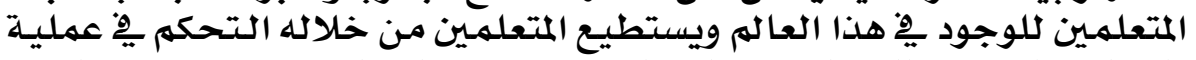

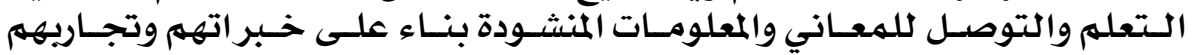

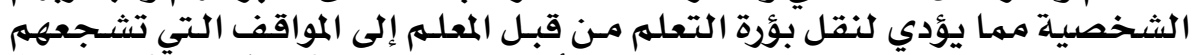

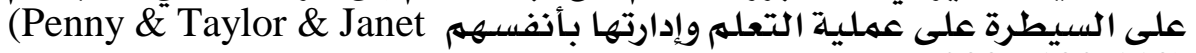

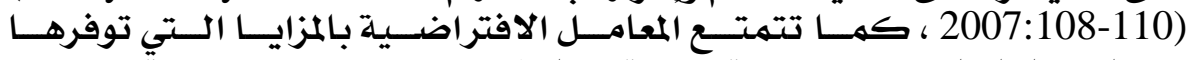

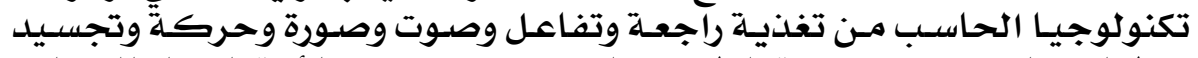

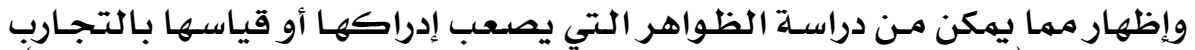

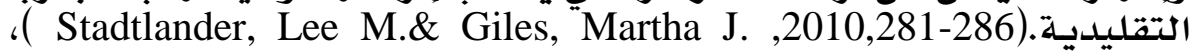

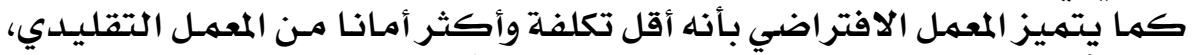

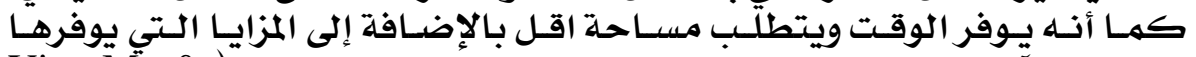

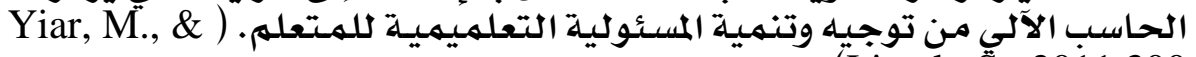
(Litvak, S. ,2011,300

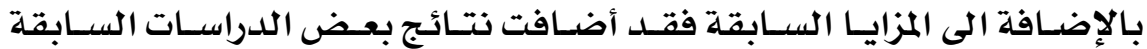
Carnevale, D.,2001; Cengiz Tuysuz, 2010; Dalgarno, B., et al.,2009; ) 
مزايـا أخرى مترتبـة على (James，J.,2011; Maldarelli， G., et al.,2009)

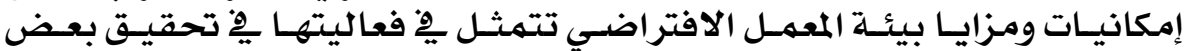

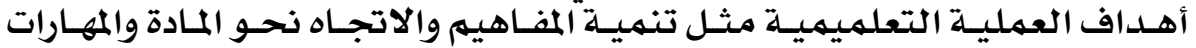

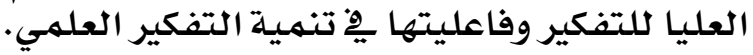

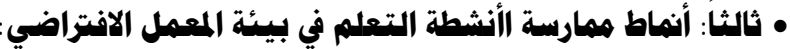

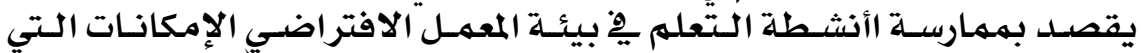

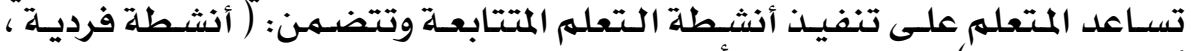

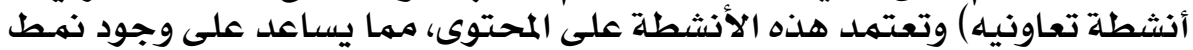

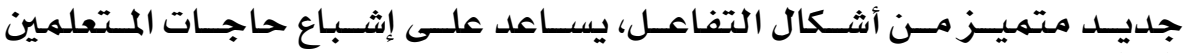
التعلميمية .

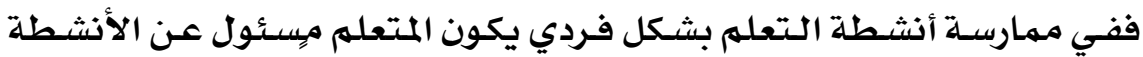

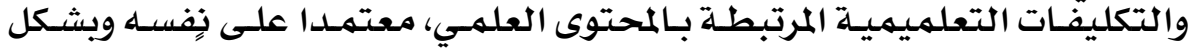

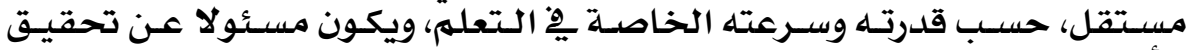

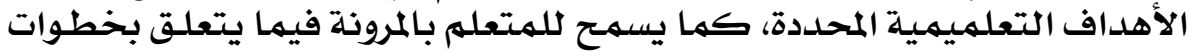

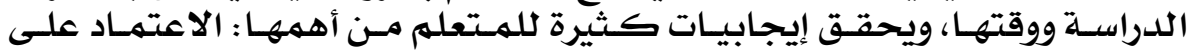

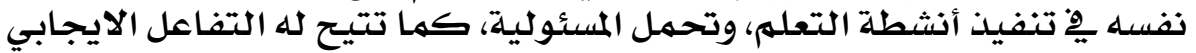

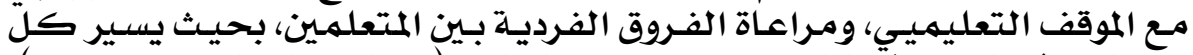

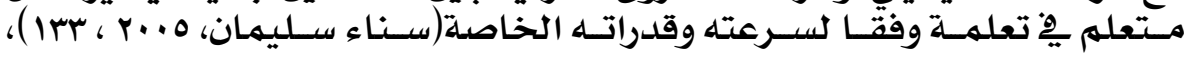

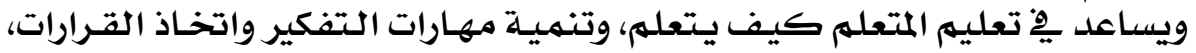

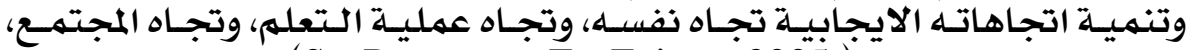

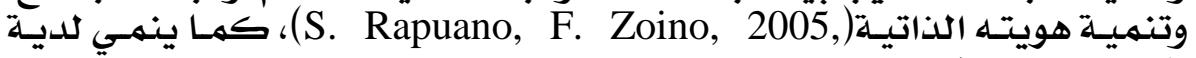

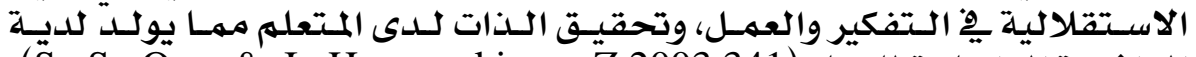

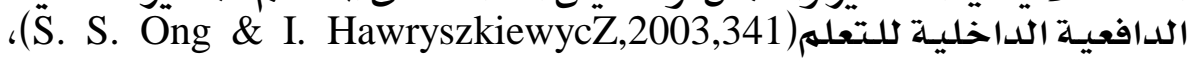

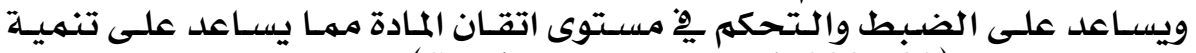
مهارات التفكير.(Sergio Rapuano, et al.,2006,32).

• • مبادئ همارسة أنشطة التعلم فردياً في المعهل الافتراضي :

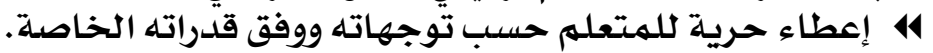

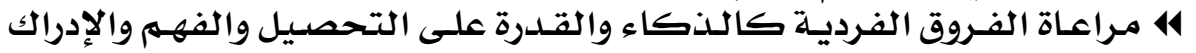

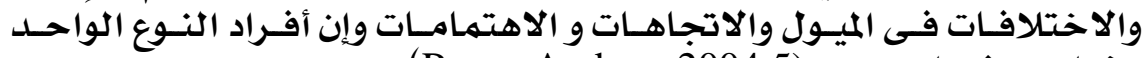

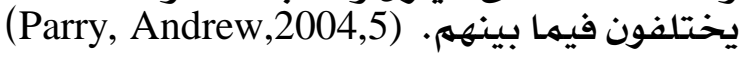

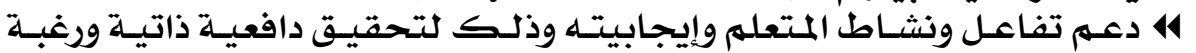

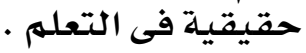

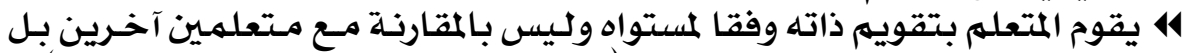

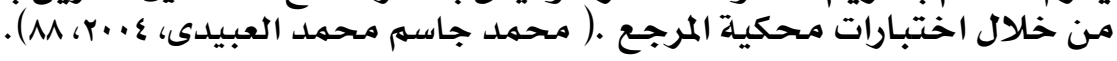

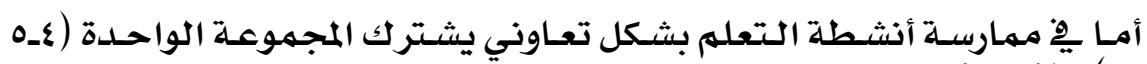

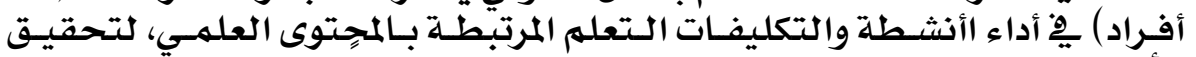

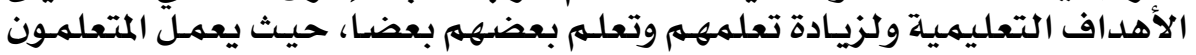

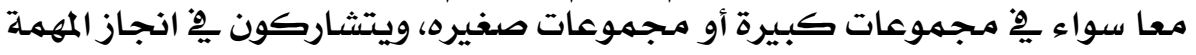

\section{IY.}




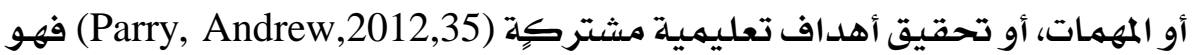

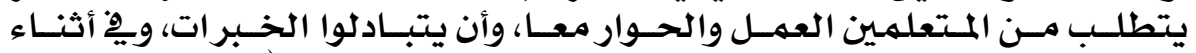

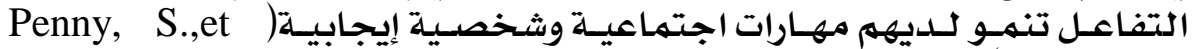

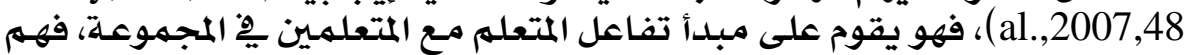

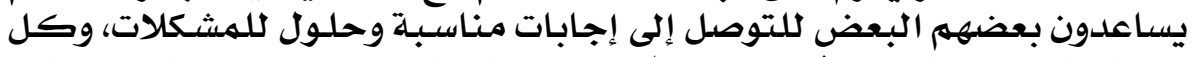

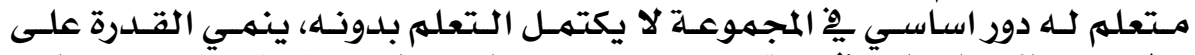

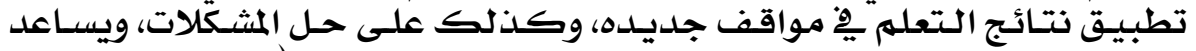

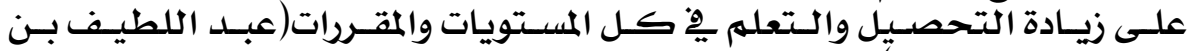

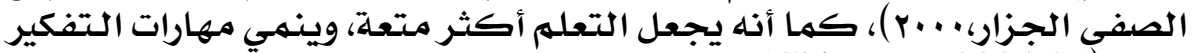

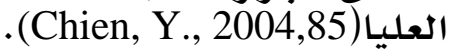

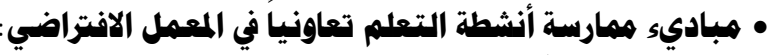

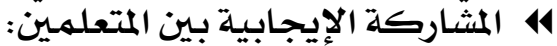

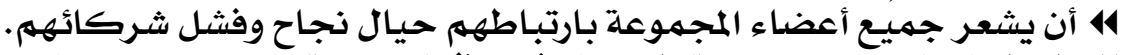

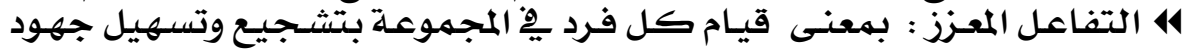

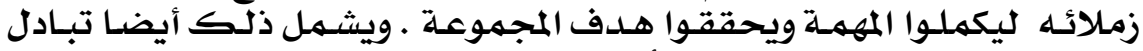

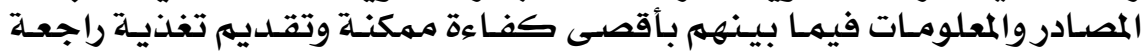

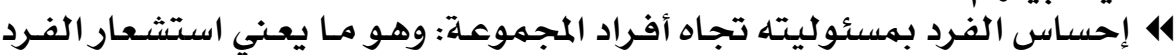

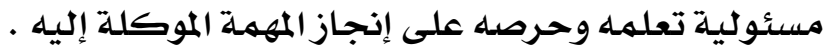

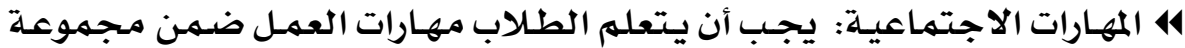

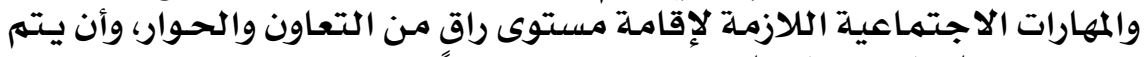

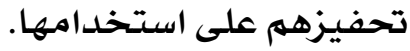

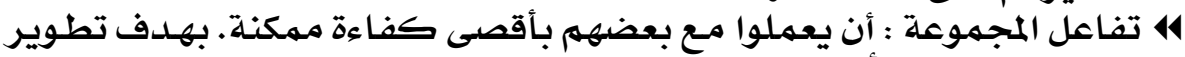

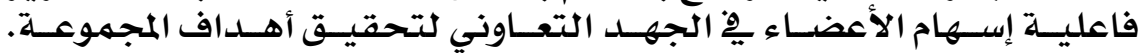
(Alsagoff,M.\& Sharifah, H. , 2012,23-28)

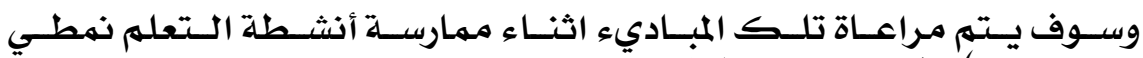

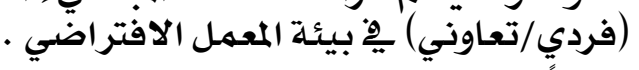

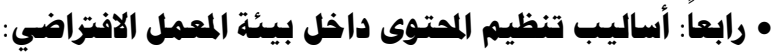

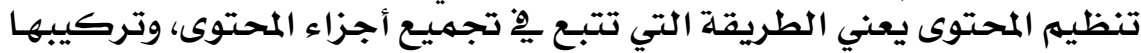

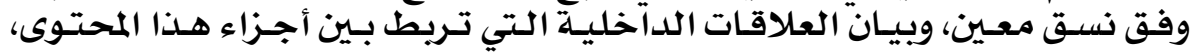

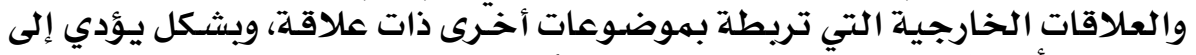

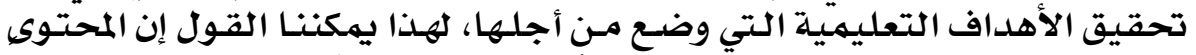

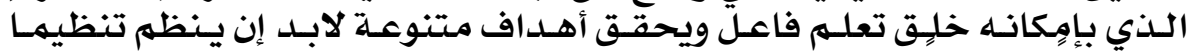

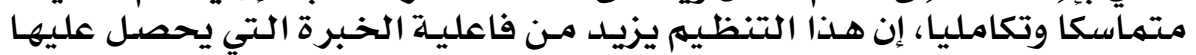

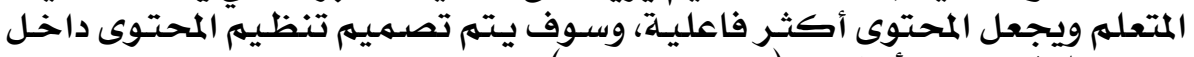

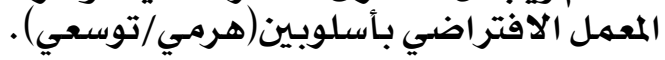

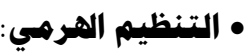

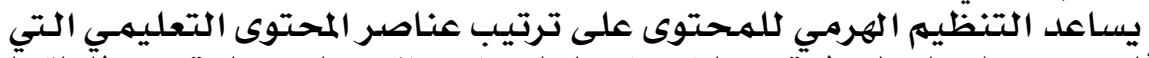

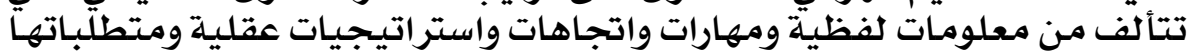

\section{$|Y|$}




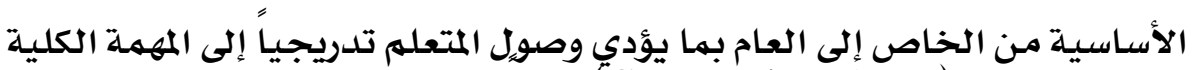

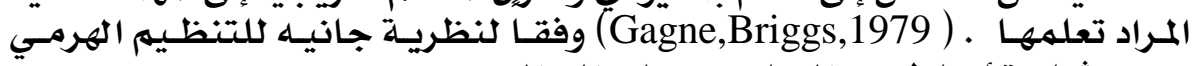

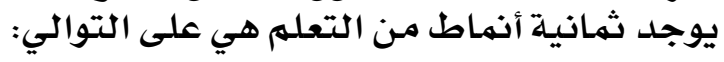

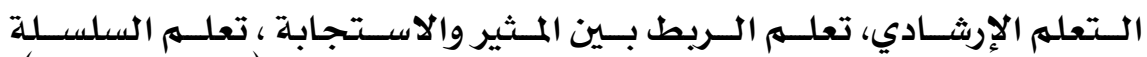

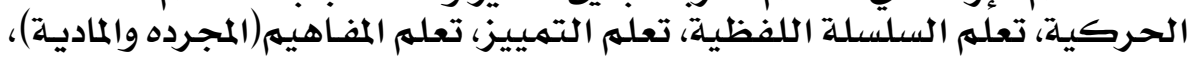

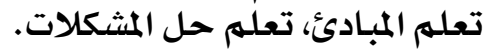

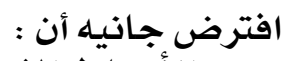

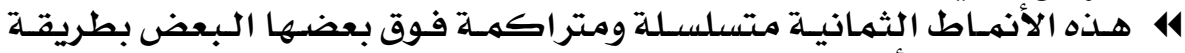

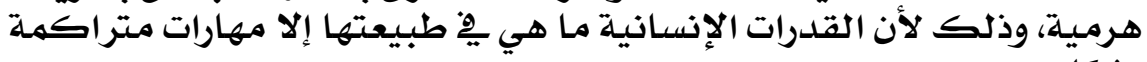

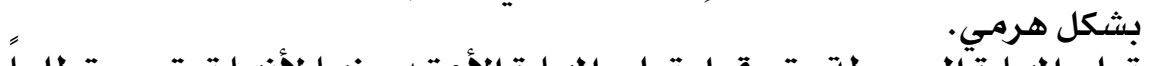

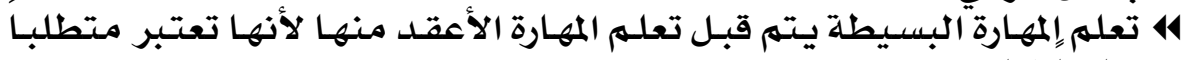
سابقا لهابا نهارة

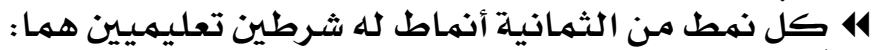

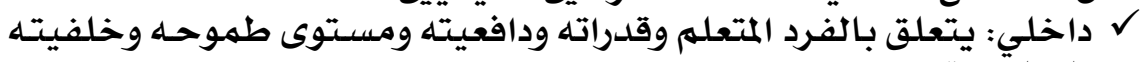
التعليتيمية.

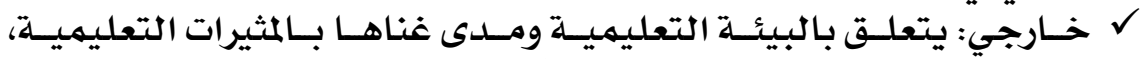

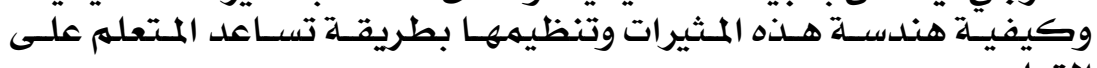
التعلمه.

• المهمات الإجرائية لتنظيم الحتوى الهرهي دائهي داخل بيئة المعهل الافتزاضي:

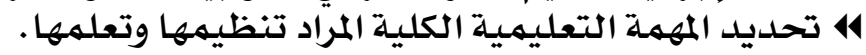

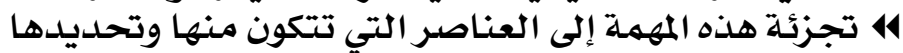

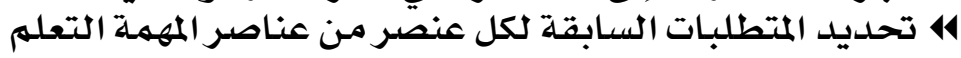

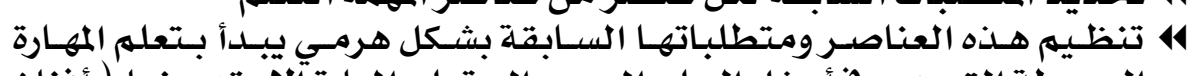

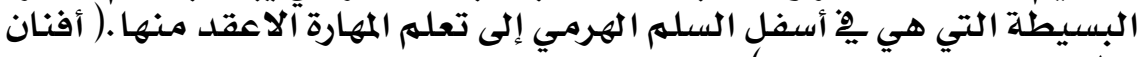

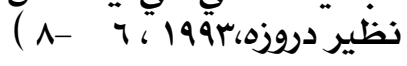

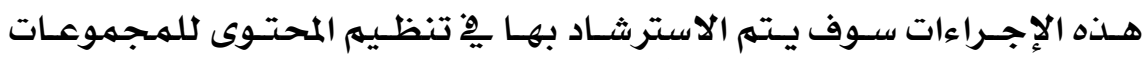

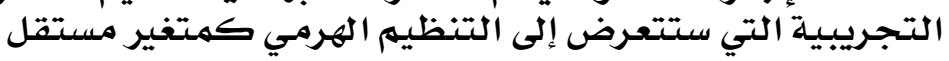

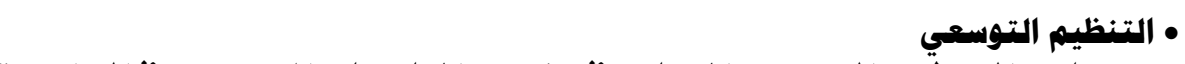

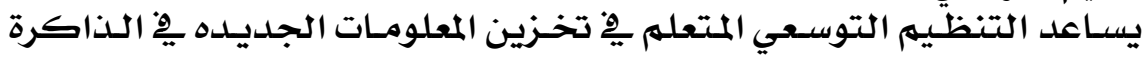

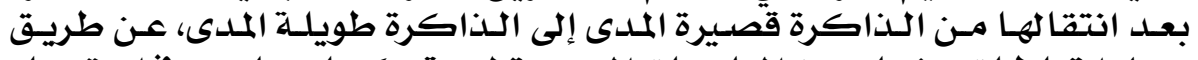

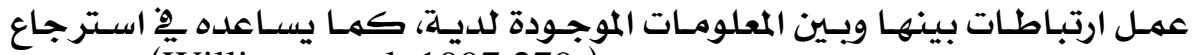

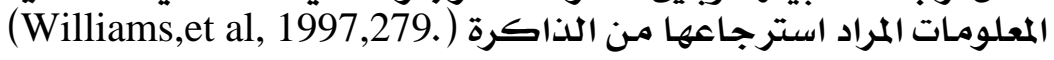

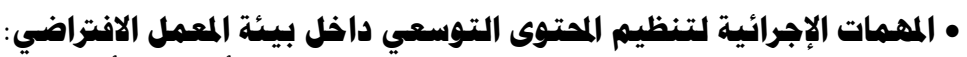

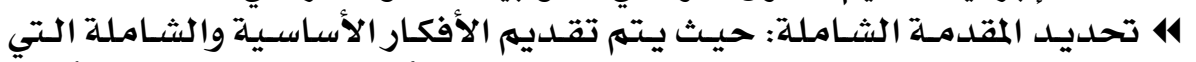

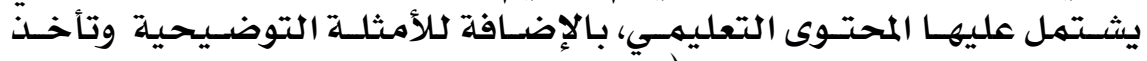

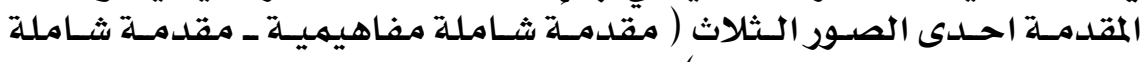

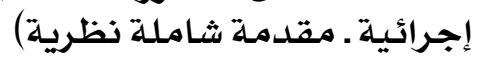

\section{IYY}




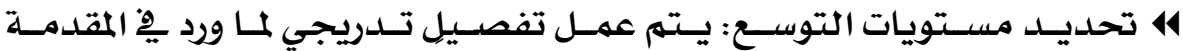

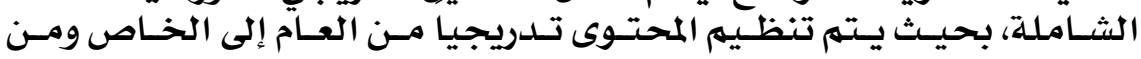

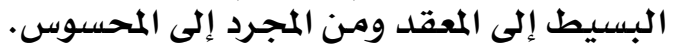

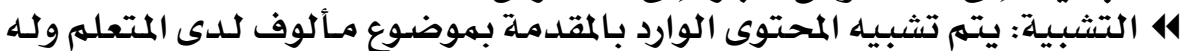

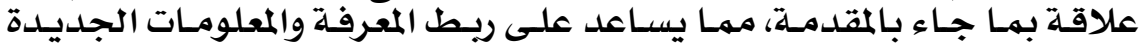

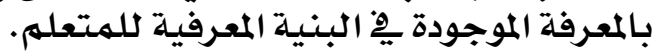

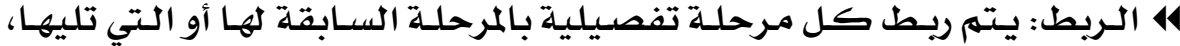

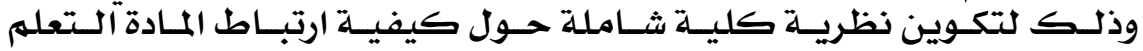

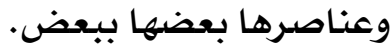

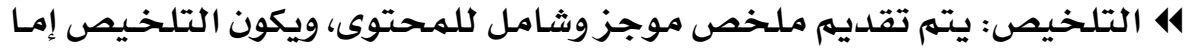

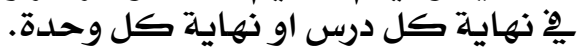
414

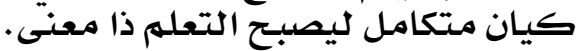

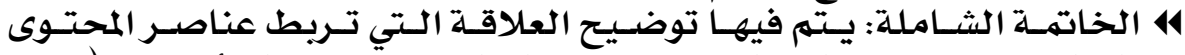

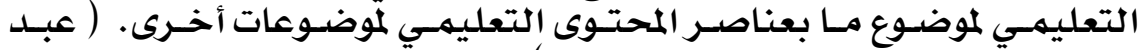

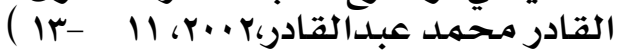

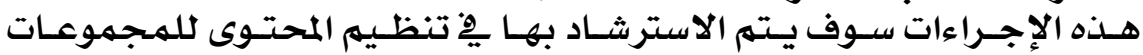

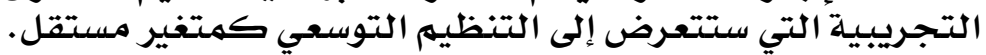

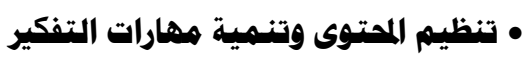

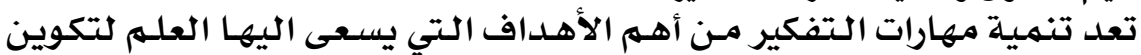

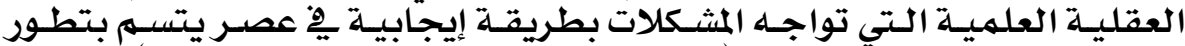

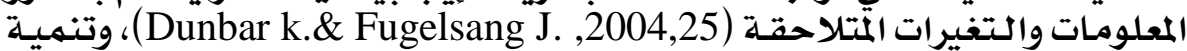

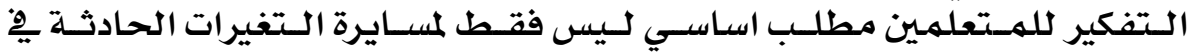

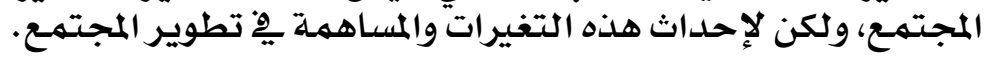

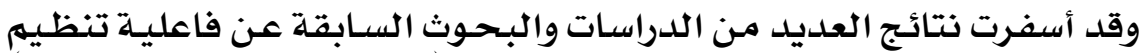

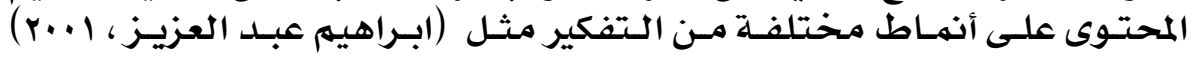

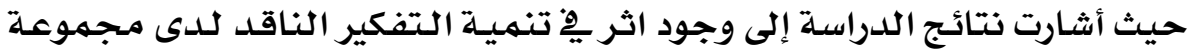

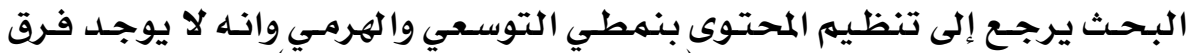

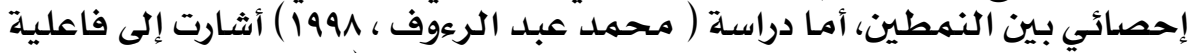

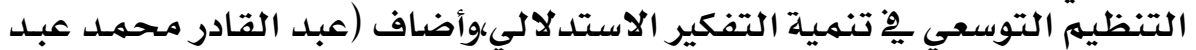

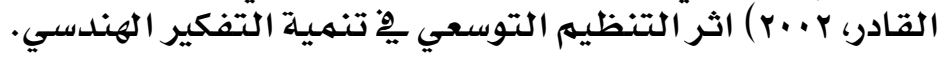

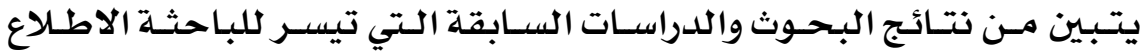

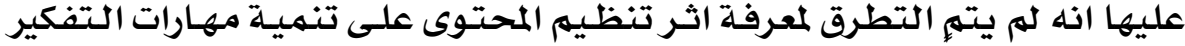

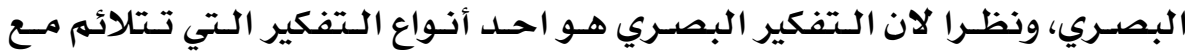

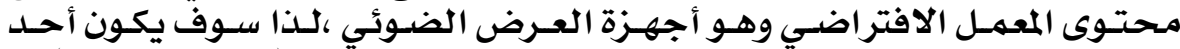

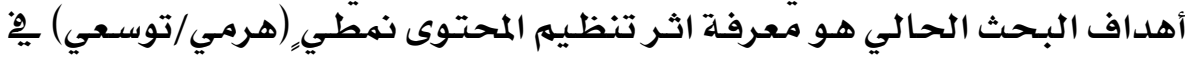

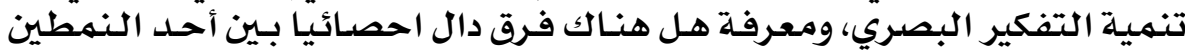
مقابل النهط التفكير البهري،

\section{IYY}


• خاهساً: هراحل وخطوات التصميم التعليـمي للامعمل الافتراضي.

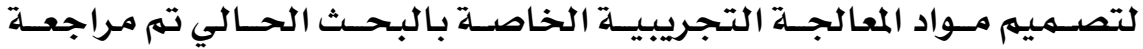

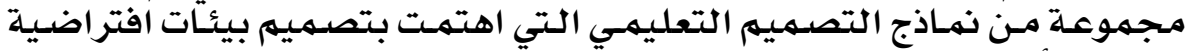

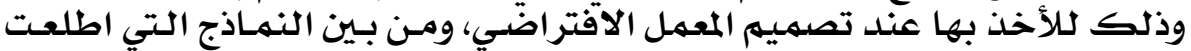

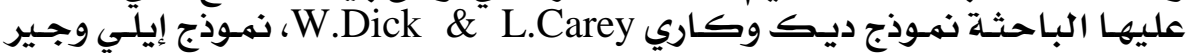

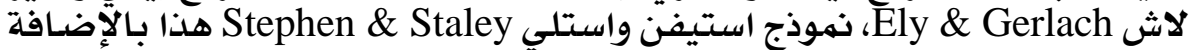

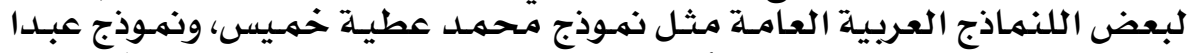

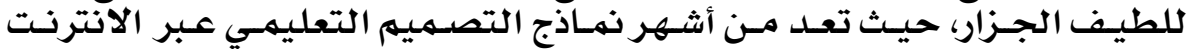

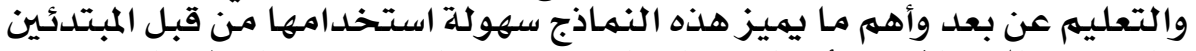

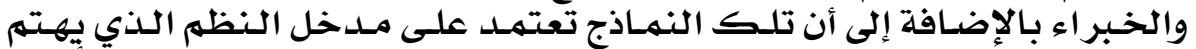

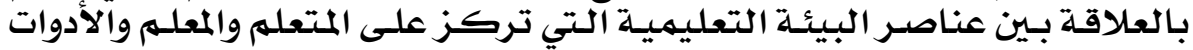

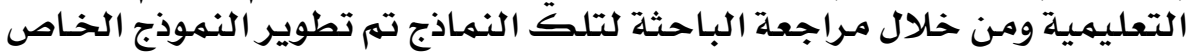

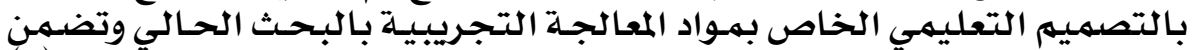

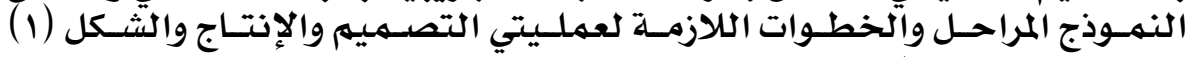

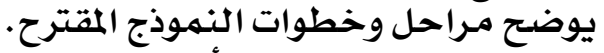
• إجراءات تجربة البحث وأدواتهاتهات النهودا:

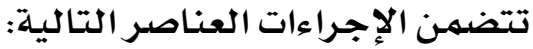

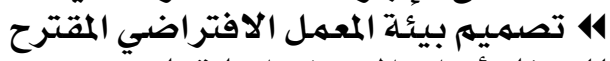

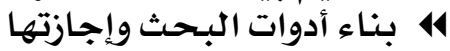
ه 414

\section{• تصـيم بيئة المعمل الافتراضي المقترح:}

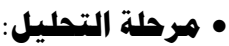

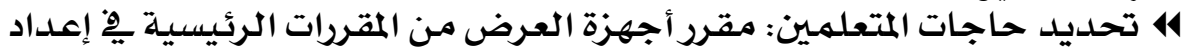

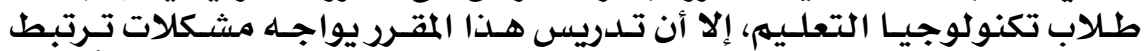

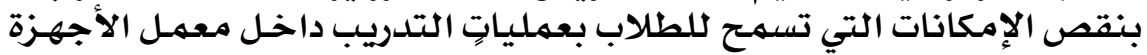

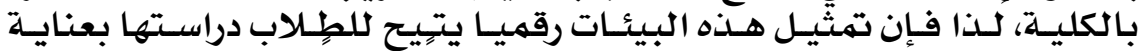

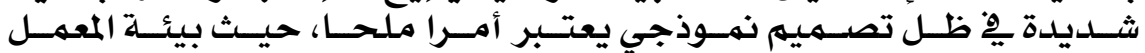

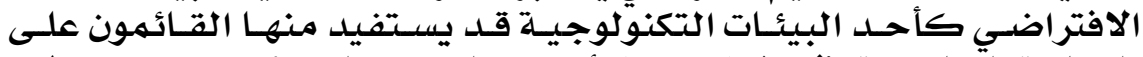

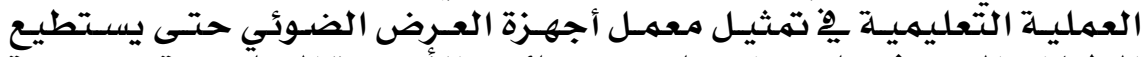

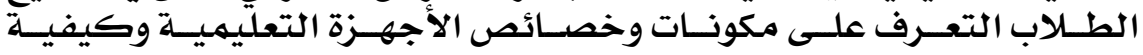

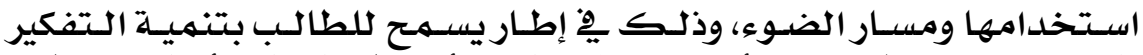

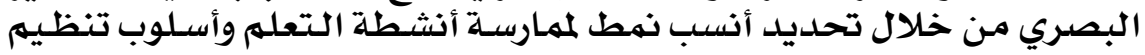

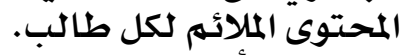

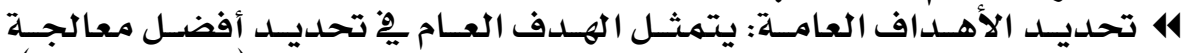

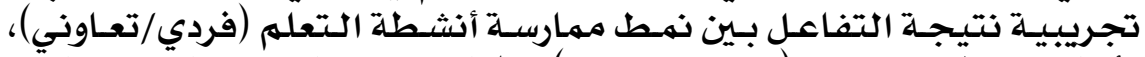

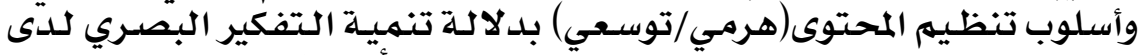

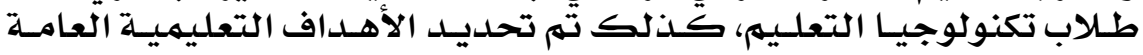

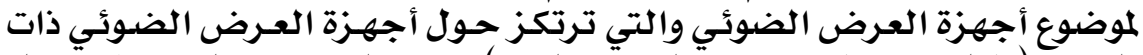

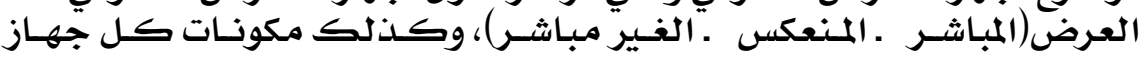
وكيفية تشغيلهـ.

\section{IY $\varepsilon$}




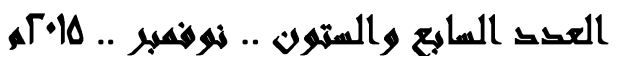

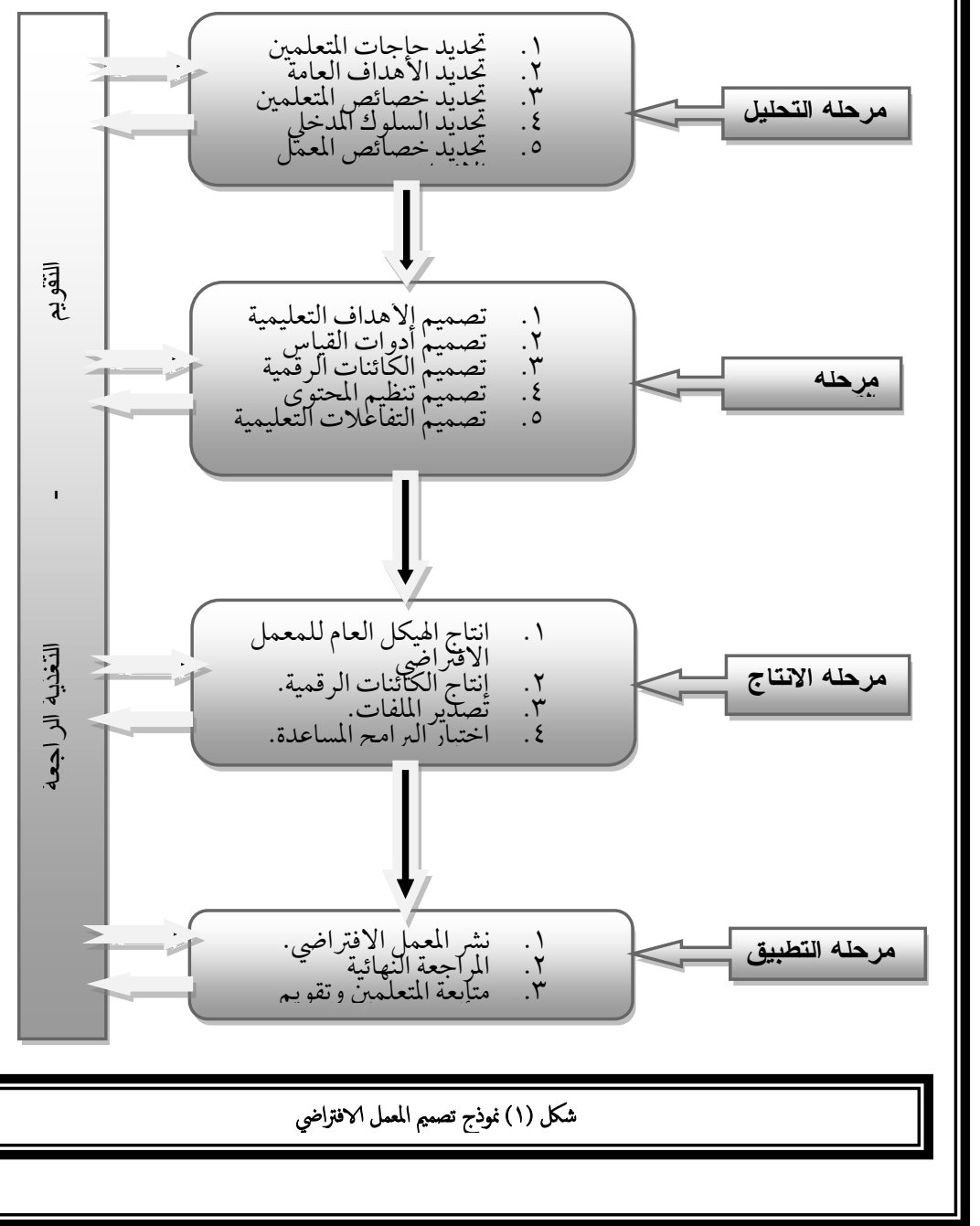

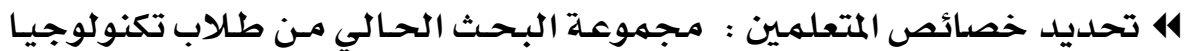

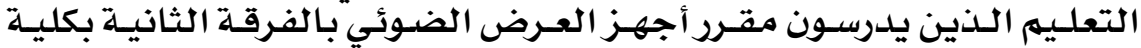

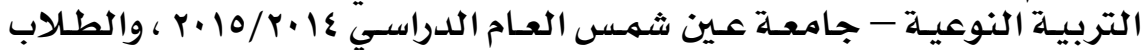

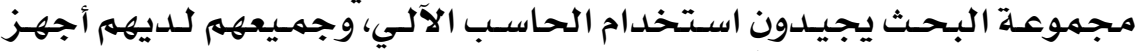
حاسب شخصوي منصي متصلية بالإنترنت

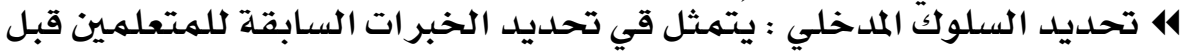

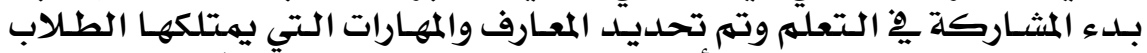

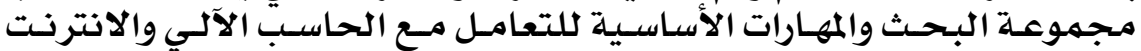

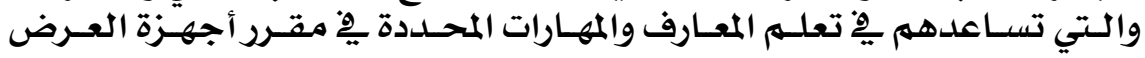

\section{Yo}




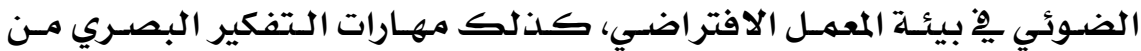

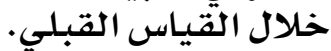

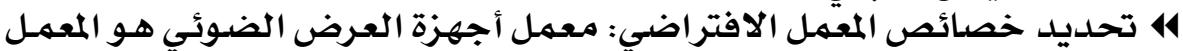

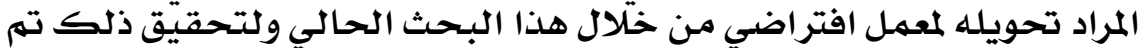

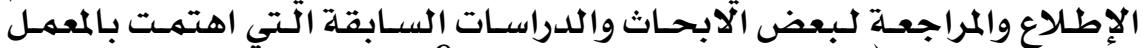

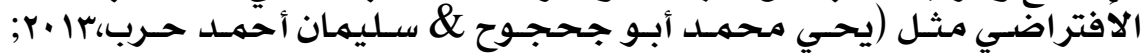
(Ahmad, A. , 2010; Hsu. N., \& Romance, S., 2012 Anonymous, S.,

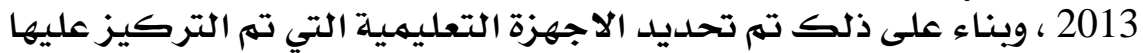

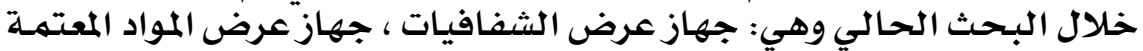
جهاز عرض البيانات الجيات السبورة الذياز الذية ، الكاميرا الوثائقية.

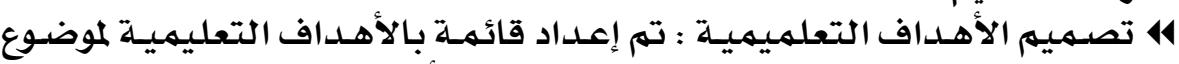

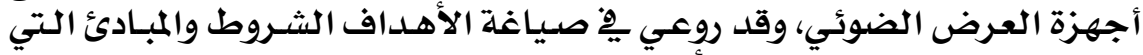

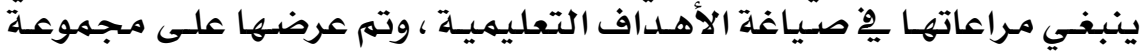

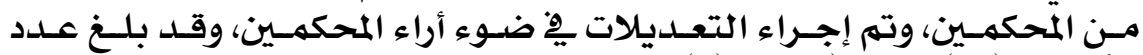

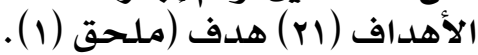

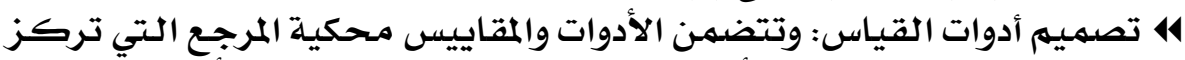

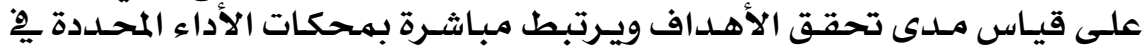

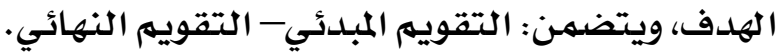

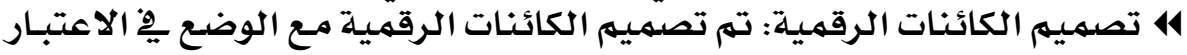

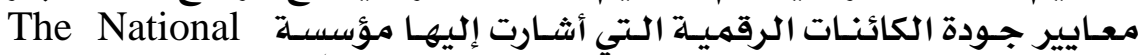
(NISO,2007 Information Standads Organization )

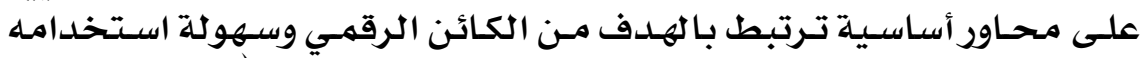

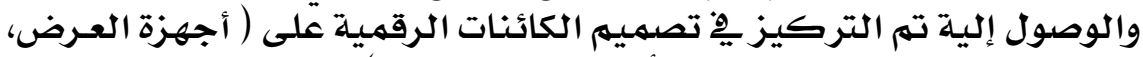

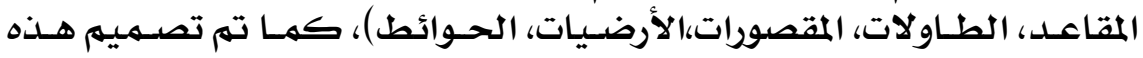

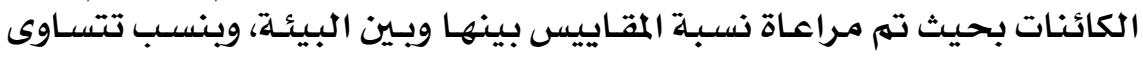

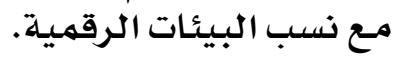

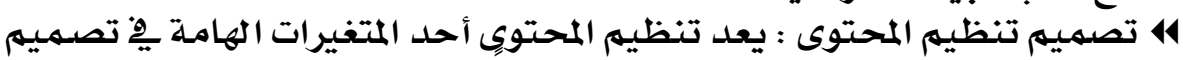

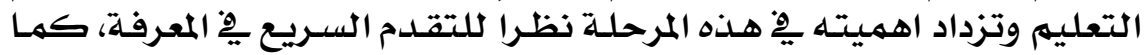

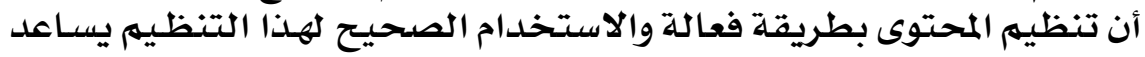

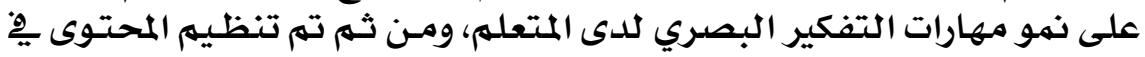

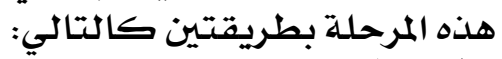

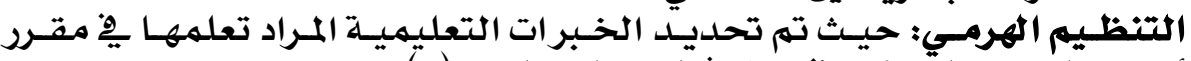

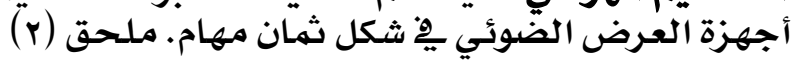

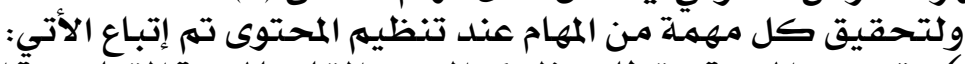

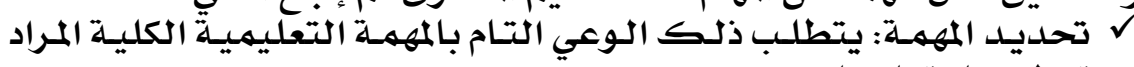
تنظيهمها وتعلهمان. ح تجزئة المهمة إلى العناصرة التي تتكون منها وتحديد هذه العناصر.

\section{1 7}




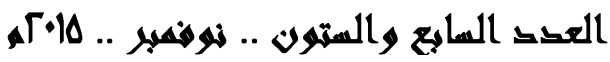
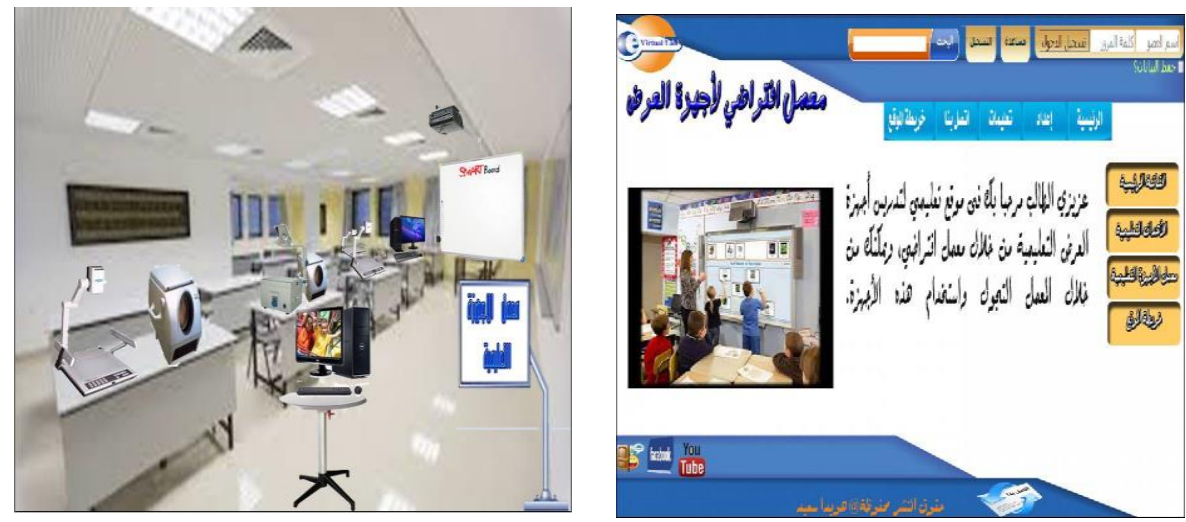

ثكل (r) ) الكائنات الرقمية لمعمل اجهزة العرض المبر

ثكل (r) الهيكل العام المعمل اجهزة العرض الافتراضي

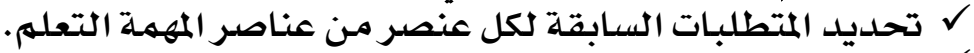

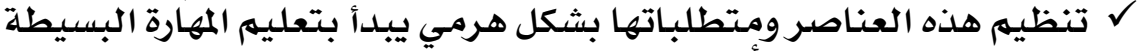

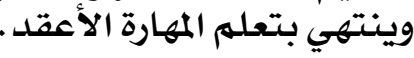

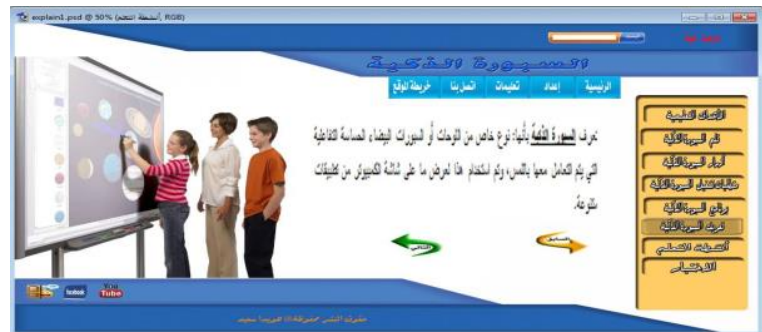

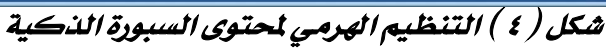

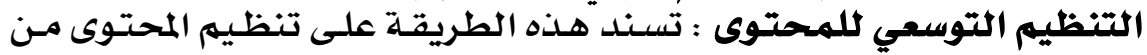

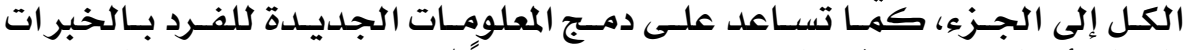

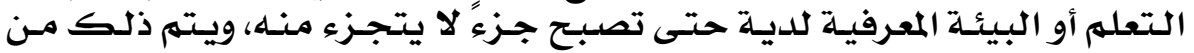

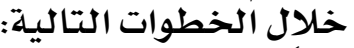

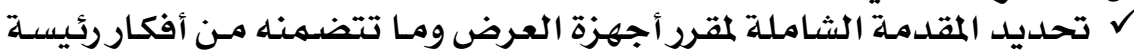

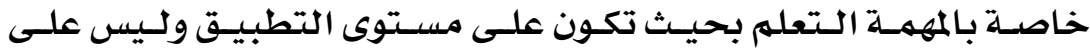
مستوى التذاكر

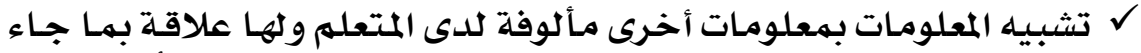

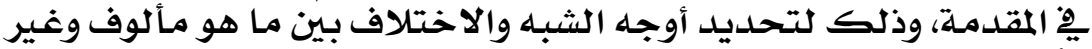
مـألوف.

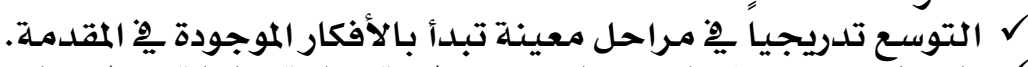

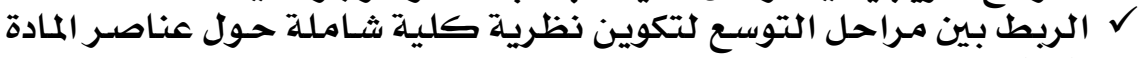
التعلمب.

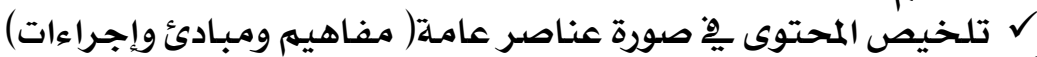

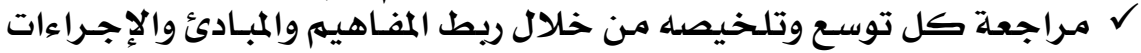

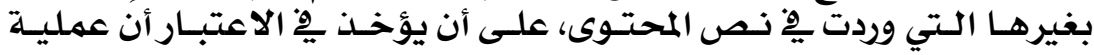




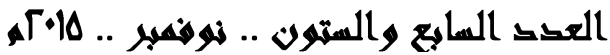

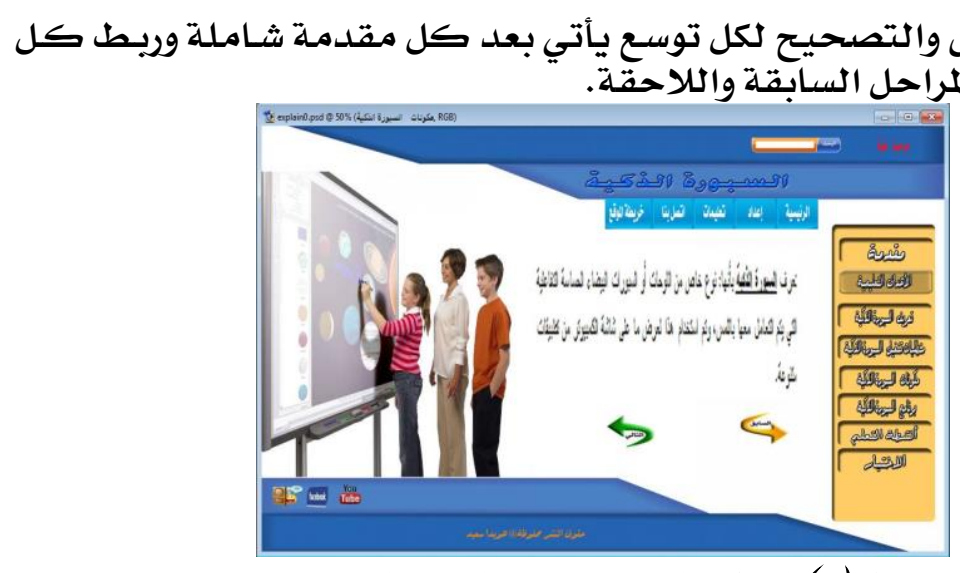

ثكل ( ) التنظيم التوسعي المحتوى السبورة النكية

ه تصهيم التفـاعلات التعليهيـة : يعـد تفاعل المتعلمه مـع المعهـل الافتراضـي مـن

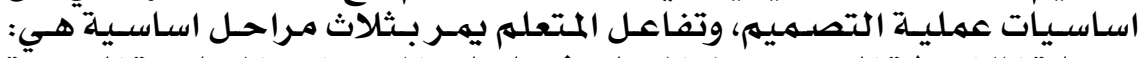

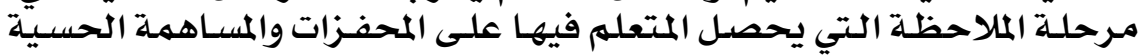

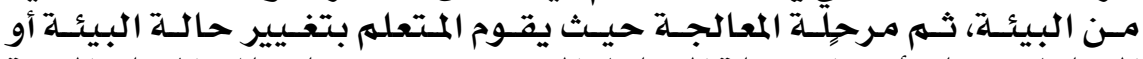

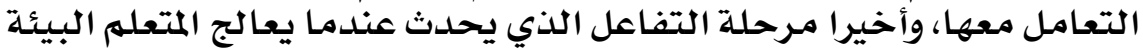

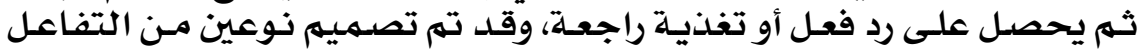

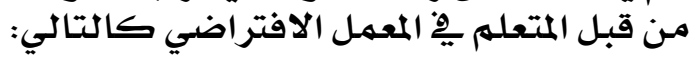

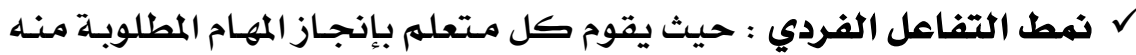

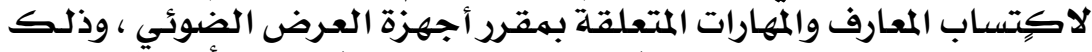

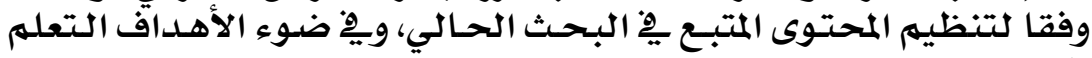
المحلددة.

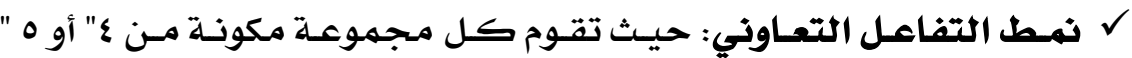

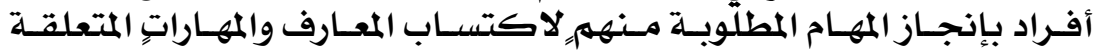

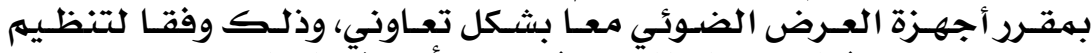

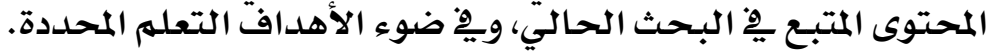

• هرحلة الانتاج:

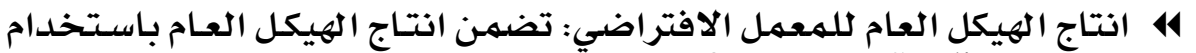

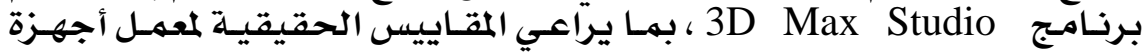

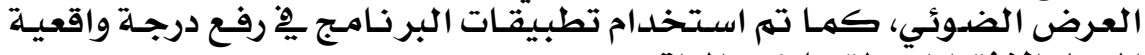

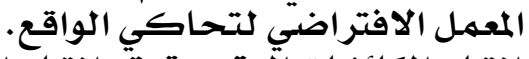

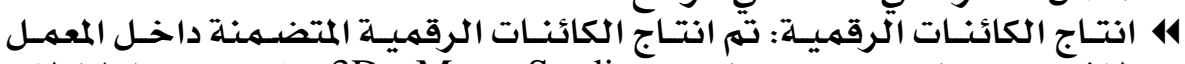

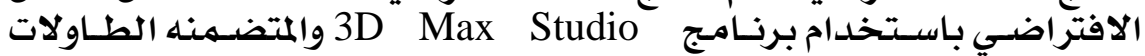

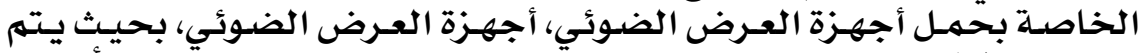

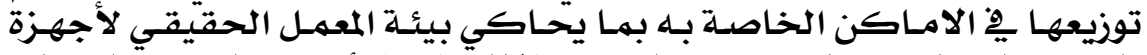

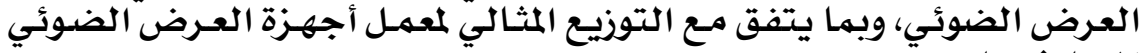
المتعارف عليـه.

\section{IYN}




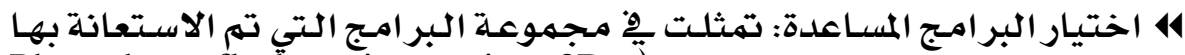

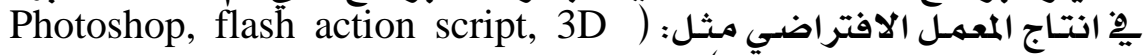
. (Max Studio, gif animator

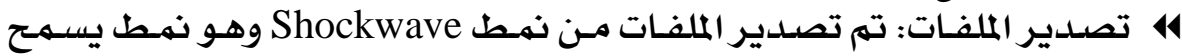

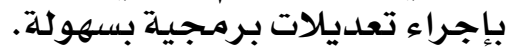

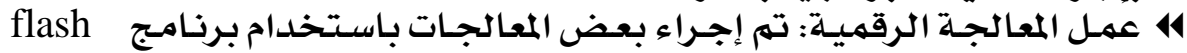

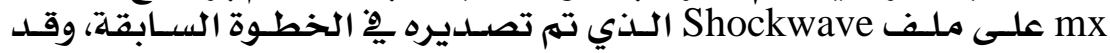

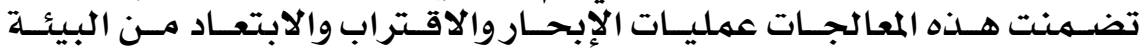

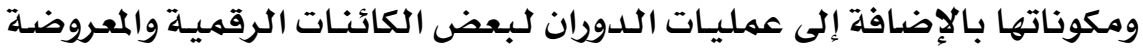

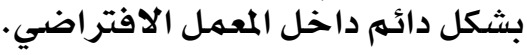

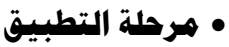

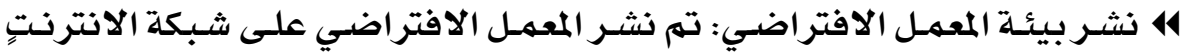

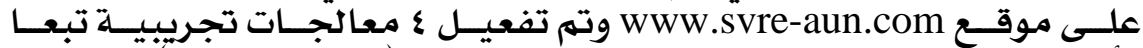

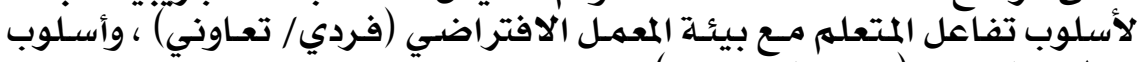

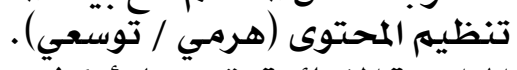

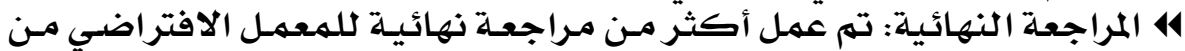

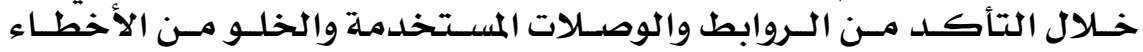

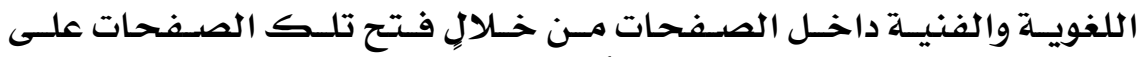

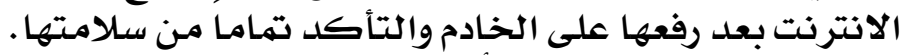

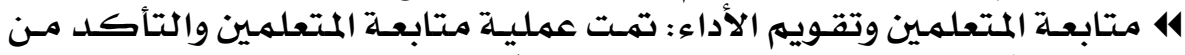

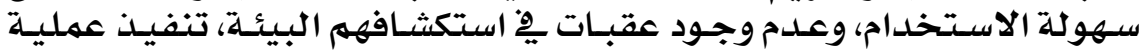

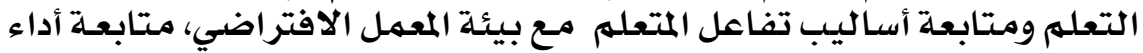

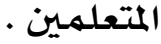

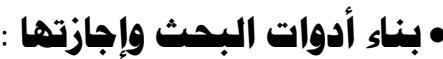

• مقياس مهارات التفكير البصري:

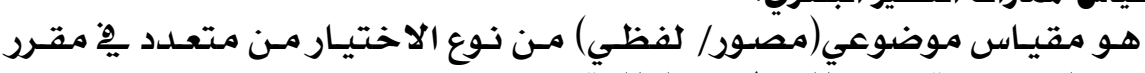

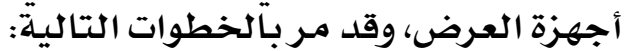

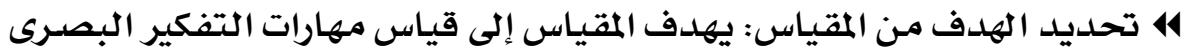

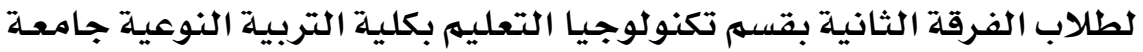

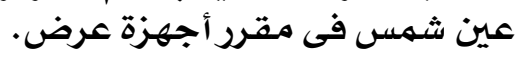

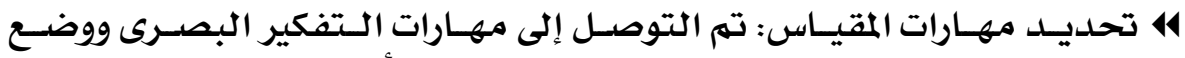

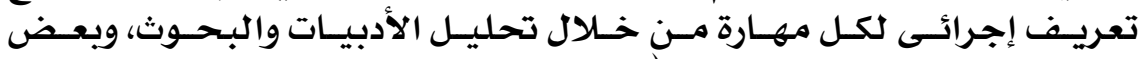

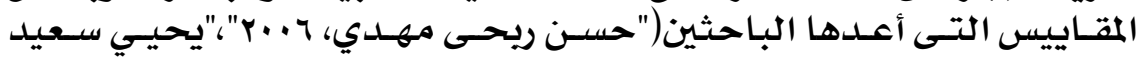

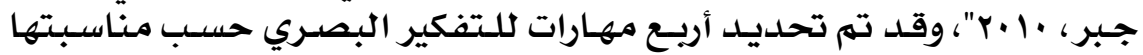

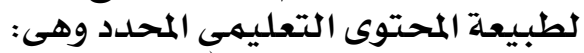

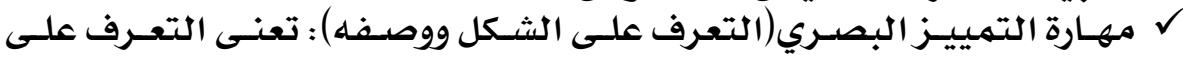

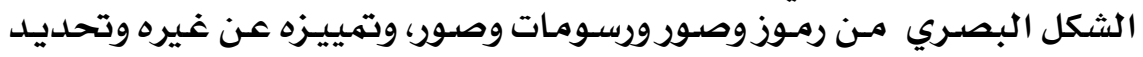

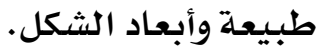

\section{Y 9}




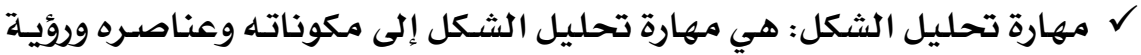

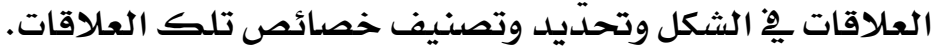

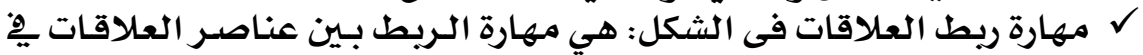

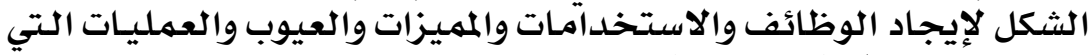

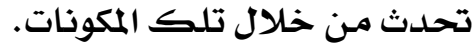

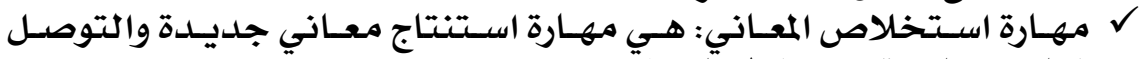

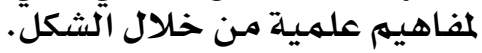

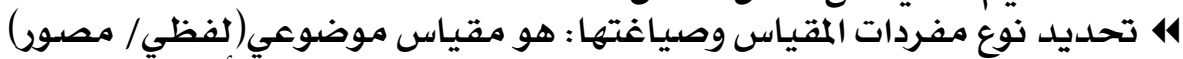

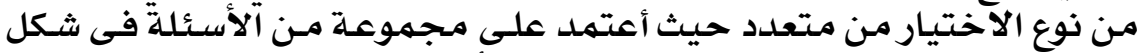

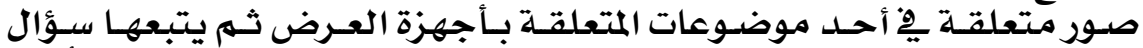

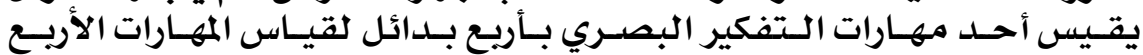

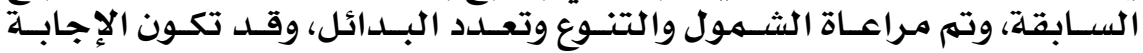

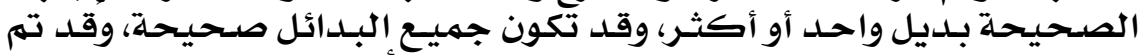

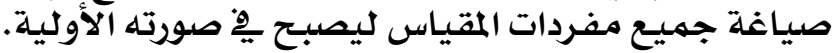

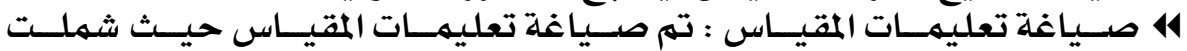

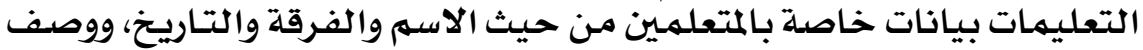

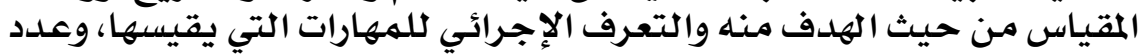

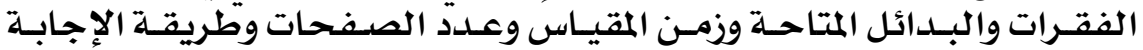

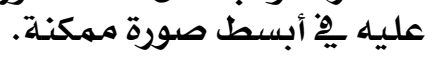

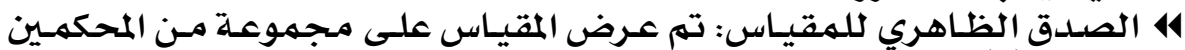

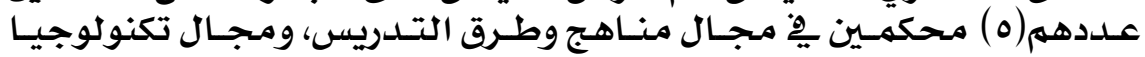

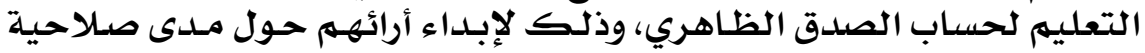

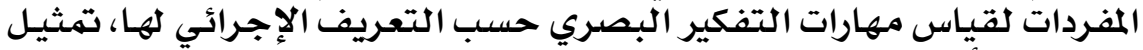

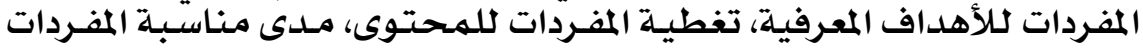

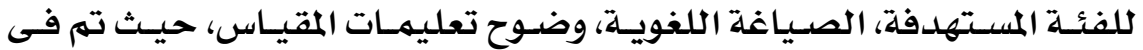

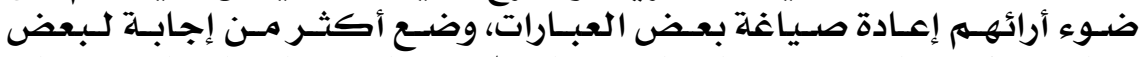

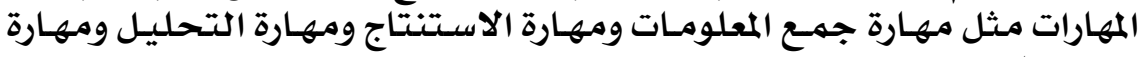

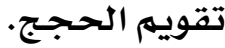

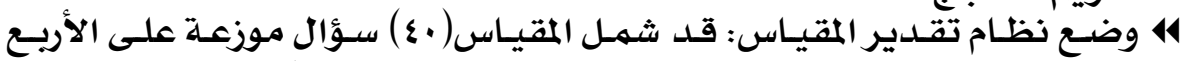

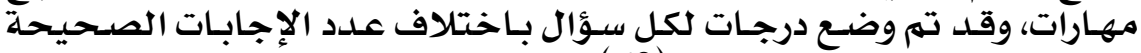

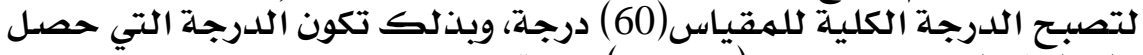

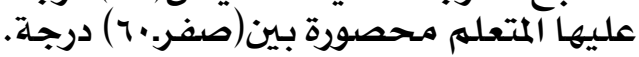
414

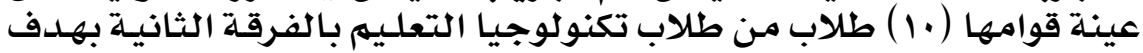

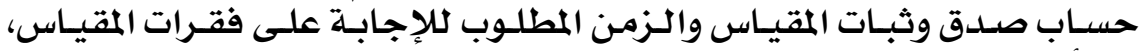
والتأكد من وضوح تعليمات وثبات المقياس.

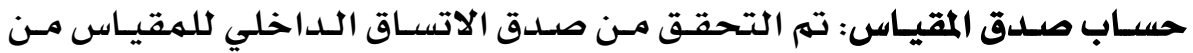

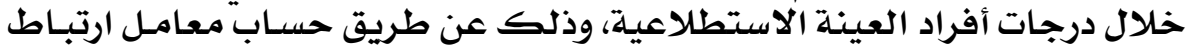

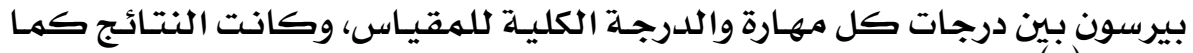

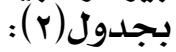

\section{$1 \%$}




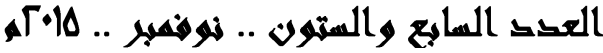

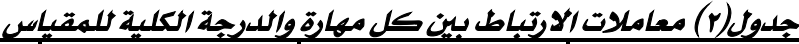

\begin{tabular}{|c|c|c|c|c|}
\hline استخلاص المعاني & ريط العلاقات -2 & تحليل الشكل & التمييز البصري & المهارة \\
\hline - . \&rY & . org & 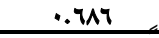 & - & معامل الارتباط \\
\hline
\end{tabular}

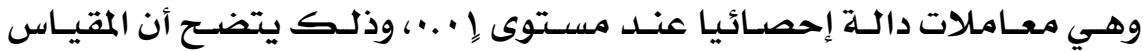

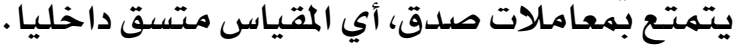

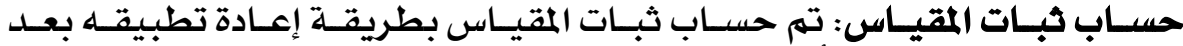

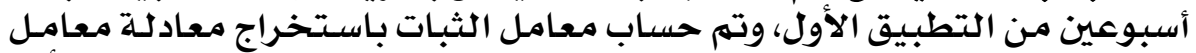

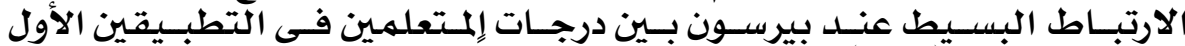

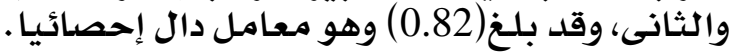

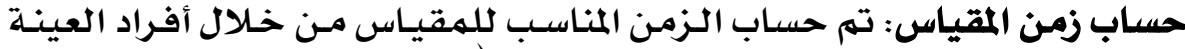

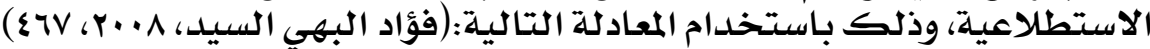

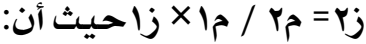

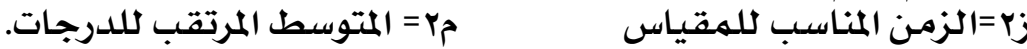

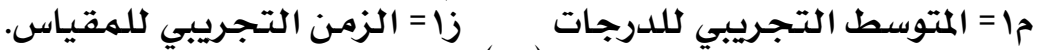

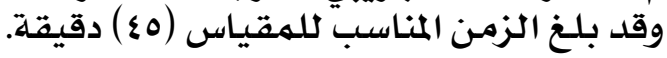

تعليمات المقياس: تبـين من استتجابات أفراد العينـة الاستطلاعية وضـوح تعليهـات

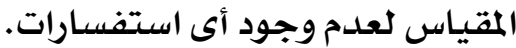

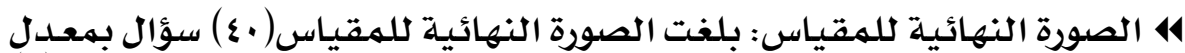

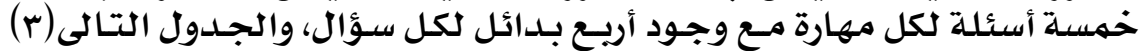

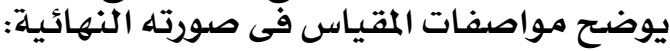
جلول (r) مواصفات مقياس التفكير البصري

\begin{tabular}{|c|c|c|c|}
\hline المئوينة & اللكليجة & أرقام المفردات & المهارة \\
\hline$\%$ ro & $1 \varepsilon$ & 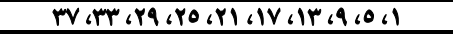 & التعرف على الشكل ووصفه \\
\hline$\%$ r. & $\mathbf{A}$ & 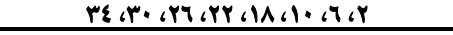 & تحليل الشكل \\
\hline 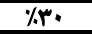 & $r$. & 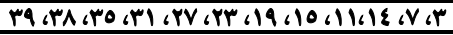 & ربط العلاقات 2) أشكل \\
\hline$\%$ Y. & 11 & 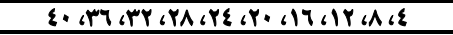 & استخلاص المعانى \\
\hline$\% 1 \cdots$ & 7. & $\varepsilon$. & 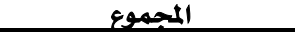 \\
\hline
\end{tabular}

تجربة البمث : تمثت إجراءات تجربة البمث كما يلي: • تطبيق أداة البحث قبلياً لتمديد تجانس المبموعات:

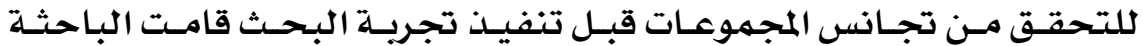

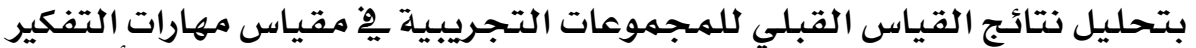

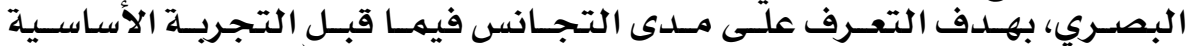

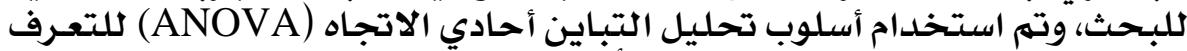

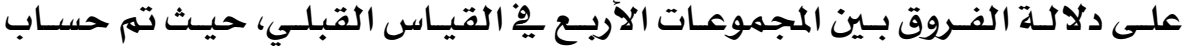

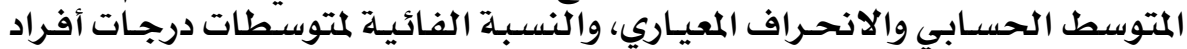

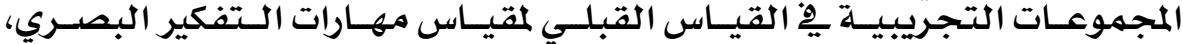

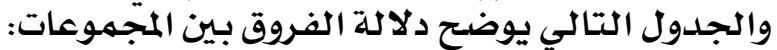

\section{$|\mu|$}




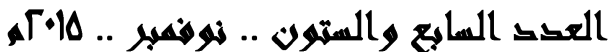

\begin{tabular}{|c|c|c|c|c|c|}
\hline مستوى الدلالة & قيمة ف & متوسط المربعات & درجات الحرية & محموع المربعات & مصدر التباين \\
\hline \multirow{3}{*}{ 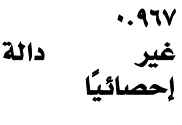 } & \multirow{3}{*}{$\cdot, \cdot \& 1$} & 7.0 .1 & $r$ & M. Y. E & بين المحموعات \\
\hline & & IYT.VAV & $v \varepsilon$ & AะqV.YIT & داخل المحجموعات \\
\hline & & & $w$ & arry.vin & لمر \\
\hline
\end{tabular}

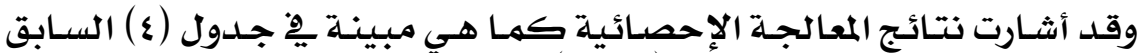

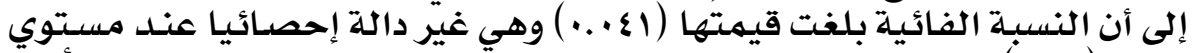

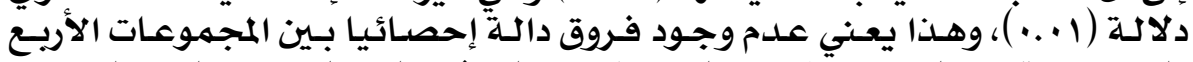

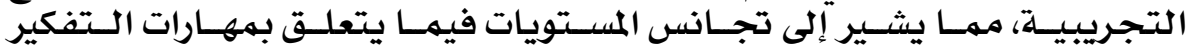

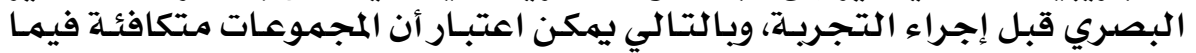

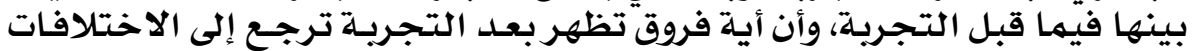

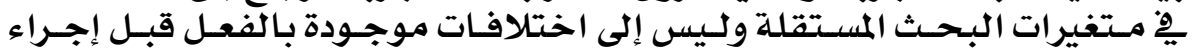

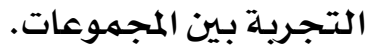

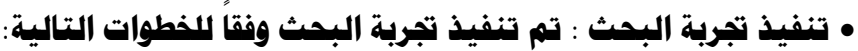

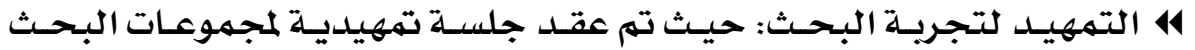

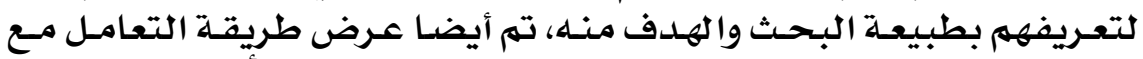

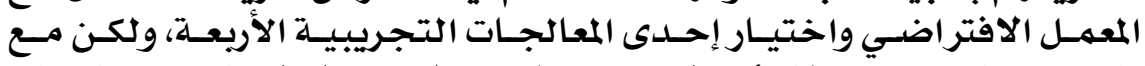

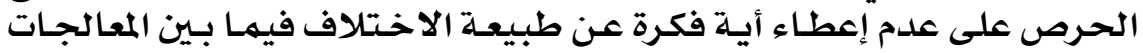

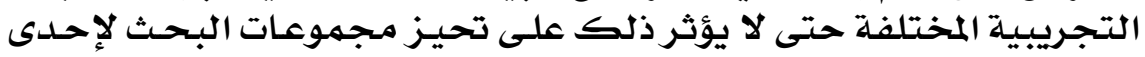
المعالجات.

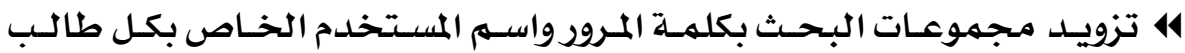

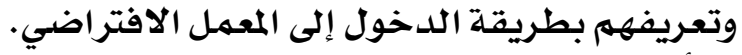

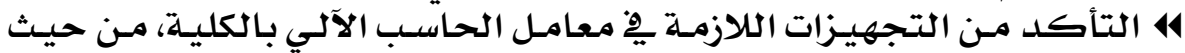

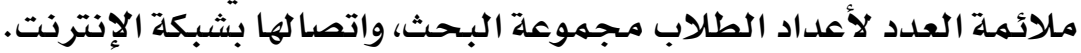

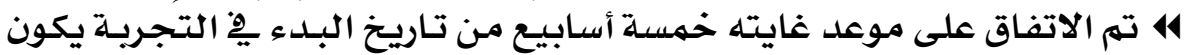

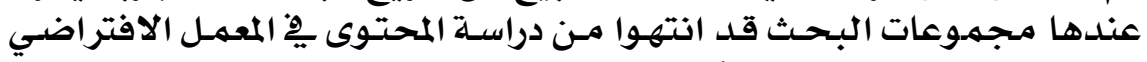

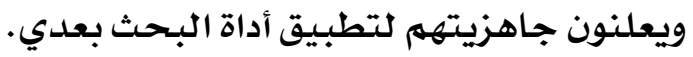

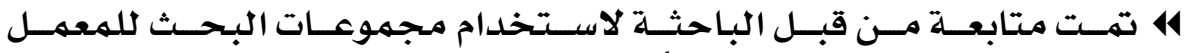

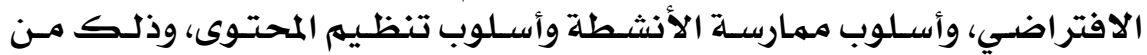

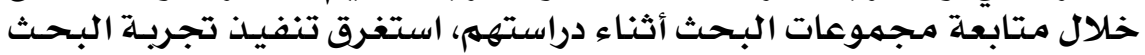

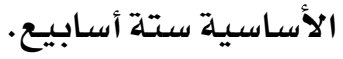
• ت تطبيق أداة البحث بعدي على هجموعات البحث البئ.

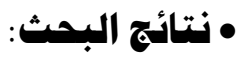

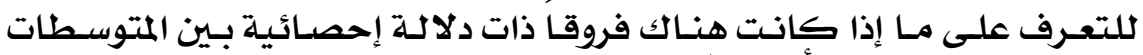

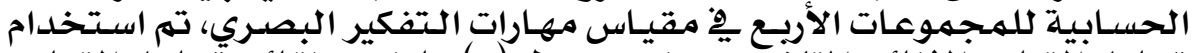

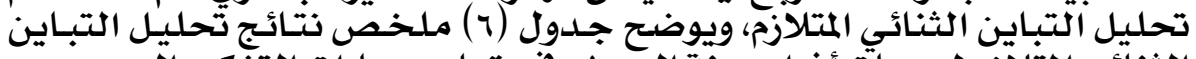

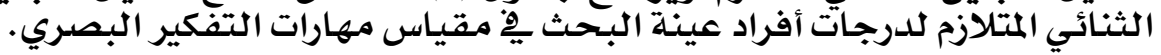

\section{IFY}




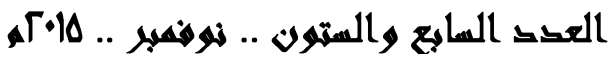

جلول (0) المتوسطات والانحرافات المعيارية للدرجات مهارات التفكير البصري وفقًا لمتغيري البحث

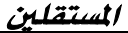

\begin{tabular}{|c|c|c|c|c|}
\hline \multirow{3}{*}{ المجموع م= } & \multicolumn{2}{|c|}{ ثمط ممارسية أثطة } & \multirow{2}{*}{\multicolumn{2}{|c|}{ المجموعة }} \\
\hline & تعاوني & فردي & & \\
\hline & $\varepsilon 9.0 \cdot=\beta$ & $\{\Lambda . \mid r=\hat{A}$ & \multirow{2}{*}{ هرمي } & \multirow{4}{*}{ أسلوبتوى تنظيم } \\
\hline $9.7 V=\varepsilon$ & $\mid Y \cdot \Lambda \Lambda=\varepsilon$ & $0 . Y=\varepsilon$ & & \\
\hline $01 . Y \ldots=0$ & \&7. $V_{r}=\rho$ & $\{\Lambda . T V=\rho$ & \multirow{2}{*}{ توسعي } & \\
\hline$\Lambda \cdot r \Lambda=\varepsilon$ & $V \cdot Y \varepsilon=\varepsilon$ & $1.9=\varepsilon$ & & \\
\hline $0 . . r r=\rho$ & $\varepsilon V . Y V=\rho$ & $\varepsilon 9 . \varepsilon \cdot=\hat{\rho}$ & \multirow{2}{*}{\multicolumn{2}{|c|}{ المجموع }} \\
\hline $9 .+1=\varepsilon$ & $1 . .01=\varepsilon$ & $0 . \wedge 1=\varepsilon$ & & \\
\hline
\end{tabular}

جلدول (7) نتائج تحليل التباين الثنائي المتلازم للرجات افراد المجموعات عينة البحث فِ مهارات

\begin{tabular}{|c|c|c|c|c|c|}
\hline \multicolumn{6}{|c|}{ التفكير البصري } \\
\hline • الدستوي & قيمة ف & متوبطات & الحرية & مجمموع & مصلدر التباين \\
\hline غير دالة & Y.V\&। & I\&Q.\&YY & 1 & IEq.\&YY & التأثير الرئيس لنمط ممارسة \\
\hline غير دالة & . Ire & V.Y৭\& & 1 & V.Y৭\& & التأثير الرئيس لأسلوب تنظيم \\
\hline غير دالة & . rar & rI.raA & 1 & YI.raA & 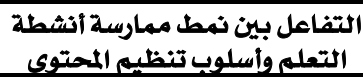 \\
\hline & & $0 \varepsilon .019$ & 170 & А१९०.77Y & الخططا \\
\hline & & & IVY & QY.\&.VAT & التباين الكلي \\
\hline
\end{tabular}

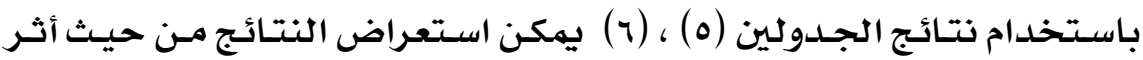

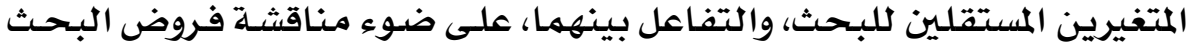

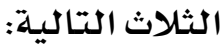

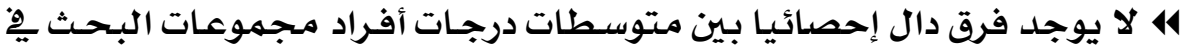

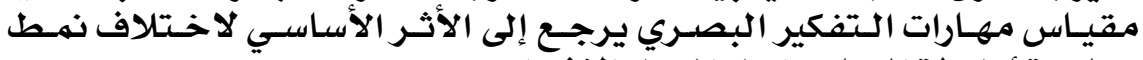

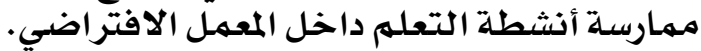

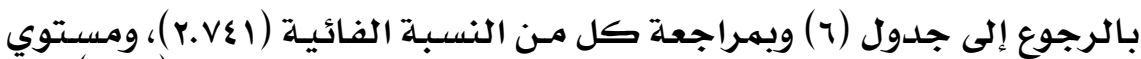

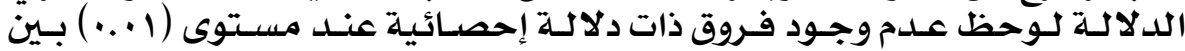

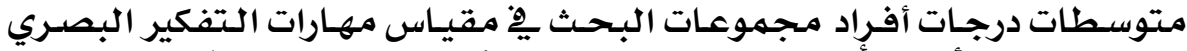

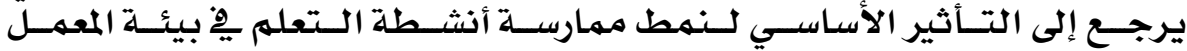
الافتراضي.

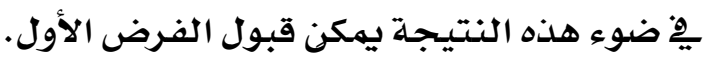

414

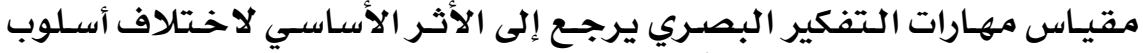

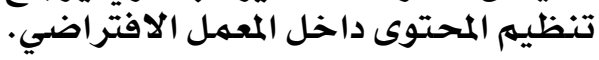

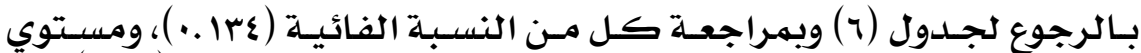

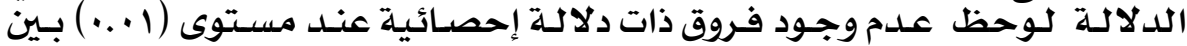

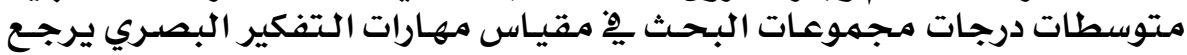

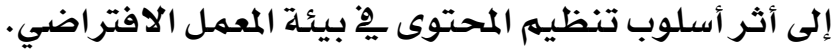

\section{$1 \mu r$}




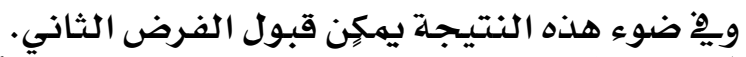

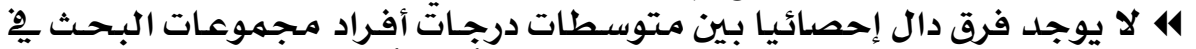

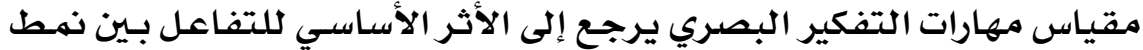

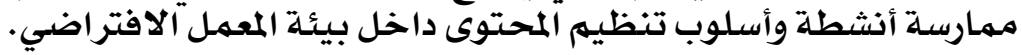

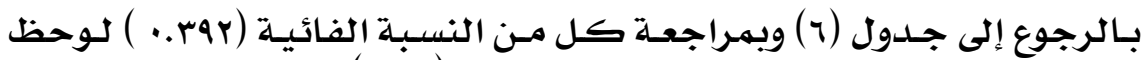

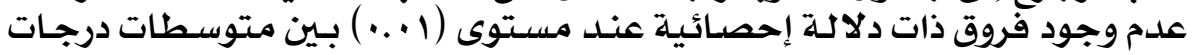

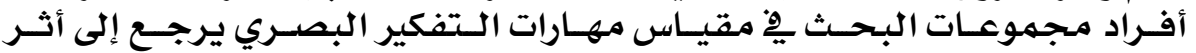

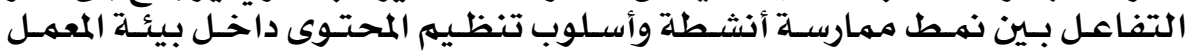
الافتراضي.

ويٌْ ضوء هذه النتيجة يمكن قبول الفرض الثالث

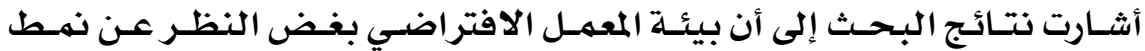

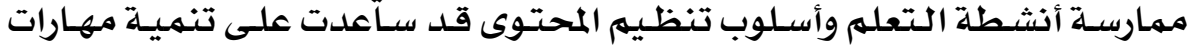

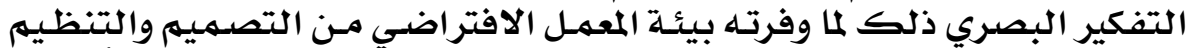

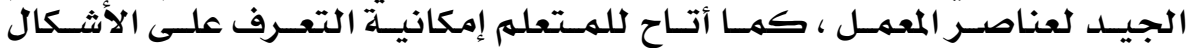

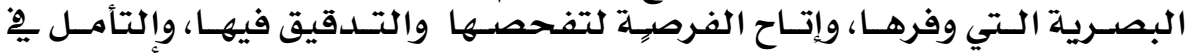

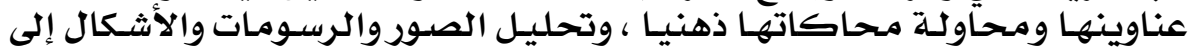

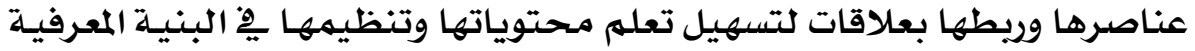

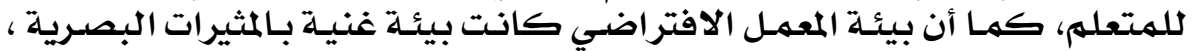

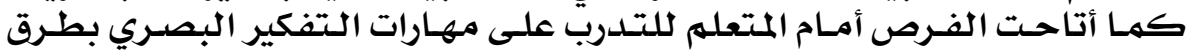

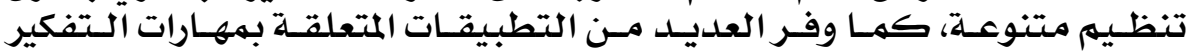

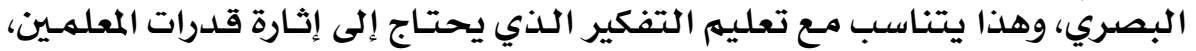

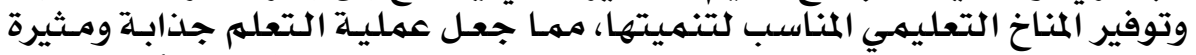

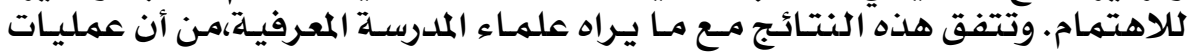

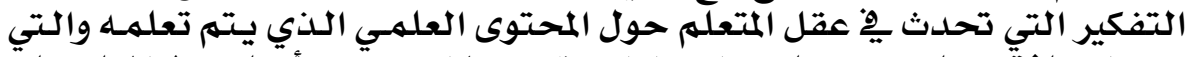

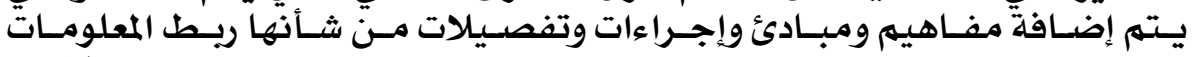

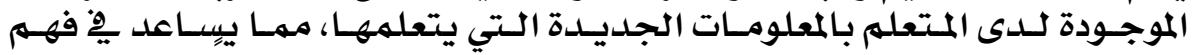

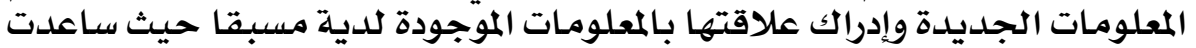

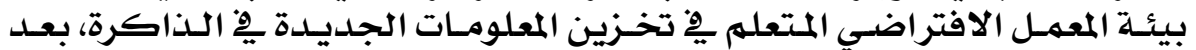

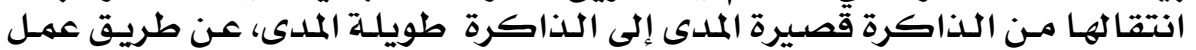

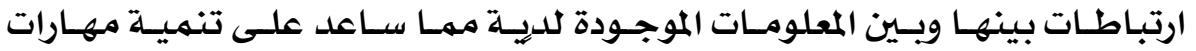

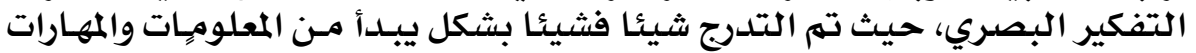

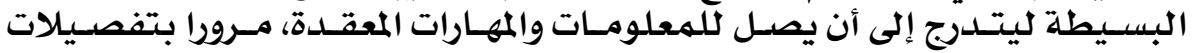

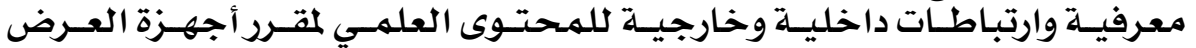

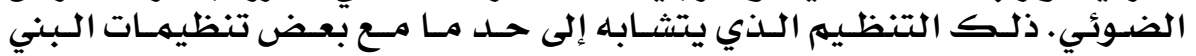

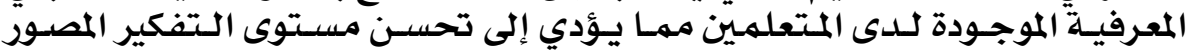

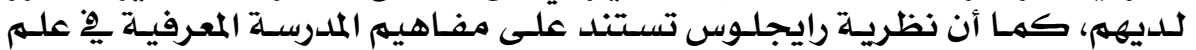

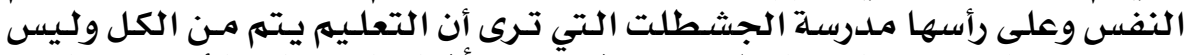

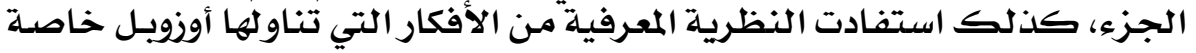

\section{$1 \% \varepsilon$}




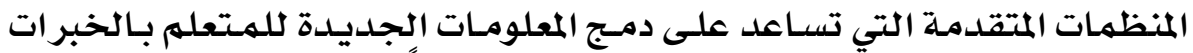

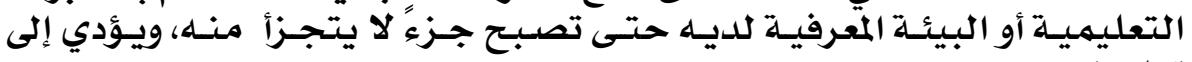
تعلهم ذي معنى.

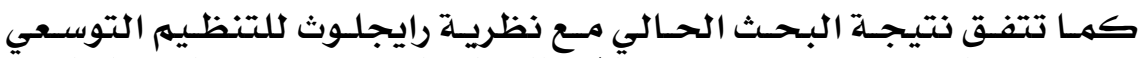

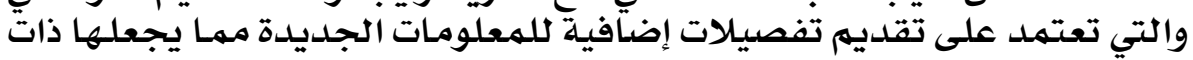

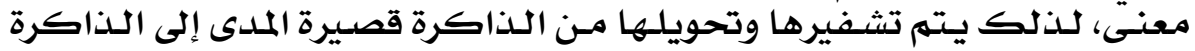

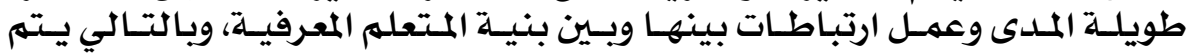

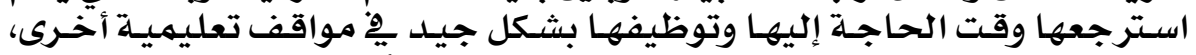

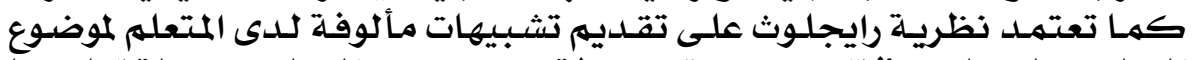

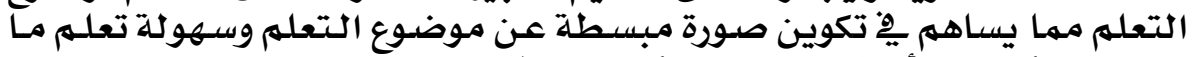

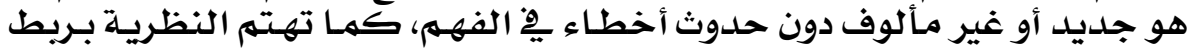

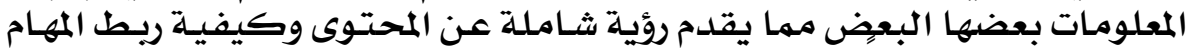

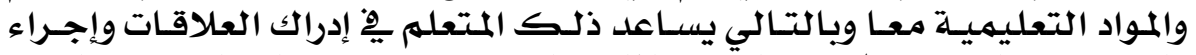

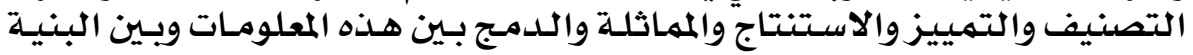

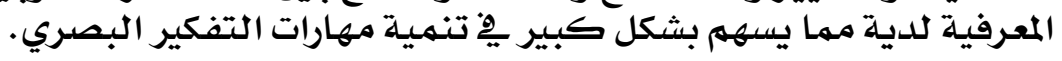

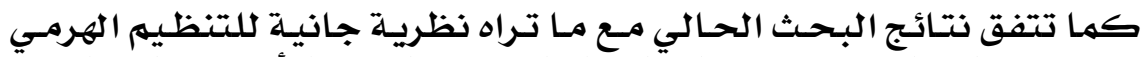

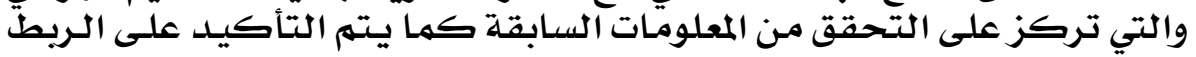

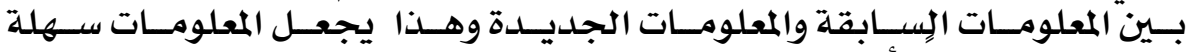

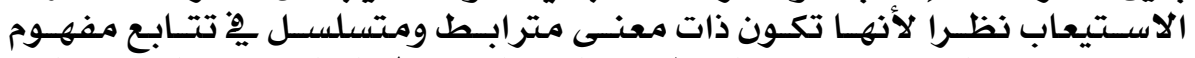

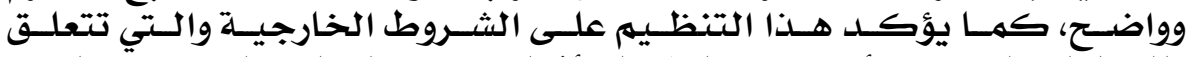

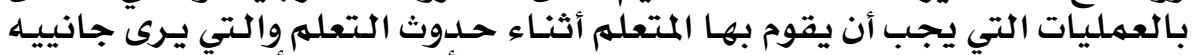

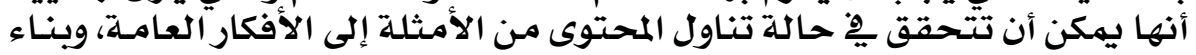

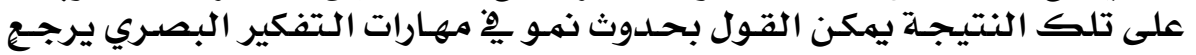

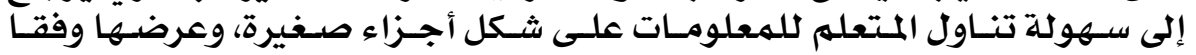

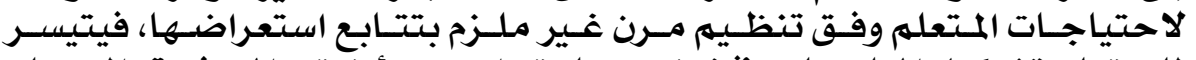

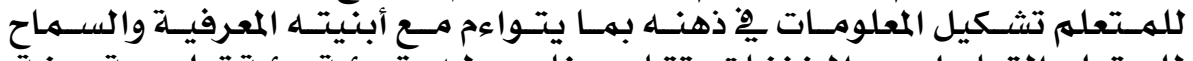

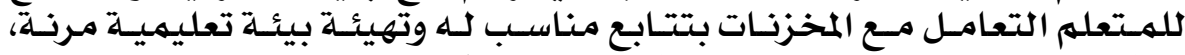

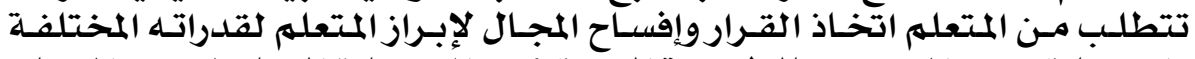

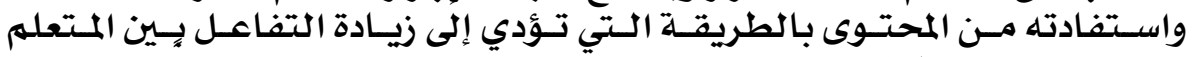

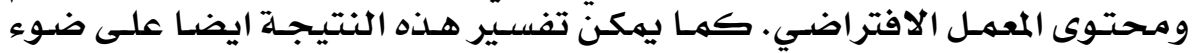

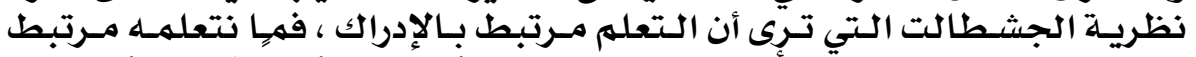

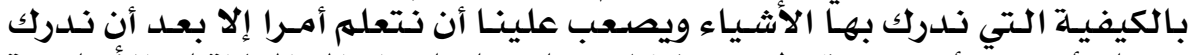

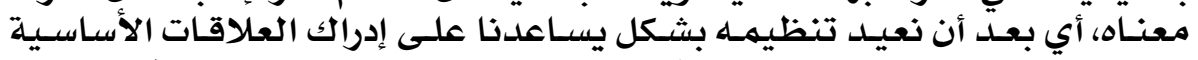

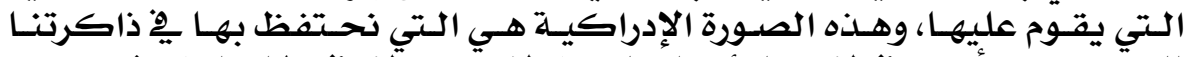

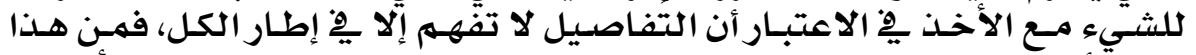

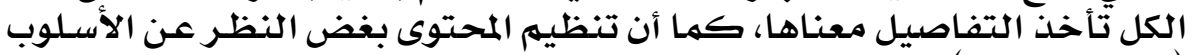

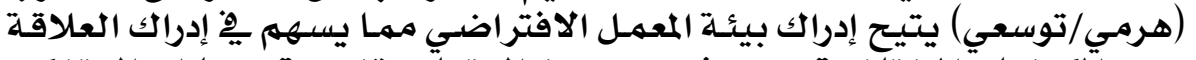

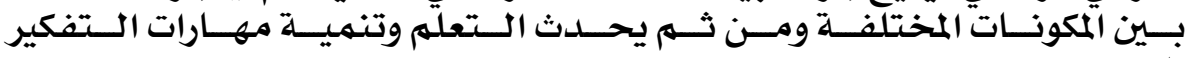
البصري.

\section{Ho}




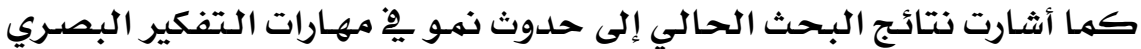

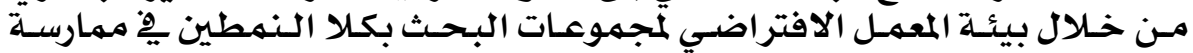

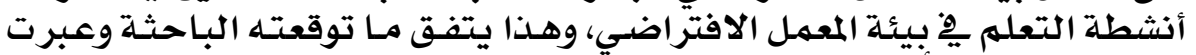

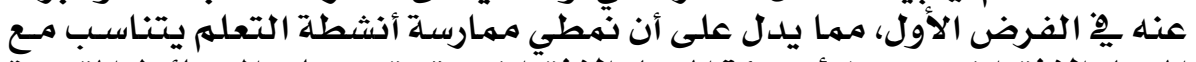

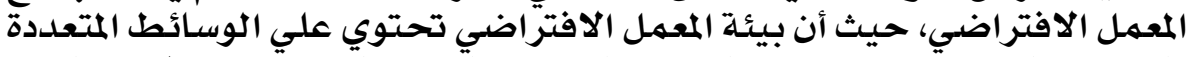

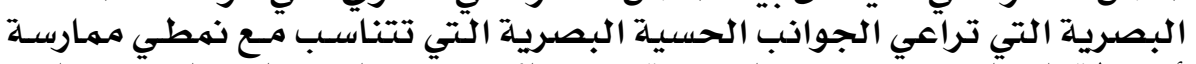

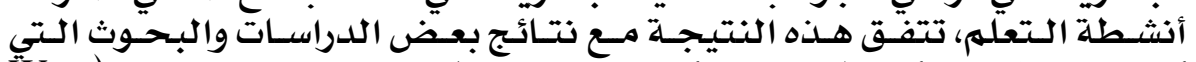

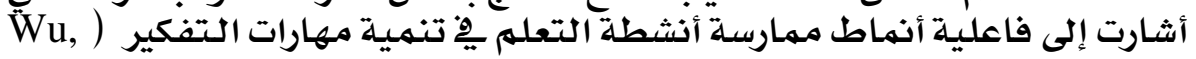
I., Chen, W., 2013; Baran, S. W., et al., 2010; Huang R. H., 2002; (Redha. H., 2010, Sergio Rapuano, et al., 2006

كها تتفق هذه النتيجة مـع نتائج بعض الأبحاث التي أشـارت إلى فاعلية نهط

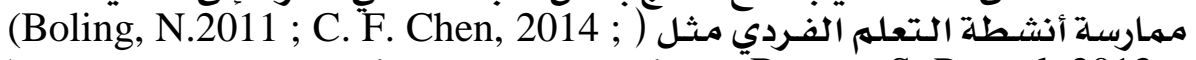

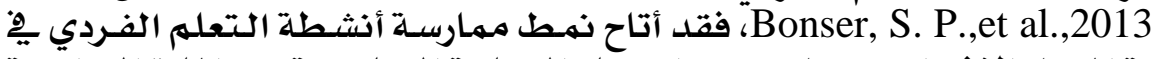

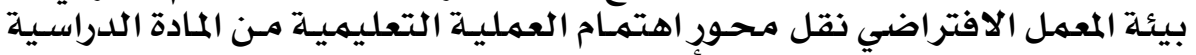

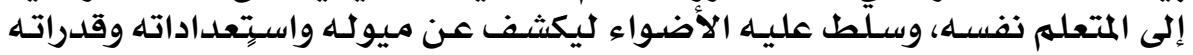

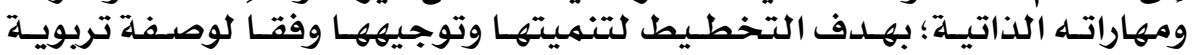

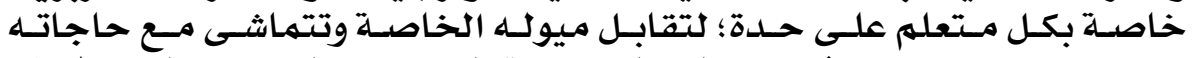

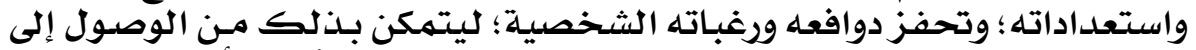

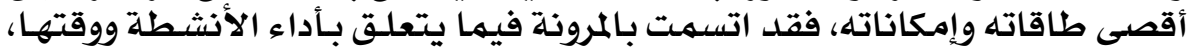

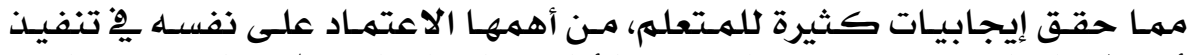

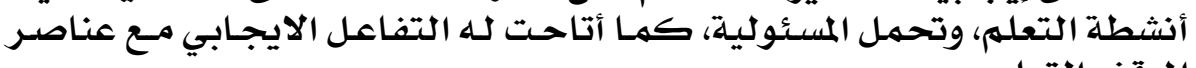
الموقف التعليهي التعلي، وتحمة

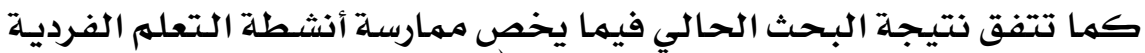

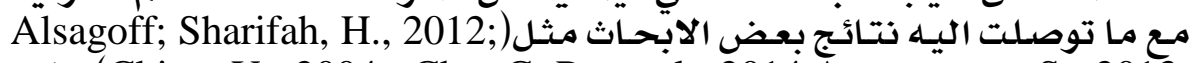
(Chien, Y., 2004 ; Chu, C. P., et al., 2014 Änonymous, S., 2013;

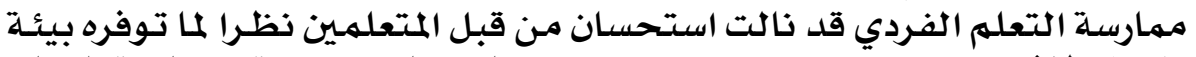

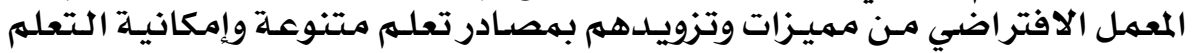

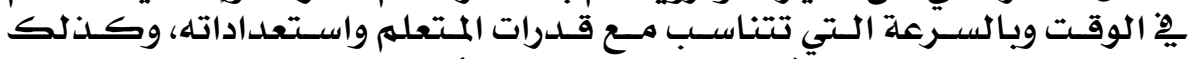

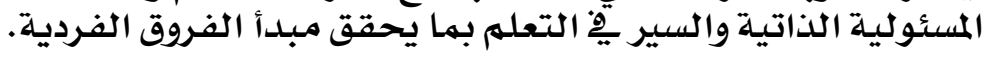

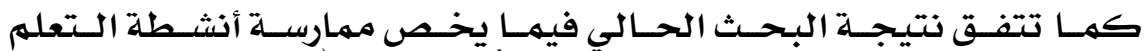

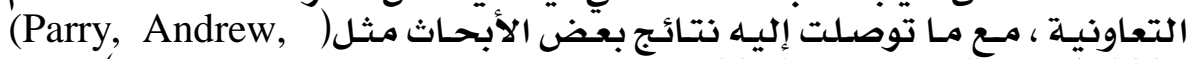

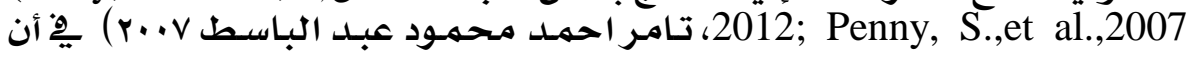

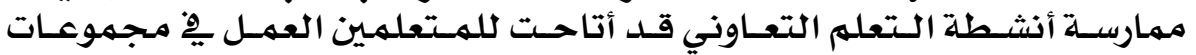

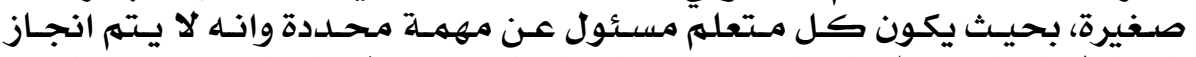

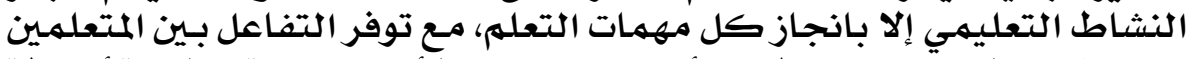

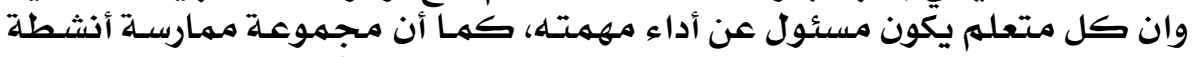

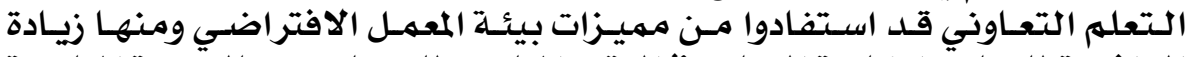

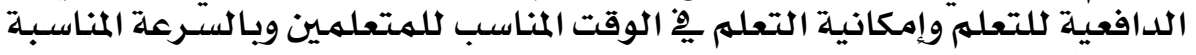

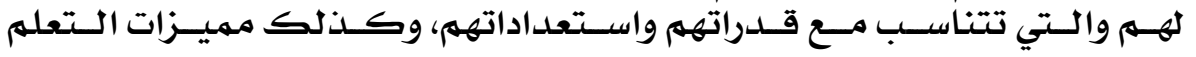

\section{$1 \% 7$}




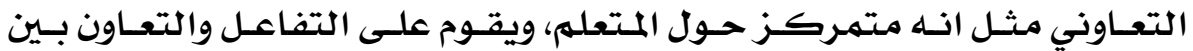
المتعلمـين.

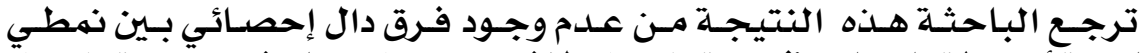

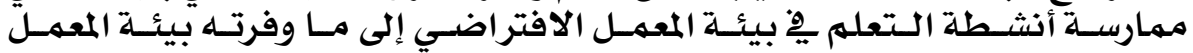

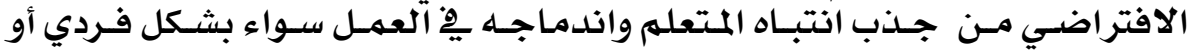

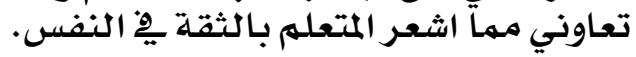

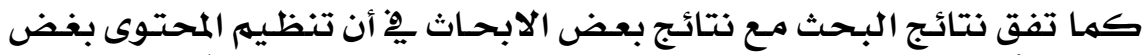

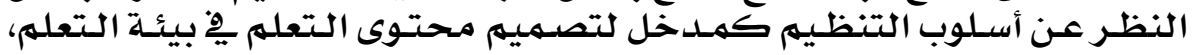

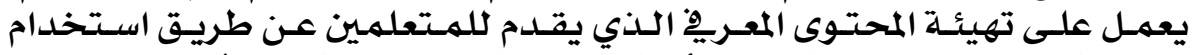

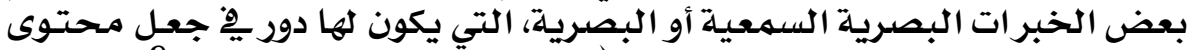

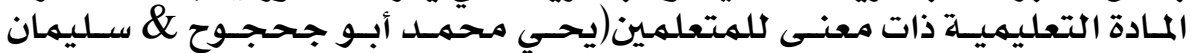

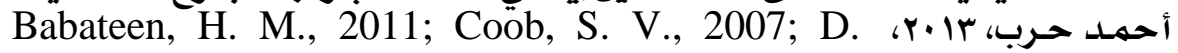
Wisell, P., et al., 2007; Mohamed Elsayed Ahmed \& Shinobu كمها أن تنظيم المحتوى سـاعد على بنـاء التصوير المرئسي

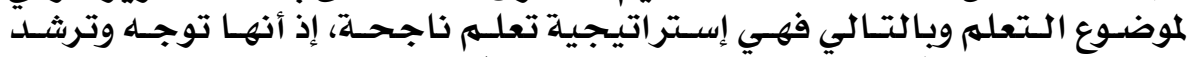

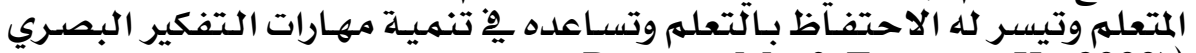

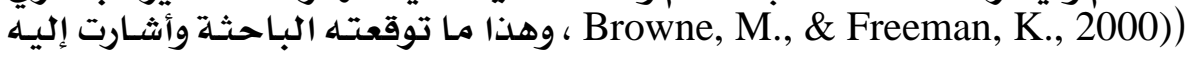
مِِّ الفرض الثاني.

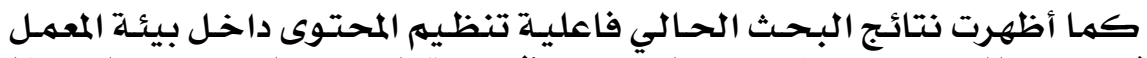

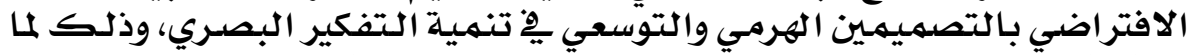

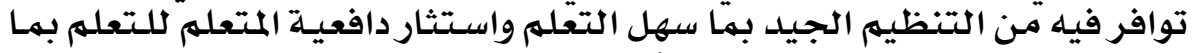

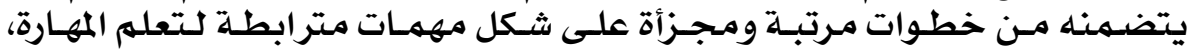

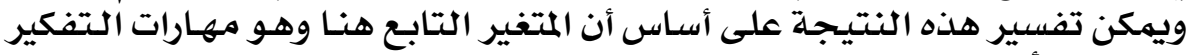

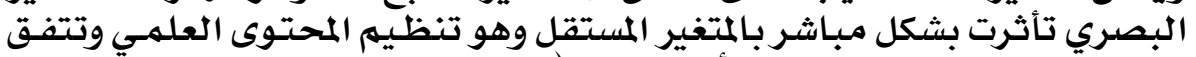

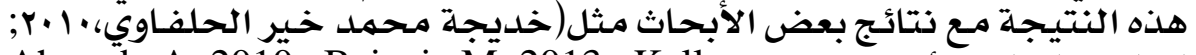

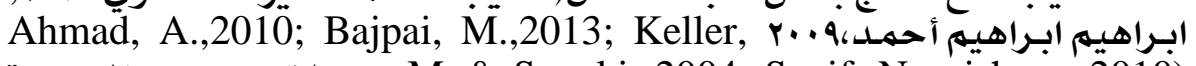
أبح.,\& Suzuki ,2004, Sanif ,Noorisham, 2010)

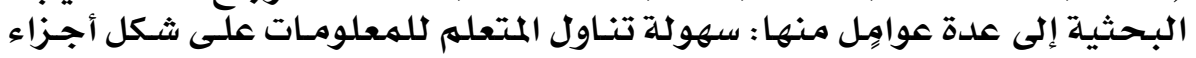

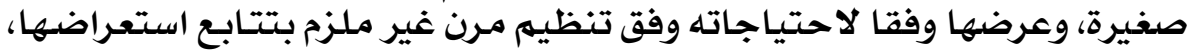

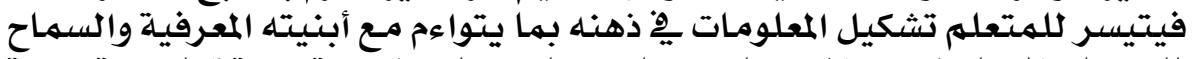

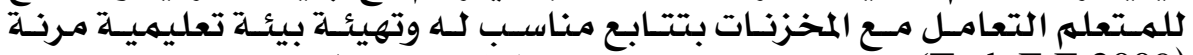

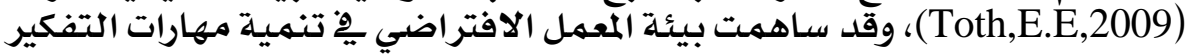

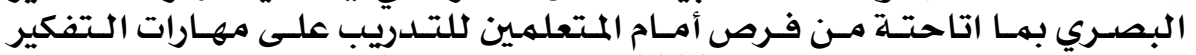
البصري بطرق عرض متننوعة، (Browne, M.\& Freeman, K.,2000)

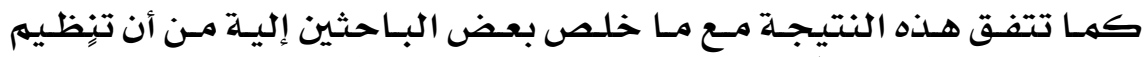

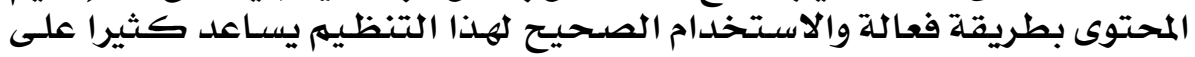

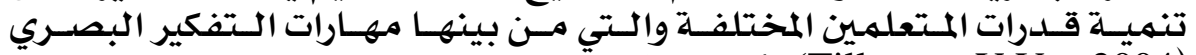

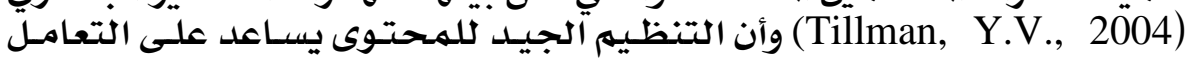

\section{ITV}




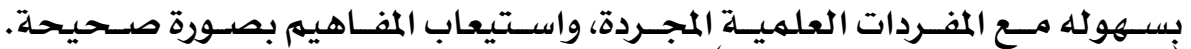
. (Yang, K, \& Heb, J. , 2007 )

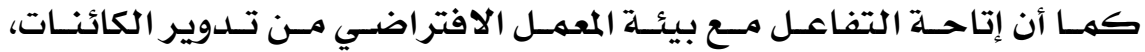

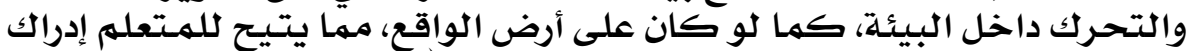

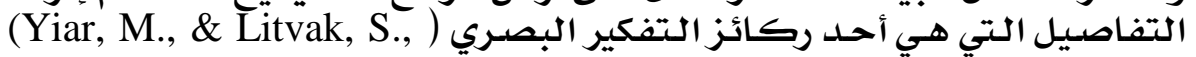

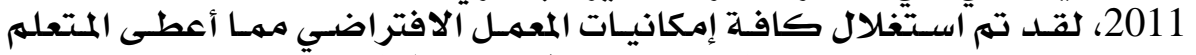

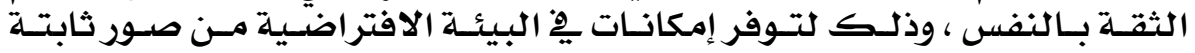

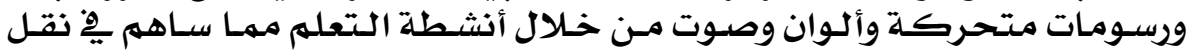

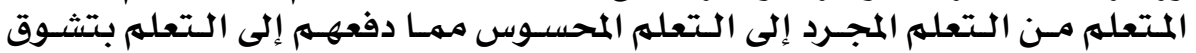

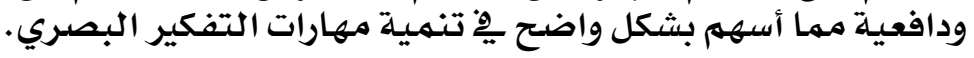

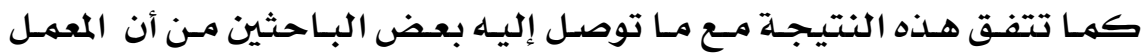

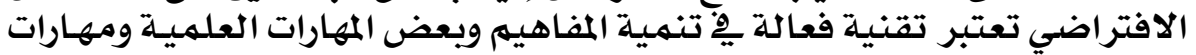

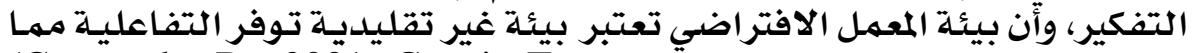

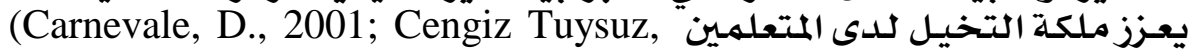
2010; Dalgarno, B., et al., 2009; James, J., 2011; Maldarelli, G., et al., 2009)

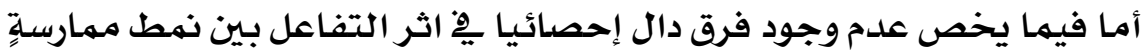

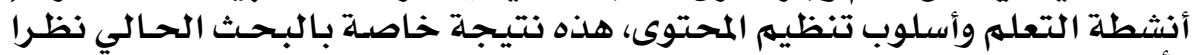

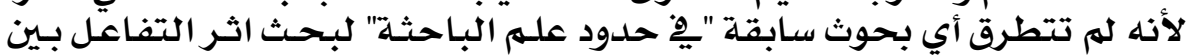

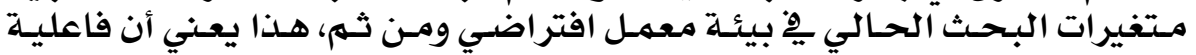

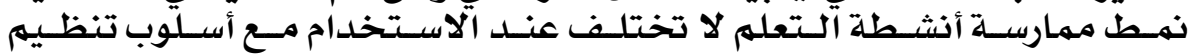

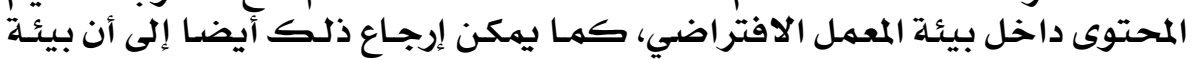

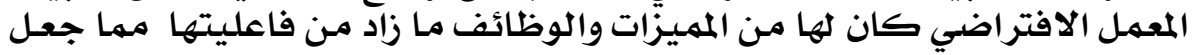

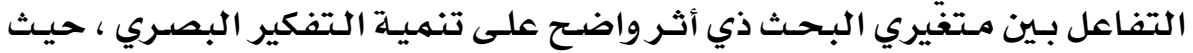

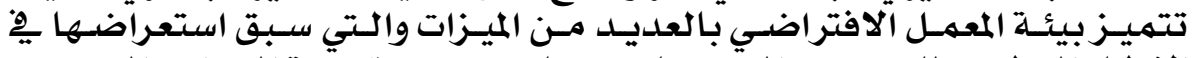

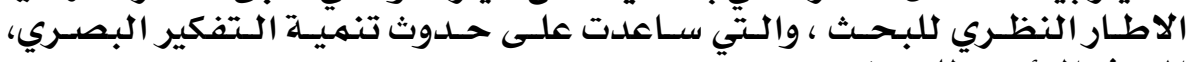

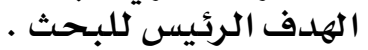

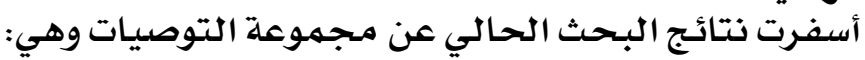

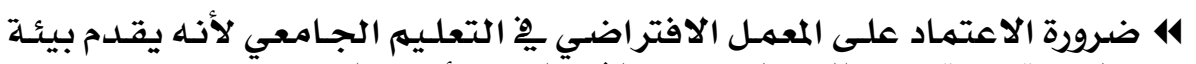

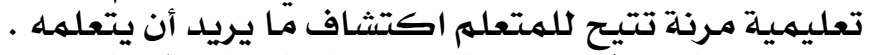

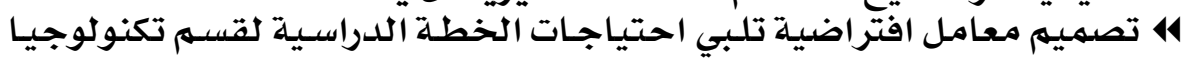
التعليهم. تصنيم.

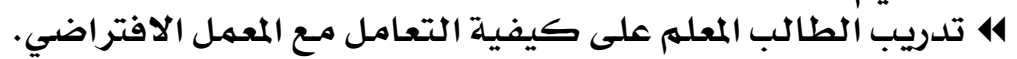

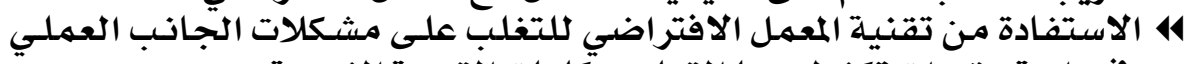

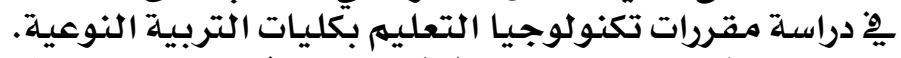

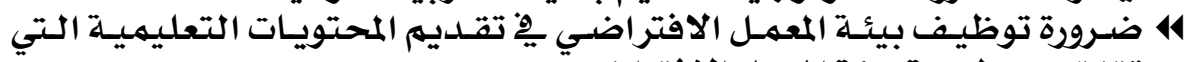

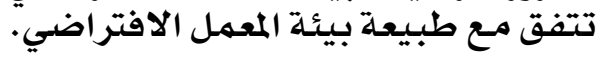

\section{in}




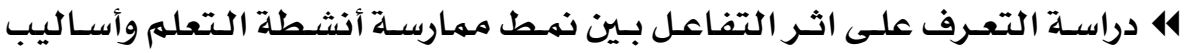

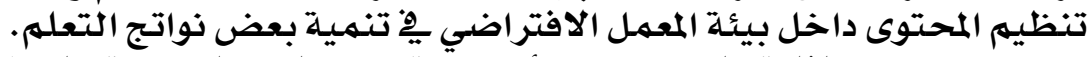

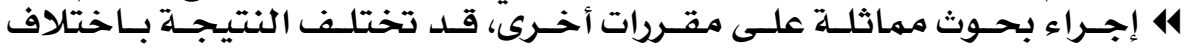
المتحتوى العلمي.

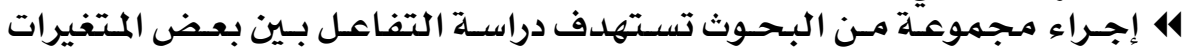

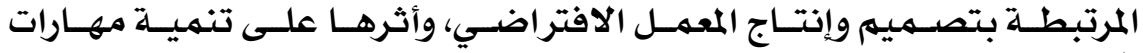

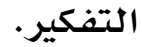

4 اجراء بحوث حول فاعلية استخدام المعمل الافتراضي على متغيرات أخرى.

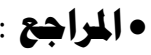

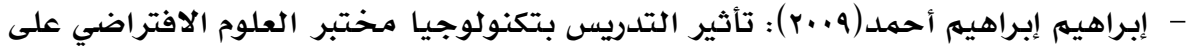

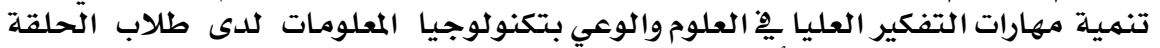

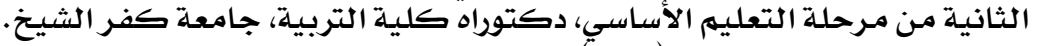

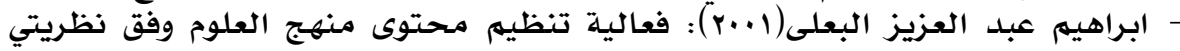

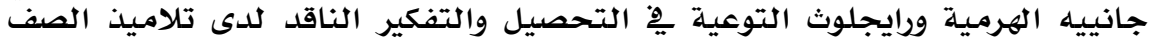

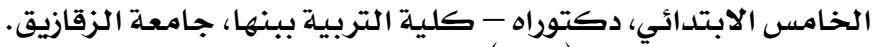

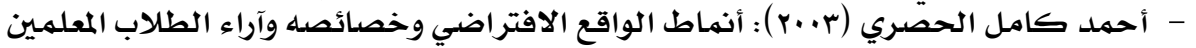

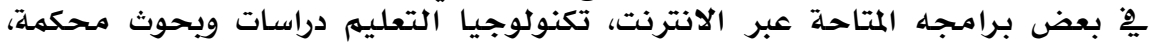

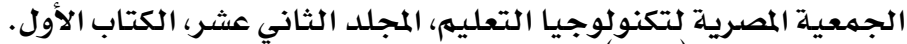

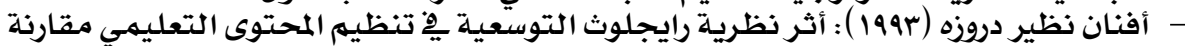

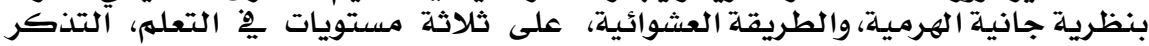

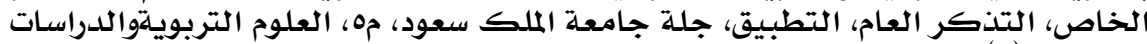

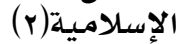

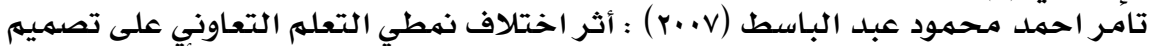

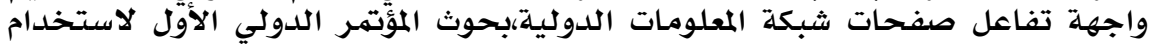

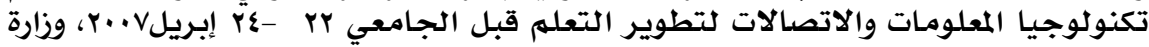
التربية والتعليم، القاهرة.

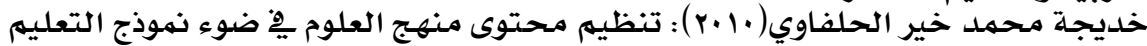

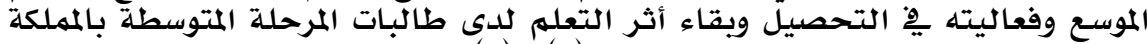

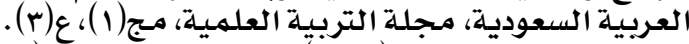

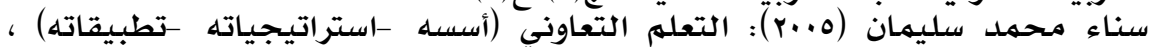

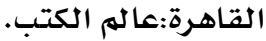

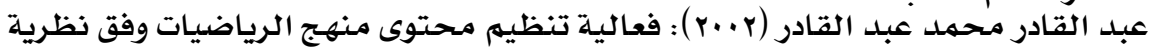

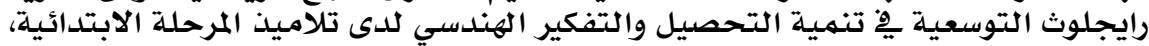

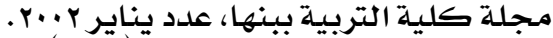

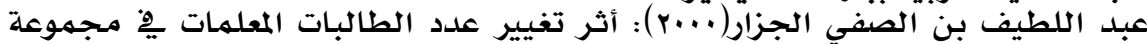

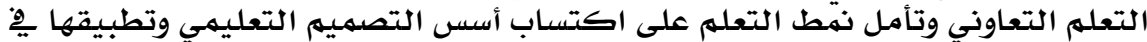

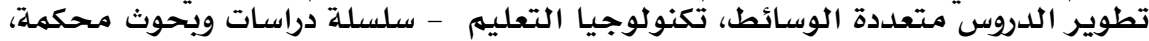

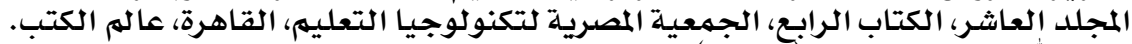

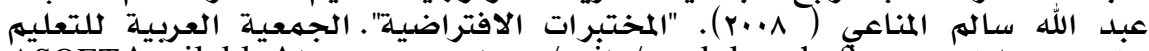

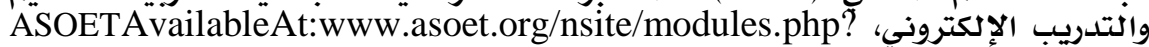
name $=$ news \& file $=$ article \&side $=4$ فؤاد أبو حطب ، آمال صادق أحمد مختار (ع^19) ): علم النفس التربوي، طץ،القاهرة: مكتبة

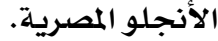


- محمد جاسهم محمد العبيدى : تفريد التعليم والتعلهم المستمر ، القاهرة ، دار الثقافة ،

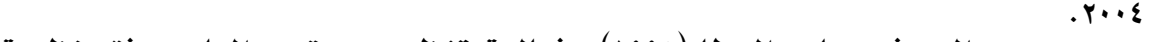

محمد عبد الرعوف صابر العطار(1991): فعالية تنظيم محتوى العلويلوم وفق نظرية

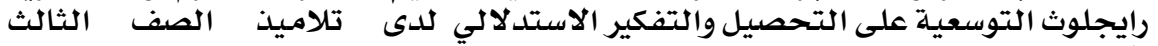

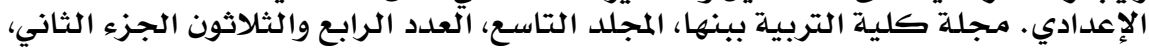

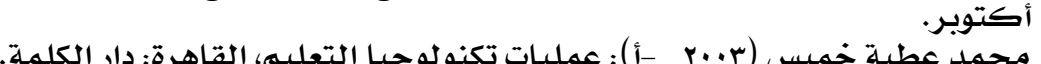

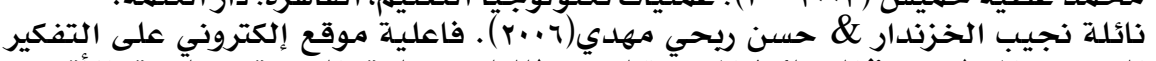

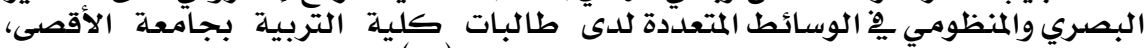

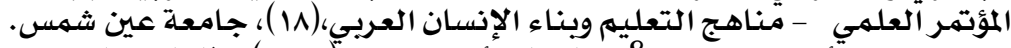

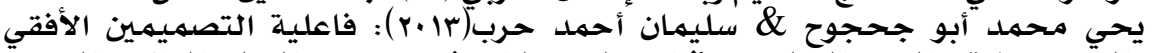

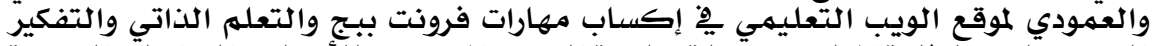

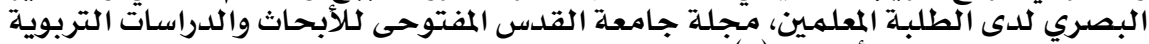

والنفسية - المجلد الأول -علمين (1).

- Ahmad, A. (2010). The effect of using a e-lab on the physics concepts achievement, acquisition of higher-order thinking skills and motivation toward science learning among students of the third preparatory class 'Scientific Journal of Education, 13(6),

- Alexiou, A. Bouras, C. \&Giannaka.E. (2008)." Virtual Laboratories In Education - A cheap way for schools to obtain laboratories for all courses, by using the Computer Laboratory" Available at: http://ru6.cti.gr/ru6/publications/72591064.pdf

- Alsagoff, M. \& Sharifah, H., (2012). A Study of Learning Styles Student Characteristics and Faculty Perceptions of the Distance Education Program at Univ., Edu. Department, Washington Univ., Dis. Abs. Int., No.: AAI8529884.

- Anonymous, S. (2013). Virtual Education in Japan: Training Strategies for Tomorrow, Journal of Educational Technology, Vol. (14), No. (3).

- Babateen, H. M. (2011). The role of Virtual Laboratories in Science Education. In: International Conference on Distance Learning and Education IPCSIT, vol. 12, IACSIT Press, Singapore.

- Bajpai, M. (2013). Developing Concepts in Physics through Virtual Lab Experiment: An Effectiveness Study, An International Journal of Educational Technology, Techno LEARN, vol.3 (1),

- Baran, S. W., Johnson, E. J., Kehler, J. and Hankenson, F.C. (2010).Development and Implementation of Multimedia Content for an Electronic Learning Course on Rodent Surgery. Journal of the American Association for Laboratory Animal Science. 49 (3).

-Bjork, R.A., \& Bjork, E.L. (2006). Optimizing treatment and instruction: Implications of a new theory of disuse.In L.-G. Nilsson and N. Ohta (Eds.), Memory and society: Psychological perspectives, New York: Psychology Press.

- Boling, N, Carol., (2011). Which Method - Individual Learning ,Cooperative Learning Or Interactive Multimedia - Best Enhances Lecture - Based Distance Education, Diss.Abs.Int.,57(11). 
- Bonser, S. P., de Permentier, P., Green, J., Velan, G. M., Adam, P. And Kumar, R. K. (2013). Engaging students by emphasising botanical concepts over techniques: innovative practical

exercises using virtual microscopy.Journal of Biological Education, $47(2)$.

- Browne, M., Freeman, K. (2000).Distinguishing Features of Critical Thinking Classrooms, Teaching in Higher Education, Vol. 5, and Issue 3.

-C. F. Chen, (2014). "The study on Scrom-Based adaptive learning model for the Learning Management System designed," Unpublished education dissertation, National Taichung Teachers College.

-C. P. Chu, C. P. Chang, C. W. Yeh, Y. F. Yeh, (2014) ."A webservice oriented framework for building SCORM compatible learning management systems", Proc. of the Int. Conf. On Information Technology: Coding and Computing (ITCC'04 ‘(Las Vegas, Nevada, USA, vol.(1),.

- Carnevale, D. (2003). The Virtual Lab Experiment some Colleges use Experiment and Science Offerings Online, the chronicle of Higher Education, Vol. (49), No. (21),.

- Cengiz Tuysuz, (2010). The Effect of the Virtual Laboratory on Students' Achievement and Attitude in Chemistry, International Online Journal of Educational Sciences, 2010, 2 (1),.

-Chien, Y. (2004) .The Use of Course Management System in Taiwan EFL Class: A Student Perspective. International Conference Chinese American Educational Research \& Association. 11- 12 April, San Diego, California, USA.

- Coob, S. V. (2007). Virtual Environment Supporting Learning and Communication in Special Needs Education, Journal Articles, Reports Descriptive, Topics in language Disorders, Vol. (27), No. (3), ERIC: (EJ 777672).

- Craig, S.D., Sullins, J., Witherspoon, A., and Gholson, B. (2006).The deep-level-reasoning-question effect: The role of dialogue and deep-level-reasoning questions during vicarious learning. Cognition and Instruction, (24),

-D. Wisell, P. Stenvard, A. Hansebacke, N .Keskitalo, (2007). "Considerations when Designing and Using Virtual Instruments as Building Blocks in Flexible Measurement System Solutions ” Proc. of IEEE IMTC, Warsaw, Poland.

-Dalgarno, B., Bishop, A,. Adlong, W,. \& Bedgood, D. (2009).Effectiveness of a Virtual Laboratory as a Preparatory Resource for Distance Education Chemistry Students, Journal of Computers \& Education, Vol. (53), No. (3),

- Dunbar k. \& Fugelsang J. (2004). Scientific Thinking and Reasoning, In Holyoake K J. \& Morrison R. G. (Eds): The Cambridge handbook of Thinking and Reasoning ,New York, Cambridge University . 
-Faramarz Malekian \& Farzane Moradi Aliabadi (2012). Review of methods of organizing the content of the curriculum in the educational system , based on ICT ( Information and Communication Technology ) from the experts' view, procediaSocial and Behavioral Sciences, Available at: www.ScienceDirect

- Gagne, R. \& Briggs, J. (1979): Principle of Instruction Design, New York,Hold,Rinehart \& Winston.

- Gall, M. (2004). Handbook for Evaluating and Selecting Curriculum Materials, Boston, Allyn and Bacon. Journal of Computers \& Education, Vol. (35), No. (1),.

- Gholson, B., and Craig, S.D. (2006). Promoting constructive activities that support vicarious learning during computer-based instruction. Educational Psychology Review, 18, .

- Hanclosky, W.V., (1986). A Cmparison of Task Analysis, Advance Organizer and Concept of Elaboration Methods in Teaching Concepts and Principles,Eric Document Education.NO.267.

- Hancock, M., (2009). Using Human Performance Technology to Identify Potential Barriers to Online School Course Development. WWW. eric. ed. gov/ ERICDocs/ data/ eriicdocs2sq1/ content.

- Hong-Min Lin, Wan-Ju Chen, and Shu-Fen Nien(2014). The Study of Achievement and Motivation by e-Learning-A Case Study, International Journal of Information and EducationTechnology, Vol. 4, No. 5, October 2014.

- Hsu. N., \& Romance, S. (2012). Virtual Lab VS Remote Labs: Between myth \& reality, center for Distance Educational Technology, Florida Atlantic University, Journal of Research on computing in education. Vol. (28), No. (4).

- Iqbal, Ahmer, Kankaanranta, Marja, Neittaanmäki, Pekka (2010). Experiences and motivations of the young for participation in virtual worlds, Procedia Social and Behavioral Sciences 2 (2010), Available online at www.sciencedirect.com

- James, J. (2011). Interactive Virtual Reality Learning Systems Are They A Better Way to Ensure Proficiency? Available at: http://www.vrmariner.com/vrlearning.html, Last Visited in 15 January, 2011.

- John \& Smith(1989). An Examination of two Approaches to Organizing Instruction .Proceedings of Selected Research Papers Presented at the Annual Meeting of the Association for Educational Communications and Technology,(1-5) February Dallas.Tx.

- Keller, John M., \& Suzuki, Katsuaki (2004). Learner motivation and E-learning design: a multinationally validated process, Florida State University, USA, Journal of Educational Media, Vol.( 29), No.( 3), October 2004.

- Maldarelli, G., Hartmann, E., Cummings, P., Horner, R. Obom, K., Shingles, R., \& Pearlman, R. (2009). Virtual Lab Demonstrations Improve Students' Mastery of Basic Biology Laboratory Techniques. Journal of Microbiology \& Biology Education, (10), 
- Matt Buxton (2008). using visual thinking skills to develop transfer and met cognition ", Djanogly City Academy - Nottingham http://www.assat- inet.net/resources/otc/papers/thinkingmaps using visual, aspx.

- Mohamed Elsayed Ahmed \& Shinobu Hasegawa(2014). An Instructional Design Model for Designing and Producing Online Virtual Labs for Educational Technology Students , International Journal of Digital Information and Wireless Communications (IJDIWC) 4(3).

-Mowshowitz, A. (2005). Virtual organization, Journal of The information society, San Francisco, Vol. (10),

- Parry, Andrew (2012). The Learning Activity Management System, 4Th Annual National VLE Conference-21 June 2004, University of Bristol Learning Technology Support Service.

- Penny, S., \& Taylor, A. \& Janet, K., (2007). "A web2.0/ web 3D Hybrid platform for Engaging Students in e-Learning environments", Journal Articles; Reports - Evaluative Online Submission, Turkish Online Journal of Distance Education- TOJDE. (8), No. (3), (Ed498814).

- Potkonjak, V; Vukobratovi, M; Jovanovi, K; \& Medenica, M. (2010). Virtual Mechatronic/Robotic Laboratory- A Step Further in distance Learning, Computers \& Education, Vol. (55), No. (2),

- R. H. Huang, (2002). "The functions and standards of e-learning management system," Information and education, vol. (89), .

-Redha. H. (2010). Effective use of e-lab for enquiry and demonstration in teaching chemistry on the development of scientific thinking, Journal of Science Education, 13(6), Egypt.

-S. Rapuano, F. Zoino, (2005) .A learning management system including laboratory experiments on measurement instrumentation", IEEE Trans. On Instrumentation and Measurement, vol.55 ‘N.(5),,

- S. S. Ong \& I. Hawryszkiewycz, (2003).“Towards personalized and collabora tive learning management systems," in Proc. 3rd IEEE ICALT Athens, Greece,.

- Sanif ,Noorisham (2010). The Effects of Inquiry-Based Computer Simulation on Scientific Thinking and Conceptual Understanding among School Pupils,http://acec2010.info/proposal/1 534/effectsinquiry-basedcomputer-simulation-scientific-thinking-andconceptual . Retrieved on 10-4-2010

- Sergio Rapuano, Member, IEEE, and Francesco Zoino(2006). A Learning Management System Including Laboratory Experimentson Measurement Instrumentation, IEEE Trasactions on Instrumentation and Measurement, VOL. (55), NO. (5), OCTOBER 2006

-Shank, R. (2012). The Rise of The Virtual University, Quarterly Review of Distance Education, Washington Vol. (3), No. (1),. 
-Stadtlander, Lee M.\& Giles, Martha J. (2010). Virtual Instruction: A Qualitative Research Laboratory Course, Journal, Teaching of Psychology, Vol. (37),

-Stone, D. (2007). Teaching Chromatography Using Virtual Laboratory Exercises, Journal of Chemical Education, Vol. (84), No. (9).

- Tatli, Z., \& Ayasb, A. (2010).Virtual laboratory applications in chemistry education. Social and Behavioral Sciences, vol.( 9),.

-Tillman, Y.V. (2004)." Improving Critical Thinking in second Graders Trough,Instruction and Teacher. Practician Report, Nova South Eastern University. (Ed.373907).

- Toth, E.E. (2009). Designing Blended Inquiry Learning in a Laboratory Context: A Study of Incorporating Hands-On and Virtual Laboratories , Innovative Higher Education , Volume 33, Number:5,march, .

- Tracey, A. \&Stuckey, M. (2007)." Virtual labs in the online biology course students perceptions of effectiveness and usability ", MERLOT Journal of Online Learning and Teaching, Vol. 3,No.2,June.Available At: http://jolt.merlot.org/vol3no2/ stuckey.pdf

- Williama, H., Watts, F., Mathews, A. (1997). Cognitive Psychology and Emotional Disorders.New York,John Wiley,Sons.

- Wu, I., Chen, W. (2013). Evaluating the E-Learning Platform from the Perspective of Knowledge Management: The AHP Approach. Journal of Library and Information Studies, vol .11(1),

- Yang, K, \& Heb, J. (2007). The Impact of Internet Virtual Physics, Science Process Skills and Computer Attitudes of 10th Grade Students, Journal of Science Education and Technology, Vol. (16), No. (5),

- Yiar, M., \& Litvak, S. (2011). 3D Virtual Reality in Science Education: An Implication for Astronomy Teaching, Journal of Computers in Mathematics Science Education, Vol. 20, No. (3),.

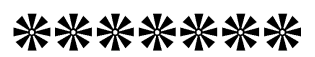




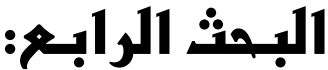

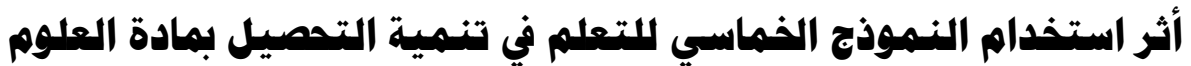
و ههارات التفكير الناقد لدى تلميذات التصف السادس الابتدائي بمدينة جدة

$$
\begin{aligned}
& \text { : إلطإ } \\
& \text { د/ وداد عبدالسميع إسماعيل نورالدين } \\
& \text { أستاذ مشارك المناهـج وطرق تدريس العلوم }
\end{aligned}
$$

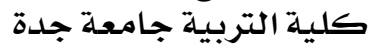





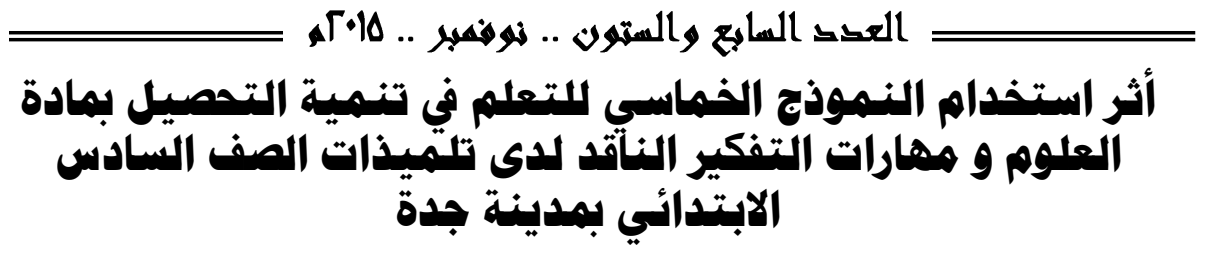

د / وداد عبل السميع إسماعيل نور اللدين

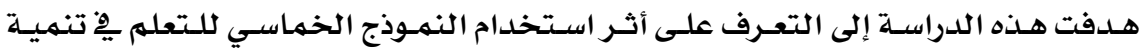

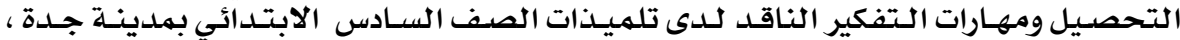

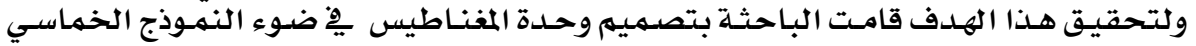

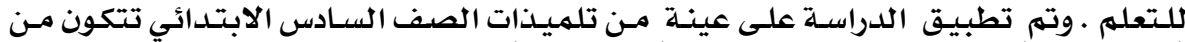

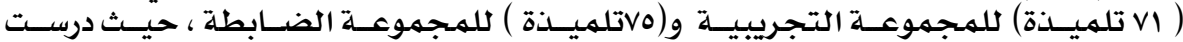

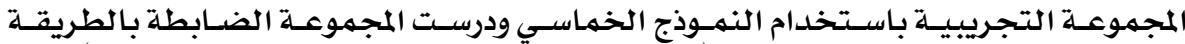

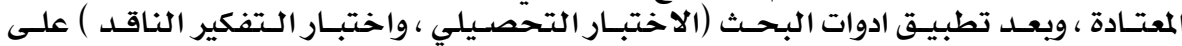

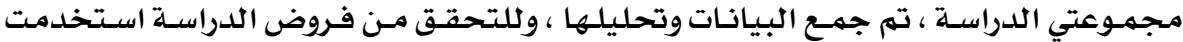

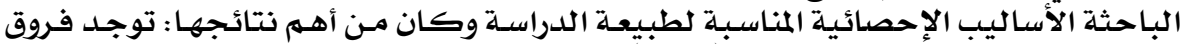

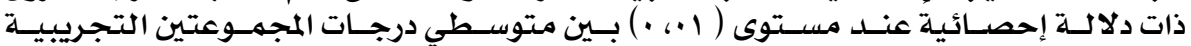

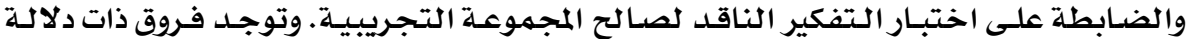

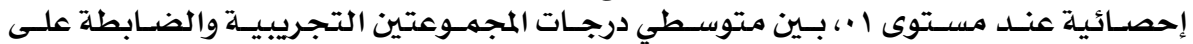

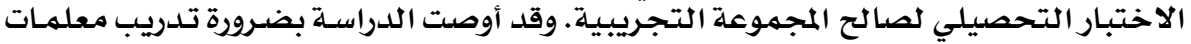

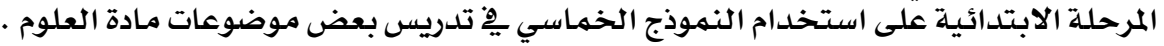

\section{The Impact of the 5-Es model of learning in the development of critical thinking skills among Students in primary school}

\section{Dr. Wedad Abdulsamie Ismail Nooraldeen}

\section{Abstract:}

This study aimed to investigate the impact of using the 5-Es model of learning in developing critical thinking skills among primary school pupils. The sample consist of (71 pupils)in the experimental group, whereas the control group consisted of (75 pupils).The finding revealed that there is significant difference in the critical thinking test between the experimental group and control group due to teaching method in favor of the experimental group at the significant level of 0.01. Also the finding revealed that there is significant difference in the achievement test between the experimental group and control group due to teaching method in favor of the experimental group at the significant level of 0.01. The research findings indicated the necessity of adapting the 5-Es model in teaching as it would raise student's performance.

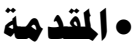

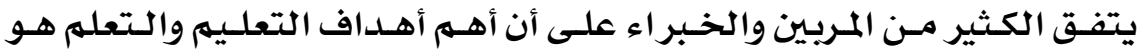

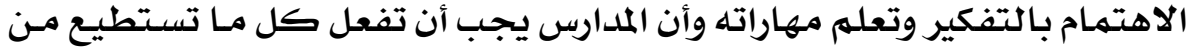

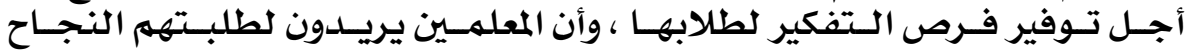




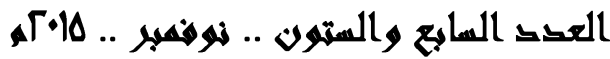

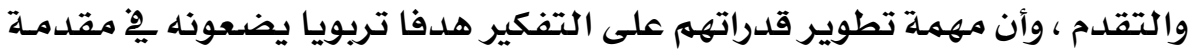

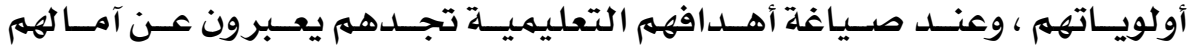

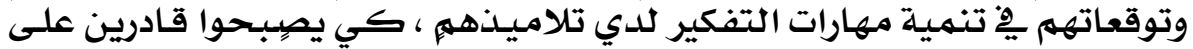

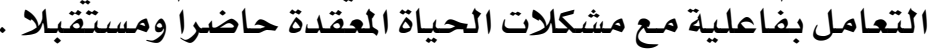

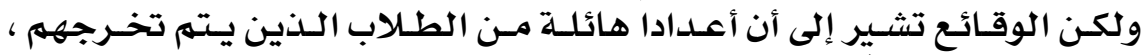

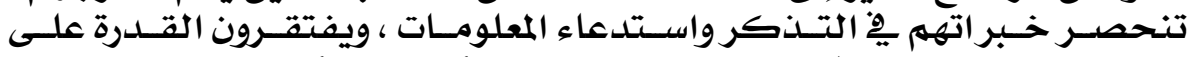

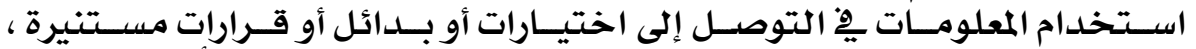

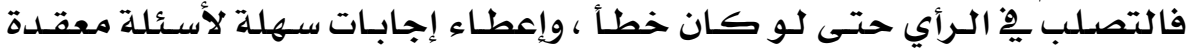

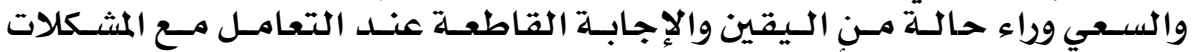

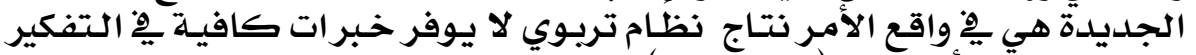

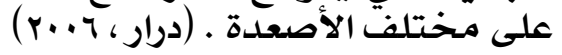

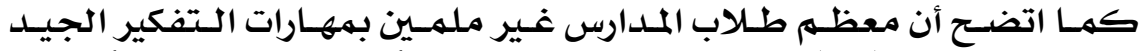

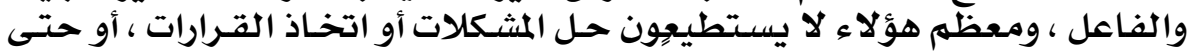

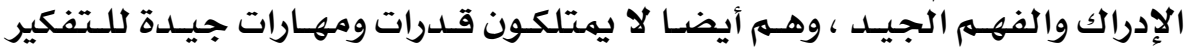

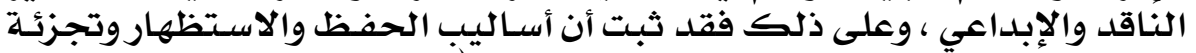

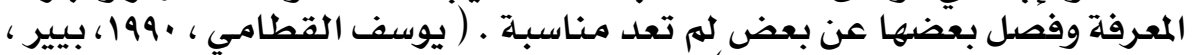

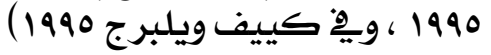

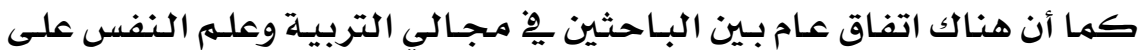

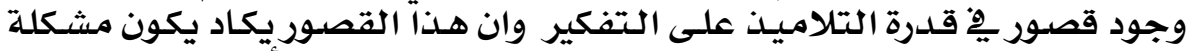

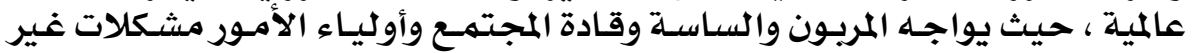

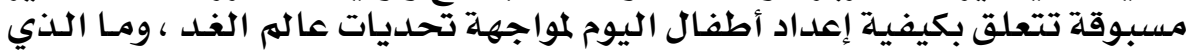

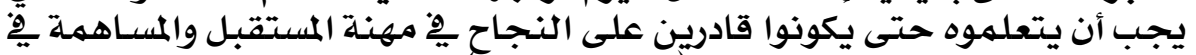

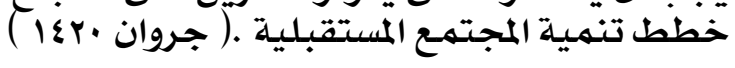

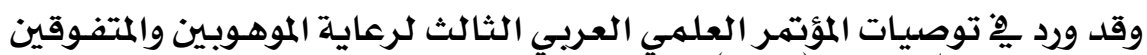

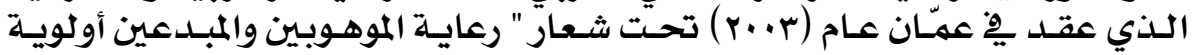

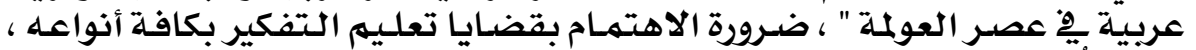

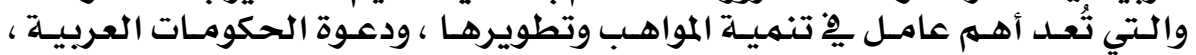

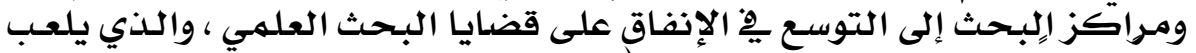

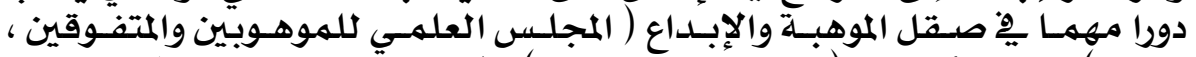

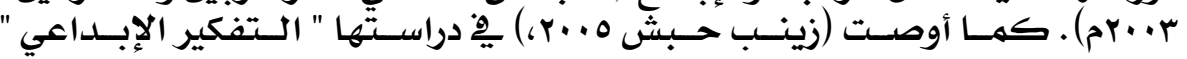

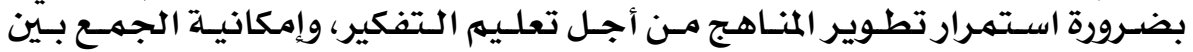

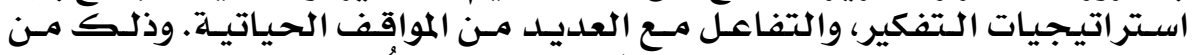

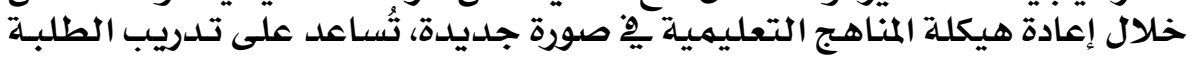

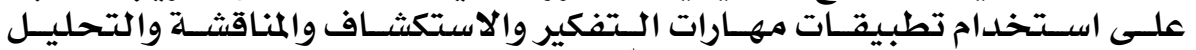

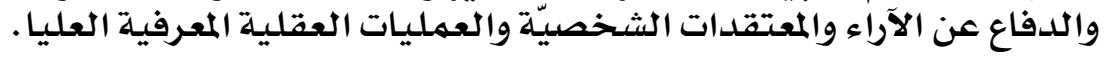

ويعتبر التفكير الناقد أحسد أنهـاط التفكير المختلفـة الـتي تسـاعد المتعلهم فِ

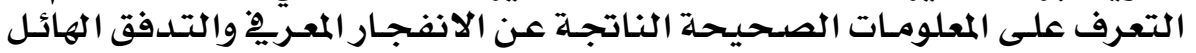




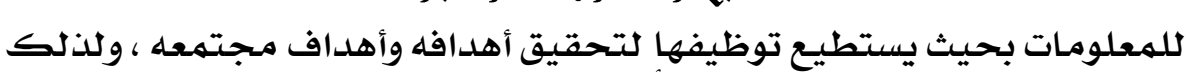

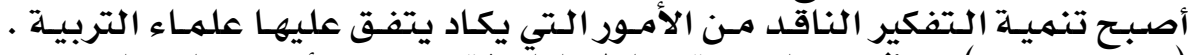

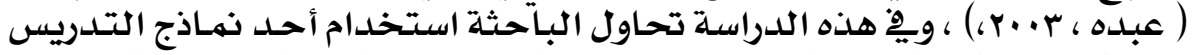

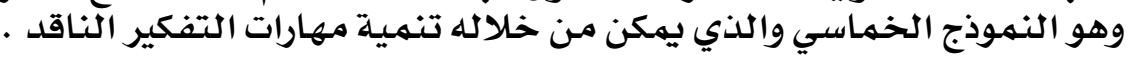

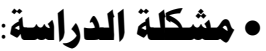

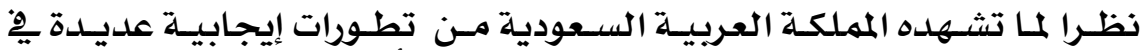

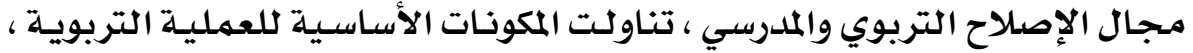

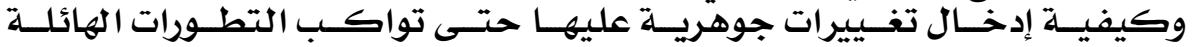

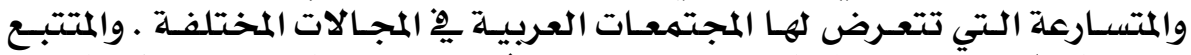

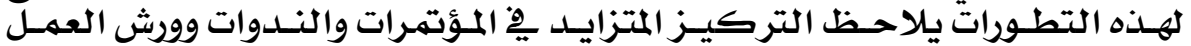

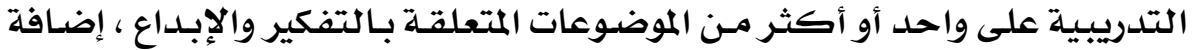

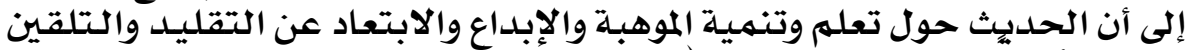

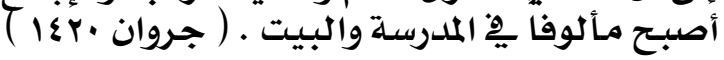

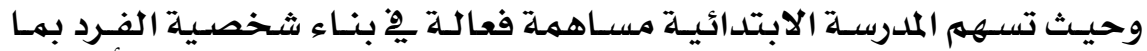

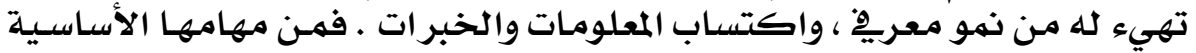

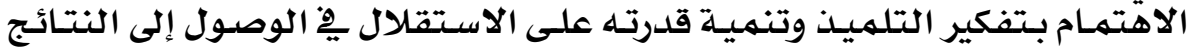

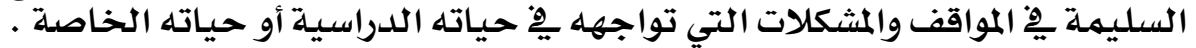

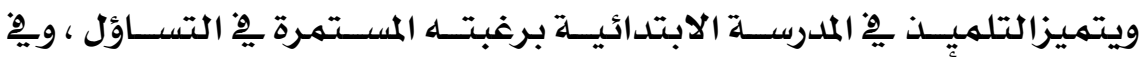

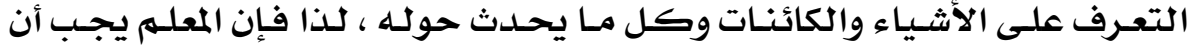

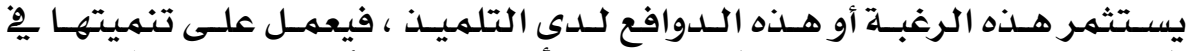

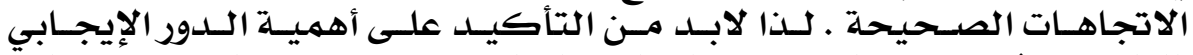

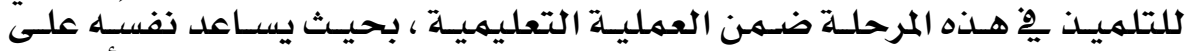

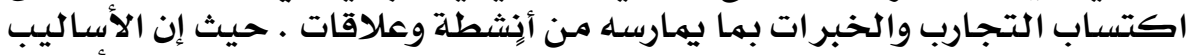

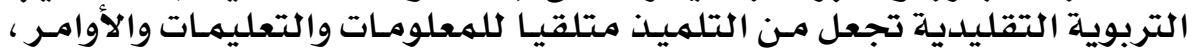

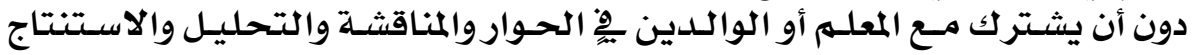

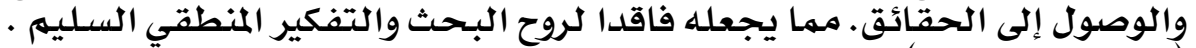

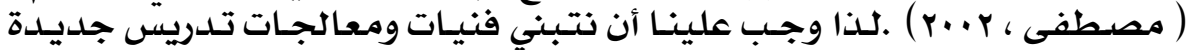

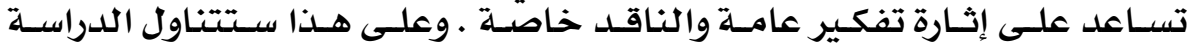

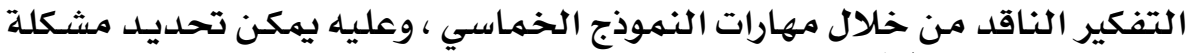

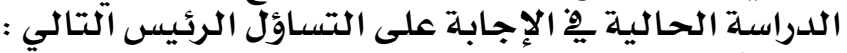

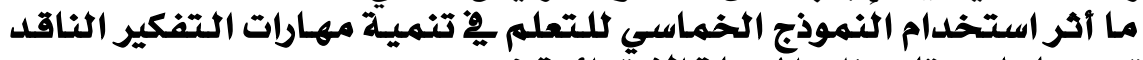

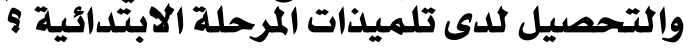

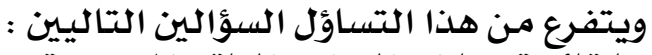

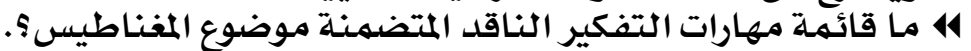

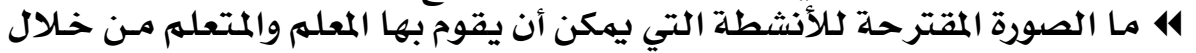

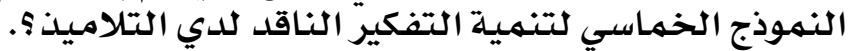

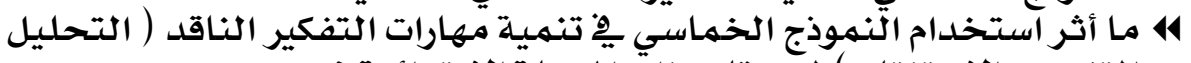

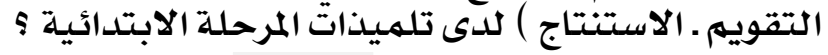

\section{$1 \& 9$}




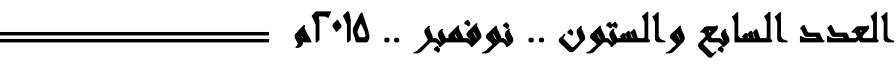

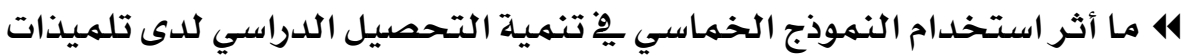

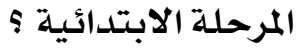

• فروض الدراسة :

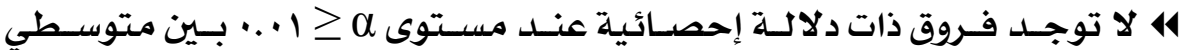

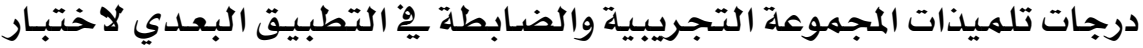

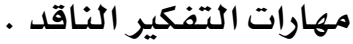

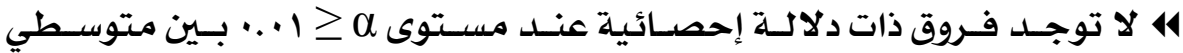

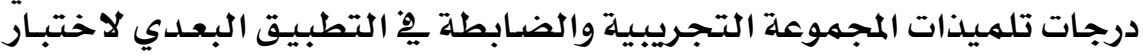
التحصيل الدراسي. • أهميسية الدراستة :

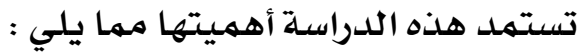

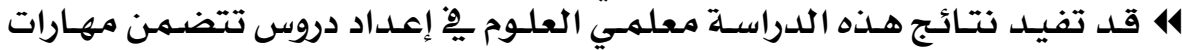
التفكير الناقد

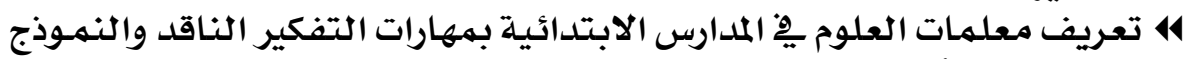

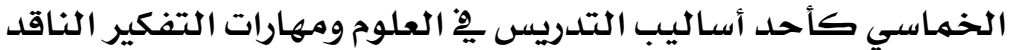

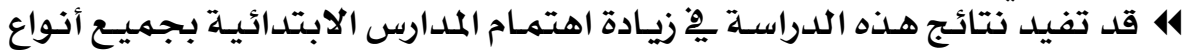
مهارات التفكير نتانج

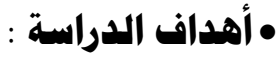
هدفت الدراسة إلى التعراسة : هدرف على :

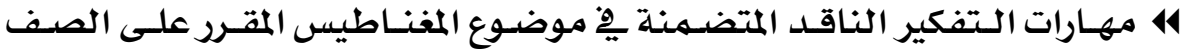

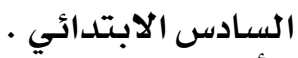

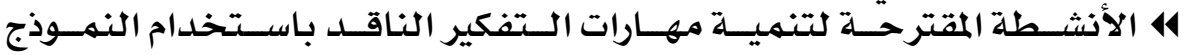

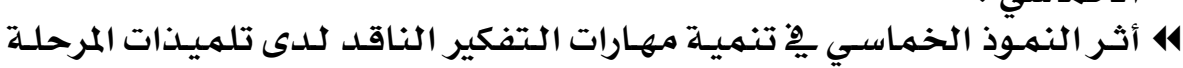

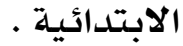

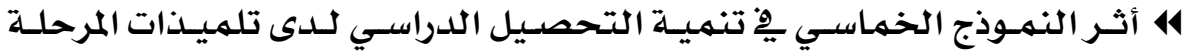
الابتدائية.

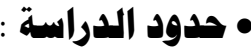

التزمت الدراسة بالحدود البدود التالية :

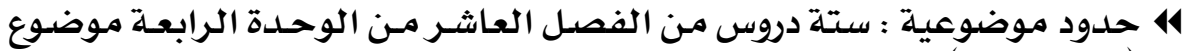

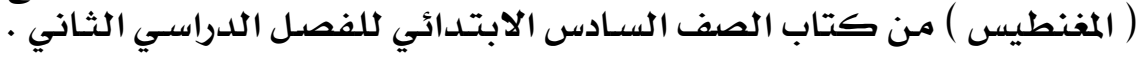

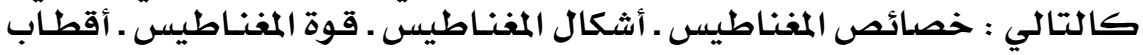

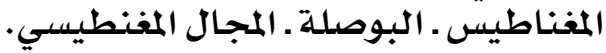
4 حلدود بشرية : تلميذات الصف السـادس الابتدائي يِّ المملكة العربية السعودية

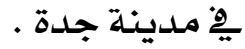
4 حلدود زمنية : الفصل مدل الدراسي الثاني من العام عبـ اهـ 


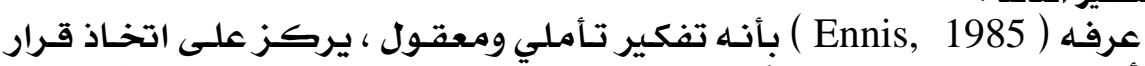

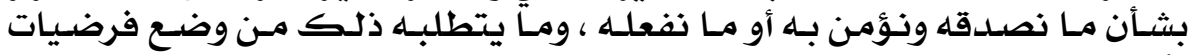

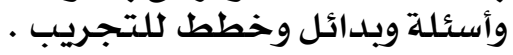

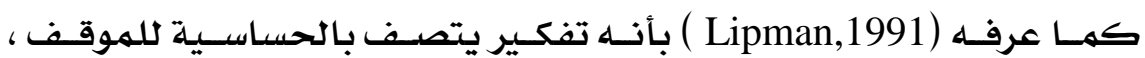

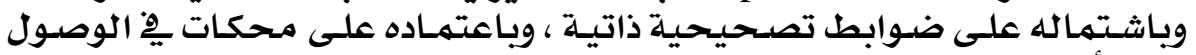

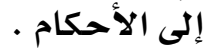

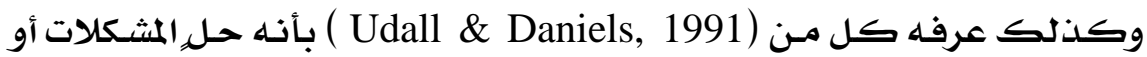

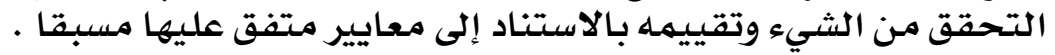

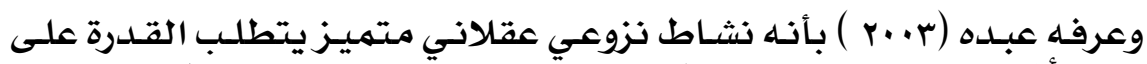

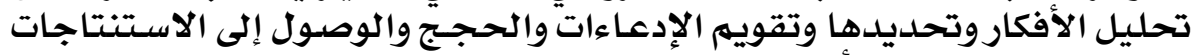

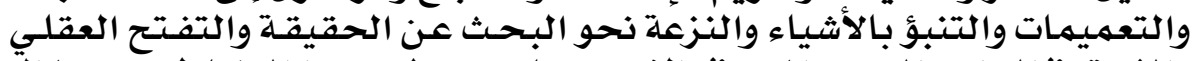

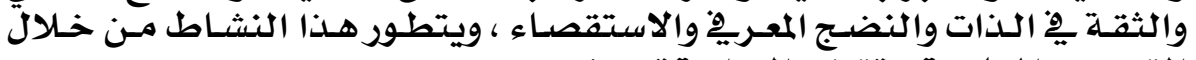

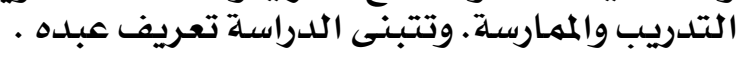

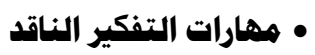

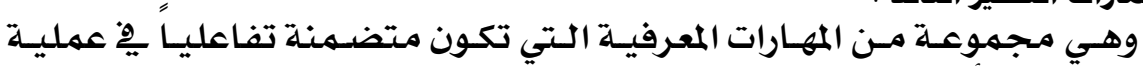

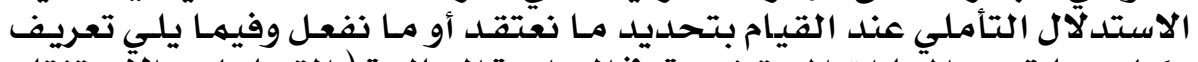

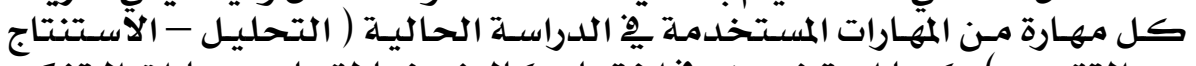

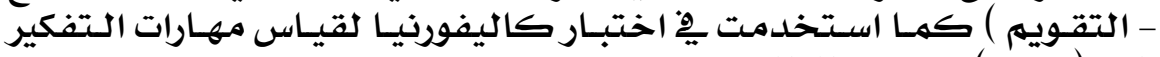

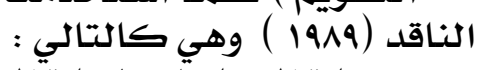

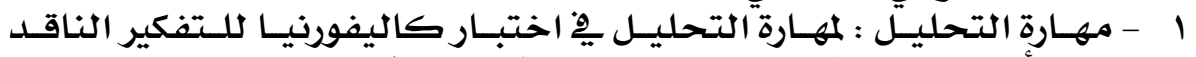

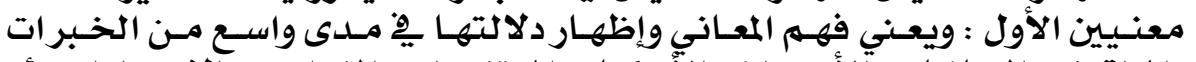

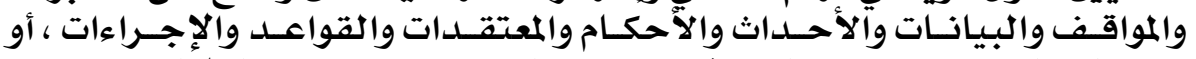

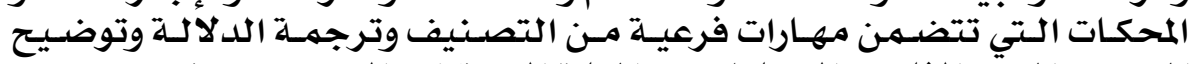

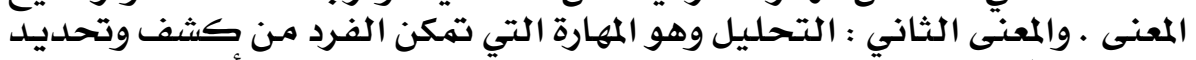

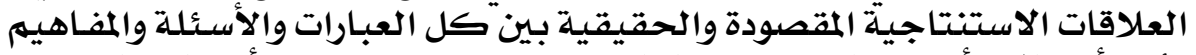

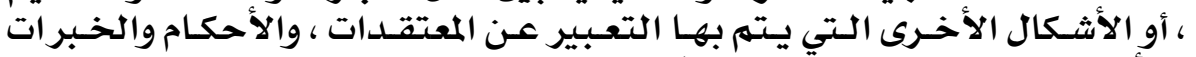

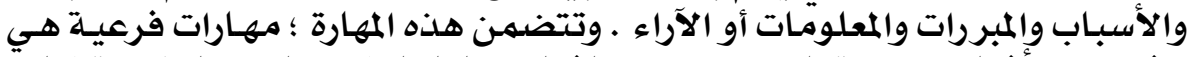

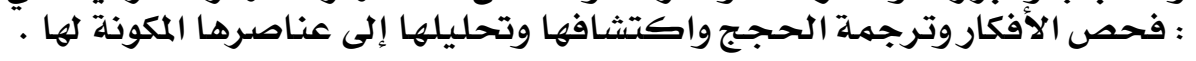

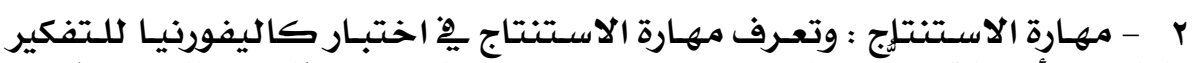

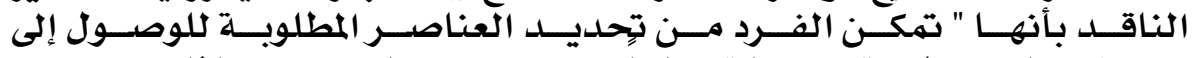

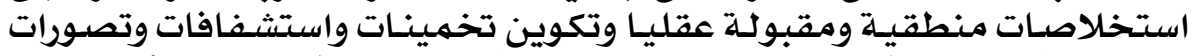

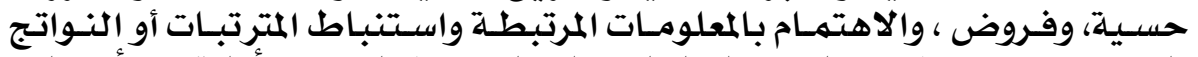

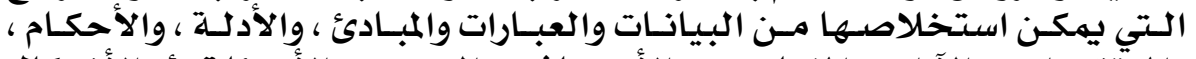

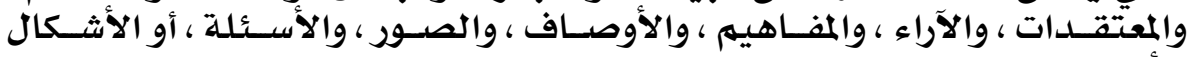

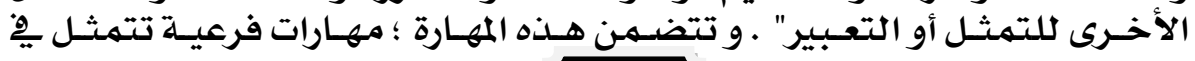

\section{1}




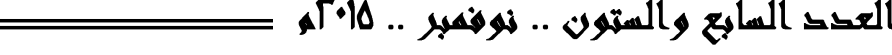

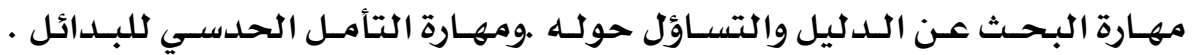

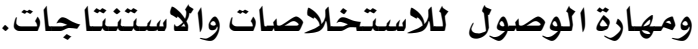

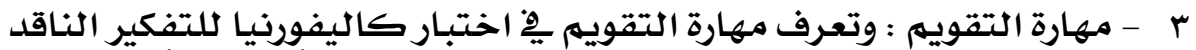

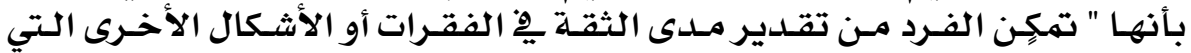

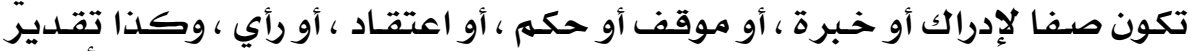

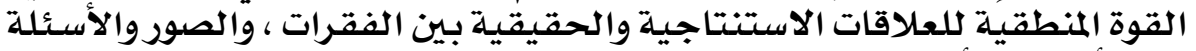

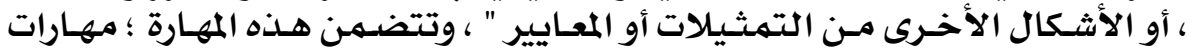

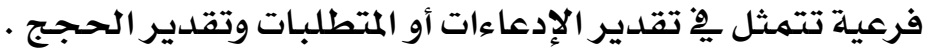

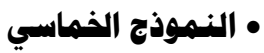

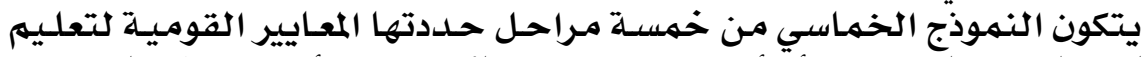

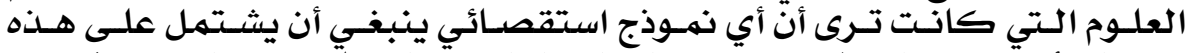

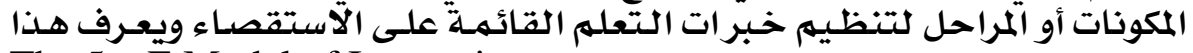

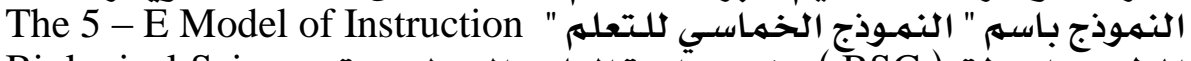

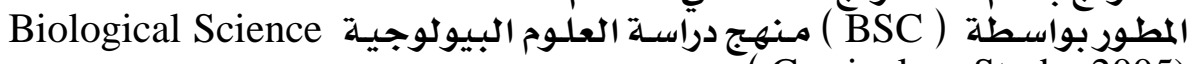

(Curriculum Study, 2005)

وقد تم الاعتمـاد على هـذا النهـوذج بنـاءً على المسلمات والافتراضـات الآتيـة :

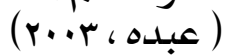

4 يستمد هذا النموذج فلسفته مـن فلسفة المعايير القومية لتعليم العلوم التئي

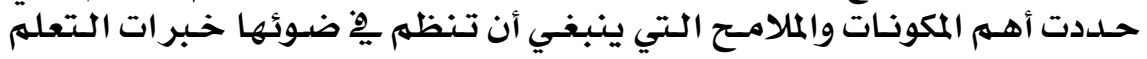

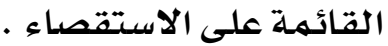

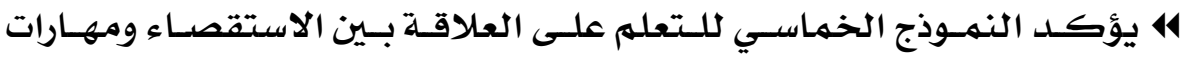

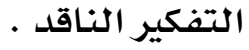
4 جميـع عمليـات النهـوذج الخماسـي المقـترح يمكسن ترجمتهـا إلى سـلوكيات

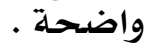

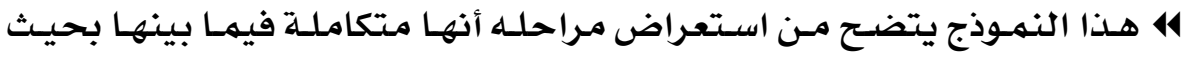

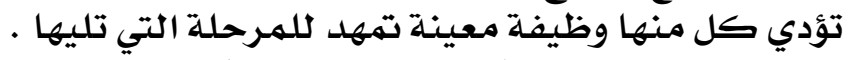

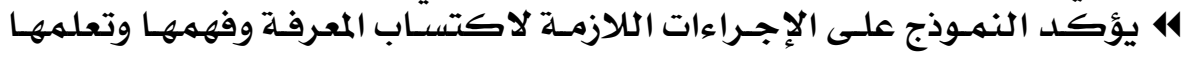

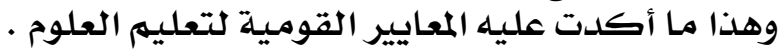

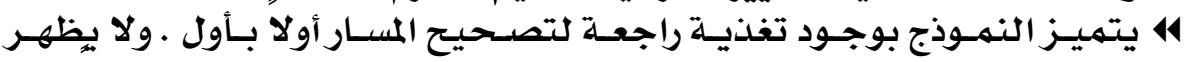

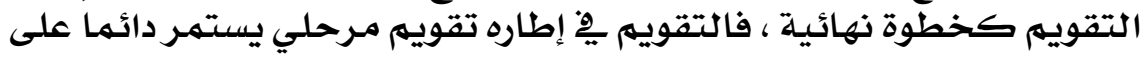

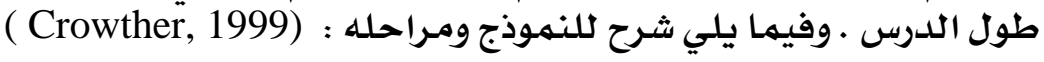

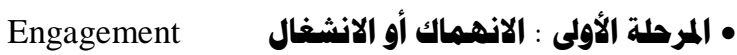

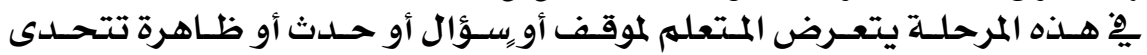

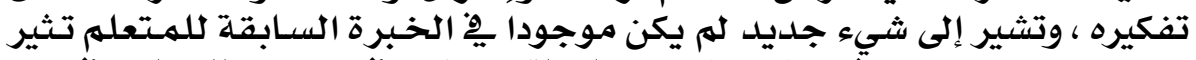

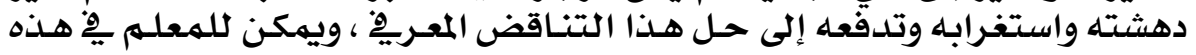

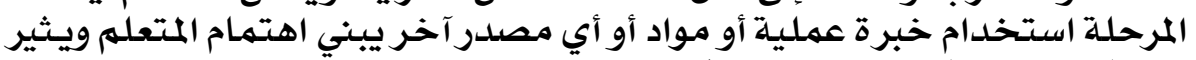

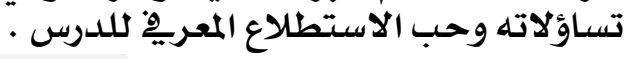

10Y

دراسات عربية في التربية وعلم النفس (ASEP) 


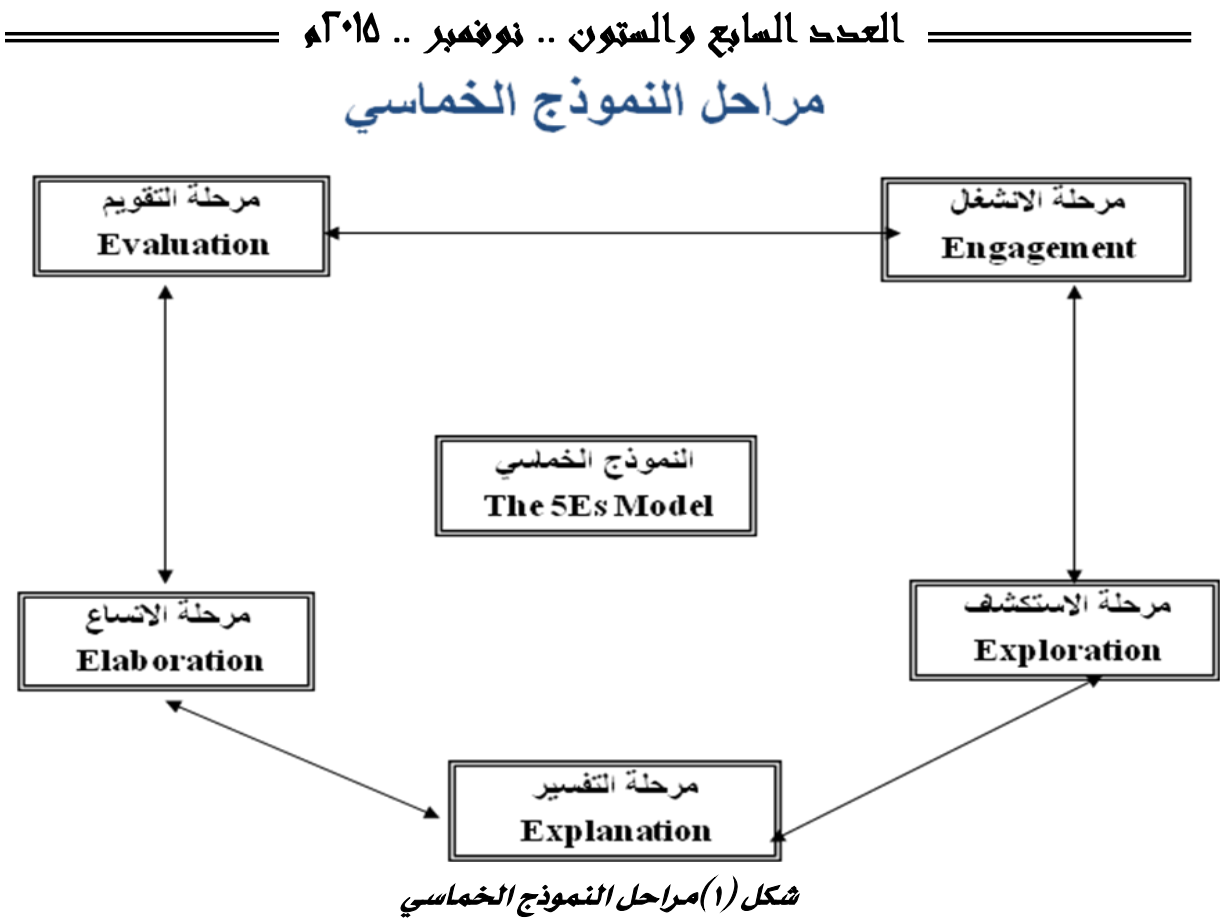

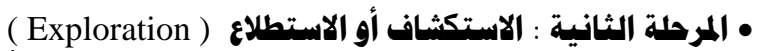

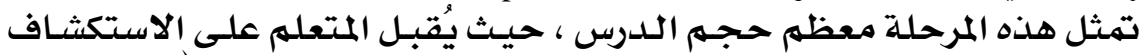

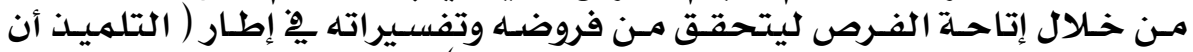

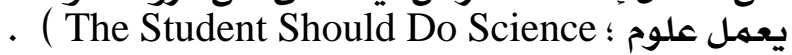

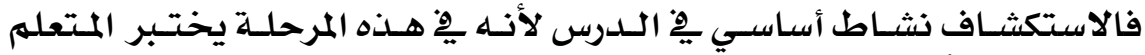

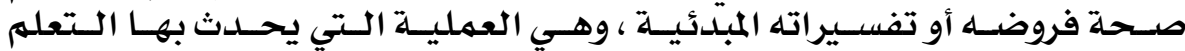

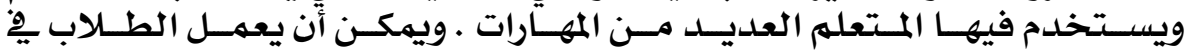

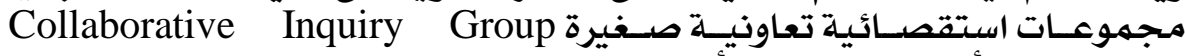

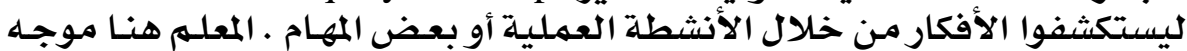

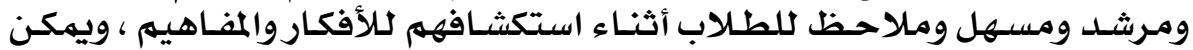

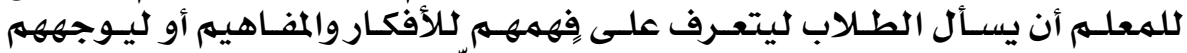

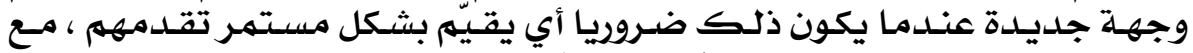

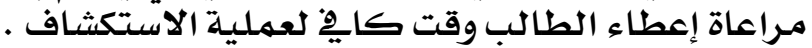

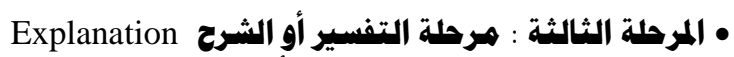

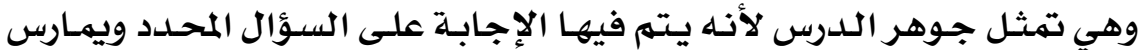

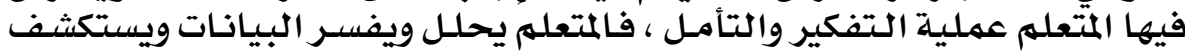

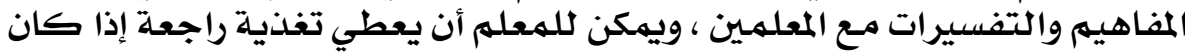

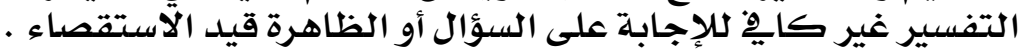




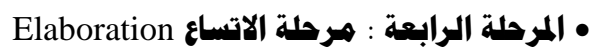

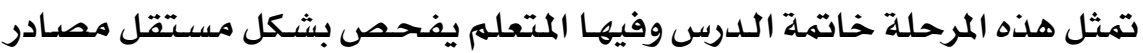

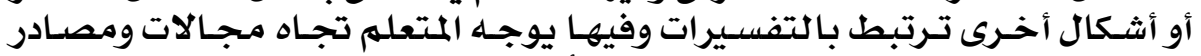

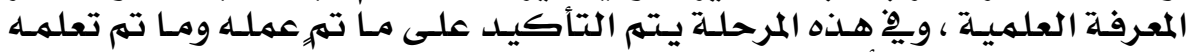

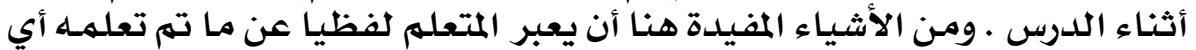

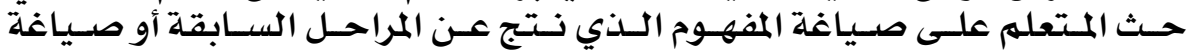

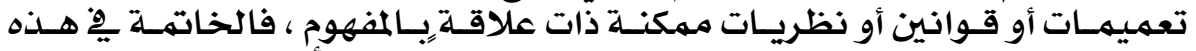

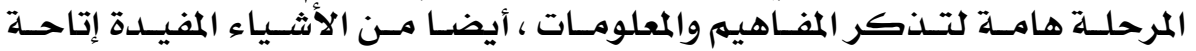

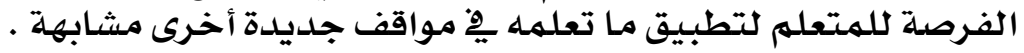

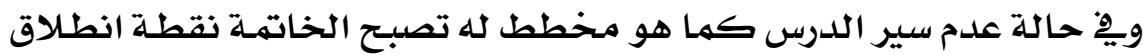

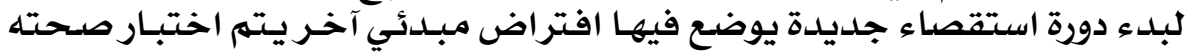

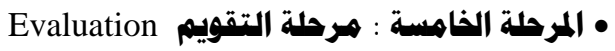

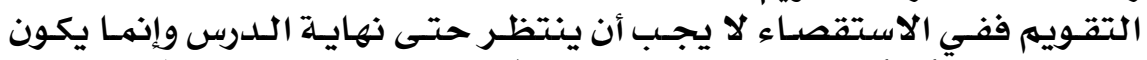

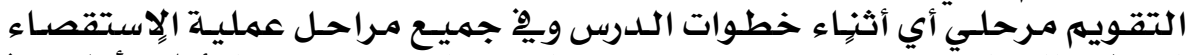

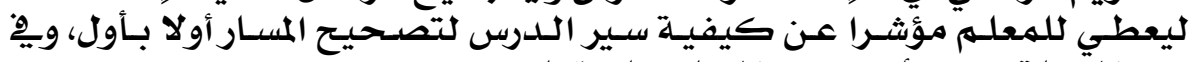

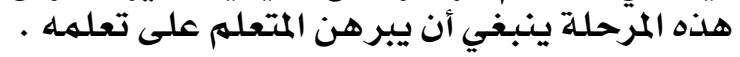

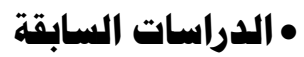
قامت كثير من البحوث البهاث للتعامل مـع التفكير الناقد من وجوه عديدة ، نـذكر

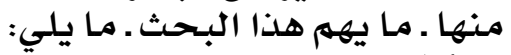

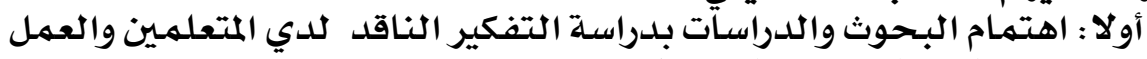

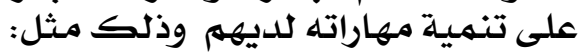

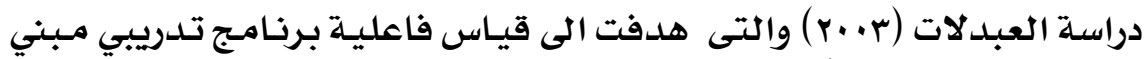

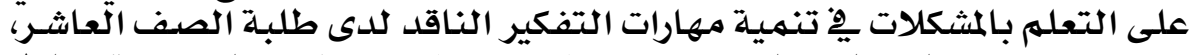

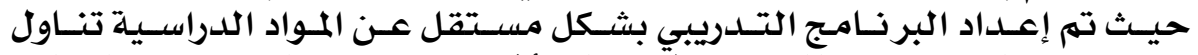

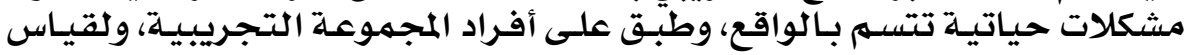

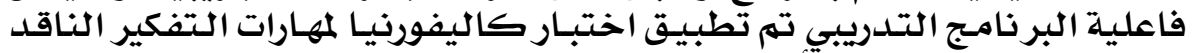

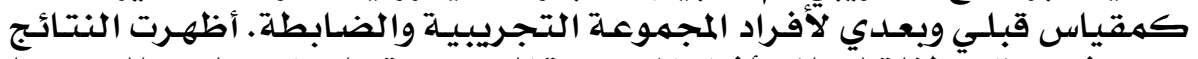

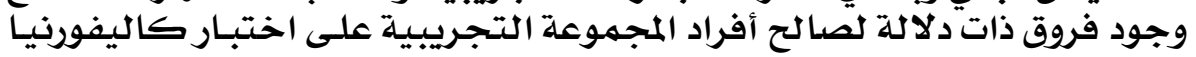

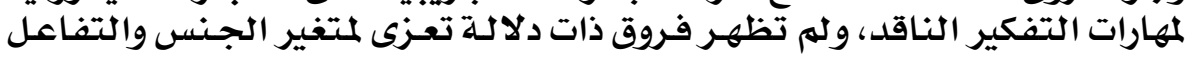

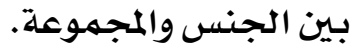

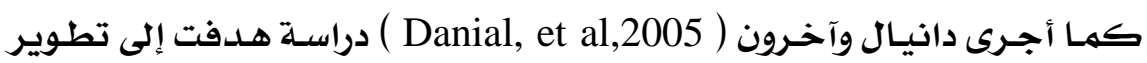

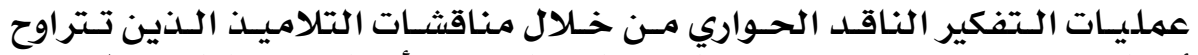

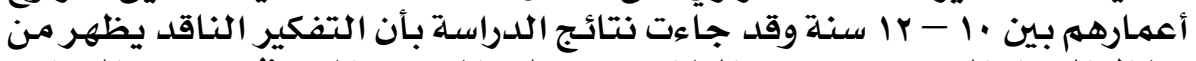

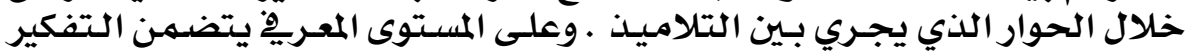

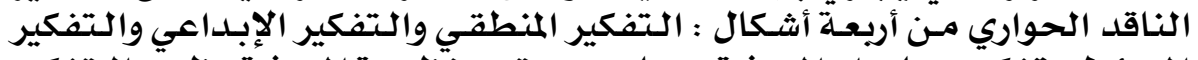

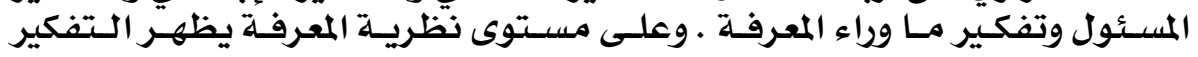

\section{$10 \varepsilon$}




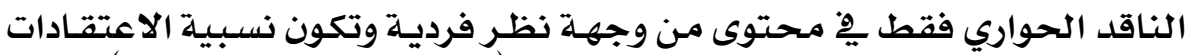

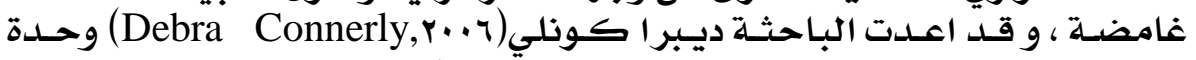

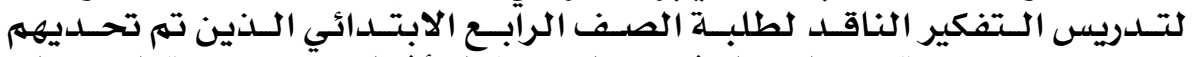

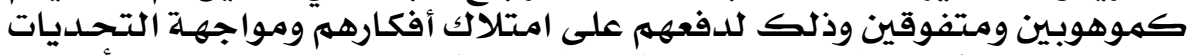

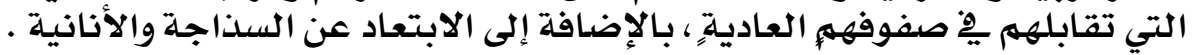

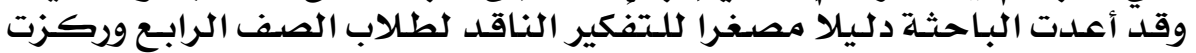

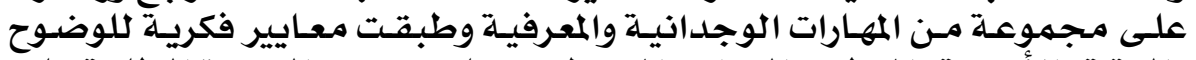

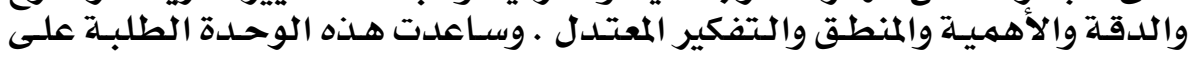

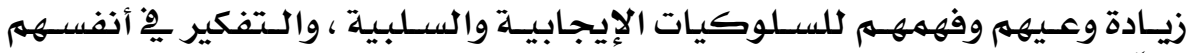

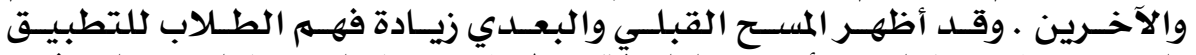

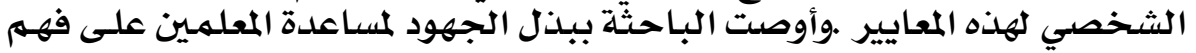

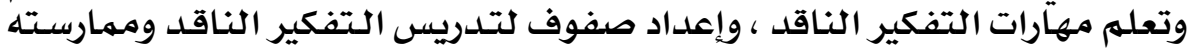
وتوقعه. - وتهار

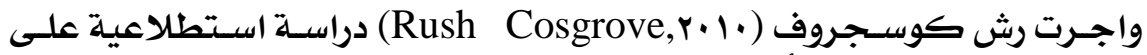

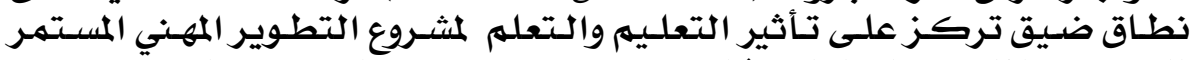

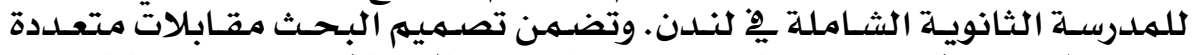

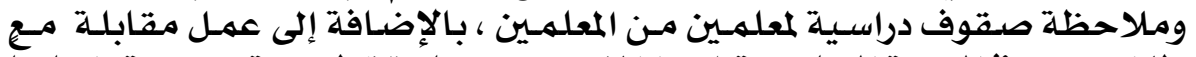

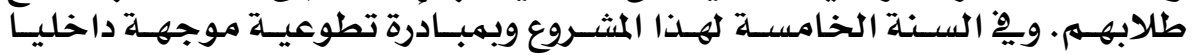

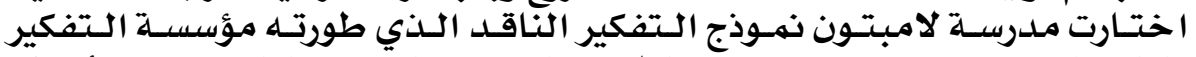

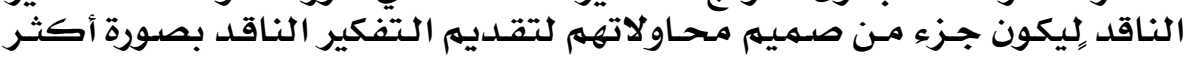

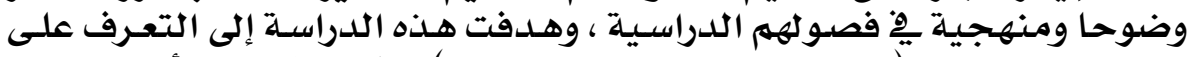

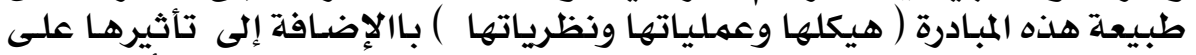

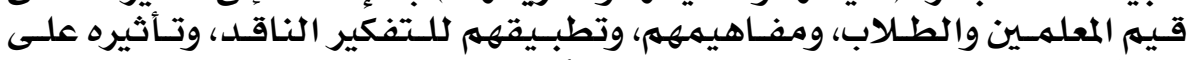

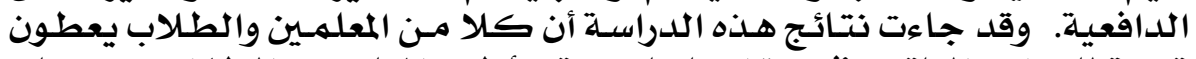

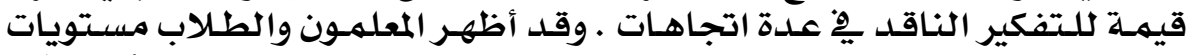

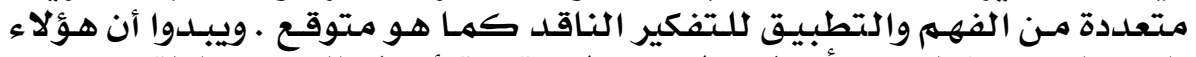

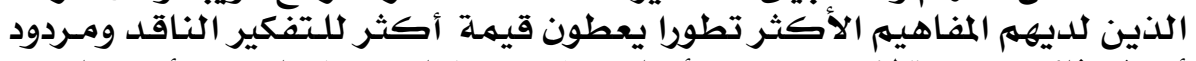

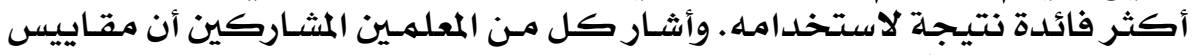

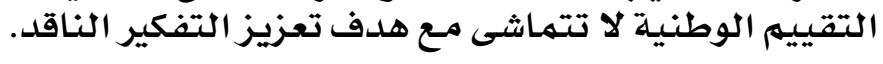

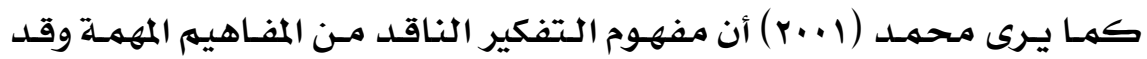

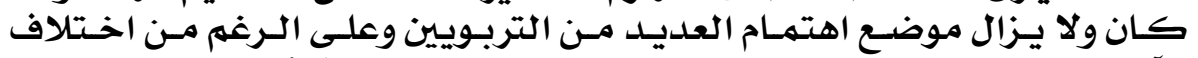

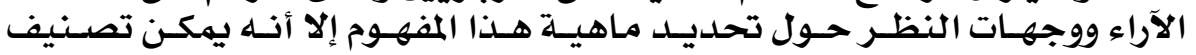

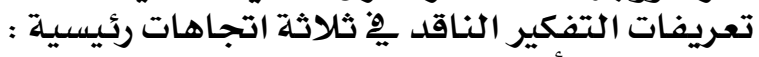

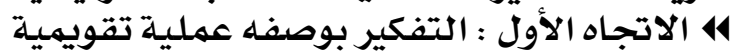

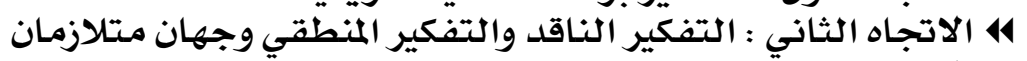

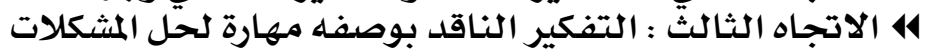

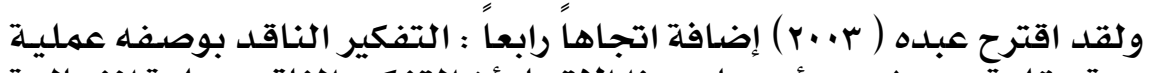

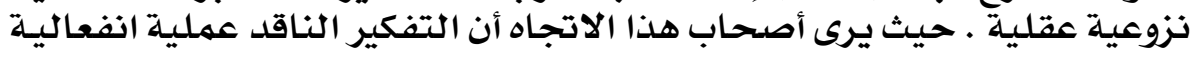

\section{0}

دراسات عربية في التربية وعلم النفس (ASEP) 


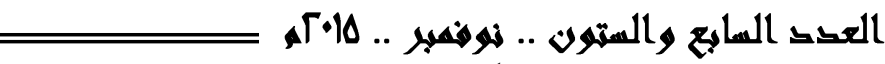

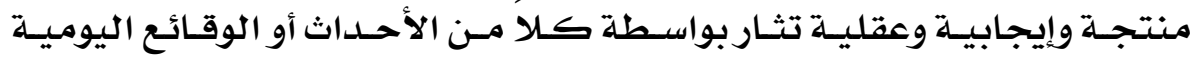
الإيجابية والسلبية .

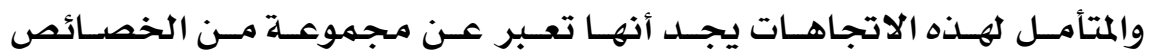

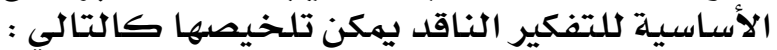

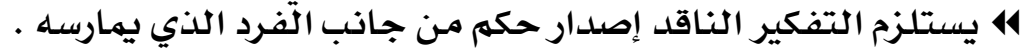

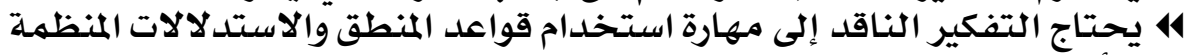

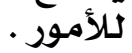
4 ينطوي التفكير الناقد على مجمهوعة من نزعات واتهات ومهارات التفكير التي يهكن

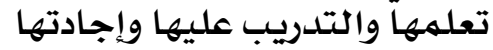

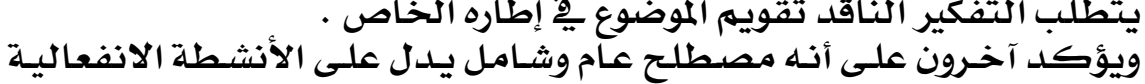

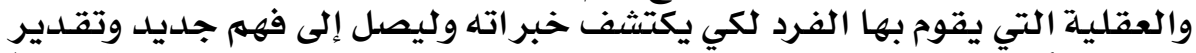

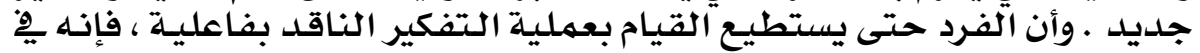

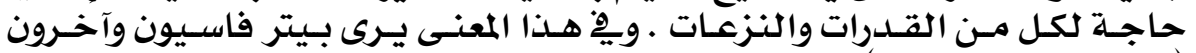

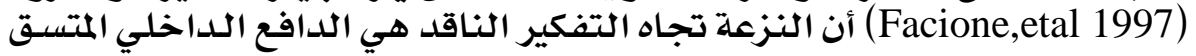

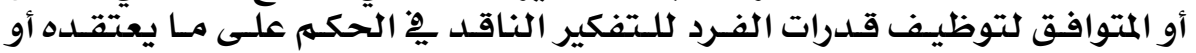

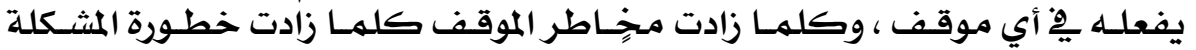

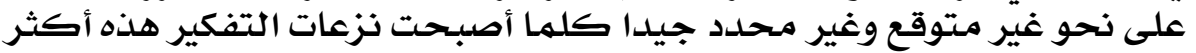

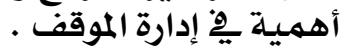

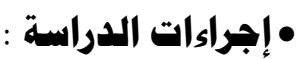

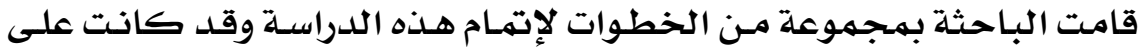
النحو التالي: قالباحت

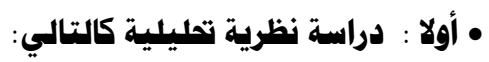
1

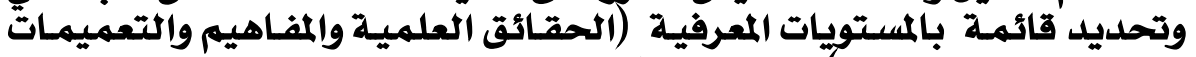

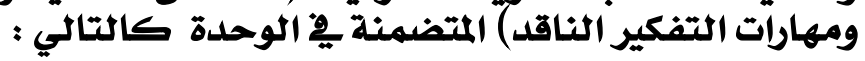

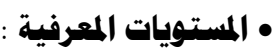
أولا : الحويات الحقائق : ل اولجذب المغناطيس الأثياء المصنوعة مـن الحديــ أو المواد التي يـدخل فيها الحديد

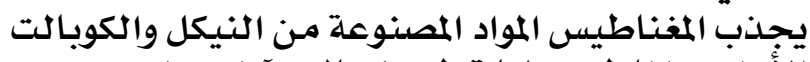

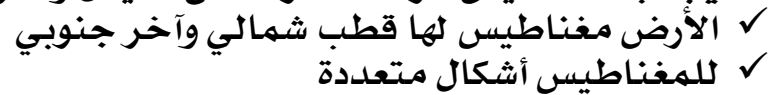
$\checkmark$

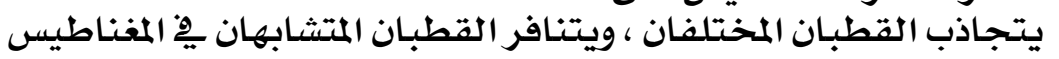

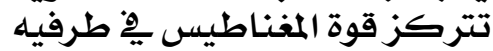

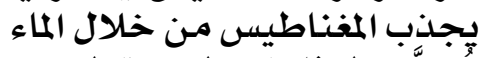
$\checkmark$

\section{7}




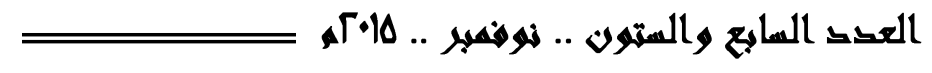
لكل مغنطيس قطبان شمالي وجنوبي

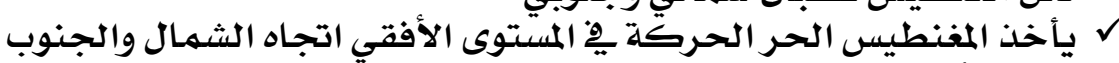
$\checkmark$ $\checkmark$

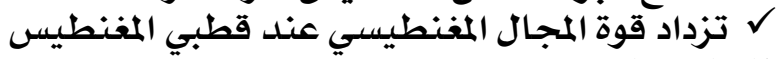
414

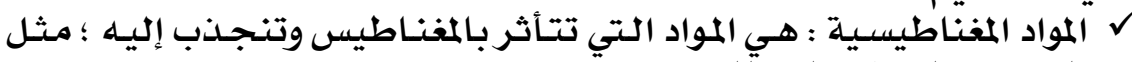

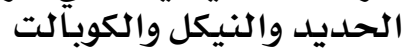

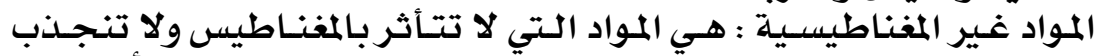

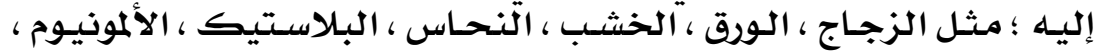
الفلين الئه ل البوصـلة : عبـارة عـن إبـرة مغناطيسـية حـرة الـدوران تسـتخدم ِِِ معرفـة الجهات الأصلية البعارة

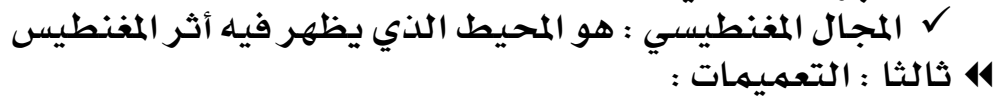
$\checkmark$

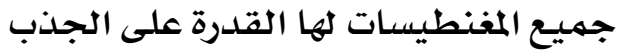

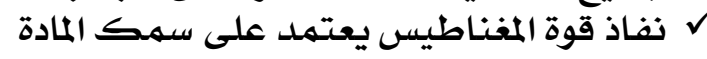
$\checkmark$ $\checkmark$

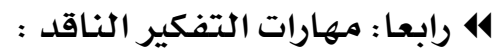

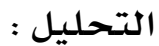
$\checkmark$ $\checkmark$ $\checkmark$

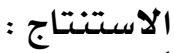
$\checkmark$ $\checkmark$

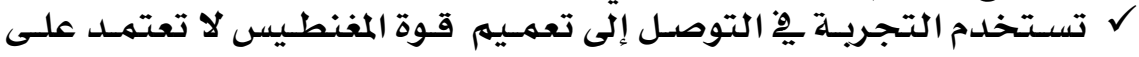
شكله أو حجمهـ التقويهم : توله

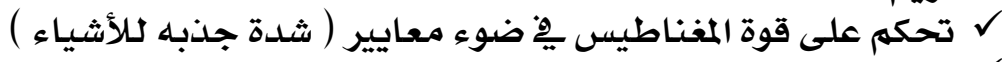
$\checkmark$ $\checkmark$ • - أ - مدق التحليل

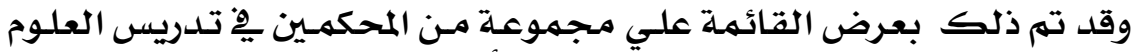

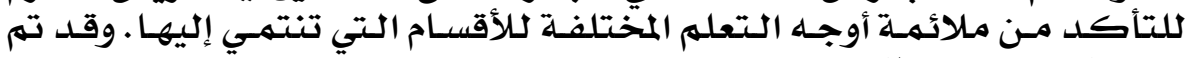

\section{IOV}




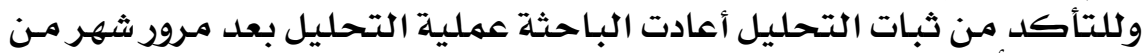

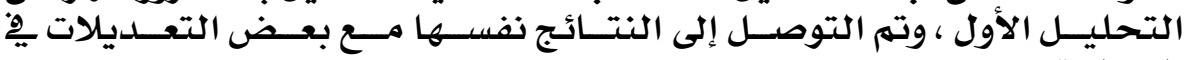
الصياغة.

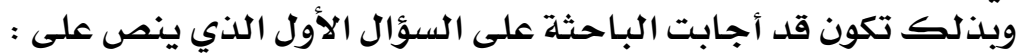

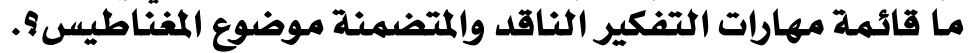

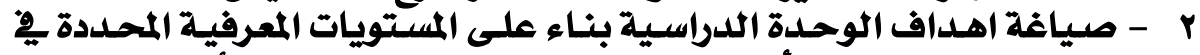

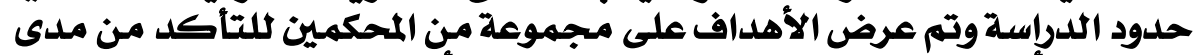

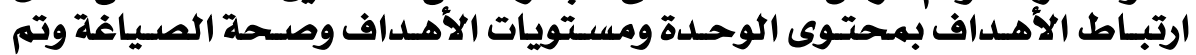

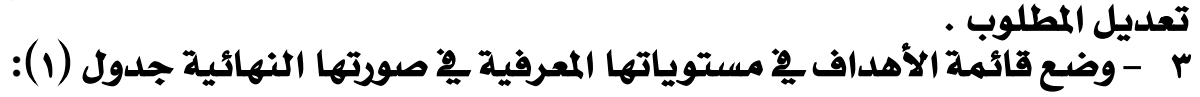
جلدول (1) قائمة الأهداف ووستوياتها المعرفية

\begin{tabular}{|c|c|c|}
\hline $\begin{array}{l}\text { المعريتوي } \\
\text { المعبري }\end{array}$ & الهدف السلوكي & p \\
\hline \multirow{8}{*}{ تلذكر } & تذكرخاصية المغناطيس الأساسية & 1 \\
\hline & تعرف مفهوم المغنطيس & $r$ \\
\hline & تسمي ثلاث من المواد التي لا يجذبها المغناطيسي & $r$ \\
\hline & تسمي ثلاث مواد بمكن أن يجذبها المغناطيسي & $\varepsilon$ \\
\hline & تذكر اسمى أطراف المغنطيس & 0 \\
\hline & تذكر تعريف البوصلة & 1 \\
\hline & تعرّف المحال المغنطيسي & $v$ \\
\hline & تذكر اسيم المنطقة التى يظهر يها تأثير المغنطيسي & $\Lambda$ \\
\hline \multirow{13}{*}{ 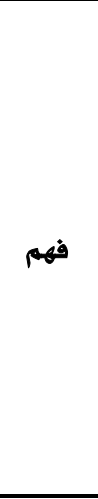 } & تقارن بين المواد المغنطيسية وغير المغناطيسية & 9 \\
\hline & توضح العلاقة بين شكل المغناطيس وقوته & 1. \\
\hline & تحلد أي من أثكال المغنطيسات قادرة على جذب المواد & 11 \\
\hline & تحدد مكان تمركز قوة المغنطيسي & ir \\
\hline & تبر رعدم جذب المفنطيس لمادة حديلية خلف قطعة خشب سميكة & ir \\
\hline & تصف كيفية تحليل قطبي المغنطيس الشمالى والجنويى & $1 \varepsilon$ \\
\hline & توضح تسيمية أقطاب المغنطيس بالقطب الشمالى والجنويى & 10 \\
\hline & تشرح لما يتجه المغنطيس للشمال الجغرإ2 دائما & 17 \\
\hline & تشرح ماذا بحلدث للأقطاب المتماثلة إذا اقتربت من بعضها البعض & iv \\
\hline & تشرح ماذا يحدث للأقطاب المختلفة إذا اقتربت من بعضها البعض & 11 \\
\hline & 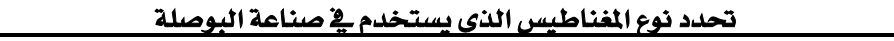 & 19 \\
\hline & تبين لما يستخدم النحاس فِ صناعة العلبح التى توضع فيها البوصلة & $r$. \\
\hline & تحلد المنطقة التي تزداد فيها قوة المجال المغنطيسي & YI \\
\hline \multirow{9}{*}{ تطبيق } & تحري تحرية بسيطة لفصل أثياء مصنوعة من الحديل & rr \\
\hline & تجري تجارب للتمييزين المغناطيس القوى والضعيف & $r r$ \\
\hline & تجري تجرية لمعرفة مدى جذب المغنطيس من خلال الماء & rq \\
\hline & باستخدام مغنطيس غير ملون تحلدد القطب الشمالى والقطب الجنويى & ro \\
\hline & تحري تحرية بسيطة لفصل أثياء مصنوعة من الحلديل عن غيرها . & YY \\
\hline & تجري تجرية لمعرفة أي المواد التي تمر من خلالها قوة المغناطيسي فتجذب الأثياء & PV \\
\hline & تجري تحرية تحلد بها القطب الشمالى والجنويى باستخدام المغنطيس حر الحركة & YA \\
\hline & تحلد الجهات الأصلية باستخدام البوصلة & rq \\
\hline & تجري تجرية توضح المجال المغنطيسي للمغنطيس المعطى لها & $r$. \\
\hline
\end{tabular}

\section{1}


العكد العابي والستون .. نهرهمبر ..

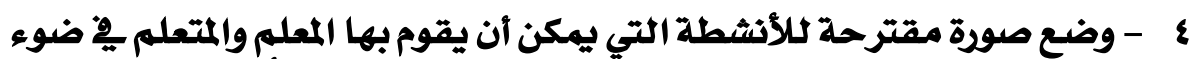

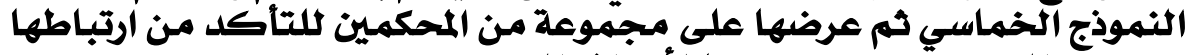

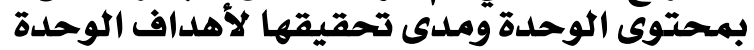

جلول (r) يوضتح الأثططة المقترحة وما يقوم به المعلم والمتعله بِ النهوذج الخماسي

\begin{tabular}{|c|c|c|c|}
\hline ما يفعله التلميذ & ما يفعله المعلم & الأشطة المقترحة & المرحلة \\
\hline 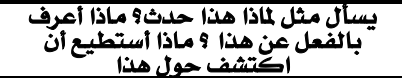 & يخلق اهتمام & شرح & \multirow{5}{*}{ 芧 } \\
\hline \multirow[t]{4}{*}{ يظير اهتمامـا بالموضوع } & يثير فضول & قراعة & \\
\hline & يسال أسئلة & كتابةحرة & \\
\hline & 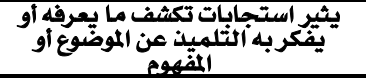 & تحليل رسوم بيانية & \\
\hline & & عصف ذهنى & \\
\hline يفكر بحرية ولكن ضمن حدود النشاط & يشجع المتعلمين للعمل معا بطريقة & أداء أو تحقق & \multirow{5}{*}{ 羿 } \\
\hline يختبر الفروض والتنبؤات & الملاحظة والاستماعاع للمتعلمين أثناء & قراءة مصادرماتقة لجمـع & \\
\hline أل ويناقش مـ الآخرين & 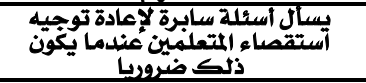 & حل مشكلة & \\
\hline يسجل الملاحظات والأفكار & 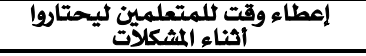 & بناء ثموذج & \\
\hline \multicolumn{3}{|l|}{ يؤحل تنفيذ الحكم أو البرهان } & \\
\hline يشرح الحلول الإحتمبلة أو يجيب على & 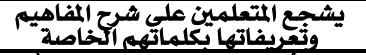 & يقوم المتعلمونيخ بالتحليل & \multirow{6}{*}{ 匀 } \\
\hline يستمع بتركيز لشرح الآخرين & يسال المتعلميلن لتقديم تبرير ( & دمم الأفكار التي ثها دليل & \\
\hline يستوضح ثرح الآخرين & وتوضيحماتِ ومسيفات اصطيات حقيلة ، & تقديم أسئلة & \\
\hline يستمع ويحاول أنه يفهلم الشرح الذئي & يستخدامسبر اتشرح المتعلمين السابقة & قراءة ومناقشة ثرح المعلم & \\
\hline \multicolumn{2}{|l|}{ يشير للأنشطة السابقة } & 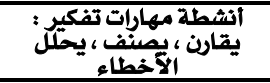 & \\
\hline \multicolumn{3}{|l|}{ يستخدم الملاحطات المسحلة 2 التوضيح } & \\
\hline 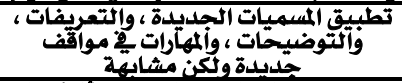 & 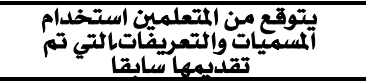 & حل مشكلة & \multirow{5}{*}{ 隺 } \\
\hline 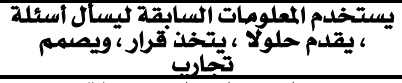 & 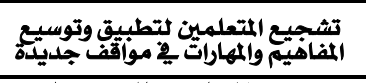 & اتخاذ قرار & \\
\hline يستخلص خلاصات معقولة من & تذكير المتعلمينينة بالتوضيحات & تجريب واستقصاء & \\
\hline ت ت واثشرح & 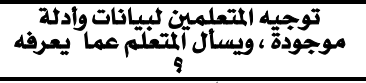 & مقارثة ، تصنيف مهارات ، تطيبيق : & \\
\hline يتفقد فهم زملائه & تستخلم هنا الاستراتيجيات الناتجة عن الشيح & & \\
\hline 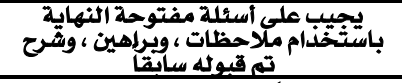 & يشهد المتعلميين أثناء تطبيقيق & تقوييم أي من السابق & \multirow{6}{*}{ 武 } \\
\hline يعرض فهماً أو معرفة للمفهوم أو المهارة & يقوم معرفة ومهارات المتعلمين & يطور أداة تقويم أو اختبار & \\
\hline يقوّم تقلدمه ومعرفته الخاصة & 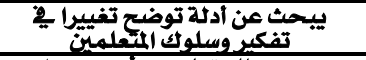 & يقوّم الأداء & \\
\hline \multirow[t]{3}{*}{ يسال أسئلة مرتبطة تؤديلّي إلى استقصاء } & 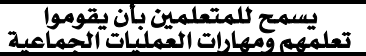 & ينتج منتجاً & \\
\hline & 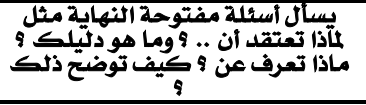 & كتابة أحداث يومية & \\
\hline & & إعداد حقيبة للتقويم & \\
\hline
\end{tabular}




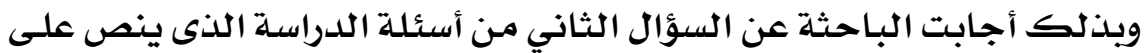

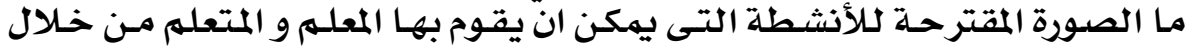

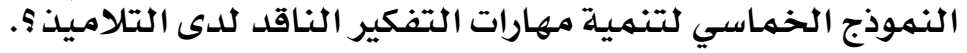

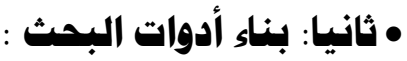

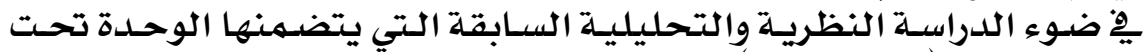

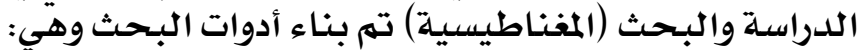

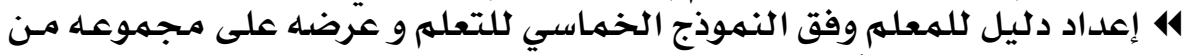

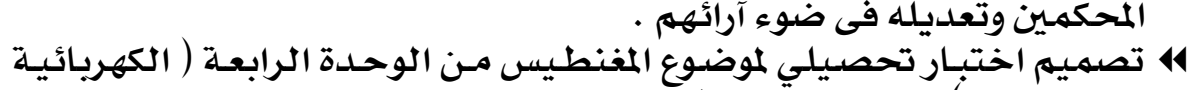

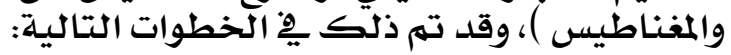

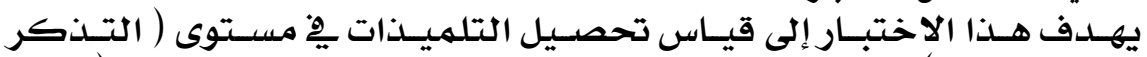

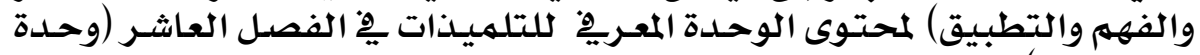

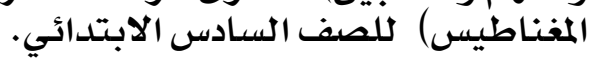

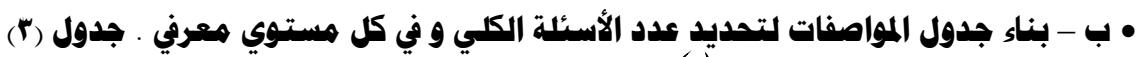
جلدول(r) مواصفات الاختبار التتحصيلي ودئي

\begin{tabular}{|c|c|c|c|c|c|}
\hline$\%$ & المفرداد & الهدف السلوكي & 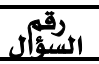 & 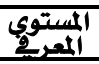 & \\
\hline \multirow{7}{*}{$\% \mathrm{rv}$} & \multirow{7}{*}{$\Lambda$} & 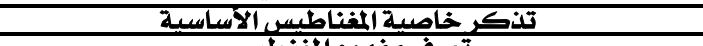 & Y & \multirow{7}{*}{ تذكر } & \\
\hline & & 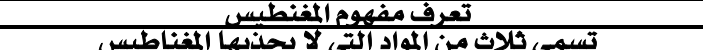 & $\frac{17}{11}$ & & $\mathbf{Y}$ \\
\hline & & 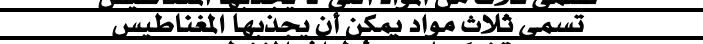 & 11 & & $\underline{\varepsilon}$ \\
\hline & & تذكر أسمى أطراف المنطيس & 19 & & \\
\hline & & ت تِنيكرتعريف البيوصلة & $r$. & & \\
\hline & & ت تعرف المحال! & Yq & & \\
\hline & & & Y⿳㇒ & & $\underline{\Lambda}$ \\
\hline \multirow{11}{*}{$\%$} & \multirow{11}{*}{ ir } & 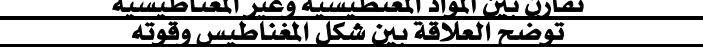 & $\frac{1}{r}$ & \multirow{11}{*}{ فهم } & \\
\hline & & تحلد أى من أفكال المغنطيسات قادرة على جلئ إلمواد & $\varepsilon$ & & \\
\hline & & 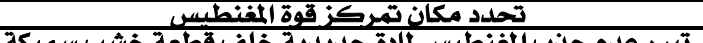 & $\div$ & & Ir \\
\hline & & 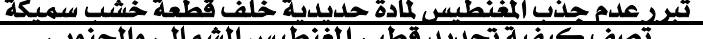 & 7 & & \\
\hline & & 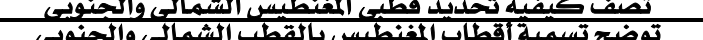 & $\frac{1}{a}$ & & \\
\hline & & 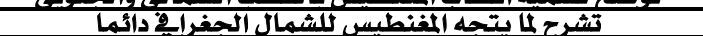 & 1. & & Ic \\
\hline & & 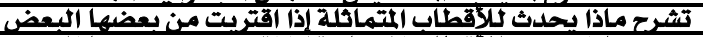 & 11 & & \\
\hline & & 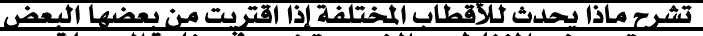 & Ir & & \\
\hline & & تحلد نوع المفناطيس الذي يستخلدم 2 صناعة البوصلة & Yr & & \\
\hline & & 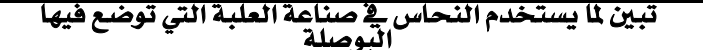 & $r v$ & & $\Gamma^{*}$ \\
\hline & & تحلد المنطقة التى تزداد فيها قوة المجال المغنطبسى & ri & & $\bar{Y}$ \\
\hline \multirow{8}{*}{ צוr\% } & \multirow{8}{*}{11} & تحرى تجرية بسيطة لفصل أشياء مصنوعة من الحدبيد & & \multirow{8}{*}{ تطبيق } & \\
\hline & & 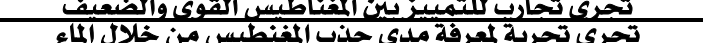 & $\frac{1 \pi}{18}$ & & $\overrightarrow{r \varepsilon}$ \\
\hline & & باستخدام مغنطيس غير ملوئ بحدد القطب الشمالي وأقطب & 10 & & Yo \\
\hline & & تجري تجرية بسيطة لفصب & $y_{1}$ & & MT \\
\hline & & 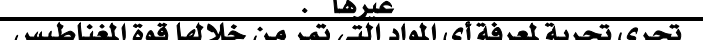 & & & \\
\hline & & 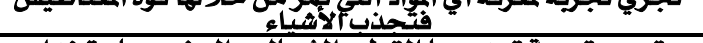 & rr & & rv \\
\hline & & 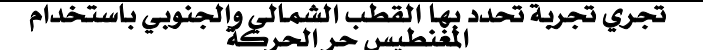 & $r \varepsilon$ & & $\mathbf{~ Y \Lambda}$ \\
\hline & & 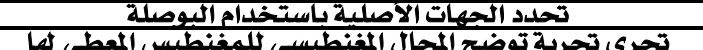 & $\frac{r \cdot 6 \mathrm{Yq}}{r \mathrm{ra}}$ & & r. \\
\hline
\end{tabular}

17. 


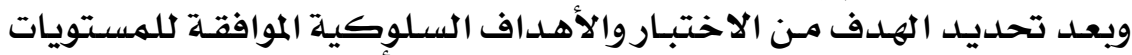

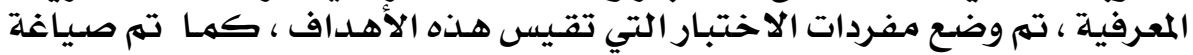

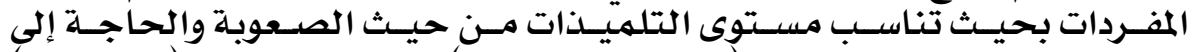

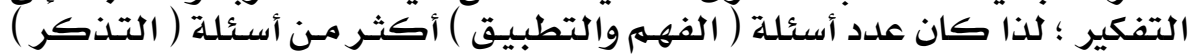

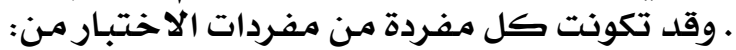

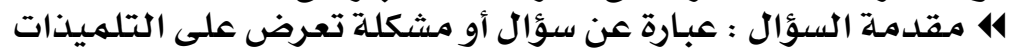

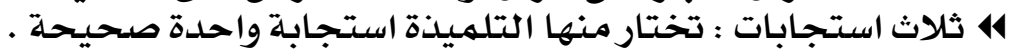

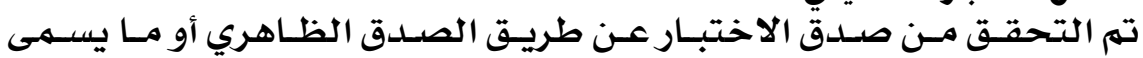

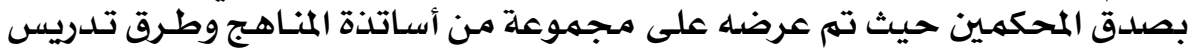

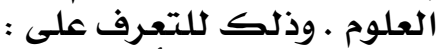

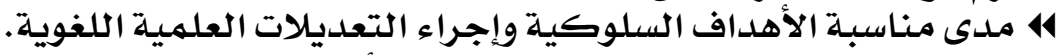

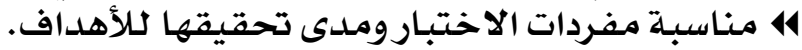

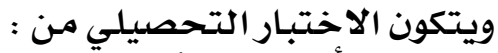

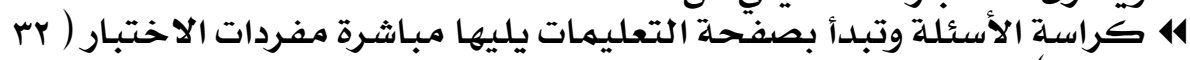

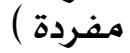

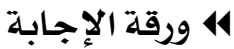

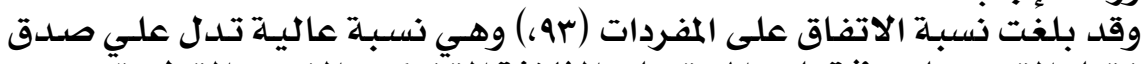

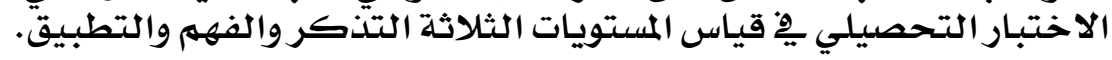

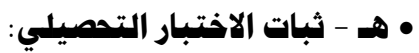

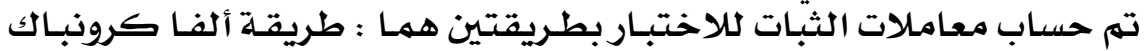

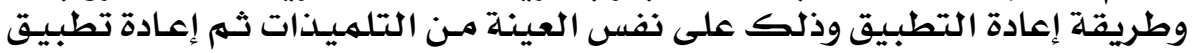

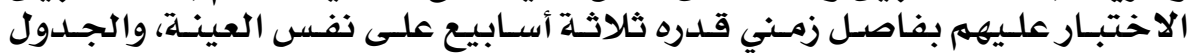

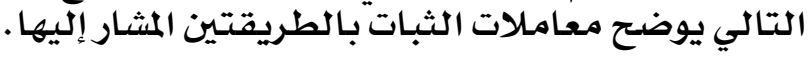

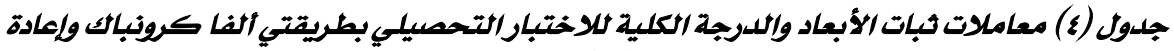
التطبيق التياريات

\begin{tabular}{|c|c|c|}
\hline الثبات بطريقة إعادة التطبيق & الثبات بطريقة الفا كرونياك & البعد البع \\
\hline$\cdot .11$ & $\cdot . \wedge \mathrm{r}$ & التذكر \\
\hline$\therefore . \mathrm{va}$ & $\because .11$ & الفهم \\
\hline$\therefore$. vo &.. $\mathrm{w}$ & التطبيق \\
\hline$\because .19$ & $\because \mathrm{vA}$ & اللرجة الكلية \\
\hline
\end{tabular}

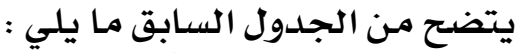

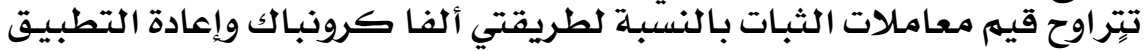

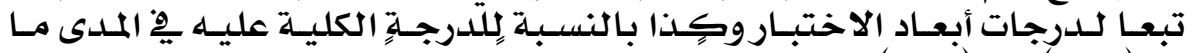

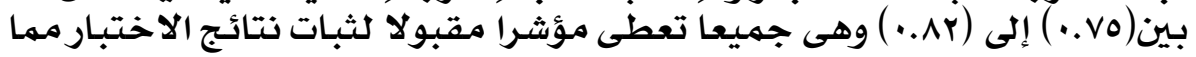

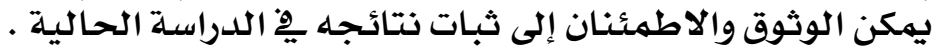

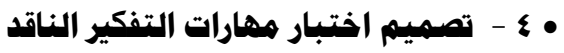
مرت عملية تصميهم هذا الاختبـار بالخطواتيرات التالية : 
• أ - تعديد الهدف هن الاختبار :

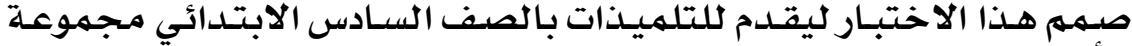

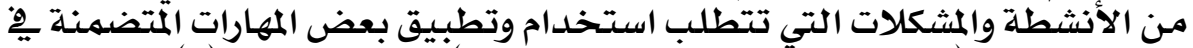

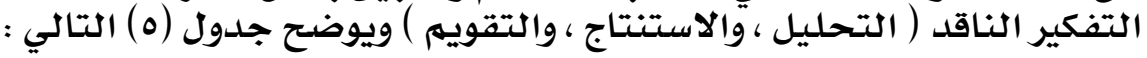

• ب - وضع هواصفات الاختبار :

\begin{tabular}{|c|c|c|c|c|}
\hline$\%$ & عدد الأسئلة & الهدف السلوكي & رقم السؤال & مهارات التفكير \\
\hline \multirow{5}{*}{ \% } & \multirow{5}{*}{$v$} & تحدد الأسباب المسئولة عن ظاهرة ما & ir & التحليل \\
\hline & & تحلل التعميم إلى مجموعة من الأمثلة & rr & \\
\hline & & تكتشف العلاقة بين الأشياء & $I V ، \varepsilon$ & \\
\hline & & تحلل الاستنتاج 2. ضوء معيار الدليل & 19.18 & \\
\hline & & تحول الاستنتاج إلى مجموعة الملاحظات & 19 & \\
\hline \multirow{5}{*}{ ז } & \multirow{5}{*}{$\wedge$} & تفسر مجموعة من الملاحتاجات للوصول إلى & ^،1. & الاستنتاج \\
\hline & & تحدد العلاقة الموجودة بين عدة مفاهيم & 10,0 & \\
\hline & & تستخدم الأمثلة ف2 تفسير موقف غامض & rI & \\
\hline & & تحدد استنتاجا مختصرا بعد دراسة & 1 & \\
\hline & & تحدد الحل الأنسب من بين عدة حلول & Ir,r & \\
\hline \multirow{4}{*}{$\%$ \%r } & \multirow{4}{*}{$\mathbf{v}$} & تستخدم معلوماتها السابقة فـ اتخاذ قرار & 9.6 & 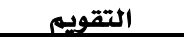 \\
\hline & & تتحقق من الاستنتاج باستخدام عدة & $r$. & \\
\hline & & تتخذ القرار بعلد دراسلة الجواثب المختلفة & 14,7 & \\
\hline & & تستخدم الحقائق فِ حل الشكلات & $11, r$ & \\
\hline
\end{tabular}

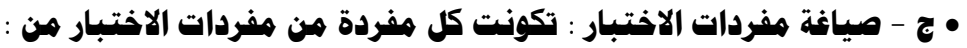

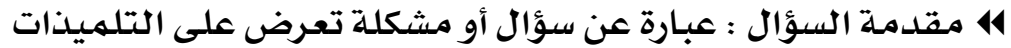

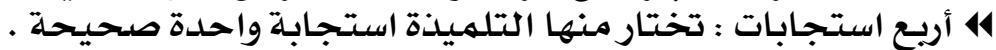

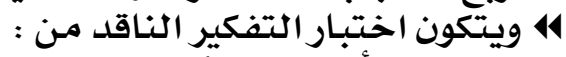

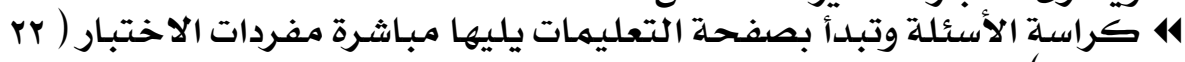
14 ورقة الإجابة ) مئة

• • د - صدق اختبار ههارات التفكير الناقد:

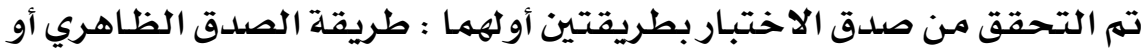

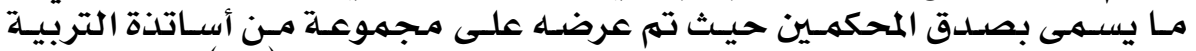

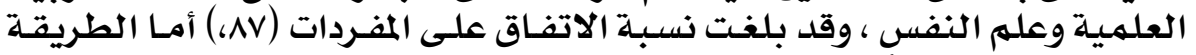

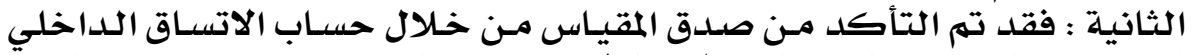

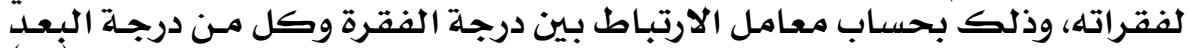

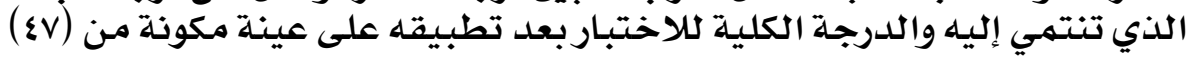




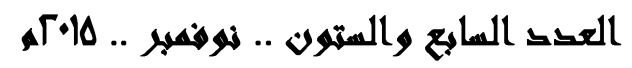

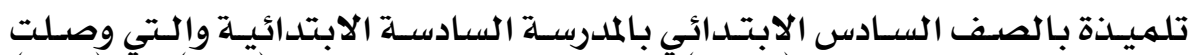

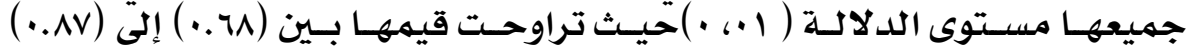

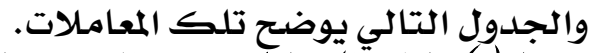

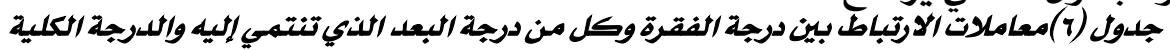

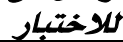

\begin{tabular}{|c|c|c|c|c|}
\hline الدرجة الكلية & التقويم & الاستنتاج & التحليل & الفقرة البعد \\
\hline$\cdot \stackrel{A N V}{ }$ & & $\therefore 11$ & & 1 \\
\hline$\therefore$. vo & $\therefore$.va & & & $r$ \\
\hline • ‘А. & & $\therefore \mathrm{v \Lambda}$ & & $r$ \\
\hline$\therefore$.va & $\therefore$. 10 & & & $\varepsilon$ \\
\hline$\cdot . \mathrm{v} \varepsilon$ & & & $\therefore v$ & 0 \\
\hline$\therefore$. vq & & ¿AY & & 1 \\
\hline$\cdot . \mathrm{WV}$ & & & $\because v \mathrm{~V} \varepsilon$ & $v$ \\
\hline • ${ }^{A \wedge Y}$ & & 610 & & $\Lambda$ \\
\hline • $\mathrm{iVA}$ & & ivo & & 9 \\
\hline$\cdot . \mathrm{Vr}$ & & $\because \mathrm{va}$ & & 1. \\
\hline 侯 & & & - CAY & 11 \\
\hline$\therefore$. $\triangle 10$ & $\begin{array}{l}. \wedge \wedge 1 \\
\end{array}$ & & & Ir \\
\hline$\therefore \mathrm{VA}$ & & - ‘Ar & & ir \\
\hline$\cdot . \wedge 1$ & & & $\because A V$ & 18 \\
\hline$\therefore$.va & $\therefore v r$ & & & 10 \\
\hline$\cdot . \mathrm{WV}$ & & & $\therefore v \varepsilon$ & 17 \\
\hline$\therefore$ va & & & • ‘Ad & IV \\
\hline$\therefore$.va & & $\therefore \mathrm{VA}$ & & 11 \\
\hline$\therefore$.va & • ‘AY & & & 19 \\
\hline • ‘AV & & & - ‘AY & $r$. \\
\hline . & • ‘A0 & & & YI \\
\hline$\cdot$. ¿AY &. . v9 & & & $r Y$ \\
\hline
\end{tabular}

يتضرح من الجدول السابق ما يلي :

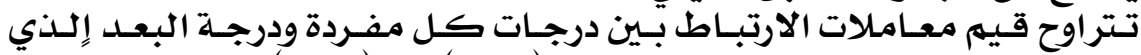

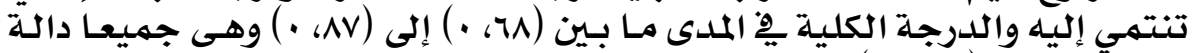

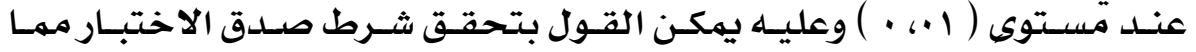

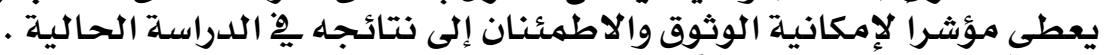

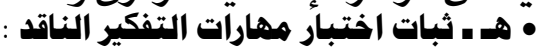

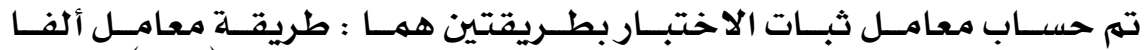

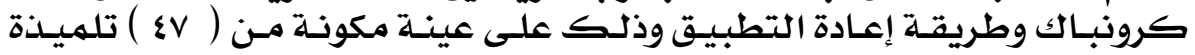
بالصف السـادس الابتدائي. جلدول (v) معامل ثبات المهارات الفرعية، واللدرجة الكلية لاختبار التفكير الناقد بطريقتي الفا

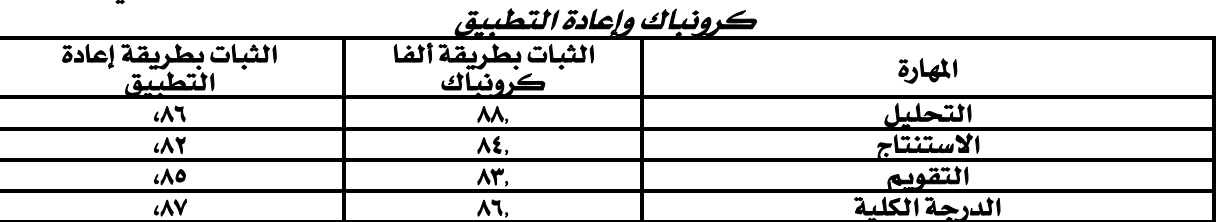




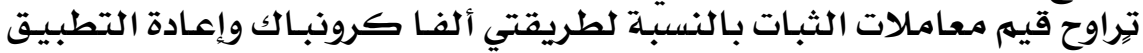

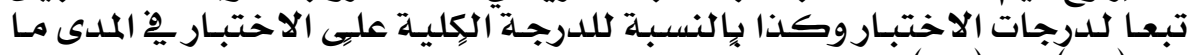

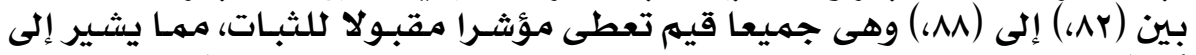

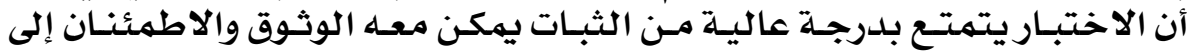

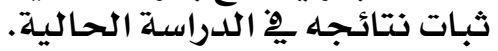

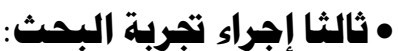

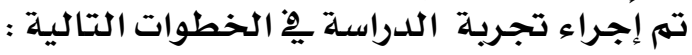

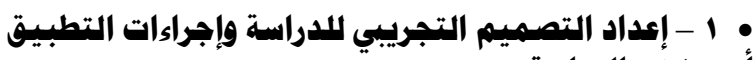

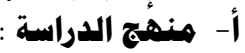

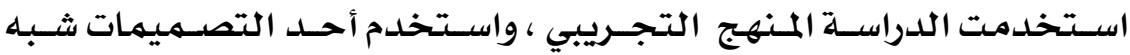

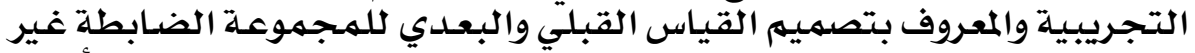

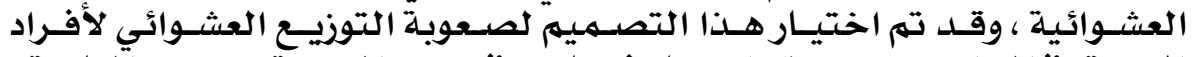

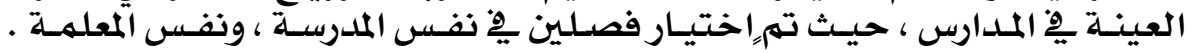

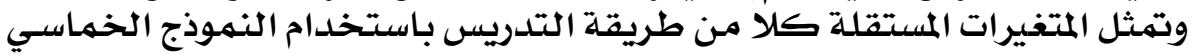

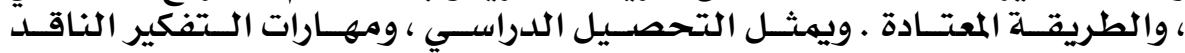

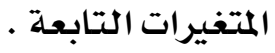

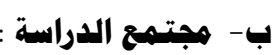

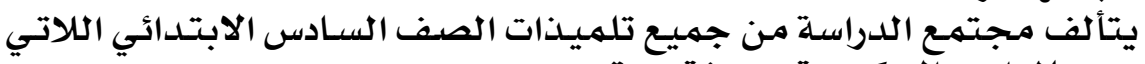
يدرسن بالمدارس الحكومية المبلة بمدينة جديعة .

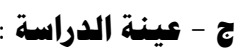

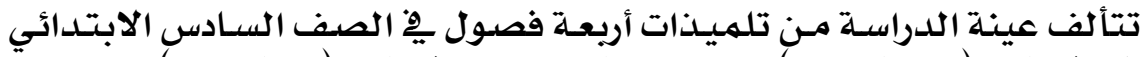

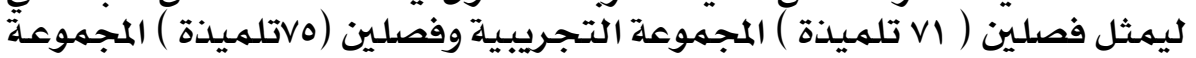

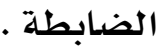

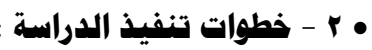

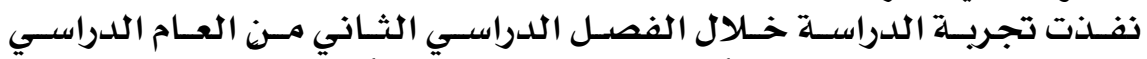

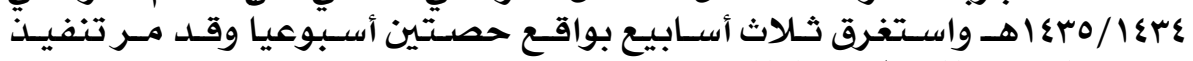

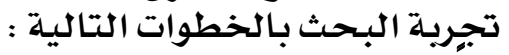

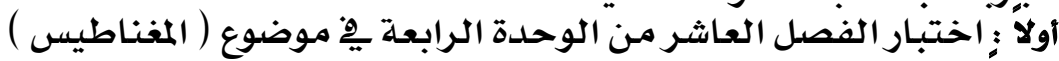

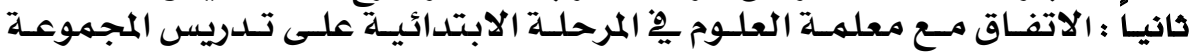

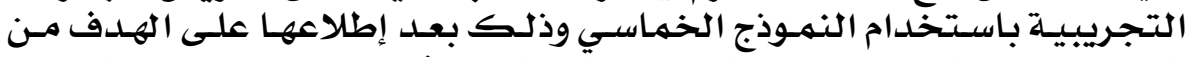

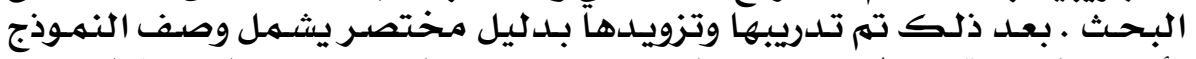

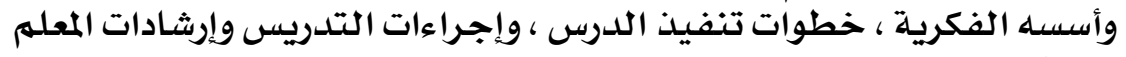

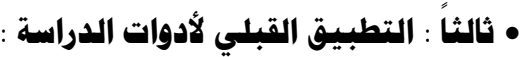
تم تطبيق كل من الاختبار التحصيلي واختبِيار مهارات التفكير الناقد على التس

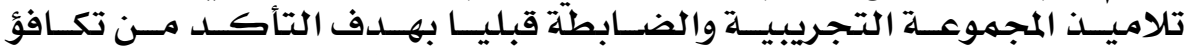
المجموعتين وقد دلت نتائج التطبيق على عدم وجود فروق دالة بين متوسطات

\section{$17 \varepsilon$}

دراسات عربية في التربية وعلم النفس (ASEP) 


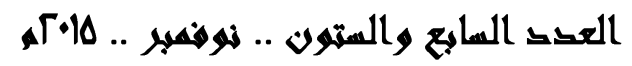

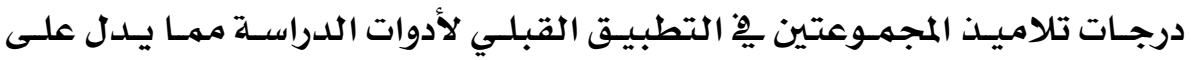

تكافؤ المجموعتين

جلدول (1) لحساب دلالة الفروق بين متوسط درجات المجموعة التجريبية والمجموعة الضابطة

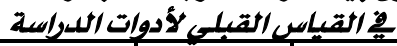

\begin{tabular}{|c|c|c|c|c|c|c|}
\hline الدلالة & قيمةت & الانحياري & المتوسط & أفراد & المجموومات & الأداة \\
\hline \multirow{2}{*}{ غير دالة } & $\cdot 180$ & $0 . r Y$ & $\{\varepsilon . \mu$ & vi & تحريبية & \multirow{2}{*}{ التحصيلي الاختبار } \\
\hline & & 0.19 & \&r.qY & vo & ضابطة & \\
\hline \multirow{2}{*}{ غير دالة } & - ‘৯. & r.A. & $\varepsilon \cdot . \varepsilon q$ & $v_{1}$ & تجريبية & \multirow{2}{*}{ التفتبر الناقد } \\
\hline & & 8.19 & r9.97 & vo & ضابطة & \\
\hline
\end{tabular}

• رابعاً : التِطبيقت البعدي لأدوات الدراسة:

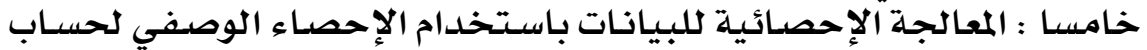

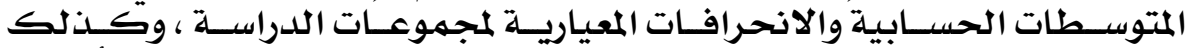

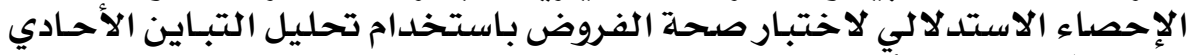

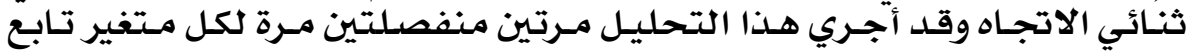

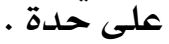

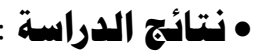

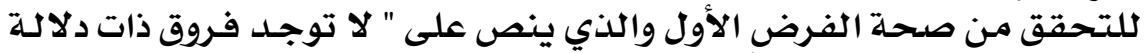

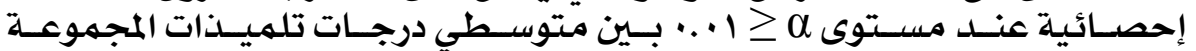

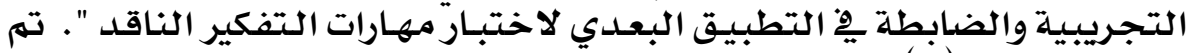

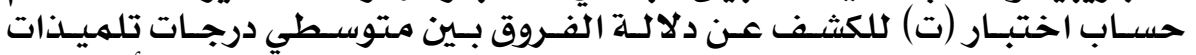

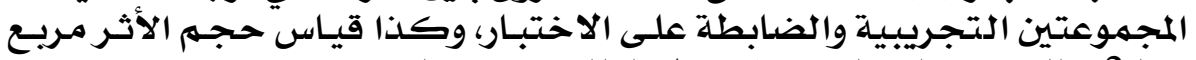

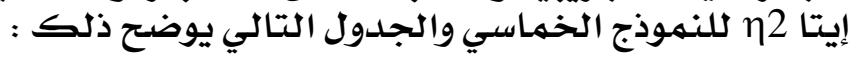

جلول (ه) دلالة الفروق بين متوسطي درجات المجموعتين التجريبية والضابطة فِ القياس البعلي

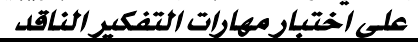

\begin{tabular}{|c|c|c|c|c|c|c|c|}
\hline حجثم & ت & الدلالة & الانحراف & المتوسط & العينة & المججموعات & المهارات \\
\hline \multirow{2}{*}{$\%$ \%М. Ir } & \multirow{2}{*}{ Yr.A. } & \multirow{2}{*}{$\cdot 1$} & r.rr & $r \cdot . T \Lambda$ & $v_{1}$ & تجرييية & \multirow{2}{*}{ التحليل } \\
\hline & & & Y.YY & $1 Y . \cdot 9$ & vo & ضابطة & \\
\hline \multirow{2}{*}{$\%$ \% r. 1 . } & \multirow{2}{*}{ YA.01 } & \multirow[b]{2}{*}{-1, } & $r_{.} \cdot A$ & $r \cdot . v_{0}$ & $v_{1}$ & تحريبية & \multirow{2}{*}{ الاستنتاج } \\
\hline & & & 1.0. & IY.Y. & vo & ضابطة & \\
\hline \multirow{2}{*}{$\% 9 r . .9$} & \multirow{2}{*}{ YA.00 } & \multirow{2}{*}{$\cdot 1$} & $r .11$ & YI.VY & $v_{1}$ & تحريبية & \multirow{2}{*}{ التقويم } \\
\hline & & & $1 . \wedge$. & $\mid Y .01$ & vo & ضابطة & \\
\hline \multirow{2}{*}{$\% 90 . \vee 0$} & \multirow{2}{*}{ ra.vo } & \multirow{2}{*}{$\cdot 1$} & 0.07 & Ao.rY & vi & تجريبية & \multirow{2}{*}{ الدرجة الكلية للاختبار } \\
\hline & & & 0.MI & \&9.0V & vo & ضابطة & \\
\hline
\end{tabular}

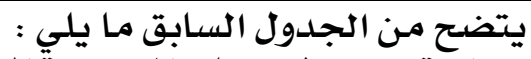

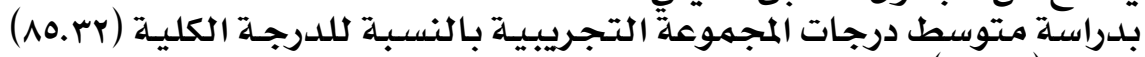

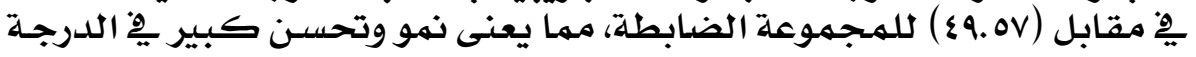

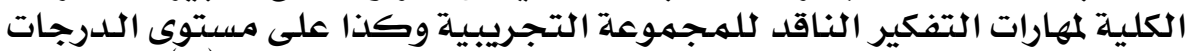

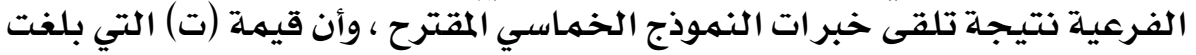




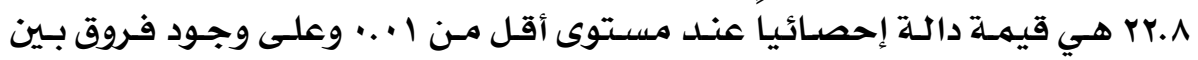

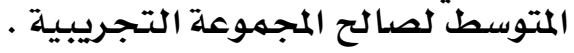

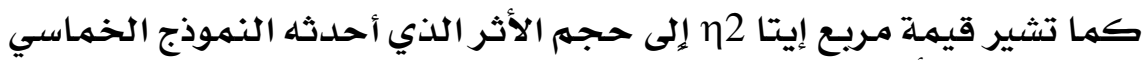

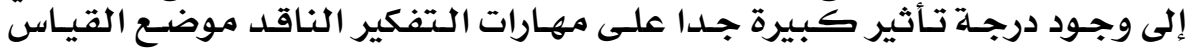

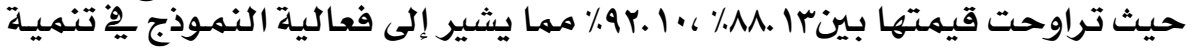

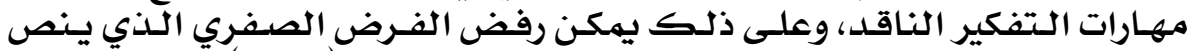

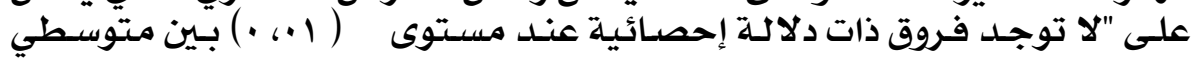

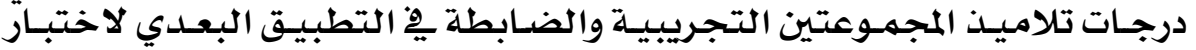

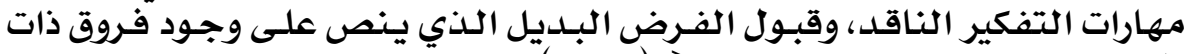

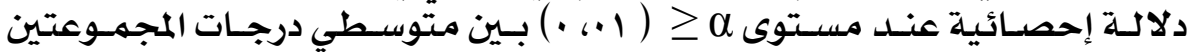

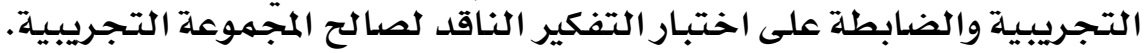

$$
\text { وبذلك أجابت الباحثة عن السؤال الثالث من أسئلة الدراسية. }
$$

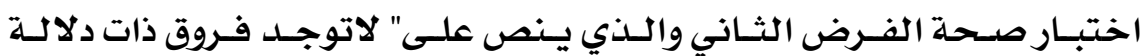

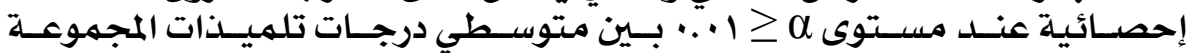

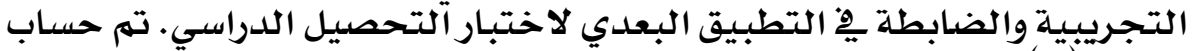

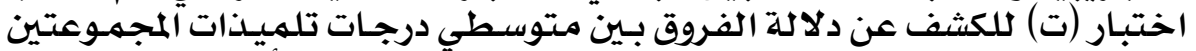

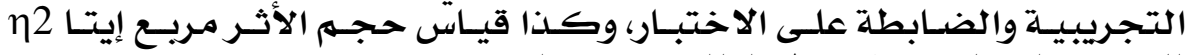

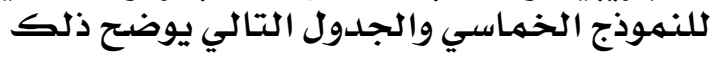

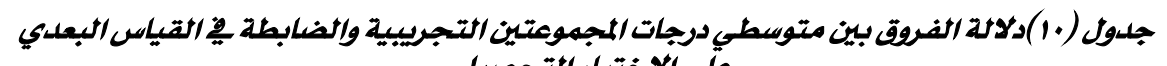

\begin{tabular}{|c|c|c|c|c|c|c|c|}
\hline الأثر & الدلالد & ت & الانحياري & المتوسط & العينة & المجموعات & \\
\hline \multirow{2}{*}{$\cdot .19$} & \multirow{2}{*}{..$\cdot 1$} & \multirow{2}{*}{ Y\&.09 } & 1.YV & $1 . . Y \varepsilon$ & $v_{1}$ & تحريبية & \multirow{2}{*}{ تذكر } \\
\hline & & & 1.17 & 0.59 & vo & ضابطة & \\
\hline \multirow{2}{*}{. .91} & \multirow{2}{*}{$\cdot . \cdot 1$} & \multirow{2}{*}{ หr.q. } & 97, & $1 . .1$ & $v_{1}$ & تحريبية & \multirow{2}{*}{ فهم } \\
\hline & & & 1.r. & $\varepsilon .19$ & vo & ضابطة & \\
\hline \multirow{2}{*}{.94} & \multirow{2}{*}{$\because . \cdot 1$} & \multirow{2}{*}{$r \cdot . q}$. & r.o. & MI.YA & $v_{1}$ & تحريبية & \multirow{2}{*}{ تطبيق } \\
\hline & & & r.rr & 17.8. & vo & ضابطة & \\
\hline \multirow{2}{*}{$\because 9 v$} & \multirow{2}{*}{$\cdots \cdot 1$} & \multirow{2}{*}{ or.qr } & $0.1 r$ & Ar.or & vi & تحريبية & \multirow{2}{*}{ الدرجة الكلية } \\
\hline & & & $r . \wedge 1$ & \&r.ov & vo & ضابطة & \\
\hline
\end{tabular}

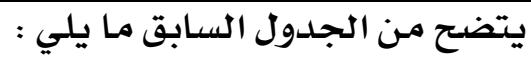

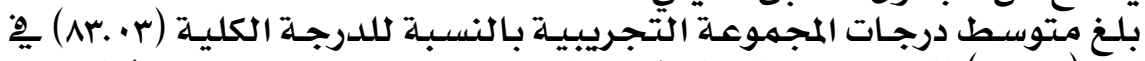

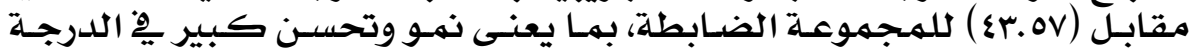

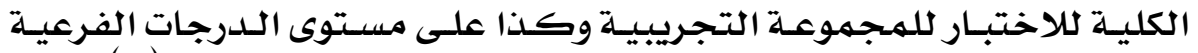

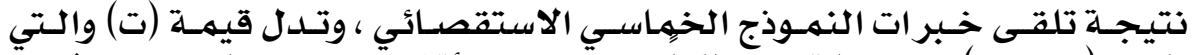

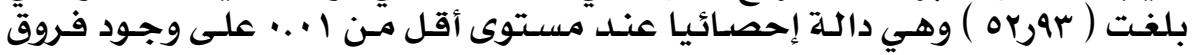

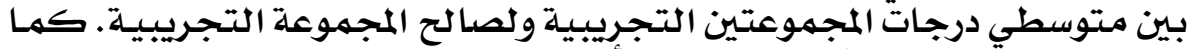

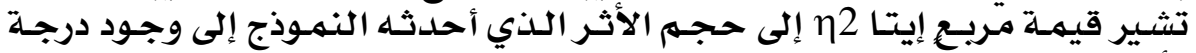

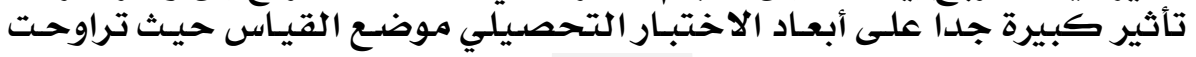

\section{7}




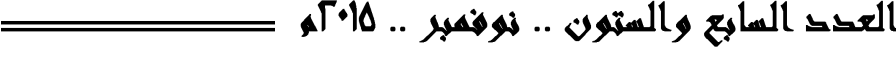

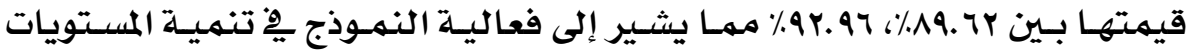

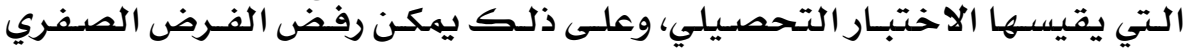

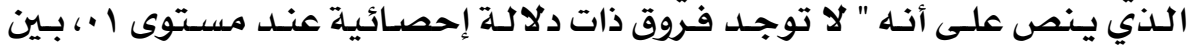

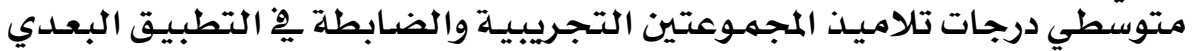

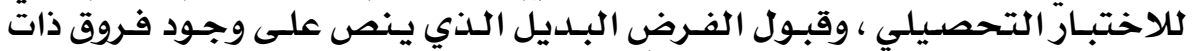

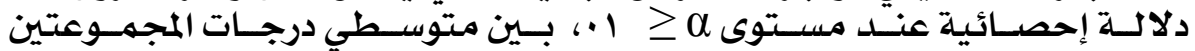

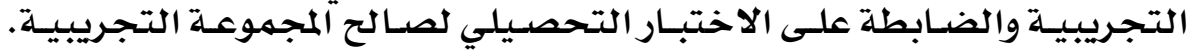

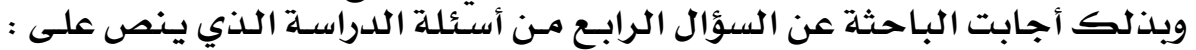

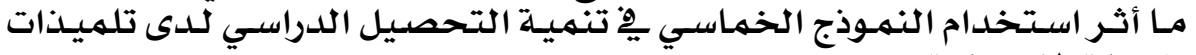

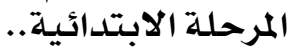

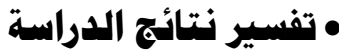

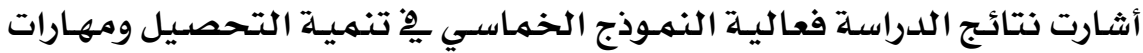

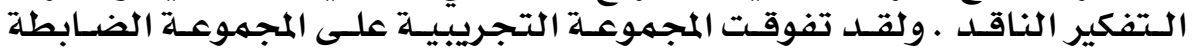

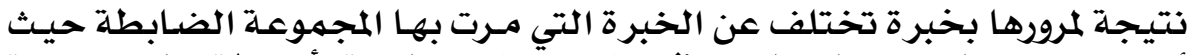

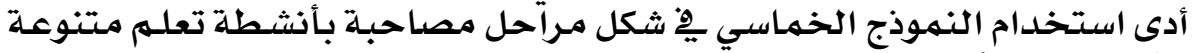

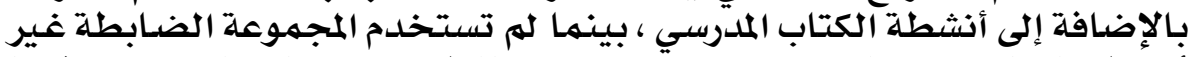

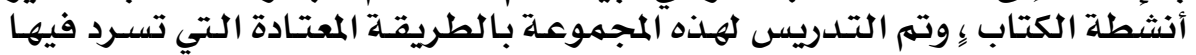

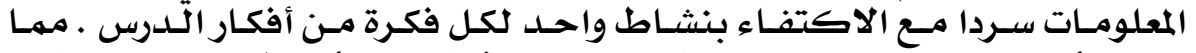

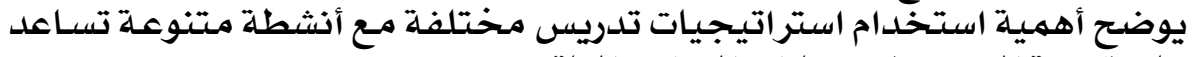

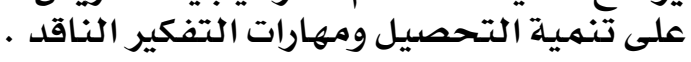

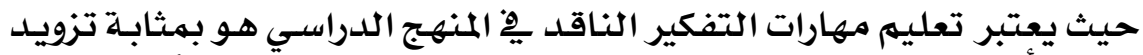

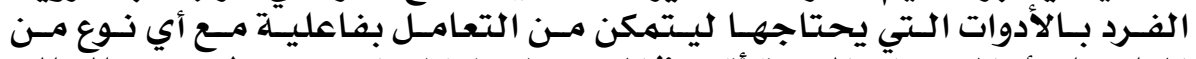

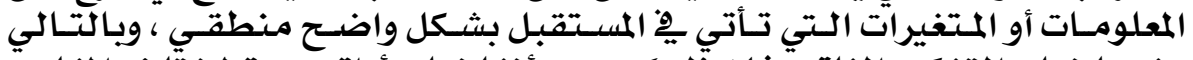

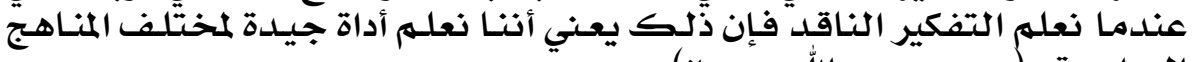

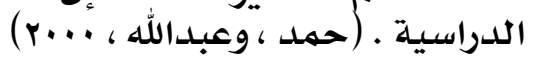

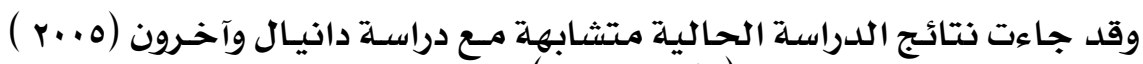

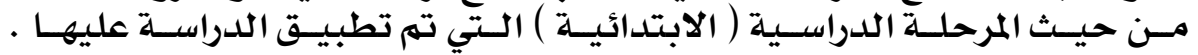

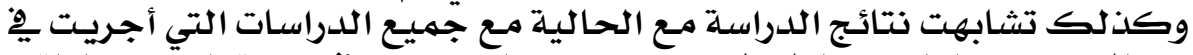

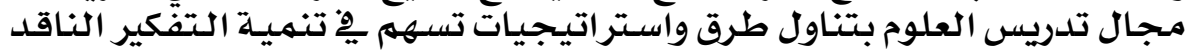

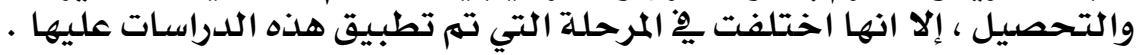

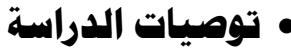

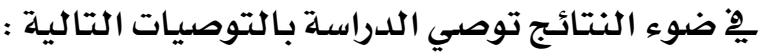

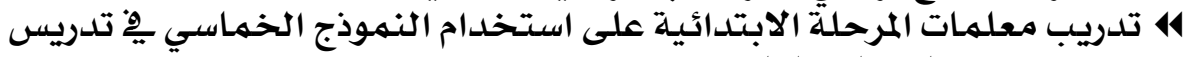

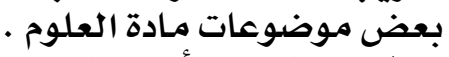

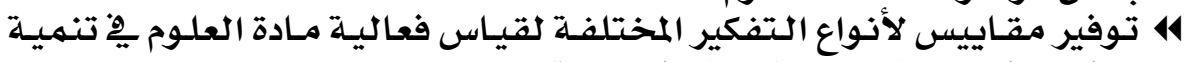

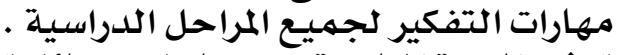

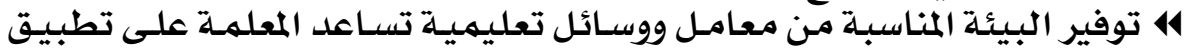

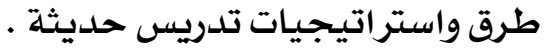

\section{$17 \mathrm{~V}$}


4 تجريب أثر استخدام النموذج الخماسي يِّ تدريس العلوم على تنمية التفكير

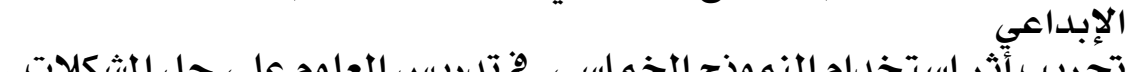

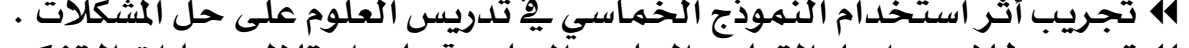

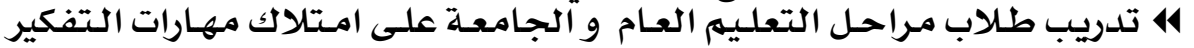

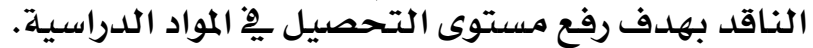

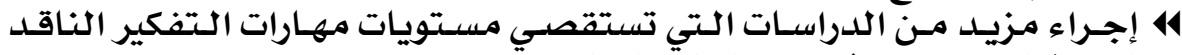

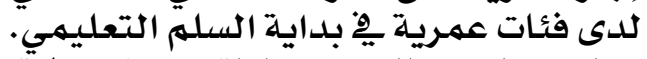

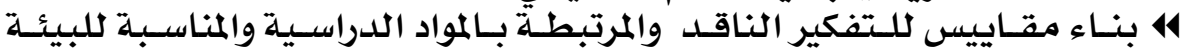

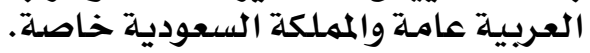
4 ه تصميم برامج تدريبية لتنمية مهارات التفكير الناقد لدى المعلمين .

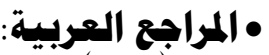
- بيير(1990) تدريس التفكير : أسلوب متكامل الترتيب ، التدريس من أجل تنمية التفكير ، ،

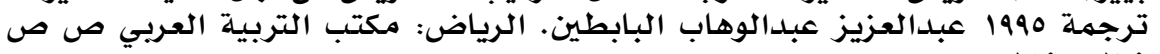
جروان ، فتحي عبدالرحمن ـ ( •r أا هـ ). تعليم التفكير مفاهيم وتطبيقات ـ طا ـ الأردن :

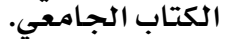

جيمس كييف وهيربرت ويلبرج 1991ا ـ التدريس من أجل تنمية التفكير ـ ترجمة 1990

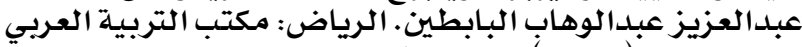

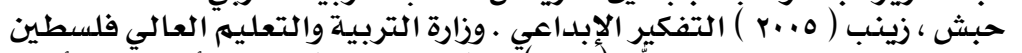

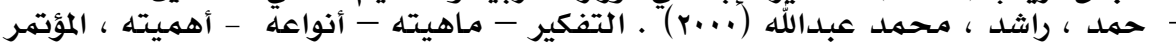

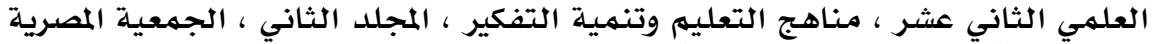

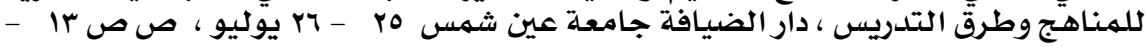

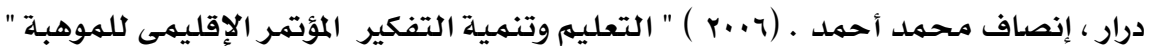

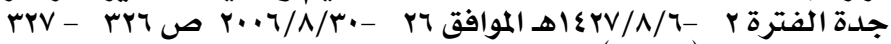

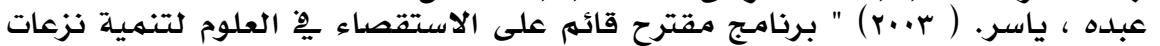

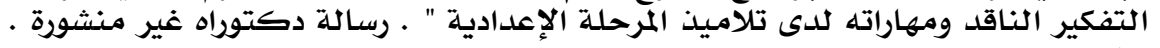

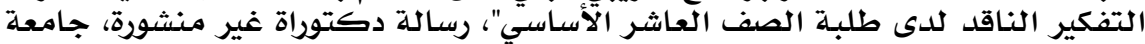

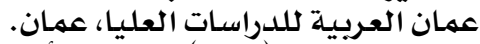

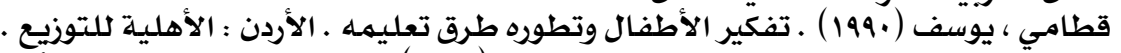

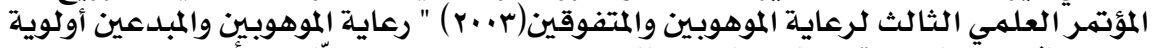

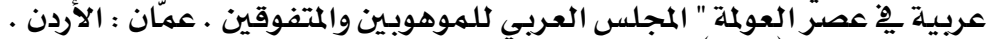

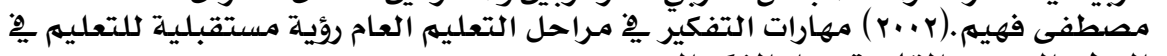

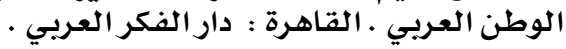

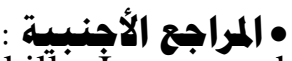

- Anita, V(1999). Critical Thinking as a Core Skill: İssues and Discussion Paper HERDSA Annual International Conference, Melbourne 12-15-July. Baccalaureate Nursing Student (Website htpp://www.lib-umi com/dissertations/fullcit1398931 
-Bers, T et al. (1996). The Disposition to Think Critically Among Community College Students $>$ The California Critical Thinking Disposition Inventory, The Journal of General Education . Vol.(45), No. (3), pp. 198-223.

- Biology Science Curriculum Study ( BSCS) ,2005. High School Biology. Student Manual. Rand McNally.

- Biology Science Curriculum Study (BSCS), Green Version (1989). High School Biology. Student Manual. Rand McNally.

- Crowther, D (1999). Applications of Research \& Model Inquiry Lessons. EJSE: Special Section on Standers - Based Exemplar Lesson Plans. Vol.(3) No. (3) pp1-3

- Daniel, Marie, France.; La fortune, Louise ; Pallasco, Richard ; Splitter, Laurance ; Slade, Christina ; Dela, Garsa, Teresa. (2005). Modeling the Development Process of Dialogical Critical Thinking in Pupils aged 10 to 12 years. Communication Education. V54(4). Oct. p. 334-354.

- Debra Connerly.2006, Master Thesis in Collaborative Teaching and Learning, Graceland University, Cedar Rapids, Iowa ,December 2006.

-Dixon, Felicia, A.; et al. .( 2004). "Teaching to Their Thinking : A strategy to Meet the Critical Thinking Needs of Gifted Students" . Journal for the Education of the Gifted. V28. No.4 p. 56-76.

-Duffy, M \& Zidler, D (1996). The Effect of Grouping and Instructional Strategies on Conceptual Understanding and Critical Thinking Skills in the Secondary Biology classroom. Paper Presented at The Annual Meeting of the National Association for Research in Science Teaching. April2, pp 23-42.

-Ennis,R.H.(1985), A Logical basis for Measuring Critical Thinking Skills, Educational Leadership, 43(2),44-48

-Evancho, S. (2000). Critical Thinking Skills and Disposition of The Undergraduate Baccalaureate Nursing Student (Web site: http:www.lib-umi-com/dissertations/fullcit1398931.

- Facione. P \& Facione ,N (1995 ). The Disposition Toward Critical Thinking. Journal of General Education. Vol. (44), No. (1). Pp. 1-25.

-Facione. P \& Facione ,N (1996 ). Assessment Design Issues For Evaluating Critical Thinking in Nursing, Holistic Nursing Practice, Vol. (101), No. (3), pp. 41-53

-Facione. P (1997). The Motivation to Think in Working and Learning , Millbrae, Ca : California academic Press.

-Ferguson, N \& Vazques-Abad, J. ( 1995). An Exploration of the Interplay of Students Dispositions to Critical Thinking, Formal Thinking and Procedural Knowledge in Science , . Paper Presented at The Annual Meeting of the American Educational Research Association . ( S.F. California, April 18- 22 pp 1-37

- Hassel, C. (1992). Why Critical Thinking? (Web site: http://www://extenstion. Umnedu/Citizenship/DH 5645.htmh). 


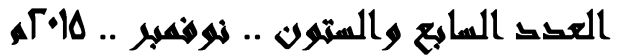

-Heath,L (2000). An Investigation of Critical Thinking, Critical Thinking Dispositions, and Preferred learning Styles or Nursing Students in a Baccalaureate Nursing Program (Web site: http://www.lib-umi-com/dissertations/fullict/9959021).

- Huit,W(1998). Critical Thinking (Web site: http://www.chironvaldosta-edu/whuitt/col/cogsys/critthink.html).

-Lipman, M.(1991), Strengthen reasoning and Judgment through Philosophy. In Maclure \& P. Davis (Eds.) Learning to think, Thinking to learn (pp. 103-133).Oxford, UK: Pergamon Press plc.

-Profetto, J. (1999). Critical Thinking Skills and critical Thinking Disposition of Baccalaureate Nursing Students (Web Site: http://www.lib-umi com/dissertations/fullict/NQ39582).

- Rush Cosgrove,2010. PH.D Thesis in Critical Thinking: Lessons from a Continuing Professional Development Initiative in a London Comprehensive Secondary School

- Udall, A. J., \& Daniel, J.E. (1991) Creating The Thoughtful Classroom: Strategies to Promote Student Thinking. Tuscan,AZ: Zephyr Press.

-Zohar, A. \& Weinberger, Y. \& Tamir, P. (1994). The Effect of the Biology Critical Thinking Project on The Development of Critical Thinking. Journal of Research in Science Teaching. Vol. (31), No. (2), pp. 183-169 


\section{البحثن الفامسر:}

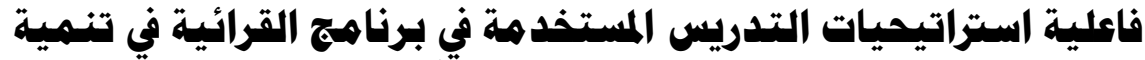

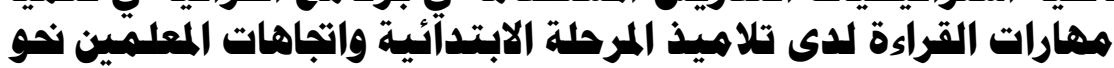
هذه الاستراتيجيات

$$
\begin{aligned}
& \text { : } \\
& \text { د ا بلدوي أحمد محمد الطيب }
\end{aligned}
$$

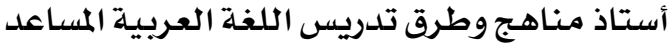

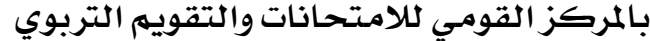

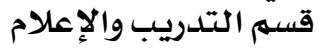





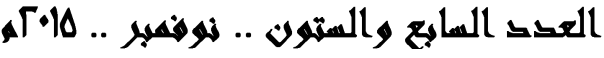

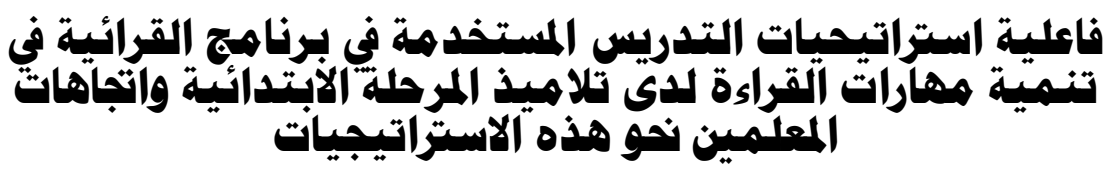

د / بلووي أحمل محمل الطيب

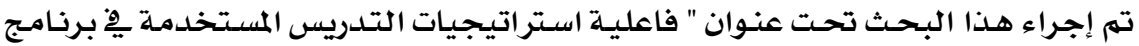

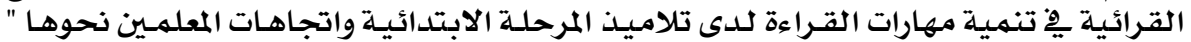

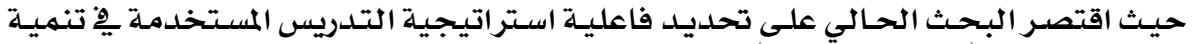

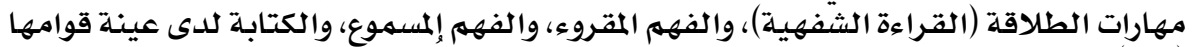

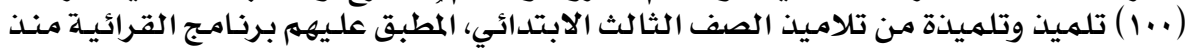

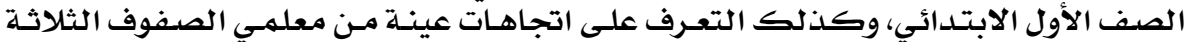

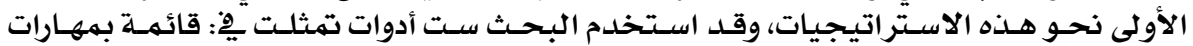

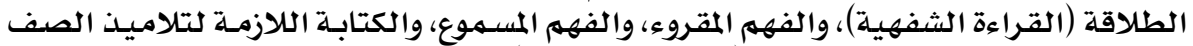

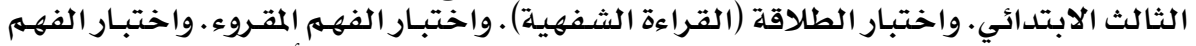

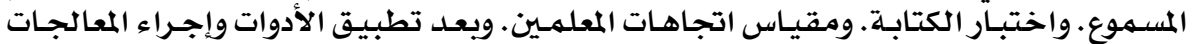

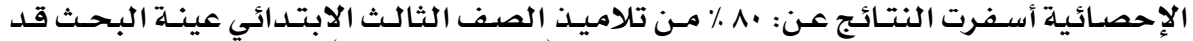

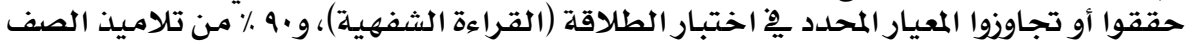

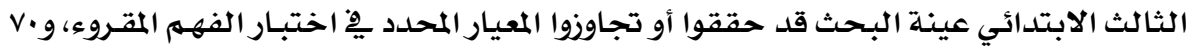

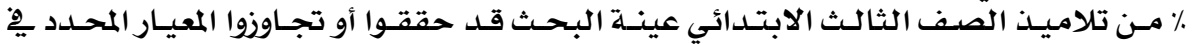

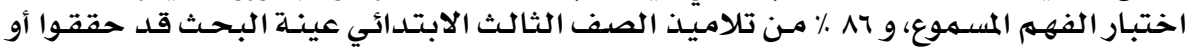

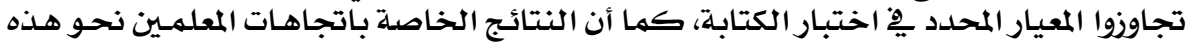

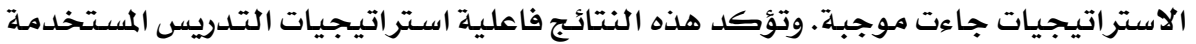

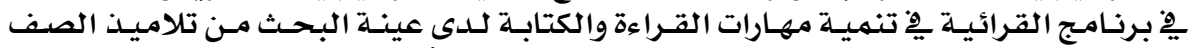

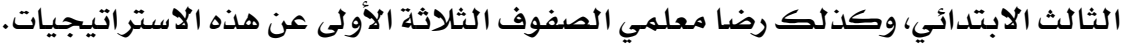

Effectiveness of the Study Strategies in aProgram Develop TheReadingSkills of Primary Stage Pupils and to assess Teachers' $\underline{\text { Abstract }}$ Attitudes Towards these Strategies

The current study aims at investigating the effectiveness of the study strategies ued to develop the skills of fluency (reading aloud), reading comprehension, listeningcomprehension and writing for asample of 100 third primary pupil'sThe study also assessesthe teachers' attitudestowards thesestrategies. The results showed: 80 \% of the pupil's achieved the fluency criterion. $90 \%$ of the pupil's achieved the reading comprehension criterion $.70 \%$ the pupils achieved the listening comprehension criterion. $86 \%$ the pupil's acheved the writing criterion. The teachers' attitudes towards the study strategies were positive.

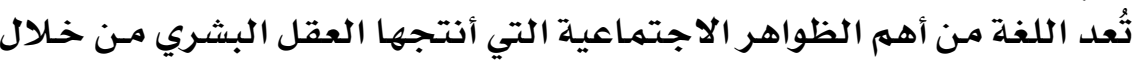

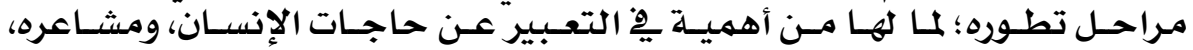

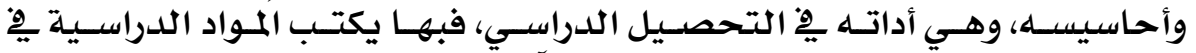

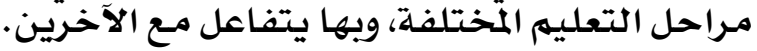

\section{IVY}




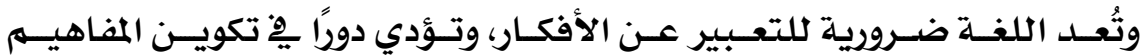

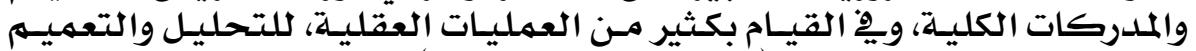

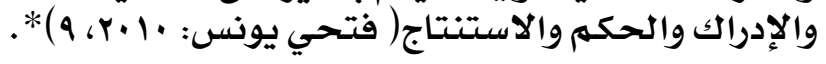

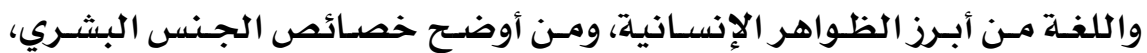

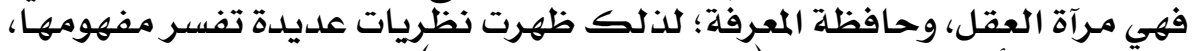

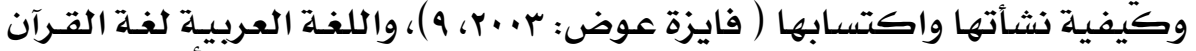

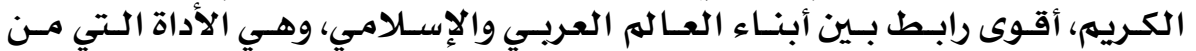

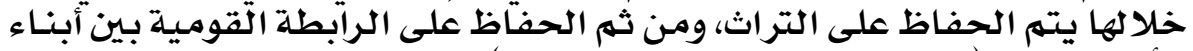

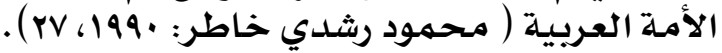

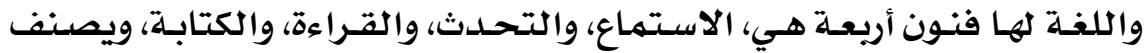

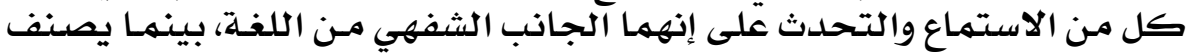

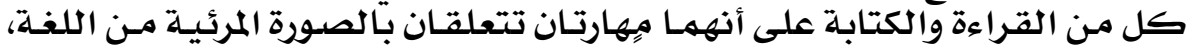

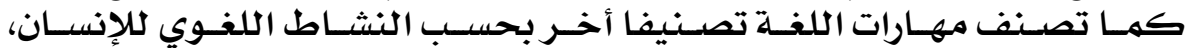

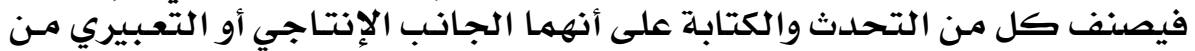

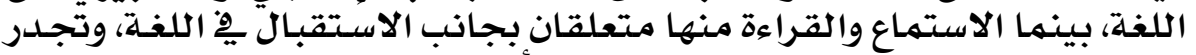

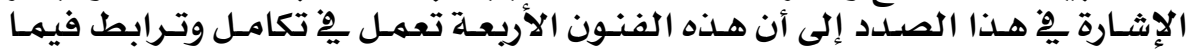

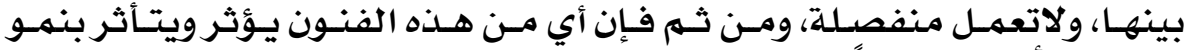

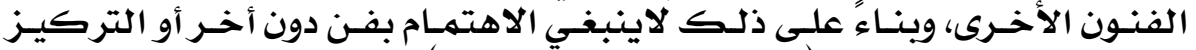

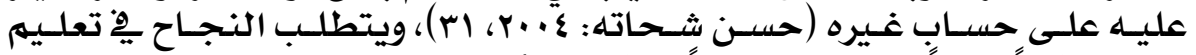

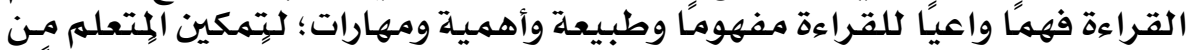

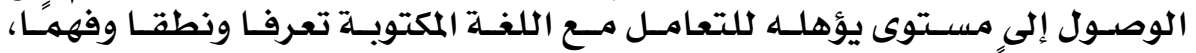

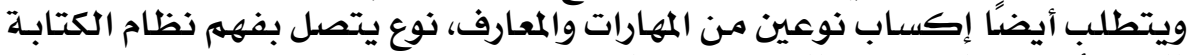

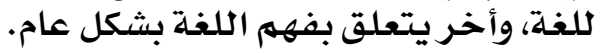

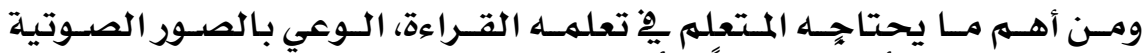

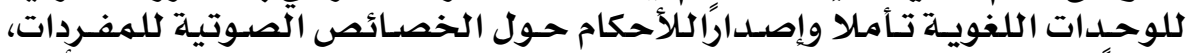

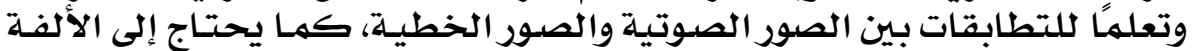

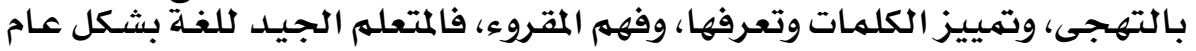

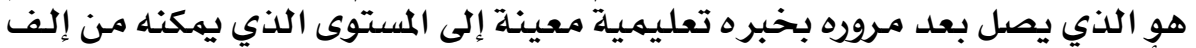

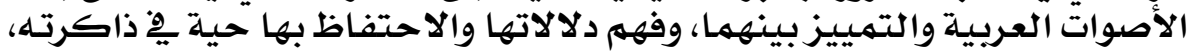

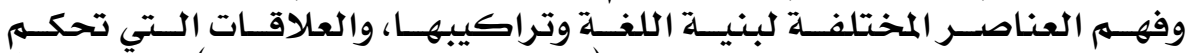

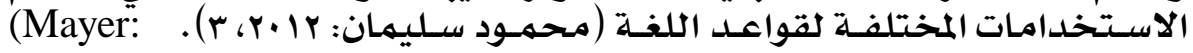
.2010)

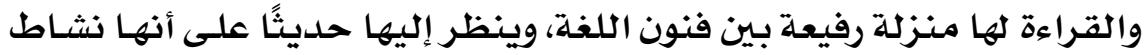

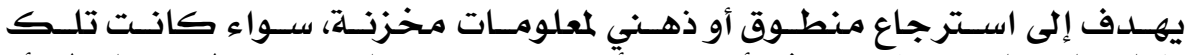

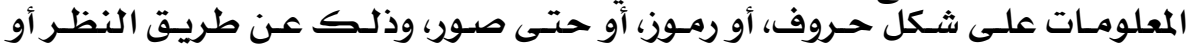

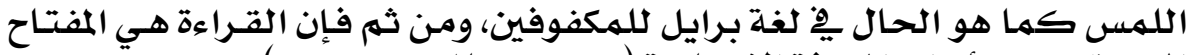

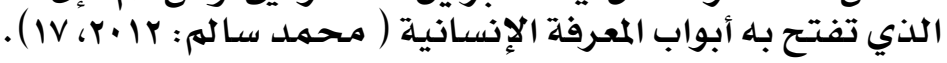




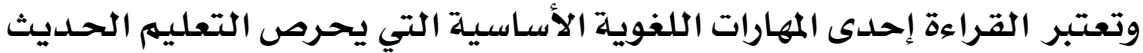

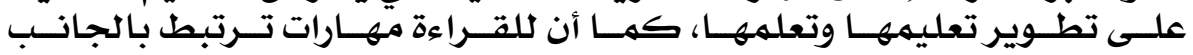

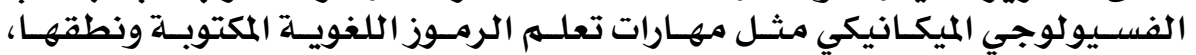

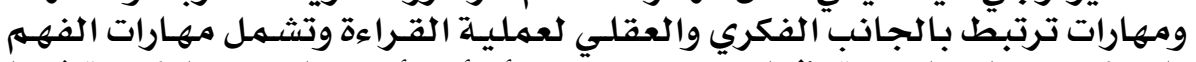

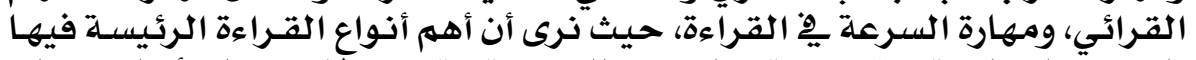

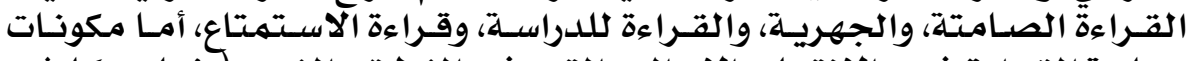

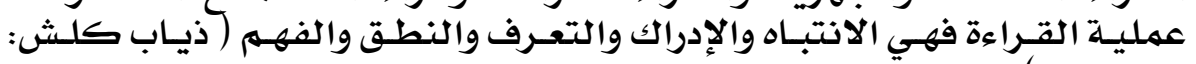
(1)

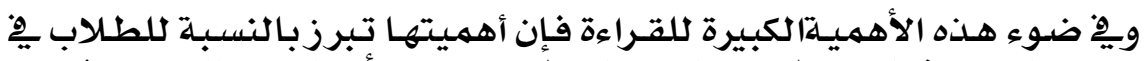

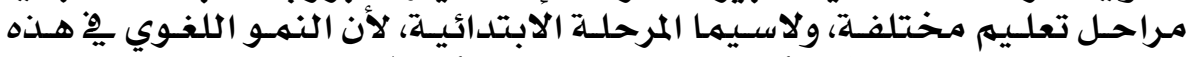

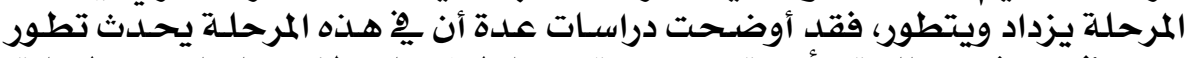

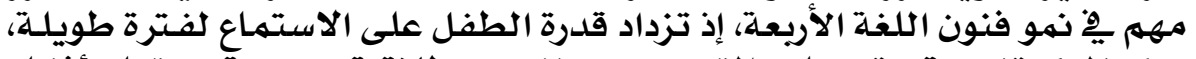

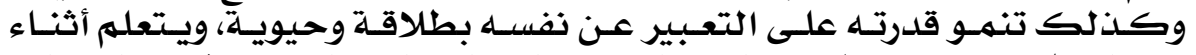

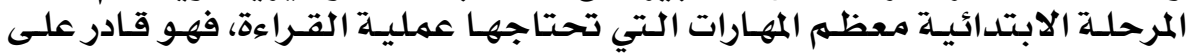

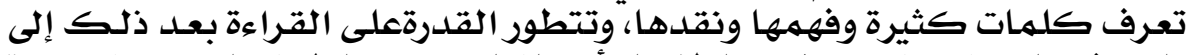

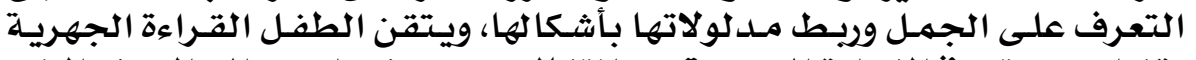

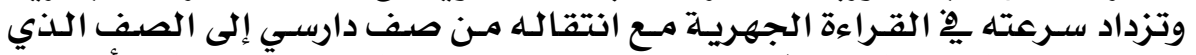

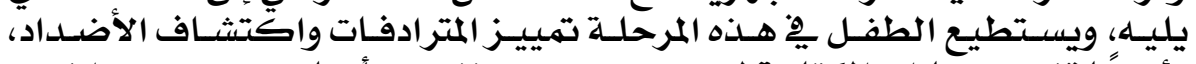

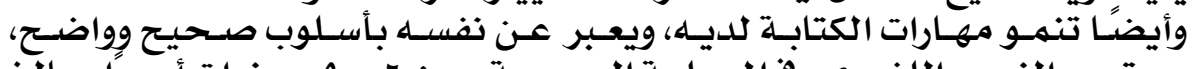

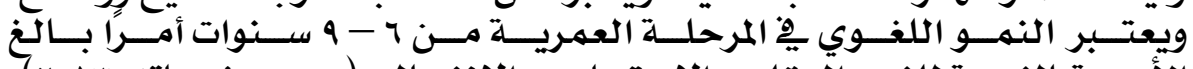

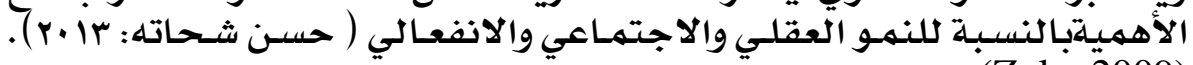
.(Zola: 2009)

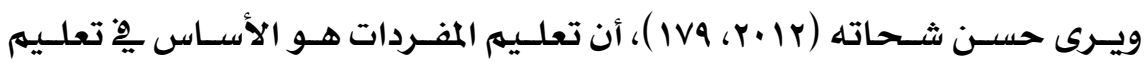

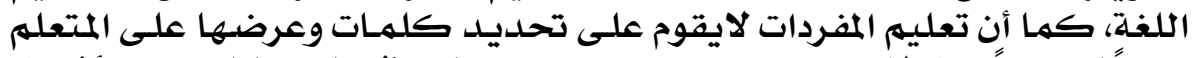

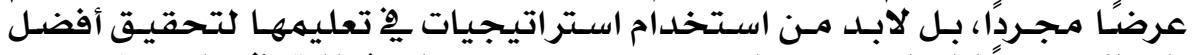

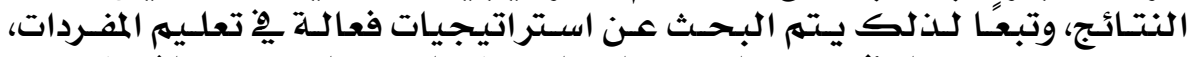

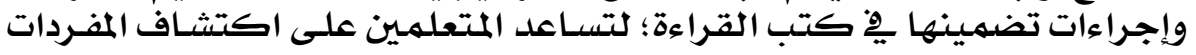

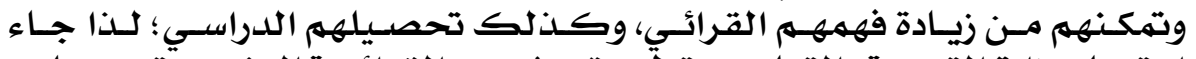

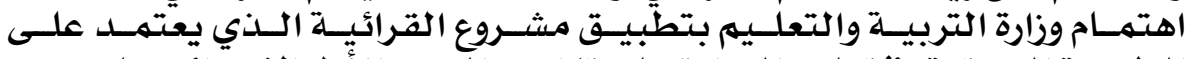

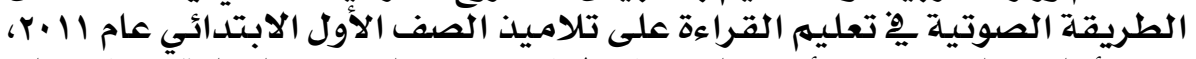

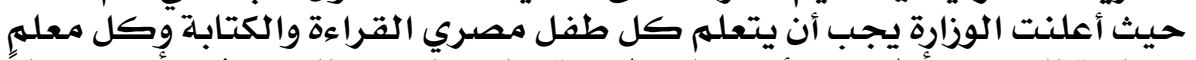

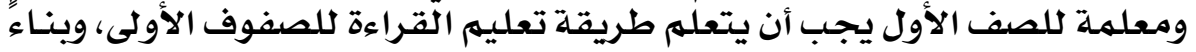

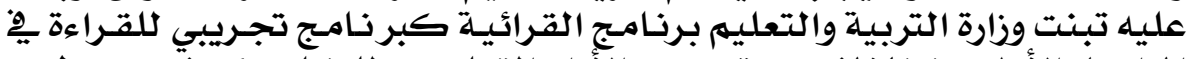

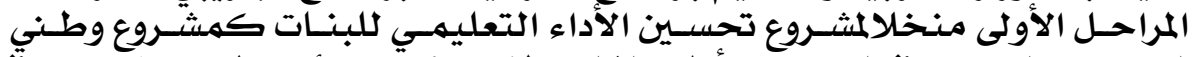

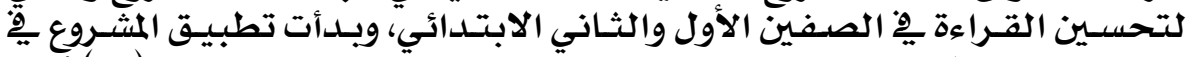

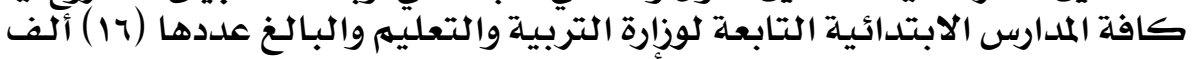

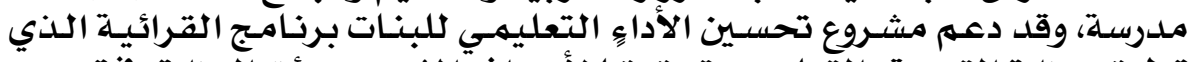

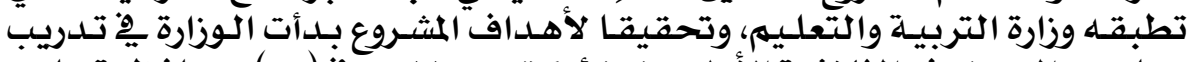

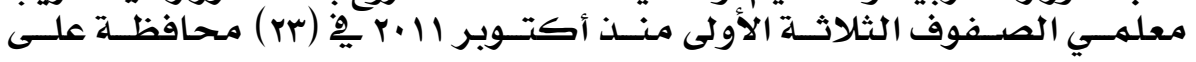

\section{$1 \vee 0$}




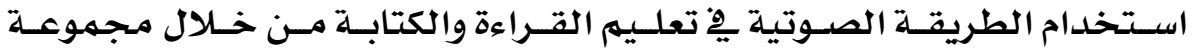

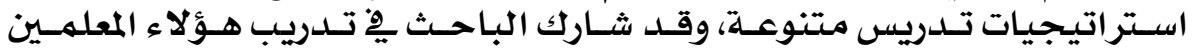

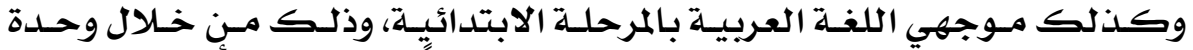

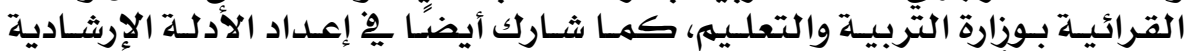

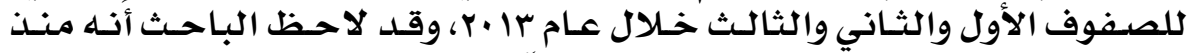

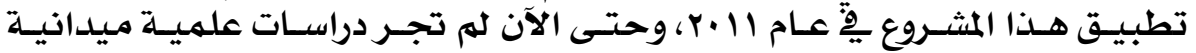

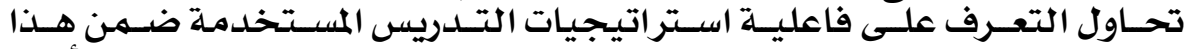

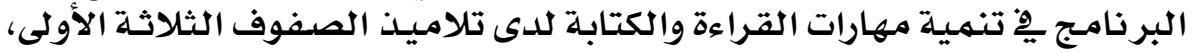

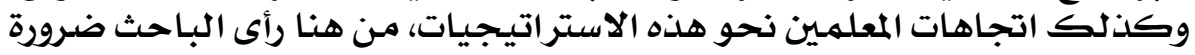
إجراء هذا البـ البحث.

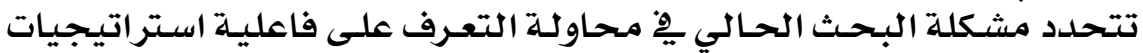

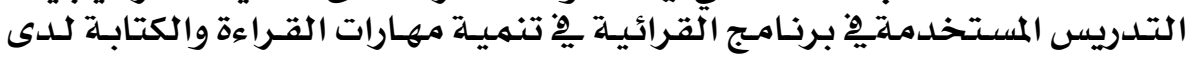

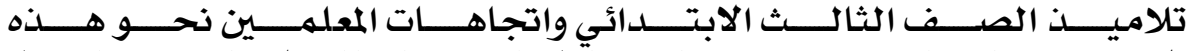

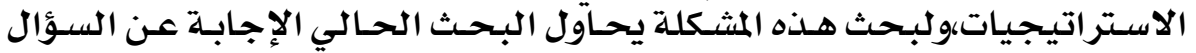

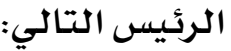

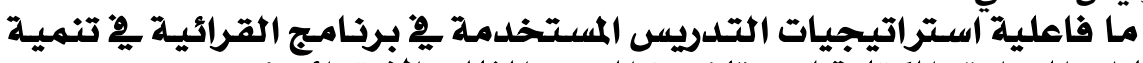

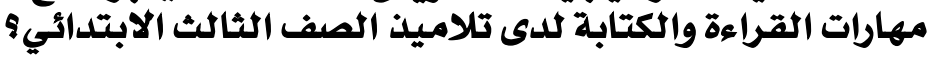

ويتفرع عن هذا السؤال الرئيس الأسئلة الفرعيـة التالية:

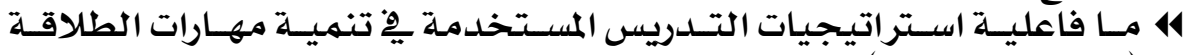

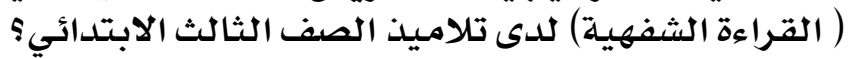

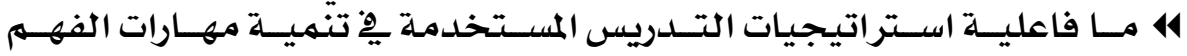

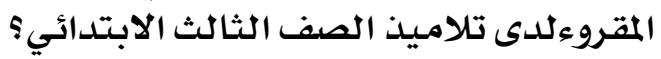

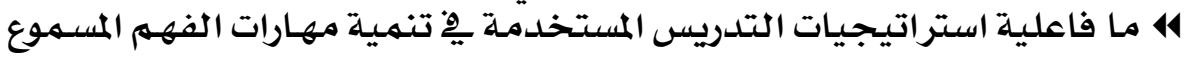

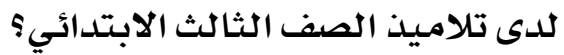

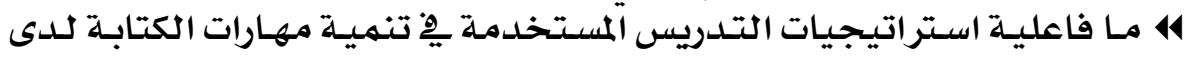

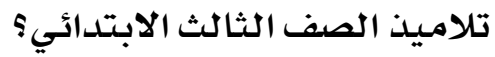

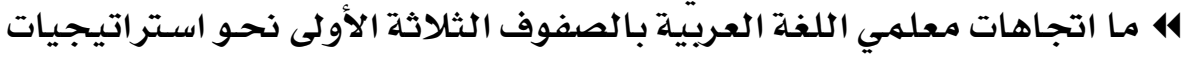

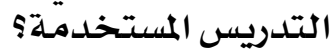
• مدورد الدراسة:

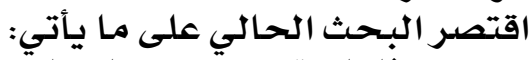

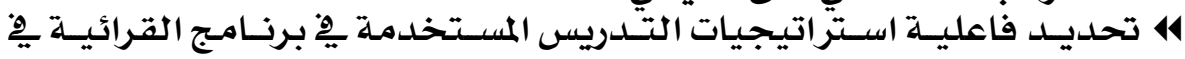
تنميـة مهارات

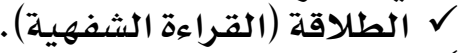
$\checkmark$

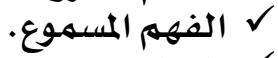
ل الكتابة. 4 عينـة مـن تلاميذ الصف الثالث الابتدائي المطبق عليهم برنامـج القرائية.

\section{$1 \vee 7$}




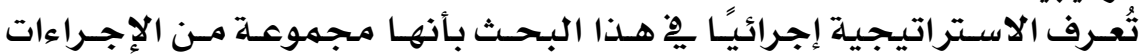

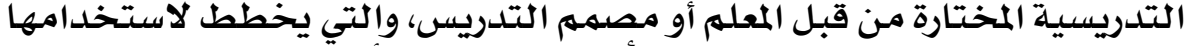

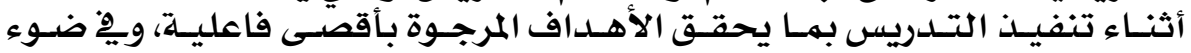

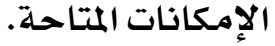

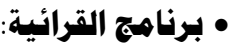

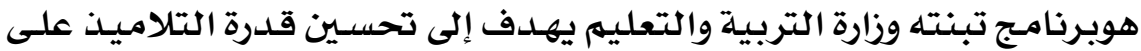

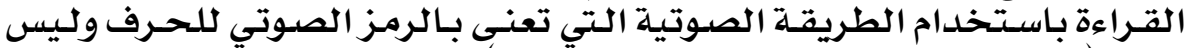
اسمه (الحرف + حركة الحرف = صوت الحرتية الحرف).

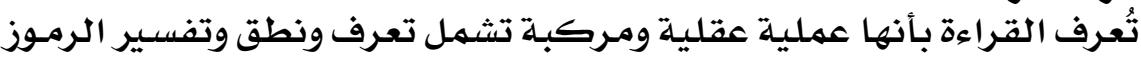

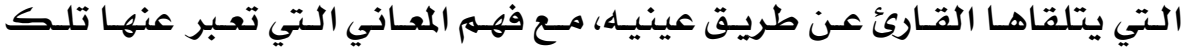

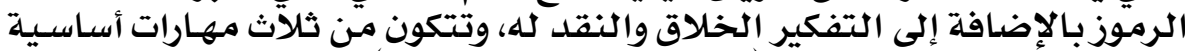

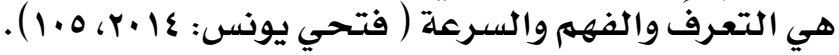

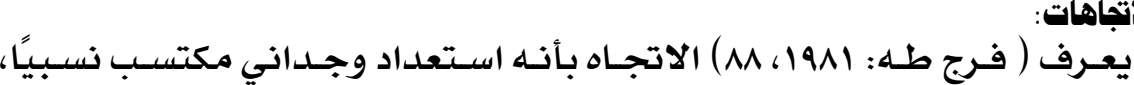

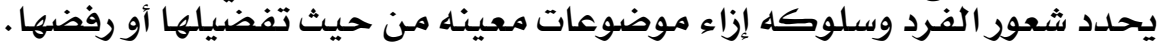

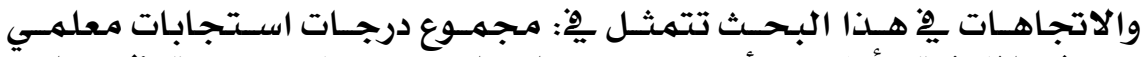

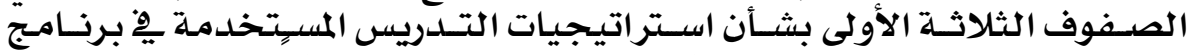

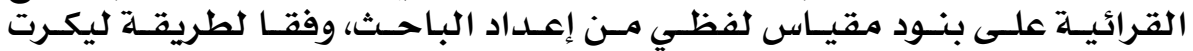
.Likart

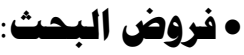

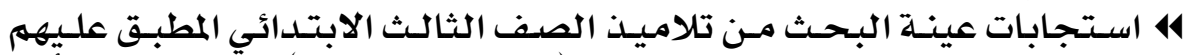

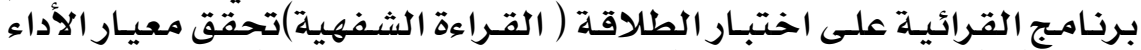

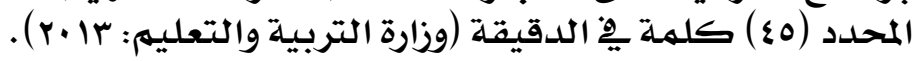

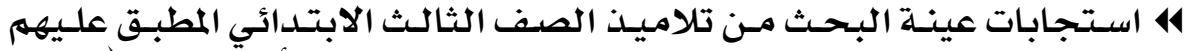

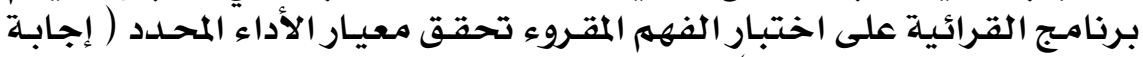
9 و أسئلة من أسئلة الاختبار).

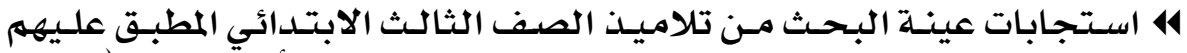
برنامج القرائية على اختبار الفهم المسموع تحقق معيار الأداء المحسد الماند ( إجابة 1 أسئلة من أسئلة الاختبار).

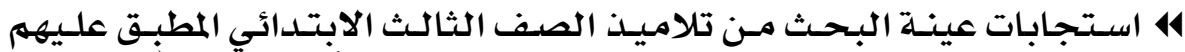

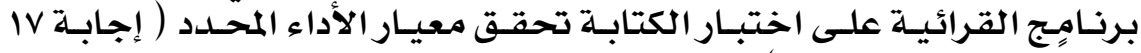

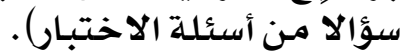

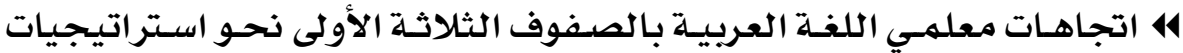

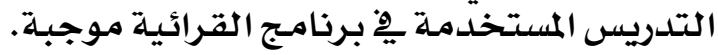

\section{IVV}




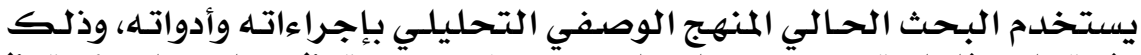

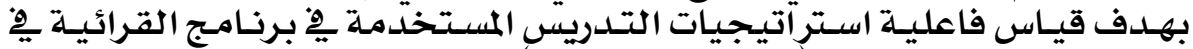

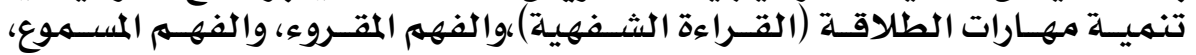

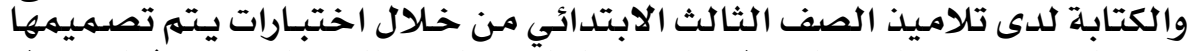

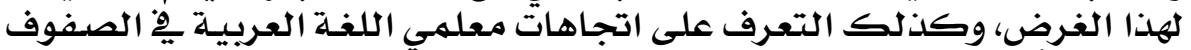

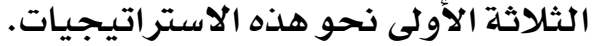

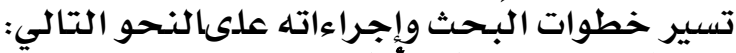

\section{• خطوات البمث وإجراءاته:}

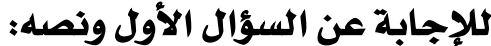

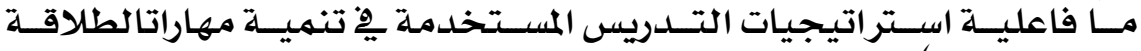

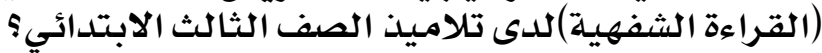

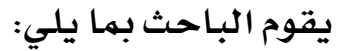

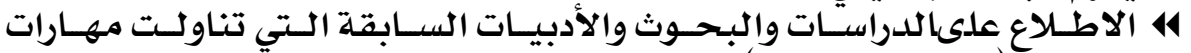

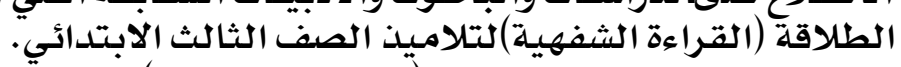

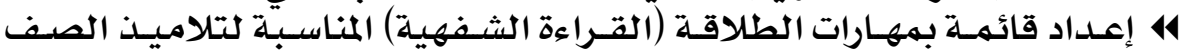

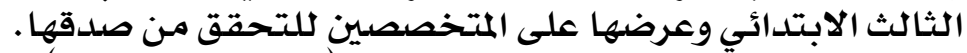

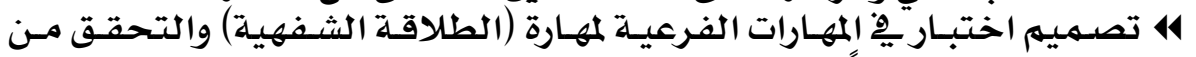

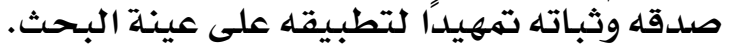

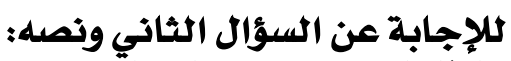

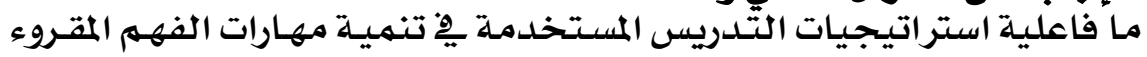

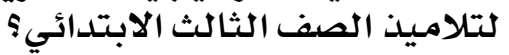

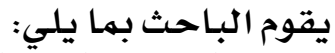

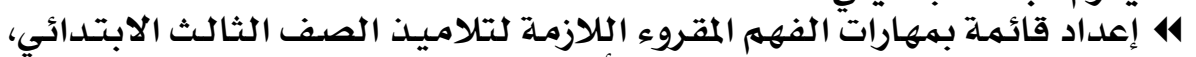

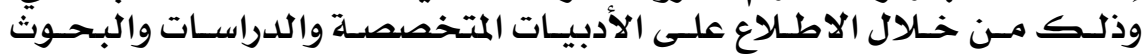

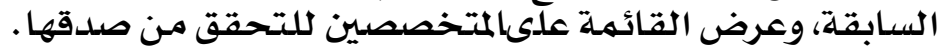

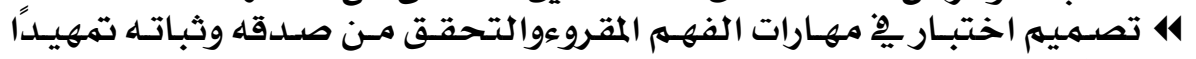
كتطبيقه على عينـة البـحث.

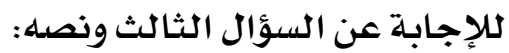

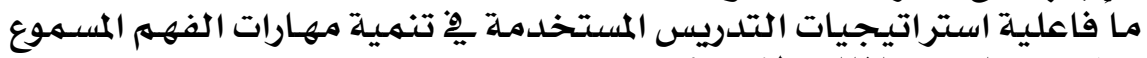

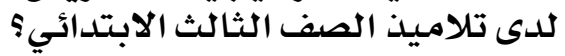

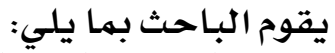

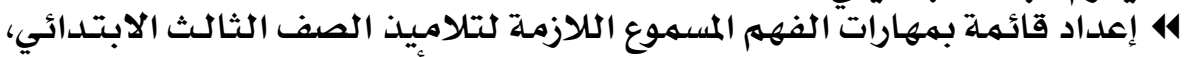

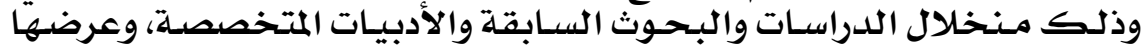

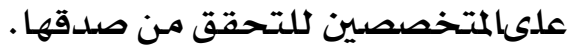

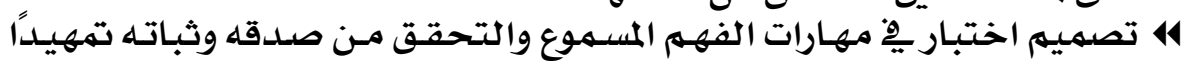
كتطبيقه على عينـة البـحث. كلإجابـة عن السؤال الرابـع ونصـه:

\section{IVA}




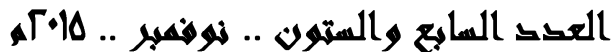

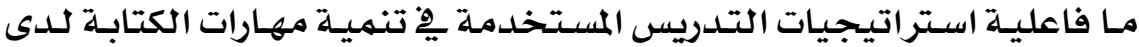

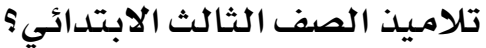

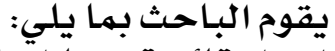

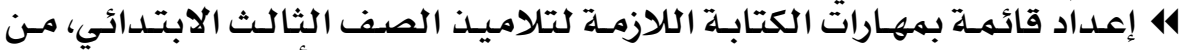

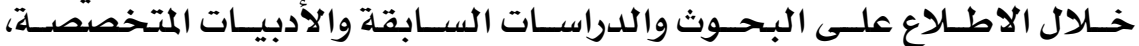

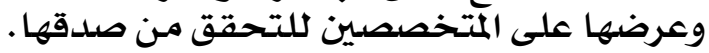

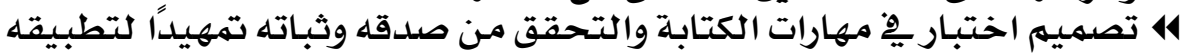

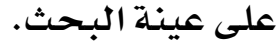

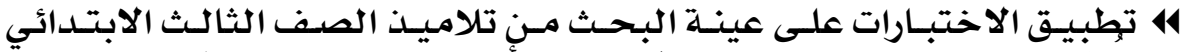

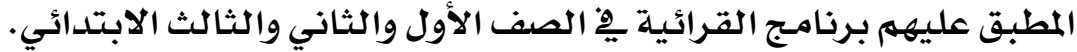

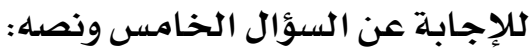

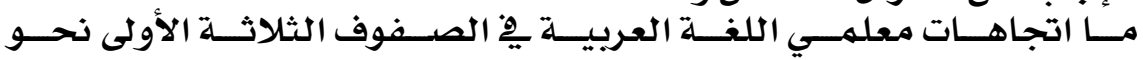

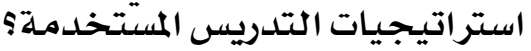

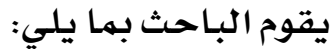

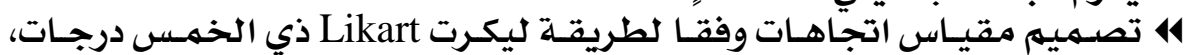

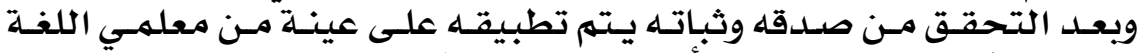

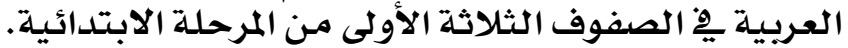

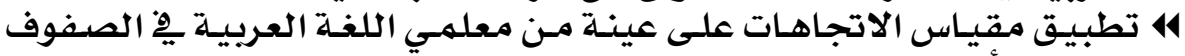

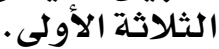
4 رصد النتائج ومعالجتها إحصائيًا وتقديم التوصيات والمقترحات.

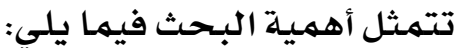

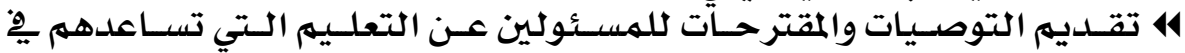

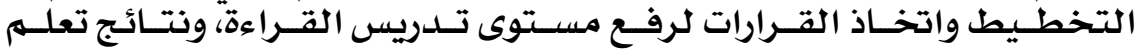

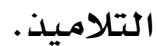

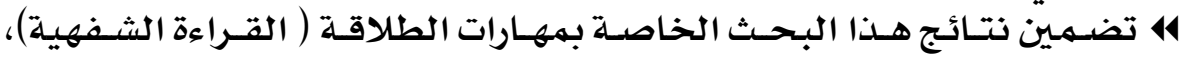

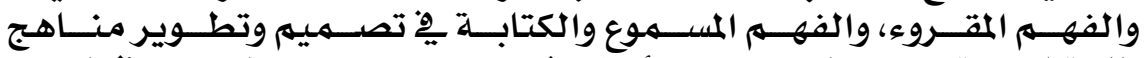

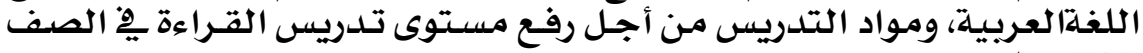

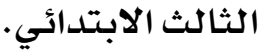

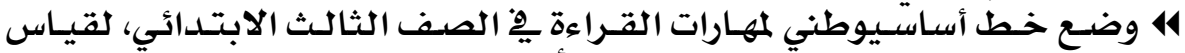

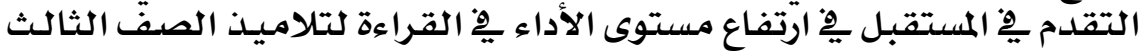
الابتدائي. 414

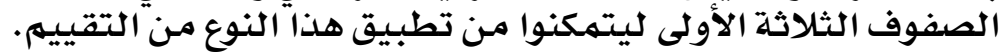

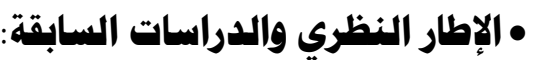

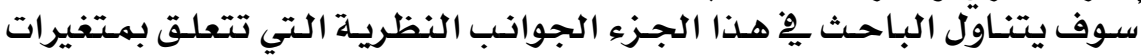

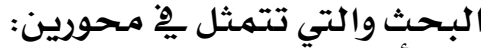

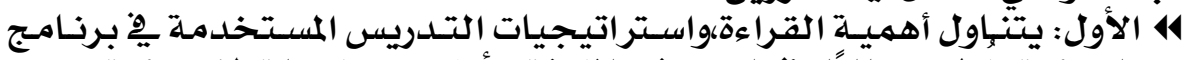

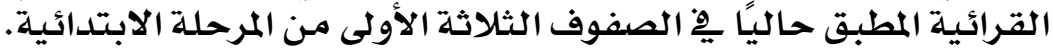

\section{$1 \vee 9$}




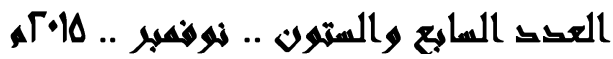

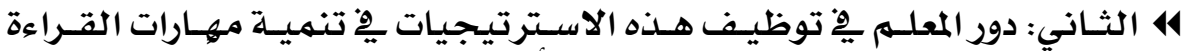

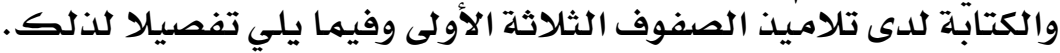

• المهور الأول:أهميسة القراءة واستراتيهيات التدريس المستخدهة في برناهمج القرائية :

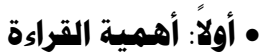

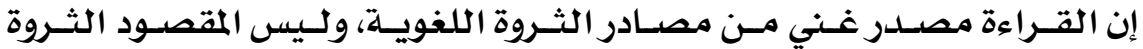

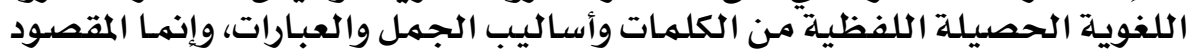

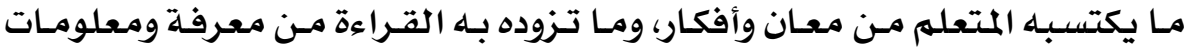

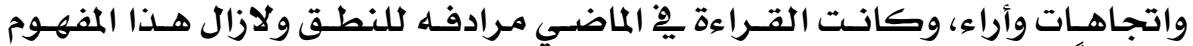

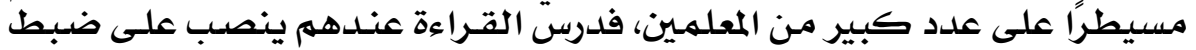

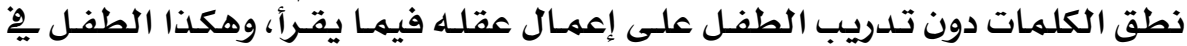

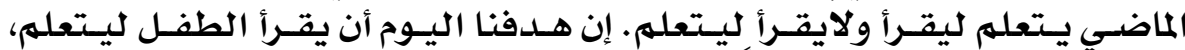

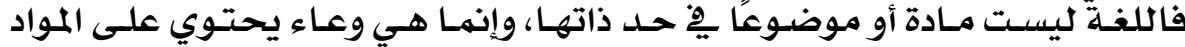

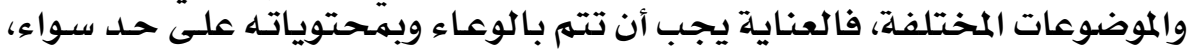

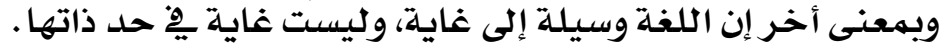

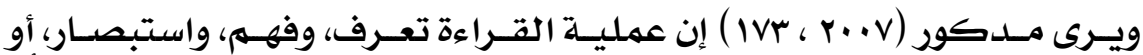

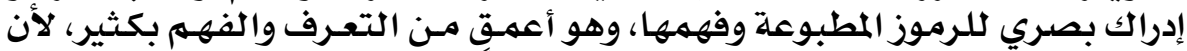

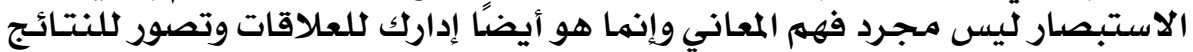

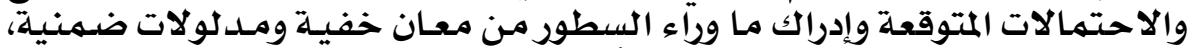

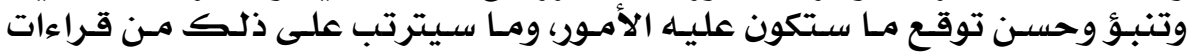
وأحكام. وتوبن.

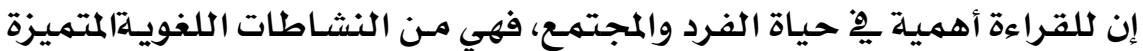

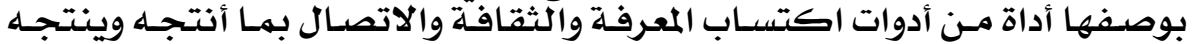

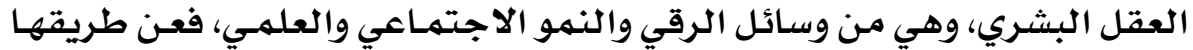

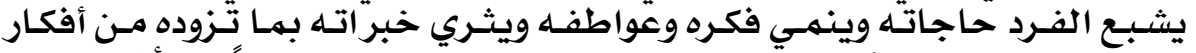

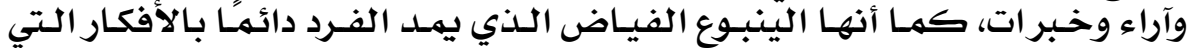

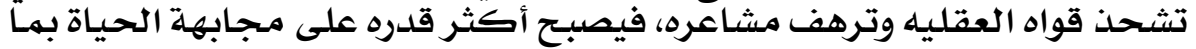

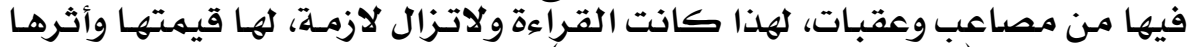

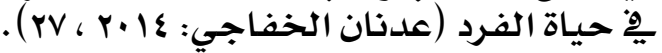

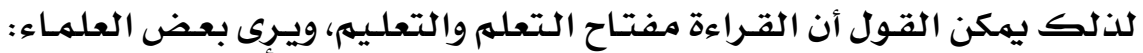

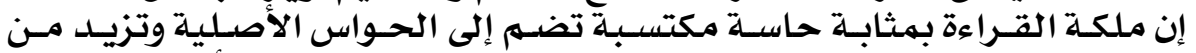

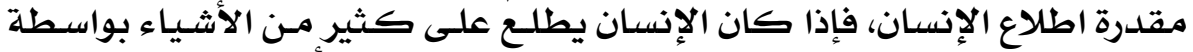

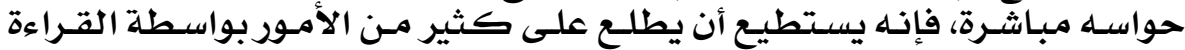

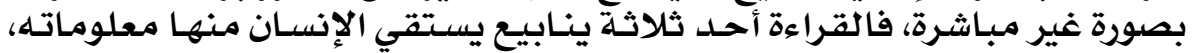

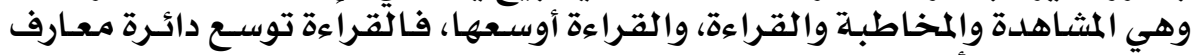

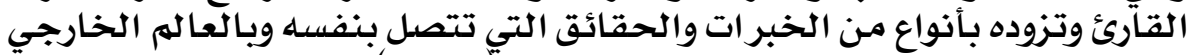

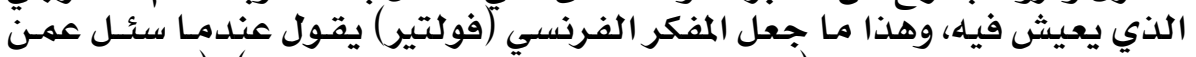

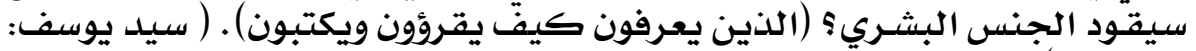
. (07 1999.

\section{$1 \wedge$}




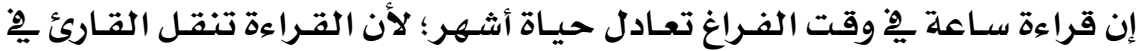

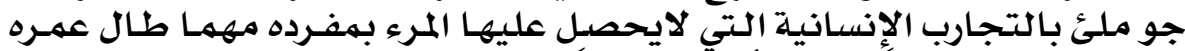

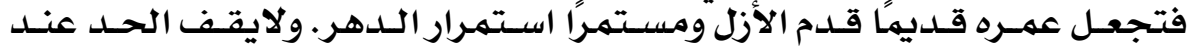

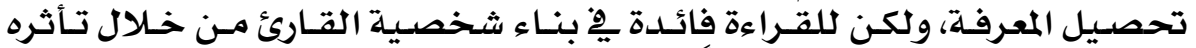

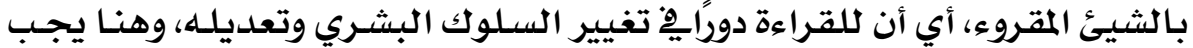

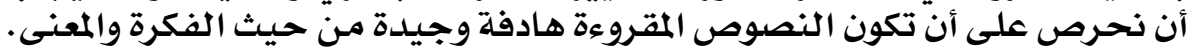

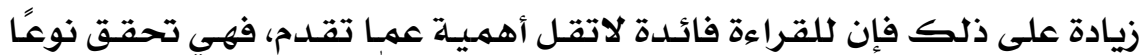

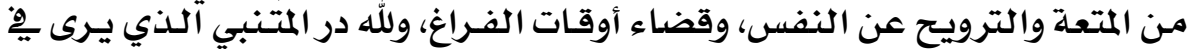

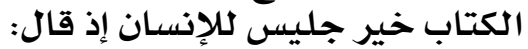
أعز مكان يف الدنى سرج سابح

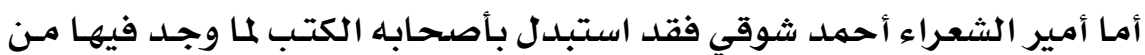

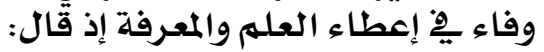

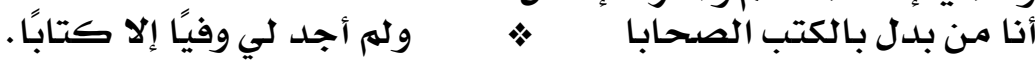

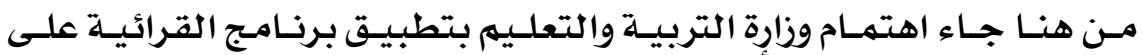

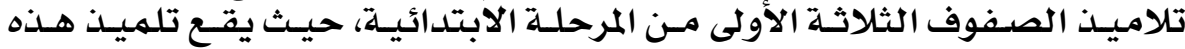

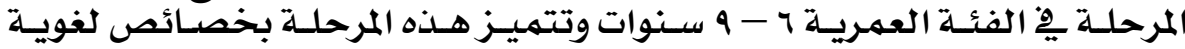

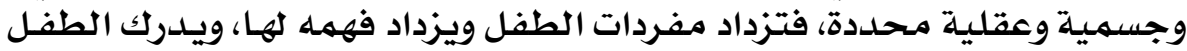

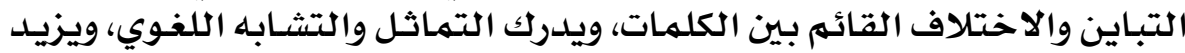

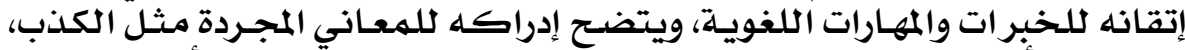

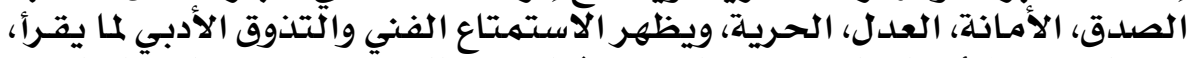

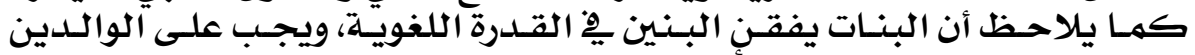

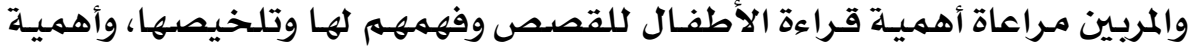

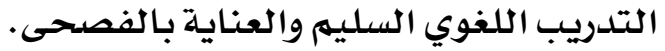

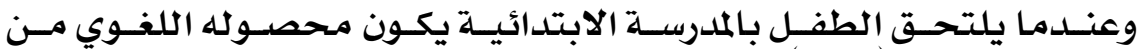

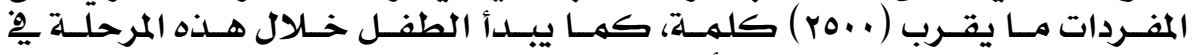

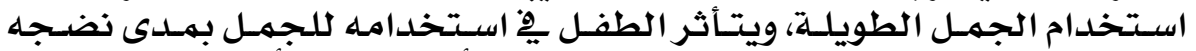

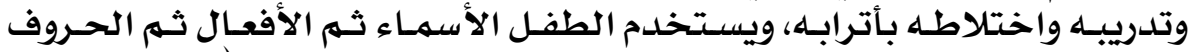

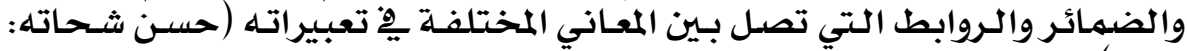
.$(r \cdot 1 r$

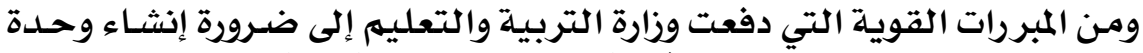

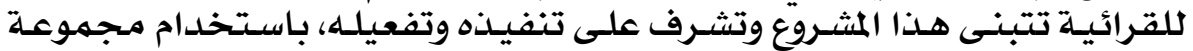

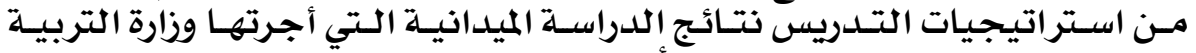

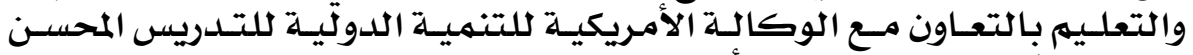

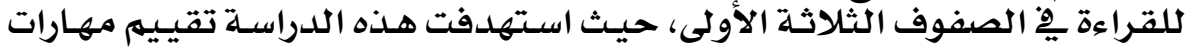

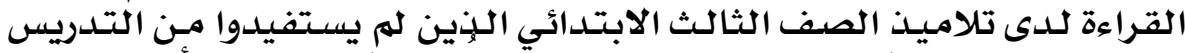

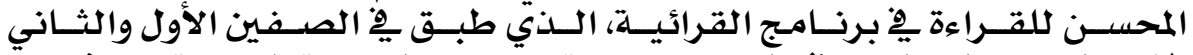

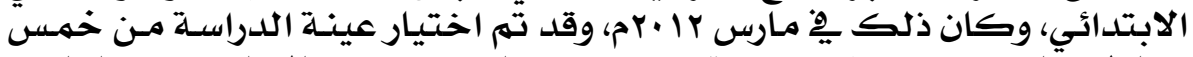

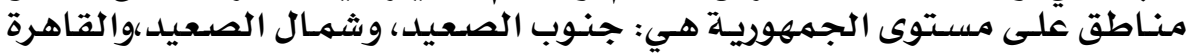

\section{$1 \wedge 1$}




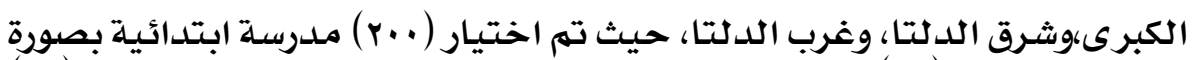

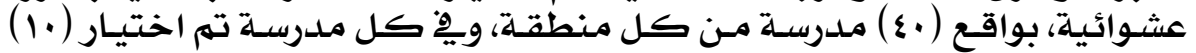

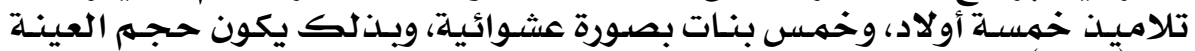

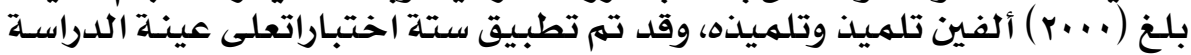
تمثلت بِ

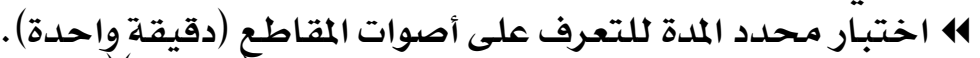

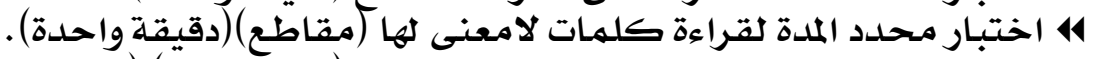

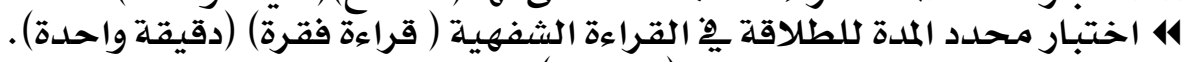

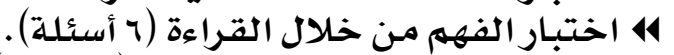

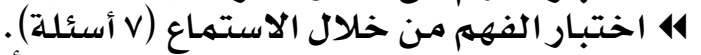

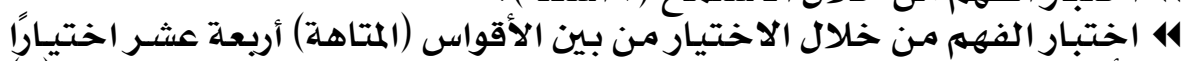

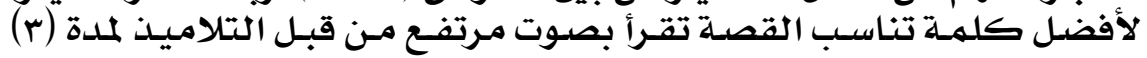
دقائق.

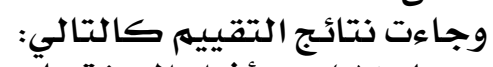

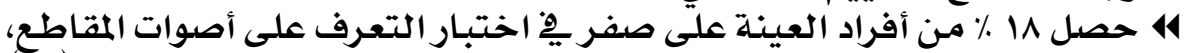

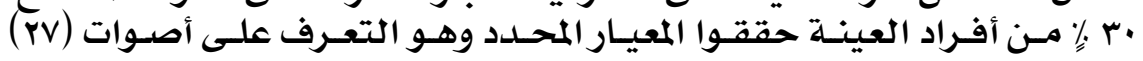

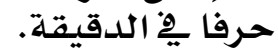

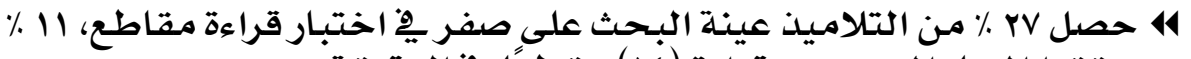

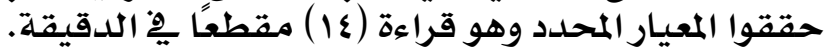

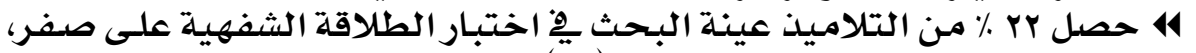

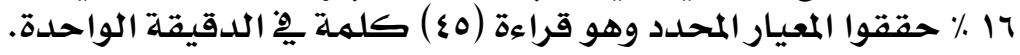

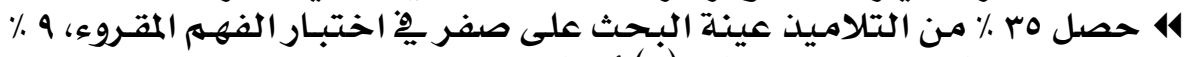

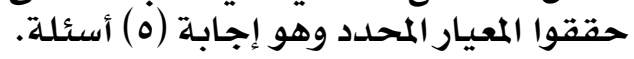

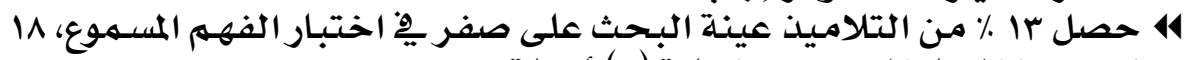

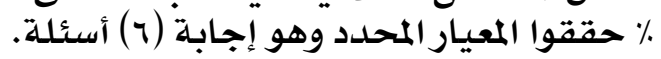

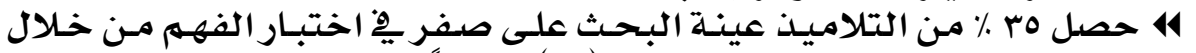

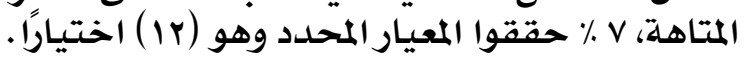

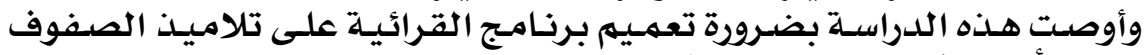

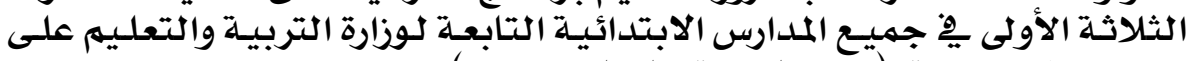

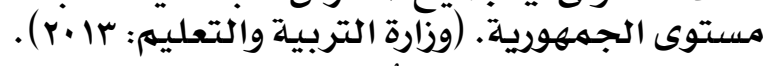

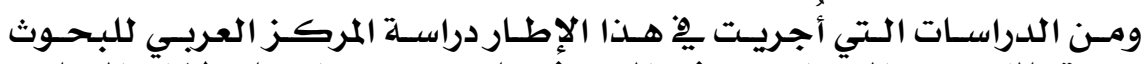

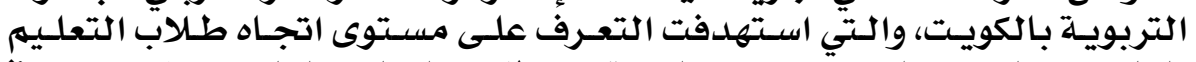

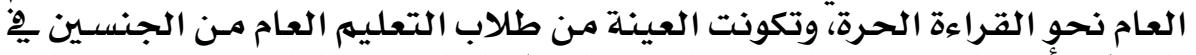

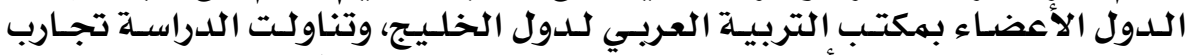

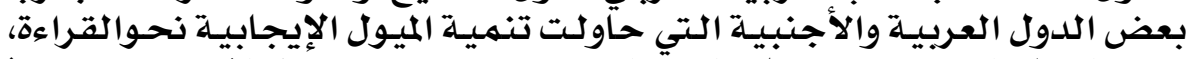

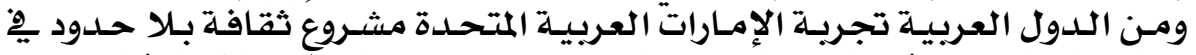

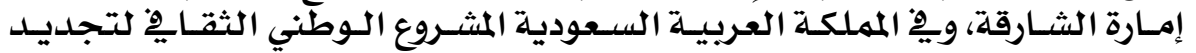

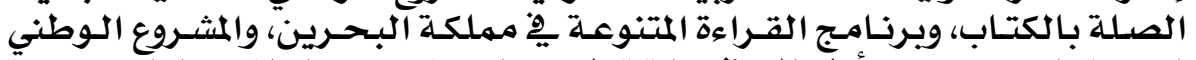

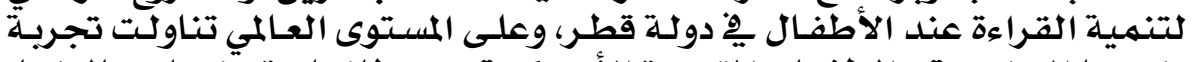

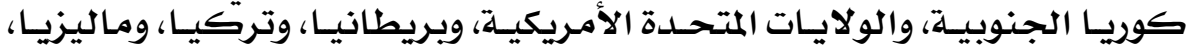

\section{$\Lambda \wedge Y$}




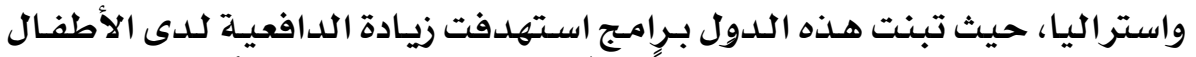

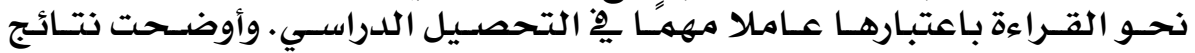

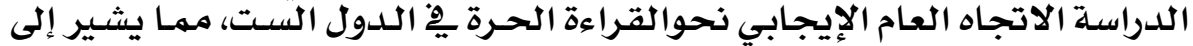

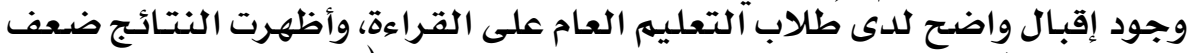

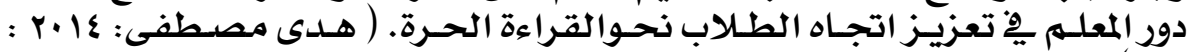

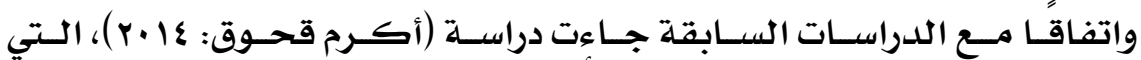

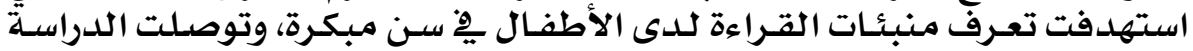

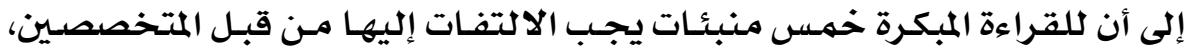

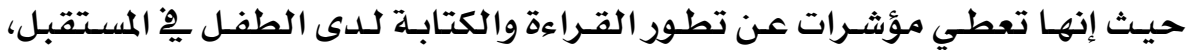

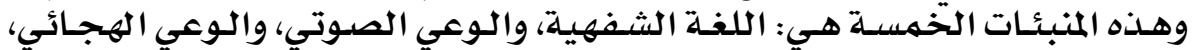

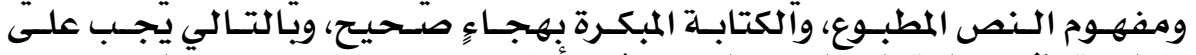

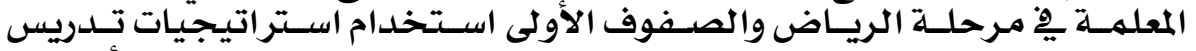

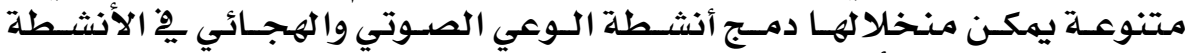

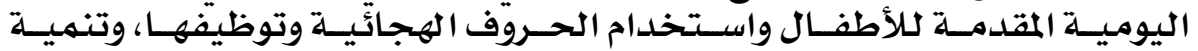

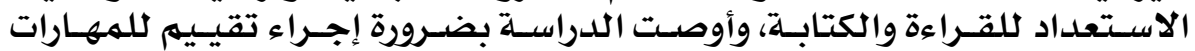

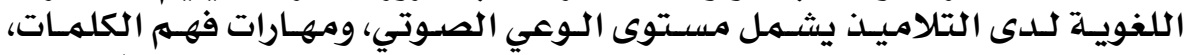

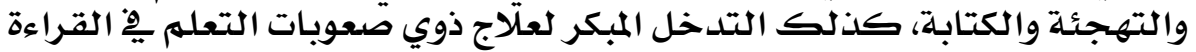

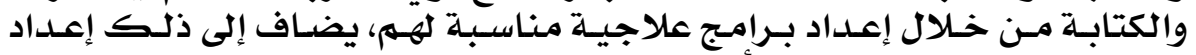

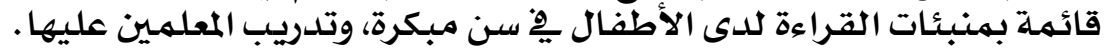

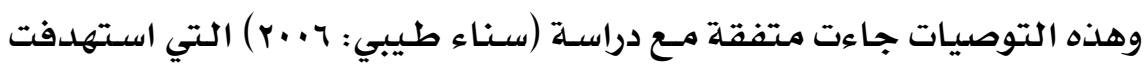

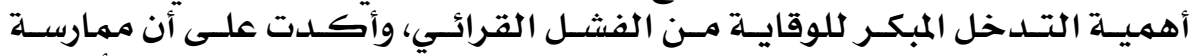

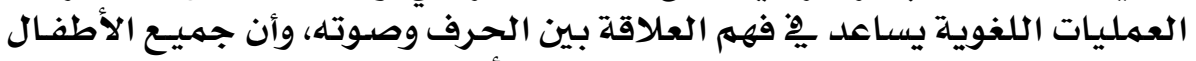

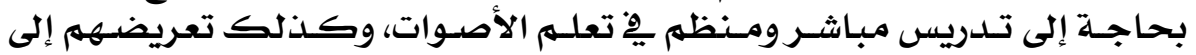

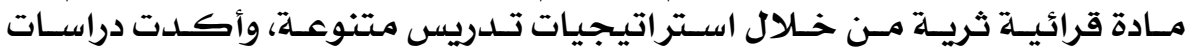

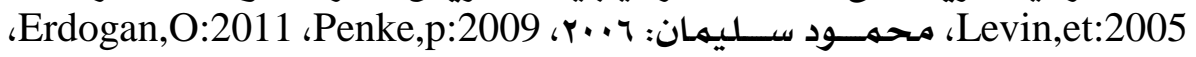

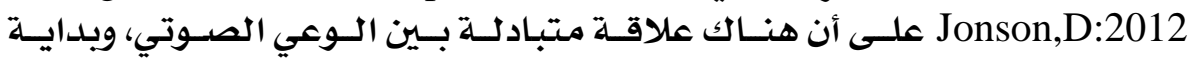

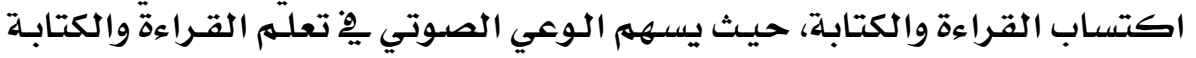

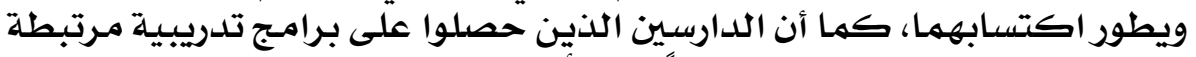

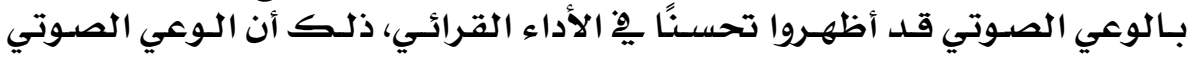

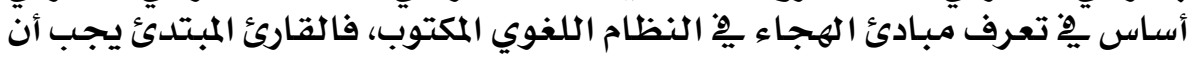

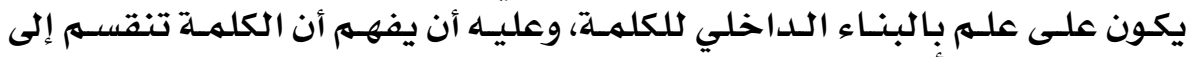

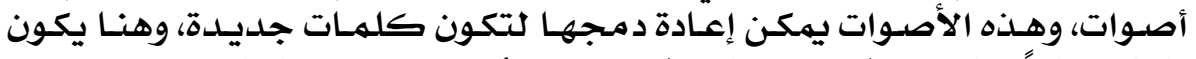

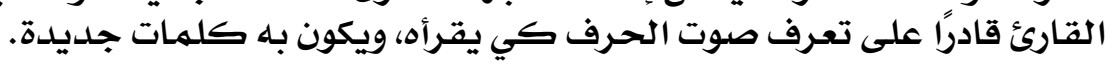

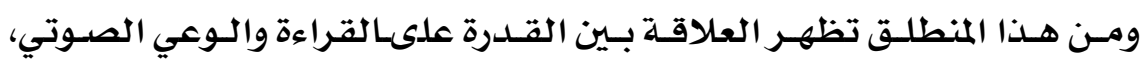

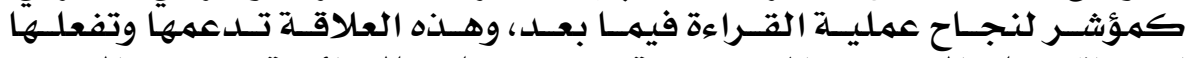

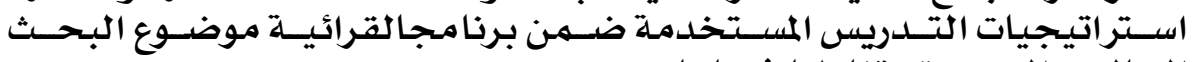
الحالي، والتي سيتهم تناولتهات التيس فيما يلي:

\section{$1 \wedge \mathrm{H}$}


العكت السابع والستون .. نوهمبر ..

• ثانيًا : استراتيجيات التدريس المستخدهة:

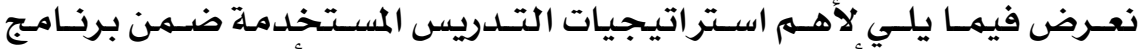

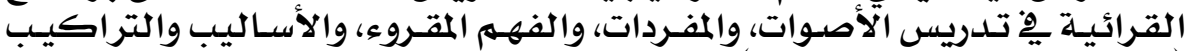

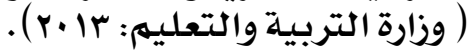

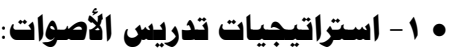

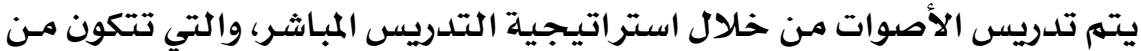

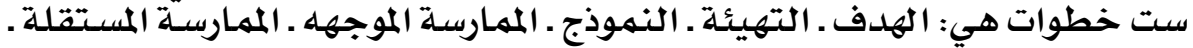

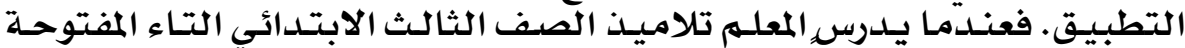

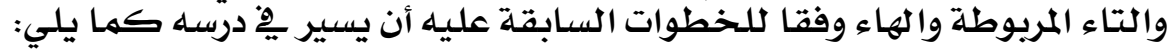

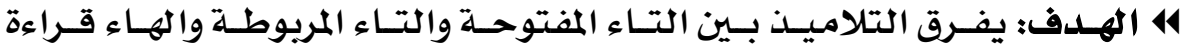

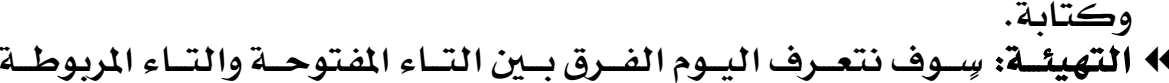
والهاءوراءة وكتابة.

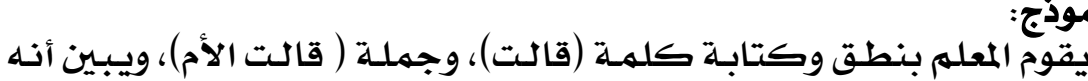

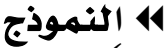

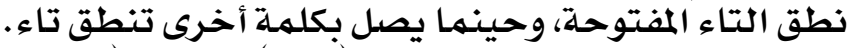

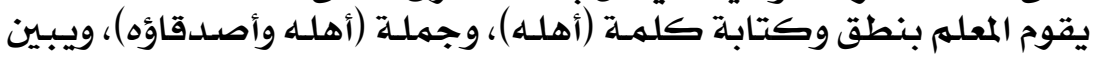

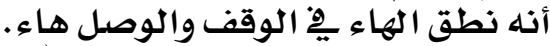

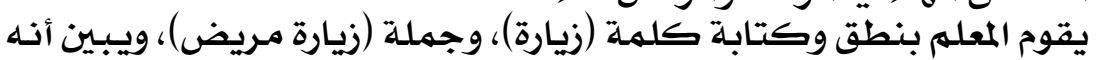

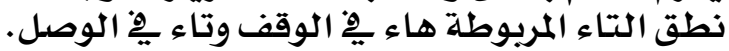

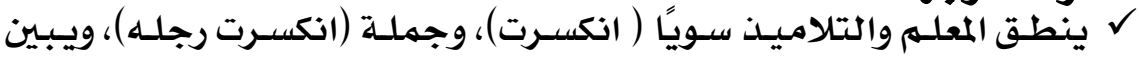

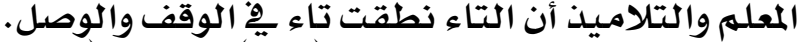

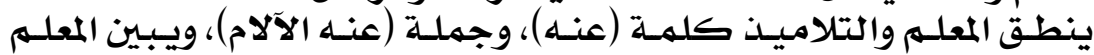

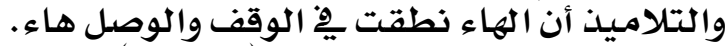

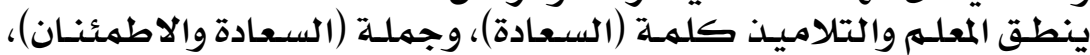

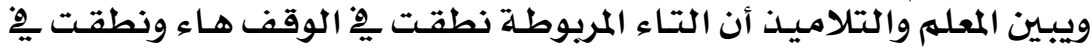

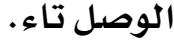

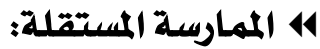

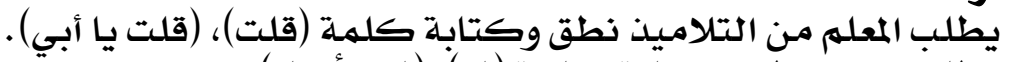

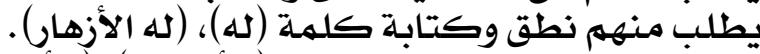

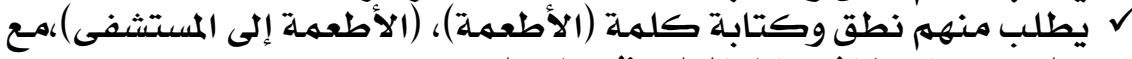

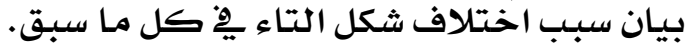

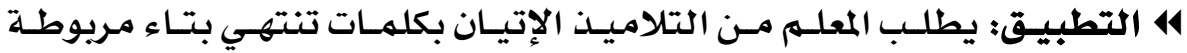
وأخرى مفتوحة ولة، وهاء.

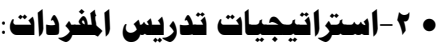

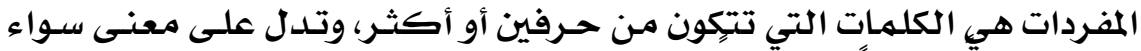

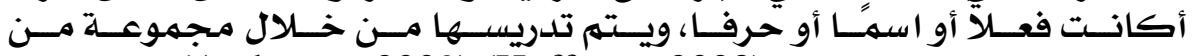
استراتيجيات التدريس منها :(Hoffman: 2008) (Anderson: 2009).

\section{$1 \wedge \varepsilon$}




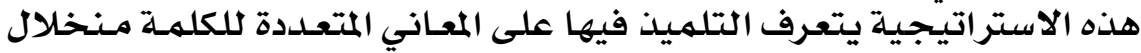

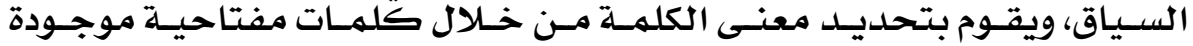
بالجملـة.

$$
\text { وتدريس المفردات وفقا لهذه الاستراتيـجية يكون كاتتالي: }
$$

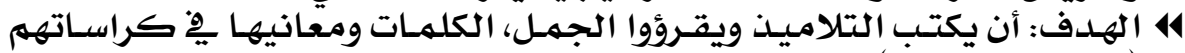

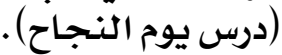

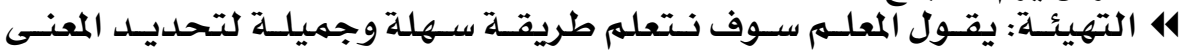

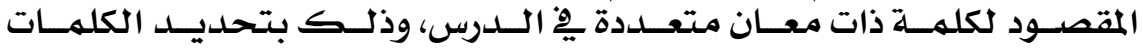

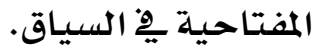

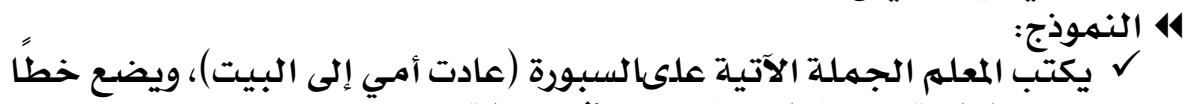

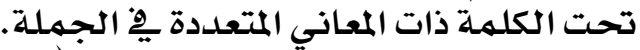

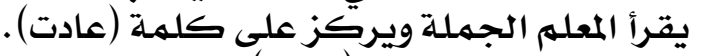

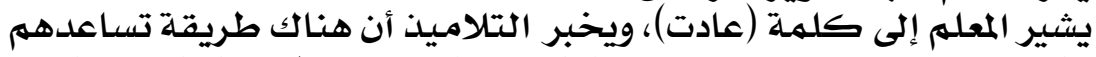

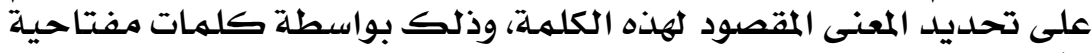

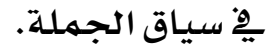

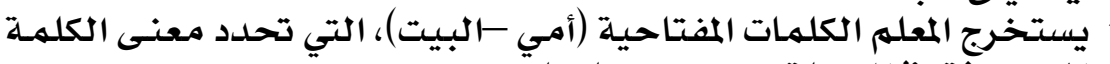

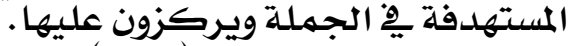

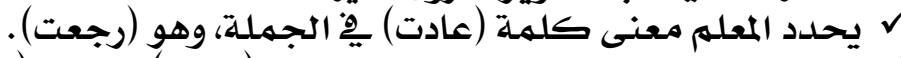

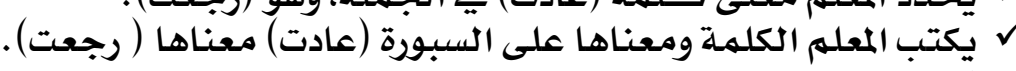

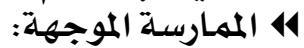

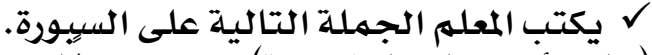

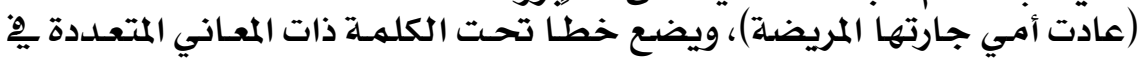
الجملة.

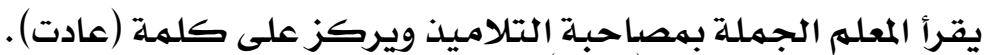

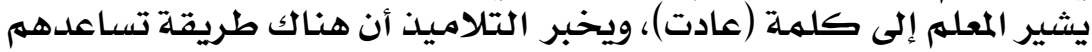

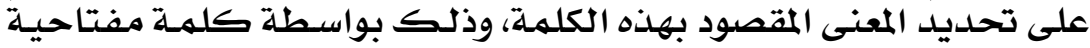

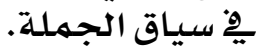

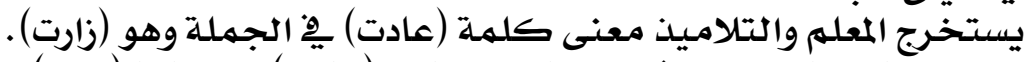

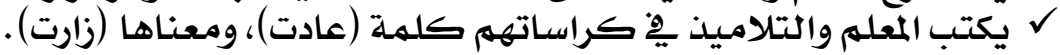

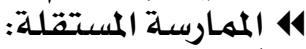

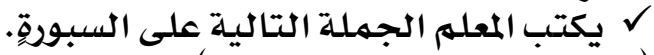

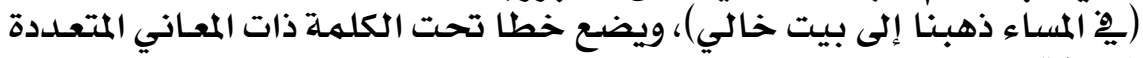

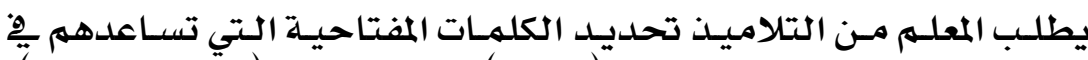
20.

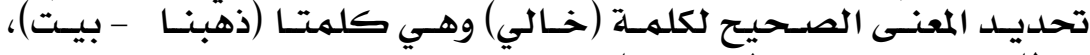

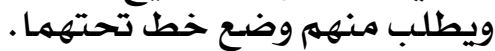

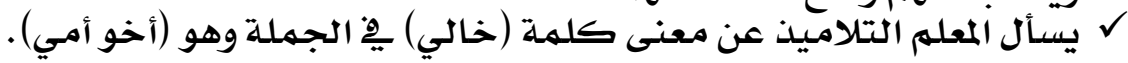

\section{$1 \wedge 0$}




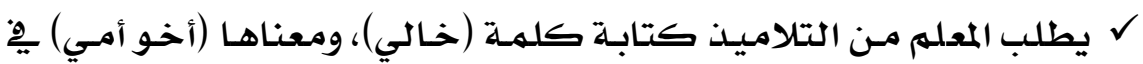

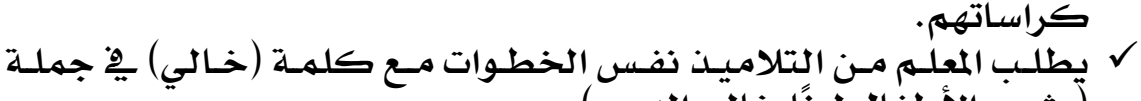
(تيشرب الأطفال لبنًا خالي الدسمى).

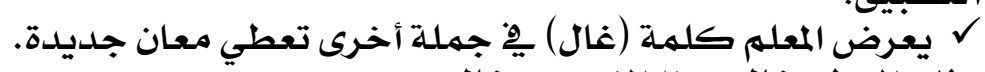

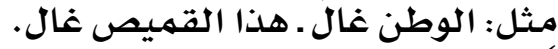
ل

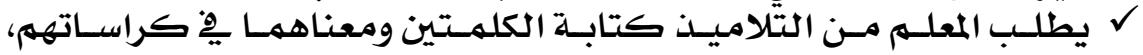

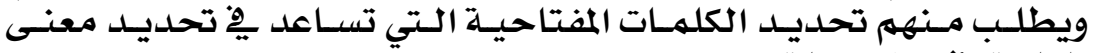

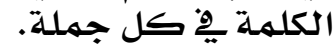

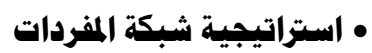

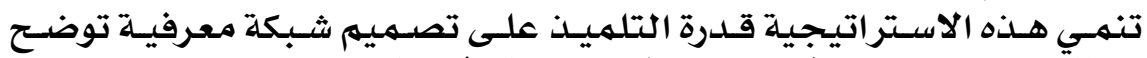

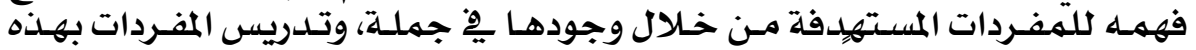
الاستراتيجية يسير وفقا للخطوات الميكات التالية:

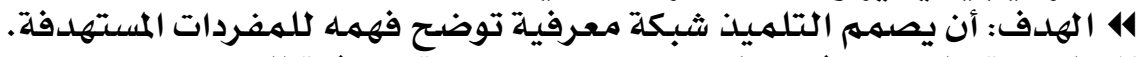
4 التهيئة: اليوم سوف نتعلم كيف نصمئم شبكة معرفية للمفردات.

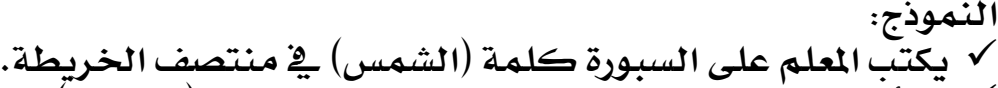

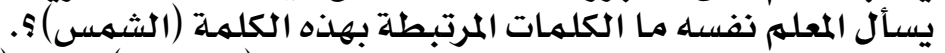

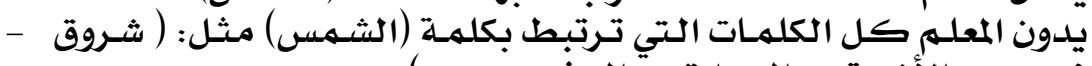
غَروب - الأثعة - الحرارة - الدفء - -.....).

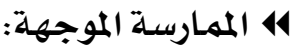
ل يكتب المعلم كلمة أخرى ( الطريق) على السبورة.

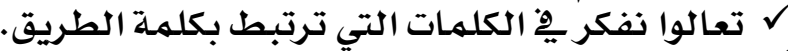

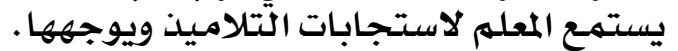

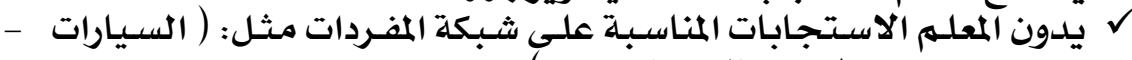

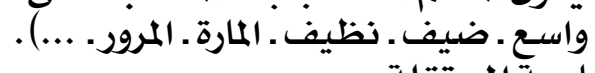
14 الممارسة المستقلة:

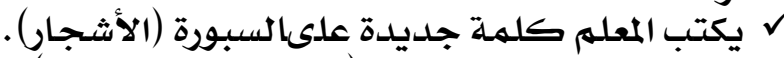

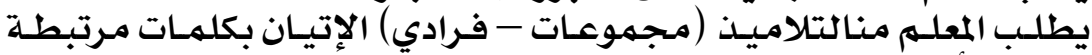
بكلمة الأشجار.

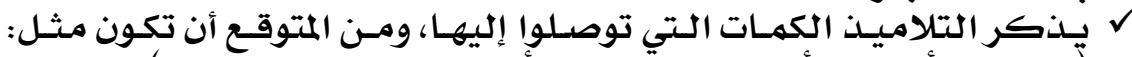

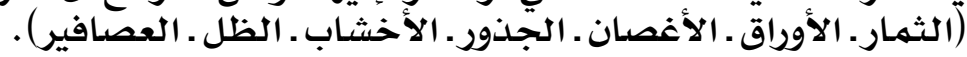

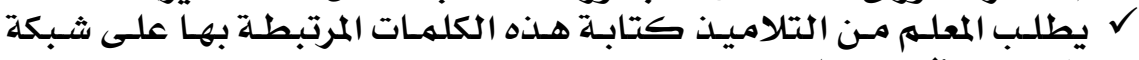

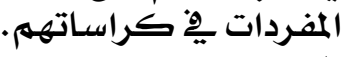

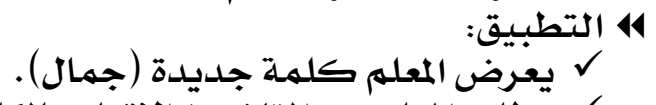

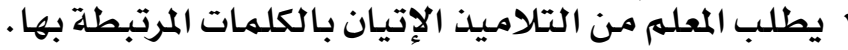

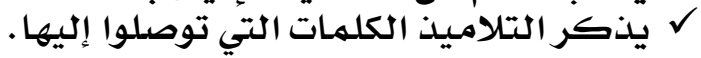

\section{$1 \wedge 7$}


ل يكتب التلاميذ هـذه الكلمسة والكلمـات المرتبطـة بها على شـبكة المفردات فِ كراساتهم.

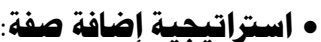

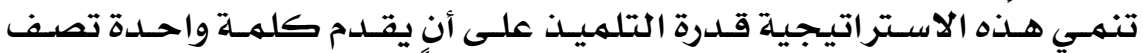

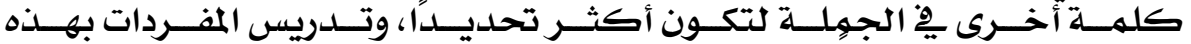

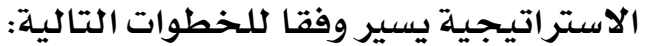

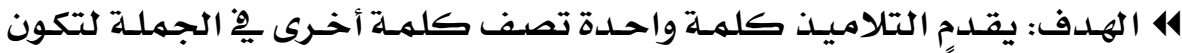

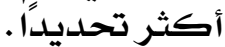

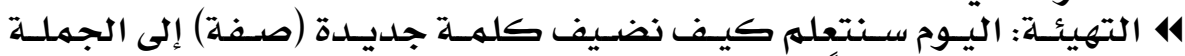

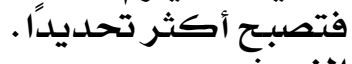

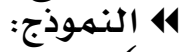

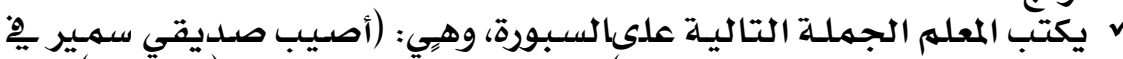

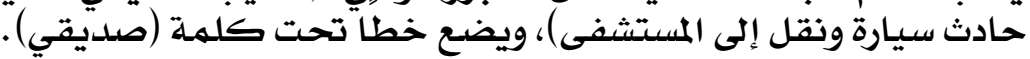

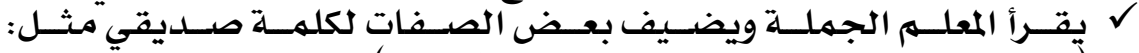

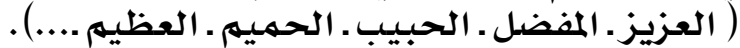

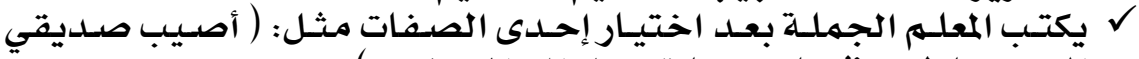

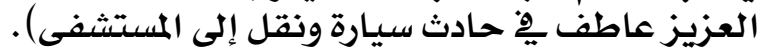

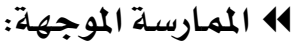

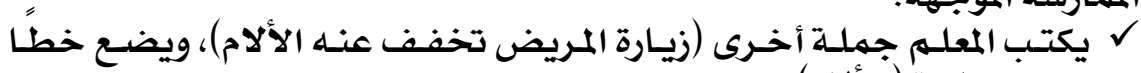
تخحت كلهمة (الألام) .

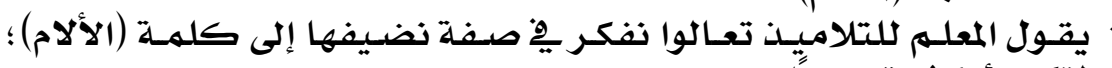

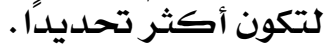

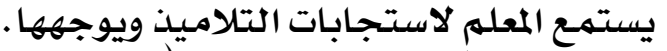

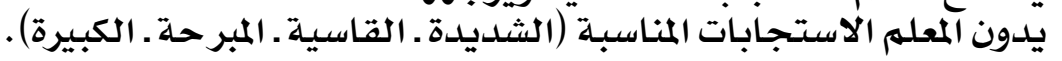

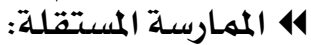

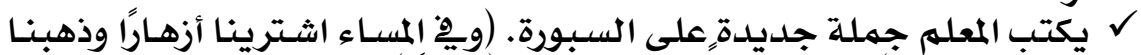

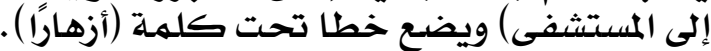

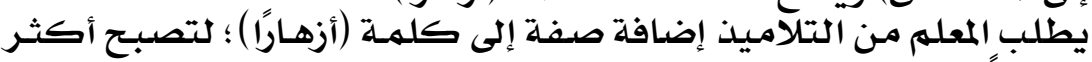
تحديدًا يذكر التلاميـذ الكلهـات التي توصلوا إليها ومـن المتوقع أن تكون (جميلـة .

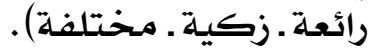

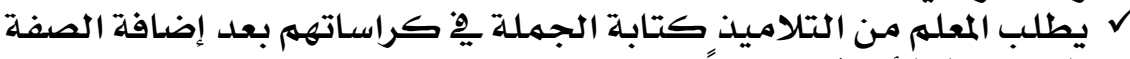

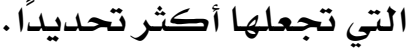
\$ التطبيق:

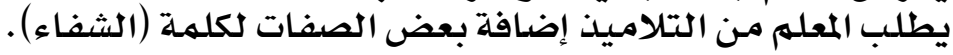

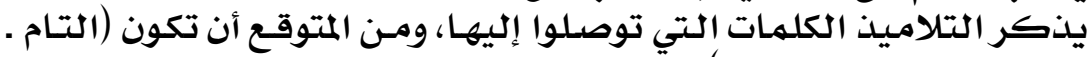

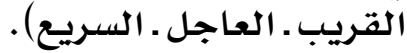

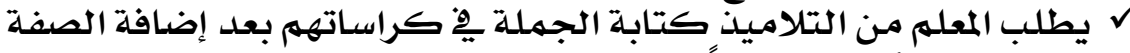

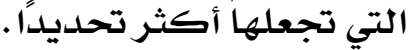

\section{IAV}




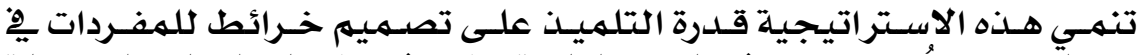

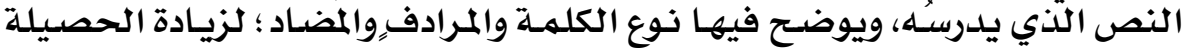

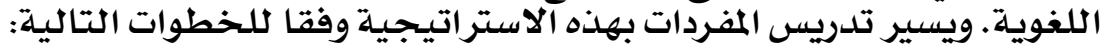

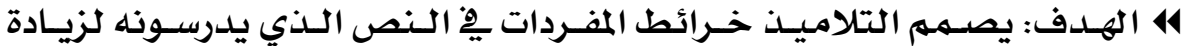
الحصيلة التئة اللغويـة.

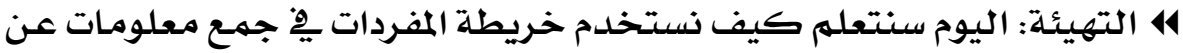

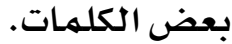

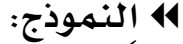
ل يعرض المعلهم خططة لخريطة المفردات كها يلي:

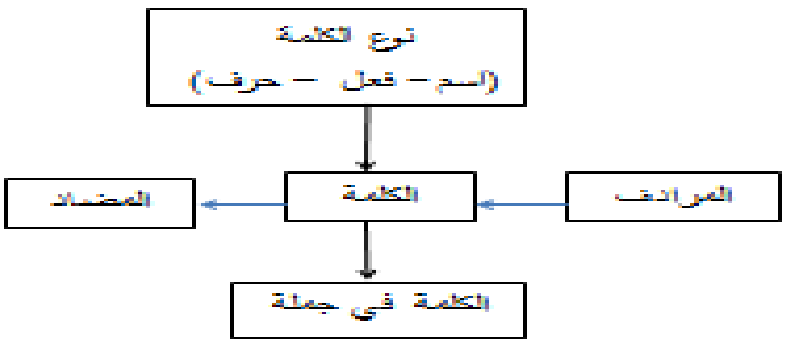

يضع المعلم كلمهة (يرتدي) على خريطة المفردات.

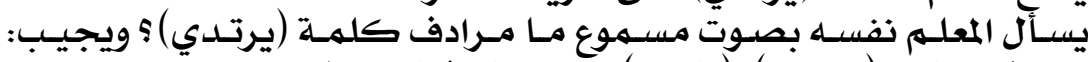

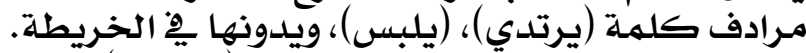

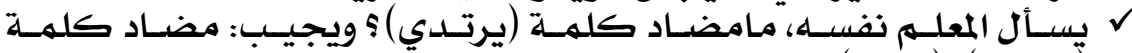

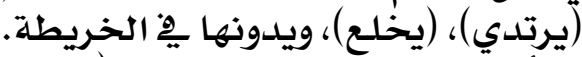

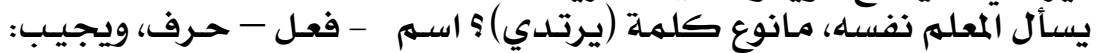

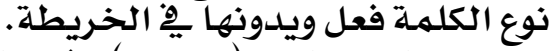

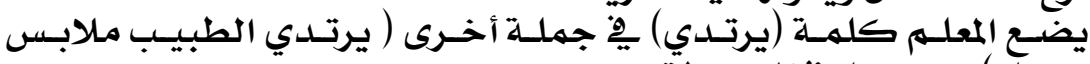

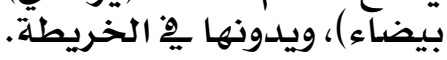

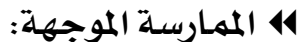

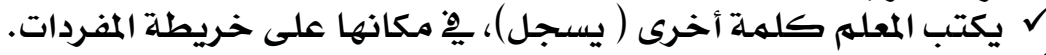

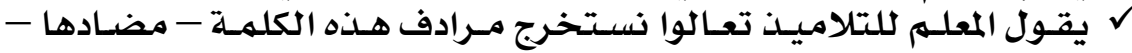

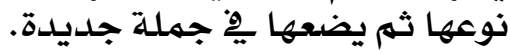

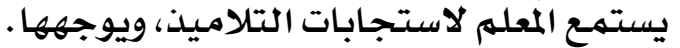

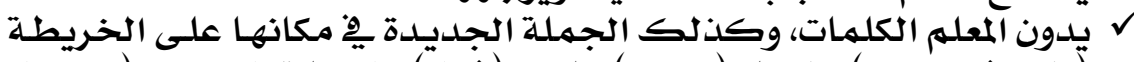

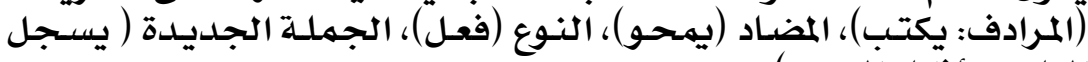

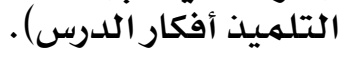

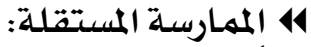

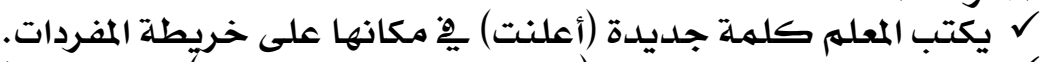

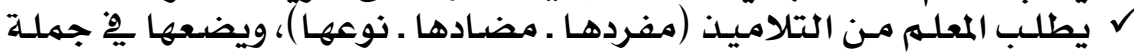
جديدة.

\section{$1 \wedge \Lambda$}




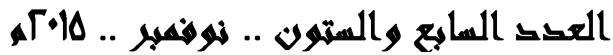

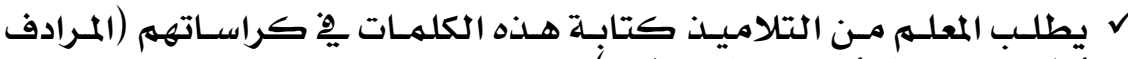

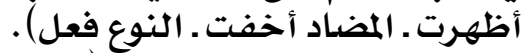

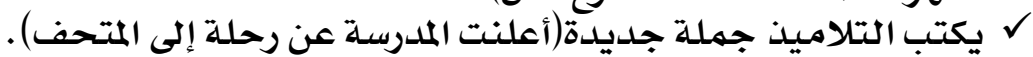

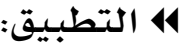

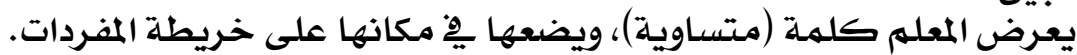

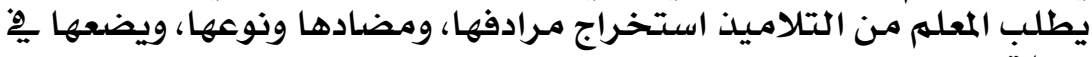

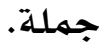

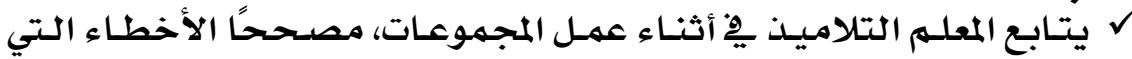
يقعون فيها.

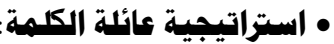

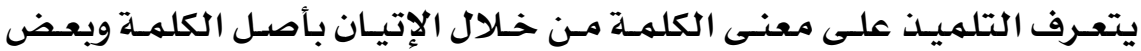

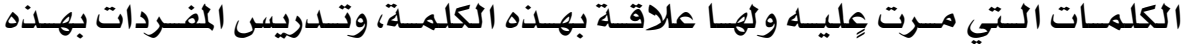

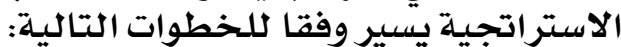

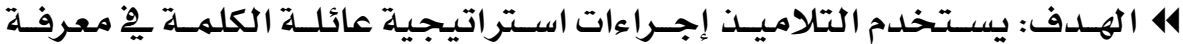

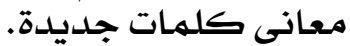

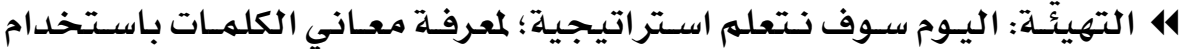
كلمات متتشابهة.

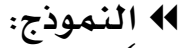

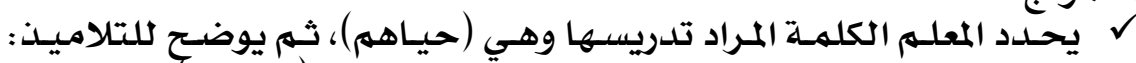

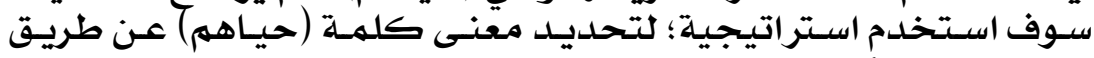

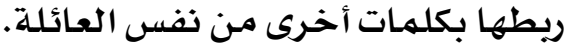

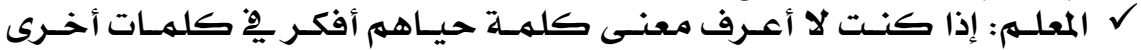

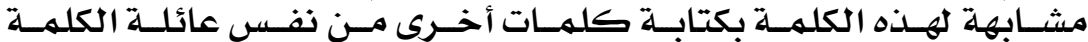

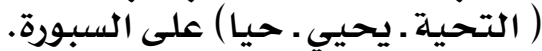

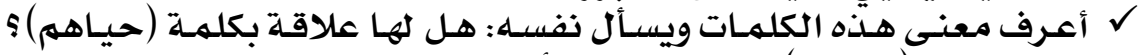

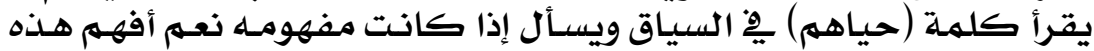

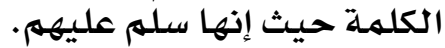
414 الممارسة الموجهة:

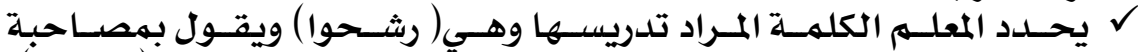

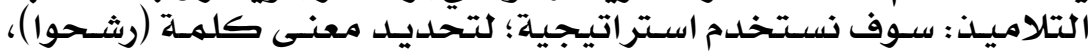

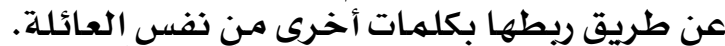

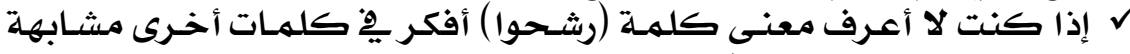

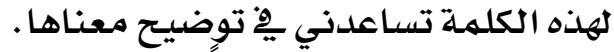

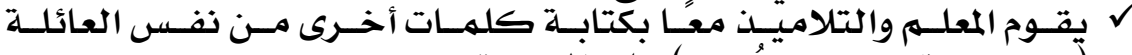

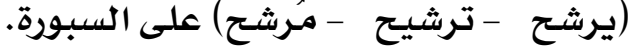

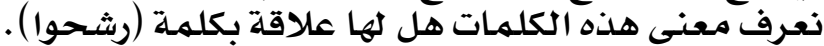

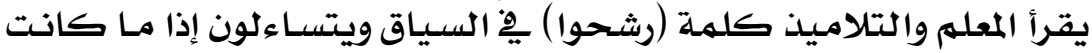

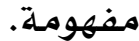

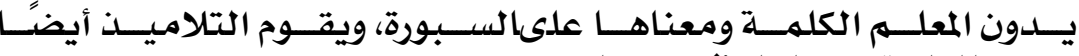

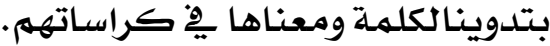

\section{9}




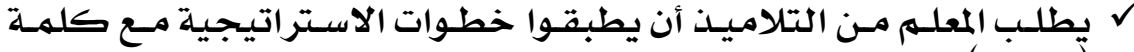

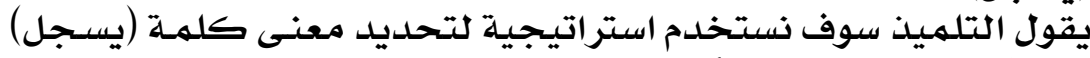

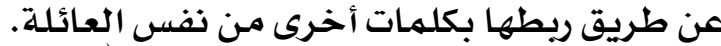

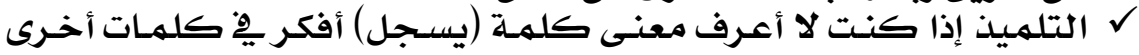

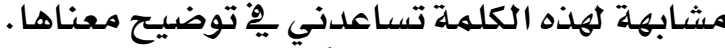

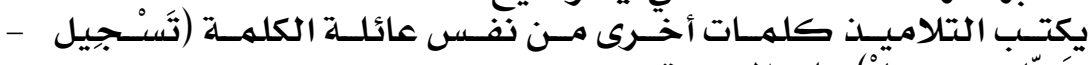

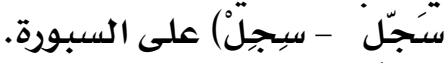

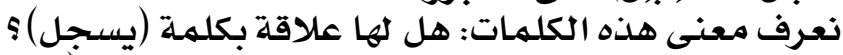

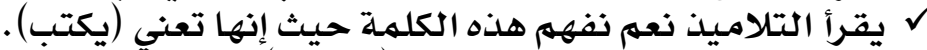

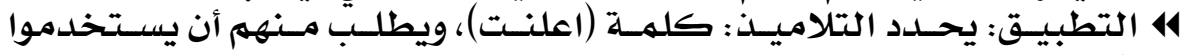

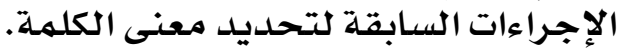

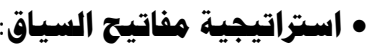

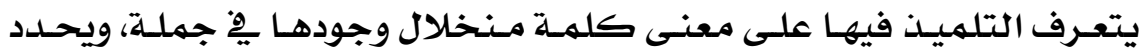

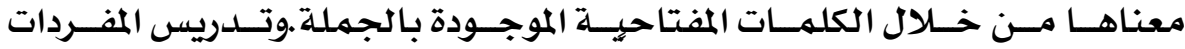

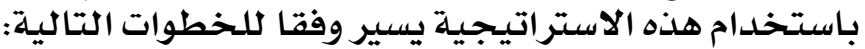

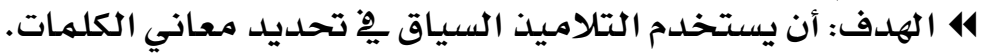

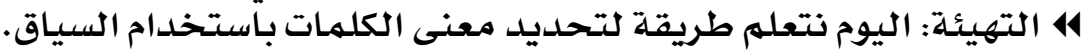
4ا النموذج:

يعرض المعلم جملة (الذباب عندما يقع على الطعام يلوثه ويفسلده).

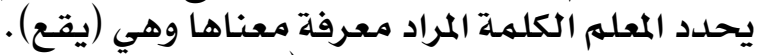

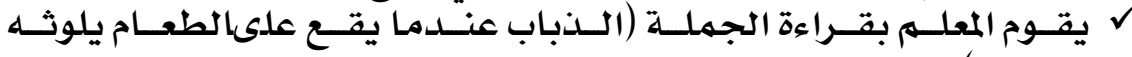
ويفسده )

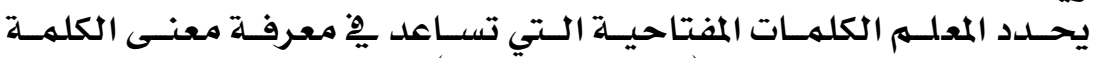

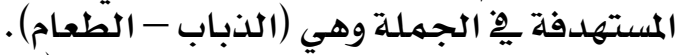

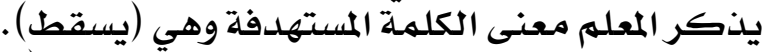

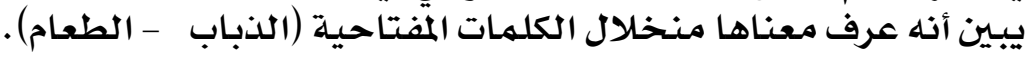

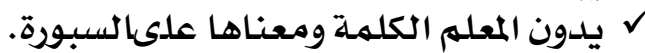

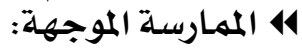

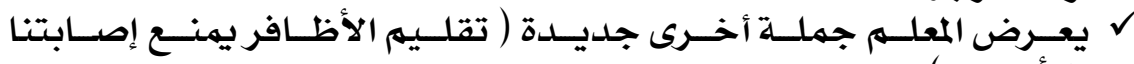

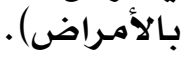
يحدد المعلم والتملاميذ الكلهمة المراد معرفة معناها، وهي (تقليهم).

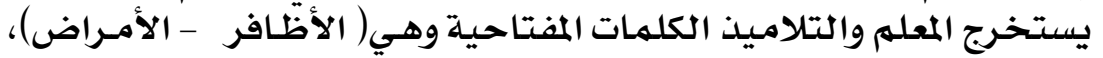

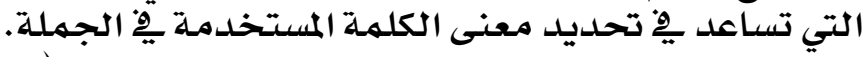

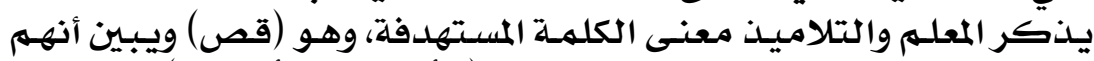

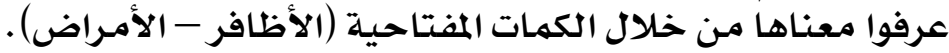

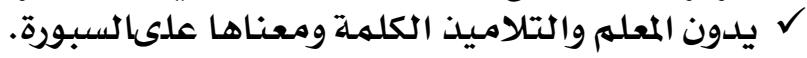

\section{9}




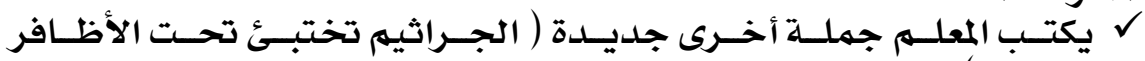
الطويلة).

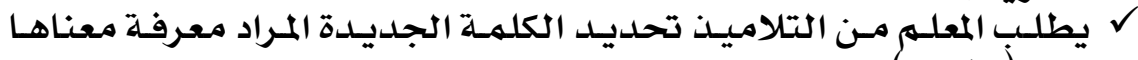
وَهي (تختبئ).

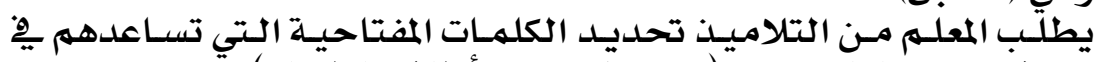

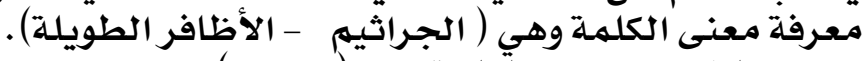

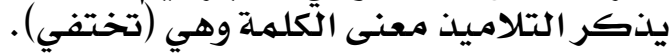

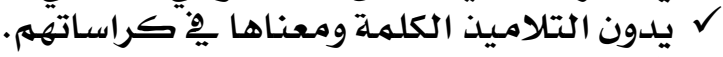

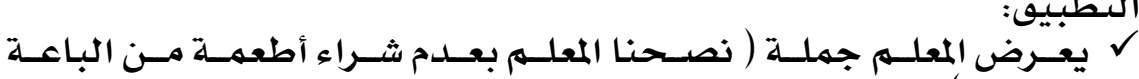
(14 4 التجائلين) علىالسبورة.

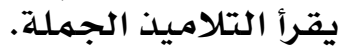

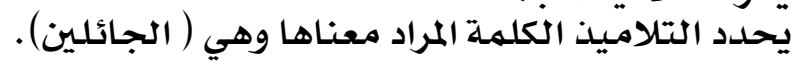

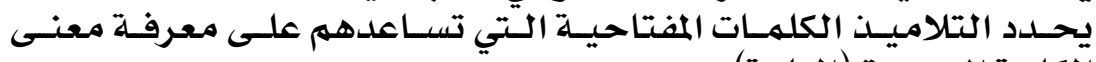
التكلمة الجديدة (الباعة).

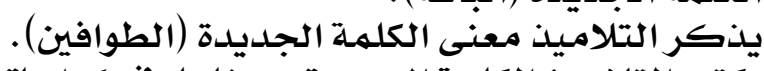

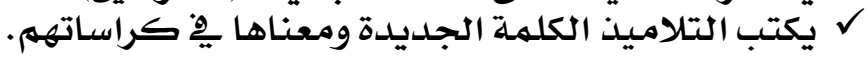

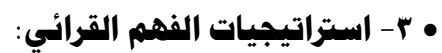

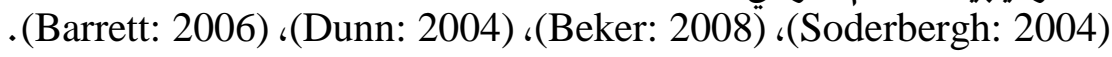

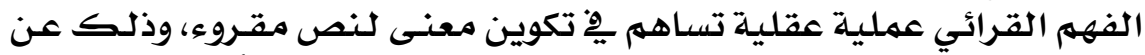

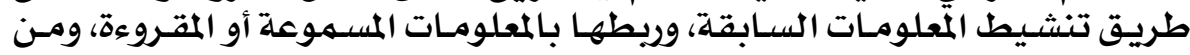

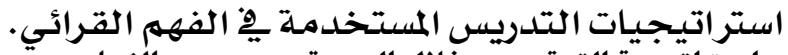

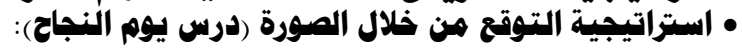

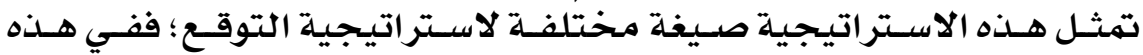

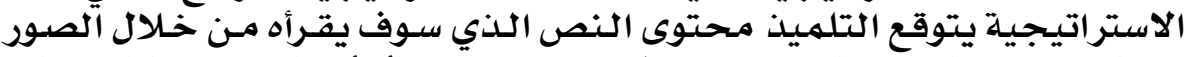

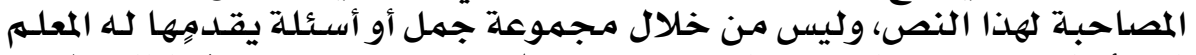

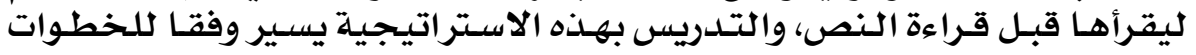

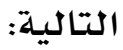

414 الهدف: يتوقع التلميذ أحداث الدرس من خلال الصورة والعنوان.

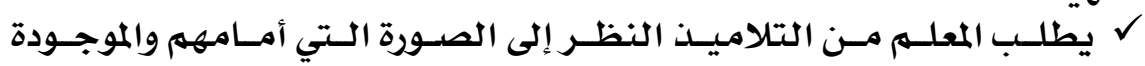
بالقصة. ل

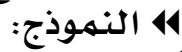

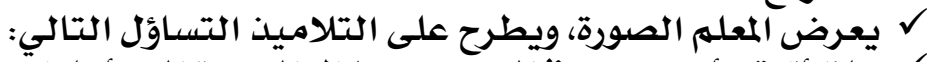

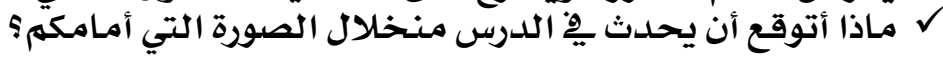

\section{1}




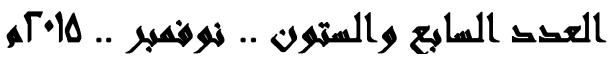

ل أنظر إلى الصورة، ثم أجب يبلدوا علىالأسـرة السعادة والفرح وأسأل نفسي:

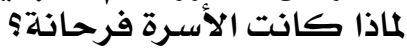

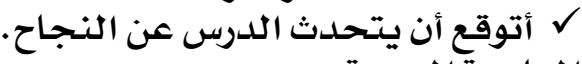

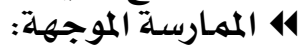

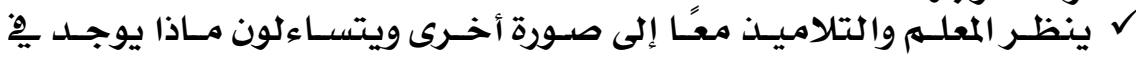

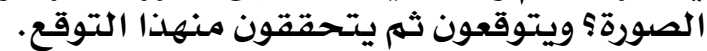

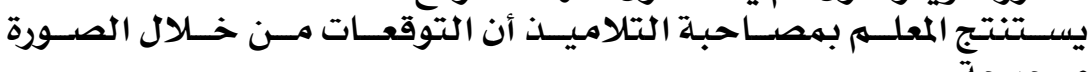
صسحيـحة. 14 الممارسلة المستقلة

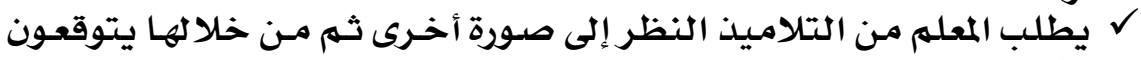

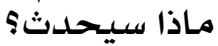

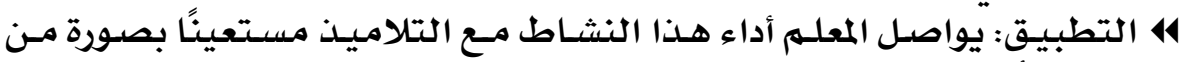
قصد أخرى.

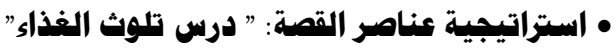

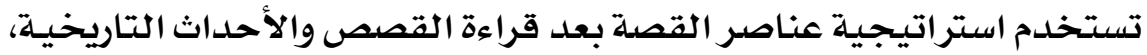

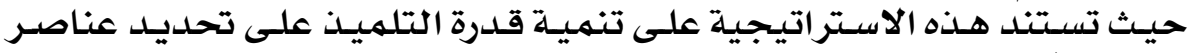

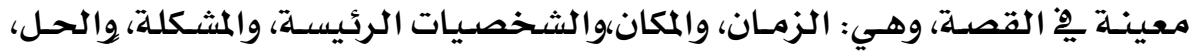

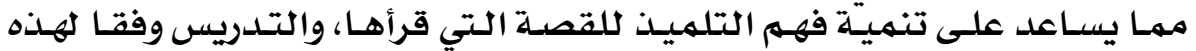

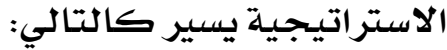

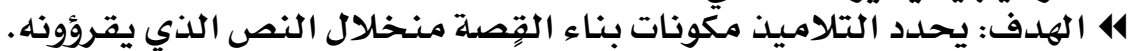

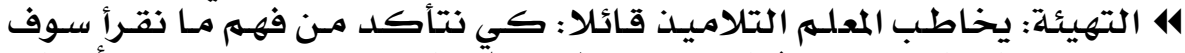

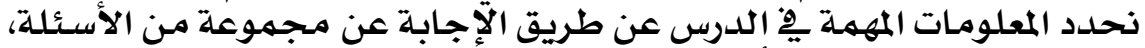

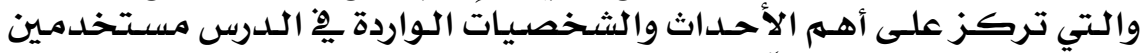

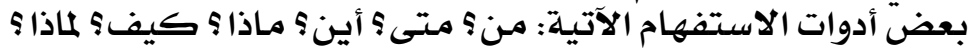

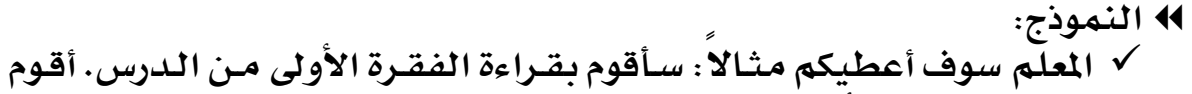

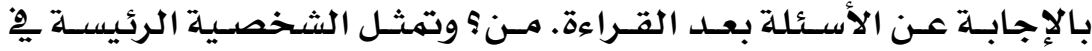

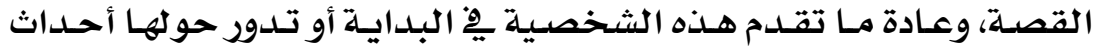
القصة.

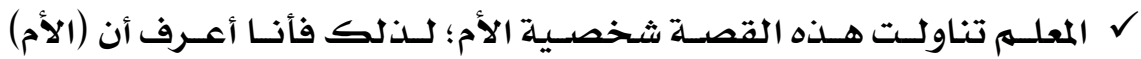

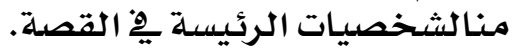

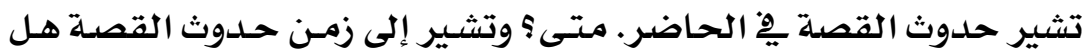

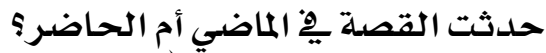

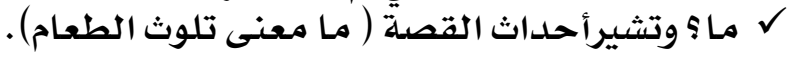

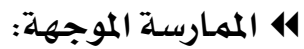

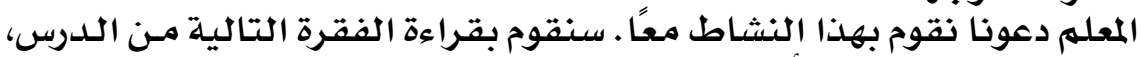

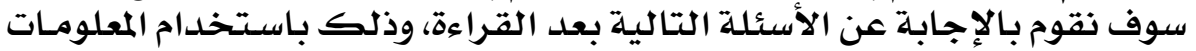

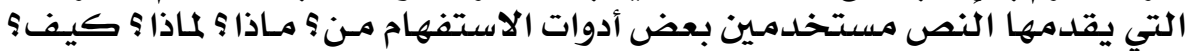

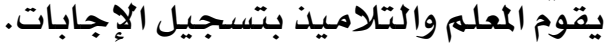

\section{$19 Y$}


14 المهارسة المستقلة:

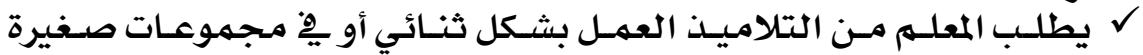

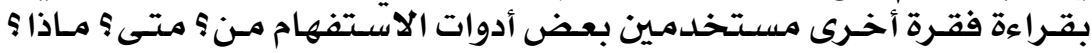

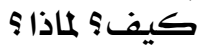

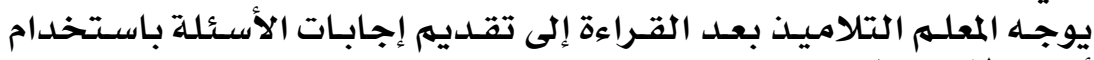
أدوات الاستفهام.

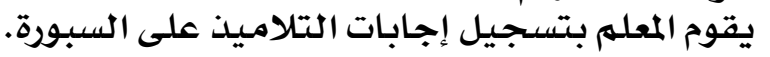

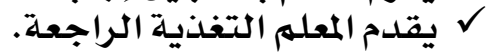

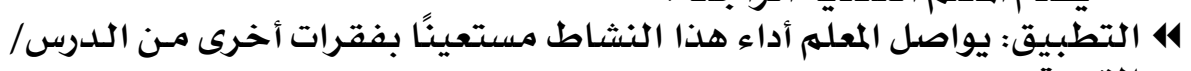
القصة.

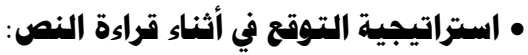

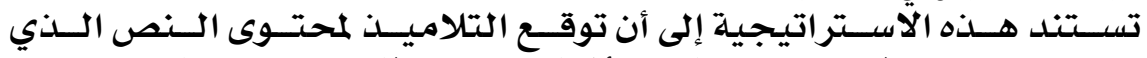

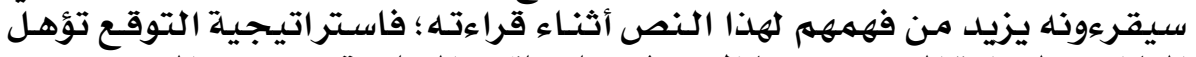

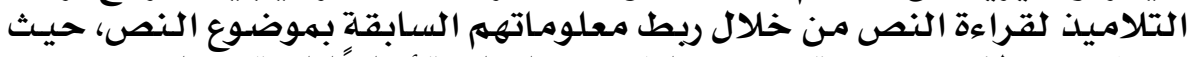

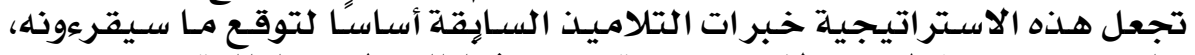

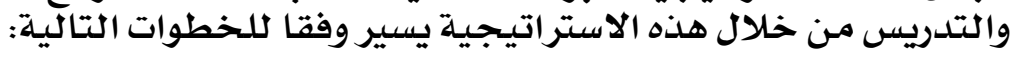

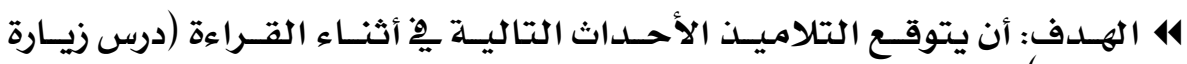

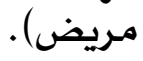

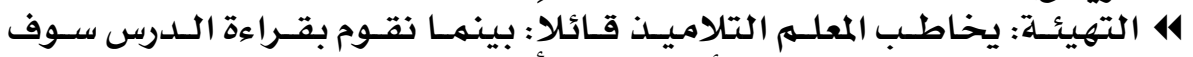

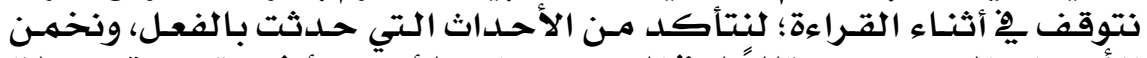

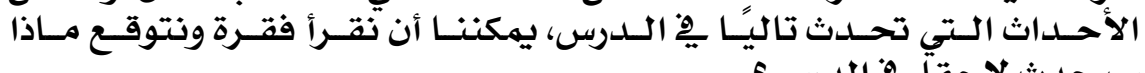

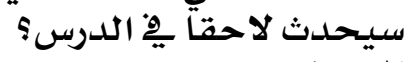

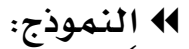

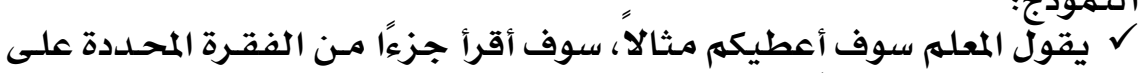

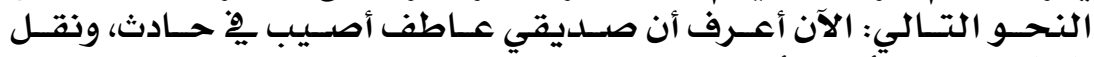

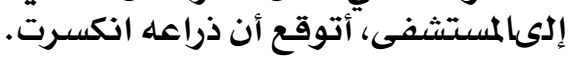

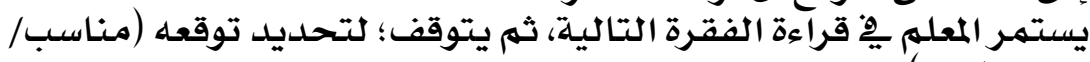
غير مناسب)

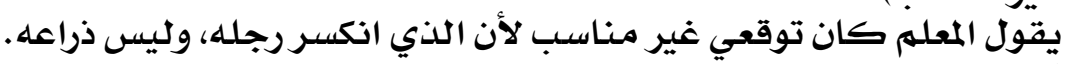

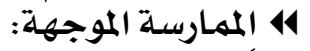

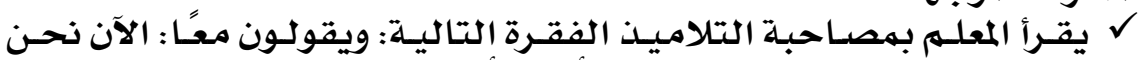

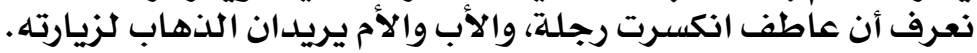

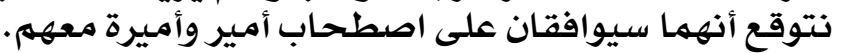

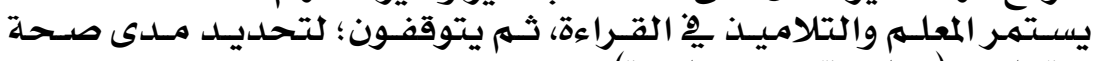

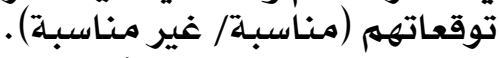

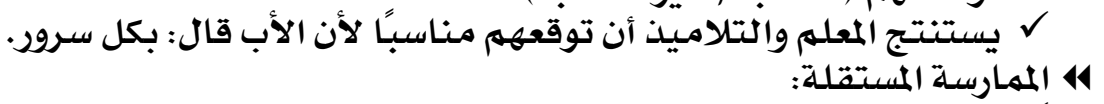
ل

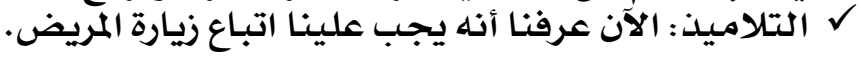

\section{$19 \%$}




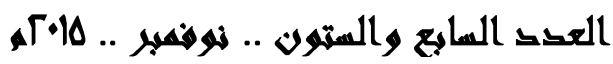

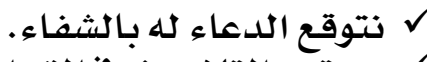

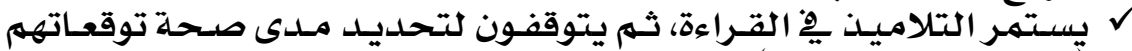

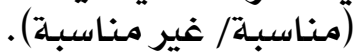
$\checkmark$ ليستنتج التلاميذ أن توقعاتهم كانت مناسبة لأن الأب قال لهم الدعاء لـه بالشفاء.

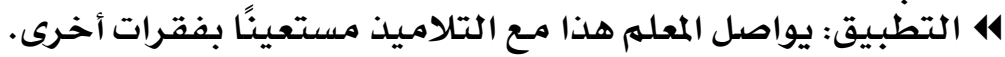

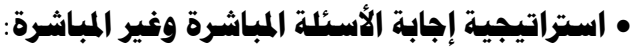

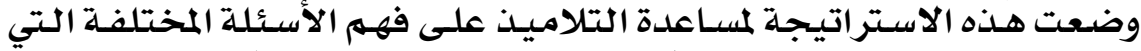

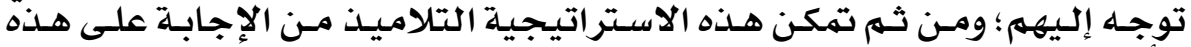

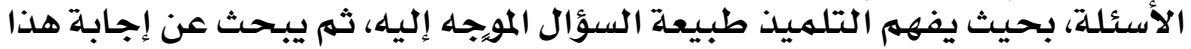

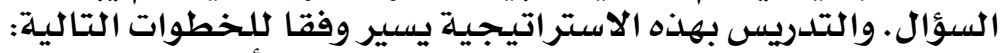

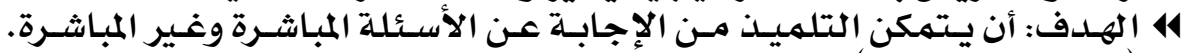
(درس أمين ألفصل).

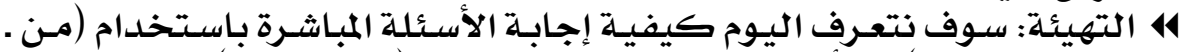

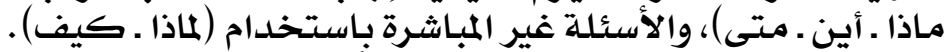

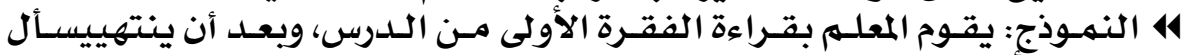

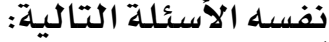
ل

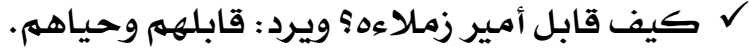

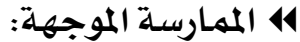
يقوم المعلهم والتلاميذ معًا بقراءة الفقرة الثانية، ثم يقوم المعلم بطرح الأسئلة

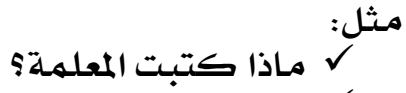

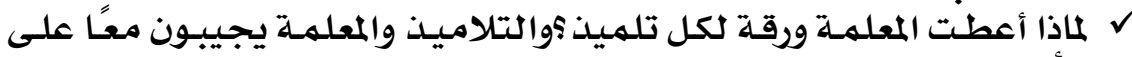

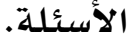

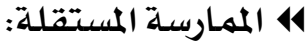
يطلب المعلـم قراءة الفقـرة الثالثة، والإجابـة على الأسئلة التي يكتبهـا على السبورة كالأسئلة التالية:

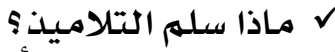
ل ك

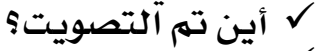

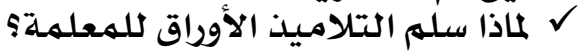

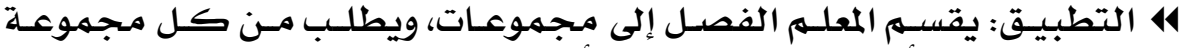
قراءة الفقرة الأخيرة والإجابة على الأسئلة التالية:

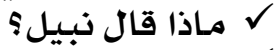

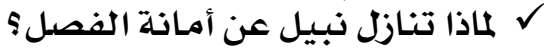

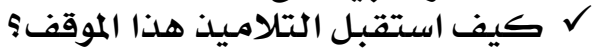

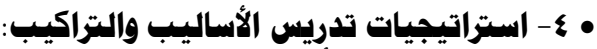

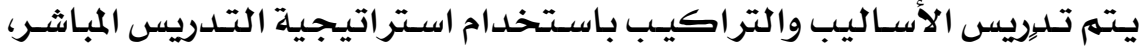
وذلك وفقا للخطوات التالية:

\section{8}


44 الهدف: أن يميز التلميذيذ بين الجملة الاسمية والفعلية.

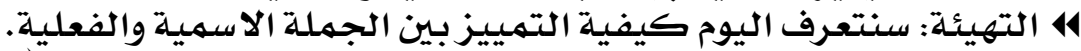

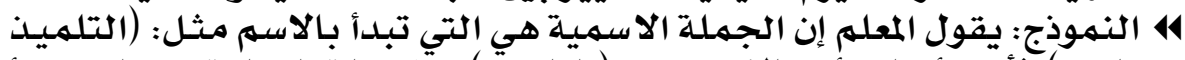

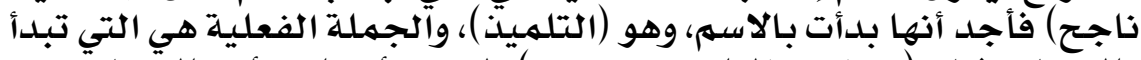

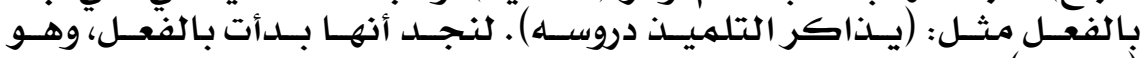
(يذاكر)

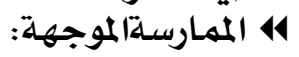

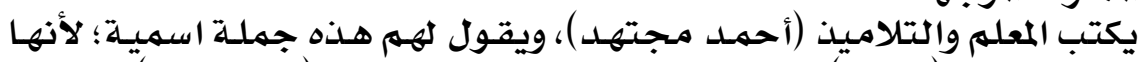

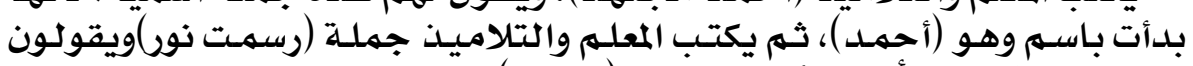

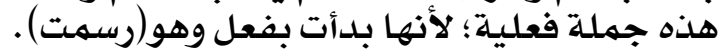
14 الممارسة المستقلة فلة:

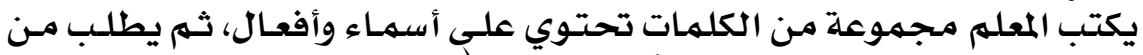

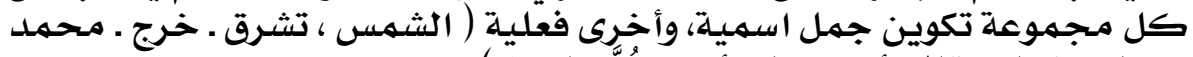

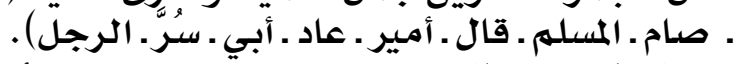

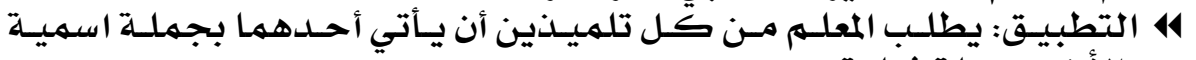
والأخر بجمبلة فعلية.

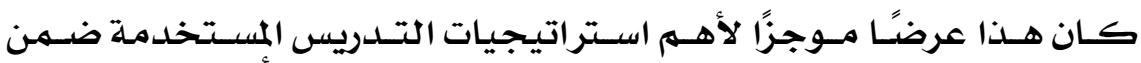

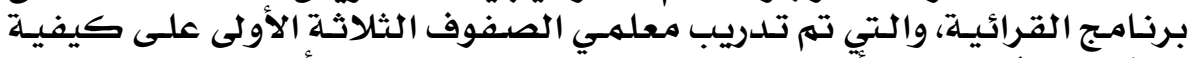

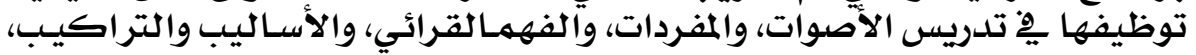

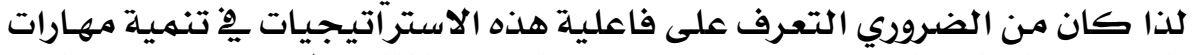

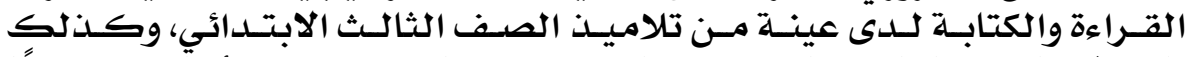

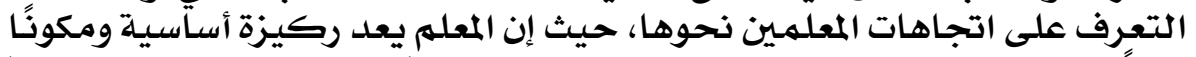

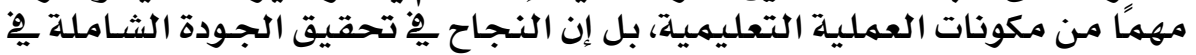

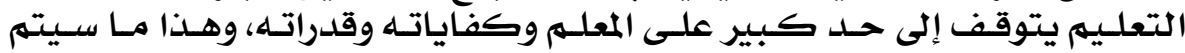

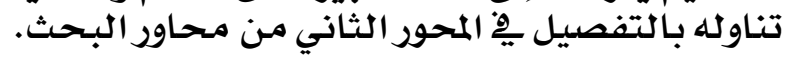

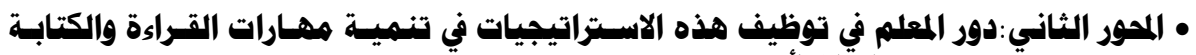

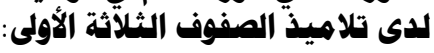

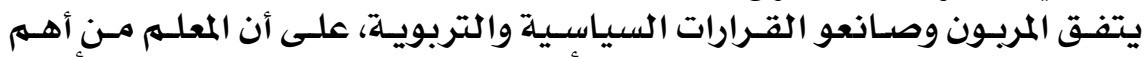

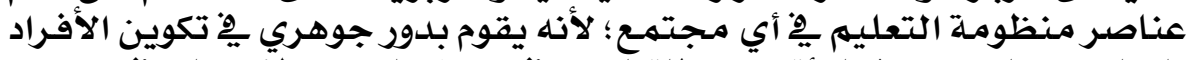

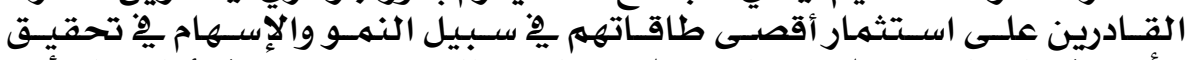

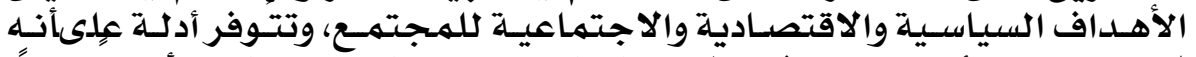

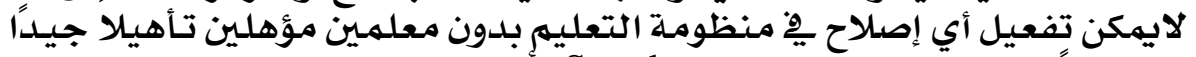

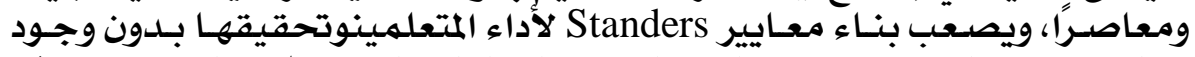

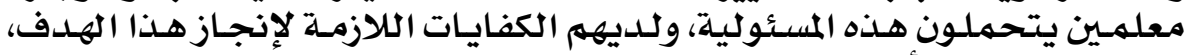

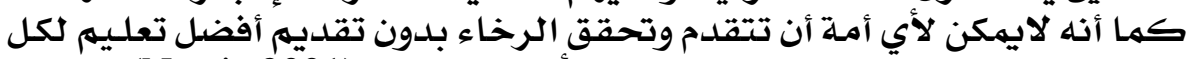

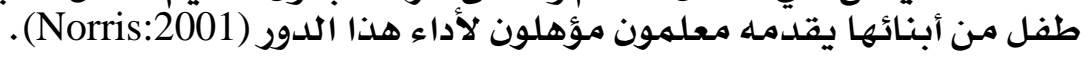

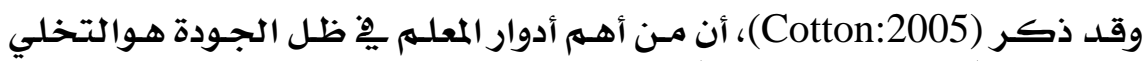

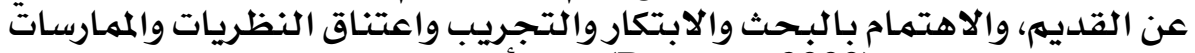

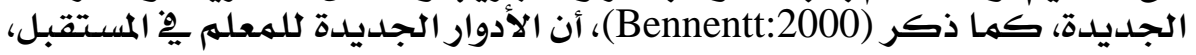

\section{0}




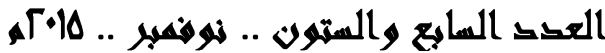

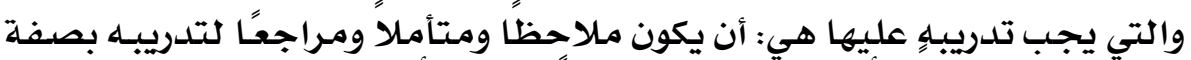

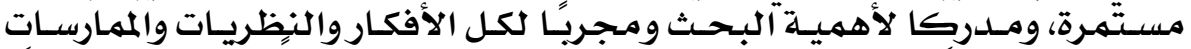

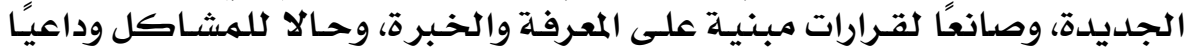
إلى التساؤل والنقد.

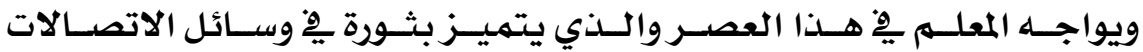

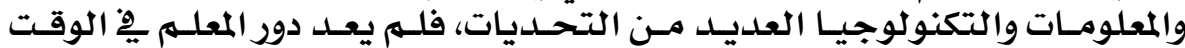

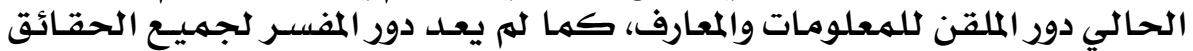

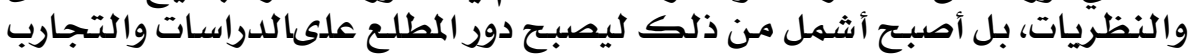

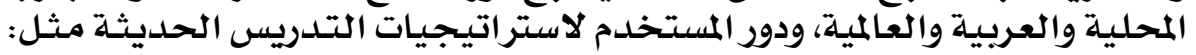

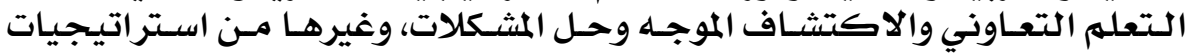

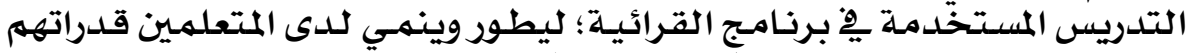

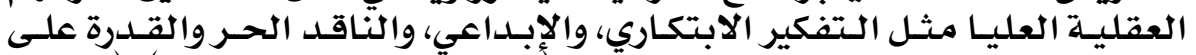

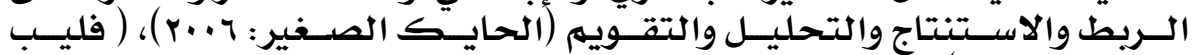

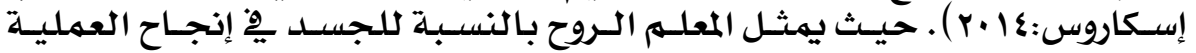

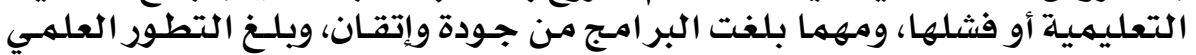

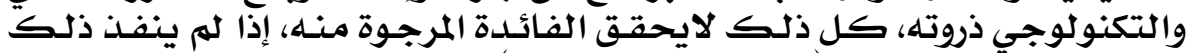

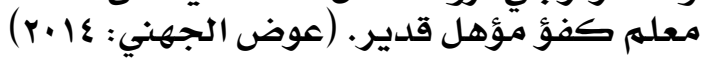

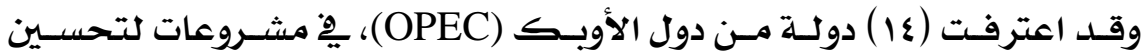

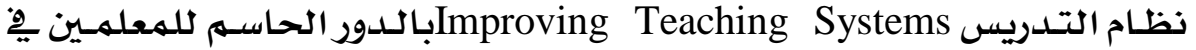

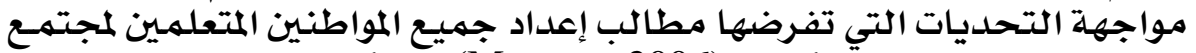

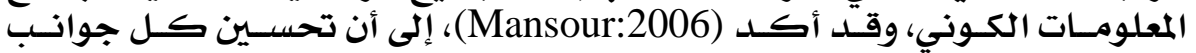

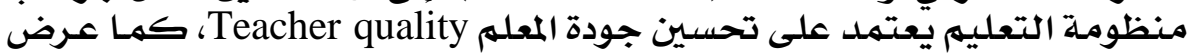
Mansour

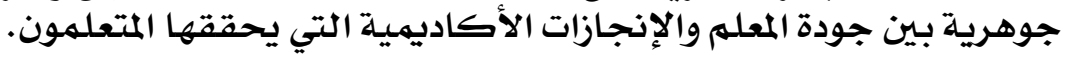

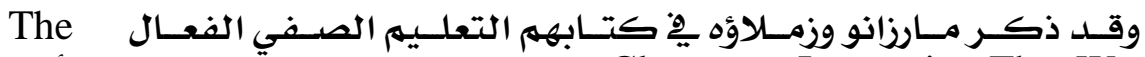
Classroom Instruction That Works

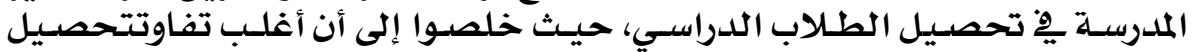

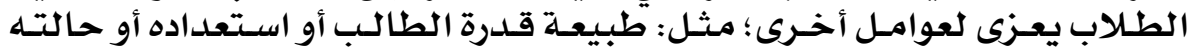

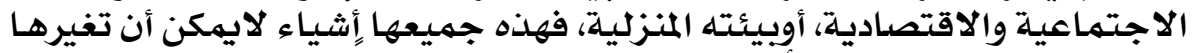

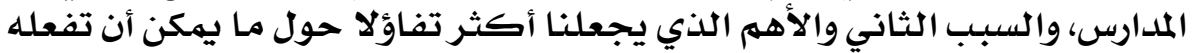

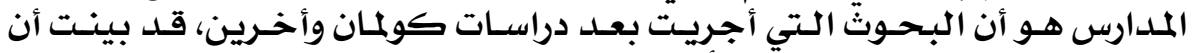

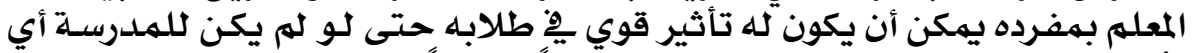

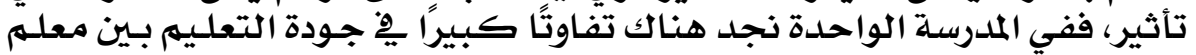

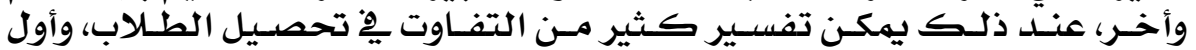

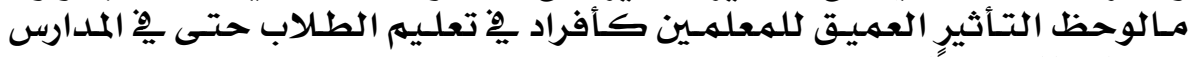
غير الفعالة نسبيياً

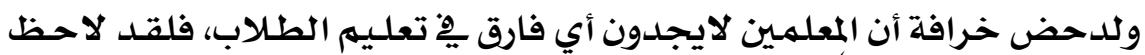

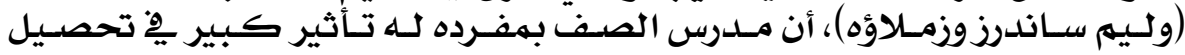

\section{7}


الطـلاب أكثر مهـا كـان يعتقــ أصـلا، وهــذا مـا أكدتـه نتـائج تحليـل درجـات

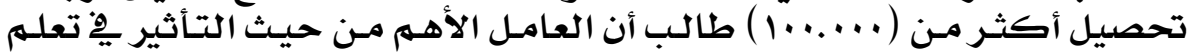

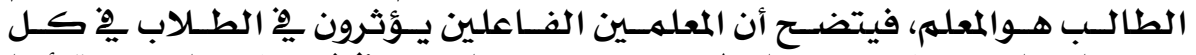

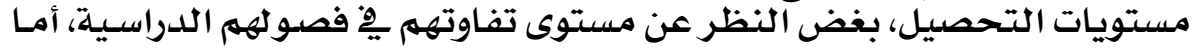

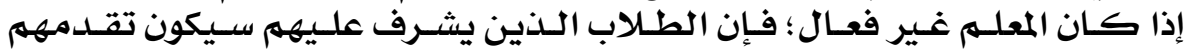

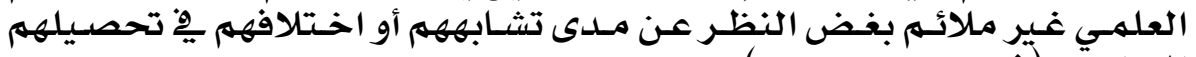

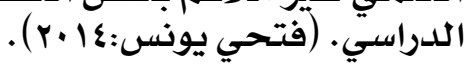

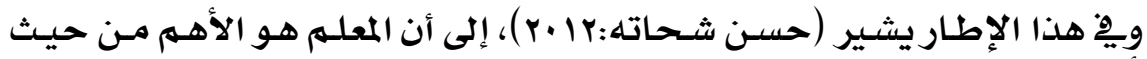

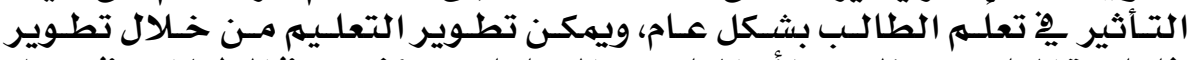

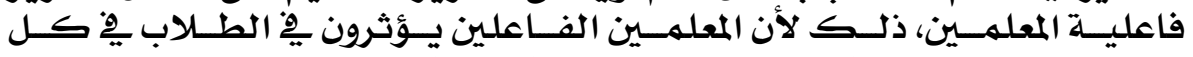

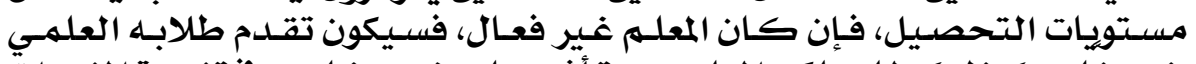

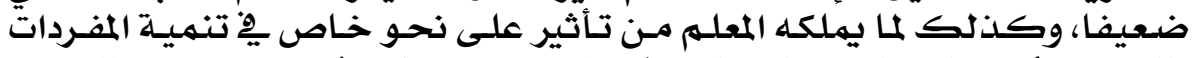

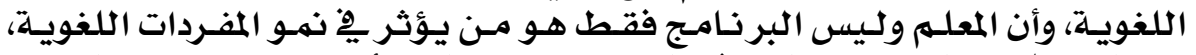

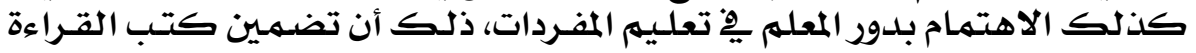

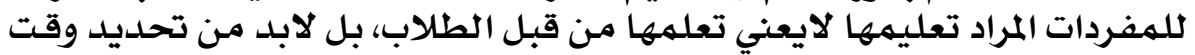

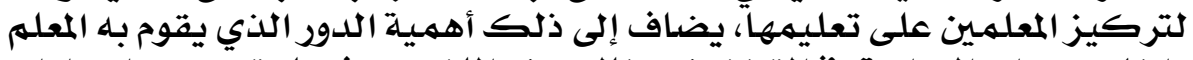

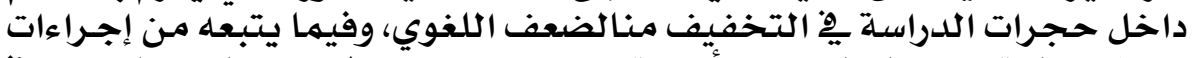

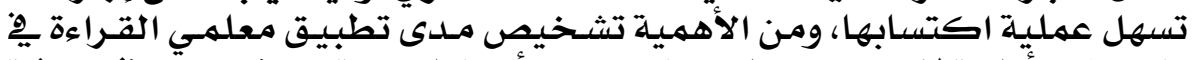

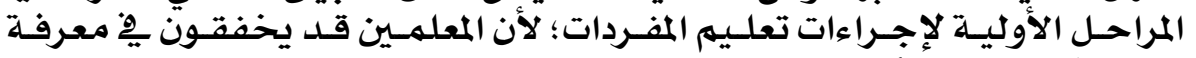

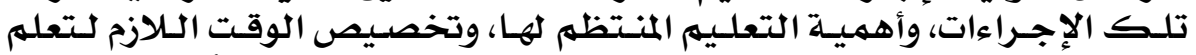

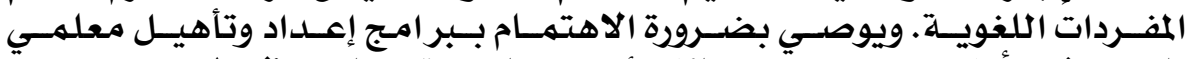

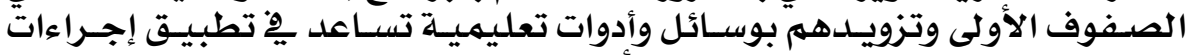

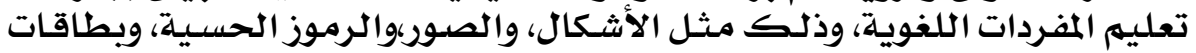

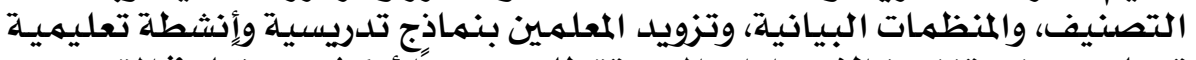

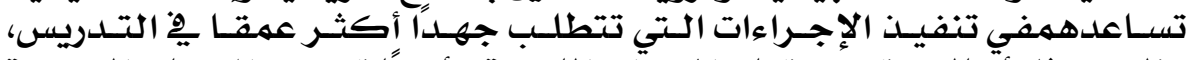

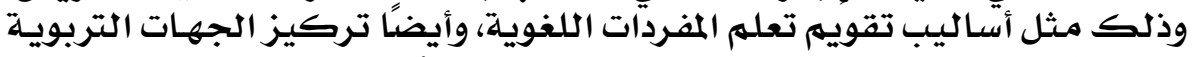

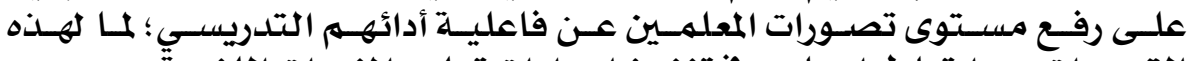

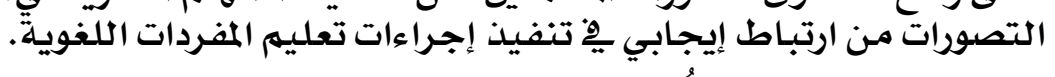

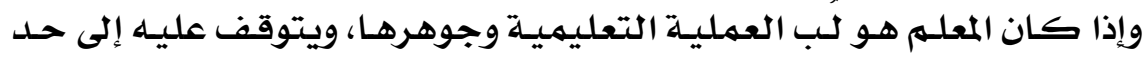

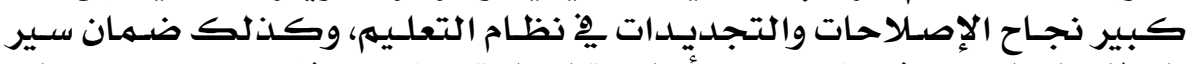

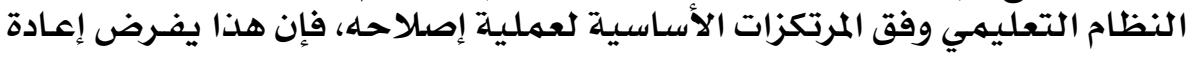

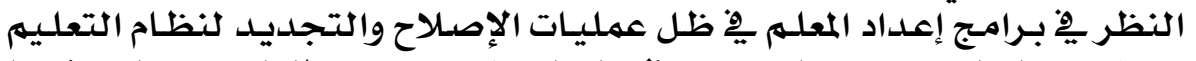

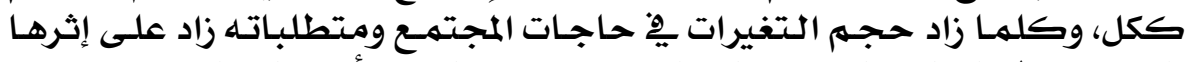

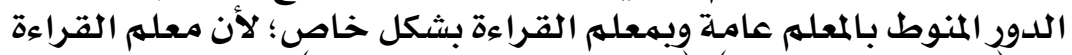

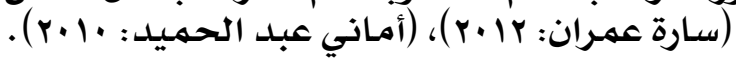

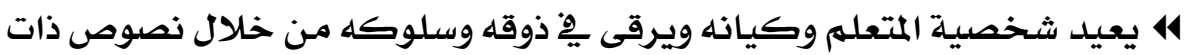

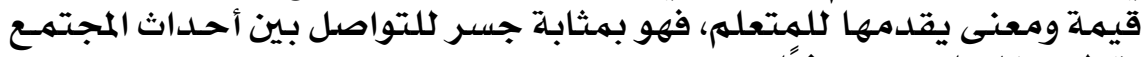

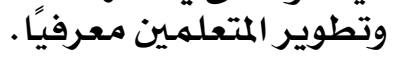

\section{$19 V$}




\section{العقد العابي والستول .. نهوهمبر ..}

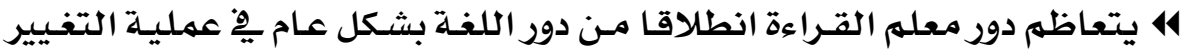

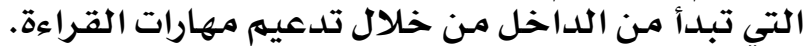

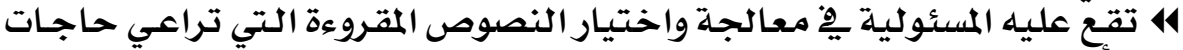

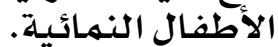

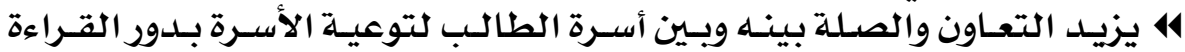

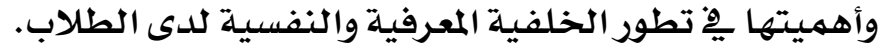

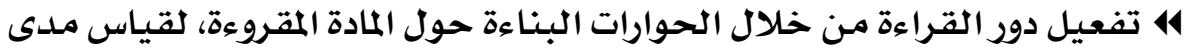

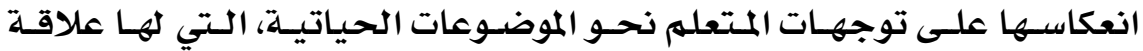

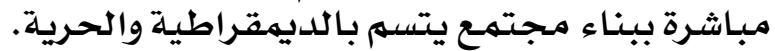

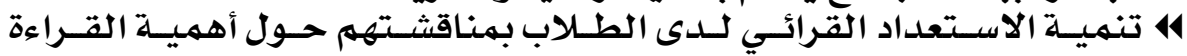

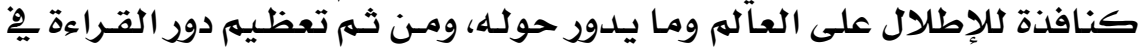

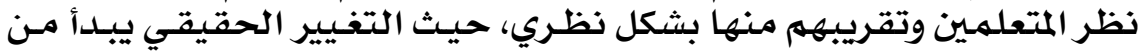

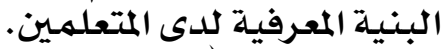

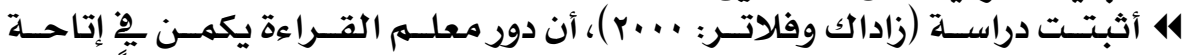

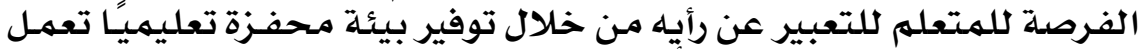

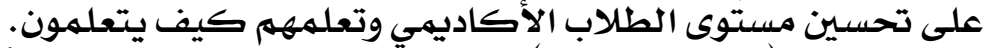

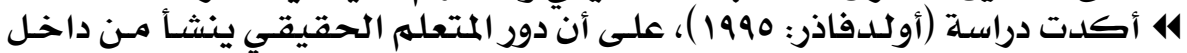

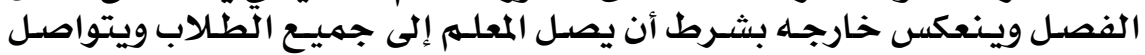

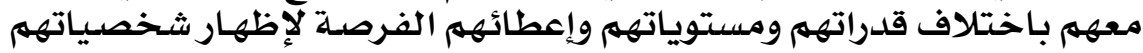

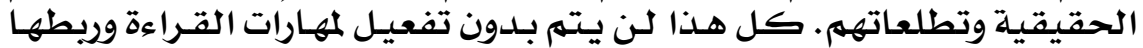

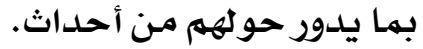

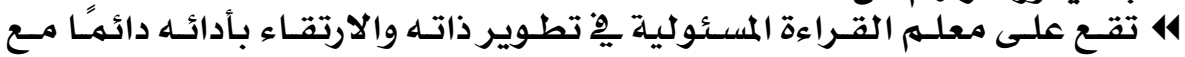

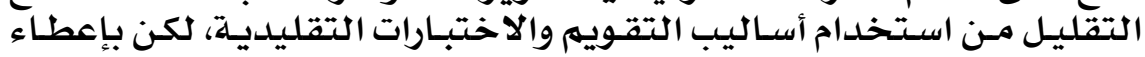

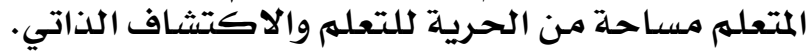

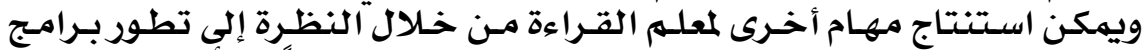

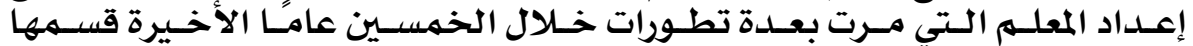

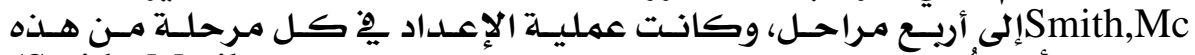

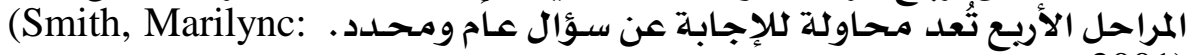
.2001)

ففي المرحلة الأولى التي استمهرت طوال العقدين الخامس والسـادس من القرن القرن

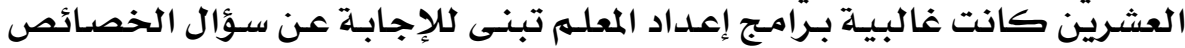

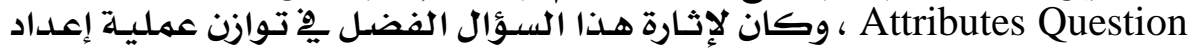

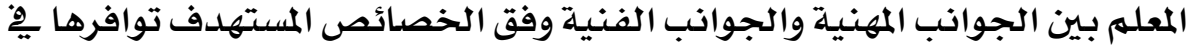

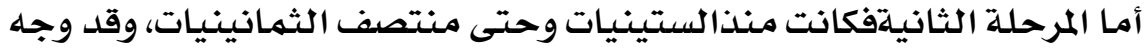

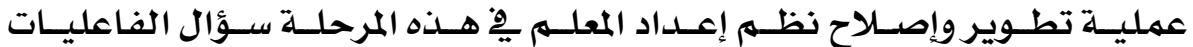

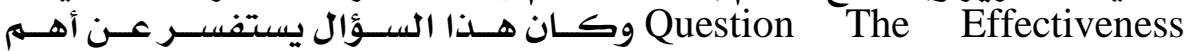

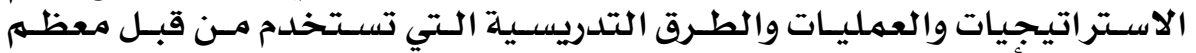

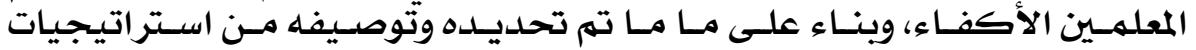

\section{$19 \Lambda$}




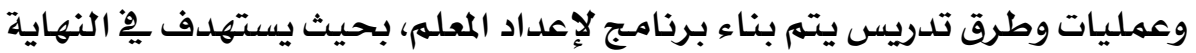

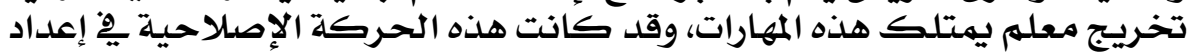

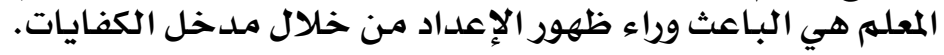

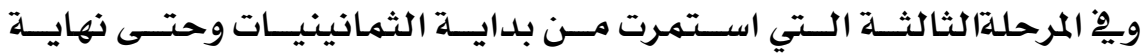

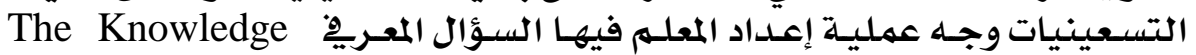

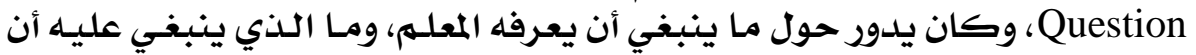

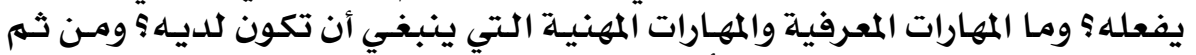

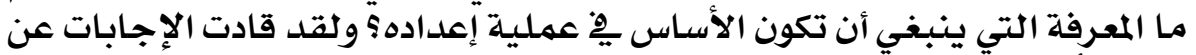

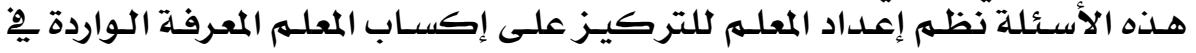

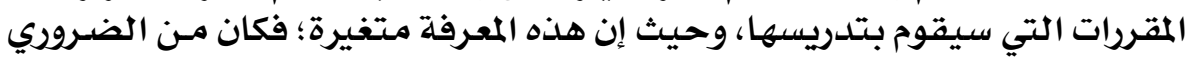

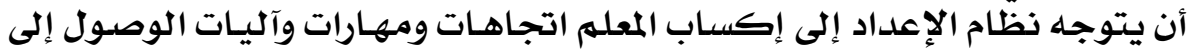

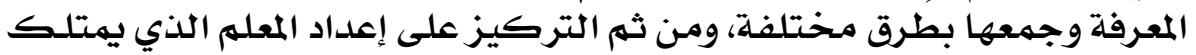

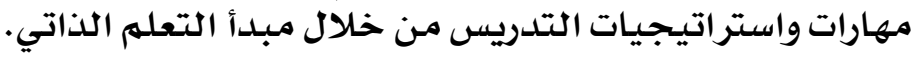

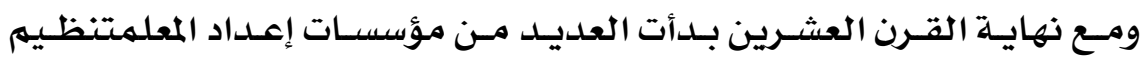

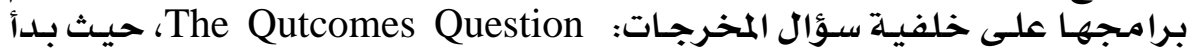

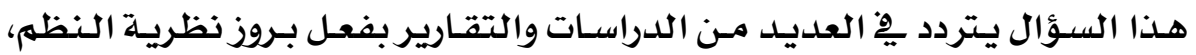

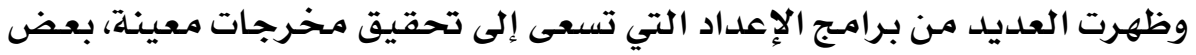

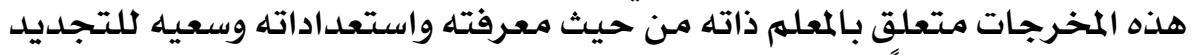

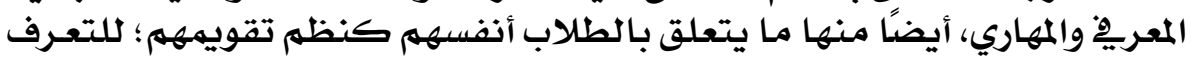

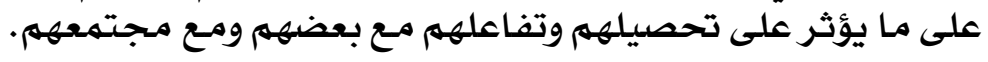

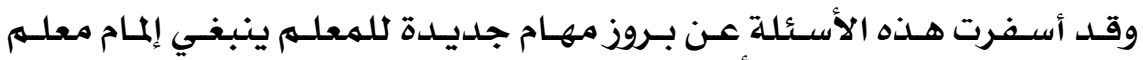

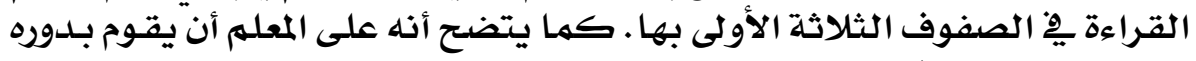

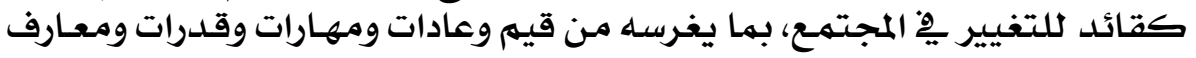

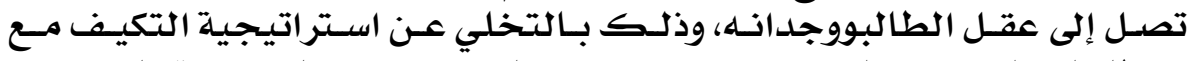

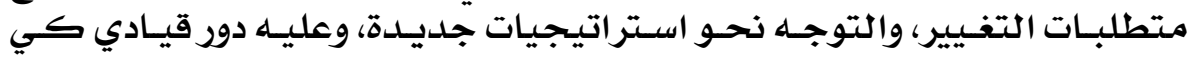

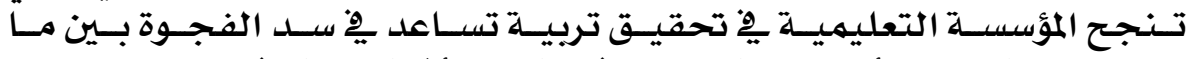

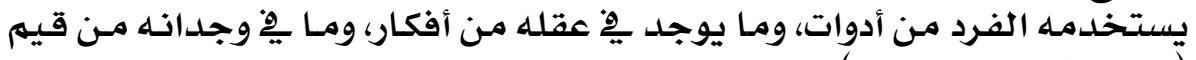

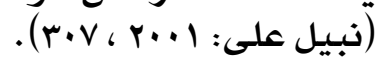

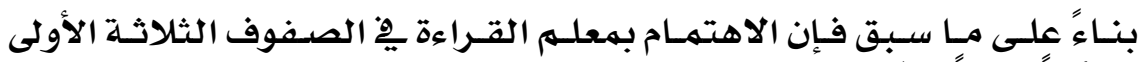

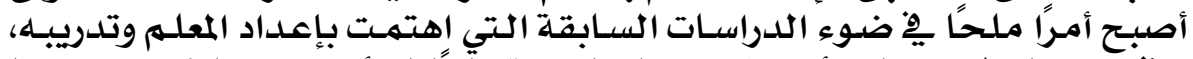

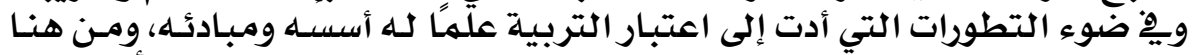

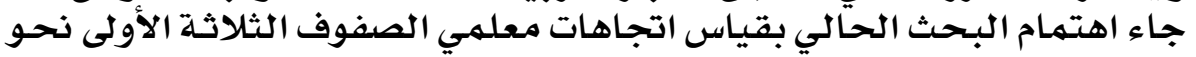

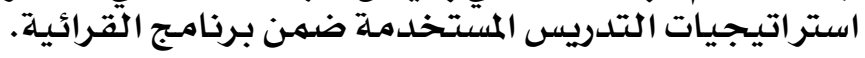

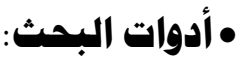

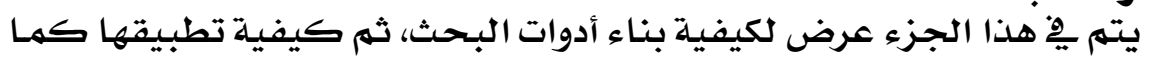
يلي:

\section{9}


العكد العابو والستهون .. نهوهمبر ..

• إ- قائمة بمهارات القراءة والكتابة اللازمة لتلاهيذ الصف الثالث الابتدائي. • أ- الهدف هن القائمة:

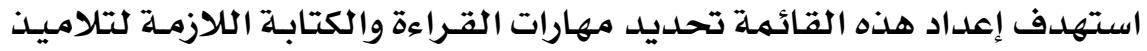

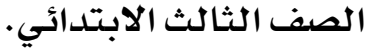
• ب- هصادر القائمة:

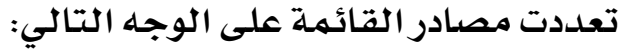

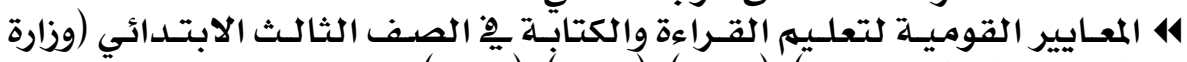

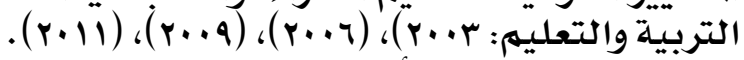
414

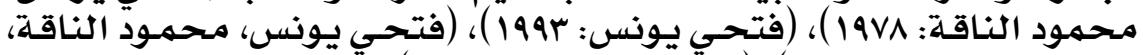

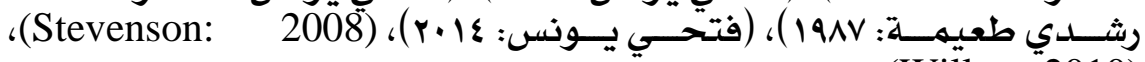

.(Willson:2010)

\section{• ج - القائمة في صورتها المبدئية:}

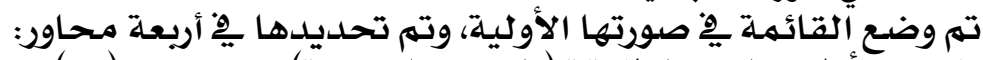

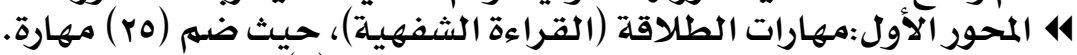

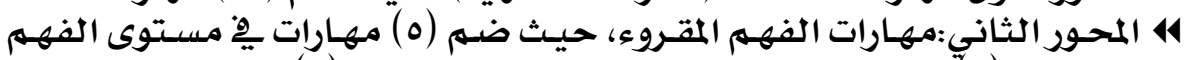

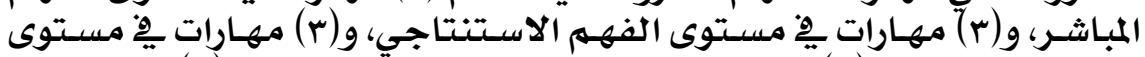

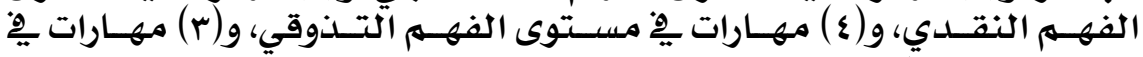

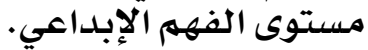

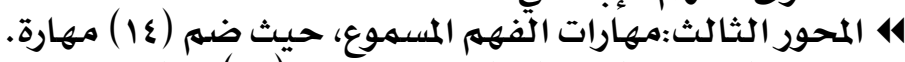

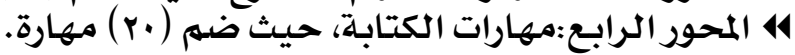

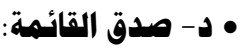

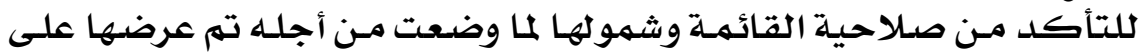

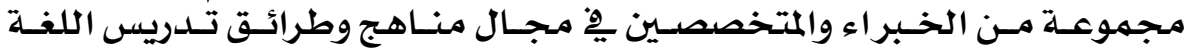

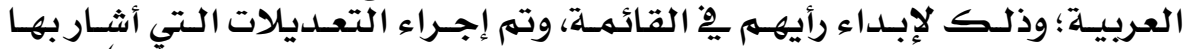

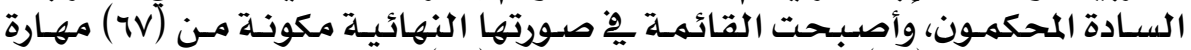

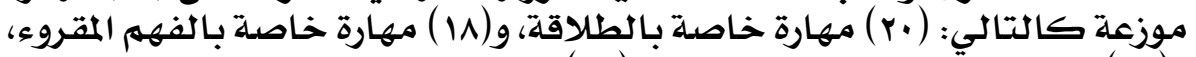

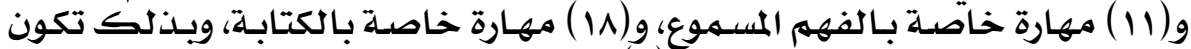

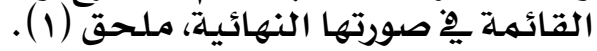
• • ا - اختبار الطلاقة (القراءة الجهرية): • أ - الهدف هن الاختبار الطلة الاخترار:

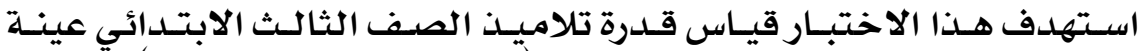

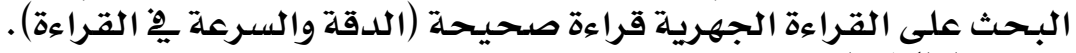

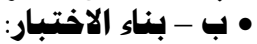

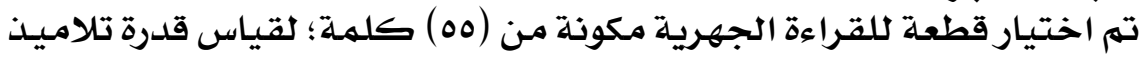

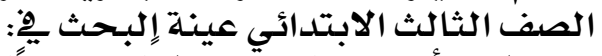

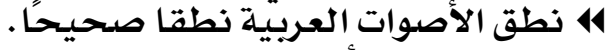

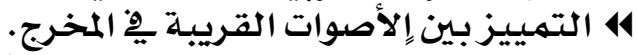
414 التمييزيز نطقا بين الحروف التي تتطق ولاتكتب. 


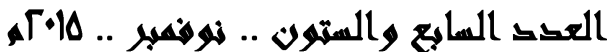

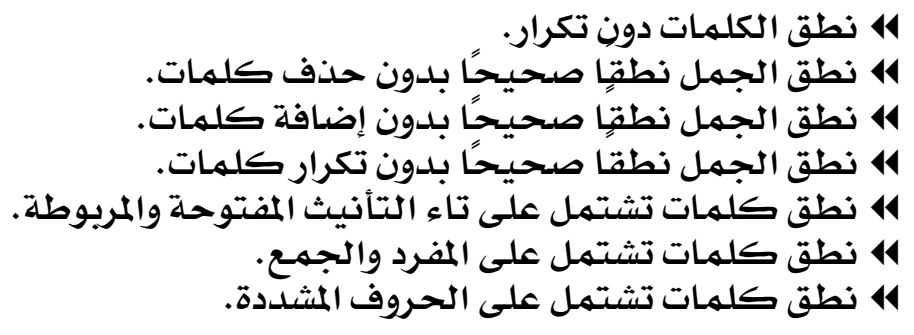

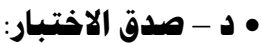

تم عرض القطعة المختـارة، ومهارات القراءة الجهرية (الطلاوقة) المراد قيـاسها،

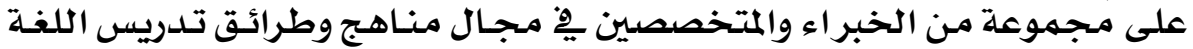

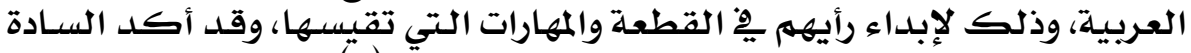

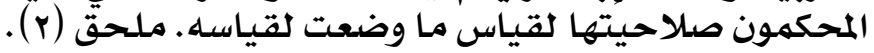

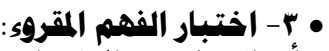

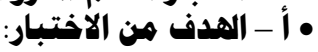

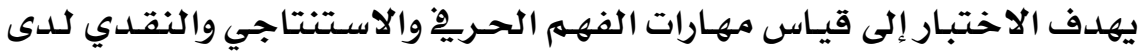

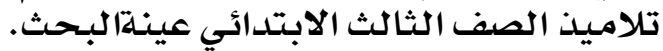

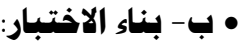

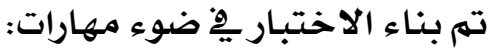

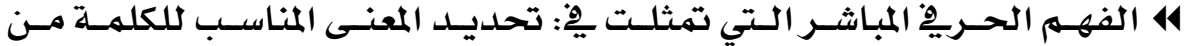

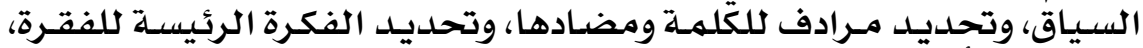

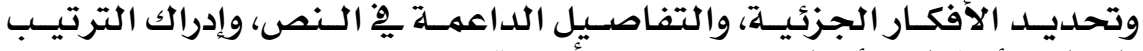

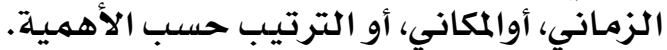

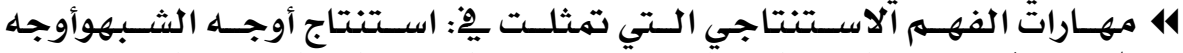

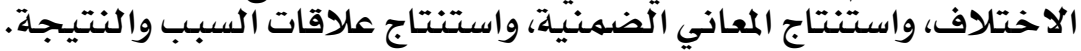

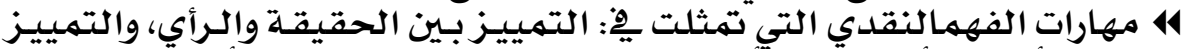

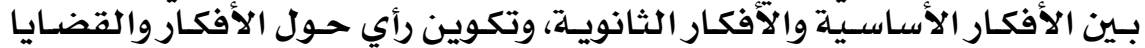

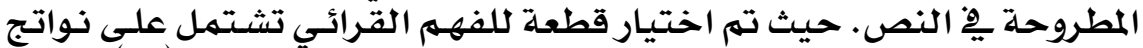

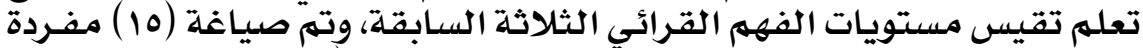

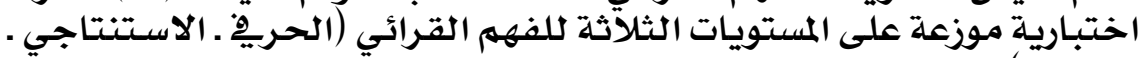

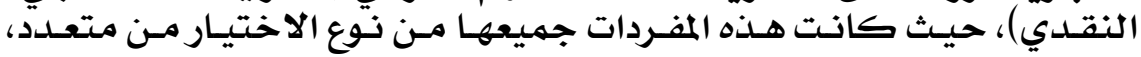

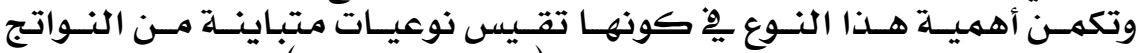

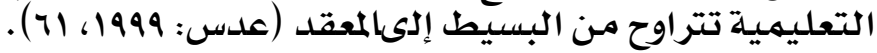

• ع- تعلميات الاختبار:

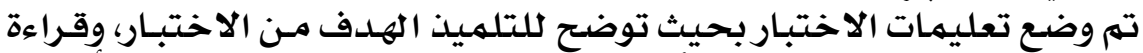

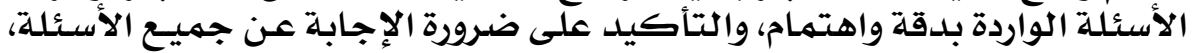

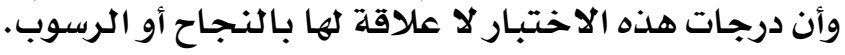

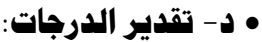

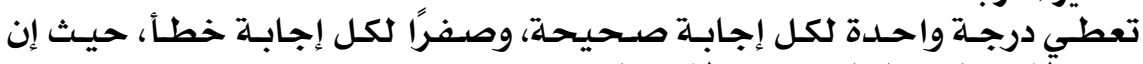

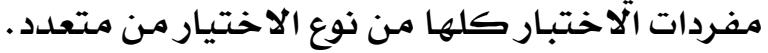




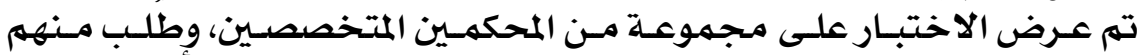

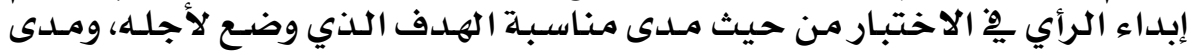

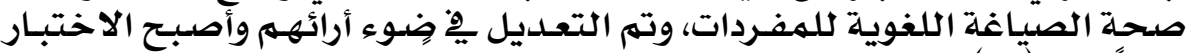

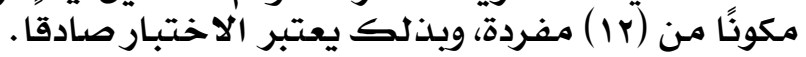

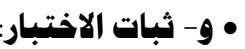

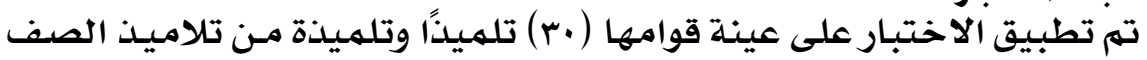

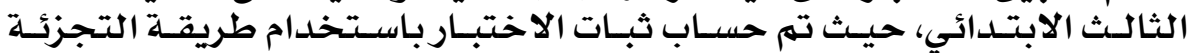

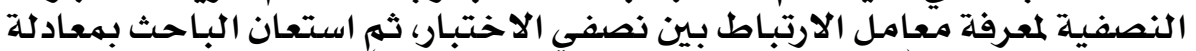

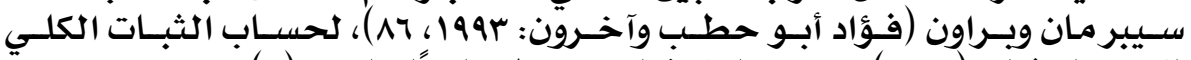

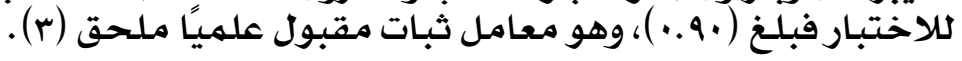

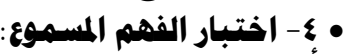
• أ - الهدف هنبار الفهم الاختبار:

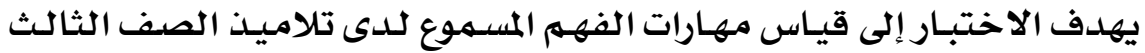

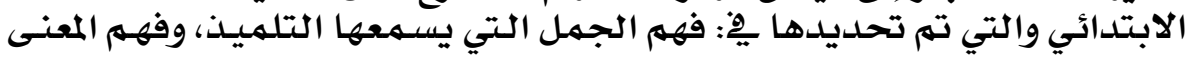

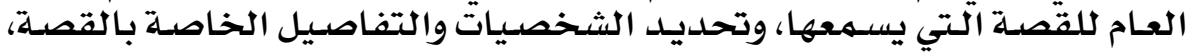

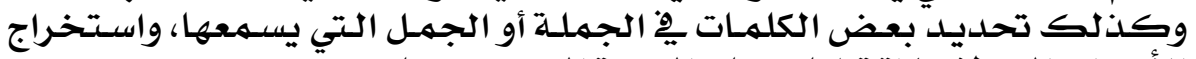

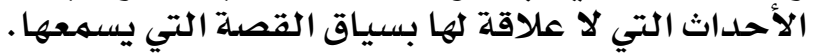

• ب ب- بناء الاختبار:

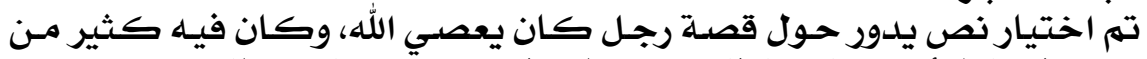

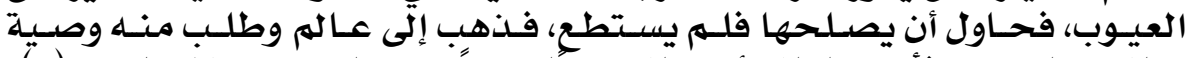

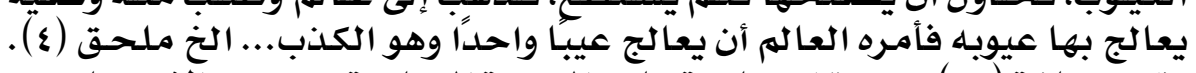

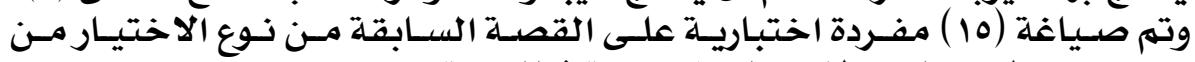

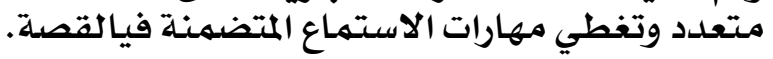

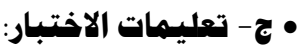

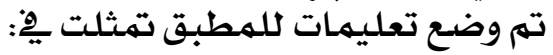

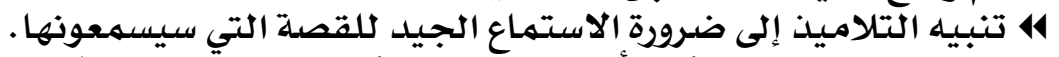

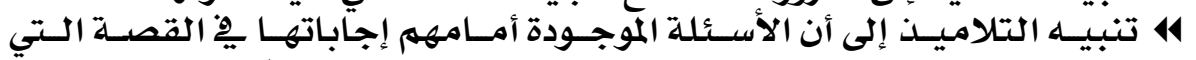

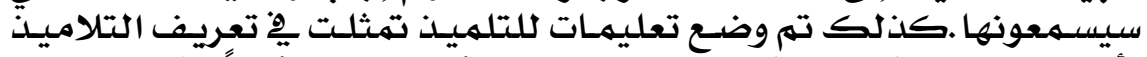

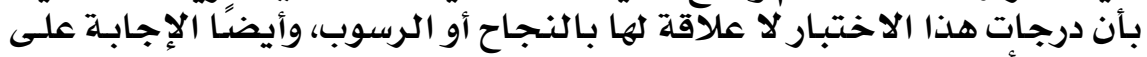

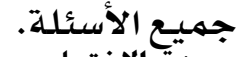
• د- صدق الاختبار:

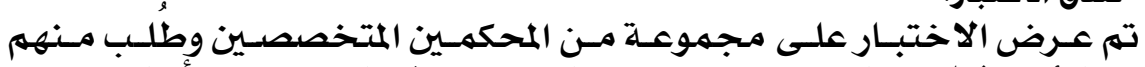

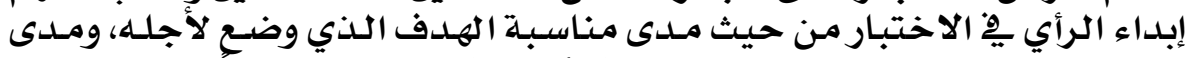

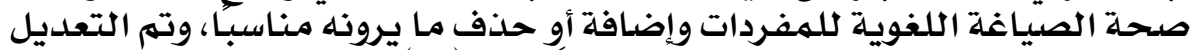

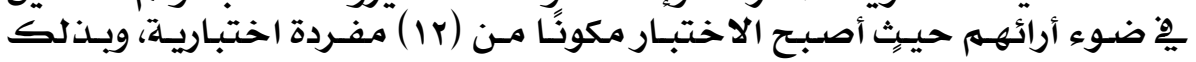

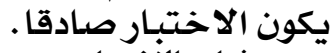

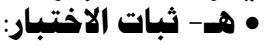

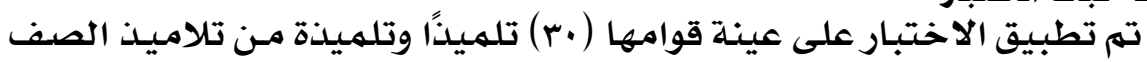

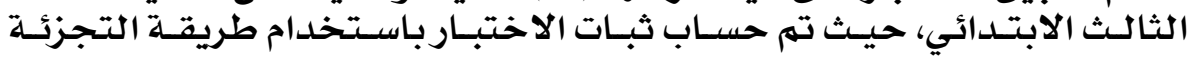




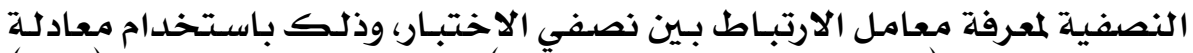

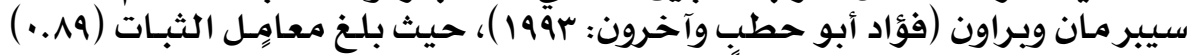

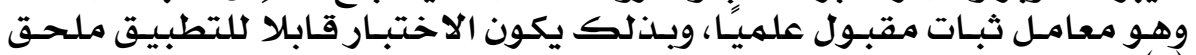

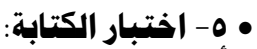

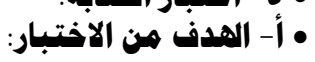

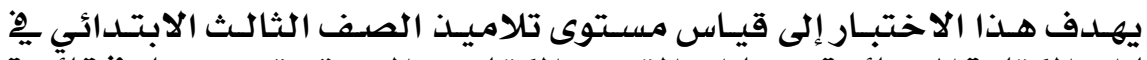

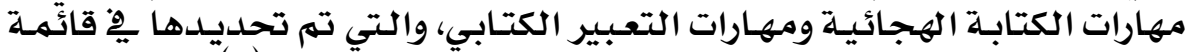

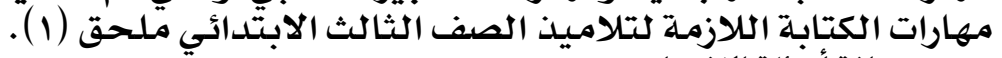

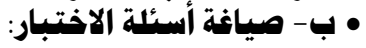

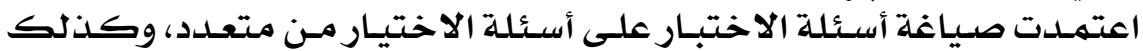

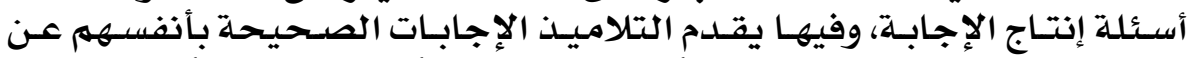

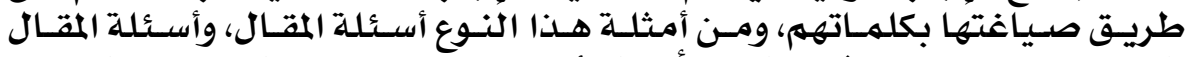

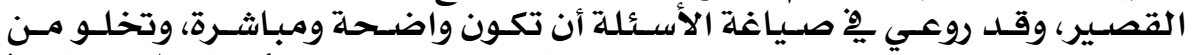

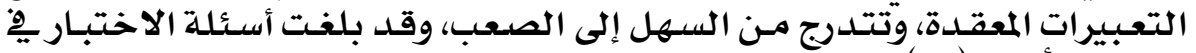

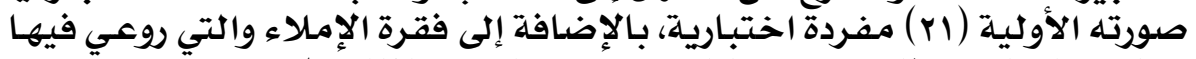

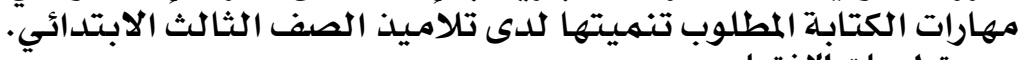

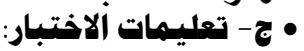

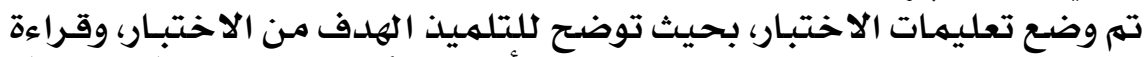

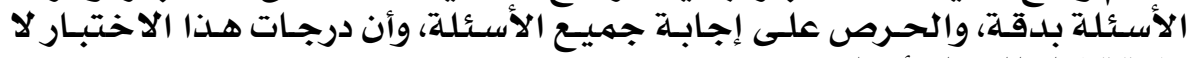

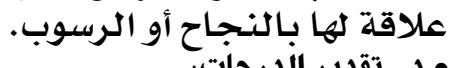
• د- تقدير الدرجات:

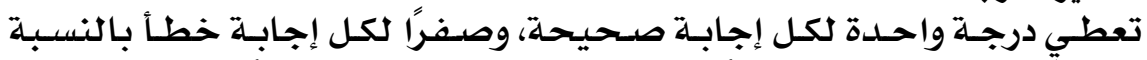

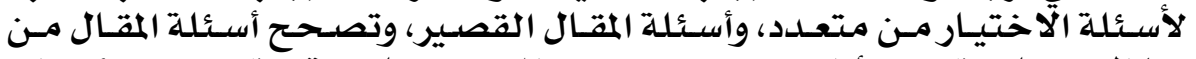

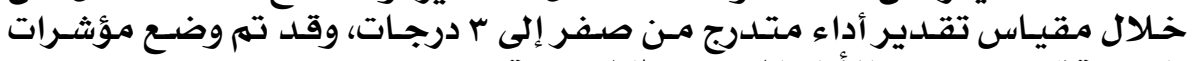

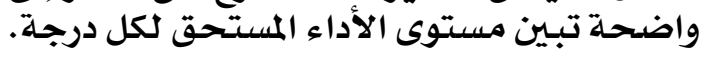

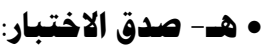

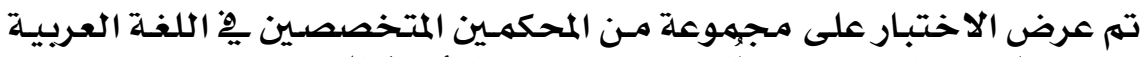

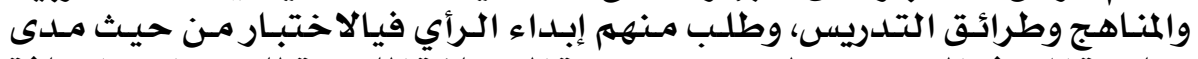

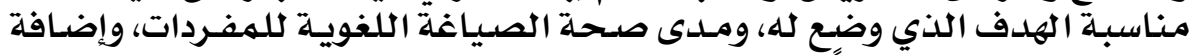

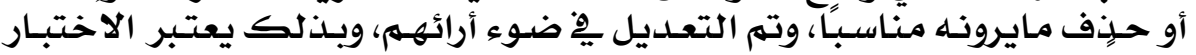
صادقا . ماح

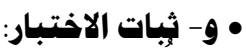

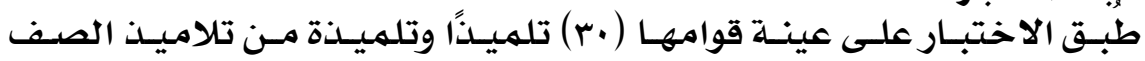

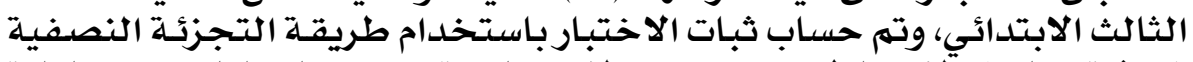

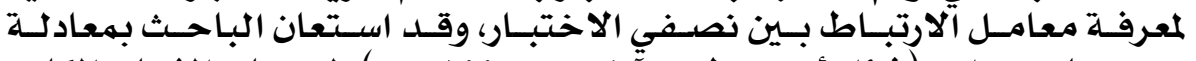

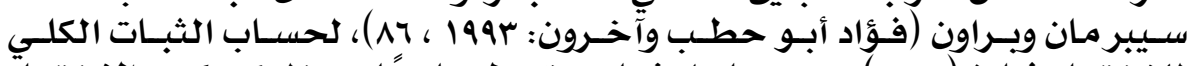

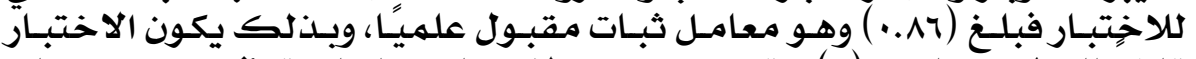

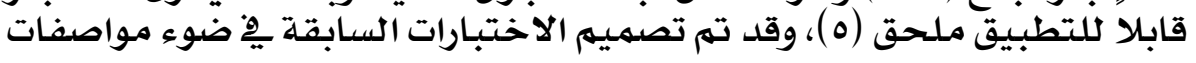

\section{$Y \cdot Y$}




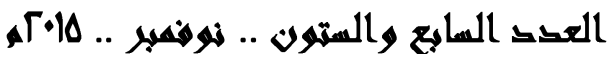

الورقـة الامتحـانيـة، ومـراعـاة الـوزن النسـبي لكـل مهــارة الطلاقـة، والفهـم المقـروء، والفهم المسهوع، والكتابة.

• • • أ - الهدفياس هن الجاهات:

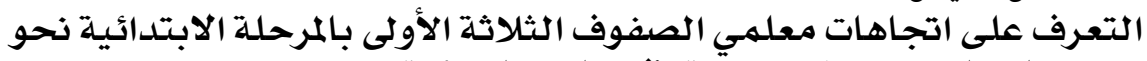

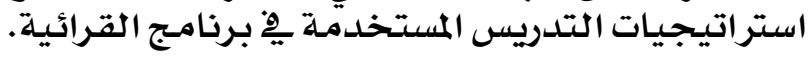

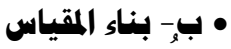

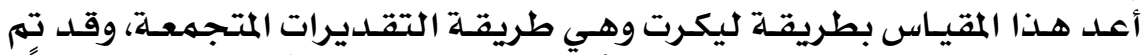

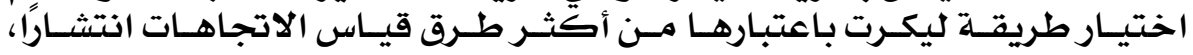

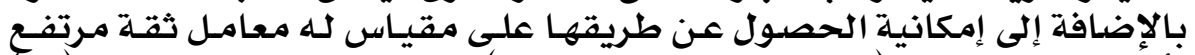

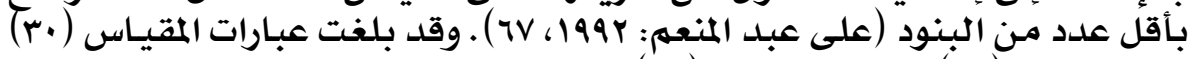

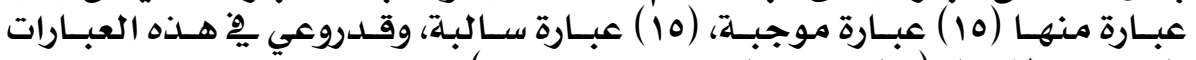

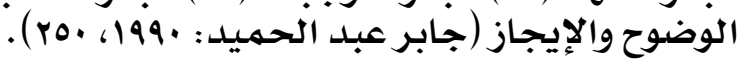

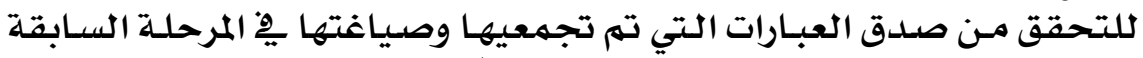

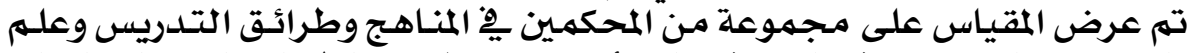

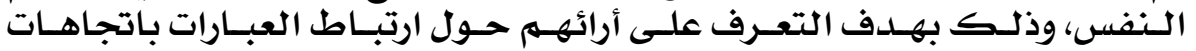

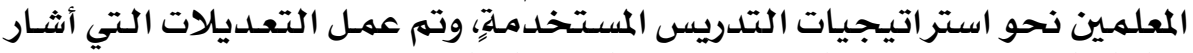

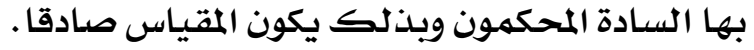

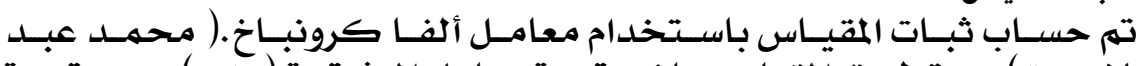

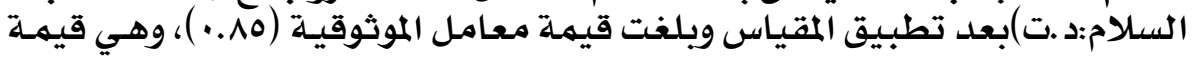

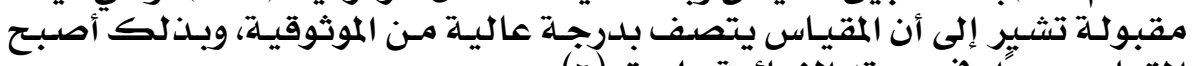

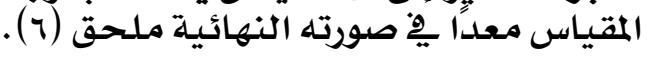

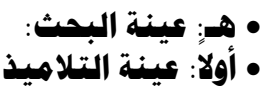

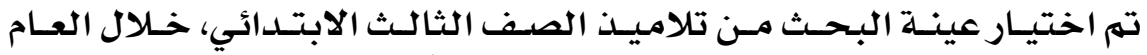

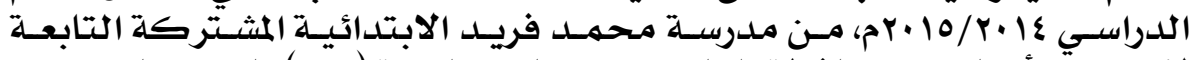

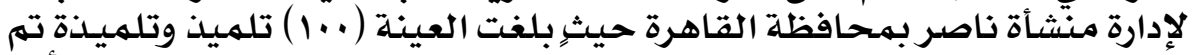

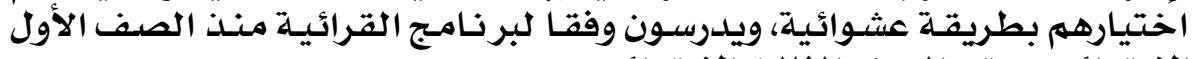
الابتدائي وحتى الصفي الصفي الثالث الابتدائي.

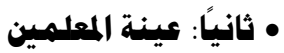

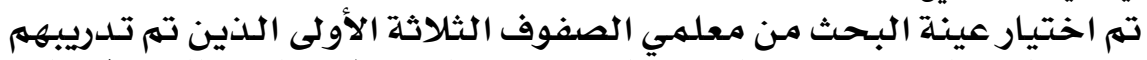

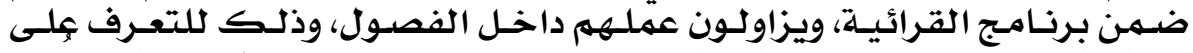

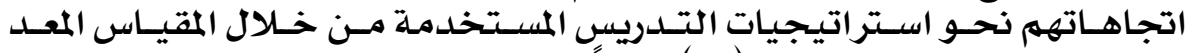

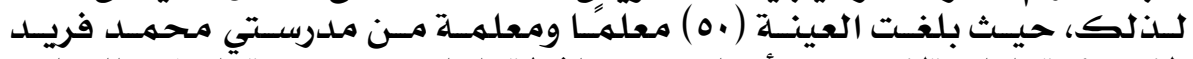

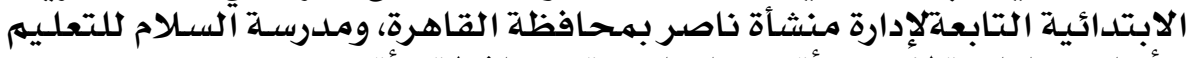

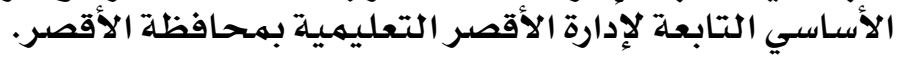




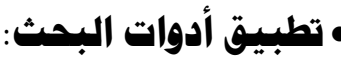

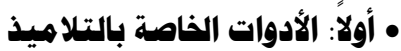

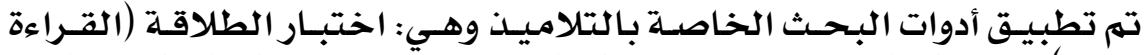

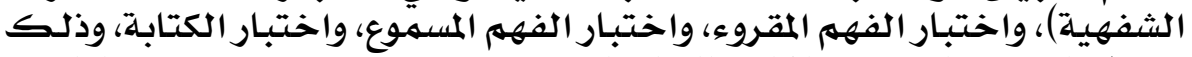

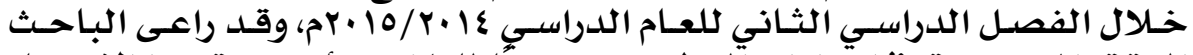

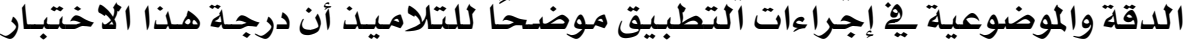

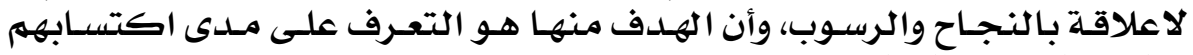
لمهارات القراءة والنجاء الكتابة.

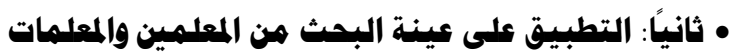

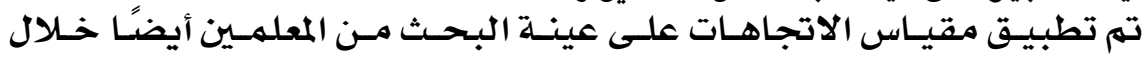

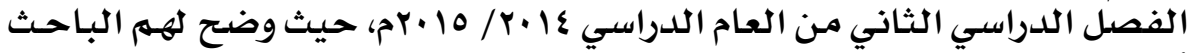

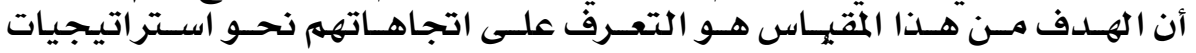

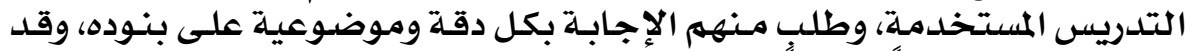

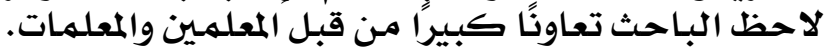

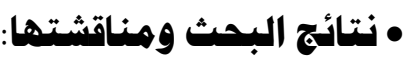

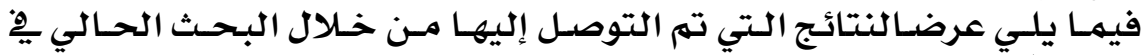

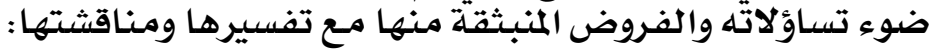
بالنسبه للسؤال الأول:

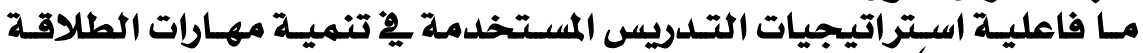

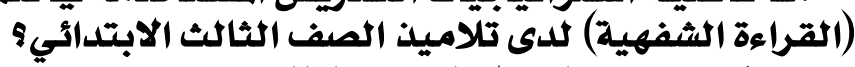

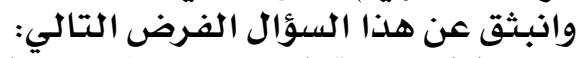

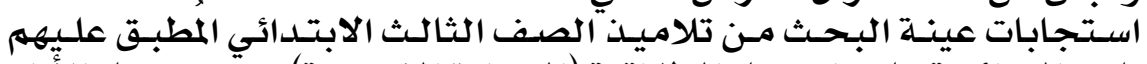

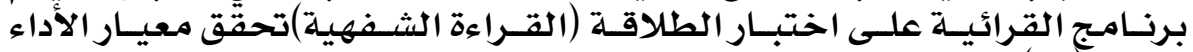

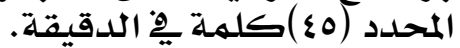

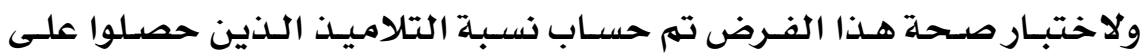

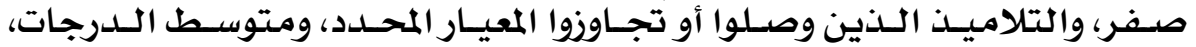

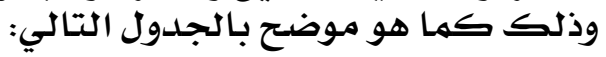
جلدول (1) يوضح درجات عينة البحث من تلاميذ الصف الثالث الابتدائي على اختبار الطلوقة (القراعة الشفهية)

\begin{tabular}{|c|c|c|c|c|}
\hline 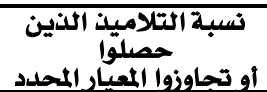 & المعيار المُطبق & مترجطات & الذين حصلية التلاميلى & الأنشطة \\
\hline$\%$. & \&o & זו & $\% r$. & الطلاقشفِيِْ القراءة \\
\hline
\end{tabular}

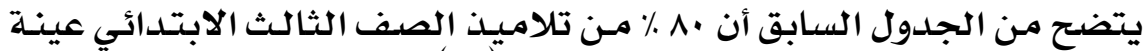

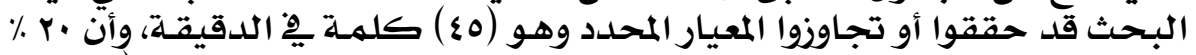

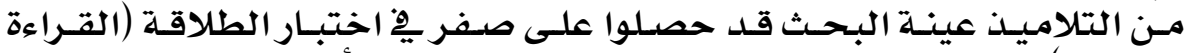

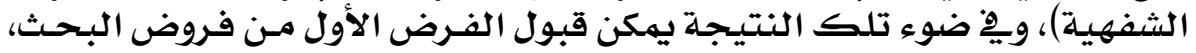

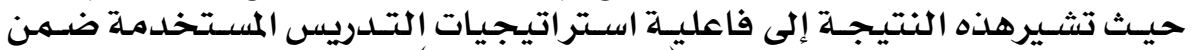

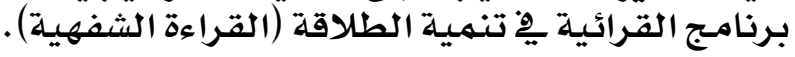

\section{Y. $\bullet$}




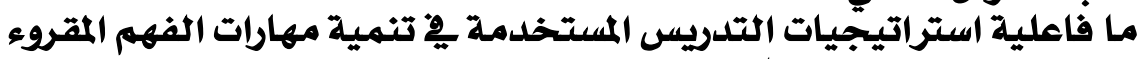

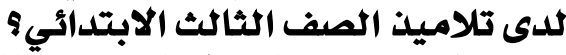

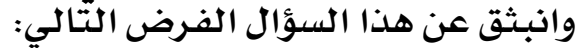

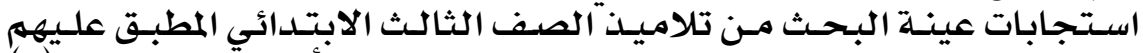

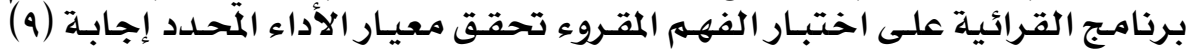

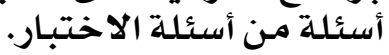

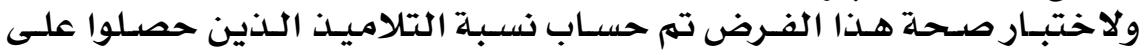

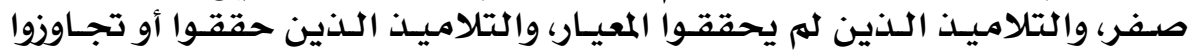

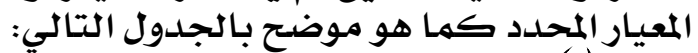

\begin{tabular}{|c|c|c|c|c|c|}
\hline حققوا أو تجلامونوا المقييار & المعيار & الدرجات & لمبن الذينتلامينيذ & 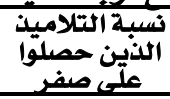 & الأنشطة \\
\hline$\% 9$. & $\begin{array}{l}(4) \\
\text { (4) }\end{array}$ & $\% 11 . r$ & $\% 1$. & - & المقروي \\
\hline
\end{tabular}

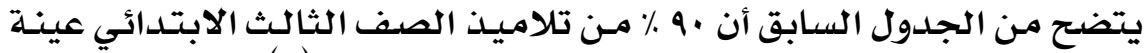

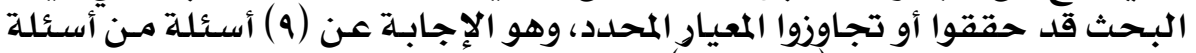

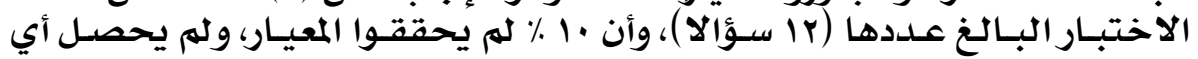

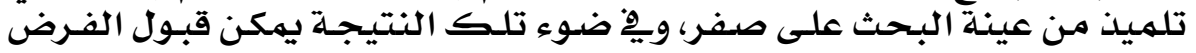

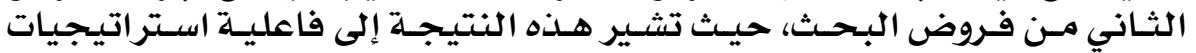

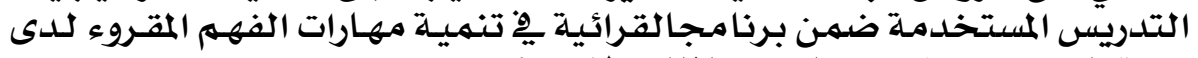

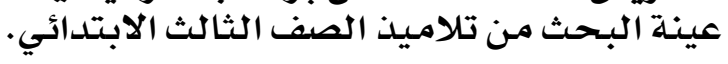

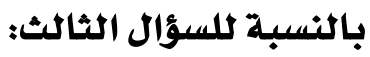

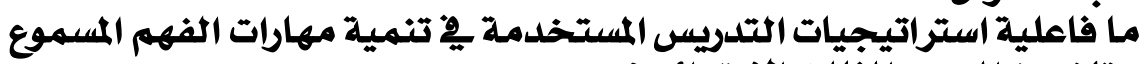

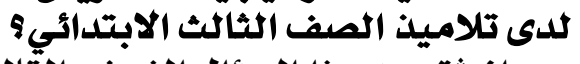

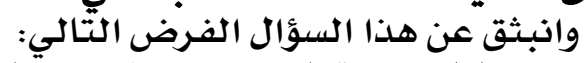

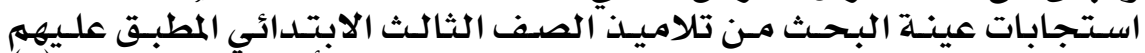

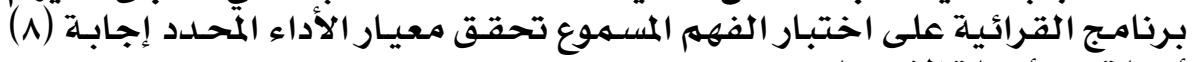

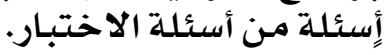

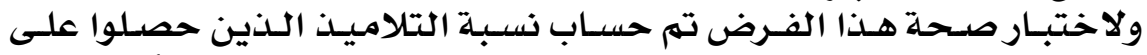

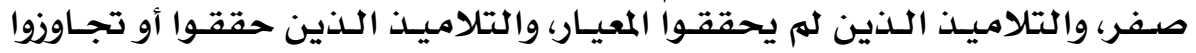

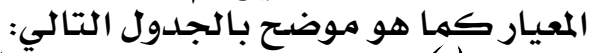

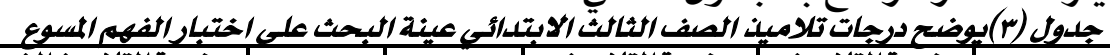

\begin{tabular}{|c|c|c|c|c|c|}
\hline 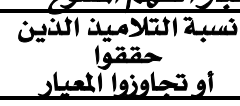 & المعيار & الدرجات & 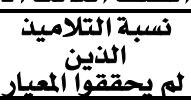 & نالذبية التتلاميلًا & كشطة \\
\hline$\% v$. & 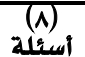 & 9.8 & $\% r$. & $\% 1$. & الفهـم المسموع \\
\hline
\end{tabular}

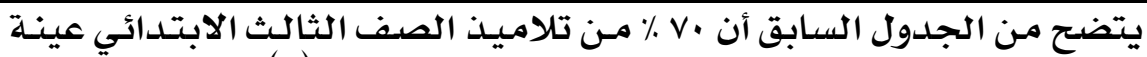

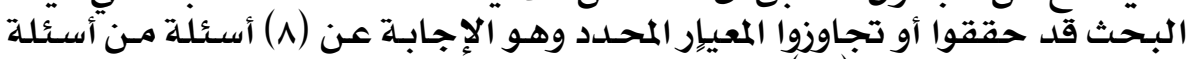

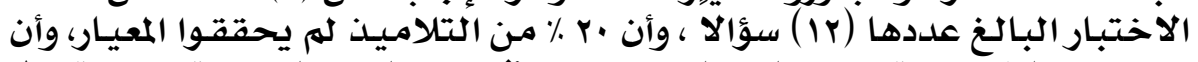

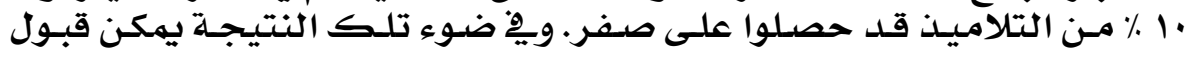




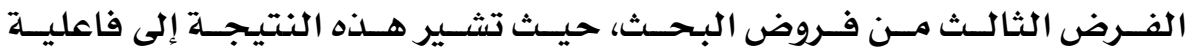

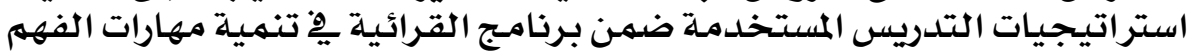

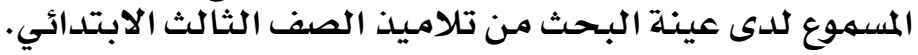

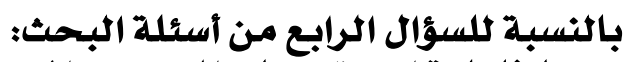

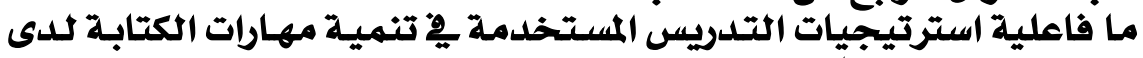

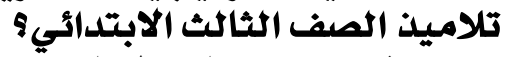

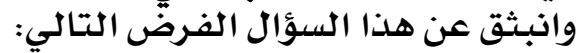

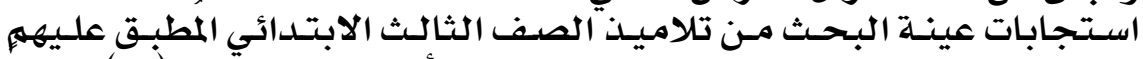

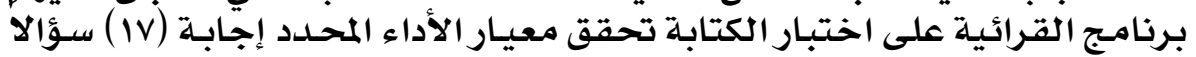
من أسئلة الاجتئلة الاختبار.

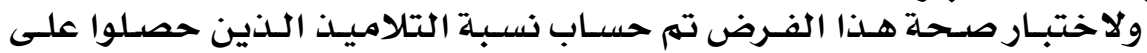

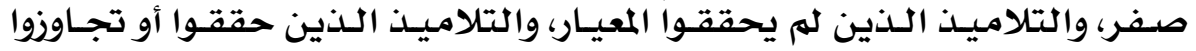

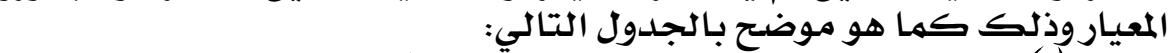

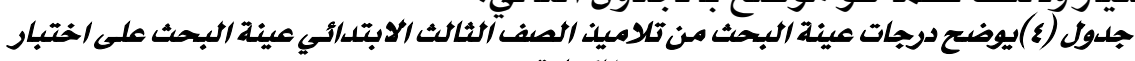
الكتابة

\begin{tabular}{|c|c|c|c|c|c|}
\hline حققبا الو تجاؤيذا اللذينيار & المعيار & الدرجات & ثمبية التتلاميذ & نالذبية التصلاميلذا & شططة \\
\hline$\%$ \% & IV أوالا & rv.0 & $\% 1 \varepsilon$ & - & يهارات لكتابية \\
\hline
\end{tabular}

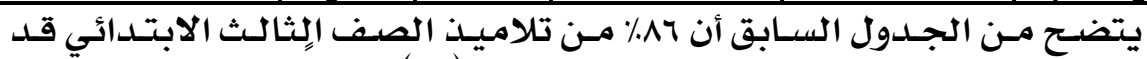

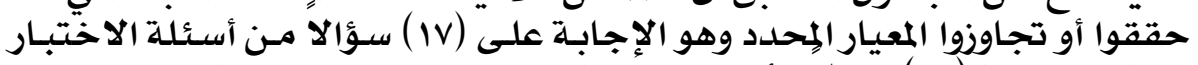

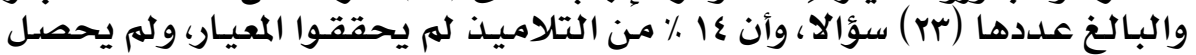

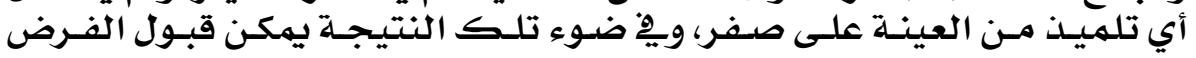

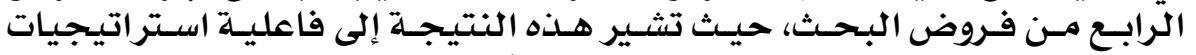

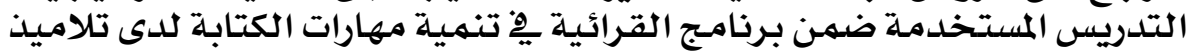
الصف الثالث الابتدائي. الماني.

بالثسبة ثلسؤال الخامس من أسئلة البهث:

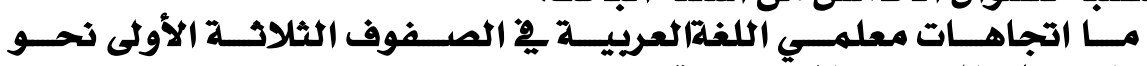

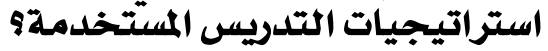

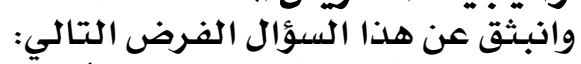

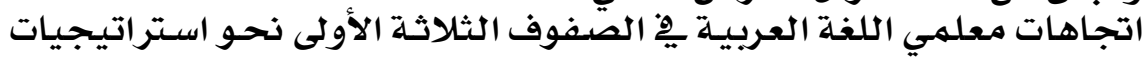

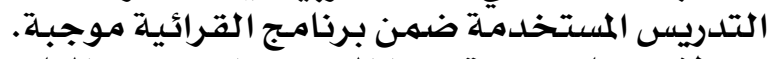

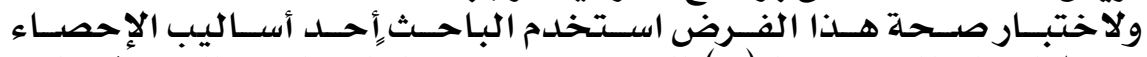

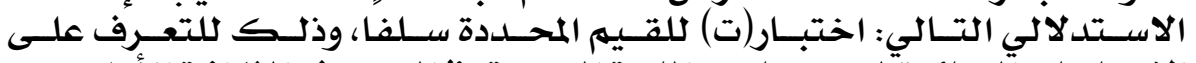

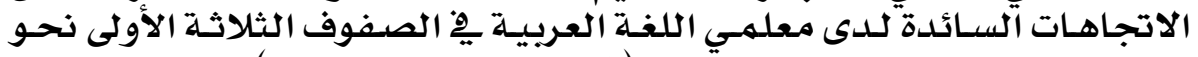

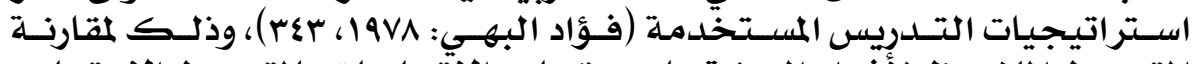

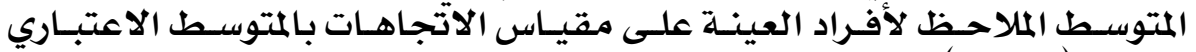

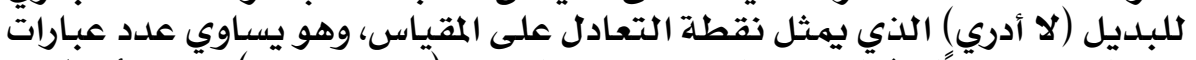

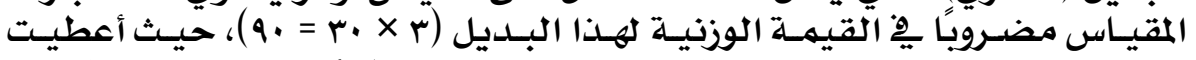

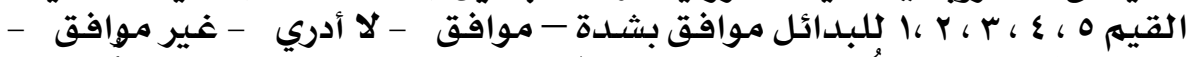

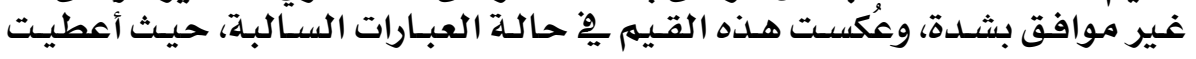

\section{$Y \cdot V$}


العقد العابي والستهن .. نهوهمبر ..

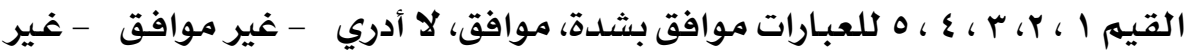

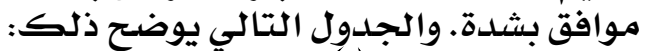

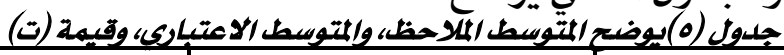

\begin{tabular}{|c|c|c|}
\hline قيمة (ت) & المتوسط الاعتباري & المتوسط الملاحط \\
\hline$r \cdot .10$ & 9. & $11 \cdot .10$ \\
\hline
\end{tabular}

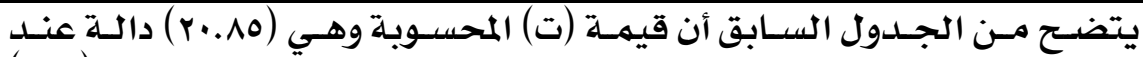

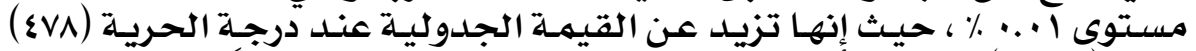

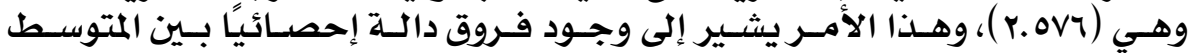

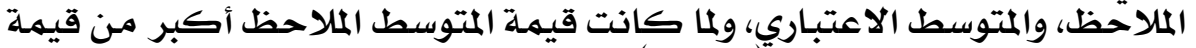

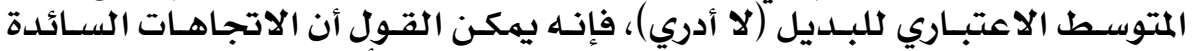

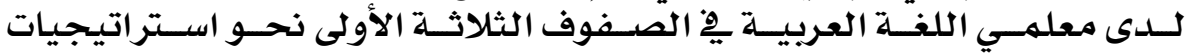

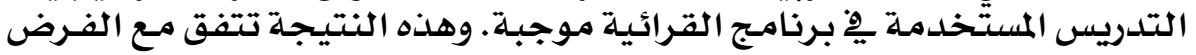

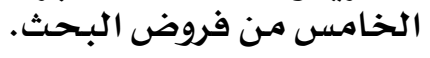

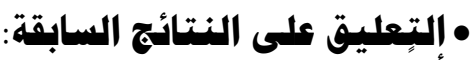

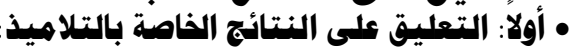

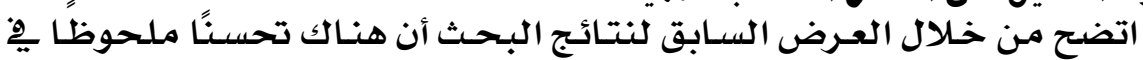

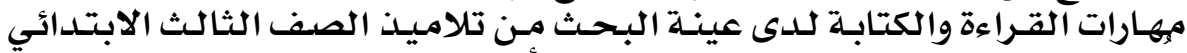

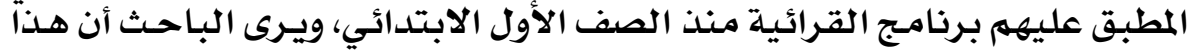

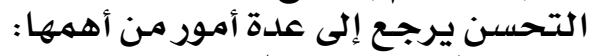

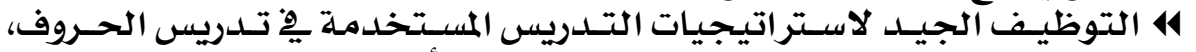

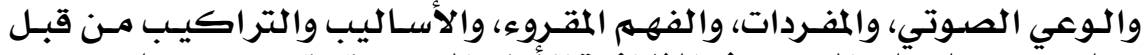

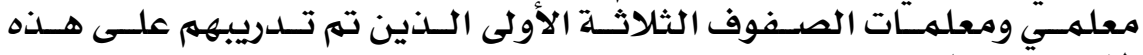
الاستراتيجيات. الإنيات

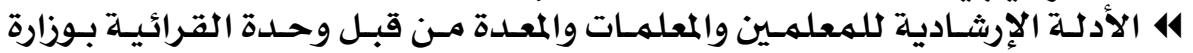

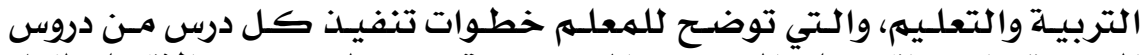

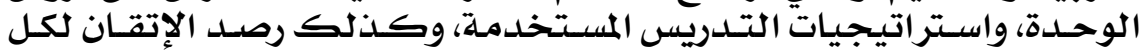
وحدة دراسية.

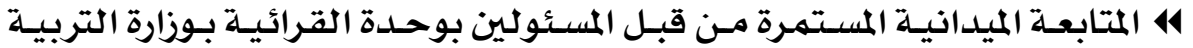

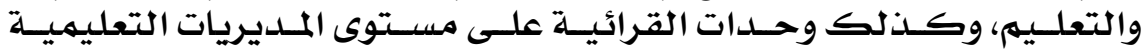

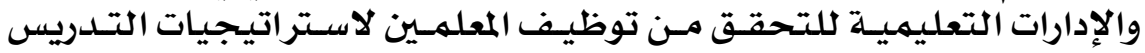

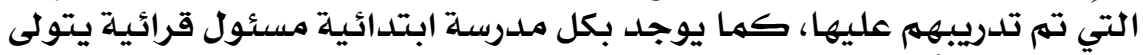

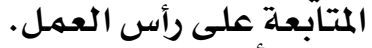

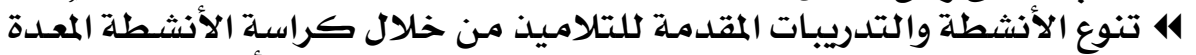

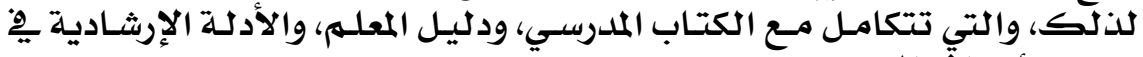

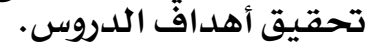

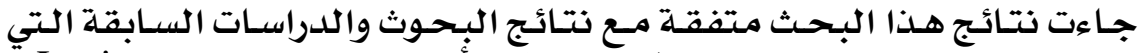

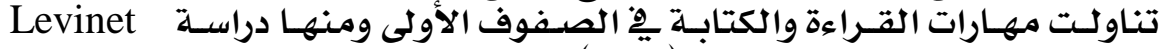

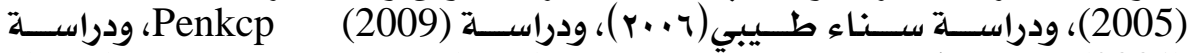

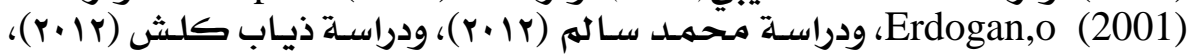

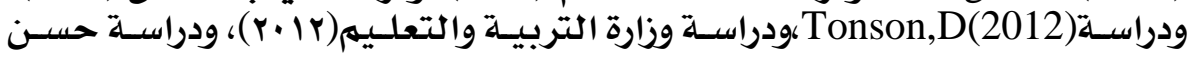

\section{$Y \cdot \Lambda$}




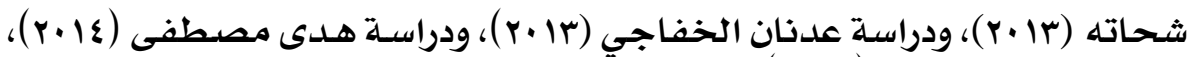

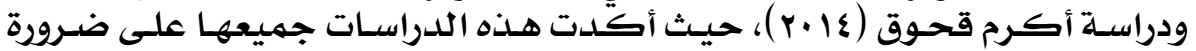

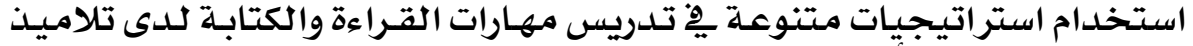

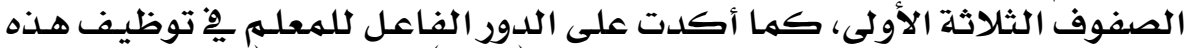

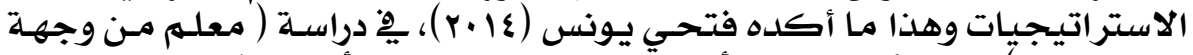

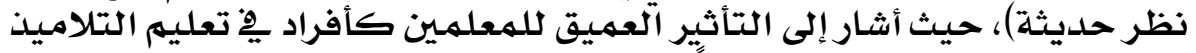

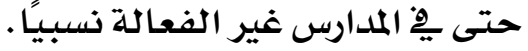

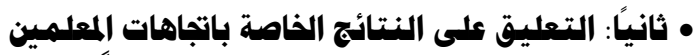

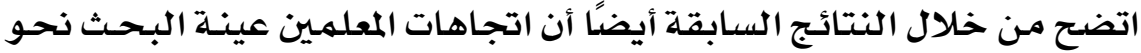

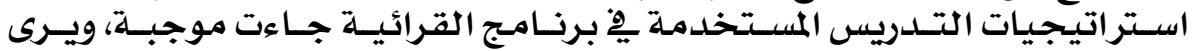

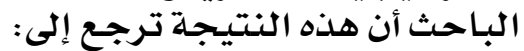

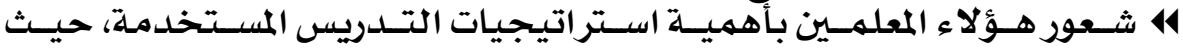

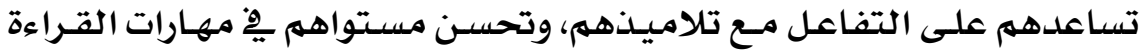

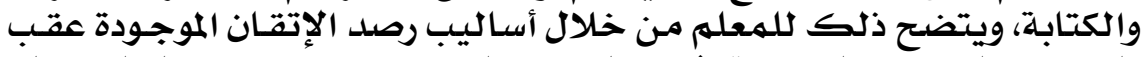

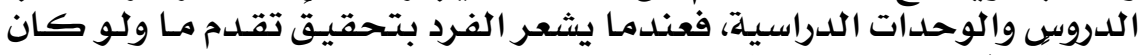

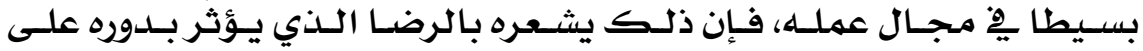

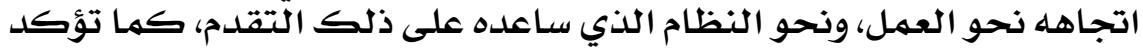

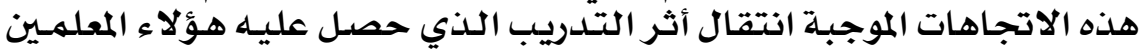

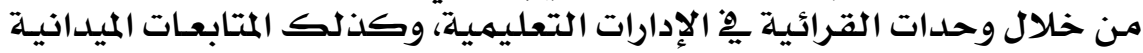

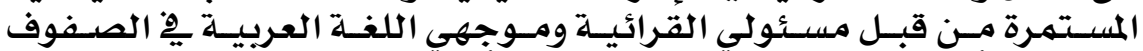

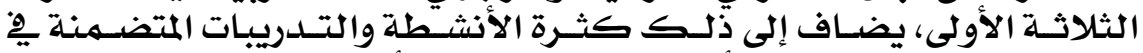

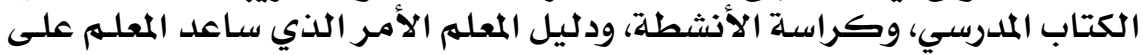

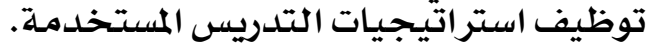

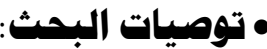

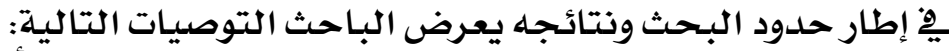

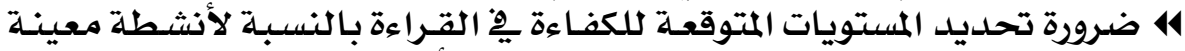

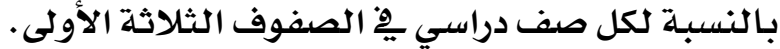

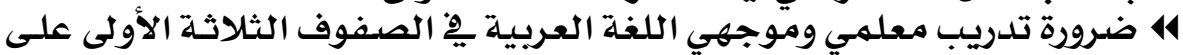

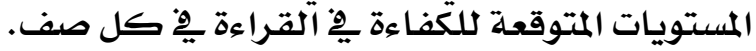

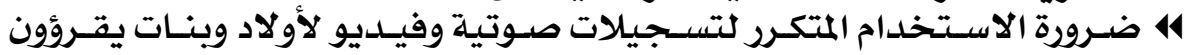

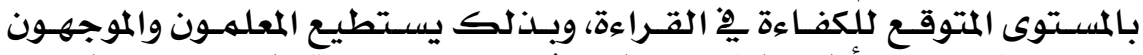

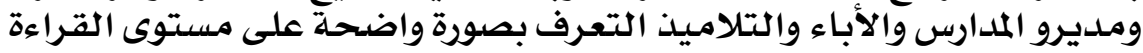

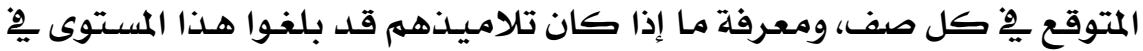

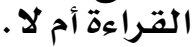

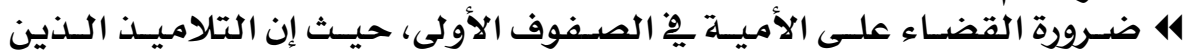

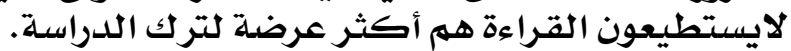

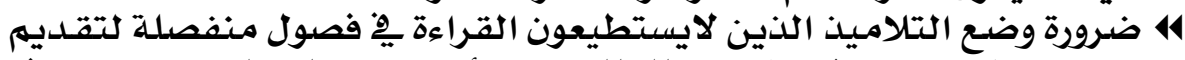

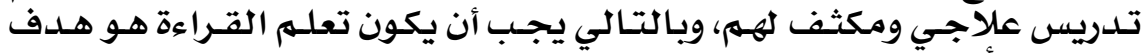
التعليهم الأول بألنسبة لهمه 


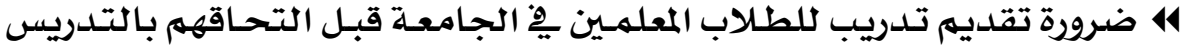

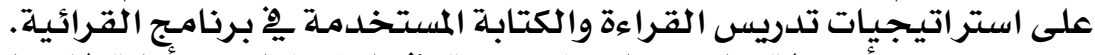

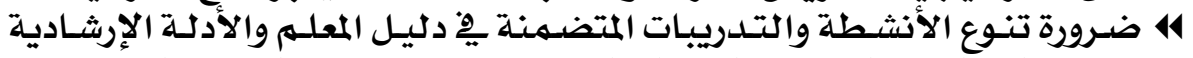
وكراسات التدريبات إلى جانب الكتاب المدرسي، وتزويد المعلهـين بها وتلدريبهم عليها . وقران.

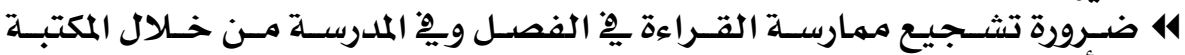

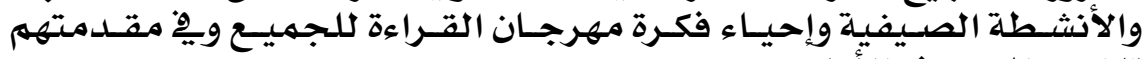

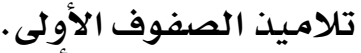

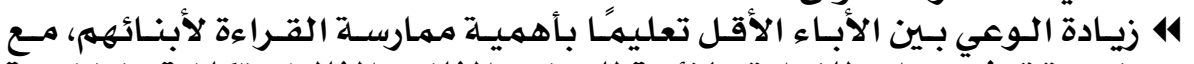

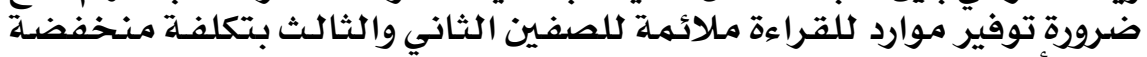

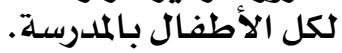

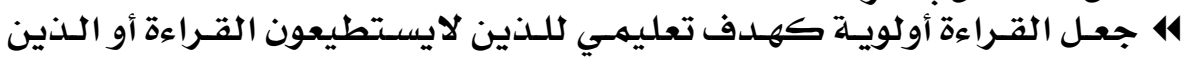

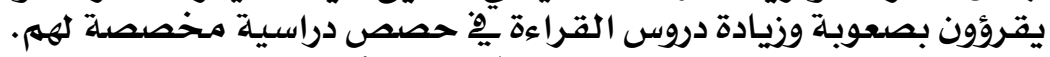

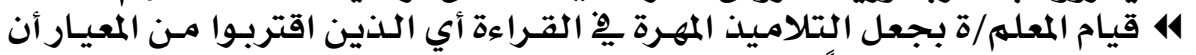

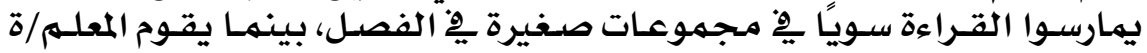

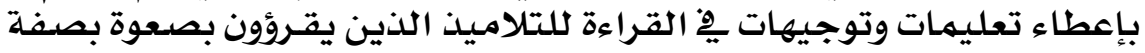
أسـاسية.

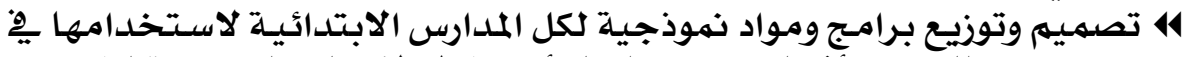

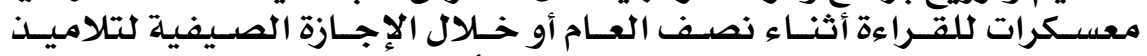

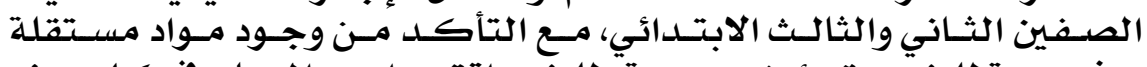

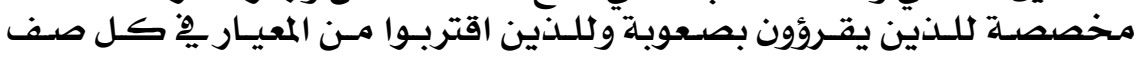

$$
\text { دراسي. }
$$

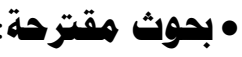

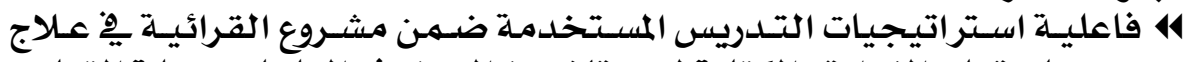

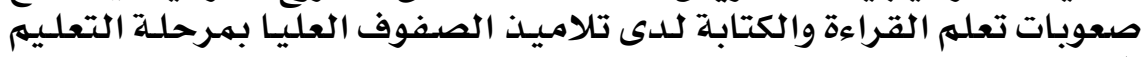
الابتدائي.

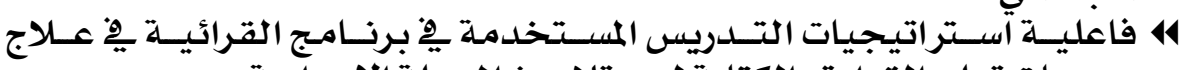

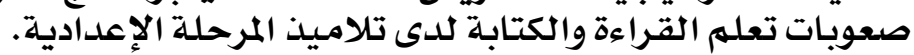

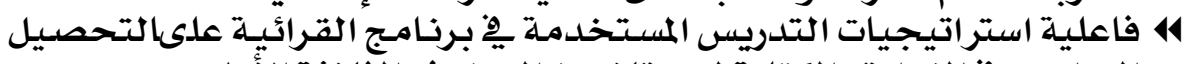

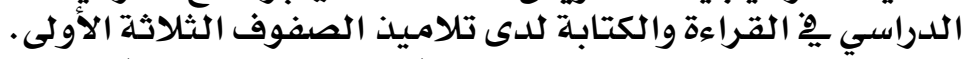

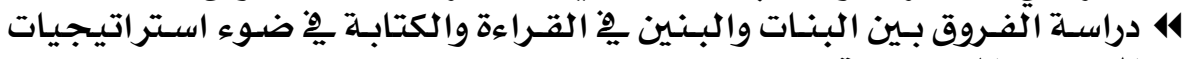

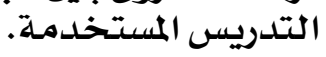

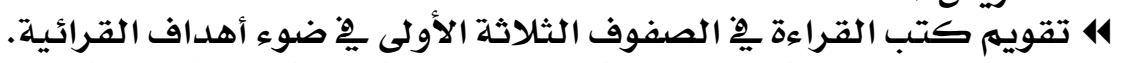

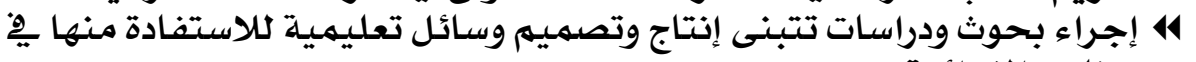
برنامـج القرائيـة.

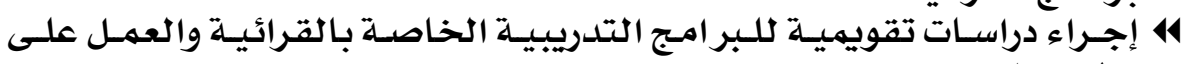
تطويرها إحراء دراء 4 إجـراء دراســات تقويهيـة لوحسـات القرائيـة بـالإدارات التعليهيـة والعمـل على تطويرهـا.

\section{Y).}




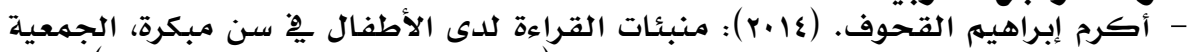

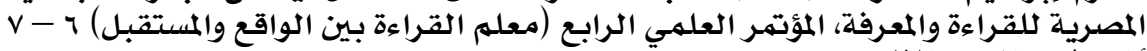

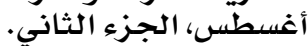

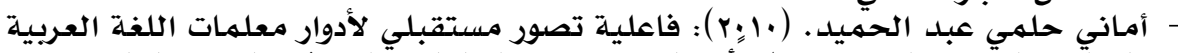

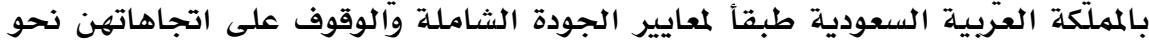

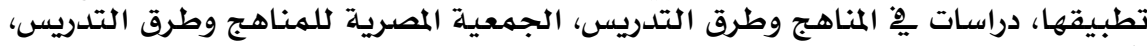

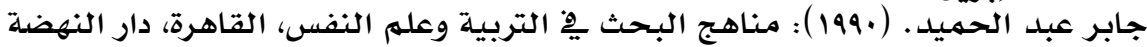

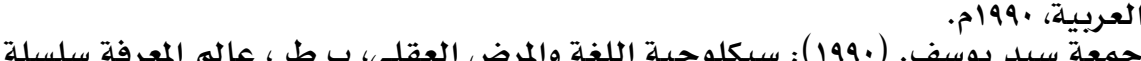

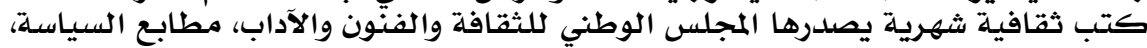
الكويت.

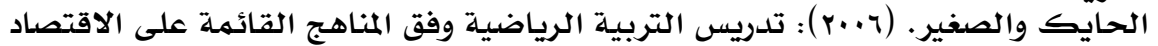

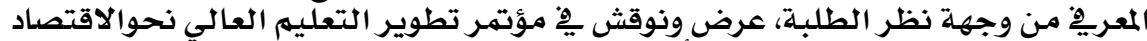

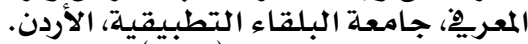

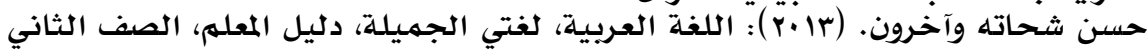

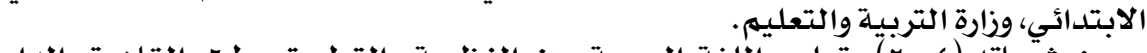

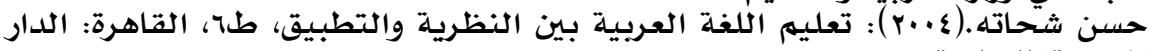

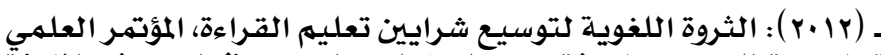
المصريـة اللبنانية.

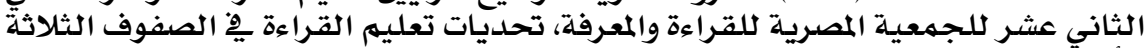

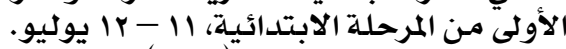

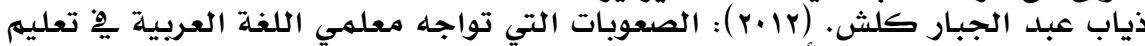

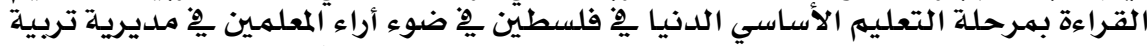

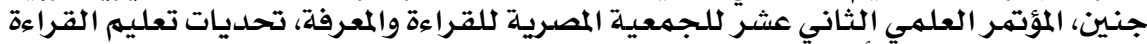

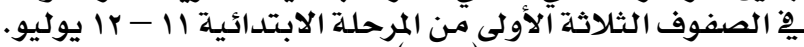

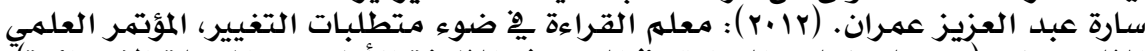

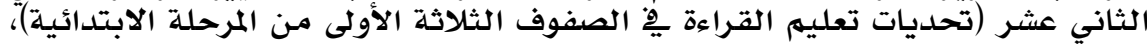

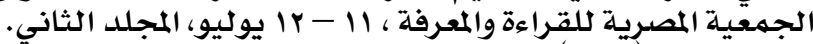

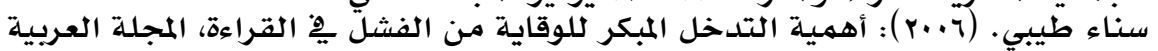

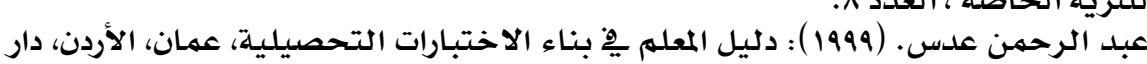

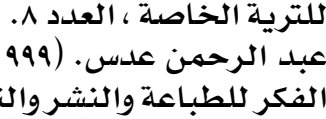

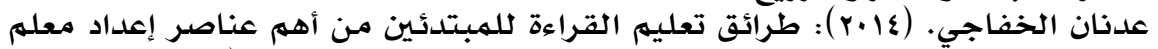

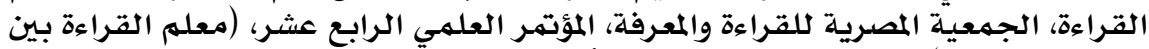

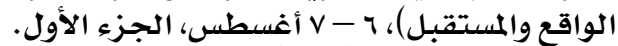

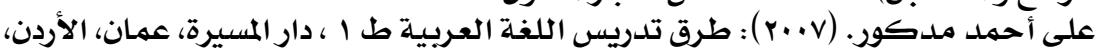

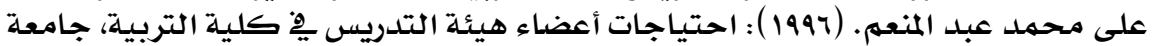

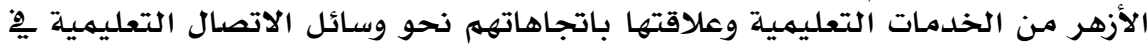

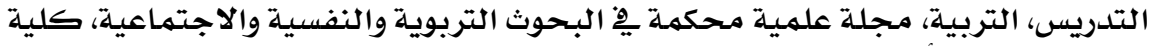

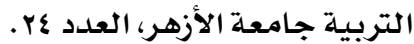

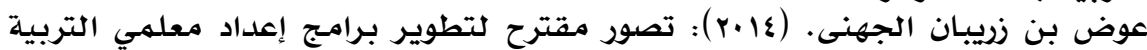

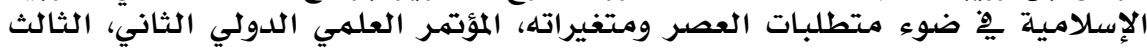

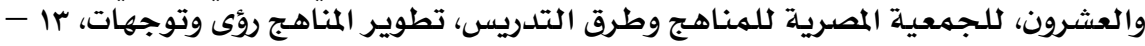

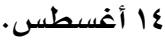

\section{YI}




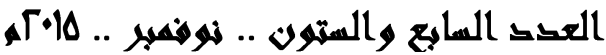

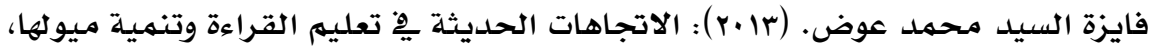

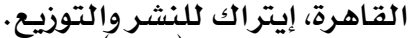

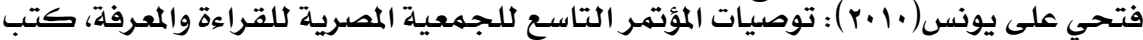

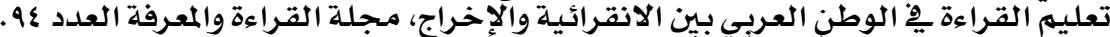

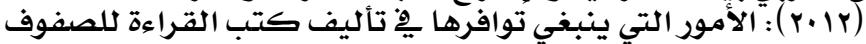

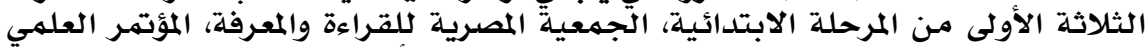

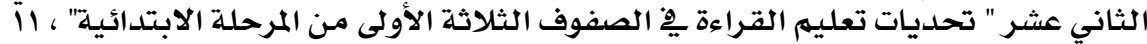

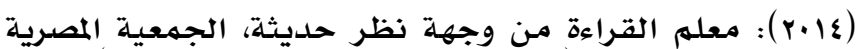

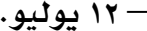

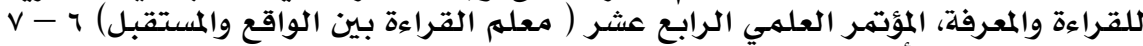
(1999): تعليهم اللغة العربية للمبتدئين الصغار والكبار، القاهرة،

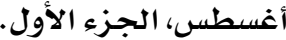
كلية التربية، جامعة عين شمس.

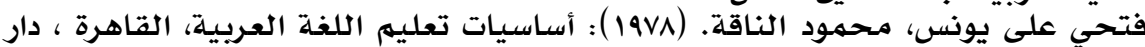

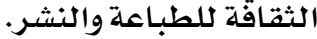

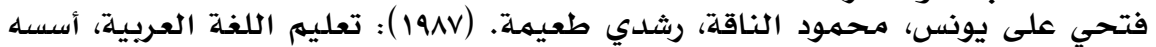

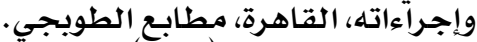

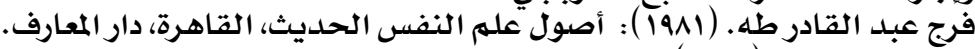

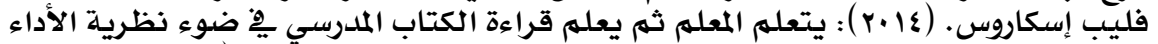

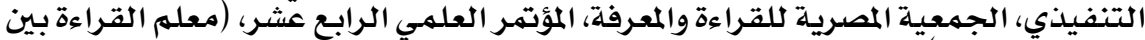

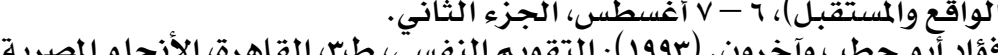

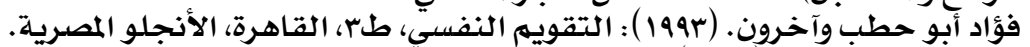

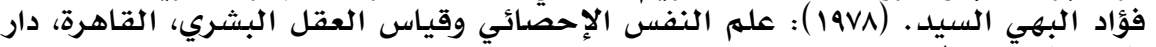

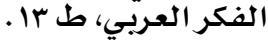

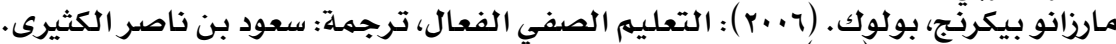

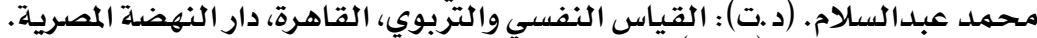

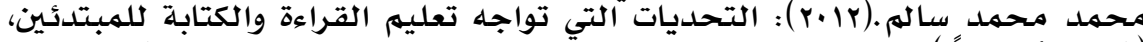

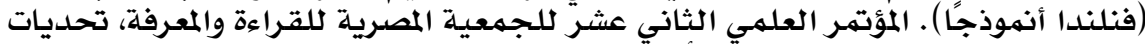

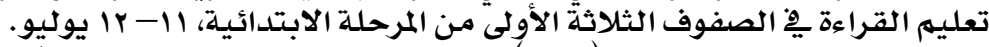

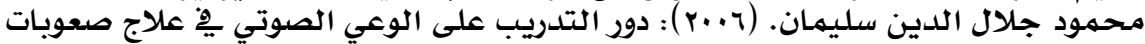

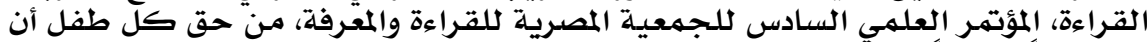

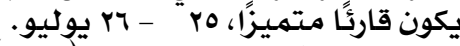

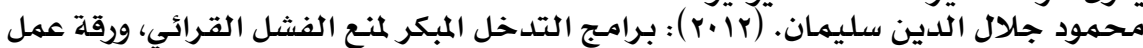

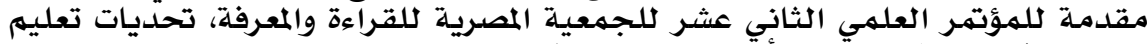

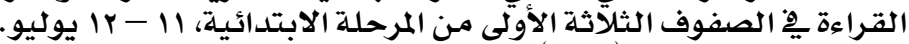

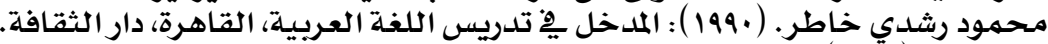

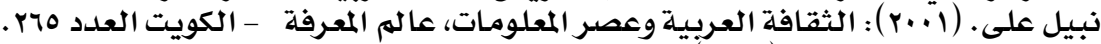

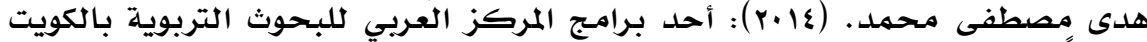

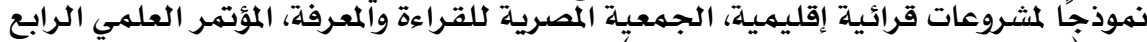

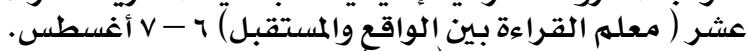

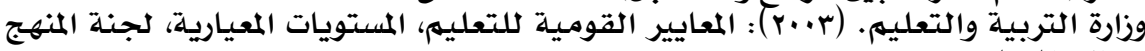

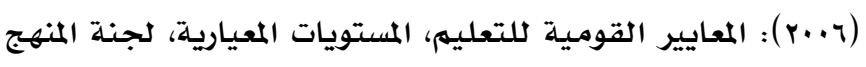

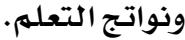

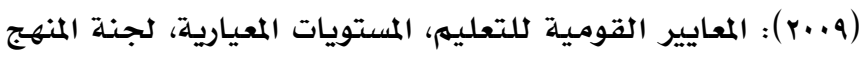
ونواتج التعلهم. |l+r) المعايير القومية للتعليه، المستويات المعيارية، لجنـة المنهج ونواتج التعلهم.

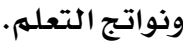

\section{YIY}




\section{العكق السابع والستون .. نه همهبر ..}

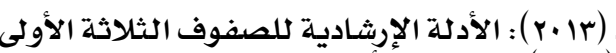

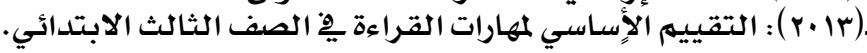

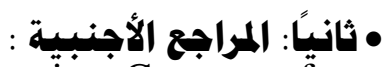

- Aderson, R.C, \& Kuihavy R.W. (2009): Learning Concepts from definition American Eductional Reasearch Journal, 9, 385 - 390.

- Barrett, T. C. (2006): Atoxonomy of reading Comprehension in R.F. Smith \& Barrett reading in the middle Grades Addison-wesley Publishing CO.

- Becker, W. C., \& Engelmann, S.(2008): Analysis of achievement data on six Cohots of Low- income Children from 20 School districts in the Universty of Oregon Direct Instruction Follow Through Model ) Follow Through Project, Tech, Rep. No 1- 78) Eugene, OR: University of Oregon.

- Bennent, H, O and Others. (2000): Freshman South Africaica Student Sviewson the Study of Chemisty the Annual Mettingof the national Association of Research in Science Teaching, new Orkleans, LA, April28 May.

-Cotton: (2005): Applying Total Quality Management Principles to Secondary Education, http:///www. Nworl sopd sivs 8035.html.

-Dunn, N.E. (2004): Children achievement at School-entry age as sfunction of mothers and fathers teaching, Elementary Journal $81,245-253$.

-Erdogan,O.,(2010): Relationship between The Phonological awareness skills and writing skills of The first student at Primary School, Journal of education Sciences Theory \& Practice, Turkish, Vol(11),No.3,pp.1506-1510.

- Hoffman, J.V., Oneal, S.f., kaster, L, A., Clements, R.O., Segal, K. w., \& Nash, M.F. (2008): Guided Oral reading and miscue focused verbal feedback in second-grade Classroms. Reading Research Quarterly, 19,367-384.

- Johnson, D, (2012): Spanish reading Comprehension, Phonological awareness, and Oral Fiuency among Spanish speaking adolescent Latino Students Publication info: Capella University, Pro Quest, umI Dissertations Publishing, Ph.D.

-Levin, I, ET (2005): Learning of Letter names and Sound and Their Contribution to word recognition, Journal of Experimental Child Phycology, No. (93) pp. (139).

- Mansour, M.D. (2006): Embarching Teacher Quality \& Excellence: Pereeption, Reality, And Causality pH.D. School of Education, University of Pittsbarg.

- Mayer, D.E, \& Schvaneveidt, R.W. (2010): Facilitation in recognizing pairs of words: Evidence of a dependence between retrieval operations. Journal of Exprimental. 
-Morris, E. (2001): Professionalism and Trust: The Future of Teacher to Social market Foundation, New, from: www, Teacher net. GoV.UKL.

-Penke, M., (2009): The role of Phonology in reading, written Language and Literacy journal, Vol (11) No. (2), pp. (147-166).

-Smith, Manilync (2001): The Ouicomes question in Teacher education, Teacher and Teaching Education, 17, pp. (527546).

-Soderbergh, W.C., (2004)\& Reading early childhood: Linguistic Study of the Preschool child gradual acquisition of reading ability. Washington, DC: Georetown Universty Press.

-Stevenson, H.W. (2008): Making the grade School achievement in Japan, Taiwan, and United States. Annual Report of the Center for Advanced Study in Behaviral Sciences. Stanford, CA.

- Wilson, P.T., \& Anderson, R.C (2010): Reading Comprehension and School Learning. In J. Osborn, P.T. Wilson, R.C. Anderson (Eds), Reading Education: Foundation for a Literate America. Lexington, MA: Lexington Books.

-Zola, D. (2009): Redunandancy and Word Perception during reading Perception and Psychophics, 36,277-284. 


\section{البحن السادسر:}

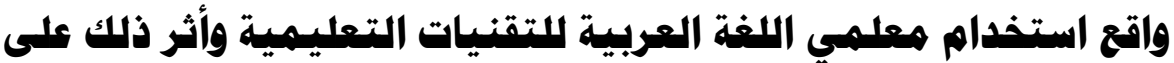
تصيل طلابهم بالمرحلة المتوسطة في هحافظة الجوف بالمبملكة العربية السعودية فئية

:

د الم / حامد فلاح الأسعدي

دكتوراة من جامعـة Western Sydney بـاستر اليا

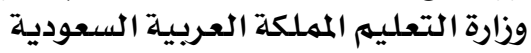





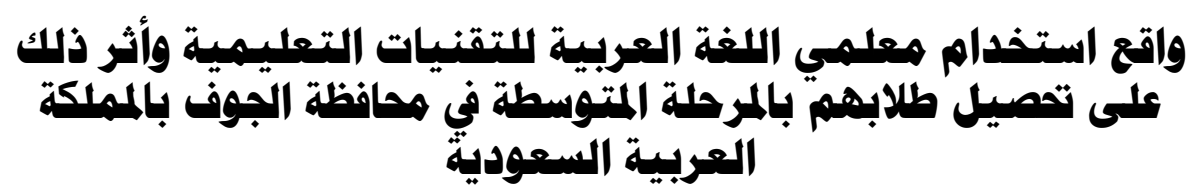

د / حامل فلاح الأسعلدي

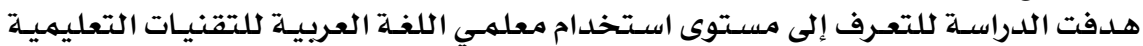

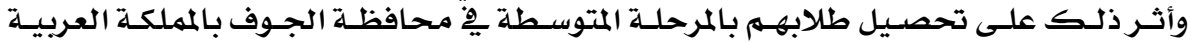

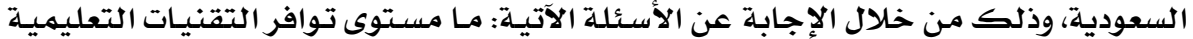

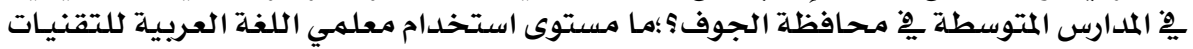

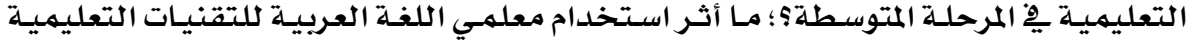

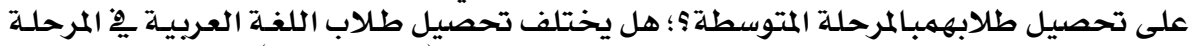

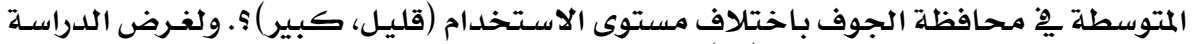

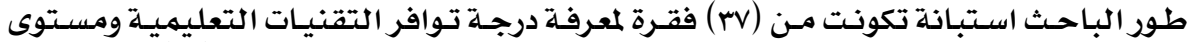

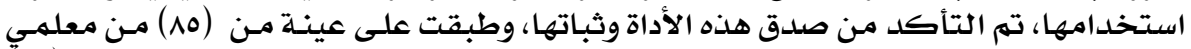

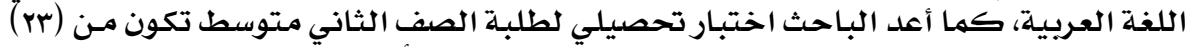

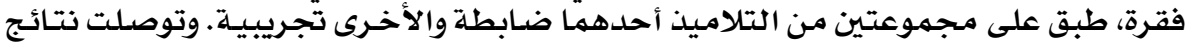

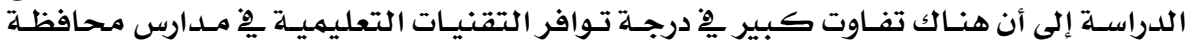

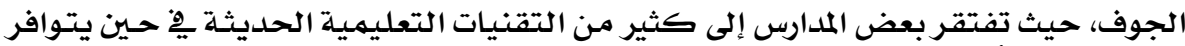

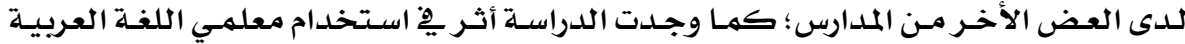

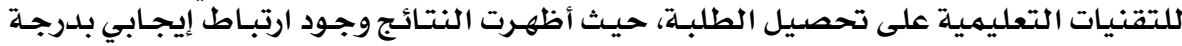

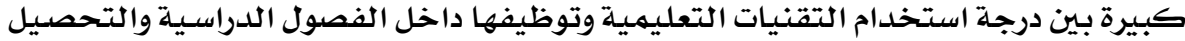

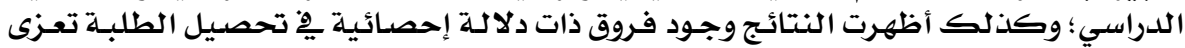

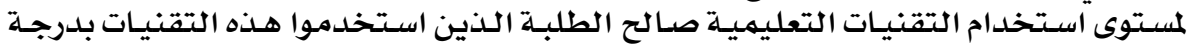

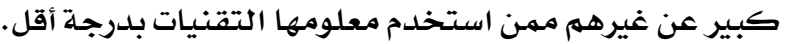

\section{The Reality of Using Arabic Language Teachers the Educational}

Technologies and its Impact on the Achievement of the middle Abstract: school Students in Al-Jowf Governorate in Saudi Arabia

The aim of the present study is to identify the level of using Arabic language teachers the educational technologies and its impact on the achievement of their students in middle school in al-Jowf governorate, Saudi Arabia, through answering the following questions: What is the level of the educational technologies in middle schools in al-Jowf governorate?; What the level of using the Arabic language teachers the educational technologies in the middle stage ?; what is the effect of using Arabic language teachers the educational techniques on their students' achievement ?; Is the Arabic language students' achievement at the middle school in alJowf governorate differs according to the level of usage (high, low)? For achieving the purpose of the study, the researcher prepared a questionnaire consisted of thirty - seven (37) paragraphs to identify the availability of the educational technologies and the level of its usage. In order to confirm the validity and the reliability of this instrument, it was applied to a sample of eighty five (85) of the Arabic language teachers. The researcher also 
prepared an achievement test for students in the second grade consisted of twenty three (23) paragraphs, and applied to two groups of students, one is a control group and the other is experimental. The results of the study reveals that there is a difference in the availability of the educational technologies in the schools of al-Jowf governorate, where some schools lack many of the modern teaching techniques while they are available for some schools. The study also confirmed the impact of using the Arabic language teachers the educational technologies on students' achievement. The results showed a positive correlation between the degree of using the educational technologies and employing it in classrooms and academic achievement. The results showed a statistically significant difference in students' achievement related to the level of using the educational technologies in favor of the students who used these technologies.

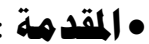

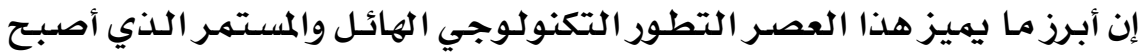

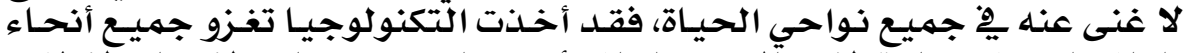

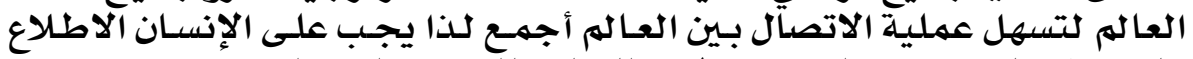

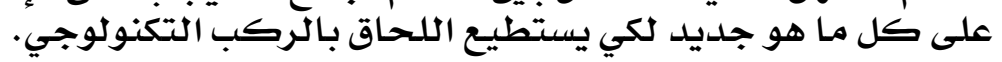

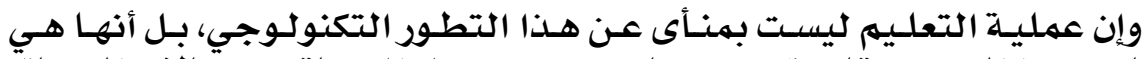

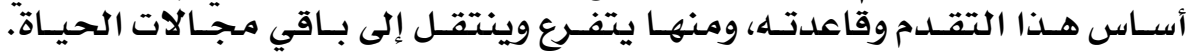

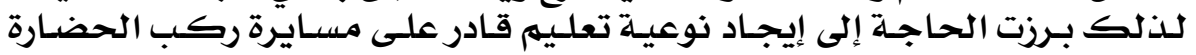

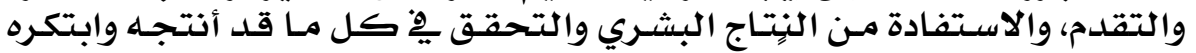

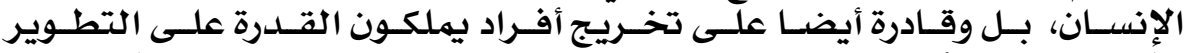

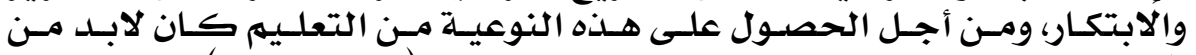

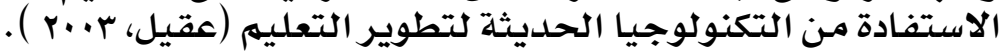

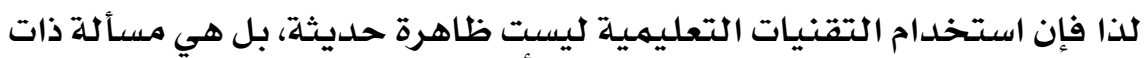

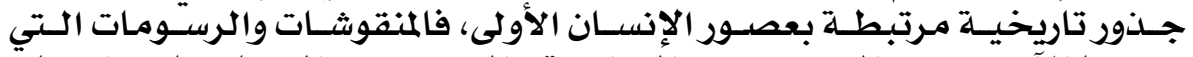

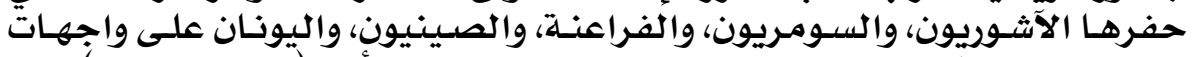

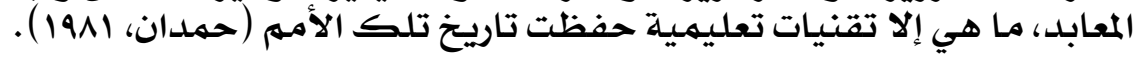

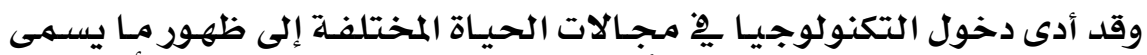

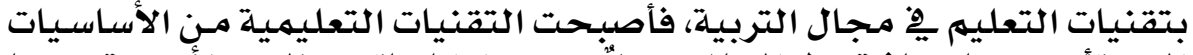

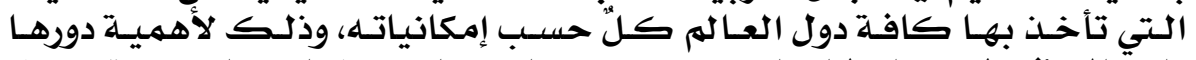

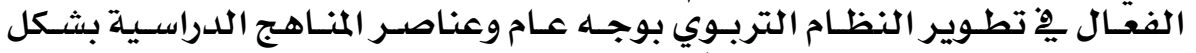

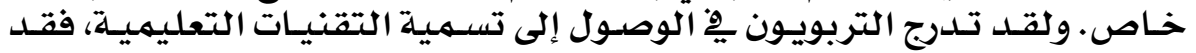

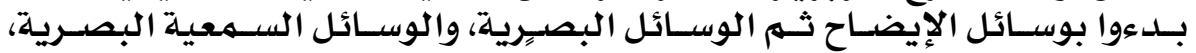

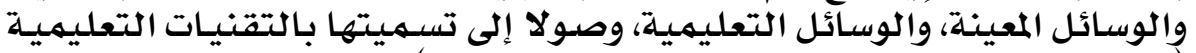

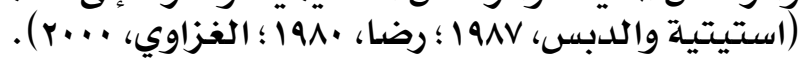

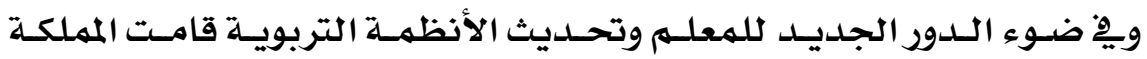

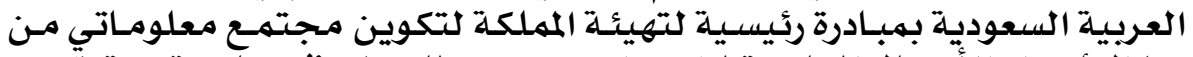

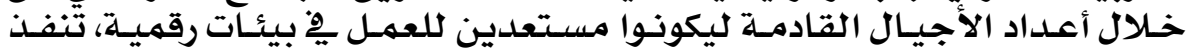




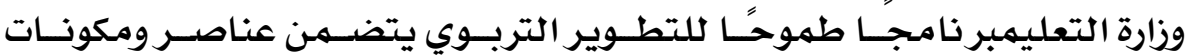

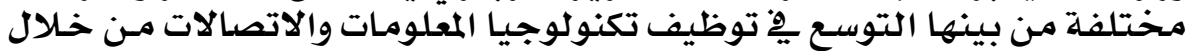

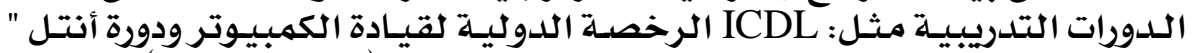

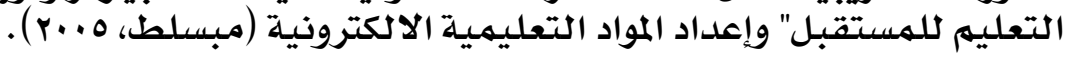

• مشكلة الدراسة وتساؤلاتها:

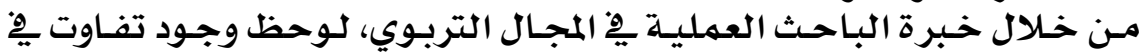

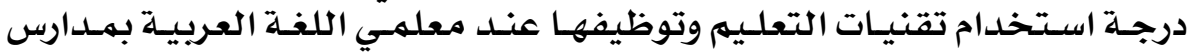

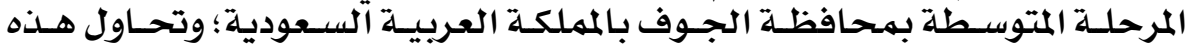

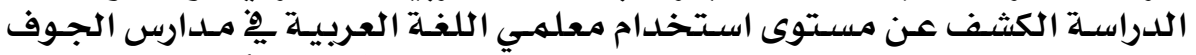

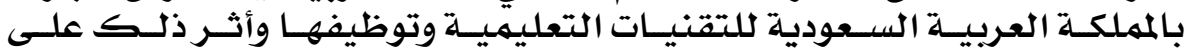

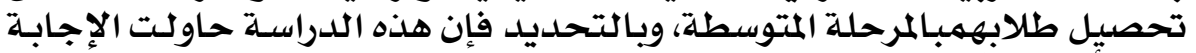

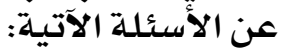

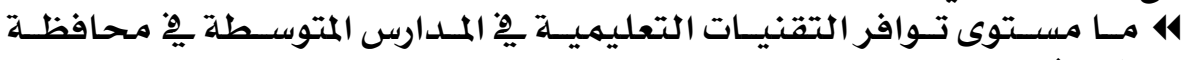

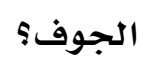

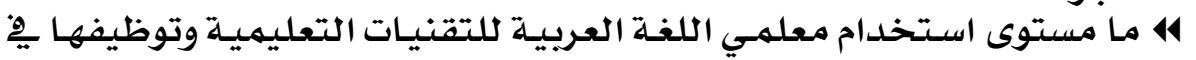

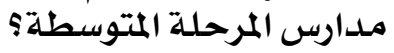

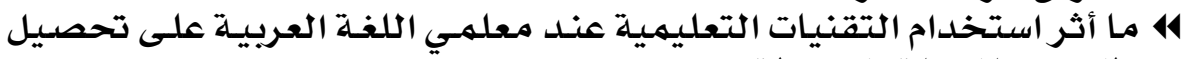

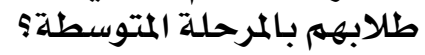

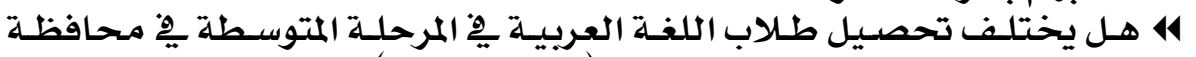

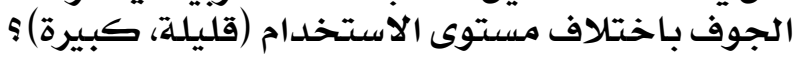

• أهمئية الدراستة:

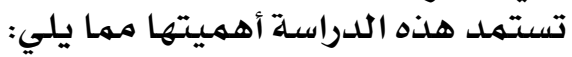

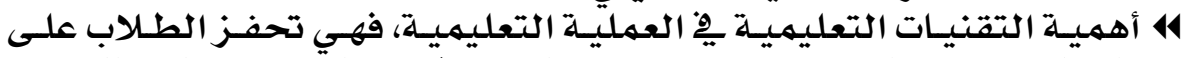

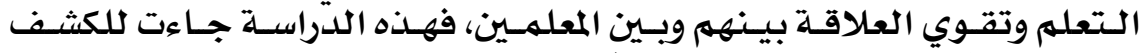

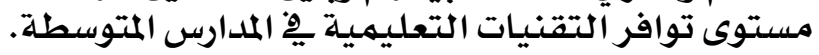

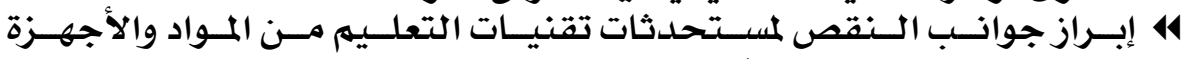

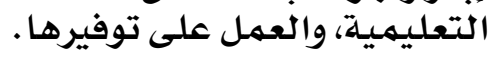

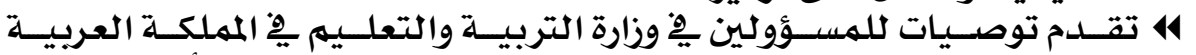

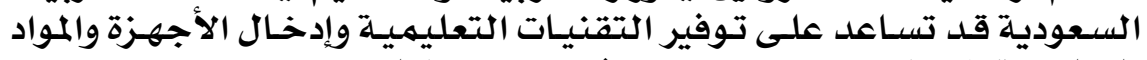

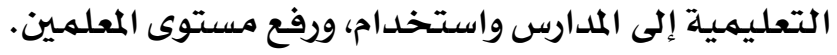

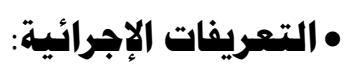

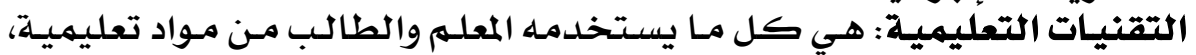

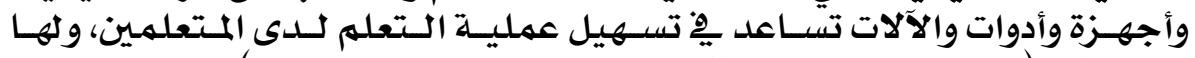

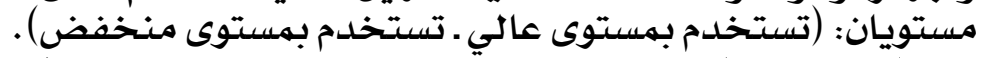

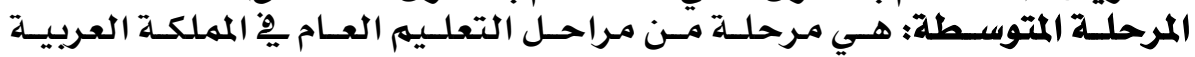

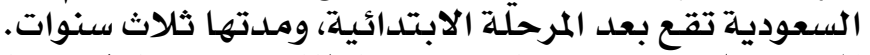

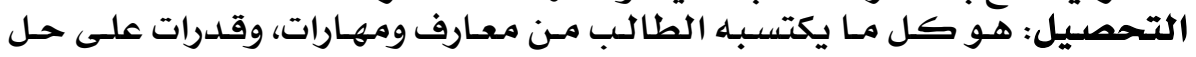

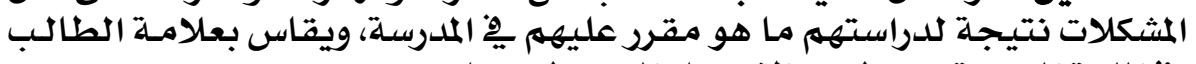

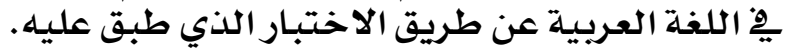

\section{Y 9}




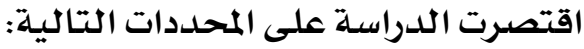

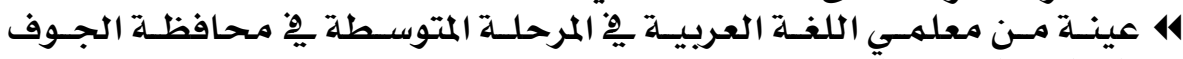

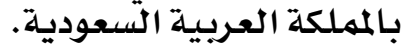

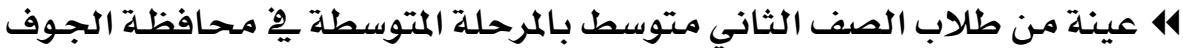

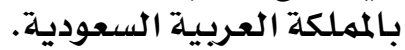

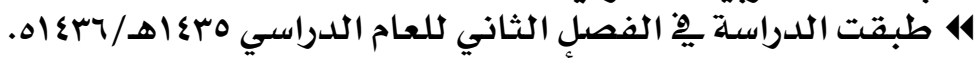

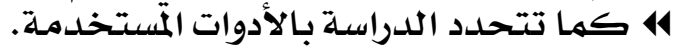

• الدراسات السابقة:

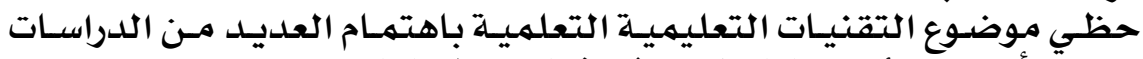

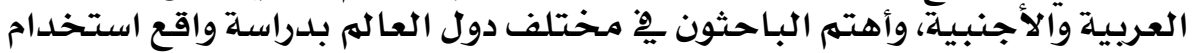

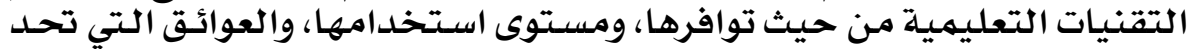

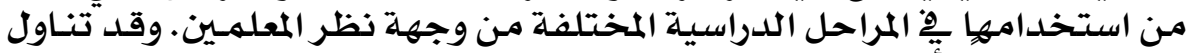

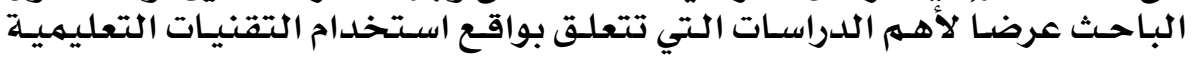

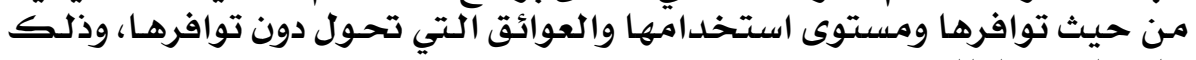
على النحو التالي: مئ توافي

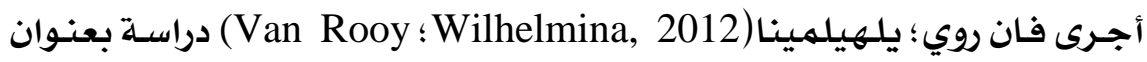

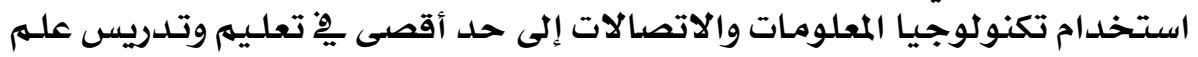

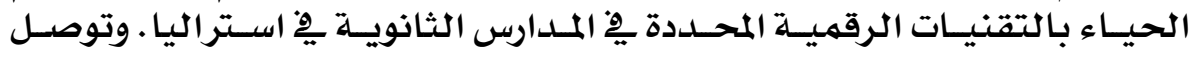

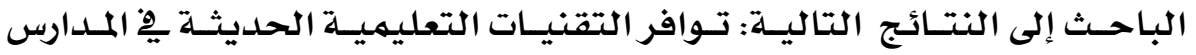

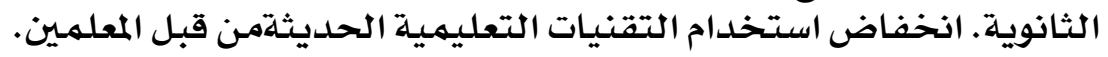

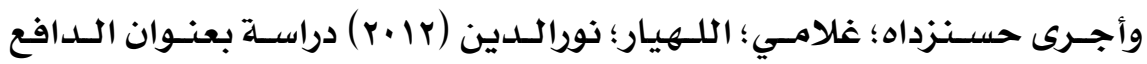

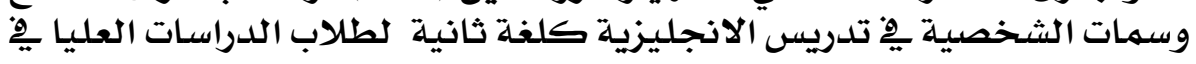

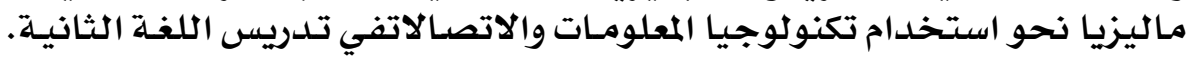

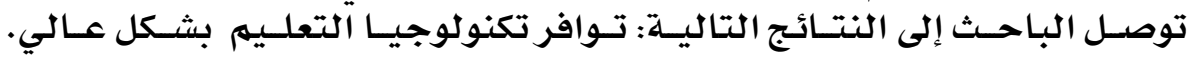

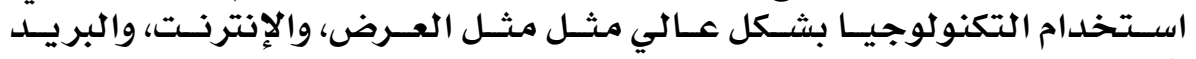

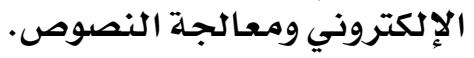

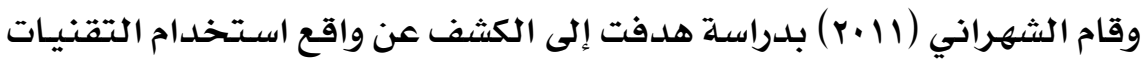

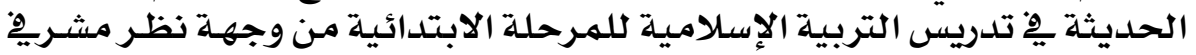

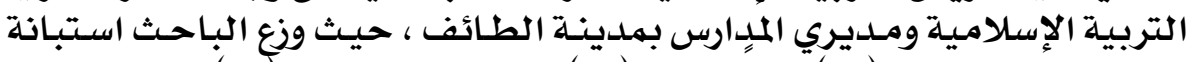

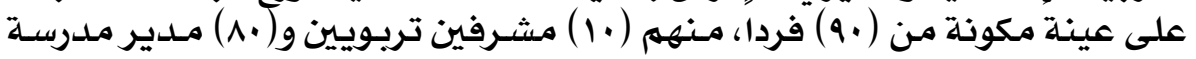

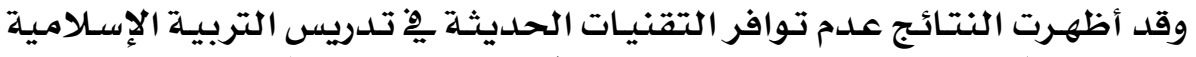

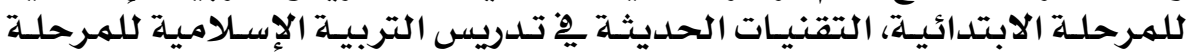

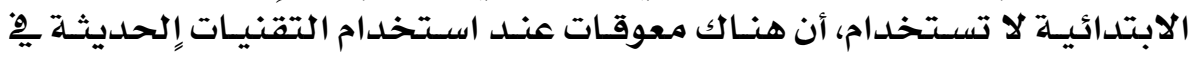

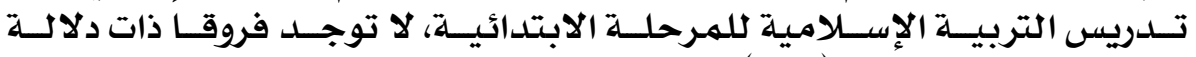

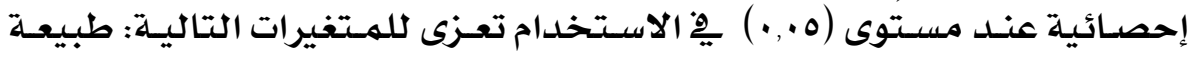

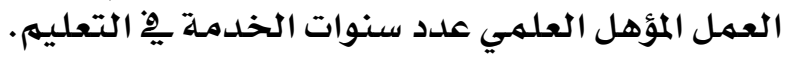




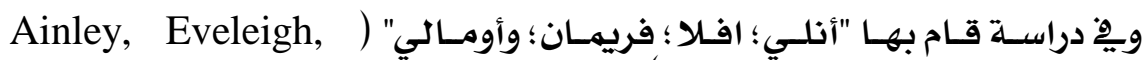

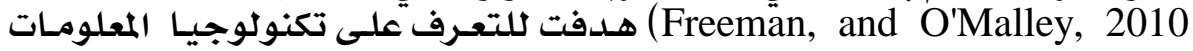

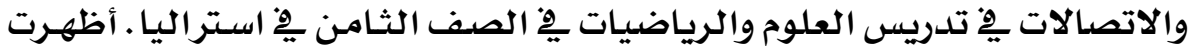

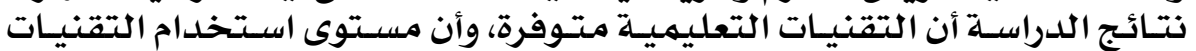

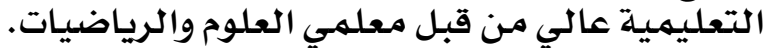

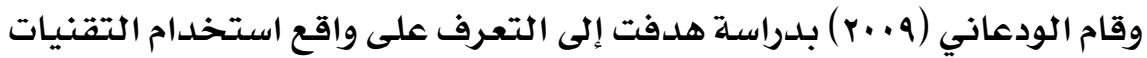

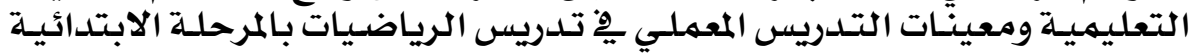

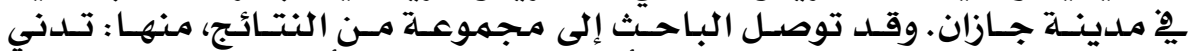

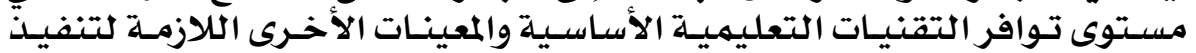

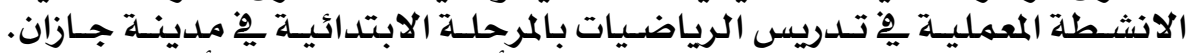

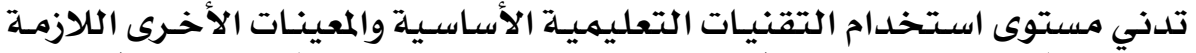

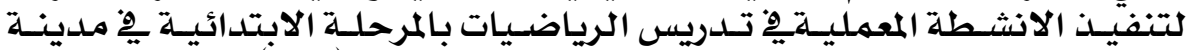

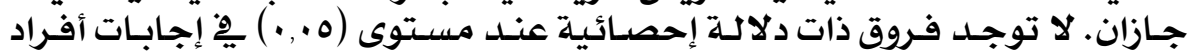

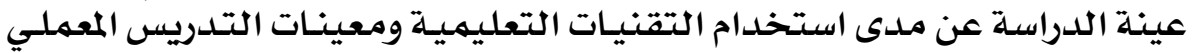

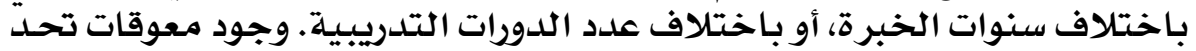

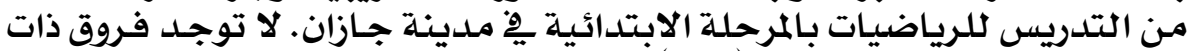

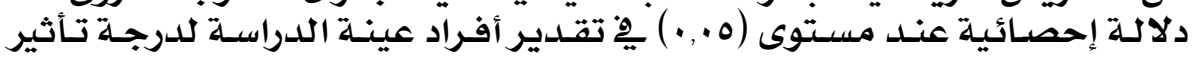

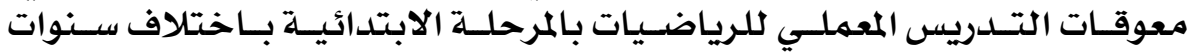

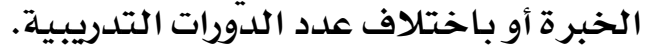

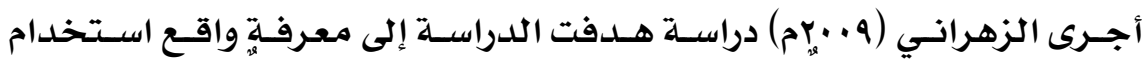

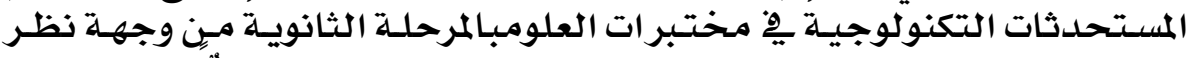

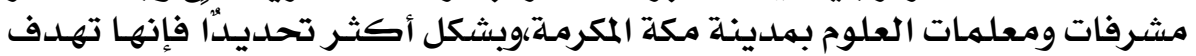

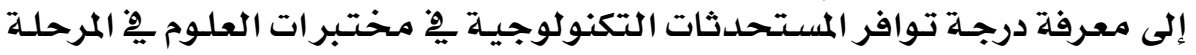

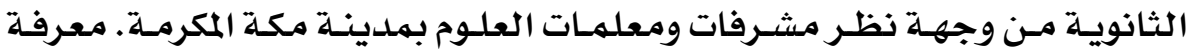

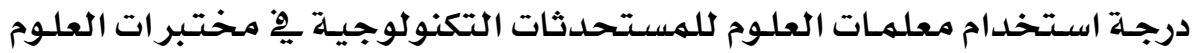

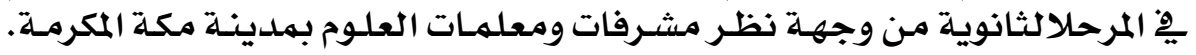

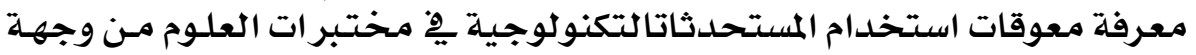

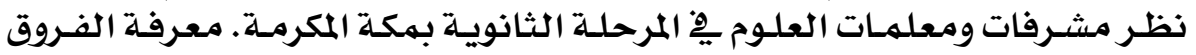

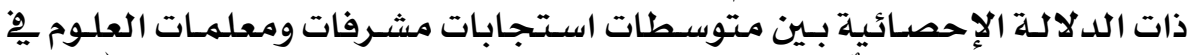

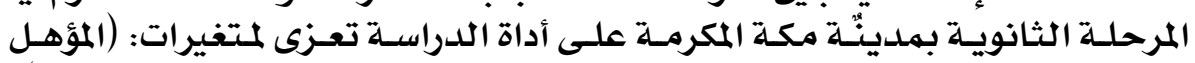

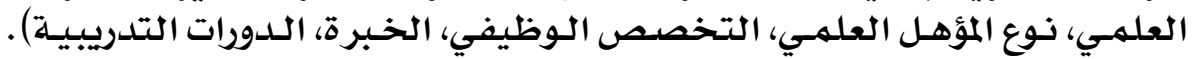

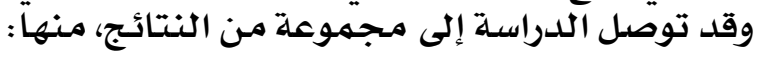

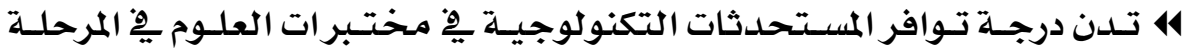

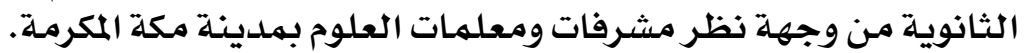

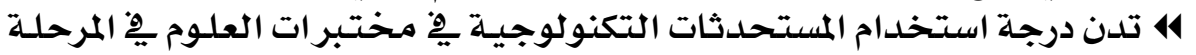

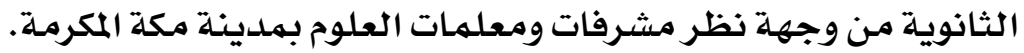

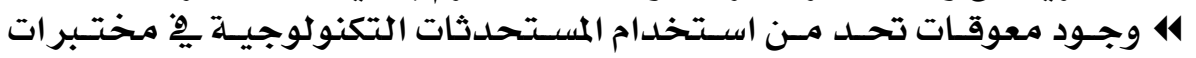
العلوم.

\section{YY}




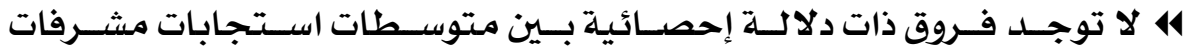

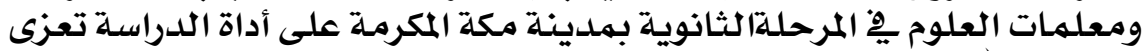

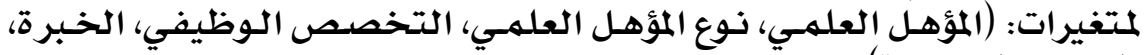

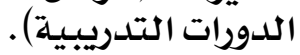

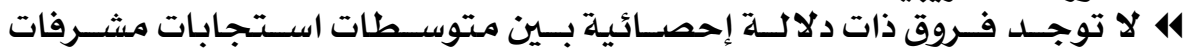

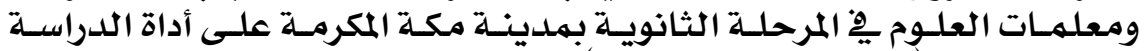

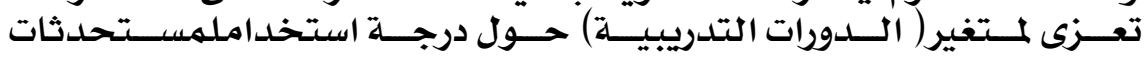

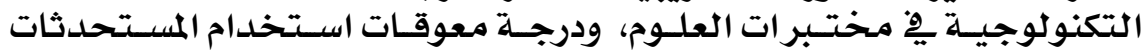

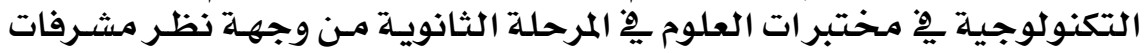

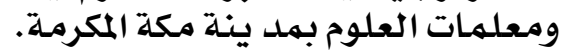

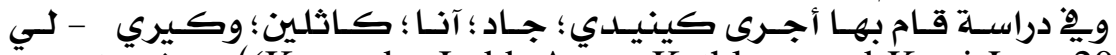
() (Kennedy, Judd, Añna, Kathleen and Kerri-Lee, 2008

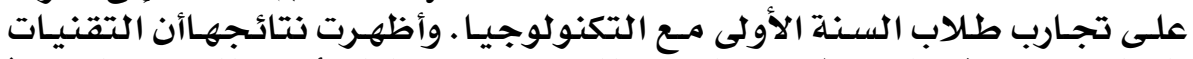

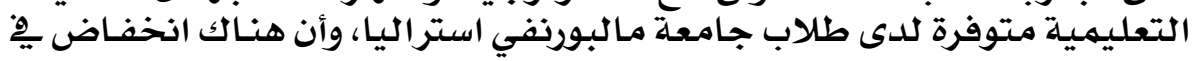

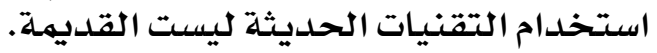

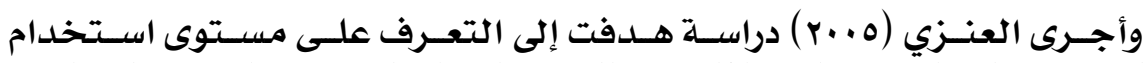

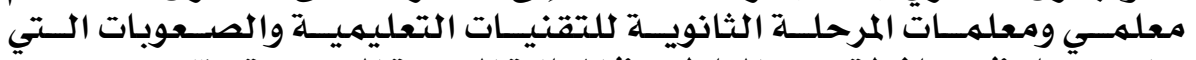

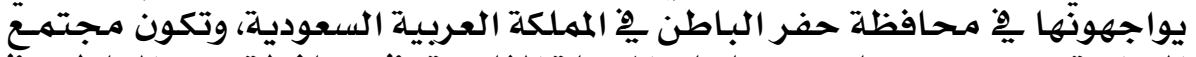

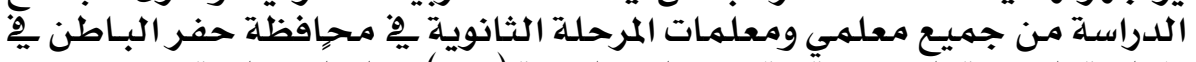

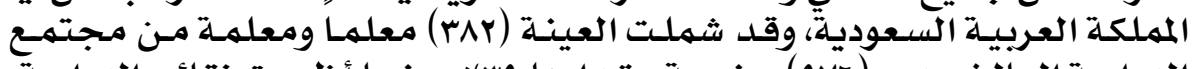

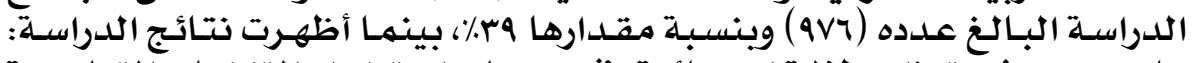

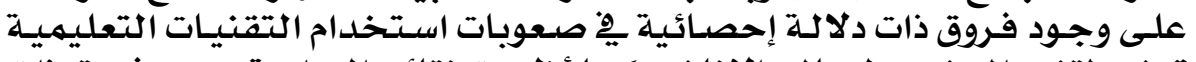

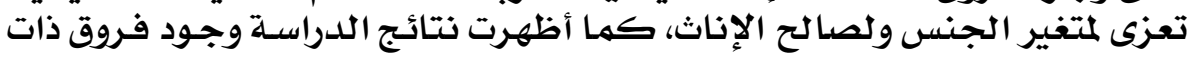

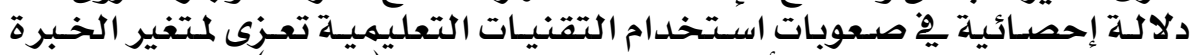

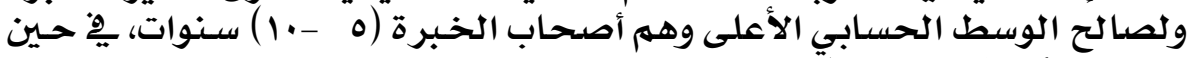

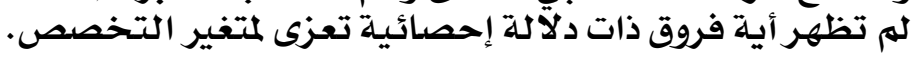

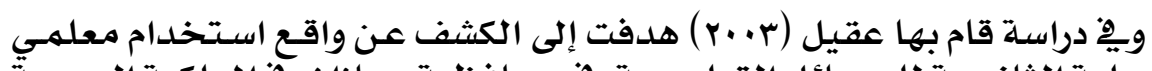

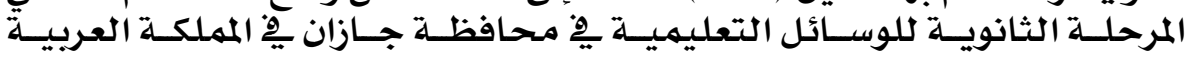

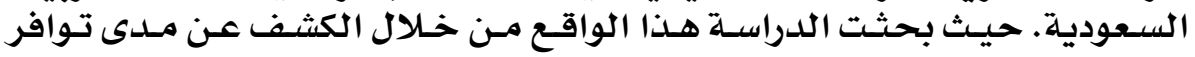

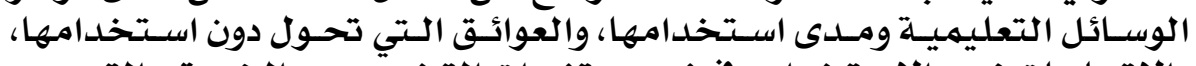

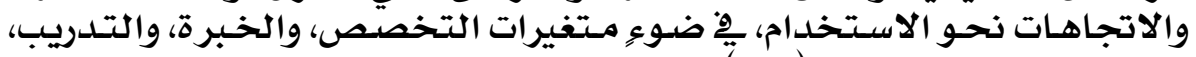

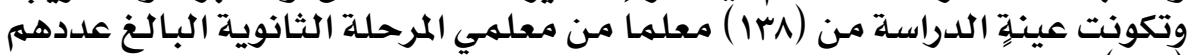

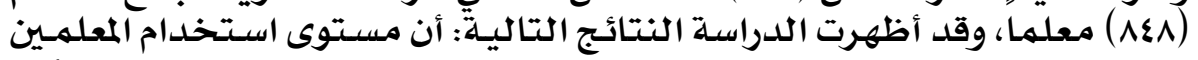

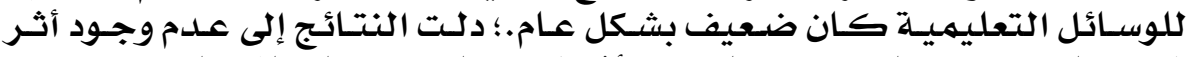

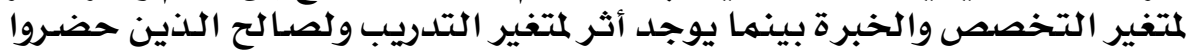
دورات تدريبـيـة.

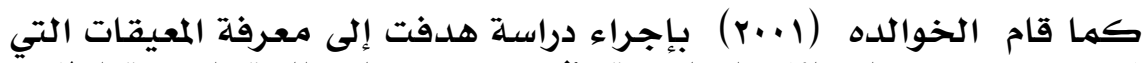

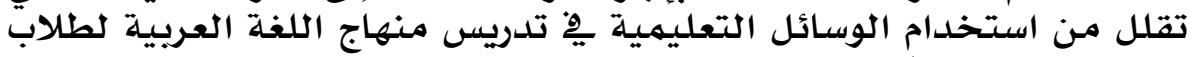

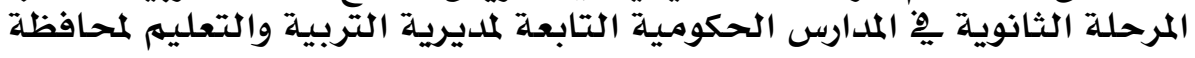

\section{YYY}




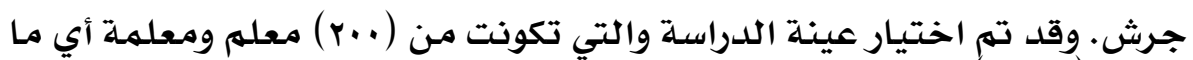

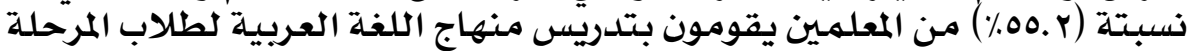

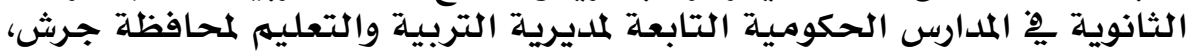

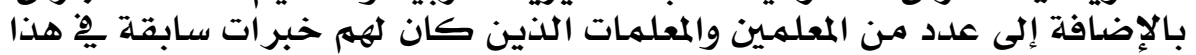

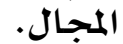

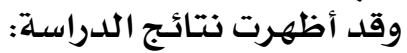

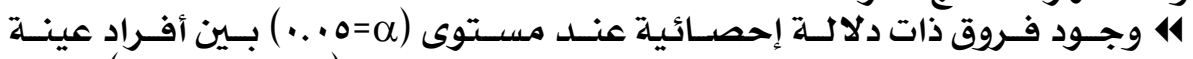

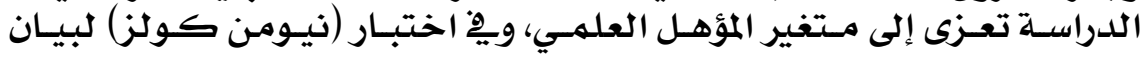

الفروق بين المجموات تهوعات.

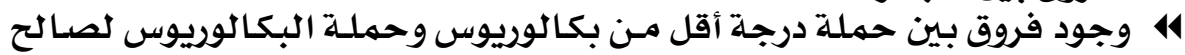

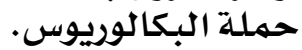

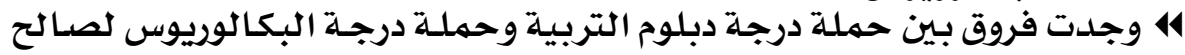

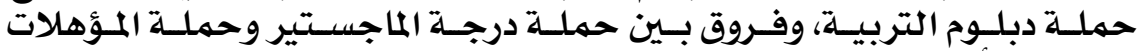

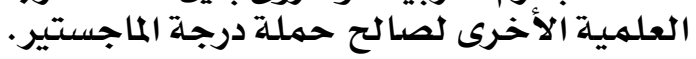

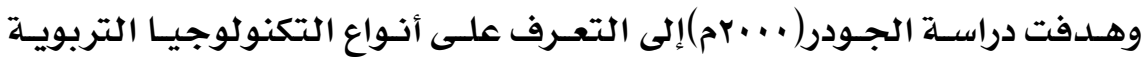

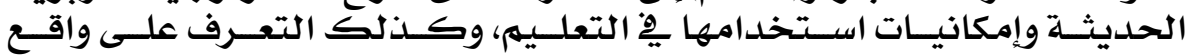

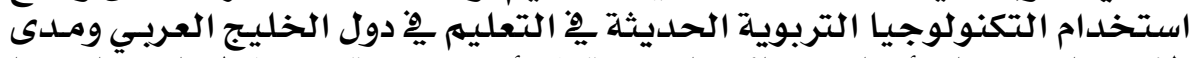

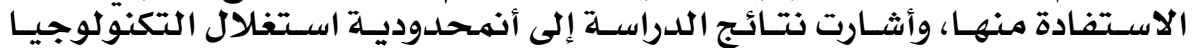

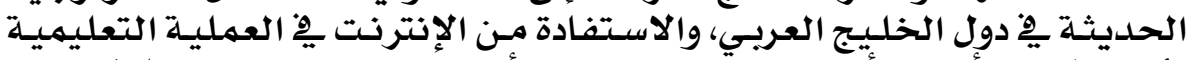

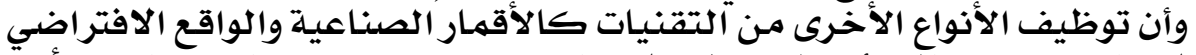

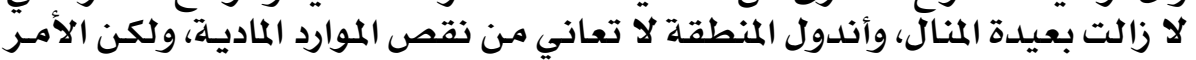

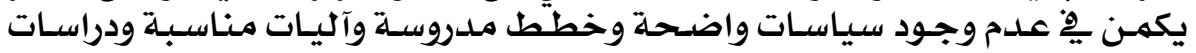

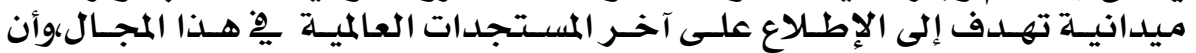

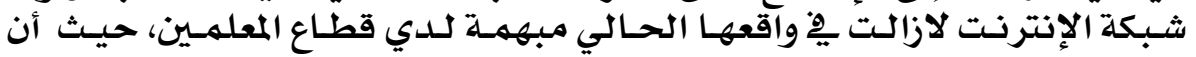

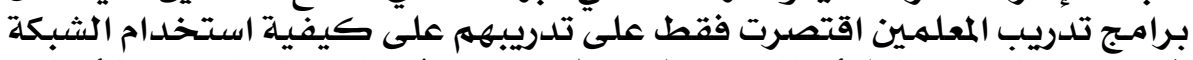

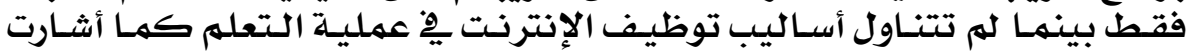

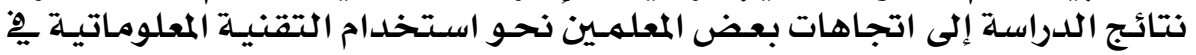

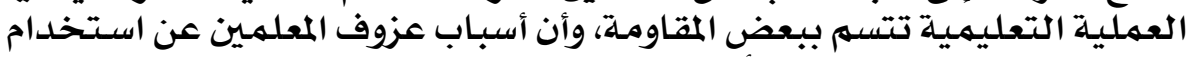

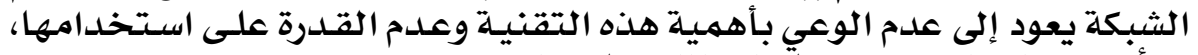

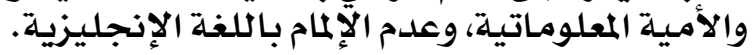

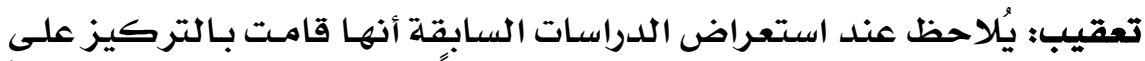

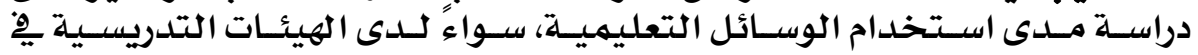

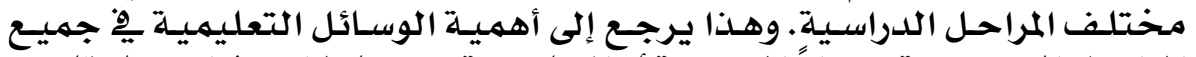

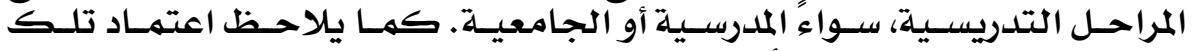

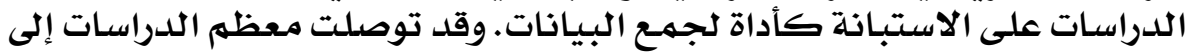

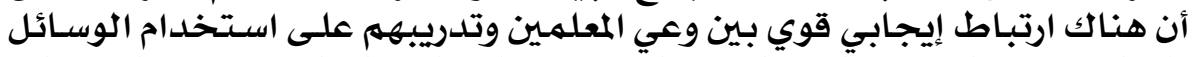

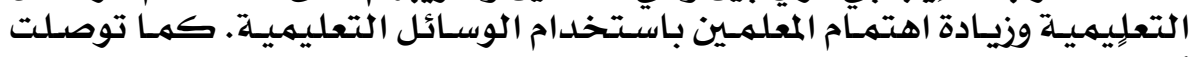

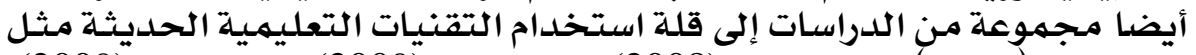

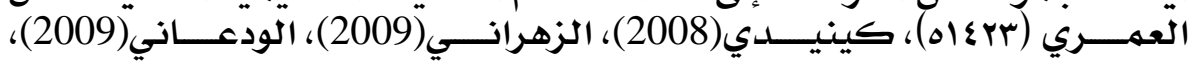

\section{YYM}




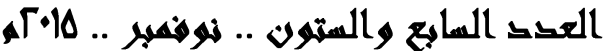

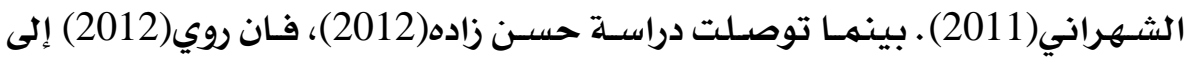

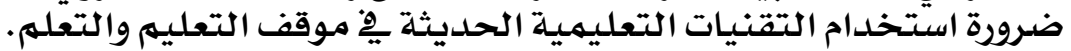

• الطريقة والإجراءات:

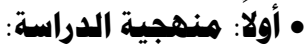

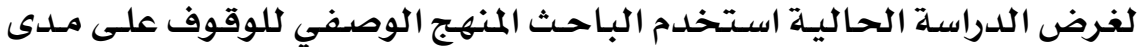

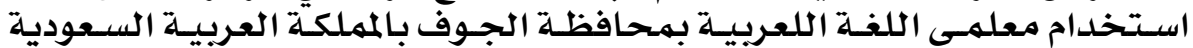

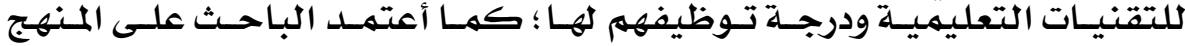

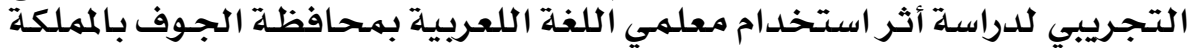

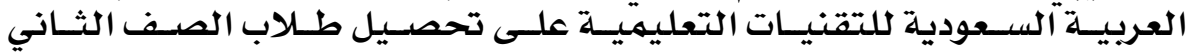

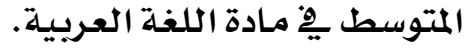
• ثانيا: هجتمع الدراسة والعينة:

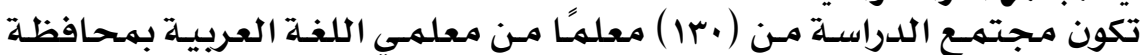

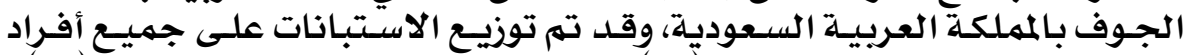

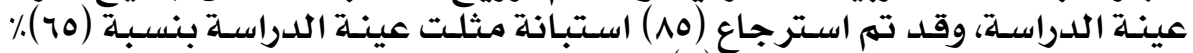

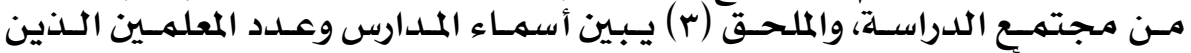
استجابوا لآداة الدراسـة الدراسة

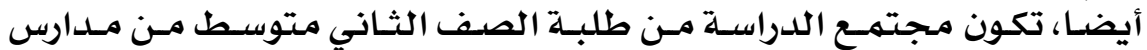

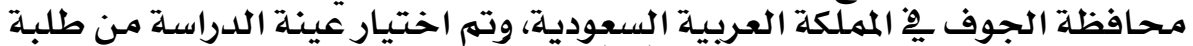

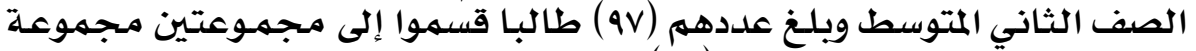

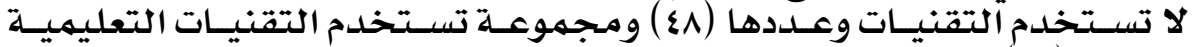

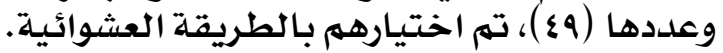

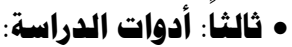

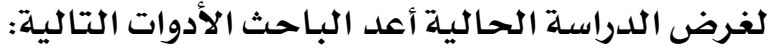

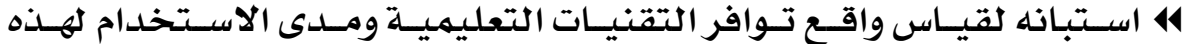

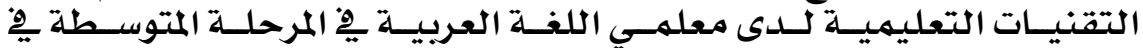

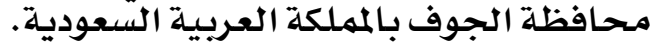

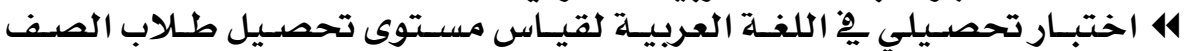

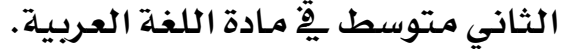

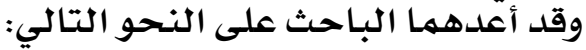

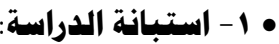

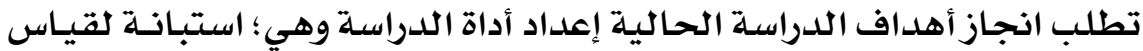

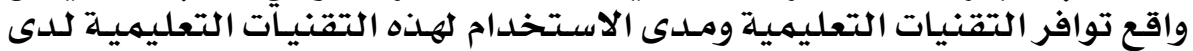

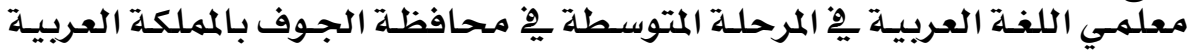

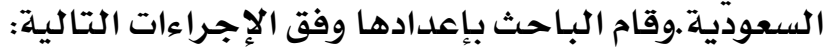

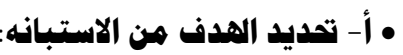

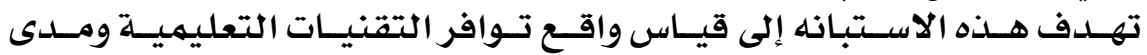

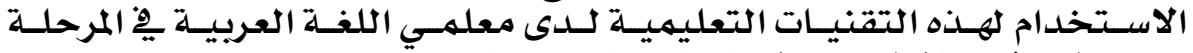

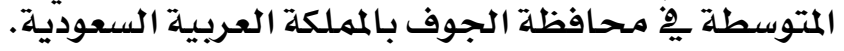

\section{YY\&}




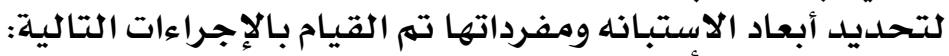

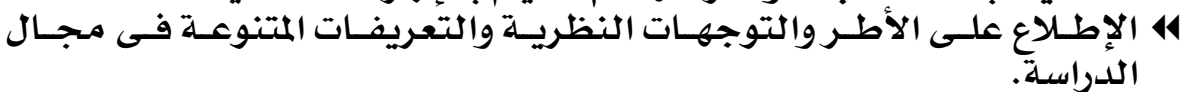

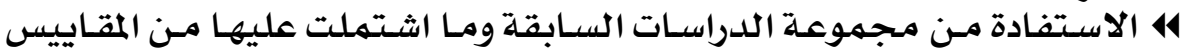

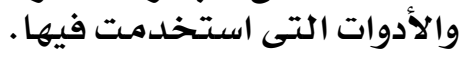

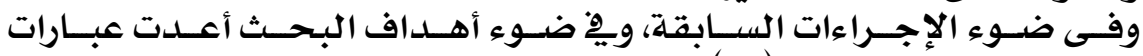

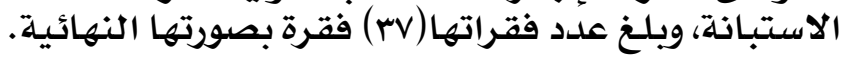

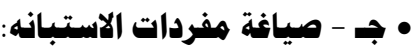

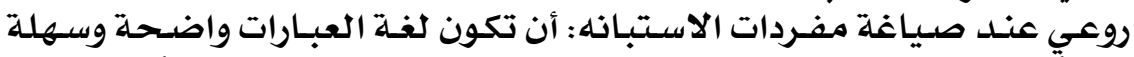

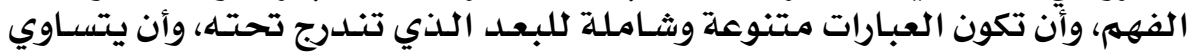

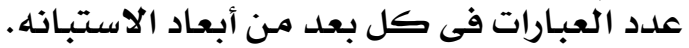

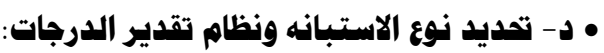

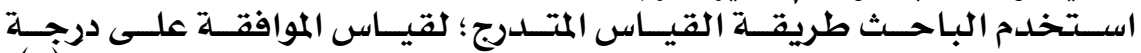

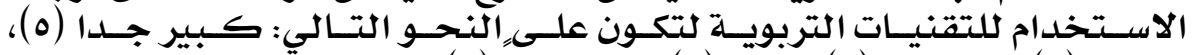

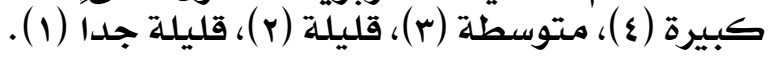
• هـ- صدق الاستبانه وثباتها:

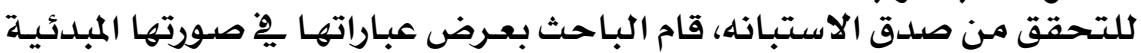

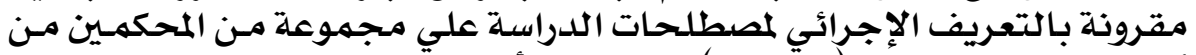

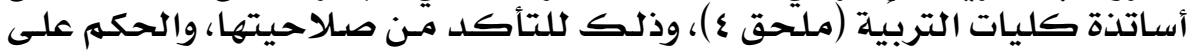

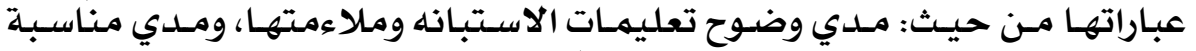

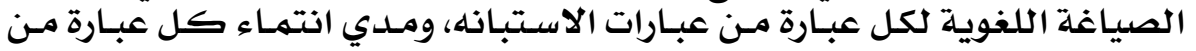

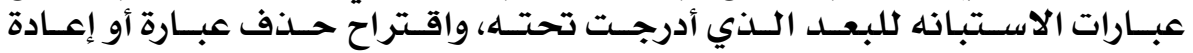

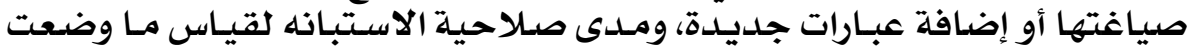

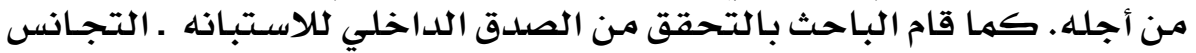

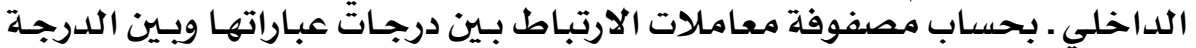

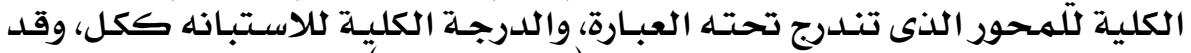

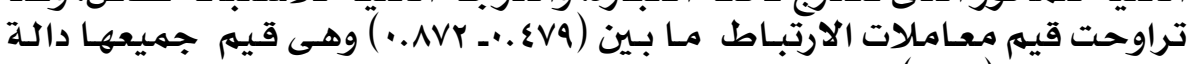

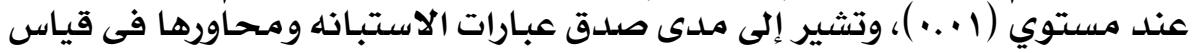

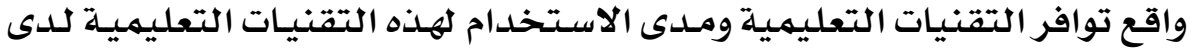

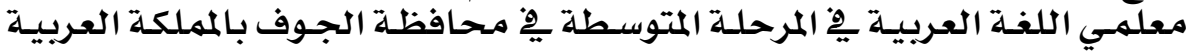

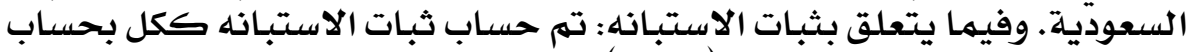

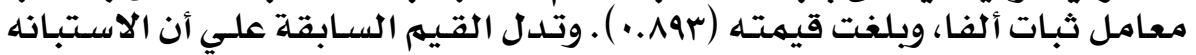

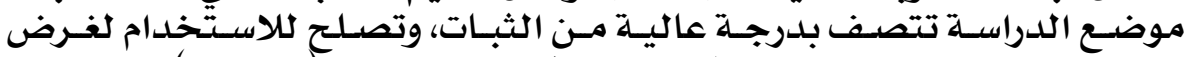

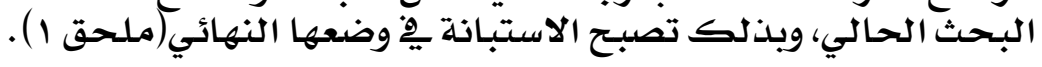

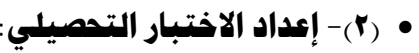

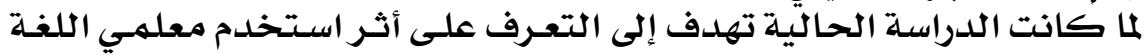

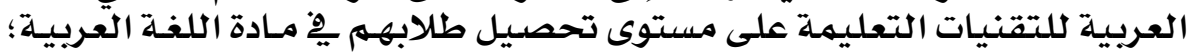

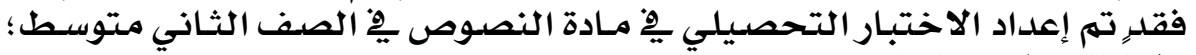

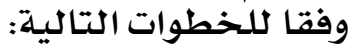




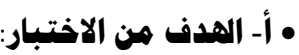

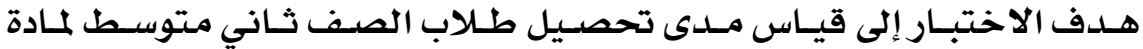

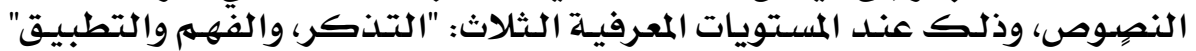

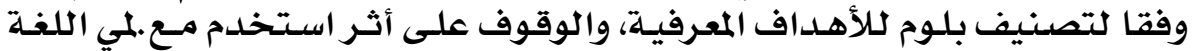

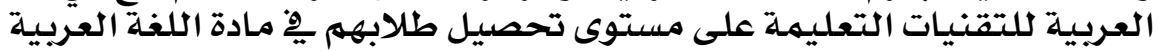

• ب- تهديد نوع هفردات الاختبار وصياغتها:

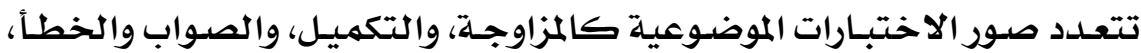

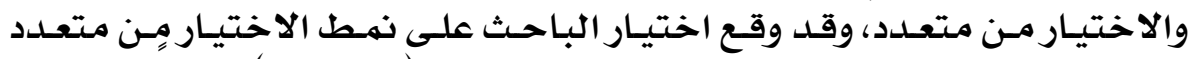

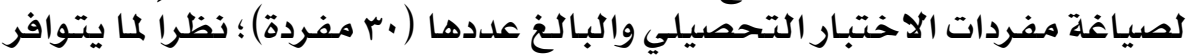

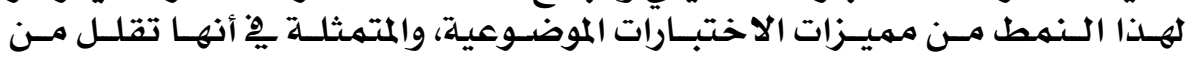

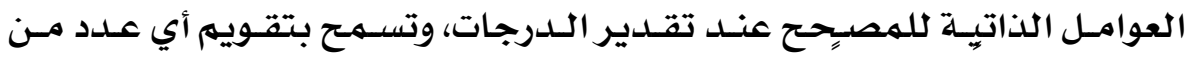

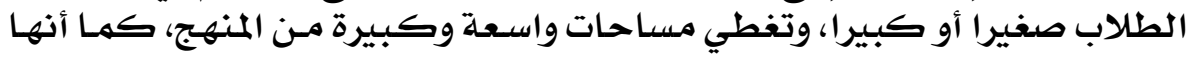

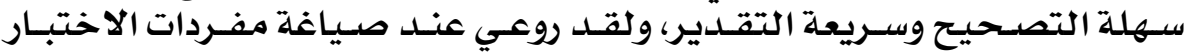

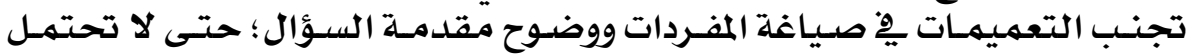

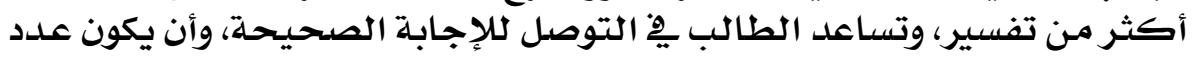

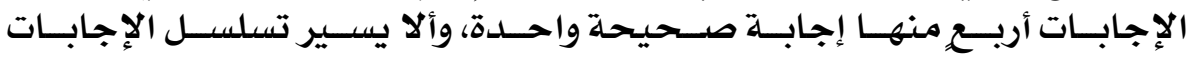

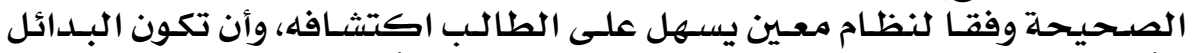

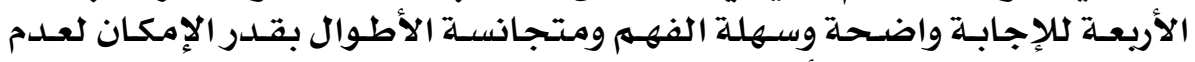

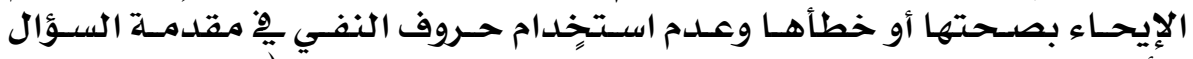

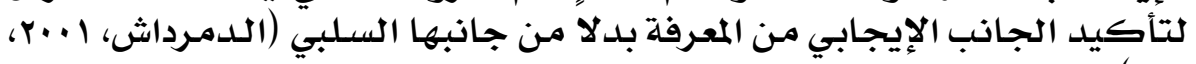

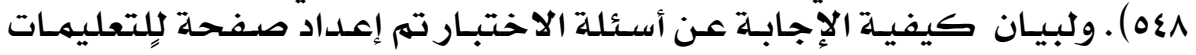

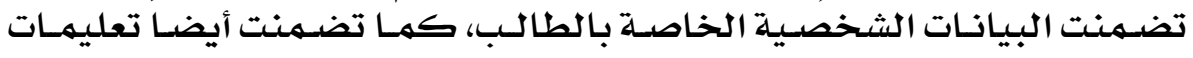

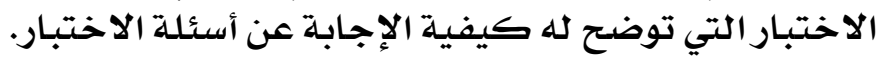

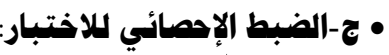

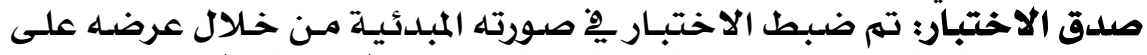

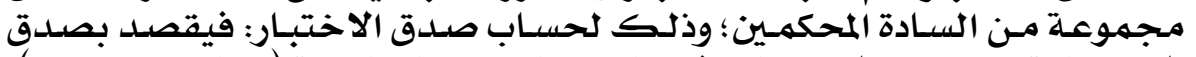

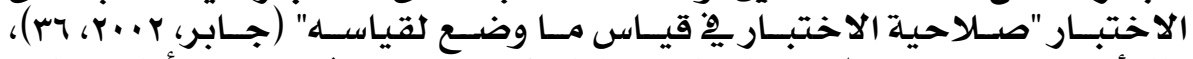

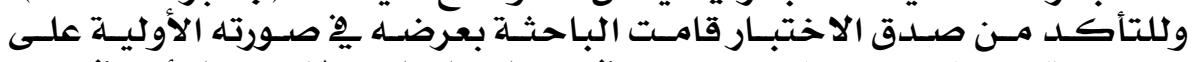

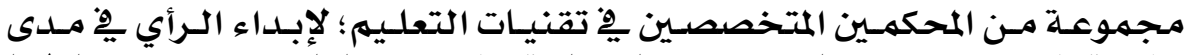

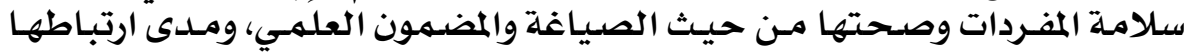

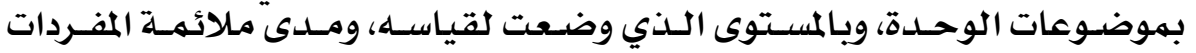

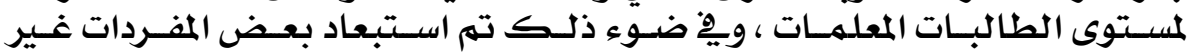

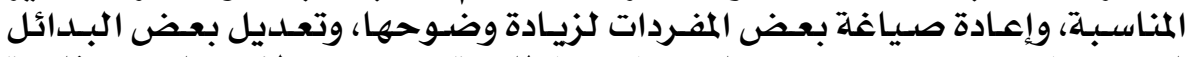

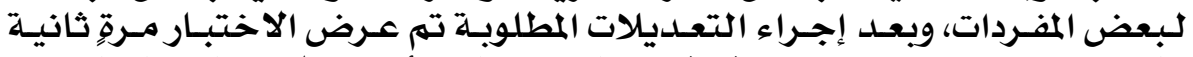

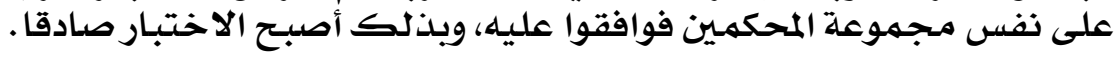

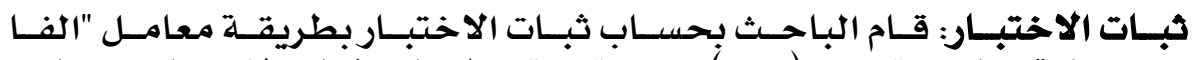

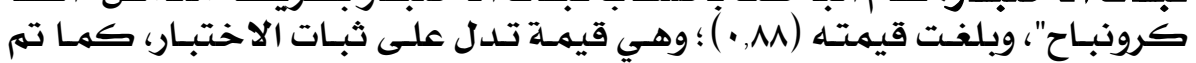

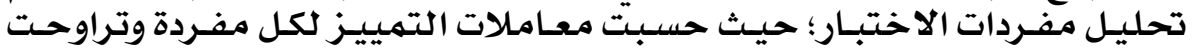




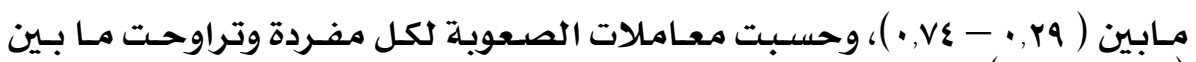

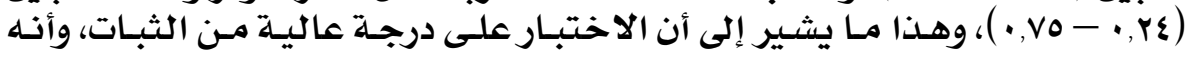

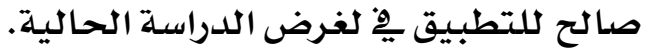

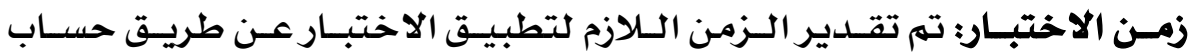

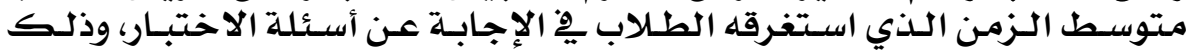

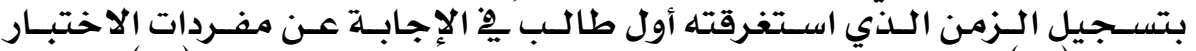

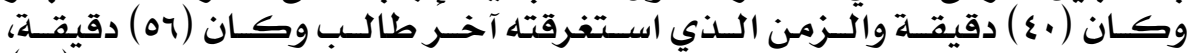

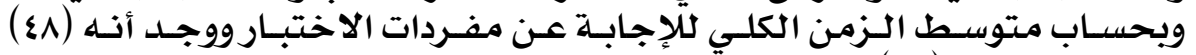

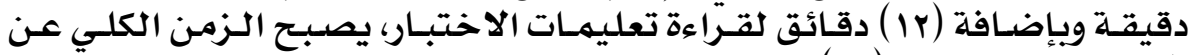

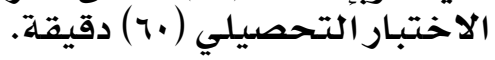

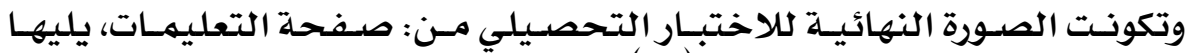

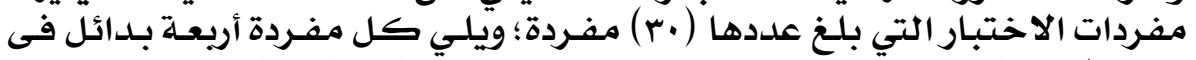

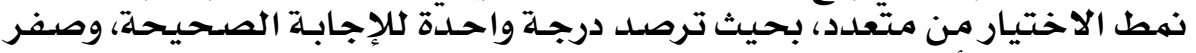

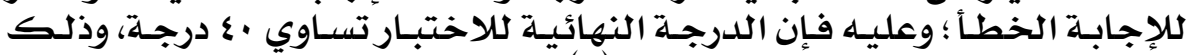

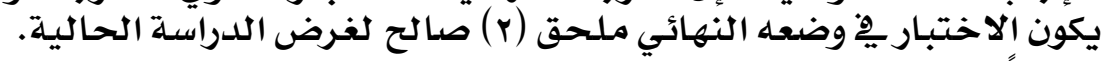

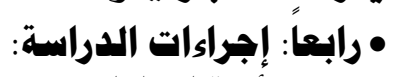

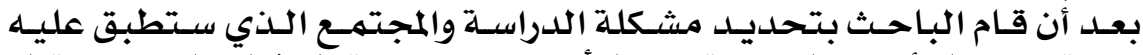

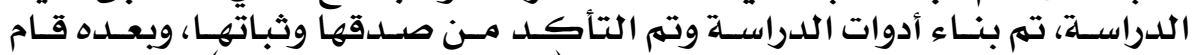

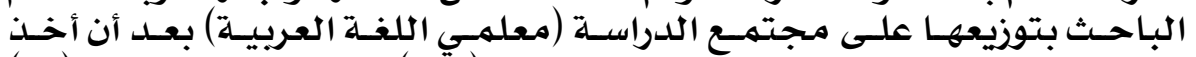

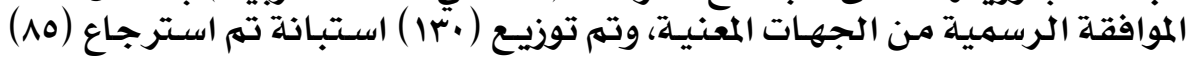

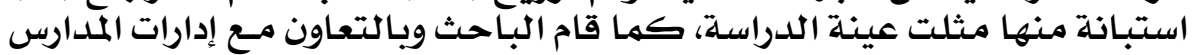

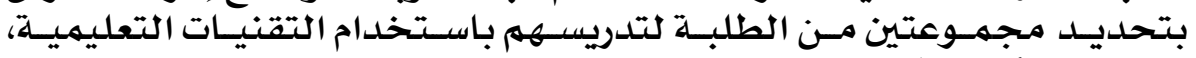

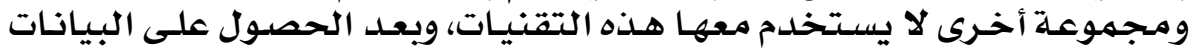

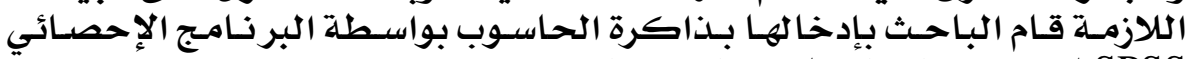

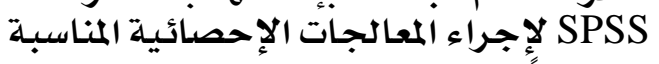

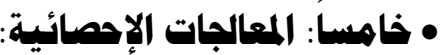

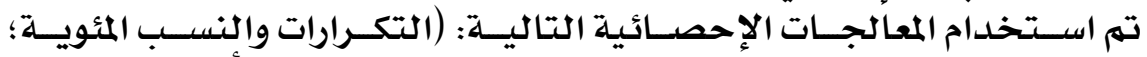

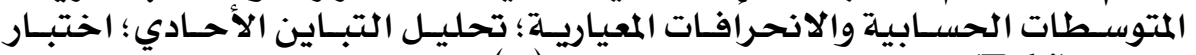

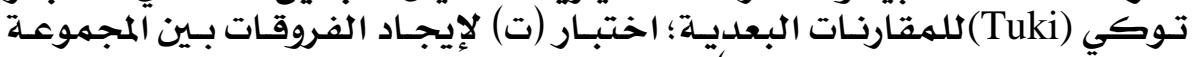

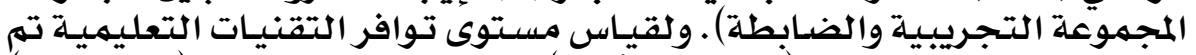

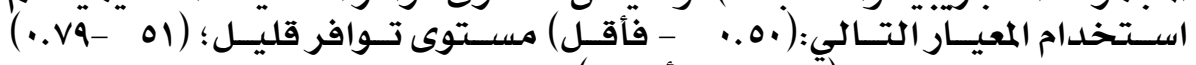

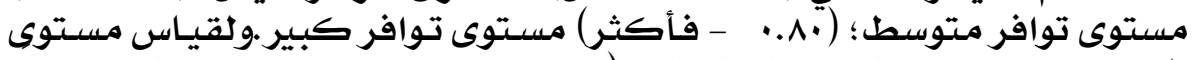

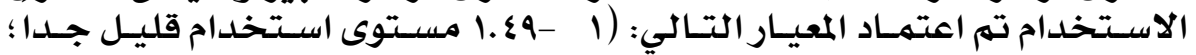

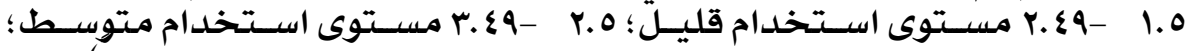

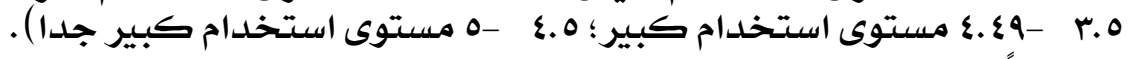

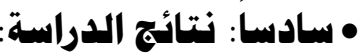

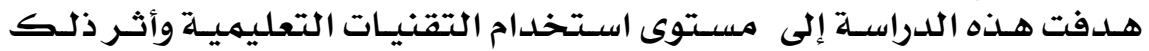

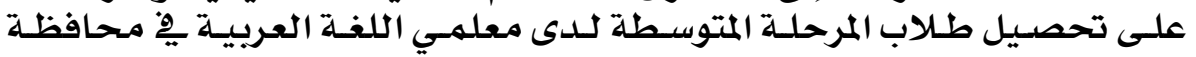

\section{YYV}




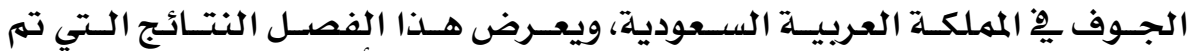

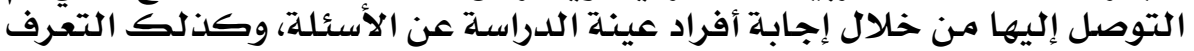

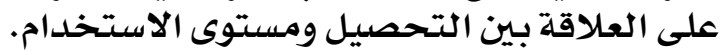

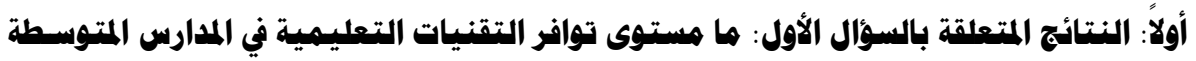

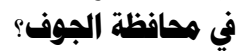

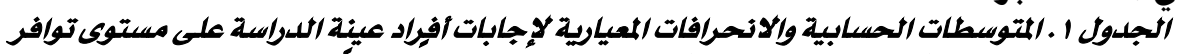

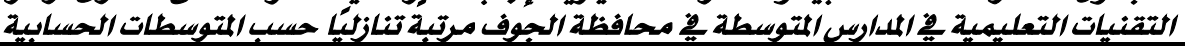

\begin{tabular}{|c|c|c|c|}
\hline الالانحراف & الحسابط & الفقرات & الرتبة \\
\hline, 277 & $\overline{\mathbf{9 2}}$ & التلوحات الفلينية & 1 \\
\hline 294 & 91 & الإذاعة المدرسية & $r$ \\
\hline ,310 & $\mathbf{8 9}$ & الطباشيروالأقلام الملونة & $r$ \\
\hline, 324 & $\mathbf{8 8}$ & الحاسوب & $\varepsilon$ \\
\hline ,324 & $\mathbf{8 8}$ & اللوحات الورقية & $\varepsilon$ \\
\hline ,362 &, 85 & عرض الشفافيات (البروجكتوي) & 1 \\
\hline ,402 & $\mathbf{8 0}$ & جهاز عرض الشرائح & $\mathrm{v}$ \\
\hline, 402 &, 80 & الطابعات & $\mathrm{v}$ \\
\hline, 402 & $\mathbf{8 0}$ & الكتب والمرجع والدوريات (المكتبة) & $\mathrm{v}$ \\
\hline ,411 & ,79 & جهاز التلفاز & 1. \\
\hline, 419 & ,78 & أشرطة التسجيل (الكاسيت) & 11 \\
\hline ,427 &, 76 & المسجلات الصوتية & ir \\
\hline ,434 &, 75 & برامج الحاسوب & ir \\
\hline $\mathbf{4 3 4}$ &, 75 & اللوحات الخشبية & ir \\
\hline, 441 & ,74 & الأقراص المرنة (Floppy) & 10 \\
\hline ,447 & ,73 & الإنترنت & 17 \\
\hline, 453 &, 72 & جهاز الفيديو & IV \\
\hline ,458 & ,71 & الشرائح & 11 \\
\hline, 458 & ,71 & الإسطونات المضغوطة CD & 11 \\
\hline ,464 &, 69 & الشفافيات & $r$. \\
\hline ,464 &, 69 & الرسوم البيانية التوضيحية & $r$. \\
\hline ,468 &, 68 & الصور الفوتوغرافية & $r r$ \\
\hline ,468 &, 68 & النماذج & $r r$ \\
\hline $\mathbf{4 8 4}$ &, 64 & كاميرا التصوير الفوتوغرإ2 & $r \varepsilon$ \\
\hline, 484 &, 64 & السبورة الطباشيرية & $r \varepsilon$ \\
\hline ,487 &, 62 & التمثيليات والمسرحيات & 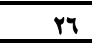 \\
\hline, 495 &, 59 & الراديو (المذياع) & $r v$ \\
\hline ,497 &, 58 & بطاقات الصوروالملصقات & $\mathrm{r \Lambda}$ \\
\hline $\mathbf{5 0 3}$ & $\overline{\mathbf{5 2}}$ & جهاز الداتا شو(DataShow) & rq \\
\hline $\mathbf{5 0 3}$ &, 51 & جهاز عرض الصور المعتمة((الفانويس السحري) & $r$. \\
\hline, $\mathbf{5 0 3}$ & ,48 & الأفلام الثابتة & $r_{1}$ \\
\hline $\mathbf{5 0 0}$ &, 45 & الأفلام السينمائية التعليمية & $r r$ \\
\hline, 495 &, 41 & السبورة المغناطيسية & $r$ \\
\hline $\mathbf{4 8 4}$ & ,36 & الكاميرا الرقمية & $r \varepsilon$ \\
\hline ,484 & ,36 & كاميرا تصوير الفيديو & $r \varepsilon$ \\
\hline ,468 &, 32 & جهاز السينما (جهاز عرض الأفلام السينمائية) & rq \\
\hline ,464 & ,31 & مختبر الصوتيات والمرئيات & $r v$ \\
\hline
\end{tabular}




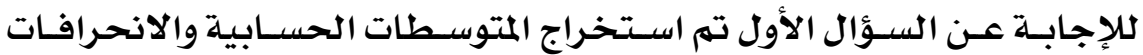

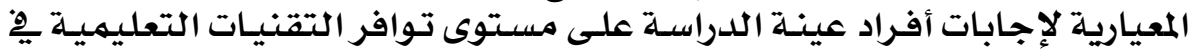

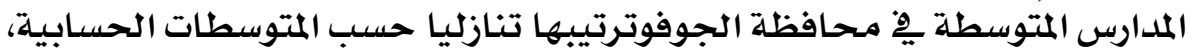

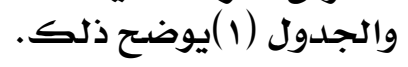

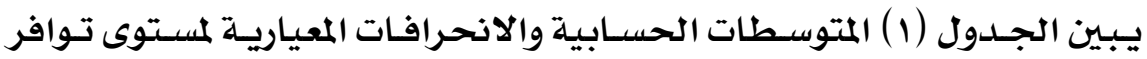

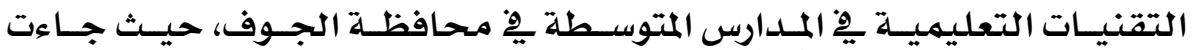

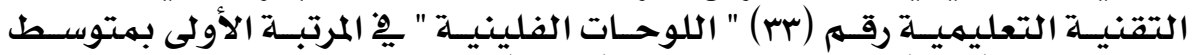

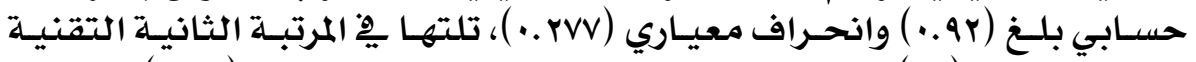

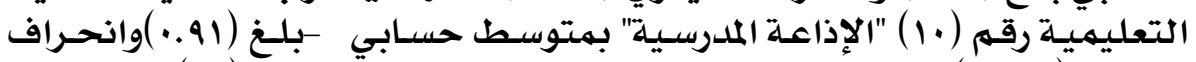

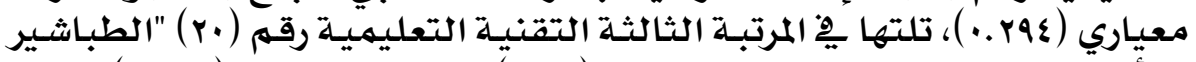

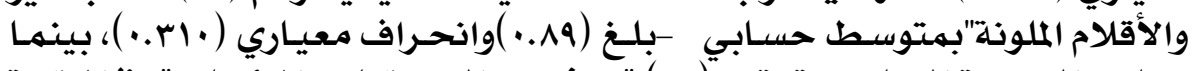

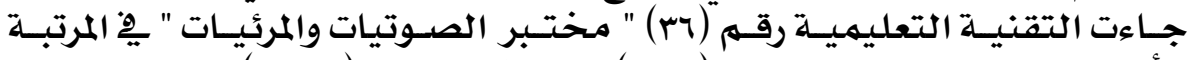

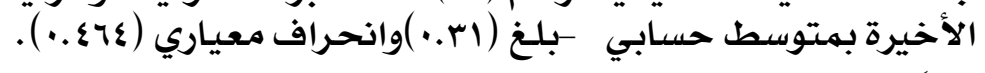

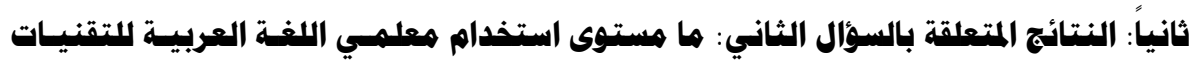

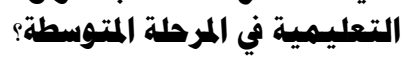

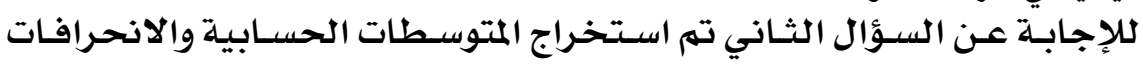

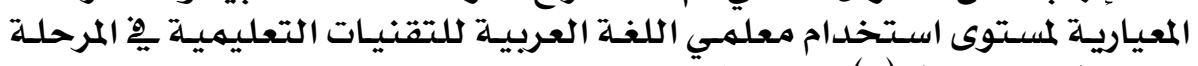

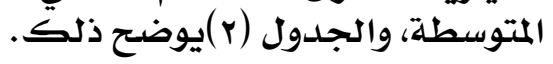

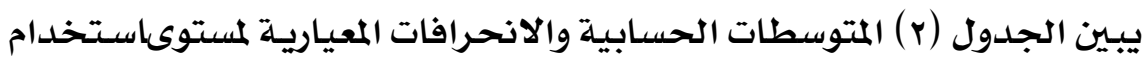

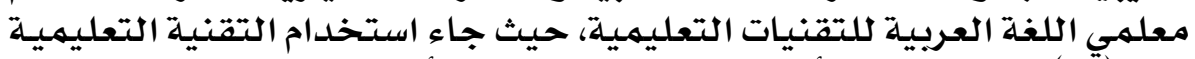

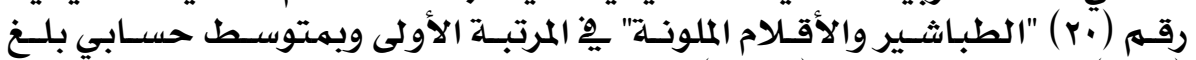

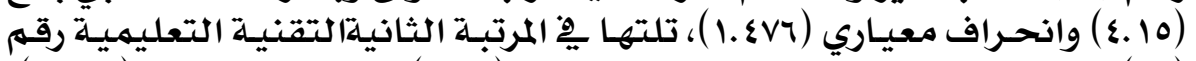

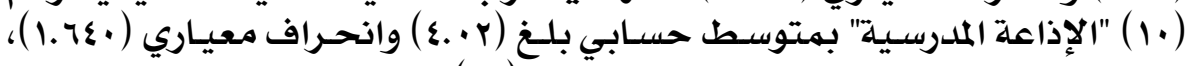

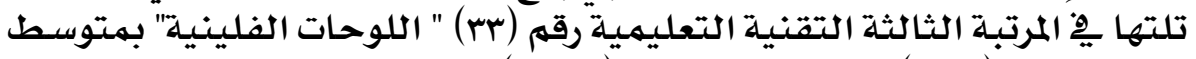

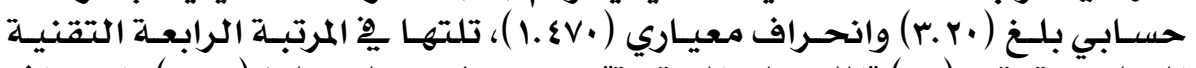

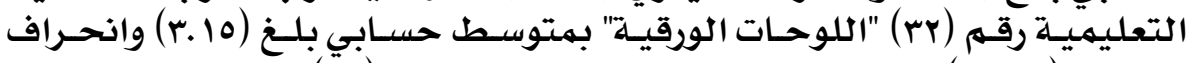

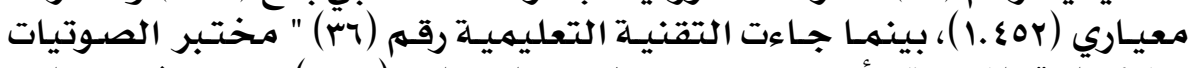

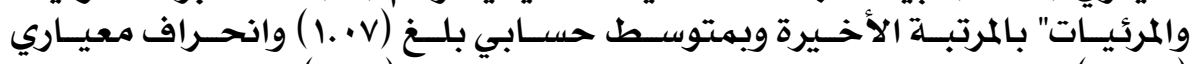

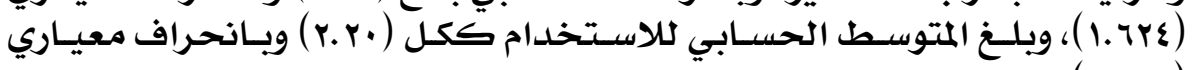
.$(\cdot .901)$

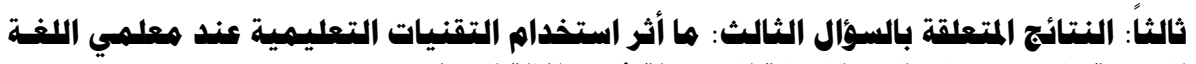

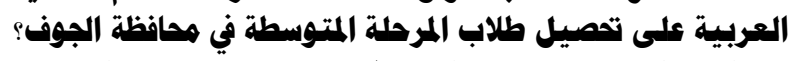

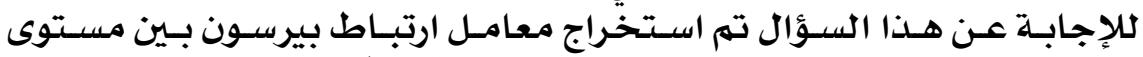

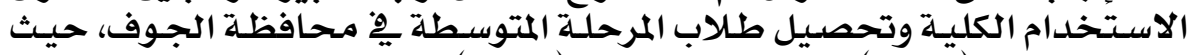

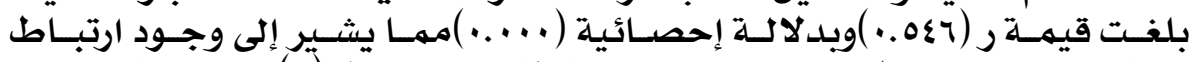

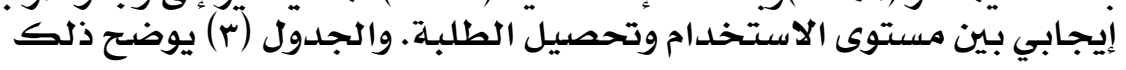




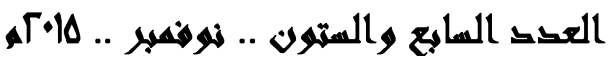

الجلول r ـ المتوسطات الحسابية والانحرافات المعيارية المستوى استخلام معلمي اللغة العريبية للتقنيات التعليمية

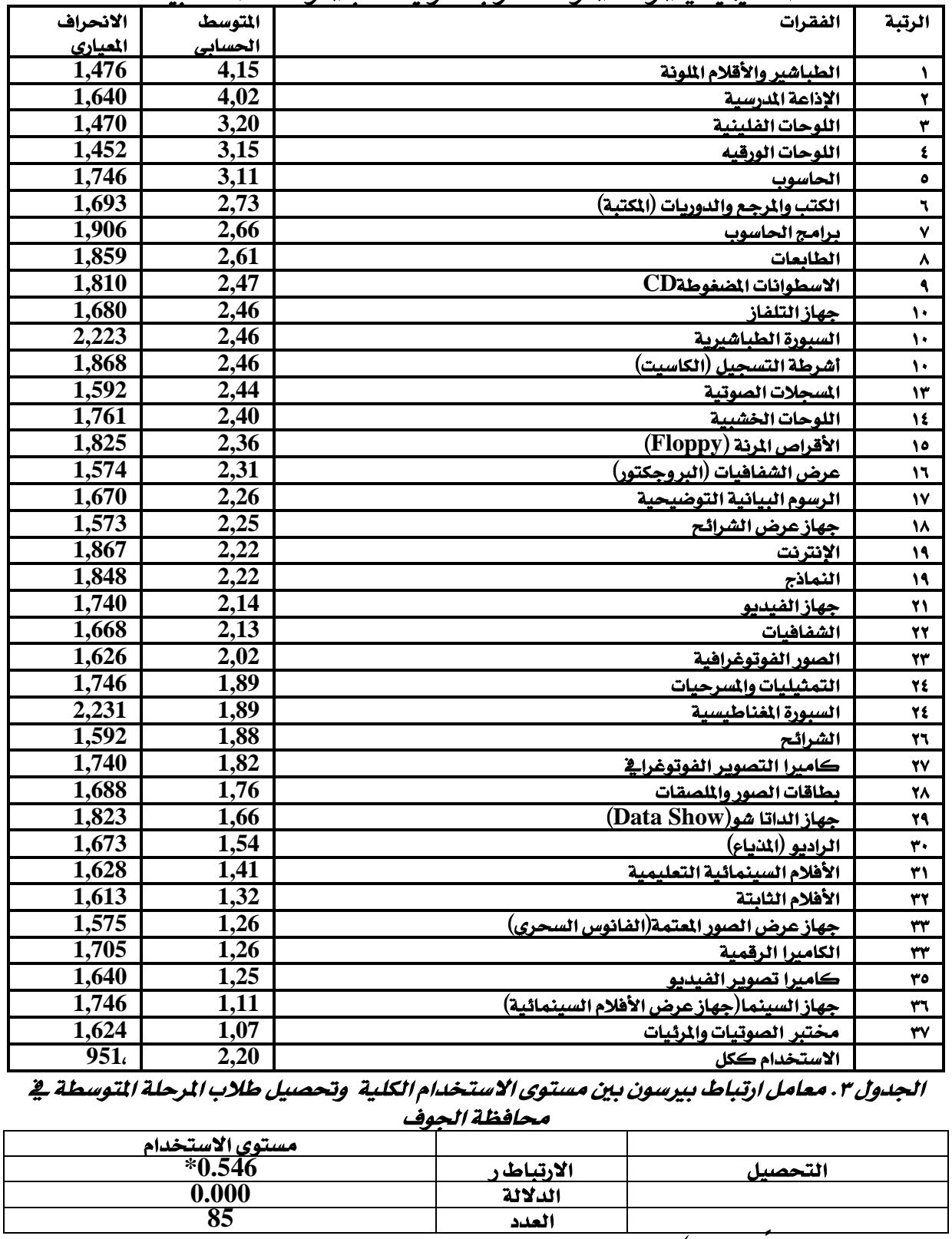

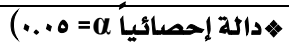

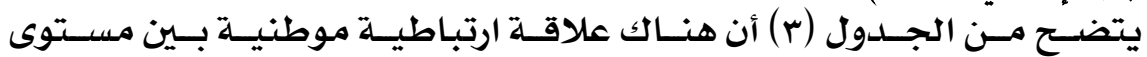

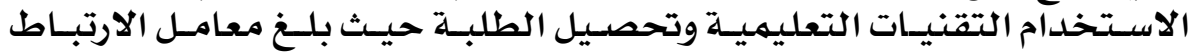




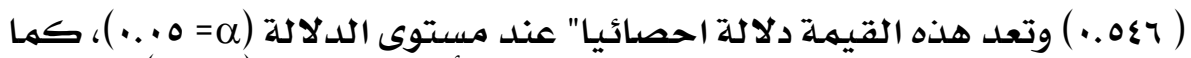

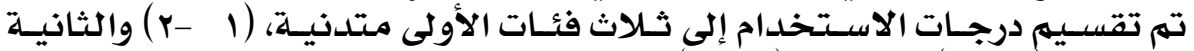

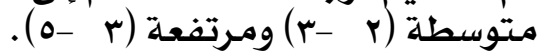
الجلدول ؛ . التكرارات والنسب المئوية لتوزيع فئات الاستخلام

\begin{tabular}{|c|c|c|c|c|}
\hline النسبة التراكمية & النسبة الفعلية & النسبة & التكرار & الفئات \\
\hline 44.7 & 44.7 & 44.7 & 38 & متدنية (1 - (Y) \\
\hline 84.7 & 40.0 & 40.0 & 34 & متوسطة (r- r) \\
\hline 100.0 & 15.3 & 15.3 & 13 & مرتفعة (q -ه) \\
\hline & 100.0 & 100.0 & 85 & المجموع \\
\hline
\end{tabular}

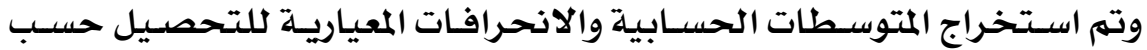
فئات استخدام التخراج التمنيات التعليمية. الجلدول ه. المتوسطات الحسابية والانحرافات المعيارية للتحصيل حسب فئات استخلام التقنيات التعلبهية

\begin{tabular}{|c|c|c|c|}
\hline الانحراف المعياري & المتوسط الحسابع & العدد العد & الفئات \\
\hline 9.223 & $\% 54.74$ & 38 & متدنية (1 - Y (Y) \\
\hline 13.098 & $\% 67.35$ & 34 & متوسطة r r r) \\
\hline 10.682 & $\% 71.54$ & 13 & مرتفعة (r -o) \\
\hline 13.061 & $\% 62.35$ & 85 & المجموع \\
\hline
\end{tabular}

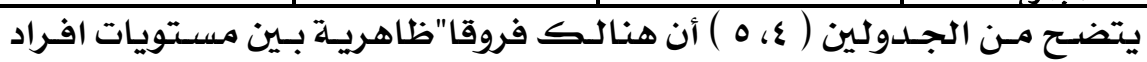

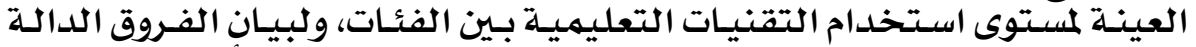

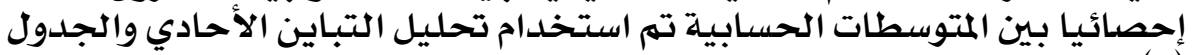

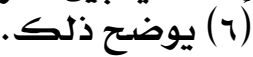

الجلدول 9 . تحليل التباين الأحادي لفحص الفروق ف درجات التحصيل حسب فئات الاستخلام

\begin{tabular}{|c|c|c|c|c|c|}
\hline الإحصائية & قيمة ف & متروسط & درجات الحرية & مجموعات المربعات & \\
\hline .000 & $\begin{array}{l}16.721 \\
\end{array}$ & 2075.524 & 2 & 4151.048 & بين الجمبوعات \\
\hline & & 124.126 & 82 & $\mathbf{1 0 1 7 8 . 3 6 4}$ & داخل المجموعات \\
\hline & & & 84 & 14329.412 & آكلي \\
\hline
\end{tabular}

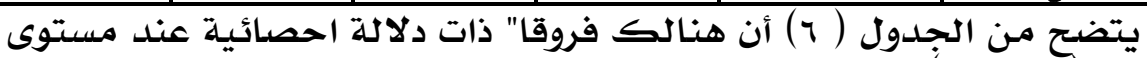

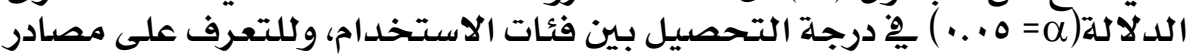

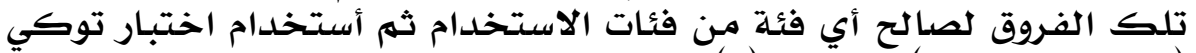

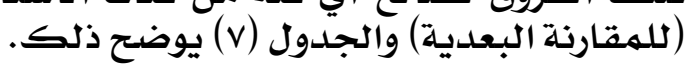

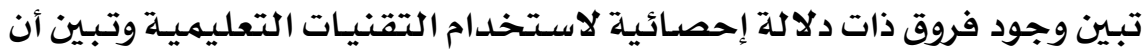

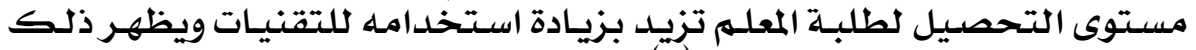

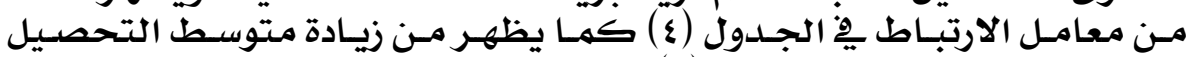

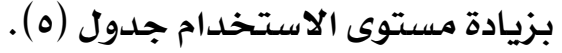

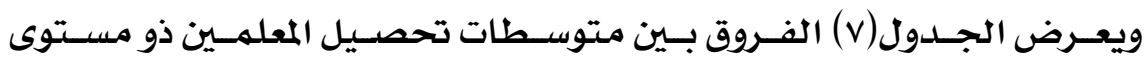

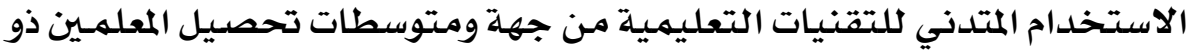

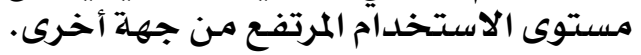

\begin{tabular}{|c|c|c|c|}
\hline مرتفعة & متوسطة & متدنية & \\
\hline$\ldots \ldots$ & $\ldots \ldots$ & & متدنية (1 - r) \\
\hline$\therefore\{10$ & & & متوسطة (r - r) \\
\hline & & & مرتفعة (r -0) \\
\hline
\end{tabular}




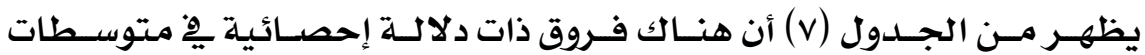

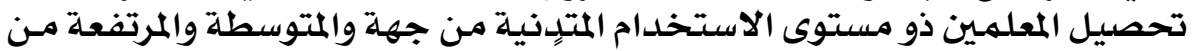

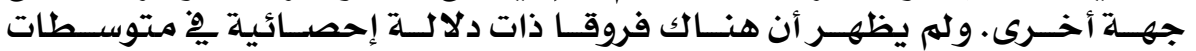

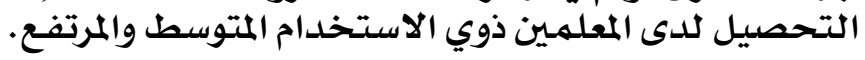

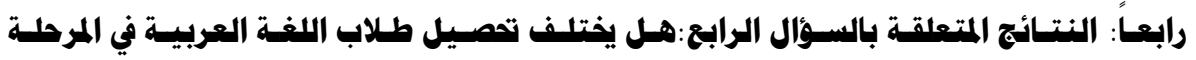

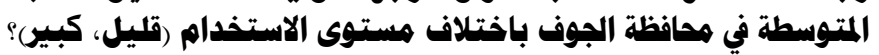

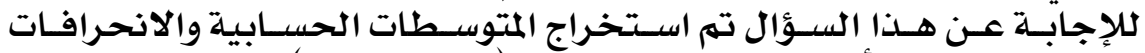

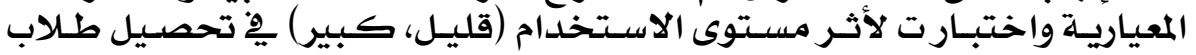

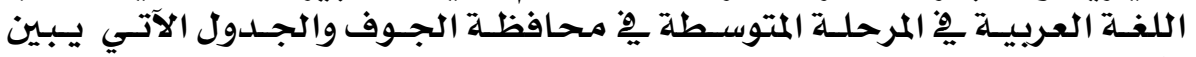
ذلكلك.

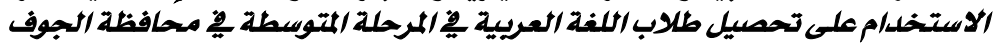

\begin{tabular}{|c|c|c|c|c|c|}
\hline الإحصائية اللالة & "تيمة & الالانحراف & المستوسطي & العلدد & الاستخلوى \\
\hline .001 & -5.489 & 2.55 & 4.63 & 16 & قليل \\
\hline & & 1.31 & 8.79 & 14 & كبير \\
\hline
\end{tabular}

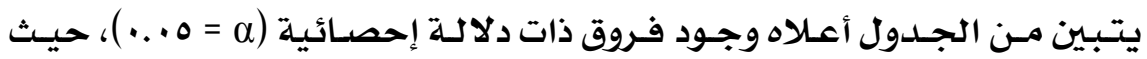

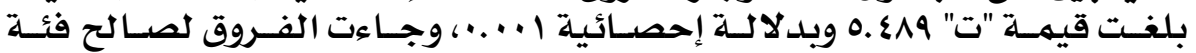

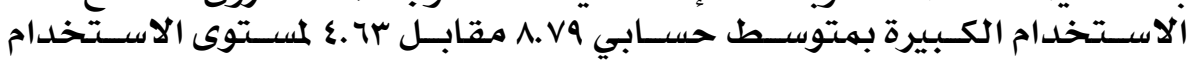
القليل.

\section{• هـناقشة النشتائهج:}

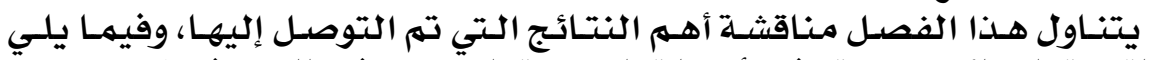

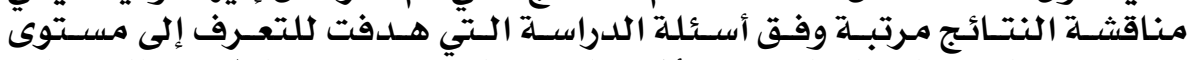

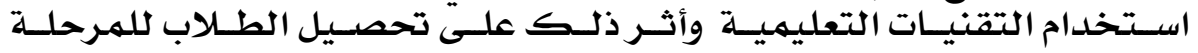
المتوسطة.

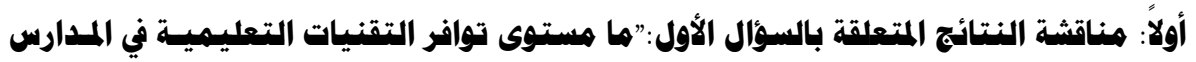

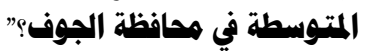

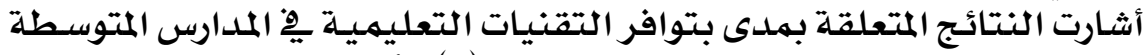

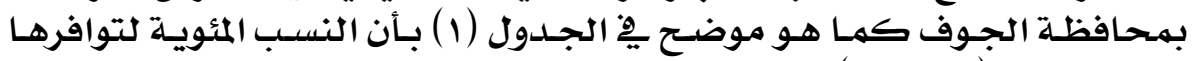

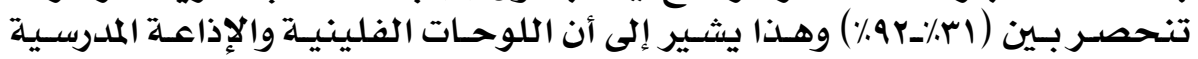

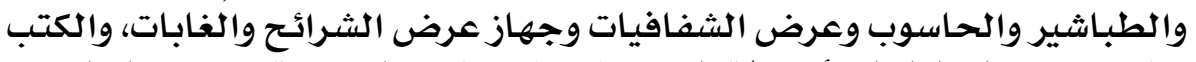

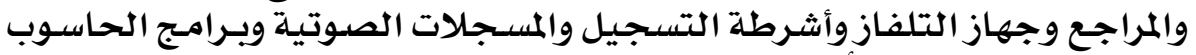

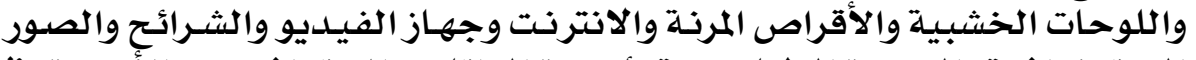

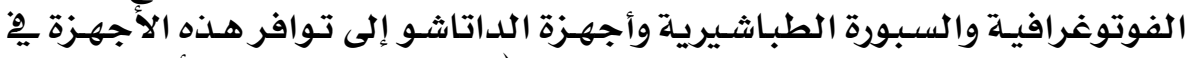

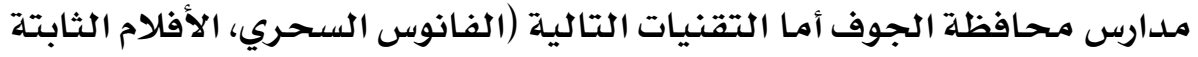

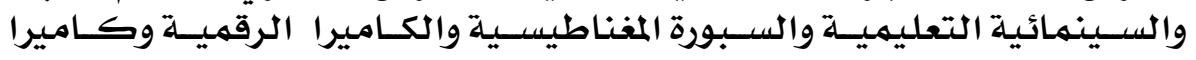

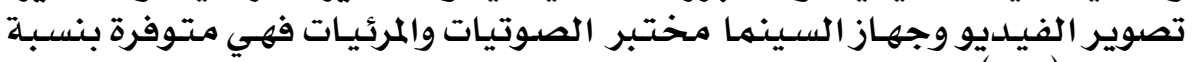

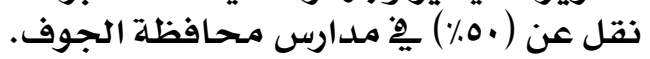

\section{YYY}




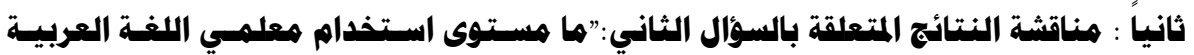

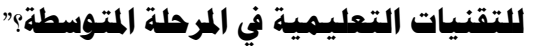

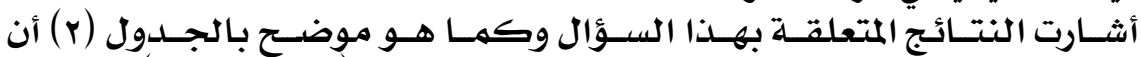

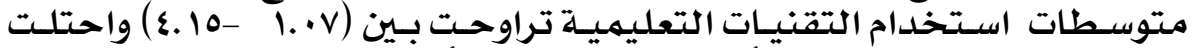

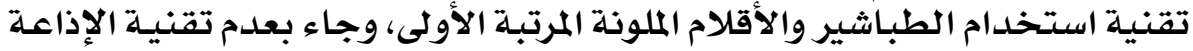

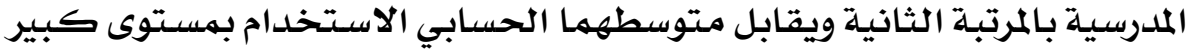

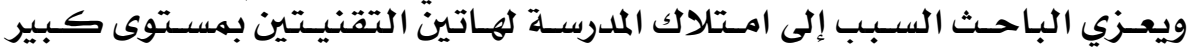

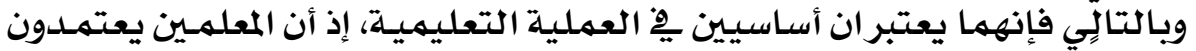

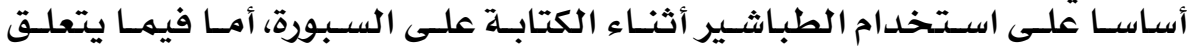

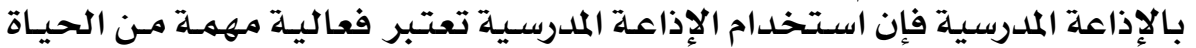

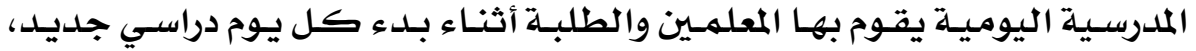

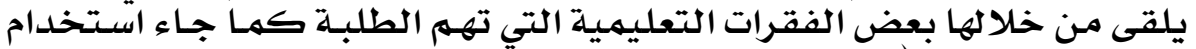

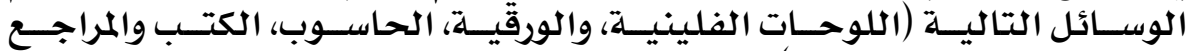

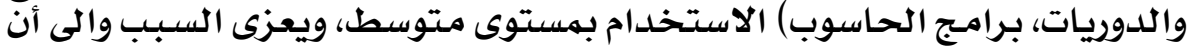

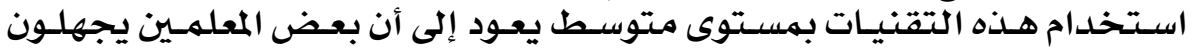

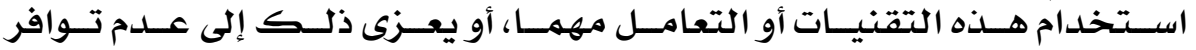

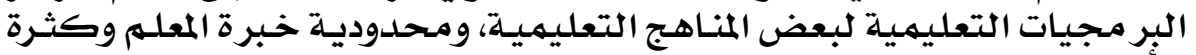

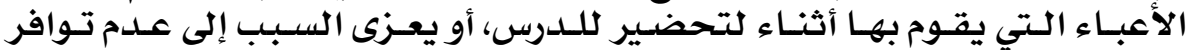

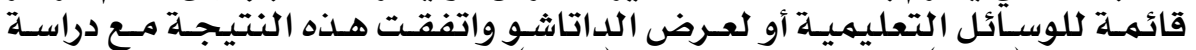

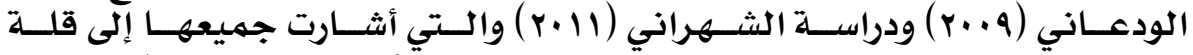

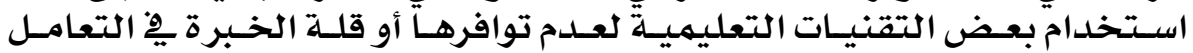

معها.

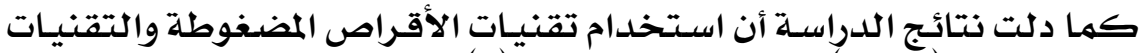

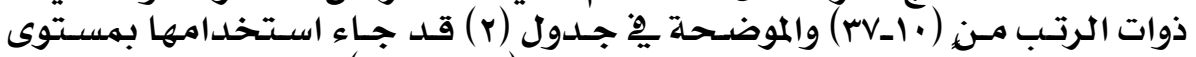

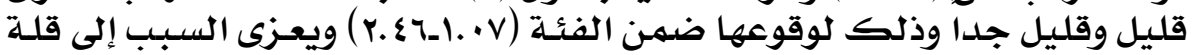

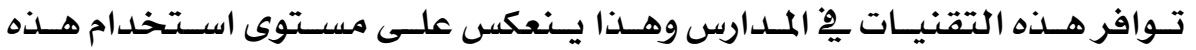

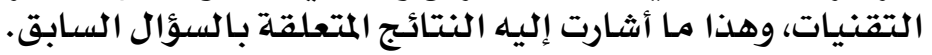

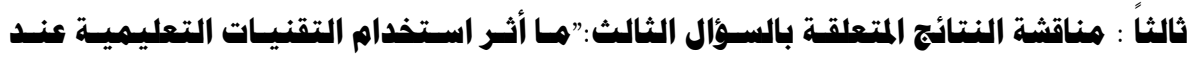

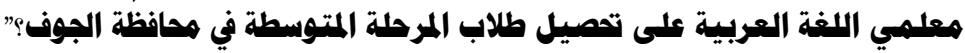

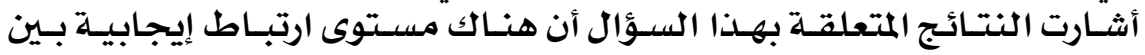

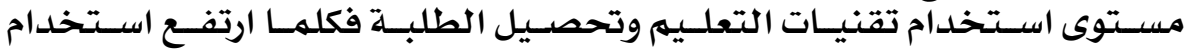

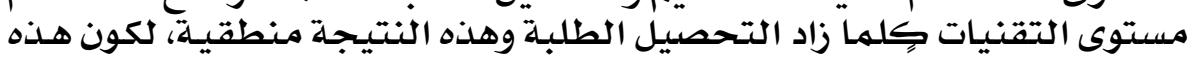

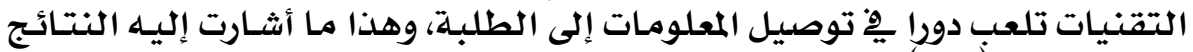

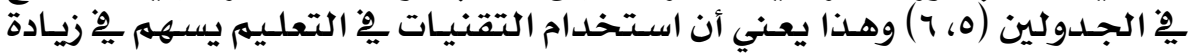

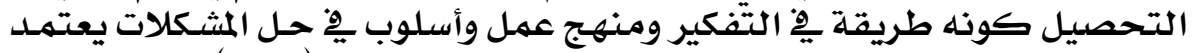

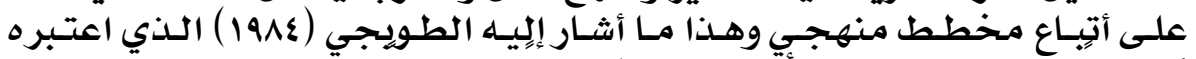

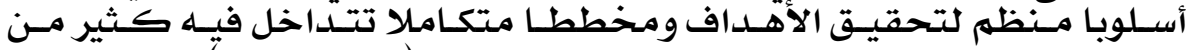

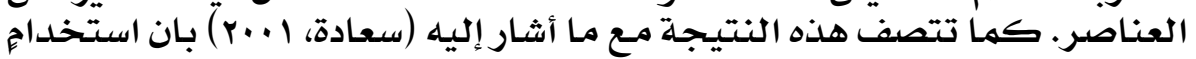

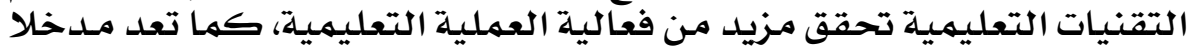

\section{YMT}




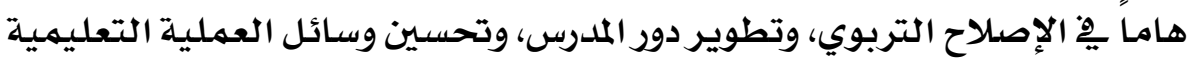

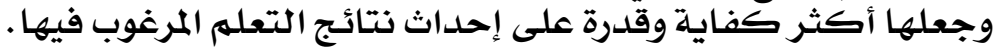

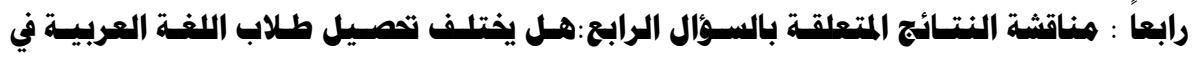

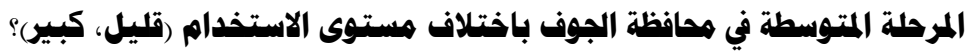

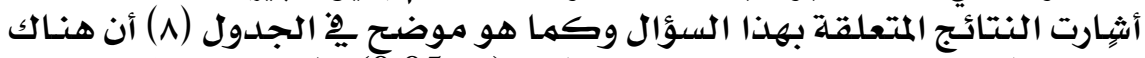

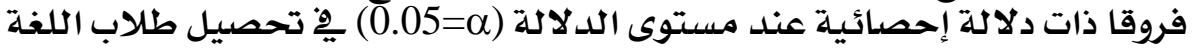

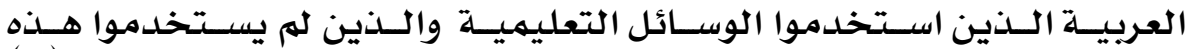

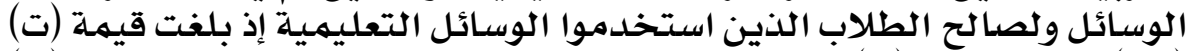

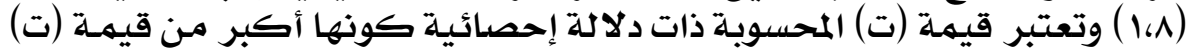

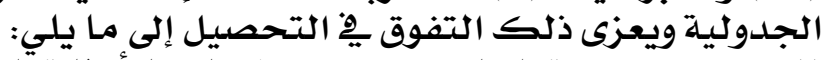

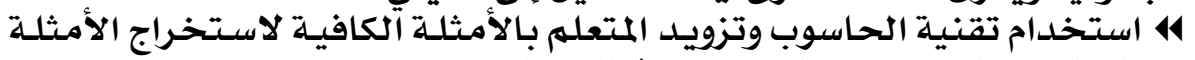

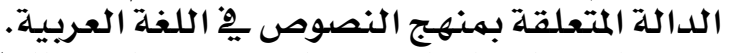

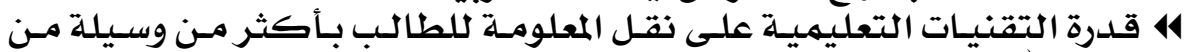

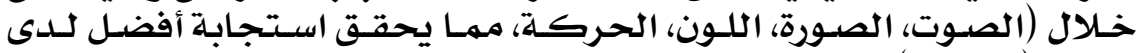

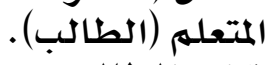

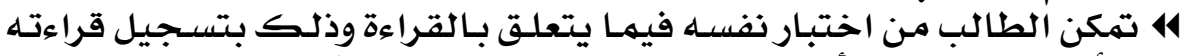

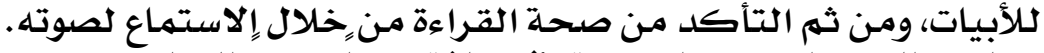

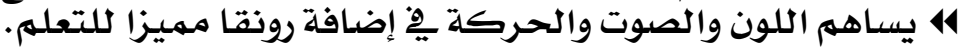

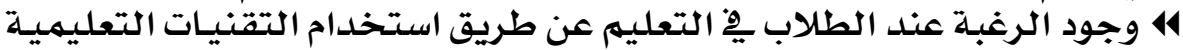
وخاصسة الحاسوب.

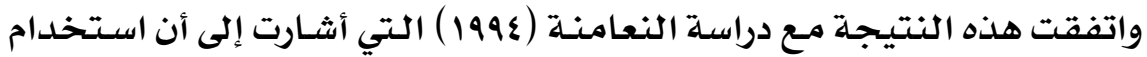

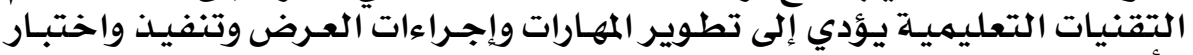
الأنشطة المنافسية، والتقيهويهم.

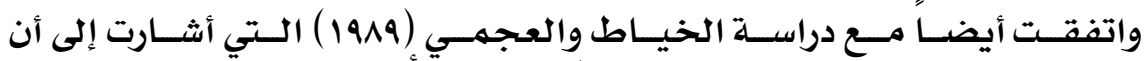

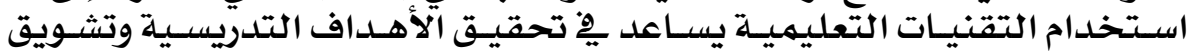

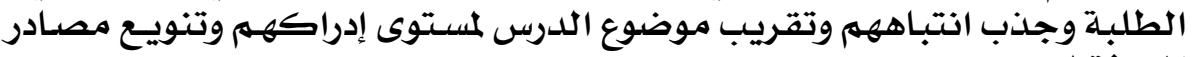
المعرفة لديهمه.

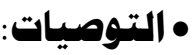

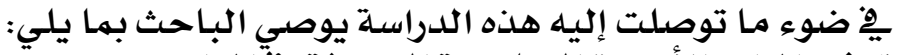

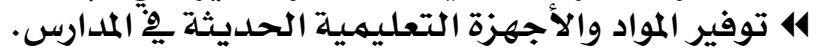

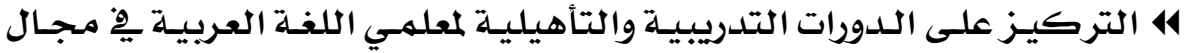

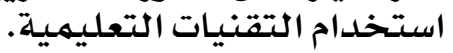

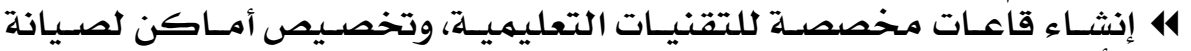

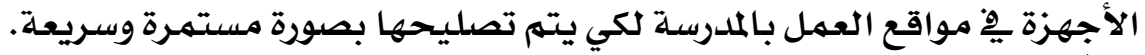

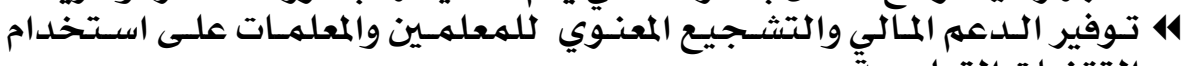
التقنيات التعليميلة.

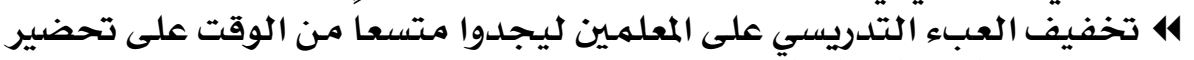
استخدام التقنيات التعليمية. تلتية.

\section{YrE}




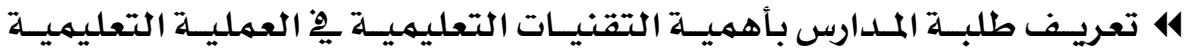

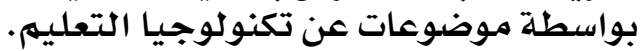

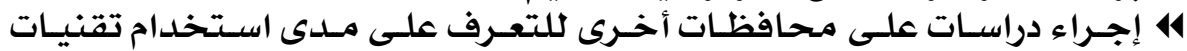

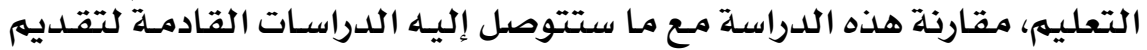

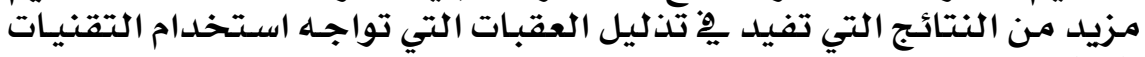

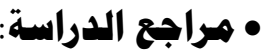

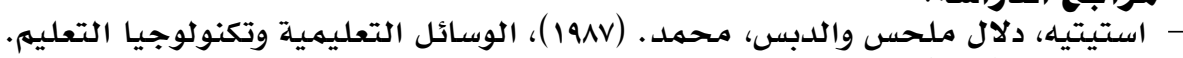

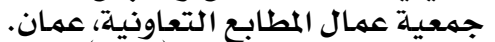

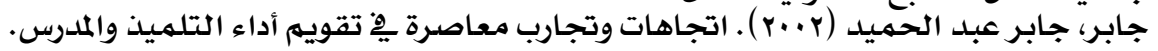
القاهرة، دار الفكر العـربي.

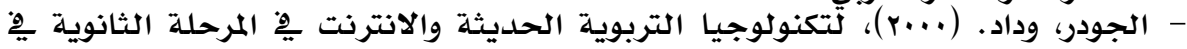

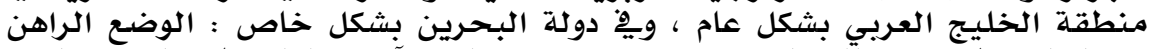

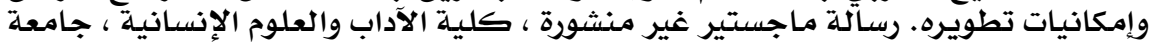

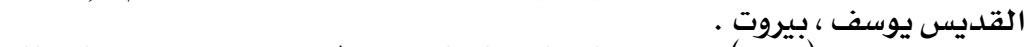

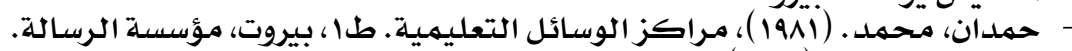

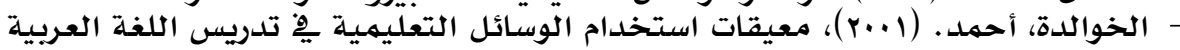

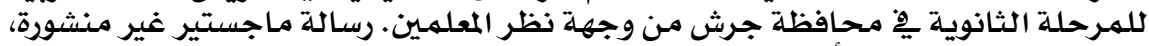

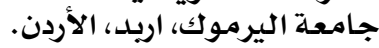

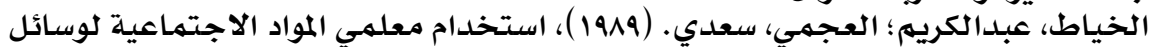

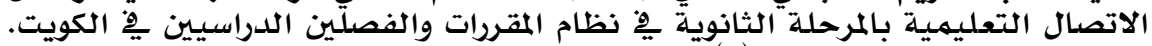

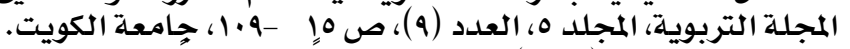

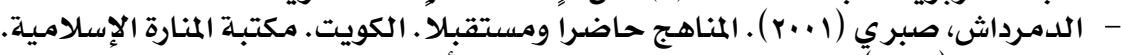

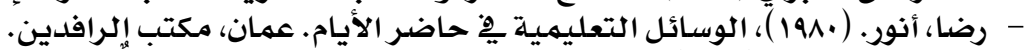

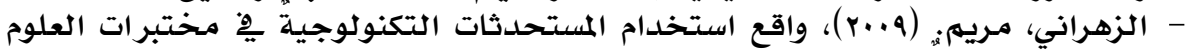

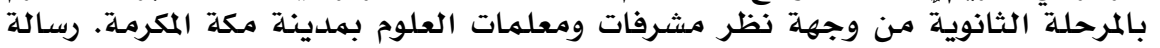

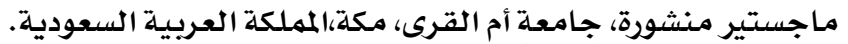

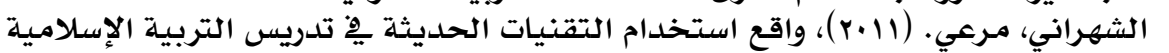

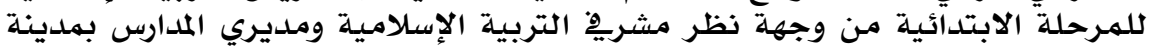

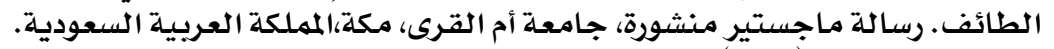

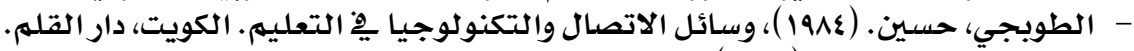

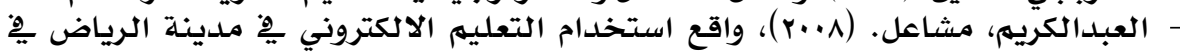

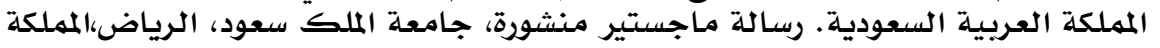

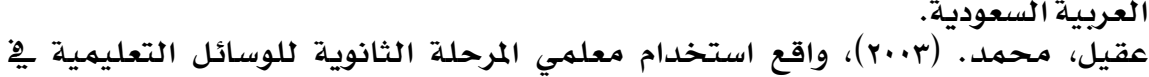

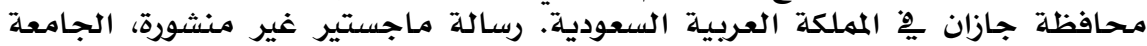
الأردنية، عمان، الأردن.

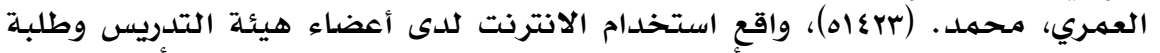

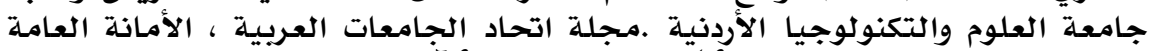

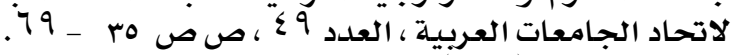

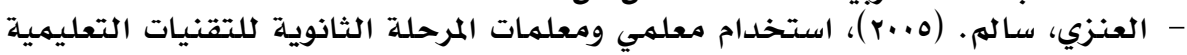

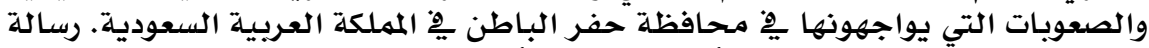

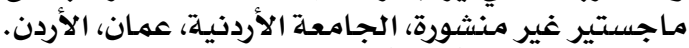

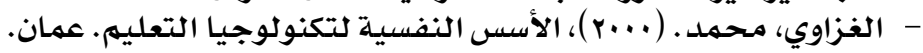




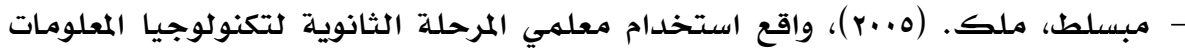

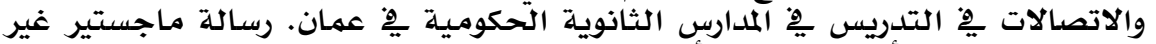

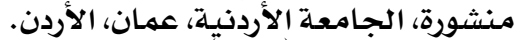

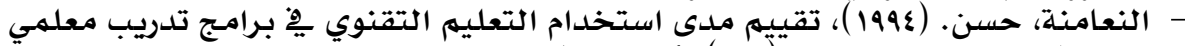

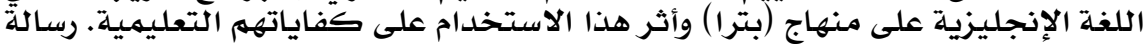

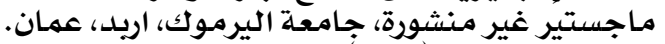

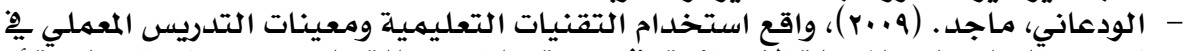

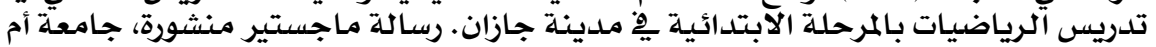
القرى، مكة:المملكة ألعربية المرحلة السعوديتية.

- Ainley, J., Eveleigh, F., Freeman, C., \& O'Malley, K. (2010). ICT in the teaching of science and mathematics in year 8 in Australia: Report from the IEA second international technology in education study (SITES) survey. Camberwell, Victoria, Australia: Australian Council for Educational Research Ltd.

- Hassanzadeh, V., Gholami, R., Allahyar, N., \& Noordin, N. (2012). Motivation and personality traits of TESL postgraduatestudents towards the use of information and communications technology (ICT) in second language teaching in Malaysia. English Language Teaching, 5(4), 74-86. doi: 10.5539/elt.v5n4p74.

- Kennedy, G. E., Judd, T. S., Anna, C., Kathleen, G., \& Kerri-Lee, K. (2008). First year students' experiences with technology: Are they really digital natives? Australasian Journal of Educational Technology, 24(1), 108-122.

- Van Rooy, W. S. (2012). Using information and communication technology (ICT) to the maximum: Learning and teaching biology with limited digital technologies in secondary schools. Research in Science \& Technological Education, 30(1), 65-80. doi: 10.1080/02635143.2011.653877.5n4p 


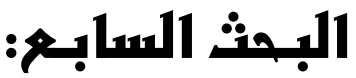

الاحتياجات التدريبيه اللازمة لتسين الأداء الوظيفى لمشرفات رياض الماض

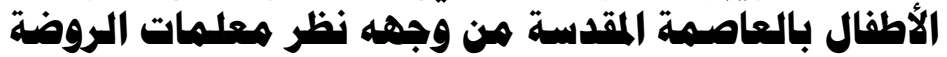

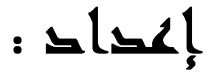

د/ منال محمد درويث سبحى

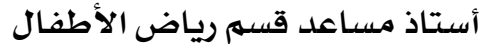

كلية التربية جامعة الطائف الطفال 



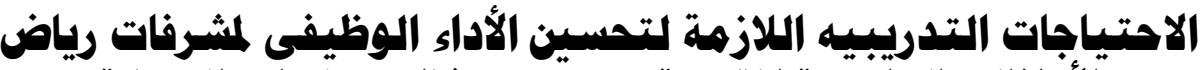

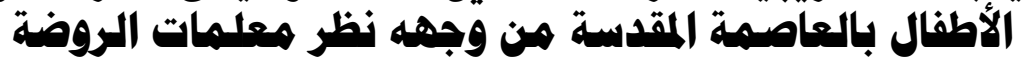

د/ منال محمل درويثل سبحى

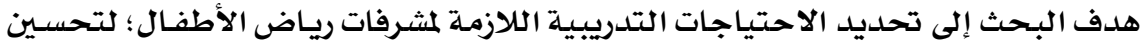

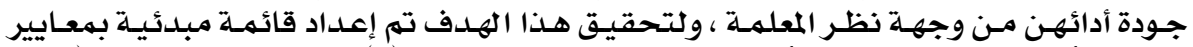

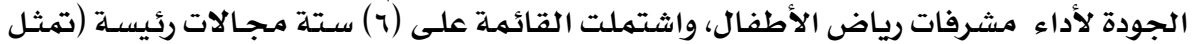

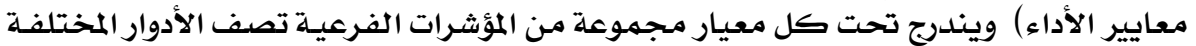

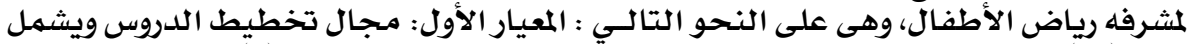

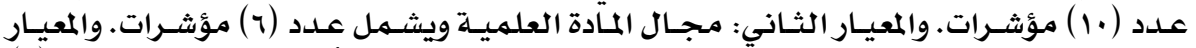

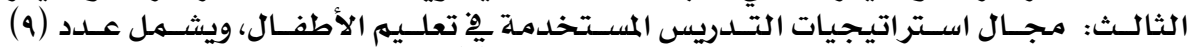

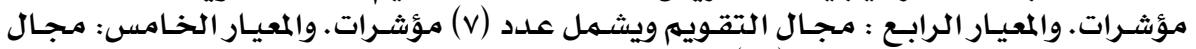

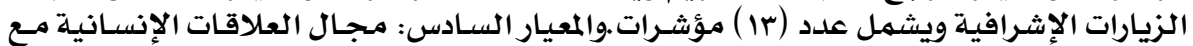

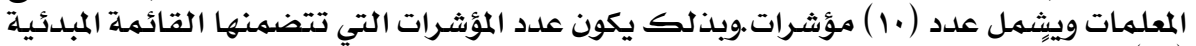

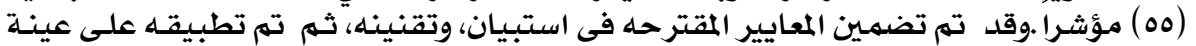

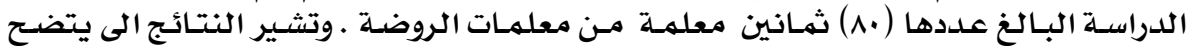

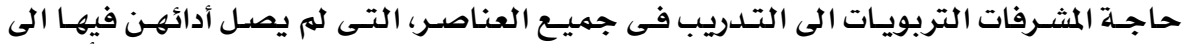

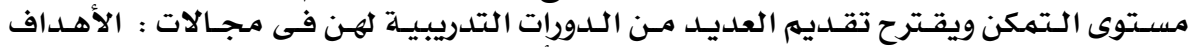

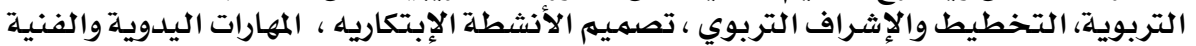

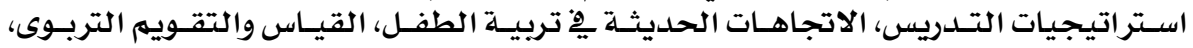

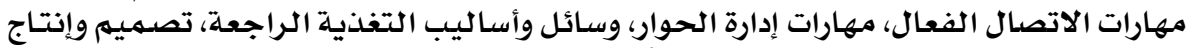

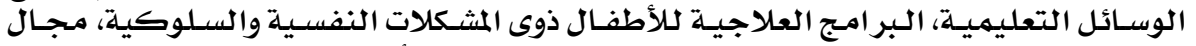

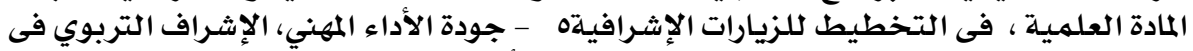

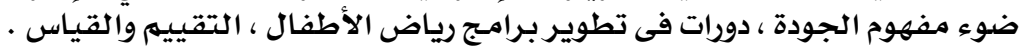

\section{Determine training needs required for $K G$ supervisors to improve} quality of their performance according to teacher viewpoint

\section{Abestract:}

The research aims to determine training needs required for $K G$ supervisors to improve quality of their performance according to teacher viewpoint. To achieve that aim there is a primary list according to quality criterions of $K G$ supervisors' performance. The list contains (6) six main fields (performance criterions). Each criterion contains some sub-indicators reflects different roles of $K G$ supervisor as follow: $\mathbf{1}^{\text {st }}$ criterion: field of planning lessons which contains (10) indicators. $2^{\text {nd }}$ criterion: filed of scientific material which contains (6) indicators. $3^{\text {rd }}$ criterion: filed of teaching strategies used in teaching kids which contains (9) indicators. $4^{\text {in }}$ criterion: filed of evaluation which contains (7) indicators. $5^{\text {th }}$ criterion: filed of supervision visits which contains (13) indicators. $\boldsymbol{6}^{\text {th }}$ criterion: filed of human relations with teachers which contains (10) indicators. So, the indicators included in the primary list are (55) indicators. and applied on study sample which contains (80) eighty teacher of KG teachers. Referring to the above mentioned, it is clear that supervisors need training in all elements which their performance did not reach in them the quality limit. It 
is suggested to offer several training courses in the following fields : Educational aims, planning, educational supervision, designing creative activities - hand and art skills - teaching strategies - modern directions in growing child - measuring and educational evaluation - skills of effective communication - skills of managing dialogs - feeding methods - designing and producing educational methods - medication programs for kids who has psychological or manners problems - field of scientific material - in planning for supervising visits - quality of professional performance educational supervision according to quality - courses in improving $K G$ programs - evaluation and measuring.

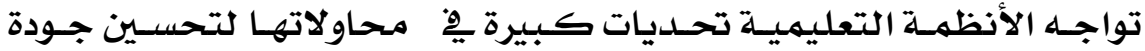

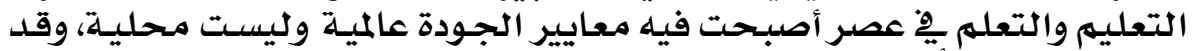

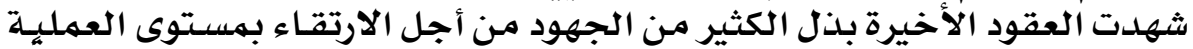

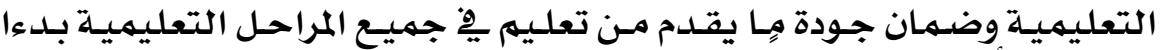

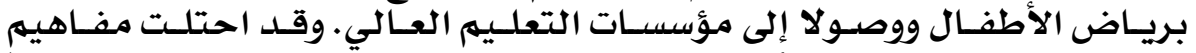

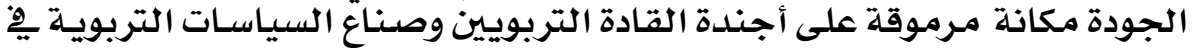

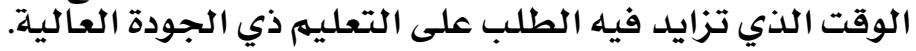

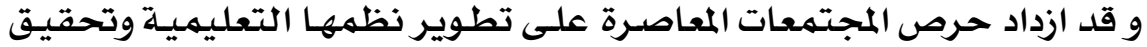

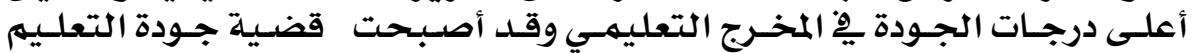

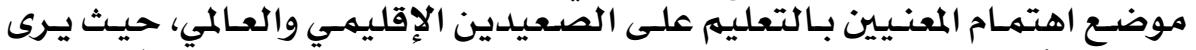

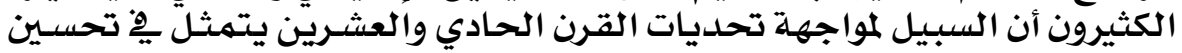

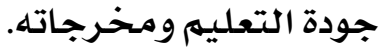

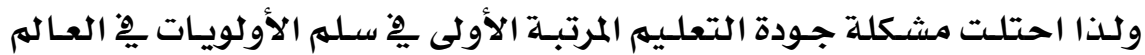

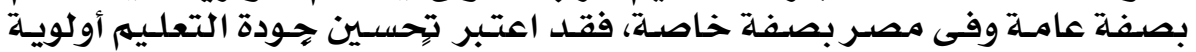

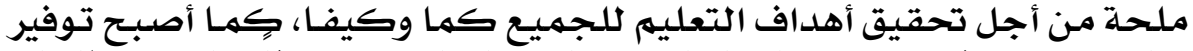

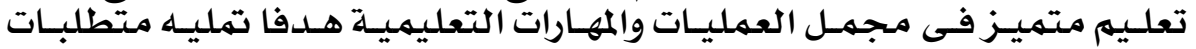

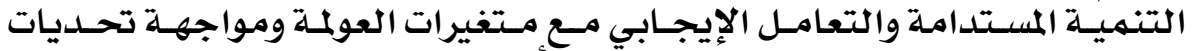

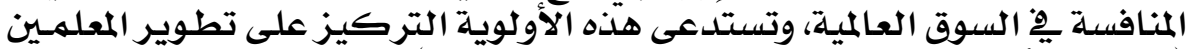

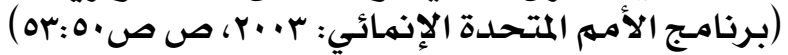

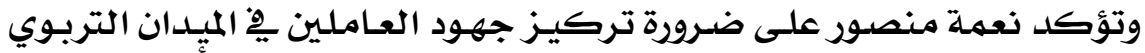

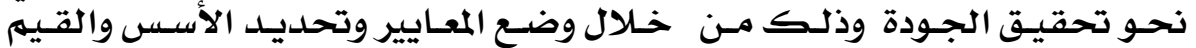

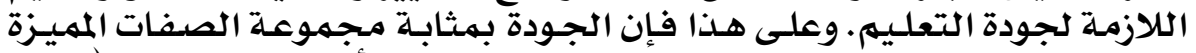

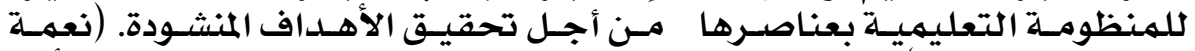

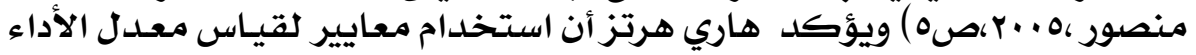

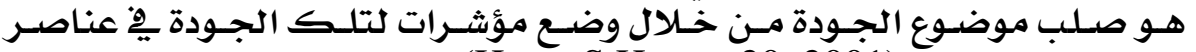
العملية التعليمية. (Harry S.Hertz,p20, 2001)

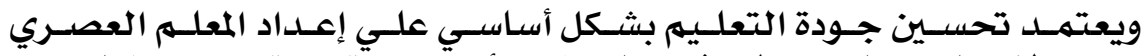

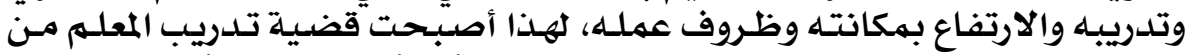

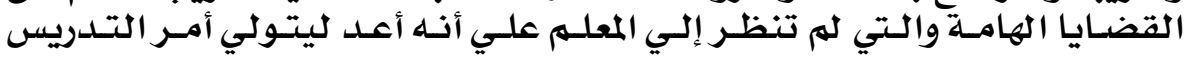




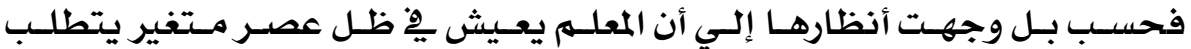

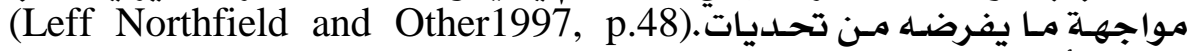

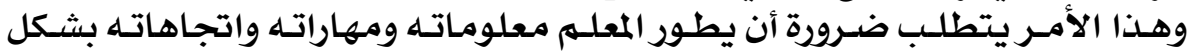

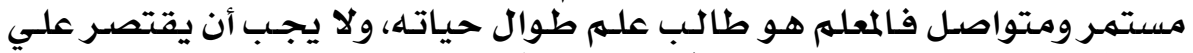

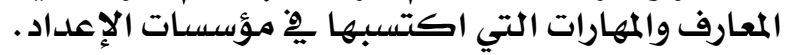

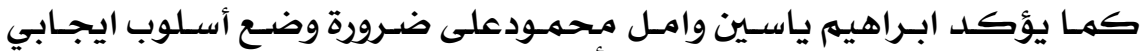

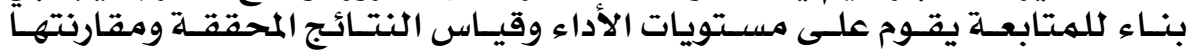

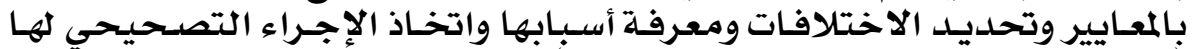

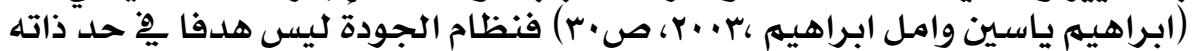

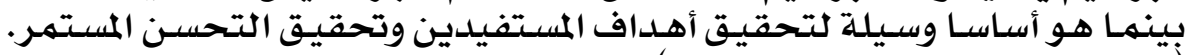

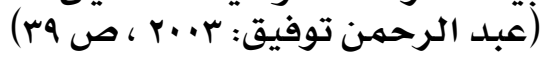

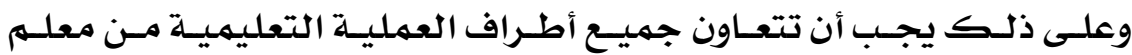

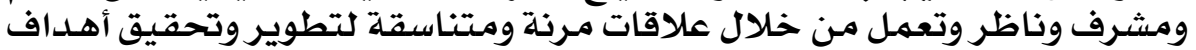

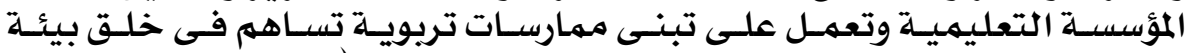

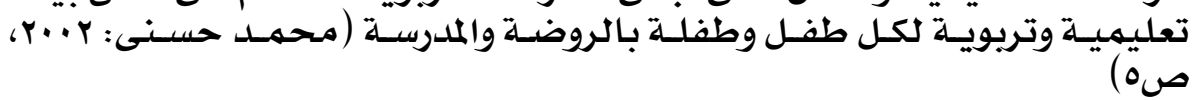

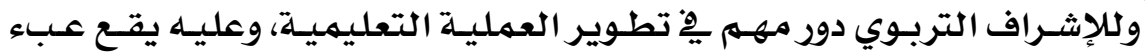

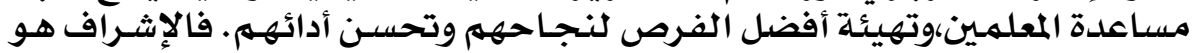

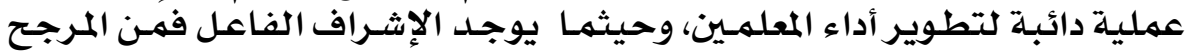

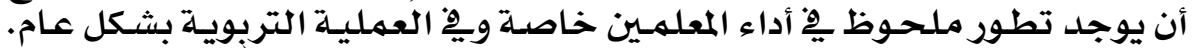

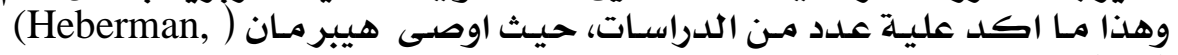

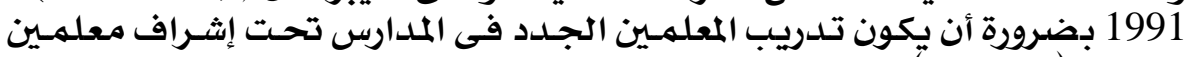

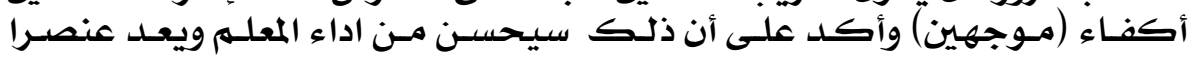

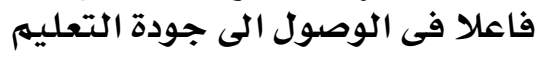
ويؤكد كليمنت وفاندنبرج: (Clement and Vandenberghe,1997,p27)

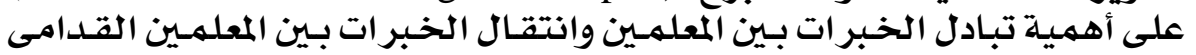

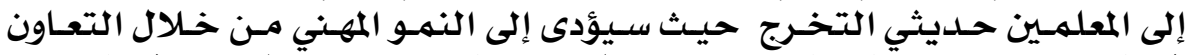

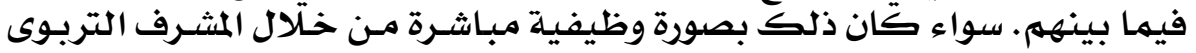

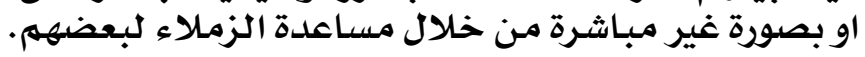

وقد اختلف مفهوم الإشراف التربوي يخ الحاضـر عن الماضي حيث كـان ينظر

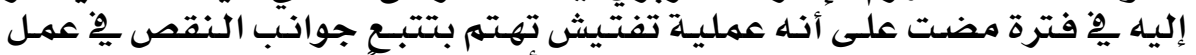

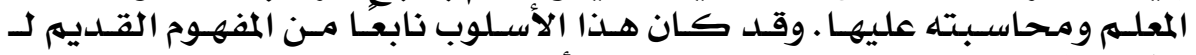

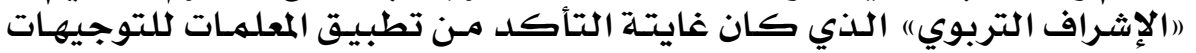

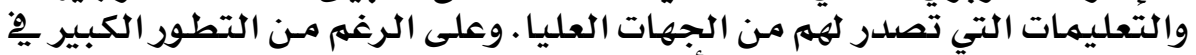

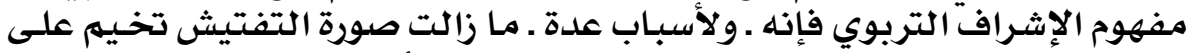

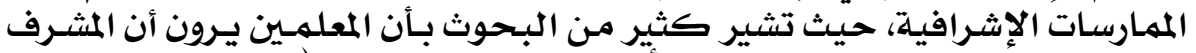

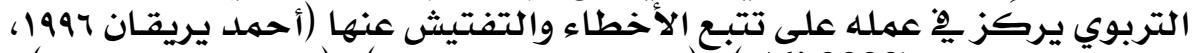

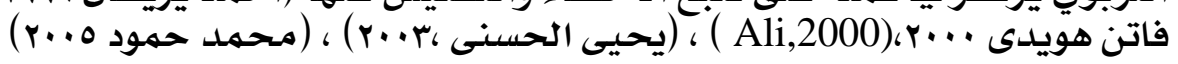

\section{Y 1}




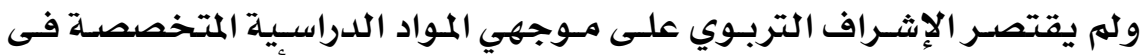

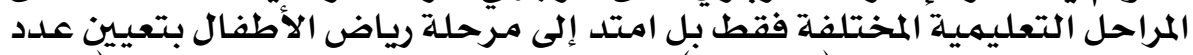

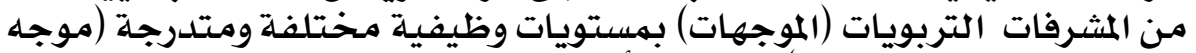

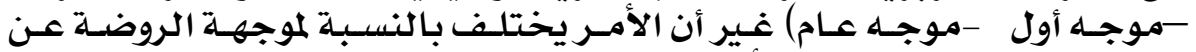

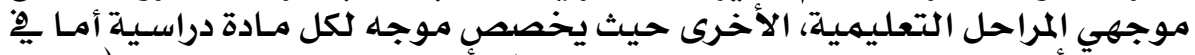

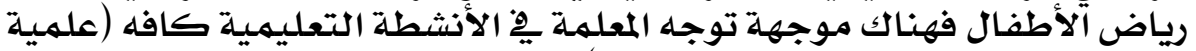

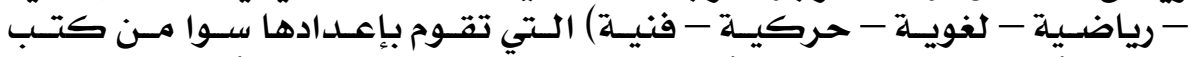

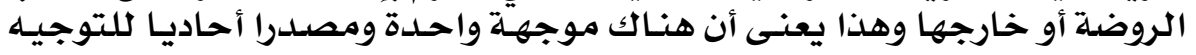

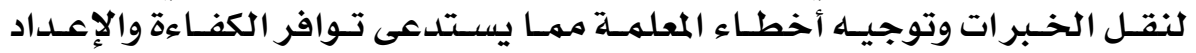

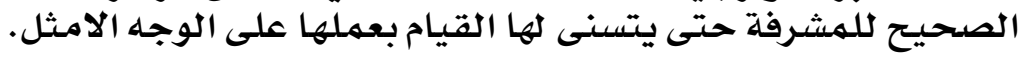

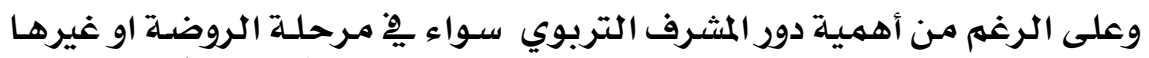

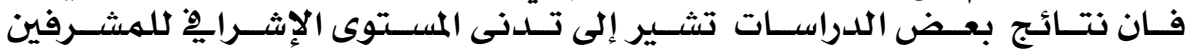

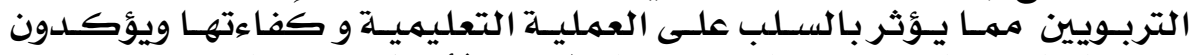

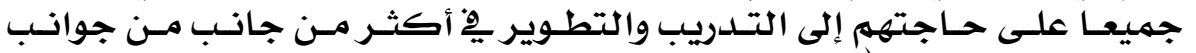

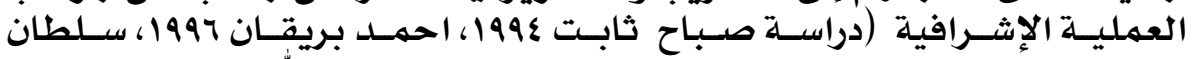

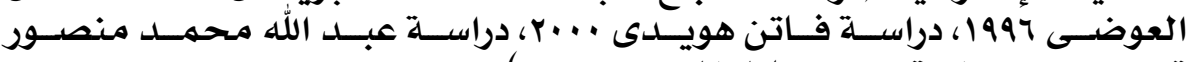

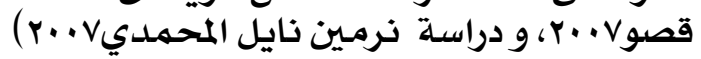

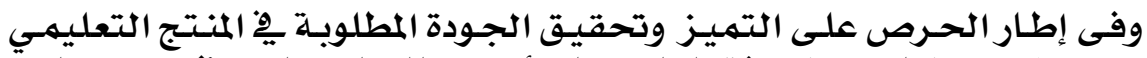

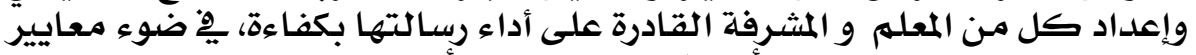

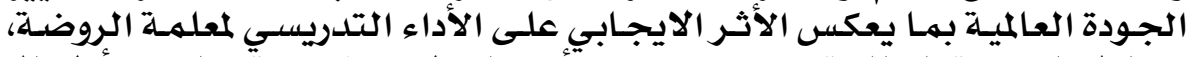

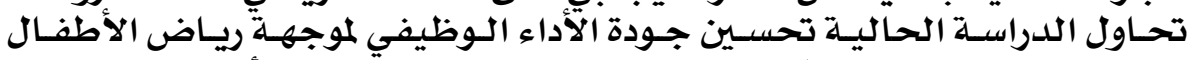

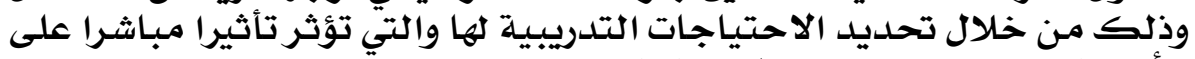

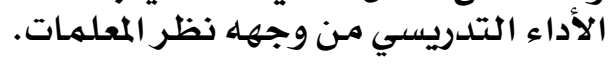

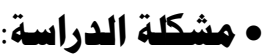

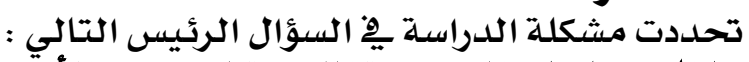

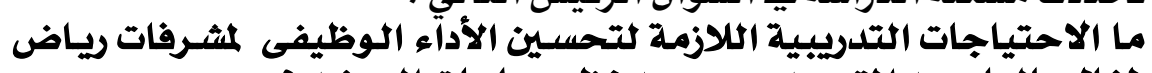

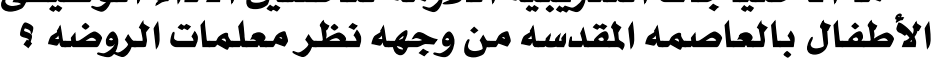
ويتفرع من هذا السؤال الرئيس مجهموعة من الأسئلة الفرعية :

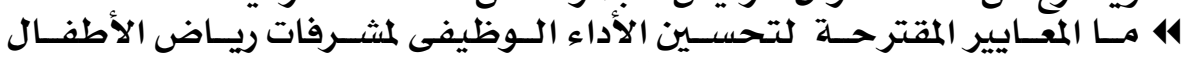

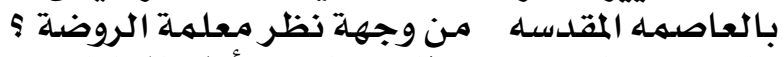

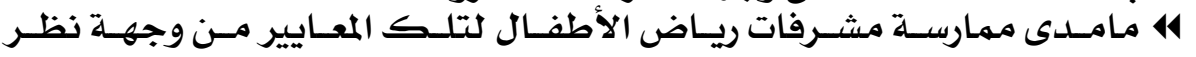

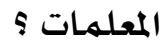

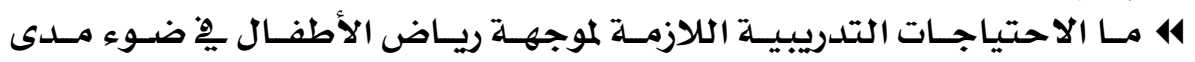

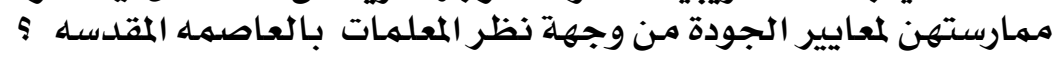

•أهدافـ الدراسةة:

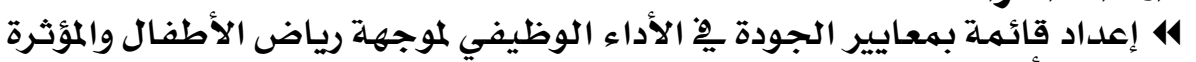

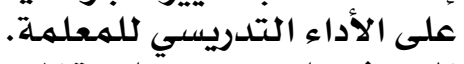

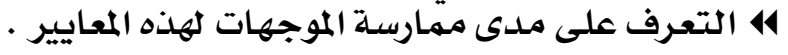


العكد المابي والسترن .. نه همهبر ..

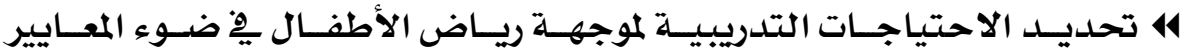
المقرحة.

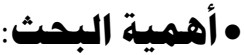

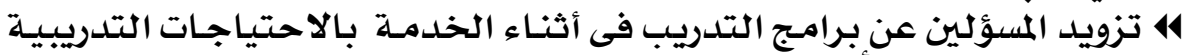

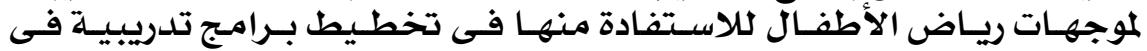
ضوئها.

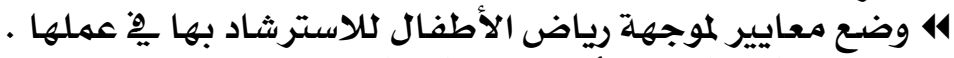

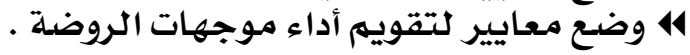

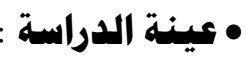

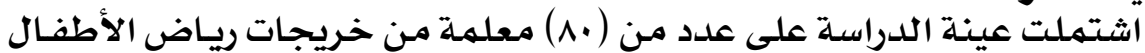

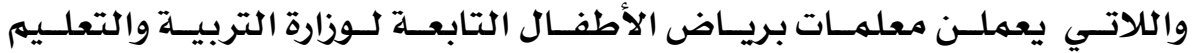
بالعاصهمـه المقدسلهـ

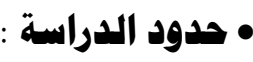

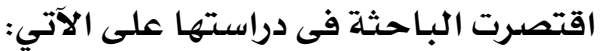

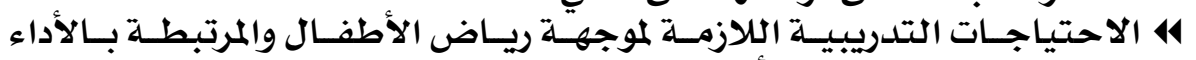

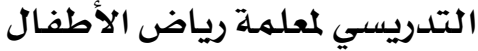

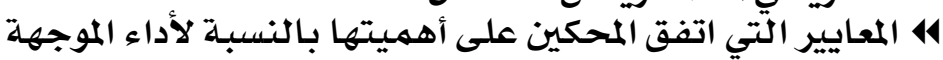

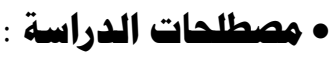
• • الجودة:

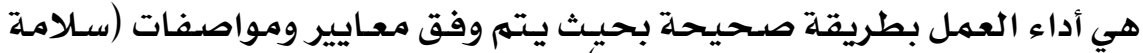

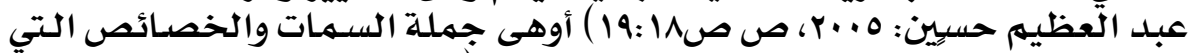

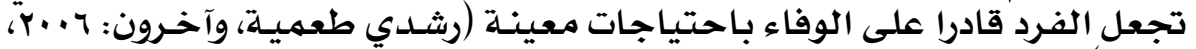

صا (r) • (الاحتياجات التدريبيه

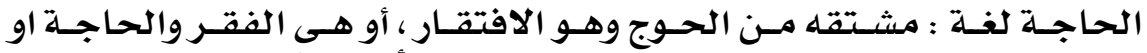

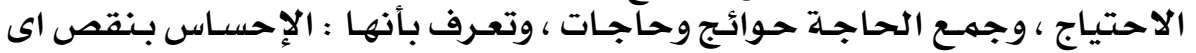

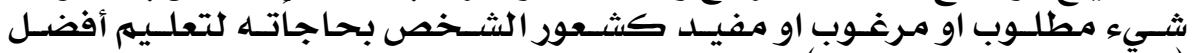

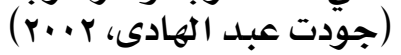

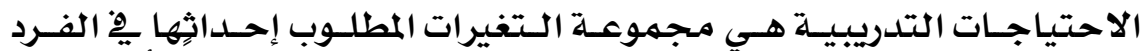

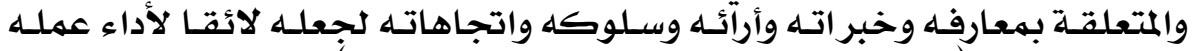

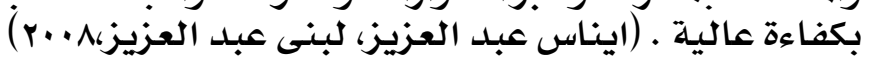

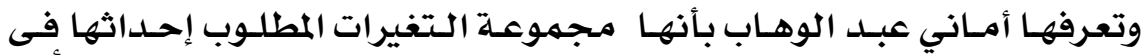

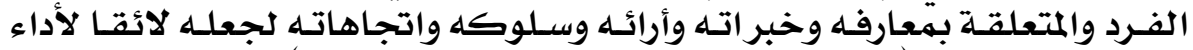

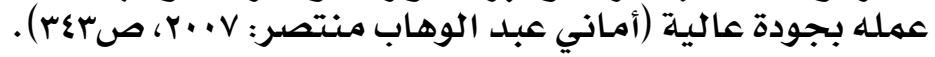

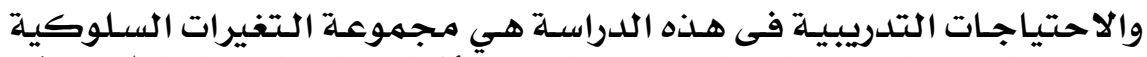

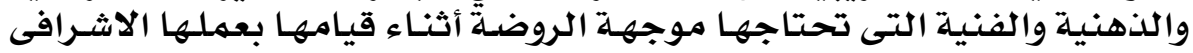

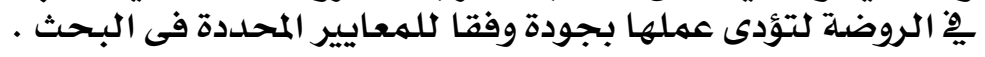

\section{$Y \varepsilon r$}




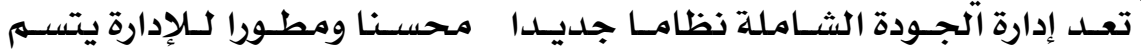

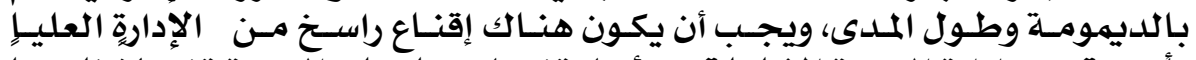

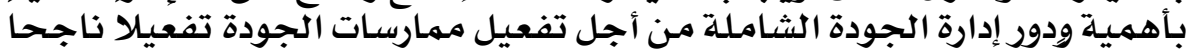
ومستمهرا

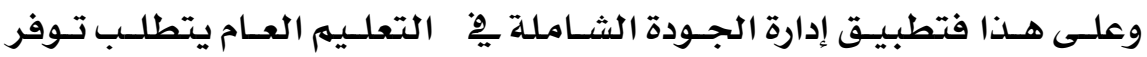

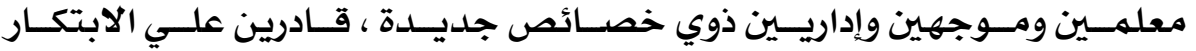

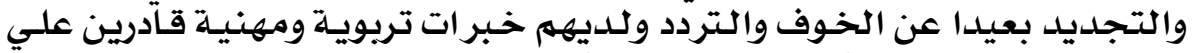

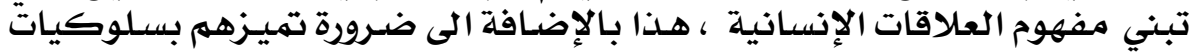

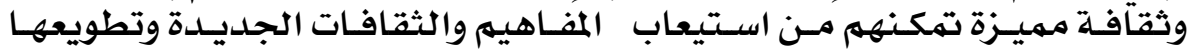

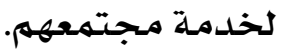

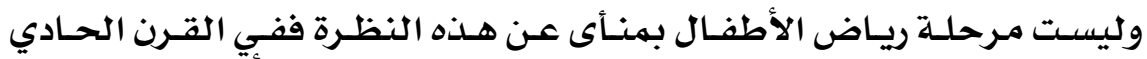

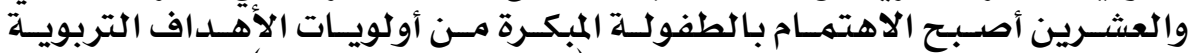

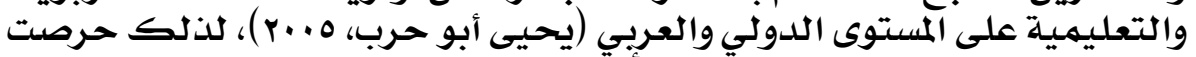

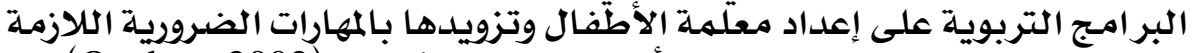

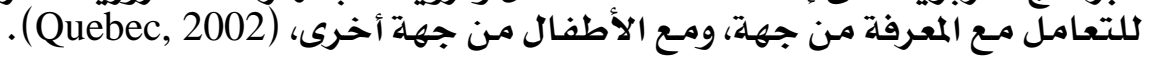

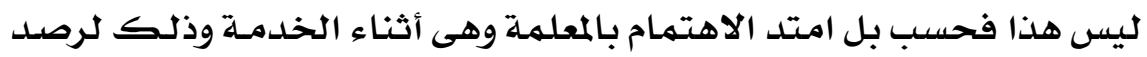

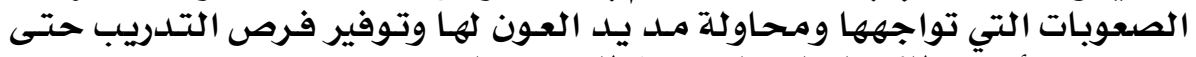

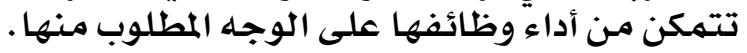

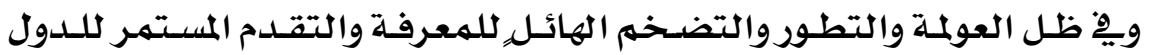

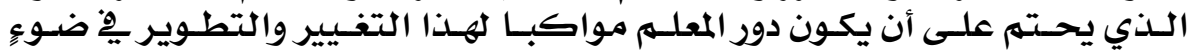

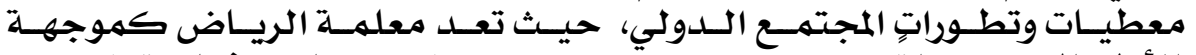

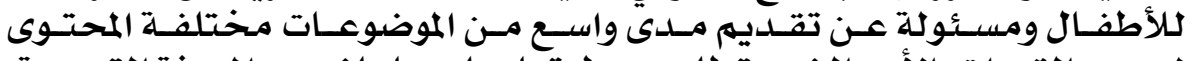

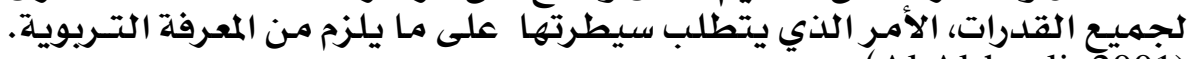
(Al Al-hooli, 2001)

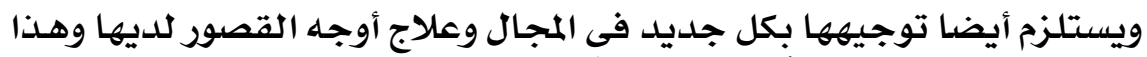

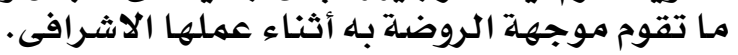

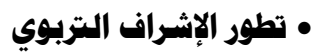

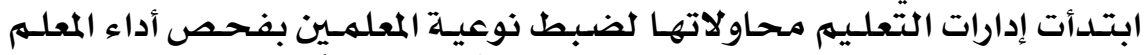

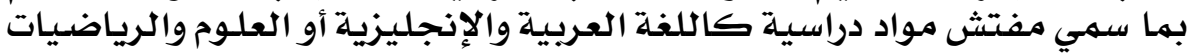

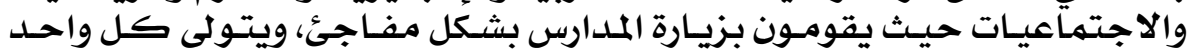

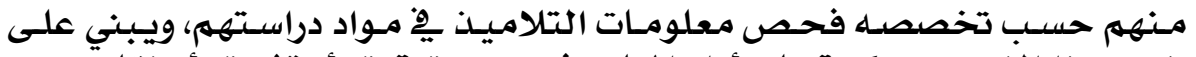

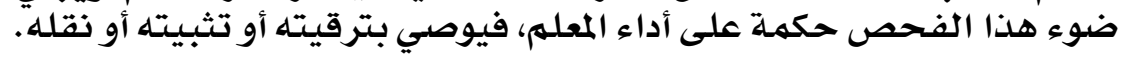
وخلال العقود الثثلاث الأخيرة من القرن العشـرين توصسلت الدراسـات التربويـة

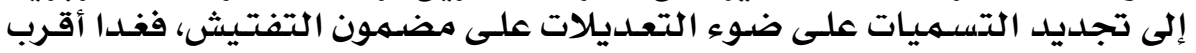

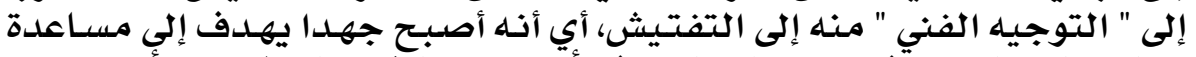

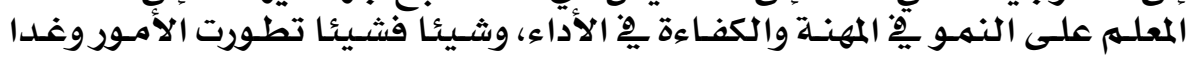

\section{$Y \varepsilon \varepsilon$}




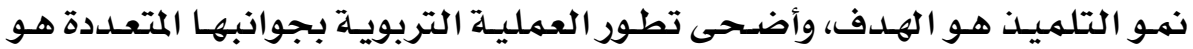

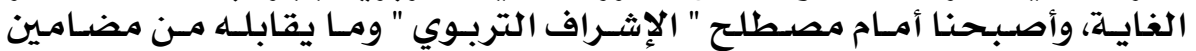

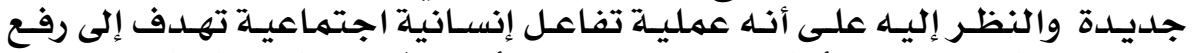

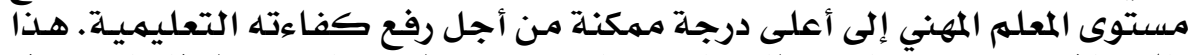

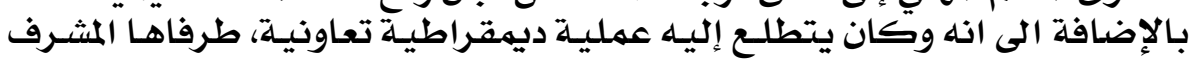

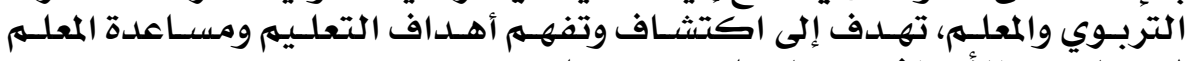
ليتقبل هذه الأهداف ويعهمل على إلى تحقيقها.

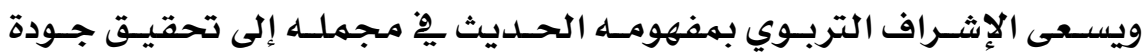

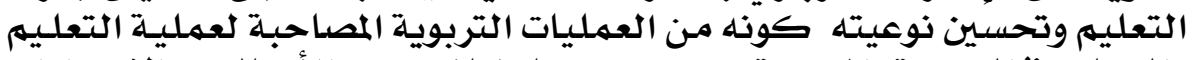

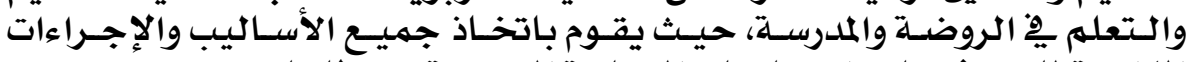

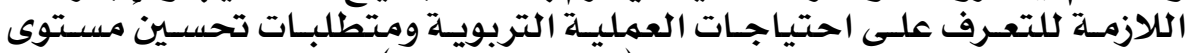

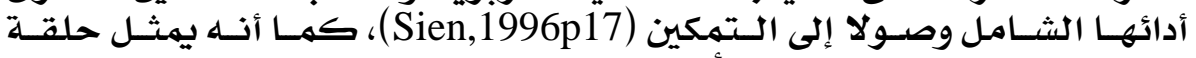

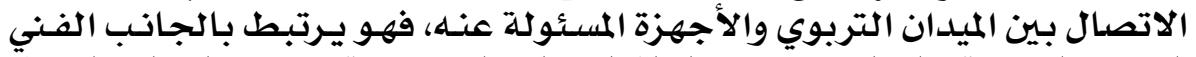

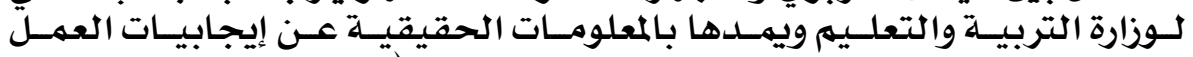

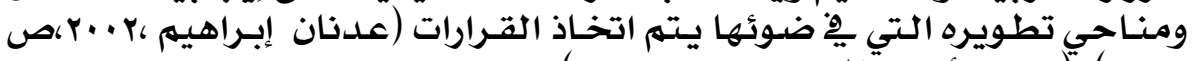

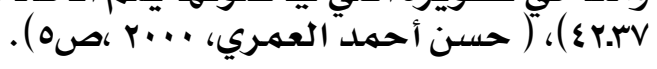

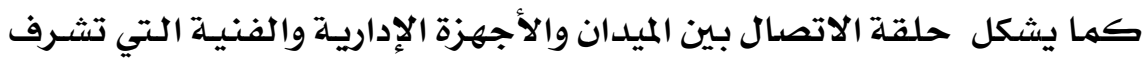

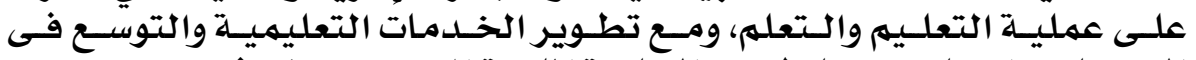

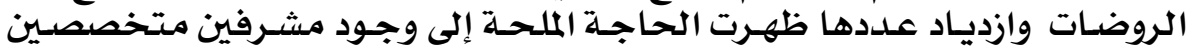

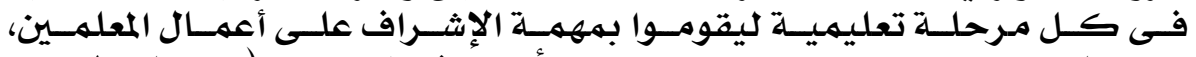

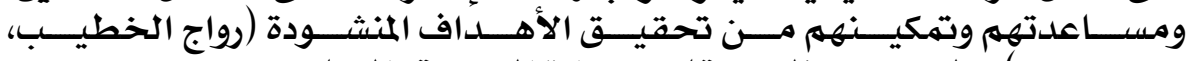

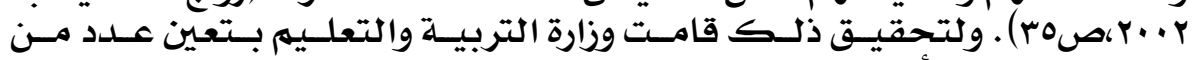

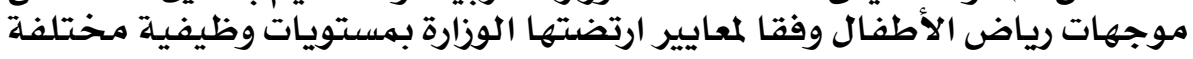

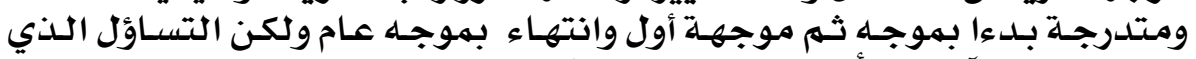

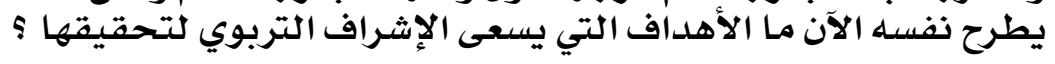

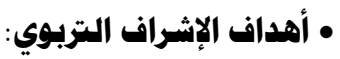

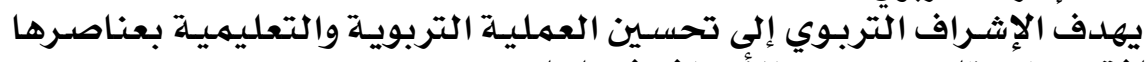

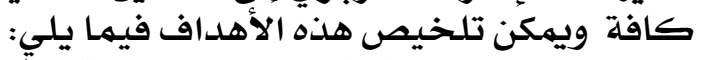

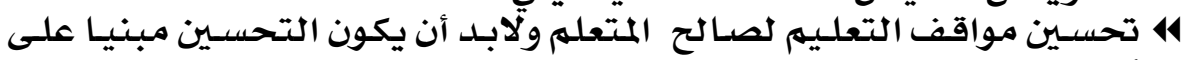

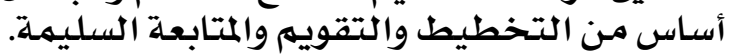

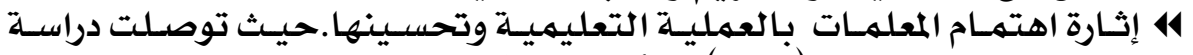

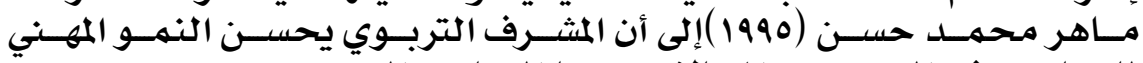

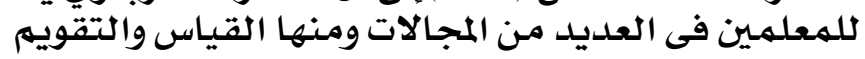

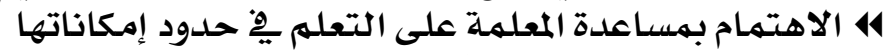

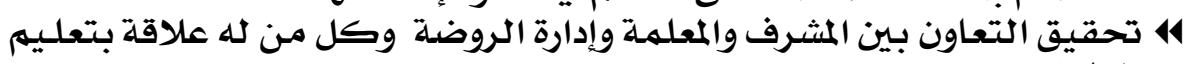
الطفل

4 ه تدريب المعلمات على عملية المعلية التقويهم الذاتي.

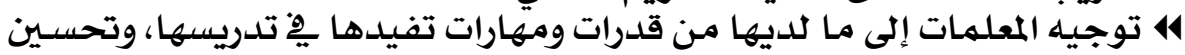

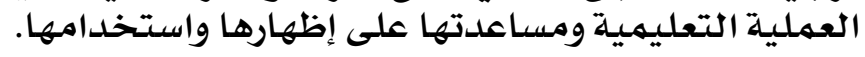

\section{$Y \varepsilon \theta$}




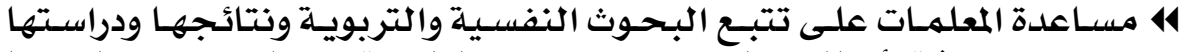

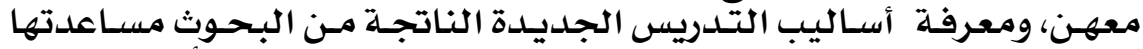

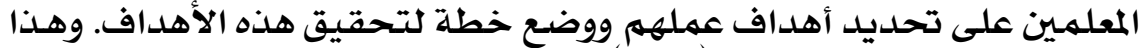

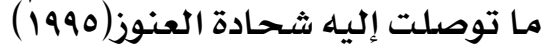

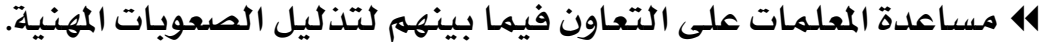

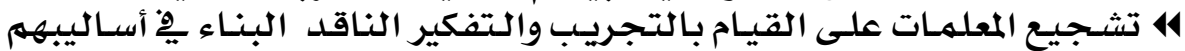

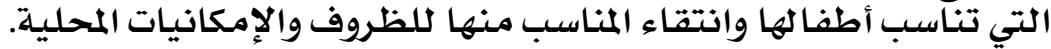

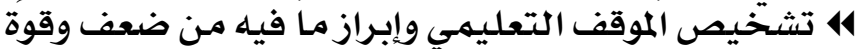

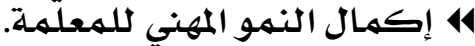

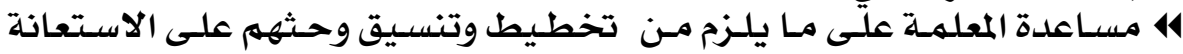
بالبيئة المحلية.

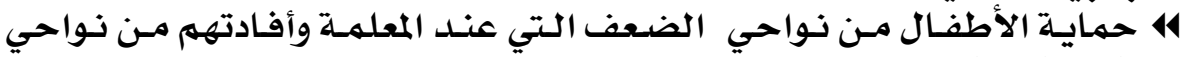

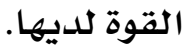

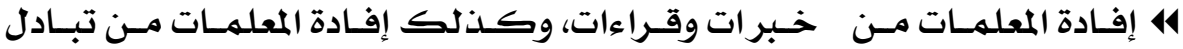
خبر اتهن السليمة المعادة 4 توفير قيادة تربوية متخصصية التصة تبعا لميادين المعرفة وما يتصل بها من أنشطة

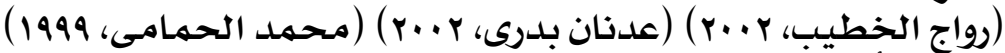

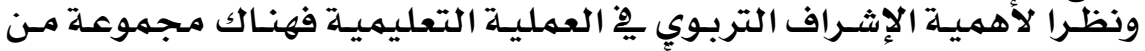

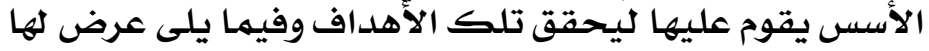

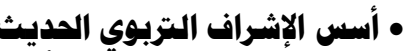

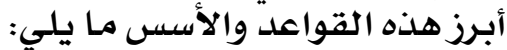

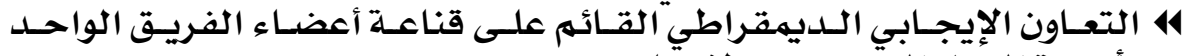

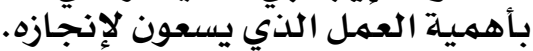

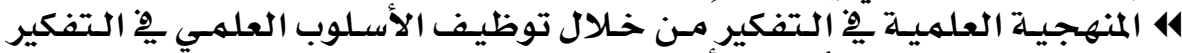

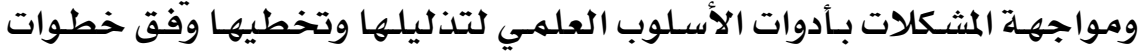

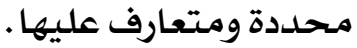

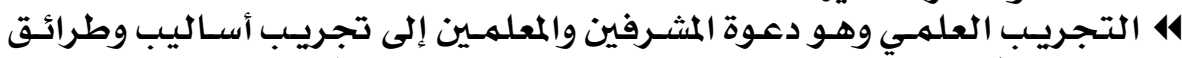

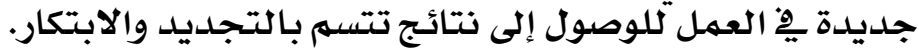

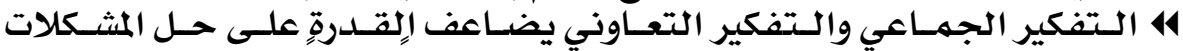

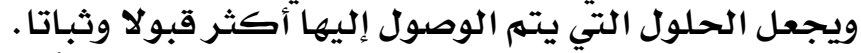

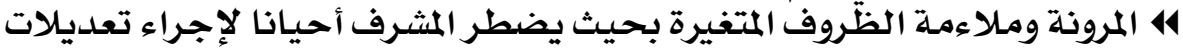

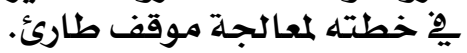
414

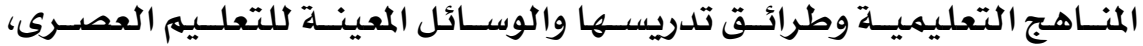

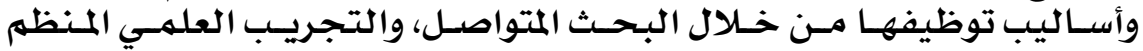

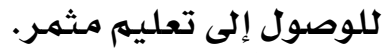

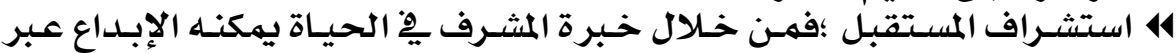

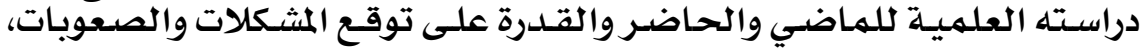

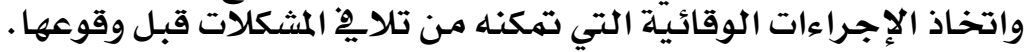

\section{Y $₹ 7$}




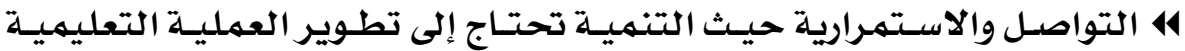

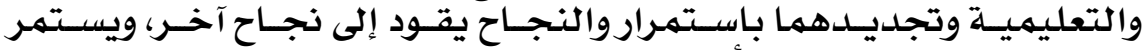

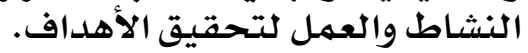

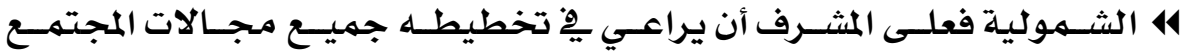

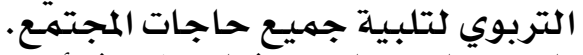

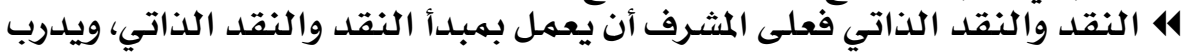

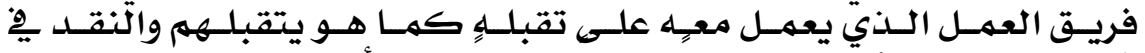

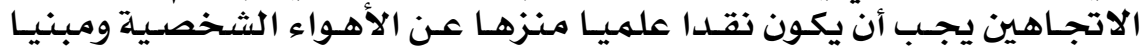

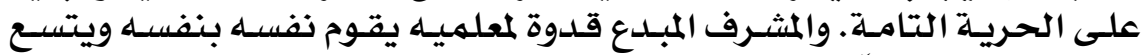
صدره الملاحظات الآخرين.

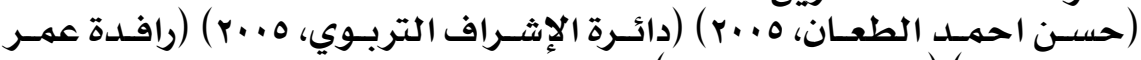

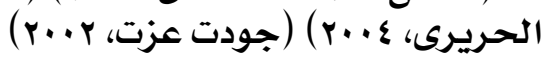

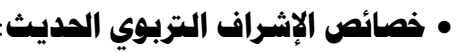

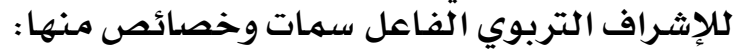

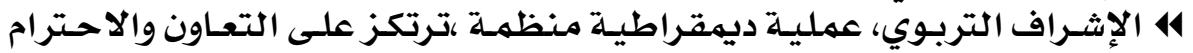

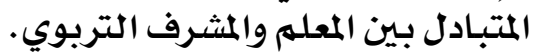

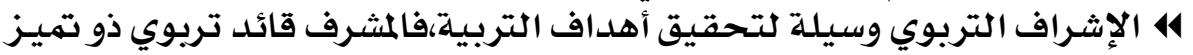

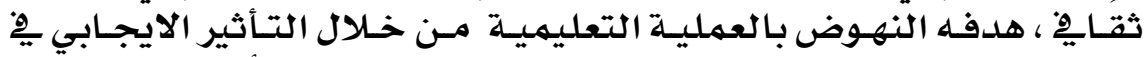

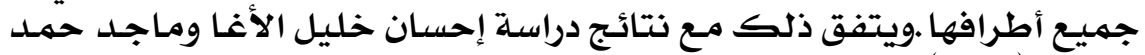

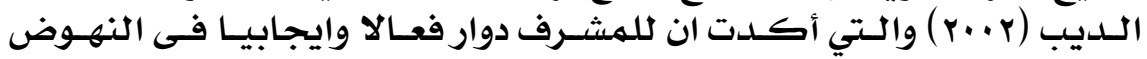

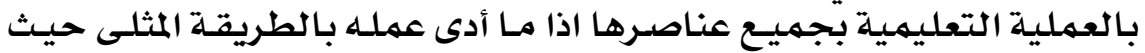

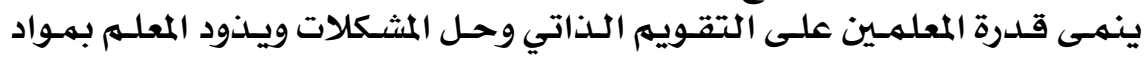
اثرائية.

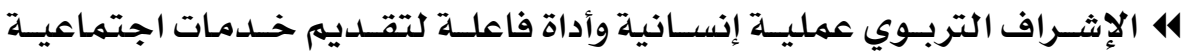

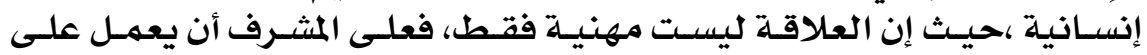

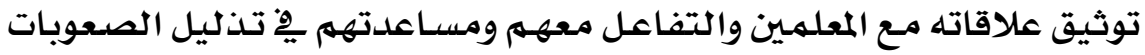

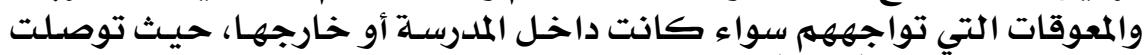

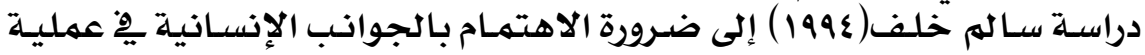

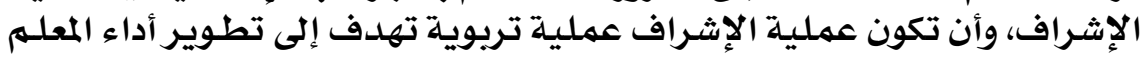
وفق نظرة إلنسانية.

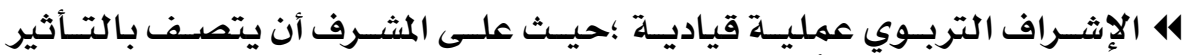

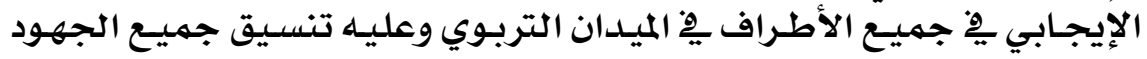

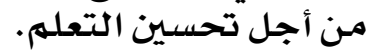

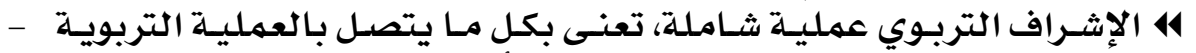

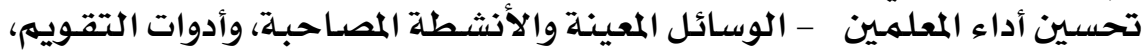

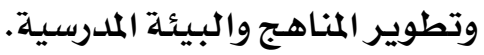

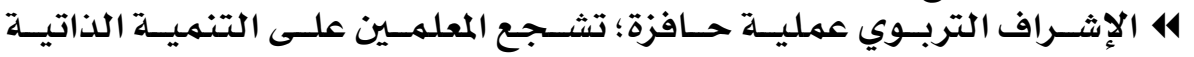
والتجديد والابتكار. 


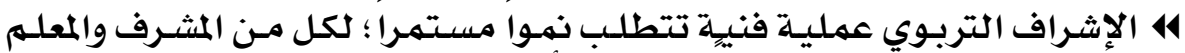

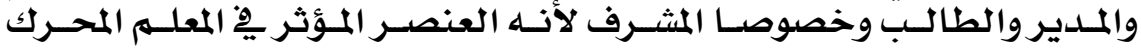

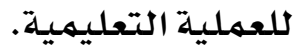

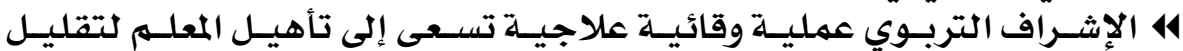

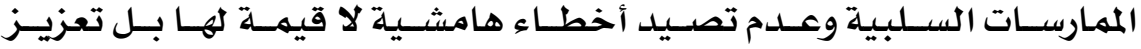
الاتجاهات الايجابية الإسية واستثمارها.

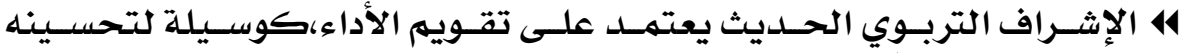

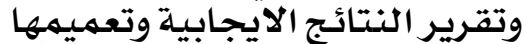

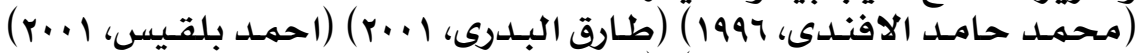

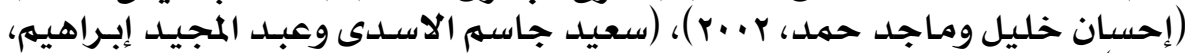

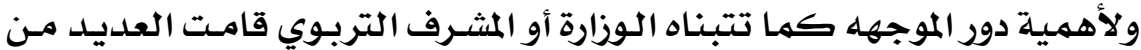

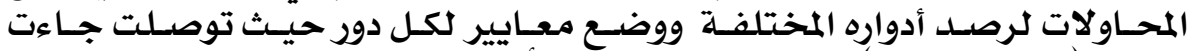

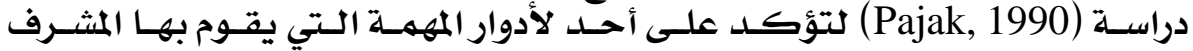

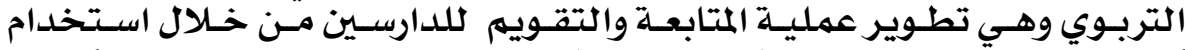

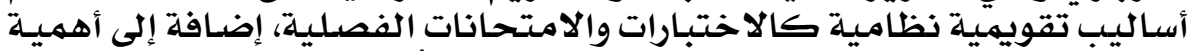

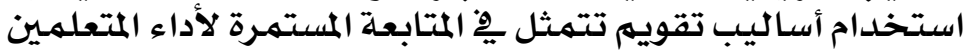

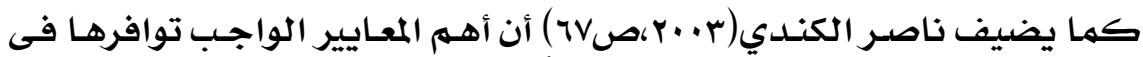

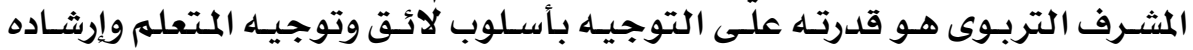
ليتحسن أداؤه

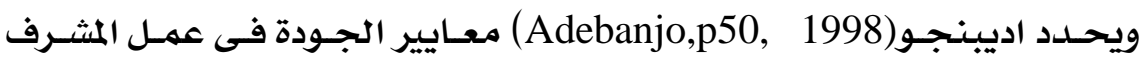

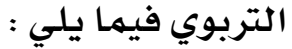

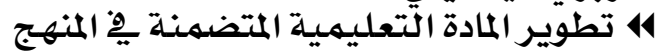

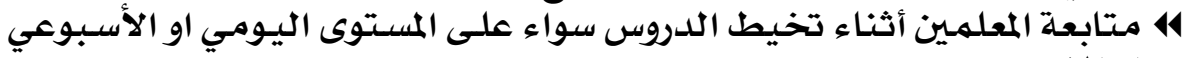

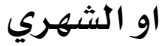

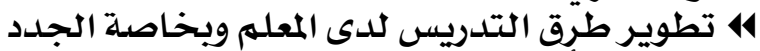

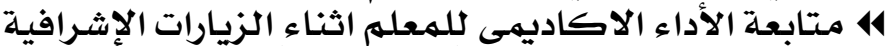

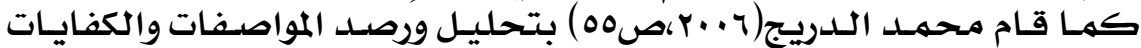

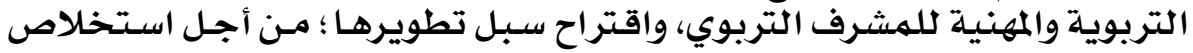

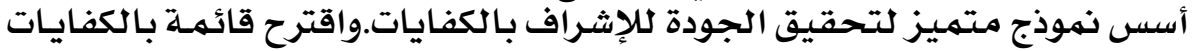

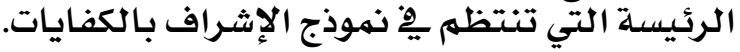

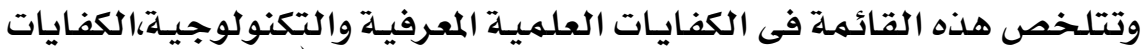

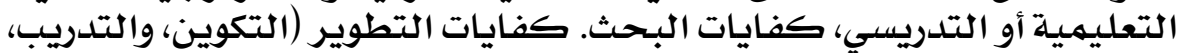

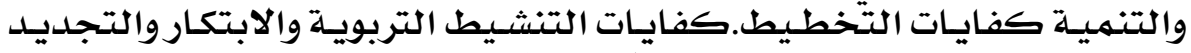

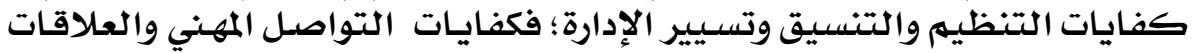
الإنسانية كفايات التقويهم والمتابعة.

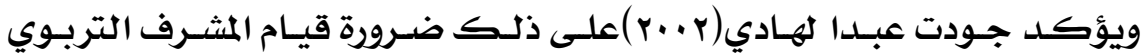

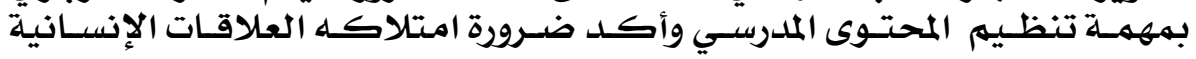

\section{$Y \varepsilon \Lambda$}




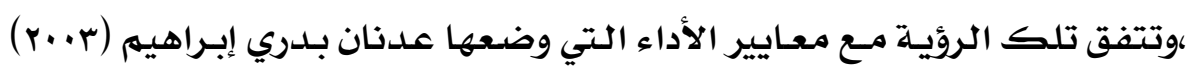

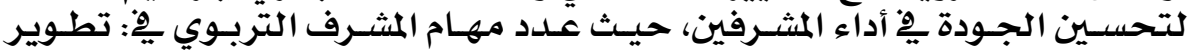

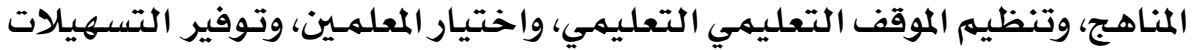

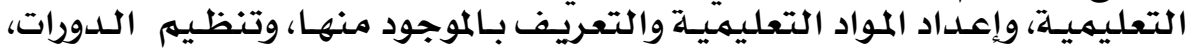

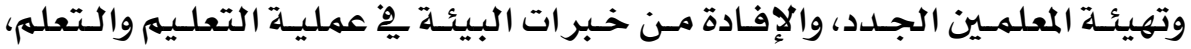

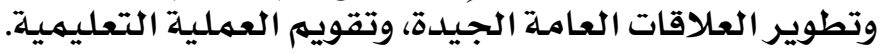

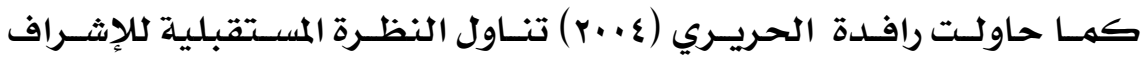

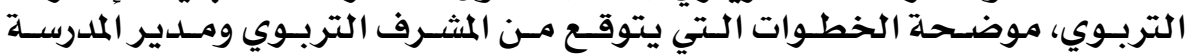

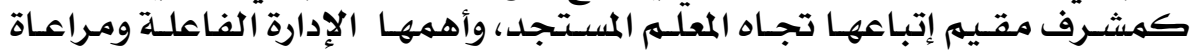

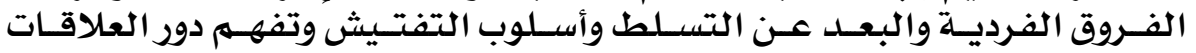

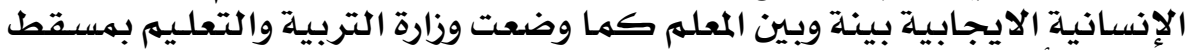

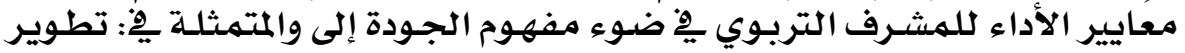

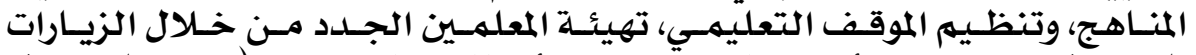

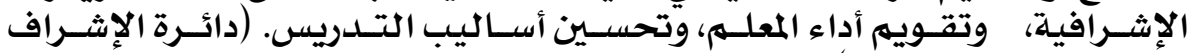

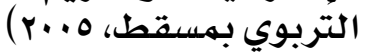

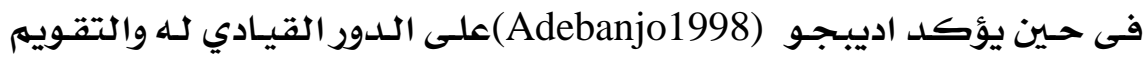

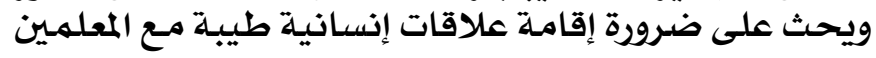

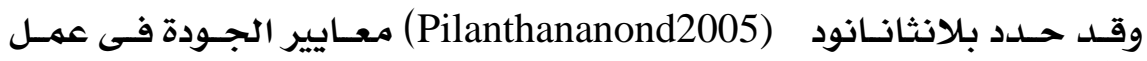

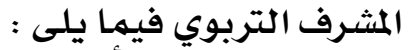

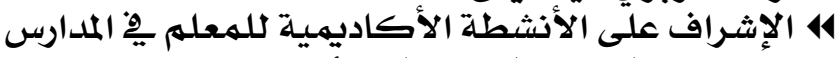

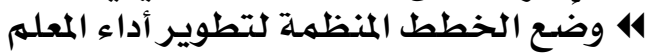

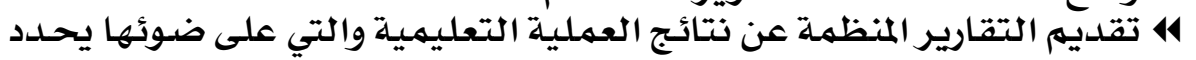

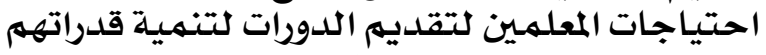

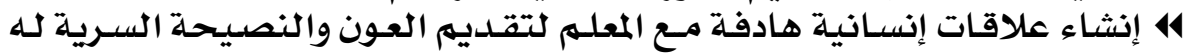
كتطوير أداءه.

ويحدد ادنيك (denaike2010) معايير الجودة هِّ عمل المشـرف التربـوي فيما

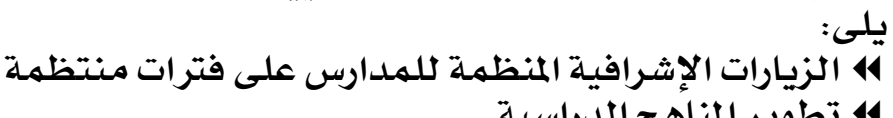

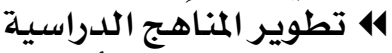

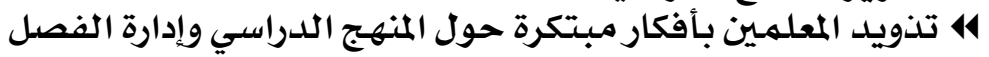

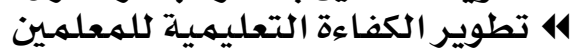

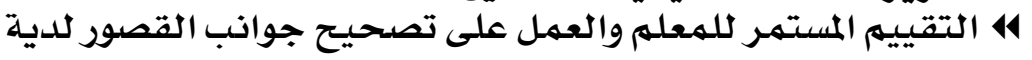

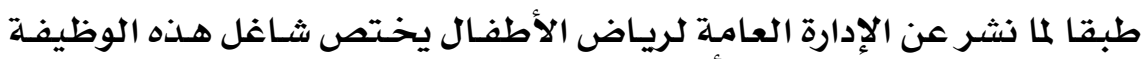

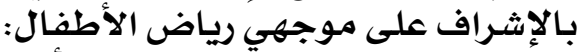

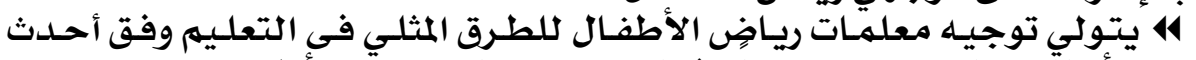

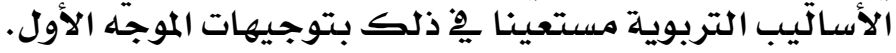

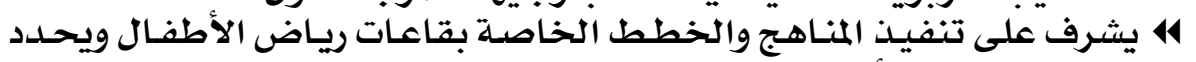
مدي تحقيقها تلأهداف تلفئن

\section{$r \varepsilon q$}




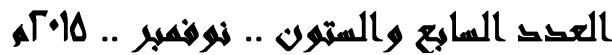

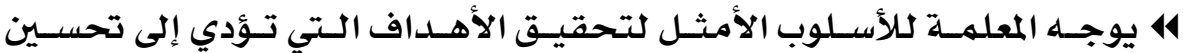

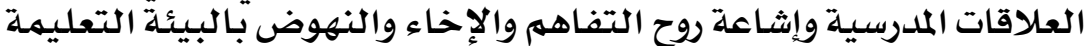

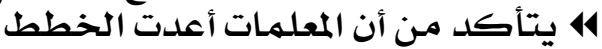

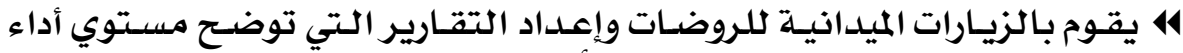

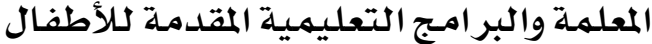

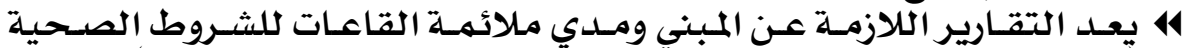

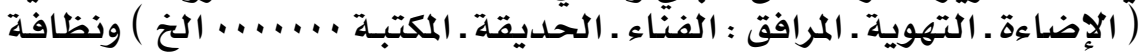

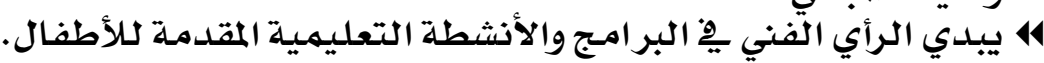

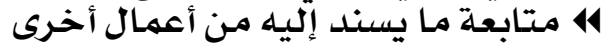

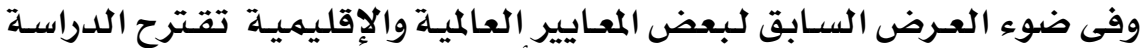

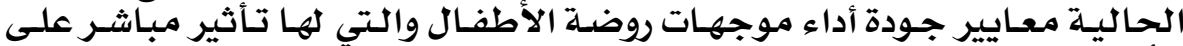

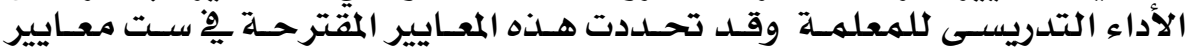

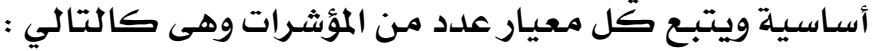

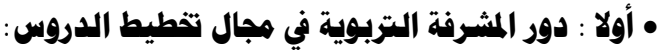

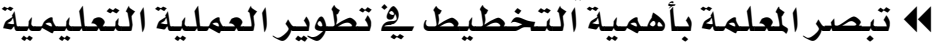

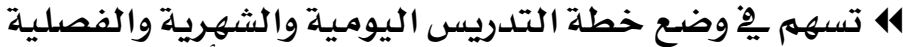

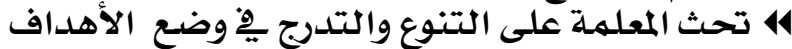

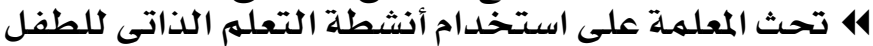

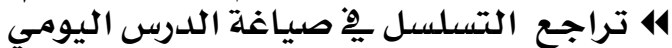

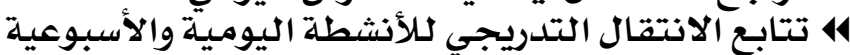

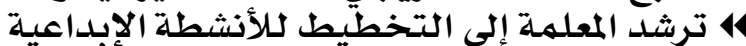

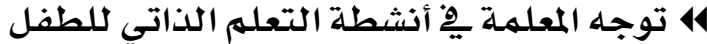

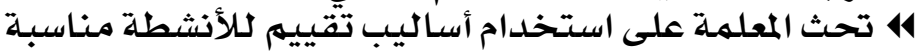

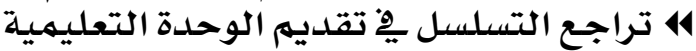

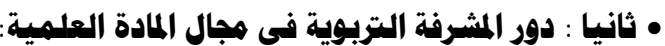

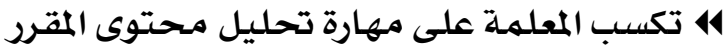

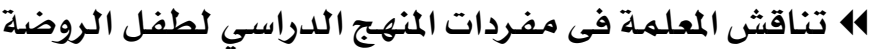

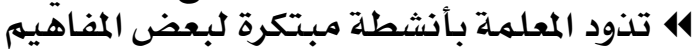

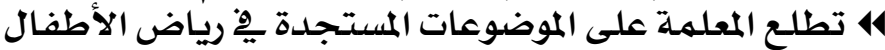

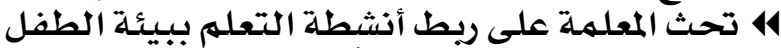

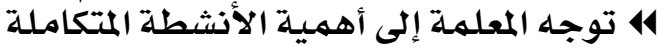

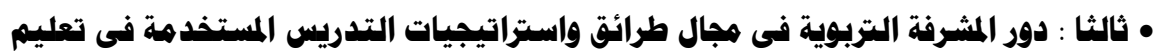

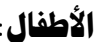

414 تدرب المعلمة على اختيار الأساليب المناسبة للموقف المقات التعليمي

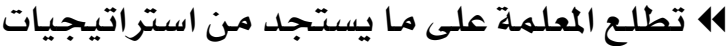

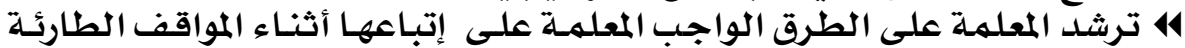

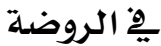
4 توجـه المعلمة إلى مهارة طرح الأسئلة المناسبة لطفل الروضدة

\section{Y०.}




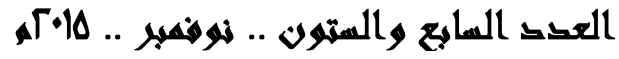

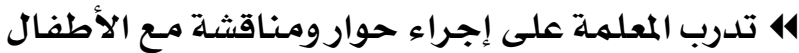

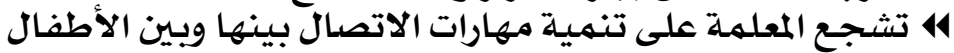

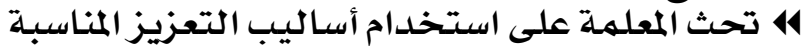

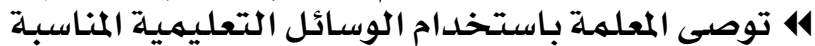

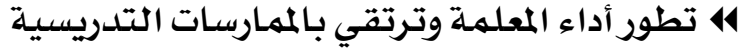

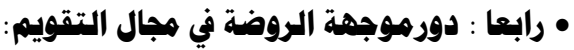

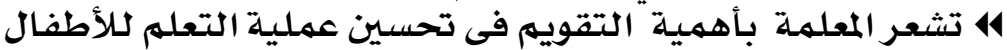

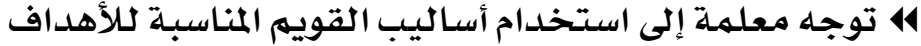

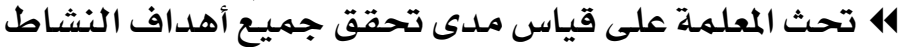

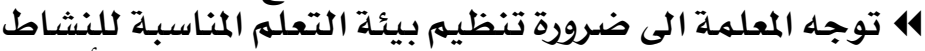

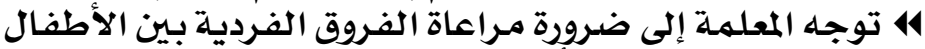

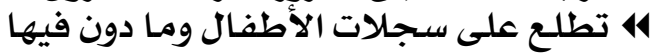

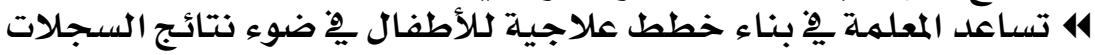

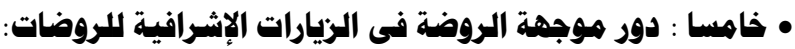

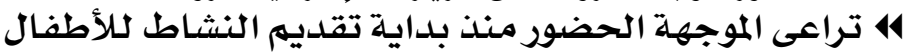

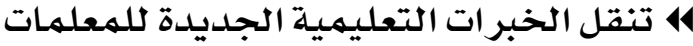

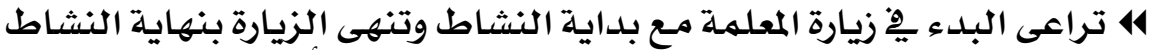

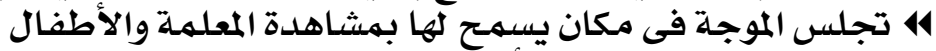

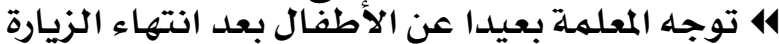

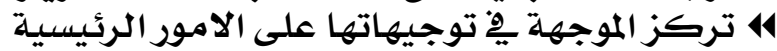

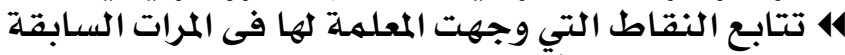

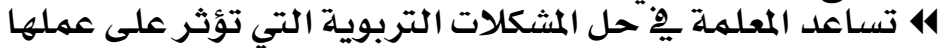

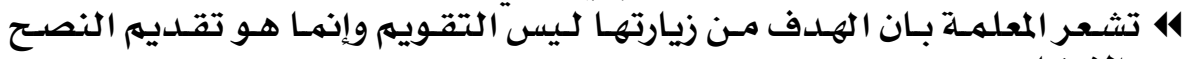
والإرشاد

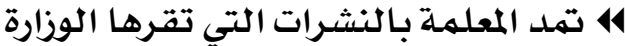

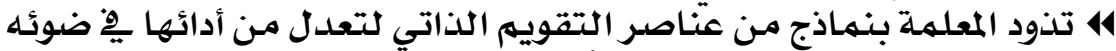

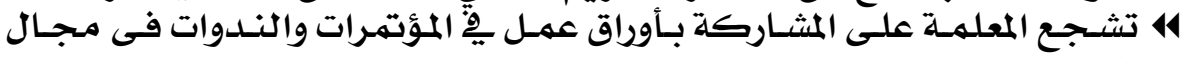

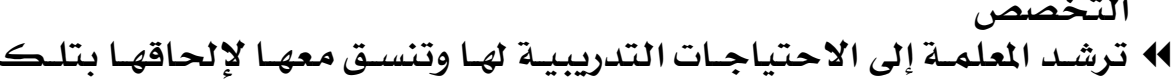

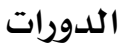

• سادسا : دور هوجهة الروضة فى هجال العلاقات الإنسانية هم المعلمات :

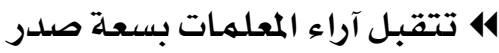

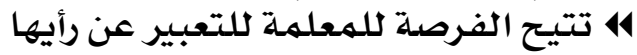

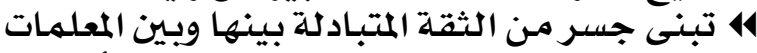

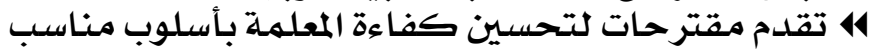

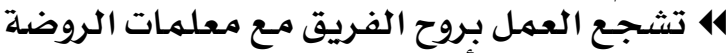

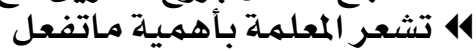

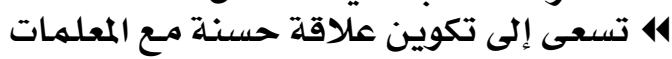

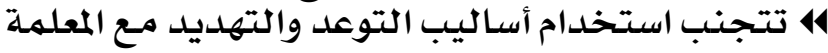

\section{Y 1}


العكى العابي والستون .. نوهمبر ..

44 تشعر المعلمة بالأمن النفسي أثناء التعامل معها

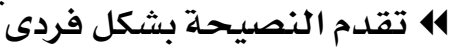

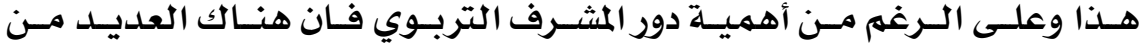

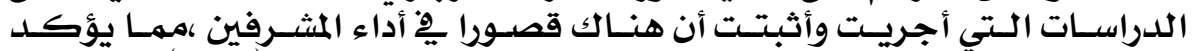

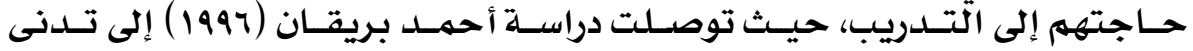

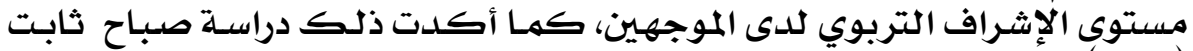

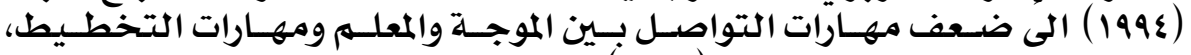

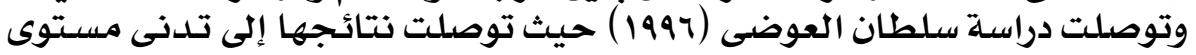

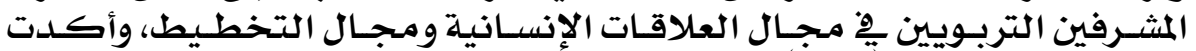

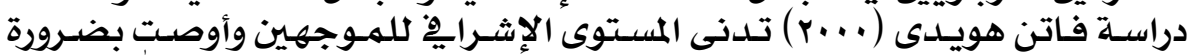

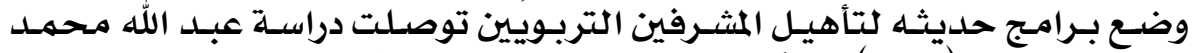

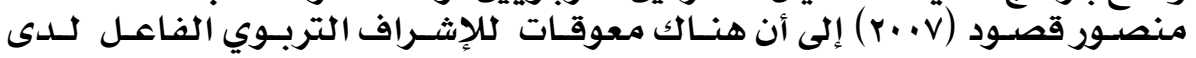

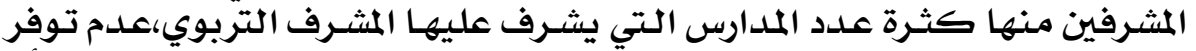

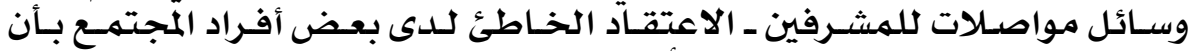

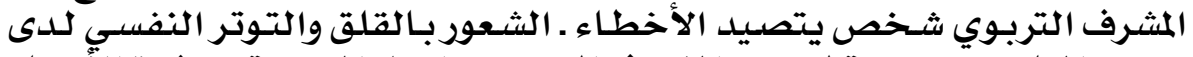

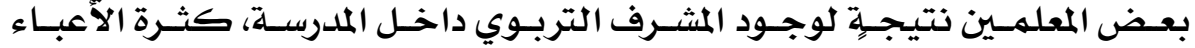

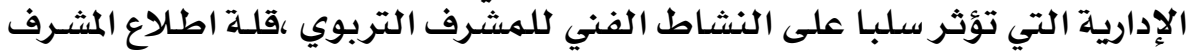

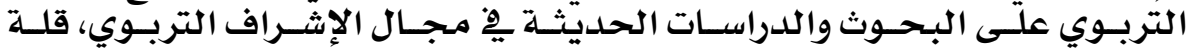

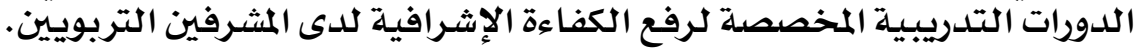

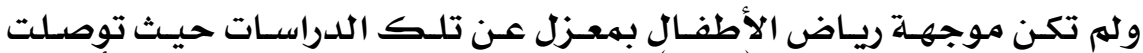

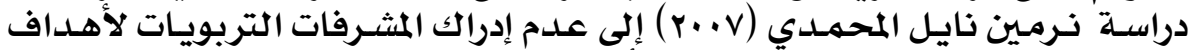

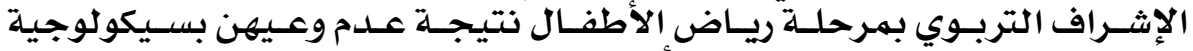

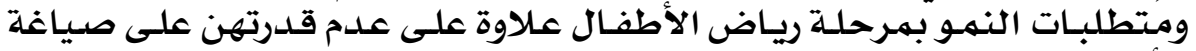

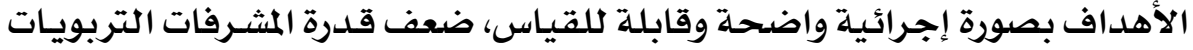

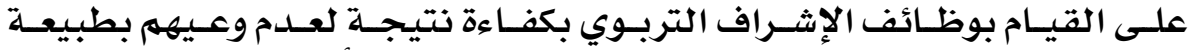

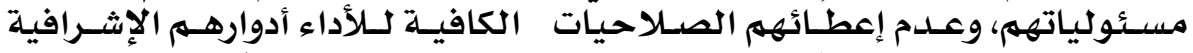

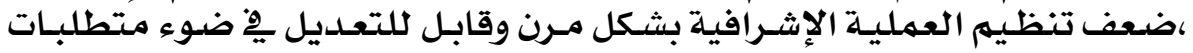

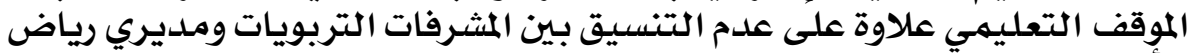

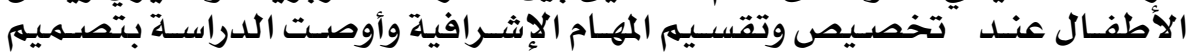

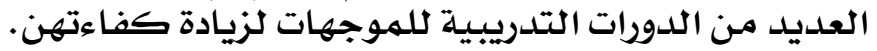

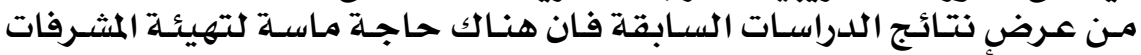

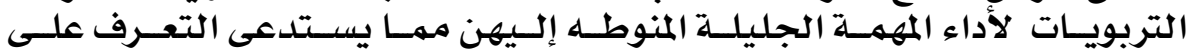

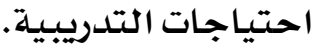

• الاحتياجات التدريبية أثناء الخدهية.

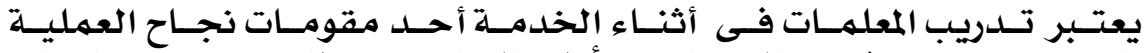

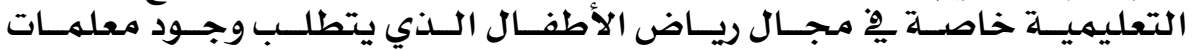

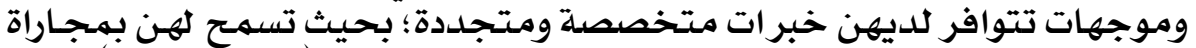

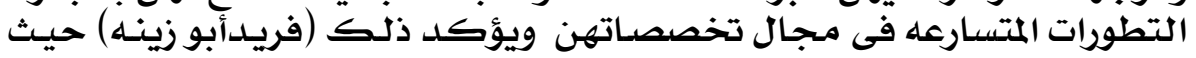

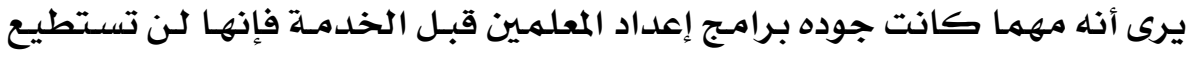




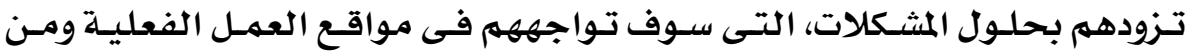

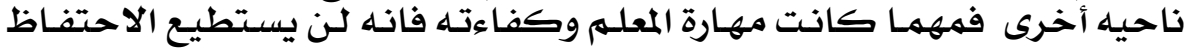

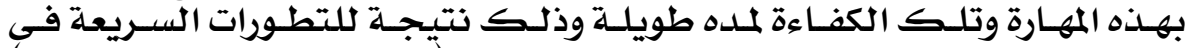

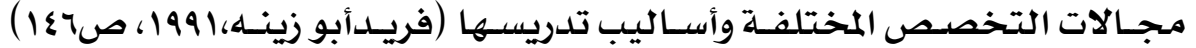

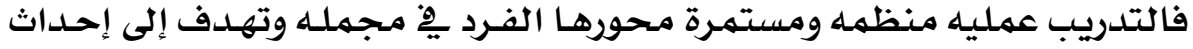

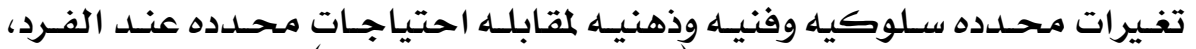

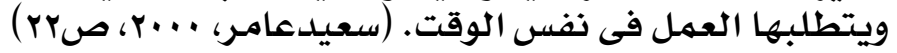

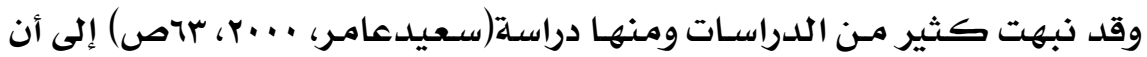

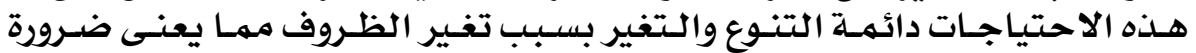

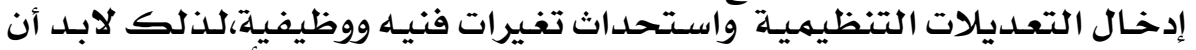

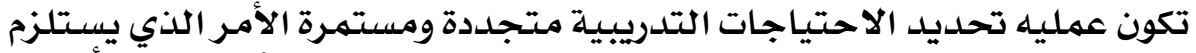

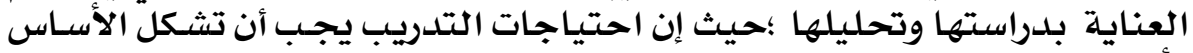

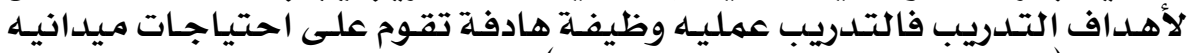

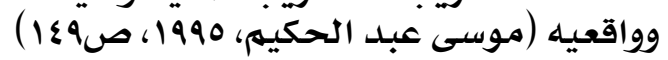

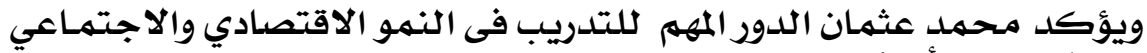

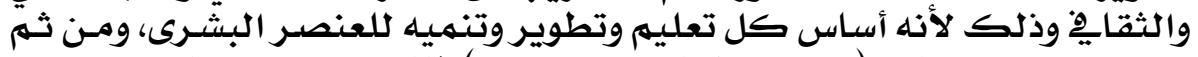

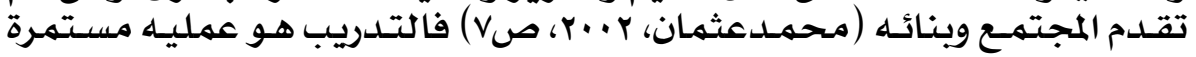

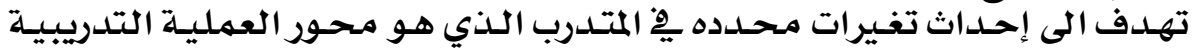

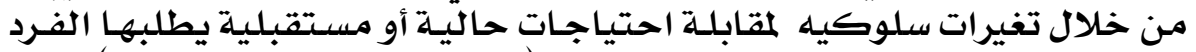

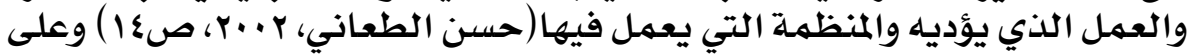

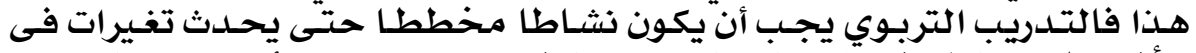

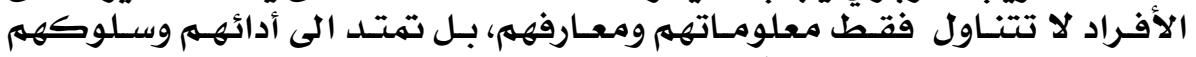

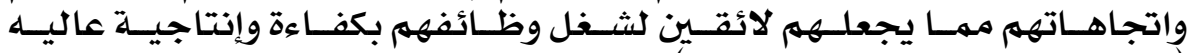

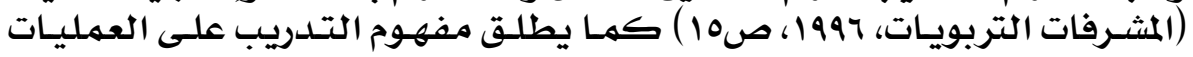

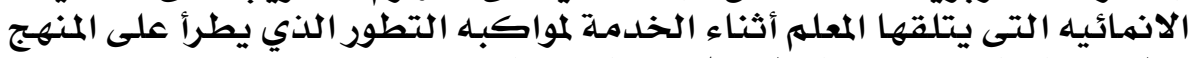

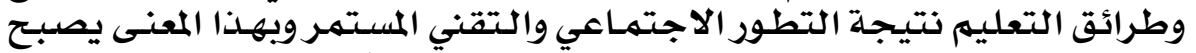

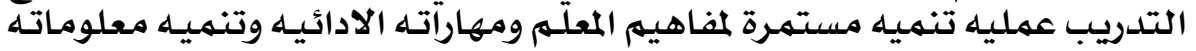

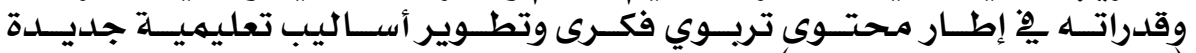

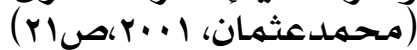

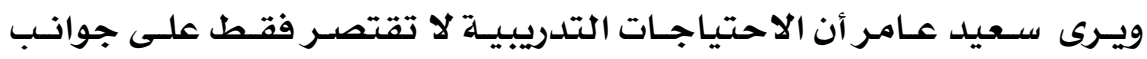

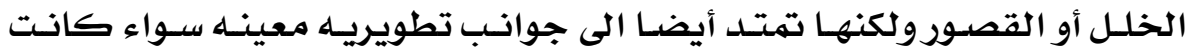

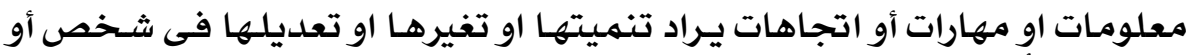

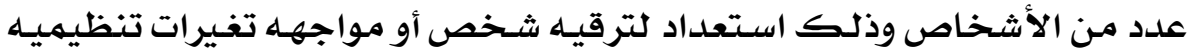

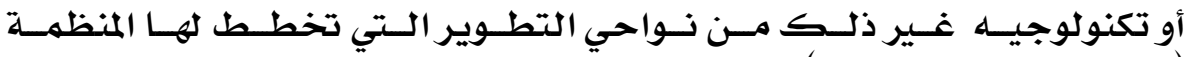

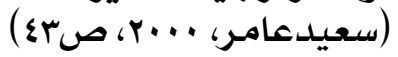

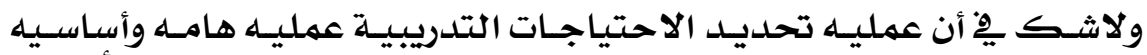

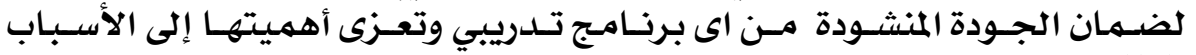
التالية : انفيان

\section{$Y \bullet Y$}




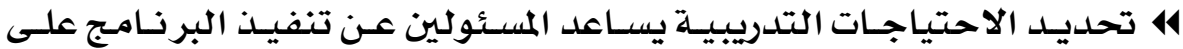

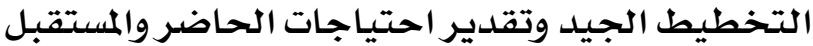

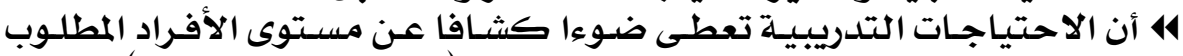

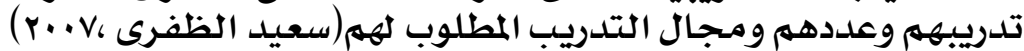

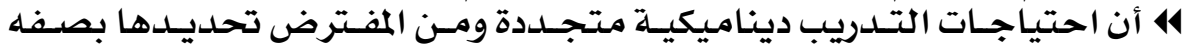

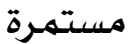

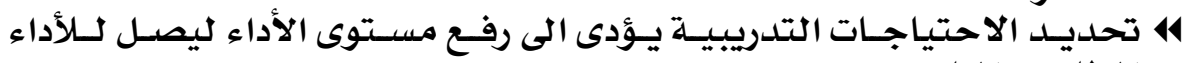
المطلوب والمناسب الاحتياجات

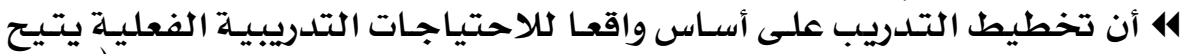

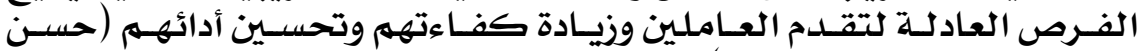

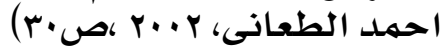

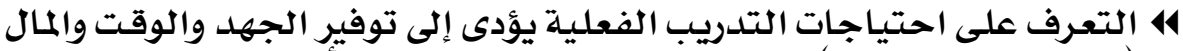

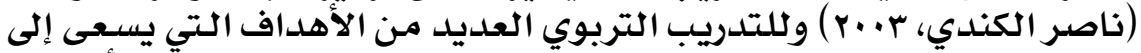

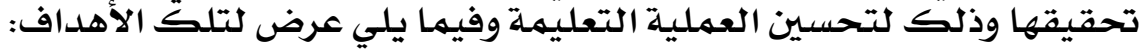

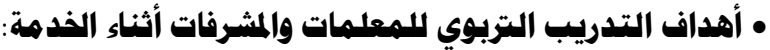
414

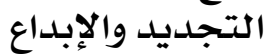
4 تعزيز خبر ات المعلمـين يِّ تطوير مهاراتهم وتعريفهم بمشكلات التعليهم وطرق علاجها 4 تبصير المعله بالطرق المناسبـة وتسـاعده على أداء عملـه بطريقـه جيـلده وبجهـد

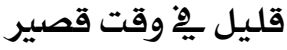

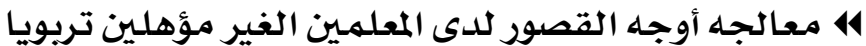

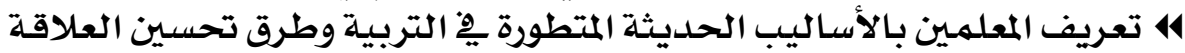

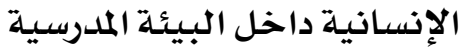

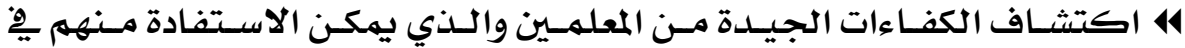

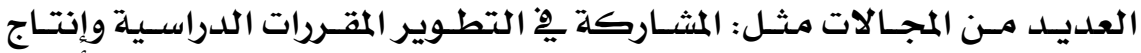

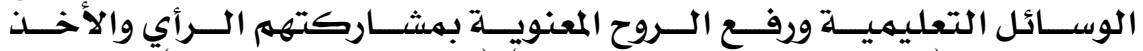

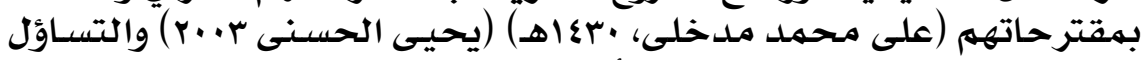

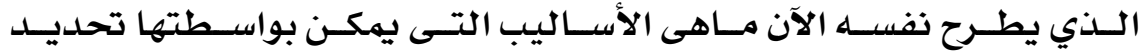

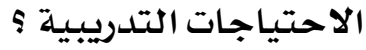

• أساليب تهديد الاحتياجات التدريبية وهى : تهابل

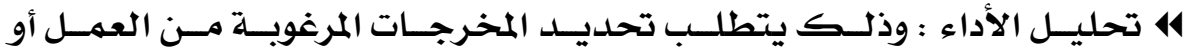

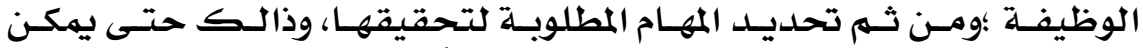

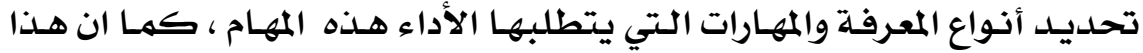

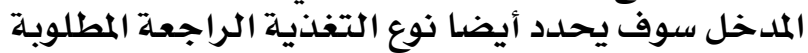

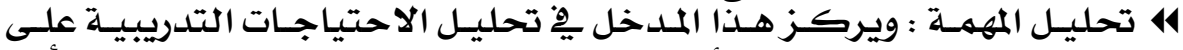

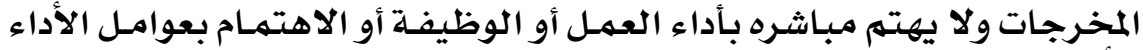

\section{$Y \odot \varepsilon$}




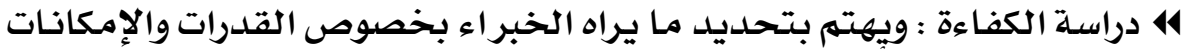

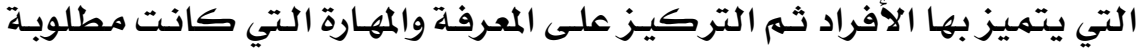

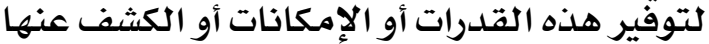

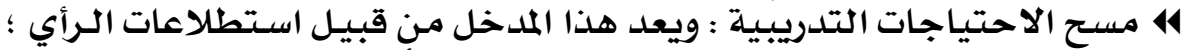

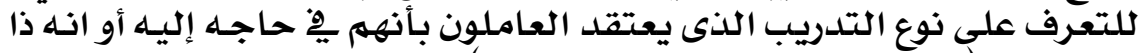

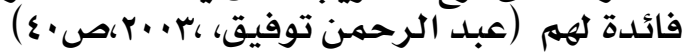

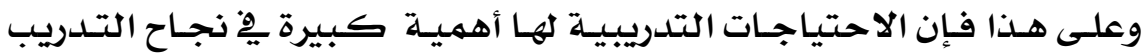

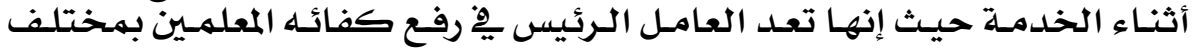

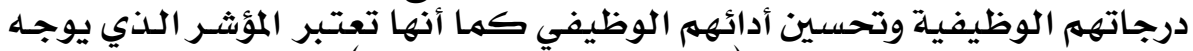

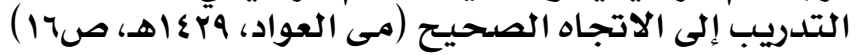

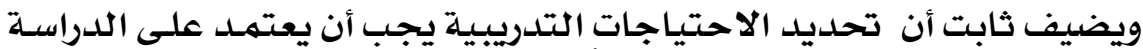

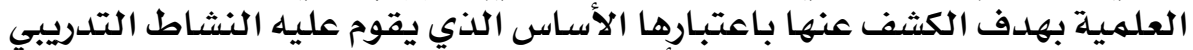

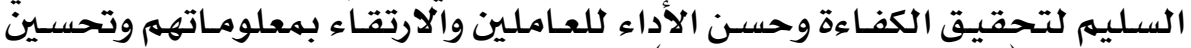

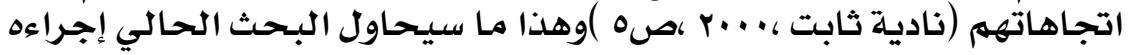

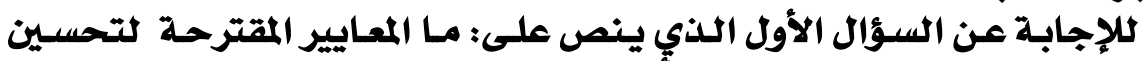

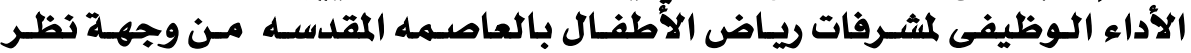

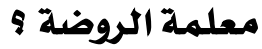

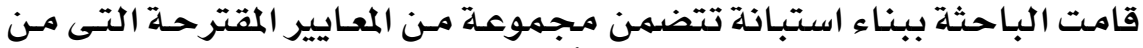

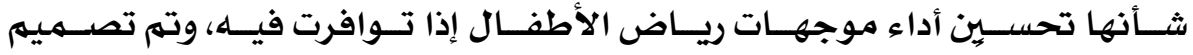
الاستبانه وفقا للخطوات أدوات التالية:

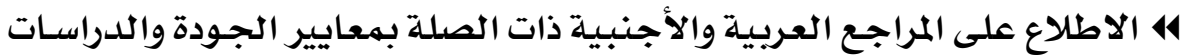

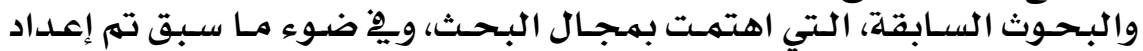

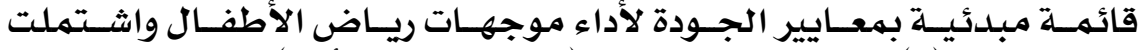

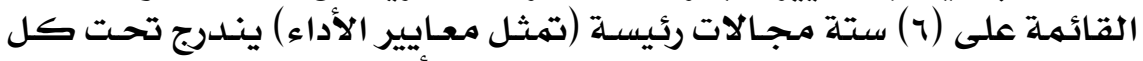

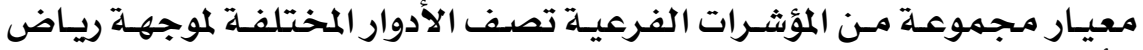

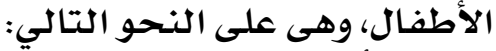

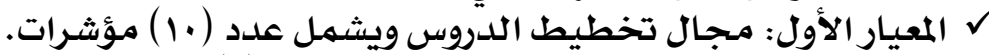

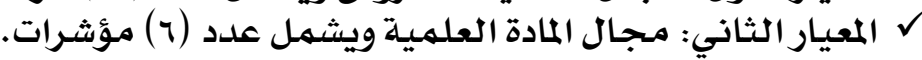

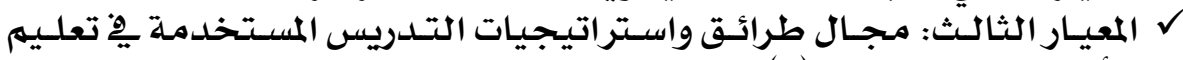

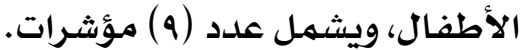

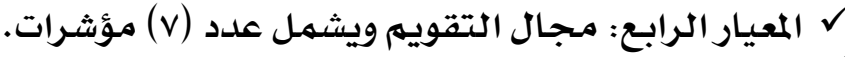

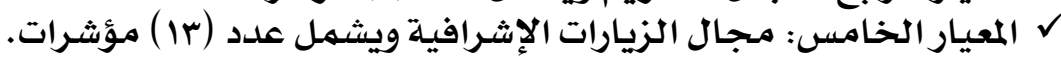

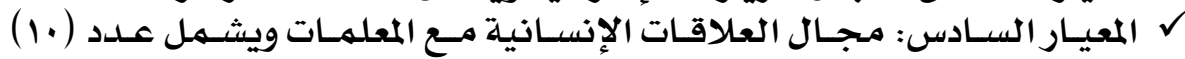

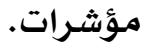
وبـذلك يكون عدد المؤشرات التي تنضمنها القائمة المبدئية (ه0) مؤشـرا. 


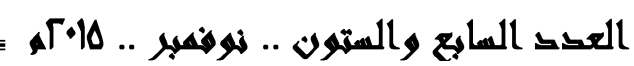

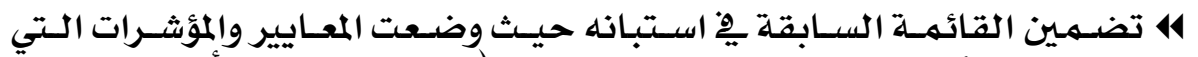

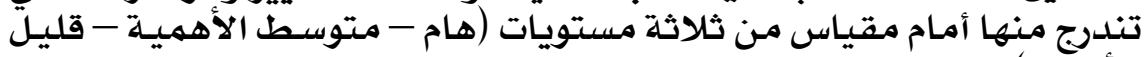

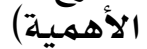

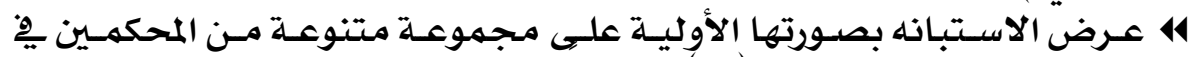

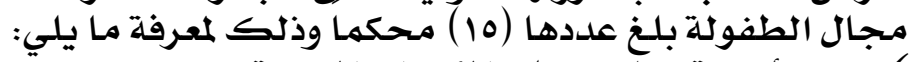

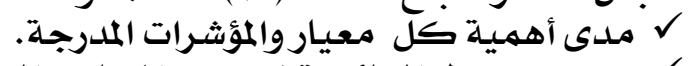

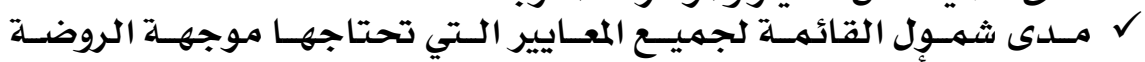

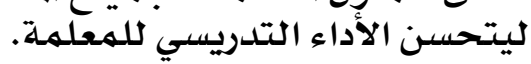

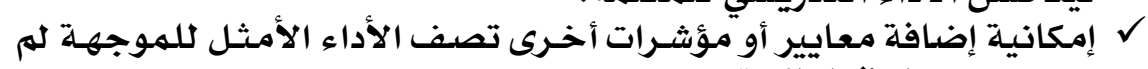

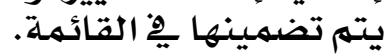

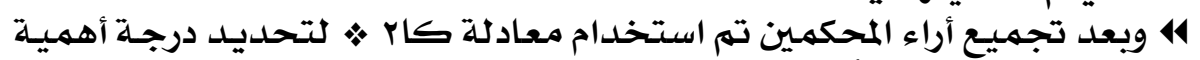

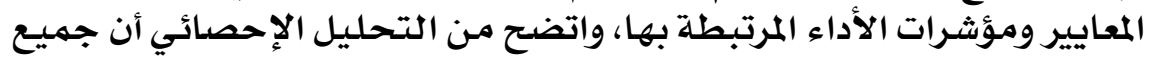

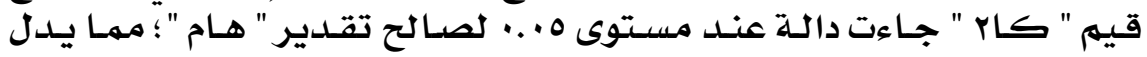

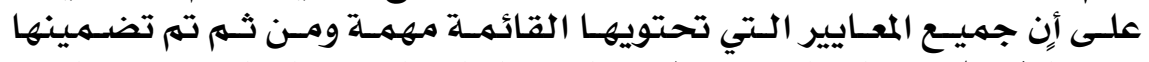

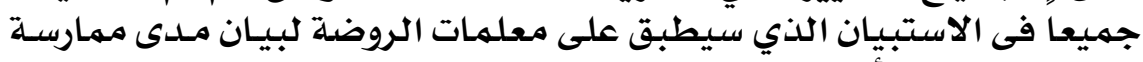

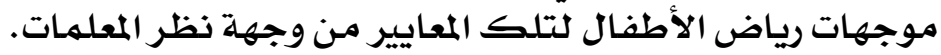

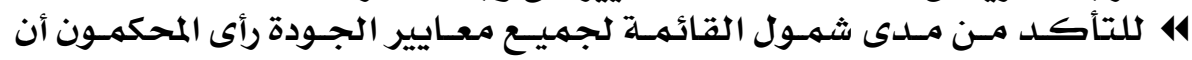

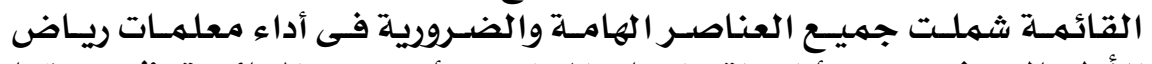

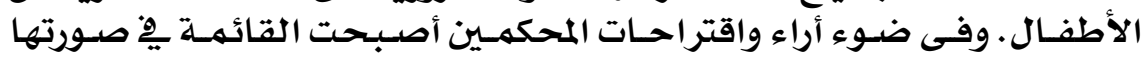

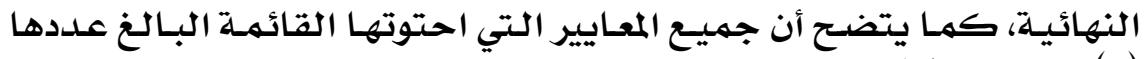

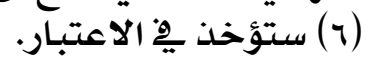

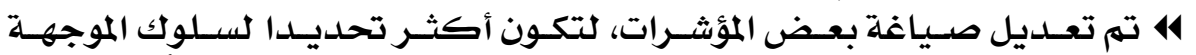

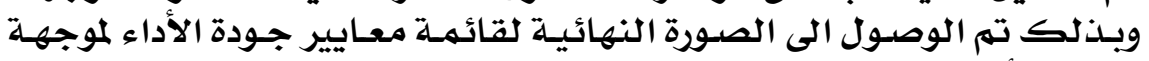

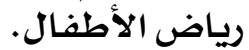

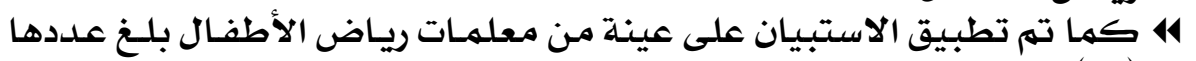

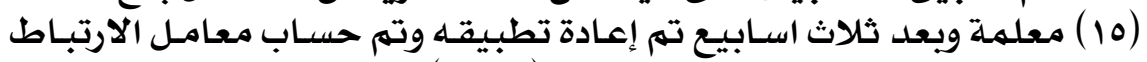

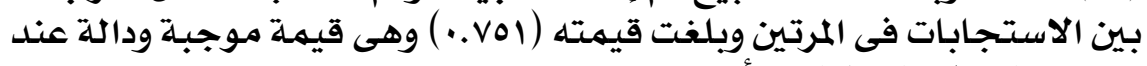

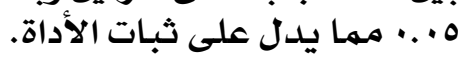

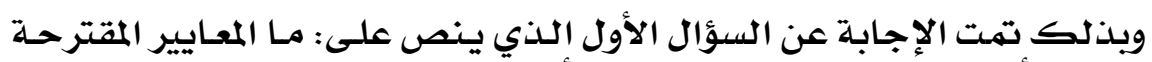

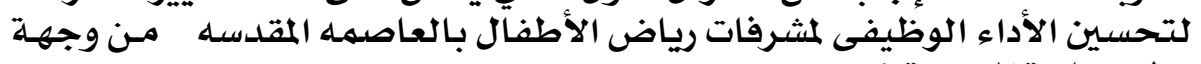

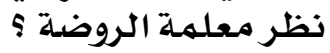

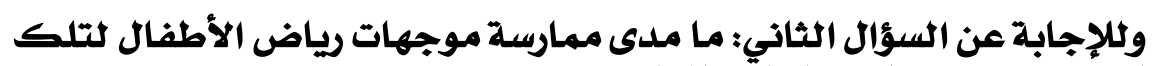

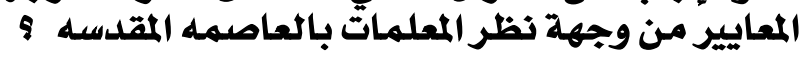

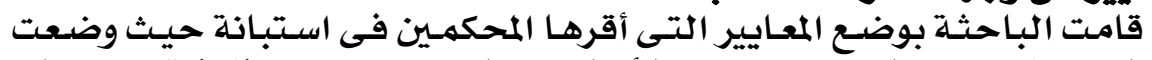

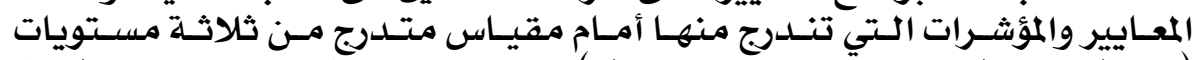

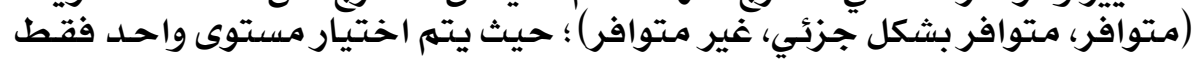

" القيمة الجدولية لـ " كاء " عند درجة حرية ب، ومستوى دلالة 0.05 تساوى 99. 


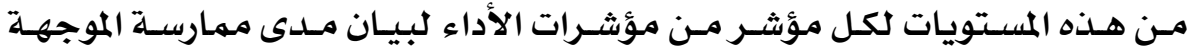
لتلك المؤشرات.

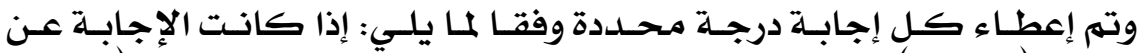

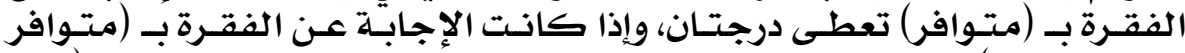

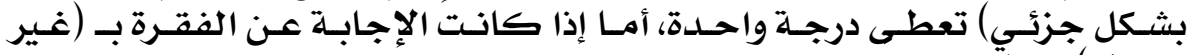
متتوافر) تعطى جرئ صفرا. تصفى

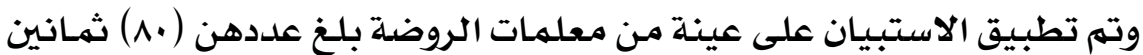

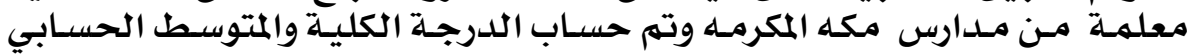

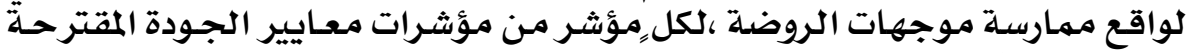

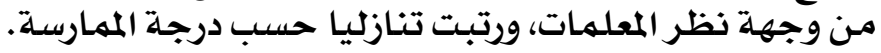

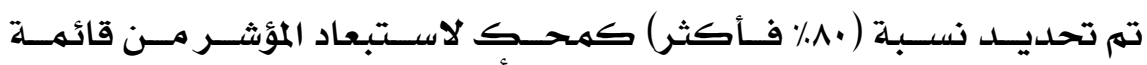

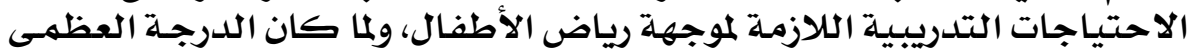

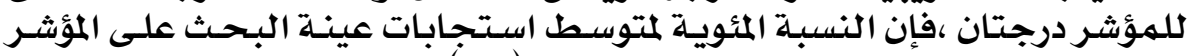

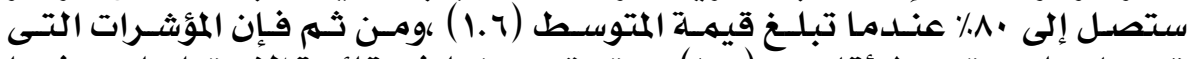

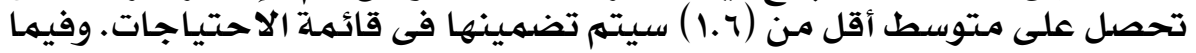

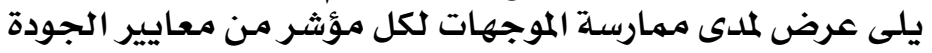

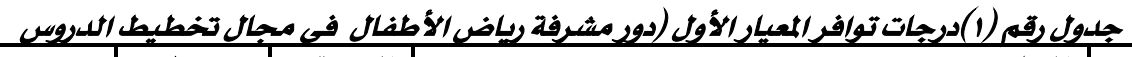

\begin{tabular}{|c|c|c|c|c|}
\hline ترتيب & متوسط الضرجمات & الدرجة الكلية & المعيار & م \\
\hline 1 & $1 . \wedge V_{0}$ & 10. & تشعر المعلمة بأهمية التخطيط فى تطوير العملية & 1 \\
\hline$r$ & 1.10 & I\&A & تساهم في وضع خطة التدريس اليومية والشهرية والفصلية & $r$ \\
\hline$r$ & 1. Alr & $1 \varepsilon 0$ & تحث المعلمة على التنوع والتدرج فِوضع الأهداف & $r$ \\
\hline 1. &. .0 & $\varepsilon$. & تحث المعلمة على تحقيق أهداف المرحلة ككل & $\varepsilon$ \\
\hline$\varepsilon$ & 1.60 & IEY & تراجع التسلسل ـِ صياغة الدربي اليومي & $\mathbf{0}$ \\
\hline - & $1.7 Y_{0}$ & ir. & والشتابع الانتقال التدريجي ثلأثشة اليومية والأسبوعية & 7 \\
\hline 7 & 1.rvo & 11. & ترثل المعلمة إلى التخطيط كلأنشطة الإبلاعية & $\mathbf{v}$ \\
\hline 9 &. $.0 \mathrm{~V}$ & $\varepsilon 7$ & توجه المعلمة _2 أشططة التعلم الذاتى للطفل & $\hat{\Lambda}$ \\
\hline$\Lambda$ & $\because$ Vo & 7. & تحث المعلمة على استخدام أساليب تقييم للأثشطة مناسبة & 9 \\
\hline $\mathrm{v}$ & $1 . Y 0$ & $1 \ldots$ & تراجع التسلسل ـٍ تقديم الوحلدة التعليمية & 1. \\
\hline
\end{tabular}

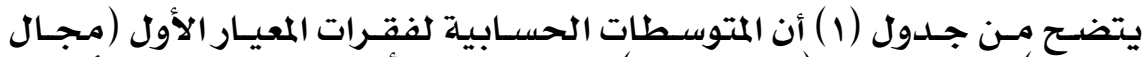

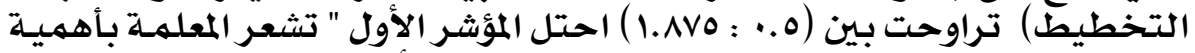

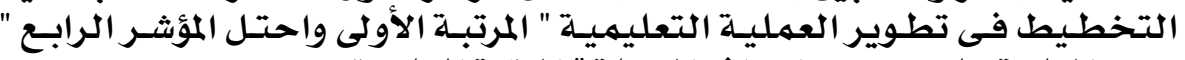

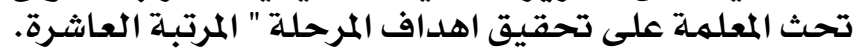

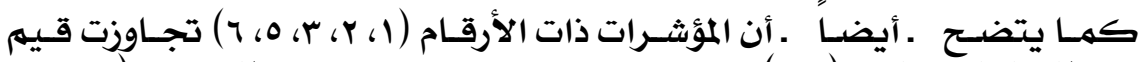

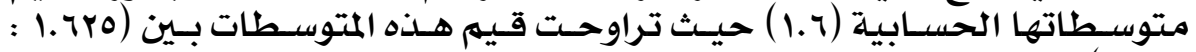

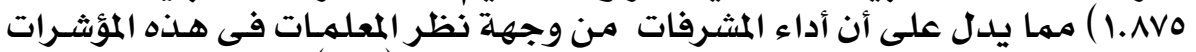

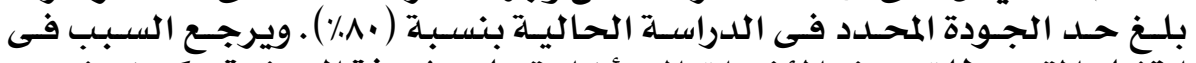

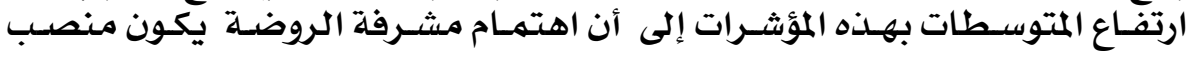

\section{$Y \otimes V$}




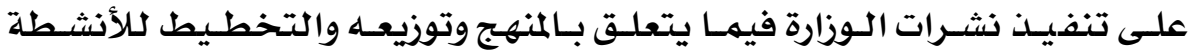

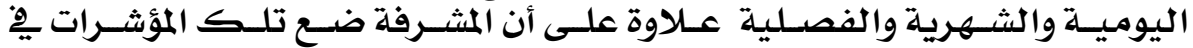

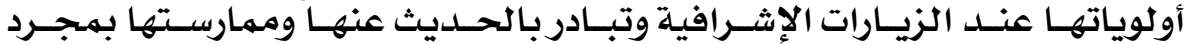
الالتقاء بالمعلمات.

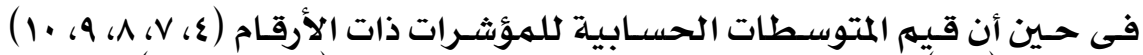

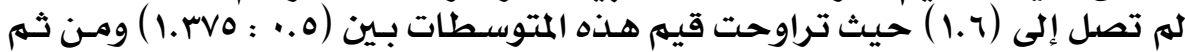

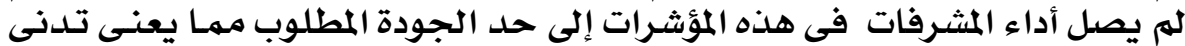

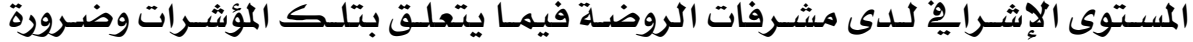

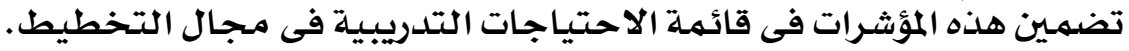

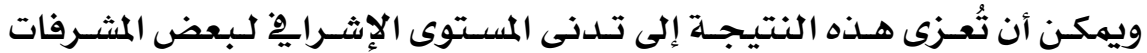

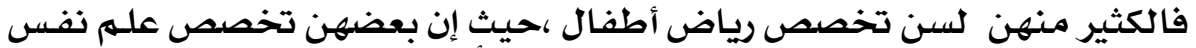

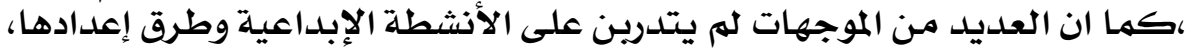

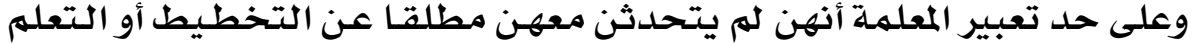

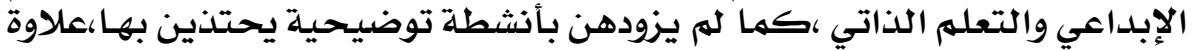

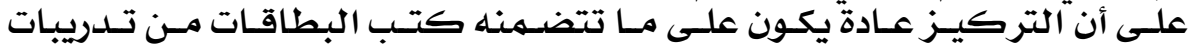

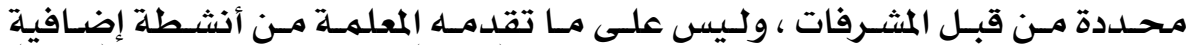

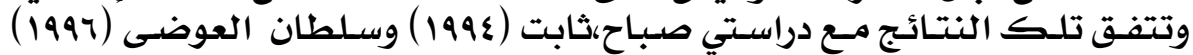

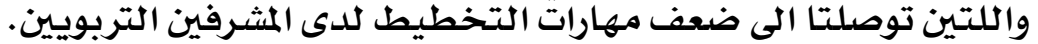

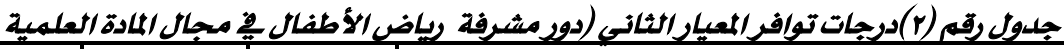

\begin{tabular}{|c|c|c|c|c|}
\hline ترتيبي & متوسط & الكلدرجة & المعيار & p \\
\hline$r$ & $1 . \mathrm{YM}$ & $1 . \mu$ & تكسب المعلمة على مهارة تحليل محتوى المقرر & 1 \\
\hline$\varepsilon$ & $1 \ldots$ & A. & تناقش المعلمة يِ مفردات المنهج الدراسى لطفل الروضة & $r$ \\
\hline 9 & - Alr & 70 & تذود المعلمة بأشطة مبتكرة لبعض المفاهيم & \\
\hline 0 & $.94 \mathrm{r}$ & vo & تطلع المعلمة على الموضوعات المستجدة في رياض الأطفال & $\varepsilon$ \\
\hline$r$ & 1. Avo & 10. & تحث المعلمة على ريط أنشطة التعلم بيئة الطفل & 。 \\
\hline 1 & $1.9 \mathrm{r} \Lambda$ & 100 & توجه المعلمح إلى أهمية الأثشطة المتكاملة & 7 \\
\hline
\end{tabular}

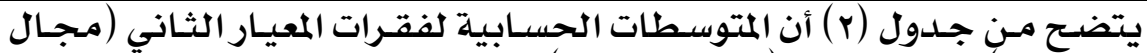

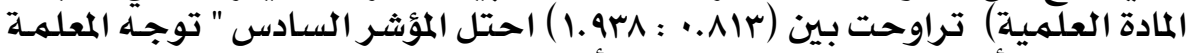

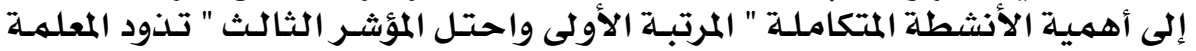

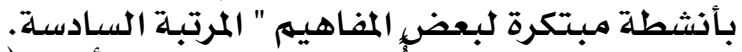

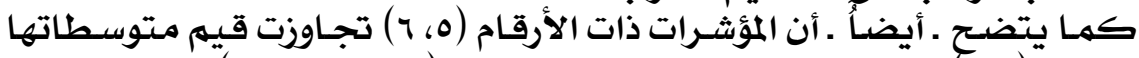

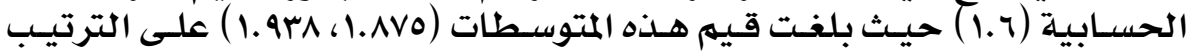

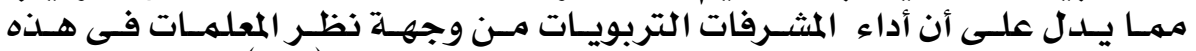

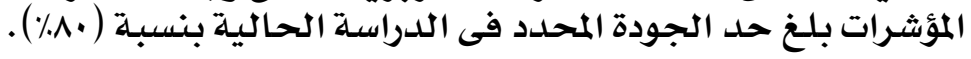

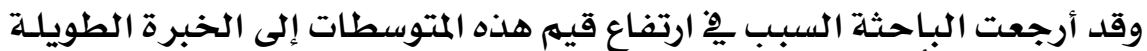

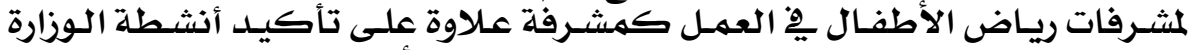

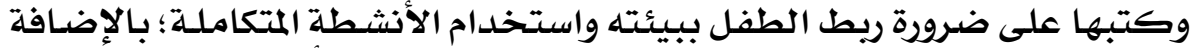

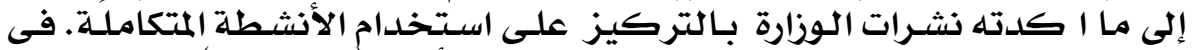

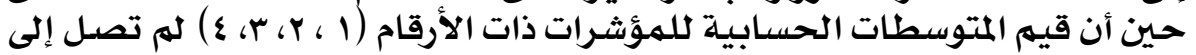

\section{$Y \odot \wedge$}




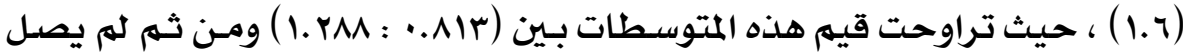

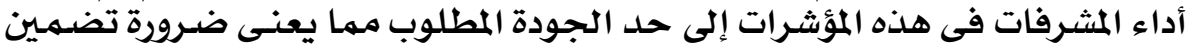

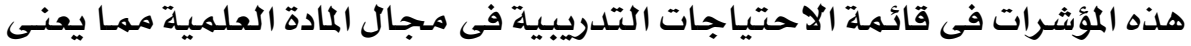

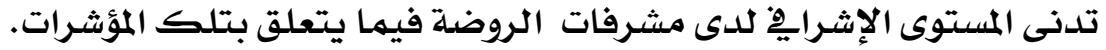

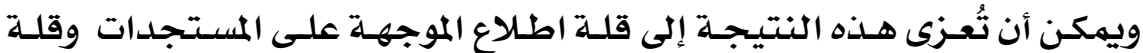

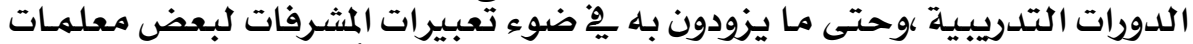

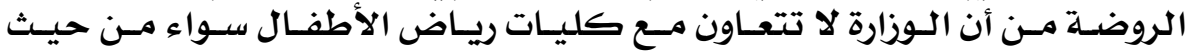

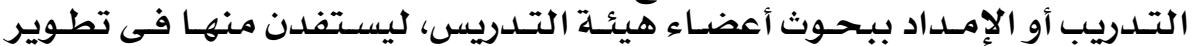

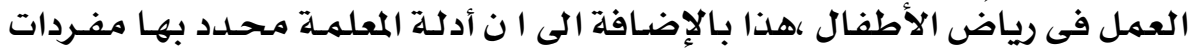

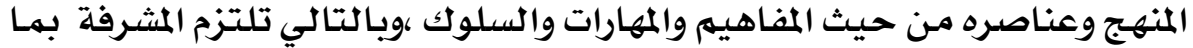

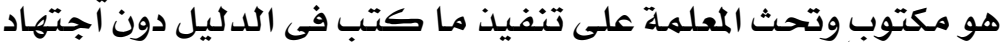

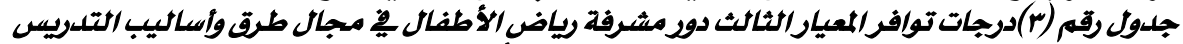

\begin{tabular}{|c|c|c|c|c|}
\hline \multicolumn{5}{|c|}{ المتخخدمة في تعليم/الأطفال } \\
\hline ترتيبير & متوسط الدرجات & ال الدلية & المعيار & \\
\hline 7 & 1.80 & $1 \ldots$ & تلتعليمي المعلمة على اختيار الأساليب المناسبة للموقف & \\
\hline A & $1.1 \mathrm{rr}$ & $\Lambda 9$ & تطلع المعلمة على مايستجد من استراتيجيات & $r$ \\
\hline $\mathrm{v}$ & $1.1 \% 0$ & 9. & ترائد المعلمة إلىوضي الطرق الواجب اتباعها أثناء المواقف & $r$ \\
\hline$\varepsilon$ & 1.ro & $1 \cdot 1$ & توجه المعلمة إلى مهارة طرح الأسئلة المناسبة لطفل الروضة & $\varepsilon$ \\
\hline 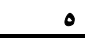 & $1 . \mathrm{rar}$ & 1.1 & تدرب المعلمة على إجراء حوارومناقشة مع الأطفال & - \\
\hline$r$ & 1.VYo & ira & تشجيح المعلمة على تنمية مهارات الاتصال بينها وبين & 7 \\
\hline 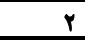 & $1 . v_{0}$ & $1 \varepsilon$. & تحث المعلمة على استخدام أساليب التعزيز المناسبة & $\mathbf{v}$ \\
\hline 1 & $1 . \wedge 1 \mathrm{r}$ & 180 & توصى المعلمة باستخدام الوسائل التعليمية المناسبة & $\mathbf{A}$ \\
\hline 9 & $.9 \mathrm{vo}$ & $\mathrm{va}$ & تمد المعلمة بحقائب تعليمية & 9 \\
\hline
\end{tabular}

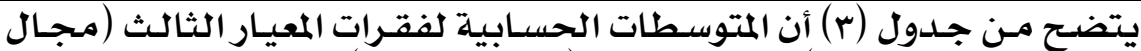

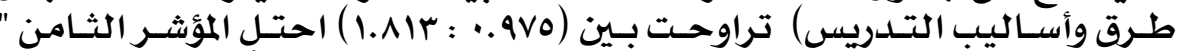

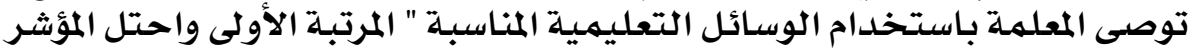

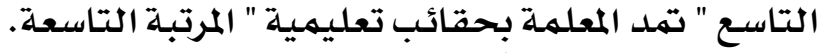

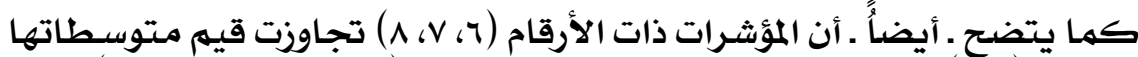

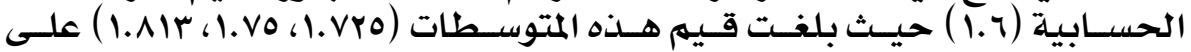

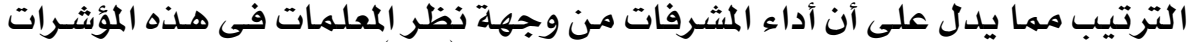

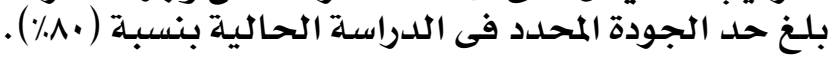

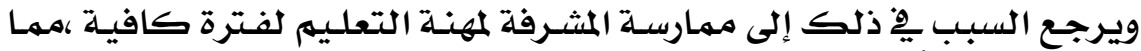

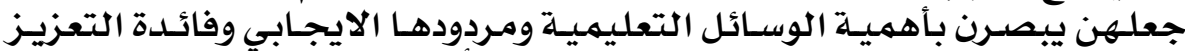

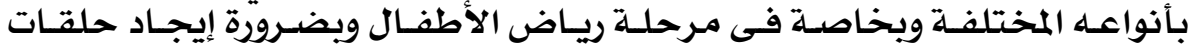
وصل بين المعلمهة والطفل.

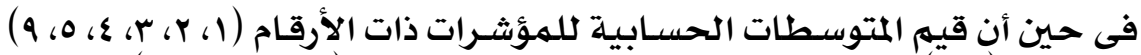

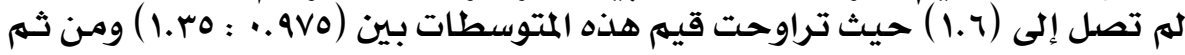

\section{Y०Q}




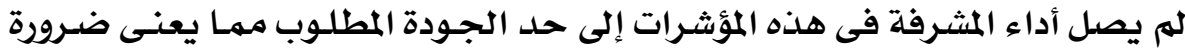

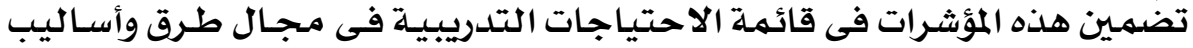

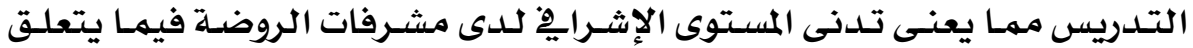
بتلك المؤشرات.

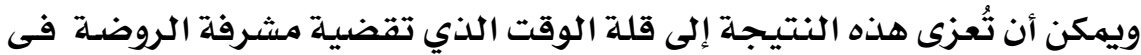

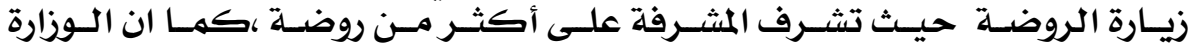

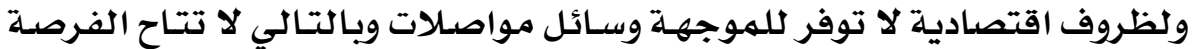

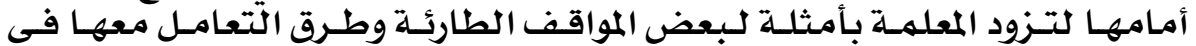

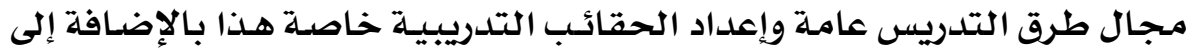

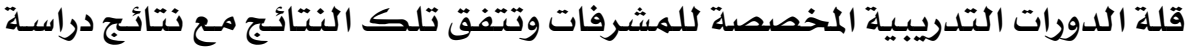

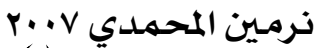

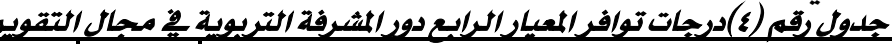

\begin{tabular}{|c|c|c|c|c|}
\hline ترتيبي & الدروحطات & الكلية & المعيار & p \\
\hline 1 & 1.9 & 10r & تشعر المعلمح بأهمية التقويم في تحسين عملية التعلم للأطفال & 1 \\
\hline $\bar{r}$ & 1.10 & IEA & توجه معلمح إلى استخدام أساليب القويم المناسبح كلأهداف & $r$ \\
\hline$\varepsilon$ & $1.2 \mathrm{rA}$ & 110 & تحث المعلمة على قياس مدى تحقق جميع أهداف النشاط & $\underline{r}$ \\
\hline$r$ & $1 . v 0$ & $1 \varepsilon$. & توجه المعلمة إلى ضرورة تنظيم بيئة التعلم المناسبة للنشاط & $\varepsilon$ \\
\hline - & $1 . r v o$ & 11. & توجه المعلمة إلى ضرورة مراعاة الفروق الفردية بين الأطفال & - \\
\hline 9 & 1.rir & 1.0 & تطلع على سجلات الأطفال وما دون فيها & \\
\hline $\mathrm{v}$ & $1 . Y M$ & 1.r & 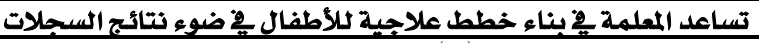 & \\
\hline
\end{tabular}

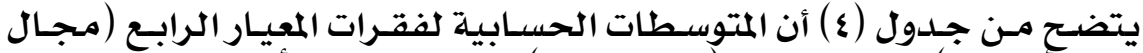

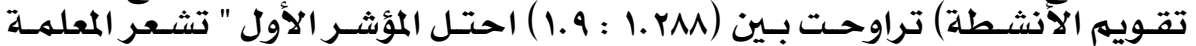

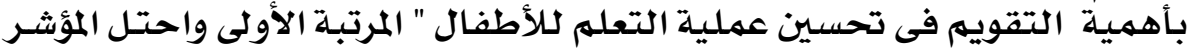

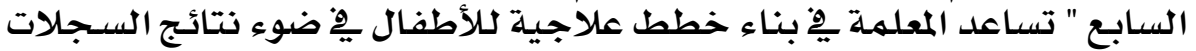

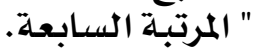

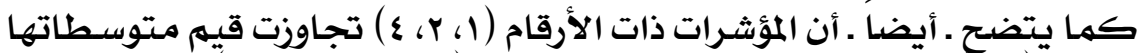

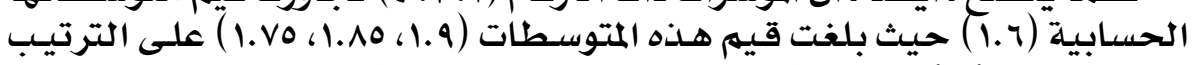

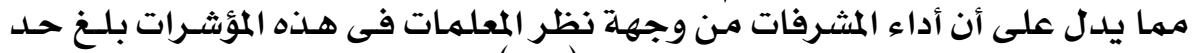

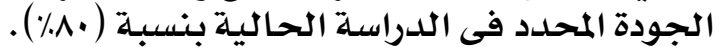

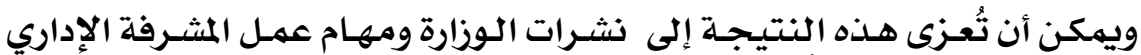

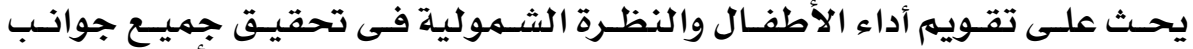

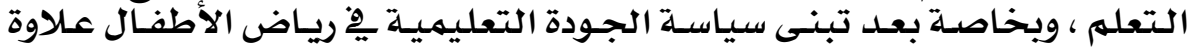

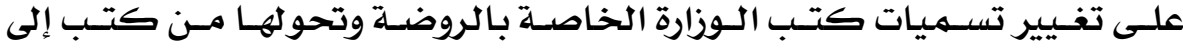
بطاقات تعليمية وتقويميلة.

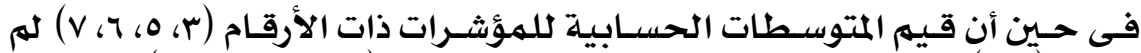

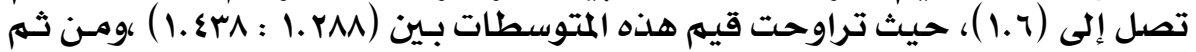

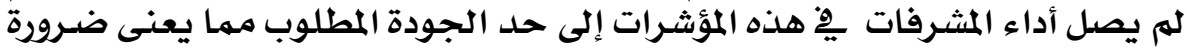

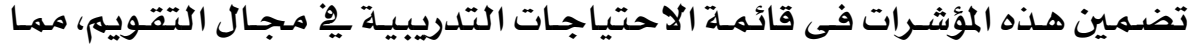

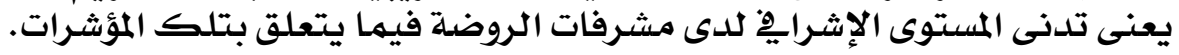

\section{Y 7.}




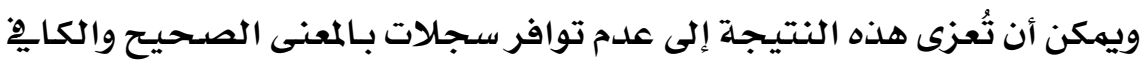

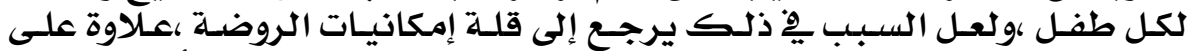

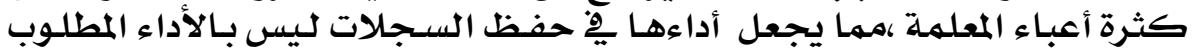

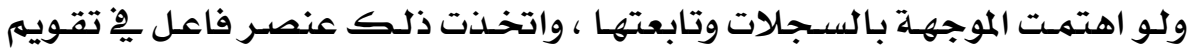

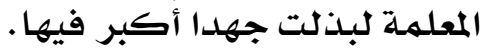

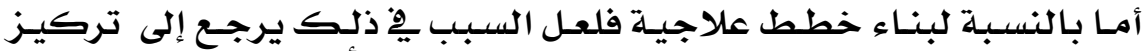

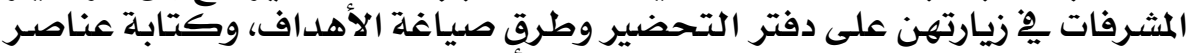

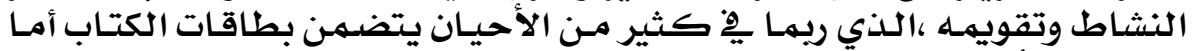

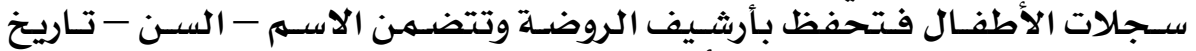

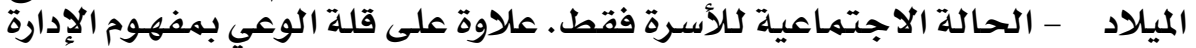

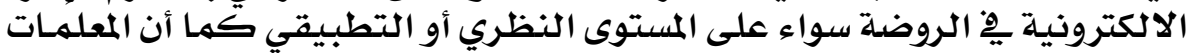

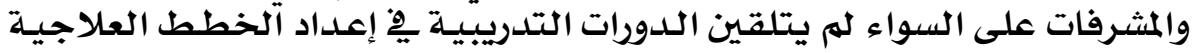

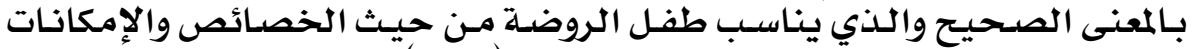

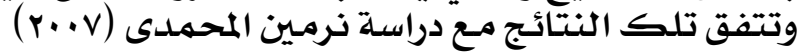

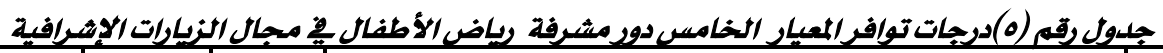

\begin{tabular}{|c|c|c|c|c|}
\hline ترتيبي & متوسطات & 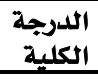 & المعيار & p \\
\hline$r$ & $1.0 Y 0$ & IrY & تراعى الموجهة الحضور منذ بداية تقديم النشاط ثلأطفال & 1 \\
\hline$r$ & $1.7 \% 0$ & ir. & تنقل الخبرات التعليمية الجليلة للمعلمات & $r$ \\
\hline$\varepsilon$ & 1.0 & ir. & النشاطى البدء يٌ زيارة المعلمة مـع بداية النشاط وتنهى الزيارة بنهاية & r \\
\hline 0 & $1.2 \mathrm{Vo}$ & 111 & تحلس الموجة في مكان يسمح لها بمشاهدة المعلمة والأطفال & $\varepsilon$ \\
\hline 1 & $1.1 \mathrm{No}$ & 10. & توجه بعيدا عن الأطفال بعد انتهاء الزيارة المعلمة & 0 \\
\hline A & 1.rre & $1 \cdot v$ & تركز الموجهة في توجيهاتها على الأمور الرئيسية & 7 \\
\hline 1 & 1.20 & 117 & تتابع النقاط التى وجهت المعلمة لها في المرات السابقة & $\mathbf{v}$ \\
\hline 9 & 1.YMA & 1.r & تساعد المعلمة في حل المشكلات التريوية التي تؤثر على عملها & $\hat{\Lambda}$ \\
\hline$\checkmark$ & 1.81r & lir & تشعرب المعلمة بان الهدف من زيارتها ليس التقويم وإنما هو تقديم النصح & 9 \\
\hline 1. & 1.YYo & $1 \cdot r$ & تمد المعلمة بالنشرات التى تقرها الوزارة & 1. \\
\hline 11 & $1 . .$. & A. & ضزود المعلمة بنماذج من مناصر التقويم الذاتى لتعدل من أدائها فى & 11 \\
\hline ir &. $.1 \% 0$ & 1. & تشجيع المعلمة على المشاركة باوداق عمل فى المؤتمرات والندوات فى & ir \\
\hline ir & .rvo & $r$. & ترثدر المعلمة الى الاحتياجات التدريبية لها وتنسق لإلحاقها بالدورات & ir \\
\hline
\end{tabular}

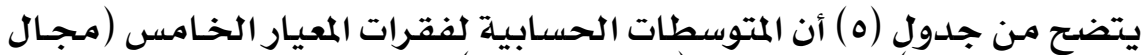

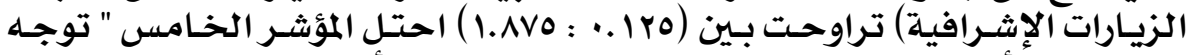

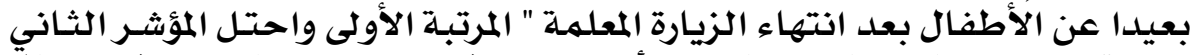

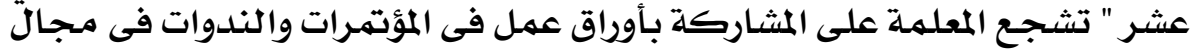
التخصص " "المرتبـة الثالثة عشلى عشر.

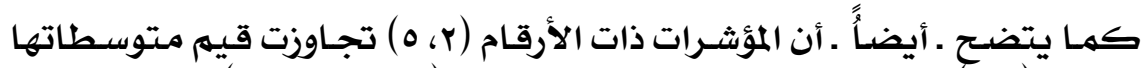

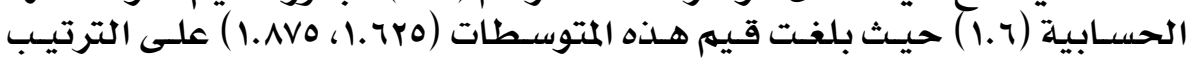

\section{หั1}




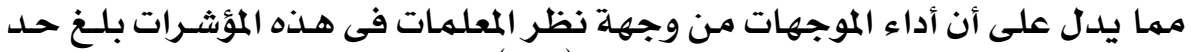

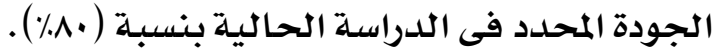

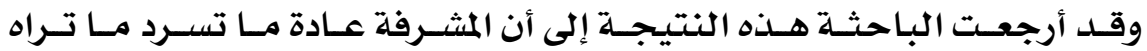

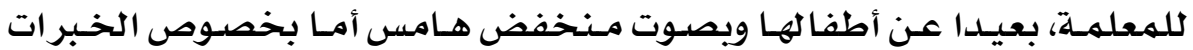

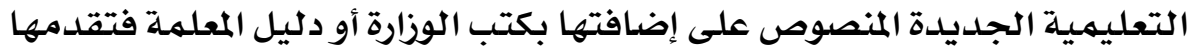

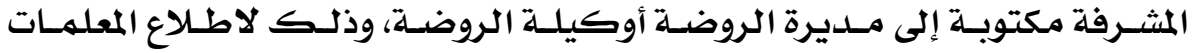

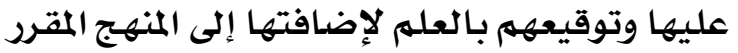

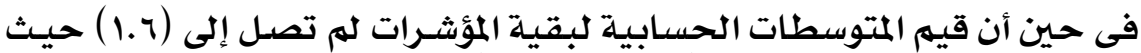

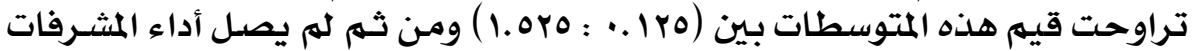

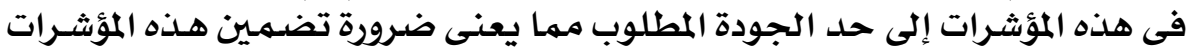

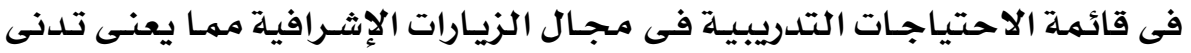

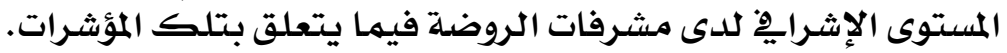

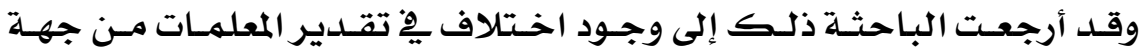

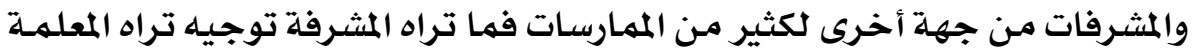

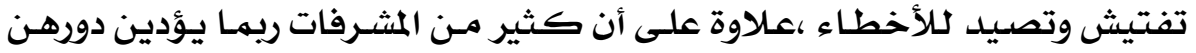
بشكل آلي بعيد عن التوجيد لتهيه الهادف.

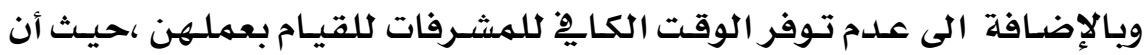

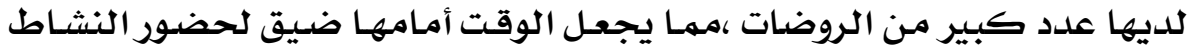

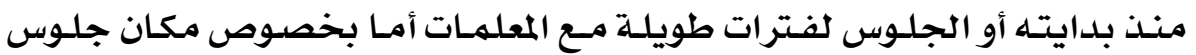

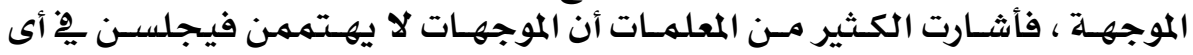

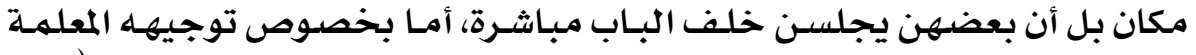

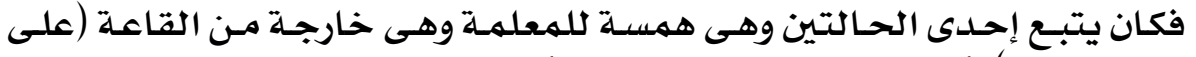

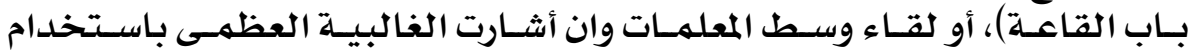

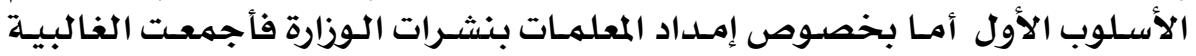

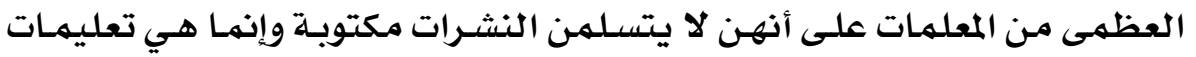

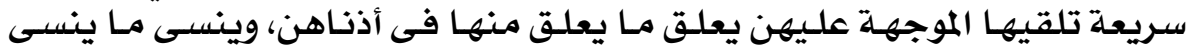

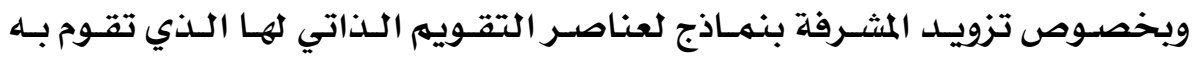

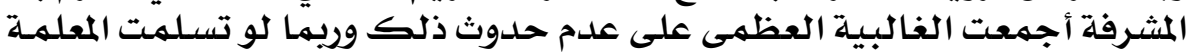

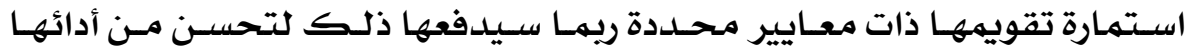

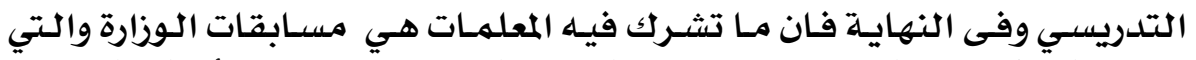

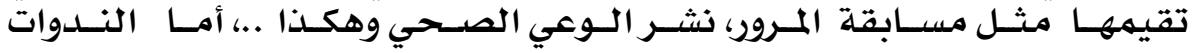

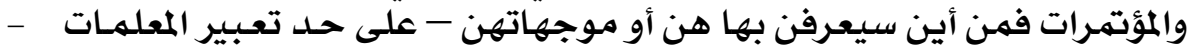

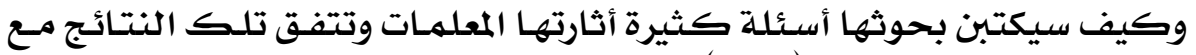

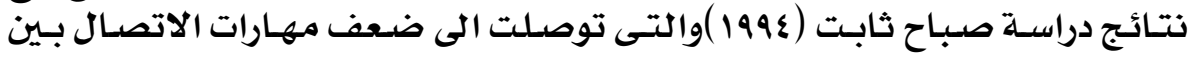
المشرفة والمعلمهة . 


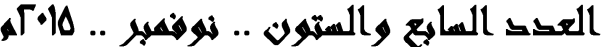

جلول رقه (7) درجات توافر المعيار السادس دور المشرفة محجال العلاوقات الإنسانية

\begin{tabular}{|c|c|c|c|c|}
\hline ترتيبي & متوسطات & الكليجة & المعيار & ค \\
\hline 0 & 1.10 & $9 r$ & تتقبل أراء المعلمات بسعة صدر & 1 \\
\hline 7 & 1.1 & 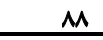 & تتبح الفرصة للمعلمة للتعبير عن إليها & r \\
\hline$\checkmark$ & $1 . . \mathrm{vo}$ & AT & تبنى جسر من الثقة المتبادلة بينها وبين المعلمات & $r$ \\
\hline$r$ & 1.70 & Irr & تقدم مقترحات لتحسين كفاءة المعلمة & $\varepsilon$ \\
\hline$r$ & 1.rAV & 111 & تشحع العمل بروح الفريق مـع معلمات الروضة & ○ \\
\hline$\varepsilon$ & 1.rvo & $1 \cdot r$ & تشعر المعلمة باهمية ماتفعل & 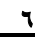 \\
\hline 슨 &. .90 & vi & تسعى إلى تكوين علاقة حسنة مـ المعلمات & $\underline{v}$ \\
\hline 9 &. AYo & 79 & تتجنب استخلدام أساليب التوعد والتهديد مـع المعلمة & $\Lambda$ \\
\hline 1. & . Alr & 70 & تشعر المعلمة بالأمن النفسي أثناء التعامل & 9 \\
\hline 1 & 1.vo & 1乏. & تقلدم النصيحة للمعلمة بشكل فردي & 1. \\
\hline
\end{tabular}

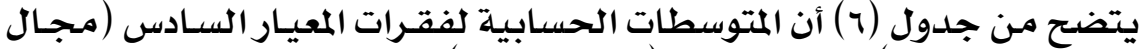

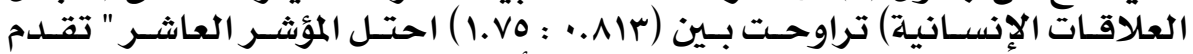

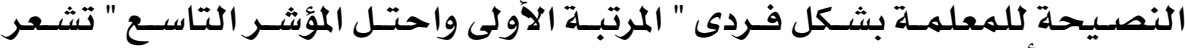

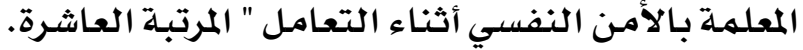

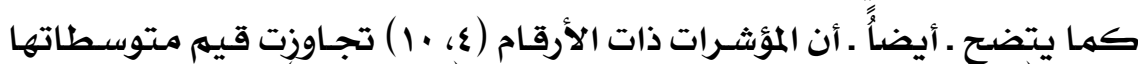

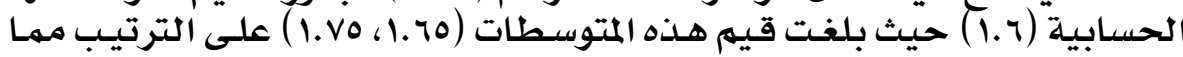

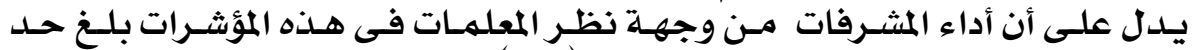

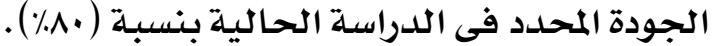

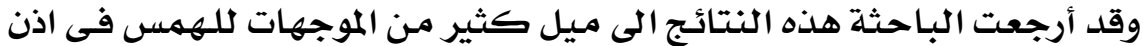

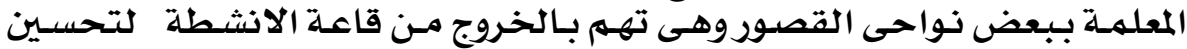

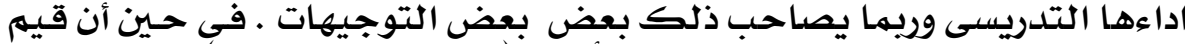

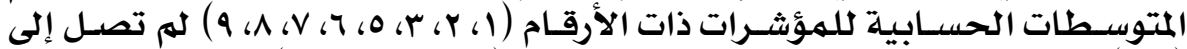

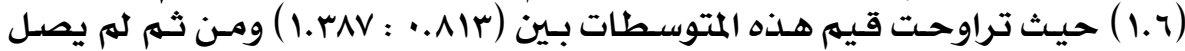

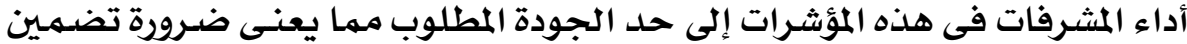

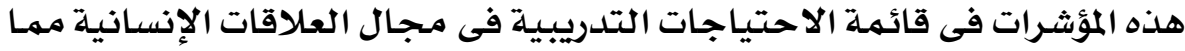

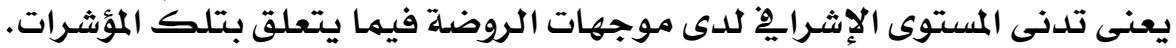

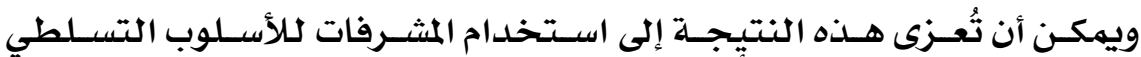

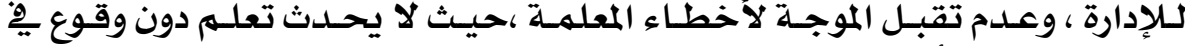

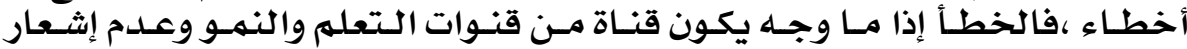

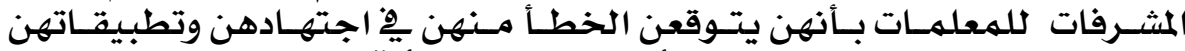

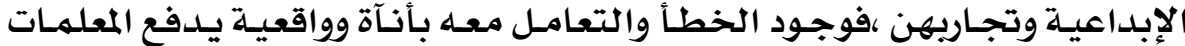

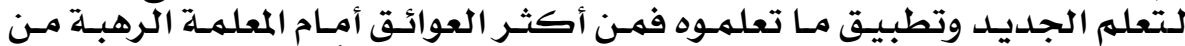

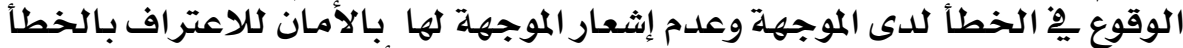

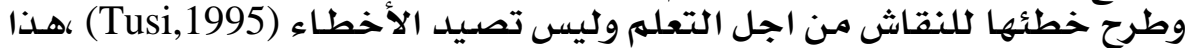

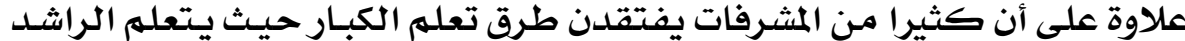

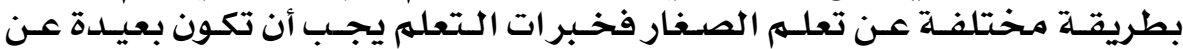

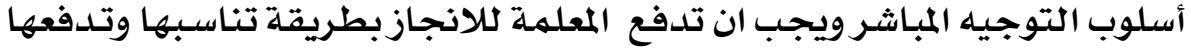




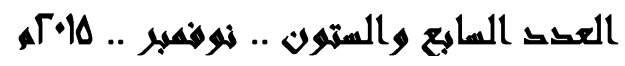

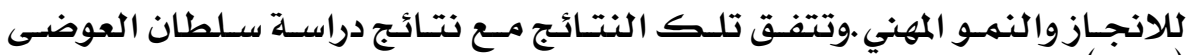

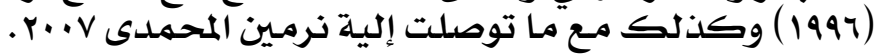

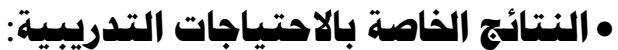

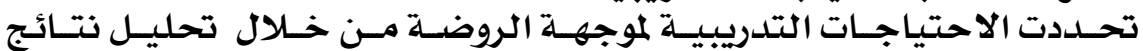

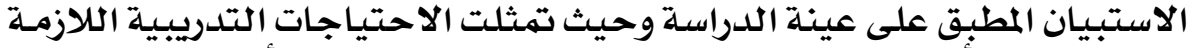

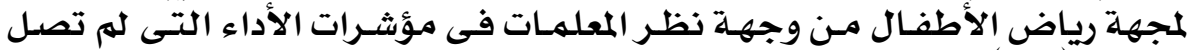

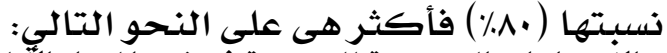

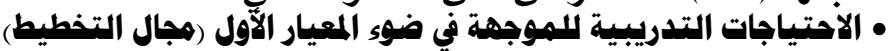

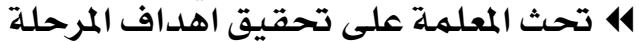

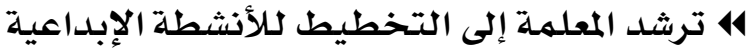

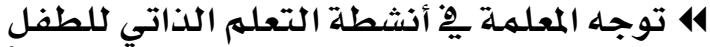

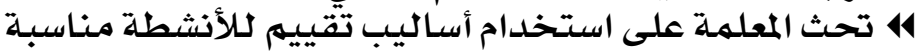

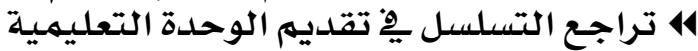

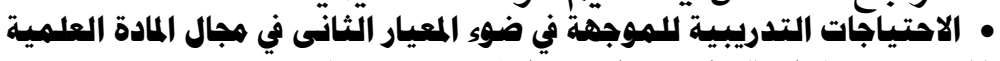

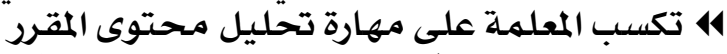

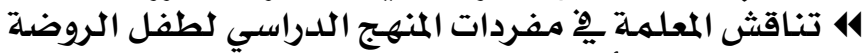

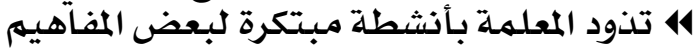

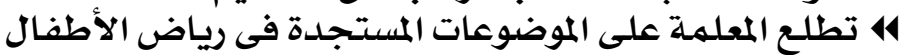

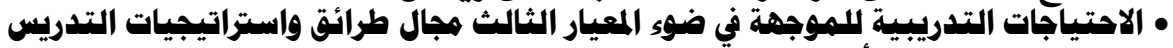

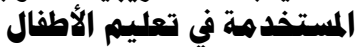

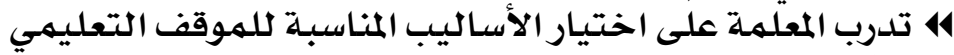

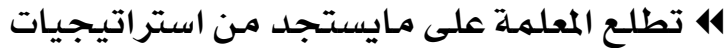

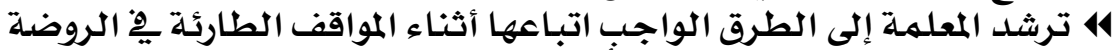

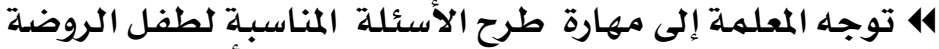

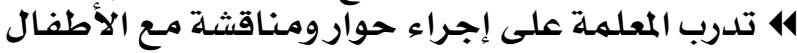

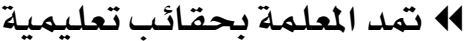

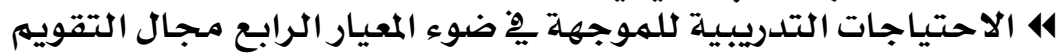

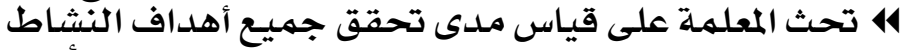

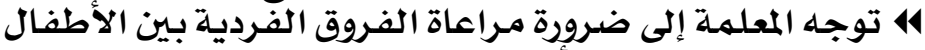

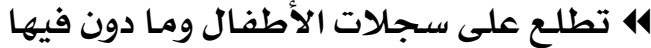

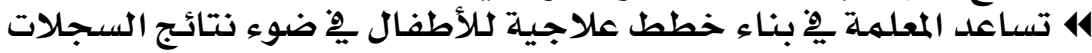

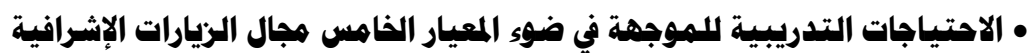

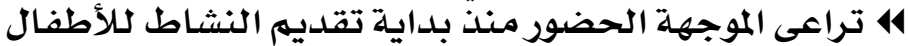

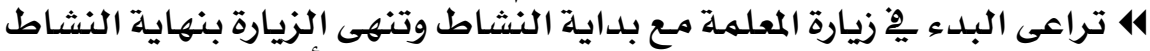

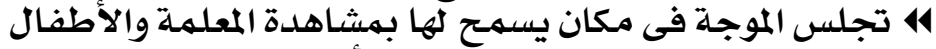

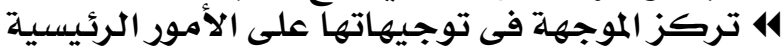

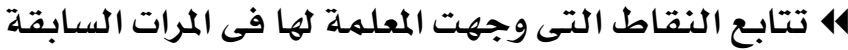

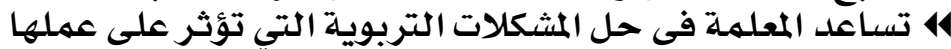

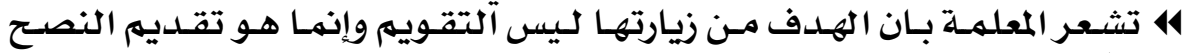

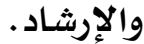

\section{Y7\&}




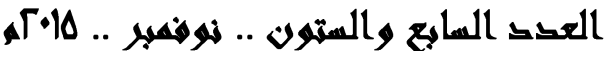

414 تمد المعلمة بالنشرات التى تقرها الوزارة

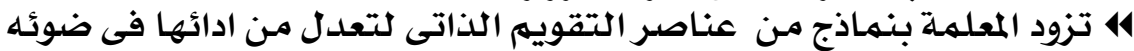

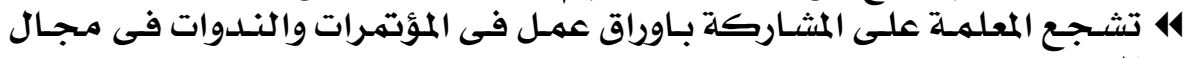

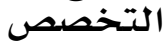

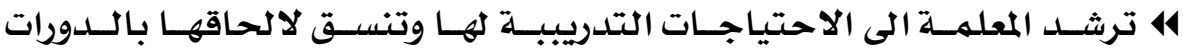

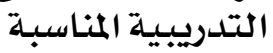
• الاحتياجات التدريبية لإمبهوجهة في ضوء المعيار السادس هجال العلاقات الإنسانية:

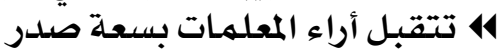

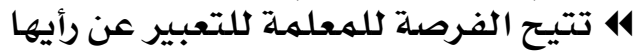

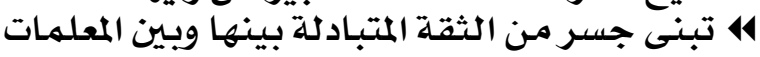

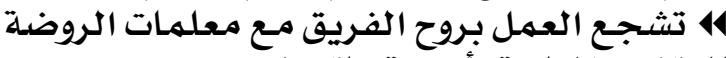

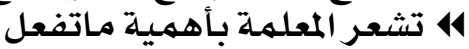

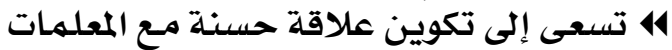

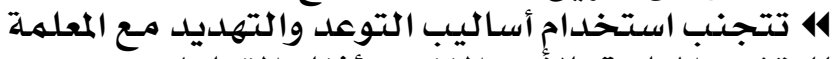

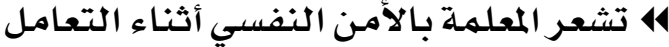

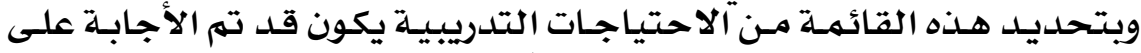

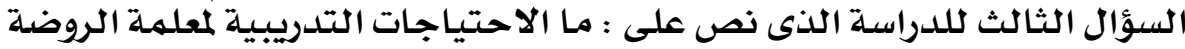

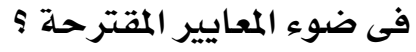

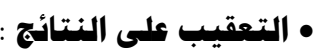

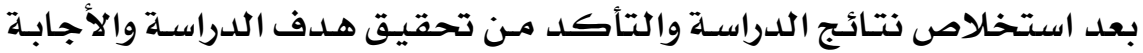

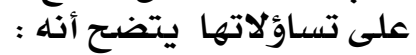

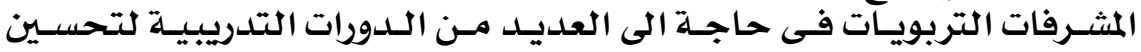

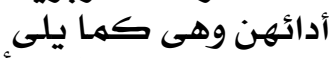

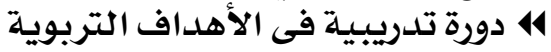

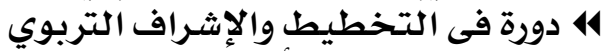

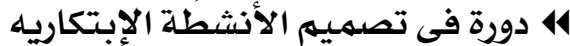

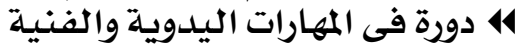
414

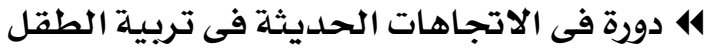

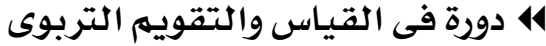
414 دورة في مهارة في القيات الاتصال التقويم الفعال 414

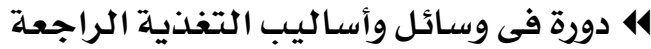

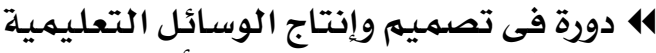

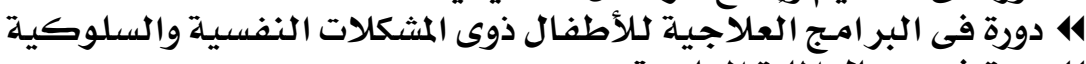

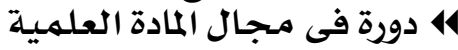
414 دورة فى فى التخطيط للزيارات التمادة الإشرافية

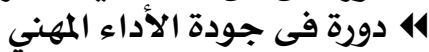

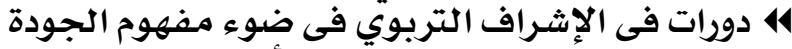

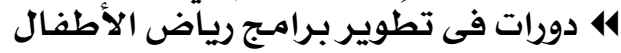

\section{Y७}




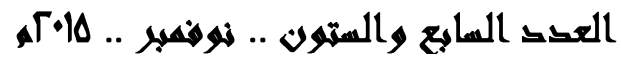

$$
\text { • } 14 \text { دورات في التقييهم والقياس }
$$

وقد توصلت الدراسة إلى إلى عدة توصيات كان كان من أهمها ما يلئى :

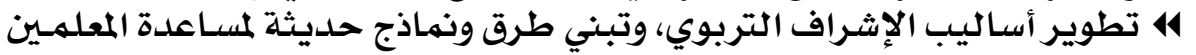

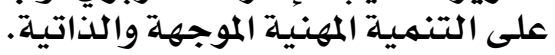

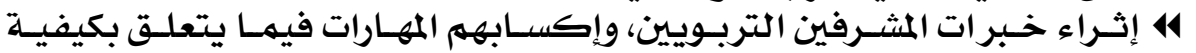

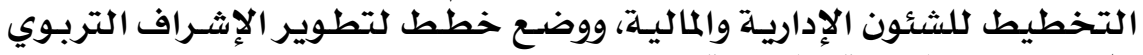

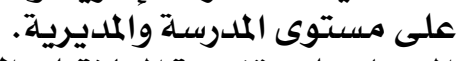

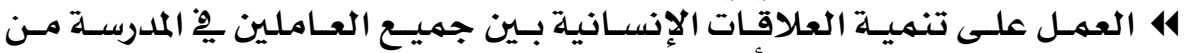

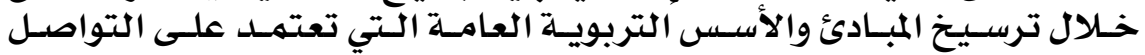

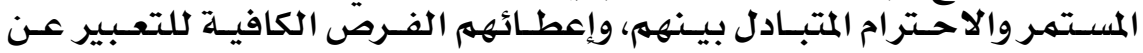

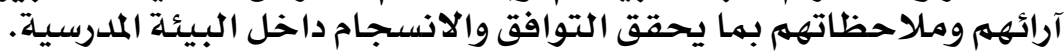

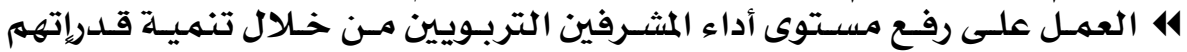

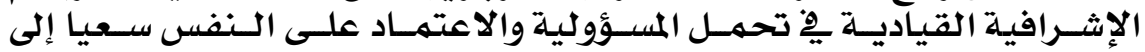

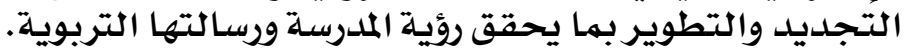

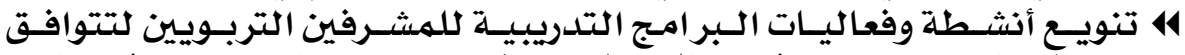

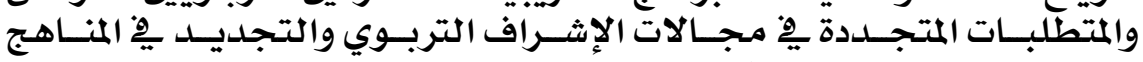

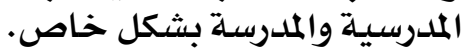

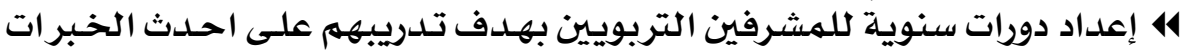
التربوية العورات

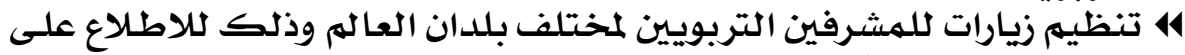

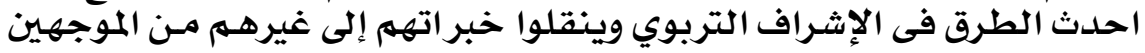
فيما بعد

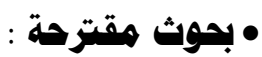
4 الاحتياجات التدريبية للمعلمات ليتحسـن أدائهـن التدريسي مـن وجهة نظر

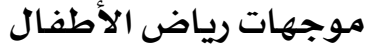
4 الاحتياجات التدريبية لموجهاض الإل الإيات رياض الأطفال لتطبيق الإدارة الالكترونية فى

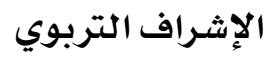

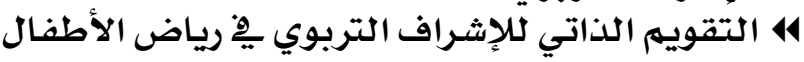

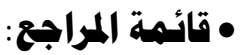

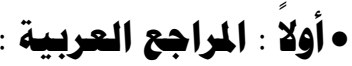

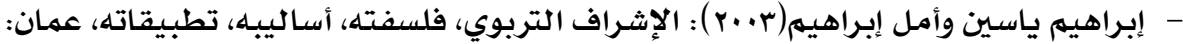

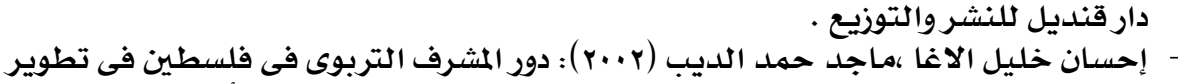

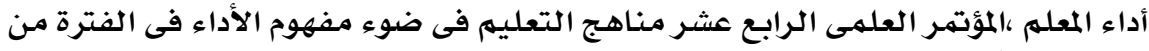

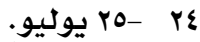

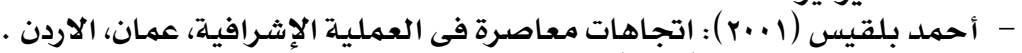

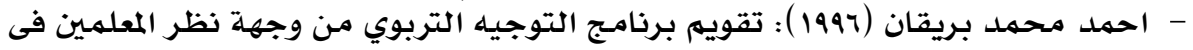

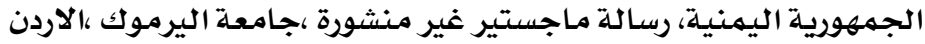

\section{Y77}




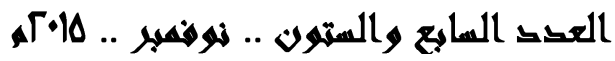

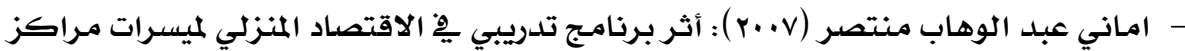

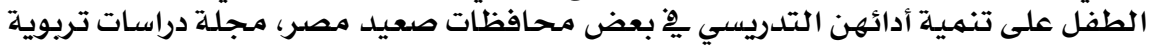

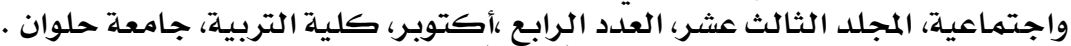

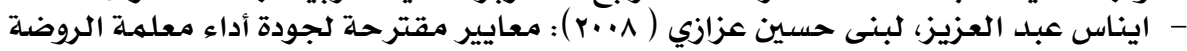

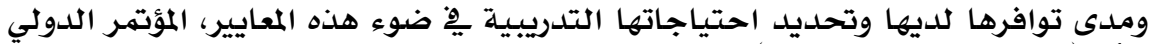

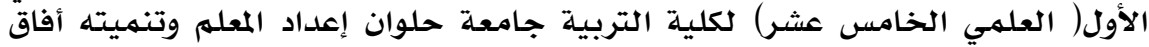

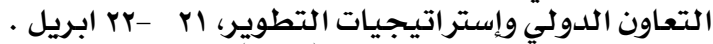

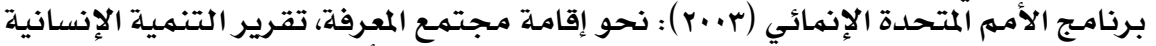

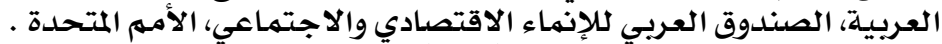

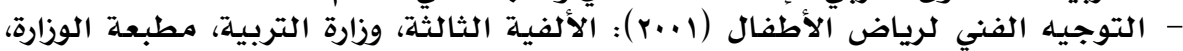
الكويت.

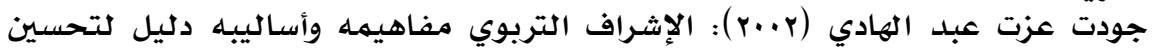

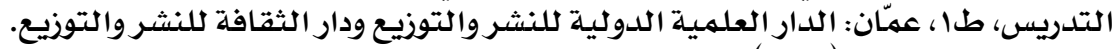

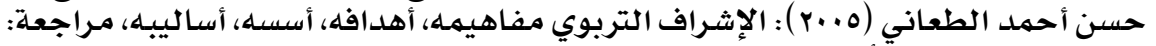

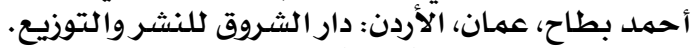

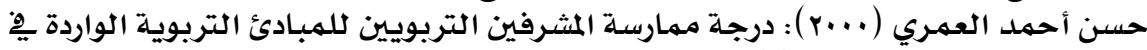

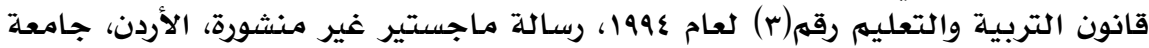
اليرموك.

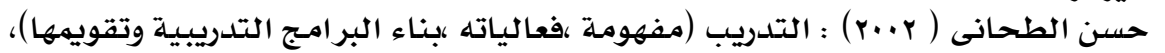

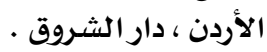

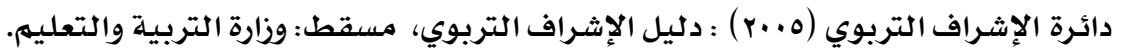

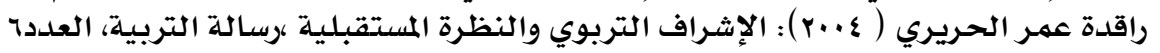

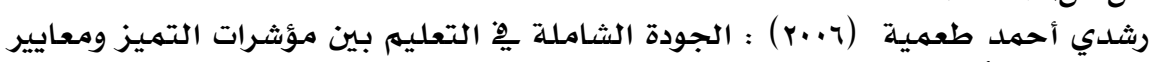

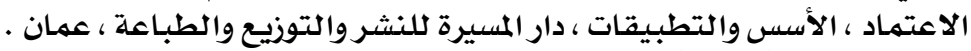

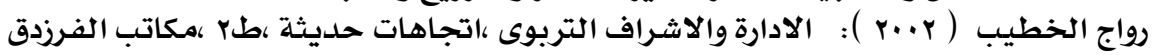

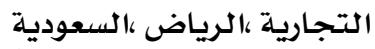

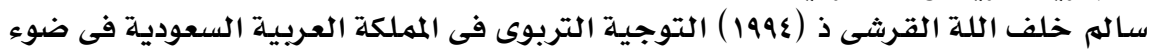

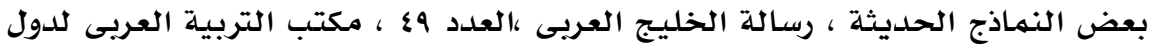

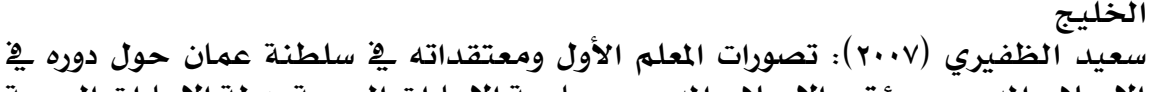

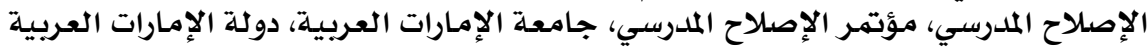

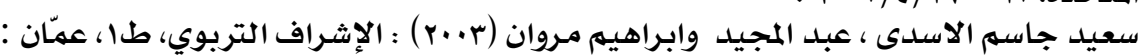

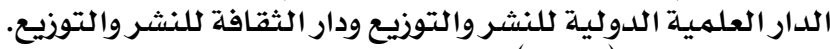

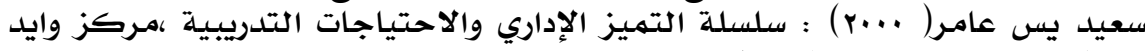

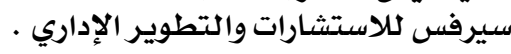

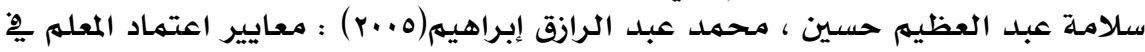

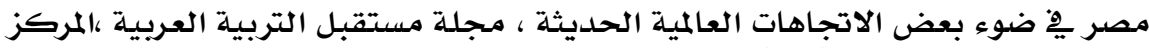

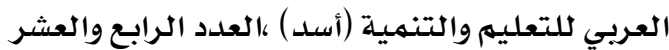

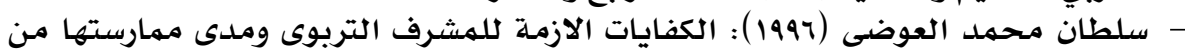

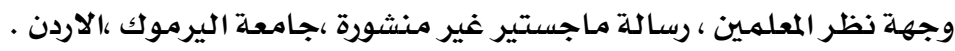

\section{YTV}




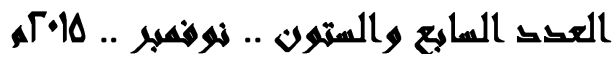

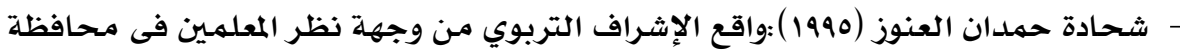

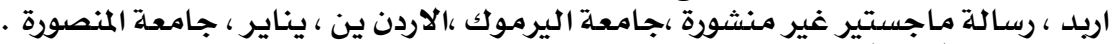

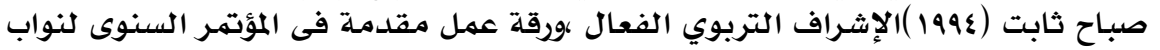

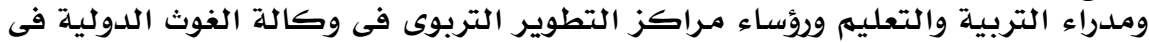

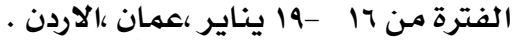

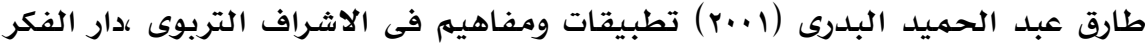

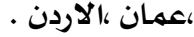

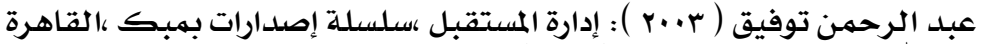

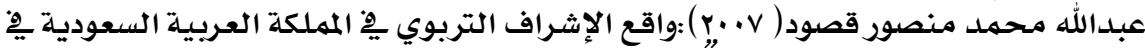

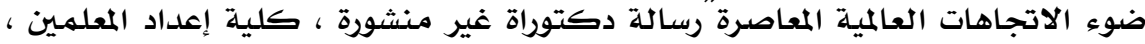

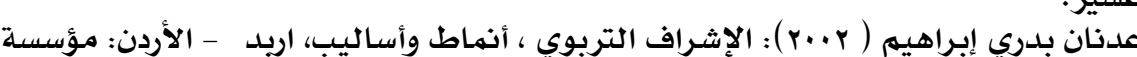

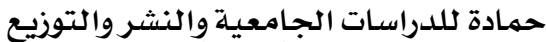

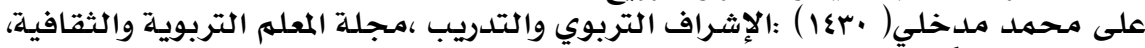

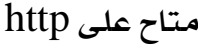

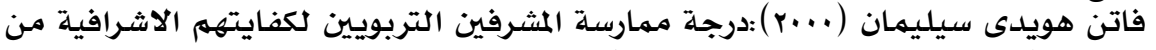

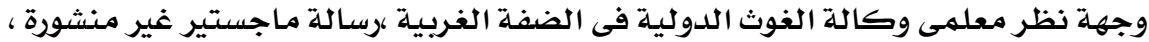

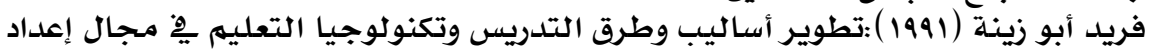

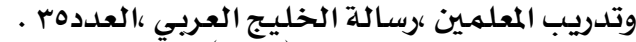

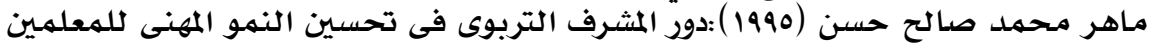

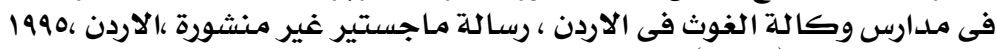

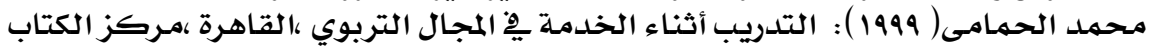

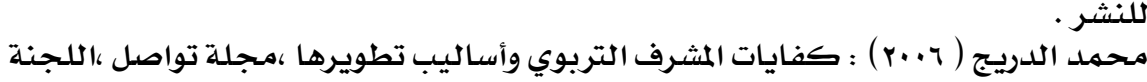

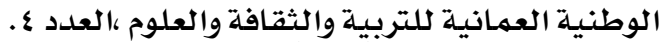

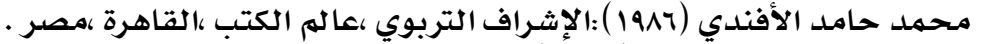

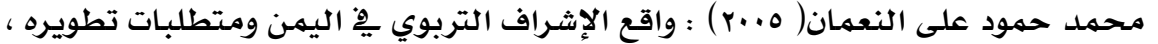

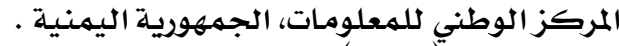

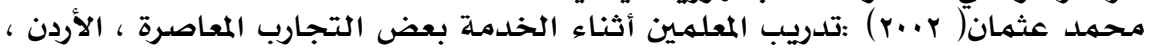
مكتبـة الخنيثى للثقافية

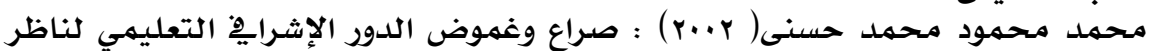

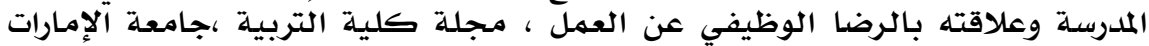

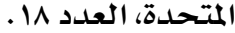
- المشرفات التربويات( 1997) : واقع إعداد المبداد المعلمات ،مكتب الإشراف التربوي بمكة ، قسم

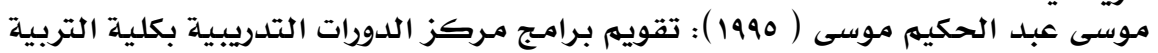

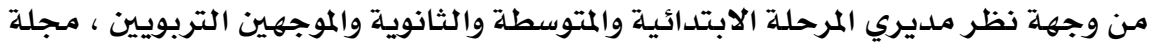

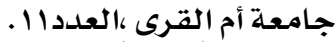

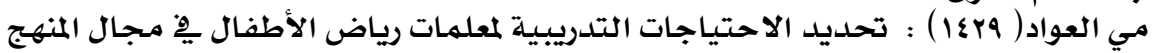

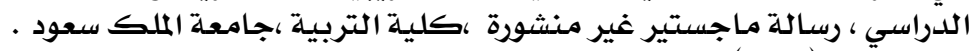

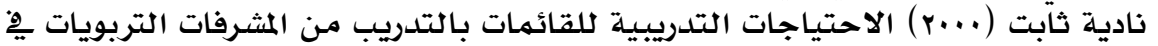

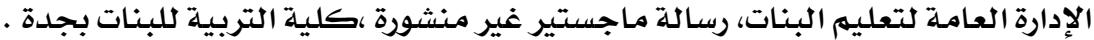

\section{Y\}




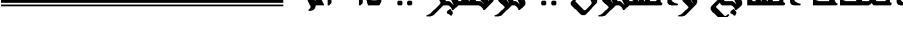

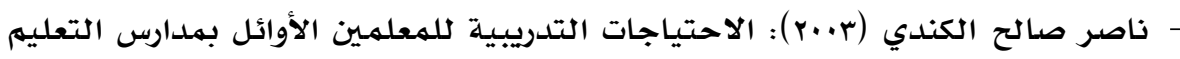

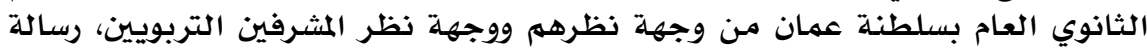

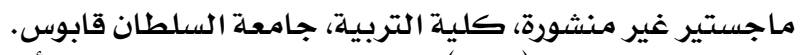

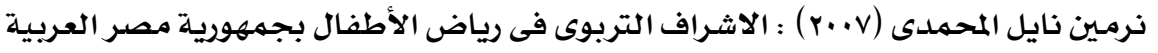

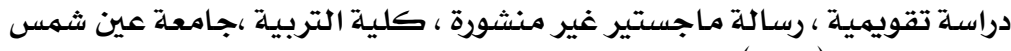

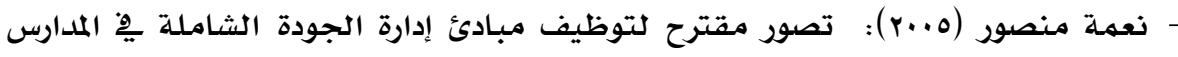

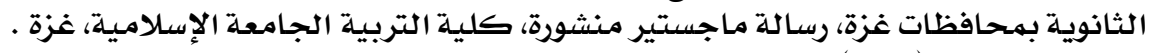

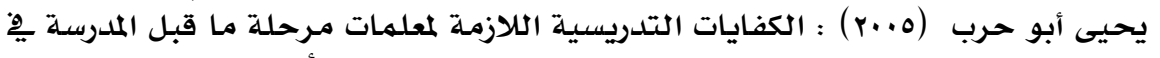

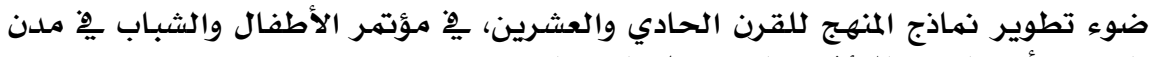

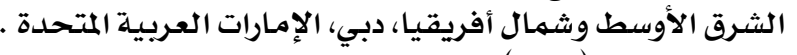

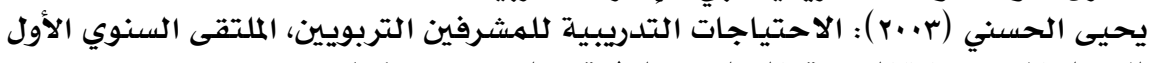

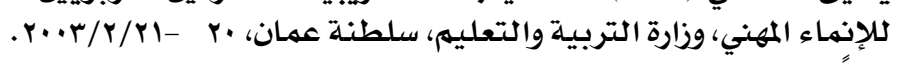

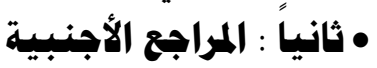
-Al-Hooli, Abeer. (2001). Kuwaiti Kindergarten Teachers' Attitudes and Content Knowledge of Teaching Science and Using Children's Literature for Science Instruction. (Doctoral dissertation, University of Virginia, 2001). Dissertation Abstracts International.

- Adebanjo,o.o(1998): School Inspection and Quality control. Paper presented at Seminar Organ Eduation ,Tai Solarin

- Adenaike,O.S. (2010): Impact of Total Quality Control Measures On Secondary School Studen Performance In Ogun State Academic Leaderships, V.8,N.4,2010

- Adeyinka,A.(1998):Towards Effective quality Control of Productive School in Nigeria Management .vol .(2) p2

-Clement, M and Vandenberghe, R (1997): Teacher Professional Development, a solitary on collegial adventure, paper presented at the annual meeting of the American educational research association, Chicago march 24-28.

- Harry S. Hertz (2001): Baldrige National Quality Program, National Institute of Technology, available online at .www.quality.nist-gov.

-Leff Northfield and Other (1997): Teacher Education as process of Developing Teacher Knowledge, cited in: Teaching about purpose, passion pedagogic teacher education, the flamer press

- Methi,p.(2007):Education Professional standards in Thailand. Paper presented in Education ,Thailand ,Eric .34678 Faculty of Quebec Education Program-Preschool Education (2002). Website http:// www.meq.gouv.qc.ca//virage/publications/prog-form-preschoola.htm $\{$ Accessed 4/5/2002\} 
- Tsui, A., Exploring collaborative supervision in in-service teacher education. Journal of Curriculum and Supervision, 10(4), (1995). 346-371.

-Siens, C., M., \& Ebmeier, H., Developmental supervision and the reflective thinking of teachers. Journal of Curriculum and Supervision, 11(4), (1996). 299-319-a.

-Pajak‘E. Dimensions of supervision، Educational Leadership، 48(1) P(1990). P.78-81.

- Ali, Mehrunnisa Supervision for teacher development: an alternative model in Pakistan. International Journal of Educational Development. 


\section{البحث الثنامن:}

أفضل همارسات زيادة دافعية التعلم لطلاب المرحلة الثانوية في ضوء إشباع حاجاتهم الإنسانية

$$
\begin{aligned}
& \text { : }
\end{aligned}
$$

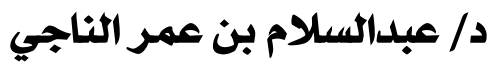

$$
\begin{aligned}
& \text { كلية التربية جامعة الأمير سطام بن عبد العزيز }
\end{aligned}
$$



د / عبل السلام بن عمر الناجي

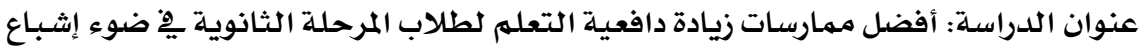

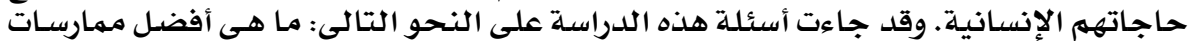

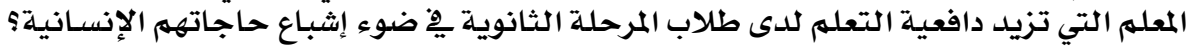

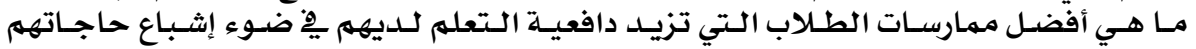

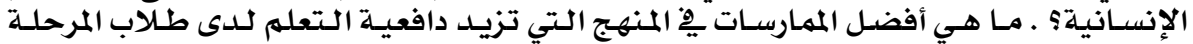

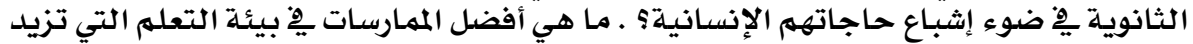

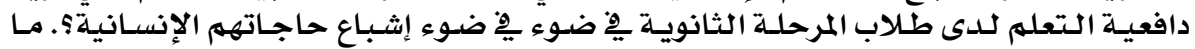

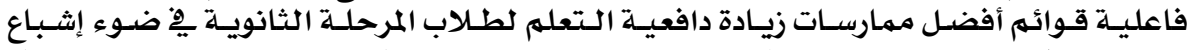

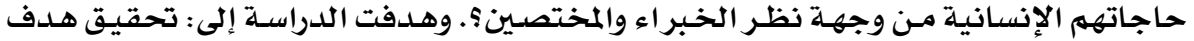

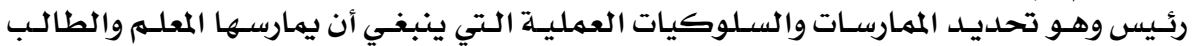

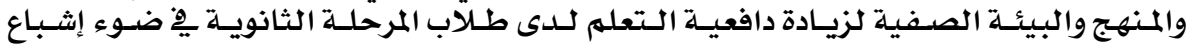

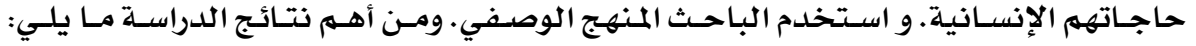

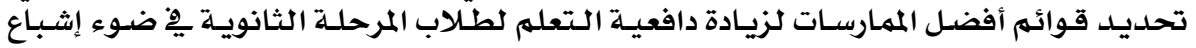

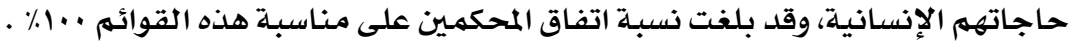

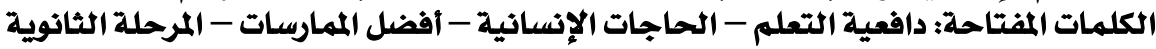

Best practices to increase learning motivation for students of high Abestract: school on the light of satisfying human needs'.

The questions in this study are as follows:1-What is the best teacher practices that increase the motivation of learning in secondary school students in light of satisfying human needs. 2-What are the best practices that increase students' motivation to learn what they have in light of the satisfaction of human needs.3-What are the best practices in curriculum that increase the motivation of learning in secondary school students in light of satisfying human needs.4-What are the best practices in the learning environment that increases the motivation of learning in secondary school students in the light of the light satisfy human needs.5-How effective is the best lists of practices to increase motivation for learning high school students in light of satisfying human needs from the point of view of experts and specialists.The study aimed to: achieve the main goal, which determine the behaviors and practices process that should be exercised by the teacher and the student and the curriculum and classroom environment to increase the motivation of learning in secondary school students in light of satisfying their human needs.Methodology of the study: The researcher used the descriptive approach in this study. Among the most important findings of the study include;Accurate identification of the best practices to increase the motivation of learning to high school students in light of satisfying their human needs, the arbitrators have reached agreement on an appropriate proportion of $100 \%$ these lists.

Key words:Learning motivation - human needs - best practices Secondary School. 


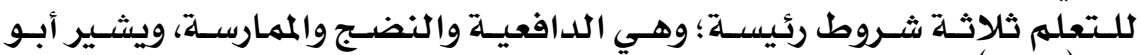

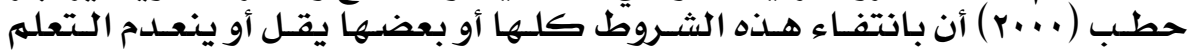
الحقيقي.

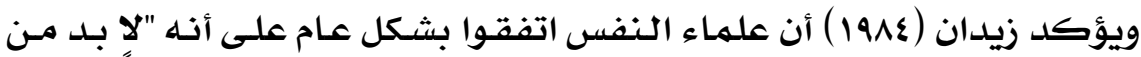

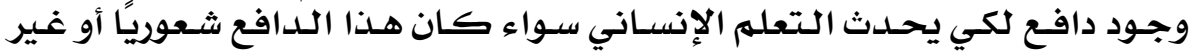

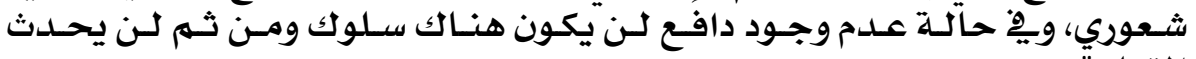

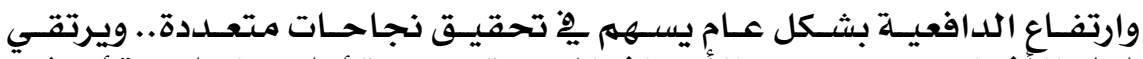

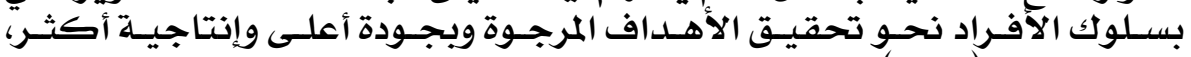

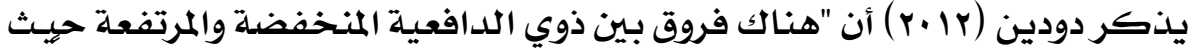

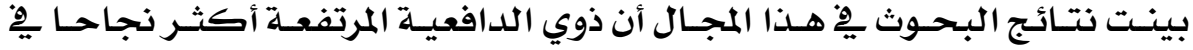

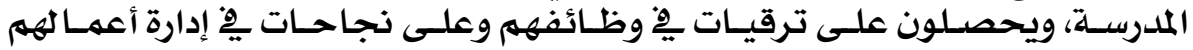

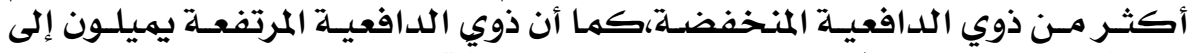
اختيار مهمات متوسطة الصعوبة المنية وتتضمن تحدياً "

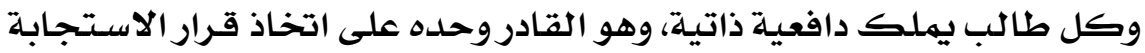

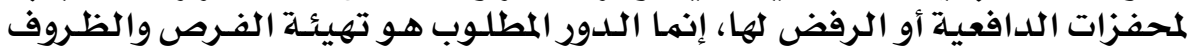

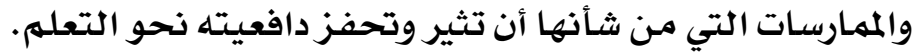

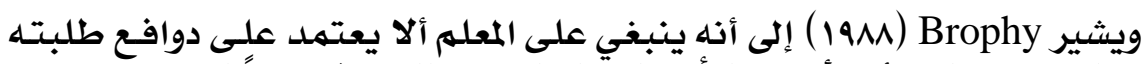

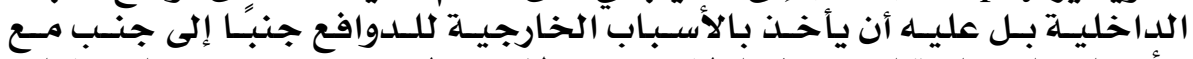

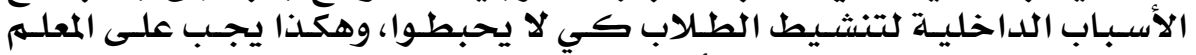

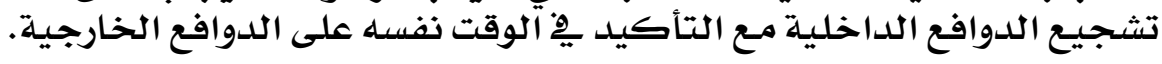

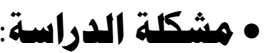

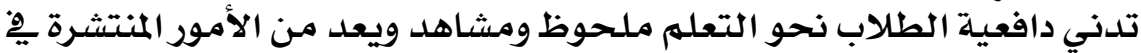

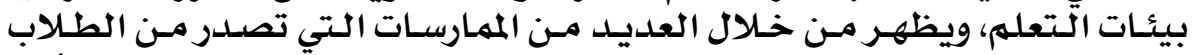

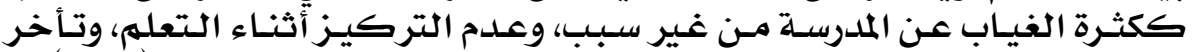

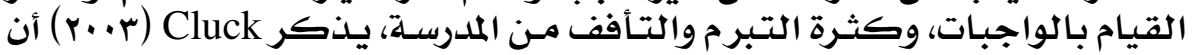

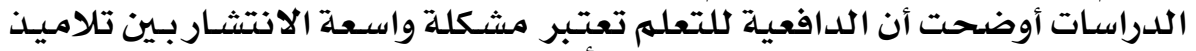

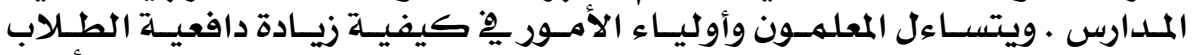

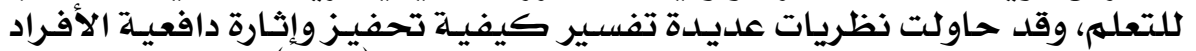

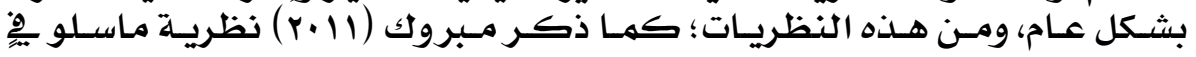

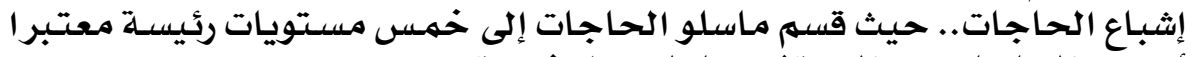

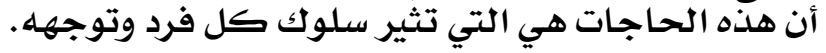

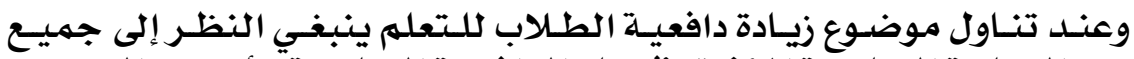

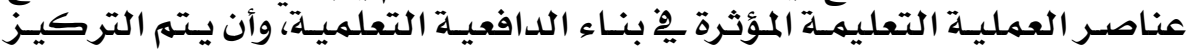

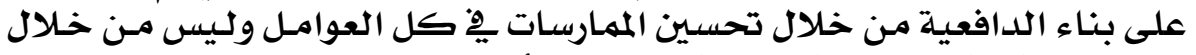

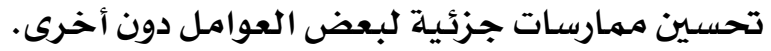

\section{YV $\varepsilon$}




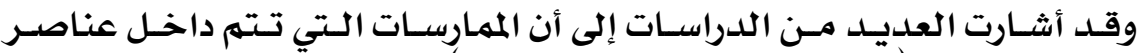

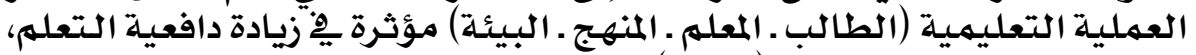

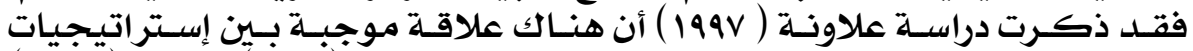

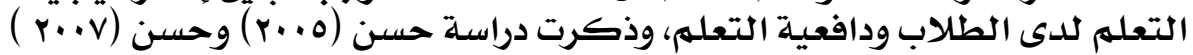

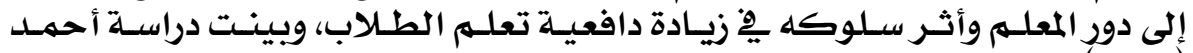

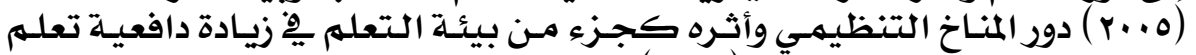

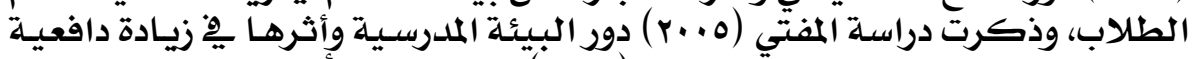

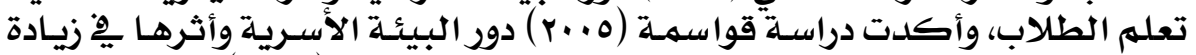

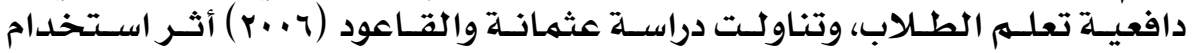

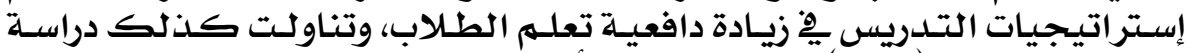

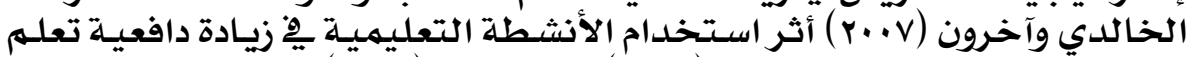

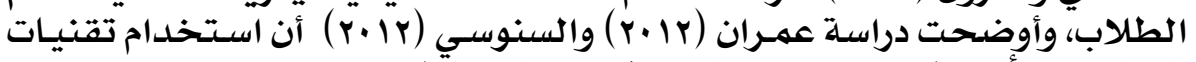

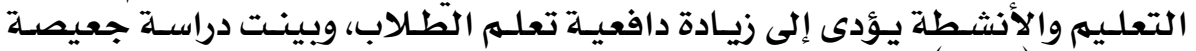

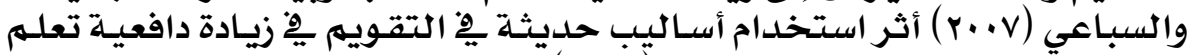

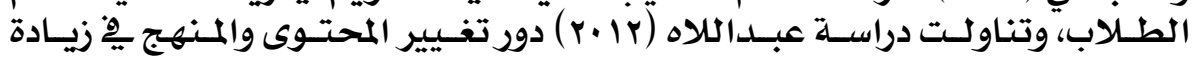
دافعية تعلهم الطلاب، وتناوبت

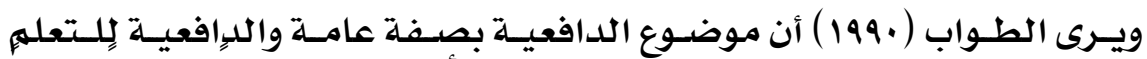

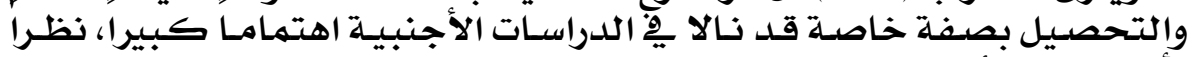

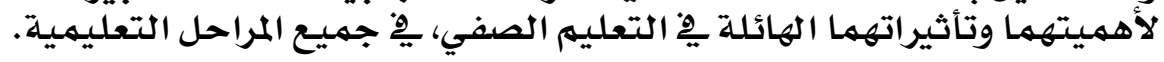

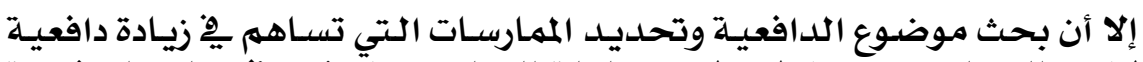

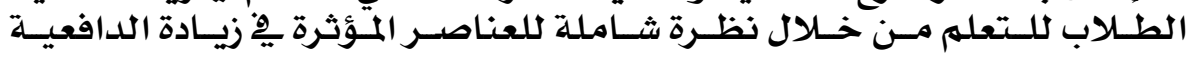

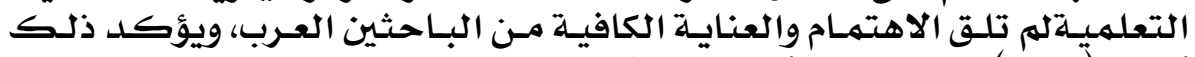

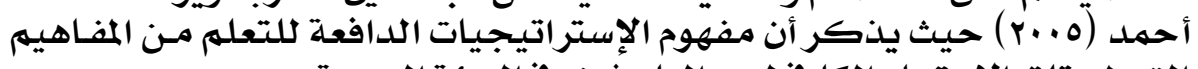

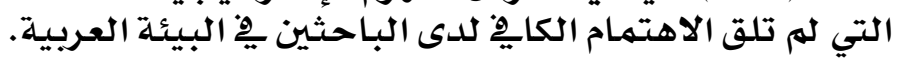

وقـد سـعى البـاحـث إلى دراسـة كيفيـة زيـادة دافعيـة طـلاب المرحلــة الثانويـة

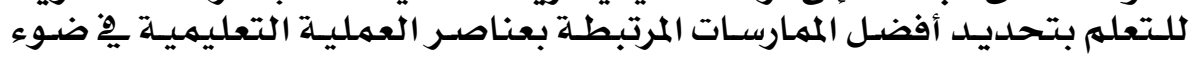

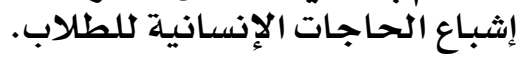

ويهكن إبراز مشكلة الدراسـة الرئيس من خلال العنوان التالي:

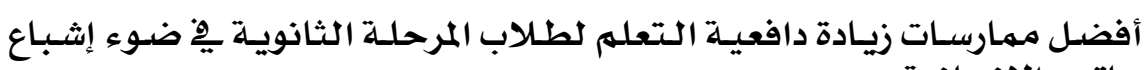
حاجاتهم الإنسانيـة.

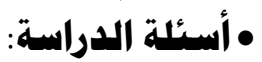

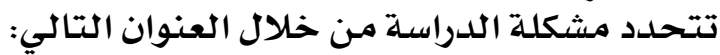

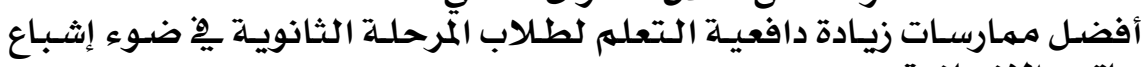
حاجاتهم الإنسانيـة.

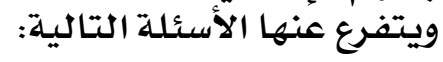

14 مـا أفضل مهارسـات المعلم التي تزيلد دافعيلة التعلهم لدى طلاب المرحلة الثانويـة

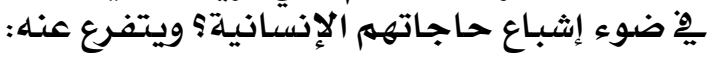




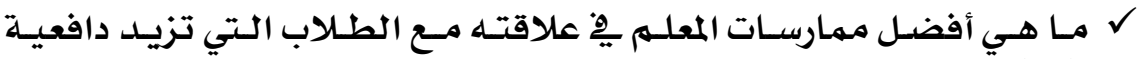

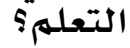

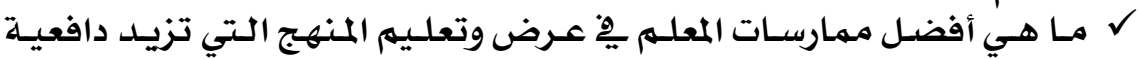

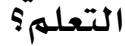
$\checkmark$

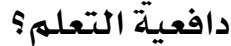

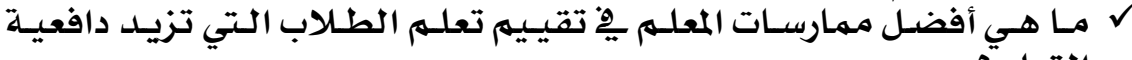

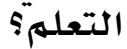

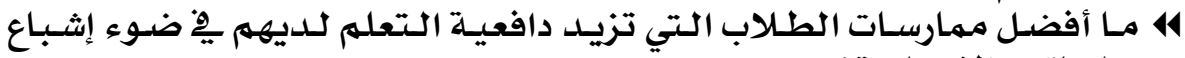

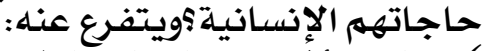

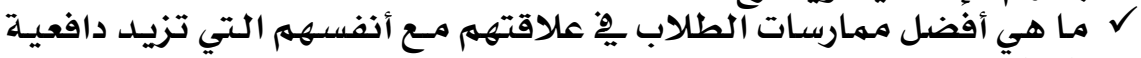

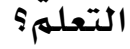

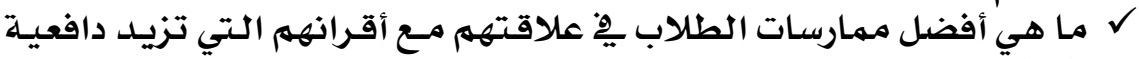

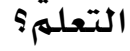
$\checkmark$ ما هي أفضل ممارسات الطلاب المرتبطة بدورهم وطريقتهم هِِ التعلهم التي

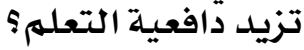

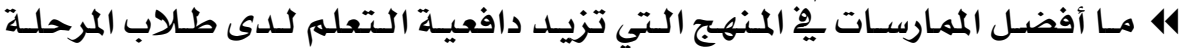

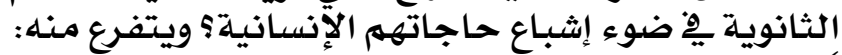

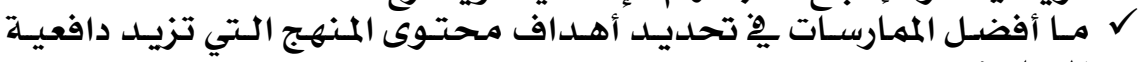

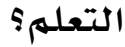

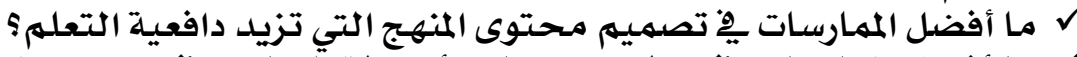
$\checkmark$

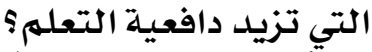

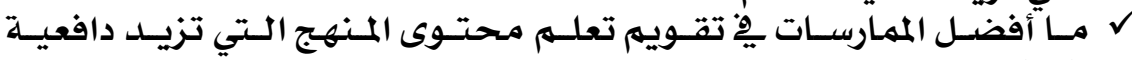

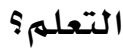

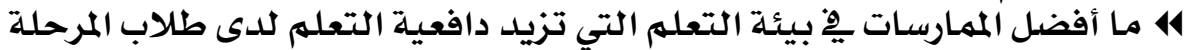

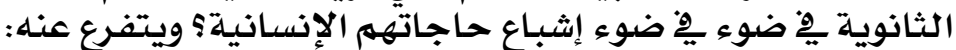
$\checkmark$ $\checkmark$ $\checkmark$

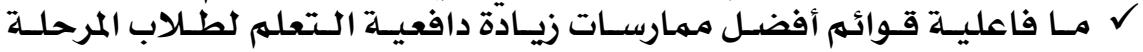

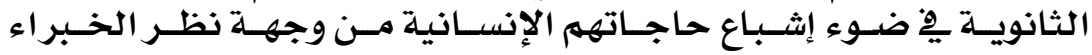

$$
\begin{aligned}
& \text { والمختصين؟ } \\
& \text { •أهدف الدراسة : } \\
& \text { تهدف الدراسـة إلى تحديد : }
\end{aligned}
$$

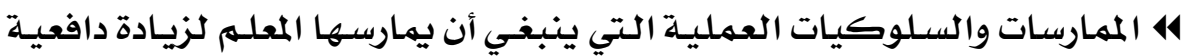

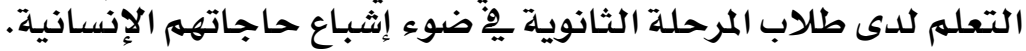

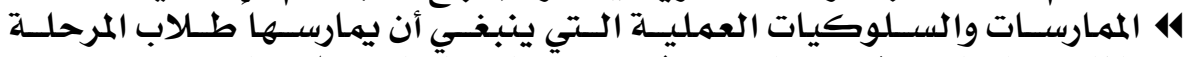

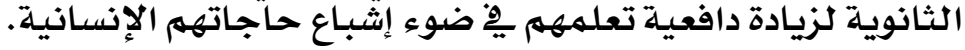

\section{YVT}


414

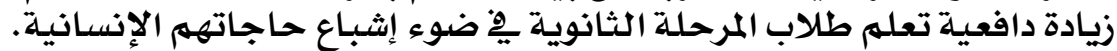

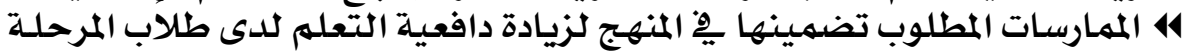

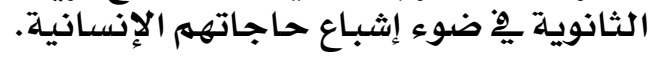

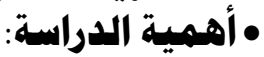

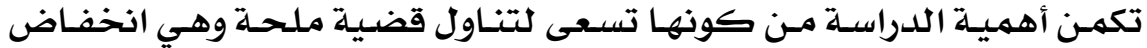

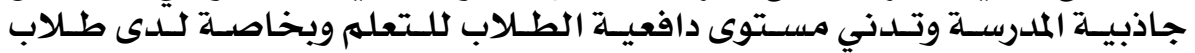

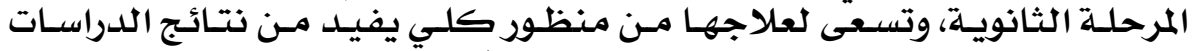

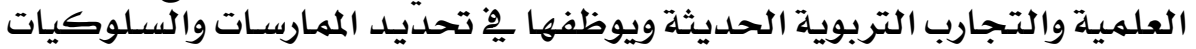

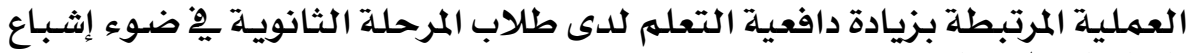
الحاجات الإنسانية. • هدود الدراسة الإنة:

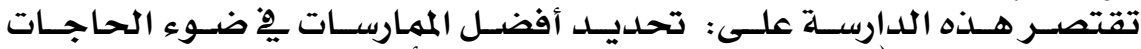

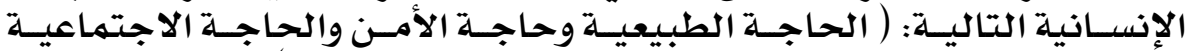

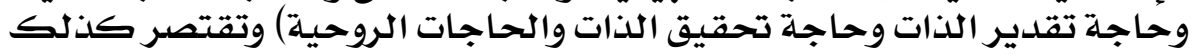

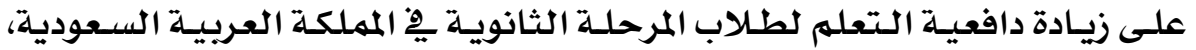

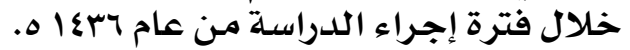

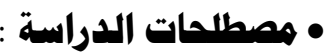

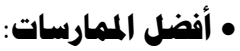

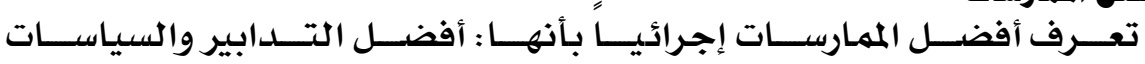

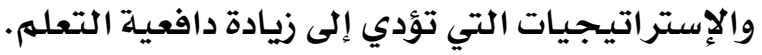

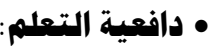

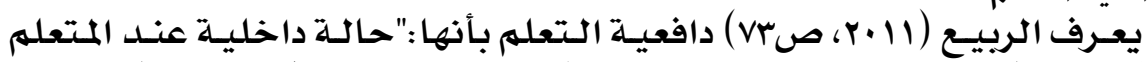

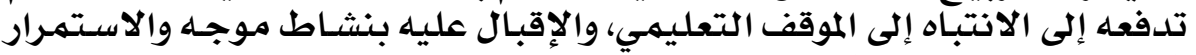

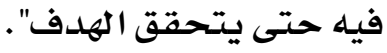

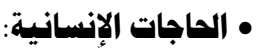

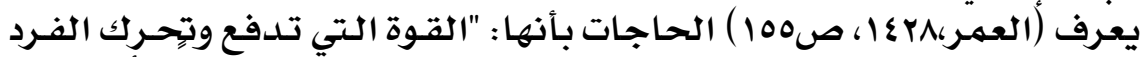

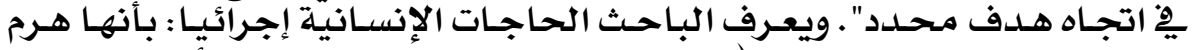

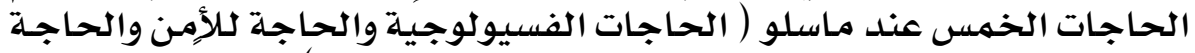

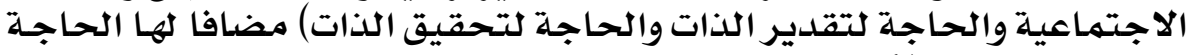

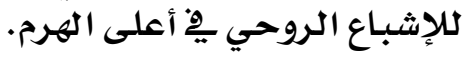

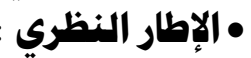

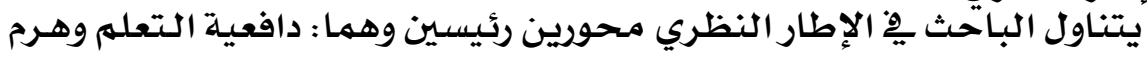

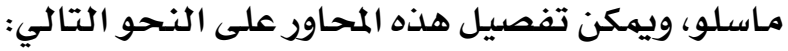

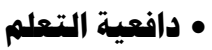

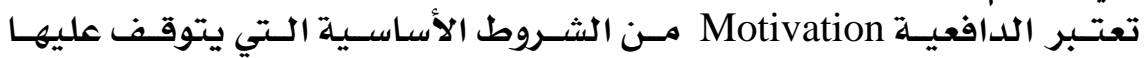

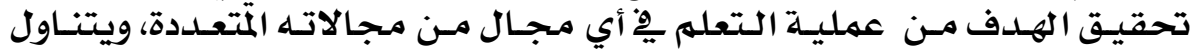

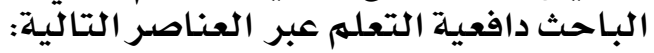

\section{YVV}




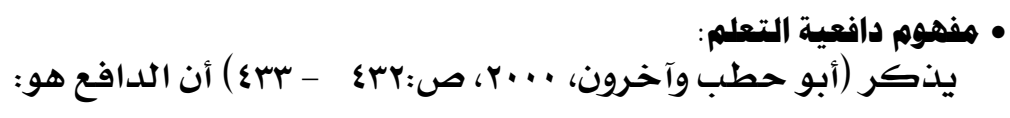

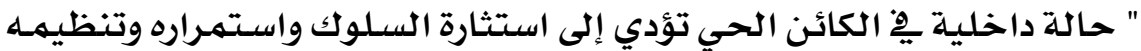
وتوجيهه نحو هدف معـين" دانه

وتعرف (قطامي، ..........

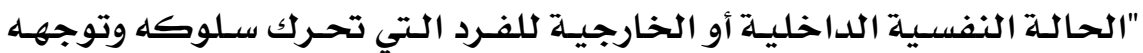

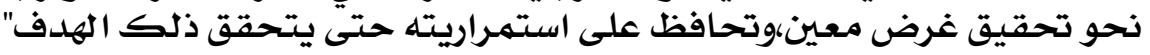

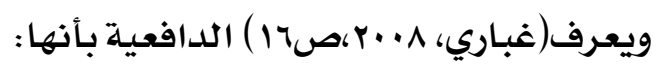

"حالة استثارة وتوتر داخلي تثير السلوك وتدفعه إلى تحقيق هدف معين."

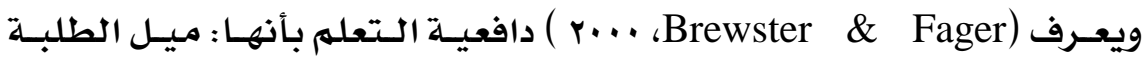

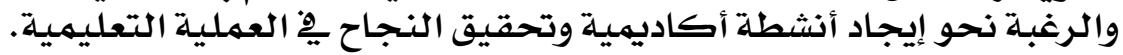

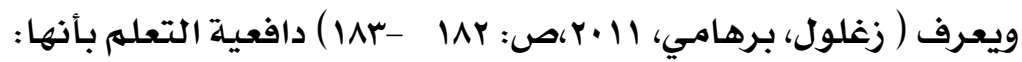

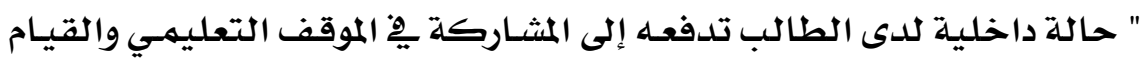

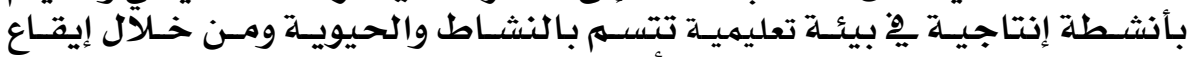

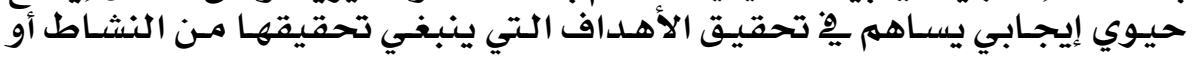

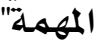

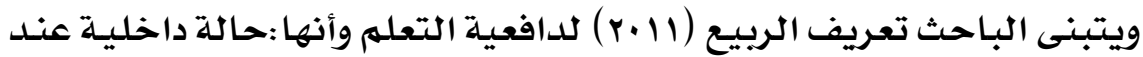

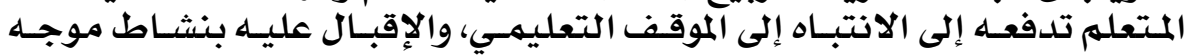

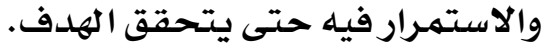

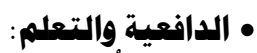

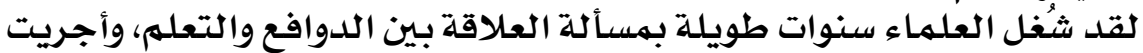

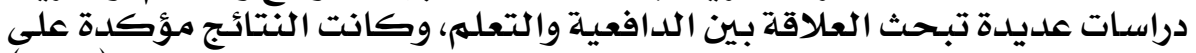

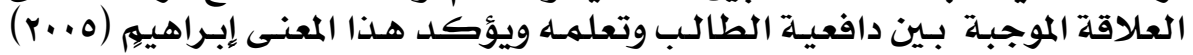

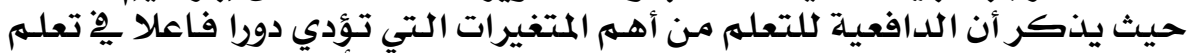

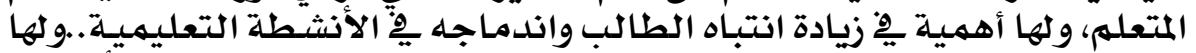

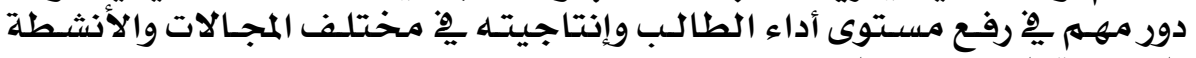

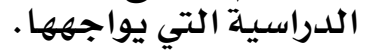

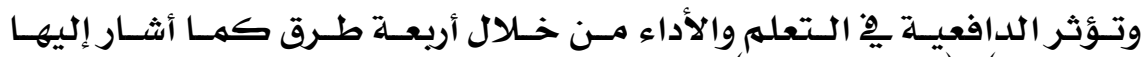

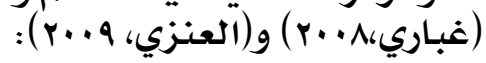

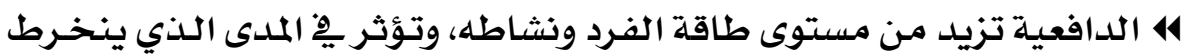

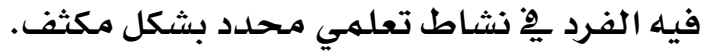

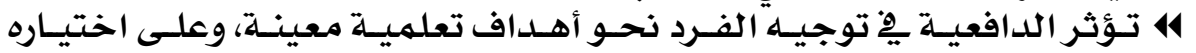

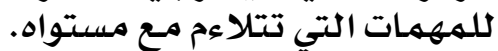

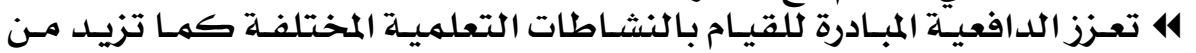

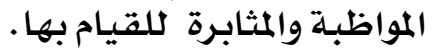

\section{rVA}




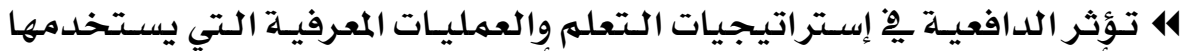

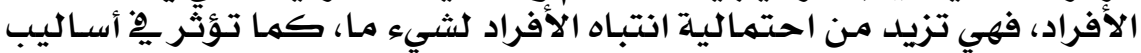

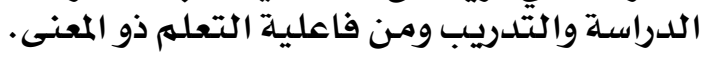

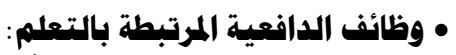

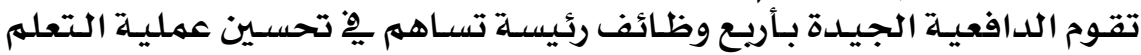

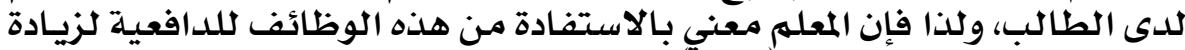

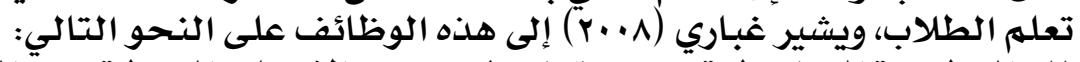

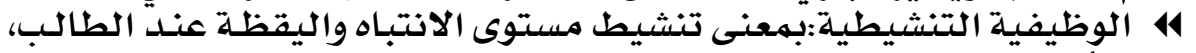

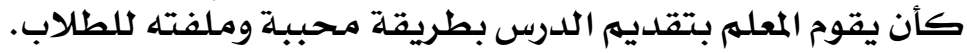

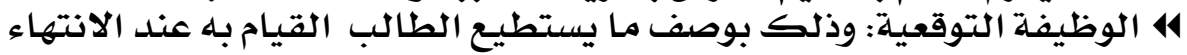

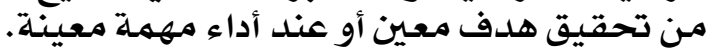

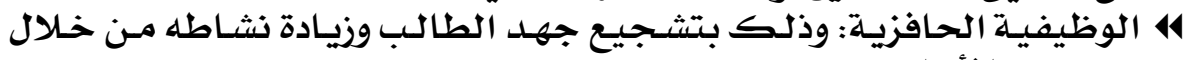
تقديه مكافأة له.

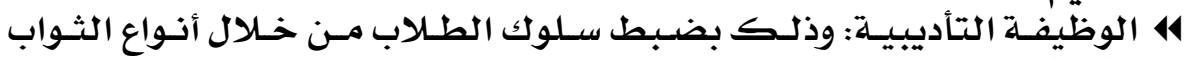
والعقاب.

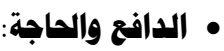

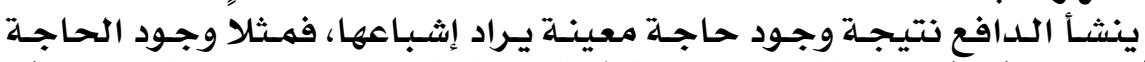

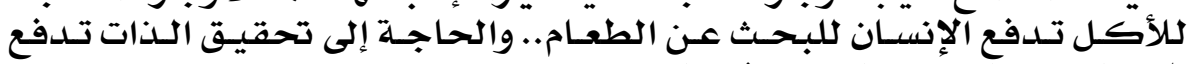

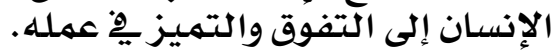

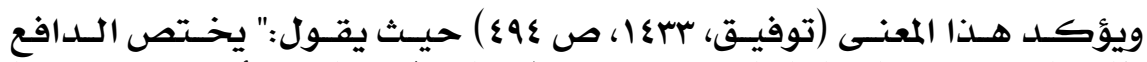

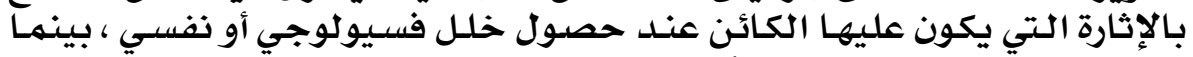

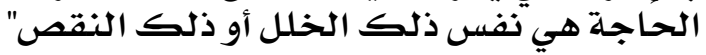

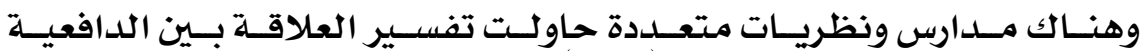

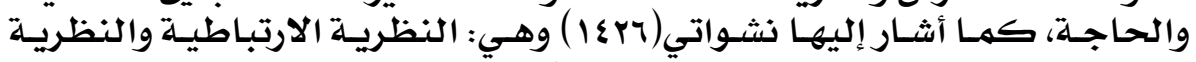

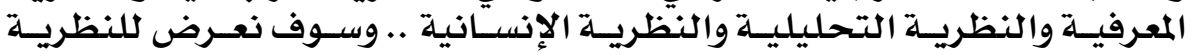

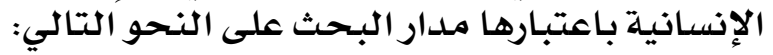

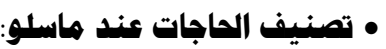

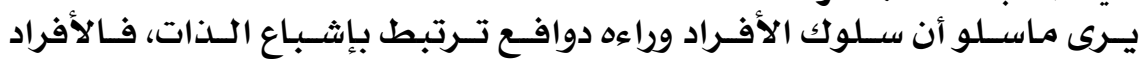

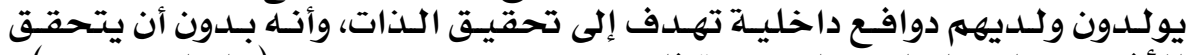

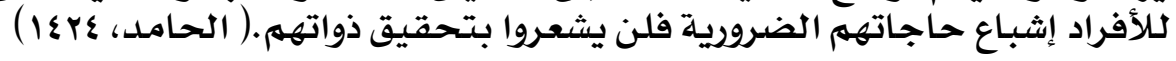

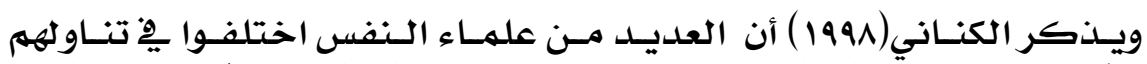

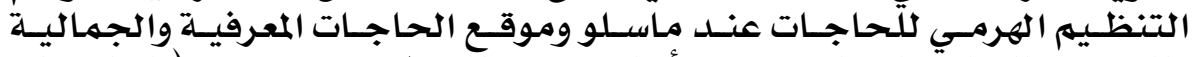

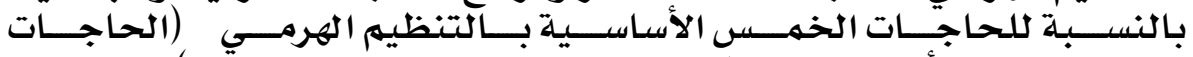

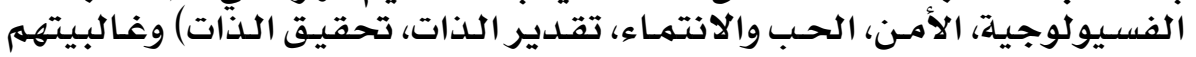

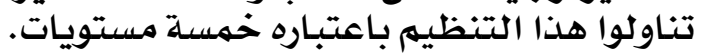

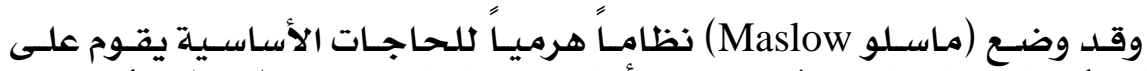

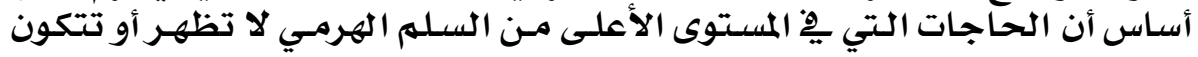

\section{rVq}




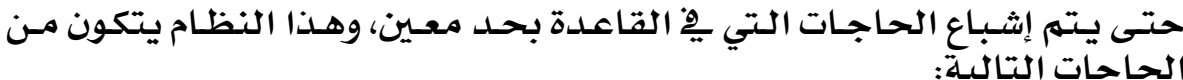

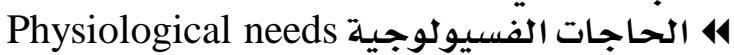

Safety needs 14

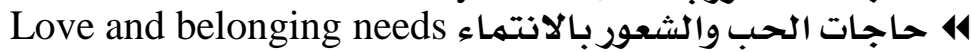

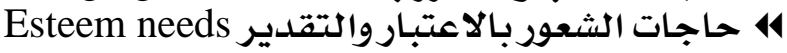

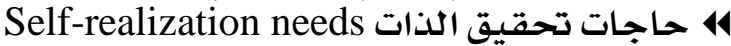

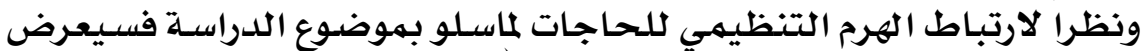

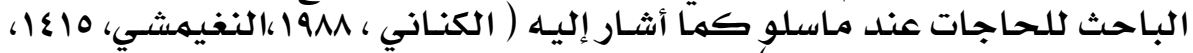

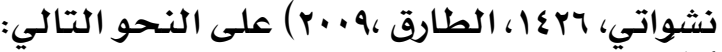

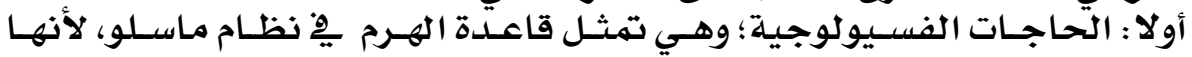

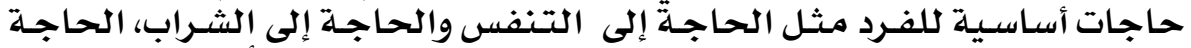

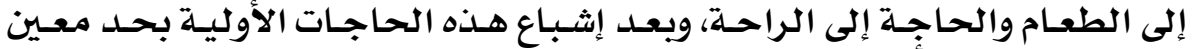

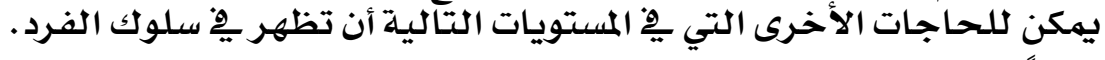

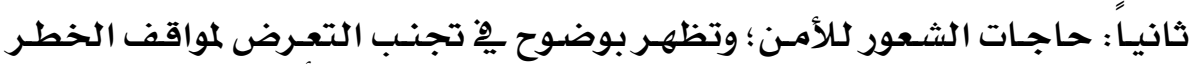

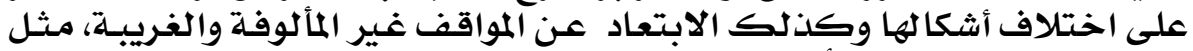

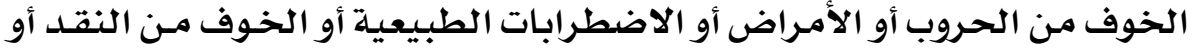

الظلهم ونحو ذلك.

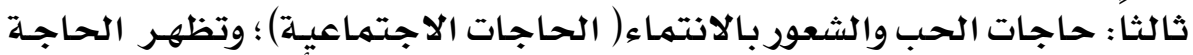

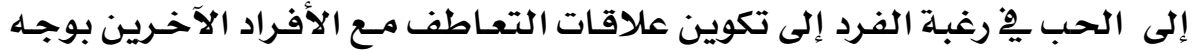

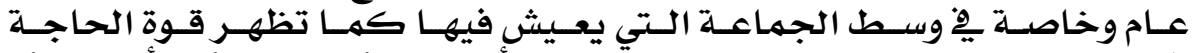

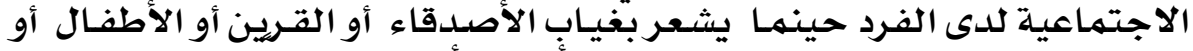

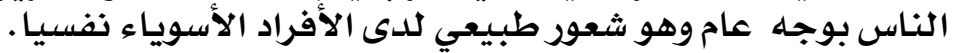

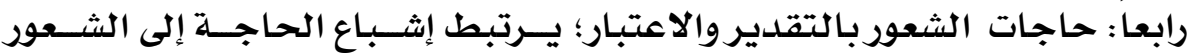

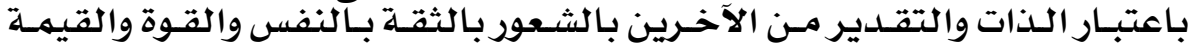

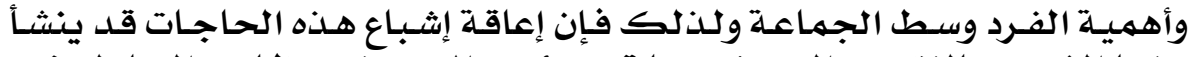

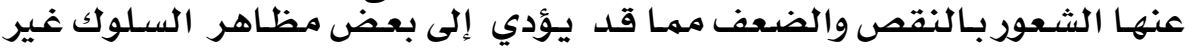
السوي.

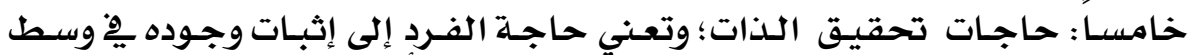

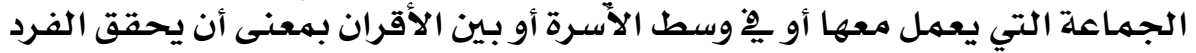

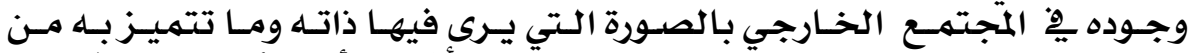

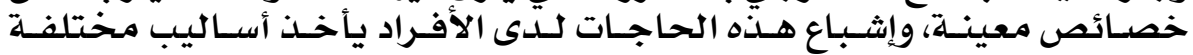

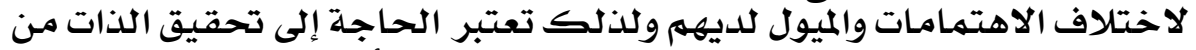

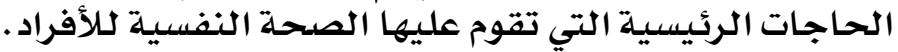

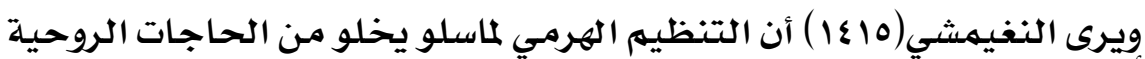

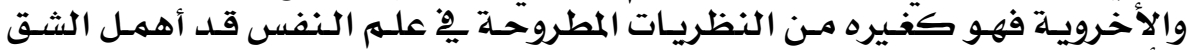

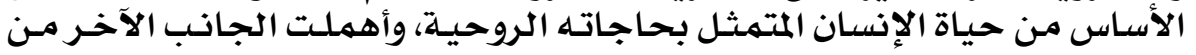

\section{Y^}




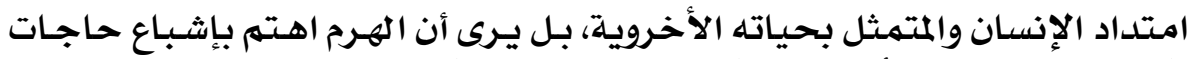

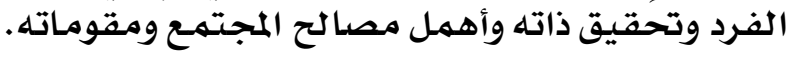

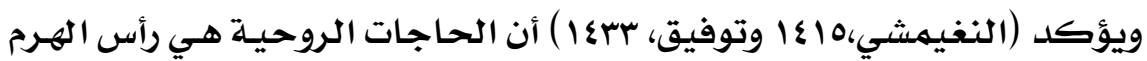

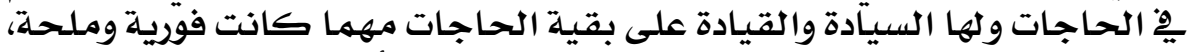

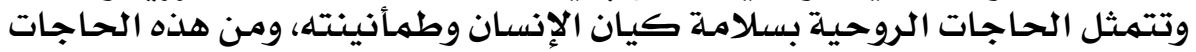

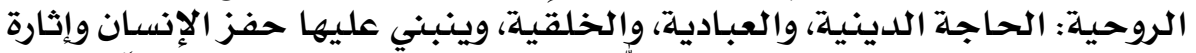

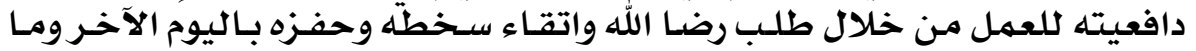

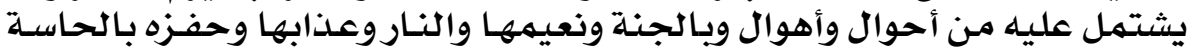
الخخلقية.

ويتبنى البـاحث يِّ هذه الدراسلة تصنيف الحهاجـات لماسـلو مضـافا لـه الحاجـات

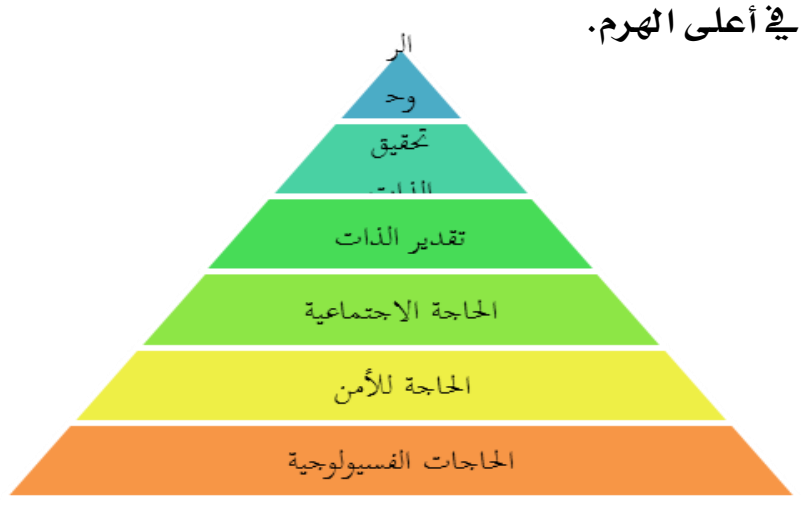

ثكل (1) هرم الحاجات الإنسانية

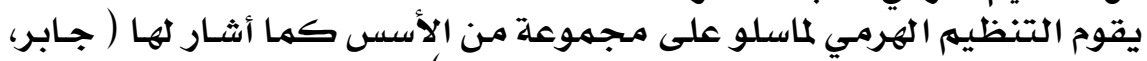

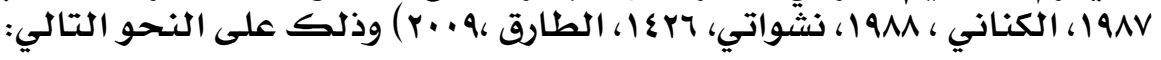

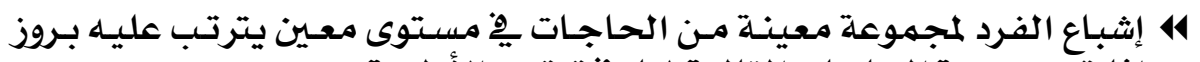

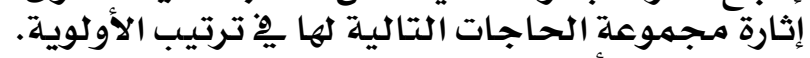

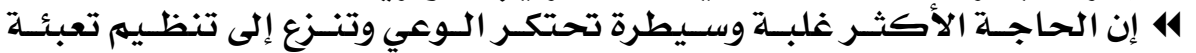

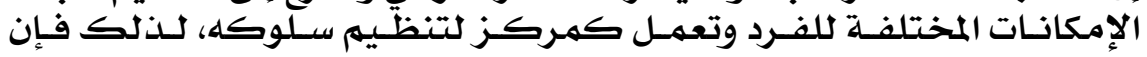

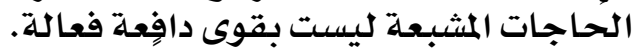

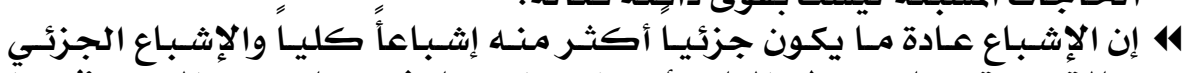

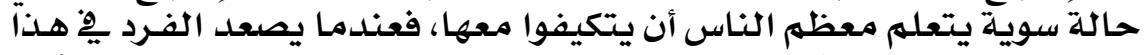

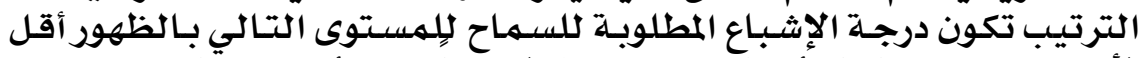

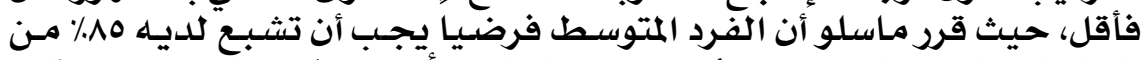

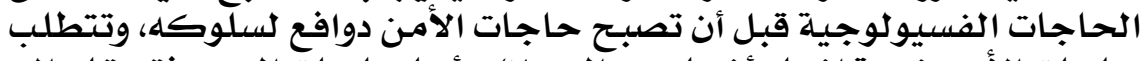

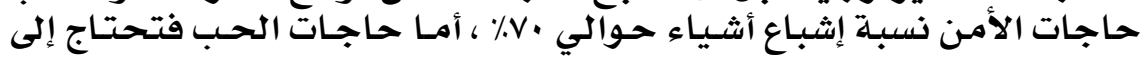

\section{Y^}




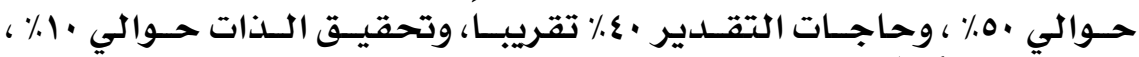

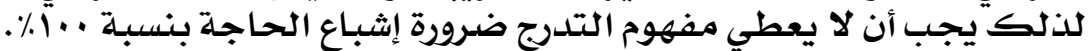

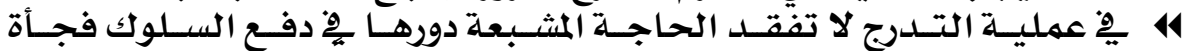

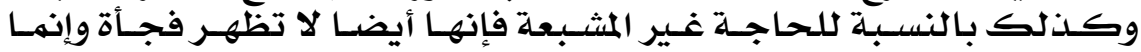
بالتدرج.

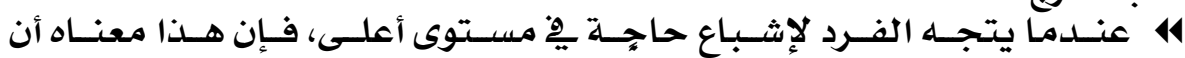

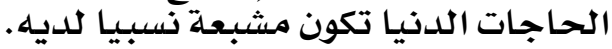

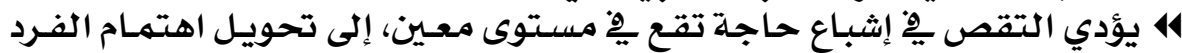

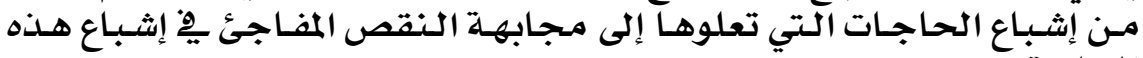
الحاجة.

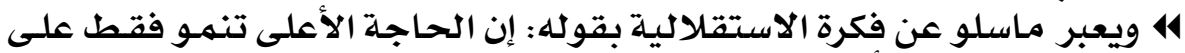

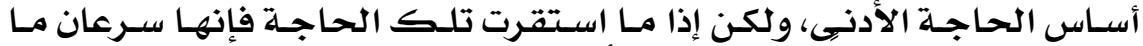

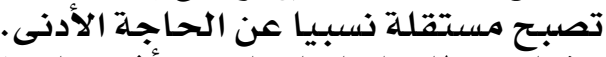

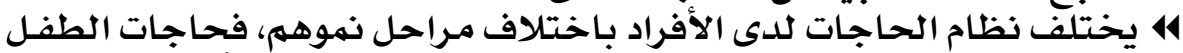

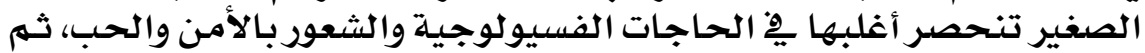

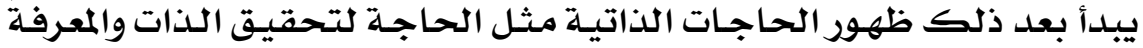

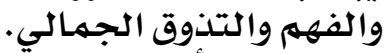

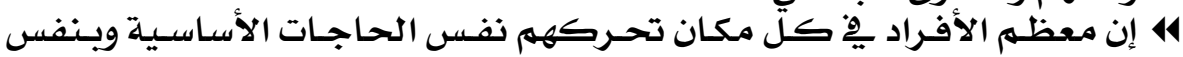

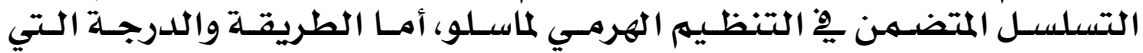

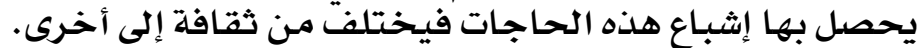

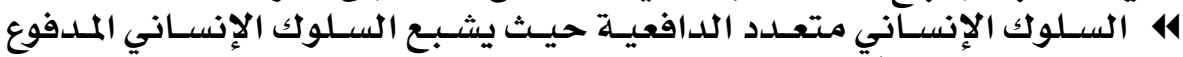

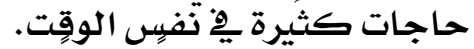

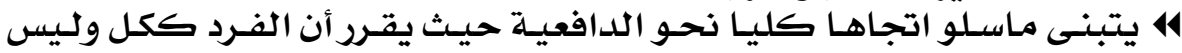

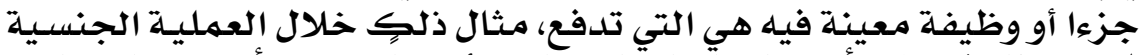

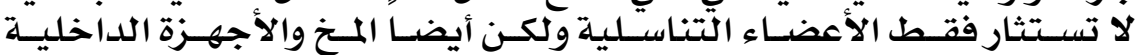

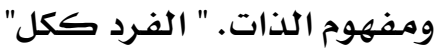

• الحاجات وها تتضمنه هن هماور في المرحلة الثانوية:

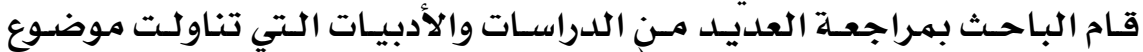

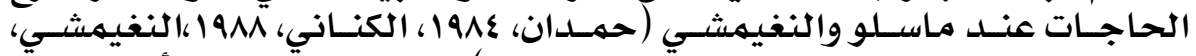

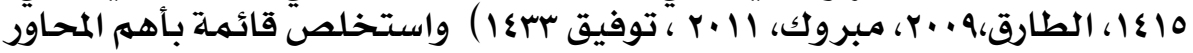

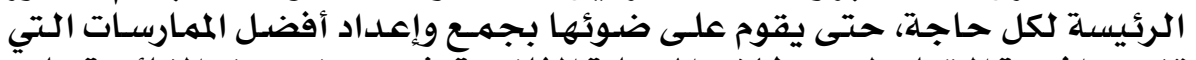

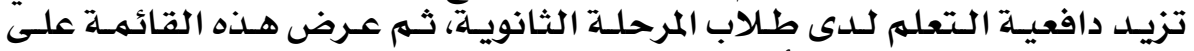

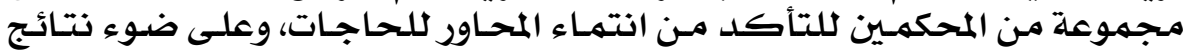

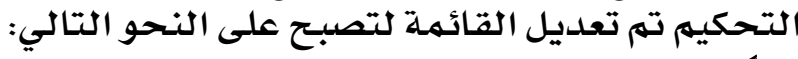
اولاً : الحماجمات الطبيعية، وتتضمن المحاور التالية: 14 ألأكل والشرب. 414 النوم. 14 قضشاء الحماجة. 14 توفير الحقوق المدنية والاجتهماعيـة. 


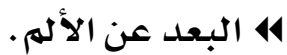
4 لهنب المجاقبة بالحبالحرمان من الحاجات الأساسية.

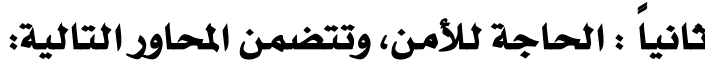
414 414 وضوح معايير تقييم الأداء. 414 العدل فِ التعامل والمكافأة. 414 نظام عادل للقبول والتسريح.

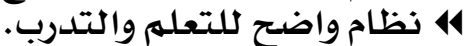

4 الأمان النفسي من التجريح والنقد الكراذع. 4 الأمان النفس من الإهانة والنتقاص النقاص الكرامـة. 4 الأمان من إصابات العمل وأخطاره.

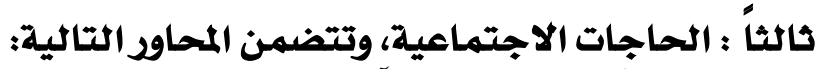

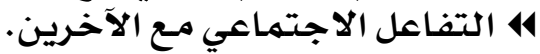
414

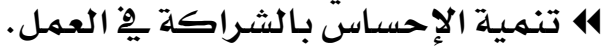
4 4 تعزيز العلاقات الإنسانية. 414 تنمية وتعزيز الأخوة والصداتية الإنة. 4 14 دعم التواصل عبر الإبر الشبكات الاجتماتواعية.

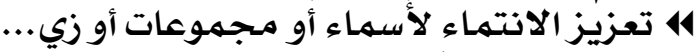
41 القبول لدى الآخرين.

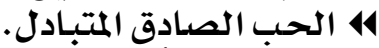
414 العلاقات الأسرية الجيدة.

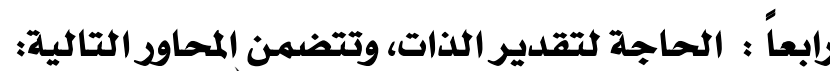
4 إظهاروتوثيق إنجازاتهم الشخصية ـ ( نسبة إسهاماتهم الناجحة لهمه ) 4 الاستماع لهمه. 4 4ه إبراز مواهبهـ وقدراتهم. 4ا المداح والثناء عليهم.

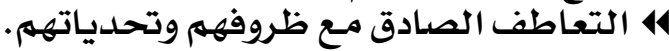
414 التقدير والاهتمام بهم وبهشار كاتهم وإسهاماتهمهم.

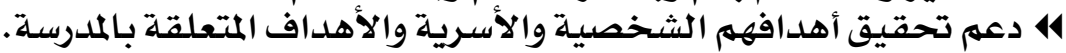
414 تعزيز الشعور بالكفاءة الشخصية الشيق والقوة والمكانة. 4 تشجيع تحقيق إنجازات مادية وعائلية ... متميزة. (الإنجاز)

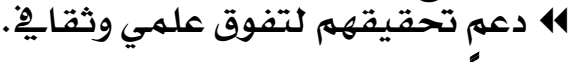

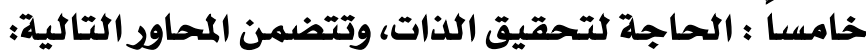

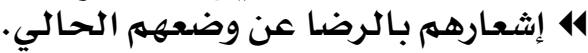
414 د اعم امتلاكهم المهارات. 414 414 المشاركة فِّ اتخاذ القرار.

\section{YA}




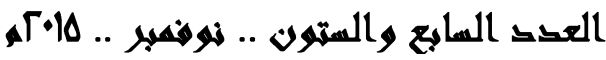

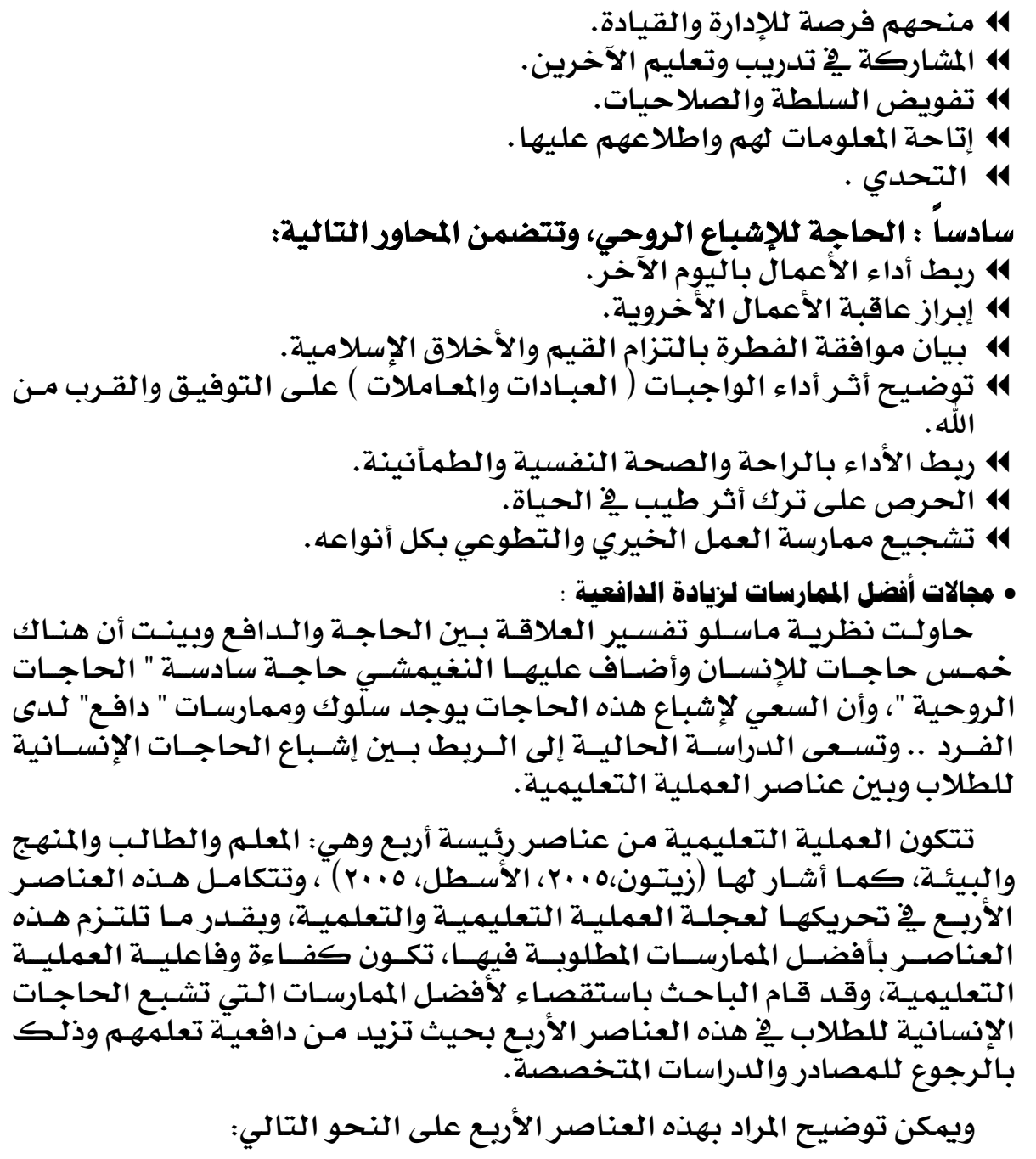

:pello

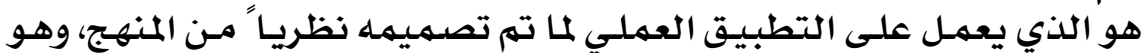

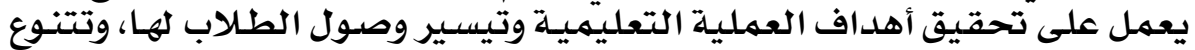

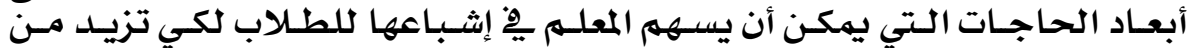

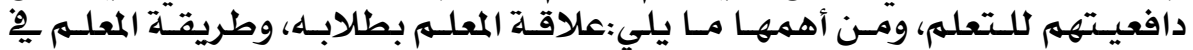

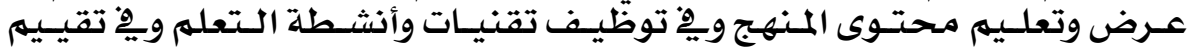
الطابلاب.

•

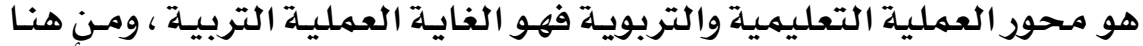

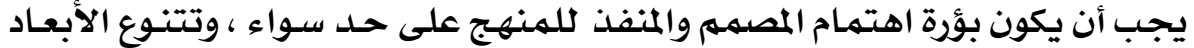

\section{$Y \wedge \varepsilon$}




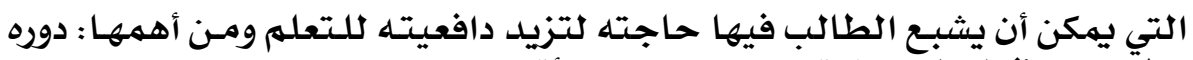

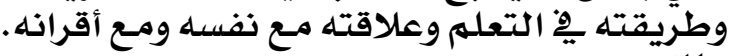
• المنهج:

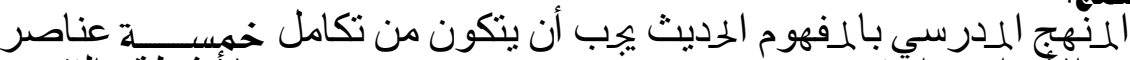

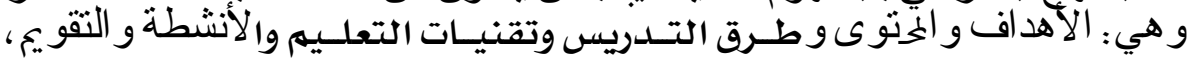

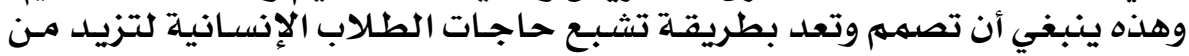

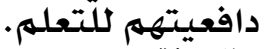
• البيئية:

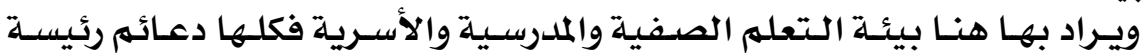

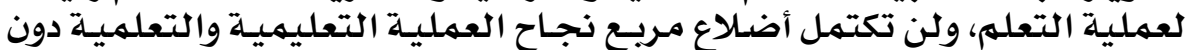

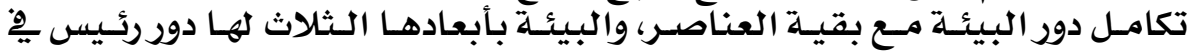

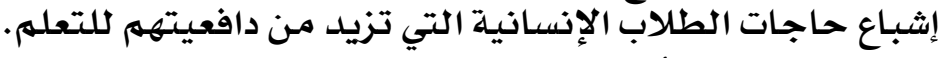

\section{• هن:هج الدراسة وأدواتها:}

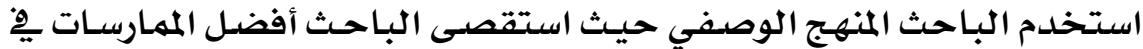

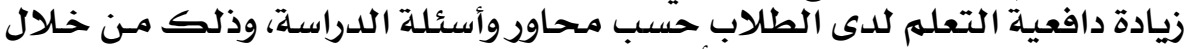

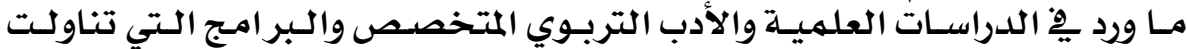

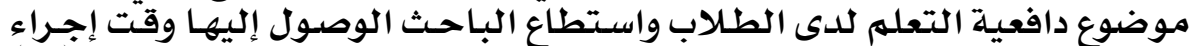

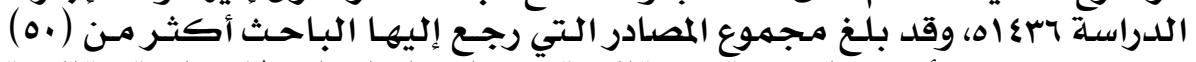

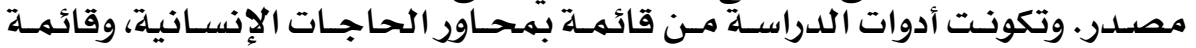

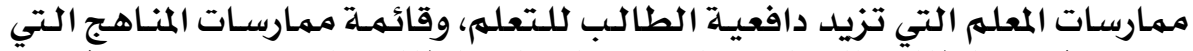

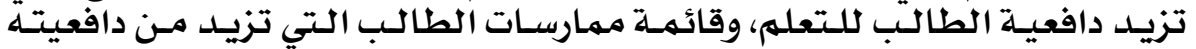

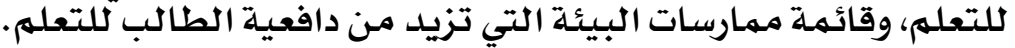

\section{• مإجراءات الدراسة:}

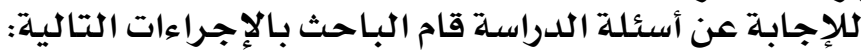

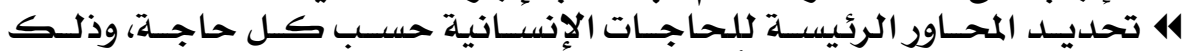

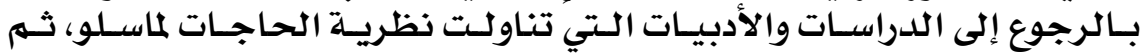

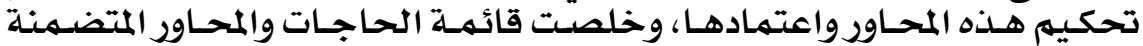

\begin{tabular}{|c|c|}
\hline علد المحاور & "الحاجات \\
\hline 7 & الحاجات الطبيعية \\
\hline$\Lambda$ & الحاجة كلأمن \\
\hline 1. & الحاجات الاجتماعية \\
\hline 1. & الحاجة لتقدير الذات \\
\hline 9 & الحاجة لتحقيق الذات \\
\hline$v$ & الحاجات الروحية \\
\hline .0 محصو & المجموع \\
\hline
\end{tabular}

4 تحديد أفضل مهارسات عناصر العملية التعليميـة (المعلمى - الطالب - المنهج

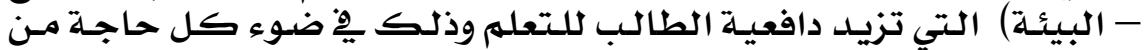

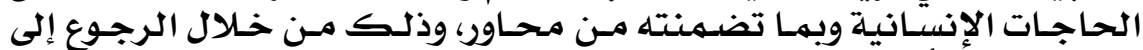

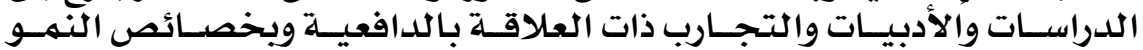
لطلاب المرحلة الثانويـة.

\section{Y^O}




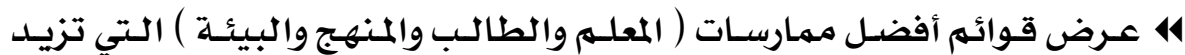

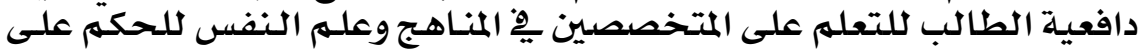

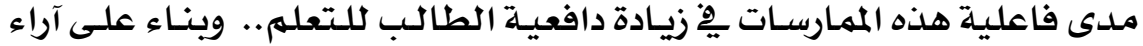

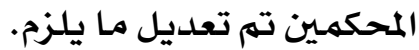

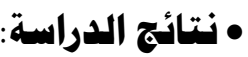

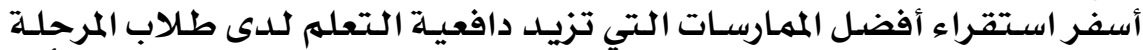

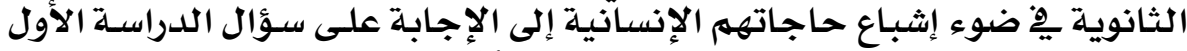

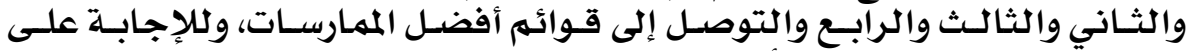

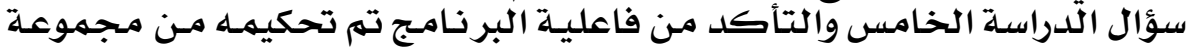

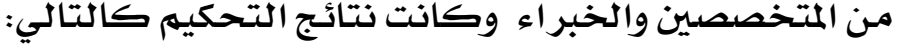

\begin{tabular}{|c|c|c|c|c|c|c|c|c|c|}
\hline \multicolumn{7}{|c|}{ التقييم } & \multirow{3}{*}{ بند التحكيم } & \multirow{3}{*}{ 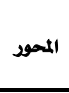 } & \multirow{3}{*}{$\rho$} \\
\hline \multicolumn{2}{|c|}{ غير مناسب } & \multicolumn{3}{|c|}{ مناسب بدرجة متوسطة } & \multicolumn{2}{|c|}{ مناسب بدرجة عالية } & & & \\
\hline النسبة & التكرار & \multicolumn{2}{|c|}{ النسبة } & التكرار & النسبة & التكرار & & & \\
\hline- & - & \multicolumn{2}{|c|}{$\%$. } & 1 & $\%$ \%. & 9 & سلامة الصياغة اللغوية & \multirow{3}{*}{ 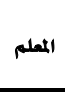 } & \multirow{3}{*}{1} \\
\hline- & - & \multicolumn{2}{|c|}{ - } & - & $\% \ldots$ & 1. & انتماء الممارسات للحاجة & & \\
\hline - & - & \multicolumn{2}{|c|}{-} & - & $\%$... & 1. & انتماء الممارسات للمحور & & \\
\hline- & - & \multicolumn{2}{|c|}{$\%}$. & 1 & $\%$ \%. & 9 & سلامة الصياغة اللغوية & \multirow{3}{*}{ الطالب } & \multirow{3}{*}{$r$} \\
\hline - & - & \multicolumn{2}{|c|}{$\%$. } & 1 & $\%$ \%. & 9 & اتتماء الممارسات للحاجة & & \\
\hline - & - & \multicolumn{2}{|c|}{ - } & - & $\% \ldots$ & 1. & انتماء الممارسات للمحور & & \\
\hline - & - & \multicolumn{2}{|c|}{$\%$ r. } & $r$ & $\%$. & $\wedge$ & سلامة الصياغة اللغوية & \multirow{3}{*}{ 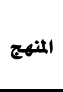 } & \multirow{3}{*}{$r$} \\
\hline- & - & \multicolumn{2}{|c|}{$\%$. } & 1 & $\%$ \%. & 9 & انتماء الممارسات للحاجة & & \\
\hline - & - & \multicolumn{2}{|c|}{ - } & - & $\% \ldots$ & 1. & انتماء الممارسات للمحور & & \\
\hline- & - & \multicolumn{2}{|c|}{-} & - & $\% \ldots$ & 1. & سلامة الصياغة اللغوية & \multirow{3}{*}{ البيئة } & \multirow{3}{*}{$\varepsilon$} \\
\hline - & - & \multicolumn{2}{|c|}{ - } & - & $\% \ldots$ & 1. & انتماء الممارسات للحاجة & & \\
\hline - & - & \multicolumn{2}{|c|}{ - } & - & $\% \ldots$ & 1. & انتماء الممارسات للمحور & & \\
\hline \multicolumn{10}{|c|}{ الراي النهائي للتحكيم } \\
\hline \multicolumn{2}{|c|}{ ملائمير } & \multicolumn{2}{|c|}{ برجة ملائمة } & \multicolumn{2}{|c|}{ بدرجة عالية } & & \multirow[t]{2}{*}{ البند البند } & & \\
\hline النسبة & التكرار & النسبة & التكرار & 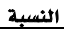 & التكرار - ار & & & & \\
\hline - & - & - & - & $\% \ldots$ & 1. & 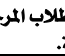 & 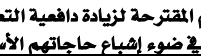 & ملائمة إ & \\
\hline
\end{tabular}

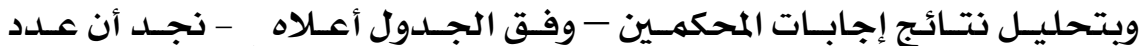

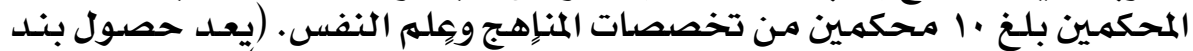

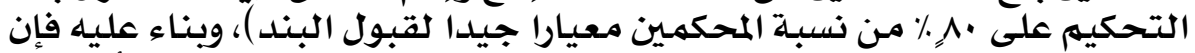

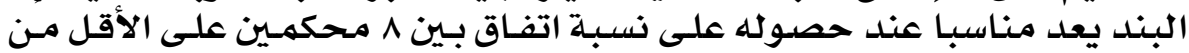

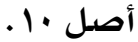

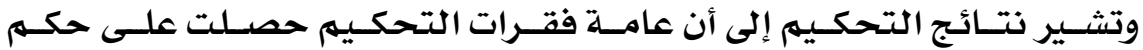

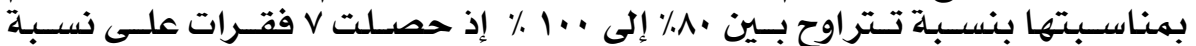

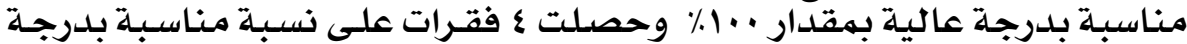

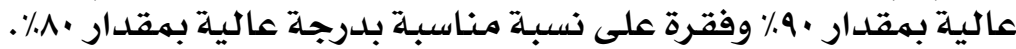

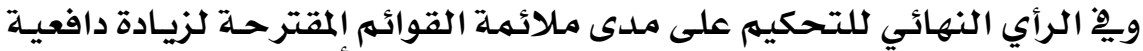

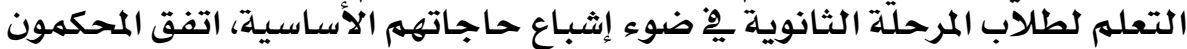

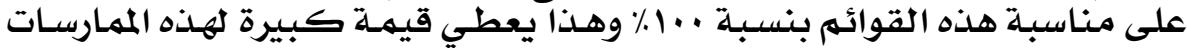
ولقدرتها على زيادة دافعية التعلهم. 


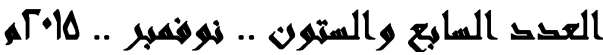

$$
\text { وفيما يلي عرض لقوائم أفضل الممارسـات بعد تحكيمها : }
$$

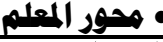

\begin{tabular}{|c|c|}
\hline \multicolumn{2}{|c|}{ 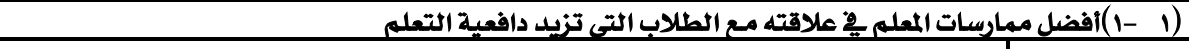 } \\
\hline 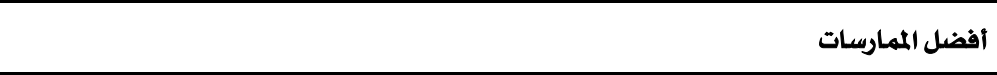 & الإنساجية \\
\hline يسمح بالخروج من الصف لإثباع الحاجات الأساسية من أكل وثرب وقضاء حاجة & \multirow{3}{*}{ 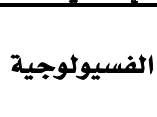 } \\
\hline يعطى فترات راحة بين اجززاء الدربي عندما يكون طويلا. & \\
\hline يراعى الظروف الصحية والنفسية التي بيريها الطلاب. & \\
\hline يبتعد عن التهديد البدني ( الضرب ..) والمعنوي ( خصم الدرجات ..) لتحفيز الطلاب للتعلم & \multirow{7}{*}{ الأمن } \\
\hline يتجنب التعريض باجناس الطلاب أو أمراقهـ أو أعرافهم. & \\
\hline يعدل 2ِ التعامل معهم ويتيح لهم فرصا متساوية 2ِ التعلم. & \\
\hline يوفر جو نفسى آمن يستطيع الطالب أن يتحمل فيه مخاطرة الاختيار بارادة ذاتية. & \\
\hline يوضح بموضوعية أسباب تفضيله وتقدبمه لأي من الطلاب. . . & \\
\hline التعلمنب العقوية ويلجا إلى النظام والنتائج المنطقية عندما يكون سلوك الطالب معيقا عند & \\
\hline 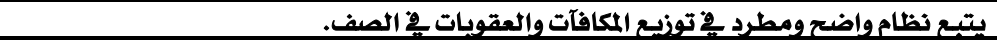 & \\
\hline يعبر عن حبه ومشاعره الإيجابية نحو الطلاب. & \multirow{5}{*}{ 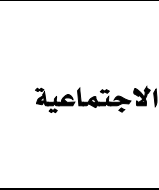 } \\
\hline يبنى علاقات صداقة وأخوة مـ الطلاب. & \\
\hline يشجع الطلاب على تبنى أسماء وثعارات لمجموعاتهم وأعمالهم. & \\
\hline يستعمل الحد الأدنى من السيطرة عند التعامل مـع الطلاب وإدارة الفصل. & \\
\hline يعتنى المعلم بالطلاب ( بمشاكله ومواهيه وظروفهم ..) فرادي وحماعات. & \\
\hline يثنى على نجاحات الطلاب بشكل محلدد. & \multirow{8}{*}{ تقدير الذات } \\
\hline يدون إعجابه وتقديره للممارسة التعلمية الصحيحة على أوراق ودفاتر وكتب الطلاب. & \\
\hline يساعد الطلاب على تحليد أهدافهم الشخصية وكيفية تحقيقها. & \\
\hline يظهر اهتمامه بالطلاب وحاجاتهم ومشكلاتهم الشخصية والتعليمية. & \\
\hline يستخدم عبارات لطيفة يُ تعامله مـع الطلاب. & \\
\hline \multirow{3}{*}{ 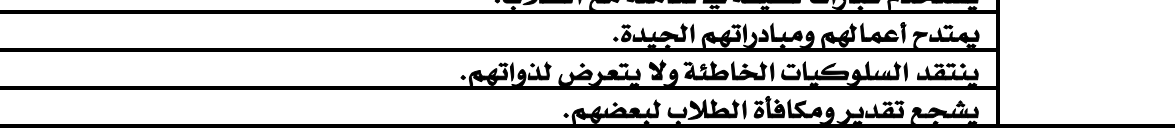 } & \\
\hline & \\
\hline & \\
\hline يلدعو الطلاب إلى التعريف بمنجزاتهم ونجاحاتهم أمامه. & \multirow{5}{*}{ 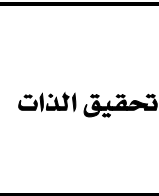 } \\
\hline يحث طلابه على تقديم مساندة ودعم لزملائهم الآخرين. & \\
\hline يشع طلابه على خوض التجاري وتعلم المهارات والخبر ات الجليدة. & \\
\hline يتيح لهم فرصا لابتكار حلول وتطبيقات جديلة. & \\
\hline يظهر مواهب وقدرات الطلاب لزملائهم ومعلميه ويثنى عليها. & \\
\hline \multicolumn{2}{|l|}{ يعود الطلاب على الأذكاروالأدعية. } \\
\hline يستثير كوامن الفطرة الطيية فِ نفوسي الطلاب للاستحابة للتعلموممارساته الصحيحة . & \multirow{6}{*}{ الروحبي } \\
\hline يشحع على ربط الإقدام على العمل وتركه بمدى ارتباطه براحة القلب والنفس لفعله. & \\
\hline ويبذوذه. للطلاب بان الاختفاء بالسلوك وإخفاته يدل يُ كثير من الأحيان على اعوجاج السلوك & \\
\hline يستثمر ميل الطلاب للعدل ومقتهم للطليم بفطرتهم للرجوع للحق والإنصاف من النفس. & \\
\hline يؤكد أن أنواع القلق والضيق والتأنيب النفسى ترجع فِ جاثب منها إلى مصادمة الفطرة. & \\
\hline يذكر الطلاب باستمرار يفضل طلب العلم والثواب عليه من الله. & \\
\hline \multicolumn{2}{|c|}{ 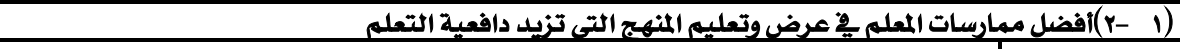 } \\
\hline أفضل الممارسعات & الإنساجنة \\
\hline يراعى عند الشرح الظروف الفيزيقية ( حرارة - برودة .. ) المحيطة بالطلاب داخل الفصل. & \multirow{2}{*}{ الفسيولوجية } \\
\hline يتجنب تأخير الطلاب عن الانصراف للفسحة بسبب إكمال الشرح. & \\
\hline
\end{tabular}

\section{YAV}




\begin{tabular}{|c|c|}
\hline يبتعد عن تخويف الطلاب من صعوية محتوى المنهج. & \\
\hline يؤكد ارتباط محتوى المنهج بحاجات الطلاب المستقبلية التعليمية والوظيفية. & \\
\hline يبدي استعداده للدعم الطلاب فيما يصعب عليهم فهمه. & \\
\hline 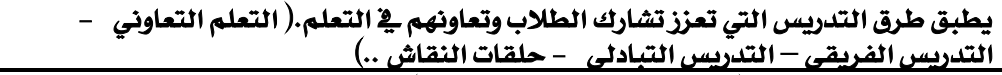 & \multirow{6}{*}{ الاجتماعية } \\
\hline ينوع هُ مسارات التعلم (فردي - ثنائى - ثلاثى - ...) & \\
\hline يسمح بالتشكيل الحروالموجه لمجوعات التعلم. & \\
\hline يمارس المهارات التواصلية مـع الطلاب باتقان ( استماع - حوار - إقناع - تعاطف ..) & \\
\hline يربط المحتوى والتعلم بسياقات حياتيح واقعيح للطلاب. & \\
\hline يشحع التلقائية والعفوية بِ التعامل وفِ سير الأحداث التعلمية والتعليمية. & \\
\hline يؤكد قدرتهم واستطاعتهم على تحقيق النجاح والتفوق فِ محتوى المنهج. & \multirow{7}{*}{ 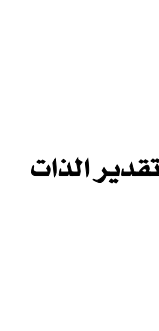 } \\
\hline يحترم تنوعهم يُ عرض أفكارهم وتعليقاتهم أثناء تعلى محتوى المنهج. & \\
\hline يدثلهم على برامـج مساندة وإثرائية تلدمى تعلمه لمحتوى المنهج. & \\
\hline 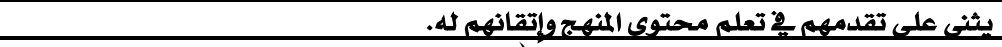 & \\
\hline ينلفزها) الطالب يختار عندما يكون ذلك ممكنا ( يختار المهمة أو متى وكيف وأين ومع .. & \\
\hline مراجعر ومواد مساندة للتعليم. بـ التعلم ويطلب منهم المساعدة والتوضيح والشرح وإحضار & \\
\hline يربط بين محتوى المنهج وأهداف الطلاب العامة. & \\
\hline يتيح الفرصة للطلاب لتعليم بعضهم. & \multirow{7}{*}{ 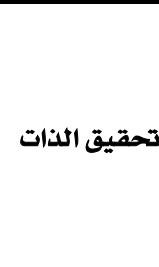 } \\
\hline يغير المفاهيم الثابتة لدى الطلاب من خلال عرض مفاهيم مخالفة لها. & \\
\hline يتيح فرصة للطلاب لمساعدته ف2 تقديم بعض اجززاء الدربص. & \\
\hline يسمح لهم بابتكارطرق وحلول جليدة للتعلم. . & \\
\hline يستثير ويتحلدى تفكير وعقول الطلاب بالأسئلة غير المتوقعة وفير المألوفة ويالألغاز التعليمية. & \\
\hline يؤكد دور تعلم محتوى المنهج يُ بناء الحضارة وصناعة المجلد. & \\
\hline يستخلدم طرق التدريس التى تتبح وتشجع الطلاب على الاستكشاف. & \\
\hline يريط تعلم المحتوى بلدور الإنسان ف2 تحقيق العبودية وإعمار الكون. & \multirow{3}{*}{ الإوحبياع } \\
\hline ييرز الجانب القيمى والأخلاقى ف2 محتوى المنهج. & \\
\hline يؤكد دور الدعاء والاستعانة بالله فِ تيسير تعلم المحتوى. & \\
\hline \multicolumn{2}{|c|}{ | } \\
\hline 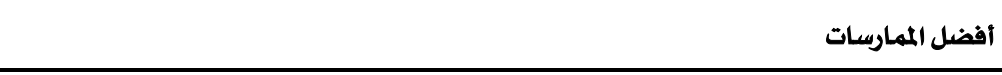 & الإنساجنة \\
\hline يعتنى بمناسبة الأنشطة والتقنيات المستخلمة لخصائص نمو وقدرات الطلاب العضلية. & \multirow{2}{*}{ الفسيولوجية } \\
\hline يبتعد عن الأنشطة والتقنيات التى تسبب الألم للطلاب. & \\
\hline يتاكد من سلامة النشاط أو الأجهزة من الأخطار بأنواعها. & \multirow{3}{*}{ 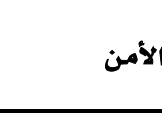 } \\
\hline يلتزم ياتاحة الفرص المتساوية لجميع الطلاب للمشاركة في الأثشطة. & \\
\hline يعتنى يـاتاحة الفرص المتساوية لجميع الطلاب للتعامل مـع تقنيات التعليم ومشاهدتها. & \\
\hline يعز الأثشطة الجماعية التعليمية بين الطلاب. & \multirow{6}{*}{ الاجتماعية } \\
\hline يشجع مشاركة الطلاب ه الأثشطة المدرسية. & \\
\hline يحوريعض الأنشطة لتدعم العمل الحماعى والتعاونى. & \\
\hline يضيف بعض الأنثطة لتعزز التواصل مـ المجتمع المدربيى والمحتمع الخارجي. & \\
\hline يكلف الطلاب بمشاريع ومهمات أدائية جماعية . & \\
\hline يوظف التقنيات التي تعزز العمل الجماعى هِ الدربي . & \\
\hline يتيح لهم حرية اختيار مكان وزمان وطريقة تنفيذ الأنشطة واستخدام التقنية. & \multirow{5}{*}{ 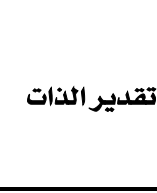 } \\
\hline يكتشف مواهب الطلاب يخ الأثشطة وتقنيات التعليمويوظفها لخلمة التعليموالتعلم. & \\
\hline يتجنب تأنيب وتعنيف المحاولات والتحاري الخاطئة للتفاعل مـ الأنشطة أو تقنيات التعليم. & \\
\hline يحتفى بمشاركات وإنحازات الطلاب ف تقنيات التعليموالأنشطة. & \\
\hline يعطى مرونة كافية يخ تنفيذ النشاط وتوظيف التقنية ويتيح مساحة للإبلاع. & \\
\hline
\end{tabular}

\section{Y^A}




\begin{tabular}{|c|c|}
\hline يشحع على ابتكار أنشطة وتقنيات تعليم تساعد على التعلم. & \multirow{4}{*}{ 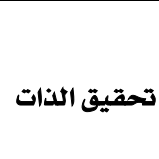 } \\
\hline يلدعم مساندة الطلاب لبعضهم ف تنفيذ الأنشطة وتقنيات التعليه. & \\
\hline ييسر سبل وطرق الاستكشاف والوصول للمعلومة من خلال الأثشطة وتقنيات التعلم. & \\
\hline ستخدم الصوروالمرئيات التى تتحدى وتستثير الطلاب وتوجد ووابط مع محتوى التعلم. & \\
\hline \multicolumn{2}{|l|}{ يلرب الطلاب على متطلبات تفوقهم ـ2 الأنشطة وتقنيات التعليه. } \\
\hline يشحع طلابه على أداء أشطة تطوعية داخل وخارج المدرسة. & \multirow{4}{*}{ الروحبياع } \\
\hline يذكر فضائل وأجر العمل الحماعى والإحسان للآخرين. & \\
\hline يحث طلابه على توظيف التقنية فِ نفع الناس وخلمتهم. & \\
\hline يؤكد فضل المؤمن القوي الفاعل والإيجابى والنشيط فِ عمله. & \\
\hline \multicolumn{2}{|c|}{ 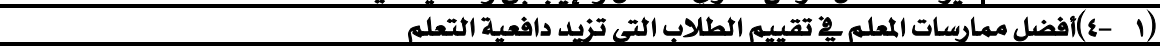 } \\
\hline افضل الممارسات & الإنساجة \\
\hline يهتم براحة الطالب النفسية والصحية أثناء تقييمه وأداته للاختبارات. & \multirow{2}{*}{ الفسيولوجية } \\
\hline يسمح للطالب بإثباع حاجاته من شرب وقضاء حاجة ونحو ذلك عند أداء الاختباد. & \\
\hline يتبع معايير واضحة ومعلنة ف2 تقييم أداء الطلاب. & \multirow{5}{*}{ الأمن } \\
\hline يطمئن الطلاب بارتباط التقييم بما تعلموه ِِ محتوى المنهج. & \\
\hline يتجنب تهديد الطلاب بالدرجات والاختبارات. & \\
\hline 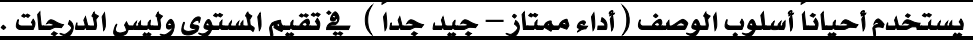 & \\
\hline يؤكد سعيه وحرصه على مساندة الطلاب للحصول على أعلى الدرجات. & \\
\hline يستخلدم التقويم الجماعى للمجموعات والتقويم الفردي. & \multirow{4}{*}{ الاجتماعية } \\
\hline 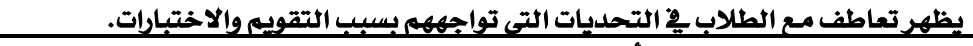 & \\
\hline يمارس احيانا أساليب تقويم الأقران. & \\
\hline ييتعل عن مقارنة درجات ومستوى الطالب بالآخرين وإنما بنفسه أو بمحكات موضوعية. & \\
\hline يجزيع ويمرحل الواجبات وإلمهمات الكبيرة إلى أجزاء ومراحل لتساعد الطلاب على الإنجاز. & \multirow{7}{*}{ 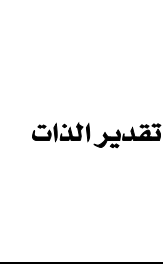 } \\
\hline يؤكد ثقة الطلاب بانفسه وقدرتهم على التفوق والنحاح. & \\
\hline يقدم تغذية راجعة مباشرة علي أداء الطلاب وواجباتهم واختباراتهم. & \\
\hline يطلع الطلاب على الأعمال الجيلة التى قام بها أقرانهم. & \\
\hline يحترم الطلاب الأقل تفوقا ولا يحتقر قدراتهم ومستواهم. & \\
\hline يستخدم نتائج التقويى فِ تعزيز نقاط القوة لدى الطلاب وتحسين تعلمهم. & \\
\hline يثنى على الطلاب الذين أظهروا تقدما أو تفوقا ِ2 مستواهم التعليمي. & \\
\hline يتيح فرصة للطلاب الأكثر تفوقا بمساندة ومعاوثة زملائهم. & \multirow{6}{*}{ 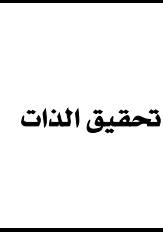 } \\
\hline يشحع الطلاب على المساهمة يُ تطوير أدوات وأساليب التقويم المتبعة. & \\
\hline يزود الطلاب بنتائج أعمالهم ويقدم التغلية الراجعة لهم. & \\
\hline يشرك الطلاب ف2 تحلديد واختيار بعض طرق وآليات تقويمهم. & \\
\hline يؤكد أهمية الطموح والتفوق وتنوعه 2. محالات وخيارات متعددة. & \\
\hline يتيح للطلاب تقييم أنفسهم وتقييمه لبعض. & \\
\hline 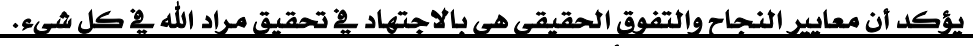 & \multirow{4}{*}{ الروحبي الإثباع } \\
\hline يعزز أهمية التصحيح المستمر للأخطاء والتوبة من كل ذنب وخطيئة وتقصير. & \\
\hline يذكر بفضائل العمل والصبر عليه والإصراروعدم اليأس. & \\
\hline ينبه أن خيرة الله فيما يختار لك، وأن المطلوب هو السعى والعمل . & \\
\hline
\end{tabular}

• همور الطالب :

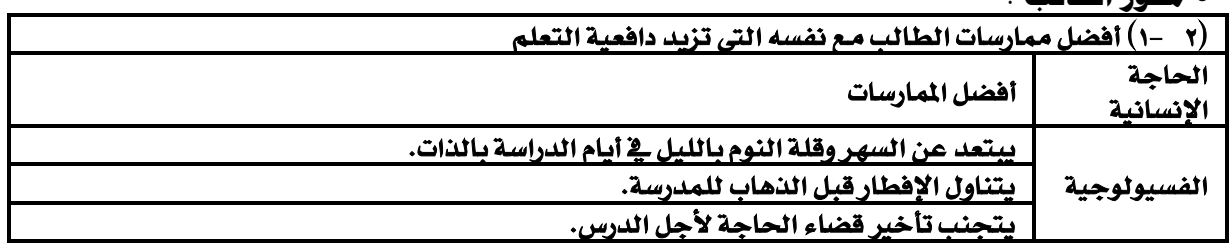




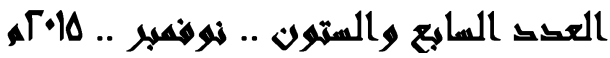

\begin{tabular}{|c|c|}
\hline \multirow{2}{*}{\multicolumn{2}{|c|}{ 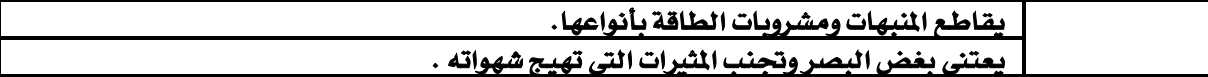 }} \\
\hline & \\
\hline يبتعد عن ذم النفس وتقبيحها. & \multirow{4}{*}{ الأمن } \\
\hline ياخذذ احتياطات السلامة عند اللعب أو مزاولة النشاط ِي المدرسة. & \\
\hline يطالب بحقوقه بلطف وأدب. & \\
\hline يؤكد ذاته وينفى عبارات السوء والذم التى يتهمه بها. & \\
\hline يحب نفسيه ويتقبلها كما هي. & \multirow{5}{*}{ الاجتماعية } \\
\hline يعتنى بتكوين صداقات إيحيابية. & \\
\hline يلدرب نفسه على التعاون والعمل مـع الآخرين. & \\
\hline يشترك ف2 الأنشطة والبر امتج المدرسية. & \\
\hline يعبر عن حبه لأصدقائه. & \\
\hline يثق بقدراته من غير غرور. & \multirow{4}{*}{ تقدير الذات } \\
\hline يكافئ نفسل ويثنى عليها عند تحقيق إنجازات. & \\
\hline يحدد أهدافا ويسعى لتحقيقها. & \\
\hline يوثق نجاحاته المدرسية ويشارك الآخرين بها. & \\
\hline يبادر لتحريب بعض الفرص القيادية م2 المدرسة. & \multirow{5}{*}{ 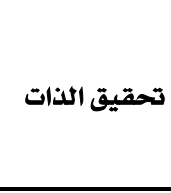 } \\
\hline يتدرب على مهارات الإيداعوالابتكار. . & \\
\hline يسعى لتعليه زملائه ومساندتهم ِ2 التعلم. & \\
\hline يقدم وؤاه وأفكاره لحل الشكلات وتطوير الأعمال المدرسية. & \\
\hline ييادر للإسهام فِ صناعة القرارات المدرسية. & \\
\hline يذكر نفسيه بالأجروالثواب من الله فيما يتعلم هو المدرسة. & \multirow{4}{*}{ الرإثباع } \\
\hline ستحضره استخلاف الله له ي الأرض لإعمارها وإقامة ثرع الله. & \\
\hline 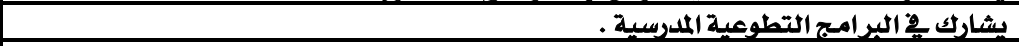 & \\
\hline يسابق لنفع الطلاب والإحسان إليهم. & \\
\hline \multicolumn{2}{|c|}{ 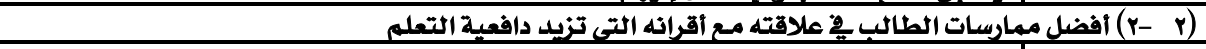 } \\
\hline أفضل الممارسات & الإنساجية \\
\hline يؤكد حق زملائه ـ 2 إثباع حاجاتهم للأكل والشرب وقضاء الحاجة ... & \multirow{5}{*}{ الفسيولوجية الفية } \\
\hline يلعمويشحع العادات الصحية والغذائية الحيدة. & \\
\hline يتجنب الطلاب ذوي السلوكيات والممارسات فير الأخلاقية. & \\
\hline يتعاهد مـع زملائه بتجنب الششرويات والأفذية الضارة. & \\
\hline يتجنب الأصلدقاء المصرين على العادات الصحية والغذائية السيئة. & \\
\hline يترك المزح واللعب المؤذي. & \multirow{5}{*}{ الأمن } \\
\hline يحافظ على أدوات وكتب .. زملائه. & \\
\hline يحفظ الأسرارولا ينقلها كلآخرين. & \\
\hline يتجنب الإساءة اللفظية والحسية والمعنوية للطلاب. & \\
\hline يبتعلد عن تمييز الطلاب بسبب أمراقهم وأجناسهـ ويلدانهم. & \\
\hline يعبر عن حبه وتقديره لزملائه. & \multirow{5}{*}{ الاجتماعية } \\
\hline يلدعم زملائه هِ المشاركات والعمل الجماعى. & \\
\hline يقيل بتكوين صداقات وعلاقات أخوية مفيدة. & \\
\hline يشارك زملائه يُ برامجحولقاءات اجتماعية تفاعلية. & \\
\hline ينضيم لبعض مجموعات التواصل الاجتماعى مـعزملائه. & \\
\hline يثنى ويمدح نجاحات زملائه. & \multirow{5}{*}{ تقدير الذات } \\
\hline يستمع باهتمام لحلديث ورأي زملائه. & \\
\hline يقدر زملائه وينزئهم المنزلة اللائقة بهم. & \\
\hline يظهر التعاطف والاهتمام بتحدياتهمومشاكلهم. & \\
\hline يذكر إنجازات وتفوق زملائه ويشهرها. & \\
\hline
\end{tabular}




\begin{tabular}{|c|c|}
\hline يظهر الرغبة ف2 التعلم من بعض خبر ات زملائه ومواهبهم. & \multirow{5}{*}{ 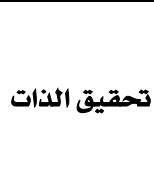 } \\
\hline يلدور القيادة ف2 فرق العمل والمحوعات. & \\
\hline يلدعم مشاركة أعضاء الفريق والمجموعة يُ اتخاذ القرارات. & \\
\hline يّجع زملائه على تقديم حلول ومقترحات تطويرية. & \\
\hline يسانل زملائه ِِ تحقيق تفوق علمى أو شخصى. & \\
\hline يذكر زملائه بثواب وأجر الأعمال التى يقومون بها. & \multirow{4}{*}{ الرإِشباع } \\
\hline يريط التفوق والنجاح الحقيقى برضا الله. & \\
\hline شحع المساهمة 2 أعمال البر والخير. & \\
\hline يعظم أمر التوكل على الله أولا ويذل الأسباب ثانيا ــ تحقيق النجاح. & \\
\hline \multicolumn{2}{|c|}{ 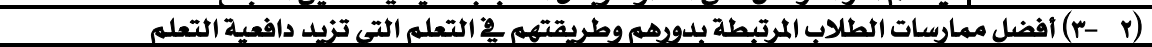 } \\
\hline أفضل الممارسات & الإنساجة \\
\hline يتجنب تأخير تلبية حاجته للنوم والأكل والشرب لأجل الدراسة. & \multirow{4}{*}{ 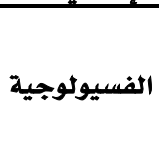 } \\
\hline يستثمروقت الصباح الباكر فِ المذاكرة والتعلم. & \\
\hline يأخذ قسط يسير من الراحة بين فترات المذاكرة لتجديد النشاط والذهن. & \\
\hline يتناول الأفذية الطبيعية التى تساعد على تقوية الذاكرة والتركيز. & \\
\hline يتجنب المبالغة من الخوف من الاختبار. & \multirow{4}{*}{ الأمن } \\
\hline يتعامل بهدوء مع مصادر القلق المتعلقة بالتعلم. & \\
\hline ييتعد عن المثالية ف2 طلب الكمال والعدل التام من معلميه. & \\
\hline يتفاءل بنجاحه وتفوقه فِ التعلم. & \\
\hline يتشارك مـع بعض زملائه يُ التعلم داخل الصف وخارجه. & \multirow{5}{*}{ الاجتماعية } \\
\hline يقارك بِ برامج تفاعلية تعليمية. & \\
\hline يكون علاقات قوية مع الطلاب المتفوقين. & \\
\hline ينشيو مجموعة تواصل اجتماعية مرتطة بالتعلم. & \\
\hline يعتنى بتوثيق علاقته مـ معلميه. & \\
\hline يكافيء نفسه ويثنى على أي تحسن يحققه يُ التعلم. & \multirow{4}{*}{ 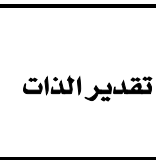 } \\
\hline يبينين لمعلمه أهدافه التى يطمح لتحقيقها يُ المادة أو التعلم بشكل عام. & \\
\hline يوثق إنجازاته هِ التعلم لكل مادة ويعرضها على المعلمبن. & \\
\hline يستمع لمعلمه بكل حواسيه ويساعد معلمه على أن بعامله بالمثل. & \\
\hline يشارك يُ برامج وفعاليات تنافسية 2خ التعلم تلاءم قدراته وإمكاناته. & \multirow{6}{*}{ تحقيق الذات } \\
\hline يسعى لابتكار طرق جديدة تساعده على التعلم. & \\
\hline ييادر لحل المشكلات التى تعترض تعلمه ولا يراكمها ويؤخرها. & \\
\hline يبحث عن فرص جديدة لتطبيق وتعليم وتشر ما تعلمه. & \\
\hline يسعى باستمرار لتعلم مهارات جديلة تلدمه وتقوي تعلمه. & \\
\hline يقدم على اتخاذ القرارات المتعلقة بتعلمه ومستقبله التعليمى ولا يبالغ و2 التاخروالتردد. & \\
\hline بذكر نفسه دوما باجر التعلم وطلب العلم. & \multirow{4}{*}{ الروحبياع } \\
\hline ييني لنفسه متعة ولذة خاصة فِ التعلم. & \\
\hline يؤمل نفسه دوما بعاقبة النجاح وثمرته المريحة. & \\
\hline بعتنى بتصحيح وإخلاص نيته يُ التعلم. & \\
\hline
\end{tabular}

• مصور المنهمج :

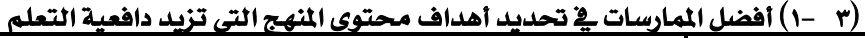

\begin{tabular}{|c|c|}
\hline \multicolumn{2}{|c|}{ 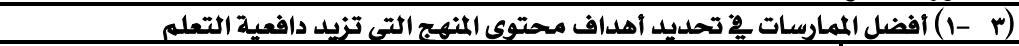 } \\
\hline أفضل الممارسات & الإنساجنية \\
\hline التاكيد من خلال أهداف المنهج على أهمية إثباع حاجات الطالب الأساسية. & الفسيولوجية \\
\hline إثراك الطالب بشكل آمن يخ اقتراح بعض الأهداف المناسبة للدرب أو الوحدة . & \multirow{3}{*}{ الأمن } \\
\hline العناية بتضمين بعض أهداف المنهج تاكيد ممارسات السلامة. & \\
\hline تضمين بعض أهداف المنهج ما يعزز احترام الآخرين والعدل معهم. & \\
\hline
\end{tabular}




\begin{tabular}{|c|c|}
\hline تضمين بعض أهداف المنهج ما يؤكد أهمية الاستقراروالأمن الفردي والمجتمعى. & \\
\hline العناية بتوجيه بعض أهداف المنهج لتحقيق أمورا اجتماعية تعاونية بين الطلاب. & \multirow{5}{*}{ الاجتماعية } \\
\hline التاكيد على تضمين بعض أهداف المنهج بعض الأمور الوجداثية المعززة للمحبة والتآلف. & \\
\hline التوجيه لبعض أهداف المنهج لتبرز الهوية المجتمعية الإسلامية وتشحع على التمسك بها. & \\
\hline العناية بتضمين أهداف المنهج ما يعزز العلاقات الإنسانية والتفاعل الإيحابى مـع الآخرين. & \\
\hline 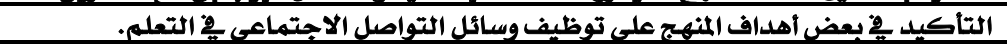 & \\
\hline الاهتمام بتضمين بعض أهداف المنهج ما يعزز تقدير الطلاب وإنجازاتهم. & \multirow{4}{*}{ تقدير الذات } \\
\hline التاكيل على احتواء بعض أهداف المنهج ما يسهـ ف2 اكتشاف وتنمية مواهب الطلاب. & \\
\hline العناية بتضمين بعض أهداف المنهج مـا يشحع على التفوق والطموح وتحقيق المراتب العالية. & \\
\hline العناية بصياغة أهداف المنهج وإيرازها بالقدر الذي يوضح للطلاب الأداء الدقيق المتوقع منهم. & \\
\hline الاهتمام بتضمين بعض أهداف المنهج ما يؤكد إيجابية الطالب وقدرته على كسب التحلدي . & \multirow{4}{*}{ 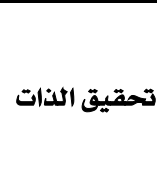 } \\
\hline العناية بمشاركة الطالب خُوضع أو اختياريعض أهداف المنهج. & \\
\hline 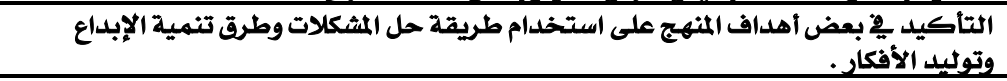 & \\
\hline التاكيد يُ أهداف المنهج ملي إعطاء دور أكبر ومساحة أوسع لششاركة الطلاب. & \\
\hline الاهتمام بتضمين بعض أهداف المنهج ما يشجع العمل التطوعى والمشاركة المجتمعية. & \multirow{5}{*}{ الروحبياع } \\
\hline التاكيد ـ2 اهداف المنهج على الاهتمام بالحوانب القيمية والأخلاقية. & \\
\hline العناية بتضمين بعض أهداف المنهج ما يعزز السكينة والصحة النفسية للطالب . & \\
\hline التركيز على مصاحبة الدافع الأخروي للمتعلم 2. كل ثنايا المنهج. & \\
\hline الاهتمام بتضمين بعض أهداف المنهج ما يربط الطالب بتحقيق العبودية الشاملة فِ الحياة. & \\
\hline \multicolumn{2}{|c|}{ 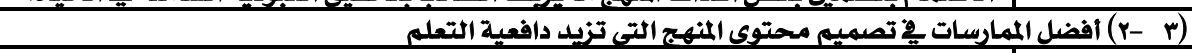 } \\
\hline 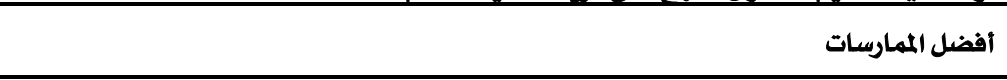 & الإنسانية \\
\hline تضمين ما يناسب من المحتوى كيفية إثباع الحاجات الأساسية ( الأكل - الشرب - النوم & الفسيولوجية \\
\hline تضمين المحتوى الصور التى تؤكد ممارسات الأمن والسلامة . & \multirow{4}{*}{ الأمن } \\
\hline وإضافة النصوص الشرعية والأدبية والنظامية التي تؤكد حفظ حقوق الآخرين الشخصية & \\
\hline مالإثارة إلى مصادر التشريعات والأنظمة التي تبين حقوق وواجبات الطالب وكيفية التعامل & \\
\hline العناية بالكلمات والجمل والنصوص التي تؤكد احترام الطالب وحفظ كرامته . & \\
\hline تضمين المحتوى ما يعزز المحبة والعلاقات الطيبة مـ الآخرين. & \multirow{3}{*}{ الاجتماعية } \\
\hline تأكيد دور العمل الجماعى والتعاون ـ2 النجاح. & \\
\hline تشحيع استثمار قنوات التواصل فِ تمتين العلاقة الإيحابية مع الآخرين. & \\
\hline تضمين المحتوى بعض سير الناجين والمبلدين ومواهبهم. & \multirow{3}{*}{ تقدير الذات } \\
\hline التوعية بكيفية وضع الأهداف وتحقيقها واكتشاف المواهب وتنميتها. & \\
\hline تأكيد الاستماع للطلاب والتعاطف مـع قضاياهم وتحلدياتهم. & \\
\hline تضمين المحتوى مهارات التفكير وقواعد وقوانين الإبداعوالابتكار. & \multirow{3}{*}{ 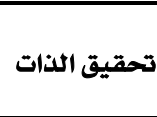 } \\
\hline تشحيع القيادة واستلامزمام المبادرة والإقدام. & \\
\hline إيراز نجاحات الطلاب وأدوارهم يف التنمية. & \\
\hline تضمين المحتوى المقارئة بين أثياء الدثيا والآخرة مستثمرا الآيات والأحاديث. & \multirow{6}{*}{ الرإلشباع } \\
\hline توجيه الطالب لعدم التعلق بالمتع القليلة الزائلة إلى التعلق بالمتع الشاملة الدائمة. & \\
\hline تنويع عرض الحزاء واستخدام قاعدة الحزاء من جنس العمل . & \\
\hline ريط الطلاب بالتوبة والإنابة والمففرة التي تؤول بهم إلى الفوزوالنجاح . & \\
\hline عرض الدافع الأخروي بشكل مباشر فِ سياق الحث على فعل الصالحات وترك المنكرات. & \\
\hline تعرض يتوازن وترادف الترغيب والترهيب 22 فعل الخير وترك الشر. & \\
\hline \multicolumn{2}{|c|}{ 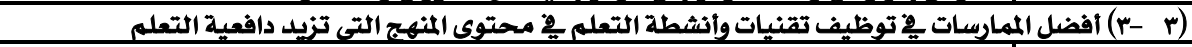 } \\
\hline افضضل الممارسعات & الحاجة \\
\hline
\end{tabular}

\section{YqY}




\begin{tabular}{|c|c|}
\hline & الإنسانية \\
\hline استخدام الأنشطة والتقنيات لتكوين اتجاه إيجابي نحو أهمية إثباع الحاجات الأساسية دون & \multirow{3}{*}{ 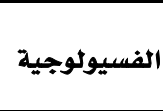 } \\
\hline إسراف. 1. & \\
\hline توظيف بعض الأثطة لمعالجة بعض الصور الخاطئة هُ إثباع الحاجات. & \\
\hline وضع معابير واضحة لأداء وممارسة النشاط بطريقة صحيحة. & \multirow{2}{*}{ الأمن } \\
\hline صياغة بعض الأنشطة بما يسهـ 2ِ التنفير من احتقار لآخرين أو التعلي عليهم أو ظلمهم. & \\
\hline تنويـع طريقة تنفيذ الأثطة واستخدام التقنية ( فردي - ثنائي - جماعي ..) & \multirow{5}{*}{ الاجتماعية } \\
\hline زميلك ...) صياغة النشاط لتعزيز المفاهيم والمهارات الاجتماعية.( بالتعاون - تشاريك مع & \\
\hline صياغة بعض الأنشطة لتنفذ من خلال شبكات التواصل الاجتماعى. & \\
\hline ربط بعض الأنشطة المدرسية بحضوروممارسة أنشطة اجتماعية وأسرية. & \\
\hline ريط الأنشطة وتطبيقاتها بالمواقف المحتمعية والأسرية للطلاب. & \\
\hline توظيف بعض الأنشطة لمعالجة بعض الصور الخاطئة فِ تقدير الذات. & \multirow{4}{*}{ 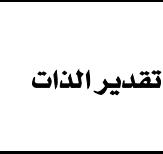 } \\
\hline تنويع الأنشطة والتقنيات المدمجة ي2 المحتوى لتناسب مواهب وقدرات الطلاب. & \\
\hline تضمين بعض الأثشطة ما يتيح للطلاب التعبير عن إنجازهم وأداثهم ِِ النشاط. & \\
\hline تضمين بعض الأنشطة ما يعزز قدرات الطلاب فِ وضع أهداف وتحقيقها. & \\
\hline توفير أشطة إثرائية للطلاب المتفوقين والمبدعين. & \multirow{6}{*}{ 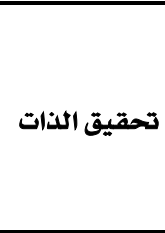 } \\
\hline تضمين بعض الأنشطة ما يعزز تعلم قوانين وأدوات توليد الأفكار الإبداعية. & \\
\hline صياغة بعض الأثشطة بحيث تثير التحدي بين الطلاب والتحلدي بين الطالب ونفسه & \\
\hline تضمين الأثشطة وتقنيات التعليم المعلومات المساعدة على التنفيذ والأداء الجيد لها. & \\
\hline صياغة بعض الأنشطة بما يعزز تعليم الطلاب لبعضهمونقل الخبرات بينهم. & \\
\hline صياغة بعض الأنشطة بحيث تعزز اختيار قائد المحموعة بالانتخاب وتدوير ذلك. & \\
\hline ربط بعض الأثطة باعمال تطومية مجتمعية. & \multirow{4}{*}{ الرإِشباع } \\
\hline جعل جزاء النجاح هِ تنفيذ بعض الأنشطة طلب الأجروالثواب من الله. & \\
\hline تنويع غايات الأنشطة بين ما يعززويوضح المفاهييم الشرعية والمادية. & \\
\hline صياغة بعض الأثشطة بما يعززوينمى القيي الإبمانية. & \\
\hline \multicolumn{2}{|c|}{ 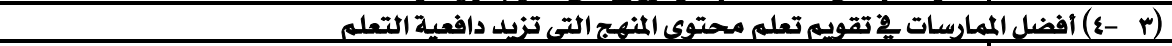 } \\
\hline 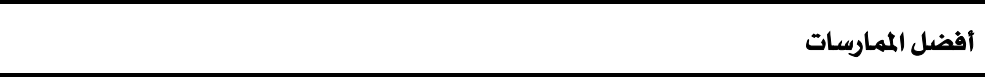 & الإنساجية \\
\hline استخدام التقويم للتعرف على التزام الطلاب بالأداء الأمثل - 2 إثباع الحاجات الأساسية. & \multirow{2}{*}{ الفسيولوجية } \\
\hline تعزيز التقويم الذاتى الذي يساعد ملي تقييم جودة إثباع الحاجات الأساسية . & \\
\hline تأكئل ومتطبل الإجابات التقويم. المتنوعة وتشجيع محاولة البحث عن الحل أثناء صياغة توجيهات & \multirow{4}{*}{ الأمن } \\
\hline دقة صياغة المطلوب ومعابير الأداء ف2 أسئلة وأدوات التقويم. & \\
\hline توجيه نتائج التقويم لتعزيز التعلم وتحسينه وليس الحكم عليه فقط. & \\
\hline عدمريط التقويم دوما بالدرجات. & \\
\hline صياغة أسئلة وأساليب التقويم بما بعزز التعاون والمشاركة بين الطلاب. & \multirow{3}{*}{ الاجتماعية } \\
\hline تأكيد التعاونية لا التنافسية فِ أداء وإجابة بعض متطلبات التقويم. & \\
\hline ربط التقويم بسياقات حياتية واجتماعية وأسرية. & \\
\hline توظيف ملفات الإنجاز لتوثيق إنجازات الطلاب وتقدمهـ ـ2 التعلم. & \multirow{5}{*}{ 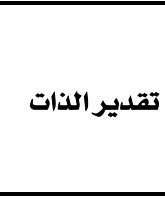 } \\
\hline تقديم تغذية راجعة واضحة ومعززة لأداء الطلاب 22 متطلبيات التقويى. & \\
\hline تنويع مستويات التقويم لتناسب اختلاف قدرات الطلاب ومواهبهم. & \\
\hline تعزيز من أدى متطلبات التقويمومن اجتهد ِِ اداء ذلك. & \\
\hline إتاحة الفرصة لسماع وجهة نظر الطلاب الذين أدوا متطلبات التقويم بطريقة خاطئة. & \\
\hline إتاحة الفرصة للطلاب لتصميم أسئلة وأدوات جلبلدة تساهم ف2 تقييم تعلمهـم. & \multirow{4}{*}{ تحقيق الذات } \\
\hline صياغة متطلبات التقويم بطريقة تشحع الإبداع والبحث والابتكار. & \\
\hline وضع أسئلة ومتطلبات تقييم تستثير تحلدي الطلاب أفرادا ومحموعات. & \\
\hline تعزيز تبادل تقويم الطلاب لبعضهم وعدم ربط ذلك بالدرجات. & \\
\hline
\end{tabular}




\begin{tabular}{|c|c|}
\hline صياغة أسئلة التقويمومتطلباته بلغة تعزز القيموالأخلاق. & \multirow{4}{*}{ الروحبياع } \\
\hline 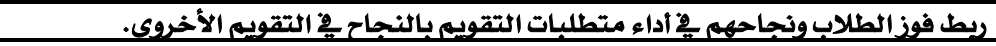 & \\
\hline تأكيد تجنب الغش والخداع هِ تحقيق متطلبات التقييم. & \\
\hline تقديم الأولى على الموازئة الأخرى. تحقيق متطلبات التقويم الدنيوي ومتطلبات التقويم الأخروي ومدم & \\
\hline
\end{tabular}

\begin{tabular}{|c|c|}
\hline \multicolumn{2}{|c|}{ (ع - 1) أفضل الممارسات يف البيئة الصفية التى تزيلد دافعية التعلم } \\
\hline أفضل الممارسات & الإنساجية \\
\hline تهوية الصف واختيار الأماكن الواسعة للتعلم. & \multirow{4}{*}{ 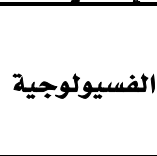 } \\
\hline إضاءة الصف بالأنوار الكافية والمناسبة. & \\
\hline مراعاة اعتدال الحو 2ِ الصف من حيث البرودة والحرارة. & \\
\hline الابتعاد عن الاختلاط بين الجنسين أو عرض المثيرات من صوروأفلام ونحوها. & \\
\hline وضع نظام وميثاق واضح للمحاسبية 20 الصف. & \multirow{3}{*}{ 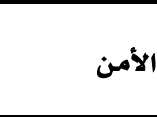 } \\
\hline منع الإساءة المعنوية والحسية للاخرين بائ صورة كانت. & \\
\hline التأكد من سلامة التجهيزات الكهريائية فِ الصف. & \\
\hline دعم العمل الجماعى وتشحيعه بين الطلاب. & \multirow{5}{*}{ الاجتماعية } \\
\hline تلطنلبع. التفاعل مع المناسبات الاجتماعية ( زواج مثلا ) والأحداث الإنسانية ( مرض مثلا) & \\
\hline تقليل الممارسيات التنافسية وتشحيـع التعاونية. & \\
\hline تبنى وتفعيل قنوات التواصل الاجتماعى بين الطلاب. & \\
\hline تنظييم فعاليات ترفيهية تربوية جماعية للطلاب. & \\
\hline تأكيد تبادل عبارات وسلوكيات التقديروالاحترام بين الطلاب . & \multirow{4}{*}{ تقدير الذات } \\
\hline احترامومساندة ذوي الظروف الخاصة. & \\
\hline تبنى لقاءات دورية للطلاب للتعبير عن آرائهم ووجهات نظرهم ومقترحاتهم. & \\
\hline إبراز المتفوقين وإمجتهدين 2. كافة المجالات. & \\
\hline إثراك الطلاب 22 اتخاذ القرارات المتعلقة بصفهـموتعلمهم. & \multirow{5}{*}{ 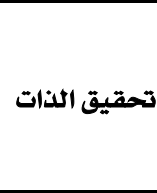 } \\
\hline دعم توزيع وتبادل الأدوار القيادية بين مجموعات الطلاب. & \\
\hline تيسير قيام الطلاب بتطوير بيئة تعلمهم المادية والمعنوية. & \\
\hline مساعدة الطلاب علي تقديم حلول وافكار إبداعية للمشكلات والتحديات الصفية. & \\
\hline تزويد الطلاب بالمعلومات ذات العلاقة بتعلمهه وييتتهم المدرسية. & \\
\hline تشحيع تعاون الطلاب على أداء بعض العبادات. & \multirow{4}{*}{ الرإوحباع } \\
\hline تبنى طلاب الفصل لبعض المبادرات ذات النفع العام. & \\
\hline التذكير باستمراريفضل العلموالتعلم وخيرية المعلمين ومكانتهم. & \\
\hline تينى وتشر الممارسيات والسلوكيات القيمية والأخلاقية 2خ الصف. & \\
\hline \multicolumn{2}{|c|}{ 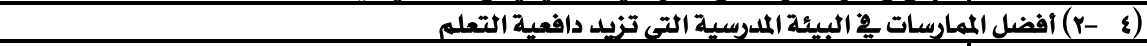 } \\
\hline أفضل الممارسعات & الإنساجنة \\
\hline تنويع خيارات بيئات التعلم وتجليدها (صف - مختبر - ساحة - مصنع - حلبقة ..) & \multirow{5}{*}{ 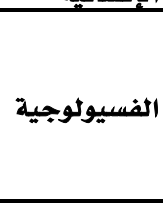 } \\
\hline توفير مصادر تغذية نظيفة وصحية. & \\
\hline عمل صيانة دورية للمكيفات ومصادر التهوية. & \\
\hline توفير رعاية صحية أولية للطلاب. & \\
\hline تهيئة دورات المياه وتوابعها للاستخدام بشكل لائق وراقىى. & \\
\hline تطبيق الأنظمة المدرسية على الجميع بعدالة وثفافية. & \multirow{4}{*}{ الأمن } \\
\hline حماية البيئة المدرسية من المخاطر بانواعها. ( الكهريائية - الصحية - البنائية ..) & \\
\hline حماية ثرف وسمعة الطلاب من أسباب ومصادر المشكلات غير الأخلاقية. & \\
\hline تنظيم حملات ويرامج توعوية تعزز السلامة والأمان المدرسي. & \\
\hline
\end{tabular}

\section{Yq\&}




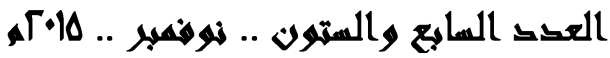

\begin{tabular}{|c|c|}
\hline مقاومة العنف بحميع أشكاله وأنواعه ف2 البيئة المدرسية بعامة. & \\
\hline توفير التعليمات المناسبة لاجراءات السلامة فِ المختبرات. & \\
\hline ضبط إحراءات استخداموإتلاف المواد الخطرة يـ المختبرات. & \\
\hline توفير أنظمة وأدوات السلامة فِ البيئة المدرسية بعامة. & \\
\hline الاهتمام بالعلاقات الإنسانية مـع البيئة الداخلية والخارجية للمدرسة. & \multirow{6}{*}{ الاجتماعية } \\
\hline تعزيز الشراكة بين المدرسة وأولياء الأموروالمجتمع. & \\
\hline تفعيل وتنويع قنوات التواصل الاجتماعى داخل وخارج المدرسة. & \\
\hline تأكيل ثقافة العمل المؤسسى والحماعى ج المدرسة. & \\
\hline تبنى البر امج التفاعلية الحماعية المدرسية. & \\
\hline إيراز مكانة المدرسة وتفوقها وامتيازاتها للطلاب. & \\
\hline رعاية وحماية كرامة الطلاب من خلال القوانين والأنظمة والممارسات. & \multirow{4}{*}{ تقدير الذات } \\
\hline دعم الطلاب 2خ تحقيق أهدافهم التعلمية. & \\
\hline إبراز المتفوقين وتكريمهم 2ِ البيئة المدرسية. & \\
\hline وضع نظام واضح ومعلن لسماع مقترحات وثيكاوى الطلاب. & \\
\hline دعم مشاركة الطلاب غ2 اتخاذ القرارات المدرسية. & \multirow{5}{*}{ 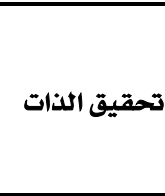 } \\
\hline تشجيع الطلاب على تقديم حلول ومبادرات تطويرية للمدرسة. & \\
\hline تهيئة فرص امتلاك الطلاب للمهارات والقدرات المناسبة لمرحلتهم. & \\
\hline إتاحة أدوار قيادية وريادية للطلاب. & \\
\hline إتاحة جميع المعلومات التى يحتاجها الطلاب وتختص بهم. & \\
\hline تيسير قيام الطلاب بير امج تطوعية مدرسية ومجتمعية. & \multirow{4}{*}{ الروحبياع } \\
\hline دعم أداء ومماربسة الطلاب للعبادات والشعائر الدينية. & \\
\hline تشجيع البر امجحوالمبادرات التي تعززخيرية الطلاب وصلاحهم. & \\
\hline تاكيد فاية تحقيق العبودية لله فِ برامج وأنشطة المدرسة التعليمية والتريوية. & \\
\hline \multicolumn{2}{|c|}{ 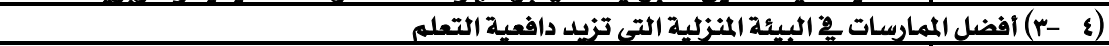 } \\
\hline أفضل الممارسات & الإنساجية \\
\hline تعتنى باخذ الجسم كفايته من النوم وعدم السهر. & \multirow{5}{*}{ 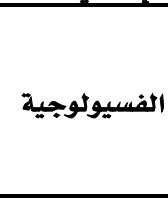 } \\
\hline تهتم بتناول وجبة الإفطارقيل الذهاب للمدرسية. & \\
\hline تعطى الطالب مصروف مدرسى مناسب. & \\
\hline تعتنى ياعداد مكان مناسب ومجهز للتعلم ( إضاءة وتهوية وهدوء .. ) & \\
\hline تتجنب التهليل بالحرمان من الحاجات الأساسية للتحفيز للمذاكرة والتعله. & \\
\hline تبتعلد عن التهليل والتخويف لتحفيز الطلاب للمذاطرة والتعلم. & \multirow{4}{*}{ 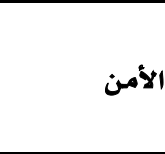 } \\
\hline تتجنب الإلحاح على تحصيل أعلى الدرجات ف غ كل شيء. & \\
\hline تبتعد عن العقاب البلدى والنفسى عند الإخفاق هِ التعلم. & \\
\hline 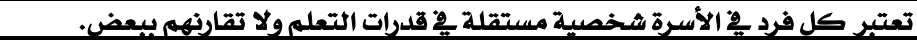 & \\
\hline تشجع المذاكرة الجماعية بشرط الانسجام والانضباط & \multirow{7}{*}{ 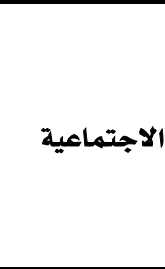 } \\
\hline تبتعد عن ربط الحب والقبول بالتفوق الدراسي. & \\
\hline تتجنب الحرمان من الأصدقاء لأجل المذاكرة والتعلم. & \\
\hline تشجع وتوفر برامجج التعلم عبر الشبكات والتواصل الاجتماعى. & \\
\hline تدعم مشاركة الأبناء فِ الأنشطة المدرسية. & \\
\hline تعتنى يلبعاد الأبناء عن المشكلات والخلافات الأسرية بين الأبوين. & \\
\hline تحافظ على مقومات الاستقرار الأسري. & \\
\hline تشحع نجاحات التعلمولو كانت صغيرة وتثنى عليها. & \multirow{5}{*}{ 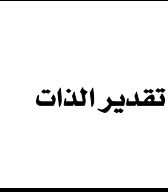 } \\
\hline تمنح استقلال موجه لاختيار مكان وزمان وطريقة التعلم والمذاكرة. & \\
\hline 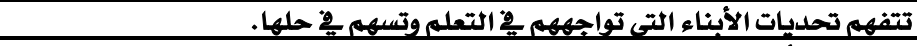 & \\
\hline تتفق مع الأبناء على التوقعات المنتظرة منهم بلدقة ووضوح هِ قضايا المذاكرة والتعلم. & \\
\hline تبرزوتفتخر بنحاحات الأبناء وإنجازاتهم 22 التعلم والابتكار التعليمي. & \\
\hline
\end{tabular}




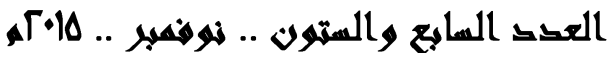

\begin{tabular}{|c|c|}
\hline توفر الدعم المعنوي والحسي للوصول للتعلم والتفوق المطلوب. & \\
\hline تلدعم تحقيق أهداف الأبناء فير التعليمية ولا تربطها بضرورة نحاحات الأهداف التعليمية. & \\
\hline تشرك الأبناء يو اختيار المدرسة المناسبة لهم. & \multirow{5}{*}{ 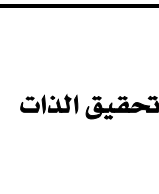 } \\
\hline تمنح الاستقلال للأبناء يف اختيار التخصص وتقدم المعلومات والدعم اللازم. & \\
\hline تسمح للأبناء بابتكار طرق جليدة لتعلمهم وتحقيق أهدافهم التعليمية. & \\
\hline تمكن الأبناء من حل مشكلاتهم التعليمية وتحمل مسؤولية ذلك والإثراف عليهم. & \\
\hline تزود الأبناء بالخير ات والمعلومات المناسبة لدعم تعلمهـوتفوقهم الدراسيى. & \\
\hline ربط التعلم باستمراريتحقيق الأجروالثواب من الله. & \multirow{3}{*}{ الرإثباع } \\
\hline تاكيد دور تحصيل العلم ف2 تحقيق الراحة والرضا النفسي. & \\
\hline تعزز أن الاجتهاد يِ التعلم من طرق إرضاء الوالدين وكسب الأجر . & \\
\hline
\end{tabular}

\section{• ت توصيات الدراسة:}

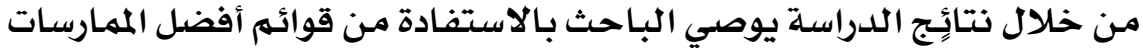

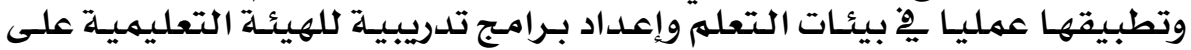

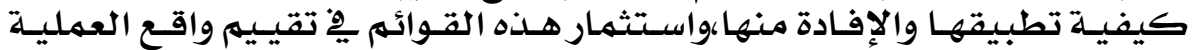

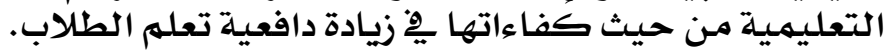

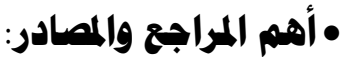

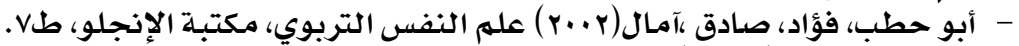

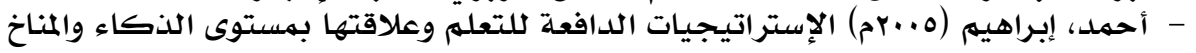

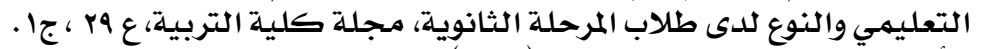

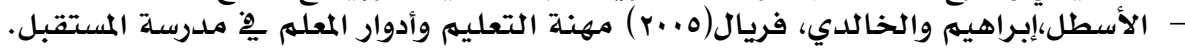
دار الكتاب الجامعي.

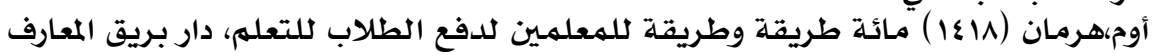

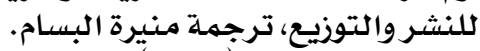

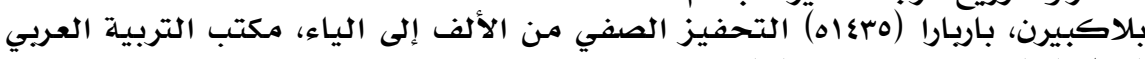

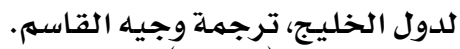

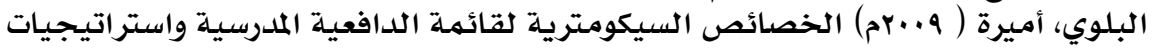

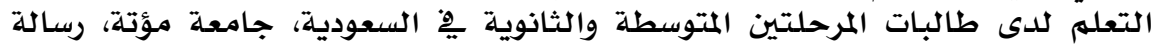

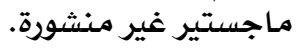

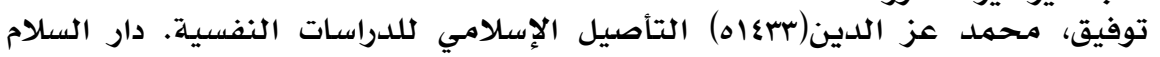

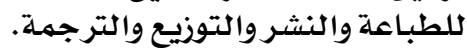

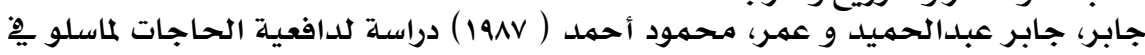

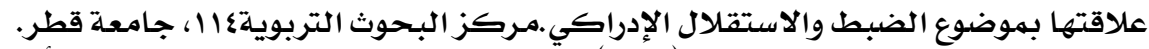

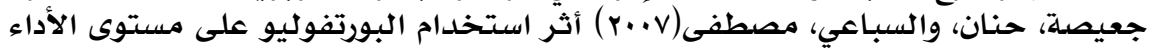

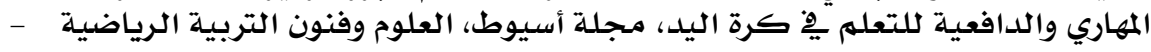

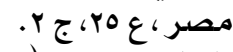

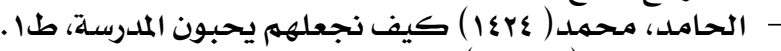

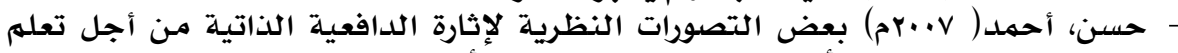

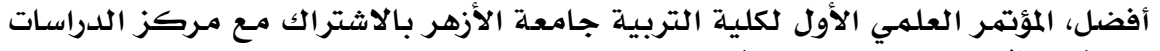

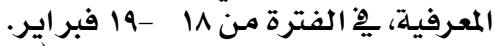

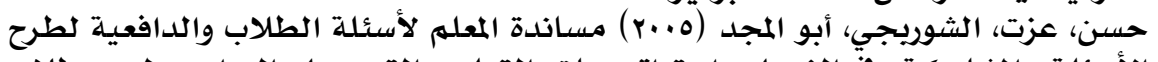

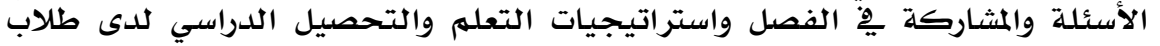

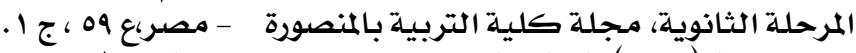

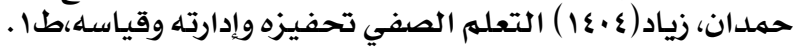




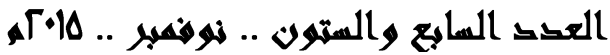

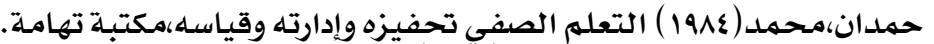

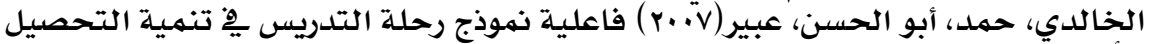

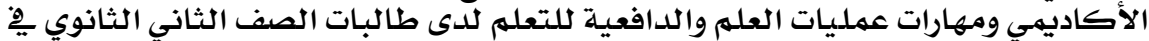

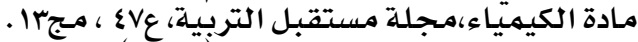

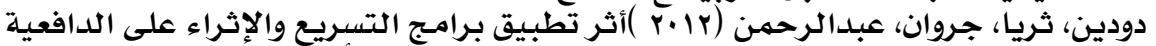

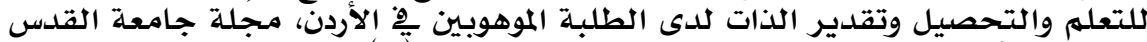

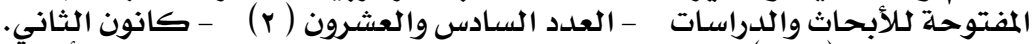

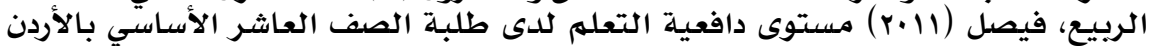

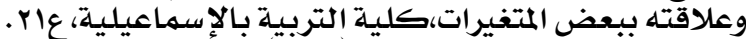

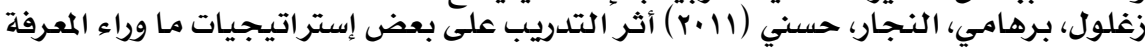

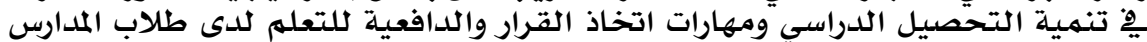

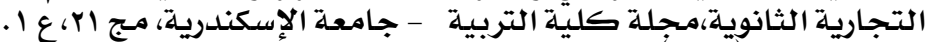

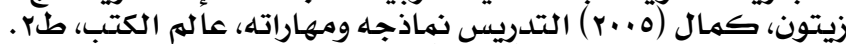

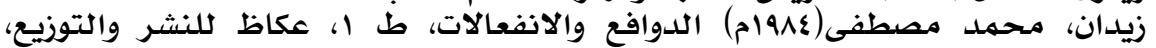
السعوديـة.

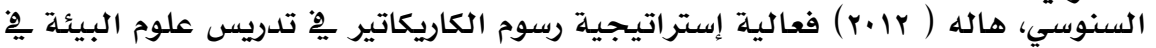

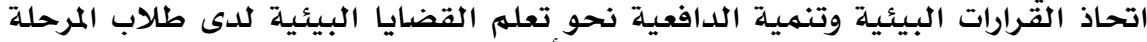

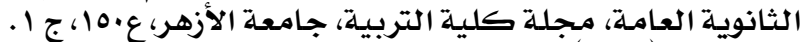

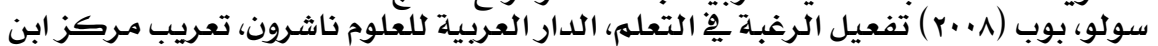

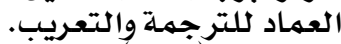
سولو،بوب ( • +r ) تعزيز دافعية الطالب، مكتب التربية العربي لدول الخليجج، ترجمة سعيد

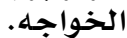

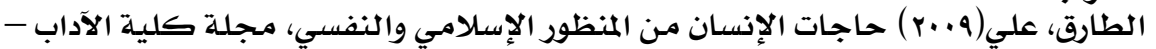

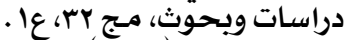

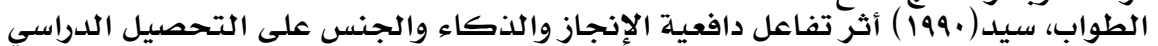

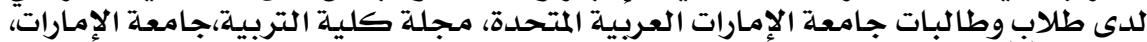

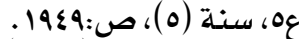

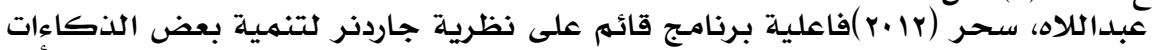

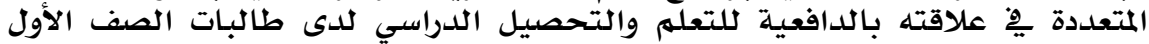

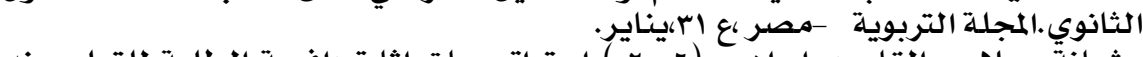

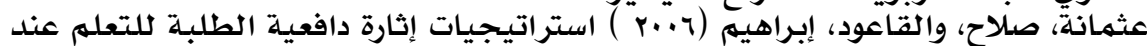

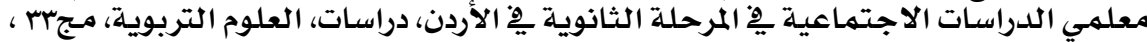

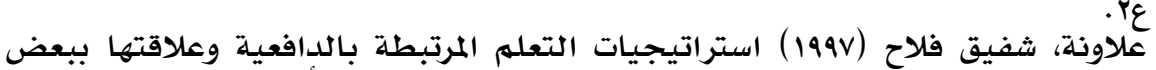

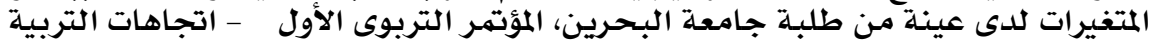

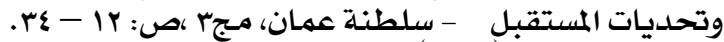

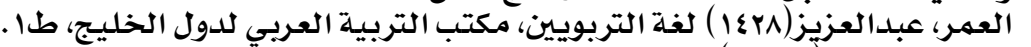

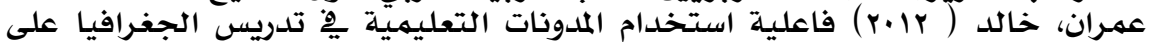

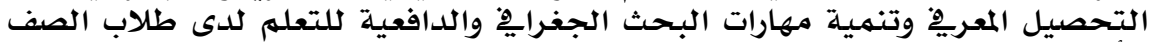

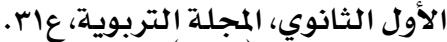

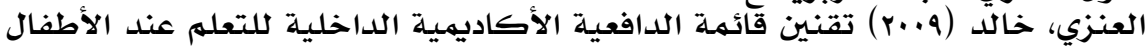

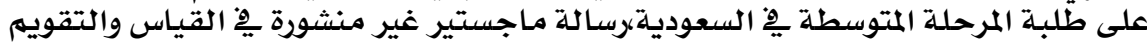

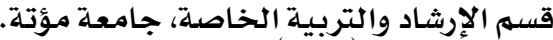

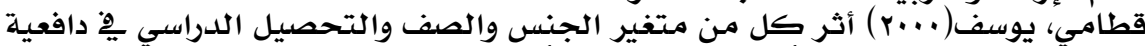

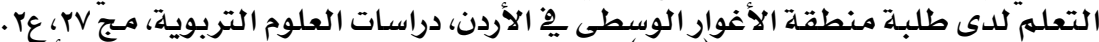

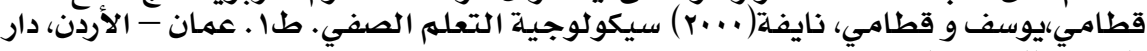

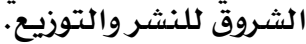




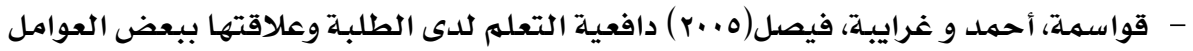

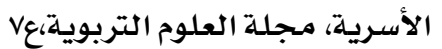

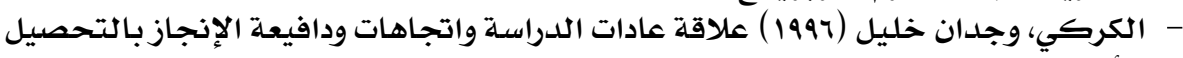

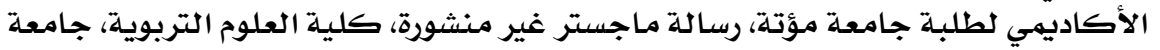

- الكناني ، مهدوح (1991) مدىى تحقق التتظيهم الهرمي للحاجـات عند ماسلو، مجلدة كلية

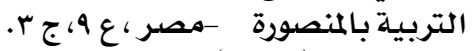

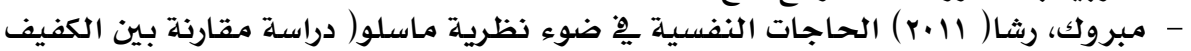

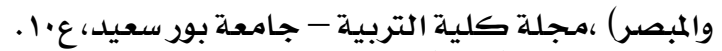

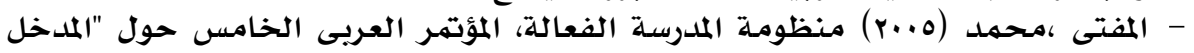

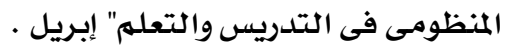

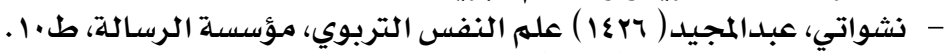

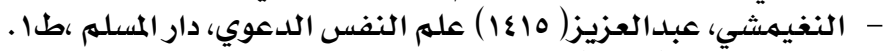

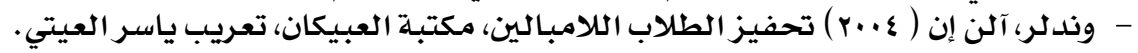

-Brewster, Cori \& Fager, Jenifer (2000). Increasing Student Engagement

- and Motivation: From Time- on - Task to Homework. Washington: Northwest Regional Educational Laboratory.

-Brophy, J. 1998. Research on the Self-Fulfilling and Teacher Expections, Paper Presented at the Annual Meaning of the American Educational Research Association, New York.

-Cluck,M.(2003). Improving student motivation through the use of the multiple intelligences. Mater Research project, Saint Xavier University, Illinois.

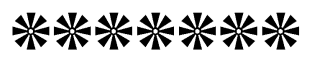




\section{البحث النتاسع:}

واقع التربية الاقتصادية في الأسرة السعودية ” دراسة هيدانية ”

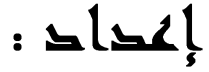

د/ محمل عمر أحمل الملدخلي

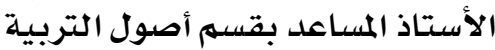

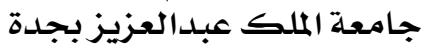





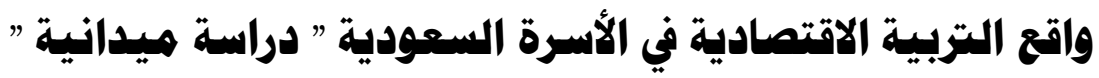

د/ محمل عمر احملد الملدخلي

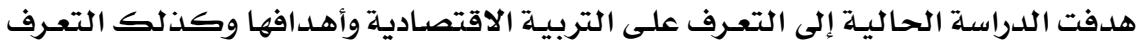

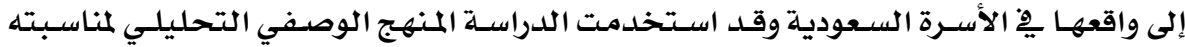

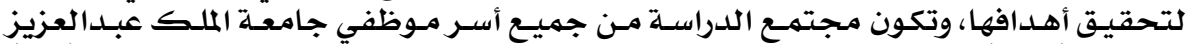

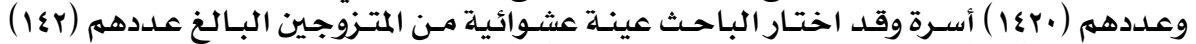

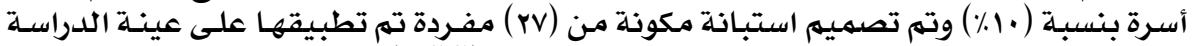

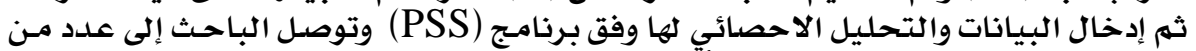

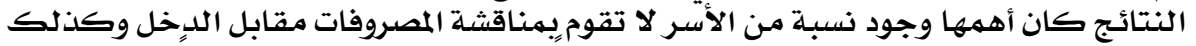

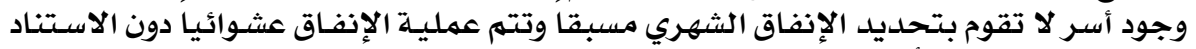

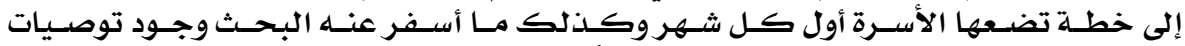

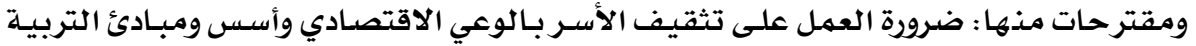

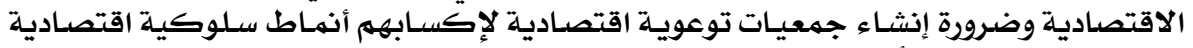

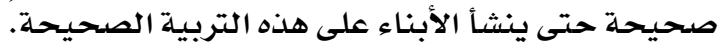

\section{The reality of Economic Education the Saudi Family (field study)}

\section{$\underline{\text { Abstract }}$}

The current study aimed to identify the educational and economic goals as well as the situation in the family and have used descriptive analytical study of the appropriateness of objectives, and the population of the study consisted of all families of staff at King Abdul Aziz University's (1420) family has chosen a random sample of couples (142) family rate (10\%) And is designed to identify a single (27) have been applied to the sample and data entry and statistical analysis with the program (PSS) and the researcher found a number of results including a proportion of families do not discuss expenses vs. income and families do not select monthly expenditure and expenditure process randomly without plan developed by family first every month as well as its research recommendations and proposals of: The need to educate families with economic awareness and fundamentals of economic and the need to create awareness of economic associations to provide them with proper economic behaviors to children arises on the correct education

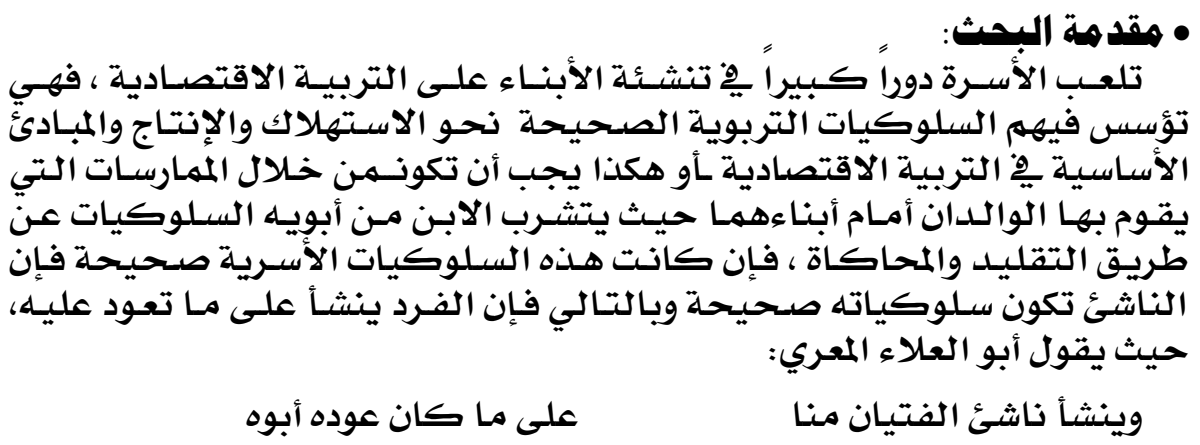

\section{$r+1$}




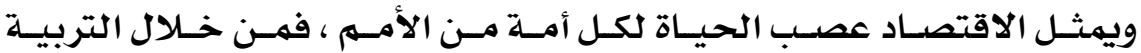

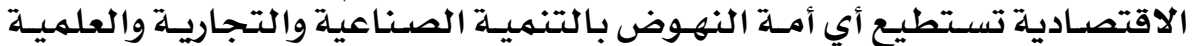

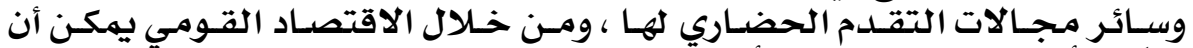

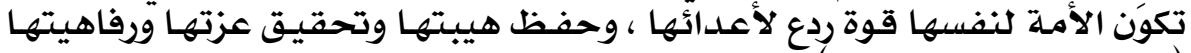

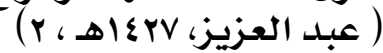

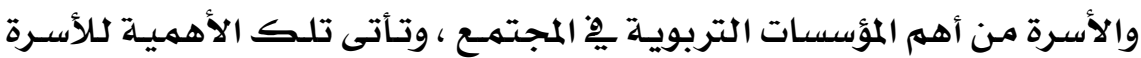

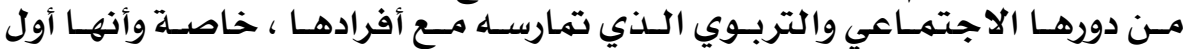

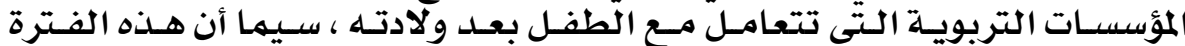

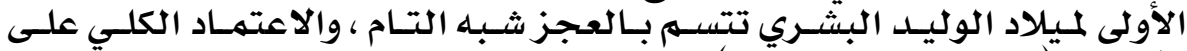

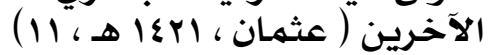

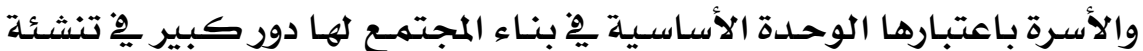

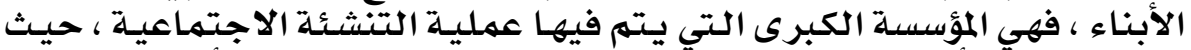

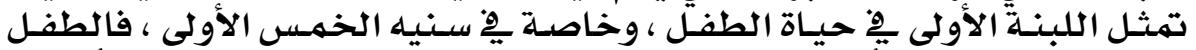

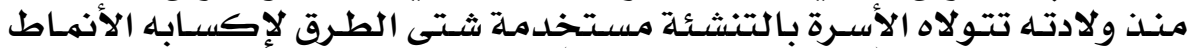

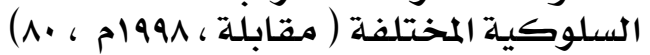

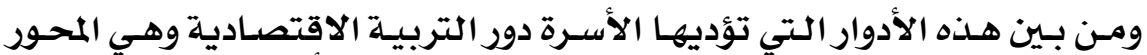

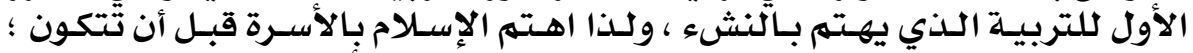

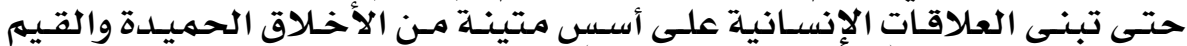

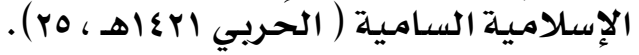

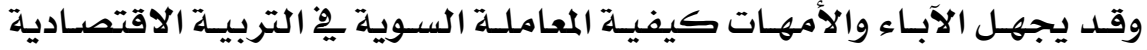

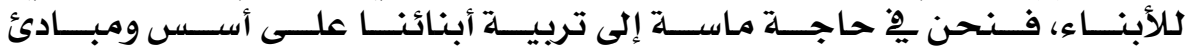

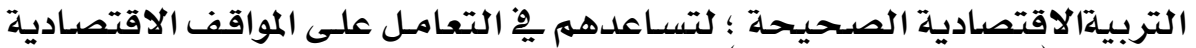

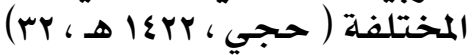

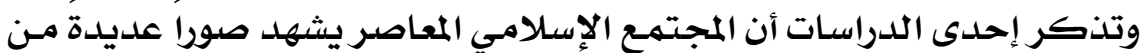

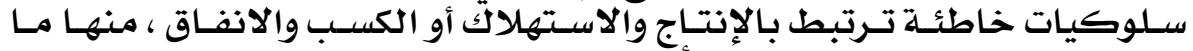

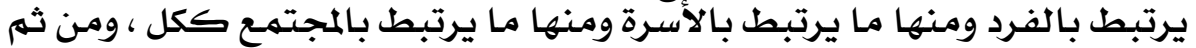

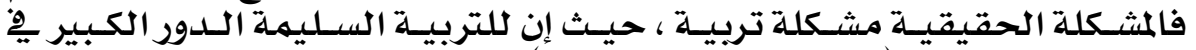

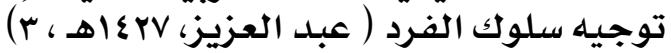

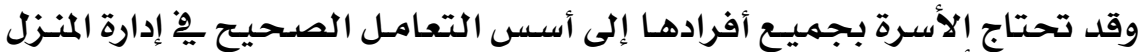

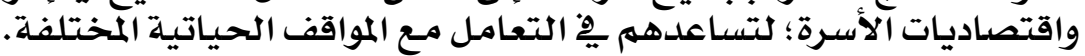

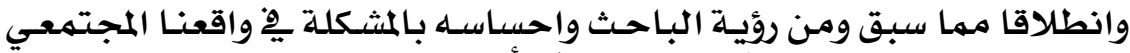

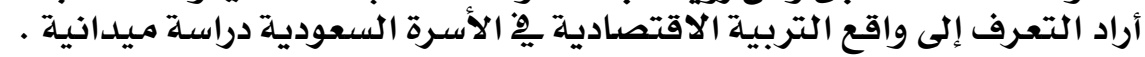

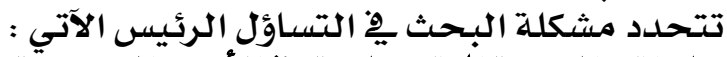

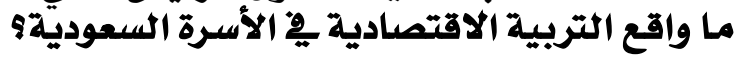
ويتفرع من هذا السؤال الرئيس التساؤلات الفرعية الآتية: 
العقد العابي والمتهون .. نه همبر ..

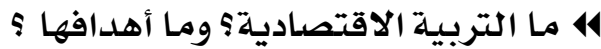

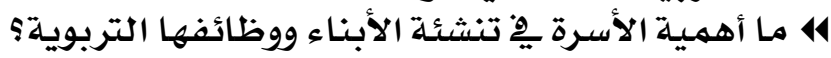

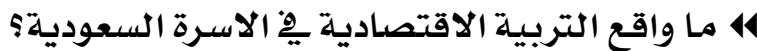

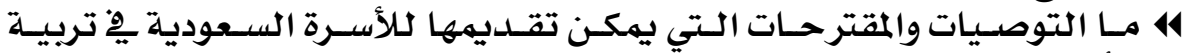

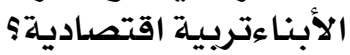

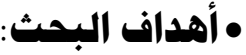

$$
\text { تنطلق أهداف البـحث مما يأتي: التئي }
$$

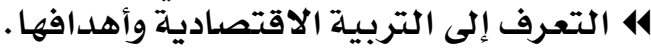

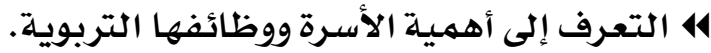

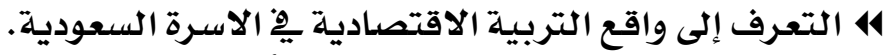

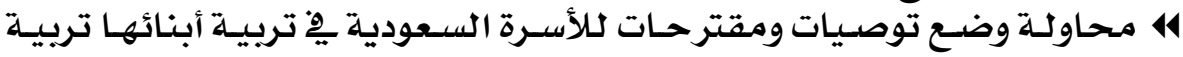

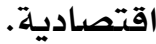

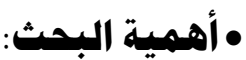

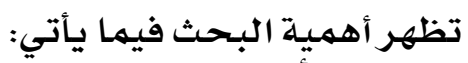

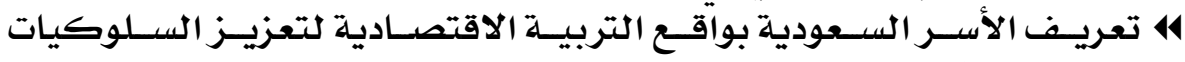

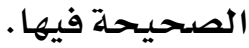

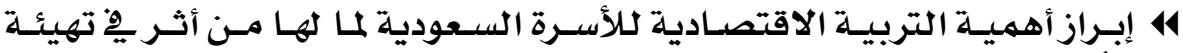

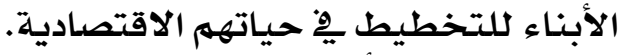

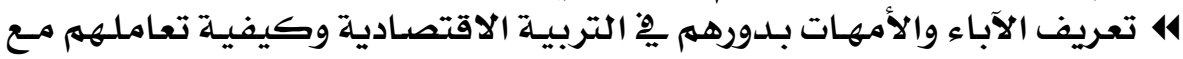

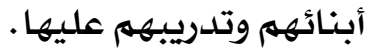

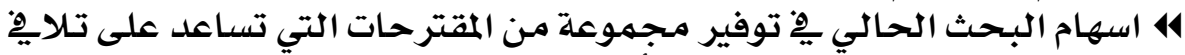

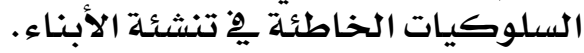

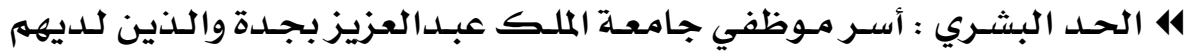
أبناء.

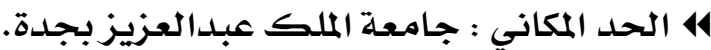

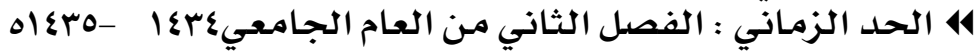

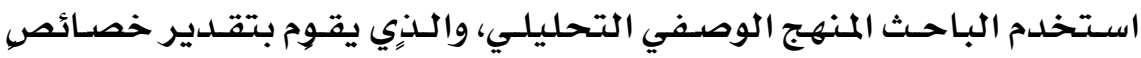

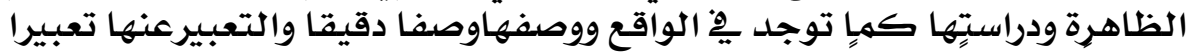

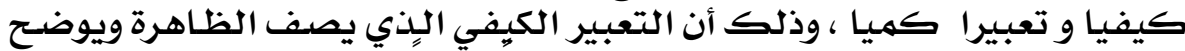

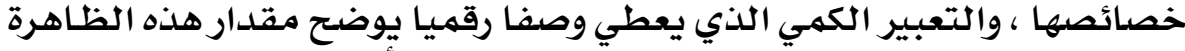

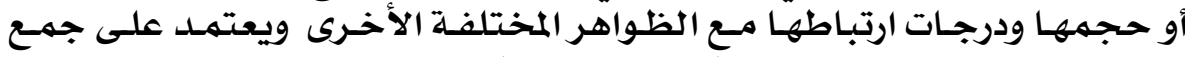

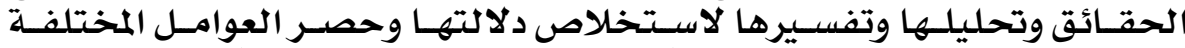

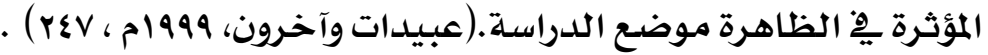




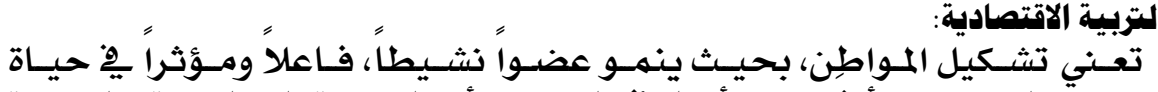

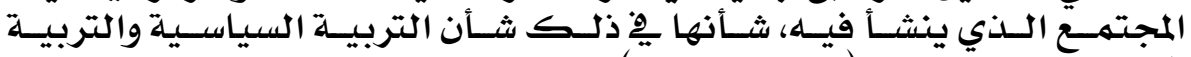

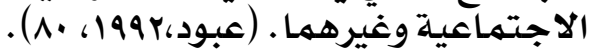

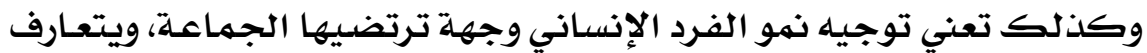

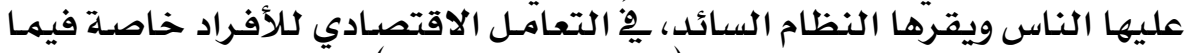

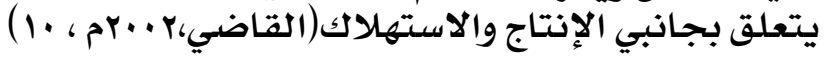

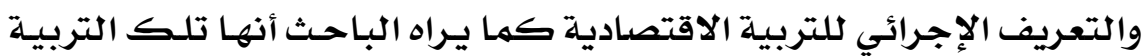

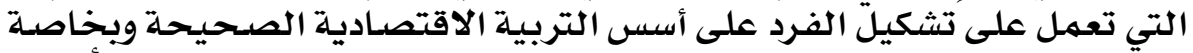

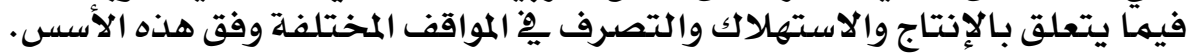

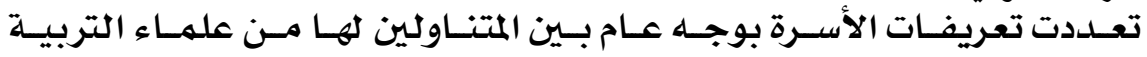

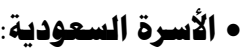

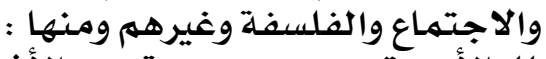

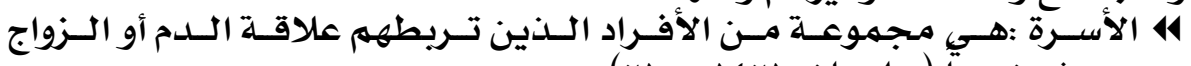

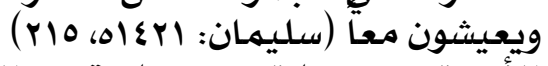

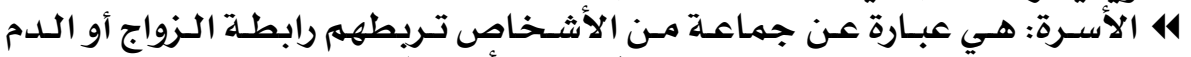

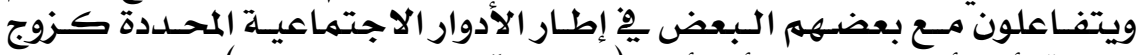

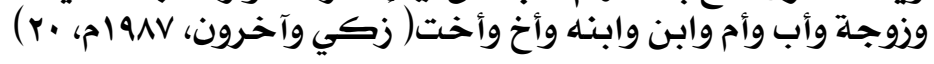

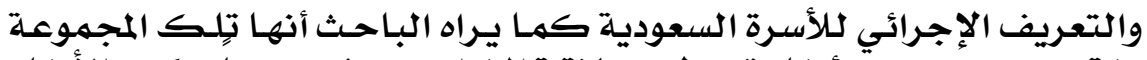

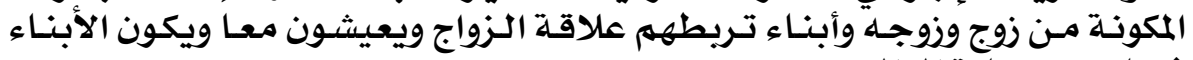
فيها تحت رعايية الوالدين.

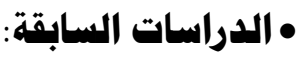
تتعدد الدراسـات السـابقة سـواء أكانت فِ المجـال أو الموضـوع ويـذكر الباحث

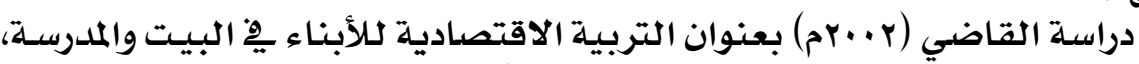

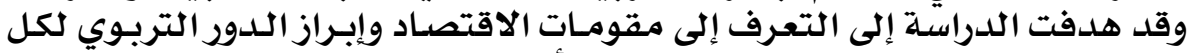

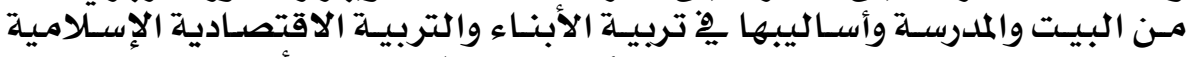

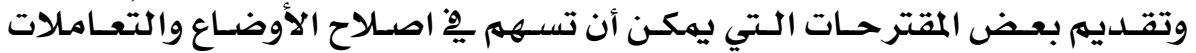

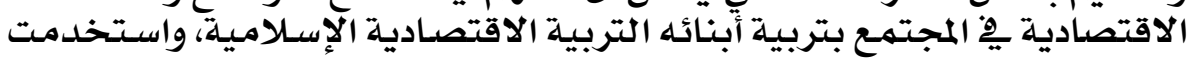

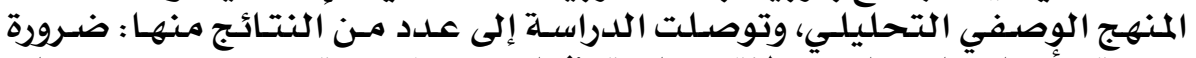

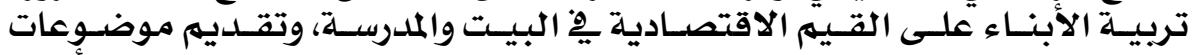

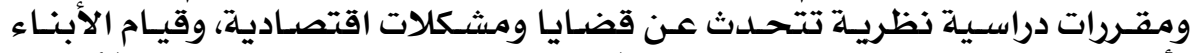

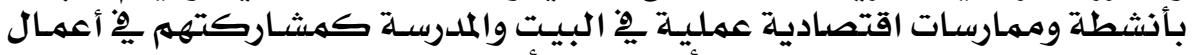

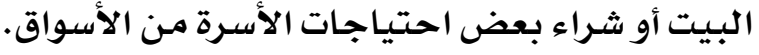

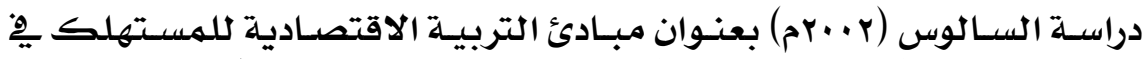

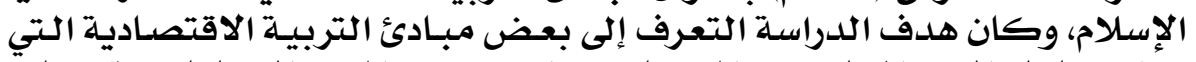

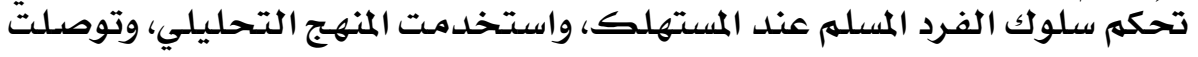

\section{$\boldsymbol{r}, \varepsilon$}




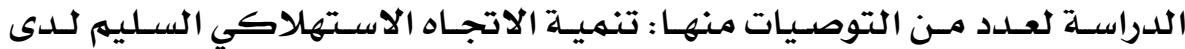

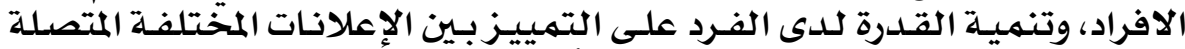

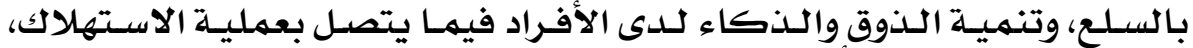

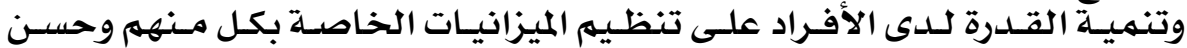
الاختيار للسلعة الواحلدة.

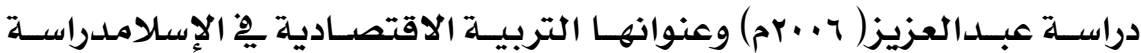

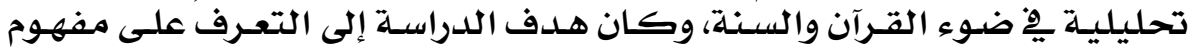

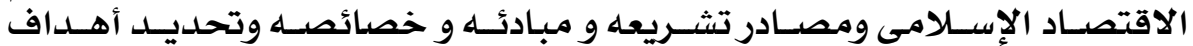

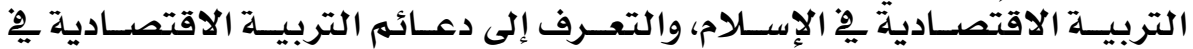

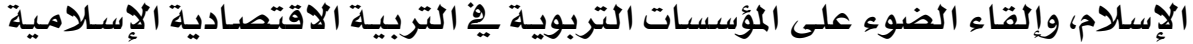

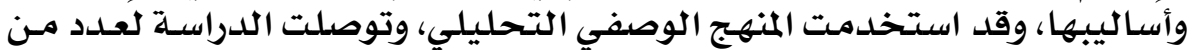

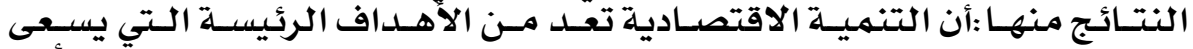

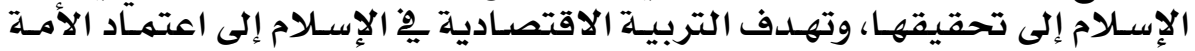

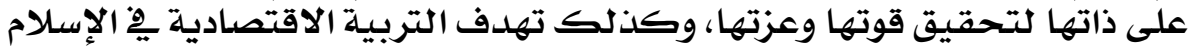

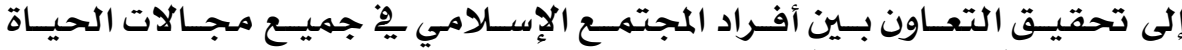

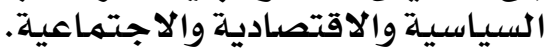

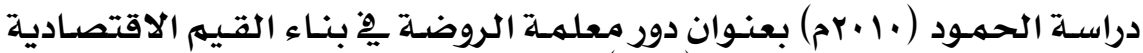

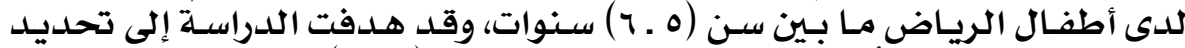

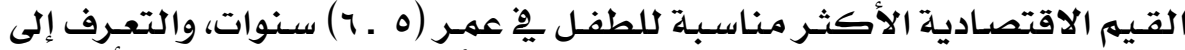

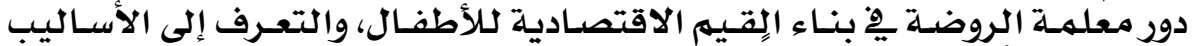

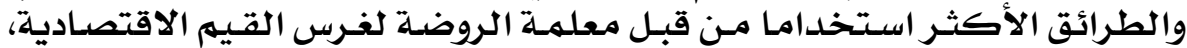

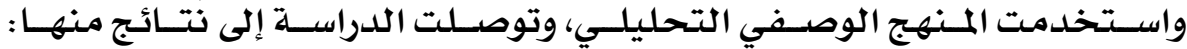

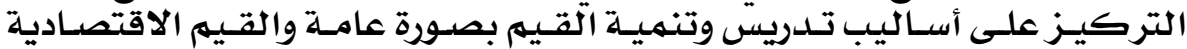

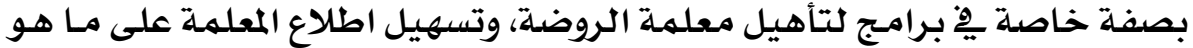

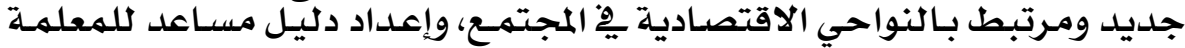

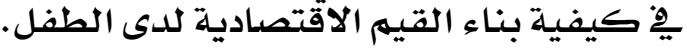

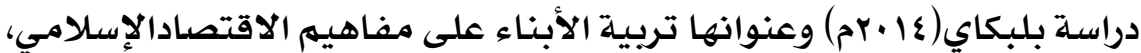

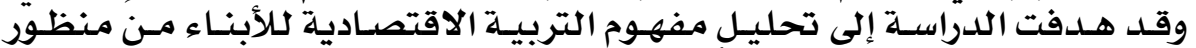

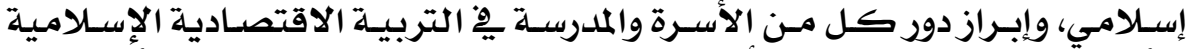

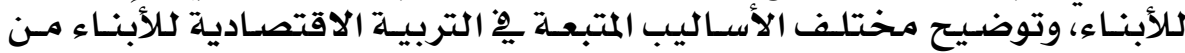

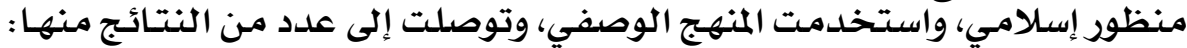

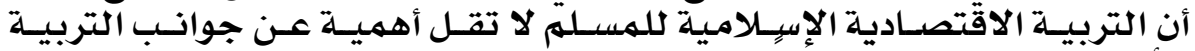

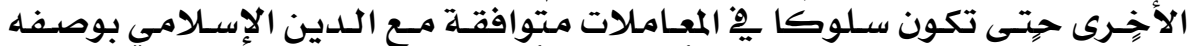

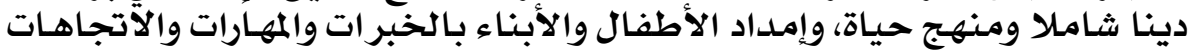

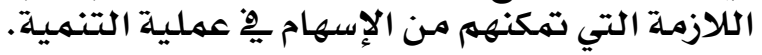

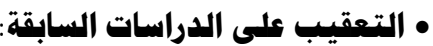

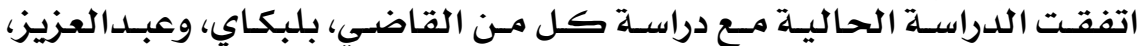

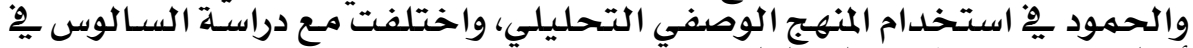
أنها استخدمت المنهج التحليلي. 


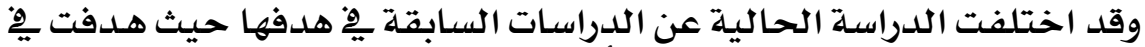

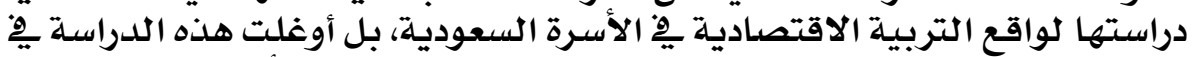

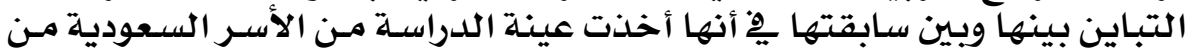

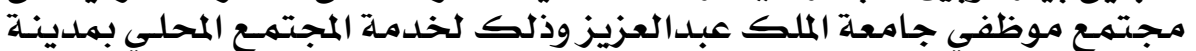

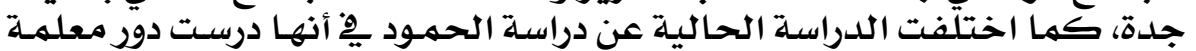

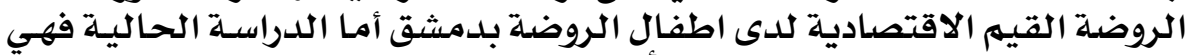

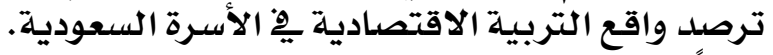

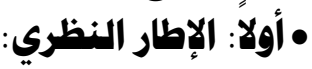

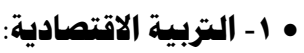

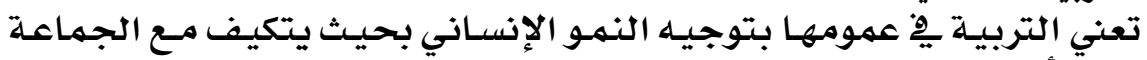

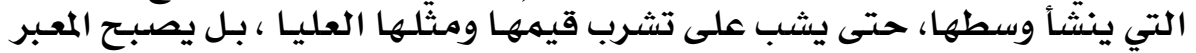

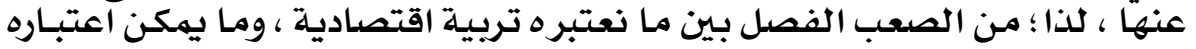

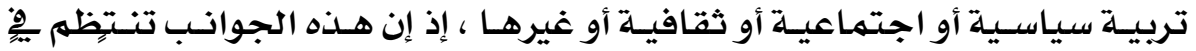

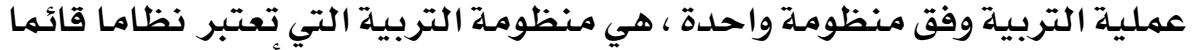

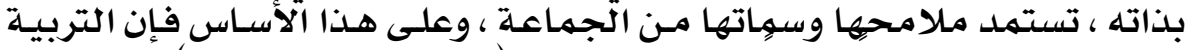

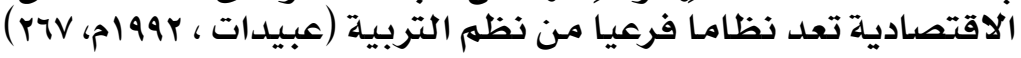

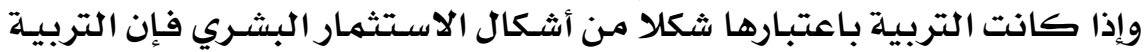

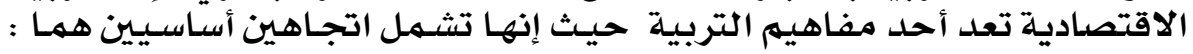

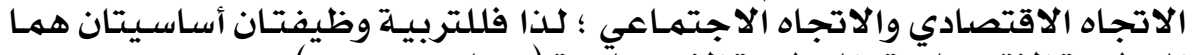

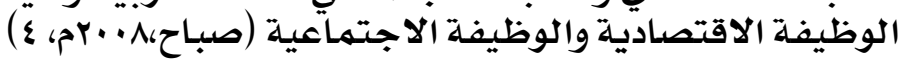

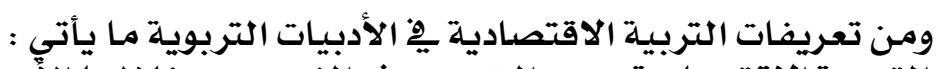

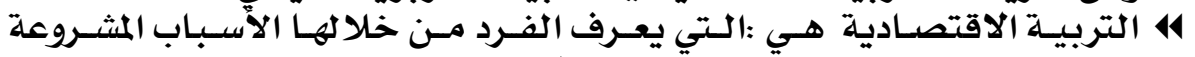

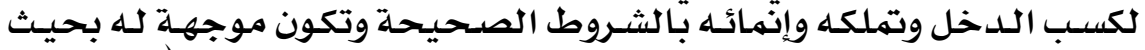

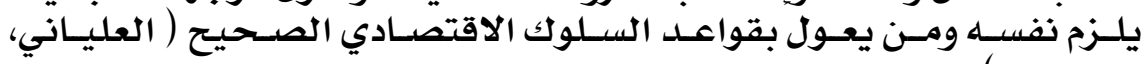
( $\{0$ ،

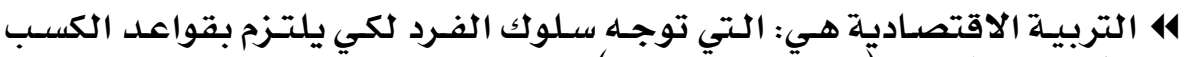

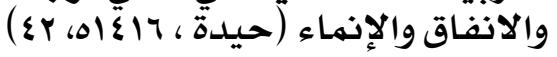

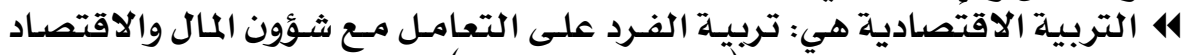

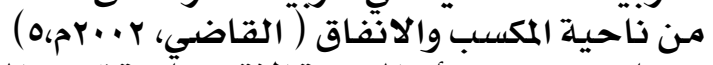

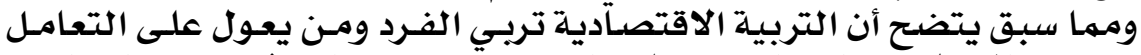

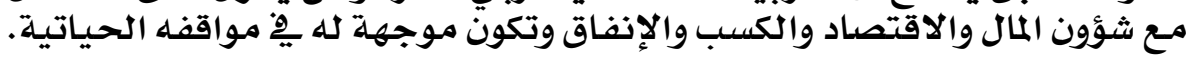

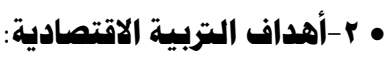

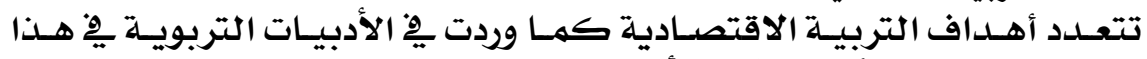

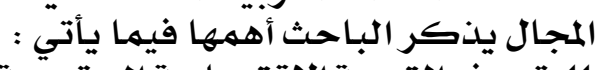

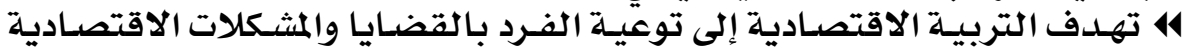

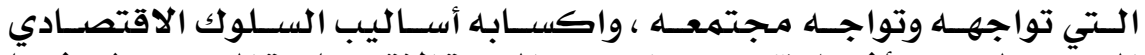

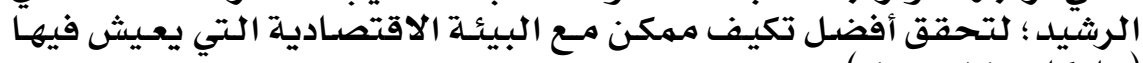

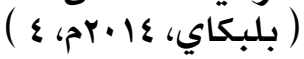

\section{$r+7$}




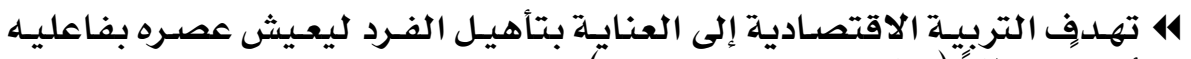

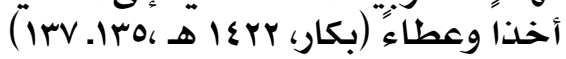

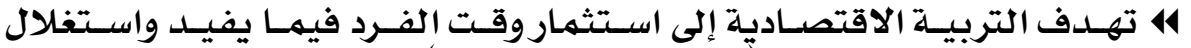

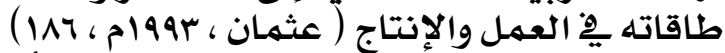

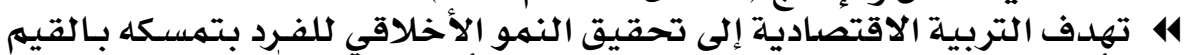

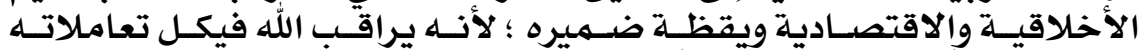

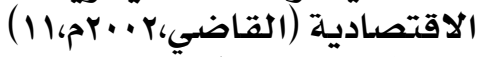

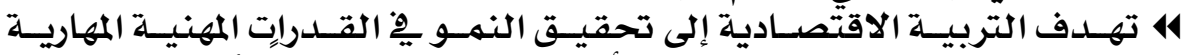

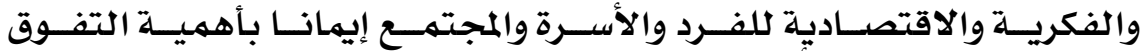

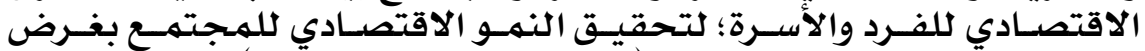

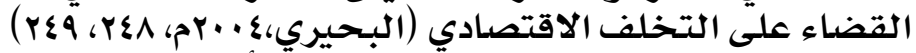

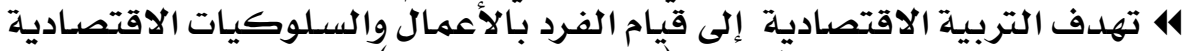

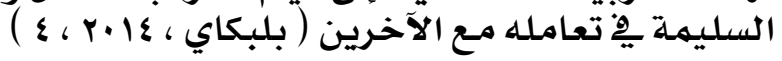

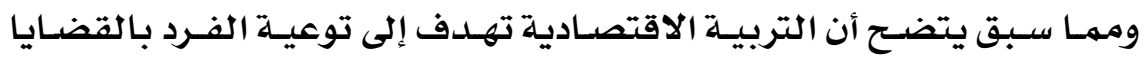

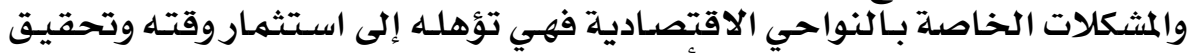

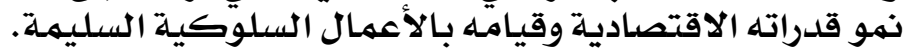
• r-أهمية الأسرة في تنشئة الأبناء ووظائفها التزبوية:

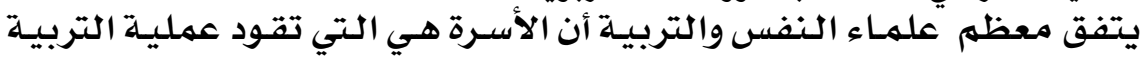

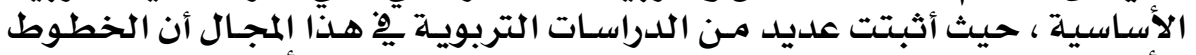

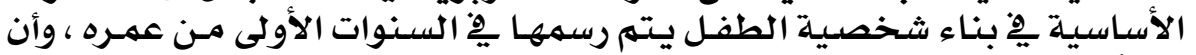

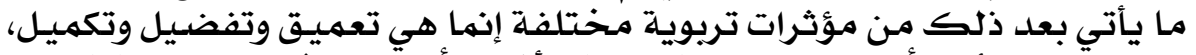

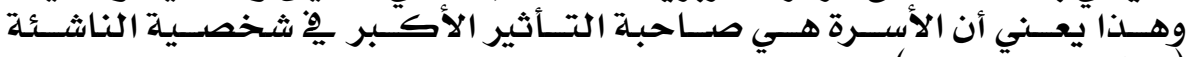

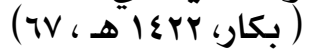

والأسـرة هي أقدم المؤسسـات ذات الوجهة التربويـة التي مـا تزال إلى يومنـا هـذا،

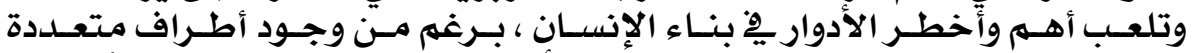

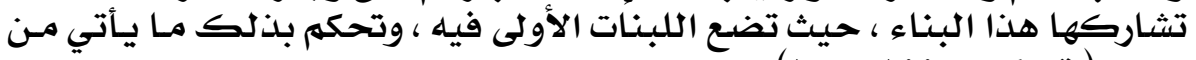

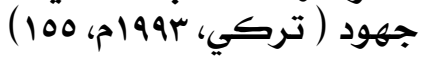

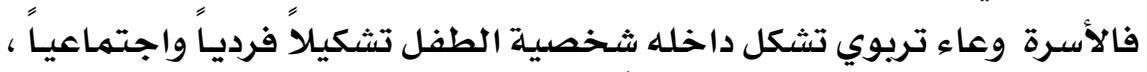

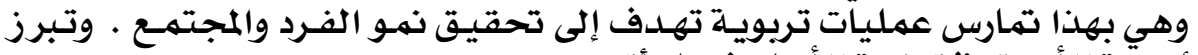

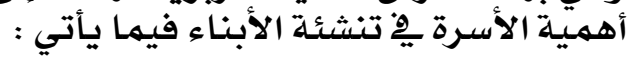

• أ- الأسرة جماعة أولية الأهرة

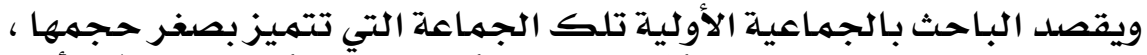

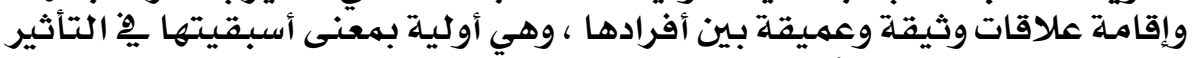

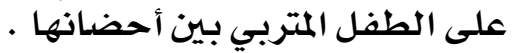

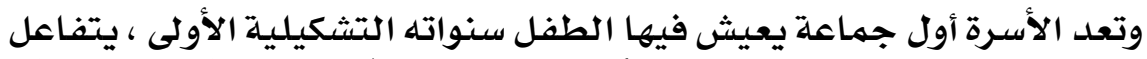

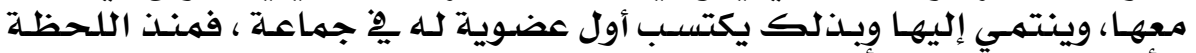

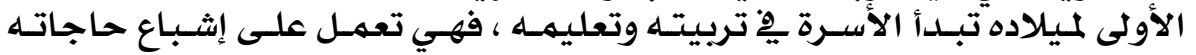

\section{$r \cdot V$}




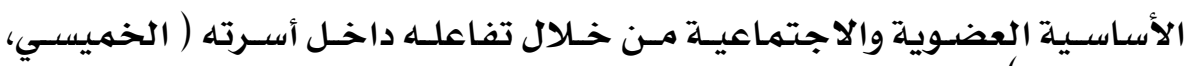

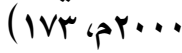

والأسرة جماعة أولية لها أكبر الأثر ِِّحياة أبنائها وعلاقتهم مـع الجماعات

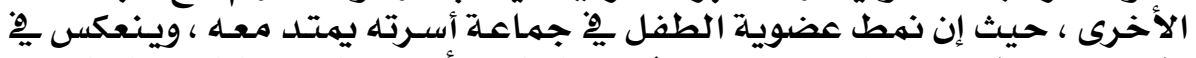

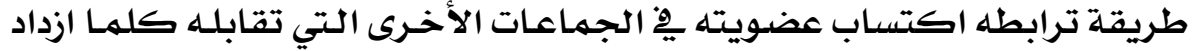

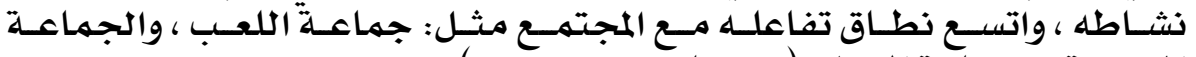

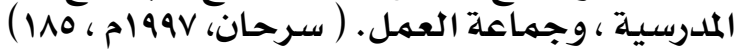

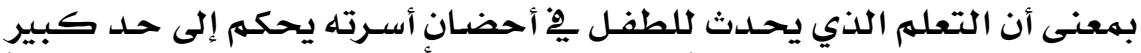

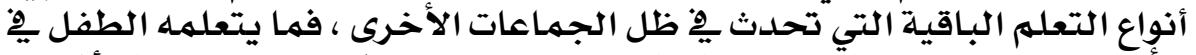

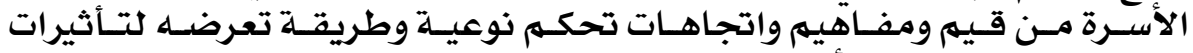

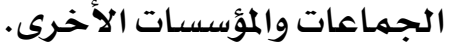

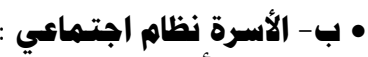

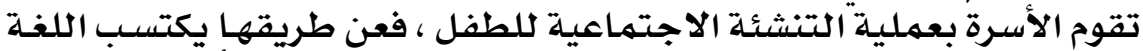

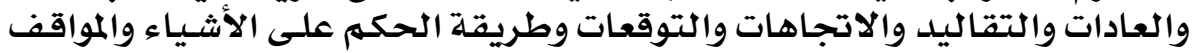

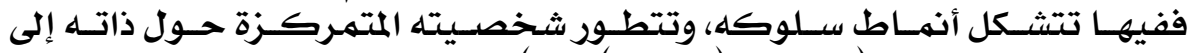
شخصية اجتماعية · ( سرحان (199V م) 1110)

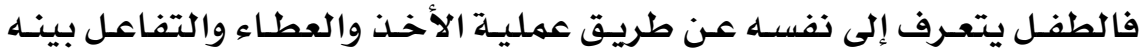

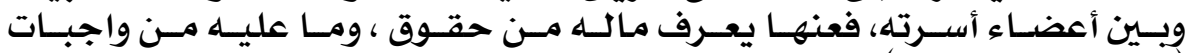

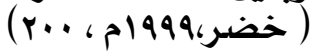

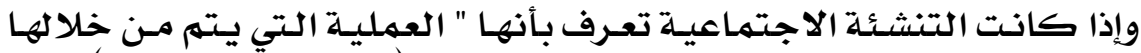

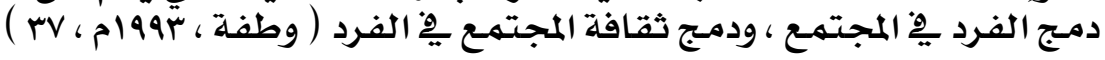

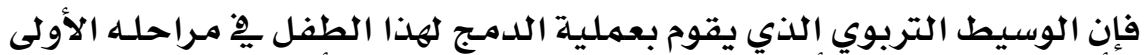
هو الأسرة ، لذا كانت الأسرة من أهم الوسائط التربو لوبرية لأبنائها .

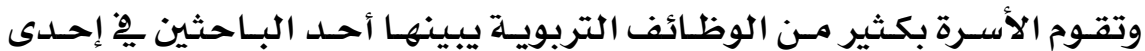

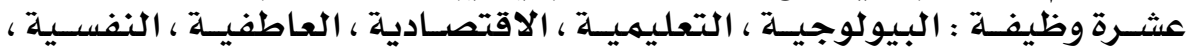

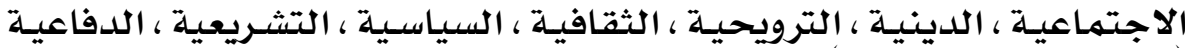

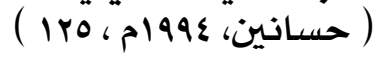

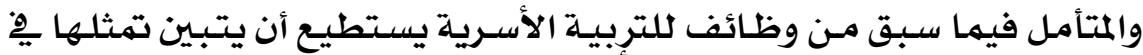

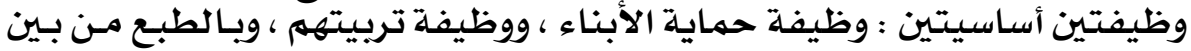

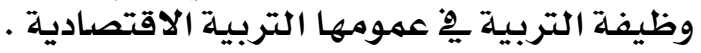

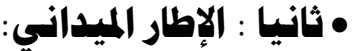

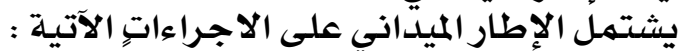

4ه قام الباحث بتصميم ألاستبانة مراعيا واقتح التربية الاقتصادية داخل الأسـرة لأبنائها الحاح

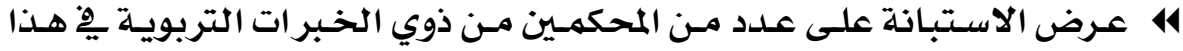

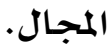

\section{$\mu \cdot \Lambda$}


414

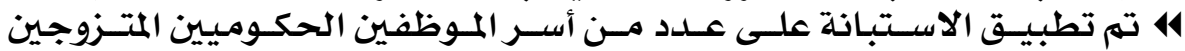

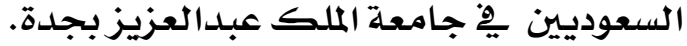

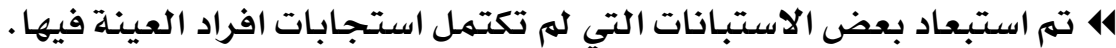

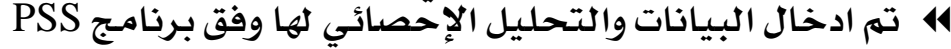
414 النتائبج الموجودة.

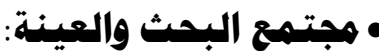

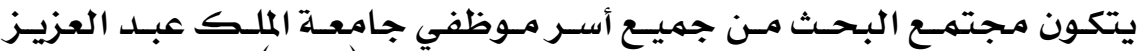

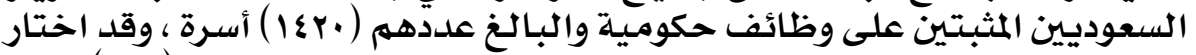

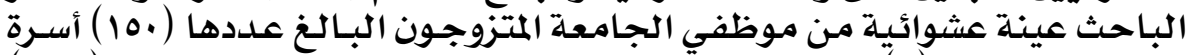

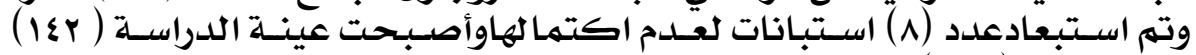

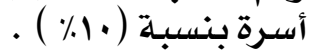

جلدول رقهم (1) يوضح توزيع عينة افراد اللدراسة من الأسر السعودية تبعاً لمتغيرات الدراسة (المؤهل العلميا)

\begin{tabular}{|c|c|c|c|}
\hline النسبة \% & العدد & فئات المتغير & المتغير \\
\hline$\% . r . \wedge 1$ & $\varepsilon$ & أمى & \multirow{6}{*}{ مؤهل الآب } \\
\hline$\%$. .20 & ir & الابتدائية & \\
\hline$\%$. . 80 & ir & المتوسطة & \\
\hline \%.rr.or & $r Y$ & الثانوية & \\
\hline$\%$ \&9..१ & $\mathrm{v}$. & البكالوريوسي & \\
\hline$\%$ 1. $\varepsilon 0$ & Ir & ماجستير فأكثر & \\
\hline$\%$. . \&o & Ir & أمى & \multirow{6}{*}{ مؤهل الأم } \\
\hline$\% 9.10$ & $1 \varepsilon$ & الابتدائية & \\
\hline$\%$ YI. Ir & $r$. & المتوسطة & \\
\hline \% rr.or & $r Y$ & الثانوية & \\
\hline$\%$ rr.A. & $\varepsilon \wedge$ & البكالوريوسي & \\
\hline$\% \varepsilon . r Y$ & 7 & ماجستير فأكثر & \\
\hline
\end{tabular}

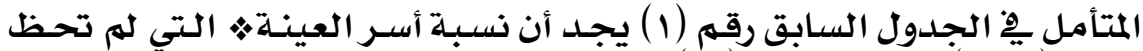

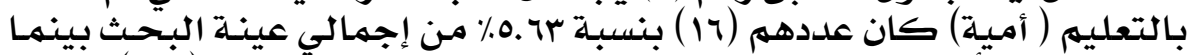

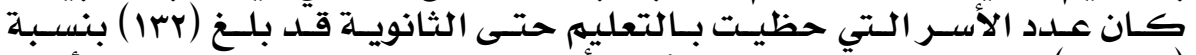

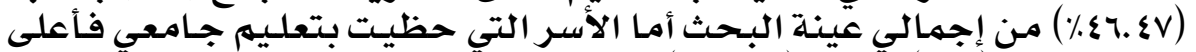

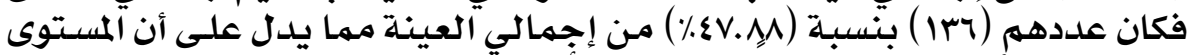

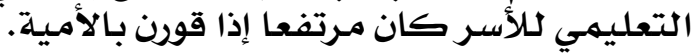

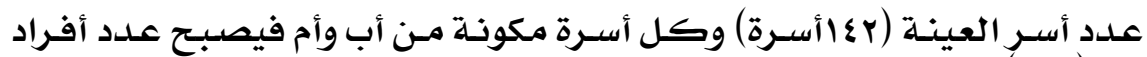

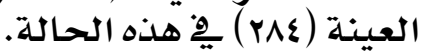

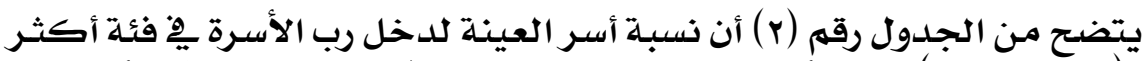

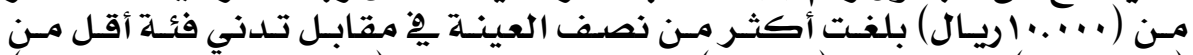

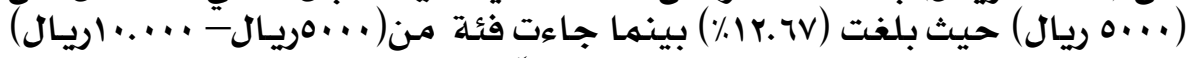

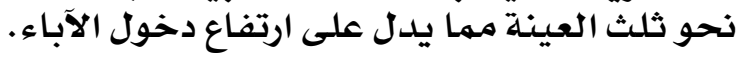


العقد العابg والمتهون .. نه همبر ..

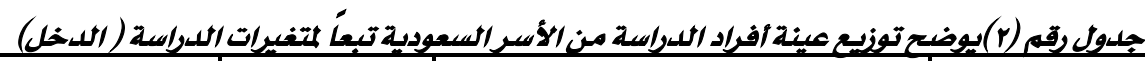

\begin{tabular}{|c|c|c|c|}
\hline النسبة ٪ & العدد العد & فئات المتفير & المتغير \\
\hline$\% 1 Y . T V$ & 14 & أقل من .... & \multirow{3}{*}{ دخل الأب } \\
\hline$\%$ r.7.71 & or & من ... 0 إلى .... إيال & \\
\hline$\% 0 . . v$. & $\begin{array}{rr}v_{Y} \\
\end{array}$ & أكثرمن .... اريال & \\
\hline$\%$. $7 . .0$ & 1.1 & لا يوجد & \multirow{4}{*}{ دخل الأم } \\
\hline$\% 0.7 r$ & $\wedge$ & أقل من....0 & \\
\hline \%.Yr.TV & 11 & من ... 0 إلى .... إيال & \\
\hline$\% 0.7 r$ & $\mathbf{A}$ & اكثثرمن ..... ريال & \\
\hline
\end{tabular}

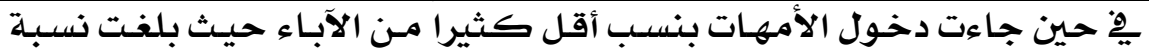

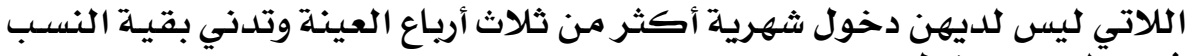

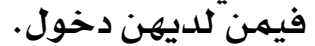

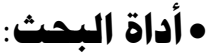

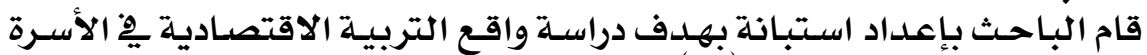

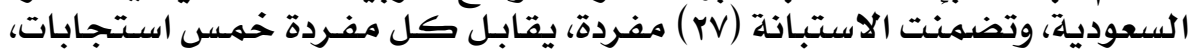

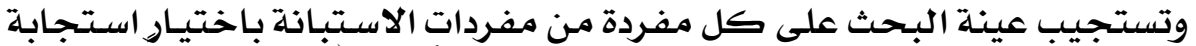

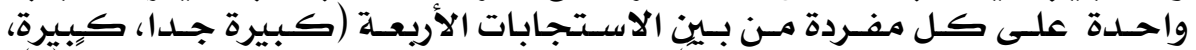

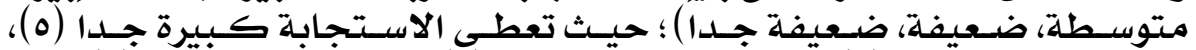

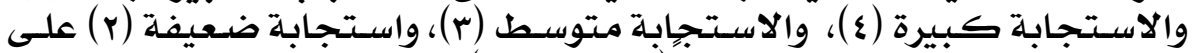

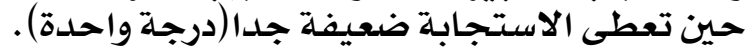

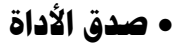

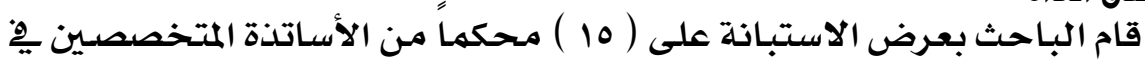

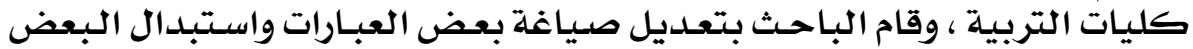
الآخر وفقا درأي بعض ، وقام المحكمـين.

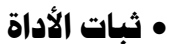

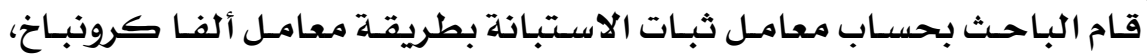

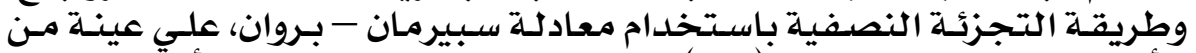

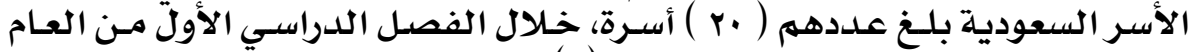

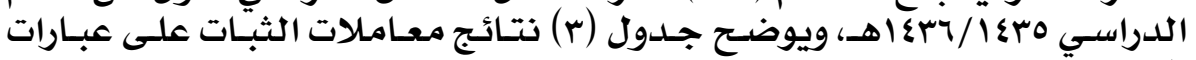

جلول (r) قيم معاملات الثبات لاستبانة واقع التربية الاقتصادبية 2خ الاسر السعودية

\begin{tabular}{|c|c|c|}
\hline سيبرمان - بروان & ألفا & معامل الثيات \\
\hline. .11 &. .97 & علي فقرات الاستبانة \\
\hline
\end{tabular}

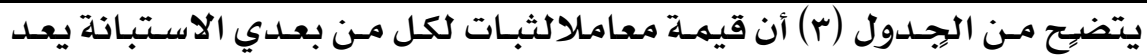

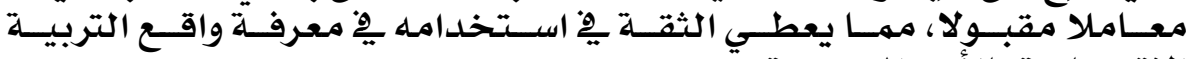

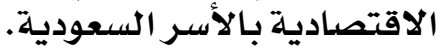

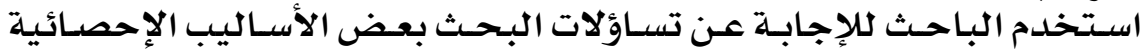

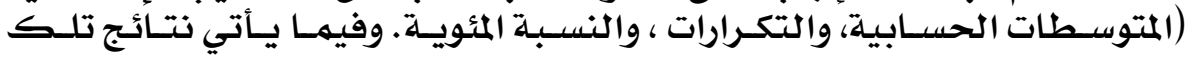
الفروض وتفسيرها ومناقشتها المتيا. 


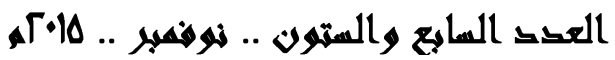

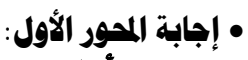

المحور الأول :حينما ياتي أول الشهرويصرف العائل الراتب الشهري فهل \&

جلدول رقهر (ع) التكرارات والنسب المئوبية والمتوسطاتالحسابيةلاستجابات عينة اللدراسة حول حينما

ياتتى أول الشهرويصرف الثعائل الراتب الشهريفهل

\begin{tabular}{|c|c|c|c|c|c|c|c|c|c|c|c|}
\hline \multirow{3}{*}{ 雪哥。 } & \multicolumn{10}{|c|}{ التكراروالنسب المئوية لدرجة الموافقة } & \multirow{3}{*}{ العبارة } \\
\hline & \multicolumn{2}{|c|}{ ضعيفة جلأ } & \multicolumn{2}{|c|}{ ضعيفة } & \multicolumn{2}{|c|}{ متوسطة } & \multicolumn{2}{|c|}{ كبيرة } & \multicolumn{2}{|c|}{ كبيرة جدا } & \\
\hline & $\%$ & ت & $\%$ & ت & $\%$ & ت & $\%$ & ت & $\%$ & ت & \\
\hline ar.ru & A. $\{0$ & Ir & $11 . \mathrm{YT}$ & 17 & $r \Lambda_{0} \cdot r$ & O\& & $Y 1.1 Y$ & $r$. & $Y 1.1 Y$ & $r$. & 1 \\
\hline A $\varepsilon_{.} \gamma_{.}$ & 19.11 & $\mathbf{~ Y \Lambda}$ & 17.9. & $r \varepsilon$ & YQ.०V & $\varepsilon r$ & 19.21 & YA & $1 \varepsilon_{0} \cdot 1$ & $r$. & $r$ \\
\hline V৭.V & Yo.ro & $m$ & A. $\leqslant 0$ & Ir & \&r.T\} & $\pi Y$ & M.r. & YT & Q.YY & 9 & $r$ \\
\hline
\end{tabular}

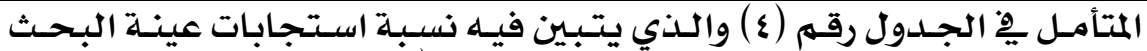

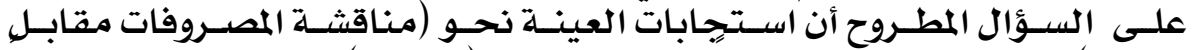

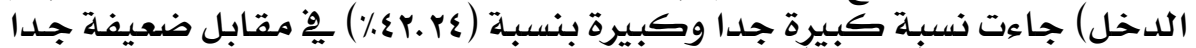

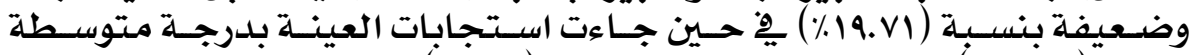

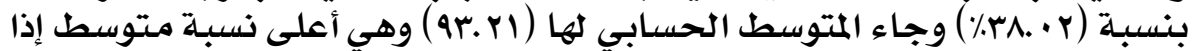

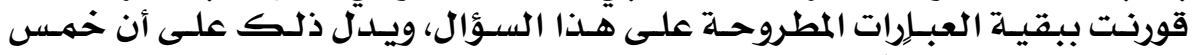

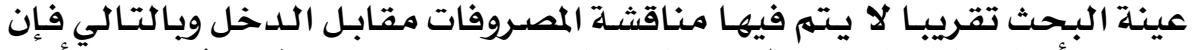

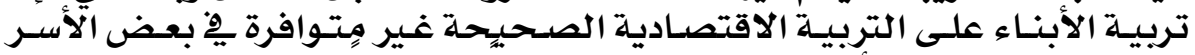

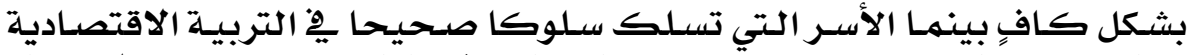

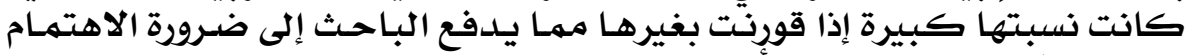

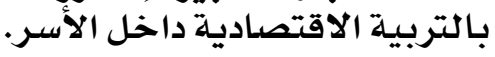

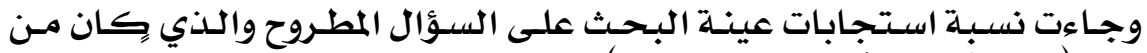

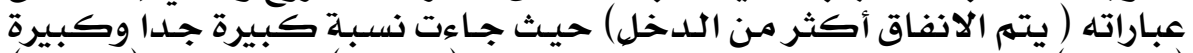

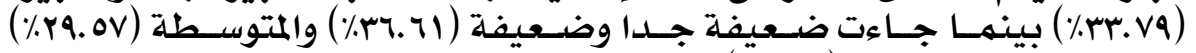

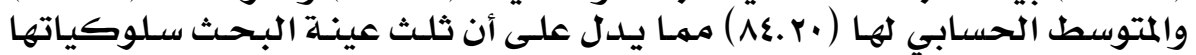

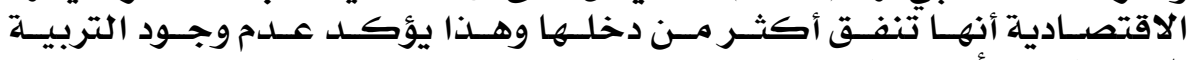

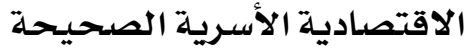

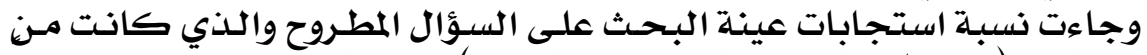

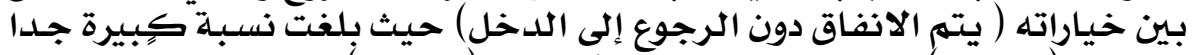

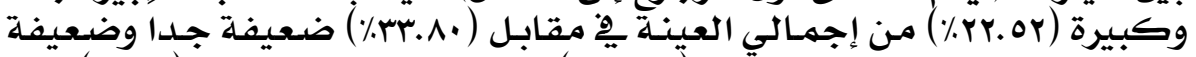

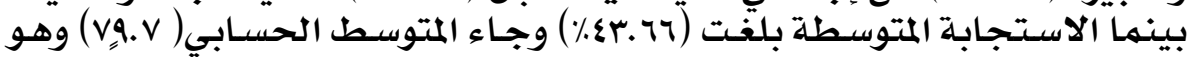

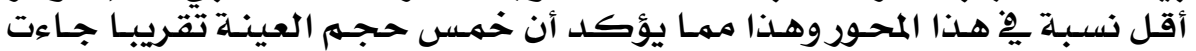

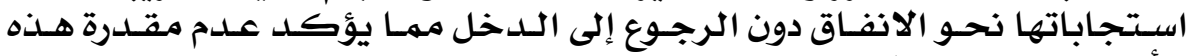

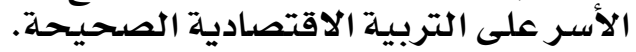

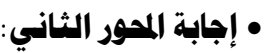
المحور الثناني :عنّدما تصرف الثاني: الأسرة الراتب الشهري فهل ؟

$$
\text { والجدول (0) يوضح ذلك : }
$$

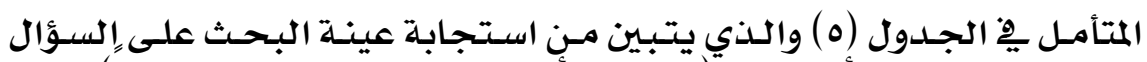

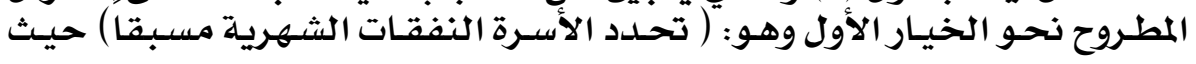




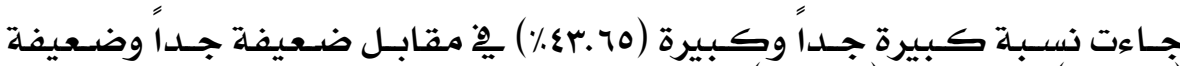
(1.Y0)

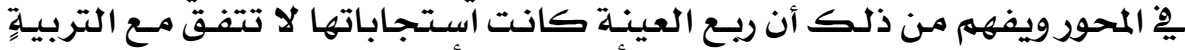

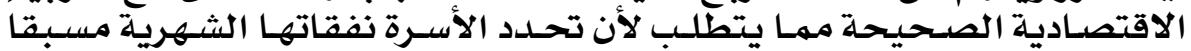

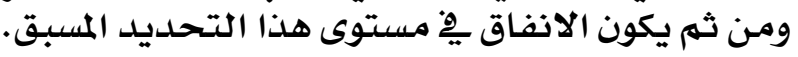

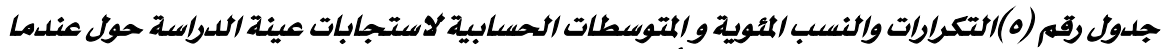
تصرف الأسرة الراتب الشهريفيله

\begin{tabular}{|c|c|c|c|c|c|c|c|c|c|c|c|}
\hline \multirow{3}{*}{ 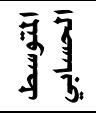 } & \multicolumn{10}{|c|}{ التكراروالنسب المئوية لدرجة الموافقة } & \multirow{3}{*}{ العبارة } \\
\hline & \multicolumn{2}{|c|}{ ضعيفة جدا } & \multicolumn{2}{|c|}{ ضعيفة } & \multicolumn{2}{|c|}{ | متوسطة } & \multicolumn{2}{|c|}{ كبيرة } & \multicolumn{2}{|c|}{ كبيرةجدا } & \\
\hline & $\%$ & $\Xi$ & $\%$ & $ت$ & $\%$ & $\Xi$ & $\%$ & $\Xi$ & $\%$ & $ت$ & \\
\hline$\Delta 7.17$ & 10.29 & $\overline{r Y}$ & $11 . \mathrm{rq}$ & 17 & YA.17 & $\varepsilon$ & YY.OY & $\overline{r r}$ & rI.IY & $r$. & 1 \\
\hline VT.rY & r9.0v & $\varepsilon r$ & rY.rq & 27 & 10.29 & $r Y$ & 10.29 & $r Y$ & $v . \cdot \varepsilon$ & 1. & $r$ \\
\hline W. & Y1.17 & $\varepsilon$. & 1A.r. & Y & rr.or & rr & rI.1Y & $r$. & 9.10 & $1 \xi$ & $\boldsymbol{r}$ \\
\hline
\end{tabular}

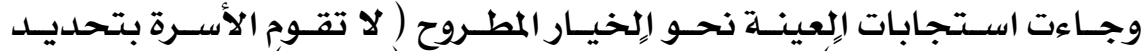

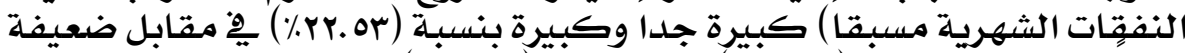

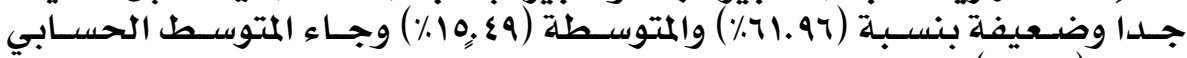

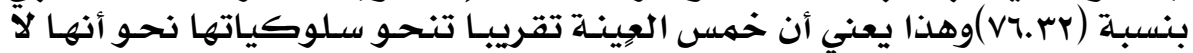

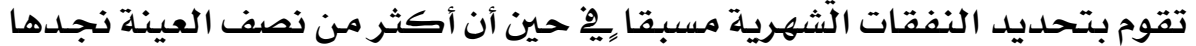

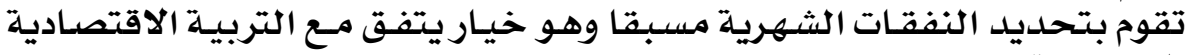

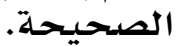

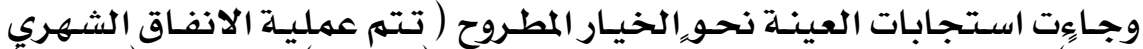

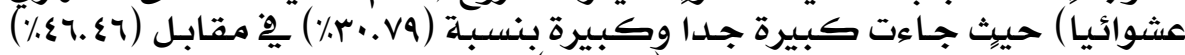

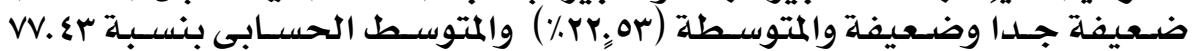

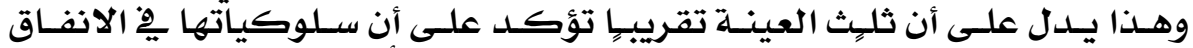

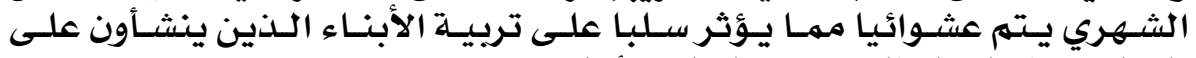

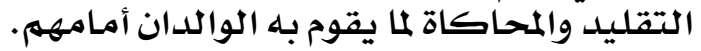

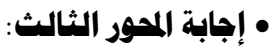
المحور الثالث: تقوم الأسرة بعمل خطة ثهرية لاحتياجاتها الضـرورية تتماثى

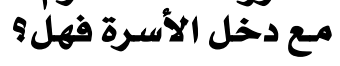

جلدول رقه (7) التكرارات والنسب المئوبية و المتوسطات الحسابية لاستجابات عينة اللدراسة حول تقوم

\begin{tabular}{|c|c|c|c|c|c|c|c|c|c|c|c|}
\hline \multirow{3}{*}{ 牙亩 } & \multicolumn{10}{|c|}{ التكراروالنسب المئوية لدرجة الموافقة } & \multirow{3}{*}{ العبارة } \\
\hline & \multicolumn{2}{|c|}{ ضعيفة جدا } & \multicolumn{2}{|c|}{ ضعيفة } & \multicolumn{2}{|c|}{ متوسطة } & \multicolumn{2}{|c|}{ كبيرة } & \multicolumn{2}{|c|}{ كييرة جدا } & \\
\hline & $\%$ & ت & $\%$ & $ت$ & $\%$ & ت & $\%$ & ت & $\%$ & $ت$ & \\
\hline 90.27 & $0.7 r$ & $\Lambda$ & Q.YY & 9 & M.r. & rq & $r \cdot .94$ & $\varepsilon \varepsilon$ & $\varepsilon \cdot . \wedge \varepsilon$ & OA & 1 \\
\hline$W . \varepsilon r$ & YA.17 & $\varepsilon$. & rI.IY & r. & YA.17 & $\varepsilon$. & M.r. & rT & \&.rY & 7 & $r$ \\
\hline VY.१E & Mr.A. & $\varepsilon \wedge$ & rr.ą & r & IV.T. & ro & IV.T. & ro & $v . \cdot \varepsilon$ & 1. & $r$ \\
\hline
\end{tabular}

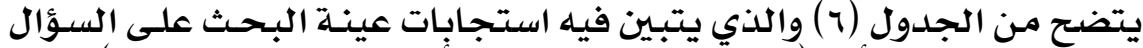

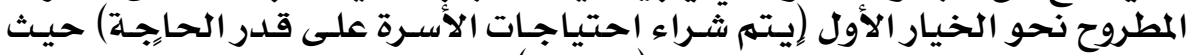

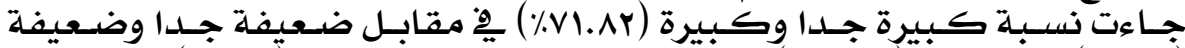

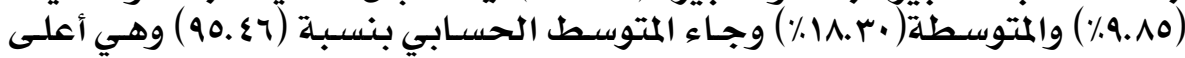

\section{Mr}




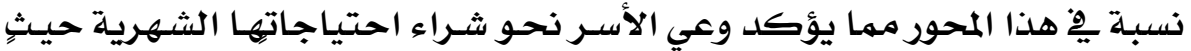

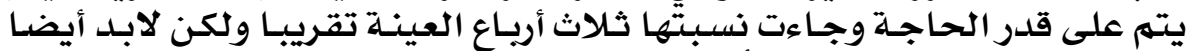

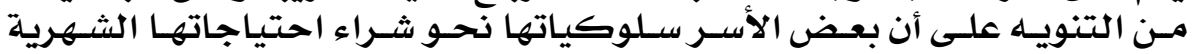
لايكون بمقدار حاجتها.

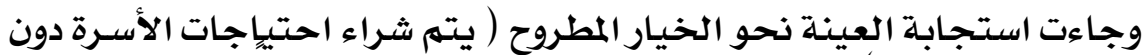

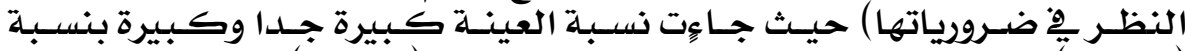

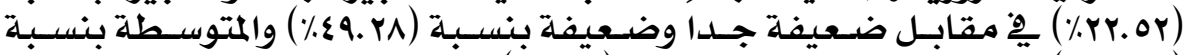

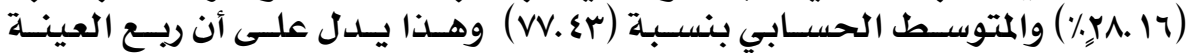

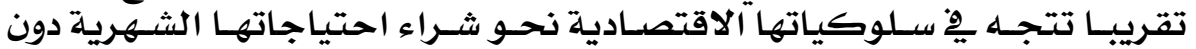
النظر إلى ضرورتها.

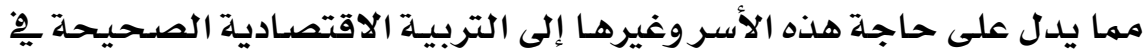

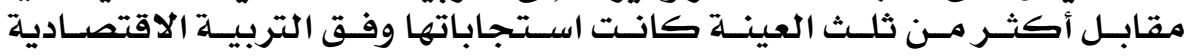
الصحيحة أصنا.

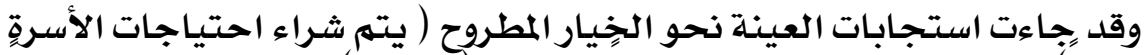

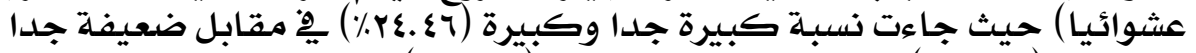

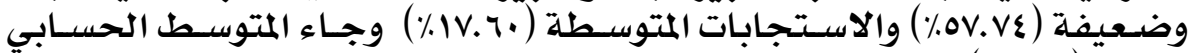

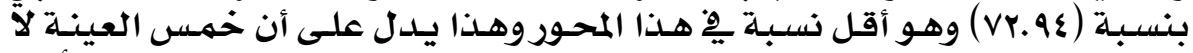

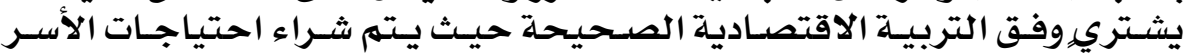

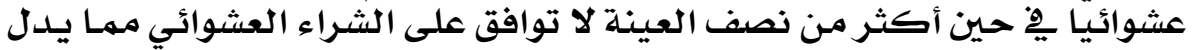

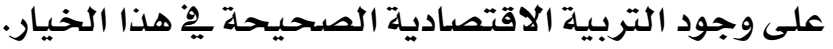

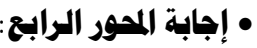

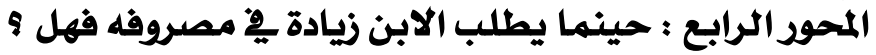
جلدول رقه (v) التكرارات والنسب المئوية والمتوسطات الحسابية/لمعيارية لاستجابات عينة اللدراسة حول حينما بطلب زيادة في مصروفهفهل

\begin{tabular}{|c|c|c|c|c|c|c|c|c|c|c|c|}
\hline \multirow{3}{*}{ 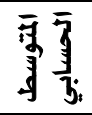 } & \multicolumn{10}{|c|}{ التكراروالنسب المئوية لدرجمة الموافقة } & \multirow{3}{*}{ العبارة } \\
\hline & \multicolumn{2}{|c|}{ ضعيفة جدا } & \multicolumn{2}{|c|}{ ضعيفة } & \multicolumn{2}{|c|}{ متوسطة } & \multicolumn{2}{|c|}{ كبيرة } & \multicolumn{2}{|c|}{ كبيرة جدا } & \\
\hline & $\%$ & 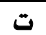 & $\%$ & ت & $\%$ & ت & $\%$ & ت & $\%$ & $ت$ & \\
\hline$V 1 . \Delta 1$ & ro.rI & 0. & $r . .91$ & $\varepsilon \varepsilon$ & $19 . v 1$ & YA & $0.7 r$ & $\Lambda$ & A. $\{0$ & ir & 1 \\
\hline 9 QY.०Q & 9.10 & $1 \varepsilon$ & $\varepsilon . Y Y$ & 7 & $11 . Y 4$ & 17 & YT.VT & ra & $\varepsilon V . \wedge M$ & Th & $r$ \\
\hline 70.0 & ד. ד. & $\pi r$ & $11 . \mathrm{YT}$ & 17 & ro.ro & rq & $0 . \pi r$ & $\Lambda$ & $1 \varepsilon . \cdot 1$ & $r$. & $r$ \\
\hline
\end{tabular}

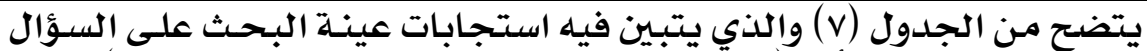

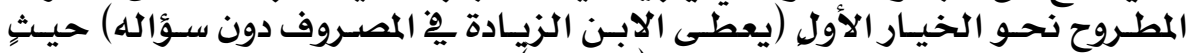

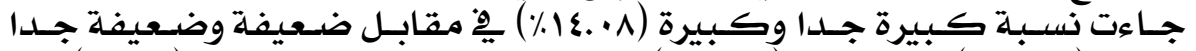

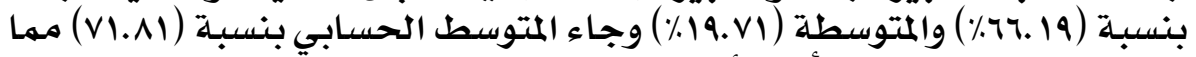

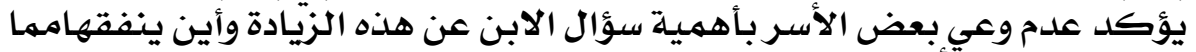

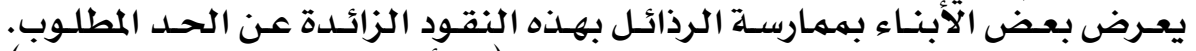

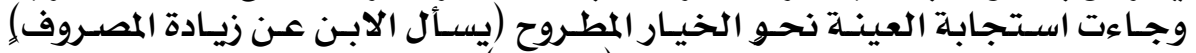

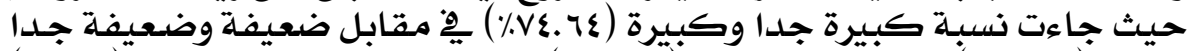

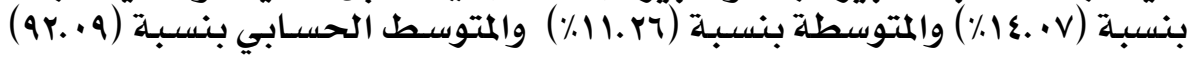

\section{$\boldsymbol{M} r$}




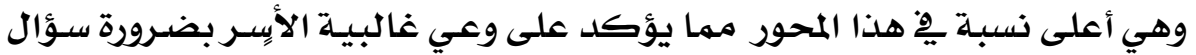

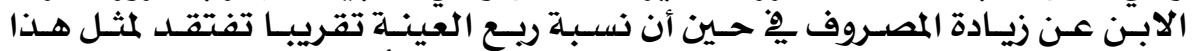

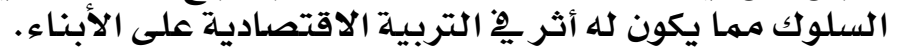

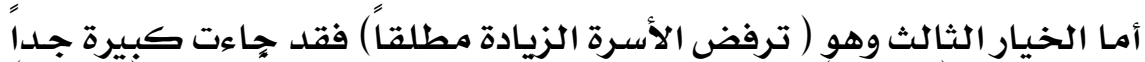

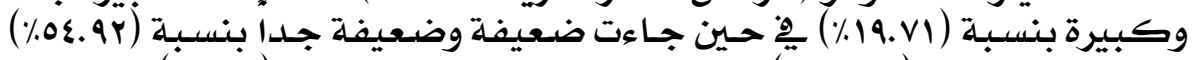

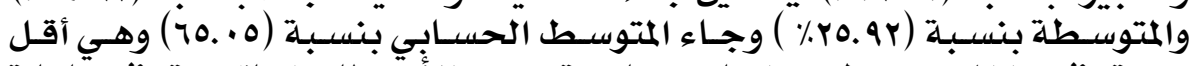

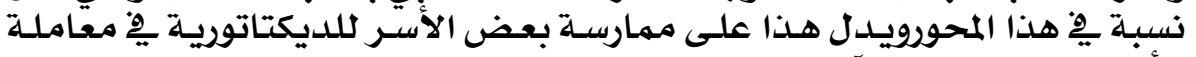

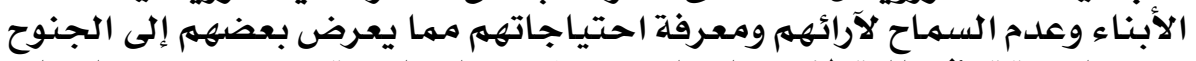

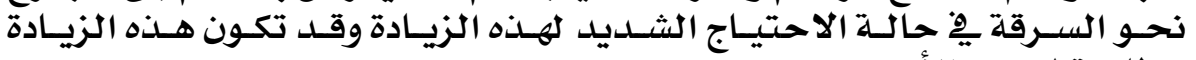
مطلوبـة لبعض الأمور.

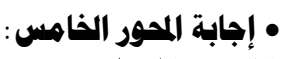
المحصور الخامس: الحور عندما تتبقى بعض الأطعمة الزائدة عن حاجة الأسرة اليومية فهل جلدول رقه (A) التكرارات والنسب المئوبية و المتوسطات الحسابية لاستحابات عينة اللرواسة حول عنلما

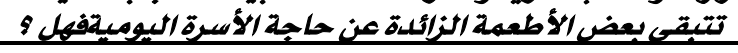

\begin{tabular}{|c|c|c|c|c|c|c|c|c|c|c|c|}
\hline \multirow{3}{*}{ 牙雪 } & \multicolumn{10}{|c|}{ التكراروالنسب المئوية لدرجة الموافقة } & \multirow{3}{*}{ العبارة } \\
\hline & \multicolumn{2}{|c|}{ ضعيفة جدا } & \multicolumn{2}{|c|}{ ضعيفة } & \multicolumn{2}{|c|}{ متوسطة } & \multicolumn{2}{|c|}{ كبيرة } & \multicolumn{2}{|c|}{ كبيرة جدا } & \\
\hline & $\%$ & ت & $\%$ & ت & $\%$ & ت & $\%$ & ت & $\%$ & ت & \\
\hline Th.r. & \&Y.YO & 7. & Yr.Q\& & $r \varepsilon$ & YT.VT & rA & - & - & $v_{0} \cdot \varepsilon$ & 1. & 1 \\
\hline 90.80 & $0.7 \pi$ & $\Lambda$ & P.AI & $\varepsilon$ & M.r. & Y & MA.r. & YT & 0 Qצ.9Y & $\mathrm{VA}$ & $r$ \\
\hline 9r.1 & 9.10 & $1 \varepsilon$ & A. $\{0$ & ir & YT.VT & rA & Yr.qE & $r \varepsilon$ & $r \cdot .91$ & $\varepsilon \varepsilon$ & $r$ \\
\hline
\end{tabular}

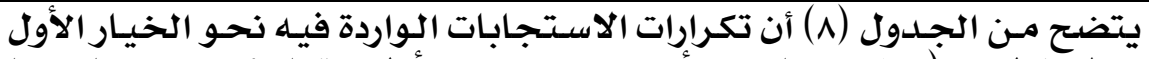

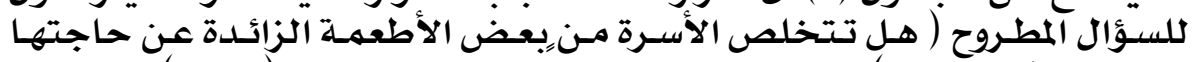

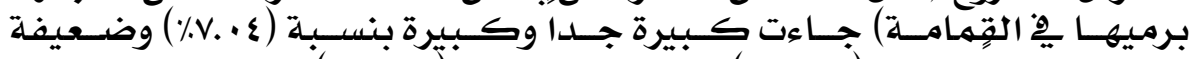

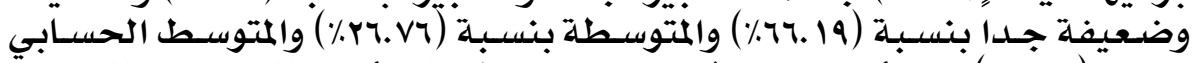

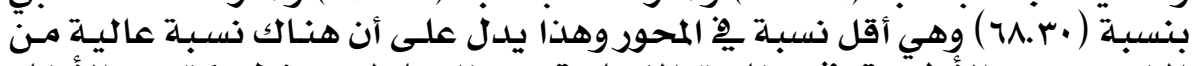

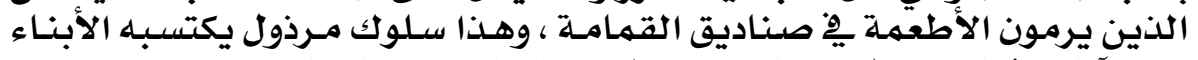

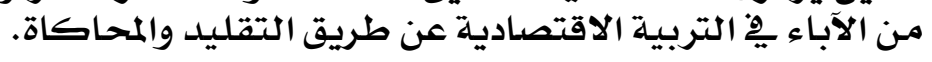

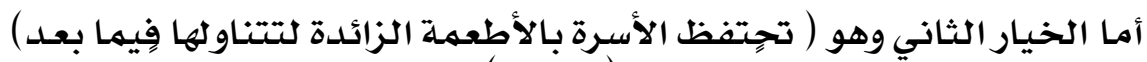

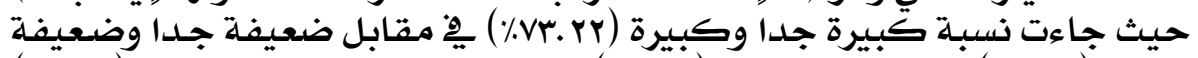

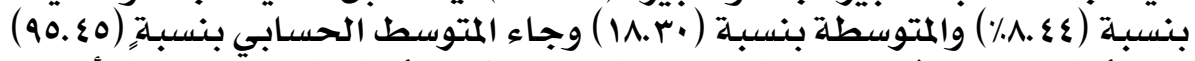

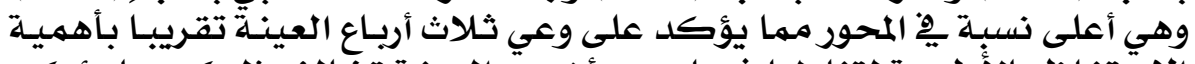

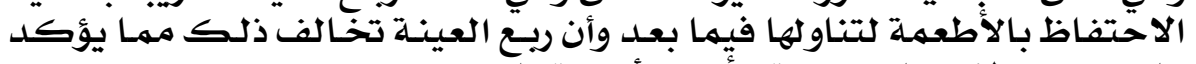

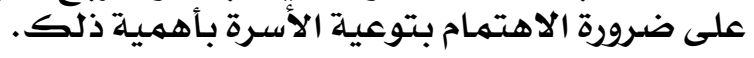

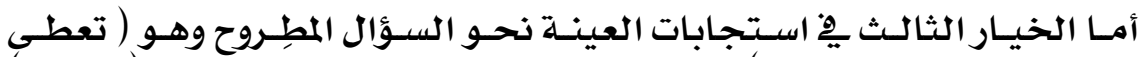

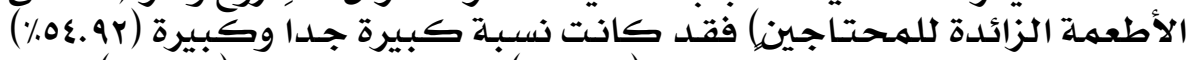

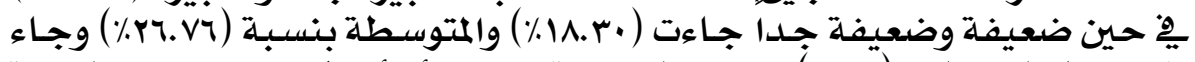

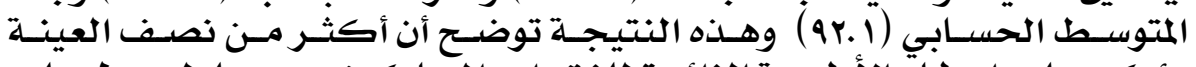

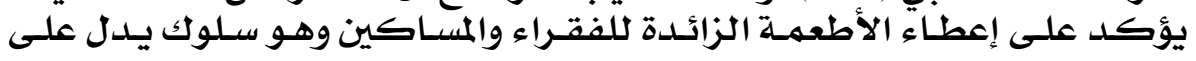

\section{$r \mid \varepsilon$}


الوعي بين تلك الأسـر هِ التكافل الاجتمهاعي بـين النـاس وبـث قيمـة العطـاء مـن جانب الموسرين.

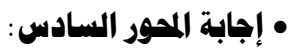

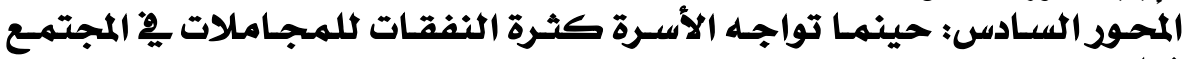

فهل

جلدول رقه (ه) التكرارات والنسب المئوية و المتوسطات الحسابية لاستجابات عينة اللدراسة حول حينما

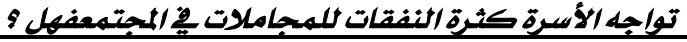

\begin{tabular}{|c|c|c|c|c|c|c|c|c|c|c|c|}
\hline$\overline{\bar{y}} \overline{7}$ & \multicolumn{10}{|c|}{ التكراروالنسب المئوية لدرجة الموافقة } & \multirow{3}{*}{ العبارة } \\
\hline & \multicolumn{2}{|c|}{ ضعيفة جدا } & \multicolumn{2}{|c|}{ ضعيفة } & \multicolumn{2}{|c|}{ متوسطة } & \multicolumn{2}{|c|}{ كبيرة } & \multicolumn{2}{|c|}{ كبيرة جدا } & \\
\hline & $\%$ & ت & $\%$ & ت & $\%$ & ت & $\%$ & ت & $\%$ & $ت$ & \\
\hline Aт. \&0 & 17.9. & $r \varepsilon$ & $11 . \mathrm{YT}$ & 17 & Y9. OV & $\varepsilon r$ & M.r. & YT & Yr.q\& & $r \varepsilon$ & 1 \\
\hline $9 Y_{0} \cdot 9$ & 9.10 & $1 \varepsilon$ & $1 . .07$ & 10 & $r \cdot . \varepsilon r$ & rq & rrr..q & $\varepsilon V$ & Yr..O & $r V$ & $r$ \\
\hline $77 . \wedge 1$ & EY.YO & 7. & 10.29 & Yr & 10.29 & Yr & M.r. & YT & A. $\{0$ & ir & $r$ \\
\hline
\end{tabular}

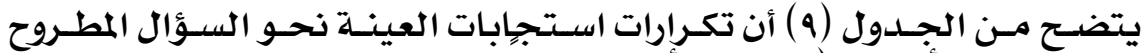

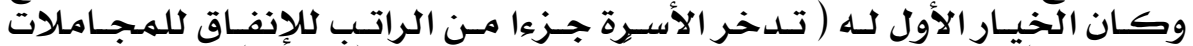

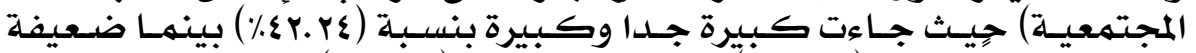

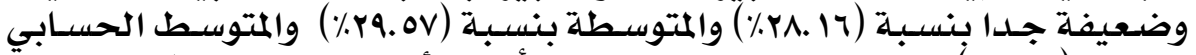

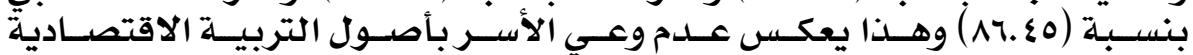

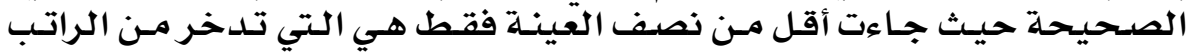

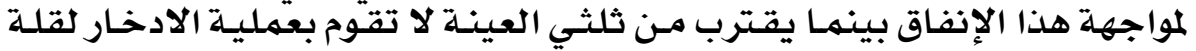

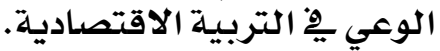

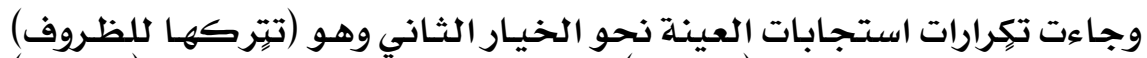

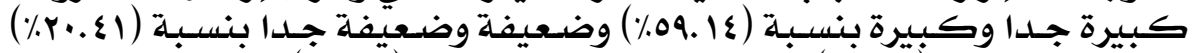

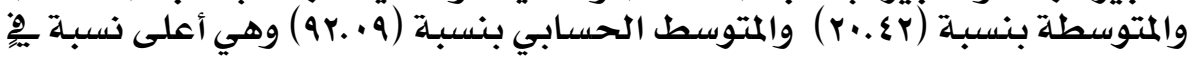

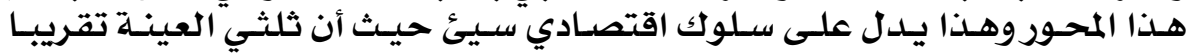

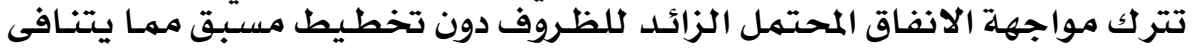

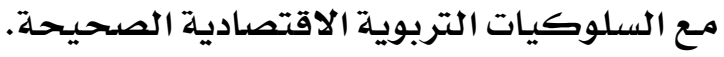

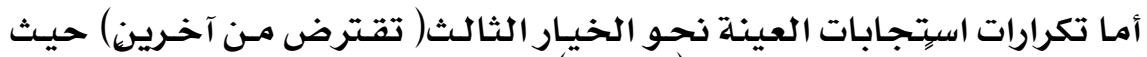

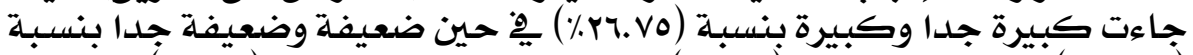

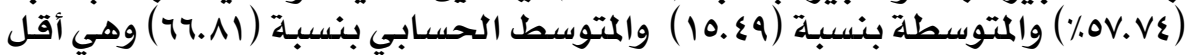

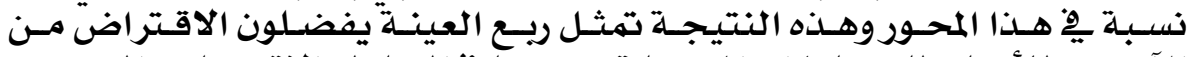

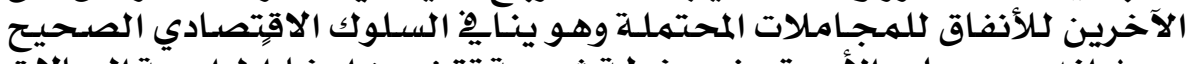

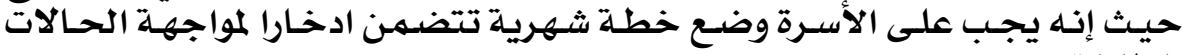
الطارئة.

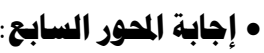

المحور السابع :عندما يصل الهول الابن الأكبر إلى مرحلة الرثشد فهل \&

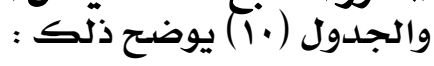

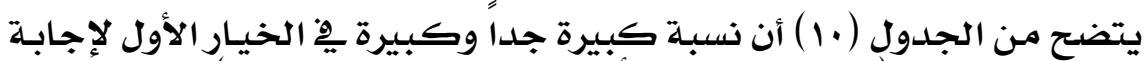

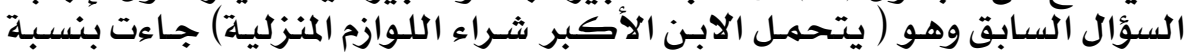

\section{Y 10}




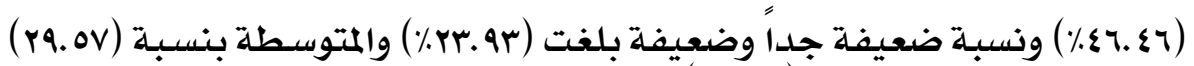

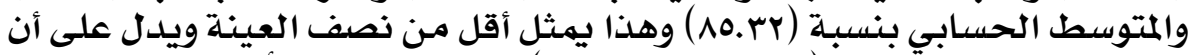

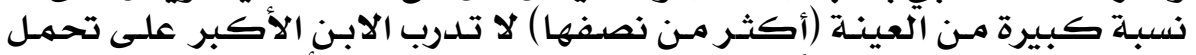

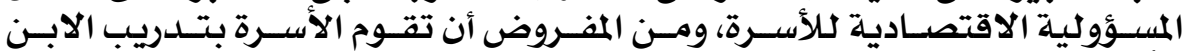

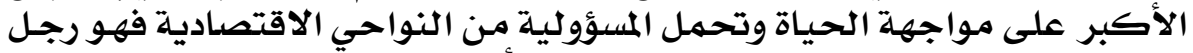

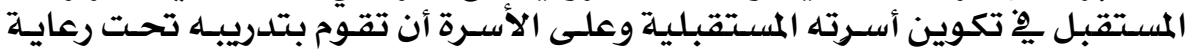

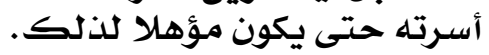

جلدول رقهر (. 1) التكرارات والنسب المئوية والمتوسطاتالحسابيةلاستجابات عينة اللدراسة حول عنلدما

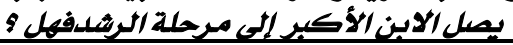

\begin{tabular}{|c|c|c|c|c|c|c|c|c|c|c|c|}
\hline \multirow{3}{*}{ 哥象。 } & \multicolumn{10}{|c|}{ التكراروالنسب المئوية لدرجة الموافقة } & \multirow{3}{*}{ العبارة } \\
\hline & \multicolumn{2}{|c|}{ ضعيفة جداً } & \multicolumn{2}{|c|}{ ضعيفة } & \multicolumn{2}{|c|}{ متوسطة } & \multicolumn{2}{|c|}{ كبيرة } & \multicolumn{2}{|c|}{ كبيرة جدأ } & \\
\hline & $\%$ & $ت$ & $\%$ & ت & $\%$ & ت & $\%$ & ت & $\%$ & ت & \\
\hline No.rr & M.r. & rq & $0.7 r$ & $\Lambda$ & Y9.० V & $\varepsilon r$ & $9 . \wedge 0$ & 18 & r..71 & or & 1 \\
\hline$A \cdot . \wedge r$ & rr.१६ & $r \varepsilon$ & 10.29 & rr & ro.ri & 0. & Ir.TV & in & Ir.Tr & M & $r$ \\
\hline $9 . .97$ & $11 . r 7$ & 17 & 9.10 & $1 \varepsilon$ & rr.or & rr & Y9.० V & $\varepsilon r$ & rr.vr & ra & $r$ \\
\hline
\end{tabular}

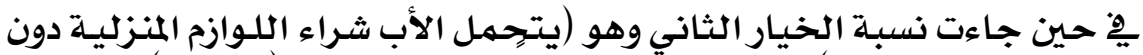

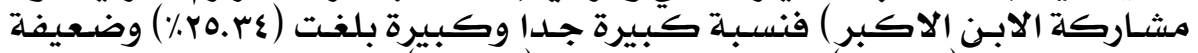

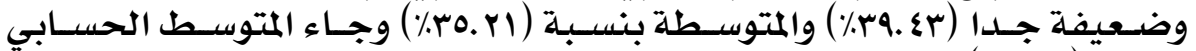

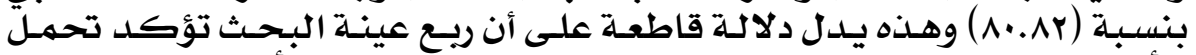

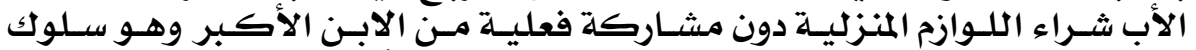

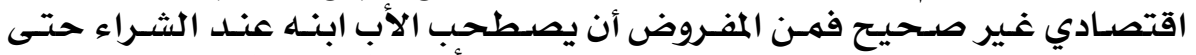

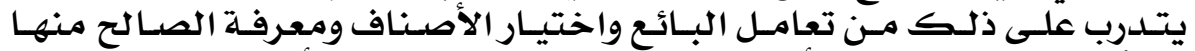

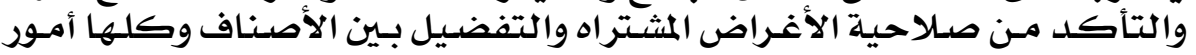

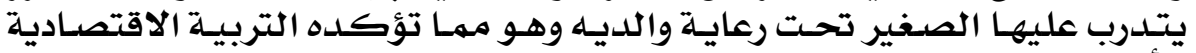

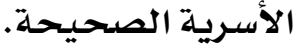

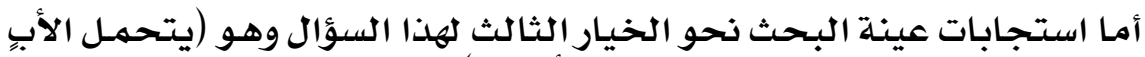

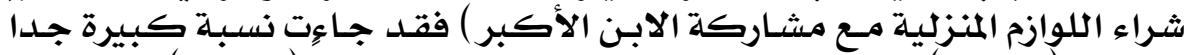

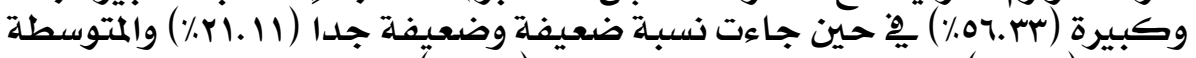

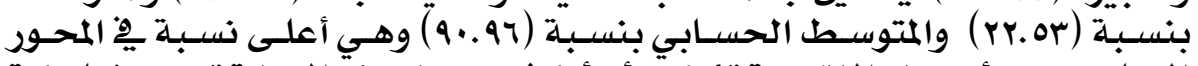

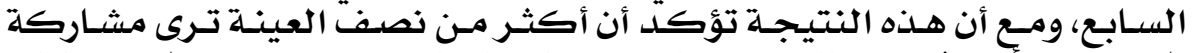

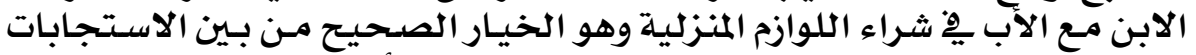

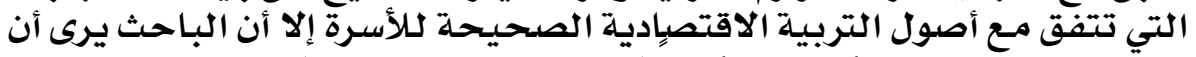

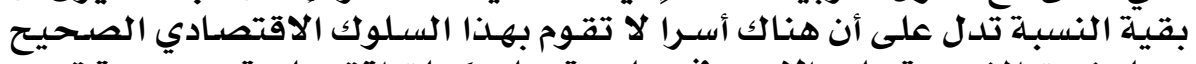

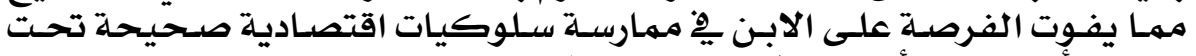

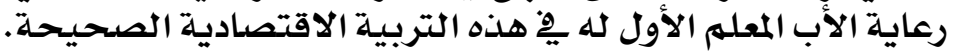

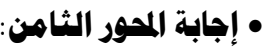
المحور الثامن :عندما تناقش الأسرة الميزانية ـِ أول الشهر فهل

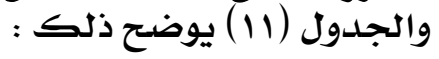

\section{MIT}


العكد العابو والمتهون .. نه همبر ..

جلدول رقه (1 ) التكرارات والنسب الميكوية و المتوسطات الحسابية لاستجابات عينة اللدراسة حول عنلما

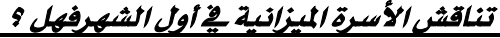

\begin{tabular}{|c|c|c|c|c|c|c|c|c|c|c|c|}
\hline \multirow{3}{*}{ 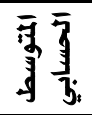 } & \multicolumn{10}{|c|}{ التكراروالنسب المئوية لدرجة الموافقة } & \multirow{3}{*}{ العبارة } \\
\hline & \multicolumn{2}{|c|}{ ضعيفة جدا } & \multicolumn{2}{|c|}{ ضعيفة } & \multicolumn{2}{|c|}{ متوسطة } & \multicolumn{2}{|c|}{ كبيرة } & \multicolumn{2}{|c|}{ كبيرة جدا } & \\
\hline & $\%$ & ت & $\%$ & $ت$ & $\%$ & ت & $\%$ & ت & $\%$ & ت & \\
\hline Tr.Vq & $\varepsilon 7 . \& V$ & 77 & rr.or & rr & 10.29 & rr & E.YY & 7 & $11 . \mathrm{YT}$ & 17 & 1 \\
\hline 11.9\& & rr.or & rr & IY.TV & IN & 17.9. & $r \varepsilon$ & M.r. & rT & rq. OV & $\varepsilon r$ & $r$ \\
\hline 77.11 & $0 . . v$. & Vr & rA. $\cdot r$ & of & $11 . \mathrm{rq}$ & 17 & - & - & - & - & $r$ \\
\hline
\end{tabular}

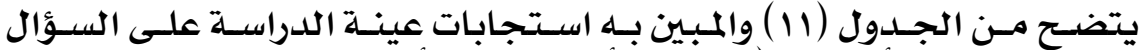

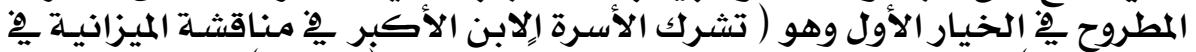

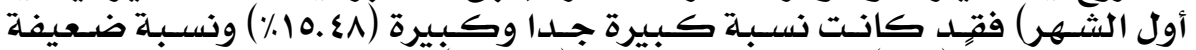

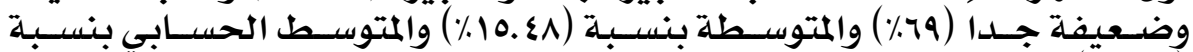
(Tr.Vq)

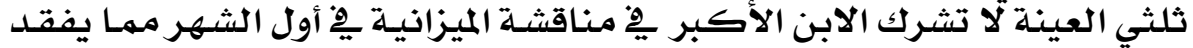

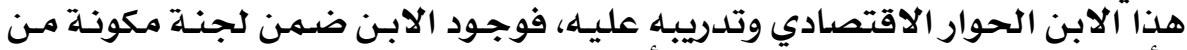

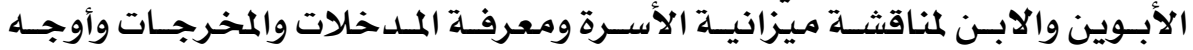

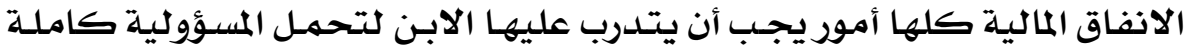

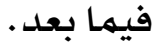

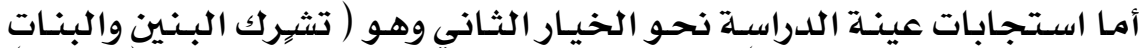

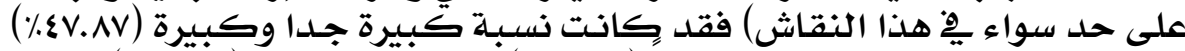

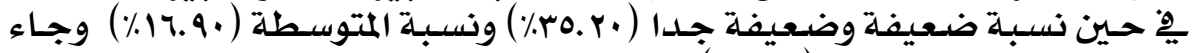

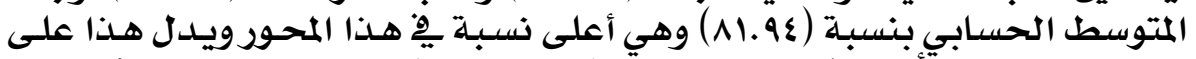

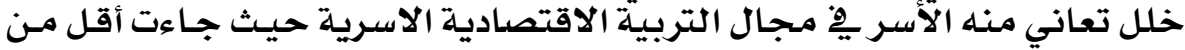

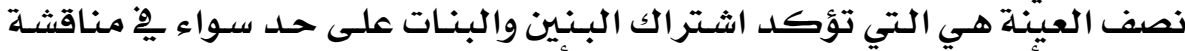

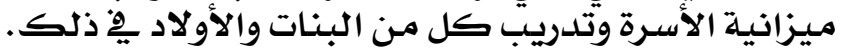

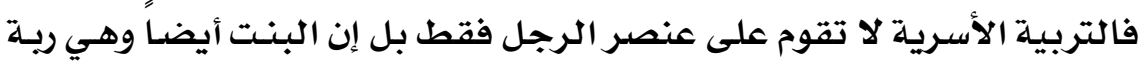

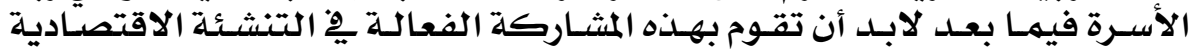

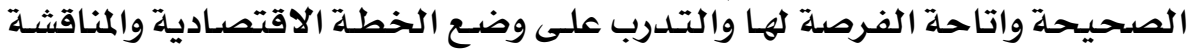

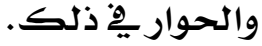

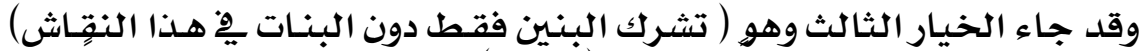

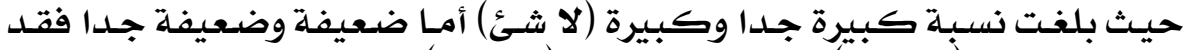

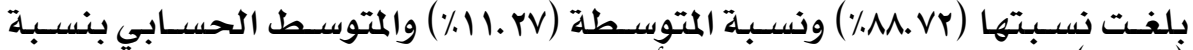

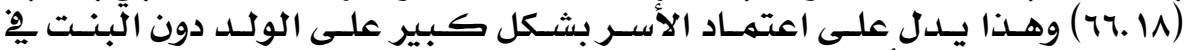

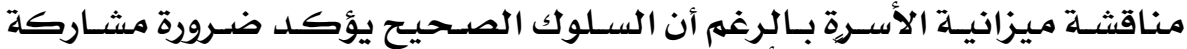

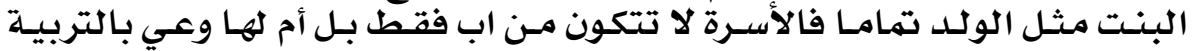

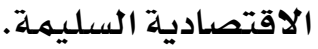

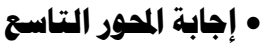
المحور التاسع : عند تكليف أحل الأبناء بشراء اللوازم المنزلية فهل ؟ والجدول (r) يوضح ذلك : 


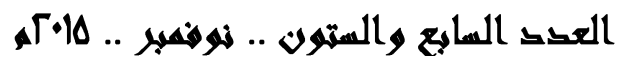

جلدول رقه (r ا )التكرارات والنسب المئوية والمتوسطات الحسابية لاستجابات عينة اللراسة حول عنل

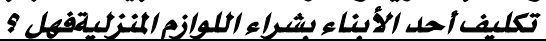

\begin{tabular}{|c|c|c|c|c|c|c|c|c|c|c|c|}
\hline \multirow{3}{*}{ 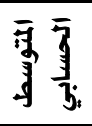 } & \multicolumn{10}{|c|}{ التكراروالنسب المئوية لدرجة الموافقة } & \multirow{3}{*}{ العبارة } \\
\hline & \multicolumn{2}{|c|}{ ضعيفة جدا } & \multicolumn{2}{|c|}{ ضعيفة } & \multicolumn{2}{|c|}{ متوسطة } & \multicolumn{2}{|c|}{ كبيرة } & \multicolumn{2}{|c|}{ كبيرة جلدا } & \\
\hline & $\%$ & ت & $\%$ & $ت$ & $\%$ & $ت$ & $\%$ & ت & $\%$ & ت & \\
\hline qv.vr & r.AI & $\varepsilon$ & $V . \cdot \varepsilon$ & 1. & 10.29 & $r Y$ & ro.ro & דו & \&9. Y१ & v. & 1 \\
\hline W. $\varepsilon \varepsilon$ & YA.17 & $\varepsilon$. & 19.11 & YA & rr.A. & $\{\Lambda$ & $10 . \leqslant 9$ & Yr & Y.AI & $\varepsilon$ & $r$ \\
\hline M.V. & $18 .+1$ & $r$. & 9.10 & $1 \varepsilon$ & rY.or & $r Y$ & rr.A. & $\varepsilon \wedge$ & 19.21 & $\mathrm{MA}$ & $r$ \\
\hline
\end{tabular}

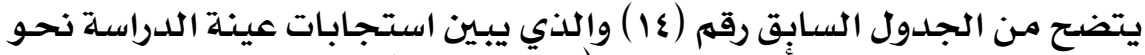

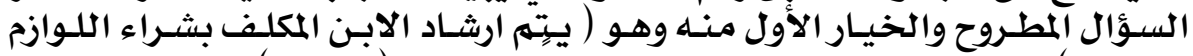

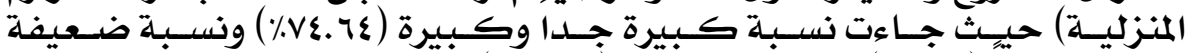

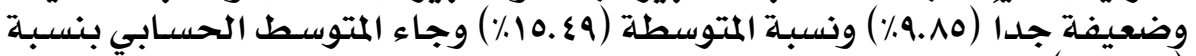

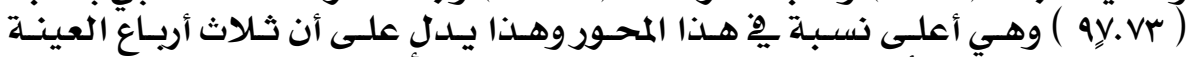

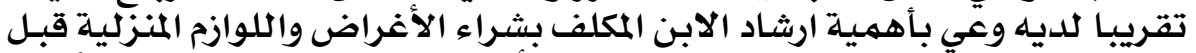

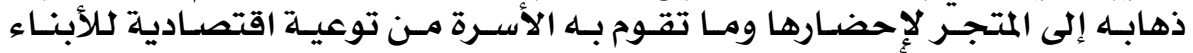

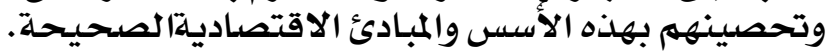

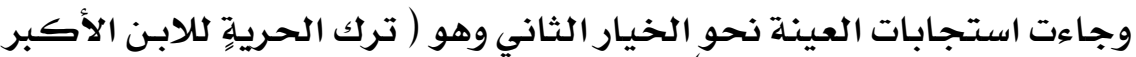

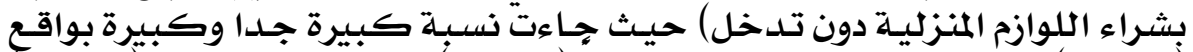

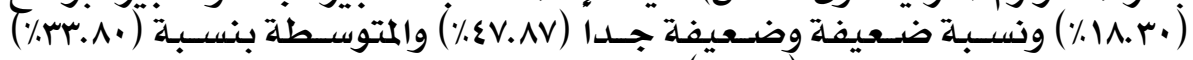
والمتوسط الحسـابي بنسبـة (

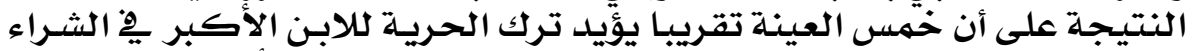

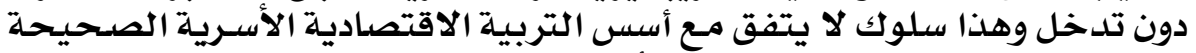

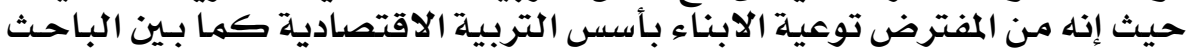

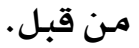

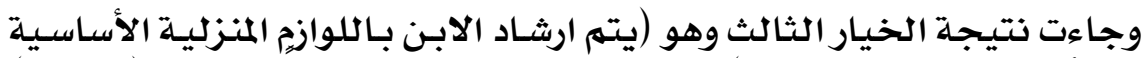

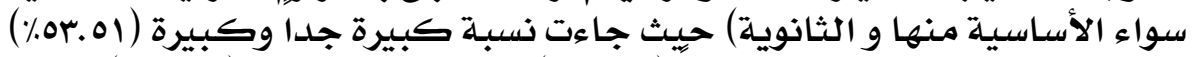

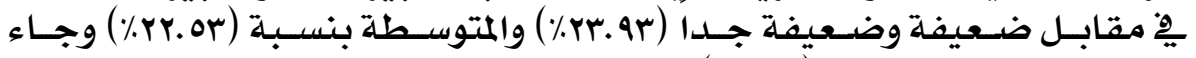

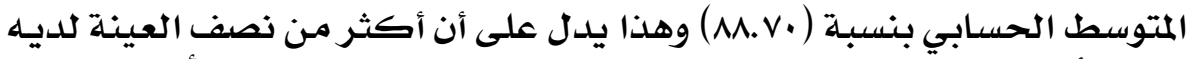

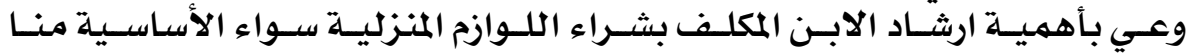

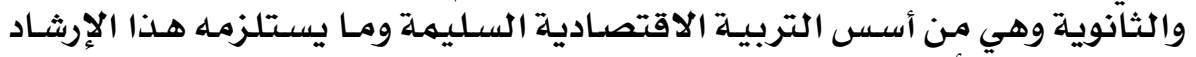

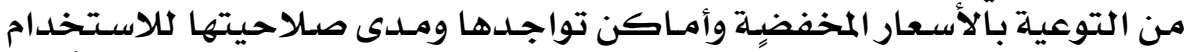

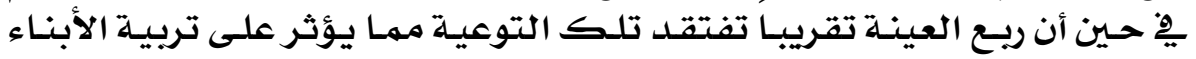

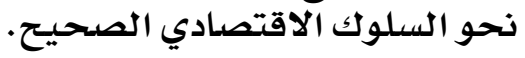

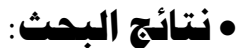

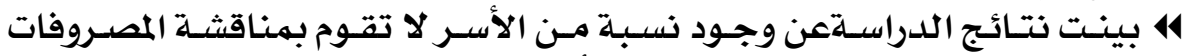

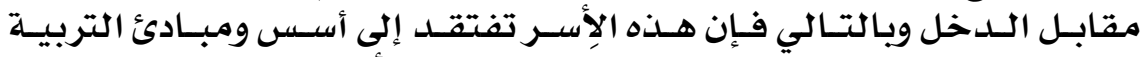

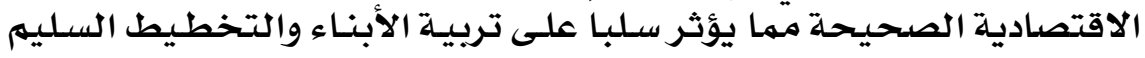

لهم.

\section{r\}}




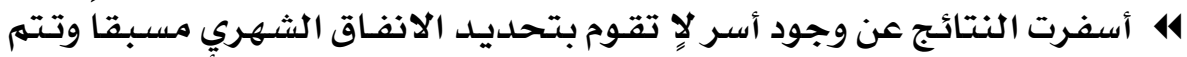

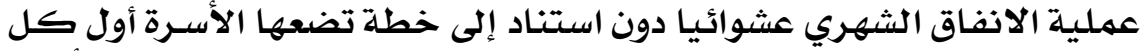

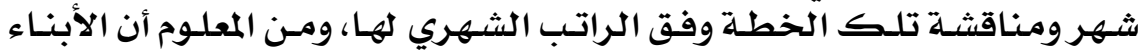

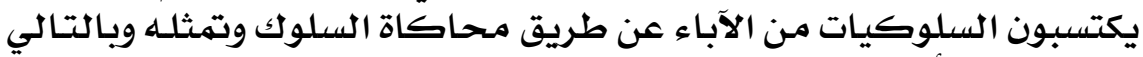

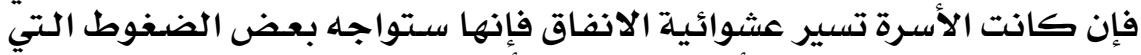

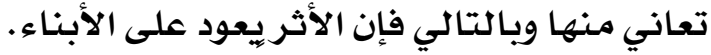

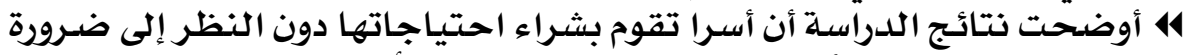

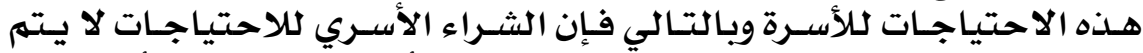

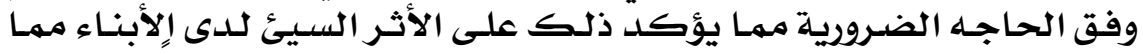

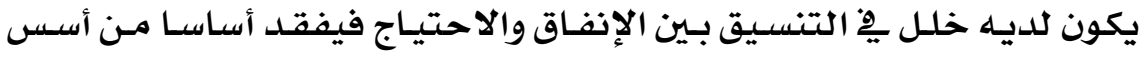

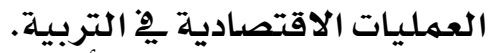

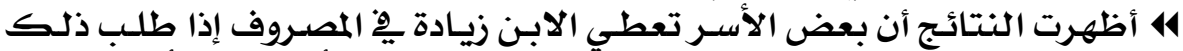

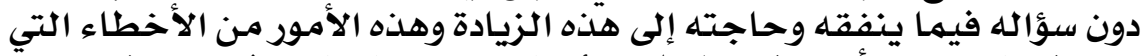

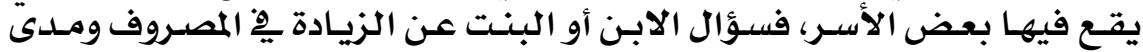

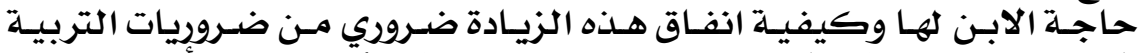

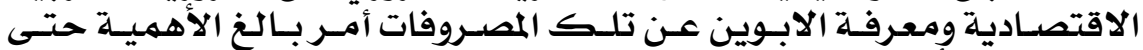

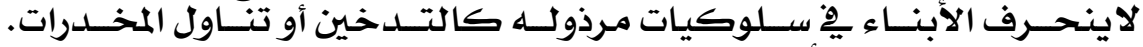

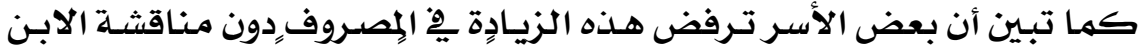

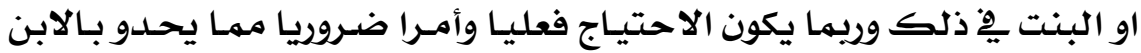

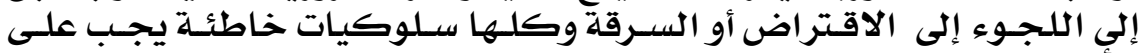

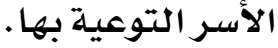

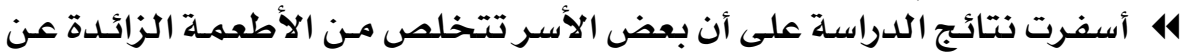

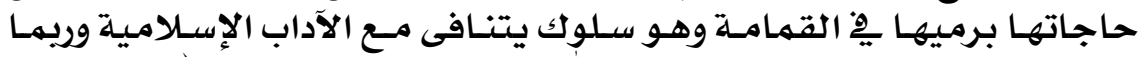

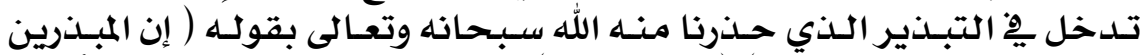

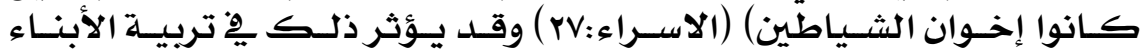

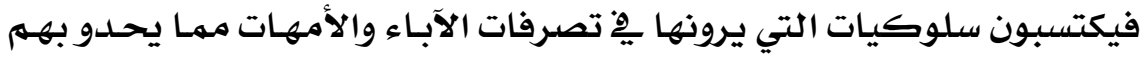

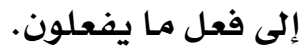

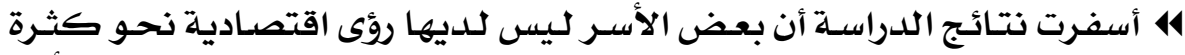

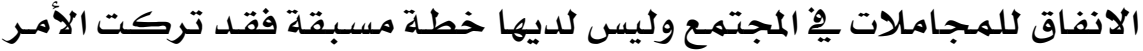

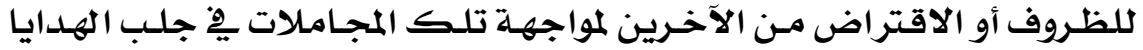

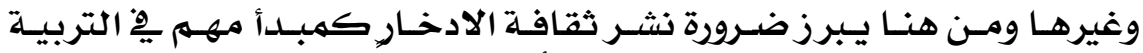

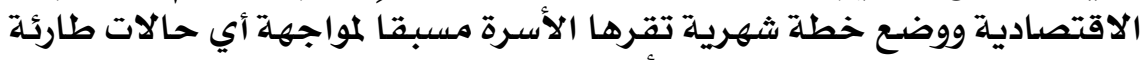

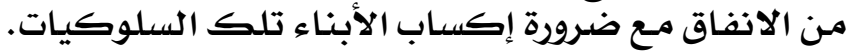

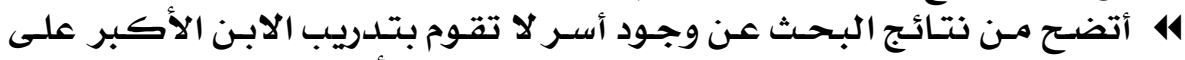

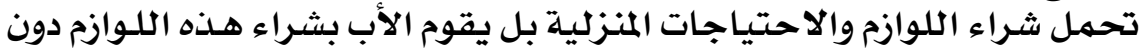

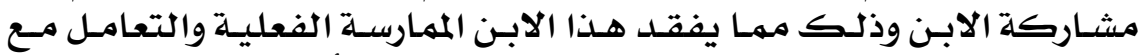

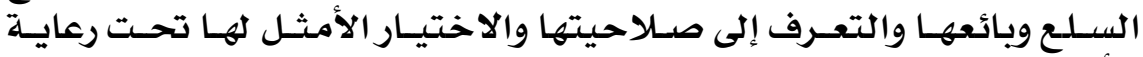

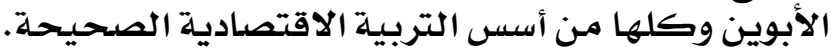

\section{r) 9}




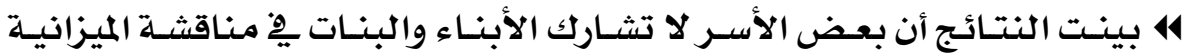

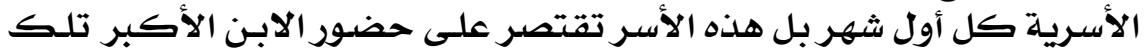

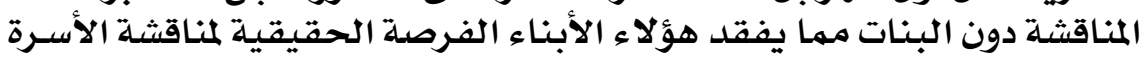

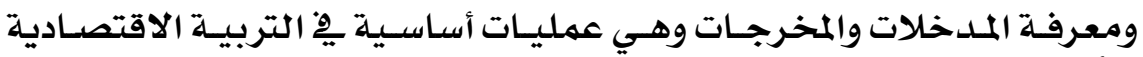
لـلأبناء.

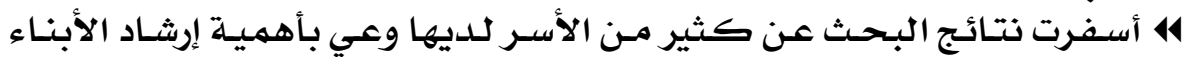

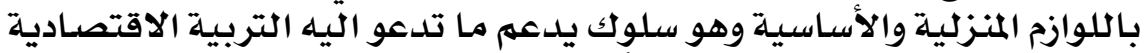

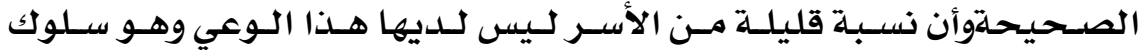

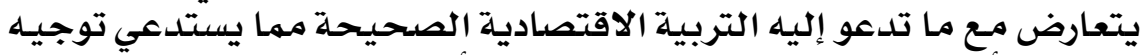

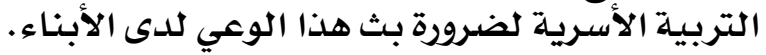

• التوصيات والاقتزحات:

بعد اطلاع الباحث على النتائج السابقة وما توصلت إليـه فيإن الباحث يوصي بها يأتي:

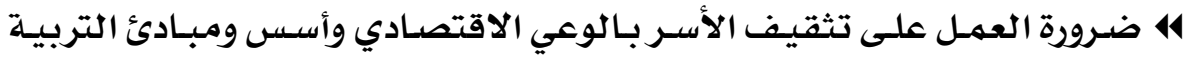

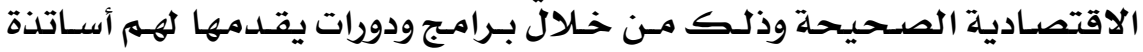

$$
\text { متخصصصون يِّ هذا المجال. }
$$

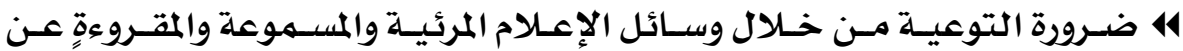

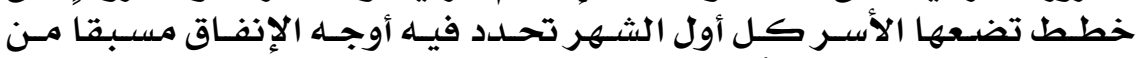

$$
\text { احتياجات ومستلزمات تصات الأسرة. }
$$

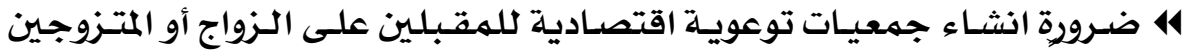

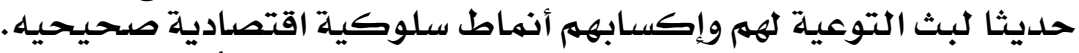

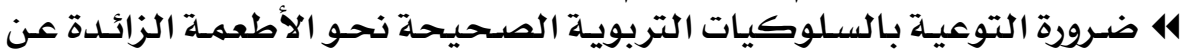

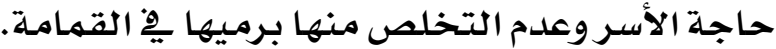
414

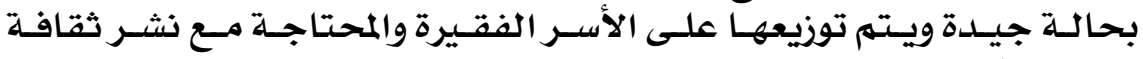

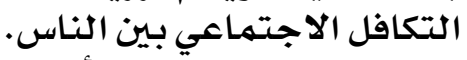

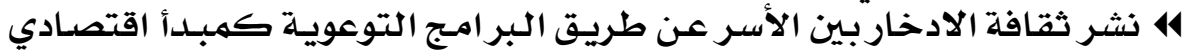

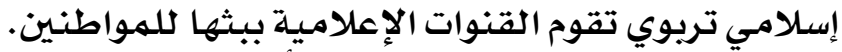

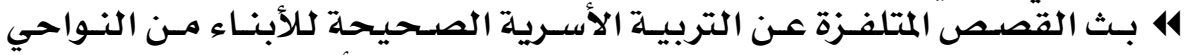

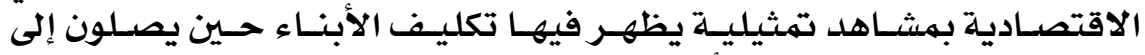

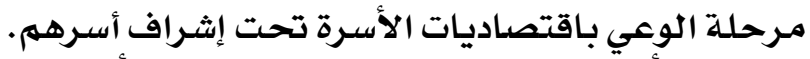

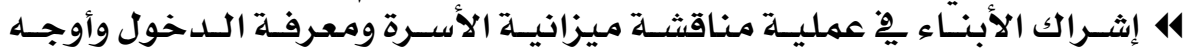

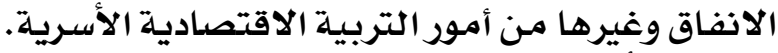

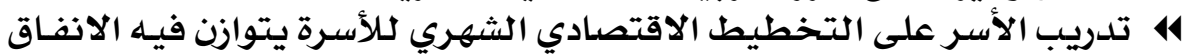

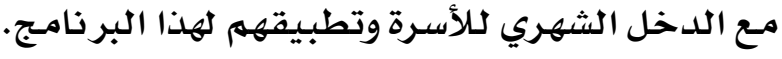




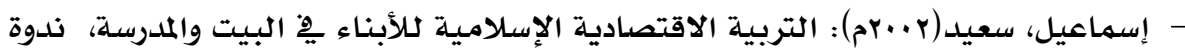

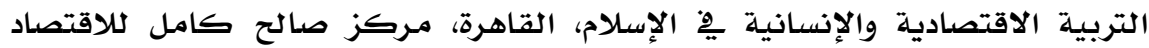

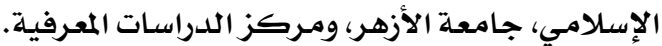

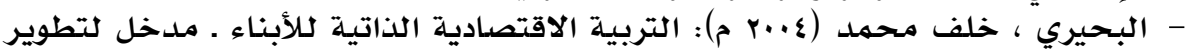

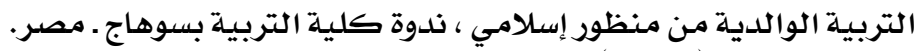

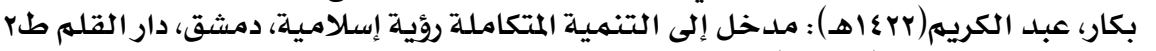

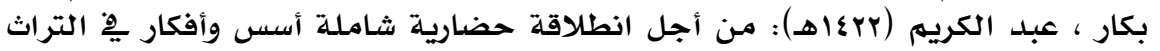

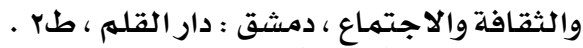

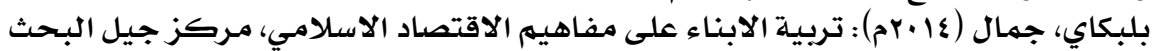

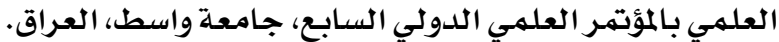

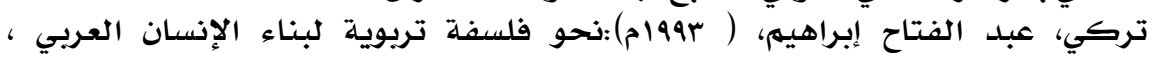

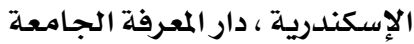

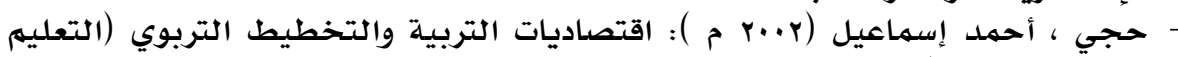

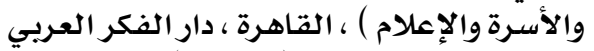

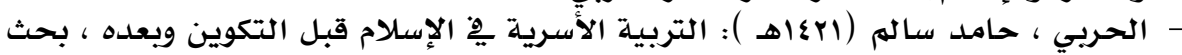

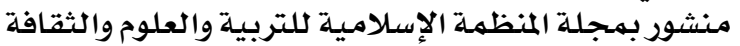

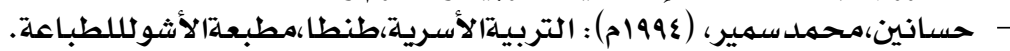

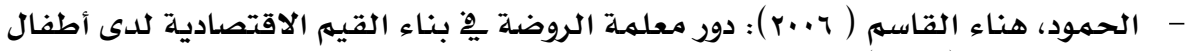

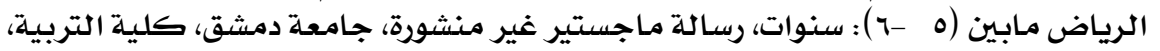

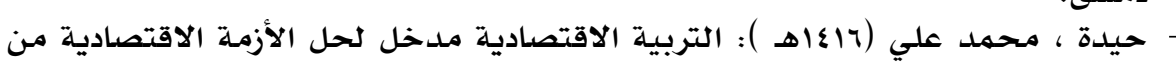

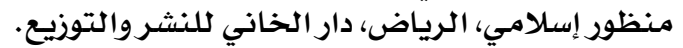

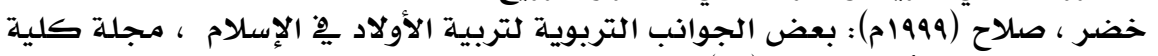

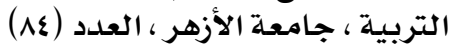

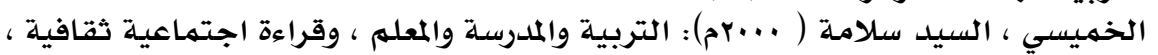

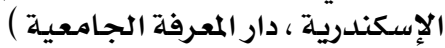

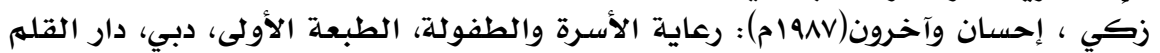
للنشر والتوزيـع ، إحسيان

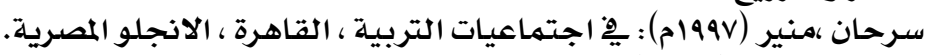

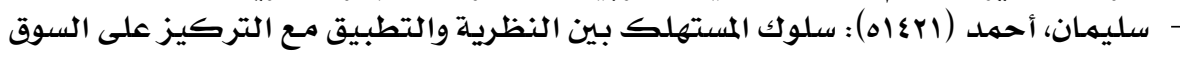

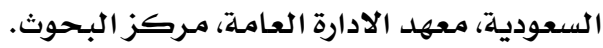

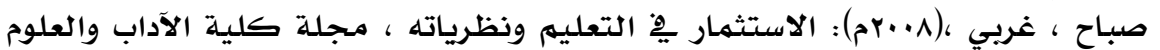

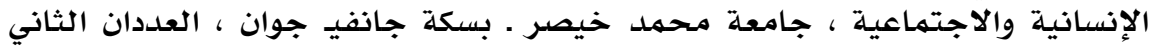
والثالث.

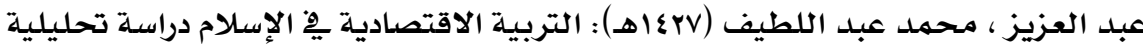

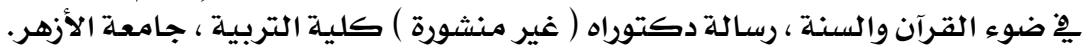

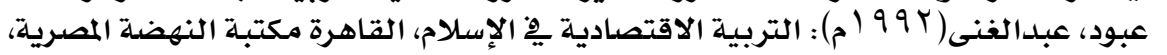
القاهرة، مصر.

\section{MYI}




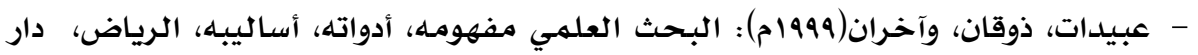

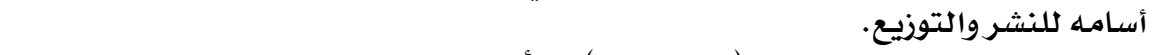

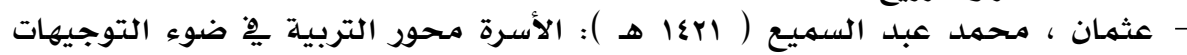

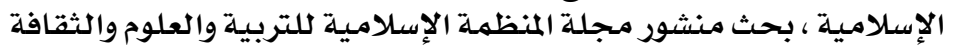

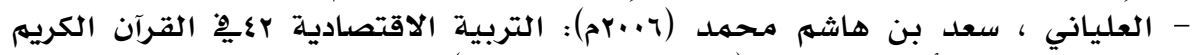

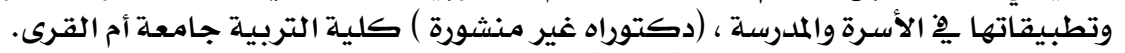

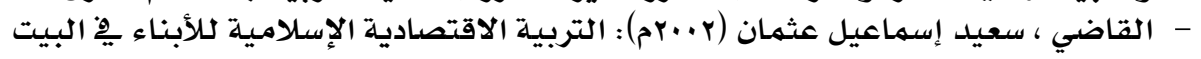

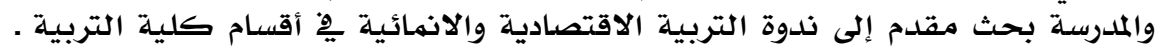

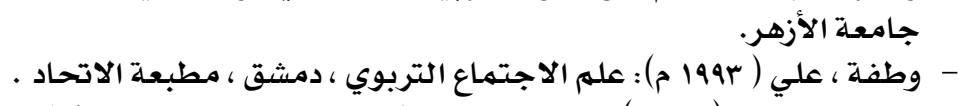

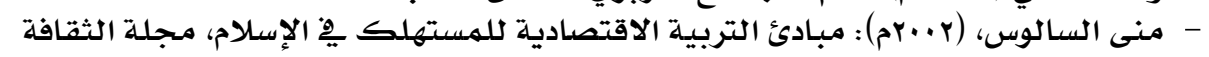

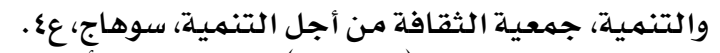

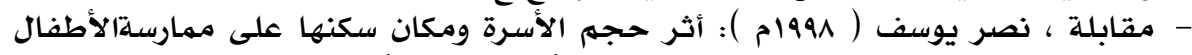

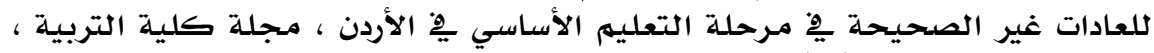

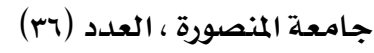

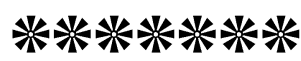




\section{البحثَ العاشُر:}

الاتجاهات الحديثة في تمكين المرأة لتنمية المتهمع

: إحطای

د/ أميرة عبدالسعلام زايل

أستاذ أصول التربية

كلية التربية جامعة كفر الشيخ 



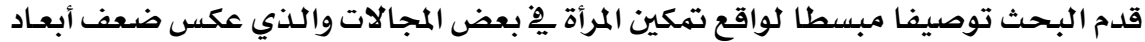

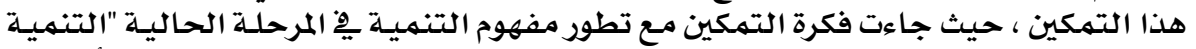

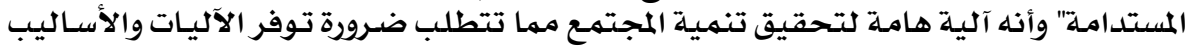

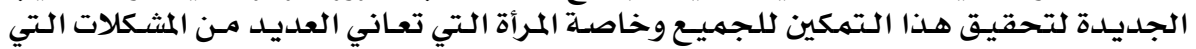

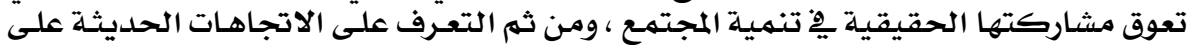

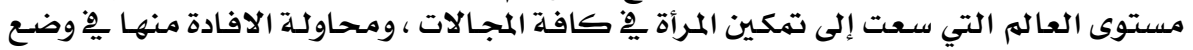

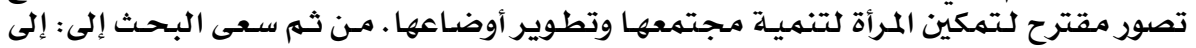

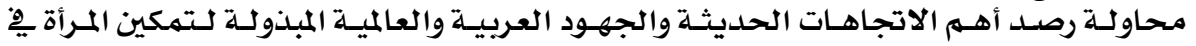

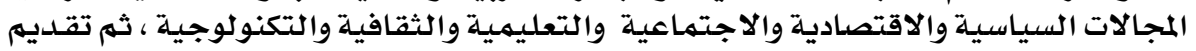

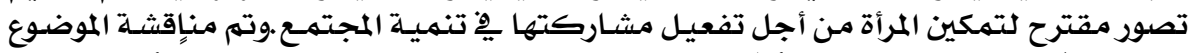

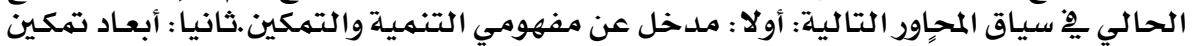

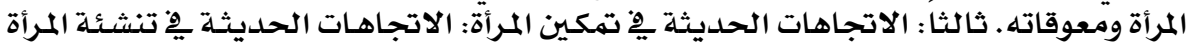

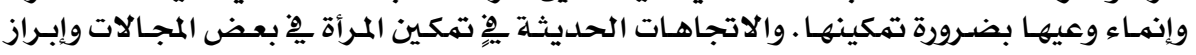

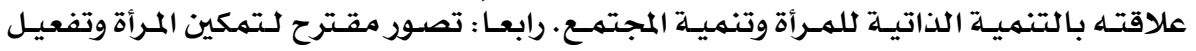

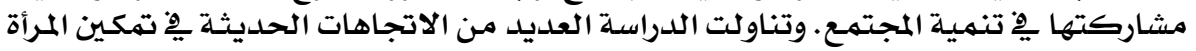

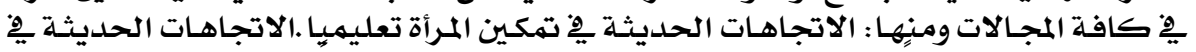

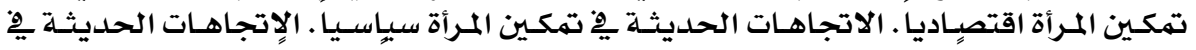

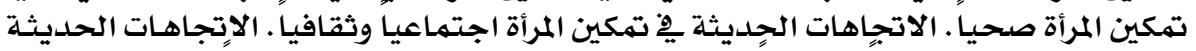

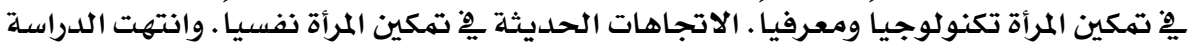

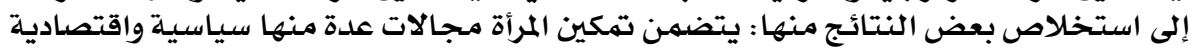

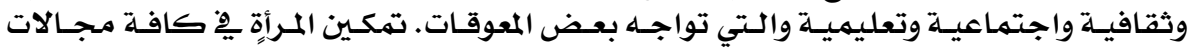

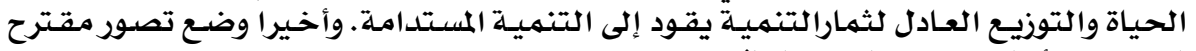

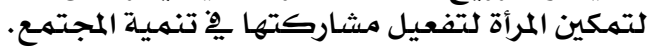

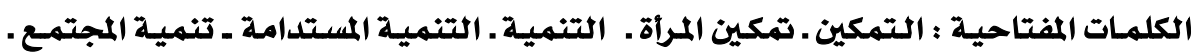
Recent trends in women's empowerment for Community

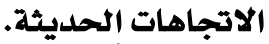

\section{Development}

Abstract:

The research was presented rated simplified reality empowerment of women in some areas, which reversed twice the dimensions of this empowerment, where the idea of empowerment with the evolution of the concept of development in the current phase of "sustainable development" and that an important mechanism for achieving community development Which requires the need for new mechanisms and methods to achieve this empowerment for all, especially women, who suffer many of the problems that hinder the real participation in community development, And then to identify recent trends in the world, which has sought to empower women in all fields, and try to utilize them in visualizing the proposal to empower women to the development of society and the development of their positions.Then research seeks to: attempt to monitor the most important recent trends and the efforts of Arab and international efforts to empower 
women in the political, economic, social, educational, cultural and technological fields, and then submit a proposal for the perception of women's empowerment in order to activate its participation in the development of society. They discussed the current topic in the context of the following themes:First, the entrance for the concepts of development and empowerment.Second: the dimensions of women's empowerment and its obstacles.Third: Recent trends in women's empowerment:Fourth: imagine a proposal to empower women and activating their participation in community development.The study dealt with a number of recent trends in the empowerment of women in all areas, including: Recent trends in women's empowerment education. Recent trends in women's economic empowerment. Recent trends in women's political empowerment. Recent trends in the health of women's empowerment.Recent trends in social and cultural empowerment of women.Recent trends in technology and cognitive empowerment of women. Recent trends in the empowerment of women psychologically. The study ended to draw some conclusions, including:Includes the empowerment of women several areas of political, economic, cultural, social, educational, and some of the obstacles facing them.The empowerment of women in all spheres of life and equitable distribution of the proceeds of development leads to sustainable development. Finally conceived proposal for raising and empowerment of women to the development of society.

Keywords: empowerment - the empowerment of women - development sustainable development - the development of society - the modern trends.

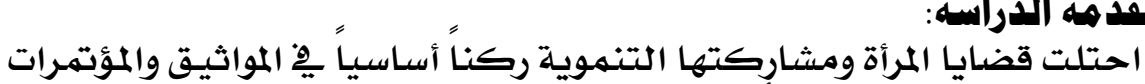

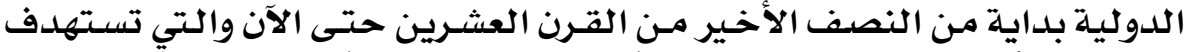

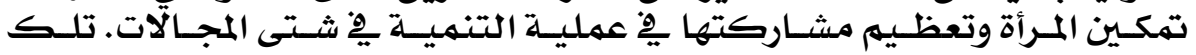

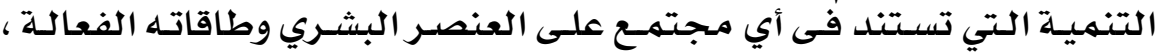

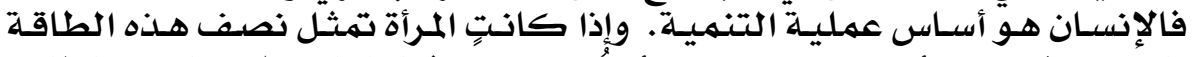

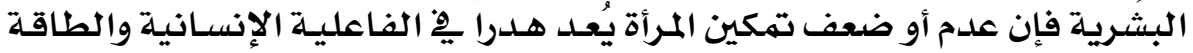

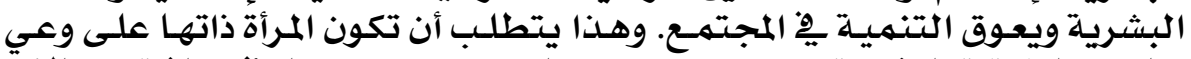

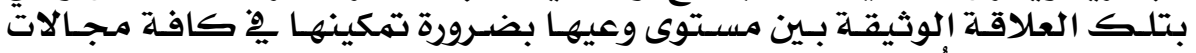

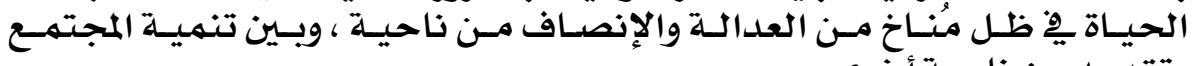
وتقدمـه مـن ناحية أخرى مئخ.

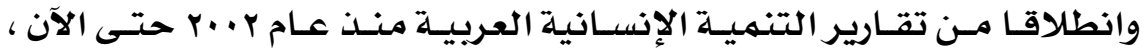

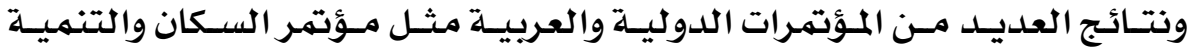

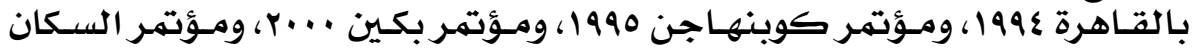

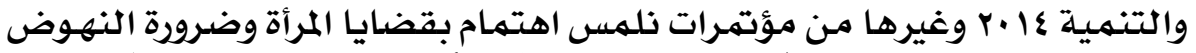

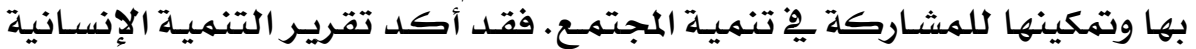

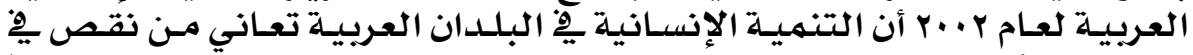

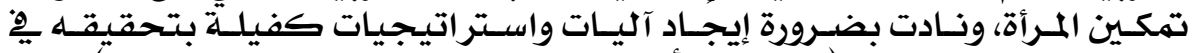

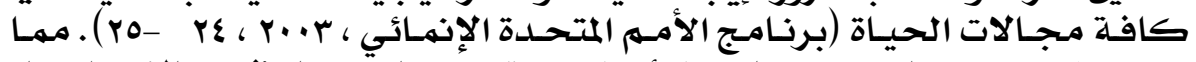

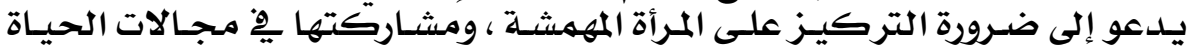




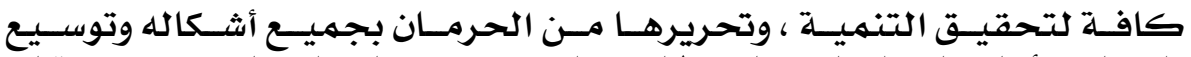

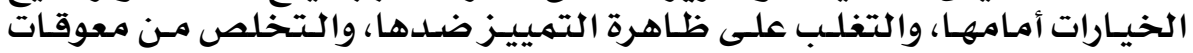

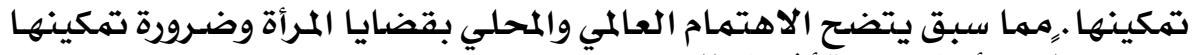

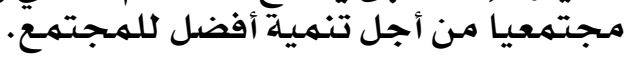

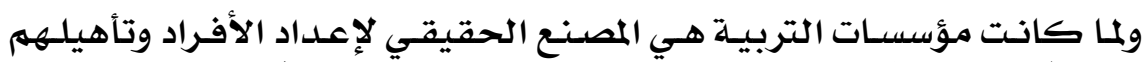

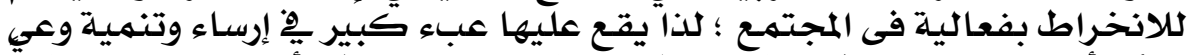

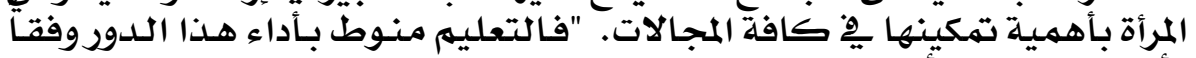

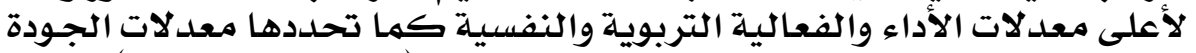

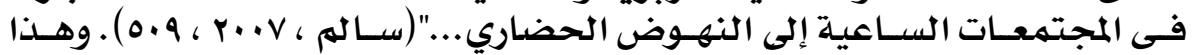

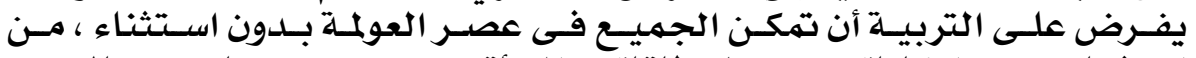

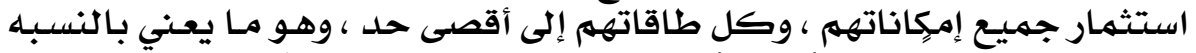

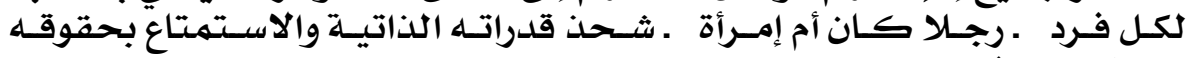

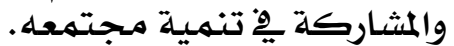

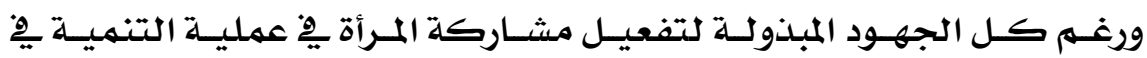

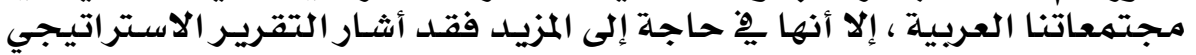

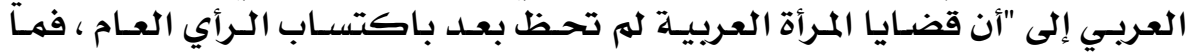

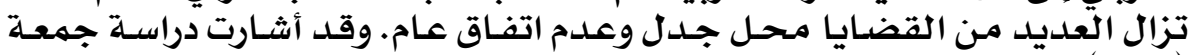

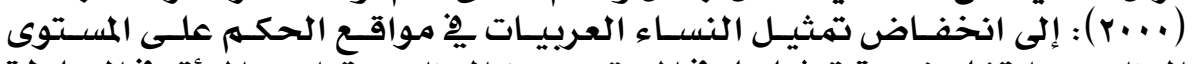

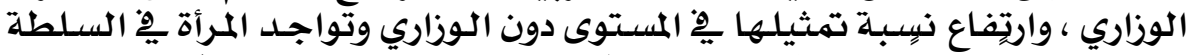

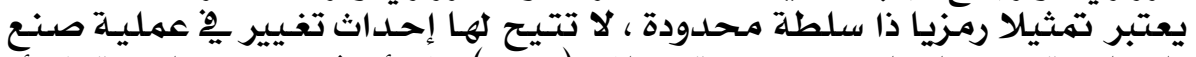

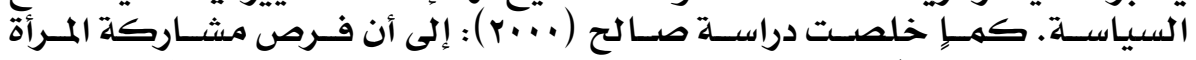

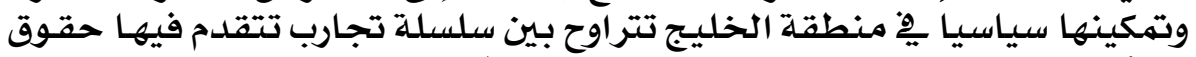

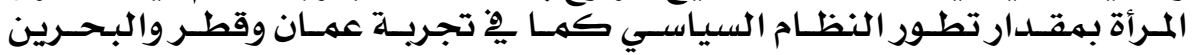

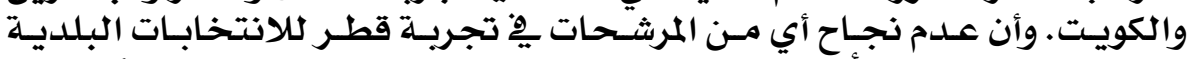

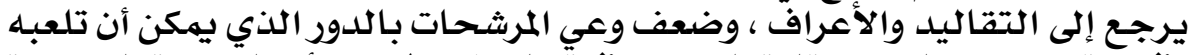

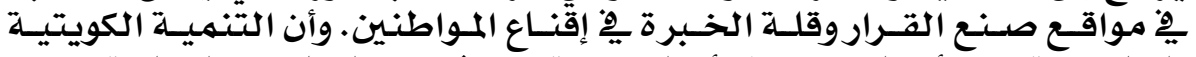

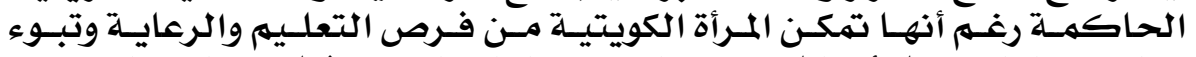

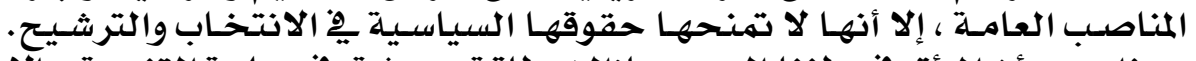

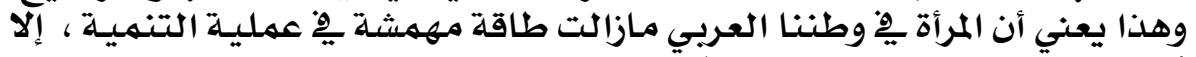

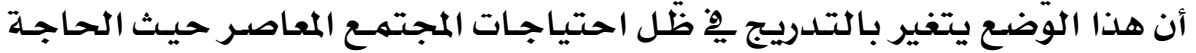

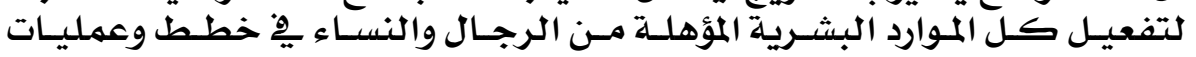

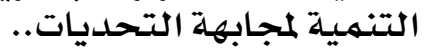

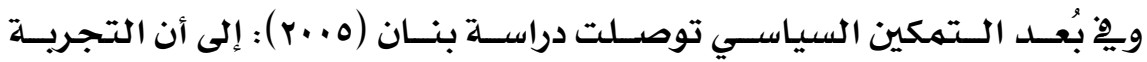

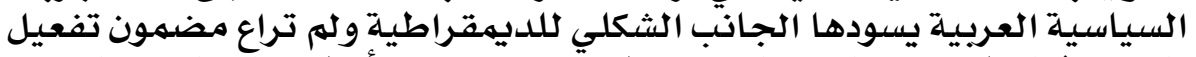

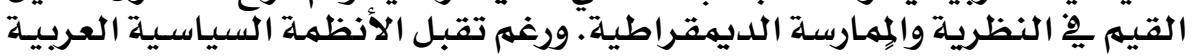

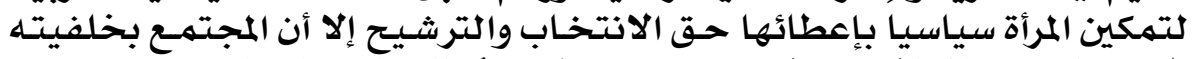

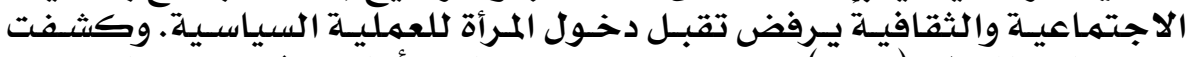

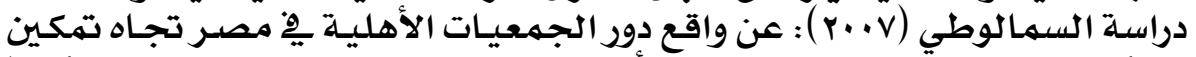

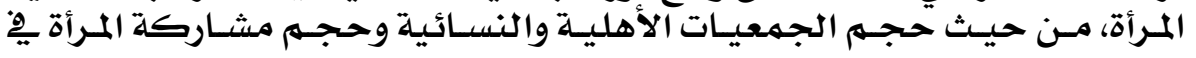




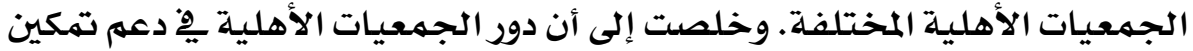

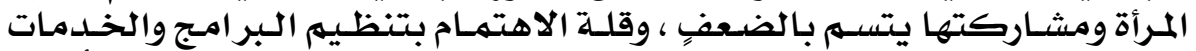

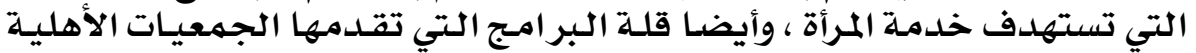

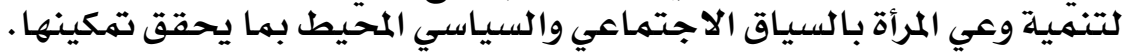

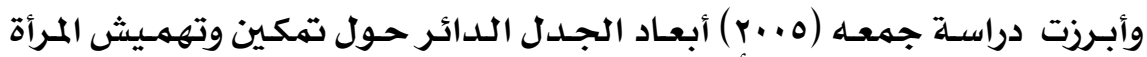

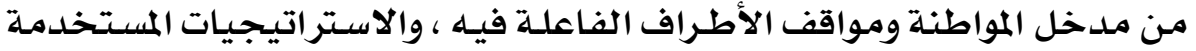

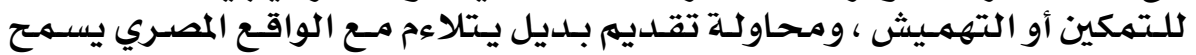

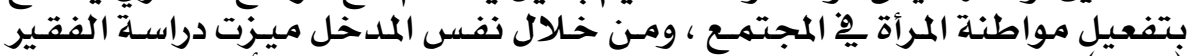

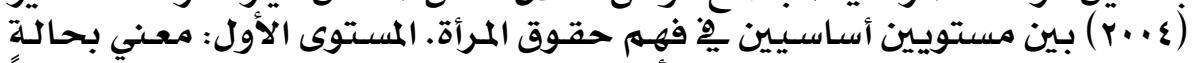

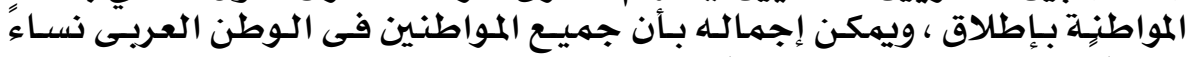

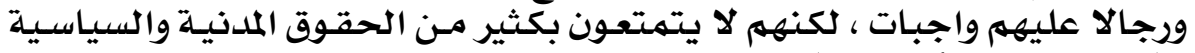

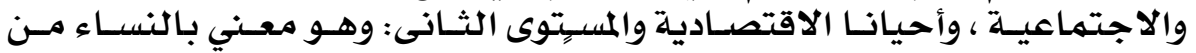

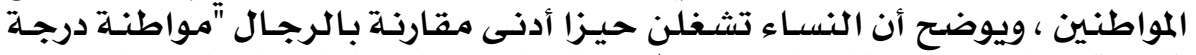

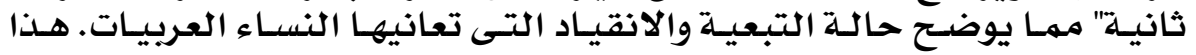

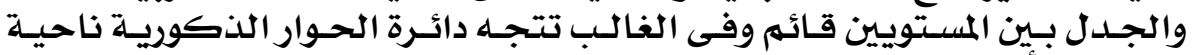

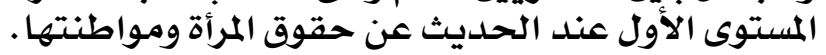

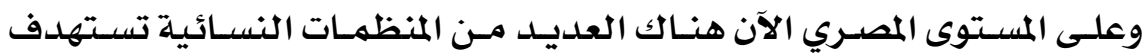

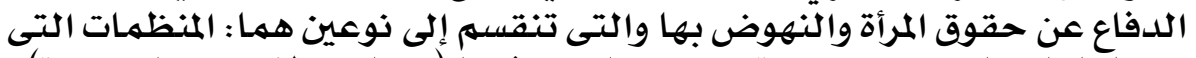

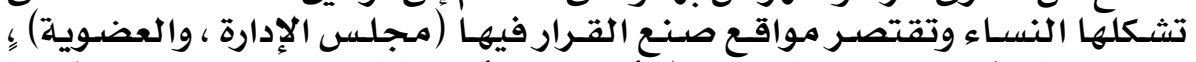

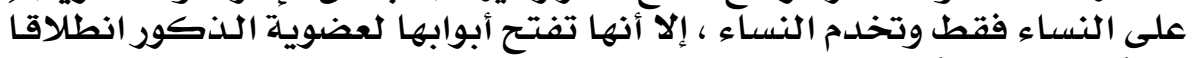

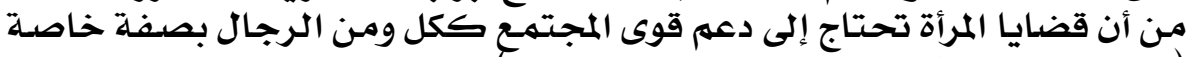

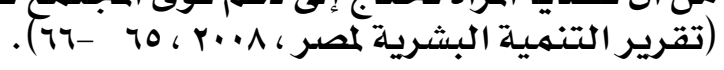

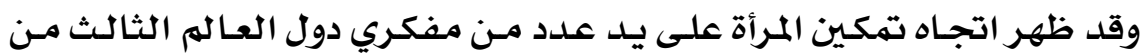

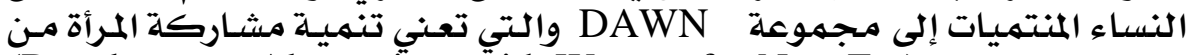

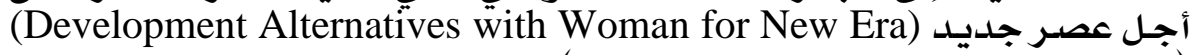

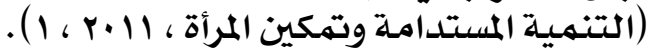

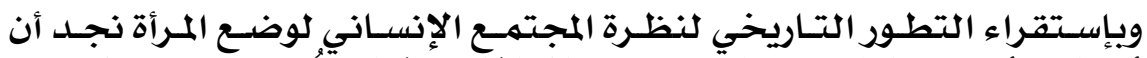

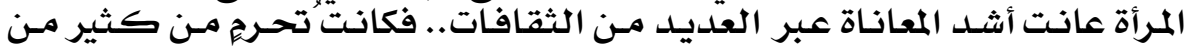

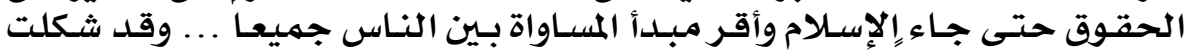

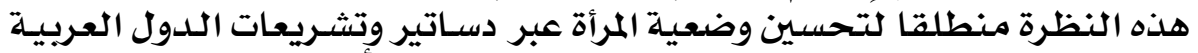

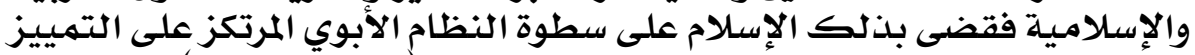

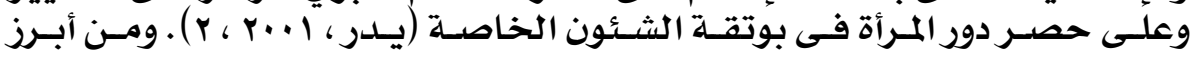

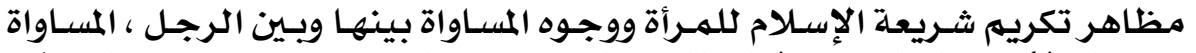

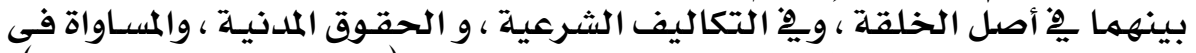

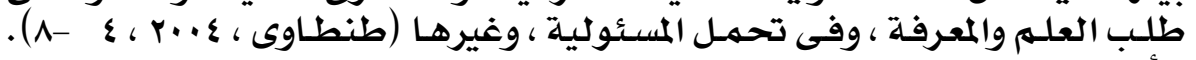

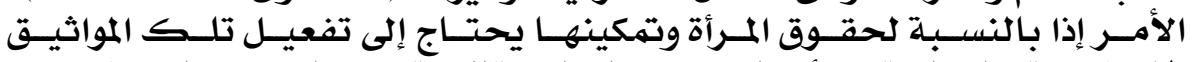

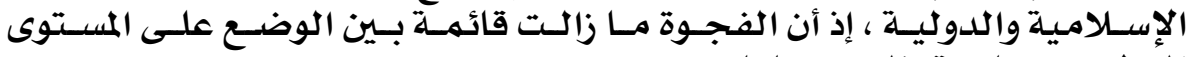

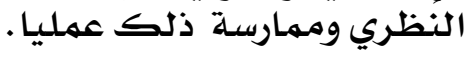




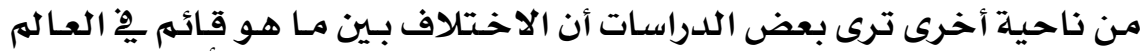

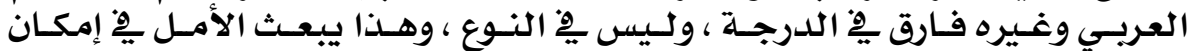

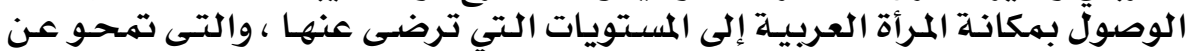

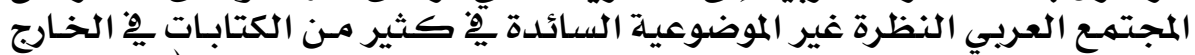

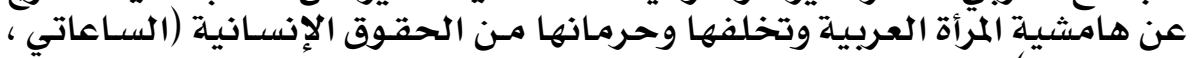
. (r) \& r... T

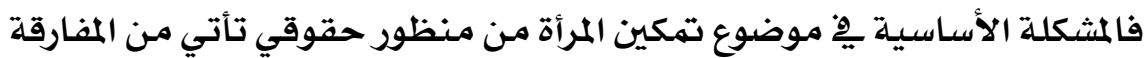

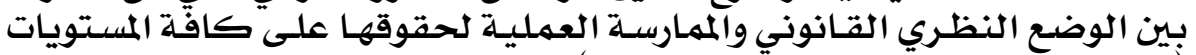

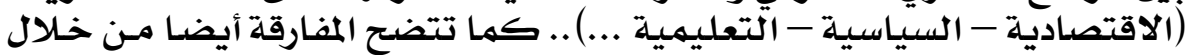

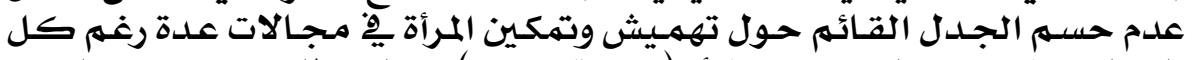

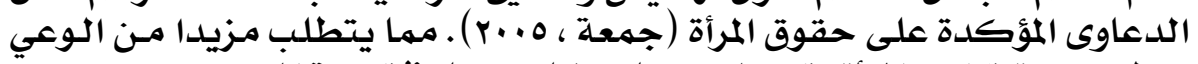

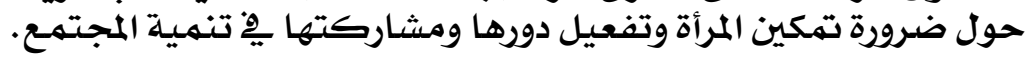

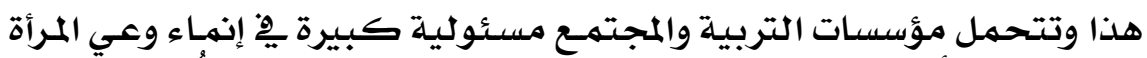

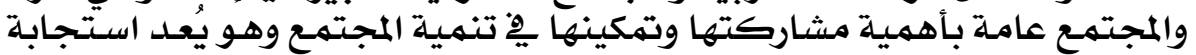

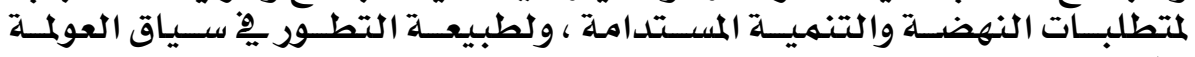

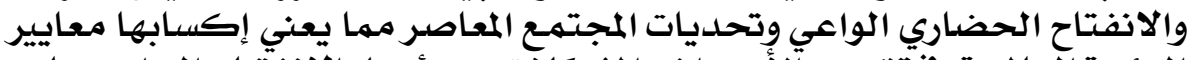

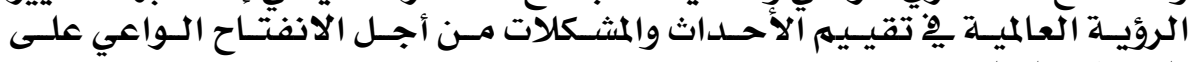
الداخل والخارج.

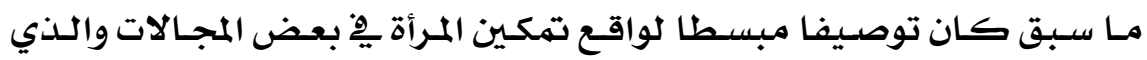

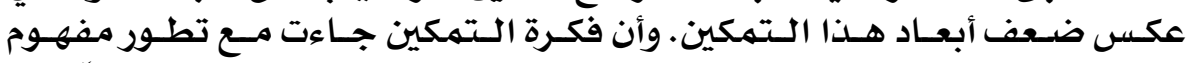

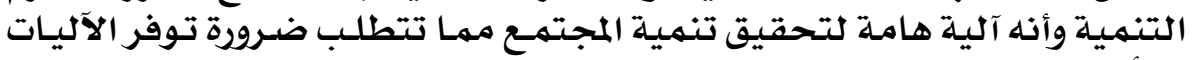

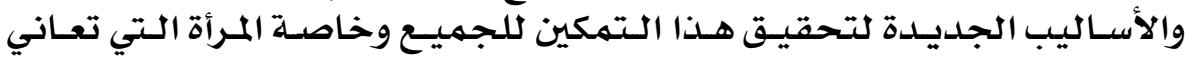

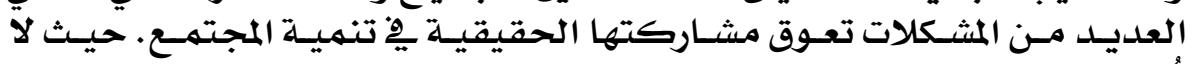

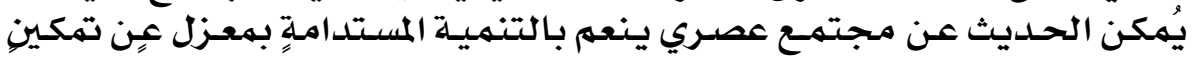

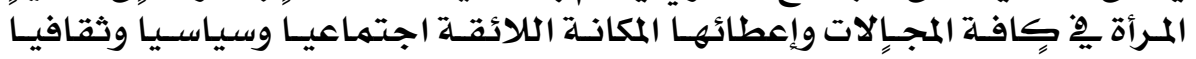

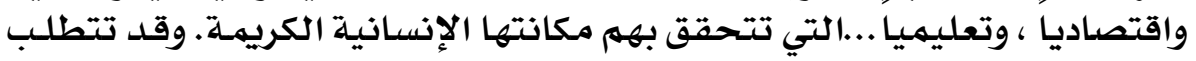

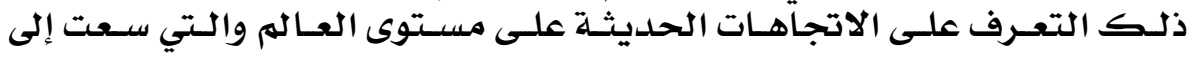

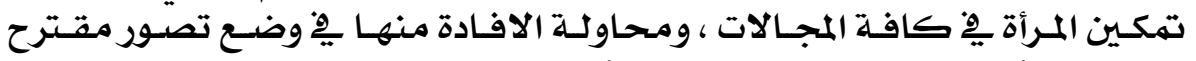

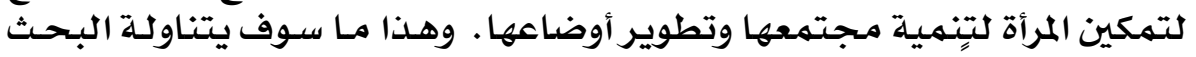

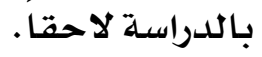
• ت هدف الدراسة:

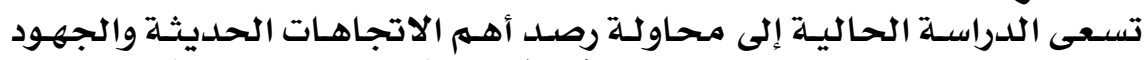

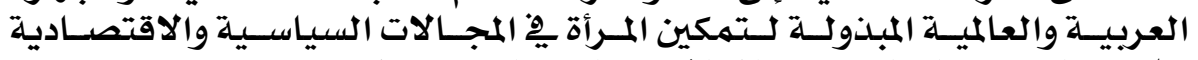

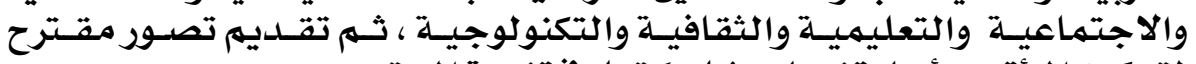

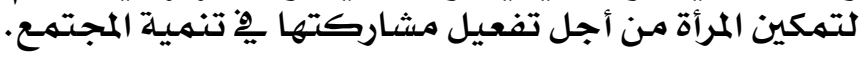

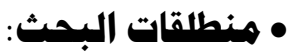
تنطلق الدراسـة الحالية من القناعات التالية: 


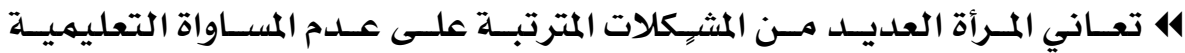

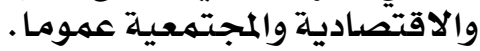

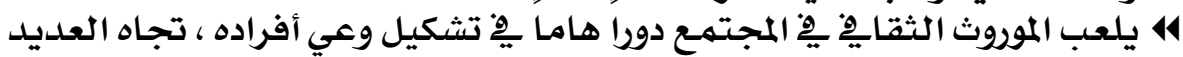

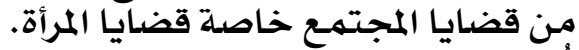

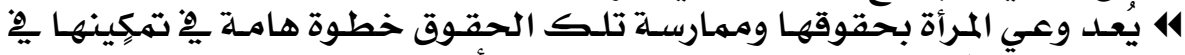

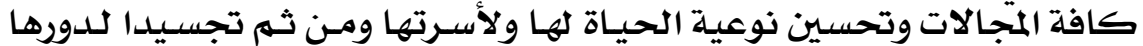

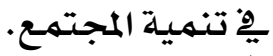

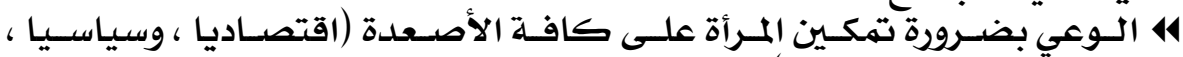

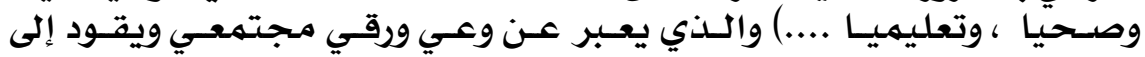

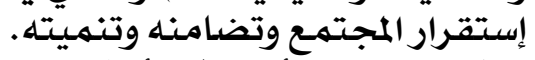

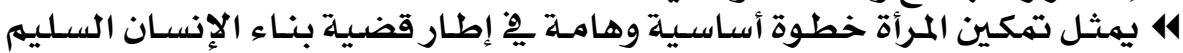

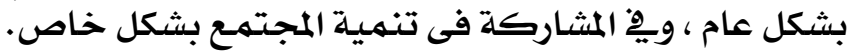

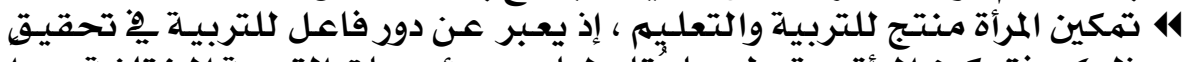

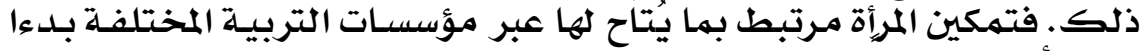

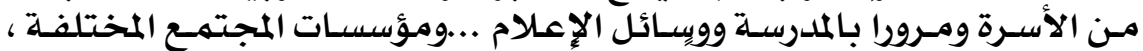

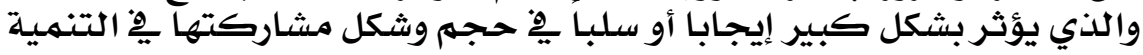

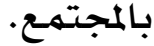

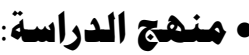

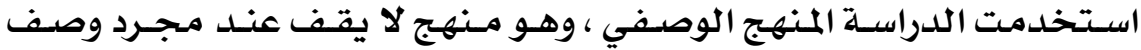

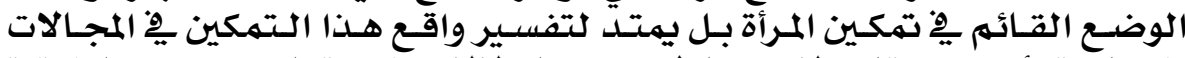

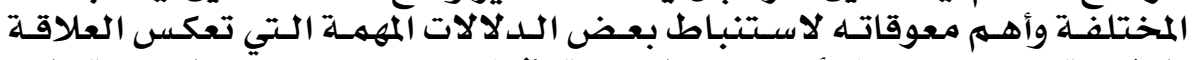

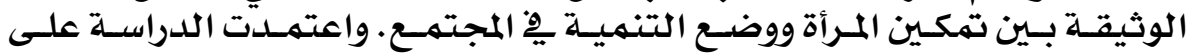

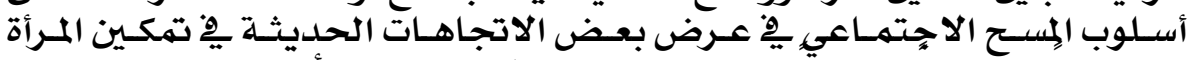

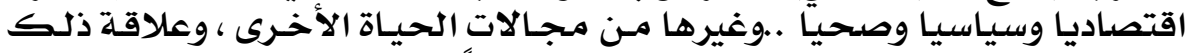

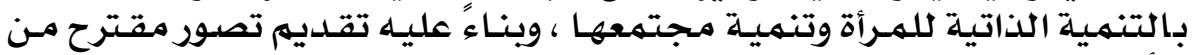

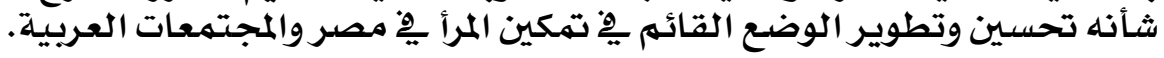

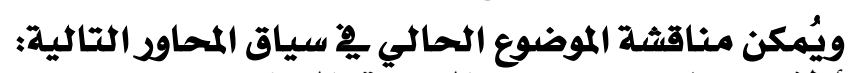

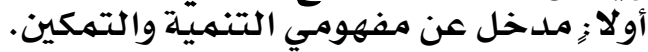

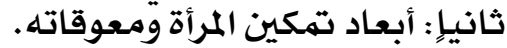

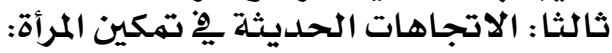

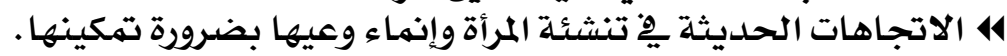

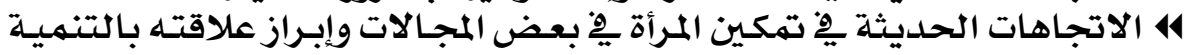

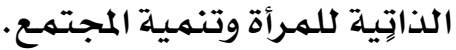

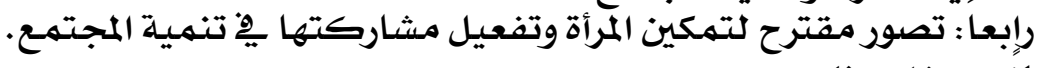

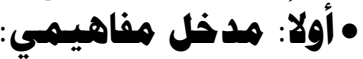

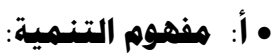

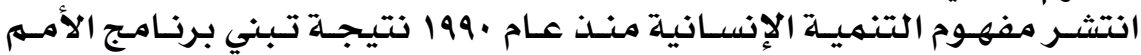

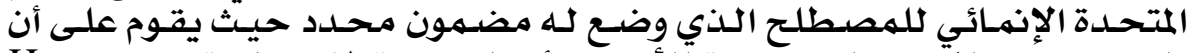

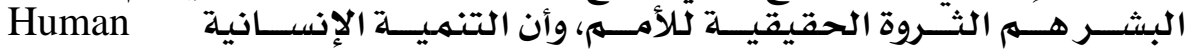


عeloelopment

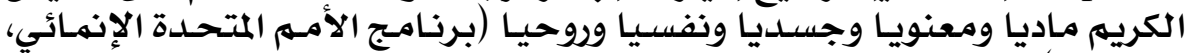

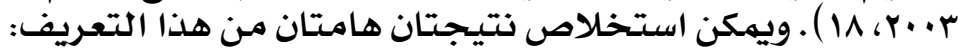

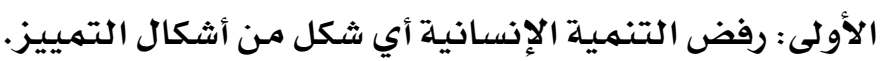

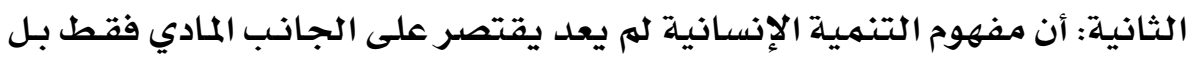
تجاوزها إلى الجوانب المعنومية التبنة.

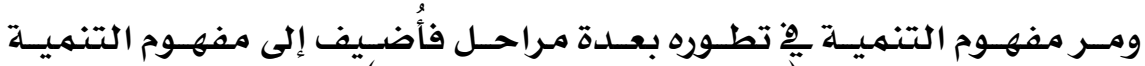

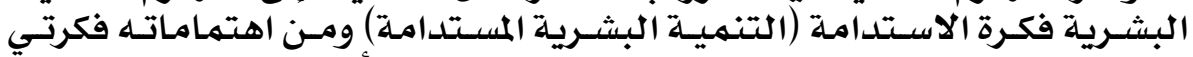

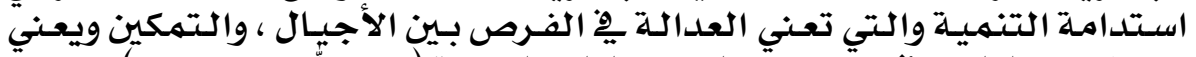

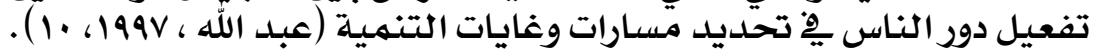

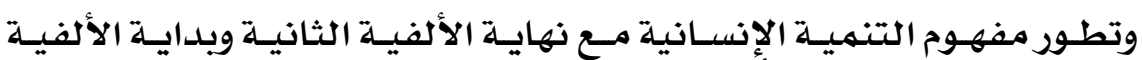

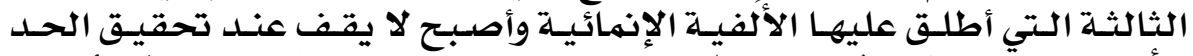

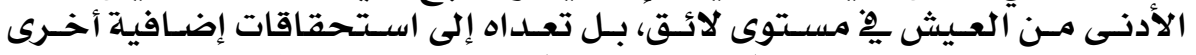

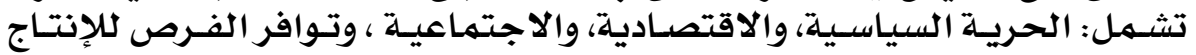

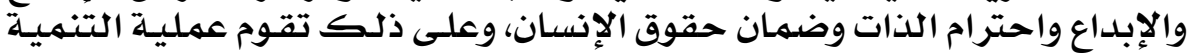

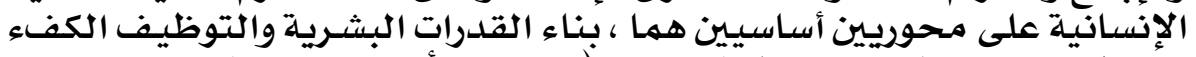

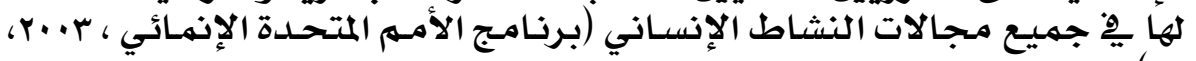
. (11

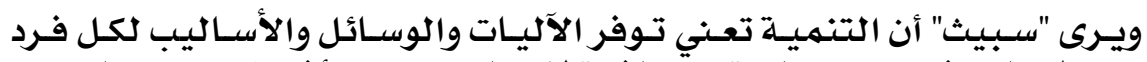

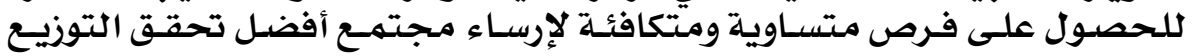

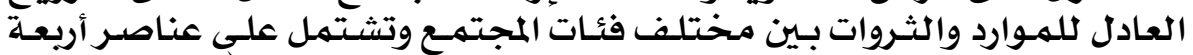

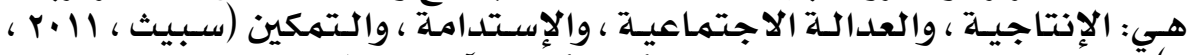

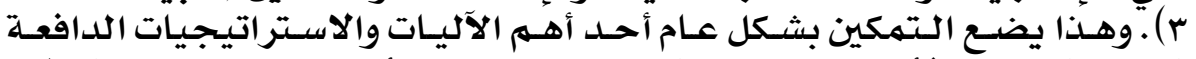

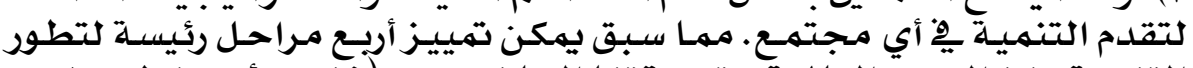

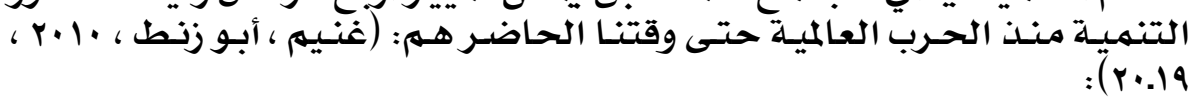

414 التنمية بوصفها رديفاً للنمو الاقتصادي. 414

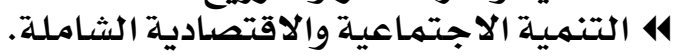

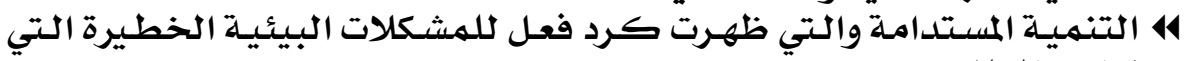
تواجه العالهم.

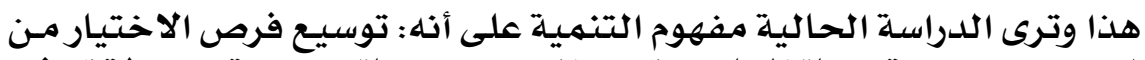

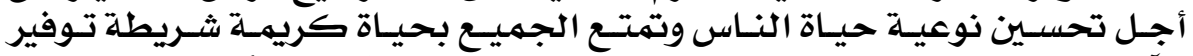

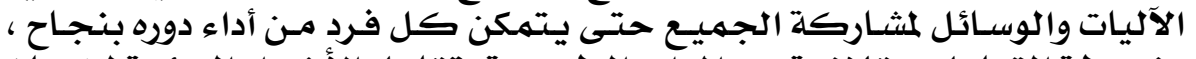

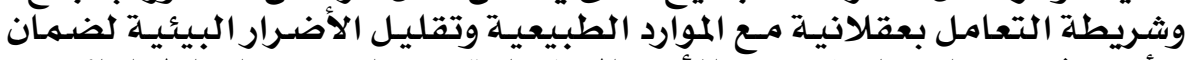

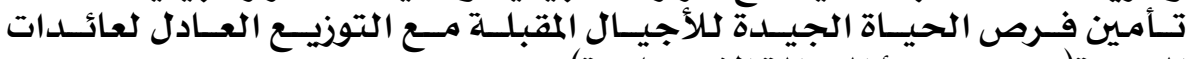

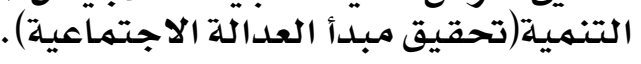




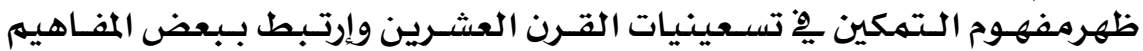

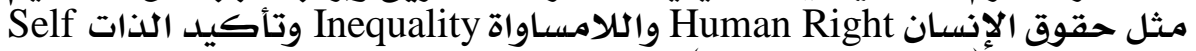
Determines

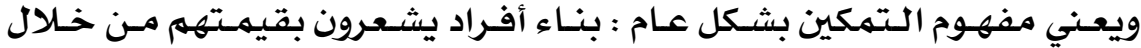

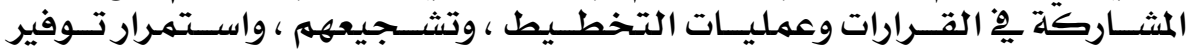

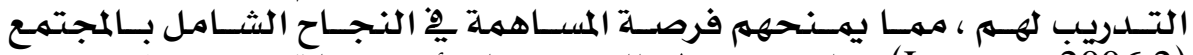

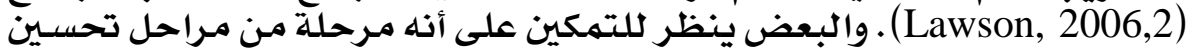

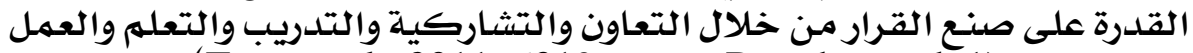

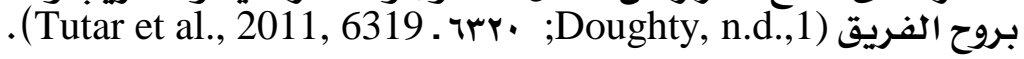

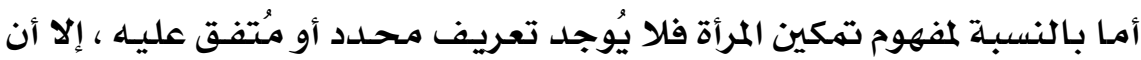

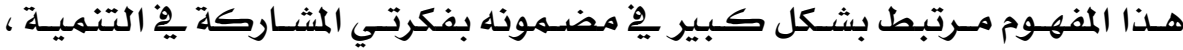

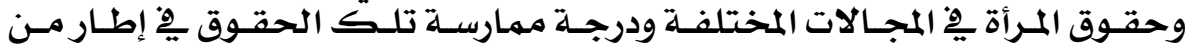

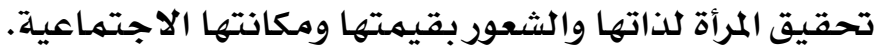

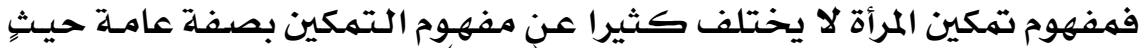

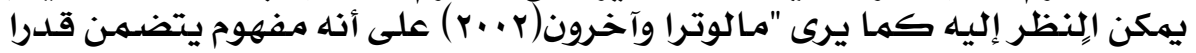

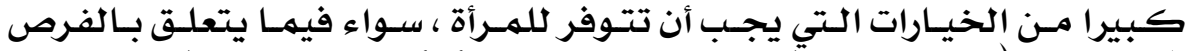

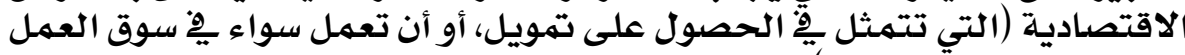

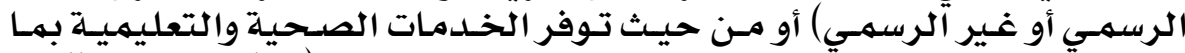

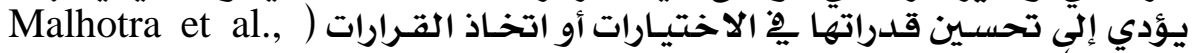

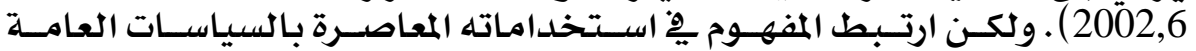

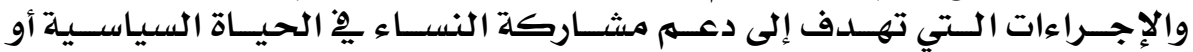

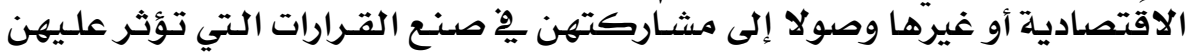

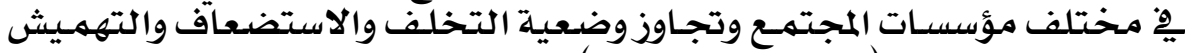

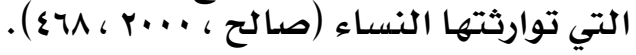

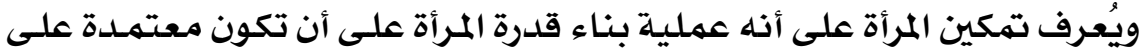

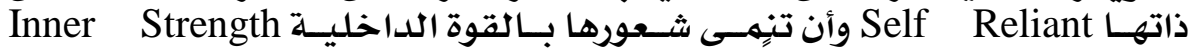

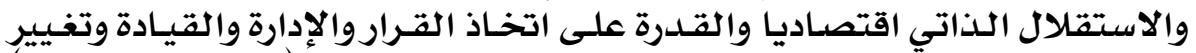

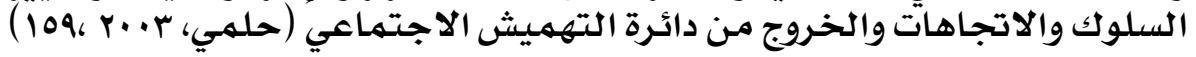

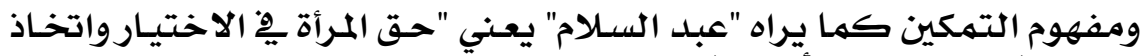

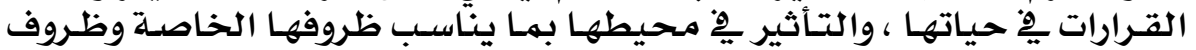

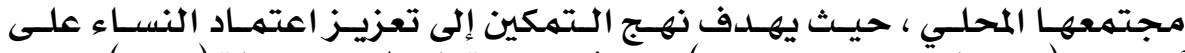

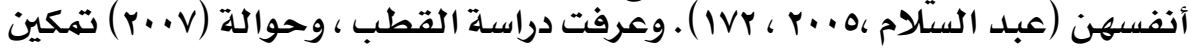

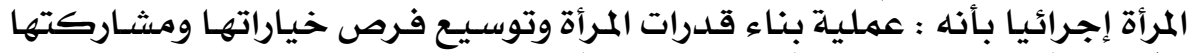

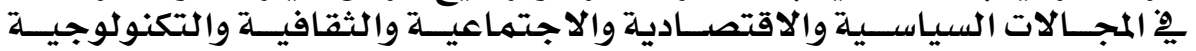

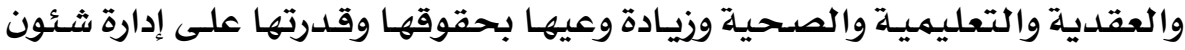

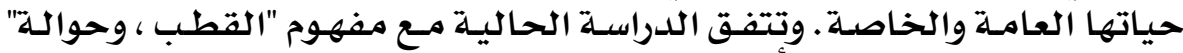

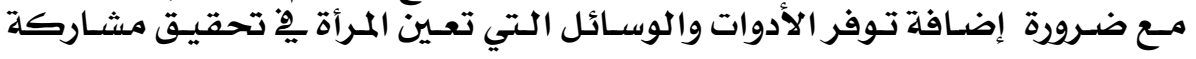




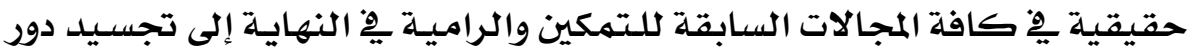

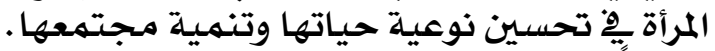

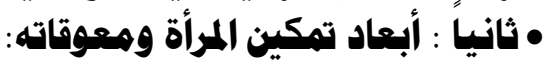

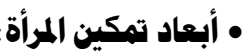

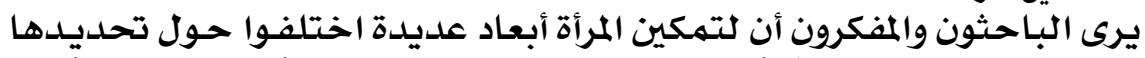

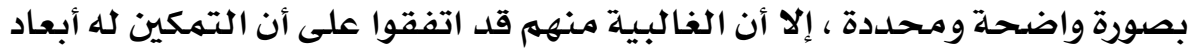
أريع كما يلي:

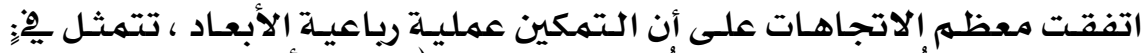

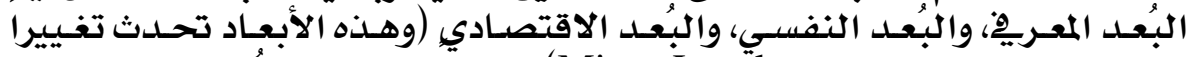

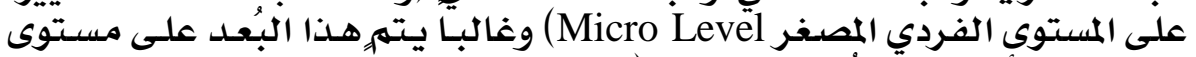

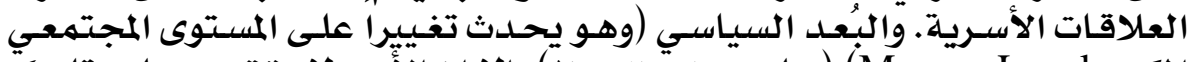

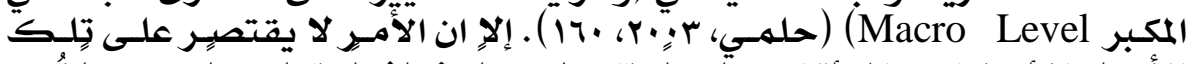

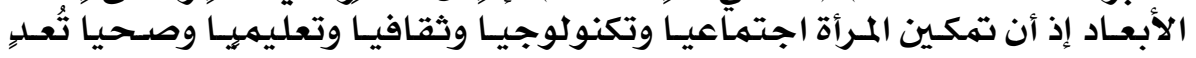

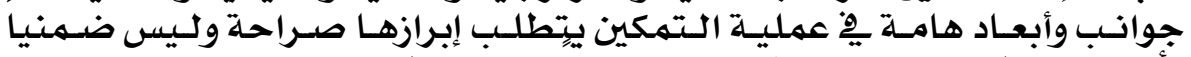

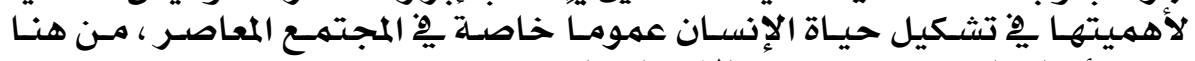

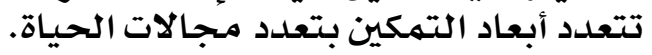

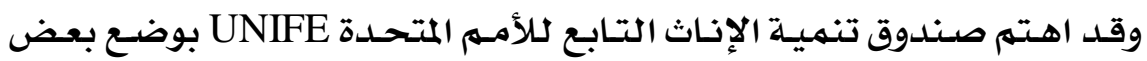

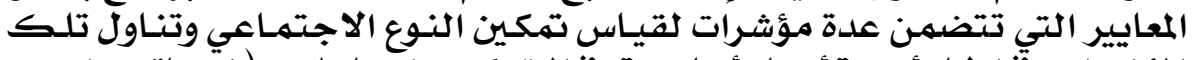

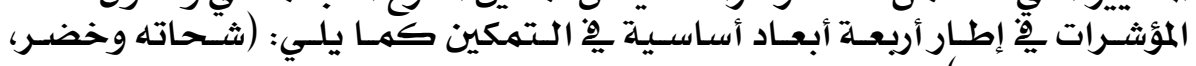
: VTr. VTr. r..V

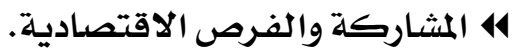

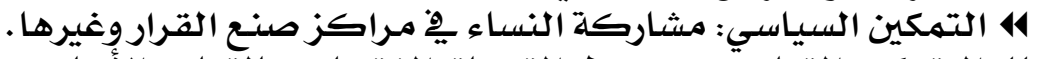

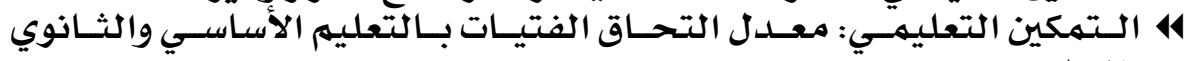

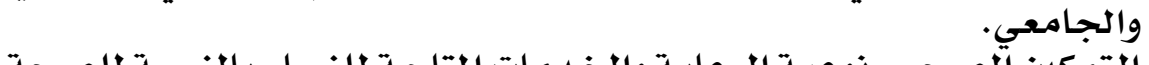

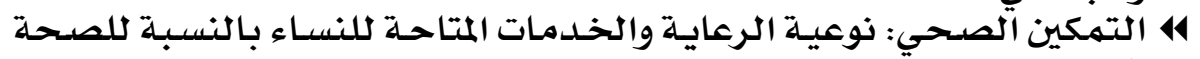
الإنجابية.

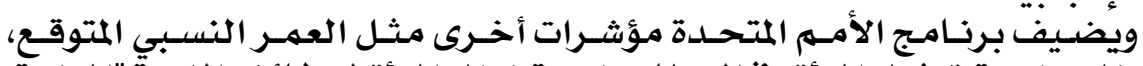

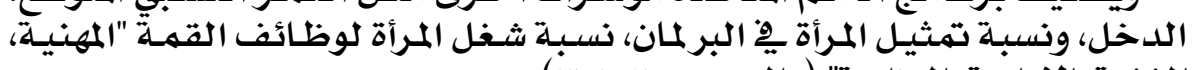

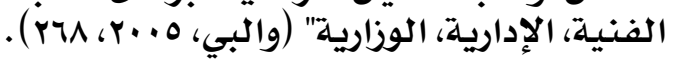

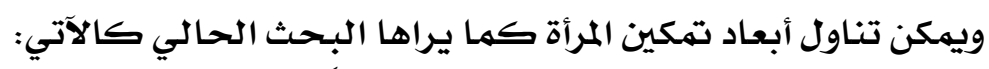

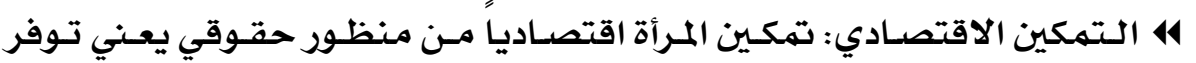

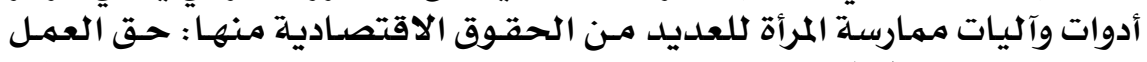

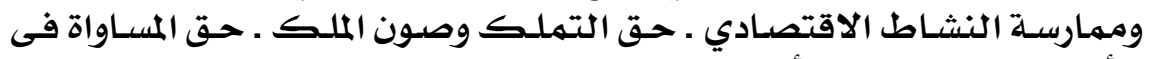

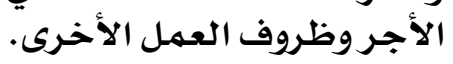

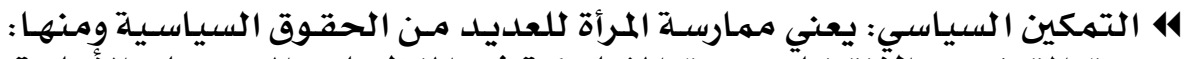

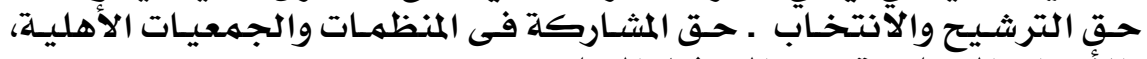

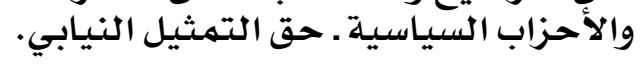




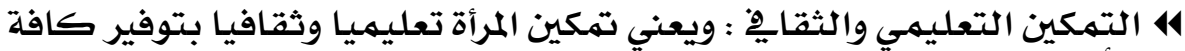

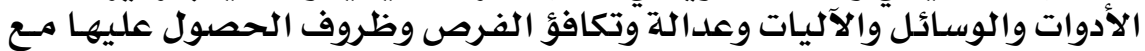

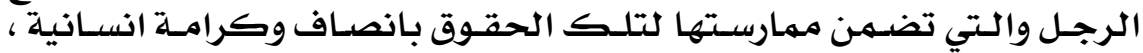

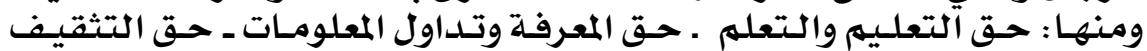

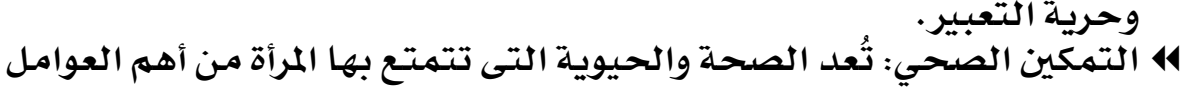

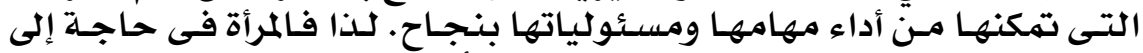

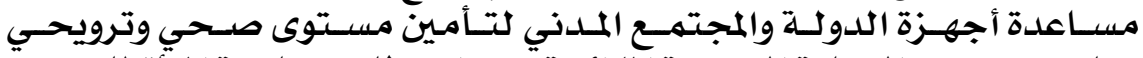

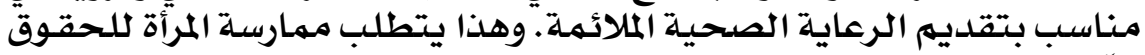

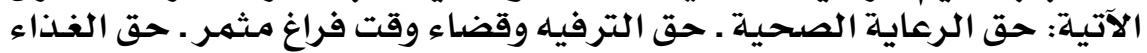
الكاية

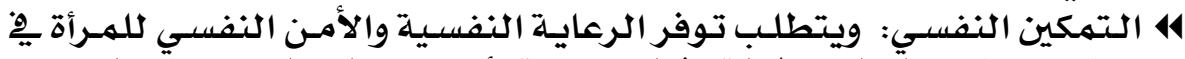

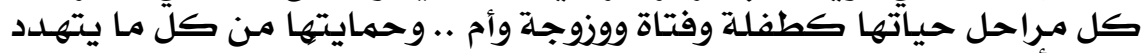

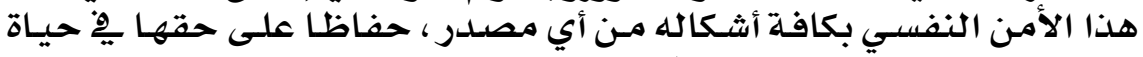

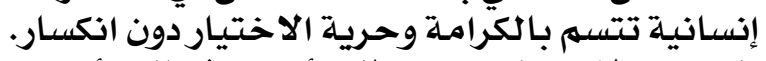

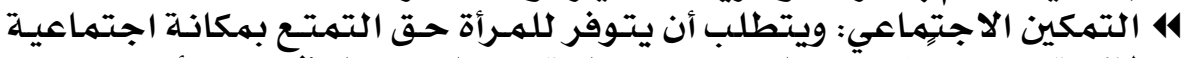

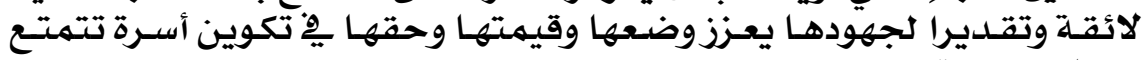
بحياة كريمة وتةديرا

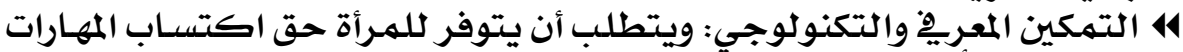

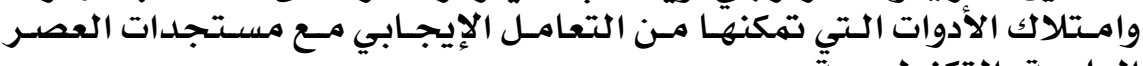

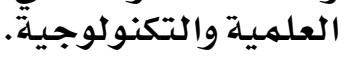

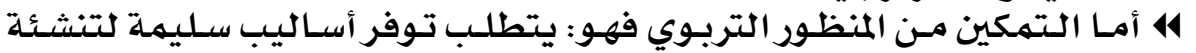

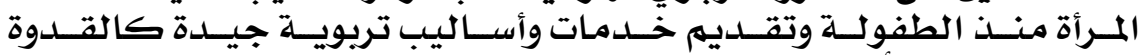

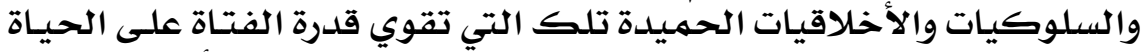

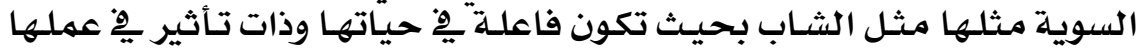

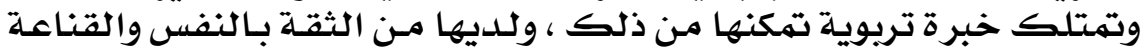

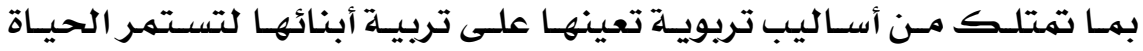

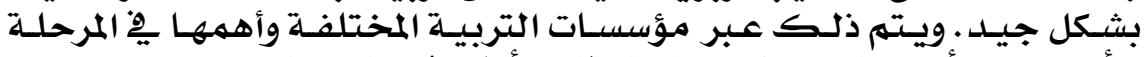

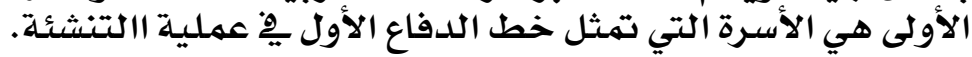

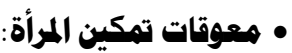

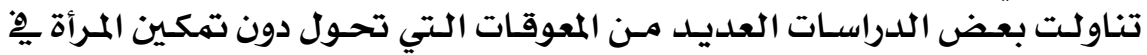

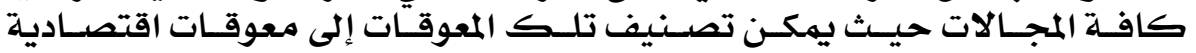

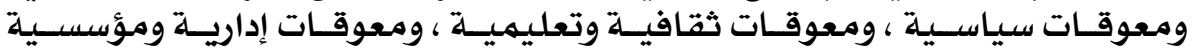

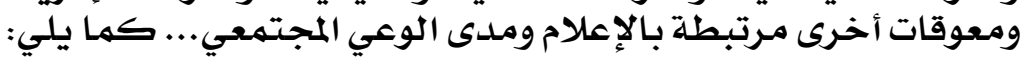

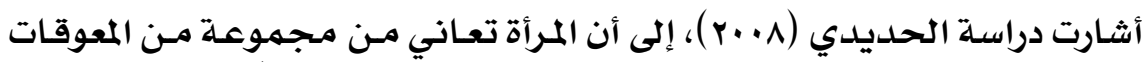

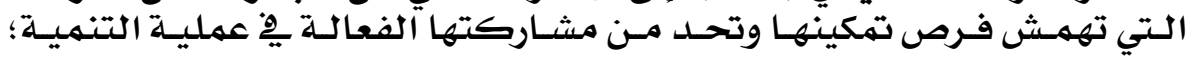
ومنها:

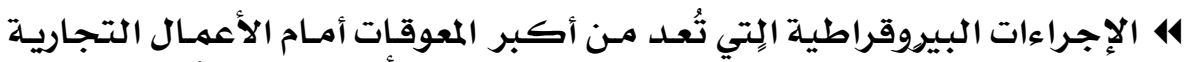

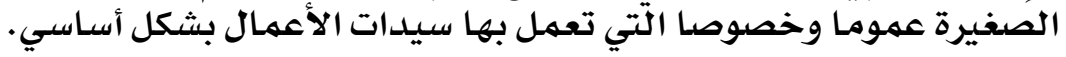




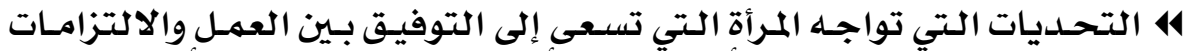

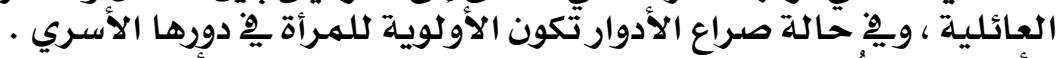

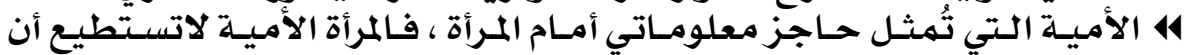

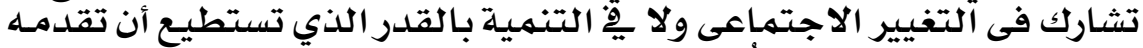

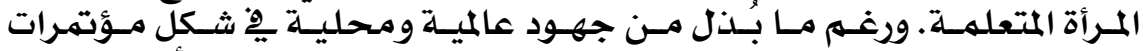

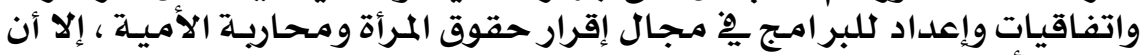

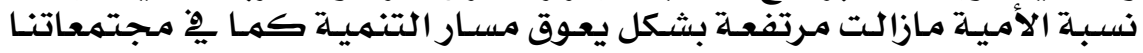

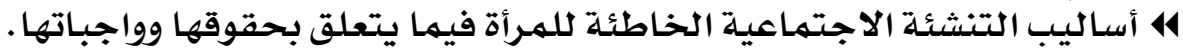

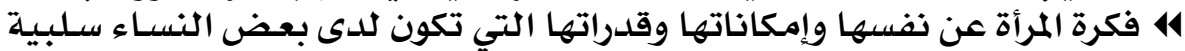

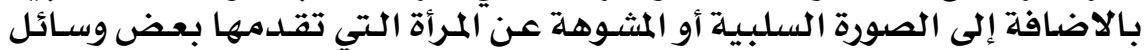

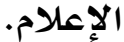

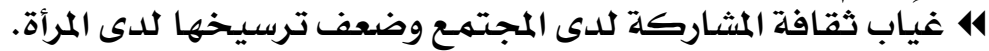

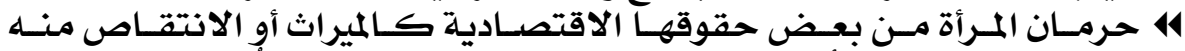

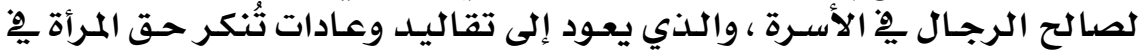
المفيلة الخاصية.

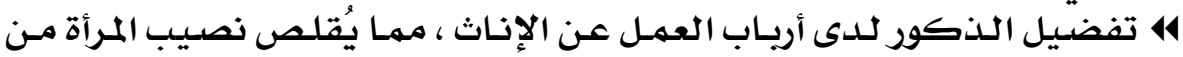
الوظائف.

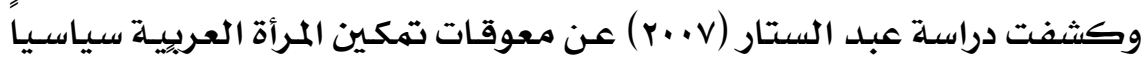

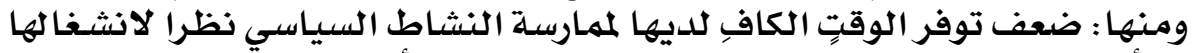

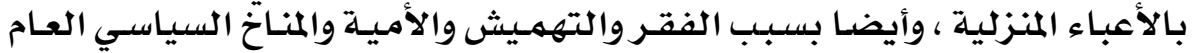

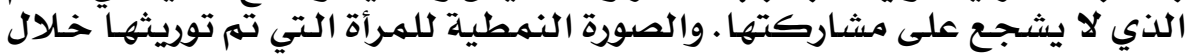

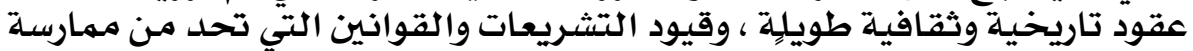

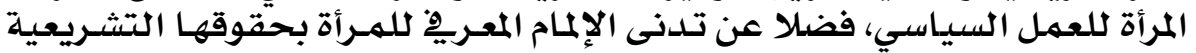

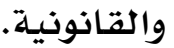

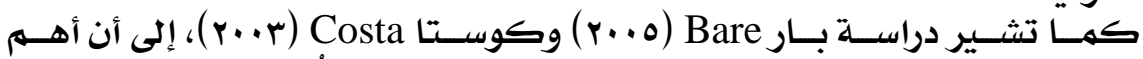

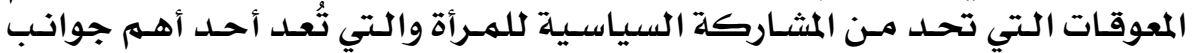

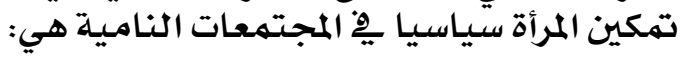

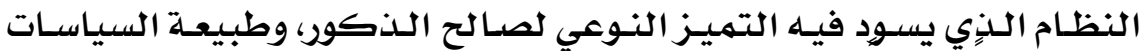

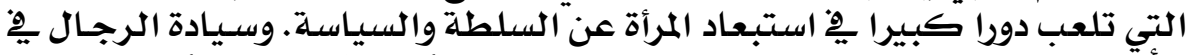

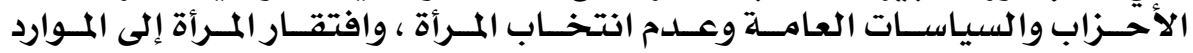

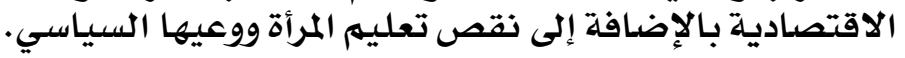

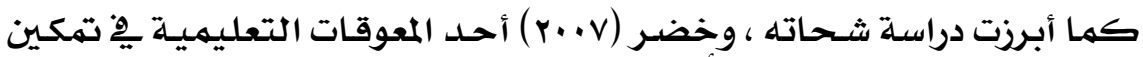

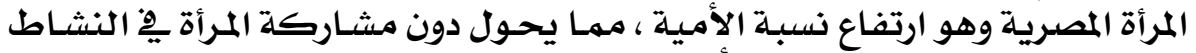

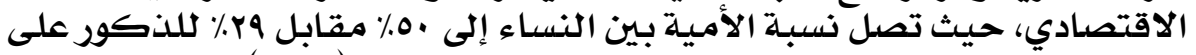

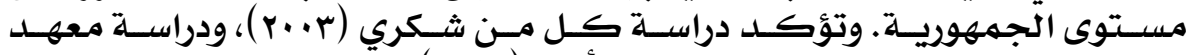

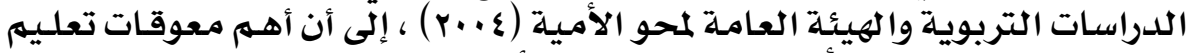

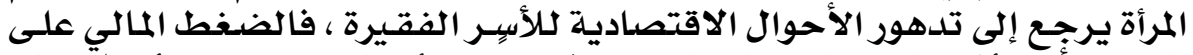

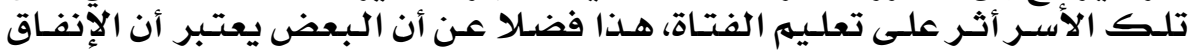




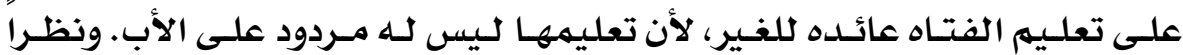

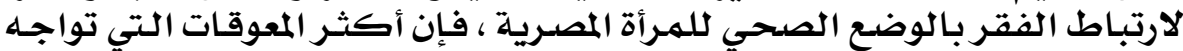

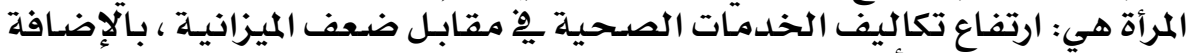

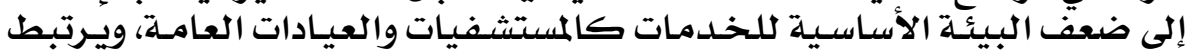

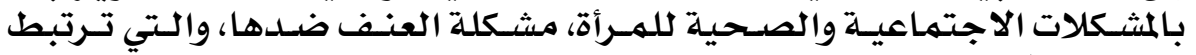
بالتنشئية الاجتماعية الاجتهاعية.

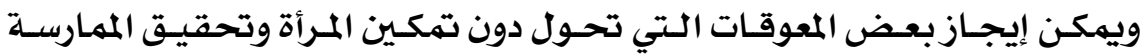

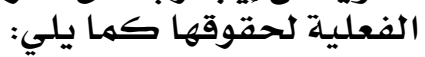

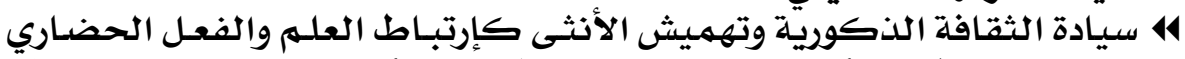

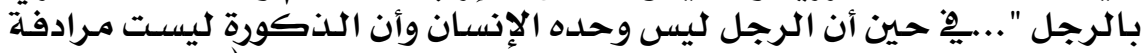

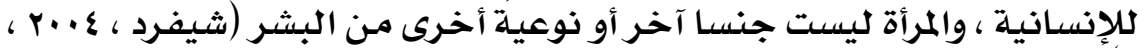
. ( 11

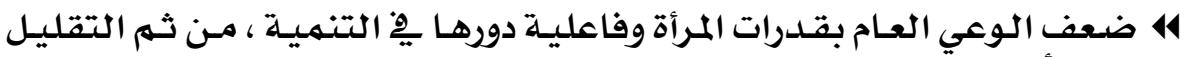

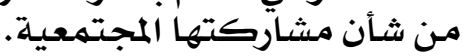

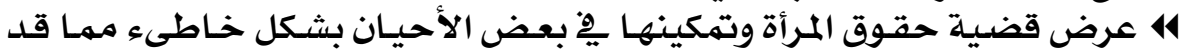

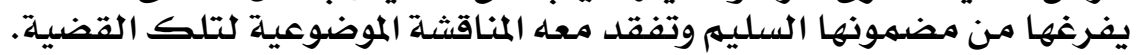

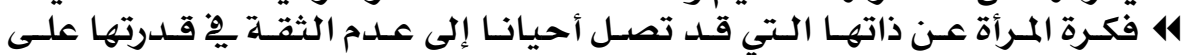

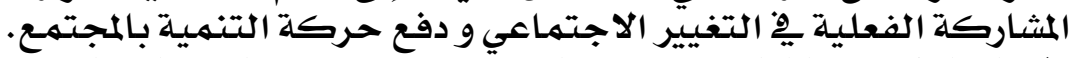

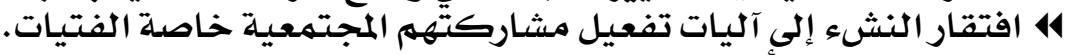

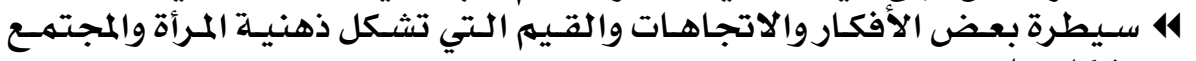
بشكل سلبي.

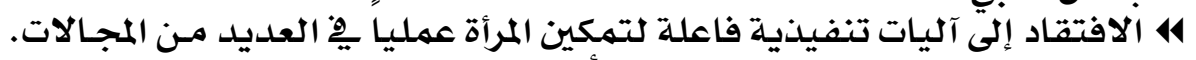

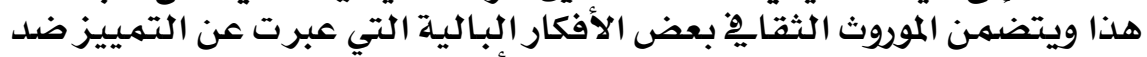

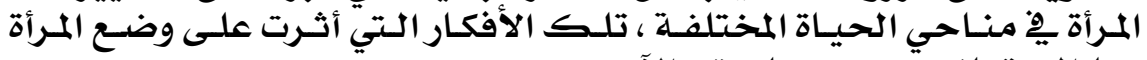

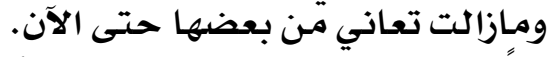

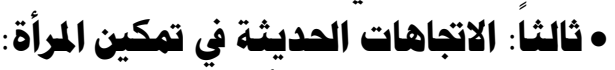

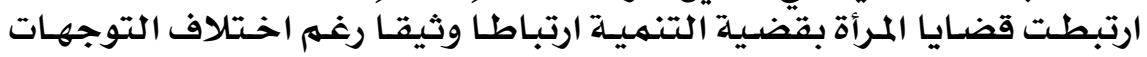

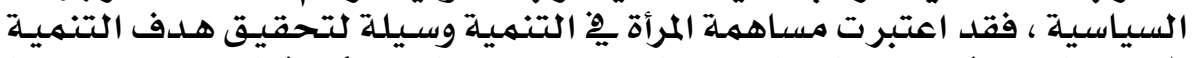

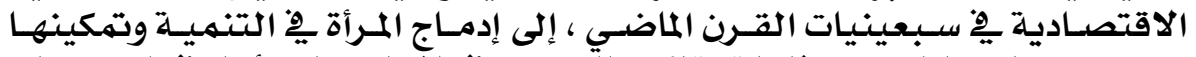

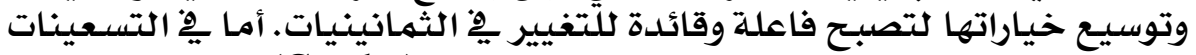

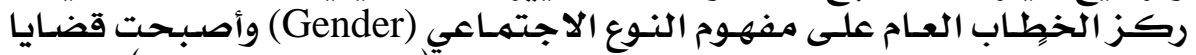

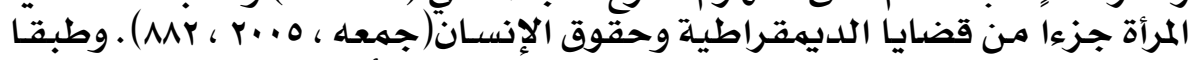

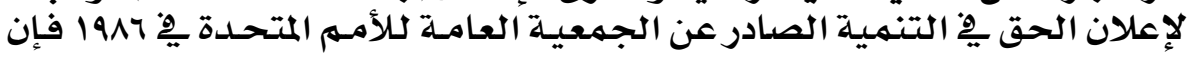

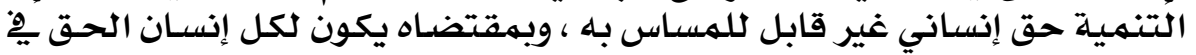

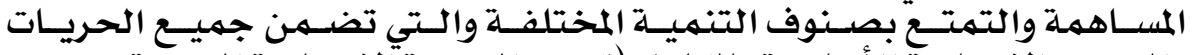

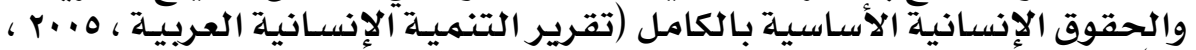

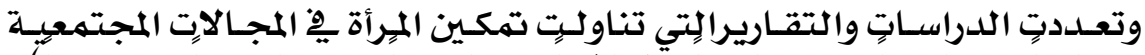

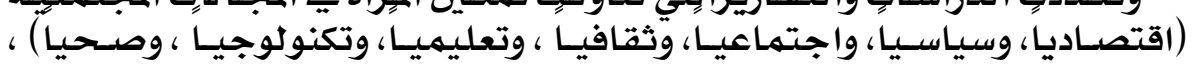




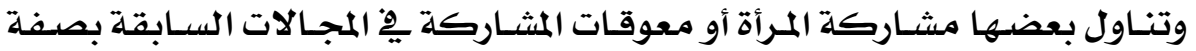

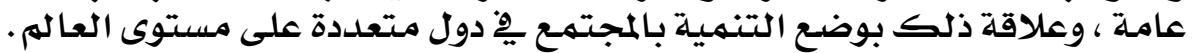

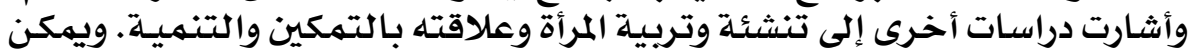

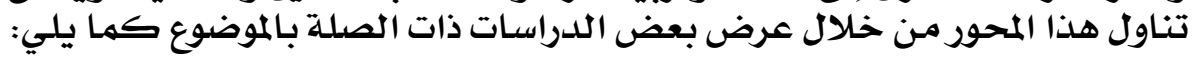

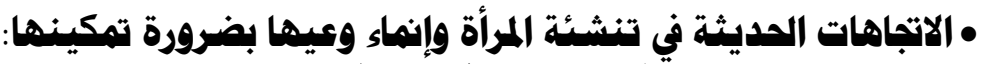

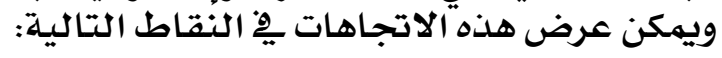

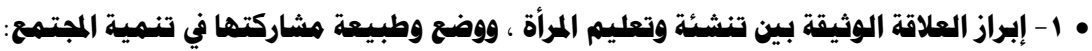

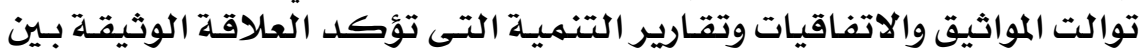

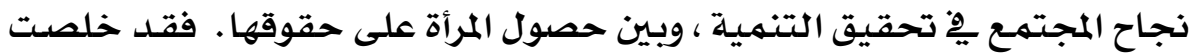

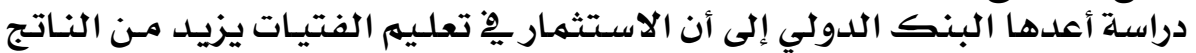

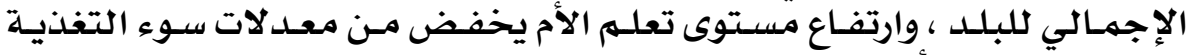

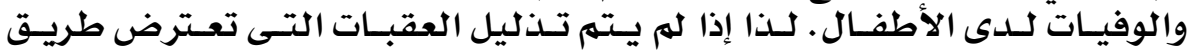

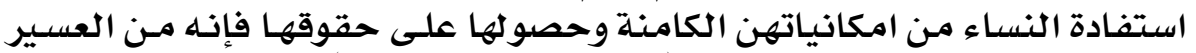

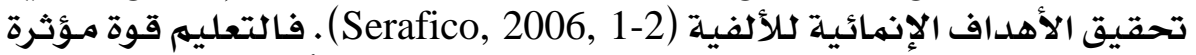

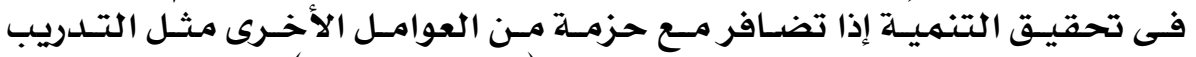

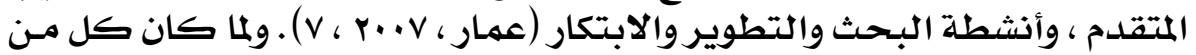

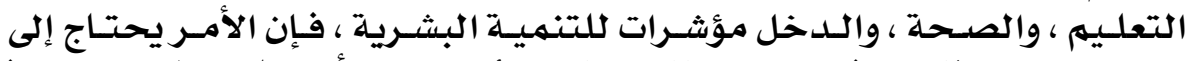

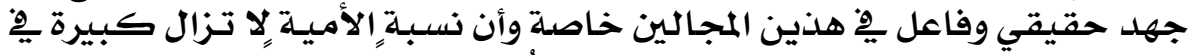

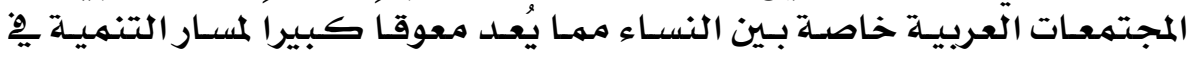

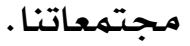

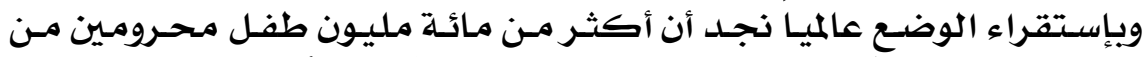

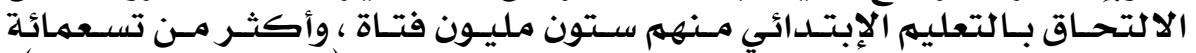

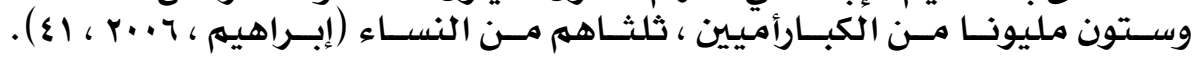

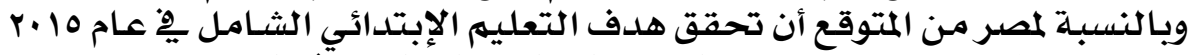

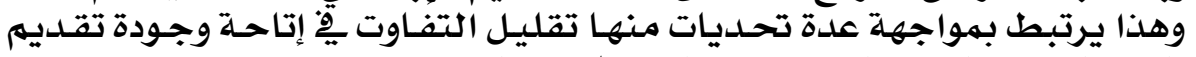

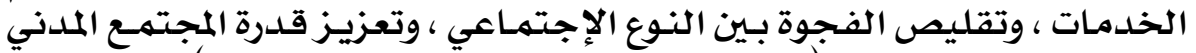

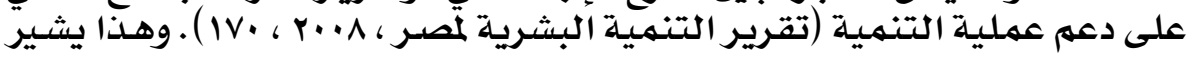

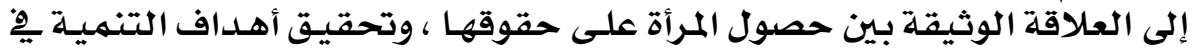
المجتمع المعادة

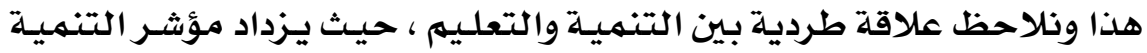

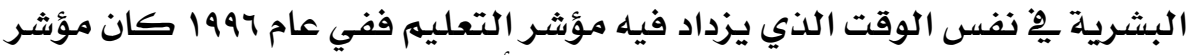

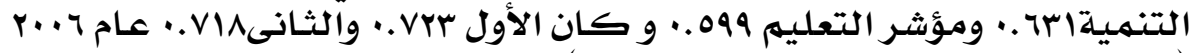

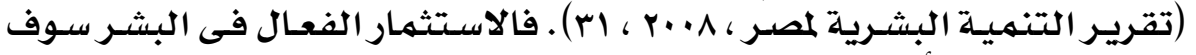

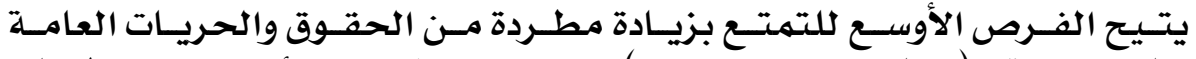

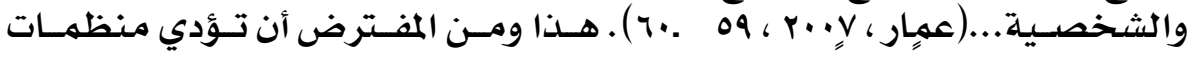

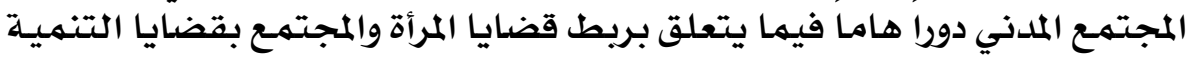

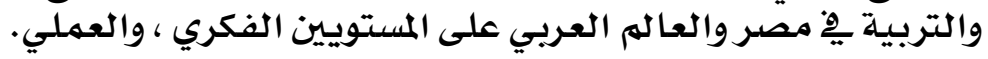


• r- التوجه نهو تربية المرأة على المشاركة ودهمها في المجتمع هن هنظهور حقوقي:

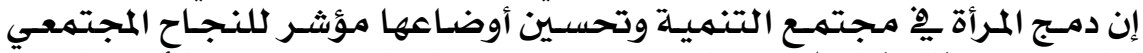

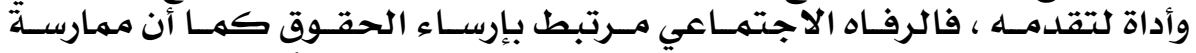

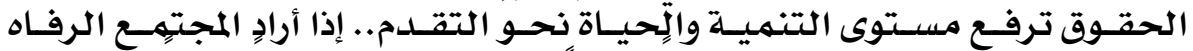

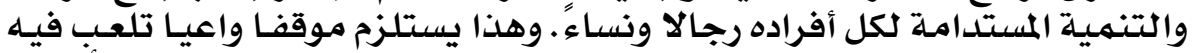

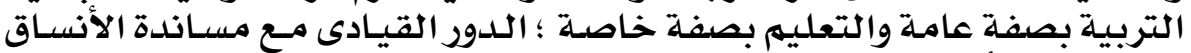

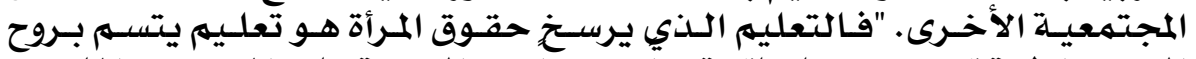

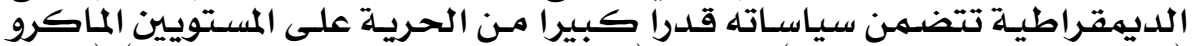

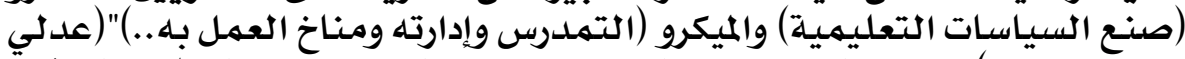

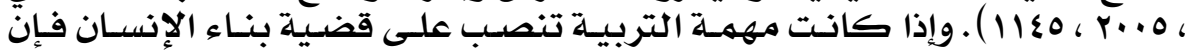

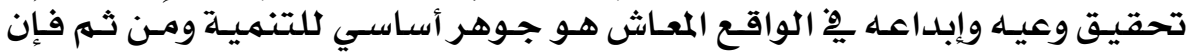

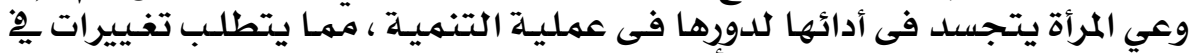

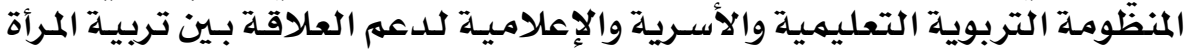

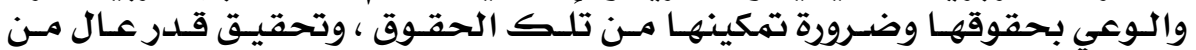

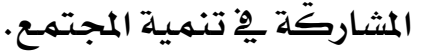

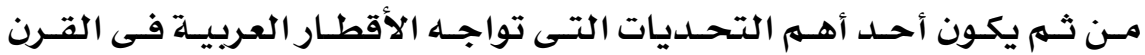

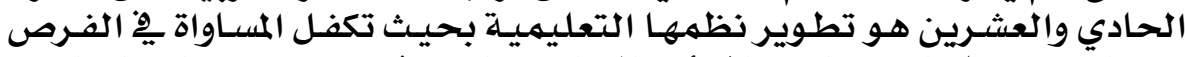

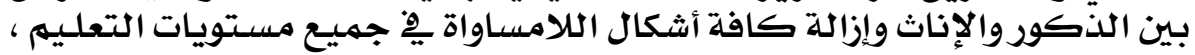

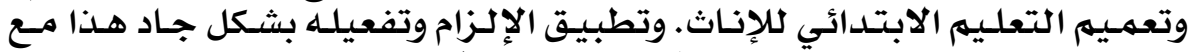

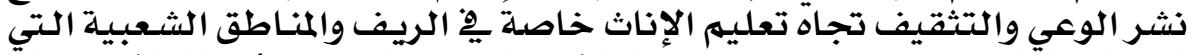

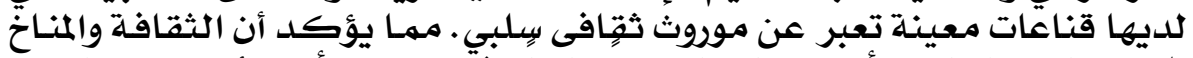

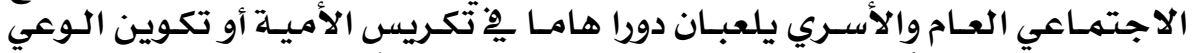

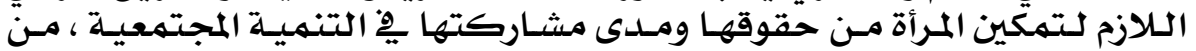

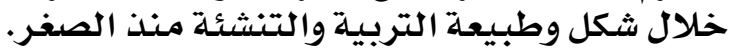

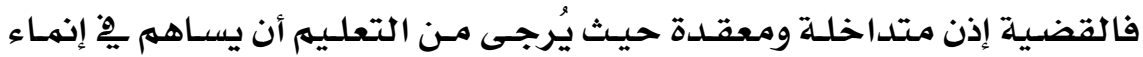

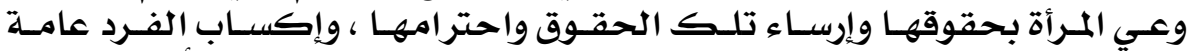

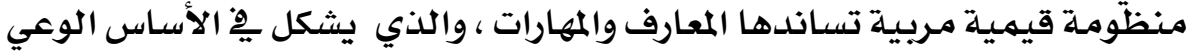

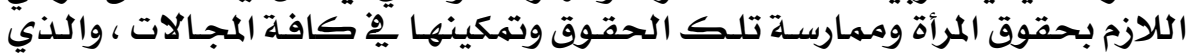

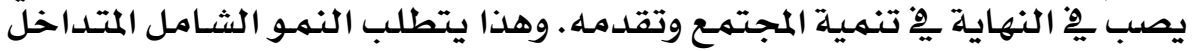

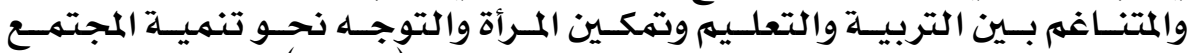

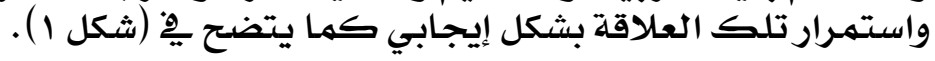
• r- تغيير أساليب التنشئة الاجتهماعية للهمرأة:

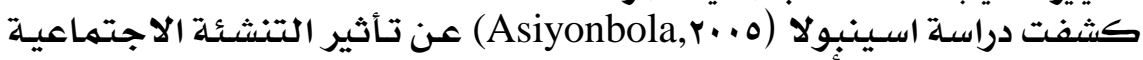

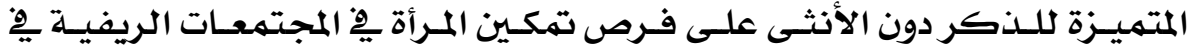

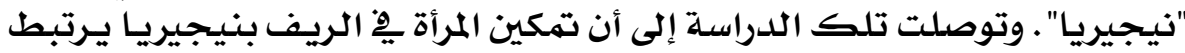

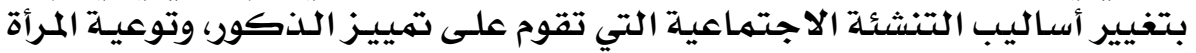

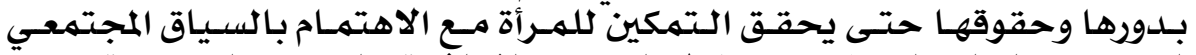

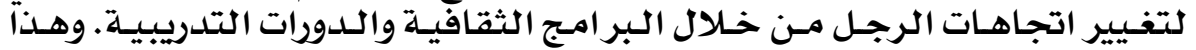


يدعو إلى تغيير بعض أسـاليب التنشئهة للهـرأة فِ مـجتهعاتنـا العربيـة والتي تقـوم على أفكار سلبيـية موروثة تفيير.

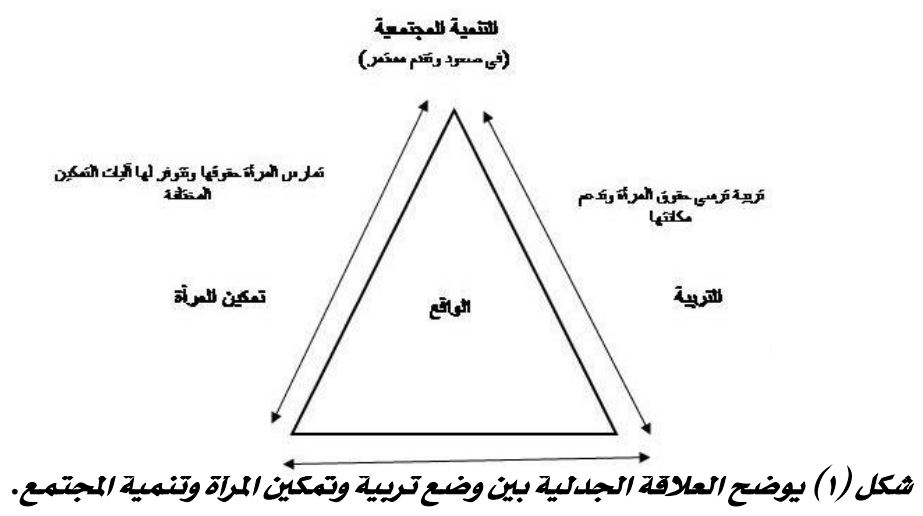

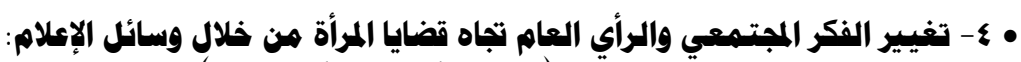

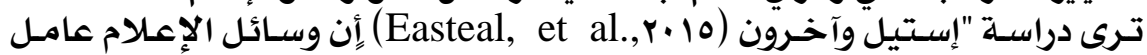

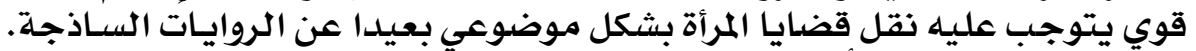

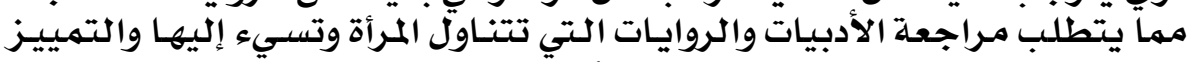

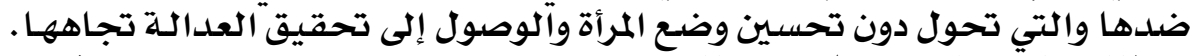

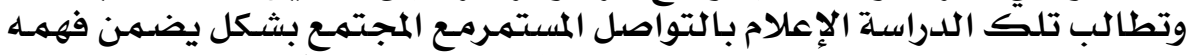

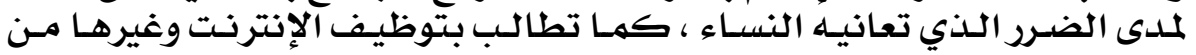

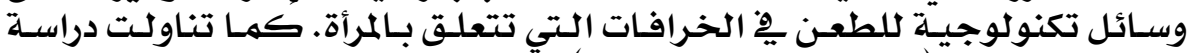

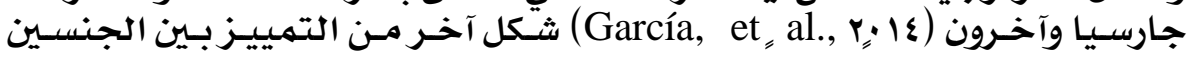

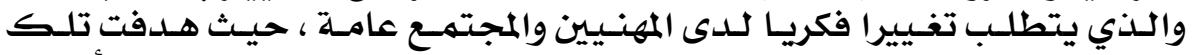

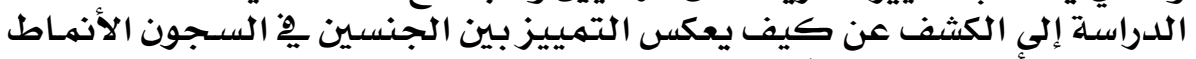

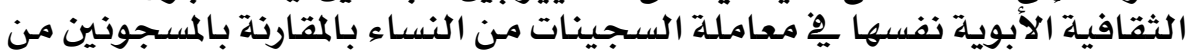

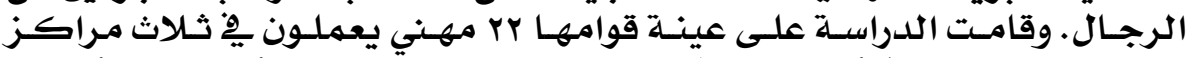

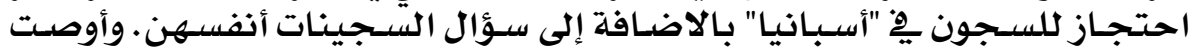

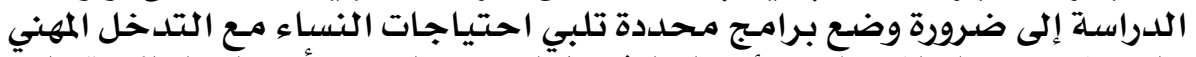

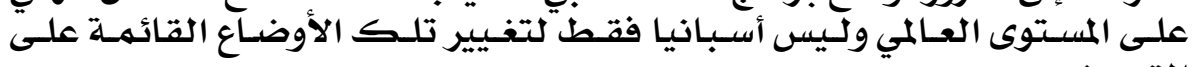
التمييز.

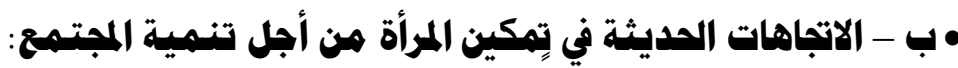

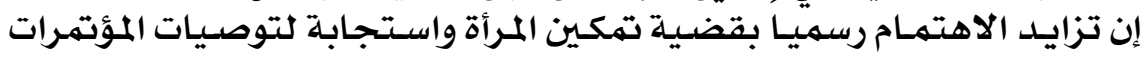

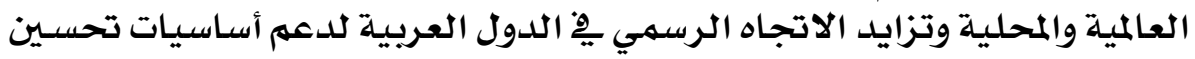

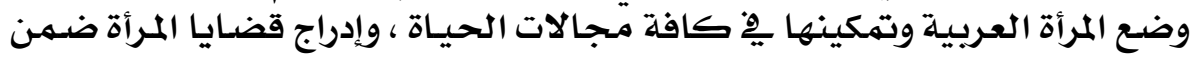

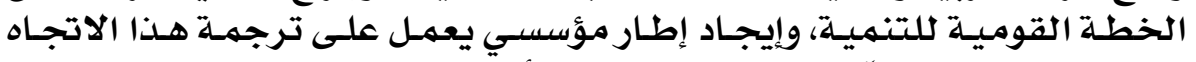

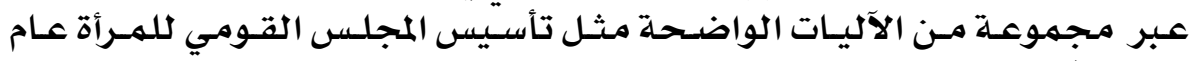

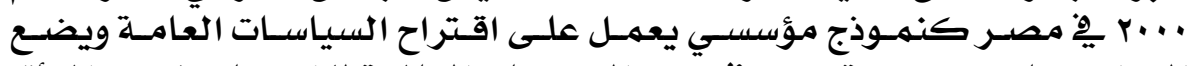

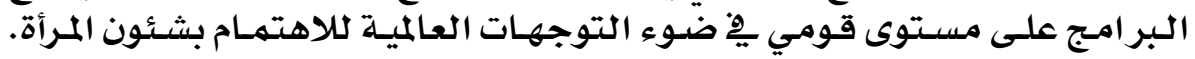




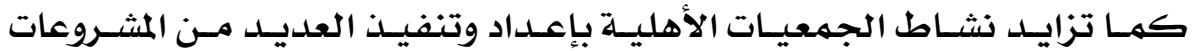

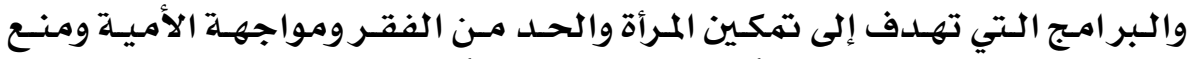

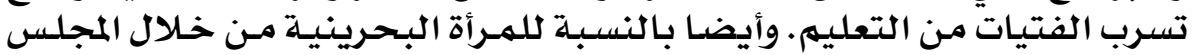

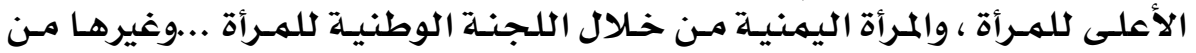

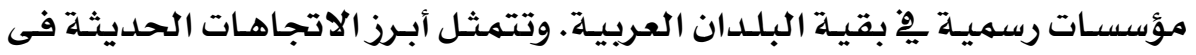

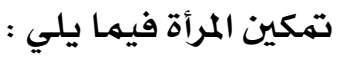

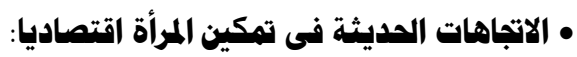

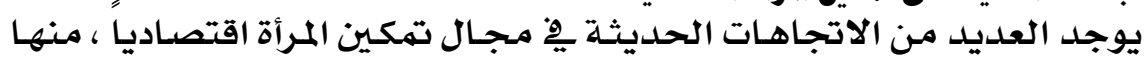
ما يلي: • 1 - تمكين المرأة اقتصادياً هن خلال المشاريع الصغيرة والكبيرة ، ودعم الأسر المنتجة:

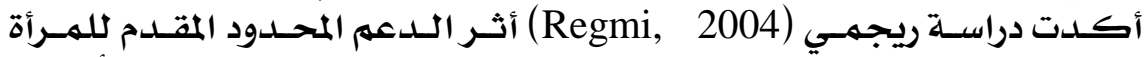

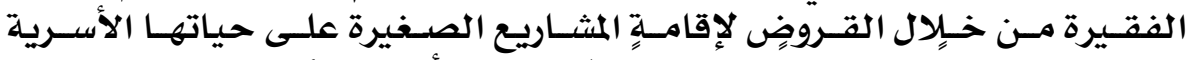

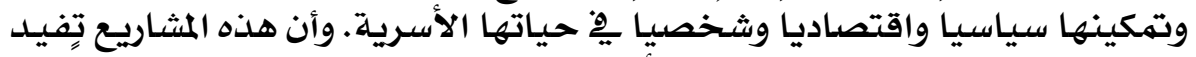

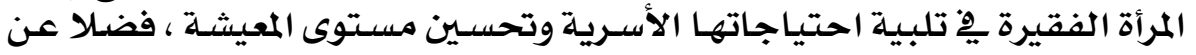

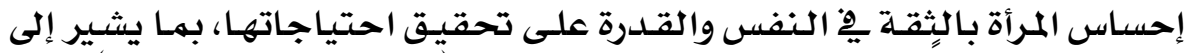

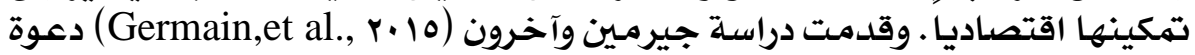

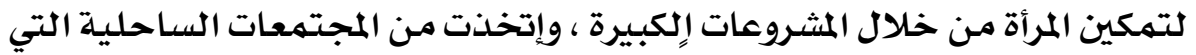

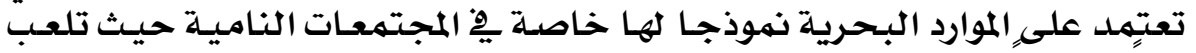

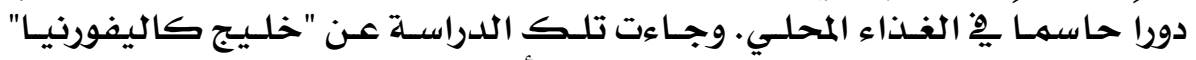

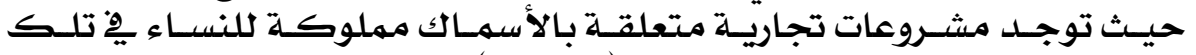

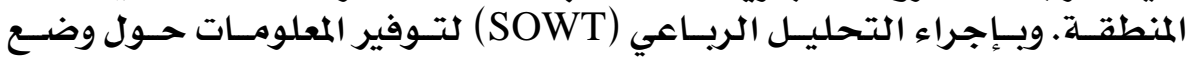

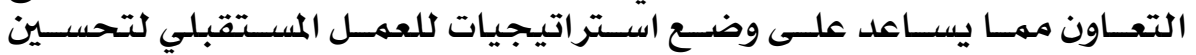

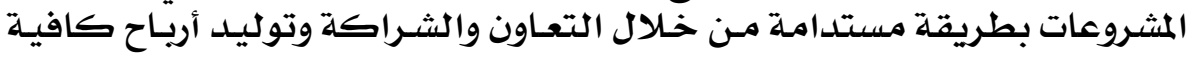

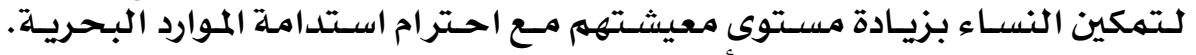

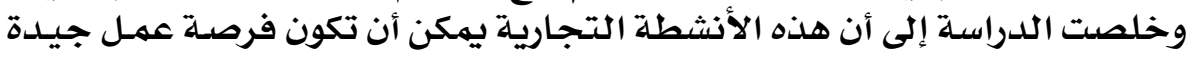

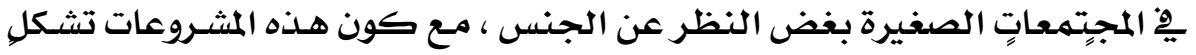

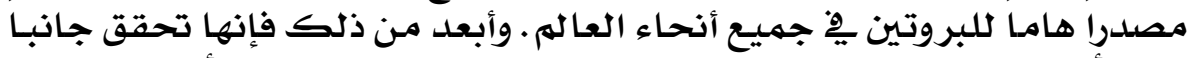

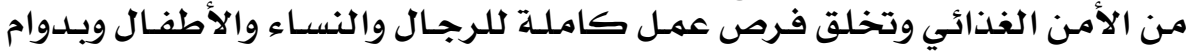

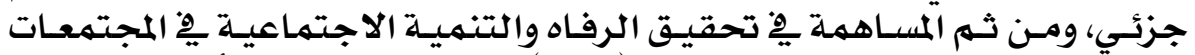

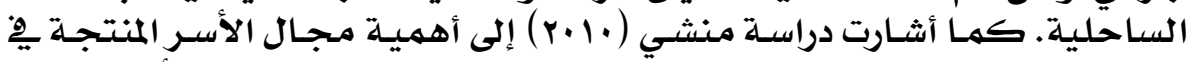

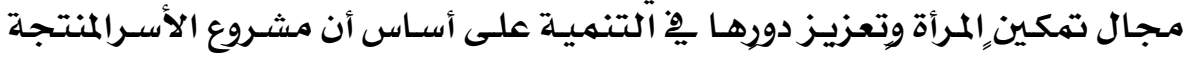

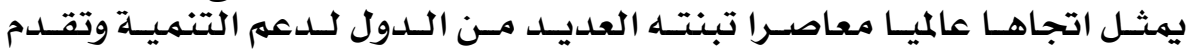

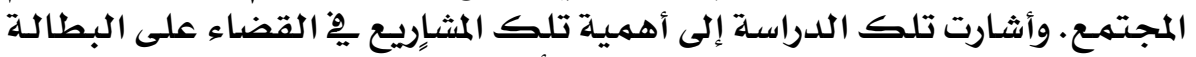

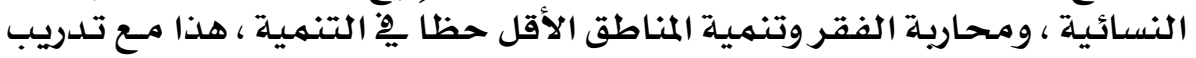

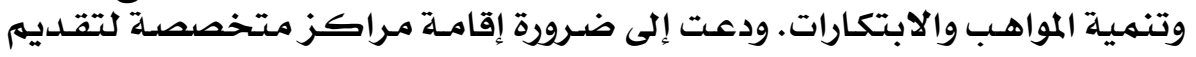

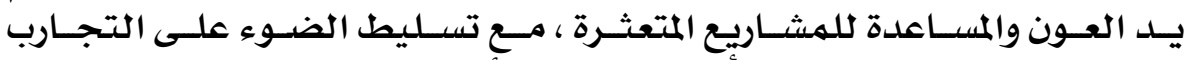

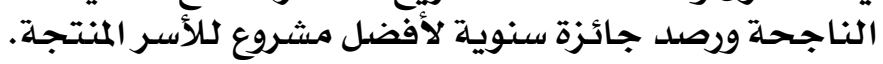

\section{Y}




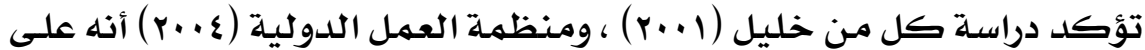

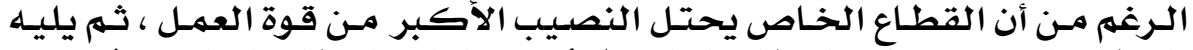

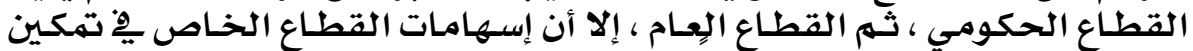

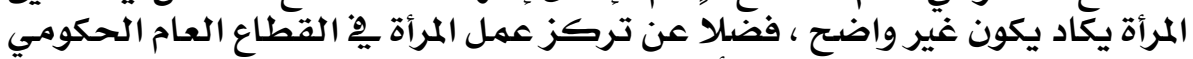

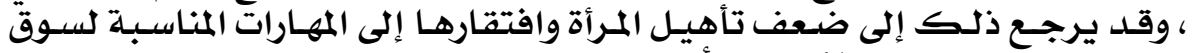

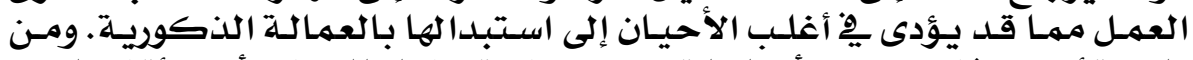

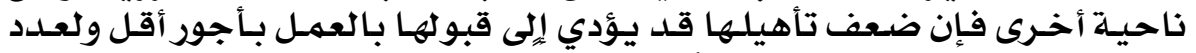

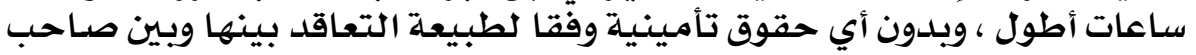

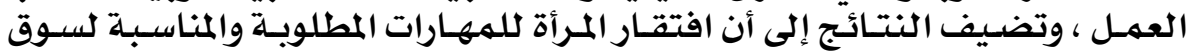

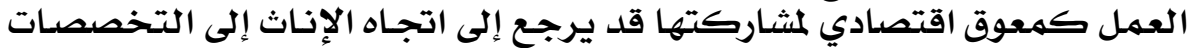

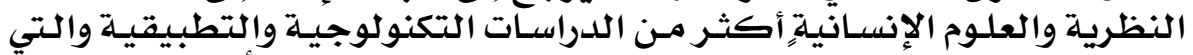

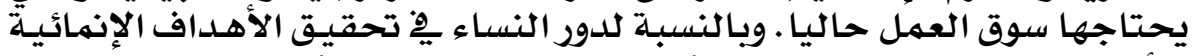

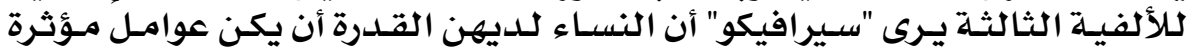

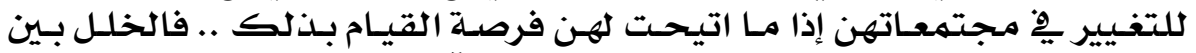

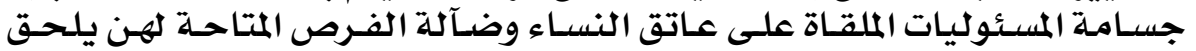

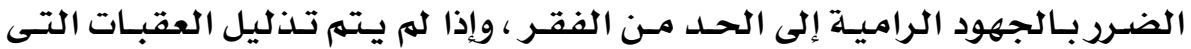

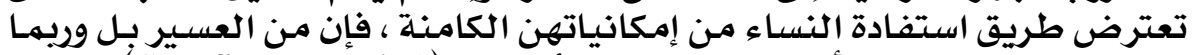

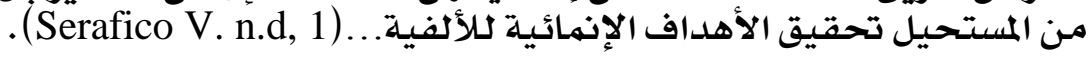

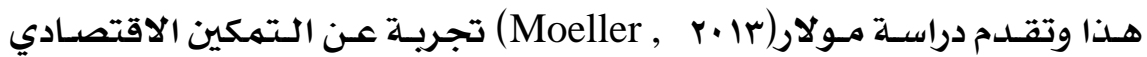

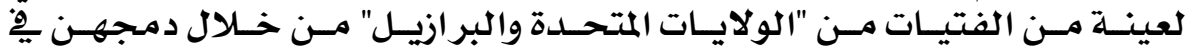

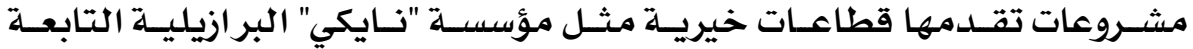

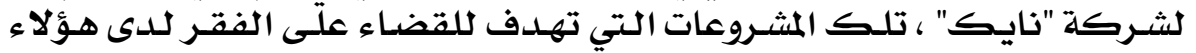

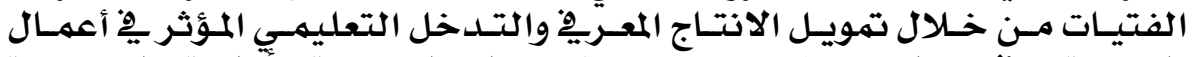

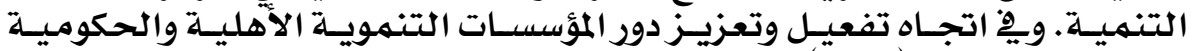

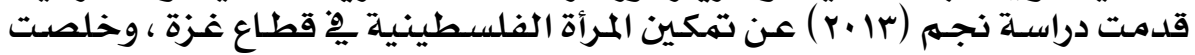

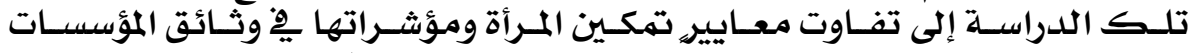

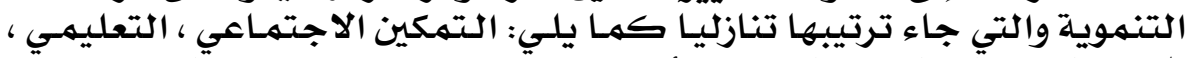

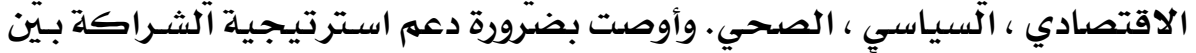

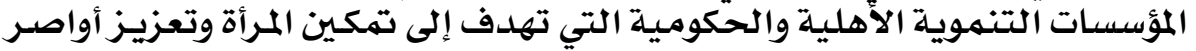

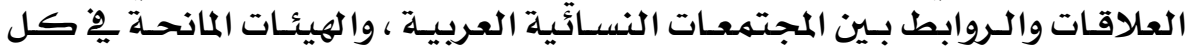

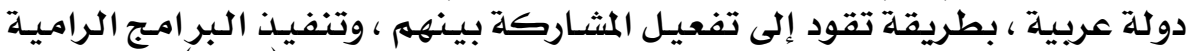

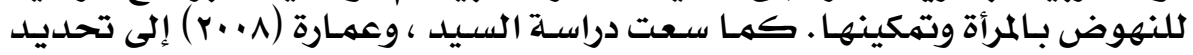

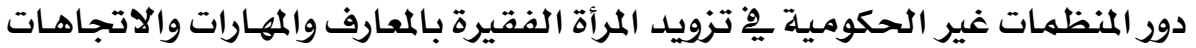

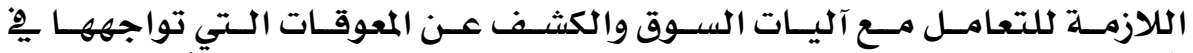

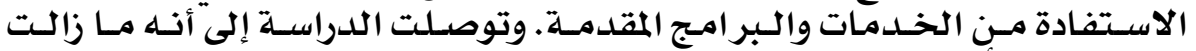

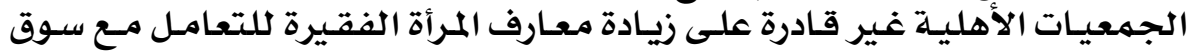
العمل.

\section{r\&}


• r-قضية تمكين المرأة كمؤشر لاتنمية الاقتصادية والمستقبل:

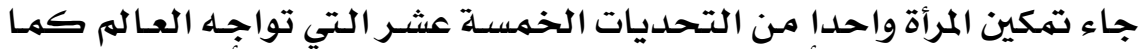

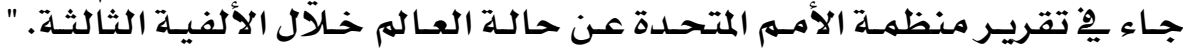

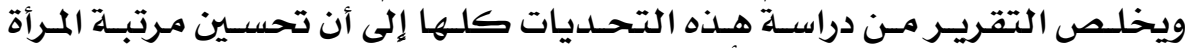

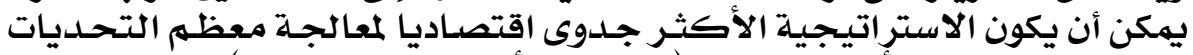

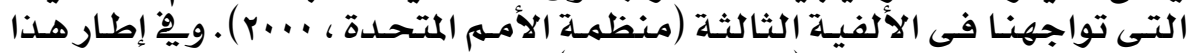

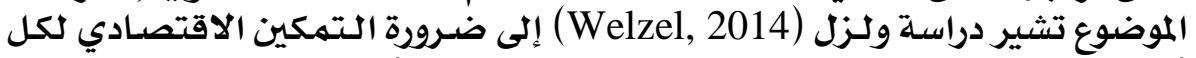

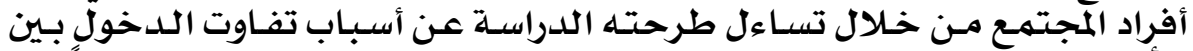

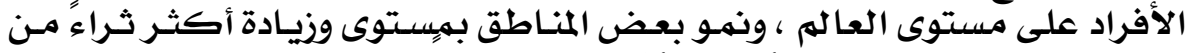

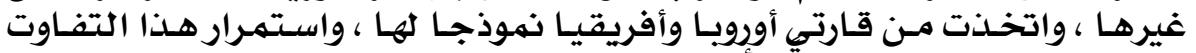

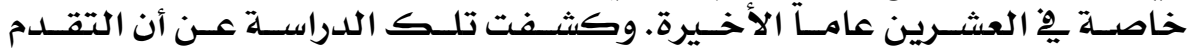

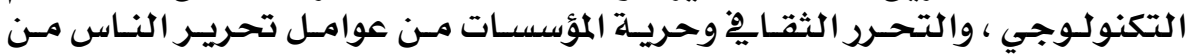

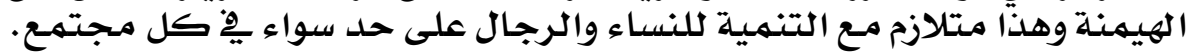

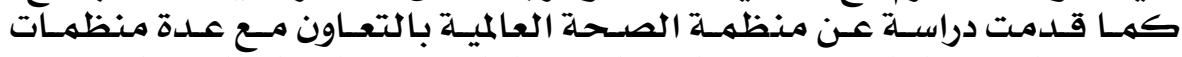

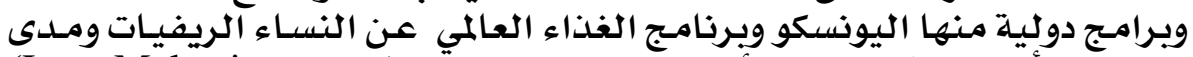

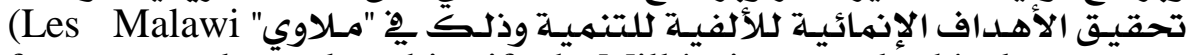
femmes rurales et les objectifs du Millénaire pour le développement,

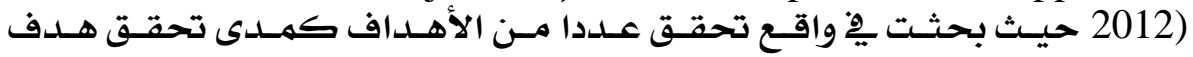

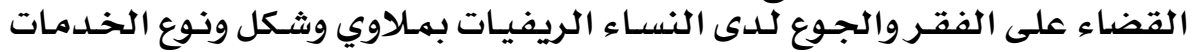

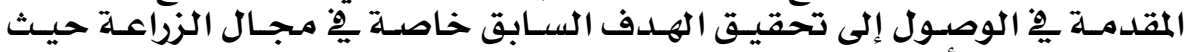

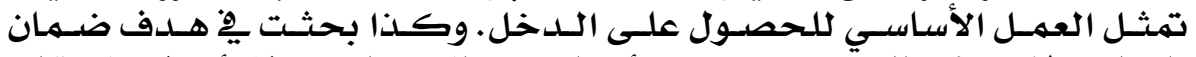

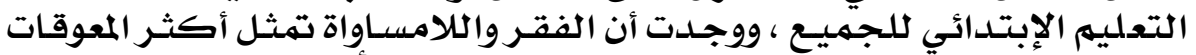

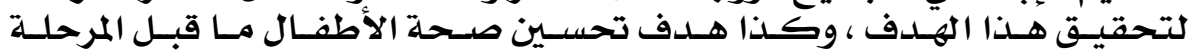

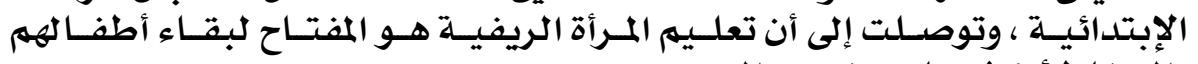

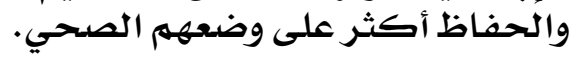

• §-تعريز المساواة بين الرجل والمرأة في سوق العمل لتقاليل خطر الفقر لدى المرأة:

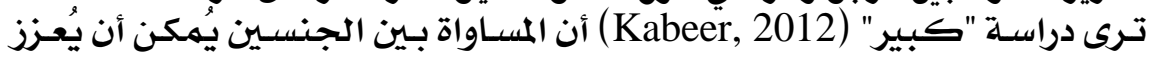

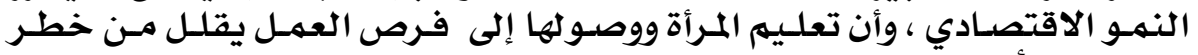

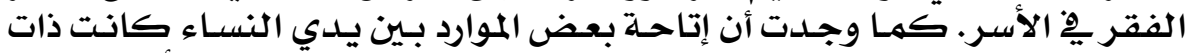

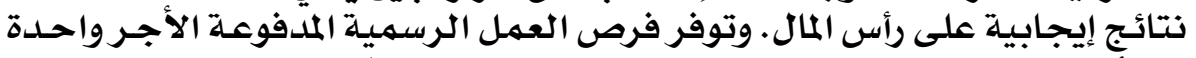

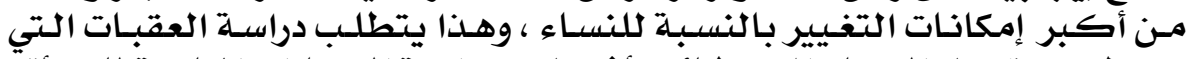

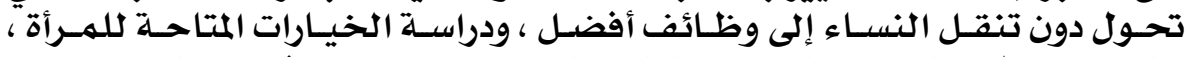

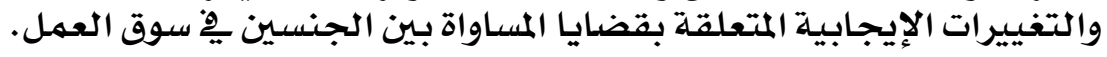

• •- تعزيز التدريب الشاهل واكساب المهارات: تـرى دراسـة "تـو ،وآخـرون (

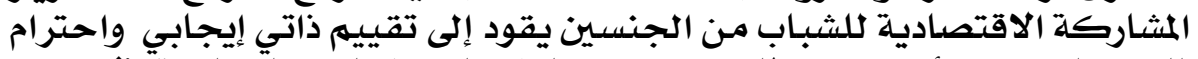

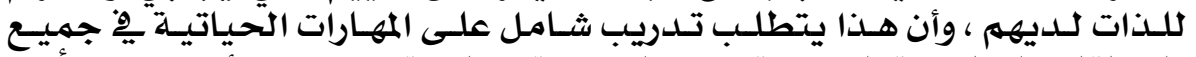

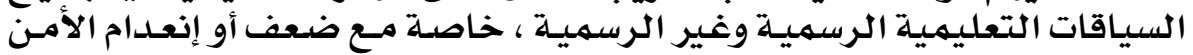

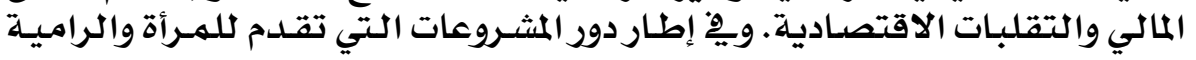




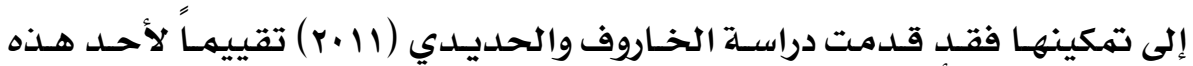

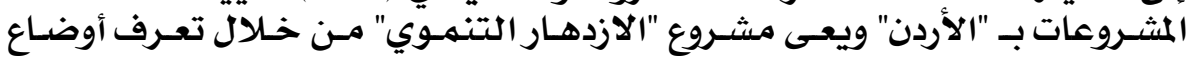

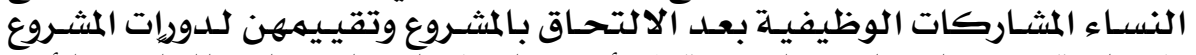

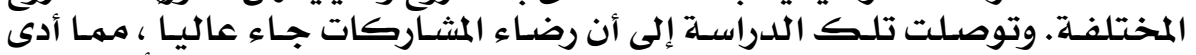

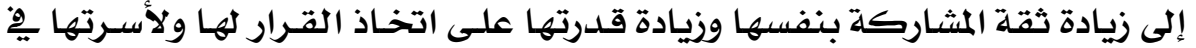

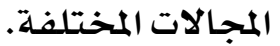

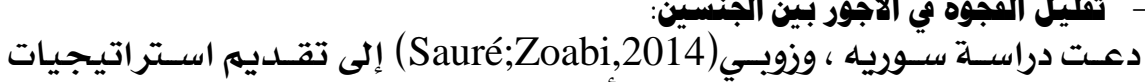

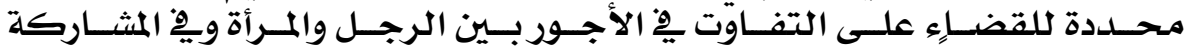

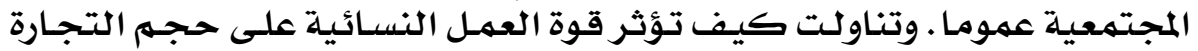

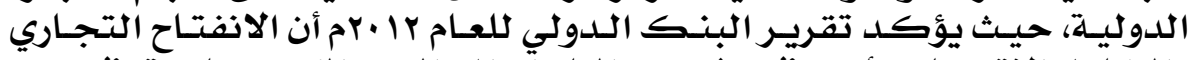

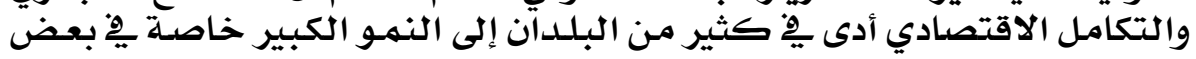

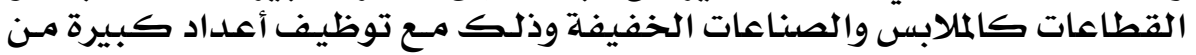

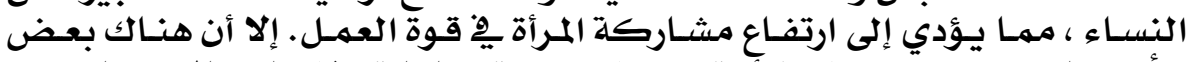

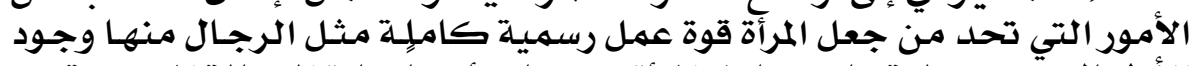

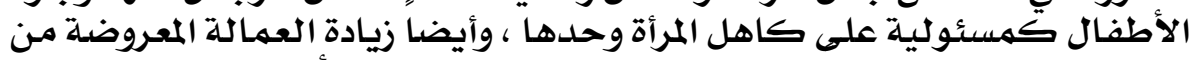

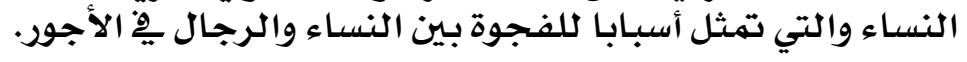

• الاتجاهات الحديثة فى تمكين المرأة صحيا:

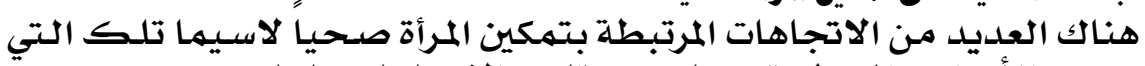

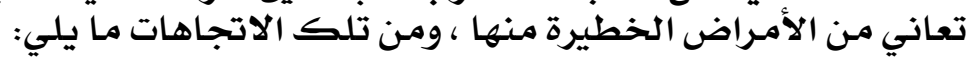

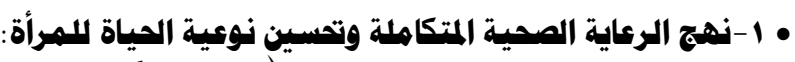

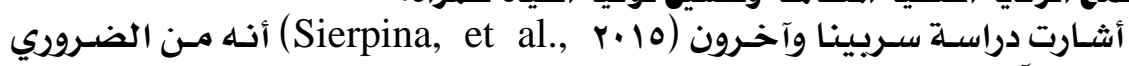

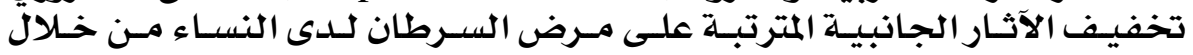

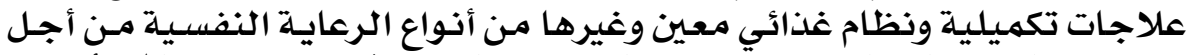

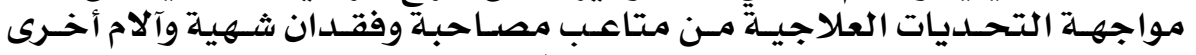

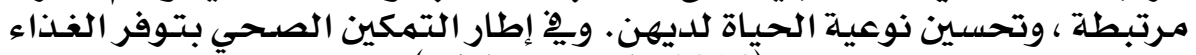

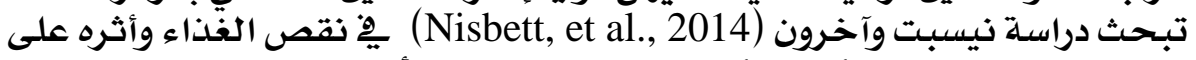

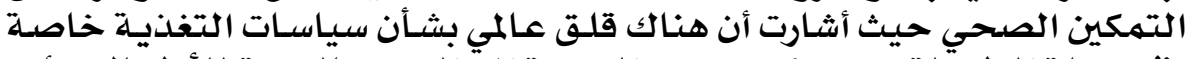

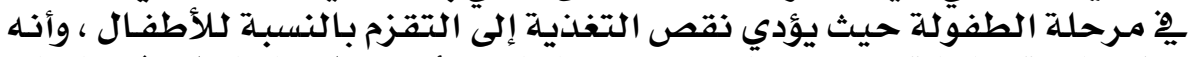

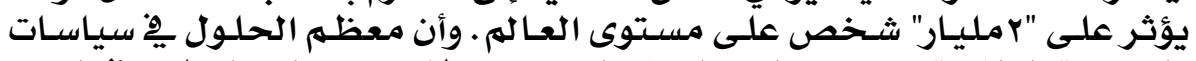

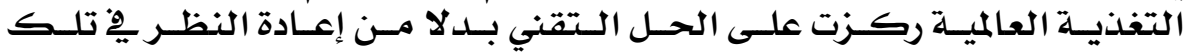

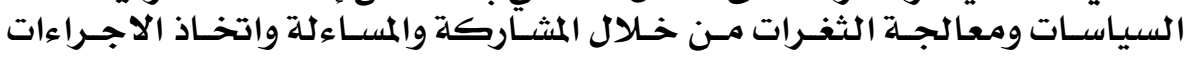

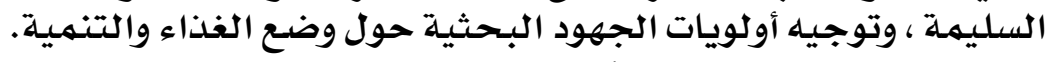

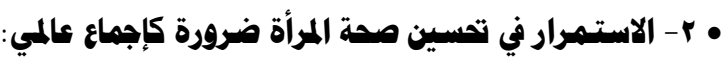

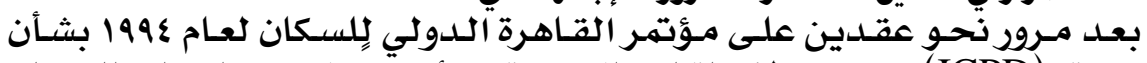

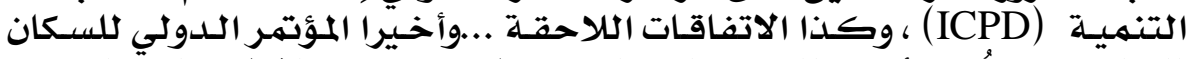

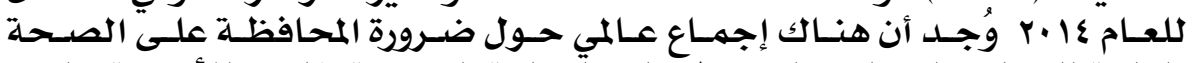

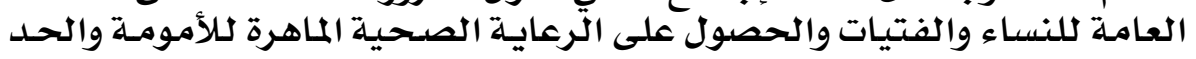

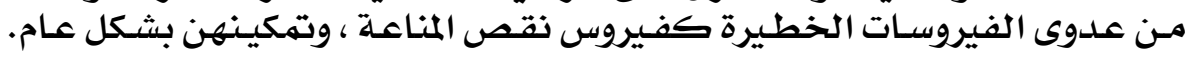




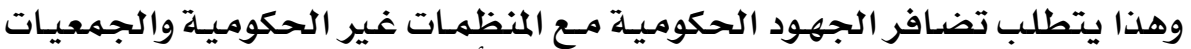

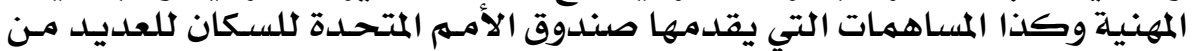

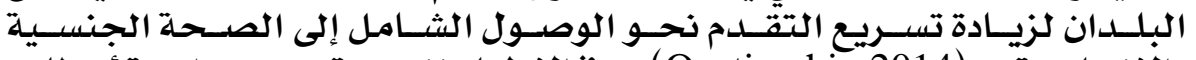

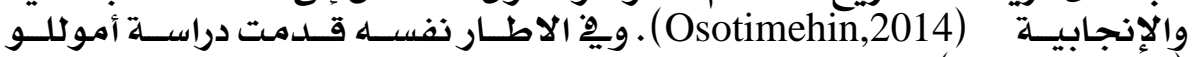

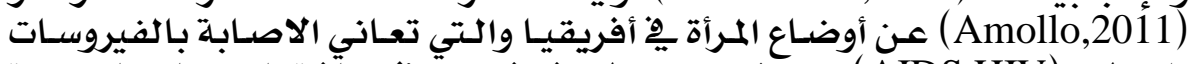

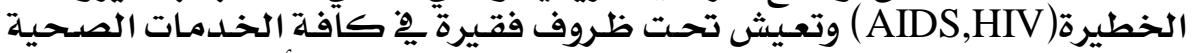

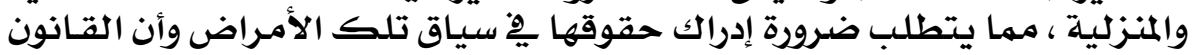

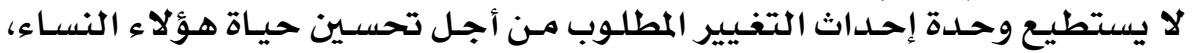

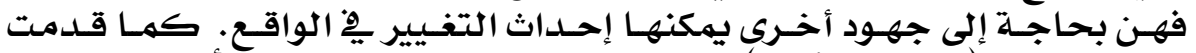

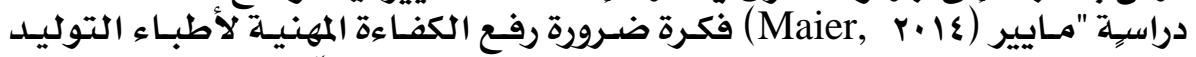

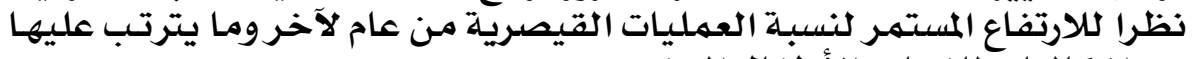

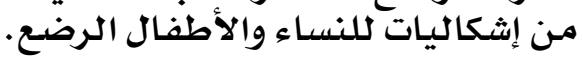

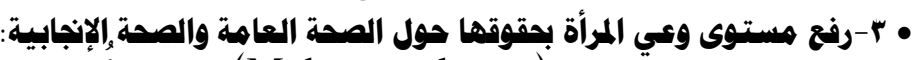

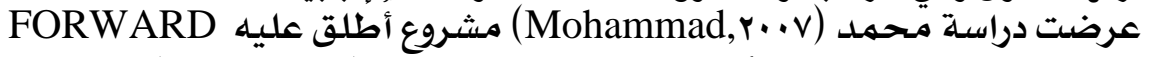

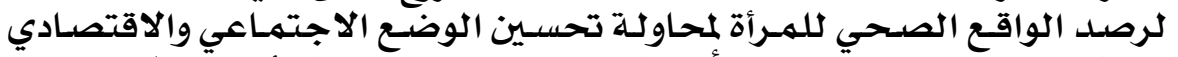

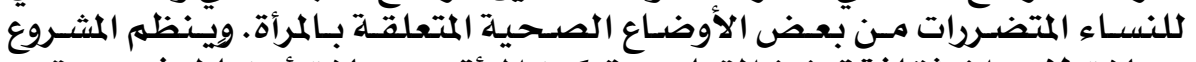

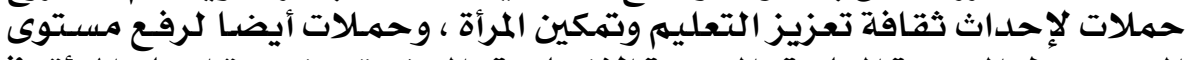

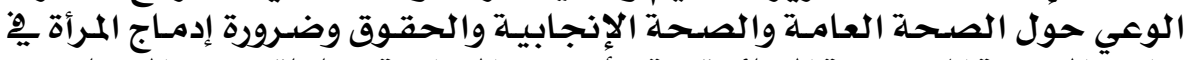

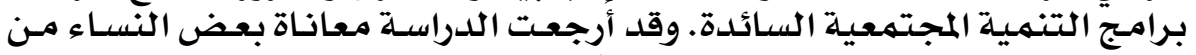

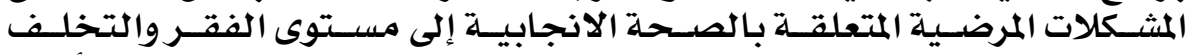

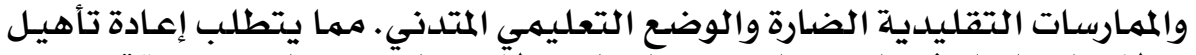

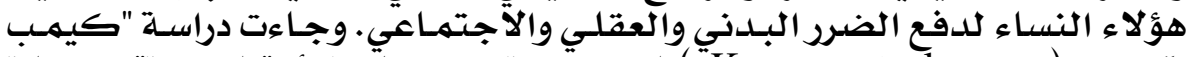

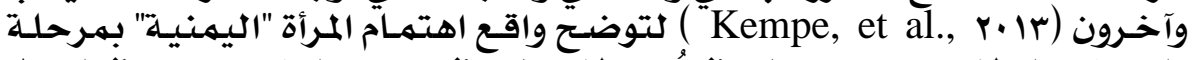

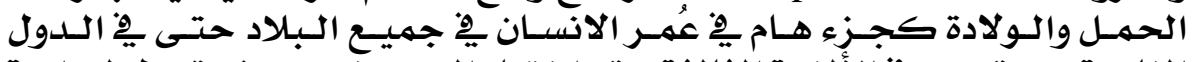

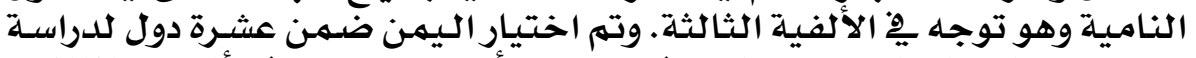

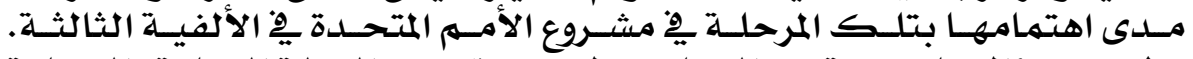

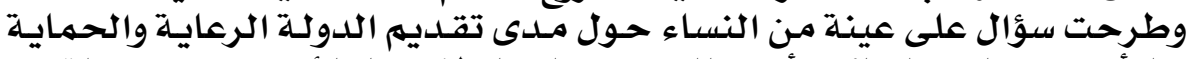

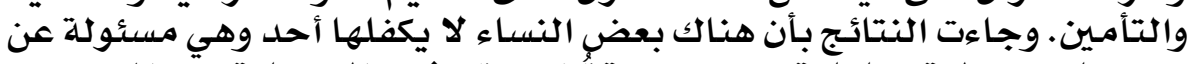

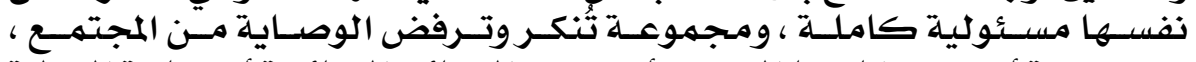

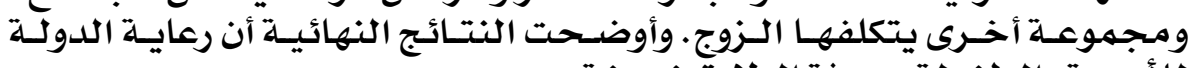

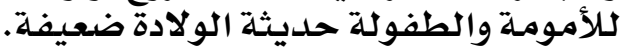
• ع- الاهتيمام بمستقبل الرعاية الصحية للألمومهة:

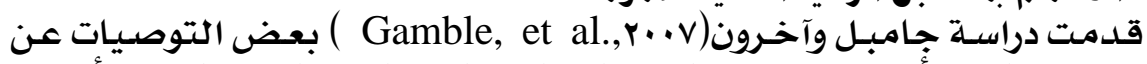

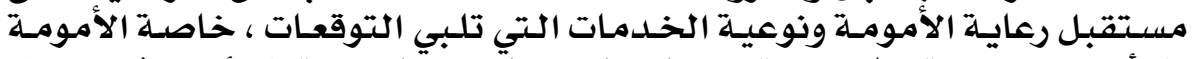

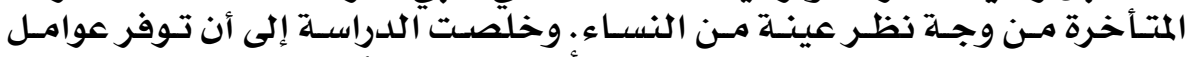

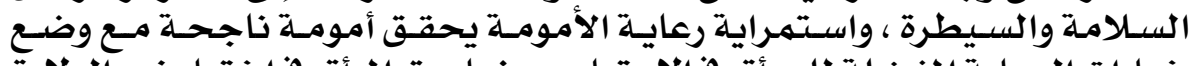

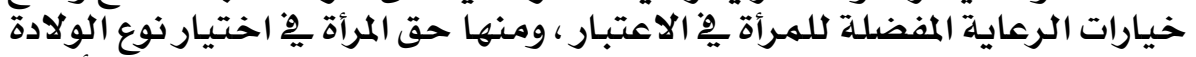

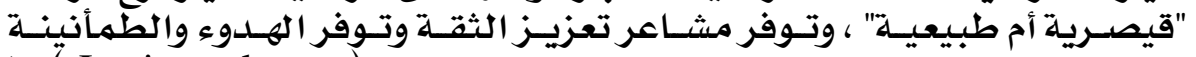

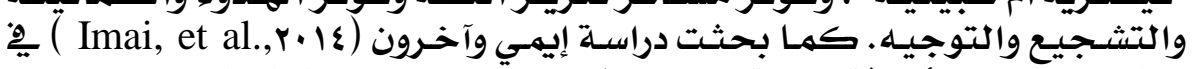

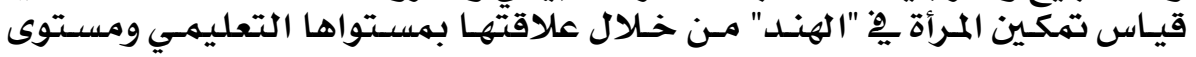




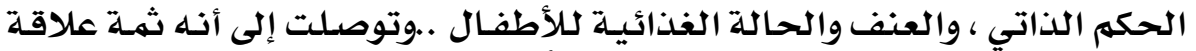

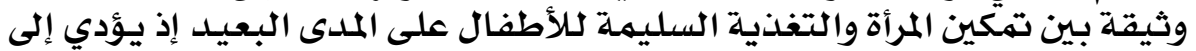

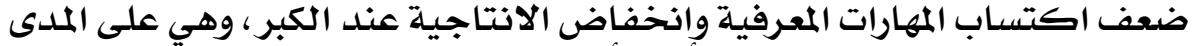

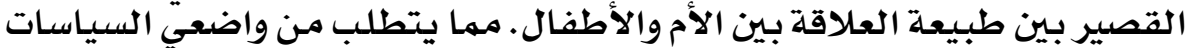

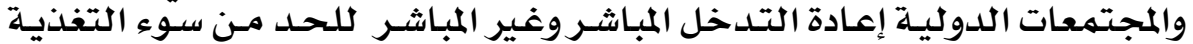

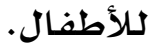

\section{• الاتجاهات الحديثة فى تمكين المرأة اجتهاعياً وثقافياً: تلإل}

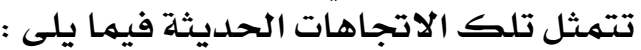

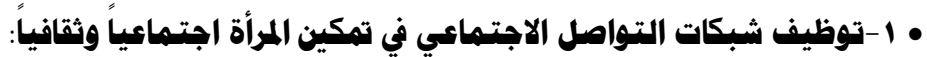

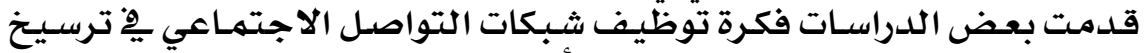

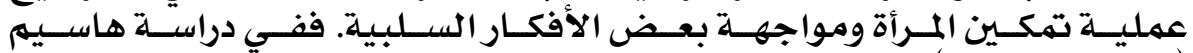

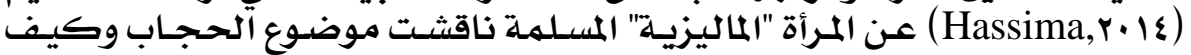

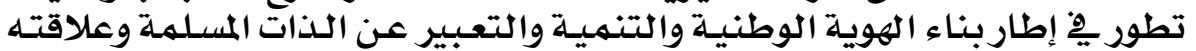

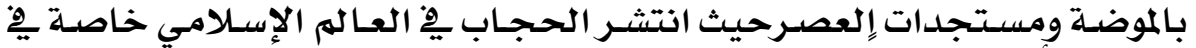

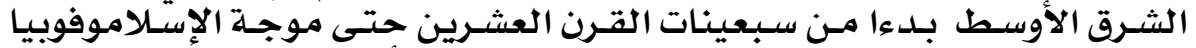

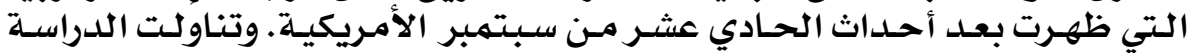

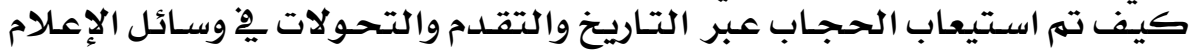

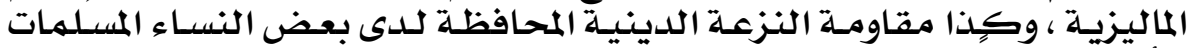

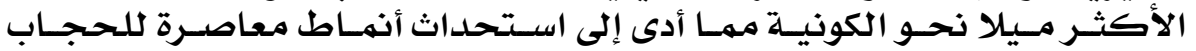

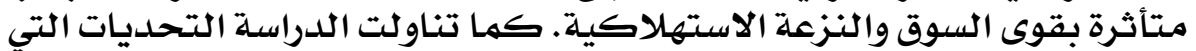

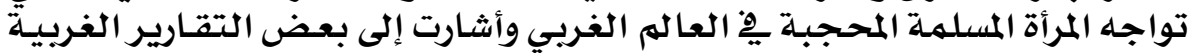

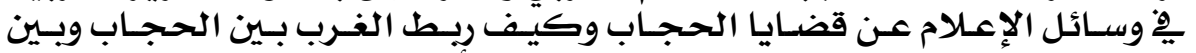

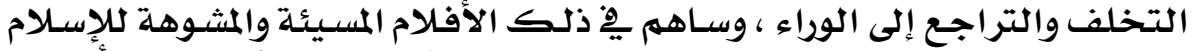

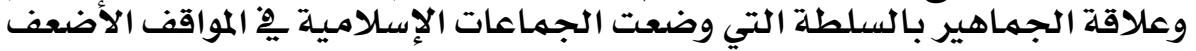

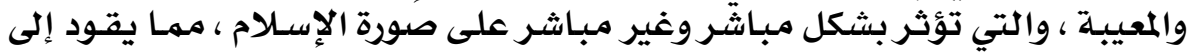

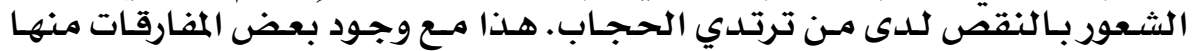

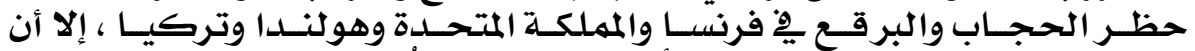

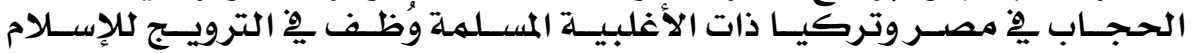

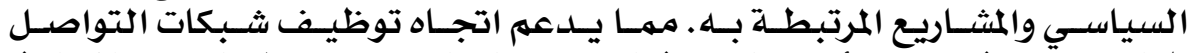

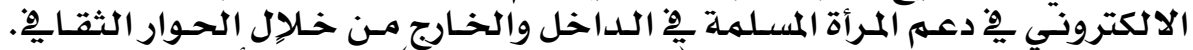

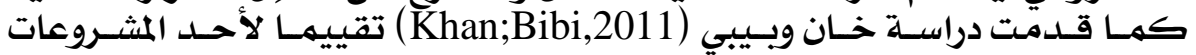

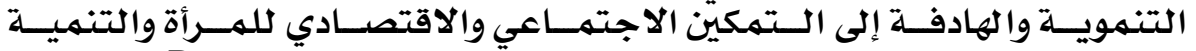

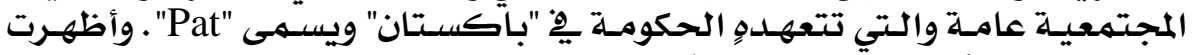

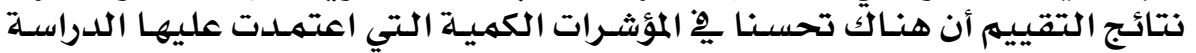

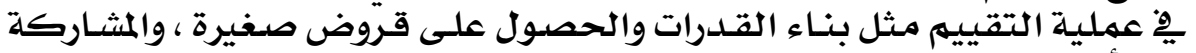

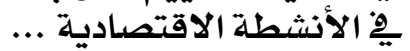

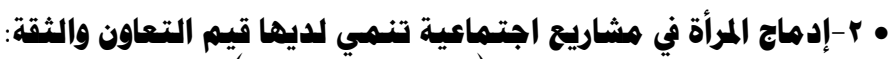

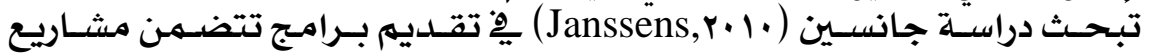

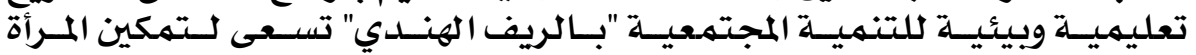




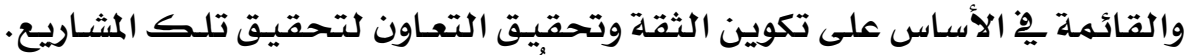

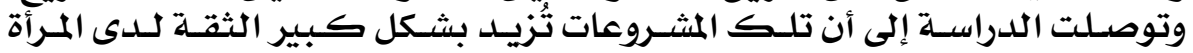

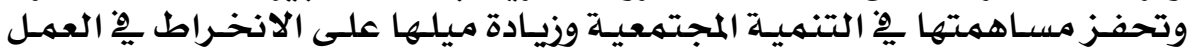

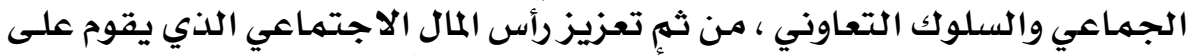

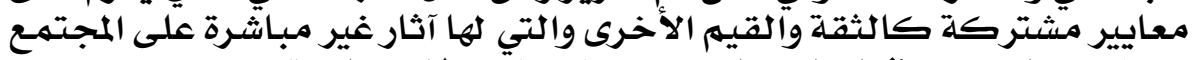

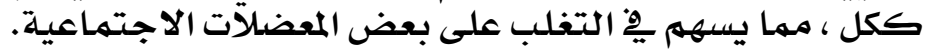

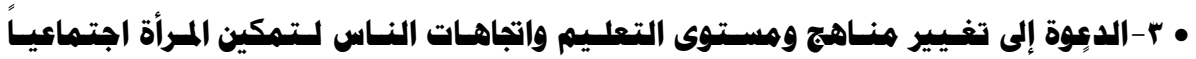

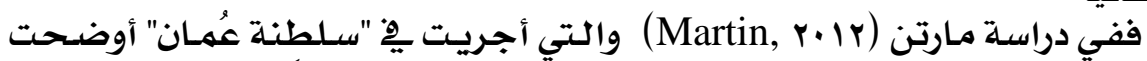

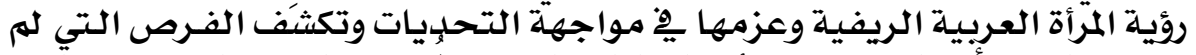

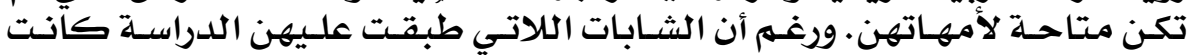

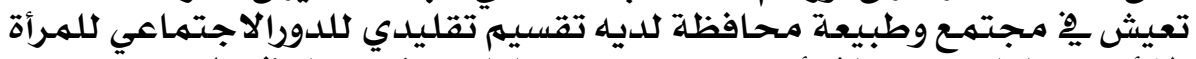

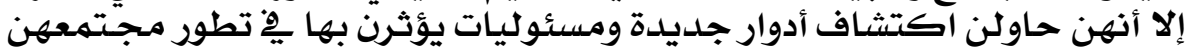

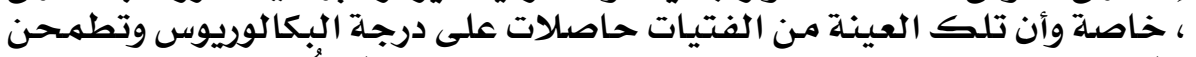

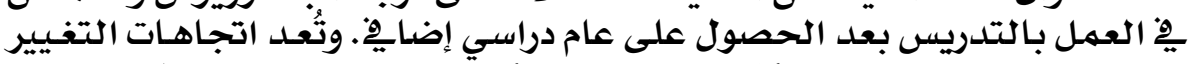

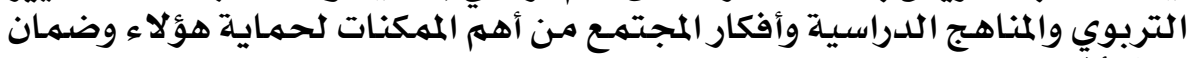
حياة أفضِ أنضل لهن.

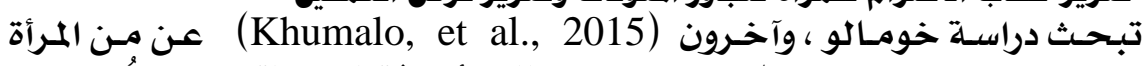

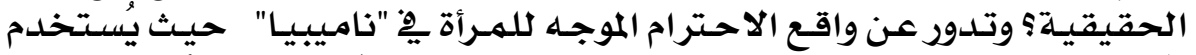

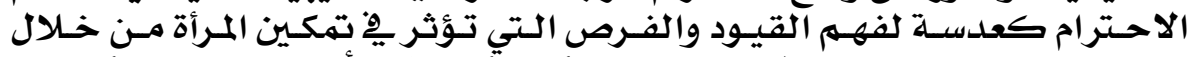

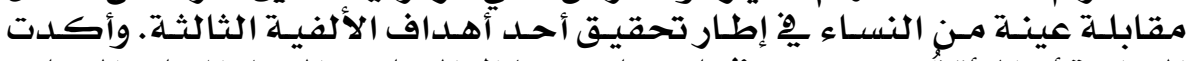

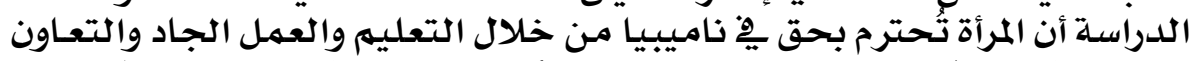

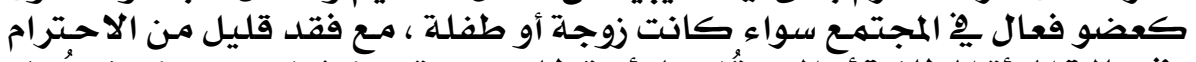

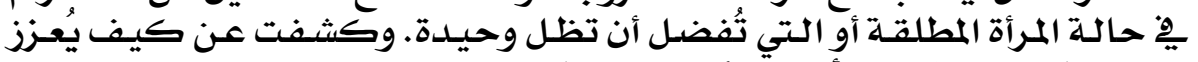

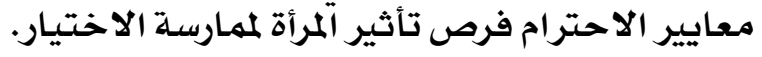

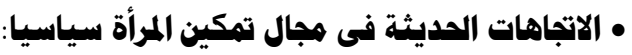

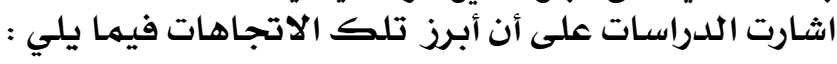

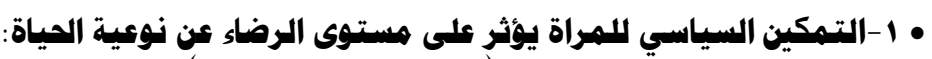

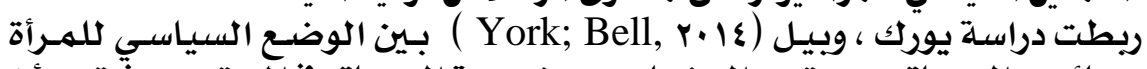

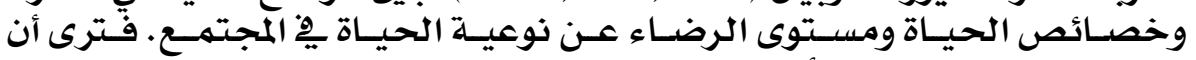

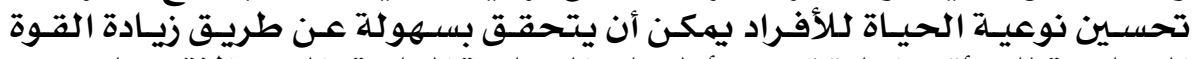

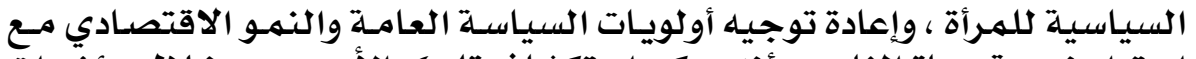

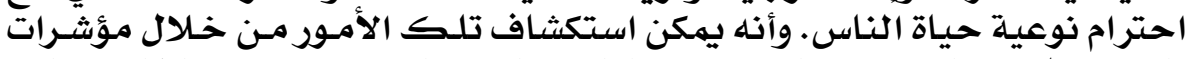

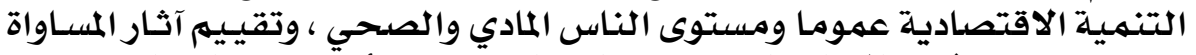

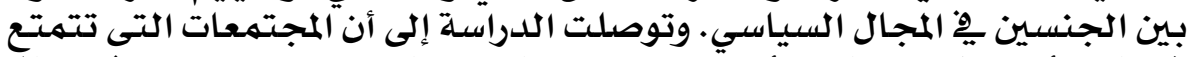

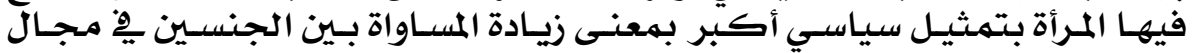

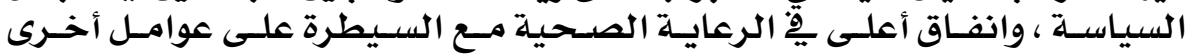

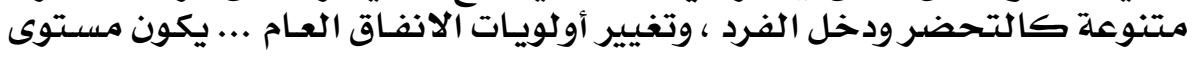

\section{$r \varepsilon 7$}




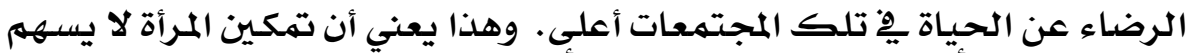

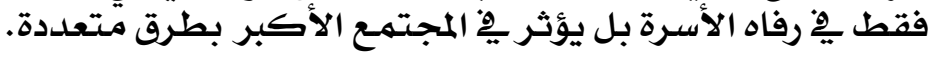

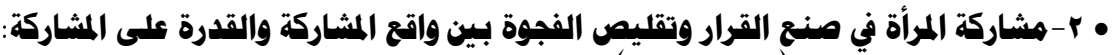

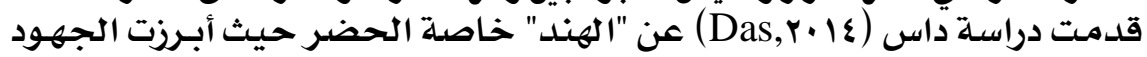

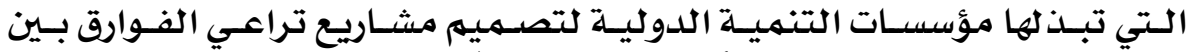

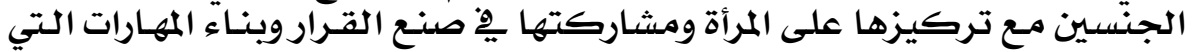

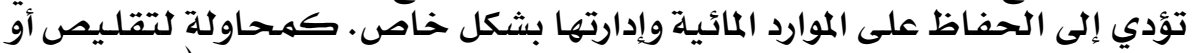

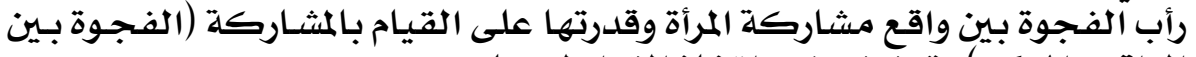

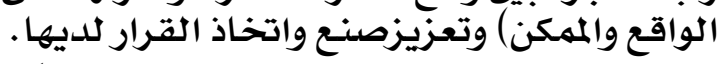

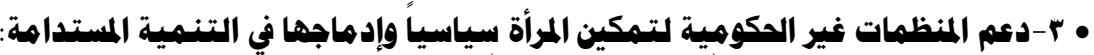

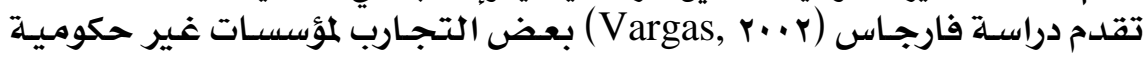

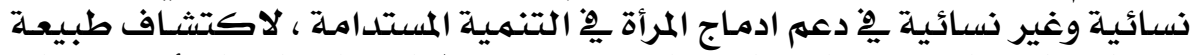

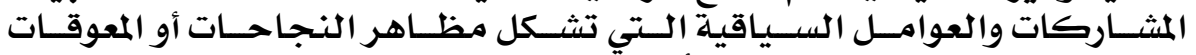

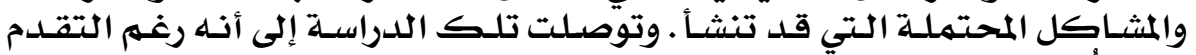

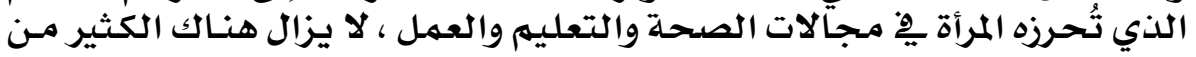

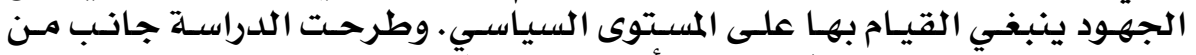

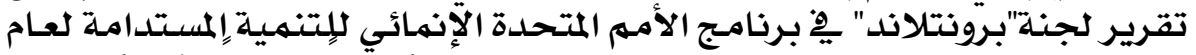

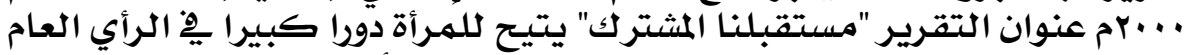

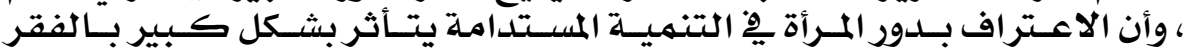

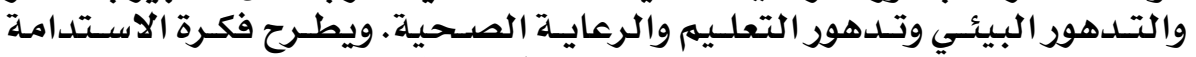

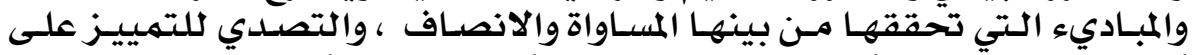

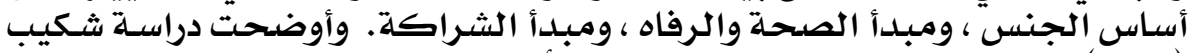

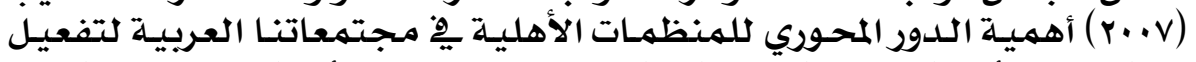

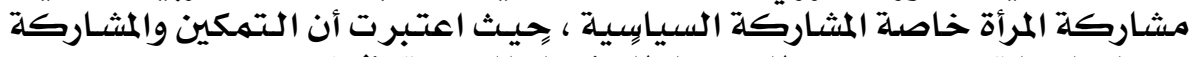

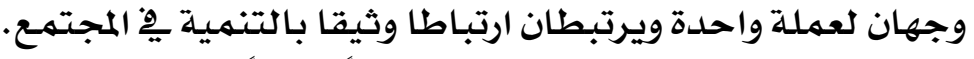

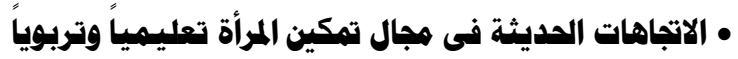

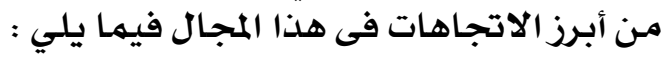

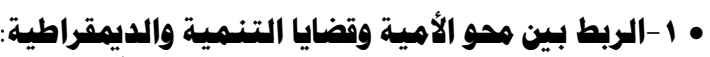

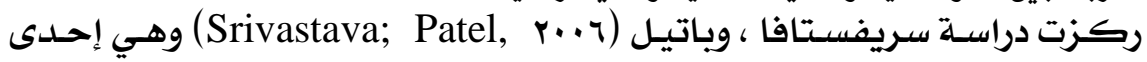

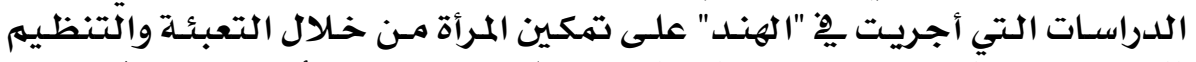

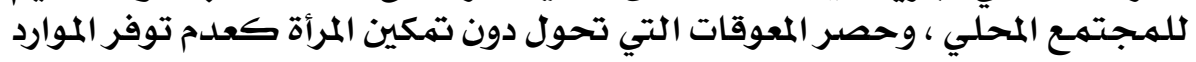

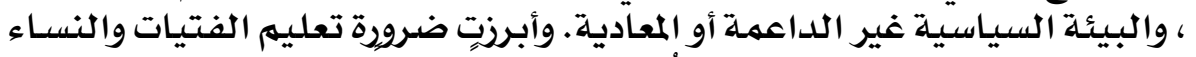

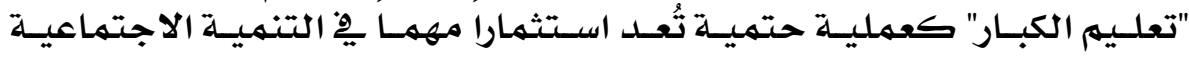

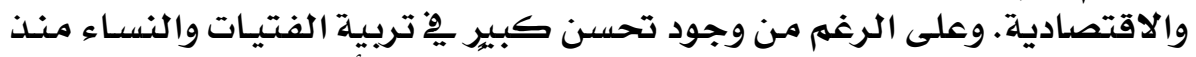

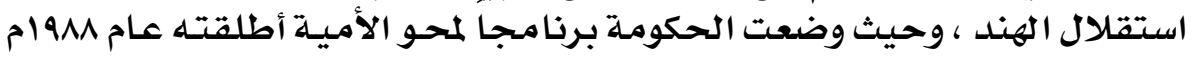

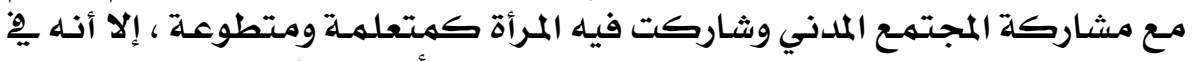

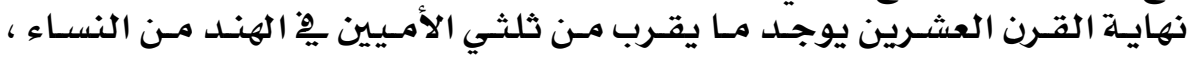

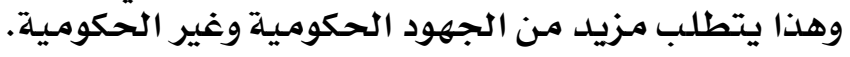




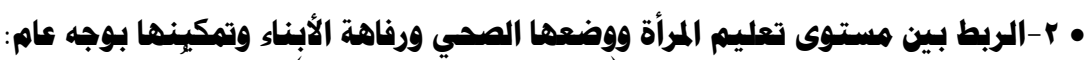

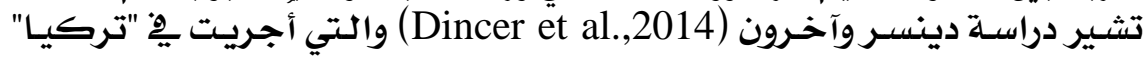

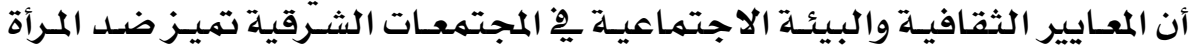

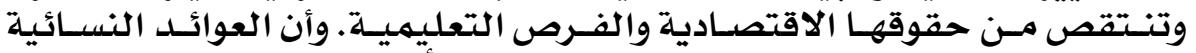

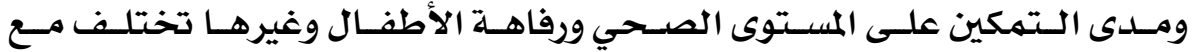

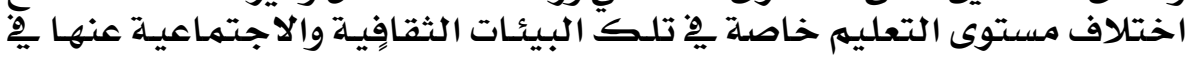

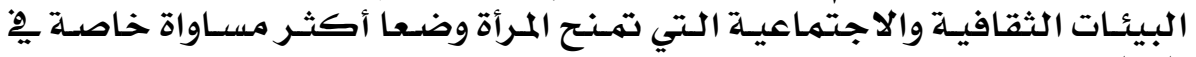
التعليهم. التيبئات

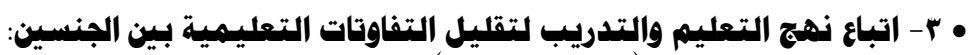

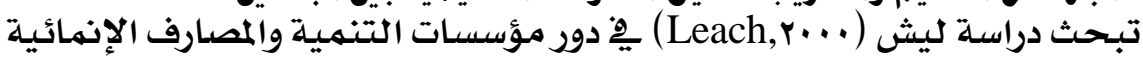

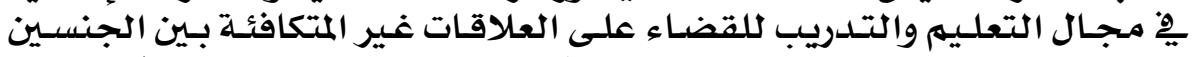

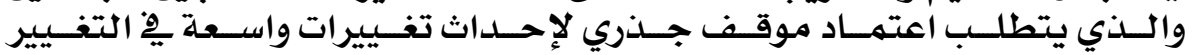

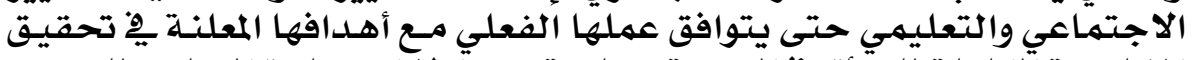

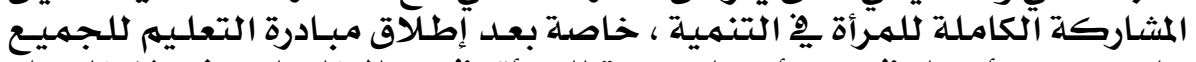

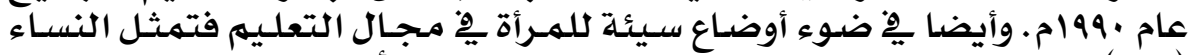

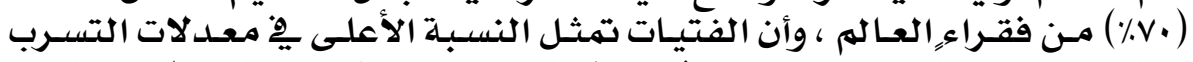

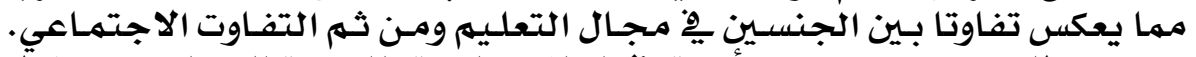

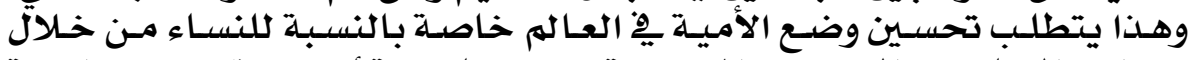

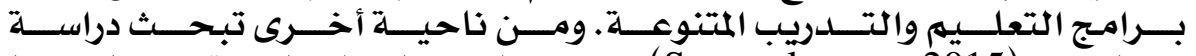

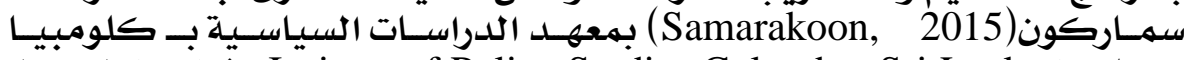

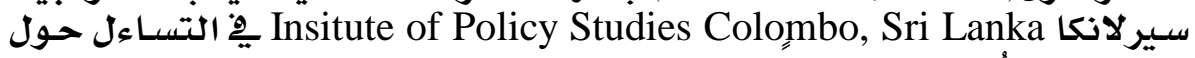

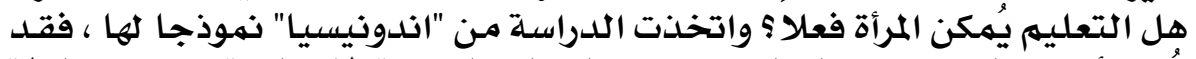

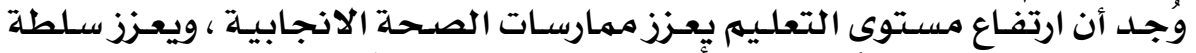

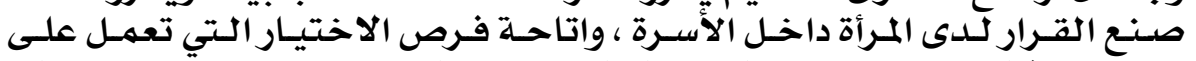

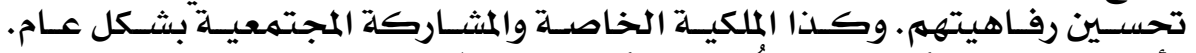

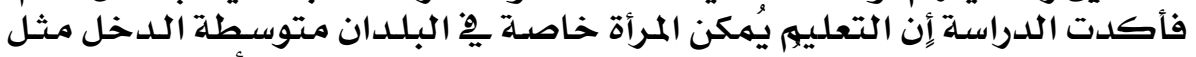

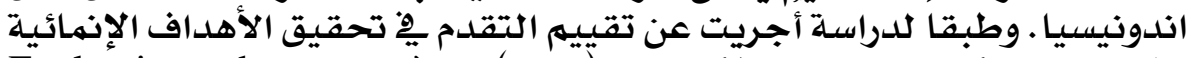

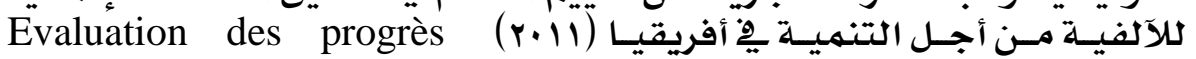
accomplis en Afrique dans la réalisation des objectifs du Millénaire وُجحد أن من ضـهـن تسعـة عشـر دولـة أفريقيـة تضهمنتها

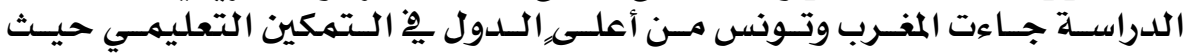

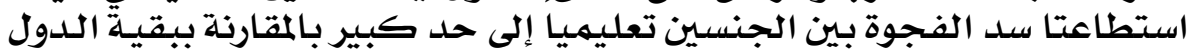

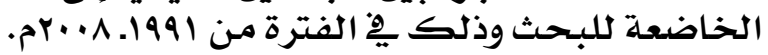

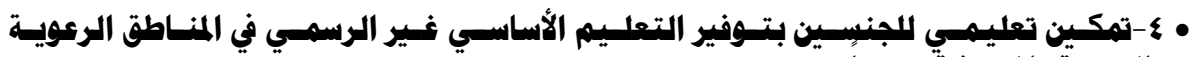

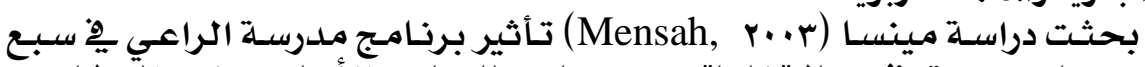

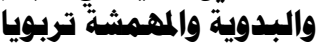

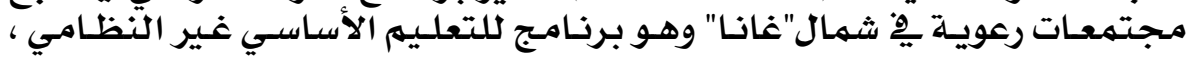

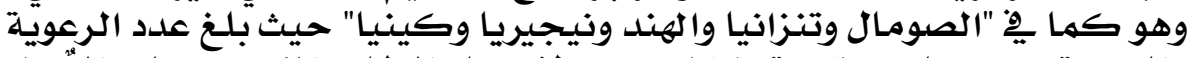

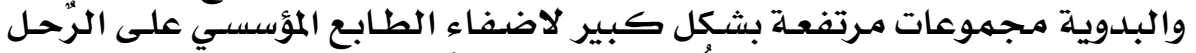

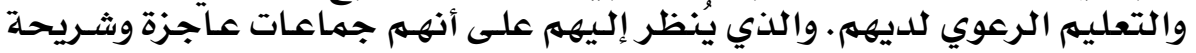




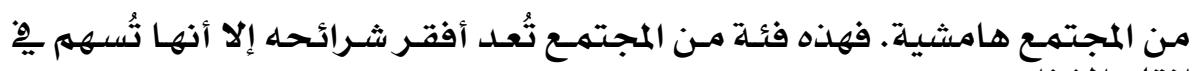

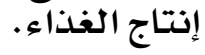

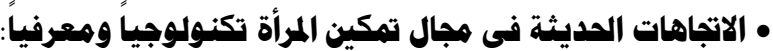

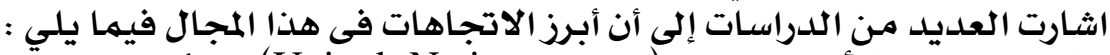

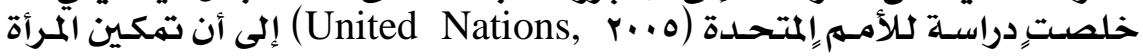

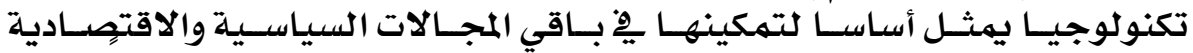

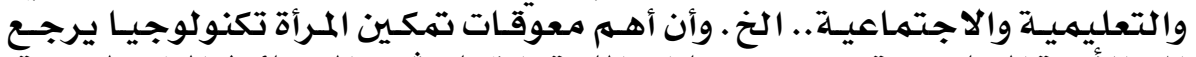

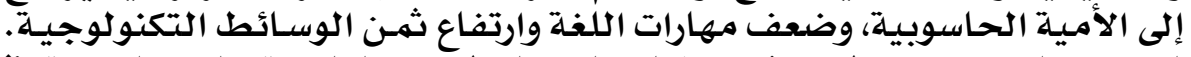

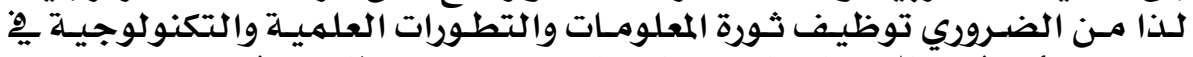

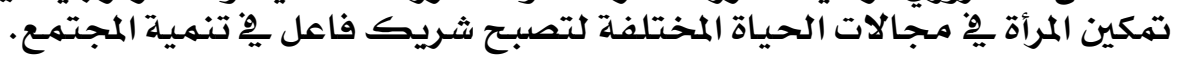

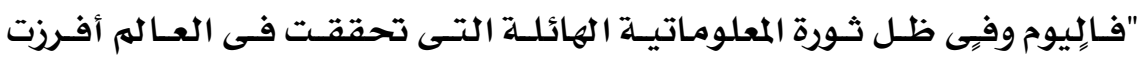

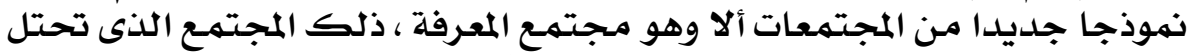

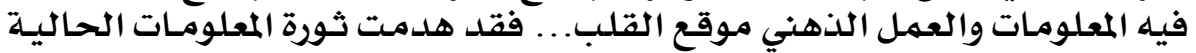

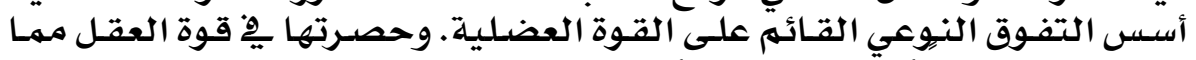

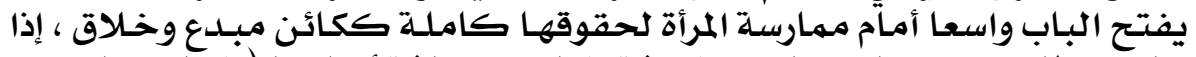

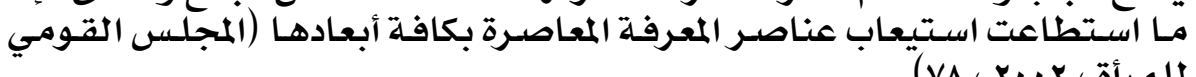

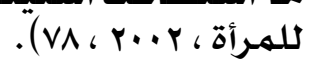

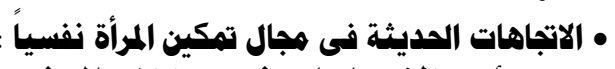

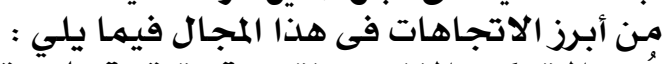

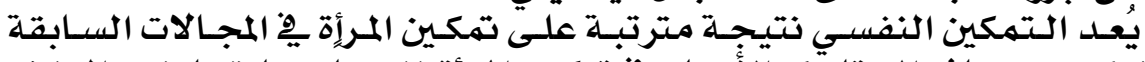

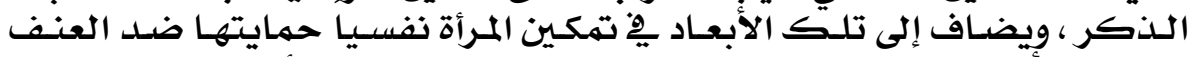

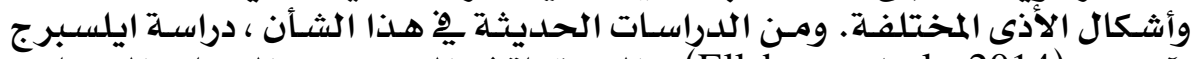

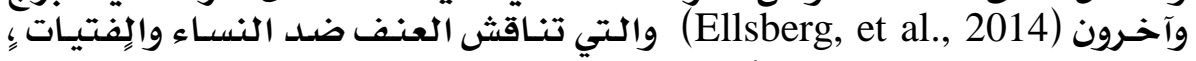

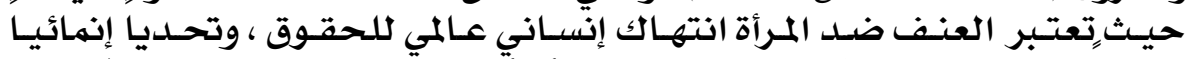

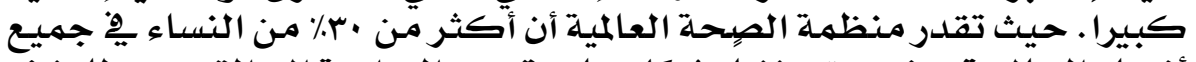

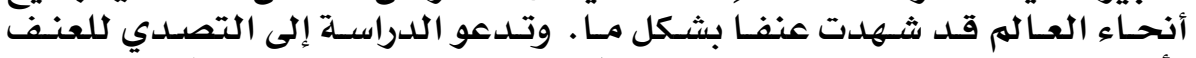

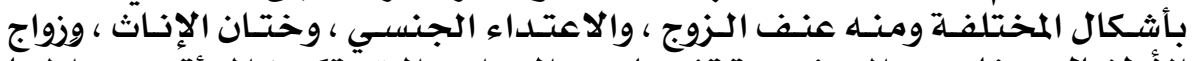

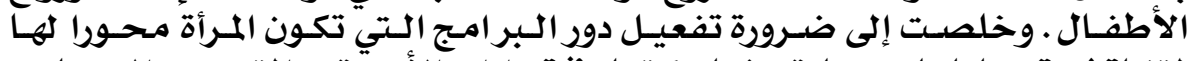

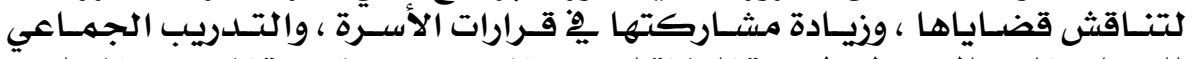

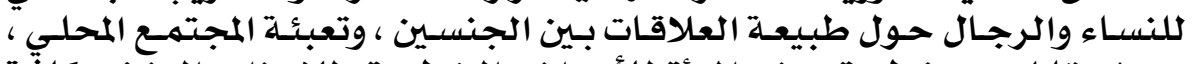

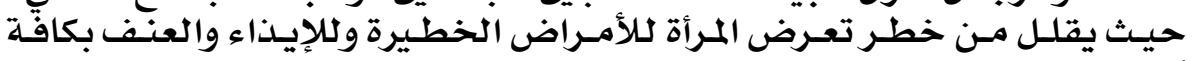
أثكاله.

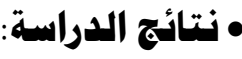

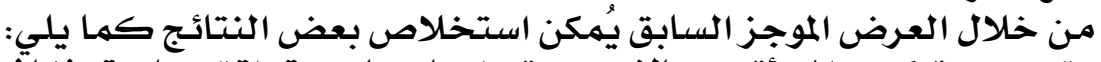

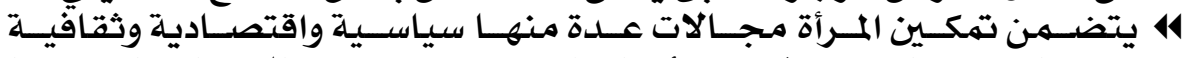

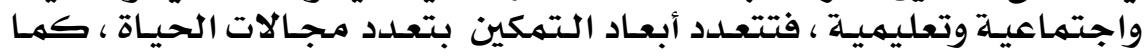

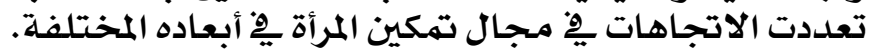

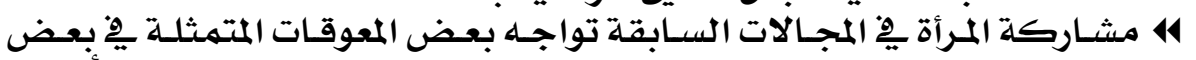

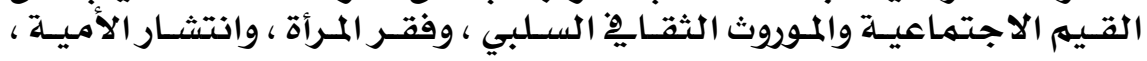




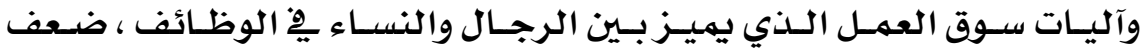

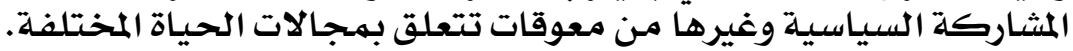

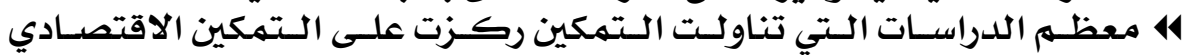

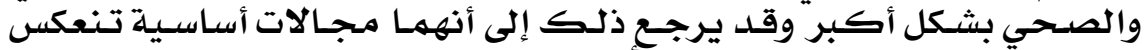

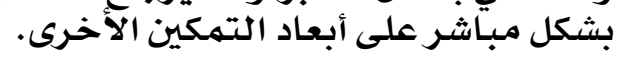

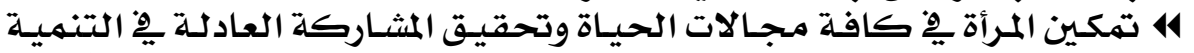

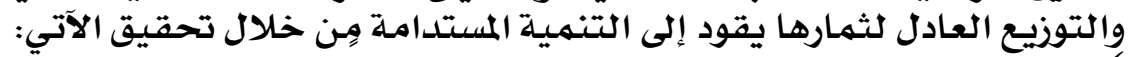

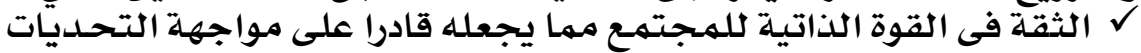
بيقظة ووعي.

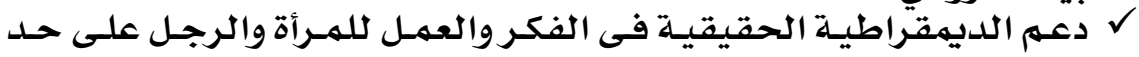

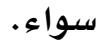

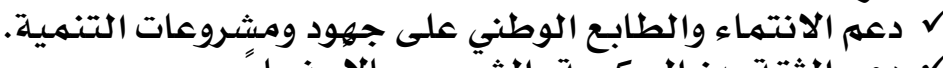

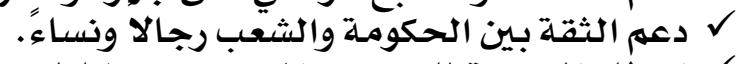

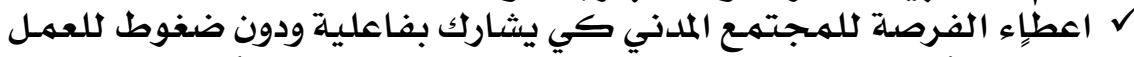

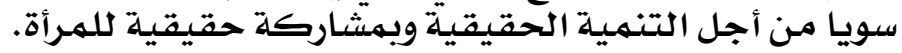

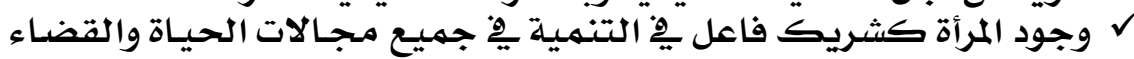

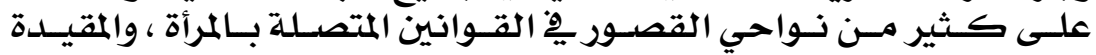

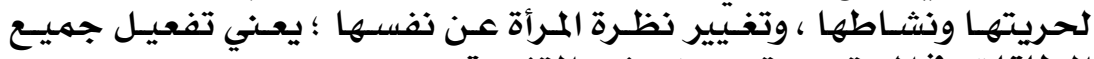

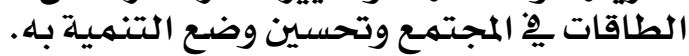

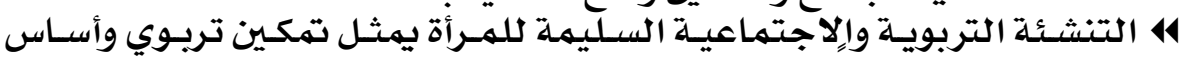

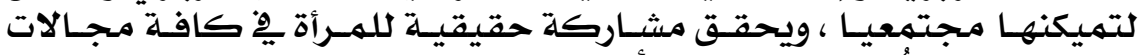

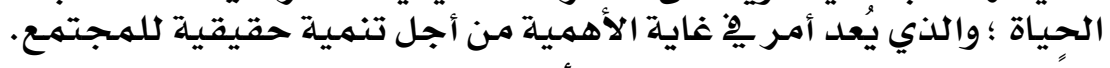

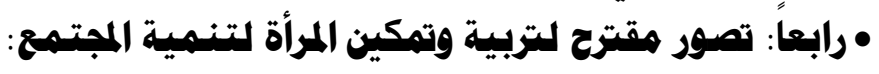

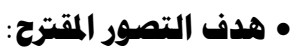

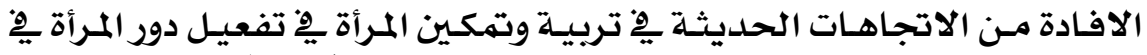

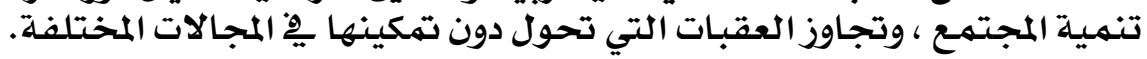

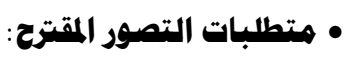

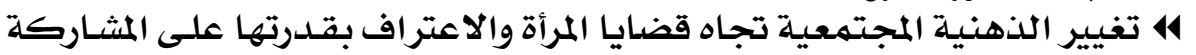

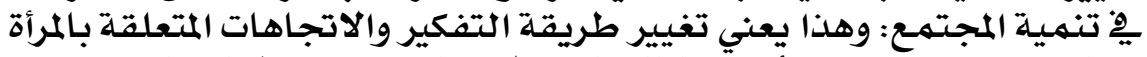

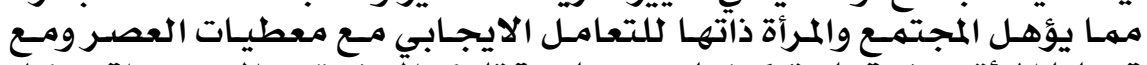

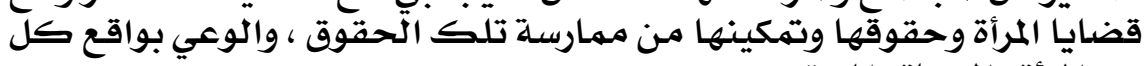

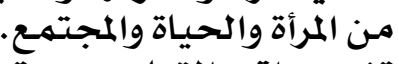

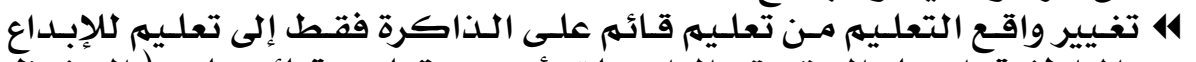

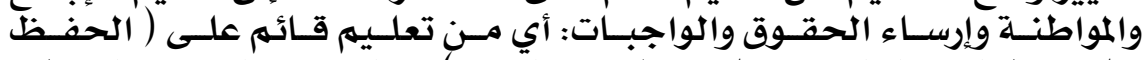

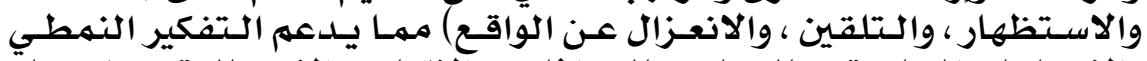

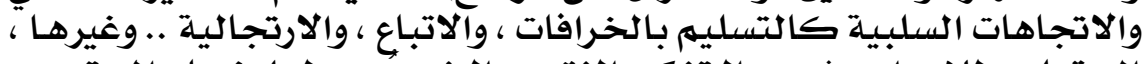

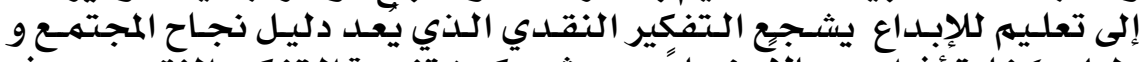

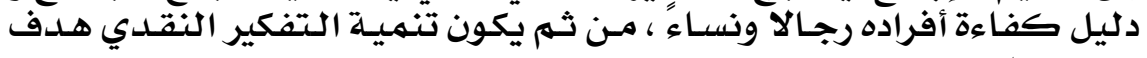
تربوي هام. 


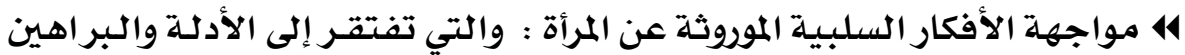

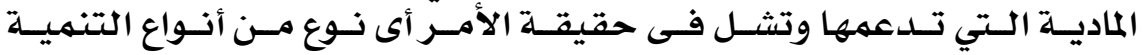

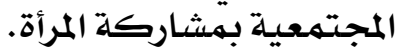

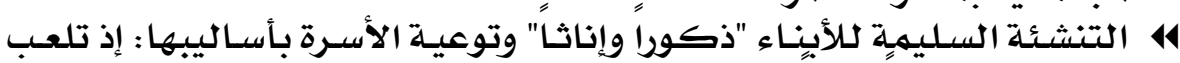

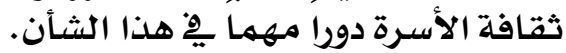

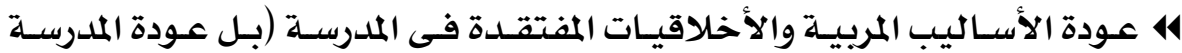

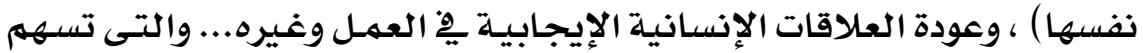

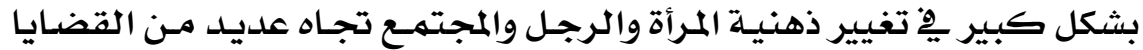

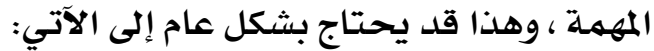

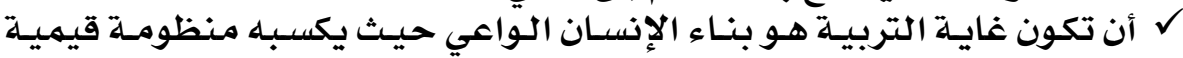

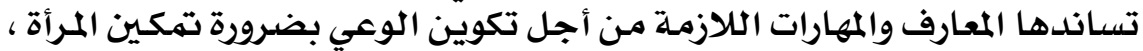

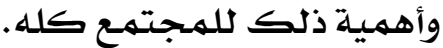

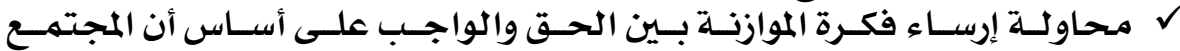

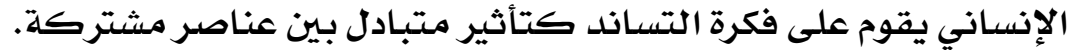

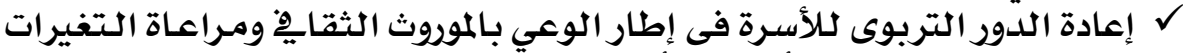

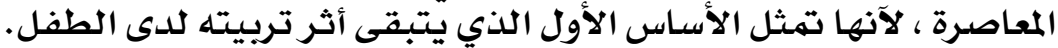

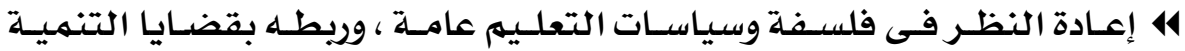

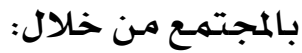

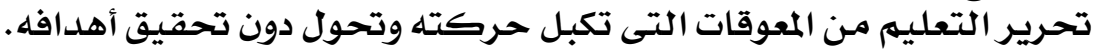

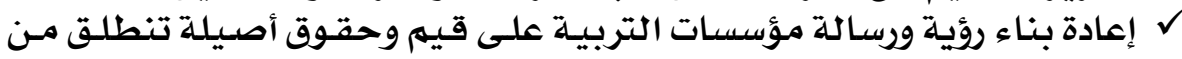

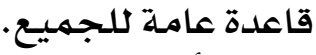

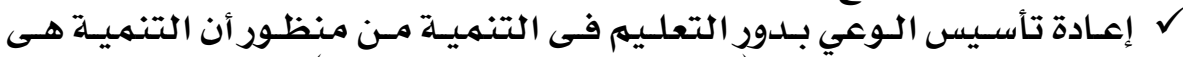

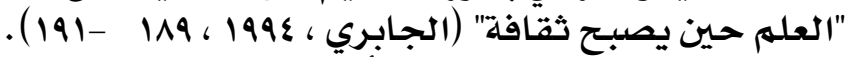

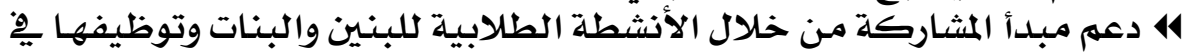

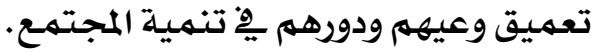

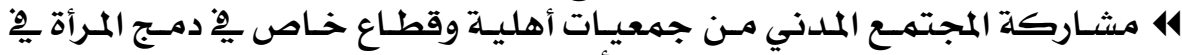

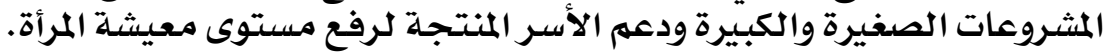

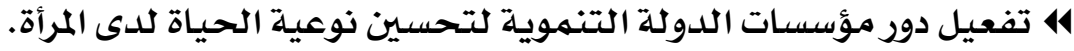

\section{• آليات تثقيق التصور المقترح:}

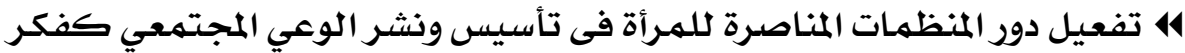

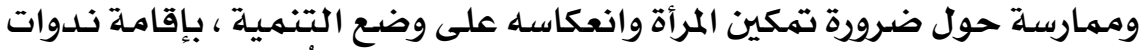

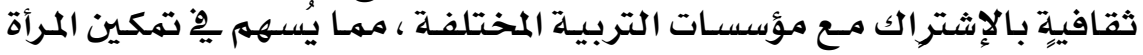

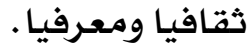

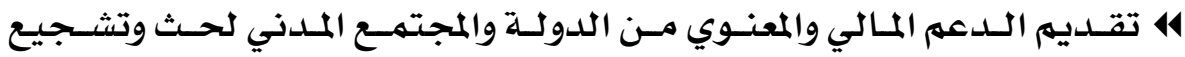

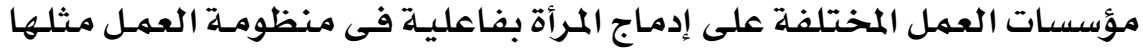

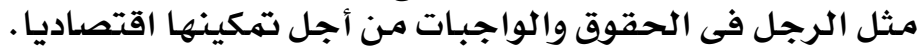




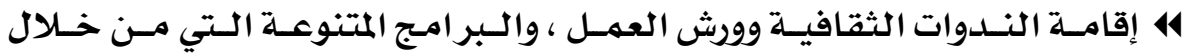

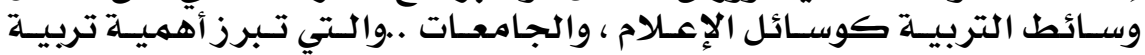

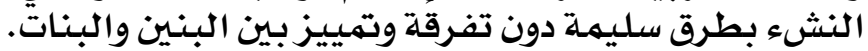

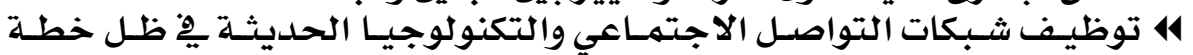

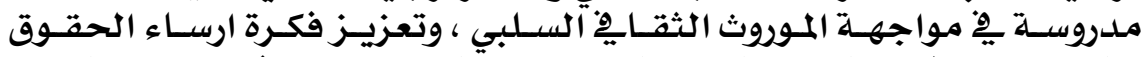

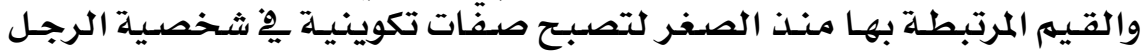
والمرأة.

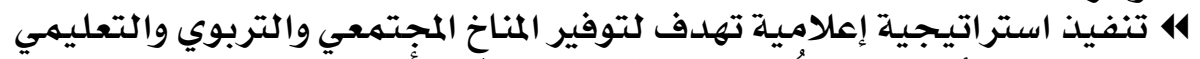

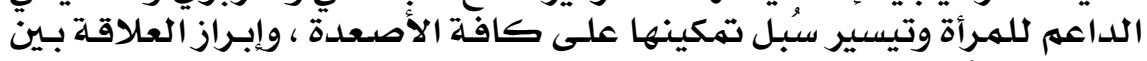

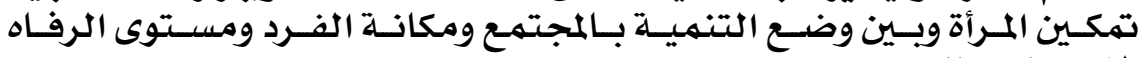

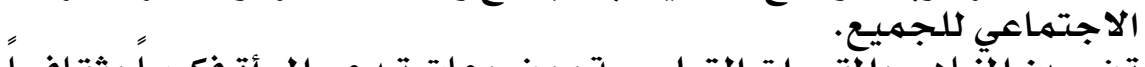

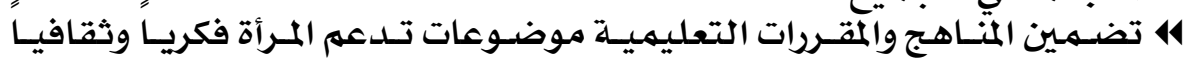

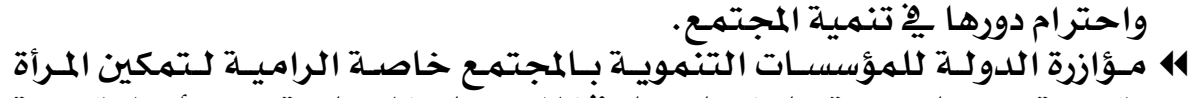

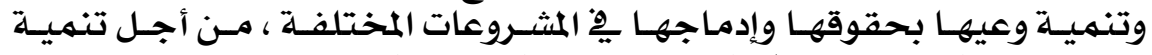

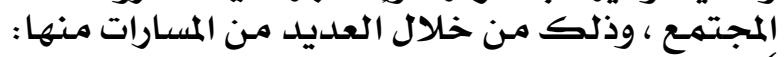

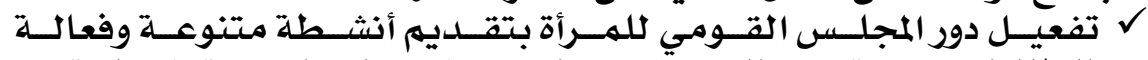

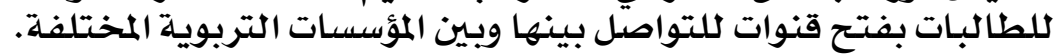

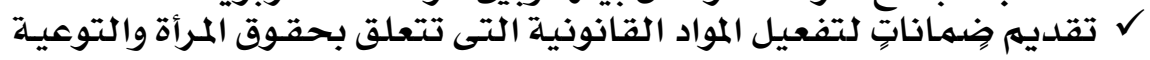
بها فكرا وعملا.

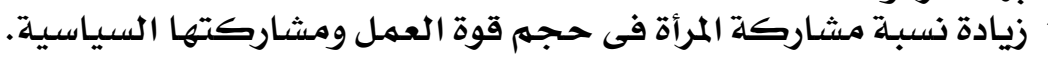

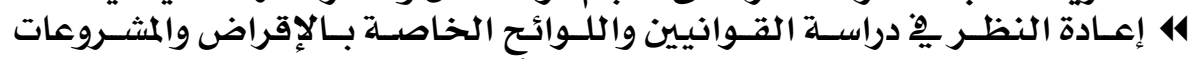

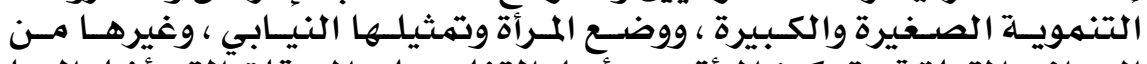

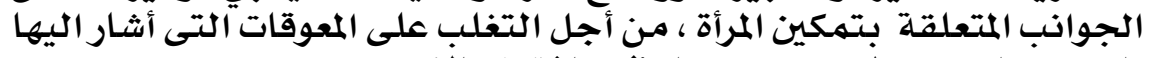

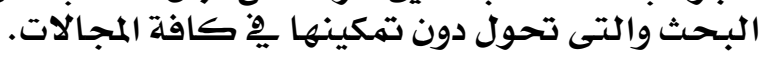

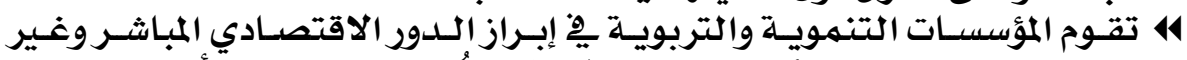

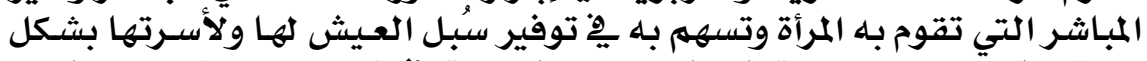

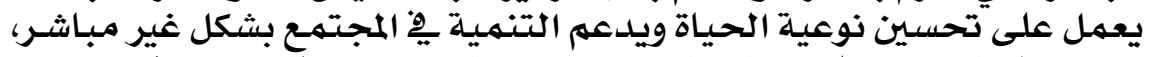

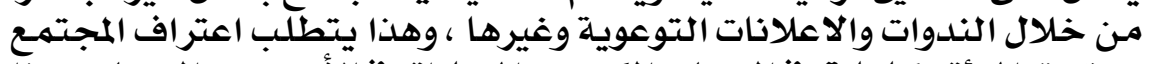

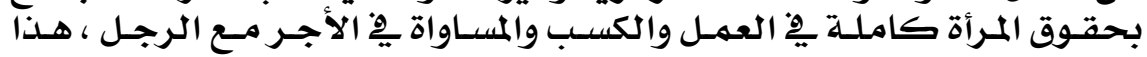

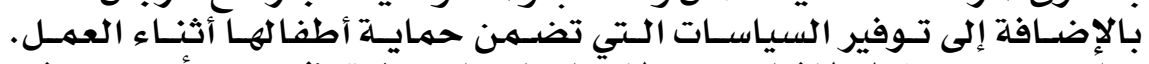

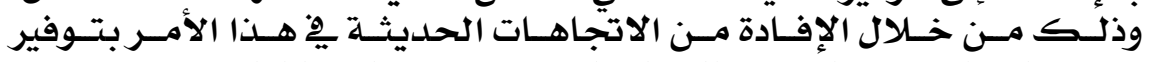

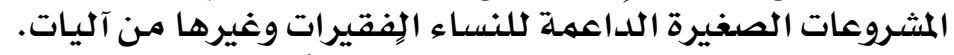

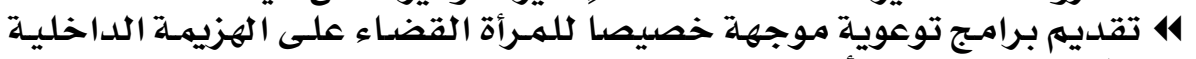

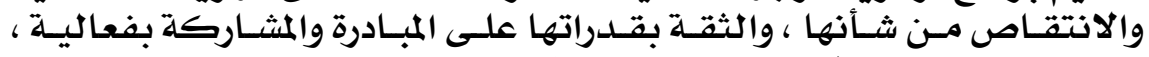

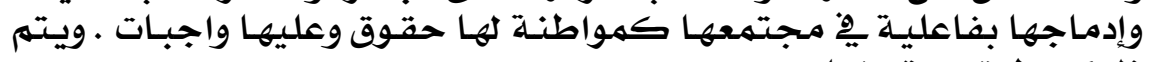

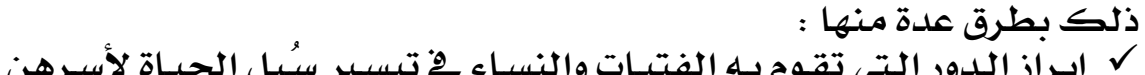

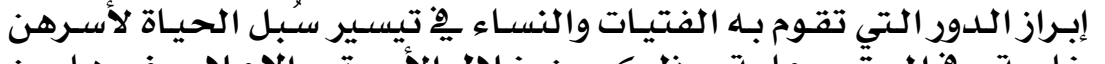

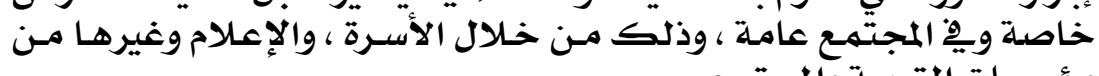

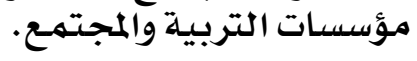




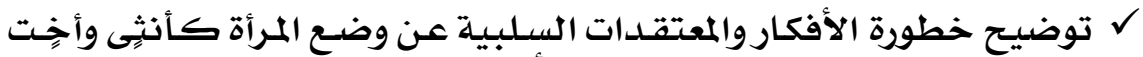

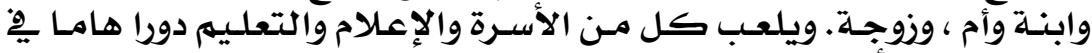
تحقيق هذا الأمر.

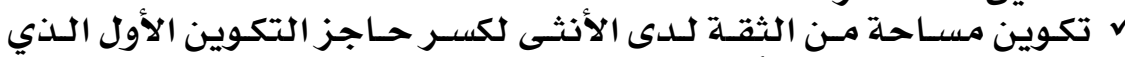

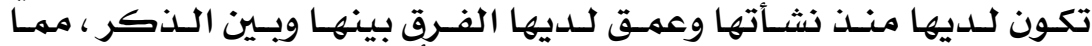

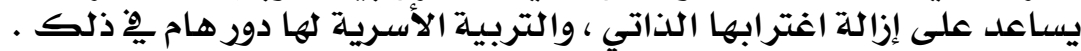

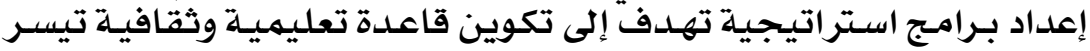

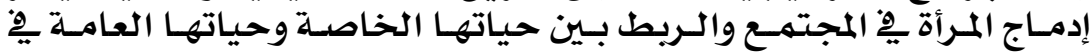

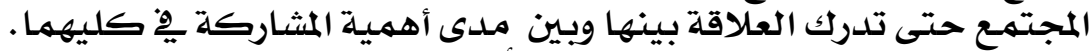

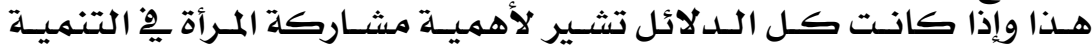

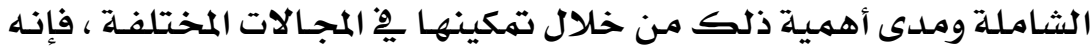

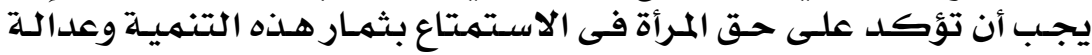

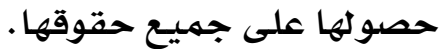

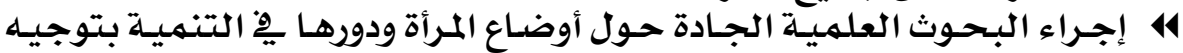

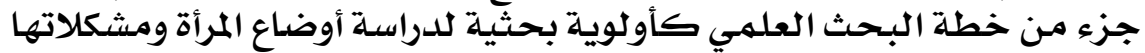

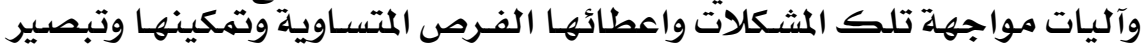

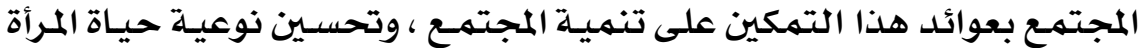

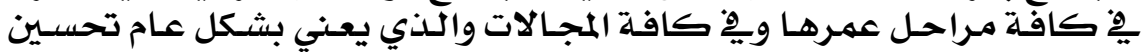

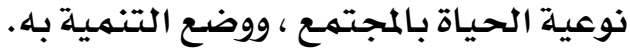

\section{• توصيات الدراسية:}

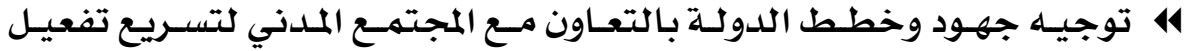

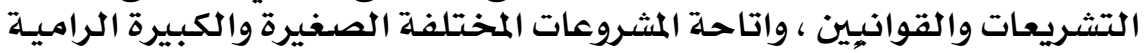

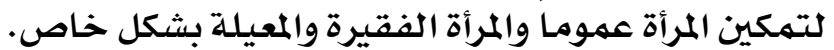

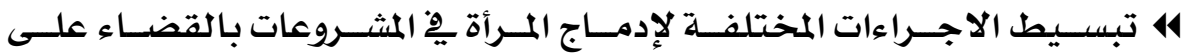

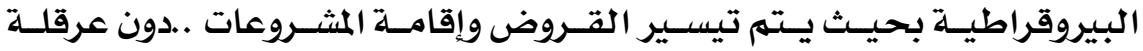
الاجراءات. الاءيرواطي.

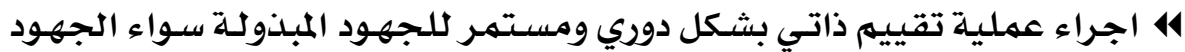

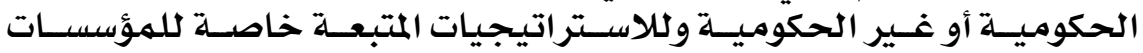

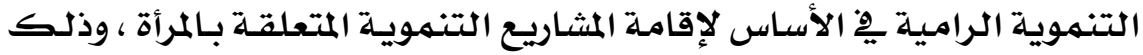

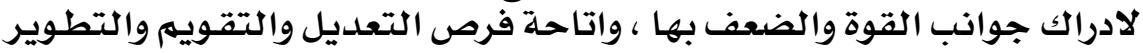

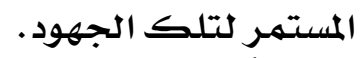

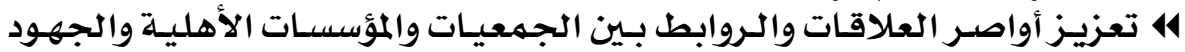

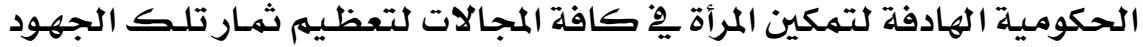

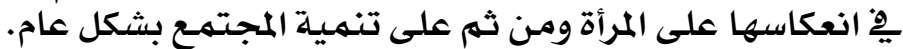

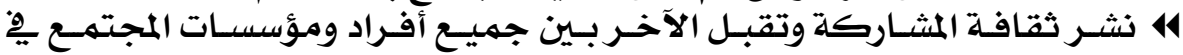

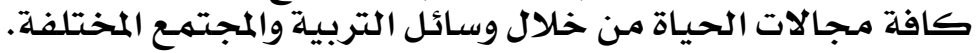

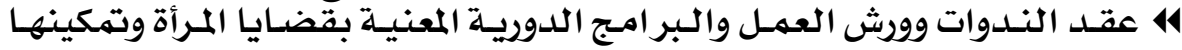

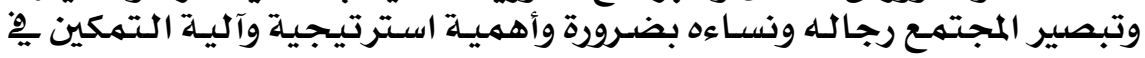
تنهية المجتهـع المجتهع رتح 


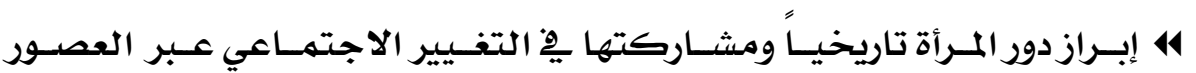

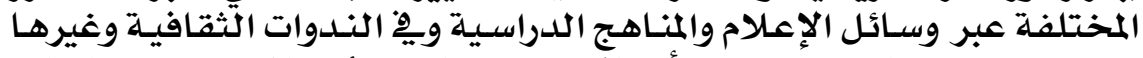

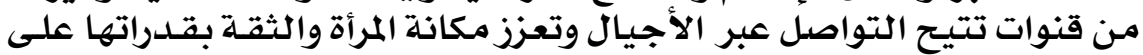

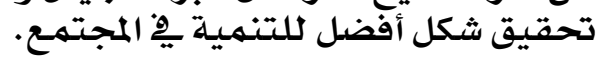

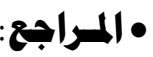

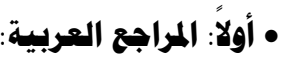

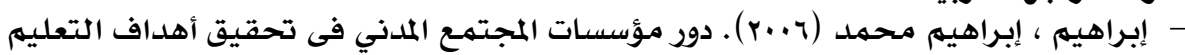

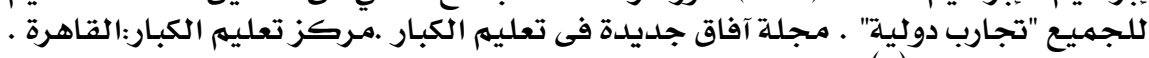

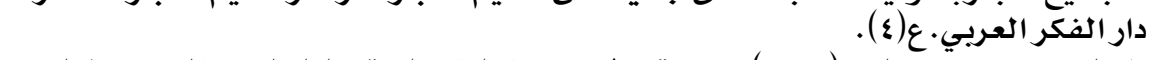

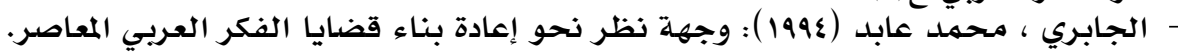

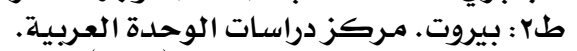

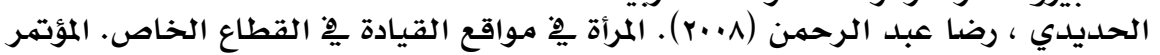

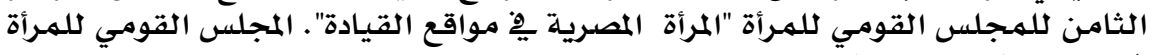

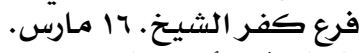

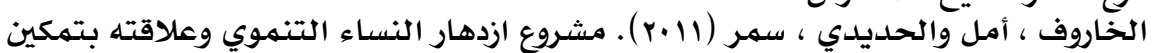

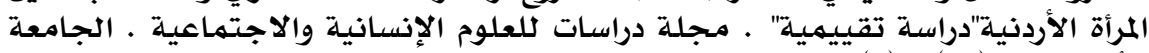

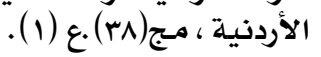

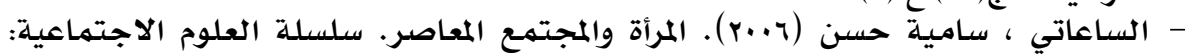

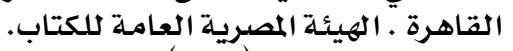

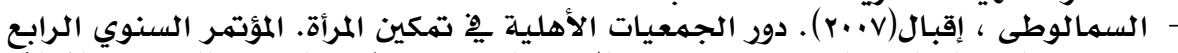

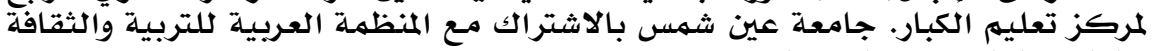

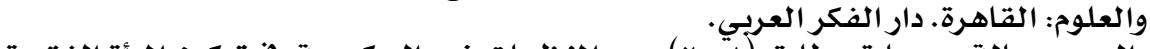

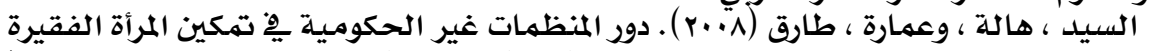

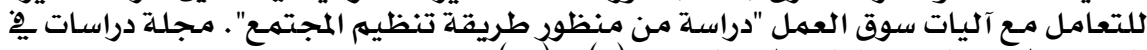

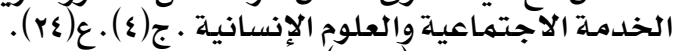

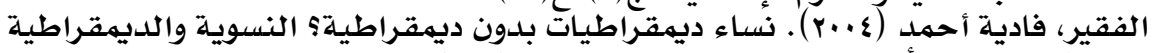

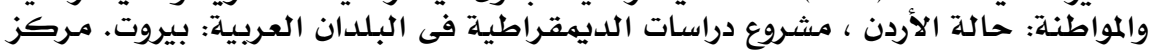

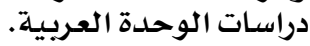

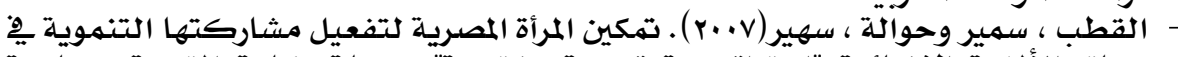

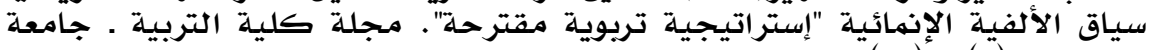

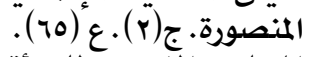

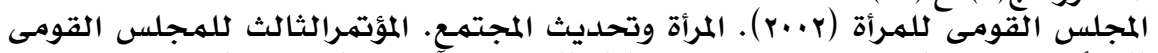

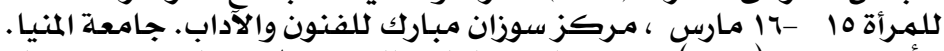

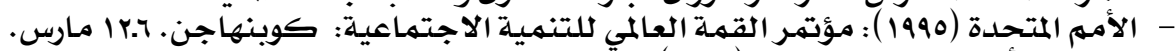

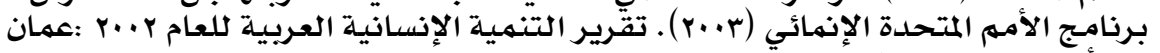

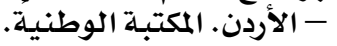

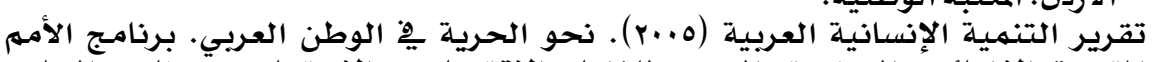

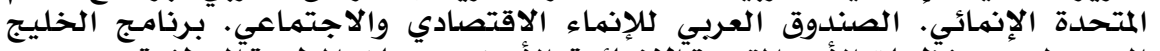

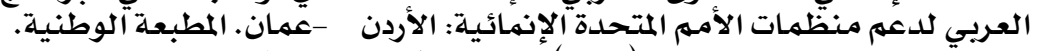

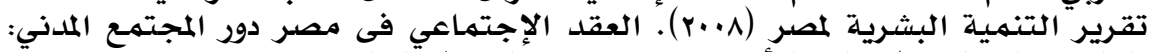

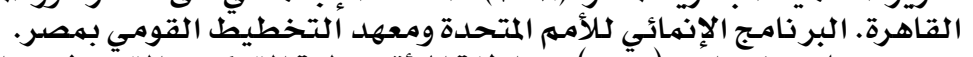

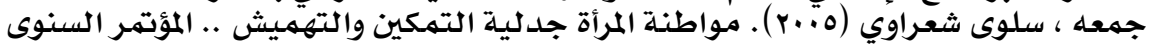

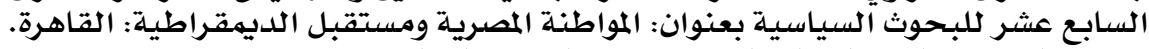

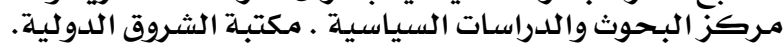




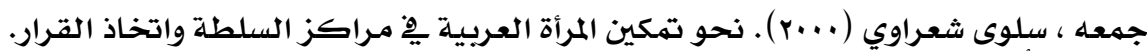

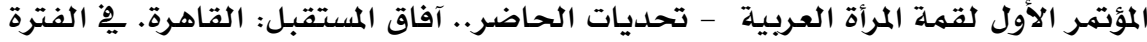

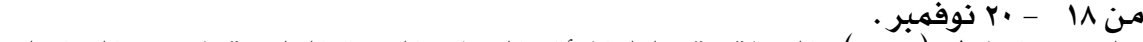

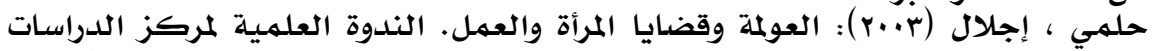

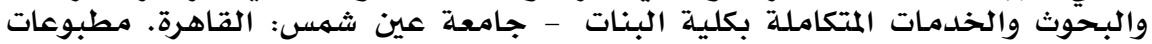

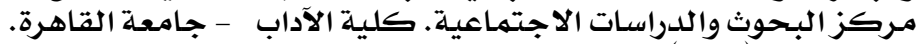

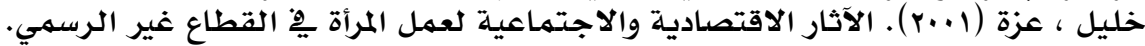

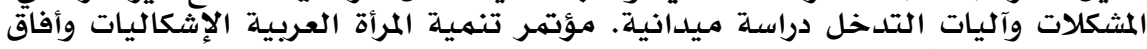

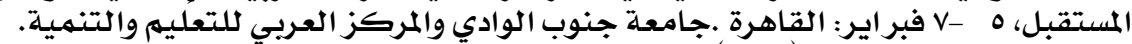

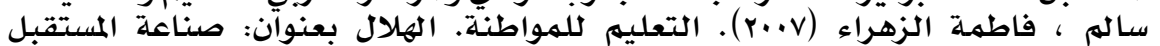

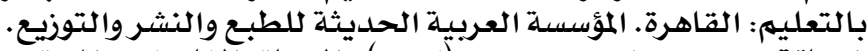

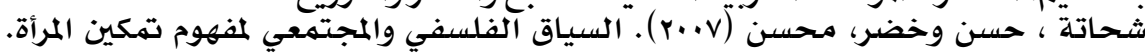

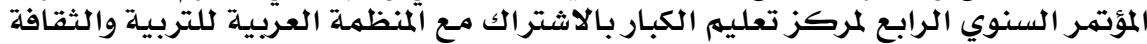

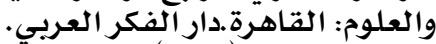

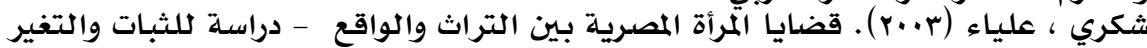

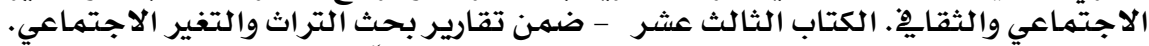

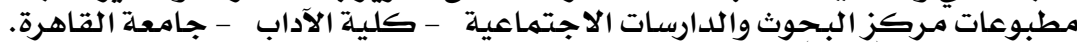

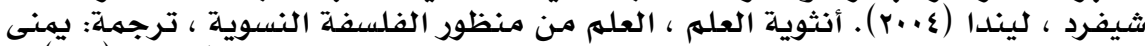

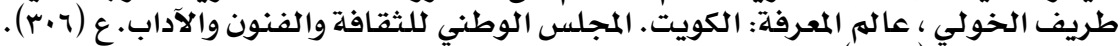

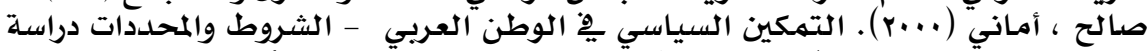

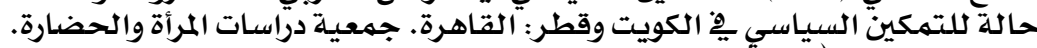

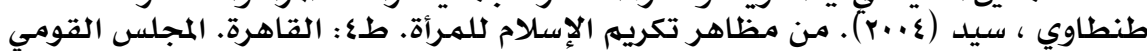
للهمرأة.

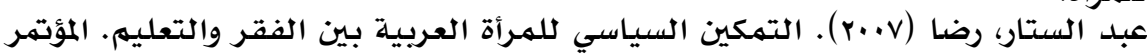

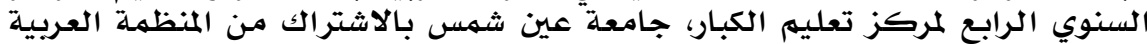

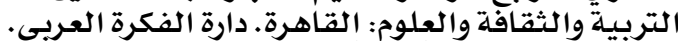

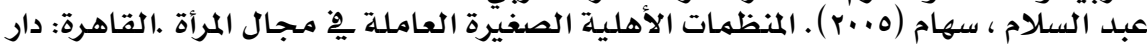

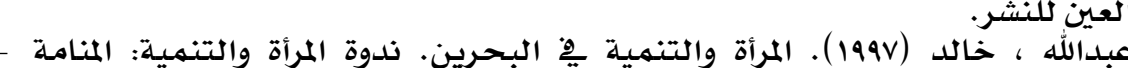

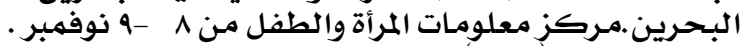

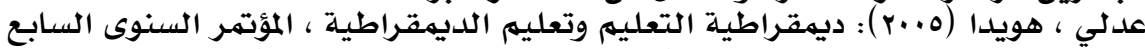

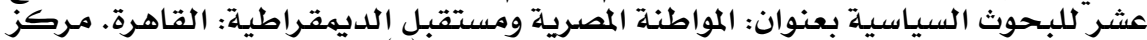

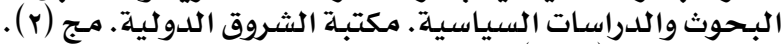

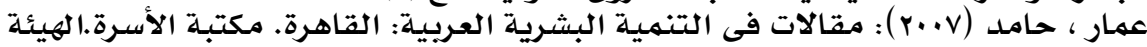
المصرية العامـة للكتاب.

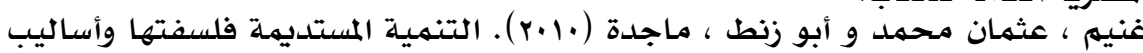

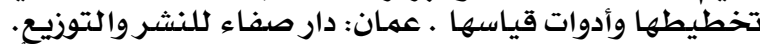

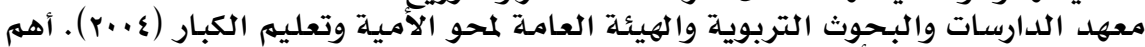

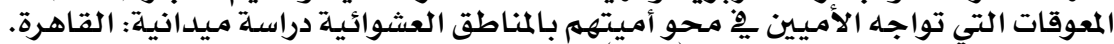

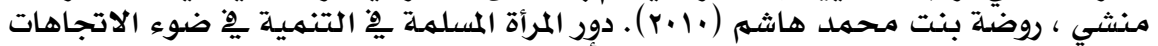

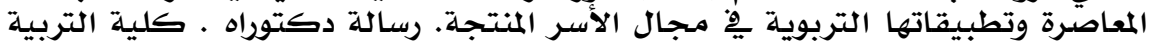

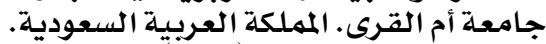

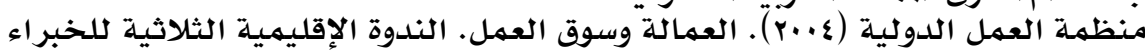

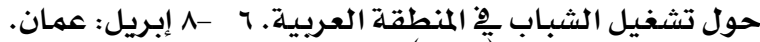

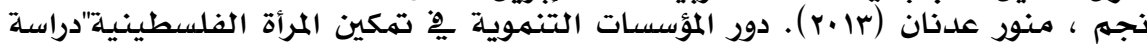

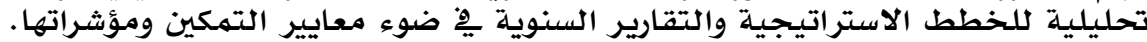

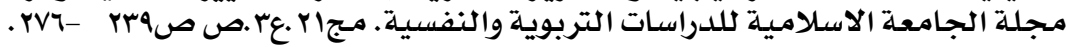




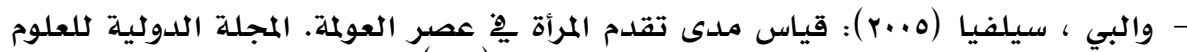

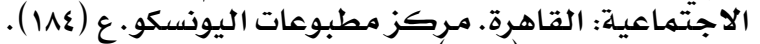

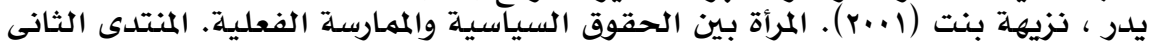

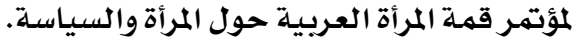
• ثانياً: المراجع الأجني

- Amollo R. (2011). Women's Socio-Economic Rights in the Context of HIV and AIDS in South Africa: Thematic Focus on Health, Housing, Property and Freedom from Violence. A thesis submitted in fulfillment of the requirements for the degree of Doctor of Laws (LLD) in the Faculty of Law, University of the Western Cape.

- Asiyonbola, A. (2005). Patriarchy, Male Dominance, the Role and Women Empowerment in Nigeria. In International Union for the Scientific Study of Population, (XXV) International Population Conference Tours, France.

- Bare, F. (2005). Women's Political Participation 'Issues and challenges'. Bangkok - Thailand, 8 - 11 November.

- Costa, B. (2003).Women's Political Participation in Bolivia 'Progress and Obstacles'. Paper Presented at International Idea Workshop Lima, peru, 23 - 24 February.

-Das, P. (2014).Women's Participation in Community-Level Water Governance in Urban India: The gap between motivation and ability. World development (64) 206-218.

-Dincer, M. Kaushal, N. Grossma, M. (2014). Women's Education: Harbinger of Another Spring? Evidence from a Natural Experiment in Turkey. World Development (64)243-258.

- Doughty, H. (n.d.). Employee empowerment: Democracy or delusion? The Innovation Journal. The public sector innovation Journal. Vo9 (1).

-Easteal, P. Holland, K. Judd, K. (2015).Enduring themes and silences in media portrayals of violence against women. Women's Studies International Forum 48 103-113.

- Gamble, J. Creedy D., Teakle B. (2007).Women's expectations of maternity services: A community-based survey. Women and Birth (20) 115-120.

- García, J., Boira, S. Gomez-Quintero D., Marcuello, C. Eito, A. (2014). Imprisoned women and professional intervention in Spain. International Journal of Law, Crime and Justice, 1-17.

- Germain, N. Hartmann, H. Melo, F. Reyes-Bonilla, H. (2015). Ornamental reef fish fisheries: New indicators of sustainability and human development at a coastal community level. Ocean \& Coastal Management (104) 13-149.

- Hassim, N. (2014). Hijab and the Malay-Muslim Woman in Media. In The International Conference on Communication and Media 2014 
(i-COME'14), 18-20 October 2014, Langkawi, MALAYSIA. Procedia - Social and Behavioral Sciences (155) 428 - 433.

-Imai, K. Annim, S. Kulkarnii V. Gaiha, R. (2014).Women's Empowerment and Prevalence of Stunted and Underweight Children in Rural India. World Development (62) 88-105.

- Janssens, W. (2010). Women's Empowerment and the Creation of Social Capital in Indian Villages. World Development 38(7) 974988. doi:10.1016/j.worlddev.2009.12.004.

- Kabeer, N. (2012). Autonomisation économique de la femme et croissance inclusive: Marchés du travail ET développement de l'entreprise. Canada. Department for International Development (DFID).

- Kempe, A. Theorell, T. Alwazer, F. Christensson, K. Johansson, A. (2013). Yemeni women's perceptions of own authority during childbirth: What does it have to do with achieving the Millennium Development Goals? Midwifery (29) 1182-1189.

-Khan, A.R. \& Bibi, Z. (2011). Woman, s socio-Economic Empowerment through participatory approach a critical assessment Pakistan. Economic and Social review, Vo.49.No.1, pp133-148.

-Khumalo, K. McKay, K. Freimund, W. (2015). Who is a "real woman"? Empowerment and the discourse of respectability in Namibia's Zambezi region. Women's Studies International Forum (48) $47-56$.

-Lawson, K. (2006). 4 Keys to employee empowerment. Growing Greatness: Series of articles to cultivate truly outstanding leaders. Lawson consulting group Inc.

-Leach, F. (2000). Gender implications of development agency policies on education and training. International Journal of Educational Development 20 (2000) 333-347.

- Maier, B. (2014).Is the narrow concept of individual autonomy compatible with or in conflict with Evidence-based Medicine in obstetric practice? A philosophical critique on the misapplication of the value concept "autonomy". Woman - Psychosomatic Gynaecology and Obstetrics (1) 40-49.

- Malhotra, A. et al (2002). Measuring Women's Empowerment as a Varible in International Development. Paper Prepared for the World Bank Workshop on poverty and Gender: New Perspectives, Final Version.

- Martin, R. (2012). Service projects and women's agency in Salalah, Oman: A portrait of pre-service Dhofari English teachers. International Journal of Educational Development (32)290-300.

- Mensah, O. (2003). Fostering educational participation in pastoral communities through non-formal education: the Ghanaian 
perspective. International Journal of Educational Development 23 (2003) 661-677.

-Moeller, K. (2013). Proving “The Girl Effect': Corporate knowledge production and educational intervention. International Journal of Educational Development (33) 612-621.

- Mohammad R. (2007). A community program for women's health and development: Implications for the long-term care of women with fistulas. International Journal of Gynecology and Obstetrics (99) S137-S142.

- Nisbett, N. Gillespie, S. Haddad, L. Harris J. (2014). Why Worry About the Politics of Childhood Undernutrition? World Development (64)420-433.

-Osotimehin, B. (2014). Continue to improve women's health: ICPD Beyond. Contraception (90) S1-S2.

- Regmi, S. (2004). Impact of Microfinance Program on Women's Empowerment and Poverty Alleviation: a Case Study of Microcredit Project for Women (MCPW) in Lalitpur District of Nepal, College of Social Science and Philosophy University of Phillippines.

-Samarakoon, S. Parinduri, R. (2015). Does Education Empower Women? Evidence from Indonesi. World Development (66) 428442.

- Sauré, P. Zoabi, H. (2014). International trade, the gender wage gap and female labor force participation. Journal of Development Economics (111) 17-33.

-Serafico, V. (2006): Women international Fund for Agricultural Development (IFAD), Rome, Italy.

- Serafico, V. (n.d.). Women international Fund for Agricultural Development (IFAD), Rome, Italy, p. 1.

- Sierpina V, Levine L, McKee J, Campbell C, Lian S, Frenkel M, (2015).Nutrition Metabolism, And Integrative Approaches In Cancer, Seminars in Oncology Nursing doi: 10.1016/j.soncn.2014.11.005.

- Srivastava, K., Patel, I. (2006). Community mobilisation, gender equality and resource mobilisation in adult education. International Journal of Educational Development (26) 153-165.

-To, S. Tam, H. Sek-yum, Ngai, S. Sung, W. (2014). Sense of meaningfulness, sources of meaning, and self-evaluation of economically disadvantaged youth in Hong Kong: implications for youth development programs. Children and Youth Services Review (47) 352-361.

- Tutar, H. et al, (2011). The effects of employee empowerment on achievement motivation and the contextual performance of 
employees. African Journal of Business Management . Academic Journals. Vol.5(15),6318-6329.

- United Nations (2005).Women 2000 and Beyond Gender Equality and Empowerment of Women through ICT. Division for the Advancement of Women. Department of Economic and Social Affairs.

- Vargas, C. (2002). Women in Sustainable Development: Empowerment through Partnerships for Healthy Living. World Development 30(9) 1539-1560.

- Welzel, C. (2014). Evolution, Empowerment, and Emancipation: How Societies Climb the Freedom Ladder. World Development (64) 33-51.

- York, R. Bell, E. (2014). Life satisfaction across nations: The effects of women's political status and public priorities. Social Science Research (48) 48-61.

http:// Bintsultan.blogspot.com

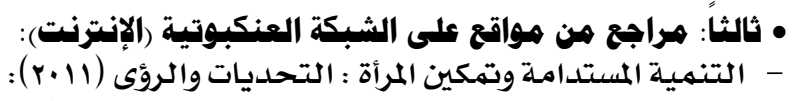

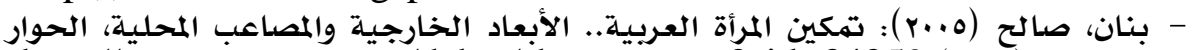

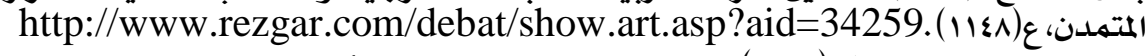

- سبيث ، جيمس غوستاف (11) - مب ). التنمية المستدامة وتمكين المرأة: التحديات والرؤى: http://bintsultan1.blogspot.com/2011/12/blog-p0st_05.html

- شكيب ، شعلة (r.vV).التمكين السياسي للمرأة العربية ودور المؤسسات الأهلية: http://www.awapp.org/wmview.php?artiD

- Evaluation des progrès accomplis en Afrique dans la réalisation des objectifs du Millénaire pour le développement, 2011

- http://www.un.org/fr/millenniumgoals/gender.shtml

-Les femmes rurales et les objectifs du Millénaire pour le développement:

- http://www.un.org/.../ruralwomen/.../Fr-Rural-Women-MD

- Ellsberg, M. Arango, D. Morton, M. Gennari, F. Kiplesund, S. Contreras, M. Watts, C. (2014). Violence against women and girls 1. Prevention of violence against women and girls: what doesthe evidence says? http://dx.doi.org/10.1016/S0140-6736(14)61703-7. 